HA N D B O O K O F B IRDSOF THE WESTERN UNITED STATES Florence Merriam Bailey

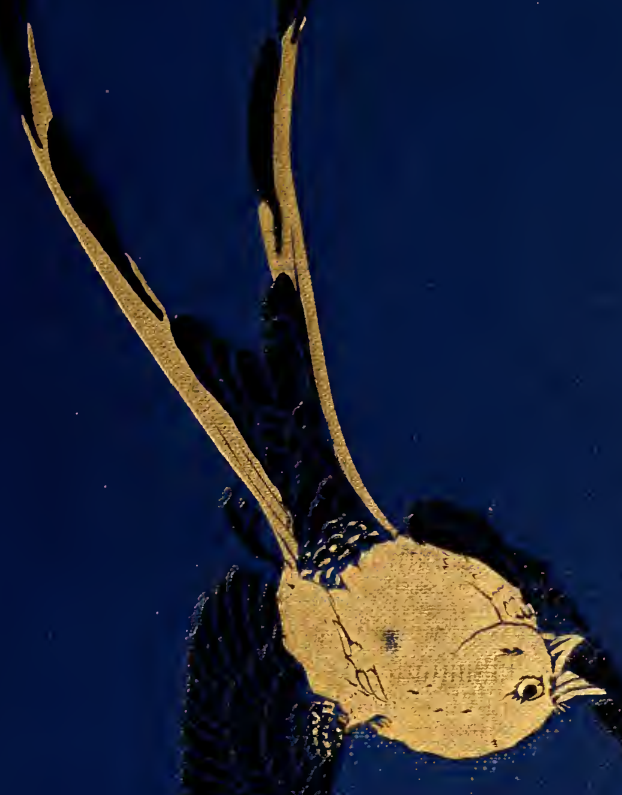




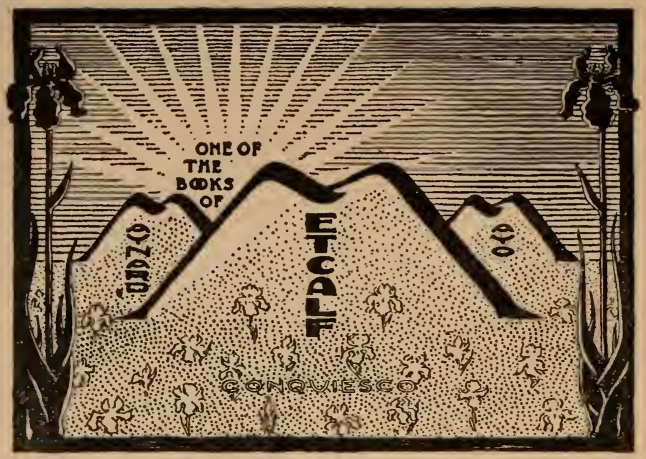


Maynaed in. Mnteal s Oborlim 1909 






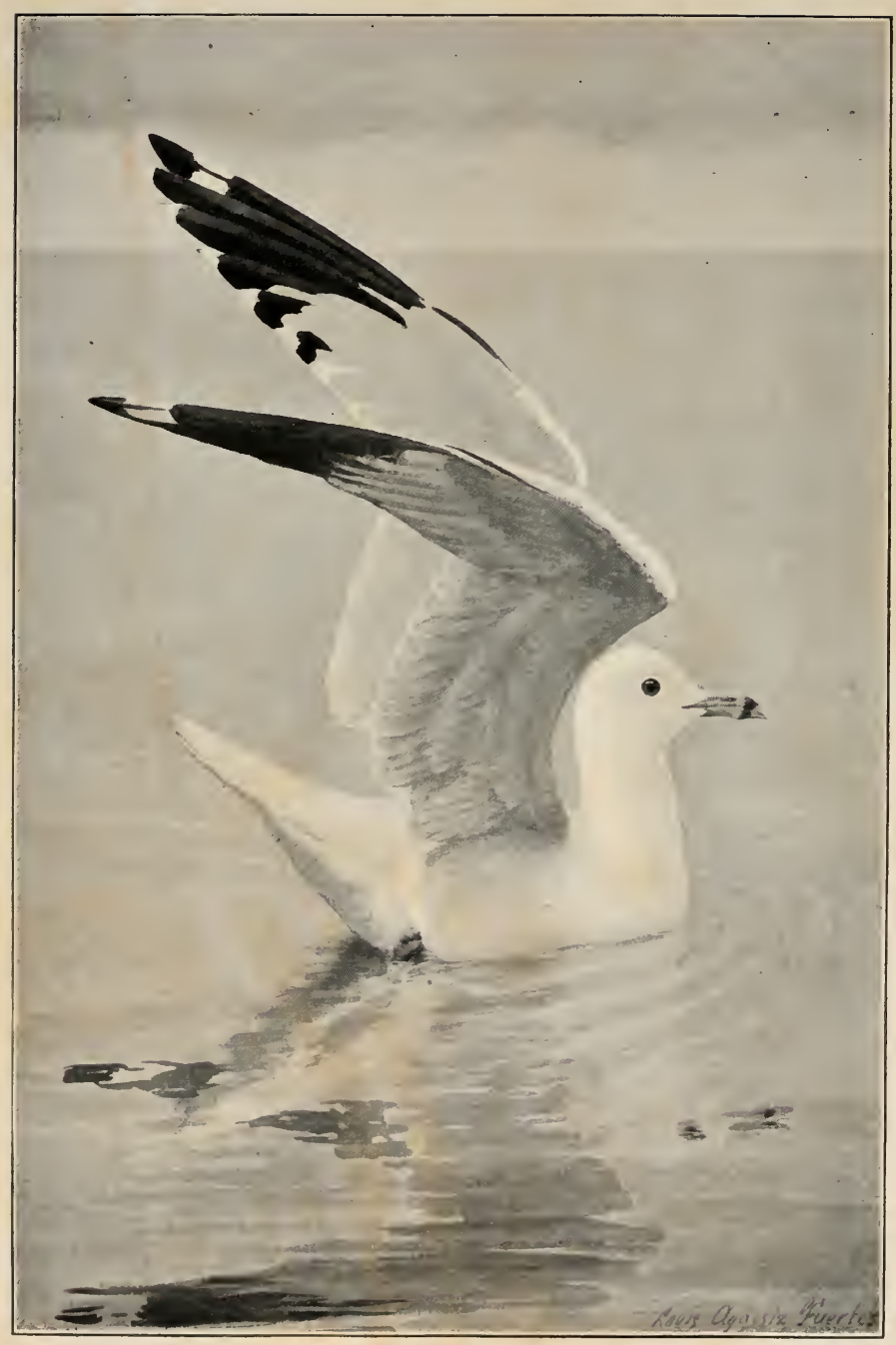

RING-BILLED GULL (Page 23) 


\title{
HANDBOOK OF B IRDS
}

O F TH E

\section{Western United States}

\author{
INCLUDING
}

THE GREAT PLAINS, GREAT BASIN, PACIFIC SLOPE,

AND LOIVER RIO GRANDE VALLEY

BY

\section{FLORENCE MERRIAM BAILEY}

WITH THIRTY-THREE FULL-PAGE PLATES BY LOUIS AGASSIZ FUERTES, AND OIER SIX

HUNDRED CUTS IN THE TEXT

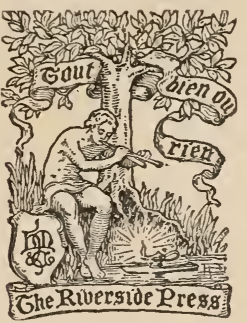

BOSTON AND NEW YORK HOUGHTON, MIFFLIN AND COMPANY

Che litureside presig, Cambrioge 



\section{CONTENTS}

List of Illustrations

PAGE

INTRODLCTION

Acknowledgments

Collecting and preparing Birds, Nests, and Eggs. By Vernon Bailey .

Collecting Birds

Measuring

Naking Bird Skins

Skinning

Stuffing .

Labeling

Sexing

Collecting and preserving Eggs and Nests

Note-Taking, Note-Books, and Jouruals . . . . . . xxxiii

Life Zones .

Migration .

Economic Ornithology

Bird Protection. By Theodore S. Palmer . . . . xxxix

Local Bird Lists

Portland, Oregon. By A. W. Anthony . . . . . xliii

San Francisco Bay. By William H. Kobbé . . . . . xlviii

Santa Clara Valley and Santa Cruz Mountains. By Walter

K. Fisher . . . . . . . . . . li

Pasadena, California. By Joseph Grinnell . . . . . lvi

Fort Sherman, Idalıo. By J. C. Merrill . . . . Ixiv

Cheyenne, Wyoming. By Frank Bond . . . . lxix

Pinal, Pima, and Gila Counties, Arizona. By W. E. D. Seott lixiv

Books of Reference . . . . . . . . . lxxxiii

Use of Handbook Kers . . . . . . . . . . . . . lxxxriii

BIRDS OF THE UNITED STATES WEST OF THE ONE HUNDREDTH MERIDIAN.

Key to Orders

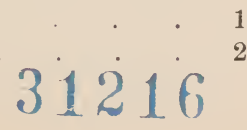


Order Prgopodes: Diving Birds . . . . . . 5

Family Podicipidæ: Grebes . . . . . . . 5

Family Gaviidæ: Loons . . . . . . . . . 9

Family Alcidæ: Auks, Murres, and Puffins . . . . 11

Order Longipennes : Long-WINGED SWIMmers . . . . 17

Family Stercorariidæ: Jaegers, ete. . . . . . . 17

Family Laridæ: Gulls and Terus . . . . . . 19

Order Tubinares: Tube-nosed Swimmers . . . . . . 32

Family Diomedeidæ: Albatrosses . . . . . . 32

Family Procellariidæ: Fulmars and Shearwaters . . . 33

Order Steganopodes : Totipalmate Swimimer . . . . 39

Fanily Anhingidæ: Darters . . . . . . . . 39

Family Phalacrocoracidae: Cormorants . . . . . . 39

Family Pelecanidæ: Pelicaus . . . . . . . 42

Family Fregatidæ: Man-o'-War Birds . . . . . 43

Order Anseres: Lamellirostral Swimmers . . . . 44

Family Anatidæ: Ducks, Geese, and Sivans . . . . . 44

Order Herodiones: Herons, Storks, Ibises, etc. . . . 70

Fanily Ibididæ: Ibises . . . . . . 70

Family Ciconiidæ: Storks and Wood Ibises . . . $\quad 72$

Family Ardeidæ: Herous, Egrets, Bitterns . . . . $\quad$. 72

Order Paludicole: Cranes, Rails, etc. . . . . . $7 \mathrm{~S}$

Family Gruidæ: Cranes . . . . . . . . 78

Family Rallidæ: Rails, Gallinules, and Coots . . . $\quad 79$

Order Limicole: Shore Birds . . . . . . . S4

Fanily Phalaropodidie: Phalaropes . . . . . . 84

Family Recurvirostridæ: Avocets and Stilts . . . . . 86

Family Scolopacidæ: Snipe, Sandpipers, etc. . . . . 87

Family Charadriidæ: Plovers . . . . . . . 102

Family Aphrizidæ: Surf Birds and Turnstones . . . . . 106

Family Hæmatopodidæ: Oyster-catchers . . . . . 107

Fanily Jacanidæ: Jacanas . . . . . . . 108

Key to Families of Land Birds. . . . . . . 108

Order Galline: Gallinaceous Birds . . . . . . 119

Family Tetraonidæ: Gronse, Partridges, Quail, ete. . . . 113

Fanily Phasianidæ: Pheasants and Turkeys . . . . . . 134

Family Cracidæ: Currassows and Guans . . . . . 137

Order Columbe: Pigeons . . . . . . . . . 138

Family Columbidz: Pigeons . . . . . . . 138

Order Raptores: Birds of Prey . . . . . . . 144

Family Cathartidæ: Vultures . . . . . . . . 144

Fanily Falconidæ: Falcons, Hawks, Eagles, etc. . . . 146

Family Strigidze: Barn Owls . . . . . . . 173

Family Bubonidæe: Horned Owls, ete. . . . . . 175

Order Psittaci : Parrots, Macaws, Paroquets, etc. . . 192

Family Psittacidæ: Parrots and Paroquets . . . . . . 192 
Order Coccyges: Cuckoos, etc.

Family Cuculidæ: Anis, Road-runners, and Cuckoos . . . 193

Family Trogonidæ: Trogons . . . . . . . 197

Family Alcedinidæ: Kingfishers . . . . . . . 198

Order Pici: Woodpeckers, etc. . . . . . . . 200

Family Picidæ: Woodpeckers . . . . . . . 200

Order Macrochires : Goatsuckers, Swifts, and Humingbirds 222

Family Caprimulgidæ: Goatsuckers . . . . . . 222

Family Micropodidæ: Swifts . . . . . . . 229

Family Trochilidæ: Hummingbirds . . . . . . $2: 32$

Order Passeres: Perching Birds . . . . . . 245

Family Cotingidæ: Cotingas . . . . . . . 245

Family Tyrannidæ: Tyrant Flycatchers . . . . . 245

Family Alaudidæ: Larks . . . . . . . . 265

Family Corvidæ: Crows, Jays, Magpies, ete. . • . 269

Family Sturnidæe : Starlings . . . . . . . 28.5

Family Icteridæ: Blackbirds, Orioles, etc. . . . . . 285

Family Fringillidæ: Finches, Sparrows, etc. . . . . 303

Family Tanagridæ: Tanagers . . . . . . . . . . $\quad$. 379

Family Hirundinidæ: Swallows . . . . . . . . 382

Family Ampelidæ: Waxwings and Phainopeplas . . . . 387

Family Laniidæ: Shrikes . . . . . . . . 391

Family Vireonidæ: Vireos . . . . . . . . . . . 394

Family Mniotiltidæ: Wood Warblers . . . . . . . 401

Family Motacillidæ: Wagtails . . . . . . . 431

Family Cinclidæ: Dippers . . . . . . . . 432

Family Troglodytidæ: Wrens, Thrashers, ete. . . . . 433

Family Certhiidæ: Creepers . . . . . . . 451

Family Paridæ: Nuthatches and Tits . . . . . . 452

Family Sylviidæe: Kinglets, Gnatcatchers, ete. . . . . . 463

Family Turdidæ: Thrushes, Solitaires, Bluebirds, ete. $\quad .467$

\section{Appendix.}

Color Key to Genera of some of the Common Passerine Birds 479 INDEX . 



\title{
LIST OF ILLUSTRATIONS
}

\author{
FULL-PAGE PLATES.
}

I. RiNg-Billed GLll .

FACING PAGE

II. ZoNe MaP .

Frontispiece.

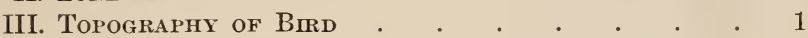

IV. EARED Grebe . . . . . . . . . . 7

V. Forster Tern . . . . . . . . . . . $\quad$. 29

VI. Pelagic Cormorant $\quad . \quad$. $\quad . \quad$. $\quad . \quad$. $\quad .42$

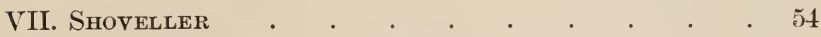

VIII. Black-Crowned Night Heron . . . . . 77

IX. Wilson Phalarope . . . . . . . . 85

X. BLACK-NECKED StILT . . . . . . . . 86

XI. Long-Billed CURlew . . . . . . . 101

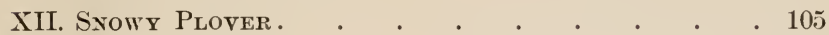

XIII. Scaled Partridge . . . . . . . . . 118

XIV. Mearns Quall. . . . . . . . . 122

XV. White-tailed Ptarmigan $\quad$. . . . . . . 129

XVI. Marsh Hawk . $\quad$ : $\quad . \quad$. . . . . . 150

XVII. Audubon Caracara . . . . . . . . . 171

XVIII. POOR-WILL $\quad . \quad$. . . . . . . . . 224

XIX. Scissor-talled Flycatcher . . . . . . . 246

XX. Arkansas and Cassin Kingbirds. . . . . 249

XXI. Ash-throated Flycatcher . . . . . . 253

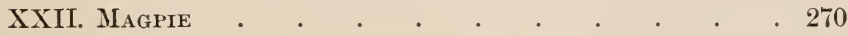

XXIII. LONG-CRESTED JAY . . . . . . . . 273

XXIV. Woodhouse JAY . . . . . . . . 274

XXV. Northern Raven . . . . . . . . . . 280

XXVI. Yellow-HEAdED BlaCKBIRD . . . . . . 288

XXVII. Western Lark Sparrow . . . . . . . 336

XXVIII. Texas Pyrrholoxia $\quad$. . . . . . . 371

XXIX. LARK Bunting . . . . . . . . . 377

XXX. Pileolated Warbler . . . . . . . . 428

XXXI. Rock WREN . . . . . . . . . . 443

XXXII. Canyon Wren . . . . . . . . 445

XXXiII. Long-Billed Marsh Wren . . . . . . 450 
XXXIV. Pygmy Nuthatch

DIAGRAMS.

Measurement of Bill .

xxviii

Measurement of Tarsus

xxviii

\section{FIGURES IN THE TEXT.}

FIGURE

1. Western Grebe, foot

PAGE

2. Loou, foot .

3. Tufted Puffin, foot

4. Herring Gull, foot

5. Parasitic Jaeger, bill

6. Short-billed Gull, bill .

7. Black-footed Albatross, bill

8. Giant Fulmar, bill

9. Cormorant, foot .

10. Man-o'-War Bird, bill .

11. White-crested Cormorant, bill

12. White Pelican, bill

13. Merganser, foot .

14. White-faced Glossy Ibis, bill

15. Green Heron, head

16. Sandhill Crane, foot .

17. Florida Gallinule, foot

18. White-rumped Sandpiper, foot

19. Killdeer, foot

20. Western Grebe, head .

21. Horned Grebe, head

22. Least Grebe

23. Pied-billed Grebe

24. Loon, bill

\section{THE TEXT.}

2

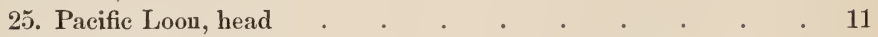

26. Tufted Puffin, bill . . . . . . . . . . . 11

27. California Murre, bill . . . . . . . . . . 11

28. Rhinoceros Auklet, bill . . . . . . . . . . 12

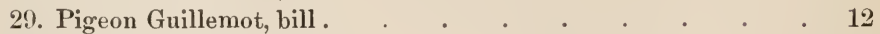

30. Paroquet Auklet, bill . . . . . . . . . . $\quad$. 12

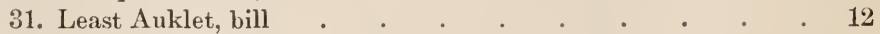

32. Tufted Puffin, lead . . . . . . . . . $\quad$. 12

33. Rlinoceros Auklet, bill . . . . . . . 13

34. Paroquet Auklet, bill . . . . . . . . . 14

35. Least Auklet, bill 
36. Marbled Murrelet

37. Pigeon Guillemot, head

38. California Murre

39. Long-tailed Jaeger, head

40. Herring Gull, bill

41. Forster Tern, bill

42. Heermann Gull .

43. Franklin Gull, head

44. Franklin Gull, wing tip . . . . . . . . 26

45. Bonaparte Gull, wing tip . . . . . . . . . 26

46. Sabine Gull, bill . . . . . . . . . . . 27

47. Sabine Gull . . . . . . . . . . . 27

48. Caspian Tern, head . . . . . . . . . 28

49. Least Tern . . . . . . . . . . . 30

j0. Black Tern . . . . . . . . . . . . . . 31

51. Sooty Albatross, bill . . . . . . . . . 32

52. Black-footed Albatross, bill . . . . . . . 32

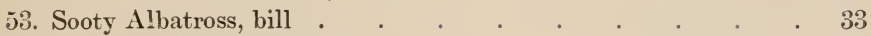

54. Forked-tailed Petrel, bill . . . . . . . . 33

55. Slender-billed Fulmar, bill . . . . . . . . . . . 33

56. Giant Fulmar, bill . . . . . . . . . 34

57. Slender-billed Fulmar, bill . . . . . . . . . . 34

58. Kaeding Petrel . . . . . . . . . . 37

59. White Pelican, bill . . . . . . . . . 42

60. Man-o'-War Bird, bill . . . . . . . . . . 43

61. Merganser, bill . . . . . . . . . . . . 44

62. Mallard, bill.$\quad$. $\quad . \quad$. $\quad . \quad$. . . . . 44

63. Red-breasted Merganser, head . . . . . . . 46

64. Hooded Merganser, head . . . . . . . . 47

65. Mallard, head . . . . . . . . . . 48

66. Baldpate, head . . . . . . . . . . 50

67. Green-winged Teal, head . . . . . . . . 51

68. Blue-winged Teal, head . . . . . . . . 52

69. Cinnamon Teal, head . . . . . . . . . . . 53

70. Pintail, head . . . . . . . . . . 54

71. Wood Duck, head . . . . . . . . . 55

72. Redhead, head . . . . . . . . . . . . . . 56

73. Canvas-back, head . . . . . . . . . 57

74. Seaup Duck, head · . . . . . . . . 58

75. Golden-eye, head . . . . . . . . . . . . . . 59

76. Buffle-head, head . . . . . . . . . 60

77. Old-squaw, head . . . . . . . . . . . 61

78. Harlequin Duck, head _ . . . . . . . 62

79. White-winged Scoter, head . . . . . . . . 63

S0. Ruddy Duck, head . . . . . . . . . 64 
81. White-fronted Goose, head . . . . . . . . 66

82. Canada Goose, head . . . . . . . . . 67

83. White-faced Glossy Ibis, head . . . . . . . 71

S4. Bittern, head . . . . . . . . . 73

85. Bittern, foot . . . . . . . . . . . . 73

S6. Green Heron, head . . . . . . . . . 76

87. Sandhill Crane, foot . . . . . . . . . . . 79

8S. California Clapper Rail . . . . . . . . . 80

\$9. Virginia Rail, head . . . . . . . . . 80

90. Virginia Rail, foot . . . . . . . . . . 80

91. Carolina Rail, head . . . . . . . . . 81

92. Yellow Rail . . . . . . . . . . 82

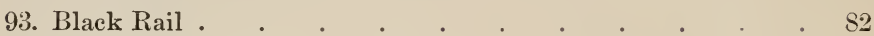

94. Florida Gallinule . . . . . . . . . 82

95. Florida Gallinule, foot . . . . . . . . . 83

96. Coot . . . . . . . . . 83

97. Coot, foot . . . . . . . . . . . . . 83

98. Red Phalarope, foot . . . . . . . . . . 84

99. Red Phalarope . . . . . . . . . . 84

100. Northern Phalarope . . . . . . . . . . . 85

101. Arocet, head . . . . . . . . . . . 86

102. Wilson Snipe, head . . . . . . . . . Ss

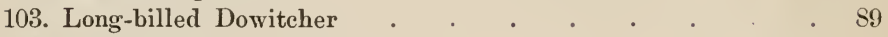

104. Stilt Sandpiper . . . . . . . . . . . 90

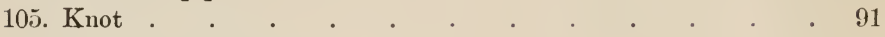

106. Pectoral Sandpiper . . . . . . . . . . . 91

107. White-rumped Sandpiper . . . . . . . . . . 92

10S. Baird Sandpiper . . . . . . . . . . 92

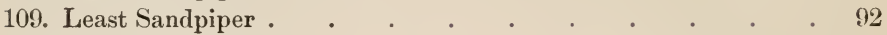

110. Red-backed Sandpiper . . . . . . . . . . 93

111. Semipalmated Sandpiper . . . . . . . . . . 93

112. Western Sandpiper . . . . . . . . . . . . 94

113. Sanderling . . . . . . . . . . . . . . 94

114. Sanderling, foot . . . . . . . . . . . . . 94

115. Marbled Godwit . . . . . . . . . . . . 95

116. Greater Yellow-legs . . . . . . . . . . . . 96

117. Lesser Yellow-legs . . . . . . . . . . . 97

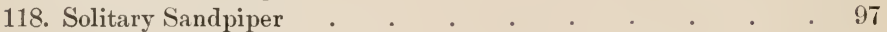

119. Black-bellied Plover, head . . . . . . . . $\quad$. 102

120. Killdeer, head . . . . . . . . . 104

121. Semipalmated Plover, head . . . . . . . 104

122. Mountain Plover. . . . . . . . . 105

123. Surf Bird . . . . . . . . . . . . 106

124. Black Turnstone, summer plumage . . . . . . . 107

125. Black Turnstone, head, winter plumage . . . . . . 107 
126. Black Oyster-catcher

127. Black Oyster-catcher, foot .

128. Bob-white, bill

129. Dove, bill

130. Turkey Vulture, bill

131. Turkey Vulture, foot .

132. Sparrow Hawk, bill

133. Fish Hawk, foot .

134. Owl, bill

135. Saw-whet Owl, head

136. Western Horned Owl, head

137. Kingfisher, head .

138. Kingfisher foot .

139. Cuckoo, foot

140. Cuckoo, bill .

141. Woodpecker (Sphyrapicus), bill

142. Woodpecker (Sphrrapicus), tail .

143. Toodpecker (Dryobates), foot

144. Woodpecker (Picoides), foot

145. Hummingbird, bill

146. Swift. bill

147. Nighthawk, foot .

14S. Swift, foot .

149. Song Sparrow, foot

150. Skylark, bill

151. Horned Lark, foot

152. Flycatcher. bill .

15.). Swallow, wing

154. Sprague Pipit, foot

155. Pipit, foot

156. Warbler (Dendroica), bill

157. Black and White Warbler, foot .

15S. Song Sparrow, bill

159. Goldfinch, bill .

160. Crossbill, bill

162. Evering Grosbeak. bill

163. Scarlet Tanager, bill

164. Summer Tanager, bill.

165. Oriole, bill 
171. Jay, bill

172. Wren-Tit, bill

173. Robin, wing feathers

174. Kinglet, foot

175. Warbling Vireo, foot

176. Warbling Vireo, bill

177. Vireo, tail .

178. Gnateatcher, tail .

179. Sage Thrasher, foot

180. Brown Creeper, bill

181. Brown Creeper, tail

182. Chickadee, bill

183. Nuthatch, bill

184. Sage Grouse, tail

185. Sharp-tailed Grouse, tail

186. Ptarmigan, foot .

187. Dusky Grouse, foot

188. Ruffed Grouse, foot

189. Mearns Quail, foot

190. Bob-white, foot .

191. Bob-white

192. Texan Bob-white

193. Masked Bob-white

194. Plumed Partridge

195. Valley Partridge, female

196. Valley Partridge, male

203. Southern White-tailed Ptarmigan 
216. Swallow-tailed Kite, tail

217. White-tailed Kite, foot

218. Audubon Caracara, bill

219. Mexican Goshawk, feather.

220. Swallow-tailed Kite

221. Mississippi Kite .

222. Sharp-shinned Hawk

223. Cooper Hawk

224. Goshawk

225. Sennett White-tailed Hawk, primaries

226. Red-bellied Hawk, primary

227. Zone-tailed Hawk, tail

22S. Red-tailed Hawk

229. Zone-tailed Hawk, tail

230. Swainson Hawk .

231. Rough-legged Hawk .

2:32. Ferruginous Rough-leg

233. Golden Eagle

234. Bald Eagle .

235. Duck Hawk

236. Pigeon Hawk 
261. Texas Kingfisher

262. Woodpecker (Dryobates), foot

26:3. Woodpecker (Sphyrapicus), bill .

264. Woodpecker (Dryobates), bill

26.5. Woodpecker (Picoides), foot

266. Northern Pileated Woodpecker .

267. Flicker

268. Northern Hairy Woodpecker

275. Alpine Three-toed Woodpecker .

276. Yellow-bellied Sapsucker .

287. Northern Flicker .

288. Whip-poor-will, head .

289. California Poor-will

290. Nighthawk, foot .

291. Nighthawk, head

292. Nighthawk, wing

293. Texas Nighthawk, wing 
306. Ruby-throated Hummingbird

235

307. Black-chinned Humminģbird, tail

235

308. Anna Hummingbird, female, tail

236

309. Anna Hummingbird, male, tail .

236

310. Costa Hummingbird

297

311. Anna Hunmingbird

$2: 37$

312. Broad-tailed Hummingbird, outer primaries

238

313. Broad-tailed Hummingbird, male, tail

238

314. Broad-tailed Hummingbird, female, tail

239

315. Rufous Humming bird, male, tail

316. Rufous Hummingbird .

240

317. Allen Hummingbird, male, tail .

318. Allen Hummingbird, female, tail

241

319. Calliope Hummingbird, tail

241

320. Calliope Hummingbird

242

242

321. Lucifer Hummingbird

244

322. Broad-billed Hummingbird

245

323. Xantus Becard .

248

324. Kingbird

248

325. Arkansas Kingbird, wing tip

249

326. Cassin Kingbird, wing tip .

327. Flycatchers

$\left\{\begin{array}{l}\text { Crested Flycatcher } \\ \text { Wood Pewee } \\ \text { Phœbe } \\ \text { Kingbird } \\ \text { Least Flycatcher }\end{array}\right\}$

328. Flycatcher (Myiarchus), foot

329. Phøbe .

330. Western Black Phœbe, head

331. Flyeatcher (Contopus), foot

332. Olive-sided Flycatcher

333. Coues Flycatcher

334. Western Wood Pewee .

335. Flycatcher (Empidonax), foot

336. Western Flycatcher, bill

337. Hammond Flyeateher, bill .

338. Wright Flycatcher, bill

339. Western Flycatcher, bill

340. Hammond Flycatcher .

341. Hammond Flyeatcher, bill .

342. Wright Flycatcher, bill 
347. Oregon Jay, head

348. Crow, bill

349. Clarke Nutcracker

350. Bobolink, tail

285

35.1. Bobolink, head

285

35\%. Cowbird, bill

285

353. Meadowlark, head

285

354. Bronzed Grackle, bill

285

355. Oriole, bill .

285

35̃6. Yellow-headed Blackbird, foct

285

357. Red-wing, head .

286

3ิ5̄\&. Bobolink

286

359. Cowbird

287

360. Red-winged Blackbird

361. Meadowlark

292

362. Scott Oriole .

294

363. Arizona Hooded Oriole

296

364. Baltimore Oriole .

297

365. Bullock Oriole, head

298

366. Brewer Blackbird

300

367. Bronzed Grackle .

301

368. Redpoll, wing

303

369. Crossbill, bill

303

370. Western Evening Grosbeak, bill .

303

371. Redpoll, head

304

372. Snowflake, head .

304

373. MeCown Longspur, tail

304

374. Pine Finch, head .

304

375. Black-headed Grosbeak, head

304

376. Western Lark Sparrow

304

377. Longspur, foot

304

378. Vesper Sparrow, tail

304

:39. Dickeissel, head .

305

380. English Sparrow, male

305

381. Pine Grosbeak, head

305

382. Pyrrhuloxia .

383. Cardinal, head

305

384. Aretic Towhee

305

385. Slate-colored Junco, head

305

386. Sparrow (Aimophila), wing

306

387. White-crowned Sparrow

306

38s. Green-tailed Towhee, head .

306

389. Fox Sparrow, head

306

390. California Towhee

391. Bunting (Cyanospiza), bill 
394. Pine Grosbeak

308

395. Califoruia Purple Finch, tail

397. Cassin Purple Finch, head . . . . . . . . 312

398. Honse Finch, male . . . . . . . . 312

399. House Finch, female . . . . . . . . . 312

400. Crossbill, bill

401. White-winged Crossbill

313

315

402. Gray-crowned Leucosticte, head .

315

403. Hoary Redpoll

318

404. Redpoll, head . . . . . . . . . . . 319

405. Goldfinch . . 321

406. Arkansas Goldfinch . . . . . . . . . 322

407. Mexican Goldfinch . . . . . . . . 323

408. Lawrence Goldfinch . . . . . . . . . 32:3

409. Pine Finch . . . . . . . . . . . 323

410. English Sparrow, male . . . . . . . . 324

411. English Sparrow, female . . . . . . . . 324

412. Snowflake . . . . . . . . . . . 325

413. Lapland Longspur, summer male . • . • . 326

414. Lapland Longspur, winter male . . . . . . . 326

415. Smith Longspur, summer male . . . . . . . . 327

416. Chestnut-collared Longspur, summer male . . . . . . 328

417. Chestnut-collared Longspur, winter male . . . . . . 328

418. MeCown Longspur . . . . . . . . . 328

419. Western Vesper Sparrow, tail . . . . . . . 329

420. Sandwich Sparrow . . . . . . . . . 331

421. Large-billed Sparrow . . . . . . . . . 333

422. Baird Sparrow . . . . . . . . . . . 333

423. Western Grasshopper Sparrow . . . . . . . . 3:34

424. Sharp-tailed Sparrow, tail . . . . . . . . 335

425. Harris Sparrow . . . . . . . . . . . 337

426. White-crowned Sparrow . . . . . . . . . 338

427. Gambel Sparrow, head . . . . . . . . . . 339

428. Golden-crowned Sparrow . . . . . . . . 340

429. White-throated Sparrow, head . . . . . . . 340

430. Western Tree Sparrow . . . . . . . . 341

431. Western Chipping Sparrow, head . . . . . . 342

432. Brewer Sparrow, head . . . . . . . . 343

433. Worthen Sparrow, head . . . . . . . . 344

434. Black-chinned Sparrow . . . . . . . . 345

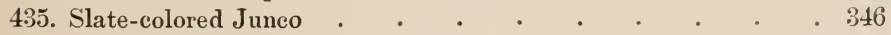

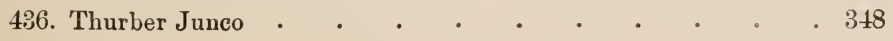


437. Red-backed Junco

43S. Black-throated Sparrow, head

439. Sage Sparrow, head

410. Cassin Sparrow

353

441. Rufous-winged Sparrow, head

442. Rufous-crowned Sparrow, head .

443. Song Sparrow, head .

444. Desert Song Sparrow .

445. Mountain Song Sparrow

446. Samuels Song Sparrow

35ร

447. Rusty Song Sparrow

355

448. Lincoln Sparrow .

359

449. Fox Sparrow

361

361

450. Townsend Sparrow

362

451. Thick-billed Sparrow, bill

363

45.3. Stephens Sparrow, bill

363

454. California Towhee

363

455. Towhee, head

363

456. Towhee, head

364

364

457. Aretic Towhee

365

45S. Spurred Towhee

365

460. California Towhee, head

367

461. Green-tailed Towhee, head .

368

462. Cardinal, head

369

463. Rose-breasted Grosbeak

372

372

464. Black-headed Grosbeak, head

374

465. Bunting (Cyanospiza), bill

377

466. Dickcissel, head

379

467. Scallet Tanager, head.

379

469. Searlet Tanager, bill .

380

382

382

471. Barn Swallow, tail

472. Rough-winged Swallow, feather .

382

473. Cliff Swallow, head

384

474. Barn Swallow, foot

385

475. Barn Swallow

385

476. White-bellied Swallow

477. Bank Swallow

386

386

478. Rough-winged Swallow, feathęr .

387

479. Rough-winged Swallow, head

387

450. Cedar Waxwing . 
482. Shrike, bill

483. Northerr Shrike .

392

484. White-rumped Shrike .

392

455. Black-capped Vireo, head

394

486. Cassin Vireo, head

394

4S7. Red-eyed Vireo, head .

394

4S8. Warbling Vireo, head .

394

459. Red-eyed Vireo, head .

395

490. Warbling Vireo, head .

395

491. Cassin Vireo, head

396

492. Black-capped Vireo, head

397

493. Redstart, bill

401

494. Red-faced Warbler, bill

401

495. Black and White Warbler, head .

401

496. Black and White Warbler, foot .

401

497. Warbler (Helminthophila), foot .

401

498. Chat, head

401

499. Northern Parula Warbler, head .

401

500. Warbler (Dendroica), bill

401

501. Black and White Warbler, head

402

502. Calaveras Warbler, head

402

503. Calaveras Warbler, head

404

504. Northern Parula Warbler, head .

406

505. Warbler (Dendroica), foot .

407

506. Blackburnian Warbler, head

407

507. Yellow Warbler, head

407

508. Magnolia Warbler, head

408

509. Olive Warbler

408

510. Black-throated Blue Warbler, head

408

511. Black-throated Gray Warbler, head

408

512. Hermit Warbler, head

$40 \mathrm{~s}$

513. Black-throated Green Warbler, head

408

514. Golden-cheeked Warbler, head

408

515. Townsend Warbler, head

408

516. Black-poll Warbler, head .

409

517. Yellow-rumped Warbler, head

409

51S. Chestnut-sided Warbler, head

409

519. Olive Warbler

410

520. Yellow Warbler, head

411

521. Black-throated Blne Warbler. head

412

522. Yellow-rumped Warbler, head .

412

52:3. Audubon Warbler

413

524. Magnolia Warbler, head

415

525. Chestnut-sided Warbler. head

416

526. Black-poll Warbler, head . 
527. Blackburnian Warbler, head

528. Black-throated Gray Warbler, head

529. Golden-cheeked Warbler, head

530. Black-throated Green Warbler, head .

531. Townsend Warbler, head

532. Hernit Warbler, head

533:. Oven-bird. head .

534. Grimnel! Water-Thrush

535̃. Macgillivray Warbler, head

536. Western Yellow-throat, head

537. Long-tailed Chat

538. Wilson Warbler, head .

428

539. Canadian Warbler, head

540. Redstart, head

541. Pipit

542. Pipit, foot .

543. Sprague Pipit, foot

544. Water Ouzel

545. Sage Thrasher

546. Brown Thrasher, head

547. California Thrasher, bill

548. Mockingbird, head

549. Catbird, head

550. Cactus IVren

551. Canyon Wren

552. Rock Wrer.

553. Western Winter Wren

554. House Wren, head

555. Long-billed Marsh Wren, head

556. Carolina Wren, head

560. Brown Thrasher .

561. Semnett Thrasher

562. Curve-billed Thrasher .

563. Palmer Thrasher.

564. Bendire Thrasher

56.). Californian Thrasher 
572. Vigors Wren

573. Parkman Wren

574. Western Winter Wren

575. Brown Creeper, bill

576. Brown Creeper, tail

577. Californian Creeper

578. Slender-billed Nuthatch, feather

579. White-breasted Nuchatch, feather

580. White-breasted Nuthatch, head .

581. Red-breasted Nuthatch, head

582. Plain Titmouse

583. Bridled Titmouse, head . . . . . . . . . . . 457

584. Chickadee, head .

585. Wren-Tit

586. Bush-Tit

587. Lloyd Bush-Tit . . . . . . . . . 462

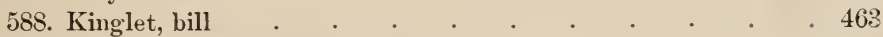

589. Golden-crowned Kinglet, head . . . . . . . 463

590. Ruby-crowned Kinglet, head . . . . . . 464

591. Gnatcatcher, tail . . . . . . . . . . 465

592. Blue-gray Gnatcatcher, head . . . . . . . 46 כ

593. Plumbeous Gnatcatcher, feather . . . . . . . 465

594. Black-tailed Gnatcatcher, feather . . . . . . 465

595. Blue-gray Gnatcatcher . . . . . . . . 465

596. Plumbeous Gnatcatcher . . . . • . . 466

597. Townsend Solitaire . . . . . . . 。 . 467

598. Wood Thrush . . . . . . . . . . . . 469

599. Robin, bill . . . . . . . . . . . 472

600. Robir . . . . . . . . . . . . . 472

601. Bluebird . . . . . . . . . . 475 



\section{INTRODUCTION.}

THE classification, nomenclature, and numeration used in this book are those of the A. O. U. Check-List of North American Birds, except that modern scientific usage has been followed in dropping the possessive form in the vernacular names of species, as Clarke putcracker and Steller jay, instead of Clarke's nutcracker and Steller's jay. The rulings of the nomenclature committee of the American Ornithologists' Union have been followed, but new species upon which the committee has not yet ruled have been included in footnotes under their proper places.

In the matter of authorities, Ridgway's Manual of North American Birds, his Hummingbird paper, and Birds of North and Middle America (Parts I. and II.) have been used at all points as standard authorities, and the substance of keys and descriptions frequently quoted.

In the general treatment of species various authorities have been followed.

General Characters. - These summaries of technical characters have been abridged from the generic descriptions in Parts I. and II. of Ridgway's Birds of North and Niddle America, his monograph on the Hummingbirds, and Coues's Key to North American Birds.

Measurements. - The measurements have been taken from the second edition of Ridgway's Manual of North American Birds, from Parts I. and II. of North and Viddle America, with the centimeters converted into inches, and, in the case of species not included in these books, from the original descriptions.

Nest and Eggs. - Descriptions of nests and eggs are taken mainly from Bendire's Life Histories of North American Birds, Ridgway's Manual, second edition, The Auk, The Condor, The Osprey, The Nidologist, The Ornithologist and Oülogist, Goss's Birds of Kansas, The Biological Survey Records, and from specimens in the Bendire and Ralph collections of the United States National IIuseum. 
Food. - Food notes have been made up mainly from Bendire's Life Histories, Fisher's Hawks and Ools of the United States, Goss's Birds of Kansas, and the records of the Biological Survey.

Distribution. - The distributions have been compiled from the manuscript maps and reports of the Biological Survey, and the North American Fauna, (3) San Francisco Mountain, Arizona; (7) Death Valley, and (16) Mount Shasta, California; (22) Hudson Bay; (5) Idaho; (21) The Queen Charlotte Islands, British Columbia; and (14) The Tres Marias Islands, Mexico; The A. O. U. Check-List of North American Birds; Belding's Land Birds of California; Bendire's Life Histories of North American Birds; Bruner's Birds of Nebraska; Bryant's Birds and Eggs of the Farallon Islands; Cooke's Bird Mi. gration in the Mississippi Valley, and Birds of Colorado; Fannin's Check-List of British Columbia Birds; Goss's Birds of Kansas; Grinnell's Birds of the Pacific Slope of Los Angeles County; Loomis's California Water Birds; Macoun's Catalogue of Canadian Birds; McGregor's Pacific Coast Avifauna; and Silloway's Summer Birds of Flathead Lake, Montana; together with local lists in The Auk, The Bulletin of the Cooper Ornithological Club, The Condor, and The Osprey.

Illustrations. - The new heads and full figures of birds are by Louis Agassiz Fuertes, the outlines by Miss Franceska Weiser, the old material from drawings of Louis Agassiz Fuertes, Ernest Thompson Seton, Robert Ridgway, John L. Ridgway, and Frank Bond, published previously by the Smithsonian Institution, the Biological Survey, The Auk, The Osprey, and Houghton, Mifflin \& Company in Birds of Village and Field and A-Birding on a Bronco.

\section{COLLEC'TING AND PREPARING BIRDS, NESTS,} AND EGGS.

\section{By Vernon Bailey.}

Collecting Birds. - Our present knowledge of birds and. their classification has come from a study of specimens, of the dead bird in the flesh, of crops and stomachs, stuffed skins, and skeletons; and without this foundation the study of birds would not have its deep interest and meaning nor its practical bearing on the economy of our lives. Even our enjoyment of the birds in life, their beauty, song, and friendship, would be far less than it is without the underlying knowlenge of their life history, the place they fill, and their importance to us. 
Naturalist collectors are far from being the ruthless destroyers of life they are often supposed to be. It is, indeed, those who collect the birds, study them most deeply, and know them best, who are doing the most for their protection. Most ornithologists have begun their study of birds by making private collections, and have turned the knowledge thus gained to the best good of the birds, while their collections have finally gone to museums, where they could benefit the greatest number of students.

In most museums, it is true, there are large collections of bird skins, often hundreds of specimens of a single species, showing every shade of variation due to age, sex, season, moult, and wear of plumage, and endless geographic variation over a wide range of country; but to many of those who have the best chance to study the birds in life these collections are inaccessible.

There are still unknown, rare, and little known species of birds that must be obtained before our knowledge of our own species can be approximately complete and our system of classification firmly established. But the more immediate and pressing question before the young ornithologist is how to identify the obscure species and the females and young of better known birds. In many cases the bird must be shot to be identified, and not infrequently it must be sent to some large museum collection for comparison for satisfactory determination. Collecting, therefore, has not only a legitimate but fundamental place in ornithology as a scientific study.

Measurements. - It should be borne in mind that measurements are not infallible, and even where the maximum and minimum of a series are given, still larger or smaller specimens may be found. In many cases measurements are useless in determining characters, but in others they are the all important differences between species and subspecies. The total length is the most variable measurement, and when taken from a skin instead of a bird in the flesh is only intended to give a general idea of the size of the bird. In quoting Mr. Ridgway's measurements throughout this book the word 'about' has been omitted from his lengths, as it applies to all length measurements. Lengths are taken from the birds in the flesh, if not specifically stated to be from skins. All measurements in the book are in inches. Wing, tail, bill, and tarsus measurements are the important ones in most species, especially so because they can be taken from the dry skin as well as from the fresh specimens. Measurements should be taken in the following manner:-

Length. - From tip of bill to tip of tail. To get this lay the 
bird on its back on a rulc or tape-measure, with neck and body straight.

Wing. - From the front of the bend of the wrist joint of the wing to the tip of the longest feather. This can be taken with either tape or dividers.

Tail. - From the extreme base of the tail to its tip. To get this exactly place one point of the dividers at the base of the tail between the two middle tail feathers, and the other point of the dividers at the tip of the tail.

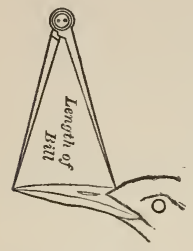

Bill. - From edge of feathers on top of bill to tip of bill. When it would be necessary to part the feathers to reach the base of the bill the expression ' exposed culmen' is used for the measurement.

Tarsus. - From heel joint to angle of toe with tarsus. If this is difficult

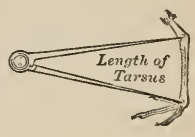
to determine, put the dividers on the outside and bend the toes.

Middle toe. - From angle of tarsus and toes to base of claw, the length of the claw not being taken unless specified.

Such measurements as length of toes, depth of bill at base, at nostril, etc., and relative lengths of certain feathers and spots and markings can usually be taken most accurately and conveniently with dividers.

Making bird skins. - For making bird skins a few simple tools and materials are needed, - two sizes of scalpels or slender-bladed knives for skinning, a pair of stout, sharp scissors, and a pair of forceps, some powdered arsenic and corn-meal, cotton (for large species tow), a round-pointed needle, thread, and labels.

The English sparrow is a good bird to begin with and practice on until skins can be made that are worth keeping, an end not attained without patient and painstaking effort.

Haring shot a bird, examine it for blooly or soiled spots, and sprinkle any that are found with corn-meal or fine sand, and plug the throat with cotton to keep any blood or liquids from coming out and soiling the feathers. If an eve is broken remore it with the forceps, and fill the orifice with cotton and corn-meal, to prevent the fluids from soiling the feathers of the head. To keep the bird from injury until you can skin it, make a paper cornucopia, and after smoothing the feathers drop the bird in bill first : then fold together the gaping edges of the cormucopia, and your bird will carry safely in your game-bag or hunting-coat pocket. 
Skinning. - Place the bird on its back with its bill to your left, and part the feathers along the breast and belly. In most species a strip of naked skin will appear. Folding the feathers back with the thumb and finger of the left hand, cut with a down stroke of the scalpel just through the skin from about the middle of the sternum back to the vent. Catch the edge of the skin at one side, and with the end of the scalpel handle or your fingers work it back from the body until the knee-joint of the leg appears, sprinkling in plenty of corn-meal as you go to absorb blood and juices and keep your fingers dry and the feathers from sticking. Cut the bone at the knee-joint with scissors or knife, and draw it up out of the fiesh, which can be cut off nearer the heel and left fast to the carcass. Loosen the skin farther back, then treat the other side in the same manner, frequently using corn-meal.

Then turn the bird's bill from ycu, and cut across below the tail to the bone, and either unjoint or snip the bone with the scissors just in front of the base of the quills, keeping the forefinger of the left hand at a point opposite on the outside as a guide to prevent cutting the skin, and work the skin up over the rump. At this point a small hook, suspended in front and hooked into the bird's rump, will help the beginner, but he will soon learn to hold up the body between the tips of the first two fingers of the left hand, using the thumb and third or little finger of the same hand to draw down the skin as he cuts with the scalpel in the right. Work the skin from the edges, being careful not to stretch it. As the wings are reached draw them back out of the skin to near the second joint, break the first bone in the middle and remove the flesh. Keep the body well sprinkled with meal, and work the skin carefully down over the neck to the head until the ears appear, picking them out rather than cutting them off; then working the skin along mainly with the finger nails over the eyes (cutting the transparent membrane without injury to the lids), and carrying it down to the base of the bill.

Next remove the eyes and cut off the base and lower part of the skull, which can be done so as to leave brains, tongue, and fleshy part of mouth attached to the neck, and the skull and bill clean and free attached to the skin. If any bits of flesh or fat have been left on the skin, remove them, and then dust dry arsenic over the inside of the skin, fill the eye sockets with pellets of cotton, and reverse the skin by pushing the bill carefully back through the neck. With the beginner the skin will become dry before it is ready to be turned back, and will need moistening, but after some practice the 
whole process of skinning should take only from two to four minutes.

As soon as the skin is turned back, the feathers should be smoothed and arranged, the eyelids adjusted, and the edges of the opening of the skin laid together before it is put down.

Stuffing. - For the sparrow, take a short thick piece of cotton tow for large birds - that will make a form the size of the body that has been removed from the skin, and press it firmly together with the fibers all one way. To fill the skull and make a firm neck, pinch one end of the cotton flat and double it over twice, holding it firmly after each time between the thumb and finger of the left hand. Then catch the hard compact point of cotton between the forceps in a position to hold it securely and push it into the bird skin, forcing the point up through the neck and base of the skull, catching it again with the left thumb and finger in the mouth of the bird. Loosen and draw out the forceps, but hold the cotton in the mouth until the skin is drawn back and adjusted over the stuffing, and superfluous bits of cotton removed or tucked in.

Then draw together the edges of the skin and catch with a couple of stitches. When the wings have been put in place under the feathers at the sides, and the feathers properly arranged and smoothed, the skin is ready to be labeled and wrapped in a thin film of cotton. Then the bill can be tied shut with a thread and the bird laid away to dry.

A beginner's skins are often greatly distorted, and only practice can teach the correct amount of cotton to use and its proper form and proportions. The best way is to keep in mind the size and form of the bird's body, and try to reproduce them. Be careful not to make bulging or weak necks. Leave each skin straight and symmetrical when put away to dry, and each feather back in its original place.

Labeling. - Skins should be fully labeled with locality, date, sex, number, and collector's name, while such additional data as color"of eyes, bill, feet, or any parts that fade, notes on breeding or locality where taken, stomach contents, etc., can be placed on the back of the label or kept in a catalogue under the number of each specimen.

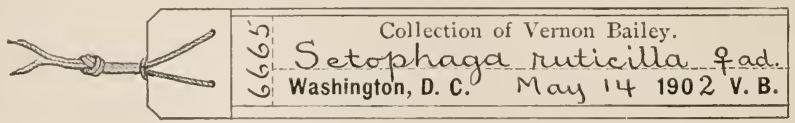

Sexing. - To determine the sex, cut through the side of the abdominal wall, push away the intestines, and close against the small 
of the back, if the bird is a male, you will see the two oval, usually light colored testes, - in the breeding season large and conspicuous, at other seasons small, and, in immature specimens, often difficult to find. If the bird is a female, in place of the two oral bodies there will be the ovary, a mass of spherical orules, large or small according to the season, and often obscure in immature specimens. The male sign is Mars' arrow ( $\hat{\delta})$, the female, Venus' mirror (q).

Collecting and preserving eggs. - Egg collecting is justifiable only when the collector's earnestness of purpose warrants the sacrifice of happy bird homes, and no amount of pains and eare should be spared to make each set a permanent and valuable illustration of the life history of the species. So far as possible only complete sets of fresh eggs should be taken. An incomplete set is of secondary importance, and eggs in which incubation is advanced are not worth troubling with unless very rare.

The first step is to identify the nest positively, which, in cases of rare species, can often be done only by collecting one or both of the birds. Eggs are worse than worthless if there is any question of their identity.

The next step should be to photograph the nest from at least two points, ove to show general setting and one at closer range to give detail of form and structure. Then notes should be made on the position, structure, and materials of the nest, the actions of the old birds, and the manner of identification, etc. When possible the nest should also be collected.

Each egg should be wrapped in cotton and each set packed snugly in a wooden box with plenty of cotton for carrying home.

The tools necessary for blowing eggs are a slender blowpipe and two drills, large and small, which can be bought of any dealer in naturalist's supplies.

For drilling, hold the egg lightly between the thumb and two fingers of the left hand, and placing the sharp point of the drill against the side twirl it evenly with a slight pressure until it sinks into the shell, grinding out a smooth round loole which points downward, from the size of a pin-head in a fresh sparrow's egg to an eighth of an inch in diameter in a larger or partly incubated egg. In much incubated eggs it is often necessary to make a much larger opening. A fine stream of air should be forced into the egg without touching the blowpipe to the opening, and the contents gently forced out. When the shell is empty, with mouth full of water blow a stream into it and rinse out thoroughly, afterwards blowing all the water out and laying carefully away to dry. 
Incubated eggs, though almost at the point of hatching, are made by experts into nearly perfect specimens. Following their methods, drill the hole and then coat the shell with flexible collodion. After removing a small part of the fluid, if the egg is small, insert a solution of pepsin or of chlorinated soda, - Labarraque's solution, - and let the egg stand for a few hours, after which blow out the softened portion of the contents. Add more of the solution, and let the eggs stand again, keeping on until you have emptied the shell. Large eggs may be treated with a solution of caustic potash, care being necessary not to allow the alkali to touch the shell. To prevent accident it is well to have a basin of water near in which to immerse the egg if necessary. The collodion is removed after the completion of the work by the use of ether.

Each set of eggs and each nest should be kept in a box, with a label something like the following, from the Bendire and Ralph collection in the National Museum :-

A. O. U. No.

Scientific name,

Private No.

Common name,

Collector,

Locality,

Date.

No. of Eggs in Set,

Identification.

Incubation,

Nest : Diameter,

Depth,

Composed of

Location.

Of whom and when received,

Nests should be kept in boxes to fit their size. Great care should be taken to protect them from moths and other destructive 
insects, as not only wool but hair and all other animal substances will be eaten and the nests ruined if they are not well looked after. The best protection for a nest is a spray of a solution of corrosive sublimate, which can be used in a common atomizer, - with a warning red label, bearing the word 'PoIson.'

\section{NOTE-TAKING, NOTE-BOOKS, AND JOURNALS.}

The value of collections is increased many fold by the field-notes which accompany the specimens, and the bird lover who does not collect may add most valuable material to our meagre knowledge of the life histories of our birds.

A compact, statistical journal may be made, as Mr. Chapman 1 and Mr. Felger ${ }^{2}$ suggest by means of a 'roll or time book,' or any sheets ruled in squares in pad form and punched along the sides to fasten into a cardboard cover. The squares should be used for daily records, the top or top and margin being used for headings, such as locality, zone, zonal plants and trees, slope exposure, temperature, condition of weather, direction and force of wind, amount of rainfall or snowfall, advance of vegetation, new insects abroad, indications of mating and of nest-building, number of nests found with eggs and with nestlings, number of young on the wing, condition of plumage, stage of moult, food, food habits, stomach contents of specimens taken, time spent in field, number of birds seen in flocks, number seen in migration flights.

For more detailed life history notes, card catalogues, with family, generic, and specific dirisions, are popular with many ornithologists. A convenient form of field journal is a pad punched at the sides to fit into a stiff cover, each sheet to be devoted to a species so that the sheets can be slipped out and arranged by species, alphabetically. On the return from the field these can be dropped into box manuscript trays and arranged by the check-list.

\section{LIFE ZONES.}

The physical geographies have long taught the division of the earth into life zones, from the arctic to the tropical regions, with the corresponding vertical divisions from the tropical base of equatorial mountains to their snow-clad arctic summits, and naturalists have long since worked out the distribution of animals and plants

1 Handbook of Birds of Eastem North America, pp. 20-22.

2 "Plan for Recording Field Notes," The A $u$, xix. 189-193. 
along these lines in Europe and eastern North America. But it is only within recent years that the Biological Survey carried on by the government has studied the old familiar generalizations in the western states in detail and mapped the life zones of the United States as a whole.

The generally accepted theory that the distribution of mammals, birds, reptiles, insects, and plants depends on temperature has been demonstrated by Dr. Merriam as a physical law that " the northward distribution of terrestrial animals and plants is governed by the sum of the positive temperatures for the entire season of growth and reproduction, and that the southward distribution is governed by the mean temperature of a brief period during the hottest part of the year." 1 With this as the working basis he has divided the United States into three parts, having the northern (Boreal), south ern (Austral), and intermediate (Transition) climates and flora and fauna. By subdivision seven zones are made, known as Alpine, Hudsonian, Canadian, Transition, Upper Sonoran, Lower Sonoran, and Tropical. East of the hundredth meridian, which, broadly speaking, is the dividing line between the eastern or humid and western or arid sections, the Austral zone is known as Austral rather than Sonoran, and divided into Alleghanian, Carolinian, and Austroriparian Faunas.

The Alpine Zone lies above the limit of trees, and is characterized by dwarf shrubs and plants, the polar bear, arctic fox, reindeer, the snow bunting, snowy owl, ptarmigan, pipit, and leucosticte.

The Hudsonian Zone is marked by dwarfed timber along "the northern or higher parts of the great transcontinental coniferous forest, . . . stretching from Labrador to Alaska. It is inhabited by the wolverine, woodland caribou, moose, great northern shrike, pine bullfinch, and white-winged crossbill." 2 On MIt. Shasta its only trees are the black alpine hemlock and white-barked pine, its characteristic mammal is the cony (Ochotono), and its characteristic bird the Clarke crow. It is also frequented by the sooty grouse, western goshawk, Williamson sapsucker, rufous hummingbird, Oregon jay, pine siskin, junco, Audubon and hermit warblers, creeper, redbreasted nuthatch, kinglets, and solitaire. ${ }^{3}$

1 Merriam's "Laws of Temperature Control of the Geographic Distribution of Terrestrial Animals and Plants," National Geographic Magazine, vi. 229-238.

2 Merrian, C. Hart, "Life Zones and Crop Zones of the United States," Bull. No. 10, Biological Survey; "Geographic Distribution of Animals and Plants in Nortlı America," Yearbook of the U. S. Department of Agriculture, 1894.

3 Merriam, C. Hart, North Americun Funna, No. 16, "Result of a Biological Survey 


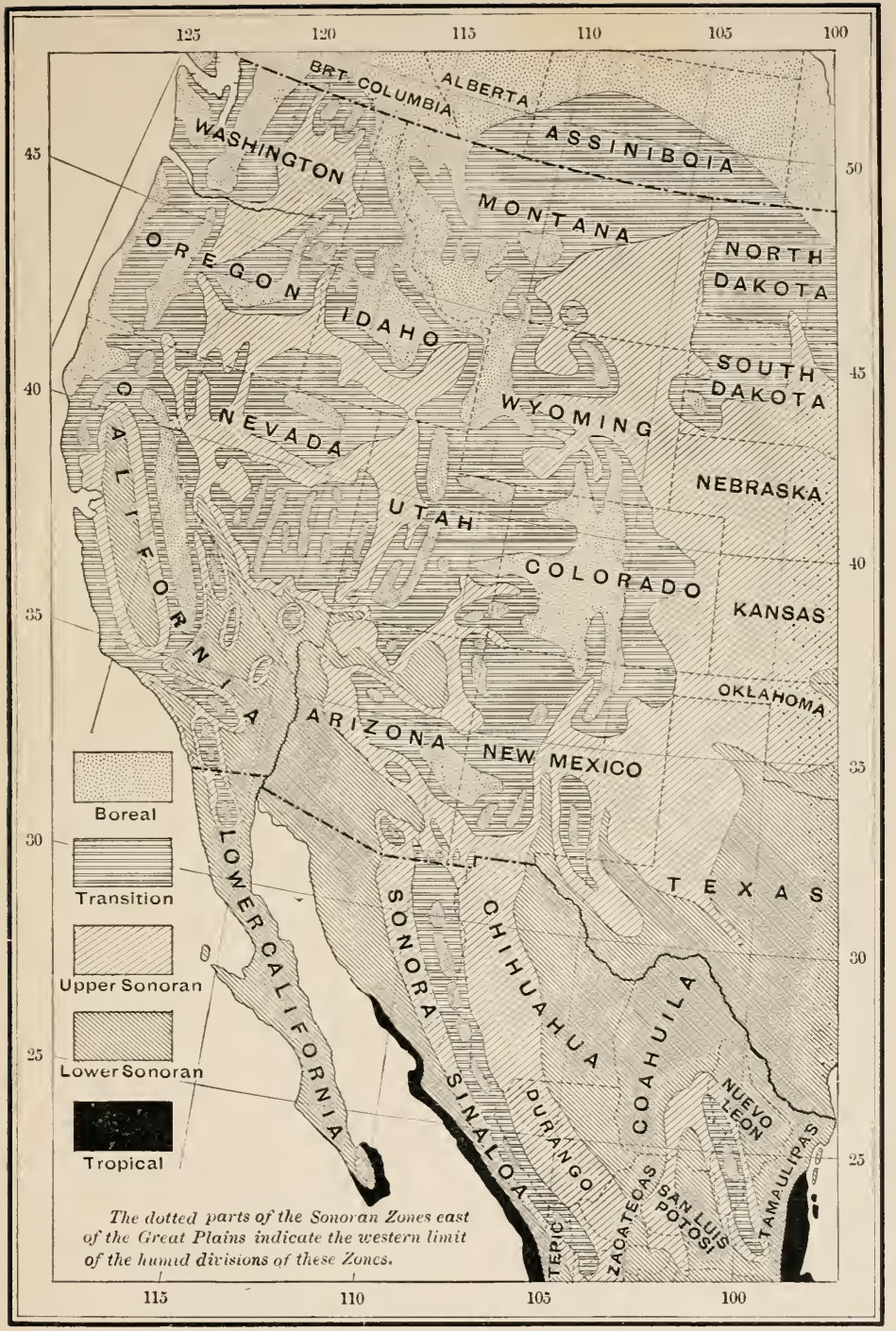

LIFE ZONES

BY C. HART MERRIAM 

The Canadian Zone comprises " the southern or lower part of the great transcontinental coniferous forest." It is the zone of firs, spruces, and white pines, which on Mt. Shasta are represented by the Shasta fir and the silver pine. One of its characteristic animals is the mountain beaver, and it has also the porcupine, pine squirrel, bear, wild cat, wolf, and other mammals. It is the home of the crossbill, Lincoln sparrow, and Arctic three-toed woodpecker, and frequented by birds found in the Hudsonian zone, such as the sooty grouse, rufous hummingbird, siskin, juncos, warblers, kinglets, and solitaire, together with a number found also in the next lower zone (the Transition), such as the white-headed, hairy, and pileated woodpeckers, nighthawk, olive-sided, Hammond, Wright, and western Hycatchers, Steller jay, Louisiana tanager, Macgillivray warbler, and robin.

The Transition Zone, in which northern and southern elements of flora and fauna often overlap, is characterized in the west by the yellow pine (Pinus ponderosi), several species of oaks and manzanita. together with buck brush and sage brush. Some of the characteristic mammals are the big gray pine squirrel, the gray fox, and various species of chipmunks, spermophiles, and pocket gophers. Among birds there are the western wood pewee, Gairdner woodpecker, Lewis woodpecker, California pygmy owl, green-tailed towhee, pygmy nuthatch, red-breasted sapsucker, and Brewer sparrow, mixed with many species from the Cpper Sonoran, the zone below, such as the California jay, valley quail, California wood pecker, and spurred towhee.

The Upper Sonoran Zone of the west is characterized by junipers, piñon, and various oaks, jack rabbits, cottontails, five-toed kangaroo rats, and several species of wood rats, the canyon wren, western lark sparrow, California chewink, and California bush-tit, while many Transition zone species also occur.

The Loxer Sonoran Zorie, coming next above the Tropical zone, is the zone of the hot valleys, where live-oaks, mesquites, and creosote bushes abound, and the characteristic mammals and birds are the four-toed kangaroo rat, cotton rat, and spotted skunk, the mockingbird, nonpareil, verdin, pyrrhuloxia, road-runner, caracara, white-necked raven, phainopepla, and scaled quail.

of MIt. Shasta ;" North American Fauna, No. 3, "Results of a Biological Survey of San Francisco Mountain Region and Desert of the Little Colorado ;" "The Geographic Distribution of Life in North America, with Special Reference to the Mammalia," Proc. Biol. Soc. Wash. vii. April, 1892, 1-64. 
Birds are naturally less restricted to zones than mammals and plants, and in the field the question of correlating them to zones is rendered difficult by the modifying conditions which complicate the zones themselves. Local conditions are constantly being met which produce a cliange of temperature within a zone, resulting in the intrusion of a tongue of a higher or lower zone. Forest fires make an artificial change in zones, a Canadian fir forest sometimes being replaced by Transition zone chaparral. Natural modifying conditions are many, and not always so patent. Slope exposure is the most important. If a ridge runs north and south, its southwestern slope, which receives the hot afternoon sun, will have, we may say, a Transition zone flora and fauna, while its cold northeast slope will liave a Canadian zone flora and fauna. A cold mountain stream, on the other liand, will bring down the flora and fauna of one or two higher zones; and Canadian and even Hudsonian plants and trees bordering such a stream may thrive on its banks in the Transition zone.

So many other modifying conditions are found that the determination of zones is a complex matter, and must be based largely on the study of trees and slirubs, as they are the most stable part of the life of a region. In relating the flora to the fauna the greatest care should be taken with the bird life, as a bird can at will change his zone by a few hours' travel. Zonal notes should always be accompanied by dates, as breeding zones alone are of much significance, birds wandering widely after the breeding season. The Lewis woodpecker is a striking example of this, for, while breeding in Transition zone, after the breeding season it wanders up into Canadian and down even into Lower Sonoran zone in its search for mast. Most mountain birds that do not migrate to the south clange their zones in this way, Canadian zone birds being found in Upper and Lower Sonoran zones in fall and winter.

\section{MIGRATION.}

Many birds wander widely east and west after the breeding season, and some even go north for a slort distance. With many mountain birds the wandering movements after the breeding season amount to a vertical migration. Birds, like the grouse and quail and certain species of juncos, that make only a vertical migration merely come down from the snow-covered mountains into the warm valleys. A number of hummingbirds perform vertical migrations 
between their first and second broods, following the seasons of flowers from the valleys where they raise their first broods, to the mountain parks, where they rear a second family, retreating rapidly down the mountain as soon as the frosts kill the flowers.

Among land birds a north and south migration is not as vital in the west as the east, especially for the seed-eaters, for the lowland winters are so mild that the food supply is not as extensively destroyed as in the east, and accordingly a much larger number of birds winter in the valleys of the western states than in the eastern. But while the western north and south migratory movement is less striking, the absence of winter birds less felt than in the east, the vertical migrations, from the superior height of the mountains and the preponderance of the mountain ranges, assume great importance; and accordingly, while the total winter population may be large, the species in a locality will be markedly different in summer and winter.

Careful notes should be taken on all these phases of the migratory movements to ascertain the exact migratory habits of each species of bird, and the character of the bird population in every season.

As the mildness of climate which lessens the impulse to southward migration in the western land birds does not affect the water birds breeding in the arctic regions, the southward migration is found in full force along the coast. At suitable points, like Monterey, vast multitudes of birds may be seen passing on their way from the arctic regions to the southern seas, and migration waves and other phenomena studied to the best adrantage. Mr. Loomis's observations at Monterey have thrown a great deal of light on this most interesting subject, and demonstrated the ricliness of the field for future investigations.

\section{ECONOMIC ORNITHOLOGY.}

The question of the food of birds assumes peculiar importance in the west from the extent of the fruit industry, and the consequent magnitude of the depredations of insect and rodent pests. Birds if left to themselves keep down the insect life, and the question is in each case if the harm a bird does in eating fruit in June equals the good he does the rest of the year in eating scale insects and other pests that take off the profits of fruit growing. As it is a matter of statistics, observers should make careful field notes on what birds are actually seen eating, and especially careful records of the stom- 
ach contents of birds shot. When these cannot be determined without microscopes and collections of insects and seeds for comparison, the stomachs should be sent for examination to Professor F. E. L. Beal, of the Biological Surrey, Department of Agriculture, Washington, D. C. ${ }^{1}$ In general it may be said that the thousands of stomachs which have already been examined have shown that birds are divided into three classes, -

1. Those that are injurious at all times, as the three accipitrine hawks, which live mainly on small birds, game, and poultry.

2. Those that are injurious part of the jear and beneficial the rest of the time, such as blackbirds that come in lordes in the fall and destroy the crops, but which when scattered out over the country at other times of the year do an immense amount of good by destroying injurious insects.

3. Those that are beneficial at all times, as many hawks and owls and a large number of insectivorous and weed-seed-eating birds.

As Professor Beal says: "If crows or blackbirds are seen in numbers about cornfields, or if woodpeckers are noticed at work in an orchard, it is perhaps not surprising that they are accused of doing harm. Careful investigation, however, often shows that they are actually destroying noxious insects; and also that even those which do harm at one season may compensate for it by eating noxious species at another. Insects are eaten at all times by the majority of land birds, and during the breeding season most kinds subsist largely and rear their young exclusively on this food. When insects are unusually plentiful, they are eaten by many birds which do not ordinarily touch them. Even birds of prey resort to this diet, and when insects are more easily obtained than other fare, the smaller hawks and owls live on them almost entirely. This was well illustrated during the recent plague of Rocky Mountain locusts in the western states, when it was found that locusts were eaten by nearly every bird in the region, and that they formed almost the entire food of a large majority of the species." 2

1 The Survey will furnish, on application, blank schedules for recording data, tags for numbering the stomachs, and franked envelopes for mailing. When collected, the stomachs (crops and gizzards) should be placed in alcohol or formalin for at least a week. Before forwarding to the department, they should be taken from the finid, spread out on a newspaper, and dried for several hours, then placed in a baking powder can or cigar box, wrapped with a franked envelope on the outside, and mailed. The collector will be reimbursed for the outlay for alcohol, and will receive five cents apiece for a limited number of stomachs of certain species.

2 Beal, F. E. L., "Some Common Birds in their Relation to Agricultnre," Farmer's Bulletin, No. 54. I. S. Inepartment of Agriculture. 
As birds are the check nature has put upon insect life, the problem is a grave one. How shall we profit by the good oflices of the birds, and prevent the injury they in turn are capable of doing to our crops?

In the east Professor Beal has found that birds as a rule prefer wild fruit to cultivated, and are drawn away from the orchard and garden by the cultivation of wild fruit-bearing bushes. In parts of the west the mulberry and elder and pepper are favorite bird foods. and might be useful for such purposes. The question is a large one, however, and can only be settled by patient study and investigation on the part of earnest bird students.

\section{BIRD PROTECTION.}

By T. S. Palmer.

Laws for the protection of birds are necessary eren in sparsely settled regions. No place, however remote, is beyond the reach of the market hunter, provided a demand for game or feathers for millinery purposes exists, and prices are sufficient to warrant capture of the birds. Game birds have been shipped by thousands from the states beyond the Missouri River; pelicans, terns, and gulls have been decimated along the gulf coast of Texas; and grebes have been slaughtered on their breeding grounds on distant lakes in the interior of Oregon, - all to supply eastern markets. To meet such conditions every western state and territory now has its game law; but few of these laws protect all the birds within the state, and several of them are capable of being improved and made much more effective.

From the legislative standpoint birds may be divided into three categories: (1) Game birds, such as quail and ducks, which are hunted at stated seasons for food or sport. (2) Non-game birds, such as thrushes and gulls, which are valuable as insect destroyers or scavengers, and hence are protected throughout the year. (3) Injurious species, such as the English sparrow and the great horned owl, which are given no protection. Under the definition framed by the Committee on Protection of Birds of the American Ornithologists' Union, game birds are restricted to four or fire well marked groups : the Anatidæ, comprising ducks, geese, and swans; the Rallidx, including rails, coots, and gallinules; the Limicolæe, or shore birds in general; the Gallinæ, including quails, pheasants, grouse, and wild turkeys; and (in some states) the Columbe, including wild pigeons and doves. All other birds are classed as 
non-game birds, and the few injurious species are mentioned by name. Such a division provides for all the birds, leaves no ambiguity as to which may be killed as game, and defines each group in the simplest and most satisfactory manner. A game law framed on this basis has been adopted with excellent results in some states, but in the west is still an ideal toward which to work rather than an accomplished fact. California, Colorado, and Nebraska have excellent laws for game birds, but they do not provide equally well for insectivorous species. Nevada, New Mexico, and Wyoming have comprehensive statutes for non-game birds, but do not afford complete protection to all their game birds.

Game Birds. - Experience has shown that a modern game law must do much more than merely prohibit the killing of certain species at stated times. It must regulate methods of hunting, restrict shipment and sale, and also prescribe means for carrying its provisions into execution. It should contain the declaration that all wild birds and animals are the property of the state. This fact, based on the decisions of the highest courts, is now generally accepted, but it is well to have it incorporated in the law, as is the case in the game laws of Colorado, Texas, and other states. Next in importance is a comprehensive definition of game birds like that given above. Another important point not fully appreciated is that a law which prohibits killing certain species is much less effective and permanent than one which simply permits, by declaring that it shall be unlawful to kill or have in possession 'any birds except as hereinafter provided.' This simple statement renders the law to a certain extent automatic, since all birds will be protected until provided with an open season. Changes in season, the bane of game legislation, cannot be made so readily without attracting attention, and if, as often happens, a proposed change in season fails of enactment, the species is left with complete protection instead of being without protection as under the old method. Little need be said as to seasons except that they should conform as nearly as possible to those of adjoining states. With improved guns, smokeless powder, and other modern appliances for hunting, no state can afford to maintain an open season from the time the birds are mature until they begin to breed the following year, for no species can withstand such an ordeal and not be locally exterminated in a few years. Open seasons are constantly growing shorter, and as they undergo change should be shifted to correspond more and more closely with those of other states. Above all, spring shooting should be abolished, and 
the close season begin as near the first of January as possible. Big guns are very properly made illegal, and an unsuccessful attempt was recently made in California to prevent the use of magazine or 'pump guns,' on the ground that they were too destructive. The same might be said of the air gun or parlor rifle, which in the hands of the reckless small boy is not only an effective but a dangerous weapon of destruction. Night hunting in all its forms, baiting, pursuing game with launches or even sailboats, are condemned by true sportsmen, and should all be prohibited. Trapping and netting should likewise be made illegal, but with some provision for taking a reasonable number of birds for propagation under the supervision of competent state officers. Restrictions on the trade are becoming more general and more necessary every year. Prohibition of shipment out of the state is effective if it can be enforced, and it can be made easier to enforce if transportation of all game for market purposes is prohibited, as is done in Iowa and Texas, but with some provision for carrying a limited amount of game for private purposes. Sale is the keynote to the situation, and if it can be prohibited the question of protection will be greatly simplified. It is now prohibited in a number of states, and probably the day is not far distant when most if not all game birds will be withdrawn from sale.

Non-game Birds. - Even more important than laws for the protection of game birds (because applying to a much larger number of species) are the statutes for the preservation of birds which are not game, and which apply to 'song,' 'insectivorous,' and 'plume' birds. In order to accomplish their purpose they must be comprehensive, and as already stated they should cover all birds except game birds and a few injurious species mentioned by name. If made applicable to certain species, or even to song, insectivorous, or plume birds, some species are sure to be omitted, and often these will be the very ones most in need of protection. Not only killing, but also nest robbing, trapping, possession, shipment, and sale should be prohibited. The traffic in cage birds, unless checked by strict regulations, may sometimes decimate certain species, particularly those distinguished for their vocal powers or bright colors. A provision prohibiting possession of plumage or ' any part of a bird' is necessary to prevent sale of birds for millinery purposes, and overcome the objection which is sometimes raised that prohibitions against the killing and possession of a bird do not apply to its plumage or to one of its wings when used as a hat decoration. 
On the other hand, provision must be made for collecting birds for scientific purposes, both for educational institutions and foi private collections, and also for keeping birds in captivity for study or as pets. These requirements can readily be met by having permits issued under the supervision of some state officer to properly accredited collectors and students. In case it is desirable to allow certain birds to be kept in captivity, sale and shipment out of the state should be prohibited in order to avoid abuse of the privilege and prevent wholesale bird-trapping for market. ${ }^{1}$

Injurious Species. - In every state there are a few injurious species from which protection should be withdrawn. In general these species comprise the English sparrow, great horned owl, goshawk, duck hawk, sharp-shinned hawk, Cooper hawk, crow, linnet or house finch, and occasionally some of the blackbirds. Sweeping provisions excluding hawks and owls from protection should be carefully aroided, as most of the species are beneficial, and a clause covering birds of prey in general without naming the injurious species will result chiefly in the destruction of those which are beneficial. It is useless to attempt anything more by legislation than simple removal of protection. No means have yet been devised by which an injurious species can be legislated out of existence, and the various methods which have been advocated have almost uniformly resulted in failure. Bounties for birds and eggs hare little effect except to drain the state or county treasury. The Colorado hawk bounty, which was in force from 1877 to 1885 , seems to have resulted chiefly in the diminution of the sparrow hawk, one of the most useful birds in destroying grasshoppers. The Utah bounty on English sparrows, in force since 1888, has not exterminated the sparrow in the state, and the provision of 1896, offering five cents per dozen for eggs, must have resulted disastrously to the native birds, for a year or two after it went into effect reports showed that in Weber County alone payments had been made on 990 dozen (nearly 12,000) eggs, while during the same period only 640 sparrows had been presented for bounty. The sparrow bounties in Illinois and Michigan and the hawk and owl bounty in Pennsylvania all failed to accomplish their objects, although each cost the state from $\$ 50,000$ to $\$ 100,000$. The expense attending bounty legislation can be readily illustrated by the records of payments for coyotes and

1 The bill prepared by the Committee on Protection of Birds of the American Ornithologists' Union covers all of these points. See "Legislation for the Protection of Birds other than Game Birds," Bulletin No. 12, Biological Survey, U. S. Dept. Agriculture, pp. 56-60, 1902. 
wolves in Wyoming, Montana, and California. The coyote bounty law in California remained in force only four years, but actually cost the state $\$ 187,485$, while the claims filed a ggregated about $\$ 400,000.1$ In the west bounties on birds are now paid only in Utah and Oregon, and in the latter state are restricted to cormorants and sheldrakes.

Enforcement. - The enforcement of game laws depends largely on public sentiment. Although most of the western states have game wardens, the laws are not enforced as they should be. Better results are attained where local wardens are under the authority of a state ofticer or state board. Unfortunately the liberal appropriations necessary to meet the expenses incident to warden service are not often arailable, but game protection might be made almost self-supporting if the money derived from licenses, fines, sale of contraband game, and similar sources, were all turned into a state game protection fund instead of going into several different funds, no one of which is available for work of this kind.

A potent influence in bird protection is the federal law popularly known as the Lacey Act, which went into effect on May 25, 1900. Under this act interstate commerce in birds killed in violation of local laws is prohibited, and through coöperation between federal and state authorities statutes which were formerly dead letters are now being enforced. The chief value of the law, howerer, lies in the interest in protection which it has aroused throughout the country even among persons who formerly gave the subject no thought. Largely through its influence game protection is now being established on broader lines, rapid progress is being made in legislation, and the laws are better observed than ever before.

\section{LOCAL LISTS.}

\section{LIST OF BIRDS IN THE VICINITY OF PORTLAND, OREGON.}

\section{By A. IV. Anthon:.}

The country embraced in this list is about ten square miles in extent. The region between the city of Portland and the Columbia River perhaps furnishes most of the species, and is farming land diversified by forest land, brush patches, and low wet meadows, which in winter are ponds upon which are found all of our species

1 See Palmer, "Extermination of Noxious Animals by Bounties," Yearbook Dept. Agr. for 1896, pp. $55-68$. 
of waterfowl. The high hills west of the city are less prolific. The heavy forest is cleared in places, offering homes for such species as white-crowned sparrows, juncos, and wrens, while the woodpeckers and forest-loving species dwell in the undisturbed parts of the region. which is as wild as a hundred years ago. Here also is found the russet-backed thrush nesting in the thickets and deep ravines.

Colymbus nigricollis californicus: Eared Grebe. - Rather common on the ponds along the Columbia.

Podilymbus podiceps: Pied-billed Grebe. - Common with the eared grebe. Gavia imber: Loon. - Seen only as a migrant.

Larus glaucescens: Glaucons-winged Gull. - Five species of gull are seen along the river during the winter, but the glaucous-winged is the commonest.'

Larus argentatus: Herring Gull.

Larus californicus : California Gull.

Larus delawarensis: Ring-billed Gull.

Larus brachyrhynchus: Short-billed Gull (?).

Phalacrocorax dilophus cincinatus: White-crested Cormorant. - In the winter a species is found on the river about Portland, which is probably the white-crested, but as no specimens have been taken I am in doubt about it.

Merganser serrator: Red-breasted Merganser. - A common winter visitor.

Lophodytes cucullatus: Hooded Merganser. - A winter visitant, less common than the red-breasted.

Anas boschas: Mallard. - Very common.

Chaulelasmus streperus: Gadwall. - The gadwall and the baldpate are about equally common, but less so than most of the ducks found.

Mareca americana: Baldpate.

Spatula clypeata: Shoveller. - Conmon during fall and winter.

Dafila acuta: Pintail. - Common during fall and winter.

Aix sponsa: Wood Duck. - Common summer resident. A few winter about Portland.

Aythya americana: Redhead. - Common in fall and winter.

Aythya vallisneria: Canvas-back. - Common in fall and winter.

Chen hyperborea: Lesser Snow Goose. - One or more species of snow geese are common. During mild winters all the ducks and geese are apt to winter about Portland, but a hard season drives them sonth.

Anser albifrons gambeli: White-frouted Goose. - Conmon miguant.

Branta canadensis minima: Cackling Goose. - Two or more races of canadensis are common, but the only species I have taken is the cackling goose.

Olor columbianus: Whistling Swan. - Not uncommon migrant and winter resident.

Ardea herodias: Great Blne Heron. - Common in summer; a few winter. Ardea virescens: Green Heron. - A few herons seen, probably of this species.

Grus canadensis: Little Brown Crane. - Common fall migrant, but very rare in spring.

Rallus virginianus: Virginia Rail. - Like the sora, more or less common, nesting in wet bottoms.

I'orzana curolina : Sora.

Fulica americana: Coot. - Not very abundant; nests. 
Tringa minutilla: Least Sandpiper. - Abundant for a few days during migration.

Tringa alpina pacifica : Red-backed Sandpiper. - Migrant; less common than the least or western sandpipers.

Ereunetes occidentulis : Western Sandpiper. - Abundant during migration for a few days.

Totunus melanoleucus : Greater Yellow-legs. - Migrant; not uncommon.

Symphemia semipalmata inornata: Western Willet. - liather rare migrant.

Eyialitis vocifera : Killdeer. - Common snmmer resident.

Oreortyx pictus: Monntain Partridge. - Common resident.

Dendragapus obscurus fuliginosus : Sooty Gronse. - Common resident.

Columba fasciata : Band-tailed Pigeon. - Not uncommon in suitable localities, but rare near Portland.

Zenaidura macroura: Mourning Dove. - Comnon summer resident.

Cathartes aura: Turkey Vulture. - Common summer resident.

Circus hudsonius: Marsh Hawk. - Rare.

Accipiter velox: Sharp-shinned Hawk. - Common. especially dnring migrations.

Accipiter cooperii: Cooper Hawk. - Not common.

Buteo borealis calurus: Western Red-tail. - Common.

Halicetus leucocephalus: Bald Eagle. - seen at times along the river.

Falco peregrinus anatum: Dnck Hawk. - Seen only once or twice.

Falco columbarius : Pigeon Hawk.

Falco columbarius suckleyi: Black Merlin. - The pigeon hawk and the black merlin are, perhaps, equally common; more common during fall and winter.

Meguscops asio kennicottii: Kennicott Screech Owl. - Quite conmon among the oaks along the river.

Bubo virginianus saturatus: Dusky Horned Owl. - Not uncommon in heavy timber.

Nyctea nyctea: Snowy Owl. - A few have been taken near Portland in winter.

Glaucidium guoma californicum: California Pygmy Owl. - Rather common; often seen in the daytime.

Coccyzus americanus occidentalis : California Cnckoo. - Rare; a few seen in low marshy places along the Columbia.

Ceryle alcyon: Belted Kingfisher. - Quite common along all watercourses.

Dryobates villosus harrisii: Harris Woodpecker. - Common in all timber.

Dryobates pubescens gairdnerii: Gairdner Woodpecker. - Common in all timber.

Sphyrapicus ruber notkensis: Northern Red-breasted Sapsucker.-Common; more often seen in alder or dogwood than in fir growth.

Ceophlous pileatus abieticola : Northem, Pileated Woodpecker. - Less common than formerly, but still fornd in heary fir growth.

Melanerpes torquutus: Lewis Woodpecker. - Common summer resident.

Colaptes cafer saturatior: Northwestern Flicker. - Abmudant resident. The flickers of this region are not constant to any race.

Phalcenoptilus nutallii californicus: Dnsky Poor-will. - A poor-will has been described to me.

Chordeiles virginianus: Nighthawk. - Comnon summer resident.

Chatura vauxii: Vaux Swift. - Rather common summer resident.

Selasphorus rufus : Rufous Hummingbird. - Very common summer resident, 
Tyrannus verticalis: Arkansas Kingbird. - A kingbird is found at Portland, but is rare, and the species not determined.

Contopus borealis: Olive-sided Flycatcher. - Common in tall firs.

Contopus richardsonii: Western Wood Pewee.-Very common everywhere; often seen in shade trees about the city.

Empidonax difficilis: Western Flycatcher. - Probably taken in migration.

Empidonax traillii: Traill Flycatcher. - Very common in alder and vine maple thickets.

Alauda arvensis: Skylark. - Introduced. Common in open fields on the east side of the river; not seen elsewhere.

Otocoris alpestris strigata: Streaked Horned Lark. - Not nucommon in suitable localities.

Pica pica hudsonica : American Magpie. - Not common; a few are found along the Columbia.

Cyanocitta stelleri: Steller Jay. - Common everywhere in the region of Portland.

Aphelocoma californica: California Jay. - Rare; more common during migrations.

Perisoreus obscurus : Oregon Jay. - Rare.

Corvus caurinus: Northwest Crow (?). - Crows are abundant, but species not determined.

Sturnus vulgaris : Starling. - Introduced; still rare.

Agelaius phoniceus caurinus : Northwestern Redwing. - More or less common.

Sturnella magna neglecta: Western Meadowlark. - Abundant resident.

Icterus bullocki: Bullock Oriole. - Rather common in cottonwoods and oaks along the river.

Scolecophagus cyanocephalus : Brewer Blackbird.-Abundant resident; more common in open fields.

Coccothraustes vespertinus montanus: Western Evening Grosbeak. - Abundant winter resident, flocking about the maples in the streets; remarkably tame.

Carpodacus purpureus californicus : California Purple Finch. - Common in fields about the city.

Loxia curvirostra minor: Crossbill. - Rare.

Astragalinus tristis salicamans : Willow Goldfinch. - Abundant.

Astragalinus psaltria: Arkansas Goldfinch. - Not nncommon.

Spinus pinus: Pine Niskin. - Not uncommon; nests about the city in large firs (?).

Passer domesticus : English sparrow. - Abundant in the city.

Poccetes gramineus affinis: Oregon Vesper Sparrow. - Common in open fields.

Ammodramus sandwichensis : Sandwich Sparrow. - Specimens taken during migrations were nearer this form than any other, but not typical.

Ammodramus sandwichensis alaudinus: Westeri Savama Sparrow. - Common in cultivated fields.

Zonotrichia leucophrys gambelii: Gambel Sparrow. - Conmon during migrations.

Zonotrichia leucophrys nuttalli: Nuttall Sparrow. - Abundant summer resident; nests in thickets aud low brush.

Zonotrichia coronata: Golden-crowned Sparrow. - Common during nigration for a few days.

Spizella socialis arizone: IVestern Chipping Sparrow. - Abundant summer resident.

Junco hyemalis oreganus: Oregon Junco. - Abundant resident. 
Melospiza melodia morphna: Rusty Song Sparrow. - Abundant resident.

Melospiza lincolnii striata: Forbush Sparrow. - A sparrow probably of this species seen a few times dnring migrations.

I'asserella iliaca annectens: Yakutat Fox Sparrow. - Common winter resident; usually seen with iusty sparrows.

Pipilo maculatus oregonus : Oregon Towhee. - Common resident; found in thickets all about the city.

Cardinalis curdinalis: Cardinal. - Several birds were released by a dealer a few years ago and are still seen in the residence part of the city.

Zamelodia melanocephala: Black-headed Grosbeak. - Not uncommon.

Cyanospiza amona: Lazuli Bunting. - Common along the bottom lands of the Columbia.

Piranga ludoviciana : Louisiana Tanager. - Common in the firs and alders, nesting in the firs.

Progne subis hesperia: Western Martin. - Not common.

Petrochelidon lunifrons : Cliff Swallow. - Common.

Hirundo erythrogastra: Barn Swallow. - Not conmon.

Tachycineta bicolor: Tree Swallow. - Not common.

Tachycineta thalassina lepida: Northern Violet-green Swallow. - Very abundant; nesting in barns and onthouses, entering through knotholes.

Riparia riparia: Bank Swallow (?).

Stelgidopteryx serripennis: Rough-winged Swallow. - Of the bank and rough-wing one or both have been seen, but neither is common.

Ampelis cedrorum : Cedar Waxwing. - Common summer resident.

Lanius borealis: Northern Shrike. - Rare winter visitant.

Vireo gilvus : Warbling Vireo. - Common; nests in the alder and dogwood thickets.

Vireo solitarius cassinii: Cassin Vireo. - Common with the warbling.

Vireo huttoni obscurus : Anthony Vireo.-Rare; seen only about oaks.

Dendroica cestiva: Yellow Warbler. - Very common everywhere about the city.

Dendroica coronata: Myrtle Warbler. - Rare migrant.

Dendroica auduboni: Audubon TVarbler. - Common; nests in the small firs.

Dendroica nigrescens : Black-throated Gray Warbler. - Common summer resident.

Dendroica townsendi: Townsend Warbler. - Not rare.

Dendroica occidentalis : Hermit Warbler. - Not rare.

Geothlypis trichas arizela: Pacific Coast Yellow-throat. - Common in open fields about the water.

Icteria virens longicauda: Long-tailed Chat. - Rare; seen only a few times.

Wilsonia pusilla pileolata: Pileolated Warbler.-Common summer resident.

Anthus pensilvanicus : Pipit.-Common winter resident.

Salpinctes obsoletus : Rock Wren. - Rare.

Thryomanes beuickii calophonus : Vigors Wren. - Common resident.

Troglodytes aëdon parkmanii: Parkman Wren. - Common summer resident.

Olbiorchilus hiemalis pacificus: Western Winter Wren. - Resident; common in deep shaded thickets.

Cistothorus palustris paludicola: Tule Wren.- Not uncommon in the marshes along the Columbia.

Certhia familiaris occidentalis: Californian Creeper. - Resident in the fir forests; not rare. 
Sitta carolinensis aculeata: Slender-billed Nuthatch. - Common.

Sitta canadensis: Red-breasted Nuthateh.-Common fall migrant; does not seem to be so abundant in spring.

Parus atricapillus occidentalis: Oregon Chickadee. - Tery common resident.

Parus rufescens : Chestnut-backed Chickadee.-Common resident.

Psaltriparus minimus: Bush-Tit. -- Abundant resident.

Regulus satrapa olivaceus : Western Golden-crowned Kinglet. - Abundant winter resident.

Regulus calenslula : Ruby-crowned Kinglet. - Conmon migrant.

Myadestes townsendii: 'Townsend Solitaire. - Seen once or twice in the residence part of the city.

Hylocichla ustulata: Russet-backed Thrush. - Common in the city and wooded thickets along the river.

Hylocichla guttata: Alaska Hermit Thrush. - A few seen during migrations.

Merula migratoria propinqua: Western Robin.-Abnndant; a few winter.

Ixoreus ncevius : Varied Thrush. - Abundant winter resident.

Sialia mexicana occidentalis : Western Bluebird. - Common.

\section{LIST OF WATER BIRDS OF SAN FRANCISCO BAY.}

By William H. Ковbé.

Echmophorus occidentalis: Western Grebe.-Abundant throughout the winter and spring.

Colymbus holbollii: Holbœll Grebe - Rare; two winter visitants taken.

Colymbus auritus: Horned Grebe. - Common winter visitant.

Colymbus nigricollis californicus: American Eared Grebe. - Winter visitant, most commonly at Oakland and Alameda.

Podilymbus podiceps: Pied-billed Grebe. - Common in the fall ; probably resident in favorable situations.

Gavia imber: Loon. - Spring migrant.

Gavia pacifica: Pacific Loon. Conmon winter visitant.

Gavia lnmme: Red-throated Loon. - Winter visitant; abundant about Oakland.

Cyclorrhynchus psittaculus : Paroquet Anklet. - Winter visitant.

Synthliboramphus antiques: Ancient Murrelet. - Winter visitant.

Brachyramiphus marmoratus : Marbled Murrelet. - Taken off Goat Island by Bryant.

Uria troile californica : California Murre. - Visitant ; mainly fall, winter, and spring; probably occurs in summer.

Stercorurius parasiticus : Parasitic Jaeger. - Fall migrant.

Rissa tridactyla pollicaris : Pacifie Kittiwake. - Winter visitant.

Larus delawarensis: Ring-billed Gull. - Common about Oakland from the last of autumm nutil summer.

Larus glancus: Glaneons Gull. - One noted by Cooper (Proc. Cal. Academy of Sciences, iv. 9-10) and one seen by Kobbé.

Larus glaucescens: Glancons-winged Gull. $-\Lambda$ bundant winter visitant.

Larus occidentalis: Western Gull. - Abundant resident.

Larus cergentatus : Herring Gull. - Abundant winter visitaut.

Larus vega?: Vega Gull. - Abundant winter visitant.

Larus californicus : California Gull. - Abuudant resident.

Larus brachyrhynchus : Short-billed Gull. - A bumdant from November to February. 
Larus canus: Mew Gull. - Very abundant from November into February. Larus heermanni: Heermann Gnll. - Abmndant on bay in summer, rare in winter.

Lurus philadelphia: Bonaparte Gull. - Common winter visitant.

Sema sabinii: Sabine Gull. - One taken by Lorquin, October (10 ?).

Sterna caspia: Caspian Tern. - One taken by Bryant, December 2.

Sterna maxima: Royal Tern. - One taken at Oakland by Bryant, August 27 .

Sterna elegans : Elegant 'Tern. - One taken by Lansing, September 17.

Sterna forsteri : Forster Term. - Winter visitant.

Diomedea albatrus: Short-tailed Albatross. - One taken near Goat Island by Bryant, March 10.

Fulmarus glaciailis glupischa: Pacific Fulmar. - Winter visitant.

Phalacrocorax dilophus cincinatus : White-crested Cormorant. - Occurs in winter.

Phalacrocorax dilophus albociliatus: Farrallone Cormorant. - Common resident.

Phalacrocorax penicillatus : Brandt Cormorant. - Common resident.

Phalacrocorax pelagicus : Pelagic Cormorant. - Common resident.

Pelecanus erythrorhynchos: American White Pelican. - Rather rare winter visitant.

Pelecanus californicus: California Brown Pelican. - Conmon winter visitant.

Merganser americanus : American Merganser. - Winter visitant.

Merganser serrator : Red-breasted Merganser. - Spring and fall migrant. Anas boschas : Mallard. - Winter visitant in all marshes bordering bay.

Mareca americana: Baldpate. - Winter visitant at Vallejo and Oakland.

Nettion carolinensis : Green-winged Teal. - Common in winter throughout the bay region.

Querquedula discors : Blue-winged Teal. - Taken at Vallejo by Golcher.

Querquedula cyanoptera: Cimnamon Teal. - Winter visitant at Vallejo.

Spatula clypeata: Shoveller. - Winter visitant.

Dafila acuta: Pintail. - Fall and winter visitant at Miller, Marin County, and Vallejo.

Aix sponsa: Wood Duck. - Taken br Slevin at Cordelia, November S. Aythya vallisneria: Canvas-back. - Abundant winter visitant at Vallejo. Aythya marila: Scaup Duck. - Winter visitant to all parts of bas.

Aythya affinis : Lesser Scaup Duck. - Winter visitant at Vallejo and Oakland.

Aythya collaris : Ring-necked Duck. - Two taken by Hornung, February 5.

Clangula clangula americana: American Golden-eye.-Fall and winter visitant.

Clangula islandica: Barrow Golden-eye. - Two taken by Bryant, November 16 and December 3 .

Charitonetta albeola: Buffle-head. - Winter visitant.

Oidemia perspicillata: Surf Scoter. - Common winter visitant.

Oidemia deglandi : White-winged Scoter. - Common winter visitant.

Erismatura jamaicensis: Ruddy Duck. - Found in lagoons from October until the middle of February.

All California geese occur in greater or less abundance in the inner portions of the bay.

Olor columbianus : Whistling Swan.- One taken by Kellogg at Cordelia, December 18.

Botaurus lentiginosus: American Bittern. - One taken by Bryant and one by Hormung. I have found it fairly common in the marshes.

Ardea herodias: Great Blue Heron. - Breeds at Alameda; resident. 
Nycticorax nycticorax nevius: Black-crowned Night Heron. - Abundant at Alameda in winter; also a colony at Tiberone; resident.

Rallus obsoletus : California Clapper Rail. - Abundant in marshes bordering the bay in fall and early winter.

Rallus virginianus: Virginia Rail. - Fall migrant.

Porzana noveboracensis: Yellow Rail. - Two taken by Bryant in December.

Porzana jamaicensis: Black Rail. - Locally common in winter; probably breeds.

Fulica americana: American Coot. - Conmon everywhere; resident.

Crymophilus fulicarius : Red Phalarope. - Found commonly, especially in calner waters on bay, from October to January.

Phalaropus lobatus: Northern Phalorope. - Fall migrant.

Recurvirostra americana: American Avocet. - Reported from Redwood City (Slevin).

Himantopus mexicanus : Black-necked Stilt. - Fall and winter migrant at Miller, Marin Co.

Gallinago delicata: Wilson Snipe. - Fall, winter, and spring visitant.

Macrorhamphus scolopaceus : Long-billed Dowitcher. - Fall and early winter visitant.

Tringa maculata: Pectoral Sandpiper. - One taken by Bryant, October 8 .

Tringa minutilla: Least Sandpiper. - Abundant in fall and winter.

Tringa alpina pacifica: Red-backed Sandpiper. - Abundant from the middle of October till the middle of May.

Ereunetes occidentalis: Western Sandpiper. - Abundant migrant.

Calidris arenaria : Sanderling. - Common migrant at Oakland.

Limosa fedoa: Marbled Godwit. - Fall and winter visitant.

Totanus melanoleucus : Greater Yellow-legs. - Winter visitant.

Helodromas solitarius cinnamomeus: Western Solitary Sandpiper. - Two taken by Bryant, April and September.

Symphemia semipalmata inornata: Western Willet. - Common in summer (Bryant).

Heteractitis incanus: Wandering Tatler. - Two taken by Kobbé in September.

Actitis macularia: Spotted Sandpiper. - Taken at Tiberone and Angel Island in May and November.

Numenius longirostris : Long-billed Curlew. - Common at Oakland in August (Bryant).

Numenius hudsonicus : Hudsonian Curlew. - Taken at Oakland in August and September (Bryant).

Squatarola squatarola: Black-bellied Plover. - Fall and winter visitant.

Charadrius dominicus : American Golden Plover. - Taken at Vallejo and Menlo Park (Hormung).

Agialitis vocifera: Killdeer. - Common everșwere in fall, winter, and spring.

Egialitis nivosa : Snowy Plover. - Taken on Presidio beach (Slevin).

Arenaria melanocephala: Black Turnstone. - Two records from Angel Island. 


\title{
LIST OF BIRDS OF SANTA CLARA VALLEY AND SANTA CRUZ MOUNTAINS, EXCLUSIVE OF WATER BIRDS.
}

\author{
By Walter K: Fisher.
}

\author{
Resident $=$ Permanent resident. \\ Winter visitunt $=$ Winter resident. \\ Summer visitant $=$ Breeding bird not occurring in winter.
}

The country covered by this list includes practically all of the Santa Clara Valley and the northern half of the Santa Cruz Mountains. The Santa Cruz Mountains send a long spur northwarl to form the backbone of the San Francisco peninsula. This ridge has numerous lateral spurs, particularly toward the sea. On the east the mountains slope down into low foothills rather abruptly, and these foothills gradually merge into the floor of the valley, which, north of San José, is largely occupied by the bay of San Francisco and its environing marsh. To the east of the bay is the Mount Hamilton range.

To the Transition zone belong most of the Santa Cruz Mountains, and the country between them and the seacoast. In the mountains are magnificent stretches of redwood forest, mixed with Douglas spruce, tan-bark oak, and madrone, and underbrush of evergreen huckleberry, myrtle, azalea, rhododendron, wild lilac (Ceanothus thyrsiflorus), and several species of manzanita.

The Upper Sonoran zone includes all the main foothill region and many of the outlying spurs of the Santa Cruz Mountains, much of the Mount Hamilton range, and the greater part of the floor of the valley. The valley contains an infusion of Lower Sonoran elements, but the proximity of the sea, with its tempering breezes, many high fogs during summer, and a rather heavy rainfall (for a valley), so reduces the total quantity of heat for the year that the region is really a peculiar humid Upper Sonoran, or perhaps a mixture of the two Sonoran zones. Characteristic valley types are the white oak (Quercus lobata), blue oak (Q. douglasii), valley live-oak (Q. agrifolia), bay tree, buckeye, Christmas berry (Heteromeles arbutifolia), and sycamore. In the Mount Hamilton range is found the digger pine, and on many of the foothills of this range and of the Santa Cruz, chamiso (Adenostoma fasciculatum), sage (Artemisia californica), highland oak (Quercus wislizeni), scrub oak (Q. dumosc), ceanothus, and various manzanitas form large areas of dense chaparral. 
The broad Salicornia marshes surrounding the bay support a rather numerous fauna that does not occur inland.

Lophortyx californicus : California Partridge. - Abundant resident in hills and vallevs.

Columba fasciata: Band-tailed Pigeon. - Autumn and winter visitant.

Zenaidura macroura: Mourning Dove. - Summer visitant; oceasionally seen in winter; open valleys.

Gymnogyps californianus: California Vulture.-Oceasional visitant in Santa Cruz Mountains.

Cathartes aura : Turkey Buzzard. - Summer visitants of valley and mountain.

Elanus leucurus : White-tailed Kite. - Resident among oak groves of the valley.

Accipiter velox: Sharp-shimned Hawk - Common winter visitant.

Accipiter cooper $\ddot{i i}$ : Cooper Hawk. - Oceasional transient visitant.

Circus hudsonius: Marsh Hawk. - A resident of the marshes about San Francisco bay.

Buteo borealis calurus : Western Red-tail. - Common resident of the valley and mountains.

Buteo lineatus elegans: Red-bellied Hawk. - Rare resident of the valley.

Buteo suainsoni: Swainson Hawk. - Rare transient visitant.

Archibuteo lagopus sancti-johannis: American Rongh-legged Hawk.Rare transient visitant.

Archibuteo ferrugineus: Ferruginous Rough-leg. - Irregular winter visitant near San José (R. H. Beck).

Aquita chrysätos : Golden Eagle. - Common resident of valley and foothills.

Halicetus leucocephalus : Bald Eagle. - Occasional visitant.

Falco sparverius deserticola: Desert Sparrow Hawk. - Common resident.

Falco mexicanus: Prairie Falcon. - Oceasional winter visitant in valley; resident near Santa Cruz.

Falco peregrinus anatum: Duck Hawk. - Marshes.

Falco columbarius : Pigeon Hawk. - Fairly common winter visitant.

Strix pratincola: Barn Owl. - Common resident in valley.

Asio wilsonianus: Long-eared Owl. - Recorded from Santa Cruz Mountains.

Asio accipitrinus: Short-eared Owl.-Common resident on the broad marshes about San Francisco bay.

Megascops asio bendirei: California Screech Owl. - Common resident.

Bubo virginianus pacificus : Pacific Horned Owl. - Permanent resident of the vallers.

Speotyto cunicularia hypogea : Burrowing Owl. - Common resident of the low valleys.

Glaucidium gnoma californicum : California Pygmy Owl. - A fairly common but inconspicuous resident of the Santa Cruz Mountains.

Geococcyx californianus: Road-runner. - Uncommon resident in hot valleys.

Coccyzus americanus occidentalis : California Cuckoo. - Summer visitant in heavy thickets.

Ceryle alcyon: Belted Kingfisher. - Resident along the larger streams.

Iryobates villosus harrisii: Harris Woodpecker. - Resident in santa Cruz Mlountains.

Iryobates pubescens gairdnerii: Gairdner Woodpecker. - Common resident in Santa ('ruz Mountains, and breeds sparingly in valley. 
Mryobates nnttallii: Nuttall Wroodpecker. - Recorded from Mount Hanilton.

siphyrapicns rnber: Red-breasted Sapsucker. - Fairly common winter visitant. principally to Santa Cruz Mlountains.

Melanerpes formicivorus bairdi : California Woodpecker. - Abundant resident among the oaks of the valleys.

Melanerpes torquatus: Lewis Woodpecker. - Winter visitant.

Colaptes cafer collaris : Red-shafted Flicker. - Abundant resident.

Phalcenoptilus nuttallii californicus: Dusky Poor-will. - Uncommon resident.

Chatura vauxii: Vaux Swift. - Summer visitant among redwoods; occasionally seen in valley.

Aëronautes melanoleucus: White-throated Swift. Occasionally seen in migration; breeds near Santa Cruz.

Calypte anna : Amua Hummingbird. - Abundant resident in valleys.

Selasphorus rufus: Rufous Hummingbird. - Occurs plentifully in the spring as a migrant.

Selasphorus alleni: Allen Hummingbird. - Abundant summer visitant in valley and hills.

Tyrannus verticalis: Arkansas Kingbird. - Rather common summer visitant.

Myiarchus cinerascens : Ash-throated Flycatcher. - Summer visitant.

Sayornis saya: Say Phobe. - Rather common winter visitant.

Sayornis nigricans semiatra: Western Black Phøebe. - Common resident.

Contopus borealis: Olive-sided Flycatcher. - Summer visitant in Santa Cruz Mountains; not common.

Contopus richardsonii: Western Wood Pewee-Common summer visitant.

Empidonax difficilis: Western Flycatcher. - Common summer visitant.

Empidonax traillii: Traill Flycatcher. - Summer visitant in willow patches along creeks.

Otocoris alpestris chrysolıma: Mexican Horned Lark. - Common in the open valley.

Pica nuttalli: Yellow-billed Magpie. - Resident in colonies south of San José.

Cyanocitta stelleri carbonacea: ${ }^{1}$ Coast Jay. - Abundant permanent resident in Santa Cruz Mountains.

Aphelocoma californica : California Jay. - Abundant resident.

Corvus americanus: American Crow. - Resident in southern part of Santa Clara valley.

Agelaius gubernator californicus: Bicolored Blackbird.-Breeds abundantly in meadows bordering marshes.

Agelaius tricolor: Tricolored Blackbird. - Occurs locally ; rare.

Yanthocephalus xanthocephalus: Yellow-headed Blackbird. - Breeds in the marshes south of San José.

Sturnella magna neglecta: Western Meadowlark. Abundant permanent resident.

Icterus bullocki: Bullock Oriole. - Resident for nesting season; conmon.

Scolecophagus cyanocephalus : Brewer Blackbird. - Abundant permanent resident.

Coccothraustes vespertinus montanus: Western Evening Grosbeak. - Oceasional winter visitants in flocks.

Carpodacus purpureus californicus: California Purple Finch. - Common resident in valley and mountains.

1 A form commonly called frontalis. but really closer to typical stelleri than to the Sierran form. 
Carpodacus mexicanus frontalis: House Finch. - Abundant resident.

Astragalinus tristis salicamans: Willow Goldfinch. - Resident in willows and mustard patehes.

Astragalinus psaltria : Arkansas Goldfinch. - Abundant resident.

Astragalinus laurencei: Lawrence Goldfinch. - A rare summer visitant, and erratic in its visits.

Spinus pinus: Pine Siskin. - Resident in the Santa Cruz Mountains ; migrant in valley.

Ammodramus sandwichensis alaudinus: Western Savanna Sparrow. Abundant fall and winter visitant in valley fields.

Ammodramus sandwichensis bryanti: Bryant Marsh Sparrow. - Abundant resident in marshes about San Francisco bay.

Aimmodramus savannarum bimaculatus: Western Grasshopper Sparrow. Recorded from near San José (R. H. Beck).

Ammodramus nelsoni: Nelson Sparrow. - Two records from Milpitas marshes.

Pocecetes gramineus confinis: Western Vesper Sparrow. - Recorded from near San José (MeGregor).

Chondestes grammacus strigatus: Western Lark Sparrow. - Commoner on the east than on the west side of the bar.

Zonotrichia leucophrys gambelii: Gambel Sparrow. - Abundant winter visitant, leaving in April.

Zonotrichia leucophrys nuttalli: Nuttall Sparrow. - Resident in damp coast belt; winter visitant in Santa Clara valley.

Zonotrichia coronata: Golden-crowned Sparrow. - An abundant winter visitant.

Spizella socialis arizonce: Western Chipping Sparrow. - Not a very common resident.

Junco hyemalis thurberi: Sierra Junco. - Winter visitant; not common.

Junco hyemalis pinosus: Point Pinos Junco. - Resident in Santa Cruz Mountains, and south in humid coast belt; commonest junco in valleys in winter.

Amphispiza belli: Bell Sparrow. - Said to breed near Los Gatos (J. Van Denburgh).

Aimophila ruficeps : Rufous-crowned Sparrow. - Resident, locally, on east side of valley in sage-brush districts.

Melospiza melodia heermanni: Heermann Song Sparrow, - Resident in southernmost portions of Santa Clara valley uplands.

Melospiza melodia santcecrucis: ${ }^{1}$ Santa Cruz Song Sparrow. - Common permanent resident along streams flowing into San Francisco bay and into Pacific Ocean from Santa Cruz Mountains.

Melospiza melodia pusillula. ${ }^{1}$ - Resident in Salicornia marshes about San Francisco bay.

Melospiza melodia morphna: Rusty Song Sparrow. - Winter visitant in Santa Cruz Mountains.

Melospiza lincolnii: Lincoln Sparrow. - Winter visitant.

Melospiza lincolnii striatu: Forbush Sparrow. - Casual winter visitant; marshes.

Passerella iliaca unalaschcensis: 'Townsend Sparrow. - Common winter' visitant in valley and Tanta Cruz Monntains.

Pipilo maculatus megalonyx: Spurred Towhee. - Abundant resident in valley and in Santa Cruz Mountains.

Pipilo fuscus crissalis: California Towhee. $-\Lambda$ bundant resident in valley and monntains.

1 A local race not yet acted upon by A. O. U. committee. 
Zamelodia melanocephala: Black-headed Grosbeak. - Abundant spring and summer visitant; departs after nesting.

Cyanospiza amona : Lazuli Bunting. - A common summer visitant during nesting season.

P'iranga ludoviciana: Louisiana Tanager. - Oceurs in Santa Cruz Mountains during migrations.

Progne subis hesperia: Western Martin. - Reported from Mount Hamilton range.

Petrochelidon lunifrons: Cliff Swallow. - Common summer visitant.

Hirundo erythrogastra : Barn Swallow. - Summer resident.

Tachycineta bicolor: Tree Swallow. - Abundant in spring and summer; rare in winter.

Tachycineta thalassina lepida: Northern Violet-green Swallow. - Common summer visitant.

Stelgidopteryx serripennis: Rough-winged Swallow. - Reported as breeding at San José (J. Van Denburgh); migrant at Palo Alto.

Ampelis cedrorum: Cedar Waxwing. - Irregular winter visitant.

Phainopepla nitens: Phainopepla.- Recorded from near San José.

Lanius ludovicianus gambeli: California Shrike. - Abundant resident in valley.

Tireo gilvus: Warbling Vireo. - Common summer visitant.

Tireo huttoni: Hutton Vireo. - Abundant resident in Santa Cruz Mountains ; common summer visitant in valley.

Vireo solitarius cassinii : Cassin Vireo.- Summer visitant in Santa Cruz Momintains.

Helminthophila celata lutescens : Lutescent Warbler. - Summer visitant on chaparral slopes of Santa Cruz Mountains.

Dendroica restiva: Yellow Warbler. - Abundant summer resident.

Dendroica auduboni : Audubon Warbler. - Abundant winter visitant.

Dendroica coronata: Mrrtle Warbler. - Rather common winter visitant.

Dendroica nigrescens: Black-throated Gray Warbler. - Reported from Mount Hamilton Range.

Dendroica townsendi: Townsend Warbler. - Common winter visitant in Santa Cruz Mountains and about Monterey Bay.

Dendroica occidentalis: Hermit Warbler. - Occurs rarely during migrations.

Geothlypis tolmiei: Tolmie Warbler. - Recorded from Los Gatos; rare.

Geothlypis trichas sinuosa: ${ }^{1}$ Western Yellow-throat. - Breeds about edges of marshes of San Franciseo Bar.

Icteria virens longicauda : Long-tailed Chat. - Summer visitant along watercourses.

Wilsonia pusilla pileolata: Pileolated Warbler.-Common in copses and willow thickets.

Anthus pensilvanicus : American Pipit. - Abundant during winter months.

Cinclus mexicanus: Water Ouzel. - Permanent resident on streams in Santa Cruz Mountains.

Mimus polyglottos leucopterus: Westeru Mockingbird. - Occasional visitant at Stanford University.

Toxostoma redivivum : Californian Thrasher.-Common resident in thickets.

Salpinctes obsoletus : Rock Wren. - Permanent resident in eastern and southern valley foothills. in dry, rocky places.

Catherpes mexicanus punctulatus: Dotted Canyon Wren. - Breeds in foothills east of San José.

1 Occidentalis of authors. This form has not been acted upon by the A. O. U. committee. It is nearer arizela than occidentalis. 
Thryomanes bewickii spilurus: Vigors Wren. - Common resident.

Troglodytes aëdon parkmanii: Parkman Wren. - Summer visitant among live-oaks.

Olbiorchilus hiemalis pacificus : Western Winter Wren. - Resident in the Santa Cruz Mountains.

Cistothorus palustris paludicola: Tule Wren.-Resident on Salicornia marshes; breeds in scirpus patches altogether.

Certhia familiaris occidentalis: Californian Creeper. - Resident in Santa Cruz Mountains.

Sitta carolinensis aculeata: Slender-billed Nuthatch. - Resident in Santa Cruz Mountains; oaks.

Parus inornatus : Plain Titmouse. - Permanent resident among live, white, and blue oaks.

Parus rufescens barlowi: ${ }^{1}$ Barlow Chickadee. - Resident in Santa Cruz Mountains, migrating to the valleys in winter.

Chamce fasciata intermedia : 2 Wren-Tit. - Common permanent resident of Santa Cruz Mountains and of valley. Found usually on chaparral hills. Psaltriparus minimus californicus : California Bush-Tit. - Common permanent resident.

Regulus satrapa olivaceus: Western Golden-crowned Kinglet. - Winter visitant in Santa Cruz Mountains.

Regulus calendula: Ruby-crowned Kinglet. - Abundant winter visitant in valley and Santa Cruz Mountains.

Regulus calendula grinnelli : Sitkan Kinglet. - Winter visitant to Santa Cruz Mountains and to Monterey.

Polioptila corulea obscura: W'estem Gnatcatcher. - Recorded from near Mount Hamilton.

Myadestes townsendii: Townsend Solitaire. - Fairly common winter visitant to Santa Cruz Mountains.

Hylocichla ustulata: Russet-backed Thrush. - Abundant summer visitant, arriving in A pril.

Hylocichla guttata: Alaska Hermit Thrush. - Abundant winter visitant in vallev and Santa Cruz Mountains.

Iylocichla guttata slevini: ${ }^{3}$ Monterey Hermit Thrush. - Summer visitant in Santa Cruz Mountains, south in humid belt, along coast.

Merula migratoria propinqua: Western Robin. - A very abundant winter visitant.

Ixoreus nevius: Varied Thrush. - Abundant winter visitant: November till last of Marcl.

Sialia mexicana occidentalis: Western Bluebird. - Common resident.

Sialia arctica: Mountain Bluebird. - Rare or casual winter visitant.

\section{LIST OF BIRDS TO BE LOOKED FOR IN THE VICINITY OF PASADENA.}

By Joseph Grinnell.

This list includes only such species as are believed to be of more or less regular occurrence within a radius of ten miles of Pasadena.

1 A form occupying the Santa Cruz Mountain district and distinguished from neglectus by absence of brown on flanks.

2 Not yet acted on by A. O. U. committee. (F. M. B.)

3 This remarkable little thrush has been recently described by Joseph Grimell, and can be at once distinguished by its very small size and pale coloring. (The Auk, July, 1901, xviii. 258.) 
This area consists of 'mountains' (Sierra Madre), and 'valley' ('心an Gabriel). The mountains are divided into spruce-wooded 'higher mountains,' such as Wilson's Peak and Mt. Lowe, and brush-covered 'foothills.' The valley is separated into a 'mesa,' the dry elerated plain sloping down from the foothills; and the 'lowlands,' which include the 'willow bottoms,' such as the San Gabriel river bed in the neighborhord of El Monte. The 'oak regions' occupy an intermediate area, in places running up on to the foothills.

In general, as far as I know, it may be said that the 'lowlands,' the 'mesas,' and tongues extending up into the foothills are Lower Sonoran; that the 'oak regions,' and 'foothills,' and even the hot slopes of the highest peaks, are Upper Sonoran: while the north slopes and deep canyons of the 'mountains' to their summits, within the ten mile radius of the list, are mainly Transition, but with a trace of Canadian, and with such characteristic birds as the mountain chickadee, blue-fronted jay, plumed partridge, junco, and slenderbilled nuthatch. Pasadena itself is Lower Sonoran, having such birds as the phainopepla, mockingbird, road-runner, Texas niglithawk, and Costa hummingbird.

Aichmophorus occidentalis: Western Grebe. - Oecasional winter visitant on the larger ponds.

Podilymbus podiceps: Pied-billed Grebe.-Fairly common resident on tule-margined ponds.

Gavia imber: Loon. - Frequent in winter on large ponds and reservoirs.

Larus californicus: California Gull. - Occasional in winter about ponds and streams.

Phalacrocorax dilophus albociliatus: Farallone Cormorant. - Frequent in winter on the larger ponds.

Pelecanus erythrorhynchos: American White Peliean. - Occurs in migration; also more rarely about ponds in winter.

Merganser serrator: Red-breasted Merganer - Occasional midwinter visitant on the lowlands.

Anas boschas: Mallard. - Fairly common resident in the vicinity of streams and ponds.

Mareca americana: Baldpate. - Common winter visitant.

Nettion carolinensis: Green-winged Teal. - Common winter visitant.

Querquedula cyanoptera: Cinnamon Teal. - Common spring and summer visitant on ponds and marshes.

Spatula clypeata: Shoveller. - Common winter risitant.

Erismatura jamaicensis: Ruddy Duck. - Common resident on the larger ponds.

Botaurus lentiginosus : American Bittern. - Common winter visitant on marsh lands.

Ardea herodias: Great Blue Heron. - Common resident in the lower conntry.

Ardea virescens anthonyi : Anthony Green Heron. - Common migrant about streanı and ponds. 
Nycticorax nycticorax ncevius: Black-crowned Night Heron. - Common migrant about streams and ponds.

Grus mexicana: Sandhill Crane. - Common in migration and occasional during winter.

liallus virginianus: Virginia Rail. - Fairly common migrant on marsh lands and along streams.

I'orzuna carolina: Siora. - Fairly common resident of marsh lands.

Gallimula galeata: Florida Gallinule. - Fairly common resident on the larger tinle-bordered ponds.

Fulica americana: American Coot. - Common resident on any body of water.

IIimantopus mexicanus : Black-necked Stilt. - Fairly common migrant in the lower comintry.

Grallinago delicata: Wilson Snipe. - Fairly common winter visitant to lower grass lands.

Tringa minutilla: Least Sandpiper. - Fairly common migrant and winter visitant about streams and ponds.

Tringa alpina pacifica: Red-backed Sandpiper.-Occasional migrant, occurring at ponds.

Helodromas solitarius cinnamomeus : Western Solitary Sandpiper. - Fairly common migrant along streams.

Actitis macularia: Spotted Sandpiper-Common migrant, occurring abont any ponds or streams.

Egialitis vorifera: Killdeer. - Abundant resident on any marsh lands.

Oreortyx pictus plumiferus: Plumed Partridge. - Common resident of the monntains; occasional along their bases.

Lophortyx californicus vallicola: Valley Partridge. - Abundant resident of brush lands.

Columba fasciata: Band-tailed Pigeon. - Common winter visitant to the oak regions.

Zenaidura masmora: Monrning Dove. - Abundant resident everywhere.

Gymmgyps californianus: California Vulture. - Fairly common resident of the mountains.

Cathartes aura: 'Turkey Vulture. - Abundant resident everywhere.

Circus hudsonius: Marsh Hawk. - Common resident in the lower country.

Acripiter velox: Sharp-shinned Hawk.-Common winter visitant everywhere.

Accipiter cooperii: Cooper Hawk. - Fairly common resident along the foothills.

Buten borealis calurus: Western Red-tail.-Common resident everywhere.

Buter limeatus elegans: Red-bellied Hawk. - Fairly common resident in the lown comotry.

Buter suainsomi : Cwainson IIawk. - Common spring and summer visit:ant.

Aquilu rhrysurtos : Crolden Eagle. - Fairly common resident of the mountiains.

Fulco mericums : P'airic Falcon. - Rane visitant to the foothill regions.

Fulco columbarins: Pigen II:twk, - Fairly common winter visitant.

Fulen spurierius deserticolu: I teseret Sipanow Hawk. - Abundant resident averywhire.

Strix juratimola: Ameriean Bann ()wl, - Common resident of the oak repgions.

Asio wilsmiamus: American Long-eared Owl. - Fairly common resident of the lowlands. 
Asio accipitrinus: Short-eared Owl. - Rare winter visitant to the lowlands.

Syrnium occidentale: Spotted Owl. - Resident of the mountains; perhaps fairly common, though not often met with.

Megascops asio bendirei: California Screech Owl. - Common resident everywhere.

Bubo virginianus pacificus: Pacific Horned Owl. - Fairly common resident in the oak region.

Speotyto cunicularia hypogcea: Burrowing Owl. - Common resident of the mesas and lowlands.

Glaucidium gnoma: Pygmy Owl. - Resident of the mountains; perhaps fairly common, thongh by natnre of its habits not of ten seen.

Geococcyx californianus: Road-rumer. - Fairly common resident of the mesas and foothills; rapidly becoming scarce.

Coccyzus americanus occidentalis : Cahifornia Cuckoo. - Rare summer visitant to the willow bottoms.

Ceryle alcyon: Belted Kingfisher. - Common migrant, appearing at reservoirs and along streams.

Dryobates villosus hyloscopus: Cabanis Woodpecker. - Fairly common in the mountains; resident.

Dryobates pubescens turati: Willow Woodpecker. ${ }^{1}$ - Fairly conmon in the willow regions; resident.

Dryobates muttallii: Nuttall Woodpecker. - Common resident in the oak and foothill regions; visits the willow bottoms in fall and winter.

Xenopicus albolarvatus: White-headed Woodpecker. - Fairly common resident in the higher mountains.

Sphyrapicus varius muchalis: Red-naped Sapsucker. - Rare midwinter visitant along the foothills.

Sphyrapicus varius daggetti: ${ }^{2}$ Sierra Sapsucker. - Common winter visitant, often about orchards and on pepper-trees along the city streets.

Sphyrapicus thyroideus: Williamson Sapsucker. - Rare winter visitant on the mountains.

Melanerpes formicivorus bairdi: Californian Woodpecker. - Common resident of the oak regions.

Melanerpes torquatus: Lewis Woodpecker. - Fairly common winter visitant to the oak regions.

Colaptes cafer collaris: Red-shafted Flicker. - Common resident of both the mountains and lowlands.

Phalcenoptilus muttallii californicus: Dusky Poor-will. - Common resident of the foothills.

Chordeiles acutipennis texensis : Texas Nighthawk. - Common summer visitant, chiefly on the dry mesas.

Chatura vauxii: Vanx Swift. - Common migrant along the foothills.

Aëronautes melanoleucus: White-throated Swift. - Fairly common, except in midwinter, along the foothills and in the mountains.

Trochilus alexandri: Black-chinned Hummingbird. - Common summer visitant along the foothills and in the momntain canyons.

Calypte coste: Costa Hnmmingbird. - Common summer visitant to the dry mesas.

Calypte anna : Anna Hummingbird. - Common resident anywhere.

Selasphorus rufus: Rinfous Hummingbird. - Common migrant everywhere.

Selasphorus alleni: Allen Hummingbird. - Fairly common spring migrant along the foothills.

${ }^{1}$ Not yet acted on by A. O. U. committee. (F. M. B.) $\quad$ S. ruber of the Check-List. 
Stellula calliope: Calliope Hummingbird. - Fairly common summer visitant on the mountains.

Tyrannus verticalis : Arkansas Kingbird. - Common snmmer visitant to the valley.

Tyrannus vociferans : Cassin Kingbird. - Fairly common winter visitant to the valley.

Myiarchus cinerascens : Ash-throated Flycatcher. - Fairly common summer visitant in the oak and foothill regions.

Sayornis saya: Say Phobe. - Common winter visitant to the valley.

Sayornis nigricans semiatra: Western Black Phœbe.-Common resident of the valley.

Contopus borealis: Olive-sided Flycatcher. - Fairly common summer visitant on the monntains; migrant throngh the valley.

Contopus richurdsomii: Western Wood Pewee. - Common summer visitant to the canyons and momntains.

Empidonax difficilis: Western Flycatcher. - Common summer visitant to the mountain canyous.

Empidonax traillii: Traill Flycatcher. - Common summer visitant to the willow bottoms.

Empidonax hammondi: Hammond Flycatcher. - Fairly common migrant along the foothills.

Empidonax griseus: Gray Flycatcher, - Rare winter visitant to the valley.

Otocoris alpestris artia : California Horned Lark. ${ }^{1}$ - Common resident of the lowland plains.

Cyanocitta stelleri frontalis : Blue-fronted Jay. - Common resident of the mountains.

Aphelocoma californica : California Jay. - Common resident of the foothill regions.

Corvus corax sinuatus : American Raven. - Erequent but irregular transient visitant to the valley.

Corvus americanus hesperis : 1 California Crow. - Common resident of the lowlands.

Cyanorephalus ryanorephalus: Piñon Jay. - Irregular fall visitant to the mesas and mountains.

Yunthorephulus xunthocephalus: Yellow-headed Blackbird. - Rare and irregular winter visitant.

Igeluius phoniceus neutralis: San Diego Redwing. - Common resident of the lowlands.

Sturnella magna neglesta: Western Meadowlark. - Common resident of the valler.

Irterus rucullatus nelsoni : Arizona Hooded Oriole. - Common summer visitant to the mesas and canyons.

Irterus bullocki : Bullock Oriole. - Common smumer visitant to the valler.

Scolerophagns ryanorephalus: Brewer lBlackbird. - Abundant resident of the lowlands and enltivated mesas.

Coccothraustes vespertinus montanus: Western Evening Grosbeak. - Rare and irregular winter visitant along the nomitains.

Carporlacus purpurens raliformicus : California l'urple Finch. - Fairly (onmom winter visitant to the valley.

Carpordurus cassini: ('assin Purple Finch. - Fairly eommon resident on the higher momntains.

Carporlarus mrxiranus firontalis: Honse Finch, - Abundant resident of the valley everywhere. 
Loxia curvirostra bendirei: ${ }^{1}$ Sierra Crossbill. - Rare and irregular winter visitant.

Astragalinus tristis salicamans: Willow Goldfinch. - Common resident of the lowlands.

Astragalinus psaltria: Arkansas Goldfinch. - Abundant resident of the valley.

Astragaiinns laurencel: Lawrence Goldfinch. - Fairly common spring and summer visitant to the mountains and mesas.

Spimns pinns : Pine Siskin. - Irregular winter visitant anywhere.

Pocectes gramineus confinis: Western Vesper Sparrow. - Fairly common winter visitant on the mesas.

Poncetes gramineus affinis: Oregon Vesper Sparrow. - Fairly common winter visitant to the valley.

Ammodramus sandwichensis alaudinns: Western Savanna Sparrow. Abundant winter visitant to the cowland plains.

Ammodramus savannarnm bimacnlatus: Westem Grasshopper Sparrow. Rare winter visitant to the valley.

Chondestes grammacns strigatns: Western Lark Sparrow. - Common resident of the valley.

Zonotrichia lencophrys gambelii: Intermediate Sparrow. - Abundant winter visitant to the valley.

Zonotrichia coronata : Golden-crowned Sparrow. - Common winter visitant to the foothill regions.

Spizella socialis arizonce: Western Chipping Sparrow. - Common summer visitant everywhere; less common during the winter on the mesas only.

spizella breveri: Brewer Sparrow. - Rare migrant along the foothills.

Spizella atrogularis: Black-chinned Sparrow. - Rare summer visitant on the mountain slopes.

Jnnco hyemalis : Slate-colored Junco. - Rare winter visitant to the valley.

Junco hyemalis thurberi: Sierra Junco. - Common midwinter visitant to the valler; resident in the mountains.

Amphispiza belli: Bell Sparrow. - Fairly common resident on the mesas.

Aimophila ruficeps: Rufous-crowned Sparrow. - Rare resident of the foothills.

Melospiza cinerea cooperi: ${ }^{1}$ San Diego Song Sparrow. - Common resident of the lowlands.

Melospiza lincolnii : Lincoln Sparrow. - Fairly common migrant and winter visitant in the valler.

Passerella iliaca insularis: Kadiak Fox sparrow. ${ }^{1}$ - Common winter visitant on the momntains.

Passerella iliaca megarhyncha: Thick-billed Fox Sparrow. - Fairly common winter visitant on the nountains.

Pipilo maculatns megalonyx: Spurred Towhee.-Common resident of brushlands evervwhere.

Pipito fuscns senicula: Anthony Towhee. - Abundant resident of the valley.

Oreospiza chlorura: Green-tailed Towhee. - Rare migrant along the foothills.

Zamelodia melanocephala: Black-headed Grosbeak. - Common summer visitant to the valley.

Gniraca cernlea laznla: Western Blue Grosbeak. - Rare summer visitant on the mesas.

Cyanospiza amona: Lazuli Bunting. - Common summer visitant to the foothills and mesas.

1 Not yet acted on by A. O. U. committee. (F. M. B.) 
Piranga ludoviciana: Western Tanager. - Common summer visitant on the mountains; common migrant on the mesas.

Progne subis hesperia: Western Martin. - Fairly common summer visitant to the mountains.

Petrockelidon lunifrons : Cliff Swallow. - Abundant migrant and summer visitant to the valley.

Hirundo erythrogastra: Barn Swallow - Fairly common migrant through the valley.

Tachycineta bicolor: Tree Swallow. - Common resident of the lowlands, a few wintering.

Tachycineta thalassina lepida: Northern Violet-green Swallow. - Common summer visitant to the monntains; abundant migrant through the valley. Stelgidopteryx serripennis : Rough-winged Swallow. - Fairly common summer visitant to the mesas.

Ampelis cedrorum: Cedar Waxwing. - Common winter visitant to the valley.

Phainopepla nitens: Phainopepla. - Common summer visitant to the mesas.

Lanius ludovicianus gambeli: California Shrike.-Common resident of the valley.

Vireo gilvus suainsoni: ${ }^{1}$ Western Warbling Vireo. - Abundant migrant through the valley; fairly common summer visitant locally.

Vireo solitarius cassinii: Cassin Vireo. - Common summer visitant in the mountain eanyons.

Vireo huttoni: Hutton Vireo. - Fairly common resident of the oak regions.

Vireo pusillus : Least Tireo. - Common summer visitant to the valley.

Helminthophila rubricapilla gutturalis: Calaveras WVarbler. - Fairly common migrant through the valley.

Helminthophila celata lutescens : Lutescent WTarbler. - Common migrant through the valley; rare summer visitant to the foothills and canyons.

Helminthophila celatu sordida: Dusky Warbler. - Common fall visitant to the valley and foothills.

Dendroica istiva morcomi: ${ }^{2}$ Western Yellow Warbler.-Common summer visitant to the willow bottoms and mountain canyons.

Dendroica coronata: Mrrtle Warbler. - Rare midwinter visitant to the valley.

Dendroica auduboni: Audubon TVarbler. - Abundant winter visitant everywhere.

Dendroica nigrescens : Black-throated Gray Warbler. - Common summer visitant to the monntains; migrant through the valley.

Dendroira tounsendi: Townsend ITarbler. - Fairly common migrant over the mesas and foothills.

Dendroira orcidentalis : Hermit Warbler. - Fairly common migrant along the foothills and mesas.

Geothlypis tolmiei: 'Tolmie Warbler. - Fairly common migrant along the foothills.

Gecothlypis trichas arizela: Pacific Yellow-throat. - Common resident of the lowlands and migrant aloner the foothills.

Geothlypis trichas scirpicola: ${ }^{3}$ 'Tule Yellow-throat. - Common resident of the lowlands.

Icteria virens longicauda: Long-tailed Chat. Fairly common summer visitant to the willow bottoms.

s Not yet acted on by A. O. U. committee. (F. M. B.) 
Wilsonia pusilla pileolata: Pileolated Warbler. - Abundant migrant through the valley; common summer visitant to the willow bottoms.

Anthus pensilvanicus: American Pipit. - Common winter visitant to the lowlands.

Cinclus mexicanus: American Dipper. - Rare resident of the mountain canyons.

Mimus polyglottos leucopterus : IVestern Mockingbird. - Abundant resident of the valley, especially on the mesas.

Toxostoma redivivum pasadenense: Pasadena Thrasher. - Common resident of brush lands anywhere.

Heleodytes brunneicapillus: Cactus Wren. - Rare resident locally on the mesas.

Salpinctes obsoletus : Rock Wren. - Fairly common winter visitant to the valley.

Catherpes mexicanus punctulatus: Dotted Canyon Wren. - Fairly common resident of the mountain canyons.

Thryomanes bewickii charienturus : San Diegan Wren. - Common resident of the mountains; common winter visitant to the brush lands in the valley.

Troglodytes aëdon parkmanï: Parkman Wren. - Fairly common summer visitant everywhere.

Olbiorchilus biemalis pacificus: Western Winter Wren. - Rare midwinter visitant to the mountains.

Cistothorus palustris paludicola: Tule Wren. - Common resident of the lowland marshes.

Certhia familiaris zelotes: Sierra Creeper. - Fairly common resident on the mountains.

Sitta carolinensis aculeata: Slender-billed Nuthatch. Fairly common resident on the mountains.

Sitta canadensis : Red-breasted Nuthatch. -- Irregular winter visitant to the mountains.

Sitta pygmea : Pygmy Nuthatch. - Fairly common resident of the higher mountains.

Parus inornatus : Plain Titmouse. - Common resident of the oak regions.

Parus gambeli: Mountain Chickadee. - Common resident on the mountains.

Chamce fasciata: Wren-Tit. - Common resident of brush lands everywhere.

Psaltriparus minimus californicus: California Bush-Tit. - Abundant resident of the oak regions of the valley and foothills.

Regulus satrapa olivaceus: Western Golden-crowned Kinglet. - Rare midwinter visitant to the mountains and mesas.

Regulus calendula: Ruby-crowned Kinglet. - Abundant winter visitant everywhere.

Polioptila carulea obscura: Western Gnatcatcher. - Common resident everywhere.

Polioptila californica: Black-tailed Gnatcatcher. - Rare resident locally on brushy mesas.

Myadestes townsendii: Towusend Solitaire. - Fairly common winter visitant to the mountains.

Hylocichla ustulata: Russet-backed Thrush. - Common summer visitant to the willow bottoms; migrant along the foothills.

Hylocichla guttata: Alaska Hermit Thrush. - Abundant winter visitant everywhere.

Hylocichla guttata slevini: ${ }^{1}$ Monterey Hermit Thrush. - Rare spring migrant over the mesas.

1 Not yet acted on by A. O. U. committee. (F. M. B.) 
Merula migratoria propinqua: Western Robin. - Common winter visitant to the valley.

Ixoreus navius meruloides: Northern Varied Thrush. - Common midwinter visitant to the mountains and mesas.

Sialia mexicana occidentalis : Western Bluebird. - Common summer visitant on the mountains; common winter visitant to the valley.

Sialia arctica: Mountain Bluebird. - Fairly common midwinter visitant to the valley.

\section{LIST OF THE BIRDS OF FORT SHERMAN, IDAHO.}

From Dr. J. C. Merrill's Notes in The Auk, vol. xiv. 347-357, 1S97, and vol. $\mathrm{xv} .14-22,189 \mathrm{~S}$.

Fort Sherman is in northern Idaho, on Coum d'Alêne Lake, which is encircled by hills clad with conifers, and near the Cour d'Alêne Mountains. The mouths of streams flowing into the lake afford flats with tules, water grasses, willows, and a few cottonwoods, which are frequented by land birds and a few marsh birds and ducks. At the southern end of the lake the marshy valley of the St. Joseph River affords good nesting and autumnal feeding ground for water birds. When the lake is open a few birds remain on it, goirg from it to the spokane River when driven out by ice. The local climatic conditions somewhat resemble those of the Northern Cascade Range, and while the avifauna is essentially that of the Rocky Mountains it has Cascade Mountain elements.

Achmophorus occidentalis : Western Grebe. - A single specimen taken.

Colymbus holbollii : Holbell Grebe. - Resident, bnt most common during migrations.

Podilymbus podiceps:- Pied-billed Grebe.-Conmon on the lake in spring and fall.

Giavia imber: Loon. - Resident and quite eommon except in winter.

Larus argentatus: Herring Gnll. - Several taken on the lake during fall and winter.

Larus delawarensis : Ring-billed Gull. - Fall and winter visitant.

Larus philadelphia: Bonaparte Gull. - One taken and several seen in November.

Sterma. - A small white tern breeds about the lake, but no specimens were taken.

I'halacrocorax dilophus cincinatus: White-crested Cormorant. - Several cormorants, probably of this form, were seen in September.

Merganser americanus: Merganser. - Common during fall and winter.

Merganser serrator: lied-breasted Merganser. - A single specimen taken.

Lophorlytes cucullatus: Hooded Merganser. - The most abundant of the mercansers, frequenting especially the rivers, and in the fall collecting in flocks of forty or fifty individuals.

Anas boschas : Mallard. - The conmonest duck of the vicinity, a few remaining thronghout the winter.

Marera umericana: Baldpate. - Common fall visitant on marshes at southern end of lake. 
Nettion carolinensis : Green-winged Teal. - Quite common, especially during migrations.

Querquedula cyanoptera: Cimamon Teal. - Rare; a female with several roung two or three dars old seen, June 11.

spatula clypeata: Shoveller. - Common; breeds in St. Joseph marshes.

Dafila acuta: Pintail. - C'ommon migrant.

Aix sponsa: Wood Duck. - Common summer visitor, especially abundant in early fall.

Aythya collaris: Ring-necked Dick. - Seems to be more common than the other 'blue-bills,' one or both of which occur but were not certainly identified.

Clangula islandica: Barrow Golden-eye. - Abundant throughout the winter; all the golden-eses seen were of this species, althongh the other doubtless occurs.

Charitonetta albeola: Buffle-head. - Common dnring winter.

Histrionicus histrionicus : Harlequin Duck. - Rare. bnt oceasionally taken on the St. Joseph and Cœull d'Alêne rivers.

Erismatura jamaicensis: Ruddy Duek. - Not uneommon in spring and fall.

Chen sp. ?: Ross snow Goose. - Reported by hunters, but decidedly rare.

Anser albifrons gambeli: White-fronted Goose. - Reported by hunters, but rare.

Branta canadensis: Canada Goose. - Common- in spring, rare in fall. Most abundant goose, especially on prairie at sonthem end of lake; a few nest near the lake; on the fall flight they and many of the ducks pass south orer the open prairie fifty miles west of the lake.

Olor sp.? - In spring swans are sometimes quite common on lake and marshes. No specimens taken.

Botaurus lentiginosus: Bittem. - Rather common in suitable localities about the lake.

Grus mexicana: Sandhill Crane. - Not uncommon migrant; a few probably breed.

Porzana carolina : Sora. - Not rare in marshes; breeds.

Fulica americana: Coot. - Conmon. especially in antumn.

Phalaropus lobatus: Northern Phalarope. - Common fall migrant.

Recurvirostra americana: Arocet. - A pair seen and one taken in September.

Gallinago delicatu: Wrilson snipe. - L'snallỵ rather uncommon migrant.

Macrorhamphus griseus: Dowiteher. - Five taken in September on St. Joseph marshes.

Tringa maculata: Pectoral Sandpiper. - Common in 1896 from last of Angust till early Oetober.

Tringa minutilla: Least Sandpiper. - Three taken in Angnst.

Ereunetes occidentalis: Western Sandpiper, - One taken with the least sandpipers.

Totanus melanoleucus: Greater Yellow-legs. - Rather common fall migrant; one heard in June.

Helodromas soliturius : Solitary Sandpiper. - A young bird taken in Angnst.

Bartramia longicauda: Bartramian Sandpiper. - Breeds not uncommonly on prairie north of fort.

Actitis macularia: Spotted Sandpiper. - Common summer visitor.

Numenius longirostris: Long-billed Curlew. - Not uncommon on prairie.

Squatarola squatarola: Black-bellied Plover. - Fonr taken in September on St. Joseph marshes. 


\section{INTRODCCTION}

Charadrius dominicus : Golden Plover.-- Usually rare.

Egialitis vocifera: Killdeer. - A few pairs breed on the prairie near the Spokane River.

Dendragapus obscurns richardsonii: Richardson Grouse. - Occasionally found about the fort; breeds from lake level to top of mountains.

Canachites franklinii: Franklin Gronse. - Common in surrounding woods.

Bonasa umbellus togata: Canadian Ruffed Grouse. - Exceedingly abundaut.

Pediocetes phasianellus columbianus : Columbian Sharp-tailed Grouse.Quite conmon, particularly about ranches on prairie north of fort; winters in pine woods.

Zenaidura macroura: Mourning Dove. - Not common, but generally alistributed.

Cathartes aura: Turkey Vulture. - A few seen at intervals during the summer.

Circus hudsonius : Marsh Hawk. - Not uncommon in autumn.

Accipiter velox: Sharp-shimed Hawk. - One taken in May.

Accipiter atricapillus: Goshawk. - Rather conmon in migrations and winter, and probably breeds.

Buteo swainsoni: Swainson Hawk. - A young bird taken in September.

Archibuteo lagopus sancti-johannis: Rough-legged Hawk. - Occasionally seen in spring and fall.

Aquila chrysaëtos: Golden Eagle. - Occurs sparingly throughout the year.

Halicetus leucocephalus: Bald Eagle. - A few pairs breed abont the lake; an adult seen in February.

Falco mexicamis: Prairie Falcon. - Rare; taken in September.

Fulco richarásonii: Richardson Merlin. - Taken in August and October.

Falco sparverius deserticola: Desert sparrow Hawk. - Summer resident.

P'andion haliä̈tus carolinensis : Fish Hawk. - Frequentḷ seen in summer.

Asio wilsonians: Lomg-eared Owl. - A single specimen examined.

Asio accipitrinns: Short-eared Owl. - Often flushed on prairie and marslies.

Nyctala tengmalmi richardsoni: Richardson Owl. - Three specimens seen.

Nyctala acrdira: Saw-whet Owl. - A specinen taken in January. Notes frequently heard in spring.

Megascops asio subsp. ? - Screech owls occasionally heard, doubtless macfurlauei. Apparently quite rare.

Bubo virginiamss pallescens: Western Horned Owl.

Bubo virginianns saturatus: Dnsky Horned Owl. - Both forms of the great horned owl oceur eommonly.

Vyctea nyctea: Snowy Owl - Irregular winter visitor.

Glancidium gnoma: I’ygmy Owl. - A not nncommon resident.

Corryzus amrricams orcidentulis: California Cuckoo. - One seen in July.

Coryle alcyon: Belted Kingfisher. - Common in summer ; a few winter.

Irigubutes villosus hyloscopus: ('abanis Woodpecker. - Abundant in winter ; breeds sparingly.

Dryobates pulossens himorus: Batchelder Woodpecker, - Rather unconnoon resident.

Trnonirns albolareatus: White-headed Woodpecker. - Rare resident.

Pirvides arcticus: Aretic 'Three-toed Woodpecker. - Fairly common resident.

Siphyrupirns varius muhulis: Red-naped Sapsucker. $-\mathbf{A}$ few pairs breed anomg the cottunwoorls. 
Sphyrapicus thyroideus: Williamson Sapsucker. - Seen near Cœur d'Alêne.

Ceophlous pileatus abieticola: Pileated Woodpecker. - Rather common resident.

Melanerpes torquatus: Lewis Woodpecker. - Summer resident, breeding in cottonwoods and pines.

Colaptes cafer collaris: Red-shafted Flicker.-Common summer resident.

Chordeiles virginianus: Nighthawk. - Conmon summer resident.

Chetura vauxii: Vaux Swift. - Seen in May and July; some probably breed.

Trochilus alexandri: Black-chinned Hummingbird. - Fairly common in spring; a few remain to breed.

Selasphorus rufus: Rufous Hummingbird. - Conmon spring migrant; probably breeds.

Stellula calliope: Calliope Hummingbird. - Common summer resident.

Tyrannus tyrannus : Kingbird. - Fairly common summer resident.

Tyrannus verticalis: Arkansas Kingbird. - Rare; a pair or two breed near the fort.

Sayornis saya: Say Flyeatcher. - Common at Cœur d'Alêne.

Contopus borealis: Olive-sided Flycateher. - Breeds sparingly on hillsides.

Contopus richardsonii : Western Wood Pewee. - Very common in pines and cottonwoods.

Empidonax hammondi: Hammond Flycatcher. - Common summer resident among cottonwoods and willows along the river and near swamps.

Empidonax wrightii: Wright Flycateler. - A single specimen taken in IIay.

Otocoris alpestris arcticola: Pallid Horned Lark. - One specimen taken in September.

Otocoris alpestris merrilli: Dusky Horned Lark. - Common in spring and summer.

Pica pica hudsonica: Magpie. - Not uneommon in winter.

Cyanocitta stelleri annectens : Black-headed Jay. - Fairly common in spring and fall, a few wintering.

Perisoreus canadensis capitalis : Rocky Mountain Jay. - Rather common resident.

Corvus corax sinuatus: Raven, - Probably resident.

Corvus americanus: Crow. - Common during nigrations, a few pairs breeding.

Nucifraga columbiana: Clarke Nutcracker. - Irregular visitant; abundant in good pine cone winters.

Dolichonyx oryzivorus: Bobolink. - Breeds on St. Joseph River.

Molothrus ater: Cowbird. - Rare.

Agelaius phoeniceus caurinus: Northwestern Red-wing. - Breeds sparingly about the lake.

Sturnella magna neglecta: Western Meadowlark. - Common in summer.

Icterus bullocki: Bullock Oriole. - Breeds sparingly in cottonwoods along. the river.

Scolecophagus cyanocephalus: Brewer Blackbird. - A few breed along the river.

Coccothraustes vespertinus montanus: Western Evening Grosbeak. - Probably common, but irregular summer visitor.

Carpodacus cassini: Cassin Finch. - Abundant summer resident.

Loxia curvirostra menor: Crossbill. - Irregular visitor, breeding in hills. 
Leucosticte tephrocotis littoralis: Hepburn Lencosticte. - Apparently an irregnlar fall and winter visitant.

Acanthis linaria: Redpoll. - IVinter visitant.

Astragaliuus tristis : Goldfinch. - A fairly common summer resident.

Spinus pinus: Pine Siskin. - Resident.

Passerina nivalis: Snowflake. - An irregular winter visitor.

Calcarius lapponicus: Lapland Longspur. - A single specimen taken in November.

Poocetes gramineus confinis: Western Vesper Sparrow. - Breeds sparingly.

Ammodramus sandwichensis alaudinus : Western Savanna Sparrow. - Common migrant, a few breeding.

Ammodramus leconteii: Leconte Sparrow. - A single specimen taken.

Zonotrichia leucophrys gambelii: Gambel sparrow. - Fairly common migrant.

Spizella monticola ochracea: Western 'Tree Sparrow. - Rare in winter.

Spizella socialis arizonce: Western Chipping Sparrow. - One of the commonest summer residents.

Junco hyemalis connectens : Intermediate Junco. - Migrant.

Melospiza fasciata merrilli: Merrill Song Sparrow. - Common summer visitor.

Passerella iliaca schistacea : Slate-colored Sparrow. - Rare migrant.

Pipilo maculatus megalonyx: Spurred Towhee. - Generally but sparingly distributed in summer.

Zamelodia melanocephala: Black-headed Grosbeak. - Not uncommen.

Cyanospiza amona: Lazuli Bunting. - Not common.

Piranga ludoviciana : Lonisiana Tanager. - Common in migrations; a few breed.

Petrochelidon lunifrons: Cliff Swallow. - Common summer visitor.

Hirundo erythrogastra: Barn Swallow. - Occasionally seen near prairie in summer.

Tachycineta bicolor: White-bellied Swallow. - Breeds abundantly in cottonwoods.

Riparia riparia: Bank Swallow. - Breeds on Coenr d'Alêne River. Ampelis garrulus: Bohemian Waxwing. - Irregular winter visitant. Ampelis cedrorum: Cedar Waxwing. - Common summer resident.

Lanius borealis: Northern Shrike.-Common in fall; a few winter.

Tireo olivaceus: Red-eyed Vireo. - Abundant summer visitor.

Vireo gileus: Warbling Vireo. - Breeds somewhat sparingly.

Tireo solitarius cassinii: Cassin Vireo. - Breeds in moderate numbers.

Helminthophila rulricapilla gutturalis: Calaveras Warbler. - Breeds.

IIelminthophlila celata lutescens: Lutescent Warbler. - Several taken in May.

Dendroira astiva: Yellow Warbler. $-\Lambda$ bundant summer resident.

Dentroica auduboni: Audnbon Warbler. - Summer resident.

Dendroicn tournsendi: 'Townsend Warbler. - Breeds.

Geothlypis tolmiei: Macgillivray Warbler. - Breeds rather commonls.

Geothlypis trichas ocridentalis: Westem Yellow-throat. - Breeds sparingly.

Irteria virens longicauta: Long-tailed Chat. - Conmon at Cour d'Alêne.

IVilsomia pusilla pileoluta: P'ileolated Warbler. - Oecasional migrant.

sirtopherga ruticilln: Rendstart. - A bundant smmmer visitor.

Anthus pensilmanirus: I'ipit. - Rare in spring, abundant in fall.

Cinclus mexicunus: I)ipper. - Fairly common.

Galerseroptes curolineusis: Catbird. - Common summer visitor.

Salpiurtes obsoletus: liock IVren. $-\Lambda$ pair fomnd, evidently nesting. 
Troglodytes aëdon parkmanii: Parkman Wren. - Breeds rather commonly.

Olbiorchilus hiemalis pacificus: Western Winter Wren. - Rather common resident.

Cistothorus palnstris paludicola: Tule Wren. - Rare in fall.

Certhia familiuris montana: Rocky Mountain Creeper. - Abundant iu winter.

Sitta carolinensis acnleata: Slender-billed Nuthateh. - Breeds rather sparingly.

Sitta canadensis: Red-breasted Nuthatch. - Common winter resident, breeding less plentifully near the fort.

Sitta pygmea: Pygmy Nuthatch. - Most abundant resident.

Parus atricapillns: Chickadee. - A common resident.

Purus gambeli: Momntain Chickadee. - Abundant resident.

Purns rufescens : Chestmut-backed Chickadee.- Resident.

Regulus satrapa olivacens: Western Golden-crowned Kinglet. - Resident.

Regulus calendula: Ruby-crowned Kinglet. - simmer resident.

Myadestes townsendii: Solitaire. - Not uncommon migrant, one pair found breeding.

Hylocichla fuscescens salicicola: Willow Thrush. - Rather common summer resident among cottonwoods.

Hylocichla ustulata almce : Alma Thrush. - Breeds rather commonly about the lake and on momntain.

Merula migratoria propinqua: Westeru Robin. - Abundant summer resident.

Ixorens ncevins: Varied Thrush. - Migrant.

Sialia mexicana bairdi: Chestmnt-backed Bluebird. - Abundant summer resident.

Sialia arctica : Mountain Bluebird. - Summer resident.

\section{LIST OF BIRDS OF CHEIENNE AND VICINITY.}

\section{Br Frank Boxd.}

Chesenne is located in the midst of the Great Plains region, a little over 6000 feet above the ocean, with an annual rainfall of thirteen inches. The plains around Cheyenne are drained by streams fringed by cottonwools and willows which attract the migrants. One of these streams flows through the city, which by persistent arboriculture las been made an immense grove of trees, an oasis in the desert. Five small lakes, from within the city limits to a mile and a half beyond, offer resting places to waterfowl of all descriptions. The mountain range twenty miles west of the city, acting as a barrier to flight, completes the conditions which gire Cheyenne a peculiar and diversified avifauna. The list covers a radius of about three miles from the ciț limits

Echmophorns occidentatis : Western Grebe. - Rare visitant.

Colymbns holbollii : Holbœll Grebe. - Rare visitant.

Colymbns migricollis californicus : Eared Grebe.-Common during migrations.

Gavia imber : Loon. - Not common but tolerably regular visitor during migrations. 
Larus argentatus: Herring Gull. - Rare visitor.

Larus delawarensis: Ring-billed Gull. - Common during nigrations.

Larus philadelphia: Bonaparte Gull. - Regular but not very common visitor.

Sterna forsteri: Forster Tern. - Rare visitor.

Sterna hirundo : Conmon Tern. - Occasional visitor.

Hydrochelidon nigra surinamensis: Black Tern. - Regular visitor.

Pelecanus erythrorhynchos: White Pelican. - Oceasional visitor.

Pelecanus occidentalis : Brown Pelican. - One specimen taken in 1900.

Merganser americanus: Merganser. - Not common; sometimes winters at springs in Laramie County.

Lophodytes cucullatus: Hooded Merganser. - Rare.

Anas boschas: Mallard. - Common migrant.

Chaulelasmus streperus: Gadwall. - Common.

Mareca americuna: Baldpate. - Common.

Nettion carolinensis: Green-winged Teal. - Common.

Querquedula discors: Blue-winged Teal. - Common.

Querquedula cyanoptera: Cinnamon Teal. - Occasional on city reservoirs.

Spatula clypeata: Shoveller. - Common. The blue and green winged teal and the shoveller breed commonly in suitable localities a few miles from town.

Dafila acuta: Pintail. - Common.

Aix sponsa: Wood Duck. - Very rare visitor.

Aythya americana: Redhead. - Common migrant.

Aythya vallisneria: Canvas-back. - Common migrant, but not so common as the redhead.

Aythya marila: Scaup Dnck. - Not common.

Aythya affinis: Lesser Scaup Duck. - Rare.

Aythya collaris: Ring-necked Duck. - Not common.

Clangula clangula americana: American Golden-eye. - Rare.

Clangula islandica: Barrow Golden-eve. - Rare.

Charitonetta albeola: Buffle-head. - Tolerably common.

Oidemia americuna: Seoter. - Rare.

Erismatura jamaicensis : Ruddy Duck. - Very common migrant.

Chen hyperborea: Lesser Snow Goose. - Rare visitor.

Anser albifrons gumbeli: White-f ronted Goose. - Rare visitor.

liranta canadensis: Canada Goose. - Not common.

Branta canadensis hutchinsii: Hutchins Goose. - Common for the species.

Olor columbianus: Whistling Swan. - Rare.

Ardea herodias: Great Blue Heron. - Common, for the species.

Nycticorax nycticorax nevius: Black-crowned Night Heron. - Not common.

Porzana carolina: Sora. - Tolerably common.

Fulica americana: Coot. - Very common.

I'halaropus lobatus: Northern Phalarope. - Rare.

Steganopus tricolor: Wilson Phalarope. - Tolerably common; breeds abmndantly on Latramie plains fifty miles west of cheyeme.

Lienrvirostra americana: Avocet. - Tolerably common for the species during migrations.

Gallinago delirata: Wilson Snipe. - Not very common.

Macrorhamphlus scolopacens: Long-billed Dowitcher. - Rare.

Mirropaluma himantopus: Stilt Sandpiper. - Very rare.

Tringa bairdii: Baird Sandpiper. - Very common.

Tringa minutilla: Least Sandpiper. - Very common.

Limosa fidoa: Marbled Godwit. - Tolerably common。 
Totanus melanoleucus: Greater Yellow-legs. - Rare.

Totanus flavipes : Yellow-legs. - Tolerably common.

Symphemia semipalmata inornatu: Western Willet. - Common migrant.

Bartramia longicauda: Bartramian Sandpiper. - Not common.

Actitis macularia : Spotted Sandpiper. - Common; breeds.

Numenius longirostris : Long-billed Curlew. - Common migrant.

Squatarola squatarola: Black-bellied Plover. - Rare.

Charadrius dominicus: Golden Plover. - Rare.

Egialitis vocifera: Killdeer. - Common; breeds.

Egialitis semipalmata: Semipalmated Plover. - Rare.

Egialitis meloda circumcincta: Belted Piping Plover. - Rare.

Egialitis nivosa: Snowy Plover. - Rare.

Egialitis montana: Mountain Plover. - Common.

Zenaidura macroura: Monrning Dove.-Comnon; breeds.

Cathartes aura: Turkey Vulture.-Rare.

Accipiter velox: Sharp-shimned Hawk.- Tolerably common.

Accipiter cooperii : Cooper Hawk. - Not common.

Buteo borealis calurus : Western Red-tail. - Not common.

Buteo swainsoni : Swainson Hawk. - Tolerably common.

Archibuteo ferrugineus : Ferruginous Rough-leg. - Common.

Halicetus leucocephalus : Bald Eagle.- Rare.

Falco mexicanus: Prairie Falcon.-Common.

Falco peregrinus anatum : Dnck Hawk.- Rare.

Falco sparverius : Sparrow Hawk. - Common; breeds.

Pandion haliaëtus carolinensis : Ospres. - Not common.

Asio wilsonianus: Long-eared Owl.-Common.

Asio accipitrinus: Short-eared Owl. - Rare.

Nyctala acadica: Saw-whet Owl. - Not common.

Nyctea nyctea: Snowy Owl. - Rare.

Speotyto runicularia hypogcea: Burrowing Owl. - Common ; breeds.

Ceryle alcyon: Belted Kingfislier. - Tolerably common.

Sphyrapicus thyroideus: I! illiamson Sapsucker. - Rare.

Melanerpes erythrocephalus: Red-headed Woodpecker. - Tolerably common.

Melanerpes torquatus: Lew is Woodpecker. - Occasional visitor.

Colaptes cafer collaris: Red-shafted Flicker. - The most common woodpecker.

Phalcenoptilus nuttallii: Poor-will. - Not common.

Chordeiles virginianus henryi: Western Nighthawk. - Common.

Selasphorus platycercus: Broad-tailed Hummingbird. - Not very common.

Selasphorus rufus: Rufons Hnmmingbird. - Not very common.

Tyrannus tyrannus : Kingbird. - Common; breeds.

Tyrannus verticalis: Arkansas Kingbird. - Most common kingbird; breeds.

Tyranmus vociferans: Cassin Kingbird. - Not common.

Myiarchus cinerascens : Ash-throated Flycatcher. - Rare.

Contopus borealis : Olive-sided Flycatcher. - Not common.

Contopus richardsonii: Western ITood Pewee. - Tolerably common.

Empidonax traillii: Traill Flycatcher - Rare.

Empidonax minimus: Least Flycatcher. - Tolerably common.

Pica pica hudsonica: Magpie. - Rare in the city.

Cyanocitta stelleri diademata: Long-crested Jay. - Rare in the city.

Nucifraga columbiana: Clarke Nuteracker. - Autmmul flocks of young tolerably common.

Cyanocephalus cyanocephalus : Piñon Jay. - Regular autumn visitor, sometimes wintering. 
Dolichonyx oryzivorus: Bobolink. - Occasional summer resident.

Molothrus ater: Cowbird. - Common summer resident.

Tanthocephalus xanthocephalus: Yellow-headed Blackbird. - Not common.

Agelaius phoniceus: Red-winged Blackbird. - Common summer resident. Sturnella magna neglecta: Western Meadowlark. - Common summer resident.

Icterus bullocki: Bnllock Oriole : Tolerably common summer resident.

Scolecophagus cyanocephalus : Brewer Blackbird. - Common.

Quiscalus quiscula ceneus: Bronzed Grackle. - Rare.

Coccothranstes vespertinus montamus: Westem Evening Grosbeak. - Visitant; does not breed.

Carpodacus mexicanus frontalis: Honse Finch. - Abundant summer resident; sometimes also winter resident.

Leucosticte tephrocotis: Gray-crowned Leucosticte. - Frequent winter visitor.

Acanthis linaria: Redpoll. - Occasional winter visitor.

Astragalinus tristis : Goldfinch. - Common summer resident.

Astragalinus psaliria: Arkansas Goldfinch. - One taken in Cheyenne.

spinus pinus : Pine Siskin. - Regular autumn visitor.

Pusserinu nivalis: Snowflake. - Regular winter visitor, often in very large flocks.

Calcarius ornatus: Chestnut-collared Longspmr. - Summer resident; not common.

Rhynchophanes mccownii: McCown Longspme. - Abundant summer resident.

Poccetes gramineus confinis: Western Vesper Sparrow. - Common migrant; probably breeds near.

Ammodramus sandwichensis alaudinus: Western Savanna Sparrow. - Common migrant.

Chondestes grammacus strigatus: Western Lark Sparrow. - Common migrant.

Zonotrichia lencophrys gambelii: Gambel Sparrow. - Common migrant.

Spizella monticola ochracea: Western Tree Sparrow. - Common migrant. spizella socialis arizona: Western Chipping Sparrow. - Tolerably common migrant.

Spizella pallida: Clay-colored Sparrow.-Common ; probably breeds.

Spizellu breueri: Brewer Sparrow. - Tolerably common.

Junco hyemalis: Slate-colored Junco. - Tolerably common.

Jinco hyemulis connectens: Intermediate Junco. - Tolerably common.

Junco merrnsi: Pink-sided Junco. - Common migrant.

Amphispiza belli nevadensis: Sage Sparrow. - Rare visitor.

Melospiza melodia montana: Mountain Song Sparrow. - Tolerably common migrant.

Melospiza lincolnii: Lineoln Sparrow. - Common migrant.

Oreospiza chlorura: Green-tailed Towhee. - Common migrant.

Zamelortia melanocephula: Black-hearled Grosbeak. - Occasional city visitor only.

Cyanospiza amona : Lazuli Bunting. - Summer resident; not many nest.

Calamospiza melanocorys : Latk Bunting. - Abundant; breeds.

T'iranga ludoviciana: Louisiana 'Tanager.-Common migrant.

Piranga erythomelas: Scarlet 'Tanager. - Rine visitor.

Proyne subis: Purple Martin. - Rare visitor.

I'etrorkelidon lunifrons: ('liff Kivallow. - Common; breeds.

IVirundo erythrogastra: Barn Swallow. - Common; breeds. 
Tachycineta bicolor: White-bellied Swallow. - Yot very common.

Riparia riparia: Bank Swallow. - Tolerably common.

Stelgidopteryx serripennis : Rough-winged Swallow. - Tolerably common.

Ampelis garrulus : Bohemian IVaxwing. - Rare.

Ampelis cedrorum: Cedar Waxwing. - Rare.

Lanius borealis: Northern Shrike. - Regular winter visitor.

Lanius ludovicianus excubitorides: Thite-rumperi Shrike. - Common summer resident.

Vireo olivaceus : Red-ered Vireo. - Not conmmon.

Vireo gilvus sucainsoni: 1 Western Warbling Vireo.-Common.

Helminthophila celata: Orange-crowed Warbler. - Common migrant.

Heiminthophila peregrina: Tennessee Warbler. - Rare.

Compsothlypis americana usnece: Norther'n Parula Warbler. - Rare.

Dendroica astiva: Yellow Warbler. - Common summer resident.

Dendroica coronata: Yellow-rumped Warbler. - Commou migrant.

Dendroica auduboni: Audubon WTarbler. - Common migrant.

Dendroica striata: Black-poll Warbler. - Tolerably common migrant.

Seiurus noveboracensis notabilis : Grimell Water-Thrush, - Rave visitor.

Geothlypis tolmiei: Macgillivray Warbler. - Common migrant.

Geothlypis trichas occidentalis. - Western Yellow-thoat. - Common migrant.

Setophaga ruticilla: Redstart. - Tolerably common migrant.

Anthus spragueii : sprague Pipit. - Common migrant.

Cinclus mexicanus: 1)ipper. - Rare visitor.

Oroscoptes montanus : Sage Thrasher. - Common migrant.

Mimus polyglottos leucopterus: Western Mockingloird. - Regular summer resident; a few pairs breed.

Galeoscoptes curolinensis : Catbird. - Tolerably common migrant.

Toxostoma rufum: Brown Thrasher. - C'ommon; breeds.

Sulpinctes obsoletus: Rock Wren. - Common migrant.

Troglodytes ä̈don aztecus: Western House Wren. - Tolerably common nigrant.

Certhia familiaris montana: Roeky Mountain Creeper. - Casual visitor.

Sitta carolinensis aculeuta: Slender-billed Nuthatch. - Rare visitor.

Sitta canadensis : Red-breasted Nuthatch. - Oceasional visitor.

Sitta pygmcea: Pyomy Nuthatel. - Rare visitor.

l'arus gambeli: Momntain Chickadee. - A flock occasionally visits the eity.

Regulus calendula: Ruby-crowned Kinglet. - Tolerably regular spring: migrant.

Myadestes townsendii: Townsend Solitaire. - Regular migrant; tolerably conmmon.

Iylocichla ustulata sucainsoni: Olive-backed Thrush. - Common migrant.

Merula migratoria: Robin. - Tolerably common sumner resident.

Merula migratoria propinqua: Westeru Robin. - Frequently winters.

Sialia sialis: Bluebird. - Oceasionally seen both in winter and in midsum. ner; may breed.

Sialia arctica: Mountain Blnebird. - Abundant breeder for species.

1 V. gilvus of Check-List. (F. M. B.) 


\section{BIRDS OF PINAL, PIMA, AND GILA COUNTIES, ARIZONA.}

From W. E. D. Scott, in The Auk, vol. iii. $383,421,1886$; vol. iv. 16,196 , 1857 ; vol. v. $29,159,1858$.

The region covered by Mr. Scott's paper extends eighty miles north and forty miles south of Tueson. The Santa Catalina Mountains form its backbone, and the Gila, Santa Cruz, and San Pedro rivers flow through it. The region about Tueson is a plain of about 2300 feet altitude, arid and cactus-grown except where it is watered by springs and sporadic streams which support cottonwoods and other trees. The Florence region in the valley of the Gila is similar to that about Tueson. At Riverside the valley is much narrower. Iineral Creek rises at about 5000 feet altitude in the Pinal Mountains. The birds of the entire region may be divided into birds of the plains and valleys, birds of the oak belt, and birds of the pine regions, though of course the species shift back and forth, the vertical migration being here as important as the north and south migrations.

Podilymbus poriceps: Pied-billed Grebe. - Two taken by Mr. Herbert Brown near Tueson in February.

Gavia lumme: Red-throated Loon. - One taken in December near Tneson. Merganser americanus: Merganser. - Seen at San Pedro River in Jannary.

Lophodytes cucullatus: Hooded Merganser. - One taken by Mr. Brown near Tneson in December.

Anas boschas: Mallard. - One of the commonest ducks about Tneson in fall and winter.

Chaulelasmus streperus: Gadwall. - One taken by Mr. Brown near Tucson.

Mareca americana: Baldpate. - Found on San Pedro River in small flocks in January.

Nettion carolinensis: Green-winged Teal. - Abundant abont Tneson at times during the winter (Brown).

Querquedula discors: Blne-winged Teal. $-\mathrm{A}$ few seen on San Pedro River; unconmon abont Tueson (Brown).

Querquedula cyanoptera : Cinnamon Teal. - Common winter visitant about Tueson (Brown).

Spatula clypeata: Shoveller. - Common abont Tneson in winter (Brown). Dafila aruta : Pintail. - Not uncommon on San Pedro River in March.

Aythya amerirana: Redhead. - Conmon abont Tueson in winter (Brown), and found in small flocks on San Pedro River in Jimmary.

Aythya vallisneria: ('anvas-back. - A small flock seen on San Pedro in January.

Aythya marila: Scanp Dnck. - Rather common on San Pedro River in winter.

Aythya affinis: Lesser Scaup Duck. $-\Lambda$ few seen on the San Pedro in Jannary. 
Charitonetta albeola: Buffle-head. - One taken in December near Tucson, and one on San Pedro in January.

Erismatura jamaicensis : Ruddy Duck. - Not uncommon about Tueson at times.

Branta canadensis (subsp.?): Canada Goose. - Three seen on pond near the San Pedro in January.

Plegadis autumnalis: Glossy Ibis. - Not infrequent about bottom lands near Tucson (Brown).

Plegadis guarauna: White-faced Glossy Ibis. - Common in May near Tucson.

Tantalus loculator: Wood Ibis. - Rather common on Gila and San Pedro river's most of the year.

Botaurus lentiginosus: Bittern. - Rare about Tucson (Brown).

Ardea herodias: Great Blue Heron. - Rather common resident.

Ardea egretta: Egret. - Rather common about Tueson in May.

Ardea candidissima : Snowy Heron. - Five seen near Tueson in May.

Ardea virescens anthonyi : Anthony Green Heron. - Rather rare about Tneson (Brown).

Nycticorax nycticorax nevius: Black-crowned Night Heron.-Rather rare abont Tueson (Brown); found on the Santa Cruz in May.

Rallus virginianus: Virginia Rail. - One seen on the San Pedro in January.

Porzana carolina: Sora. - One taken at Tueson in April (Brown).

Gallinula galeata: Florida Gallinule. - Not uncommon about Tueson (Brown); rare on San Pedro in late January.

Fulica americana: Coot. - Common except in summer.

Steganopus tricolor: Wilson Phalarope. - Common during migration about 'T'ueson.

Recurvirostra americana: Avocet. - Common at times in fall migration near Tueson (Brown).

Gallinago delicata: Wilson Snipe. - Common in migrations about Tuesou. a few wintering there and in San Pedro River region.

Tringa minutilla: Least Sandpiper. - Common about Tueson in migrations (Brown).

Tringa alpina pacifica: Red-backed Sandpiper.-Flocks seen in April near Tucson.

Ereunetes occidentalis: Western Sandpiper. - Common migrant about Tueson.

Limosa fedoa: Marbled Godwit (?). - A godwit probably of this species seen in January on San Pedro River.

Totanus melanoleucus: Greater Yellow-legs. - Two taken by Mr. Brown near Tueson in October.

Helodromas solitarius cinnamomeus: Western Solitary Sandpiper. - Not uncommon about Tueson in migrations.

Actitis macularia: Spotted Sandpiper.-Occasional about Tueson in spring.

Numenius longirostris : Long-billed Curlew. - Not common in migrations about Tueson (Brown).

Eyialitis vocifera: Killdeer. - Common about Tueson in spring and fall, breeding in small numbers in the San Pedro region.

Egialitis semipalmata: Semipalmated Plover. - Doubtless common about Tueson in migrations.

Colinus ridgwayi: Masked Bob-white. - Found by Mr. Brown in the Barboquivari Mountains.

Callipepla squamata: Scaled Partridge. - Most abundant on the dry mesas of the San Pedro slope of the Santa Catalina Mountains. 
Lophortyx yambelii: Gambel Partridge. - Common below 5000 feet.

Cyrtonyx montezumce mearnsi: Mearns Massena Partridge. - Conmon in oak regions of the mountains.

Meleagris gallapavo merriami: Merrian Turkey. - Found on the San Pedro River and in oak and pine regions of the Catalina Mountains.

Columba fasciata: Band-tailed Pigeon. - Common in Catalina Mountains.

Zenaidura macroura: Mourning Dove. - Resident except in pine region.

Melopelia leucoptera: White-winged Dove.-Generally distributed up to ;:50) 0 feet.

Columbigallina passerina pallescens : Mexican Ground Dove. - Not uncommon about 'Tucson, Riverside, and Florence.

Scardafella inca: Inca Dove. - Found at Treson and Florence.

Cathartes aura: 'Turkey Vulture. - Common at low altitudes thronghout the rear.

Circus hudsonius : Marsh Hawk. - Recorded from 'Tueson in fall, winter, and spring.

Accipiter velox: Sharp-shimed Hawk. - Common in fall migration in oak region of Santa Catalina range.

Accipiter cooperii: Cooper Hawk. - Common resident.

Parabuteo unicinctus harrisi: Harris Hawk. - One taken by Mr. Brown near T'neson.

Buteo borealis calurus: Western Red Tail. - Abundant resident throughont the entire region.

Buteo abbreviatus : Zone-tailed Hawk. - Breeds throughout the region.

Buteo swainsoni: Swainson Hawk. - Common near Tueson in warmer part of year.

Asturina playiata: Mexican Goshawk. - Not uncommon in spring and summer abont Tueson.

Aquila chrysätos: Golden Eagle. - Common resident above 4000 feet.

Falco mexicanus: Prairie Falcon. - Rather common resident of the plains.

Falco columbarius: Pigeon Hawk (?). - A small falcon seen at a distance in the Catalina pine region.

Falco sparverius deserticola: Desert Suarrow Hawk. - Common resident

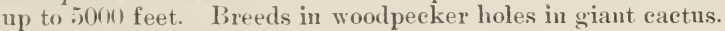

Polyborus cheriuay: Andubon Caracara. - Rather common about Tueson in warmer part of year ; a few apparently resident.

Pandion haliä̈tus carolinensis: Osprey. - Not nncommon along large watercomrses.

Strix pratimcola: Barn ()wl. - Three specimens taken near Tueson.

Meyass(n)s trichopsis: Spotted ciereech Owl. - Common resident about Tueson: also taken at Riverside and in Catalinas.

Bubo virgimianus pallescens: Wrestern Horned Owl. - Common resident.

sjentyto cunimelaria hypogya : Burrowing Owl. - A colony reported from neir lienson and another near Florence. but numsual in region.

Filancidinm phalanoides: Ferruginous Pygniy Owl. - Not uneommon about T'mesom.

Mirropullas whitmeyi : Elf Owl. - C'ommonest resident owl up to :000 feet.

Grosorcy.r raliforminums: liond-rumner. - Common resident up to 4000 fert.

Corryzus amerimmus orcidentalis: ('alifornia Cnekoo, - Rare in Jnne and July on san Perlio slope of C'atalinas.

Trogom (sp). "). - I species of trogon molonbtedly oceurs in Catalina Mountains. lisported. 
Ceryle alcyon: Belted Kingfisher. - Resident.

Dryobates villosus hyloscopus : Cabanis Woodpecker. - Resident in pine forest; winter visitor to lower altitudes.

Dryobates pubescens homorus : Batchelder IToodpecker. - One seen on Gila River.

Dryobates scalaris bairdi: Texan Woodpecker. - Common below 4000 feet.

Dryobates arizonce : Arizona Woodpecker. - Not uncommon in Santa Ritas and Catalinas.

Sphyrapicus varius nuchalis : Red-naped Sapsncker. - Migrant.

Sphyrupicus thyroideus: Williamson Sapsucker. - Found in pines of Catalina Mountains.

Melanerpes formicivorus : Ant-eating Woodpecker. - Common resident of mountains down to 4000 feet.

Melanerpes torquatus: Lewis Woodpecker. - Abundant though irregular migrant in Catalina Mountains at low altitudes.

Melanerpes uropygialis : Gila WToodpecker. - Common resident, especially in giant cactus region, and occurs in numbers up to 4500 feet.

Coluptes cafer collaris: Red-shafted Flicker. - Conmon throughout the region, but breeding above 6000 feet

Colaptes chrysoides : Gilded Flicker. - Rather common resident in giant cactus belt.

Antrostomus vociferus macromystax: Stephens Whip-poor-will. - A whippoor-will, undonbtedly of this species, heard in the Catalinas.

Phalcenoptilus nuttallii: Poor-will. - An abundant migrant; breeds in mountain regions.

Chordeiles virginiamus henryi: Western Nighthawk. - Seen in Catalinas in early spring above $40(0)$ feet.

Chordeiles acutipennis texensis : Texan Nighthawk. - Abundant migrant below 4500 feet.

Chatura vauxii: Vanx Swift. - Seen between 3000 and 4000 feet in the Catalinas in October.

Ä̈ronautes melanoleucus: White-throated Swift. - An abundaut migrant; a few probably winter.

Trochilus alexandri: Black-chimed Hummingbird. - Common summer resident in Catalina Monntains.

Calypte costce : Costa Hummingbird. - Common in Catalinas.

Calypte anna: Anna Hummingbird. - One seen in Catalina Mountains at 5000 feet in October.

Selasphorus platycercus : Broad-tailed Hummingbird. - Common migrant, doubtless breeding in Catalinas.

Selasphorus rufus: Rufous Hummingbird. - Probably breeds at higher altitudes in Catalinas; abundant in August and September from 4000 to 6000 feet.

Selasphorus alleni: Allen Hummingbird. - One taken in Catalina Mountains.

Stellula calliope: Calliope Hummingbird. - Two taken in Catalinas at ¡000 feet.

Iache latirostris : Broad-billed Hummingbird. - Summer resident in Catalina Mountains.

Tyrannus verticalis: Arkansas Kingbird. - One of the commonest summer resident birds of the plaius, and common in April up to 9000 feet.

Tyrannus vociferans: Cassin Kingbird. - Found in foothills about Riverside and in Catalina Mountains.

Myiarchus mexicamus magister: Arizona Crested Flycatcher. - Common in spring and summer about Tucson. Florence, Riverside, and the Catalinas up to 4500 feet. 
Myiarchus cinerascens : Ash-throated Flycatcher. - Abundant migrant and simmmer resident.

Myiarchus laurencei olivascens : Olivaceous Flycatcher. - One taken at )(1)0 feet in Catalina Mountains; common in Santa Rita Mountains

(Stephens). Sayornis saya : Say Phobe. - Common winter resident, breeding sparingly
Say in Catalina Momtains.

Sayornis nigricans: Black Phœbe. - Regular resident in valleys about watercourses, and summer resident of mountains.

C'ontopus borealis: Olive-sided Flycatcher. - Rather common migrant in monntains.

Contopus pertinax pallidiventris : Coues Flycatcher. - Two recorded from the Catalinas.

Contopus richardsonii: Western Wood Pewee. - Common summer resident in Catalina Nominains.

Empidonax difficilis: Western Flycatcher. - Found in Catalinas from Jume till last of Oetober.

Empidonax traillii: Traill Flycatcher. - Two taken in the Catalina Mountains.

Empidonax hammondi: Hammond Flycatcher. - Migrant in Catalina Mountains.

Empidonax urightii: Wright Flycatcher, - Four taken in Catalina Mountains. 3.000 to 4.500 feet.

Pyrocephalus rubineus mexicanus: Vermilion Flscatcher. - Resident at 'Tueson and Florence; a few breeding up to 450 f feet in the Catalinas.

Otocoris alpestris (subsp.?): Horned Lark. - Found about Tueson in fall and winter.

Cyanocitta stelleri diademata: Long-crested Jas. - Resident in pines in Catalina Mountains, descending to oak region in winter.

Apheloroma uondhouseii: Woodhouse Jay. - Common resident at headwaters of Mineral creek and in foothills of the Catalinas.

Aphelocoma sieberii arizonce: Arizona Jay. - Abundant resident in oak region of Catalinas.

Corvus corax sinuatus: Raven. - Common abont Tneson throughout the year.

Corvus cryptoleucus: White-necked Raven. - Common at times about Tueson and other points.

Corv's americanus : Crow. - I Large flocks seen in spring and fall on footliills of ('atalinas.

Cyanorephalus cyunocephalus : Piñon Jay, - Seen in oak belt of Catalinas.

Molothrus ater obscurns : I)warf ('owbird. - Common at Riverside and not uncommon about 'Theson and Florence.

Xunthocephalus xanthorephalus : Yellow-liearled Plackbird. - Abundant about Tureson. Flopener, and valley of the San Pedro in winter.

Agrains phunirens sonoriensis: Sonoran Red-wing. - Common resident.

Sinurnella ma!nu hoppesi: Rio Grande Meadowlark. - Resident.

Interus porisurmm: Sontt ()riole. - Breeds near water, and on arid plains

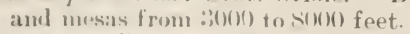

Irterus rucullatus wlsoni: Arizma Hooded Oriole. - Common thronghont the region. luing absent only about fonr montlis. ranging in summer up ti) nearly $(i())()$ foret.

Irterns lullecki : Bullock Oriole. - Not meommon abont Tneson and Florcouer ; rare in the ('at:alinas.

Sicolerophlangus ryanorephalus: Brewer IBlackbird. - Abundant winter resident beluw :;ox) feet. 
Coccothraustes vespertinus montanus : Western Evening Grosbeak. - Seen in pine woods of Catalinas.

Carpodacus purpureus californicus : California Purple Finch. - Large flocks seen in Catalina Mountains in fall and winter of 1S5..

Carpodacus cassini : Cassin Purple Finch. - Seen in Catalinas in winter.

Carpodacus mexicanus frontalis: House Finch. - Abundant summer resident; less coumon wiuter resident.

Loxia curvirostra stricklandi: Mexican Crossbill. - Irregularly abundant in Catalinas.

Astragalinus tristis pallidus: Western Goldfinch. - Seen in Catalinas in winter.

Astragalinus psaltria : Arkansas Goldfinch. - Nomadic and not very common in the Catalinas.

Astragalinus psaltria arizonce: Arizona Goldfinch. - Less common than the Arkansas.

Astragalinus laurencei: Lawrence Goldfinch. - One taken by Mr. Brown in February.

Spinus pinus: Pine Siskin. - Common and at times an abundant winter visitor in the Catalinas.

Calcarius ornatus: Chestnut-collared Longspur. - A large flock seen in November on mesa of Catalina foothills.

Poccetes gramineus confinis : Western Vesper Sparrow. - Migrant in Catalina region.

Ammodramus sandwichensis alaudinus : Western Savanna Sparrow. - Occurs rather sparingly about Tueson in fall, winter, and spring (Brown).

Ammodranus savannarum bimaculatus: IVestem Grasshopper Sparrow. Apparently rather an uncommon resident of the mesas of the Catalina foothills.

Chondestes grammacus strigatus : Western Lark Sparrow. - Resident about Tucson and common in the Catalina region up to 5000 feet in the warmer montlis.

Zonotrichia leucophrys : White-crowned Sparrow. - Apparently rare.

Zonotrichia leucophrys gambelii: Internediate Sparrow. - Winter resident.

Spizella socialis arizonce: Western Chipping sparrow. - In Catalinas ; rare in summer. abundant in fall. winter, and spring.

Spizella pallida: Clay-colored Sparrow. - Seen at Mineral Creek in October. November, and March.

Spizella atrogularis : Black-chinmed Sparrow. - Apparently rare.

Junco hyemalis : Slate-colored Junco. - Rare, but of regular occurrence in the Catalina region.

Junco hyemalis connectens : Intermediate Jumco. - Common winter resident. Junco mearnsi: Pink-sided Junco. - Apparently not very common in the Catalinas.

Junco caniceps : Gray-headed Junco. - Common in winter in foothill region of the Catalinas.

Junco pheonotus palliatus : Arizona Junco. - Found in Catalinas and Pinal mountains in pine woods in fall and winter.

Junco phconotus dorsaiis : Red-backed Juuco. - Three specimens taken in the Catalinas.

Amphispiza bilineata deserticola: Desert Sparrow. - Common resident of the foothill region of the Catalinas. and abundant about Tueson.

Amphispiza belli nevadensis : Sage Sparrow. - One seen in Catalina Mountains; not common at Tucson. A number seen on low mesa near the San Pedro in November.

dimophila carpalis : Rufous-winged Sparrow. - Common in Catalina foothills in migrations. :3000 to 4500 feet. 
Simophila ruficeps scottii: Seott. Spanow. - Resident in the Catalinas down to : Boin teest in winter.

Melospiza melodia fallax: Desert song sparrow. - Apparently resident about 'lineson.

Melospiza melortia montana : Momintain Song Nparrow. - Not nncommon on S:u Pelro River in Jamnary ; irregnlar winter visitor abont Tnesen.

Melospiza lincolnii: Lineoln Sparrow. - Regular migrant in the ('atalina Momtans : a few probably winter.

Pipile maculatus megalony : Spmred 'Towhese - Common resident of the Canalinas, breading above ive) feet.

Pypilo t uscus mesolencus: Canyon 'Towhee. - C'ommon resident thronghont the entire regrion, ranging nip to pine forests in warmer months.

Pipilo aberti: Ibert 'Towher. - Resident abont. 'Tueson and Florence.

Oreospiza chlorura: (roesu-tailed Towher. - Common migrant in the ('atalinas, a few winterine.

Cardimalis cordinalis superbus: Arizona Cardinal. - Generally distributed, 1:anging up to about if(x) feet.

l'yrrhuloriu simuata: Arizonia Pyrrhuloxia. - Rare or casnal in foothills of the Catalinas. liather eommon about 'Tnesom.

Zamulodia mulunocephula: Black-headed Grosbeak. - Fomel breeding at Ello) foet at Mlineral ('reek: foumd also in Cistalina Momitains.

Guiraca corulea lazula: Western line Grosbeak. - Rather rare abont 'Tucson in spring (lirown).

Cyanospiza amana: Laznli Bnnting. - Fonnd at Mineral Creek and in ('atalinas; byeeds, but not commonly, about 'Theson.

Spiza americana: Dickeissel. - One taken near.'Tneson in September by Mr. Brown.

Calemospizu melanocorys: lark Bming. - Seen nearly thronghout the rear, sometimes in enormons flocks.

P'iranga ludericiana : Lomisiana 'Tanager. - Summer resident in pine forests of the momitins.

Piranga hepatica: Hepatic Tanager. - Simmer resident in the oak regions.

l'iranga rubra cooperi : ('oopere 'T:anager. - C'ommon summer resident abont 'lueson, liverside, Florence, Mineral ('reek, and the san l'edro Vialley. A few breed in the ('atalinas.

I'roune subis hesperia: Western Martin. - Rather nncommon abont Tueson.

l'irochelidon lunifons: Eave swallow. - Seen in umbers about liverside ii, Ipril.

Lirumlo erythrogustra : Barn swallow. - Common migrant. Breeds sparingly in the ('at:alinis at ionol) feet.

Turhyeinete bioser: 'Pree swallow. - Rare abont Tneson (Brown).

Tuehycimet thalassina lepida: Violet-green -wallow, - Commonest swallow of the ('atalinas.

liipuria ripariu: Bank Swallow. - Breeds abont Fort Lowell (13rown).

Stelgideptery.r strifu mnis: liongh-winged swallow. - liather rare about lineson (Brown).

Impelis celrurum: Cedar Waxwing. - Taken near Tueson in May and Jitue.

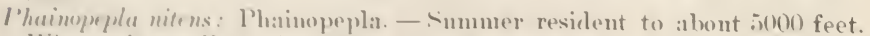

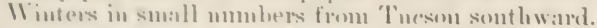

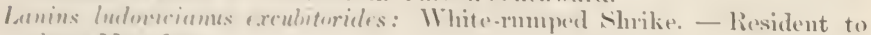
alout istoll fent.

Viro gilms: II ahling Vireo. - Commen migrant. I few breed in the ('ataliuas as low as :

lion soliturius cessinil: ('assin Vireo. - Rather meommon migrant in the C'atalinas. 
Vireo solitarius plumbers: P'lumbeous Vireo. - Cudoubtcedly breerls in the monutains aboves $7(1)(0)$ feret.

Yiren, huttoni stephensi: Stephens Viren.- Four specinens taken in the monntains.

Viren pusilius: Least Vireo. - Common summer ressident up to for(f) foet.

Vireo vicinior: Gray Vireos. - Fiarly alsundant on Catalina foothills from

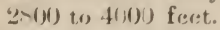

Melmivethophila lucie: Lacy Warbler. - A common migrant and summer resident in suitable places up to $f(0)(0)$ feret.

Helminthophila virgivios: Virginia Warbler. - Jonbtless breeds in the ('atalinas above for)() feet.

Melminthophila rulrirapilla gntturalis: Calaveras Warbler. - Migrant in the Catalinas at 4000 foest.

Helminthophila colata lutescens: Lutesecont Warbler. - Rather common spring and fall migrant in the Catalimas at $40(0)$ feet and probably breceds in the pine forests of the higher altitudes.

Drndroica olivacea: ()live Warbler. - Seen in the ('atalinas at about 10.()(5) feet in Vovenubrer. in company with bluebirds.

Dendroicle astioge somorance: Sonora Yellow Warbler. - Rather conmon, breseding in the Catalinas up, to f.jo) feet.

Dendroira comomata: Yellow-lonmperl Warbler. - Not ucarly so common as 1). auduloni, but of regular oceurrence as is migrant.

Dendroica auduloni: Audubon Warbler. - I eommon migrant; is few probably breed in the pine forests. 'They winter in small numbers in the liver valleys.

Denelroica gracie: : Grace Warbler. - Sern in pine forests of Catalinas iu spring.

Denilroica nigrescens: Black-throated Gray Warbler. - Qnite eommon migrant in the Catalinas. breeding rarely above 4.0$)(0)$ feret.

Dendroice townsendi: Townsend Warbler. - Foumd migrating in tho I'inal and Catalina rangres.

Dendroica occidentalis: Irsmit Warbler. - Found once in Catalinas at :3), ()) feet.

Seiurus noveboracensis notabilis: Grinnell Water Thrush. - Two birls probably of this subspecies taken at :Jf() foet in the ('atalinas, in Septernber.

Geothlypis tolmiei: Macgillivray Wartsler. - Rather a common migrant, a few probably breeding in the C'atalinas.

Geothlypis trichas occidentalis: Western Yellow-throat. - A rather comunon micrant; hroeds abourt Tuceson.

Icteria virens longirauda : Iong-tailed ('lnat. - r'onmon migrant and summer resident in snitable localities up to $40(0)$ feet.

Wilsonia pusilla pileolata: I'ileolated Warblex, - Rather common migritnt.

Setoplarga rutirilla: Reelstart. - One taken near Tucson by Mr. Brown, aurl one in Cataliua Monntains.

Setophaga picta: Painted Redstart. - Dimmer resident in the Catalinas, breeding as low as if() foet in the oak belt.

Cardellina rulrifrons: Red-faced Warbler. - Common in the pine forests of the Catalinas in April.

Anthus pensilvanicus : Pipit. - Not uncommon as a migrant throughout the regrion.

Oroscoptes montunus: Sage Thrasher - Common fall migrant in I'inal Iountains; common migrant and winter resident of Catalina foothills up) to): $; j()()$ fret. 
Mimus polyglottos leucopterus : Western Mockingbird. - Common resident thronghont the region up to 5000 feet.

Toxustuma bendirei: Bendire Thrasher. - Resident on the plains from 'Tnesun sonthward, and quite common about Florence in the warmer montlıs. Breeds in Catalinas below 4000 feet.

Toxostona curvirostre palmeri: Palmer 'Thrasher. - Common resident in eloblla cactus region.

Toxostoma crissulis : Crissal Thrasher. - Apparently resident throughout the region.

Meleodytes brunneicapillus: Cactus Wren. - Common resident throughout the region below 4000 feet.

Salpinctes obsoletus: Rock Wren. - More or less abundant in the counties considered.

Catherpes mexicauns conspersus: Canyon Wren. - Resident in mountain canyous up to 5000 feet.

Thryomanes beuickii lencogaster: Baird WVren. - Resident in the Catalinas and Pinal Momntains up to about 6000 feet.

Trogludytes aëdon aztecus: Western Honse Wren.-Breeds in pine regions.

Cistothorus palustris plesius: Western Marsh Wren.-One taken by Mr. Brown near Tueson.

C'erthia fumiliaris albescens: Mexican Creeper. - One taken in pine forests of Catalinas in April.

Sitta carolinensis aculeata: Slender-billed Nuthatch. - Common resident in pine woods and higher altitudes.

Sittu canadensis: Red-breasted Nuthatch. - One taken at 4500 feet in the Cantialintas.

sitta pygmea: Pyomy Nuthatch. - Found in pine forests of Pinal and Catalina Mountains.

I'arus wollweberi: Bridled Titmonse. - Rather common resident of the oak region in the Pinal and Catalina Mountains.

I'saltripurus plumbeus: Lead-colored Bush-Tit. - Resident in the Catalinas up to about 7.000 feet.

Auriparus flaviceps: Verdin. - Resident throughout the entire region up to $f(10)$ f feet.

liegulus caltudula: Rinby-erowned Kinglet. - Common migrant and winter resident in the oak leelt.

I'olioptila rerulea obscura: Western Gnatcatcher. - Breeds commonly in the Catalinas, but winters on the plains and mesas.

I'olioptila plumbea: Plmmbeons Guatcateher. - Common resident about 'Tueson and in valley of Sian Pedro.

Myalestes tourusrulii: "Townseml holitaire. - Found in the momntains.

IIylorichlu fusreserens salicirola: Willow 'Thushs. - One taken by Mr. Brown at 'Tuseson.

IMylorichlı ynttatı: Alaska Hermit Thrush, - Winter visitant.

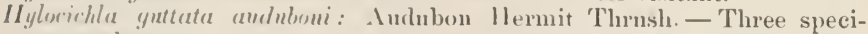
umens takens.

Merula migratoria proprinqua: Western Robin. - Common winter resident, :isoc) to ti(x)e feet.

Siralia mericana mcidrmalis: Wrstern Blurbird. - Winter resident of the fouthills: alsu breeds in small ummbers in the Cantilinas.

Siulia arrtirn: Mountain Bluebird. - Irregular fall amrl winter visitant of the fouthills. 


\title{
BOOKS OF REFERENCE.
}

\author{
GENERAL WORKS.
}

American Ornithologists' Union. Check-List of North American Birds. Second Edition (1S95).

Audumon, John Jaxies. Birds of America. - Ornithological Biography. Baird, Spencer F. Review of American Birds. Smithsonian Mis. Col. 186t-1s66; U. S. and Mexican Boundary Survey, vol. ii. part ii. 1859.

Baikd, s. F.. Cassin, J., and Lawrence, G. N. Pacifie R. R. Reports, vol. ix., Birds, 18.js.

BaIRD, S. F., Brewer. T. M., and Ridgway, R. History of North American Birds. Little, Brown \& Co., Boston, 3 vols., Land Birds, 1 sit; 2 vols., Water Birds, 1854.

BEDDARD, F. E. Study and Classification of Birds. Longmans, Green \& Co., New York, 1s9s.

Bendire. Charles E. Life Histories of North American Birds. Smitlsonian Institution, 2 vols. 1892, 1895. (Land birds through Ieteridæ.)

Cassin, J. Illustrations of the Birds of Texas, California, etc., 1853, 1855, 1556 .

Cooper, J. G., and Suckley, G. Pacific R. R. Report, vol. xii. No. ii. 1860.

Coues, Elliotr. Bibliography of Ornithology, Part i.. Faunal Papers, Appendix to Birds of Colorado Valles, 566-7st, 1878; Parts ii. and iii., Systematic Papers. Bull. Geol. and Geog. Surv. Terr., Hayden, vol. v. Nos. 2 and 4, 1879; Part iv., Faunal Papers on British Birds, Proc. U. S. Nat. Mus. vol. ii. for 1879 - Birds of the Colorado Valley, U. S. Geol. Surv. Terr. 1878. - Birds of the Northwest, U. S. Geol. Surv. Terr. 1874. - Key to North American Birds, 20d ed. 1884.

Evass, A. H. Cambridge Nat. Hist., vol. ix., Birds. Macmillan Co., New York. 1899.

Fisher, A. K. Rept. Orn. Death Valley Exped., N. A. Fanna No. 7 , 189:3. U. S. Devt. Agr.

Heerman, A. L. Pacific R. R. Rept., vol. x. part iv. Nos. i. and ii., Birds, 18599.

Hexshaw, H. W. Rept. Orn. Spec., Wheeler's Surv. for the Years 1s71, 1872, and 1873. - Exp. West Hundredth Meridian, vol. v. chap. iii. Zoology, 1875 .

Kenjerly, C. B. R. Pacific R. R. Rept., vol. x. No. 3, Birds. 19, 1859.

Merrlai, C. H. Mammals and Birds. 6th Ann. Rept. U. S. Geol. Surv. Terr. 1872 .

Nelson, E. W. Rept. Nat. Hist. Coll. Alaska Aret. Ser., No. iii. part i.. Birds, 1877.

Newton, Alfred. Dictionary of Birds. Macmillan Co., New York, 4 vols., 189:;-1896.

Ridgway, Robert. Birds of North and Middle America. Bull. No. 50, U. S. Nat. Nus. 1901, 1902. - Hummingbirds, Ann. Rept. U. S. Nat. Yus. 1890, see. iii. 253. - Nomenclature of Colors, Little, Brown \& Co., Boston, 1896. - Manual of North American Birds. J. B. Lippincott Co., Philadelphia, 2d ed. 1896. - Ornithology of Survey of 4 (1)th Parallel, U.S. Geol. Expl., part iii. 187T.

StejNeger. L., and Others. Riverside Natural Histery, vol. iv., Birds. (1885.) Houghton, Mifflin \& Co., Boston. 
Towrsexd, C. H. Notes on Birds of Kowak River, and other portions of Alaska, Crunise of the Corwin. 1s85.

Turver, L. M. Contr. to Nat. Hist. Alaska, Aretic Ser. No. ii. 1886.

Woophotsk, S. W. Rept. Sitgreaves Exped. Zuñi and Colorado Rivers, $155 \%$.

\section{PERIODICALS.}

Anficax Findo. American Field Publishing Company, S01 Masonic Temple, Clicago.

A ск, Тне. Cambridge, Mass.

Burd-Lore. The Macmillan Company, Harrisburg; Pa.

Bulletix of the Cooper Orxithological Club. (See Condor.)

Bulletix of the Nuttall Ornithological Club. Cambridge, Mass., $1870-188: 3$.

Coxpor, The. Santa Clara, California (rol. i. published as Bull. Cooper Orn. (llub).

Forest AxD Stream. 343 Broadway, New York.

Nidologist, The. Alameda, California, 189:-1896.

Ornithologist and Ö̈logist. Hyde Park, Mass., 1S81-1892.

Osprex, The. 'The Osprey Company, Washingtou, D. C.

Procendigs Califorvia Academy of Sciences. Cal. Acad. Sci., San Francisco. ('alifornia.

Rircreation. 2:) W' West 2tth Street, New York.

ZoE. Sau Diego, California, 1st ser. 1S90-1S94.

\section{STATE LISTS.}

Arizona. - Coles, Ellotr. Birds of Fort Whipple, Proc. Acad. Nat. Sci. Phila. xviii. 1s(i.), 1866; Birds of Colorado Valles, U. S. Geol. Surv. Terr. 1ऽTஃ- Hexshaw. H. IT. Amotated List of Birds of Arizona, Expl. and Surv. W'est 100th Meridian, 157. - MeAres, E. A. Avifanna of P'ortions of Arizona, Auk, vii. 45, 251, 1!)0. - Merrian, C. H., San Franciseo Momtain Region and Desert of Little Colorado, N. Anr. Famma, No. :), Biol. Surv. I. S. Dept. Agr. - Scort, W. E. D. Notes from Momntains of Southern Arizona, Ank, ii. 345, 1ss. Avifauna of Pinal County, with Remarks on Birds of Pina and Gila Counties, Auk. iii. '2t!. :38i, 421 ; iv. $16,19(6$; v. 2!), 15!).

British Columbia. - ('mapus, F. M. Collection of Birds of British Colmmlia, by ('. P. Ntreator, Am. Mus. Nat. Hist. vol. 3. No. i. 1s!o FAxis, Joux. Cleck-list of British Colmubia Birds. Provineial Musemm, 1s!h.-Oscioon, Wr. H. Natmal History of Queen Charlotte Islands, N. Am. Famua, No. 21, Biol. Surv. U. S. I)ept. Agr.

Canada. - Mlıcoux, Jonx. ('atılogue of Canadian Birds, Geol. Surv. ('anitrla, 1e)()).

California. - Cieneral. Bemneg, Lruan. Land Birds of the Pacific District, Cinl. Arat. Sei., S:m Francisco, 18:90. - Cooper, J. G. Ornitholugy of ralifornia, Geol. Smrv. ('alif. 1570) - Grinxeld, Joseph. ('hreck-List of Conliformia Birds, l'arific ('oast Avifamna, No. iii. 1902.

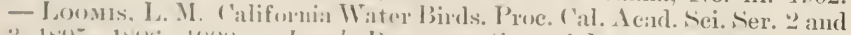

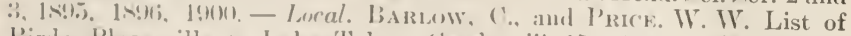
Birds, Placerville w Lake Tahoe, ('onder, iii. 15), 19)1. - BLAKE, E. II. Summer Birds of S:

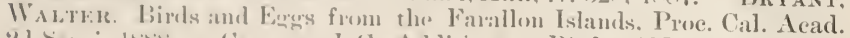

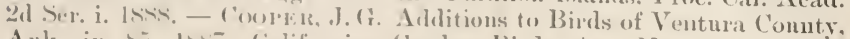

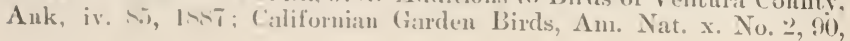


1876. - Everuane, B. IT. Birds of V'entura County, Auk, iii. S6, 179, 1S56. - Grixnell, Joseph. Birds of Pacific Slope of Los Augeles County, Pasadena Acad. Sci. No. ii. 159s. - Kénere, Chas. A. Bird Notes Afield, Elder \& Shepard, San Francisco, 1S89. - McGregor, R. C. Land Birds of Nanta Cruz County, Pac. Coast Avifauna, No. 2., 1901. - Merkia M, C. H. Biological Survey of Mount Shasta, N. Aur. Fauna, No. 16, Biol. Surv. U. S. Dept. Agr. - Oberholser, H. C. Birds from Santa Barbara Islands, Proc. U. S. Nat. Mus. vol. xxii. No. 1195, 205, 1900.- TAYlor, H. R., and BAnLow, C. Story of the Farallones, Alaneda, Cal., 1897.-- Towrsexd. C. H. Field Notes on Mammals, Birds, and Reptiles of Northern Califoruia, Birds, Proc. U. S. Nat. Mus. x. 190, 1857.- VAN Denburgh, Johs. Birds Observed in Central California in 189:3, Proc. Acad. Nat. Sci. Phila. 1898: Birds of Santa Clara County, Proc. Am. Philos. Soc. vol. xxxviii. 157, 1899.

Colorado. - Cooke, W. IV. Birds of Colorado, State Agr. Coll. Bull. 37,$1597 ; 44,1898 ; 56,1900 .-D R E w, F$. M. Vertical Range of Birds in Colorado, Auk, ii. 11, 158.5.

Hudson Bay. - Preble, Edward A. Biological Investigations of Hudson Bay Region, N. Am. Fauna. No. 2.), U. S. Dept. Agr. 1902.

Idaho. - Merriai, C. H. Biological Reconnoissance of South Central Idaho, N. Am. Fauna, No. 5. U. S. Dept. Agr. - Merrill, J. C. Notes on Birds of Fort Shermau. Auk. xiv. 347, 1897; xv. 14, 1898.

Kansas. - Goss, N. S. Birds of Kansas, Crane \& Co., Topeka, Kan., 1591.

Lower Califormia. - Beldixg, Lyman. Catalogue Coll. Birds from Western Coast and Cape Regions of Lower California, Proc. U. S. Nat. Mus. vol. v. 5:27, 1882. - Brewster, William. Birds of Cape Region, Lower California, Bull. Mus. Comp. Zoöl. xli. 1, Sept. 1902. - Brín'r, Walter. Catalogue of Birds of Lower California, Mexico, Proc. Cal. Acad. Sci. 1859.

Manitoba. - Thompsox, E. E. Birds of Manitoba, Proc. U. S. Nat. Mus. vol. xiii. 458, 1890.

Montana. - Cooper, J. G. Fauna of Montana, Am. Nat. ii. and iii. 1S69. - Richuond, Charles IV., and Knowlton, F. H. Birds of South Central Montana, Auk, xi. 295. 1\$94. - Silloway, P. M. Summer Birds of Flathead Lake. University Montana, Bull. No. 3, Biol. Ser. i. 1901. - Thorne, P. M. Birds of Fort Keogh, Auk, xii. 211 , 1895.

Nebraska. - Bruner, LAwrence. Notes on Nebraska Birds, Neb. State Horticult. Soc. 1896. - Walcotr, R. H. Corrections to Bruner, Proc. Neb. Orn. Union.

Nevada. - Fisher. A. K. Ornithology of Death Valley Exp., from N. Am. Fauna, No. 7, 1s93, U. S. Dept. Agr. - Hoffuar, IT. J. Birds of Nevada, Bull. Geol. and Geog. Surv. vol. vi. No. 2, Hayden Surv. 1881.

New Mexico.-Anthoxy, A. W. Birds of Southwestern New Mexico, Auk, ix. 357, 1592.-Henry, T. C. Catalogue of Birds of New Mexico. Proc. Acad. Nat. Sci. Phila. xi. 104, 1859; Notes on Birds of New Mexico, Proc. Acad. Nat. Sei. Phila. vii. 306, 15.5.). - Hexshaw, H. IV. Birds of Upper Pecos River, Auk, ii. :226, 1855; iii. 73, 1886. Miтchell, IV. I. Birds of San Miguel County, Auk, xv. 306, 1898.

Oregon. - Axthoxy, A. W., Birds of Washington County, Auk, iii. 161, 1S56. - Belding, Lymax. Birds of Pacific Coast, California Acad. Sci., San Francisco, 1S90. - Berdire, Charles E. Notes on Birds of Southeastern Oregon, Proc. Bost. Soc. Nat. Hist. xix. 1ST7, 109. Merrill, J. C. Birds of Fort Klamatl. Auk, v. 139, 251, 357, 1888. Townsend, J. K. Catalogue Birds of Oregon, Narrative Journ. across 
Rocky Mts., Appendix, Perkius \& Marvin. Boston, 1839. - Woodcock, A. R. Amnotated List of Birds of Oregon, Ore. Agr. Exper. Station, Bull. No. (is, 190:', Corvallis, Ore.

South Dakota. - Grixiell. G. B. Ludlow's Rept. Recomn. Black Hills, Zoöl. Rept, chap. ii., Birds, 1875. - McChesney, C. E. Birds of Cotean des Prairies of Eastern Dakota, Forest and Stream, vol. viii. 176, $1(1) \cdot 2,-2 \cdot 24,214,261$.

Texas. - Ar'water, H. P. Birds of San Antonio, Auk, ix. 3:37, 1892. Brown. N. C. Second Season in Texas, Auk, i. 120, 1854. - Chaparan, F. II. Birds of Corpus Christi, Bull. Am. Mus. Nat. Hist. iii. No. 2, art. xxii. 315. - Lloyd, WT. Birds of Tom Green and Concho Counties, Auk, iv. 1S1, 2s9, 1Ss7. - Merrill, J. C. Notes on Texan Birds, Bull. Nutt. Oruitl. Club, i. No. iv. Ss, 1876 . - Sennet'r, G. B. Notes on Ornithology of Lower Rio Grande, Bull. U. S. Geol. Surv. Terr. iv. No, i. 1, 1ミ7์; v. No. $3,371,1579$.

Utah. - Hexshaw, H. W. Annotated List of Birds of Utah, Ann. Lyc. Nat. Hist. N. Y. xi. 1STt, 1; Notes on the Bird Fauna of the Salt Lake Valley, Bull. Essex Inst. v. No. ii. xi. 168, 1873.

Washington. - Cooper, J. C.. and Sockley, G. Birds of 4th and 4!th Parallels, Pacific R. R. Rept. vol. xii. book ii. part iii. No. 3, 1860. - 1)Awson, IV. L. Birds of Okonogan County, Auk, xiv. 168, 1897; Birds of Yakina County, Wilson, Bull. New Ser. vol. ix. No. 2, No. 39, 192. - Ковве́, W. H. Birds of Cape Disappointment, Auk, xvii. 349, 19(0). - Law rexce, R. H. Birds of Gray's Harbor, Auk, ix. 39, 352, 16!2. - liathBCN, S. F. Birds of Seattle. Auk, xix. 131, 1902. RhoAds, S. N. Notes on Washington and British Columbia Birds, Auk, x. $16 ; 18 ! 9$.

Wyoming. - Cary, Merritt. Birds of Black Hills, Auk, xviii. 2:31, 19)1. - KNight, WiLbUR C. Birds of Wyoming, University of Wyoining, Laramie. In press.

\section{SPECIAL SUBJECTS AND POPULAR WORKS.}

\section{SPECIAL SUBJECTS.}

\section{Bird I'rotection.}

A. O. U. Commtef on Bind Protection. Anmual Repts., Auk, xiv. 21,

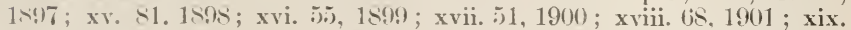
:3, 1:1(1). - Game Laws in Brief, Forest and Stream Publishing Co. ((2narterly), New York. - Palmer. T. Ṡ.. and Oluys. H. W. Digest of Game Laws, 1!k)], Bull. 16, Biol. Surv. U. S. Dept. Agr. Game Laws for 1!)(1:2, Farmer's Bull. No. 16i), U. . . lept. Agr. - Paluer, T. S. Lanislation for the l'rotection of Birds otler than Gane Birds. Bull. No. 12. Biol. Surv., revised ed. 1902.2. - LANGE, 1). Our Native Birds, How to l'motret them and Attract them to our Homes. The Macmillan

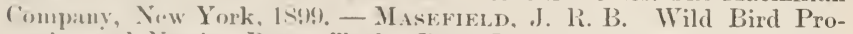
teretion and Vesting Boxes, T'aylor Bros., Leeds, England, 1897. - BirdLare. Andubon I tepartment, The Macmillan Company, IIarrisburg. Pomn. - Bласоск. C. I. Bird Dily: How to Prepare for It, Silver, Burdett de Cu., New York and Boston, 1901.

\section{Fiod of Birds.}

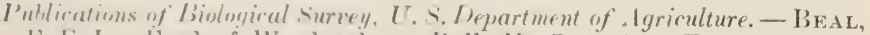

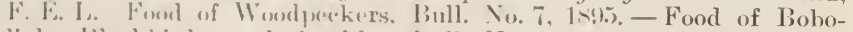
link, liklakkirds, and Grackles, liull. No. 1:), 190(); some Common 
Birds in their Relation to Agriculture, Farmer's Bulletin, No. 54, 1897; Crow Blackbirds and their Food, Yearbook for 1894; The Meadowlark and Baltimore Oriole, Yearbook for 159.); The Blue Jay and its Food, Yearbook for 1S96; Birds that Injure Grain, Yearbook for 1597; How Birds Affect the Orehard, Yearbook for 1900; The Food of Cuckoos, Bull. No. 9, 1898; The Food of Nestling Birds, Yearbook for 1900. - Frsmer, A. K. Hawks and Owls from the Standpoint of the Farmer, Yearbook for 1894; Two Vanishing Game Birds, Woodeock and Vood Duck, Yearbook for 1901. - Judd, S. D. Four Common Birds of the Farm and Garden, Yearbook for 1895; The Food of Shrikes, Bull. No. 9, 1898; The Relation of Sparrows to Agriculture, Bull. No. 15, 1901. - Merrian, C. H., and Barrows, IV. B. The English Sparrow in America, Bull. No. 1, 18s9. - PAlmer, T. S. A Review of Economic Oruithology in the United States, Yearbook for 1899.

\section{Migration.}

BAIrd, S. F. Distribution and Migration N. Am. Birds, Am. Journ. Sei. Arts, vol. xli., Jan. 18ü6. - Belding, Lyman. Land Birds of Pacific Coast District. Cal. Acad. Sci., San Franciseo, 1s90. - Brewster, WrLLLA M. Bird Migration Memoirs Nutt. Orn. Club, Cambridge, Mass., 1886. - Chapman, F. M. Remarks on Origin of Migration. Auk, xi. 12, 1894. - Сооке, IV. IV. Bird Migration in the Mississippi Valley, Div. Econ. Orı. Bull. No. 2, U. S. Dept. Agr. - GÄтке, H. Heligoland, David Douglas, Edinburgh, 1895. - Looms. L. M. Water Birds of Califoruia, Proe. Cal. Acad. Sei., San Franciseo. - Stone, Wrtmer. Bird Waves and their Graphic Representation, Auk, viii. 194, 1591 ; Graphic Representation of Bird Migration, Auk, vi. 139, 18S\%. See, also, sections on Migration in Chapman's Bird-Life and Newton's Dictionary of Birds.

\section{Moult and Protective Coloration.}

Chadbourne, A. P. Individual Dichromatism in Megascops asio, Auk, xiii. 321, 1896 ; xiv. 33, 1S97. - Clarke, H. L. Pterylography of the Caprimulgidæe. Auk, xviii. 167, 1901. - Dwight, Jonathan, JR. Moult of Quails and Gronse, Auk, xvii. 14:3, 1900; Plumage Cycles and Relation between Plumages and Moults, Auk, xix. 248, 1902; Sequenee of Moults and Plumages of Laridæ, Auk, xviii. 49, 1901 ; Sequences of Plumages aud Moults of Passerine Birds, Annals New York Acarl. Sei. vol. xiii. TT, 1S96. - Stone. Wrtuer. Moulting of Birds, Proc. Acad. Nat. Sci. Phila. 1896, 10s; Moult and Alleged Color Change in Birds, Ibis, Apr. 1901, 177 ; Summer Moulting of Plumage of Certain Ducks, Proc. Acad. Nat. Sci. Phila. 1899, 467. See, also, Newton's Dictionary, Moult, and Chapman's Bird-Life, chap. iii., Colors of Birds.

\section{Nests and Eggs.}

Bendre, Charles F. Life Histories of North American Birds, 2 vols. Smith. Inst. 1892, 1895. - DAvie, OLrver. Nests and Eggs of North American Birds, כ̌th ed. Landon Press, Columbus, Ohio, 1595. See, also, the Condor, Osprey, and Nidologist.

\section{Songs.}

Brcknell, E. P. A Study of the Singing of our Birds, Auk, i. 60, 126, 209, 322. 1884 ; ii. $144,249,185.5$. - Cheney, S. P. Wood Notes Wild, Lee \& Shepard, Boston, 1592. - Oldys, H. W. Parallel Growth of Bird 
and Human Music, Harper's Monthly, August, 1902, vol. ev. No. dexxvii. 47. - Witchell, Charles A. Evolution of Bird-Song, Adam \& Charles Black, London, 1896.

\section{POPULAR BIRD BOUKS.}

Basketт, J. N. The Story of the Birds, D. Appleton \& Co., New Tork, 1597. - Burnoughs, John. Wake-Robin; Fresh Fields; Birds and Poets; Locusts and Wild Foney; Pepacton; Winter Sunshine; rigns and Seasons: Riverby, Houghton, Mifflin \& Co., Boston. Chapuly, Fraxk M. Bird Life (popular colored ed.), 1902; Bird Studies with a Cannera, 1900; Handbook of Birds of Eastern North America, 1!(02, 1). Appleton \& Co, New York.-Eckstorm, Fannie Harny. The Bird Book, D. C. Heath \& Co., Boston, 1901; The Woodpeckers, Honghton, Mifflin \& Co., Boston, 1901.-Elliot, D. G. Shore Birds, 18!\%; Game Birds. 1897; Wild Fowl, 1s98, Franeis P. Harper, New York. - Henkick, Francis H. Home Life of Wild Birds, G. P. Putnam \& Sons, New York, 1901. - Job, Herbert K. Among the Water-Fowl, Doubleday, Page \& Co., New York, 1902. - Kefler, Charles A. Bird Notes Afield, Elder \& Shepard, San Francisco, 1sis!) - Keyser, Leander \$. Birds of the Rockies, A. C. MeClurg \& Co., Chicago, 1902. - Lord, W. R. Birds of Oregon and Washington, J. K. Gill Company, Portland, Oregon, revised edition, 190.2. - Merriam, F. A. A-Birding on a Broneo, Honghton, Mifflin \& Co., Boston, 1S!9(i. - Millek. Olive Thorne. Bird-Ways; In Nesting Time; Little Brothers of the Air; A Bird-Lover in the West; Upon the Tree-Tops ; First Book of Birds; Second Book of Birds, Honghton, Mithlin \& Co., Boston. - Torrey, Branford. Birds in the Bush; A Rambler's Lease; 'The Foot-Path Way; Everyday Birds, Houghton, Miftlin \& Co., Boston. - SAnders and YAN Dxke. Upland Game Birds, Maemillau Co., New York, 18()2. - VAN Dyke, T. S. Game Birds at Home, Fords, Howard \& Hulbert, New York. 1895. - Wright, Maвzц, Osgoon. Birderaft, ㄹd ed., Maemillan Co., New York, 1s!99. — Wrintit, Mabel Osgoon. and Dr. Elliotr Cougs. Citizen Bird, 2d ed., Macmillan Co., New York, 1900.

\section{USE OF THE KEYS.}

If you are a beginner with a bird to identify, and do not know the orders into which birds are divided, go first to the Key to Orders. 11). 1, 2. If your bird is a plover, you may not be sure whether it is rlassed with the water or land birds; so begin with the Key to IVater Birds. 'This key, as all others in the book, is dichotomous, that is to sily, at crery step) the birds are divided into two classes, which have or have not a given character - birds are black or they are not black, lhey latve crests or they have not crests, their feet are webled or their feet are not wobled. It each step of the key a number and its prime are used to set ilpart the two classes. In the rase of the Key to ()rilers of Water Birds the first two classes are birds whirle havo.

1. Firet fully wablocil 
$1^{\prime}$. Feet incompletely or not at all webbed.

If the bird you want to name has fully webbed feet, read down the key from 1; if not, go to $1^{\prime}$, and read down. The numbers fol. low consecutively from each heading. In this case the birds with fully webbed feet are divided again into sereral classes, and those without fully webbed feet also have subdivisions.

1. Feet fully webbed (except Grebes in Pygopodes, which have the toes lobed or margined).

2. Foot with three webs, all four toes connected.

Steganopodes: Totipalmate Swimmers, p. 3.

2 '. Foot with two webs, three front toes connected.

3. Nostrils tubular. Tubinares : Tube-nosed Swimmers, p. 3. $\because 3$. Nostrils not tubular.

4. Edges of mandibles toothed or serrate.

Anseres: Lamellirostral Swimmers, p. 3. $4^{\prime}$. Edges of mandibles not toothed or serrate.

j. Legs placed far back, wings short.

Pygopodes: Diving Birds, p. 2.

$5^{\prime}$. Legs placed near middle of body ; wings long and pointed.

Longipennes: Long-winged Swimmers, p. 2.

1'. Feet incompletely or not at all webbed.

2. Lores and ring around eye naked.

Herodiones: Herons, Storks, and Ibises, p. 4.

$2^{\prime}$. Lores and ring around eye feathered.

3. Hind toe long and approximately on a level with front toes (except in Cranes which are over three feet long).

Paludicolæ: Cranes, Rails, Coots, Gallinules, etc., p. 4.

3 '. Hind toe short and elevated or absent; bird never over twenty-six inches long . . . . Limicolæ: Shore Birds, p. 4.

Read down the ker, passing the orders to which it does not belong till you come to the order to which it does belong. For instance, if sour bird is a duck it has feet fully webbed (1), with two webs, three front toes conmected $\left(2^{\prime}\right)$, nostrils not tubular $\left(3^{\prime}\right)$, and edges of mandibles toothed or serrate (4). It belongs to the Order Anseres: Lamellirostral Swimmers. If, on the other hand, the bird you want to name is a great blue heron, as it has not fully webbed feet, rou throw out 1 and all its subdivisions, passing on to $1^{\prime}$, feet incompletely or not at all webbed. The first subdivision here is

2. Lores and ring around eye naked.

Herodiones: Herons, Storks, and Ibises.

You know if there is a naked ring around the eye, and to find what lores means you turn to the diagram of a bird, p. 1 . When you find that your bird belongs to Order Herodiones, turn to the page giren (4), where you will find a key to the families in the order. 
liead down this as before. when, by throwing out the families to which it does not belong, you come to Ardeida - 2'. Bill straight and sharp, neck and most of head feathered, to which it does belong. Go now to the page specified ( $\approx$ ) , and run down the Key to Genera, contained in Family Ardeidx, and you find that it belongs to the genus Ardea, to which you are referred (p. 74). Here you find the general characters of the genus and a key to its species. As rou know the bird is bluish gray and its size large you find it to be Arden herotias, of which a detailed description is given (p. 75). If you have been identifying a bird that you have shot, you will have your own fresh measurements to compare with those in the description (see page xxvii.).

In some of the more obscure birds you will find on getting to the description of the species that you have made a mistake in running down the kess, but by patience and care in following them you will be able to identify all but the most difficult birds.

After a little study you will grasp the general classification of birds so that it will not be necessary to go through the whole series of keys for each bird. You may not know what it is, but you know many things that it is not, and if you make a practice of climinating you will narrow down the possibilities so that it will be much easier to find your bird. You may not know whether it is a crow or a raven, but rou do know that it is not a water bird, a hawk, owl, or sparrow, and so you can go on throwing out what you know it is not until you have to look up only those about which you feel uncertain.

The question as to which subspecies a bird belongs to, unless determinahle by generaphic range, cain of ten be decided only by expert ornitholngists with large series of skins for comparison, and, in such cases, found often among some of the flycatchers, the song sparrows, and wrens, the only waty to be sure of pour bird is to send it to a museum for identification. The National Museum in Washington and the American Museum of Natural History in New York will both identify material sent them. 



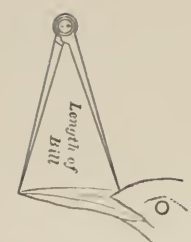

Measurement of Bill

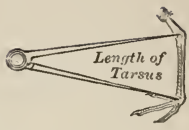

Measurement of Tarsus

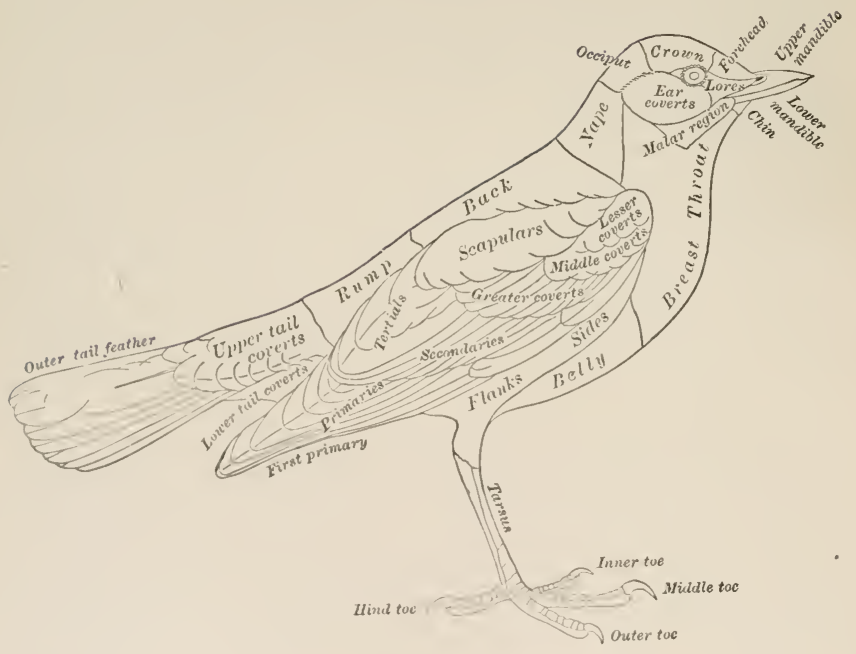

TOPOGRAPHY OF A BIRD 


\section{BIRDS OF THE WESTERN UNITED STATES}

\section{KEY TO ORDERS.}

\section{WATER BIRDS.}

1. Feet fully webbed (except grebes in Pygopodes, which have the toes lobed or margined).

2. Foot with three webs, all four toes connected.

Steganopodes: Totipalmate Swimmers, p. 3.

2 '. Foot with two webs, three front toes connected.

3. Nostrils tubnlar. Tubinares: Tube-nosed Swimmers, p. 3. 3 '. Nostrils not tubular.

4. Edges of mandibles toothed or serrate.

Anseres: Lamellirostral Swimmers, p. 3.

$4^{\prime}$. Edges of mandibles not toothed or serrate.

5. Legs placed far back; wings short.

Pygopodes: Diving Birds, p. 2. 5 '. Legs placed near middle of body; wings long and pointed.

Longipennes: Long-winged Swimmers, p. 2.

$1^{\prime}$. Feet incompletely or not at all webbed.

2. Lores and ring around eye naked.

Herodiones : Herons, Storks, and Tbises, p. 4.

$2^{\prime}$. Lores and ring around eye feathered.

3. Hind toe long and approximately on a level with front toes (except in eranes, which are over three feet long). . Paludicolæ:

Cranes, Rails, Coots, Gallinules, etc., p. 4.

$3 \prime$. Hind toe short and elevated or absent; bird never over twenty-six inches long . . . . Limicolæ: Shore Birds, p. 4.

\section{LAND BIRDS.}

1. Bill strongly hooked.

2. Toes two in front and two behind, outer toe permanently reversed.

Psittaci : Parrots, etc., p. 109.

$2^{\prime}$. Toes three in front, or outer toe reversible.

$1^{\prime}$. Bill not strongly hooked.

Raptores: Birds of Prey, p. 109.

2. Hind toe small and elevated above front ones.

Gallinæ: Gallinaceous Birds, p. 108.

2 . Hind toe not elevated above front ones.

3. Bill with soft swollen skin around nostrils.

Columbæ: Pigeons or Doves, p. 108. 
3 . Bill without soft swollen skin around nostrils.

4. Toes always three in front, middle and outer ones never connected for half their length; feet strong.

Passeres: Perching Birds, p. 110.

$4 '$. Toes two or three in front; if three, middle and outer connected for at least half their length, or feet small and weak.

5. Bill needle-like, or short, with wide gape. Macrochires : Goatsuckers, Swifts, and Hummingbirds, p. 110. 5 '. Bill not needle-like nor with wide gape.

6. Tail feathers stiff and pointed.

Pici: Woodpeckers, p. 110. 6'. Tail feathers soft, with normal tips. Coccyges: Cuckoos, Trogons, and Kingfishers, p. 109.

\section{KEY TO FAMILIES OF WATER BIRDS.}

\section{ORDER PYGOPODES: DIVING BIRDS.}

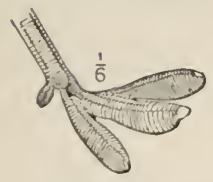

Fig. 1.

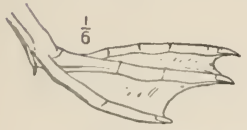

Fig. 2.

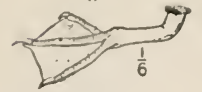

Fig. 3.
1. Tail wanting; feet not fully webbed.

Podicipidæ: Grebes, p. 5.

1'. Tail present, but short; feet webbed.

2. Hind toe present Gaviidæ: Loons, p. 9.

2'. Hind toe absent . . . . . Alcidæe: Auks, Murres, and Puffins, p. 11.

ORDER LONGIPENNES: LONG-WINGED SWIMMERS.

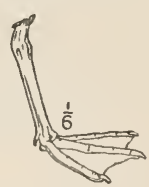

Fig. 4 .

1. Upper mandible with distinct basal saddle.

Stercorariidae: Jaegers, etc., p. 17.

Fig. 5.

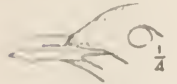

1'. Utper mandible in one piece.

Laridæ: Gulls and Terns, p. 19.

Fig. 6 . 
ORDER TUBINARES: TUBE-NOSED SWIMMERS.

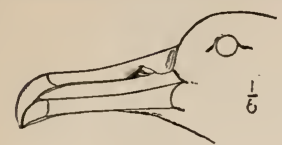

Fig. 7 .

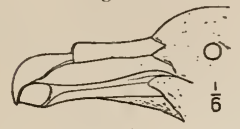

Fig. 8.

\section{Nasal tubes separated and at sides of bill.}

Diomedeidæ: Albatrosses, p. 32.

\section{1'. Nasal tubes connected on top of bill.}

Procellariidæ: Fulmars,

Shearwaters, and Petrels, p. 33.

\section{ORDER STEGANOPODES : TOTIPALMATE SWIMMERS.}

1. Bill straight and sharp, not hooked at tip.

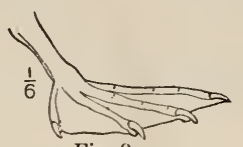

Fig. 9.

Anhingidæ: Darters, p. 39.

1'. Bill strongly hooked at tip.

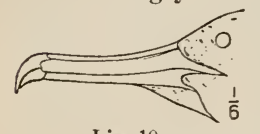

F ig. 10.

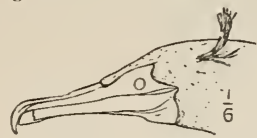

Fig. 11.

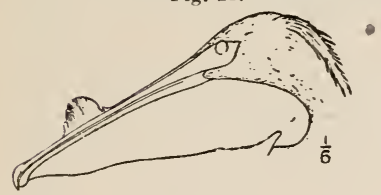

Fig. 12.
3. Bill narrow, with slight pouch at base.

Phalacrocoracidæ:

Cormorants, p. 39.

3'. Bill wide and flat, with large pouch. Pelecanidæ: Pelicans, p. 42.

\section{ORDER ANSERES: LAMELLIROSTRAL} SWIMMERS.

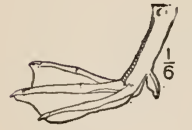

Short-legged swinmers .

Anatidæ : Ducks, Geese, and Sंwans, p. 44.

Fig. 13. 


\section{ORDER HERODIONES: HERONS, STORKS, AND IBISES.}

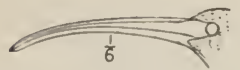

Fig. 14.

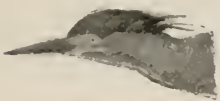

Fig, 15.
1. Bill grooved along sides from nostril to tip.

Ibididæ: Ibises, p: 70.

$1^{\prime}$. Bill not grooved along sides from nostril to tip. 2 . Bill slightly decurved or else inclined upward toward end; head and part of neck naked.

Ciconiidæ:

Storks and Wood Ibises, p. 72. 2'. Bill straight and sharp; neck and most of head feathered. Fig. 15. Ardeidæ: Herons, Bitterns, Egrets, p. 72.

ORDER PALUDICOL $Æ$ : CRANES, RAILS, COOTS, AND GALLINULES.

1. Hind toe small and much elevated: size large, wing 17 or more. Fig. 16 . . . Gruidæe : Cranes, p. 78.

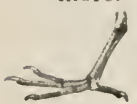

Fig. 17 . 1 . Hind toe long, nearly on a level with front toes; size small, wing 10 or less. Fig. 17. Rallidæ: Rails, Coots, Gallinules, etc., p. 79.

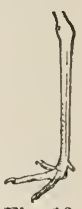

Fig. 16.

\section{ORDER LIMICOL $Æ$ : SHORE BIRDS.}

1. Hind claw, if any, not longer than its toe.

2. Front of tarsis covered with transverse scutellæ. Fig. 18.

3. Tarsus very thin, toes with lateral seallops or membranes.

Phalaropodidæ: Phalaropes, p. 84.

3'. Tarsins rounded, toes without latejal scallops or membrames.

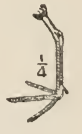

Fig. 18.

4. Bill slender, longer than middle toe without claw.

Scolopacidæ: Snipes, Sandpipers, etc.: p. 87.

4'. Bill stout, not longer than middle toe without claw.

Aphrizidæ: Surf Birds and Turnstones, p. 106.

2 '. Front of tarsus covered with hexagonal or irregular scutelle. Fig. 19.

:3. Thrsus more thin twier as long as middle toe and claw.

Recurvirostrida: Avocets and Stilts, p. 86.

:3'. Tarsus less than twice as long as micldle toe and claw.

4. Lill longer thin tarsis, laterally compressed and wedge- Fig. 19.

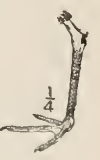

4. Bill shorter thin titrsus, pointed, not laterally compressed.

Charadriidæe: Plovers, p. 102.

1'. Hind elaw longer thau its toe; wing with spur. Jacanidæ: Jacana, p. 108. 


\section{ORDER PYGOPODES: DIVING BIRDS.}

(Families Podicipide, Gavilde, Alcide.)

\section{FAMILY PODICIPID A : GREBES.}

KEY TO GENERA.

1. Bill long and slender, tip not decurved.

2. Bill five or more times as long as depth at base.

Achmophorus, p. 5 .

$2^{\prime}$. Bill less than four times as long as depth at base.

$1^{\prime}$. Bill short and stout, tip of upper mandible decurved.

Colymbus, p. 6. Podilymbus, p. $\mathrm{s}$.

\section{GENUS झCHMOPHORUS.}

1. \#chmophorus occidentalis (Lawr.). Western Grebe.

Head without side crests; bill slender; neck nearly as long as body. Adults: top of head and line down back of neck blackish; back slaty gray; throat and under parts silvery white. Male : length 24-29, wing 7.45-8.50. bill $2.60-$ 3.05. Fe male: smaller, bill 2.102.48 .

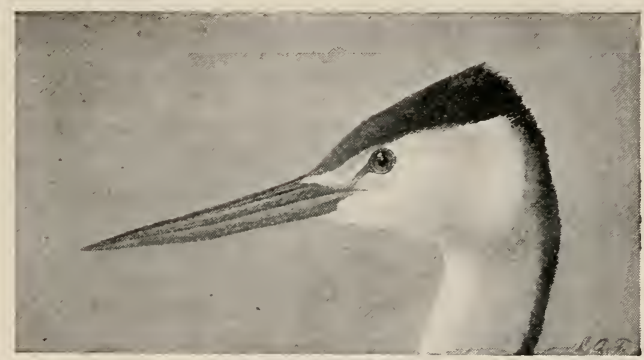

Fig. 20.

Distribution. - From the Pacific to Manitoba, and from central Mexico to British Columbia and Alberta.

Nest. - Floating on the water, a raft of tule stems, grass, and water plants, with a slight depression in the centre. Eggs: 4 to 5, white.

To find the western grebe at home go to the tule-bordered lakes of eastern Oregon. Creep through the tall grass and part the tules on the edge of a clear pond, and right before you on the water is the grebe. with its silvery throat. graceful form, and fiery eye. A sudden motion of your hand, and the needle-like bill pierces the water and the bird disappears like a flash of light, to reappear a full minute later well beyond shot-gun range from shore. If you make yourself known less suddenly the grebe instead of diving sinks slowly and without a ripple, nerer to reappear except far a way or in some hidden part of the tules.

As you watch the birds out in the lake, popping up and remaining long enough for a good breath, then going below to stay a much 
longer time, you wonder what they are finding. If you shoot one, a few tiny bones of minnows in its stomach mixed with the usual ball of feathers from its own breast tell part of the story and explain its mermaid labits, slender head, long neck, and spear-like bill.

But to get to the heart of the grebe's home you should wade out where the tules stand up to their necks in water. Here in the damp, saucer-shaped top of a floating island of tule stems, you find the eggs, warm and hastily covered with material from the sides of the nest. There is no bird in sight, but the large size of both nest and eggs serve to distinguish them from those of the smaller grebes. If you lieep still for a little while a slender head and long neck may come up out of the water near you and a pair of keen eyes watch you anxiously for a moment, then quickly sink below again, to come up a little later on the other side.

The grebes are rarely seen except on the water, but when, after much kicking and spattering, they are fairly launched on the wing, they have a steady rapid flight, and in migration make long journeys.

VERTON BaILEY.

\section{GENUS COLYMBUS.}

General Characters. - Bill straight and sharp, never four times as long as its depth at base; neck not nearly as long as body; head sometimes crested.

KEY TO SPECIES.

1. Size large, bill over 1.50

1 '. Size small or medium.

2. Suall, bill .S.2.

2 . Medimm, lill about 1.00.

holbœllii, p. 6 .

3. Lill deeper than wide at base; head of adult in breeding plumage heavily crested.

"3' Bill wider than deep at base had of adult in buritus, p. 7. lightly crested.

californicus, p. 7 .

Subgenus Colymbus.

2. Colymbus holbœllii (Reinh.). IIOLp(kLl Grebe.

liill nearly as long as leead; crests inconspicnous or wanting. Breeding plumage : twp of heat greenish black ; back blackish, with brown on wings ; silles of head and throat patcls white or grayish; neck rufous; lower parts washeel with white over gray. W'inter plumage and young: neck gray instrand of rufons. Length: is.0()-20.50, wing 7.30-8.10, bill i.6.j2.40.

Distribution. - Nonth Amrrica. Greenland, and eastern Asia, breeding north of the Inited states, migrating sonth to South Carolina, southern Colorade, and Mtouterey liat, Californiat.

Nest. - Macle of recols, griass, and mud, attached to growing reeds or. masses of dead vergetablu matter. Eggs: 4 to i. 



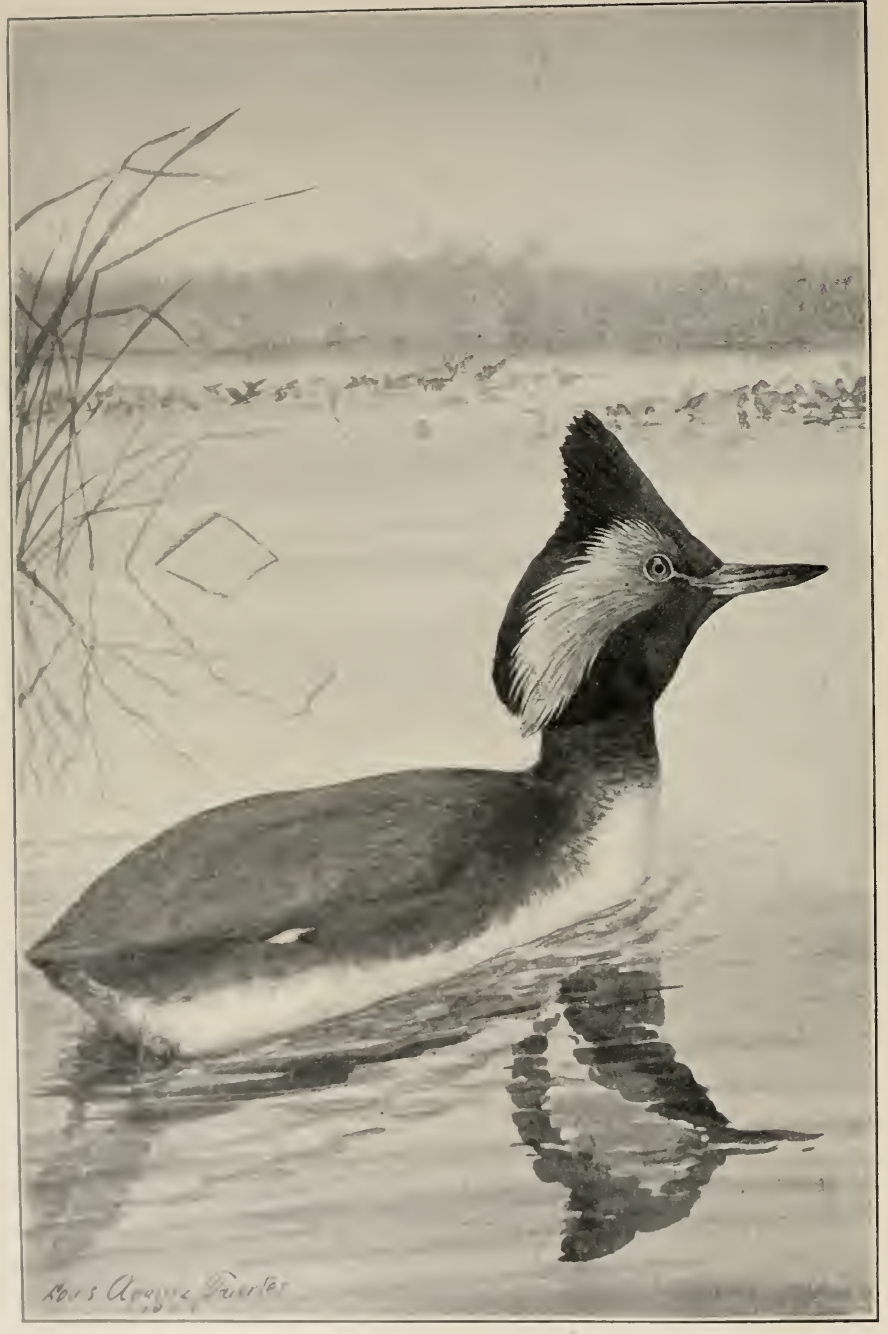

EARED GRFBE 
The Holboll grebe nests in isolated pairs in reeds along the margins of shallow, tish-frequented lakes, preferably in forested country, but also in prairie regions.

\section{Subgenus Dytes.}

\section{Colymbus auritus Linn. Horned Grebe.}

About the size of the dabchick, but slenderer; sexes similar; cheeks and sides of head with erests or ruffs in adults. Breeding plumage: sides of head with yellow tufts of silky feathers, rest of liead and throat black; upper parts dusky; lower neck, chest, and sides rufous; breast silvery white. Winter adults and young: crests seant or wanting; throat white; sides with little or no rufous. Length: 12.50-15.25, wing about 5.75, bill about .8.5-1.00.

Remarks. - The young ean usually be distinguished from young californicus by the bill, which is higher than wide at base.

Distribution. - Northern part of northern hemisphere, breeding in North America chiefly north of the United States; nigrating south over the United States.

Nest. - Made of reeds, grass, and mud, attached to reeds, or on floating masses of sticks and sedges.

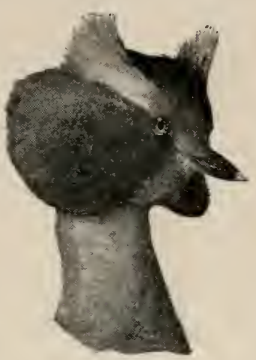

Fig. 21 .

Eggs : 5 to $\mathrm{S}$

In full plumage, with their big crests and mufflers and rich colors, the horned grebes easily rank as the handsomest of their family. In the United States they are seen on their migration journeys usually in small flocks, late in fall or following close on the retreating ice in spring. In their northern summer home their habits are said to be similar to those of other grebes.

\section{Colymbus nigricollis californicus (Heerm.). Eared Grebe.}

Breeding plumage. - A fan-shaped tuft of yellow silky feathers on each side of head; rest of head, neck, and chest black; back blackish; sides brown; breast silvery white. Winter plumage and young: upper parts and sides dusky; throat and ear patch white or grayish; bill slender, wider than deep at base ; erests wanting. Length : $12-14$, wing 5.30 , bill 1 .

Distribution. - Western North America, east to the Mississippi, north to Great Slave Lake, south to Guatemala, breeding throughout most of its range.

Nest. - Floating on shallow water in ponds or lakes; made of rushes. Eggs : 4 to 6, soiled white.

In the Great Basin country where tall tules grow half way across some of the big shallow lakes, the eared grebes have made their homes for ages, raising their young in peace and as much quiet as the cackling of coots and rails, the quacking of ducks, and laughing of stilts and avocets would allow. Out in the open ponds diving for minnows, gliding among the dark tule stems, or brooding on their floating nests and caring for their downy black chicks, they have 
been comparatively safe from enemies, and year after year have gone south when the lakes froze orer and come back again with the warm spring days.

But this life of primitive security was rudely broken into when their beautiful silvery breasts and rich brown sides attracted the attention of the plume hunters, and within five or six rears the demand for their skins for hats, muffs, and capes has grown so great as to threaten the species, and with it several other species of grebes, with extermination. Hunters go to the breeding-grounds and shoot the old birds when bold in defense of their eggs and young, stripping off their skins and shipping them in thousands to the cities. Unless some wise law intervenes, these harmless, beautiful spirits of the lake will soon have disappeared from the face of the earth.

Vernom Batlex.

\section{Subgenus Podiceps.}

5. Colymbus dominicus brachypterus Chapm. Least Grebe. A tiny dnsky grebe, abont half as big as the dabchick; bill black, tipped

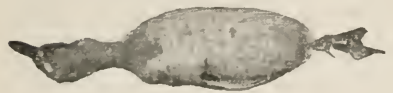

Fig. 22. with whitish. Adults : top of head and back dull greenish black; chin and throat blackish ; sides of neck and head plumbeons; breast mottled silvery gray. Wing: 3.80 , bill .82.

Distribution. - From Panama north to sonthern Texas and Lower California.

Nest. - On water, floating among the rushes, Eggs: usually 7.

These tiny crebes are as common in the ponds of southern Texas as the clabelick in the north. In open water they bob on the little waves, and in cuict pools where the willows overhang the banks swim and dive among the sedges and pink water-lilies. When not sceking foor below the surface of the water, they usually keep rlose to some 'nver, and in the middle of the day if not hidden in the sedge's are found sitting rlose under the shore grass, or in the shate of a bush or low-hanging tree.

VERTON BAILEY.

\section{GENUS PODILYMBUS.}

6. Podilymbus podiceps (Linn.). Pifd-rillem Grebe: Dabchick. Bill short and stont. head uot crested. IBreeding plumage : bill whitish,

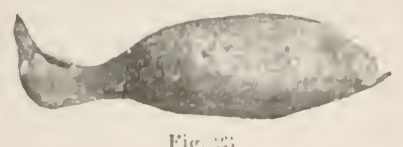

Fig. :-i; (rossed by a hlack band; upper parts hlackish; chin and throat black; breast mottled silvery gray. Winter plumage: bill brownish, with paler lower mandible; chin, throat, and breast whitish. Young: head and neck more or less striped with brown,

blacek, and white. Longth : 12-15, wing 4.50-i, (0), bill about . . 5 .

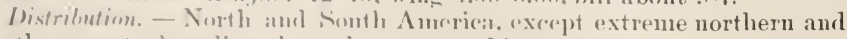
southern parts. breeding throngltont most of its range. 
Nest. - A floating or anchored raft of water-soaked plant stems among tules in shallow water. Eggs : 4 to 8, soiled whitish.

Every boy who has carried a gun and crept through tall grass to the edges of ponds and lakes, or has followed the creeks, cutting from bend to bend, and peering cautiously up stream and down, has found himself more than once face to face with a little gray duck, - only it was n't a duck - which when he raised his gun dived just as he pulled the trigger, so the shot scattered over the surface of the water. No amount of waiting or searching the banks did any good, - the bird was never seen again, dead or alive. There was a mystery about it, and when some one older and wiser than he told him. it was a water witch or hell diver, the mystery was only half solved. Where did it go? How could it stay under water through the half hour that he waited for it to come to the surface? Had he been just around the next bend he might possibly have seen a gray bill and a pair of dark eyes that came up out of the water close to the bank, stayed just long enough for a good breath of air, and then disappeared for another long swim below the surface.

Fortunately for the dabchick, its dress is all in dull colors, and as no one wants to borrow its plumes it may be hoped that, like the poor, the little plebeian may be always with us. Vervox BaILEY.

\section{FAMILY GAVIID里: LOONS.}

\section{GENUS GAVIA.}

General Characters. - Tail feathers short and stiff; front toes fully webbed; hind toe small; head and neck velvety, never crested.

\section{KEY TO SPECIES.}

1. Tarsus longer than inner toe and claw lumme, p. 11.

1'. Tarsus shorter than inner toe and claw.

2. Head and neck black . imber, p. 9 .

$2^{\prime}$. Back of head and neck smoky gray.

3. Larger, wing 12.5.5, back of lead dark gray . arctica, p. 10. 3 . Smaller, wing 11.54 , back of head light gray . . pacifica, p. 10.

\section{Gavia imber (Gunn.). Loon: Great Northern Diver.}

Adults in summer plumage. - Head and neck velvety black, glossed with green; throat and sides of neck erossed by series of white streaks; breast white; back black, spotted with white. Winter plumage and young: back slaty, without white spots; throat white. Length : 28-36, wing 14.06, bill 3.07.

Distribution. - Northern part of northern hemisphere, breeding in the northern United States and northward; south in winter to Gulf of Mexico and Lower California. 
Nest. - Usually the hollowed-out top of an old muskrat house in a lake. Eggs: 2, dark olive gray, spotted with black and more or less stained with brown.

In the north spring comes with a bound. A few warm days and a rain - the ice breaks - and then, with a wild shrill cry overhead come the loons, with strong steady flight - and spring is here. On their home waters the loons are found usually in pairs, swimming in the clear rivers and lakes, not paddling around shore or in the wild rice or tules with the ducks and grebes, but out in a big sweep of open water. If alarmed they dive, and few if any birds can equal them in long rapid journeys under water. If the lake is shallow you can follow their wake, but you must be a good rower with a good boat to keep up with one. If there is no wind a loon will often race for miles, showing only his head above water at long intervals rather than undertake the laborious water kicking performance necessary in order to get fairly on the wing. Against a stift breeze the birds rise with less effort. On land they are practically helpless, as they can neither walk nor take wing, and must slide and flap along to the nearest water. The water is their home from the time they hatch and tumble into it as furry balls of dusky down till their last cry rings over the surface.

Only on the lonely lake in the heart of the woods do you get the startling thrill of the loon's wild cry, - one clear, piercing note or a long, quavering, demoniacal laugh that to the timid suggests a herd of screaming panthers. It is one of the stirring, inspiring sounds of nature, like the scream of an eagle or the bugling of a flock of swans, and after liearing it you no longer wonder that the loon has figured in poetry and legend.

VERTON BAJLEY.

\section{Gavia arctica (Linn.). Black-throated Loon.}

Adults in summer. - Back of head and neck smoky or plumbeous gray; throat and fore neck purplish black, throat crossed by transverse bars of white streaks, a series of longitudinal white streaks separating the gray and black on sides of neck; back black, barred and spotted with white; breast pure white. ITinter and immature plumages: white markings of back wanting, and throat white. Length: 26-29), wing 12.55, bill 2.60.

Distribution. - Northern part of northern hemisphere, breeding in aretic Americal and migrating south to extreme northern states, east of the liocky Mlomintains.

Eygs. - Latid on the gromnd on a small islet in a pond; dark olive, blotcheod with blarek.

\section{Gavia pacifica (Lan r.). PAcific Loox.}

lirrding plumuge. - Back of head and neck smoky gray or whitish; thruat black, glussed with grecuish or purplish and crossed by transverse har of white streaks; sides of neck with series of longitndinal white struks; back l, lack with four series of white bars; lower parts white. 


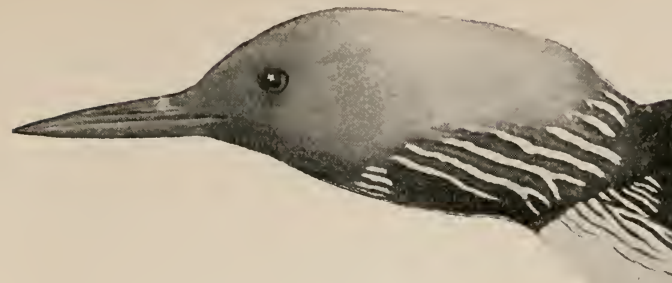

Fig. 25. Pacific Loon.

Winter plumage and young: back without white markings; throat white. Wing: 11.54 , bill 2.15 .

Distribution. - Pacific coast from Lower California to Alaska, breeding far northward; east to Hudson Bay.

Macfarlane has found nests of the Pacific loon in wooded sections, in the Barren Grounds, and on the shores of the Arctic Sea. The birds reach these breeding places in June and leave in September. In winter MIr. Loomis has found them passing up and down the coast in great numbers.

11. Gavia lumme (Gunn.). Red-throated Loon.

Adults in summer plumage. - Head and neck plumbeous gray; throat with a wedge-shaped patch of rich chestnut; back sooty : top of head and back of neck streaked and back specked with white; under parts white. Winter plumage and young: throat and fore neck white. Length: 24-27, wing 10.00-11.50, bill 2.25 .

Distribution. - Northern part of northern hemisphere, breeding in aretic regions and migrating south nearly across the United States.

Eggs. - 2, laid on the ground, like those of G. arctica, p. 10.

In Alaska the red-throated are by far the most abundant of the loons. They reach St. Michaels and the Yukon delta with the first open water, and by the end of May are to be seen in great numbers. Mr. Nelson says they are extremely noisy all through the first part of summer, their harsh $g r-r-g \breve{a}-g r-r, g r-r-g \breve{a}, g \breve{a}-g r-r$ rising everywhere from the marshes during the entire twenty-four hours.

\section{FAMILY ALCID尼: AUKS, MURRES, AND PUFFINS.}

KEY TO GENERA.

1. Bill high, much compressed, ridged down sides; a fold of naked skin at corner of mouth . . . . Lunda, p. 12.

Fig. 26. 1'. Bill not extremely high, compressed, nor ridged; corner of mouth without fold of naked skin.

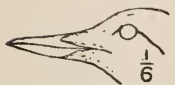

2. Nostrils covered by feathers

Uria, p. 16.

Fig. 2.

$2^{\prime}$. Nostrils exposed.

3. Bill about as long as head, 1 or more. 


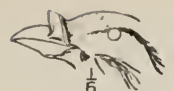

Fig. 25 .

4. Bill stout, tip decurved, base with horn in breeding season . . . . Cerorhinca, p. 13.

$4^{\prime}$. Bill slender and straight, base without horn.

Cepphus, p. 16.

Fig. 29.

3'. Bill much shorter than head, .80 or less.

4. Bill wider than deep at base.

Ptychoramphus, p. 13.

$4^{\prime}$. Bill much deeper than wide at base.

j. Cutting edge of lower mandible concave.

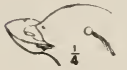

(j. Bill .60, without knob at base.

Cyclorrhynchus, p. 14.

Fig. 30 .

制 $6^{\prime}$. Bill 40 or less, with knob at base.

Fig. 31 .

Simorhynchus, p. 14.

5 '. Cutting edge of lower mandible convex.

6. Tarsus seutellate in front.

$6{ }^{\prime}$. Tarsus reticulate in front.

Synthliboramphus, p. 15.

Brachyramphus, p. 15.

\section{GENUS LUNDA.}

12. Lunda cirrhata Pall. Tufted Puffin.

Bill compressed, nearly as high as long. Adults: upper parts sooty

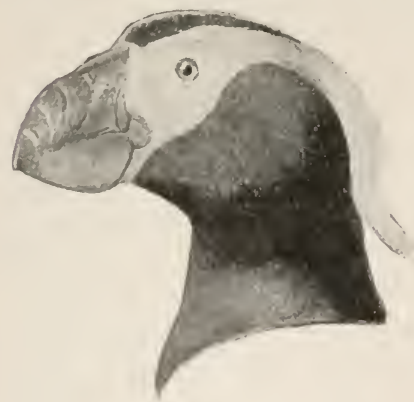

Fig. 32. black; under parts dark grayish. Breeding plumage: sides of face white, a long erest of fine silky yellow feathers over each eye; terminal half of bill, and feet, bright red. Winter plumage: sides of head dusky, and without erests; horny covering of base of bill replaced by soft dusky brown skin; feet flesh color. Young in first winter: similar to winter adnlt, but with rudiments of light brown erests, and sides of upper mandible without grooves. Length: 14.40-15.60, wing 7.75 , bill 1.3(1-1.4.).

1)istribution. - Coast and islands from sonthern California to Alaska, and from Bering Strait to Japan.

Egg. - 1, laid usually on the bare ground at the end of a burrow or in cavity anoug rocks on the face of a cliff.

The tufted puflins nest preferably among cliffs and on earth and grass-covered edges of bluffs, and in such places the ground is often 
a network of their burrows. When there is no soil to burrow in, the birds use natural cavities.

They reach the Farallone Islauds the latter part of March, and when the nests are made and incubation begun, Mr. Bryant says, they may be located by the presence of a sentinel at the entrance of the burrow.

The bright and oddly shaped bill, white eyes, and yellow nuptial tufts, which flutter in the wind, give the bird a most distinguished appearance. Its bill is not only an ornament but a most effective weapon. When caught in its burrow the puffin inflicts painful wounds with it, sometimes actually cutting to the bone, its jaws remaining set until pried apart or until it is killed.

\section{GENUS CERORHINCA.}

\section{Cerorhinca monocerata (Pall.). Rhinoceros Auklet.}

Bill much compressed, longer than deep; in breeding season base of bill surmounted by upright horn. Breeding plumage: upper parts dusky; sides of head, throat, and rest of under parts plumbeous, except for whitish belly; side of head with two series of white pointed feathers. Winter plumage : breast more uniformly gray; belly purer white; horn absent. Young: head without crests. Length: 14.00-15.50, wing 7.25 , bill from front edge of horn 1 .

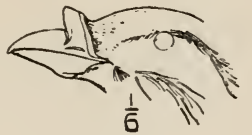

Fig. 33.

Distribution. - From coasts and islands of the north Pacific to Lower California, and to Japan.

When collecting the rhinoceros auklet at the Catalina Islands, Mr. Joseph Grinnell found it a most persistent diver and powerful swimmer under water. He did not see one of the birds on the wing. They all dived on approach. He says the auklet is so short and chunky that at a little distance it looks like a block of wood floating on the water. The food of the birds Mr. Grinnell took, on examination of their stomachs, proved to be entirely a small yellow cristacean, none of which were to be seen anywhere near the surface.

At MIonterey Mr. Loomis saw an extensive migration of the auklets on January 12, 1895. The birds came from the north in pairs, and went on down the coast without stopping.

\section{GENUS PTYCHORAMPHUS.}

\section{Ptychoramphus aleuticus (Pall.). Cassin Auknet.}

Bill broader than deep at base; upper outline nearly straight.

Upper parts slaty black; sides of head, neck, and throat plumbeons; spot on lower eyelid, and under parts, white. Length: $8.00-9.50$, wing $4.75-5.25,5$, bill .75.

Distribution. - Pacific coast of North America from Aleutian Islands to Lower California.

Egg. - 1, unmarked, laid in a natural cavity. 
At Monterey Mr. Loomis has found comparatively few Cassin auklets near land, but reports them as common off shore, especially on the ocean. In July he has found eggs and young birds on the Farallone Islands, and in one case discovered an auklet sharing its apartment with two rabbits. The numbers of these birds on the islands was impressively shown one night during Mr. Loomis's visit. At sundown he saw several flocks flying high overhead and at two in the morning awakened to find the bird population in an uproar. Although it was pitch dark the roices of the auklets - which he com. pares to those of whip-poor-wills - filled the air till the whole island appeared to be alive with birds.

\section{GENUS CYCLORRHYNCHUS.}

17. Cyclorrhynchus psittaculus (Pall.). Paroquet Auknet.

Bill dark red, high, and thin, with sickle-shaped lower mandible curved

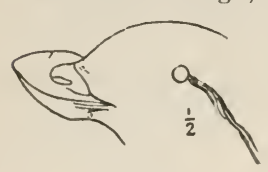

Fig. 34 .

upward. Breeding plumage: throat and upper parts sooty black; under parts white; a white line from lower eyelid back over ear ending in a thin white crest. Winter plumage and young: throat as well as rest of mider parts white. Length: $9.00-$ 10.40, wing 5.40-6.00, bill .60.

Distribution. - Coasts and islands of the north Bay to Sitka, and northward.

Pacific from the Kurile Islands and San Franciseo

Egg. - 1, pure white, deposited in a deep chink or crevice.

When sailing across Bering Sea, on the way to Norton Sound, Mr. Nelson's ressel was stopped and held by the pack ice. When the ice at last opened, he says, the water became covered by thousands of the strange little auklets, and as long as the ship was in the ice the only sounds beside the grinding of the cakes and the roar of the waves were the low whistled notes of the parrot and crested auklets, myriads of which surrounded the boat, "swimming buoyantly from side to side or skurrying away from the bow of the ressel." On the Fur seal Islands the birds were again encountered, this time breeding on the cliffs, feeding at sea and returning to their nests and mates on the islands.

\section{GENUS SIMORHYNCHUS.}

\section{Simorhynchus pusillus (Pall.). Llfast AUKLet.}

Size very small; bill with $\mathrm{kmol}$ ) at base; crests of slender white feathers $=$ in front and back of eye. Breeding plumage: upper parts blackish, mixed with white on scapulars; under parts white, irregularly spotted or mottled with dusky, of ten forming Fig. $35 . \frac{}{2}$ a dusky band across chest. Winter plumage: under parts
and sirles of neck pure white; face erests usually less de-
oped. Young: similar to winter adults but with more white on seapuFig. 35. and sides of neck pure white; face erests usually less de-
oped. Young: similar to winter adults but with more white on scapuveloped. Joung: similar to winter adults but with more white on scapu-
lars and withont the white face feathers. Length: $5.50-7.20$, wing $3.50-$ 4.00 , bill $.35-.40$. 
Distribution. - Coasts and islands of the north Pacific from Bering Strait south to Washington and Japan. Recorded from Puget Sound, Auk, x. 17 .

\section{GENUS SYNTHLIBORAMPHUS.}

\section{Synthliboramphus antiquus (Gmel.). Ancient Murrelet.}

Bill small and short, nostrils exposed; front of tarsus covered with transverse scutellæ. Breeding plumage: head and neck black, with large white patch on side of neck, a wide stripe of white filaments along back edge of crown, and scattered white filaments over back of neck; back slaty; sides black; under parts white. Winter plumage: throat white; head and back without white filaments ; sides gray. Length: 9.50-10.80, wing 5.25-5.50, bill .60.

Distribution. - Coasts and islands of the north Pacific; south to Monterey Bay.

Nest. - As described by Littlejohn, often an abandoned burrow of Cassin auklet, a crevice under a rock, or a burrow under a tussock of rank grass, lined with dry grass; but sometimes bare rocks, sand, or wet ground. Eggs : 2, deep buff, with small longitudinal markings of light brown and lavender gray.

Ancient murrelets visit California in winter in considerable numbers, and Mr. Loomis has found them near the Seaside Laboratory close to the surf in the little coves. He describes them as "great divers and swimmers under water, and voracious in their pursuit of small fry, occasionally driving the fish to the surface in the eagerness of the chase."

Mr. Littlejohn, who visited their breeding grounds on the Alaskan islands, says that on some of the favorite islands the entire surface was literally alive with murrelets, auklets, and petrels.

\section{GENUS BRACHYRAMPHUS.}

General Characters. - Bill small and slender; colors plain; head not crested.

KEY TO SPECIES.

1. Tarsus shorter than middle toe to claw . . . marmoratus, p. 15. 1 '. Tarsus as long as, or longer than, middle toe to claw.

hypoleucus, p. 16.

\section{Brachyramphus marmoratus (Gmel.). Marbled Mur-} RELET.

Breeding Plumage. - Upper parts dusky, back and sides barred with deep rusty brown; under parts white, mottled with sooty brown. Winter plumage: upper parts slaty, with white band on back of neck; scapulars mixed with white; feathers of back tipped with plumbeous; flanks with dark gray stripes. Young: upper

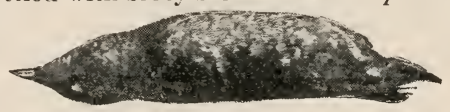

Fig. 36 . parts dusky, collar and seapular spots indistinct ; under parts white, mottled, or speckled with sooty. Length: 9.50-10.00, wing 5, bill .60-.70.

Distribution. - Pacific coast from southern California to western Alaska. 
Mr. Preble, who found these murrelets common at Neah Bay, Washington, reports that they were almost invariably seen in pairs and that they were difficult to approach, as they dived at the slightest alarm.

25. Brachyramphus hypoleucus Xantus. Xantus Murrelet.

Upper parts plain dark slaty; under parts and lining of wing pure white. Length: $9.60-10.50$, wing $4.50-5.25$, bill .70-.80.

Distribution. - Southern and Lower California from Santa Barbara Island to Cape St. Lueas.

Mr. Grinnell writes from Los Angeles that this murrelet is frequently seen in the Santa Barbara Channel at all seasons.

\section{GENUS CEPPHUS.}

29. Cepphus columba Pall. Pigeon Guillemot.

Bill black, straight, and slender, upper edge of nostril feathered;

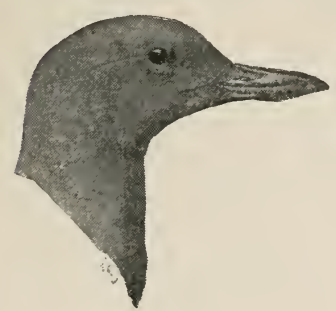

Fig. 37. feet bright red in summer, pink in winter. Breeding plumage: black, except for large white patch on base of wing which half incloses a black triangle. Winter plumage: wings and tail as in summer, rest of plumage mainly white, varied above and sometimes below with black. Foung: similar to winter adults, but white of wings obseured by dusky, tips of quills marked with white. Length: 13-14, wing 6.90-7.80, bill 1.20-1.40. Distribution. - Coast of the Pacific from southern California to the Aleutian Islands, and to northern Japan.

Eggs. - As found by Dr. Dall, 2, at the bottom of a hole under the rocks near the water's edge.

In Alaska Mr. Nelson found the pigeon guillemot one of the most abundant of the larger water birds, occurring wherever the coast was bordered by bold headlands or where there were precipitous islands. He says that their bright red legs and white wing patches make them very conspicuous. They are graceful swimmers and have the amusing habit of putting their heads under water and paddling along their headless bodies.

Mr. Bryant, who has watched them at the Farallones, says that when at rest they squat like ducks on the rocks. Before brooding begins they often sit in groups, and when disturbed stand up, open their bills, and salute each other or their returning fellows with a whistling cry.

\section{GENUS URIA.}

30a. Uria troile californica (Bryant). California MitrRe.

Bill narrow and slender, nostril concealed in feathers; a deep groove in feathers back of eye. Breeding plumage: upper parts slaty or blackish, sec- 
ondaries tipped with white; sides of head, neck. and throat velvety sooty brown; under parts pure white. Winter plumage : sides of head, neck, throat, and under parts pure white; a dusky stripe back of eye. Young: like

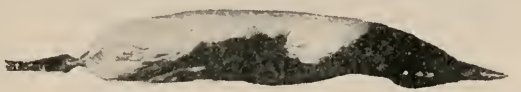

Fig. 3s. California Murre. winter adults, but with white more restricted on sides of head and lower throat faintly mottled with dusky. Wing: 8.30 , bill 1.S6.

Distribution. - Pacife coast of North America; south to southern California.

Eggs. - Deposited on the bare rock.

The attention of the ornithological world has been called to the murres by the San Francisco egg industry, which threatened to destroy the rookeries on the Farallone Islands. Between 1850 and 1856 three or four millions of eggs are said to have been brought to San Francisco, where they sold for a little less than hens' eggs. In the eighties the number of eggs marketed annually, Mr. Bryant states, averaged from 180,000 to 228,000 . This wholesale destruction decreased the numbers of the murres to such an extent that in 1897 the attention of the Lighthouse Board was called to the matter, and they put a stop to the business on the islands.

The murres' eggs are considered a delicacy not only by man, but by gulls and young sea lions. Two or three gulls will sometimes combine to rob a nest. When they try to steal the young the murres crowd their little ones from the rocks so they can escape by diving.

In describing the habits of the murres Mr. Bryant says that on the rocks they continually bow their heads and make a great noise, and when on the wing sometimes emit a curious grunting note. They are especially clamorous before a storm.

When incubating, one bird stays on the nest during the day and the other during the night, and when the exchange is made a great commotion ensues, the air being filled with quarreling, screaming masses of bird life.

\section{ORDER LONGIPENNES: LONG-WINGED SWIMMERS.}

(Families Stercoraritde, LARIDe, et:.)

FAMILY STERCORARIID王: JAEGERS, ETC.

GENUS STERCORARIUS.

General Characters. - Bill strongly hooked, nostrils near middle, section above and back of nostrils covered with a saddle-like plate; tail with middle pair of feathers much the longest. 
KEY TO SPECIES OF STERCORARIUS.

1. Middle pair of tail feathers wide, and rounded at ends.

1'. Middle pair of tail feathers narrow and sharp-pointed.

pomarinus, p. 18.

2. Middle feathers about half longer than rest of tail.

2 . Middle feathers about twice as long as rest of tail.

parasiticus, p. 18 . longicaudus, p. 18.

36. Stercorarius pomarinus (Temm.). PoMARINE JAEger.

Adults - Light phase: face, crown, and upper parts, except collar, sooty black; throat white, becoming silky yellow on clieeks and around back of neck ; breast white, chest and sides mottled with sooty. Dark phase: wholly dark sooty or plumbeous. All grades are found between the dark and light pliases. Young: back dusky, feathers tipped with buff; rest of plumage dull buff, barred with dusky. Length: 20-23, wing 13.50-14.00, tail 8-9, bill $1.45-1.75$.

Distribution. - Northern part of northern hemisphere; south in winter to Africa, Australia, and probably South Anterica; in the United States to Michigan, Nebraska, and California.

Mr. Nelson found the pomarine jaeger largely replacing the other two jaegers along the shores of the Arctic Ocean, especially on the edge of the ice pack and about the whaling fleet, where it found abundant fare. He says that the peculiar twist of its long tail feathers makes it conspicuous and easily identified as far as seen. When feeding it gives a low, harsh, chattering cry.

Compared with the parasitic jaeger, the pomarine is a clumsy cowardly bird, Mr. Nelson tells us, and is made the sport of its active little relative. When met in the air, the pomarine wards off attack from one side by a half-closed wing, and from above by raising both wings to form an arched shield over its back. One that Mr. Nelson saw attacked alighted on the river, and "at every swoop of its assailant thrust its head under water, exhibiting the most ludicrous terror."

37. Stercorarius parasiticus (Linn.). PARAsitic JAEgER.

Adults. - Light phase: upper parts slaty, becoming blackish on crown, wings, and tail; throat and under parts white; sides of head and neck white or grayish, tinged with yellow. Jark phase: entire plumage slaty or sooty, darkest on crown, wings, and tail. Young: head and neck streaked, and under parts spotted and barred with buff and dusky. Length: 15.5)-21.0.), wing 12.(7), tail 4.90-6.25, bill 1.27.

Distribution. - Northern part of northern hemisplere, breeding in arctic regions; south in winter to New York, Illinois, Colorado, and southern California.

Nest. $-\Lambda$ depression in the moss. Eggs: 2.

38. Stercorarius longicaudus Vieill. Long-TAILED JAEgER. Adults.- Top and sides of head black; back slaty ; neck and lower parts 
of head, including ear coverts, straw yellow, paler on throat; chest, and sometimes breast and belly, white, shading into gray on sides; under tail coverts, and usually belly, gray ; feet black ; tarsus light bluish. Length : 20$2: 3$, wing 12.25 , bill 1.19 , longest tail feathers 10.50-14.50.

Distribution. - Northern part of northern hemisphere, breeding in arctic regions; south in winter to Florida, Gulf of Mexico, and California. Taken at Monterey Bay by Mr. Loomis.

Eggs. - Deposited in a depression in the mossy top of a knoll.

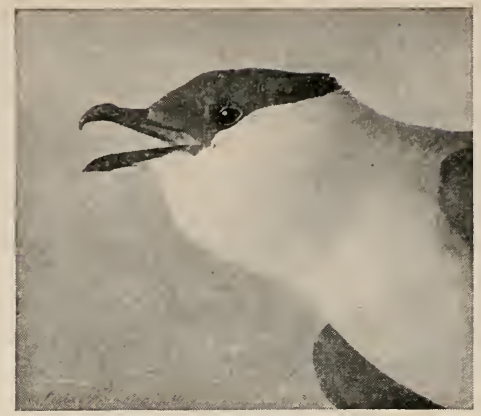

Fig. 39. Long-tailed Jaeger.

The long-tailed jaeger is so swift and graceful on the wing that Mr. Nelson compares its flight to that of the swallow-tailed kite. After chasing each other about or pursuing hapless gulls or terns, the birds may often be seen sunning themselves on an elevation, their white breasts pointing them out at a long distance.

\section{FAMILY LARIDÆE: GULLS AND TERNS.}

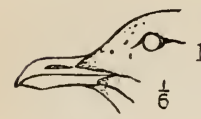

Fig. 40 .

\section{KEY TO GENERA.}

1. Bill deeper through angle of lower mandible than through nostril.

2. Hind toe wanting, or a mere rudiment.

2 '. Hind toe small but perfect.

Rissa, p. 19.

3. Tail square across end . . . Larus, p. 20. 3'. Tail deeply forked . . . Xema, p. 27.

$1^{\prime}$. Bill deeper through middle of nostril than through angle of lower mandible.

Fig. 41 .

2. Tail forked for more than one fifth its length (except sometimes in S. caspia); outer feathers narrow and pointed.

3. Length of bill less than three times its depth at base . . . Gelochelidon, p. 27.

3 . Length of bill more than three times its depth at base . . . . . Sterna, p. 27.

2 . Tail forked for about one fifth its total leugth, outer feathers wide and rounded at tips.

Hydrochelidon, p. 31.

\section{GENUS RISSA.}

40a. Rissa tridactyla pollicaris Ridgw. Pacific Kittiwake.

Appearance gull-like; hind toe minute, with or without a nail ; feet 
and legs black; tarsus shorter than middle toe with claw; bill yellow, with greatest deptl at base; tail slightly emarginate, or forked. Adults: back and wings light bluish gray, five outer primaries tipped with black; rest of plumage pure white. Young: like adults, but with black or slaty on back of neck and across ear coverts. Length: 16.00-17.70, wing 12.25, bill 1.40-1.50.

Distribution. - North Pacific and Bering Sea; south in winter casually to Lower California.

Nest. - On inaccessible shelves of rock, made of grass and moss cemented with mud. Eggs: usually 2, gray, spotted with brown.

The kittiwakes reach Alaska before the ice breaks up, and hunt for food in the tide cracks along shore. In the breeding season they take to the cliffs of the mainland or the rocky islands. From the end of August they hunt in the inner bays and mouths of small streams, but as they are strictly tide-water birds rarely go up the rivers. In October the ice forming on the bays drives them south.

\section{GENUS LARUS.}

General Characters. - Bill deeper through angle of lower mandible than through nostril; tail square across end; hind toe swall but perfect.

IIEY TO SFECIES.

1. Size large, wing 15.00 or more.

2. Wing without any black.

3. Quills white or pale gray shading to white at ends.

$3^{\prime}$. Quills clear gray with white tips

glaucus, p. 21.

2 '. Wing quills partly black at all times.

3. Mantle dark slaty gray in adult . . . . . occidentalis, p. 21.

$3^{\prime}$. Mantle light gray in adults.

4. Lower mandible in adult with subterminal spot of red and spot of black. . . . . . . . . californicus, p. 23.

4'. Lower mandible in adult with subterminal spot of red only.

5. Mantle delicate pearl gray . . . . argentatus, p. 22.

5'. Mantle slightly darker gray . . . . . . . vegae, p. 23.

$1^{\prime}$. Size medium or small, wing under 15 (rarely over in delawarensis).

2. Breast always dark slaty gray . . . . . heermanni, p. 24.

2 '. Breast always white in adult, mottled in young.

3. Head never black; white in adults.

4. Bill yellowish, witl black band near end in adults.

4'. Bill greenish, without black band.

delawarensis, p. 23.

5. Third quill witl subterminal white spot in adult.

brachyrhynchus, p. 24.

$5^{\prime}$. Third quill without subterminal white spot in adult.

canus, p 24 .

3'. Head black in summer adults, size small.

4. Bill and tips of outer quills black . philadelphia, p. 26.

4'. Bill dark red in adult, quills not tipped with black.

5 . Three outer quills mainly black . . . atricilla, p. 25.

5 . Five outer quills with tips and base white . franklinii, p. 25. 


\section{Larus glaucus Brünn. Gladcous Gull.}

Primaries white or light gray, shading into white at ends. Adults in summer: mantle, i.e. back and top of wings, light pearl gray; rest of plumage white. Adults in winter: head and neck streaked with grayish. Young: whitish, tinged below and mottled above with brownish gray. Length: 26-32, wing 16.75-18.75, bill 2.30-2.70.

Listribution. - Arctic regions; in North America south in winter to North Carolina, the Great Lakes, and San Francisco Bay. Not common in the United States.

Nest. - A depression in a ledge of rock, lined scantily with fine grass, or a bulky mass of sod and tufts of moss on an islet in a pond. Eggs: 2 or 3 .

The glaucous gull has been found by Mr. Loomis at Monterey, and by Dr. Cooper and Mr. Kobbé in San Francisco Bay.

\section{Larus glaucescens Naum. Gladcous-Winged Gull.}

Adults in summer. - Mantle light pearl gray ; primaries gray, with distinct white tips; rest of plumage white. Adults in winter: head and neck clouded with sooty gray. Young: deep ashy gray; head and neck streaked, and rest of upper parts mottled with grayish white or dull buff. Length: $23.70-27.75$, wing $16.25-17.30$, bill $2.20-2.60$, depth of bill at angle $.80-.90$.

Distribution. - From Bering Sea south in winter to southern California and Japan.

Nest. - Usually on the face of a rugged cliff, but sometimes in grass on grassy islands, or a depression in seaweed. Eggs: 3 .

Mr. Kobbe says that the glaucous-winged gulls are abundant in San Francisco Bay in winter, and Mr. Loomis has found them common in Monterey Bay. Mr. Loomis says they make up the greater number of gulls in the large trains of gulls and pelicans that attend the whales that come into the bay. Near the ocean, in the Carmel valley, he has found them in company with western gulls following the plough like blackbirds.

At Gray's Harbor, Washington, MIr. Lawrence says the gulls are very common from fall until late spring. During the salmon runs they often fly thirty miles to feed on the dead salmon along the streams, returning to the harbor to roost. The gulls also visit the salmon canneries to feed on the refuse.

\section{Larus occidentalis Aud. Westers Gull.}

Adults in summer. - Mantle dark slaty gray; primaries, including inner webs of first, second, and usually third black, tipped with white; rest of plumage white. Adults in winter: top of head and back of neck streaked with dusky. Young: upper parts brownish slaty, varied with buff and whitish; quills and tail dull black, usually tipped with white; under parts brownish grar, specked or spotted with whitish. Length:24-27, wing 15.75-17.00, bill 2.00-2.35, depth of bill at angle .85-.95.

Distribution. - Pacific coast from British Columbia to Cape St. Lucas, Lower California.

Nest. - A depression in seaweed. Eggs : usually 3, light grayish olive, spotted with shades of brown and lilac. 
The western gull is abundant on the California coast at all seasons. At San Pedro harbor it is protected by law as a useful scavenger, and at Monterey Bay is so fearless that the young will alight within a few feet of the fishing boats to get what the fishermen throw out.

On the Farallone Islands the birds assume another rôle. As Mr. Loomis says, "a more vagabond set of gulls than the western gulls inhabiting South Farallone Island during the egg season could scarcely be found. They are arrant thieves, robbing the murres wherever they have the opportunity." Before the murre egg industry was stopped they took an excited nart in the collections. Mr. Loomis, speaking of it at the time, says that "when the eggers appear on the scenes the gulls congregate and soon a large flock is formed, circling about overhead with loud cries, eagerly waiting the flight of the murres to join in the pillage. When exceptionally hungry the gulls are said to suddenly descend in a compact flock among the murres, frightening them from the eggs. One gull was seen trying to steal an egg from under a murre. The murre gave a reproachful squack and with a thrust of the bill drove the gull away."

But though the gulls enjoyed the raids of the eggers, they suffered by them, for before the murres began to lay, the men took gulls' eggs to supply the market; and when the murre harvest was ripe, recognizing the gulls as rival eggers, the men destroyed both their eggs and young. In addition to fish and eggs, the gulls eat sea-urchins, crabs, young murres, and rabbits.

They congregate at South Farallone Istand the first of April, Mr. Bryant tells us, and proceed to nest in small colonies. It takes them two weeks to repair their old nests, and even after the first egg is laic they may be seen carrying Farallone weed to the nest.

\section{Larus argentatus Brïnn. Herring Gull.}

Adults in summer. - Mantle delicate pearl gray; five outer primaries black toward ends, and tipped with white; a distinct gray wedge on inner web of second quill; rest of plumage white ; bill yellow, with red spot near end of lower mandible; feet pale flesh color. Adults in winter: head and neck streaked with grayish. Young: brownish gray; head and neck streaked with white; back mottled with buffy and gray; quills and tail blackish; bill dusky, feet purplish. Length: 22.50-26.00, wing 17.24, bill 2.24 , depth of bill through angle of lower mandible .68-.S5̃.

Distribution. - Northern hemisphere, including the whole of North America; south in winter to Cuba and Lower California; breeding from the Great Lakes northward.

Nest. - On rocks or in trees, made mainly of grass, seaweed, and earth. Eggs: usually :3, from pale olive drab to greenish or bluish white, irregularly spotted with lilac, yellowish, or brown, markings usually thickest about larger end.

The herring gulls are abundant in the bays of San Francisco and 
Monterey in winter and common down the coast to San Diego. In the harbors they alight on the masts and fly about the vessels, often following them thirty or forty miles from land. Their name probably comes from the commotion they make at sight of a school of herring or other little fish. As they follow the small fry about, the fishermen often take them for pilots and follow to get the larger fish which are in pursuit of the little ones.

\section{Larus vegæ (Palmén). Vega Gull.}

Like argentutus, but mantle darker, deep pearl or plumbeous gray; feet pale flesh color. Size about as in argentatus.

Distribution. - Southern Europe and Central Asia to Japan and Bering Sea, and down the coast of North America in winter to California.

Mr. Kobbé, in The Auk (xix. 19), after examining a large number of specimens, concludes that vegre and argentatus are identical, but as there is a difference of opinion as to its validity, the species is included on what seems to be its only character, the slightly darker mantle.

\section{Larus californicus Lawr. Califormia Gull.}

Adults. - Mantle elear bluish gray; outer primaries black, tipped with white, the first two with subterninal white spots; a distinct gray wedge on inner web of second; bill yellow, with red and black spot near end of lower mandible; feet greenish. Youny: upper parts coarsely spotted and mottled with dusky, buffy, grayish, and whitish; under parts mottled and streaked; quills and tail blackish; bill dusky, with black tip. Length: 20-2:3, wing 15.00-16.75, bill 1.65-2.15, depth of bill at angle .60-.75.

Distribution. - Western North America from Alaska to Mexico, chiefly in the interior.

Mr. Loomis sass that in the matter of numbers near Monterey in midwinter the California gull ranks with its larger congeners the glaucous-winged and the western. Mr. Grinnell finds it common along the southern coast, where it frequents the fresh-water marshes, and he has seen it on the Los Angeles river-bottoms. At Pescadero in the low fields near the ocean hundreds have been seen following the plough.

\section{Larus delawarensis Ord. Rixg-Billed Gull.}

Adults. - Mantle light pearl gray; bill greenish yellow, crossed near end by a distinct black band, tip yellow or orange; eyelids vermilion, iris pale yellow; feet pale yellow, sometimes tinged with greenish. Young: upper parts dusky, featliers bordered and marked with grayish buff or whitish ; under parts white, spotted along sides with grayish brown ; quills blackish, the shorter ones gray at base and tipped with white; base of tail grav, outer half blackish, tipped with white. Length: 18-20, wing 13.60-15.75, bill 1.5\%-1.75, depth at angle of lower mandible .50-.65.

Distribution. - Whole of North America, breeding as far south as Colorado. but mainly north of the United States; migrating south to Cuba and Mexico.

Nest. - On the ground, made of dry grass. Eygs : usually 3. 
Mr. Grinnell reports the ring-billed gull as tolerably common along the coast in mid winter, and MIr. Loomis has taken a few at Monterey. In Colorado they are the only gulls found abundantly throughout the state. Professor Cooke says they are very common in the fall migration on all bodies of water below 9000 feet, and he has found them breeding at the San Luis Lakes at an altitude of 7500 feet.

Colonel Goss says that he has often seen the gulls on fall afternoons sailing and circling about in the air, catching grasshoppers and beetles.

\section{Larus brachyrhynchus Rich. Short-Billed Guld.}

Adults in summer. - Mantle light pearl gray; rest of plumage, except quills, white; outer primary mainly black, with a large white spot near end; second primary with a smaller white spot, white tip, and wedge of gray on inner web; third with white tip and a large white space on inner web between gray and black; bill greenish, with yellow tip; feet and legs greenish. Adults in winter: head, neck, and chest mottled with dusky. Young: upper parts grayish brown, feathers bordered with pale grayish buff; liead, neck, and lower parts brownish gray; tail gray at base, brownish gray toward end, and narrowly tipped with white. Length: $16.50-18.00$, wing 13.95 , bill 1.45 , depth of bill at angle .40-.50.

Distribution. - Western North America, breeding far north; south in winter to sonthern California.

Nest. - On an islet, in a lake or pond, bulky, made of grasses and mosses. Eggs: 2 or 33 .

Mr. Loomis has found the short-billed gull common on both the bay and ocean about Point Pinos in winter.

\section{Larus canus Linn. MEW Gull.}

Adults. - Similar in general appearance to brachyrhynchus, but with inner webs of two onter quills mainly black behind the subterminal white spots, and third quill mainly black except for small white tip. Length: 17.0018.50 , wing $14.60-14.50$, bill $1.35-1.60$, depth of bill at angle $.35-.50$.

Distribution. - Northern Europe and Asia ; found in Labrador (?) and at San Franciseo Bay.

The mew gull was formerly supposed to be confined almost entirely to Europe and Asia, but Mr. Loomis finds that it is common on the California coast in winter.

\section{Larus heermanni Cass. Heermann Guld.}

Adults in summer. - Bill bright red; head and upper neck white; back

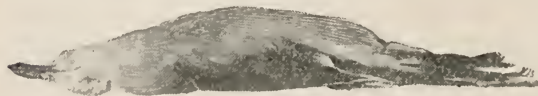

Fig. 42. sooty gray, secondaries tipped with white; primaries and tail black, tail tipped with white; under parts dark gray. Adults in winter: head darker than body, otherwise as in summer. Young: sooty gray, feathers of upper parts bordered with whitish or pale buff; or, entire plumage sooty gray except blackish tail and quills. Length: 17.50-21.00, wing 13.50, bill 1.50. 
Distribution. - Pacific coast of North America from British Columbia to Panama.

Heermann gulls are generally common winter visitors in southern California. At IIonterey Mr. Loomis has taken careful notes of their migratory movements. In Nay they were rare, in June adults were still scarce, but the latter half of the month immature birds were common. By the middle of July adults were abundant, and before $A u g u s t$ there was a great inroad of the dark-plumaged birds. Toward the end of August the western and Heermann gulls appeared to be of about equal abundance, and in November their flights rivaled or exceeded those of the western gull.

Mr. Grinnell says that on the coast near Los Angeles where the fishermen draw their seines along the beaches, clouds of gulls are usually attracted, about half of the flocks being Heermann and a quarter western gulls.

\section{Larus atricilla Linn. Ladghing Guld.}

Adults in summer. - Head slaty black, mantle bluish gray ; rest of plumage, except quills, white; three outer quills black, the fourth and fifth black towards ends, all but first usually with very small white spot at tip ; bill and feet dark red. Adults in winter: head mainly white with dusky around eyes and on back of head. Young: upper parts mottled grayish brown; breast smoky gray ; upper tail coverts white, base of tail gray, outer third black, narrowly tipped with whitish; wing quills black. Length: $15-17$, wing 13 , bill 1.75 , tarsus 2 .

Remarks. - The young of the laughing gull may be distinguished from Franklin and Bonaparte by its large size, longer bill, and wider black tail band.

Distribution. - Atlantic and Gulf coast of United States and Pacific coast of Mexico; south in winter to the Amazon. Recorded from Colorado.

Nest. - In trees, four to twenty feet from the ground, generally made of small sticks, lined with hay and moss.

\section{Larus franklinii Sw. $\oint$ Rich. Franklin Gull.}

Adults in summer. - Bill bright red, with darker subterminal band; head plumbeons black; eyelids white; mantle dark slaty; quills gray, tipped with white, the five outer with subterminal black spaces; under parts white, deeply tinted with rose pink. Adults in winter: head mainly white, with sides and back grayish dusky. Young: top and sides of head and back grayish brown; quills dusky, tipped with white; tail

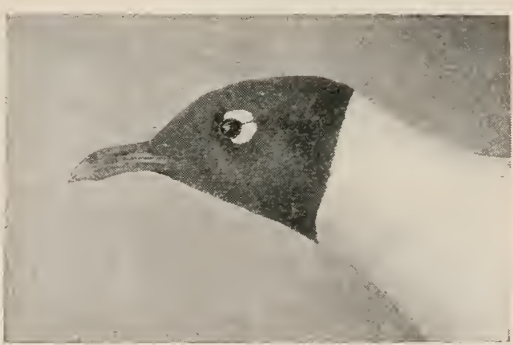

Fig. 43. 


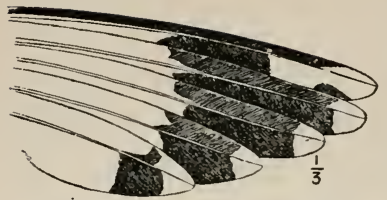

Fig. 44. Wing of Franklin Gull.

with subterminal band of dusky; rest of tail, under parts, forehead, and eyelids white. Length: $13.50-15.00$, wing 11.25, bill 1.30 , tarsus 1.60 .

Distribution. - Interi or of North America, breeding from Iowa north into Canada; migrating south to Peru.

Nest. - On broken-down rushes in shallow water, made largely of grasses and rushes. Eggs: usually 3.

In the northern plains and prairie country Franklin gulls are of the greatest economic importance, the immense flocks living mainly on grasshoppers and other destructive insects. At times a white horde will descend upon a ploughed field, a band of them following at the leels of the ploughman, while long white lines corer the mellow furrows. Recognizing the ploughman as a friend, the birds only get out of his way to let him pass, waiting for him to turn up a fresh supply of food for them. In Utah their services are so well appreciated that Brigham Young used to offer up prayers that they be sent to destroy the grasshoppers that infested the land. One often sees flocks of fifty to five hundred catching grasshoppers on the wing, wheeling, diving, and rising, till at a distance the white flock suggests a wild flurry of snowflakes. When the meal is over the birds disband, to scatter out among the sloughs, drift on lazy wings over the lakes, or float idly on the surface of the water.

\section{Verion BaILEY.}

\section{Larus philadelphia (Ord). Bonaparte Gull.}

Adults in summer. - Bill and head black; mantle delicate pearl gray;

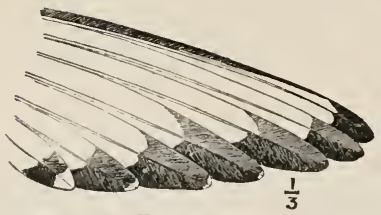

Fig. 45 . three onter quills chiefly white, outer web of the first, and terminal portion of all, black; tail and muder parts white; feet orange red. Adults in winter: head white, tinged with gray behind and with a dusky spot on ear coverts; feet pale flesh color. Young: top of head, back, and spot on ear coverts dusky; sides of head, neck, and under parts white, including tail coverts and base of tail;

band across end of tail blackish, featliers tipped witl white. Length: 1214, wing 10.25, bill 1.20 .

Distribution. - North America, breeding far northward; sonth to western Mexico.

Mr. Henshaw states that the Bonaparte gull is not uncommon in San Diego Bay in December, though he thinks it winters mainly to the southward.

Mr. Loomis has seen the gulls at Monterey during their migrations in November and May. He says that "although white-throated birds with the tail-band were in the majority, and pied-headed ones 
were plentiful, every flock had adults in nuptial plumage, showing that the young are not without experienced leaders on the return north."

\section{GENUS XEMA.}

62. Xema sabinii (Sab.). Sabine Gull.

Bill gull-like, tail conspicuously forked, the feathers rounded, not nar-

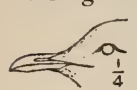

Fig. 46. row and pointed at ends. Idults in summer: head and upper neck dark plumbeous, bordered below by a black collar; mantle slaty gray; tail and middle of wing white; outer quills black, with inner webs and tips white; under parts white; bill black, tipped with yellow. Adults in winter: head and neck white, with dusky on ear coverts and back of lead. Young: like winter adults, but mantle brownish, feathers with buffy or grayish edges; tail with a subterminal black band, white tip

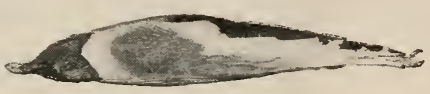

Fig. 47 . and base; bill black. Length: $13-14$, wing $10.10-11.15$, bill 1.00, tail 4.50-5.00. fork .60-1.00 deep.

Distribution. - Arctic regions of North America; south in winter to Peru. Not common in the United States. but recorded from many scattered localities.

Eggs. - Laid on the ground, or on a few grass blades and stems ; 2 to 5, olive, indistinctly spotted with brown.

\section{GENUS GELOCHELIDON.}

\section{Gelochelidon nilotica (Hasselq.). Gull-Billed Tern.}

Bill stout, depth at base equal to one third of its length; tail forked. Adults in summer : top and back of head black; upper parts light pearl gray; lower parts white; bill black; feet and legs blackisl. Adults in winter: head and neck white; ear coverts and spot in front of eye gray. Young: similar to winter adults, but upper parts washed with buffy and sometimes streaked with dusky. Length: 13.00-15.25, wing 11.75-12.25, bill 1.40, tail 5.50, forked for 1.50-1.75.

Distribution. - Almost cosmopolitan. In America from Brazil to Massachusetts along the Atlantic coast, and both coasts of Mexico and Central America ; rare inland.

\section{GENUS STERNA.}

General Characters. - Bill slender and sharp; tail deeply forked, the outer feathers narrowed or sharp-pointed; wings very long and slender.

\section{KEY TO SPECIES.}

1. Black feathers of crown elongated into a crest.

2. Size large, wing 14-15

2 '. Size smaller, wing 12.40-12.50

1'. Head not erested.

2. Size large, feet black .

2 '. Size small, feet red, orange, or yellow.

3. Crown and forehead black in summer adults, wing over 9.

4. Outer web of outer tail feather white

$4^{\prime}$. Outer web of outer tail feather dnsky.

5. Bill orange, with black tip . . .

- forsteri, p. 29.

5 '. Bill vermilion, withont black tip

$3^{\prime}$. Forehead always white, wing under 7 .

maxima, p. 28. elegans, p. 29.

. caspia, p. 28.

hirundo, p. 29. paradisæa, p. 30. antillarum, p. 30. 


\section{Subgenus Thalasseus.}

\section{Sterna caspia Pall. Casplan Tern.}

Tail not very deeply forked, the outer feathers pointed, but not much narrowed; bill red, feet black. Breeding plumage: erown and back of head black; mantle light gray; wings darker gray, the outer quills tipped

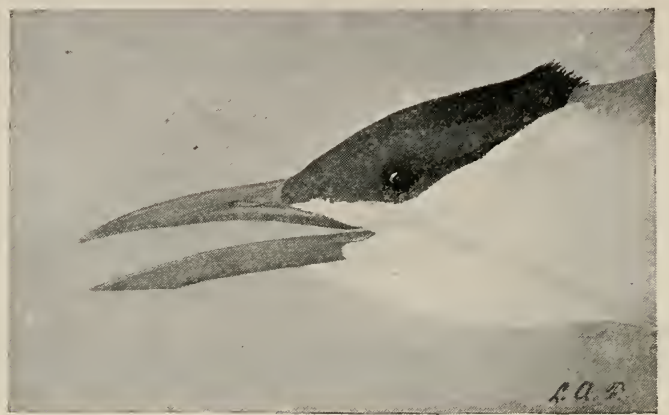

Fig. 48 .

with black. Winter plumage: black of head streaked with white. Young: crown grayish, mixed with black posteriorly; back and tail feathers with dusky spots. Lenyth: 19.00-2.2.50, wing 15.00-17.40, bill 2.48-3.10, tail $5.30-6.75$, forked for .75-1.60.

Distribution. - North America at large, breeding in isolated localities.

Nest. - In hollow in the sand. Eggs: usually 3.

But for their long wings, slender forms, and forked tails, the Caspians, the largest of our terns, could easily be mistaken for gulls. Their flight is quicker and stronger, however, and their black crowns usually conspicuous. They are eminently social in the breeding season, nesting in large colonies, and it is no uncommon sight to see several hundred of them lined up on a sandy lake beach, with the waves rippling in at their feet. After the breeding season they scatter out and wander widely orer the country. VERNon BaIley.

\section{Subgenus Actochelidon.}

\section{Sterna maxima Bodd. Royal Tern.}

Crest of long pointed feathers on back of head; tail long and forked for half its length; inner webs of quills broadly margined with white; bill orange red, feet black. Breeding plumage: upper parts light pearl gray, top and back of head, including erest, black; under parts white. Postbreeding plumage: forehead and fore part of erown white. Winter plumage: white mixed with black on back of head. Young: erown speckled with white and dnsky, erest only slightly developed; upper parts and tail feathers with spots of dusky. Length: 18-21, wing 14-15, bill 2.40$2.7 \%$, tail $6-8$, forked for :3-4.

Distribution. - Coasts and larger lakes of the United States, mainly southward. 



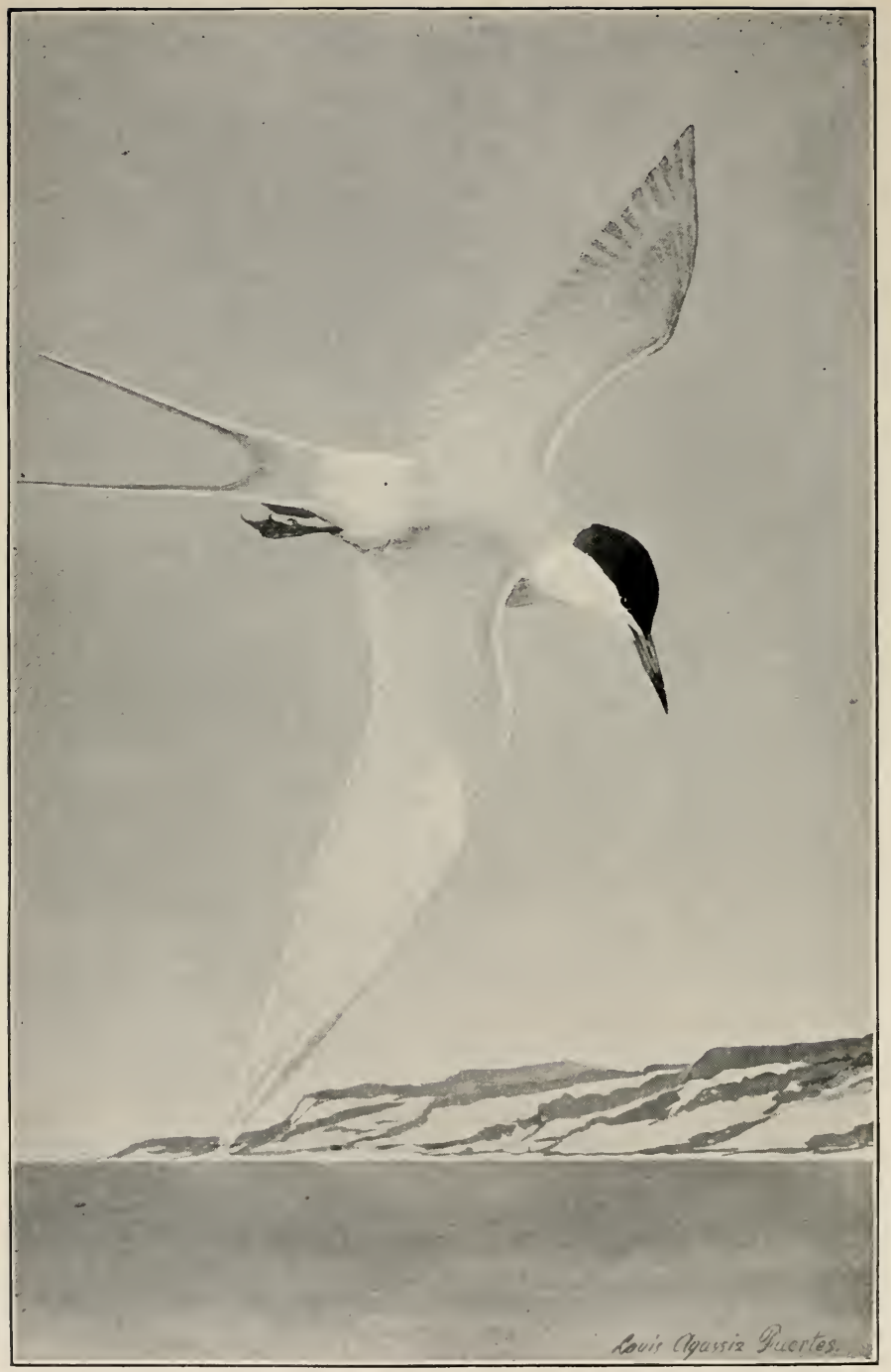

FORSTER TERN 
Mr. Loomis has found the royal tern decidedly common at times during the winter at Monterey, and Mr. Grinnell reports it as very numerous around Catalina Island in winter, and more or less common along the coast throughout the year.

\section{Sterna elegans Gamb. Elegant Tern.}

Like S. maxima, but smaller, with longer crest, and under parts deeply tinged with rose pink. Length : 16-17, wing 12.40-12.50, bill 2.25-2.55, tail 6.60-7.30, forked for about 2.60-3.50.

Distribution. - Pacific coast of middle America, and north to San Francisco.

Mr. Loomis has found the elegant terns at Monterey in autumn, but in smaller numbers than the royal tern.

\section{Subgenus Sterna.}

\section{Sterna forsteri Nutt. Forster Tern.}

Outer tail feathers very narrow and long. Adults in summer: under parts white; upper parts light pearl gray, top of head black; outer web of outer tail feather white; feet orange red, bill dull orange, dusky at tip. Adults in winter: top of head white, back of head tinged with gray, a dusky stripe around eye and across ear coverts; bill and feet duller colored. Young: upper parts, crown, and sides of head washed with brownish ; tail feathers dusky toward ends. Length: 14-15, wing 9.50-10.30, bill 1.50-1.65, tail 5.00-7.70, forked for 2.30-5.00.

Distribution. - Breeds in the United States north to Manitoba, south in winter to Brazil.

Nest. - A hollow in the sand lined with grasses, or a rude nest in marsh grass or on raft of floating tule stems. Eggs: 1 to 3, bluish green to olive buff, marked with lilae and brown.

Low over the lakes, sloughs, and big tule marshes, you see these graceful terns beating the air with long, soft strokes of their narrow wings, while the sharp bill points downward, and the eyes are intent on the surface of the water. If a minnow shows so much as a fin, there is a quick dive, a splash, and a gulp - the minnow has disappeared and the tern is beating over the water again, now skimming close to the surface, now lighting daintily on it to pick up some choice morsel. Sometimes a large number of terns are attracted by a school of minnows, and an animated diving and splashing ensues. Enter the terns' breeding grounds, or wound one of their number, and the airy creatures, all soft silent grace before, storm about you with threatening swoops and harsh, piercing screams.

Verxox Bailer.

\section{Sterna hirundo Linn. Common Tern.}

Onter web of outer tail feather dusky, inner web white. Adults in summer : bill and feet bright orange red, the bill tipped with black; top of head black; mantle light pearl gray; tail and its coverts mainly white; throat white, breast light gray. Adults in winter: crown mainly white; under parts pure white; bill and feet duller. Young: marked with 
blackish around eyes and on back of head; forehead and under parts white; back light gray with buffy edgings to feathers and dusky spots on wings; bill and feet brownish or pale reddisl. Length: $13-16$, wing $9.75-$ 11.75 , bill $1.25-1.50$, tail $5-7$, forked for about 3.50 .

Distribution. - Greater part of northern hemisphere; in America mainly east of the plains; south to Florida, Texas, Arizona, and Lower California.

Nest. - Made of grasses or seaweeds, or eggs laid on the bare rock, or in a depression in the sand. Eggs : 2 to 4 , pale bluish to greenish drab, with lilac shell markings and rather evenly distributed spots of brown.

The common terns are mainly birds of the $\Lambda$ tlantic coast, and together with other terns and gulls have been so sought after by plume hunters and eggers that a few years ago they were on the road to extermination. The Bird Protection Committee of the American Ornithologists' Union took up the matter, however, and by the appointment of wardens to protect the birds on their breeding grounds, and by protective laws enacted in the states where the terns occur, succeeded in rescuing the birds, which, in addition to their useful work as scavengers, give life and beauty to otherwise barren shores.

\section{Sterna paradisæa Brünn. Arctic Tern.}

Outer web of outer tail feather dusky, rest of tail white. Adults in summer : bill and feet bright vermilion, bill without black tip; top of head black, bordered by white superciliary; body clear deep gray. Adults in winter : under parts white, or tinged with grayish; forehead white, rest of crown streaked with black. Young: similar to young of hirundo, but with breast and throat washed with dull brownish. Length: 14-17, wing 10.0010.75 , bill 1.08-1.40, tail $6.50-8.50$, forked for $4-5$.

Distribution. - Mainly circumpolar regions; south in winter to Massachusetts, Colorado, and California, breeding in Massachusetts and Quebec.

Nest. - A bare spot on the ground, sometimes with a little grass. Eggs : 1 to 3 .

\section{Subgenus Sternula.}

\section{Sterna antillarum (Less.). Least Tern.}

Breeding plumage. - Upper parts pearl gray, with black lores and black on top and back of head; two or three outer quills mainly dusky; forehead superciliary,

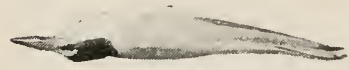

Fig. 49 . and under parts white. Adults in winter: crown grayish, whole forehead white. Young: like adults in winter but witl brownish on back, and with $U$ or $V$-shaped margins to part of feathers. Length: $8.50-9.75$, wing 6.60 , bill 1.20, tail 3.50, forked for about 1.75 .

Distribution. - United States from California, I)akota, the Great Lakes, and Massachusetts sonth to northern South America.

Eggs. - 2 to t, buff to cream white, spotted about the larger end with brown and lilac; laid in a depression in the sand on an island or sand beach.

The least tern is abundant along the coast of southern California in summer, arriving, Mr. Grinnell says, about the middle of April and leaving usually the latter part of $\Lambda$ ugust. He states that it nests abundantly in suitable places along the seacoast, generally on 
a strip of sandy beach separating the surf from the tide marsh. Colonel Goss, speaking of the terns of Kansas, says: "These little beanties, the smallest of the family, flit through the air like swallows, darting here or there for an insect, or suddenly stopping to hover, like hawks or kingfishers, over a school of minnows or shrimp, ready to drop on the first that comes to the surface."

\section{GENUS HYDROCHELIDON.}

\section{Hydrochelidon nigra surinamensis (Gmel.). American Black Tern.}

Web of feet reaching only to middle of toes. Adults in breeding plumage: head, neck, wings. and breast black; tail slaty gray; under tail coverts white; bill and feet black. Winter plumage: head, neck, and under parts white, orbital ring and

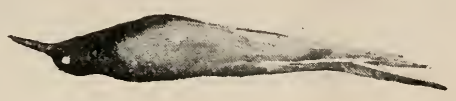

Fig. 50 . ear coverts dusky; upper parts blne gray. In late summer the white and black feathers are mixed on the breast. Young: similar to winter adults, but with edges of scapulars brown, and crown and back of head dusky. Length: $9.00-10.25$, wing 8.25 , bill 1.10 , tail 3.75 , forked for .90 .

Distribution. - Temperate part of North America, and south to Brazil and Chili.

Nest. - Usually on dead floating rushes in shallow water, sometimes on the bare ground, or on an old muskrat house or a water-soaked $\log$; made of reeds, wild rice, and grasses, and lined with leaves and fine stems. Eggs: 2 to 4 , greenish drab to olive brown, spotted with blackish brown.

The first sight of Hydrochelidon in the breeding season is an amazing one, for as you see the tern-like form approaching across a lake your imagination clothes it in white, but when it reaches you - lo! its fore parts are jet black. Another surprise comes, when, associating its kin with wide lakes and ocean shores, you find one beating over a patch of marsh between the angles of a meadow brook, or circling over a pool in a barnyard! But, in spite of the shocks given your preconceived ideas, this swallow-like tern excites your keenest inter'st, and whether on the prairies of Texas or in the valleys of the high Sierra, you soon find yourself eagerly watching for the strange bird, and every landscape graced by its form goes down to memory with a charm all its own. 


\title{
ORDER TUBINARES : TUBE-NOSED SWIMMERS.
}

\section{(Fanilies Diomedeide and Procellaritde.)}

\section{FAMILY DIOMEDEIDA: ALBATROSSES.}

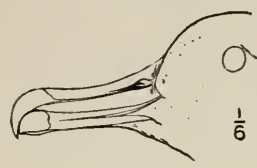

Fig. 51 .

\author{
KEY TO GENERA.
}

1. Sides of lower mandible with deep longitudinal groove; tail long and graduated.

Phœbetria, p. 33.

$1^{\prime}$. Sides of lower mandible without longitudinal groove; tail short and rounded.

2. A wide strip of bare skin from nasal tube to forehead . . Thalassogeron, p. 3:3. 2 '. Hard plates of top and sides of bill meeting between nasal tubes and forehead.

Diomedea, p. 32 .

\section{GENUS DIOMEDEA.}

General Characters. - The horny plate on top of bill widened back of nostrils and meeting the plate on side of bill ; wings very long; tail short, not reaching tip of folded wings ; size that of a large goose.

\section{KEY TO SPECIES.}

1. Feet, bill, and most of plumage, dusky or blackish . nigripes, p. 32. $1^{\prime}$. Feet and bill yellow, plumage mainly white in adult . albatrus, p. :;2.

81. Diomedea nigripes $A u d$. Black-footed Albatross.

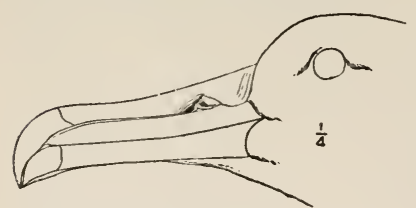

Fig. 52.

Adults. - Face and chin whitish, top of head and rest of upper parts blackish, except for whitish tail coverts and base of tail; under parts sooty gray; bill dusky, feet black. Young: face with less white, and upper tail coverts dusky. Length : $28.50-36.00$, wing 18.50-20.50, bill $4.00-4.25$.

Distribution. - North Pacific, abundant from southern California to Alaska.

Mr. Loomis once saw an albatross at Monterey Bay when there was a heavy sea on, but most of the birds keep out to sea, where they are known to the fishermen as 'goonies.'

\section{Diomedea albatrus Pall. Short-tailki Albatross.}

Adults. - Mainly white, but head and neck washed with yellowish, tail and most of wings dusky, primaries with yellow shafts; bill and feet yellowish. Young: plumage sooty brown, darker on head and neck; primary shafts yellowish. Length: $330-93$, wing 2:2-23, bill 5.50-5.50.

Distribution. - North Pacific from southern California to Alaska, but mainly north ward.

The large white albatross, unlike the black-footed, is so shy that 
instead of following vessels for food it usually gives a wide berth to any species of stiling craft. At Monterey, in stormy winter weather, Mr. Loomis has seen some of the birds in the bay. The largest number he has recorded from the region were seen off Point Pinos, a dozen being counted in an hour.

\section{GENUS THALASSOGERON.}

[83.] Thalassogeron culminatus (Gould). Yellow-Nosed AlbaTRoss.

Horny plate on top of bill not widened back of nostrils; a strip of soft skin between top and side plates; size of a large goose. Adults : head, neck, and shoulders gray, shading into blackish of back, wings, and tail ; under parts white; bill black on sides, bordered above and below with yellow. Length: $35-37$, wing $17.75-21.00$, bill $4.35-4.50$, tail 8-9.

Distribution. - Southern oceans, north easually to coast of Oregon and Gulf of St. Lawrence.

\section{GENUS PHCEBTRIA.}

\section{Phœbetria fuliginosa (Gmel.). Sooty Albatross.}

Tail long and graduated, reaching well beyond tips of folded wings; size large. Adults : eyelids white, area

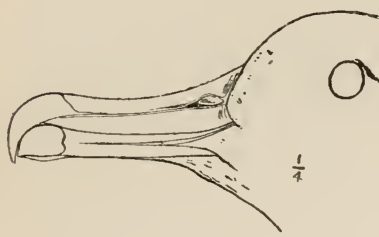

Fig. 53. around eyes blackish; sides of head and throat sooty; rest of under parts light smoky gray; back of neck and back smoky gray; wing and tail sooty; bill black, feet yellowish. Young (?): upper parts blackish except for slaty gray on middle of back; under parts slaty gray. Length: $34-37$, wing $20.00-$ 21.50 , extent $78-84$, tail $10.50-13.00$.

Distribution. - South Pacific, north (casually) to coast of Oregon.

\section{FAMILY PROCELLARIID㘴: FULMARS AND SHEARW ATERS.}

\section{KEY TO GENERA.}

1. Wing 17 or more, tail feathers 16 . . . Ossifraga, p. 34 . $1^{\prime}$. Wing 15 or less, tail feathers $12-14$.

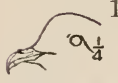

Fig. 54. 2'. Wing 9 or more, tail not forked.

2. Wing 7 or less, tail forked . Oceanodroma, p. 37.

3. Nasal tubes opening separately, with partition as wide as opening

3 '. Nasal tubes opening together and inclosing a thin partition between nostrils.

4. Bill short and stout, about twice as long as depth at base . . . . . . . . Fulmarus, p. 34.

4.' Bill long and slender, over twice as long as depth at base......... Priocella, p. 34. 


\section{GENUS OSSIFRAGA.}

[85.] Ossifraga gigantea (Gmel.). Giant Fulmar.

Nasal tubes occupying more than half the length of bill; tail feathers

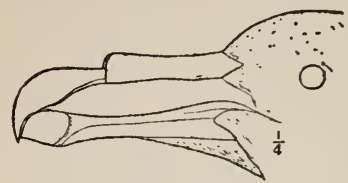

Fig. 56 .

16 ; size of a large goose. Light phase: sometimes almost entirely white, but generally with head, neck, and under parts white, and upper parts dusky; bill light yellowish. Lark phase: uniform sooty brown, sometimes whitislı around base of bill ; bill olive yellowish or grayish. Length: 30-36, wing 17-21, bill 3.50-4.00, extent of wings 72-S4.

Distribution. - Southern seas, casually nortl to coast of Oregon.

\section{GENUS FULMARUS.}

\section{Subgenus Fulmarus.}

KEY TO SPECIES.

1. Upper parts plain gray or dusky . . . . . . glupischa, p. 34. $1^{\prime}$. Upper parts gray, marked with white . . . . . rodgersi, p. 34.

86b. Flumarus glacialis glupischa Stejn. Pacific Fulnar.

Bill short and stout, wider than deep at base, nasal tubes occupying about half the length of bill and opening as one tube; nasal tubes and tip of bill yellow. Light phase: head, neck, and under parts white; upper parts bluish gray, with quills darker. Dark phase: whole plumage deep sooty plumbeous. Length : 17-19, wing 11.90-12.35, bill 1.35-1.65.

Distribution. - North Pacific, south along the American coast to Mexico.

Nest. - On high cliffs and promontories. Eggs: white.

Mr. Loomis states that when an 'oil slick' appeared on the Monterey Bay at one time, he counted over a lundred Pacific fulmars and several Rodgers fulmars scattered in groups apparently feeding on a slimy substance floating on the surface of the oil.

\subsection{Fulmarus rodgersi Cass. Rodgers Fulmar.}

Similar to the light phase of glupischa, but bluish gray of upper parts broken by mixture of white. No dark plase known. Wing: 12.10-12.90, bill 1.40-1.60, depth of bill at base .65-.75.

Distribution. - North Pacific from Bering Sea south to Monterey Bay.

Egg. - Soiled white, laid on the bare rock.

\section{GENUS PRIOCELLA.}

87. Priocella glacialoides (Smith). Slender-billed Fulmar.

IBill slender, deeper than wide at base; nasal tubes not reaching middle

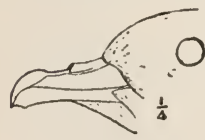

Fig. 57. of bill; nasal tubes and tip of bill black. Adults: head, neck, and under parts whitish or light gray; back and wings light pearl gray, the quills darker, with imner webs mainly white. Length: $18.00-18.50$, wing 13, bill 1.75-2.10, depth of bill at base .65.

Distribution. - Sonthern seas, north along Pacific coast to Vancouver Island. 


\section{GENUS PUFFINUS.}

General Characters. - Nasal tubes united and resting on base of bill, not reaching to middle; nostrils visible from above; the partition between them as wide or wider than nostril.

KEY TO SPECIES.

1. Under parts white or grayish.

2. Bill 2.60

2 '. Bill under 1.70.

3. Larger, wing about 13 . . . . . . . . creatopus, p. 35.

3 '.Smaller, wing about 9 . . . . . opisthomelas, p. 35.

1'. Under parts dark sooty gray.

2. Larger, wing over 11, bill over 1.55 . . . . . griseus, p. 36. $2^{\prime}$. Smaller, wing under 11 , bill under 1.28 . . . tenuirostris, p. 37.

\section{Puffinus creatopus Coues. Pink-footed Shearwater.}

Breast and throat white, shading into brownisl gray of upper parts and under tail coverts; bill yellowish, feet flesh color. Length: 19, wing $12.50-13.25$, bill $1.60-1.70$.

Distribution. - Eastern Pacific Ocean from Monterey, California, south to Chili.

At Monterey Mr. Loomis has found the pink-footed shearwater abundant in June, and in November has seen as many as two hundred in a day. In migrating, he says, their flight is not as direct as that of the black-vented and dark-bodied. They circle frequently and cross their tracks, much as swallows are wont to do when migrating singly or in small companies.

\section{Puffinus opisthomelas Coues. Black-vented Shearwater.}

Upper parts sooty gray, lighter on head and neck; under parts white, except for sooty under tail coverts. Length: 12.25-15.00, wing 9.00-9.10, tail 3.25-3.80, bill 1.30-1.42.

Distribution. - Pacific Ocean from coast of Lower California north to Vancouver Island.

A set of opisthomelres eggs was taken at Santa Barbara Island in $18 \% 3$, and $\mathrm{Mr}$. Anthony thinks the birds not uncommon on some of the smaller outlying islands. Their presence along the coast of southeru and Lower California, he says, seems to depend on the food supply. They are always common, but less so during the breeding season, their numbers being greatest in late July, August, and September, when they follow the large schools of herring and other fish that come in shore. They are often seen in flocks of several thousand when fish are plenty, and Mr. Anthony has met a flock on the coast of Lower California which he estimated at not less than fifty thousand.

It is only in very calm weather, he says, that they are seen resting on the water, but then they collect in a compact circle and wait 
until started on their journey by a rising wind. None of our Pacific coast sea birds adhere so closely to established fly lines as the puffins. Mr. Anthony tells us (Auk, xiii. 223-228) that " even when flying fifty miles or more from land the first flock that passes will, with almost absolute certainty, mark the line which the next will follow, even though they be an hour behind."

Mr. Anthony calls attention to the habit common to different species of shearwaters of flying in large circles or an advancing series of loops when quartering the sea for small fish, - a flock seen along shore going in the opposite direction from one farther out to sea.

\section{Puffinus griseus (Gmel.). Dark-Bodied Shearwater.}

Entire plumage sooty gray except for white under wing coverts, which are mottled with gray at tips; bill and feet dusky or black. Wing: $11.15-12.00$, bill $1.55-1.70$, depth of bill at base $.45-.55$, tarsus $2.12-2.35$.

Distribution. - South Pacific, north along the coast of California, and reported in great numbers from Queen Charlotte Islands, B. C.

One of the most important results of the valuable work done by Mr. Loomis on the water birds off Monterey is the light thrown on, the northward migration of birds from the south temperate zone. The dark-bodied shearwater affords conclusive evidence on the subject. The shearwaters taken at Monterey in May were in worn, moulting plumage, common with birds just after the breeding season; while their sexual organs showed none of the functional development of birds about to breed. The migratory movements of these birds increased from May until September, when there was an abrupt decrease in their numbers, only stragglers being seen afterwards. Not only were the September and October birds in fresh plumage, but those secured had their sexual organs enlarged as in birds in the flush of the breeding season. As the shearwaters are known to breed from March to October on oceanic islands in the south temperate zone, the case seems to be a simple one.

\section{Puffinus bulleri Salvin.}

Adults : mantle gray, in striking contrast to black on head, tail, and lesser wing coverts; greater coverts gray, tipped with white; outer primaries black, with two thirds of inner webs white; cheeks mottled grayish white; lower parts and under wing coverts white. Length: 16.50, wing 11.30, tail 5.20, bill 2.60.

Disiribution. - New Zealand. One record from Point Pinos, California.

Mr. Loomis secured a specimen of Puffinus bulleri about six miles west of Point Pinos, on November 6, 1896. As this was the fourth of the species known to science, and the others had come from New Zealand seas, the record is of great interest, and as pointed out suggests that persistent observation along the Pacific coast may add largely to the list of pelagic wanderers from the southern seas. 
96. Puffinus tenuirostris (Temm.). Slender-billed Shearwater.

Size small ; bill relatively small and slender; plumage sooty or blackish except for paler throat and white under wing coverts; bill and feet dusky. Wing: 10.00-11.10, tail :3.20-3.60, bill 1.20-1.28, depth at base .3.5-.50, tarsus 1.90-2.00.

Distribution. - Pacific Ocean, breeding in the southern hemisphere, but migrating north in summer to Kotzebue Sound.

The slender-billed shearwater was discovered at Monterey by Mr. Joseph Maillard, December, 1895. Between the 14th and 20th of the month he saw great numbers of the birds, and secured twenty specimens. Mr. Loomis infers that they were belated migrants on their way back to their breeding grounds in the southern hemisphere.

\section{GENUS OCEANODROMA.}

General Characters. - Bill small and weak, with nasal tnbes elevated at tip; tail slightly forked; size small; slender and tern-like; bill and feet black.

\section{KEY TO SPECIES.}

1. Upper or lower tail coverts white.

2. Lower tail coverts white, upper gray . . . . . furcata, p. 37.

2 'Upper, and sides of lower tail coverts, white . . kaedingi, p. 37.

$1^{\prime}$. Upper and lower tail coverts dusky.

2. Under wing coverts with a light-colored patch . homochroa, p. 38.

$2^{\prime}$. Under, wing coverts without light patch.

3. Side of rump with gray or whitish patch . socorroensis, p. 38. 3 '. Side of rump without gray or whitish patch . . melania, p. 38.

\section{Oceanodroma furcata (Gmel.). Forked-tailed Petrel.}

Body light bluish gray, fading to white on chin, throat, and under tail coverts; bend of wing, quills, and space around eye, dusky. Length: $8.00-9.20$, wing $5.90-6.40$, bill .60 , tail $: 3.75-4.00$, forked for about 1 .

Distribution. - From the Arctic circle south on the American side to Monterey.

Nest. - A hole in a bank, lined scantily with dry grass and fine roots. Egg: 1, white, with fine spots of lilac and dark color about the larger end.

\subsection{Oceanodroma kaedingi Anthony. Kaeding Petrel.}

Plumage mainly sooty black; wing coverts brownish; upper tail coverts and side of under coverts, white. Wing: 5.75, tail 3.25, forked for .60, tarsus .80, bill .5.5) (from type).

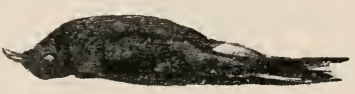

Fig. 5 s.

Distribution. - Pacific coast and islands from Socorro Island and southern California north to Cape Flattery.

Nest. - Under a pile of stones, or a burrow in a turfy bank, lined with grass, bits of bark, and wood. Egg: 1, sometimes plain white.

The slightly larger and lighter colored O. leucorhor of the Atlantic and north Pacific apparently does not occur on the west coast of the United States. A series of May and June specimens from near Cape Flattery are unquestionably licedingi. 
107. Oceanodroma melania (Bonap.). Black Petrel.

Upper parts sooty black with grayish brown on wing eoverts; under parts brownish black, without white or light colored patches. Wing: 6.80, tail 3.90 , forked for about 1.20 , tarsus 1.20 .

Distribution. - From the Pacific coast of Mexico north to southern California.

Mr. Grinnell thinks the black petrels are probably more or less common residents off the southern California coast. Mr. Nelson found them the most abundant of the petrels of the Tres Marias Islands, Mexico. He saw little that was remarkable about their habits, but says they circled about the vessel in all directions and were quick to see fragments of food that were thrown overboard.

\section{Oceanodroma homochroa (Coues). Ashy Petrel.}

Plumage mainly smoky gray or plumbeous ; quills and tail dusky; upper wing coverts brownish, under coverts with light pateh. IVing: $5.30-5.40$, tail $3.30-3.50$, forked for .70-..90, tarsus, $.80-.90$.

Distribution. - Coast of California.

Egg. - Dull creamy white, finely dotted with red around the larger end ; placed in a natural cavity.

Mr. Loomis, writing of his visit to South Farallone Island in July, 1896, gives some interesting notes on the habits of the ashy petrel. "Although these petrels were breeding abundantly in all parts of the island," he says, "every portion of it might have been passed over in daylight without a single individual being discovered, for apparently only brooding birds occurred, concealed in loose piles of stone, in stone walls, and under driftwood. After nightfall the petrels became active. They were especially conspicuous during the early morning hours of the 14 th, when the auklets held their concert. As I stood in the dooryard of a keeper's house, every few moments one or more would pass silently by, disappearing in the darkness. Their flight recalled that of a goatsucker.

"The strong musky odor of the petrels renders their discovery in the rock piles easy. It is only necessary to insert the nose into likely crevices to find them. With little practice one may become very expert in this kind of hunting, readily determining whether it is an auklet or a petrel that has its residence in any particular cranny. . . . It seemed strange to find these birds of the ocean rearing their young near the dwellings and within sereral rods of the siren. None of the feathered inhabitants of the island appeared to be alarmerl at the blast of this signal, repeated every forty-five seconds when the fog settled down."

108.1. Oceanodroma socorroensis Townsend. Socorro Petrfi. Sinilar to homochrou but slightly larger and lighter eolored; under wing 
coverts without light-colored pateh, but rump with gray or whitish patch on side. Wing: 5.80-6.28, tail $3.07-3.42$, forked for .71-.92, bill .55-.65.

Iistribution. - From islands of western coast of Mexico north to San Diego, California.

\section{ORDER STEGANOPODES: TOTIPALMATE SWIMMERS.}

(Families Axhixgide, Phalacrocoracide, Pelecanine, FREGATIDæ, ETC.)

FAMILY ANHINGID里: DARTERS.

\section{GENUS ANHINGA.}

\section{Anhinga anhinga (Linn.). Axhinga. Water Turkey.}

Bill straight and sharp; form extremely slender, tail long and rigid, without upper coverts. Adult male in breeding plumage: glossy greenish black; back of head and sides of neek with long white or grayish filaments, and back of neck with black hair-like mane; shoulders and base of wings finely spotted with gray, wing crossed with wide gray band; back striped with pearl gray; tail tipped with brownish. Adult male in winter: head and neck without elongated filaments. Adult female in breeding plumage: similar to male but head and neck brown, throat and breast buffy. Young: lower back, tail, and quills black; head and rest of body brown except for buffy or whitish throat and breast, and gray streaking on wing coverts. Length : 32.25-36.00, wing about 14 , tail 11, bill 3.2.5.

Iistribution. - Fron tropical America north in Lower Sonoran zone to South Carolina, southern Illinois, Texas, western Mexico, and casually to Kansas.

\section{FAMILY PHALACROCORACID王: CORMORANTS.}

\section{GENUS PHALACROCORAX.}

General Characters. - Bill slender and abruptly hooked at tip; mouth opening back under eye; skin around eye and at base of lower mandible naked; head smooth or variously crested.

KFY TO SPECIES.

1. Tail of 14 feathers, head never erested . . . . penicillatus, p. 41. $1^{\prime}$. Tail of 12 feathers, head with or without crest.

2. Flanks withont white patch.

3. Size large, wing over 11 , a slender crest over each eye in breeding plumage.

4. Crests entirely black

4 '. Crests mainly white.

5. Larger, wing 13 or more. Breeds in Alaska.

cincinatus, p. 40. 5 . Smaller, wing 13 or less. Breeds in Oregon and California.

$3^{\prime}$. Size small. wing under 10.50 , head without crests. albociliatus, p. 40 . mexicanus, p. 41. 
2 '. Flanks with a large white patch in breeding plumage. Top and back of head crested in breeding plumage.

3. Size larger, wing 10.00-11.40. From Washington northward.

pelagicus, p. 41.

3'. Size smaller, wing 9.30-10.50. From Cape Flattery southward.

resplendens, p. 42.

\section{Subgenus Phalacrocorax.}

\section{Phalacrocorax dilophus (Swain.). Double-Crested Cor-} MORANT.

Adults in breeding plumage. - Throat pouch orange; a narrow crest of curved black feathers above and back of each eye; back and wings slaty, feathers bordered with black; rest of plumage glossy greenish black. Post-breeding plumage: head without crests. Young: plumage brownish, becoming grayish brown on head and neck; throat and breast lighter, sometimes white before the first moult. Length: 29-34, wing 12-13, bill $2.00-2.45$.

Distribution. - Breeds from northeastern North America west to the Dakotas and north to Athabasca; migrates to Gulf coast; west to Colorado and Utah.

Nest. - In trees or on rocks, made of sticks, and usually coated with lime-like excrement. Eggs : 3 or 4 , dull bluish green.

The double-crested cormorants are common along the Atlantic coast and the lakes and rivers of the Mississippi valley, breeding in communities on cliffs and rocky islands along the coast, and mainly in trees in the interior.

Like all cormorants, they are expert fishers. With their dense glossy plumage, long, almost fish-like form, powerful leg muscles, and wide paddles, double-jointed mouths, elastic throats, and the hooked tip of their bills, they are built for pursuing, catching, and swallowing fish. Much of their time is spent in the water pursuing their prey, or perched on rocks or posts near their fishing grounds.

VERNON BAILEY.

\section{0b. P. d. cincinatus (Brandt). White-crested Cormorant.}

Like $P$. dilophus, but with crests mainly white. Length: 36 , wing 13.70 , bill $2.25-2.5 \%$.

Distribution. - Northwest coast of Nortl America, breeding on the coast of Alaska; south in winter to California.

Nest. - On islands, a mass of sticks and weeds six inches to a foot in height. Eggs : 4 or 5 .

\section{0c. P. d. albociliatus Ridgw. Falillone Cormorant.}

Similar to cincinatus, but slightly smaller. Length: 25-31, wing 11.7513.00, bill 1.90-2.8.).

Distribution. - Coast and inland lakes of southern Oregon and California, and south to western Mexico and the Socorro Islands.

Nest. - A firm structure of sticks, lined with moss and various water plants ; placed in trees and on rocks. Eggs : :3 to 5, dull bluish green.

The Farallowe cormorant is a common resident of the California 
coast, and breeds abundantly on the Farallones and other islands; also in the interior, nesting in extensive colonies in trees near some of the large lakes. Mr. Chamberlain reports a colony at Clear Lake, California, and those at Tule Lake, Oregon, are undoubtedly of this species.

On their breeding grounds, nests, rocks, trees, and ground are painted white with their excrement, and some of the trees are usually killed by it. Bones and pieces of fish are scattered about, adding to the general attractiveness of the place.

\section{Phalacrocorax mexicanus (Brandt). Mexican Conmo- RANT.}

Adults. - Head and foreparts of body mainly dark brownish, lighter on throat, and gray or whitish adjoining brown throat pouch; shoulders and wing coverts slaty; feathers bordered with black; posterior parts of body, tail, and wing quills blackish. Breeding plumage: head, neck, and belly witl slender white filaments. Young: brownish, becoming grayish browu on throat and under parts, whitish next to pouch. Before first moult : throat and breast whitish. Length: $23.00-28.75$, wing $9.95-10.40$, bill $1.70-2.00$.

Distribution. - Mexico, Cuba, and the Gulf coast ; north to New Mexico, Kansas, and Illinois.

Nest. - Rindely made of sticks and leaves, placed on bushes or trees near or over water. Eggs : bluish white, with a slight chalky deposit.

\section{Subgenus Compsohalieus.}

\section{Phalacrocorax penicillatus (Brandt). Brandt Conmo- RANT.}

Bill slender, nearly straight ; tail short, with 14 instead of 16 feathers; head without erests or elongated tufts. Adults : head and neck glossy blue black, except for light brownish patch next to gular sac; under parts glossy greenish black; scapulars and wing coverts dull greenish black. Breeding plumage : sides of neck and shoulders with long white or yellowish filaments; throat pouch blue. Young: plumage brown, throat and under parts paler; upper parts darker, becoming blackish on back of neck. Length: 35 , wing 10.50-11.75, bill 2.60-2.95, tail 5.50-6.50.

Distribution. - Pacific coast from Cape St. Lueas to Vancouver Island.

The Brandt cormorant is abundant along the Pacific coast, breeding in large colonies on rocky islands. Grinnell says it is the cormorant observed about San Pedro, hundreds sometimes being seen roosting on the breakwater. On the Farallones Bryant says they congregate in large rookeries. The young are hatched entirely naked, their skin resembling a greasy black kid glove. In this condition, and even after the down is on them, they are an irresistible morsel to the hungry gulls.

\section{Subgenus Urile.}

123. Phalacrocorax pelagicus Pall. Pelagic Cormorant.

Breeding plumage. - Throat ponch dull coral red; erown and back of 
head with purplish green crests; neck with loose white filaments; rump and large patch on flanks white; head and body dark glossy green, changing to rich purple on neck and purplish green on wings; quills and tail black. Post-breeding plumage: erests, white filaments, and white flank patch wanting. Young: dusky brown, lighter on head; upper parts darker, with a tinge of green. Wing: $10.00-11.40$, tail $6.25-8.50$, bill 1.70-2.10.

Distribution. - Coast of Alaska and British Columbia to Washington.

Nest. - Usually on a ledge of bold-faced rock, large, made of seaweed, a few grass-stalks, and excrement. Eggs : 3 to 4, pale blue to white.

The Eskimo use this cormorant's skin for clothing, and the white filaments from the flanks for fringes in their ornamental work.

\section{3b. P. p. resplendens (Aud.). Baird Cormorant.}

Coloration as in pelagicus, size smaller, bill nearly as long, but slenderer. Wing: $9.30-10.50$, tail $5.80-7.00$, bill $1.65-2.00$.

Distribution. - Pacific coast from Cape Flattery to Mazatlan, Mexico.

The Baird cormorant is usually less common than the Farallone or Brandt cormorants, breeding apart from them in communities on the islands or rocky points off shore.

\section{FAMILY PELECANID㞋: PELICANS.}

\section{GENUS PELECANUS.}

General Characters. - Bill much longer than head, upper mandible flat; a large pouch of elastic, naked skin hung as a fish-net from flexible sides of lower mandible.

KEY TO SPECIES.

1. Color mainly white . . . . . . erythrorhynchos, p. 42. $1^{\prime}$. Color mainly grayish brown . . . . . californicus, p. 43.

\section{Subgenus Cyrtopelicanus.}

\section{Pelecanus erythrorhynchos Gmel. American White Pelican.}

Tail feathers 24. Breeding plumage: mainly white, primaries and most of secondaries black; back of head with thin white or yellowish crest, breast and lesser wing eoverts with narrow lanceolate yellowish feathers; upper

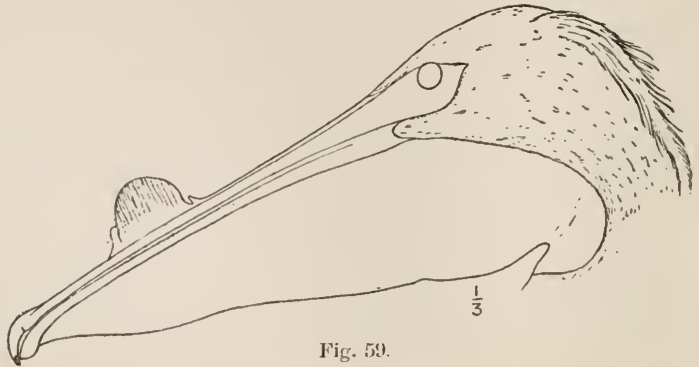




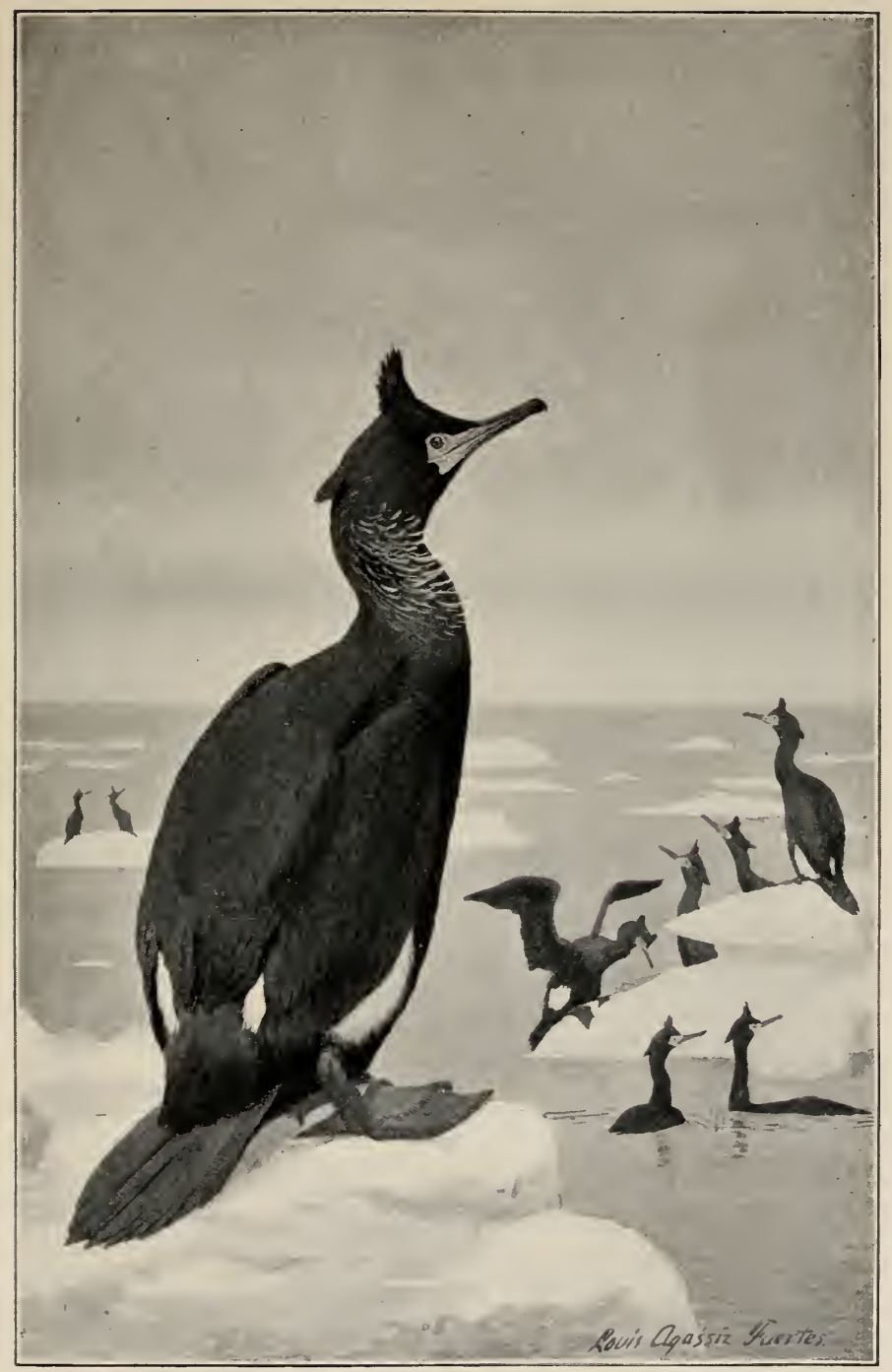

PELAGIC CORMORANT 

mandible with upriglit horn. Post-breeding plumage: crest replaced by short grayish feathers, upper mandible without horny excrescence. Adults in winter plumage: back of head white; bill pouch and feet pale yellow instead of orange. Young: white, with gray on top of head and lesser wing coverts. Length: $4 \frac{1}{2}$ to nearly 6 feet; extent $8 \frac{1}{2}$ to nearly 10 feet; wing $20.00-25.25$, bill $11.05-15.00$; weight about $17 \mathrm{lbs}$.

Distribution. - North America from latitude $61^{\circ}$ to Guatemala.

Nest. - Usually on islands, sometimes a depression in gravel or sand, lined with seaweeds; but generally a thin layer of sticks and weeds, laid on the ground or on rocks. Eggs : 1 to 3, dull white, like those of the Canada goose, but with rongher shell.

The white pelican is more a bird of the interior than of the coast districts, and still breeds in great colonies on a few of the larger lakes. Some of the little islands which used to be covered with nests are abandoned now, the splendid birds having been driven away by wanton persecution.

The pelicans are eminently social at all seasons, sometimes gathering in flocks of many hundreds along the shore, where, by beating the water with their wings, they drive the fish into the shallows, to scoop them up with their wide pouches. At other times they may be seen circling, wheeling, and soaring orerhead, in magnificent aerial drill, or riding buoyantly on the surface of the water like a squadron of white ships.

Verion BaIlex.

\section{Subgenus Leptopelicanus.}

\section{Pelecanus californicus Ridgw. California Brown Peli- CAN. 1}

Tail feathers 22. Breeding plumage : pouch reddish; head, and feathers next to ponch, white; crown tinged with yellow; neck, including manelike crest, rich velvety brown; upper parts silvery gray, streaked with brownish; under parts brownish, streaked on sides with white. "Iinter plumage : head and neck white, tinged with sellowish on throat and crown. Young: upper parts grayish brown, darker on back; under parts white, tinged on sides with brownish. Length : $4 \frac{1}{2}$ feet or more, wing $20.50-23.25$, bill 12.2.) -14.75 .

Distribution. - Pacific coast from southern British Columbia to Galapagos Islands.

\section{FAMILY FREGATID丑: MAN-O'-WAR BIRDS.}

\section{GENUS FREGATA.}

128. Fregata aquila Linn. MAN-O'-W

Wings very long; tail deeply forked; feet small, half webbed. Adult

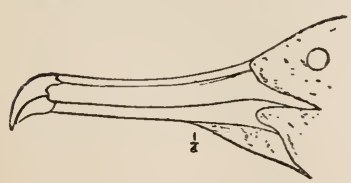

Fig. 60. male : plumage black, base of wings glossed with greenish or purplish. Adult female: plumage dull black; wings with grayish patch; sides and breast white. Young: head, neck, and under parts white; upper parts dull brownish black. Length : $37.50-$ 41.00 , wing $22.00-27.10$, tail $14.25-19.25$, forked for about 9 ; bill 4.25-5.15.

${ }^{1}$ A specimen of $P$. occidentalis was taken in Wyoming, July, 1899. (The Auk, xvi. 351.) 
Distribution. - Tropical and subtropical seas, chiefly north of the equator; north regularly to Florida, Texas, and California, and easually to Wisconsin and Nova Seotia.

Nest. - Made of sticks, placed in the tops of bushes or low trees.

\title{
ORDER ANSERES: LAMELLIROSTRAL SWIMMERS.
}

\section{FAMIIY ANATID丑: DUCKS, GEESE, AND SWANS.}

\author{
KEY TO GENERA.
}

1. Tarsus shorter than middle toe without claw.

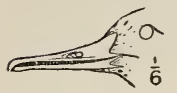

2. Lower mandible without trace of lamellæ along sides, edges of mandibles strongly toothed or serrate.

Fig. 61 .

3. Tooth-like serrations of mandibles sharp and strongly inclined backward . . . Merganser, p. 45े.

3 '. Tooth-like serrations of mandibles blmnt and not distinctly inclined backward. Lophodytes, p. 47.

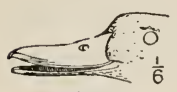

Fig. 62 .

$2^{\prime}$. Lower mandible with a distinct series of lamellæ along side as well as cutting edge.

3. Lower part of tarsus with small hexagonal plates and no transverse scutellæ in frout.

Dendrocygna, p. 69.

3 . Lower part of tarsus with a row of transverse sentelle across the front.

4. Tail without upper coverts, the base of the stiff feathers scarcely concealed.

5. Tail feathers 18 . . . Erismatura, p. 64. 5 . Tail feathers 20 . . . . Nomonyx, p. 65.

$4^{\prime}$. Tail with base well concealed by npper coverts.

5. Hind toe withont a flattened membraneous lobe.

6. Bill long and much wider near end than toward base . . . . . Spatula, p. 54.

$6{ }^{\prime}$. Bill not much wider near end than at base.

7. Tail feathers wide and ronnded at end.

$7^{\prime}$. Tail feathers narrow and pointed at tips.

8. Tail graduated more than a third of its total length.

9. Tail feathers 14 . Mareca, p. 49.

$9^{\prime}$. Tail feathers 16 .

10. Bill longer than middle toe withont claw . . . Dafila. p. 54. $10^{\prime}$. Bill shorter than middle toe withont claw. Chaulelasmus, p. 4!? $8^{\prime}$. Tail gradnated less than a third of its total length.

9. Wing more than 8 . Anas, p. 47.

9'. Wing less than $\mathrm{s}$. 
10. Upper and lower ontlines of upper mandible beyoud nostril convex.

Querquedula, p. 52.

$10^{\prime}$. Upper and lower outlines of upper mandible beyond nostrils straight.

Nettion, p. 51 .

$5^{\prime}$. Hind toe with a flattened membraneous lobe.

6. Graduation of tail less than length of bill from nostril . . . . . Ay thya, p. 56.

6 . Graduation of tail much more than length of bill from nostril.

7. Anterior edge of nostril in front of middle of culmen . . . . Clangula, p. 59.

$7^{\prime}$. Anterior edge of nostril back of middle of culmen.

S. Upper mandible widest back of nostril, and not conspicuously elevated nor swollen at base.

9. Feathers ending in straight line across forehead . . . Harelda, p. 61 .

$9^{\prime}$. Feathers ending in point of acute triangle on forehead.

10. Upper mandible constricted to small nail-like tip.

Charitonetta, p. 60 .

$10^{\prime}$. Upper mandible rounded at tip.

Histrionicus, p. 61.

8 . Upper mandible widest at anterior edge of nostril, and elevated or swollen at base (except in fenale and immature O. americana) . . Oidemia, p. 62.

$1^{\prime}$. Tarsus as long as or longer than middle toe witlout claw. 2. Neck as long as or longer than body . . Olor, p. 70 . 2 . Neck shorter than body.

3. Bill and feet always black . . . . Branta, p. 67.

$3^{\prime}$. Bill and feet never entirely black, usually reddish or yellowish.

4. Bill as wide as deep at base. . Philacte, p. 69.

4'. Bill much deeper than wide at base.

5. Depth of bill at base more than half the length of eulmen; adults mainly white. Chen, p. 65.

5 '. Depth of bill at base less than half the length of culmen; adults never white . Anser, p. 66.

\section{GENUS MERGANSER.}

General Characters. - Bill slender and approximately cylindrical in front of nostrils, armed along edges of mandibles with sharp, strongly recurved teeth; head crested in both sexes.

\section{KEY TO SPECIES.}

1. Nostril near middle of bill, about .50 from feathers.

$1^{\prime}$. Nostril near base of bill, about 25 from feathers

americanus, p. 46. serrator, p. 46. 


\section{Merganser americanus (Cass.). American Merganser: SHELDRAKE.}

Adult male. - Head and short erest black glossed with green; shoulders black; wing black, with white in middle; rump and tail gray; neck and sides white; breast creamy white or pale salmon. Adult female: head, neck, and long thin erest light brown; rest of upper parts bluish gray, except white patch on middle of wing; chin and breast white. Male: length $25-27$, wing 10.50-11.25, bill 1.90-2.20. Female: length 21-24, wing $9.60-9.75$, bill $1.80-2.00$.

Distribution. - Whole of North America, breeding from Pennsylvania and mountains of Colorado and California, northward.

Nest. - In hollow tree or on ground, lined with down. Eggs: 8 to 10, pale buffy.

The sheldrakes, while common and widely distributed, are never abundant. They are usually found in pairs or small flocks along the rivers or in open lakes where there are plenty of small fish. In summer the few that remain in the United States to breed keep principally in the high mountains, along the streams or lakes of the Boreal zone. Even the half fledgred young delight in the cold water and foaming rapids of a mountain trout stream. VERNoN BAILEY.

130. Merganser serrator (Linn.). Red-breasted Merganser.

Adult male. - Head and crest black, glossed with green; neck white; back black; middle of wings white; rump gray; chest buffy brown, streaked with blackish; belly white or ereamy; sides gray. Adult female:

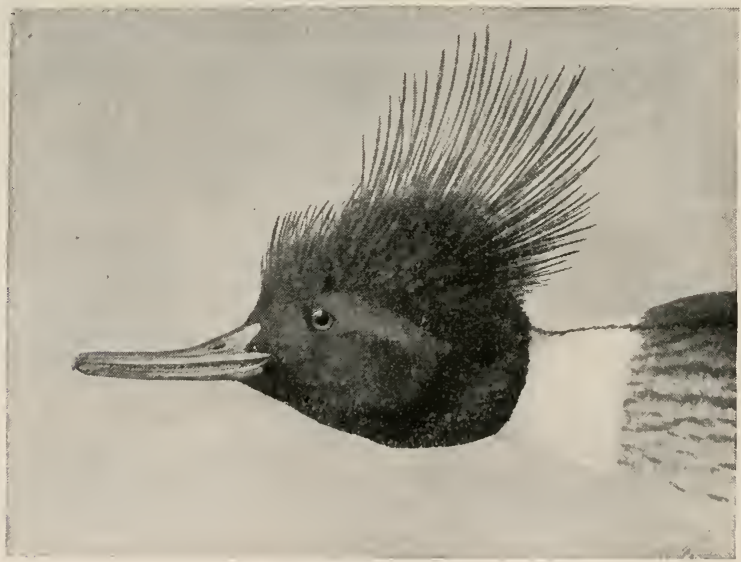

Fig. 63.

head and neck brown, darker and duller on erown and erest; rest of upper parts and tail slaty gray, except for white pateh on wings; under parts white. Length: $20-2 \tilde{5}$, wing $8.60-9.00$, bill about 2.50 . 
Remarks. - The female is distinguished from the female americanus by smaller size, slenderer bill, and position of nostril.

Distribution. - Northern part of northern hemisphere, breeding in America from Illinois and Minnesota north to Alaska and Greenland; south in winter over the United States.

Nest. - On ground near water, hidden in grass and weeds, made of leaves, grass, and moss, lined with down. Eggs : 8 to 10 , olive buff.

The red-breasted merganser is a common duck of the clear streams and lakes, a good diver and fisher, but rarely fat and often flavored by its favorite food.

\section{GENUS LOPHODYTES.}

\section{Lophodytes cucullatus (Linn.). Hooded Merganser.}

Bill narrow, slender, and with terninal part eylindrical, armed along edges of mandibles with blunt, scarcely inclined teeth; head with high thin, wheel-shaped crest, less prominent in female.

Adult mule. - Head, neck, and back black; middle of crest and nuder parts, white ; sides light brown, finely cross-lined with black. Adult female: upper parts grayish brown, browner on crest; patch on wing, throat, and belly white. Young: similar to female, but with little or no crest. Length: 17.2519.25 , wing $7.50-7.90$, bill 1.50 .

Distribution. - North America from Alaska to Cuba and Mexico, breeding throughout most of its range.

Nest. - In hollow trees,

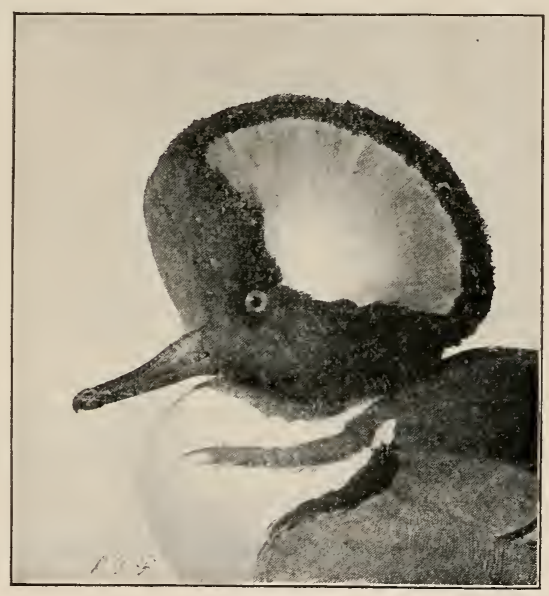

Fig. 64 . lined with grass, feathers, and down. Eggs: 6 to 10, ivory white.

The hooded merganser or saw-bill is widely distributed and often abundant during migration, frequently gathering in large flocks in the rice lakes. It becomes very fat and its flesh rarely has any flavor of fish. In fall it is one of the last ducks to leave, lingering on the half frozen lakes and streams of the northern states. A little flock may now and then be found in open rapids, when all the still water is covered with ice.

VerNoN Batley.

\section{GENUS ANAS.}

General Characters. - Bill flat, long, and slightly wider near end than toward base; wing with purple or green iridescent speculum occupying a 
large space on secondaries; head uncrested except for the slightly elongated green feathers of male mallards in winter plumage.

KEY TO SPECIES OF ANAS.

1. Head and neck iridescent green (winter male) .

1. Head and neck finely striped and specked with dusky,

2. Belly mottled gray and dusky (summer male, female, and young).

2 '. Belly mottled brown and dusky .

boschas, p. 48 .

132. Anas boschas Linn. Mallard.

Male in winter and breeding plumage. - Four of the black upper tail coverts recurved; head and neck, down to white collar, rich iridescent green ; chest dark chestnut brown; belly and sides gray; wing with iridescent violet green speculum bordered by black and white bars; rump and upper and lower tail coverts black. Male in summer plumage: like female. Female and immature: entire plumage variously mottled, scalloped, and streaked with dusky and buff. except for plain buffy chin and white under surface of wing; buff predominating on belly; wing as in male. Length: $20-25$, wing $10.25-12.00$, bill $2.00-2.40$.

Distribution. - Northern hemisphere; in America breeding from southern United States to Alaska; south in winter to Panama.

Nest. - On the ground, in grass or weeds, well lined with down. Eggs : 6 to 10 , pale olive or buffy green.

The mallard is the best known of all the American ducks, breeding at large over the country and migrating north and south in great flocks, feeding extensively on wild rice and various grains and seeds, and becoming extremely fat. Its large size and delicious flavor render it an important and much sought game bird, but at the same time threaten it with partial extermination. Nature has done her best for it in its summer dress, for nothing could be more protectively inconspicuous. The female keeps the mottled disguise all winter. In fall, however, both old and joung males acquire the rich breeding plumage which they keep until after the $\mathrm{eggs}$ are laid in spring. The male then doffs his bright dress and in his dull disguise can be distinguished from the female only by his soft voice, a mere whispered imitation of her loud quack, quack. When both old birds are away from the nest, the eggs are left carefully covered with down.

Vernon Bailey. 


\section{4a. Anas fulvigula maculosa (Senn.). Mottéd Duck.}

Sexes similar, resembling a dark-colored female mallard. Head and neck buffy, finely streaked with dusky; under parts mottled about equally with dusky and light brown; feathers of breast and back with brown centers and margins; spaculum of wing greenish purple framed in black, the feathers tipped with white. Wing: 10.05, bill 2.25.

Distribution. - From Central Mexico north to Kansas and Colorado.

Eggs. - Pale buffy.

The habits of the mottled duck are similar to those of the mallard.

\section{GENUS CHAULELASMUS.}

\section{Chaulelasmus streperus (Linn.). Gadwall.}

Tail feathers 16. Adult male: top of head with wide low crest; head and body gray, crossed with wavy lines of black and white; rump and upper and lower tail coverts black; wing marked with black, white, and bright brown; belly white. Post-breeding plumage: duller and more spotted below. Adult female: head without crest; head and neck finely specked with dusky on a buffy or whitish ground; chin and belly white; rest of body with feathers dusky, bordered with buff. Male: length 19.25-21.75, wing $10.25-11.00$, bill 1.60-1.75. Female: length 18, wing 10.00-10.25, bill 1.5.5-1.6.5.

Remarks. - The female resembles the female mallard, but may be distinguished by white chin and belly, gray under surface of wing, and white instead of green speculum.

Distribution. - Northern hemisphere, including the whole of North America.

Nest. - Like that of the mallard. Eggs : $\$$ to 12 , pale buffy or creamy white.

In habits the gadwall is much like the mallard, being a bird of the ponds and marshes and breeding more or less commonly over much of North America, especially on the plains and prairies.

\section{GENUS MARECA.}

General Characters. - Tail feathers 14; male with short crest, adult male with white crown; bill small, widest near base.

\section{KEY TO SPECIES.}

1. Sides of head and neck rich russet brown (specked with dusky in immature) . . . . . . . (male) penelope, p. 49.

$1^{\prime}$. Sides of head and neck thickly specked with dusky on light buff or whitish ground.

2. Crest and sides of crown metallic green . (male) americana, p. ว0.

2 '. Whole head and neck streaked and specked.

3. Head and neck streaked on whitish ground.

3 '. Head and neck streaked on buff ground.

(female) americana, p. 50.

(female) penelope, p. 49.

\section{Mareca penelope (Linn.). WIDGEON.}

Adult male. - Bill blue with black tip; crown white or ereamy; rest of head and neck rich russet brown, more or less specked with black; chest 
light vinaceous brown; back, rump, and sides gray crossed by fine wavy black and white lines; wing with green speculum framed in black, and bordered above by large white patch; under, and sides of upper, tail coverts, black. Adult female: head and neck thickly specked all over with dusky on buff; breast, sides, and back mottled with dusky and buff; speculum grayish, bordered above and below by narrow white tips to feathers. Young male: head and neck brown, thickly specked with black; breast and sides dull brown, back mottled dusky and brown. Length: 1S20 , wing $10-11$, bill $1.35 \overline{5}-1.45$.

Distribution. - Northern part of Old World, occurring rarely in eastern United States, Nebraska, California, and Alaska.

\section{Mareca americana (Gmel.). Baldpate.}

Adult male. - Bill blue with black tip ; crown white, bordered on sides

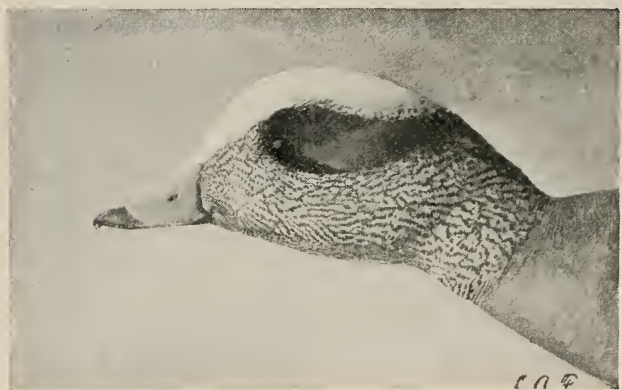

Fig. 66 . and back with wide patch of metallic green; rest of head and neck finely specked with dusky over buffy; chest and sides grayish lavender or vinaceous, often barred and specked with dusky; belly white; back dark gray crossed with vavy lines of black, white, and lavender; speculum green, franied in velvety black;

bordered above by large white patch; lower, and sides of upper, tail coverts, black. Adult female: head and neck finely specked with dusky on whitish ground, the dusky predominating on top of head; chest, sides, and back dull brown, mottled with blackish; belly white ; wing with dull black speculum bordered above and below by white. Length: 1S-22, wing 10.25-11.00, bill 1.30-1.50.

Distribution. - Whole of North America, breeding from Texas to North Dakota, and northward.

Nest. - On the ground, in a bunch of grass, under a bush, or in a depression lined with grass, leaves, and down. Eggs : 10 or 11, creamy or buffy white.

Like most of the shoal water ducks, Colonel Goss tells us, the baldpates are to be looked for along the edges of lagoons, grassy lakes, and pools of water. The birds are not shy, he says, and " their note, a sort of wher, wher, whew, uttered while feeding and swimming, enables the hunter to locate them in the thickest growth of water plants; and when in the air the whistling noise made by their wings heralds their approach." Ordinarily their food habits are the same as those of the gadwall, but in the fall they often attach themselves to a party of canvas-backs or other deep water ducks, that feed on Vallisneria, and following them about lie in wait while the 
divers are below, and as their heads appear above the surface snatch their catch and hurry away to swallow it at leisure.

\section{GENUS NETTION.}

General Characters. - Tail feathers 16 ; sides of bill parallel throughout ; upper and lower outlines in front of nostril straight; wing with speculum bright green; head of male in winter and breeding plumage with short erest.

\section{KEY TO ADULT MALES.}

1. Sides and shoulders finely lined with black and white, and shoulders crossed by white bar . . . . . . . carolinensis, p. 51.

1'. Sides and shoulders coarsely lined with black and white; shonlders without white bar . . . . . . . . . . crecca, p. 51.

\section{[138.] Nettion crecca (Linn.). European Teal.}

Adult male. - Similar to carolinensis but shoulder without white bar, and black lines and spots on body heavier and coarser. Adult female: indistinguishable from female carolinensis.

Distribution. - Northern part of Old World, occasional in northern part of North America and in California.

\section{Nettion carolinensis (Gmel.). Grefn-winged Teal.}

Adult male. - Head light chestunt, forehead and chin blackish : a wide erescent of green and black inclosing eye and reaching to base of erest; breast buffy, spotted with black; back gray, shoulders crossed by white bar; shoulders and sides finely cross-lined with black and white; wing with green and black speculum, bordered above by buff and below by white; under tail coverts black, bordered by rich buff. Adult female: back, sides, and breast dusky, scalloped and mottled with buff; throat and belly whitish; base of wing slaty; wing with speculum as in male. Young male:

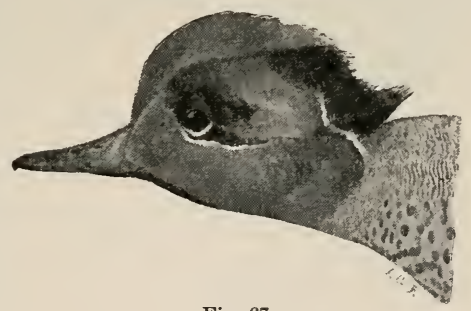

Fig. 67 . belly white. Length: $12.50-15.00$, wing $6.25-7.40$, bill 1.40-1.60.

Distribution. - Whole of North America, breeding in Colorado, Oregon. and California, but mainly north of the United States; in winter south to Honduras and Cuba.

Nest. - In a tuft of grass, or on dry ground among willows, made of grass and lined with down. Eggs: usually 9 to 12 , sometimes 16 to 18 , pale buff.

The green-winged teal, like most of its near relatives, is far more a duck of the marshes, grass-fringed ponds, meadow creeks, and irrigation ditches than of the clear lakes and streams. Like the mallard, and often in its company, the teal are fond of feeding in shallow water where, by standing on their heads, - with tails and sometimes feet sticking up out of the water, - they can reach the bottom to grub up the tender roots and water plants, and sift out 
the sunken seeds. They become excessively fat, and although the smallest, are one of the most delicious of our ducks.

$$
\text { VerNox BaILEY. }
$$

\section{GENUS QUERQUEDULA.}

General Characters. - Tail feathers 14, bill of nearly uniform width; upper and lower outlines swollen toward end; wing with large patch of light blue, speculum green in males.

\section{KEY TO ADULT MALES.}

1. Lower parts clear bright cinnamon _. . . . . cyanoptera, p. 52. $1^{\prime}$. Lower parts thickly spotted with dusky on vinaceous . discors, p. 52.

KEY TO FEMALES.

1. Under parts mottled dusky and dark buff . . . cyanoptera, p. 52. 1'. Under parts mottled dusky and gray . . . . . . discors, p. $5 z$.

140. Querquedula discors (Linn.). Blue-Winged Teal.

Adult male. - Sides of head slaty gray, with purple gloss; white crescent

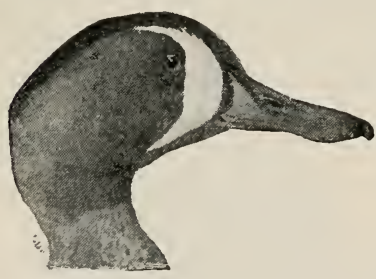

Fig. 68 . in front of eye bordered by black; under parts vinaceous, finely spotted with dusky; back scalloped and streaked with dusky and vinaceous; wing bright blie at base, middle coverts tipped with white and buffy, speculum iridescent green; under tail coverts black, base of tail with white patch on either side. Adult female: crown mainly dusky, rest of head and neck speckled and streaked with dusky; back dusky; under parts gray, mottled with dusky; wing with lesser coverts blue, greater tipped with white, speculum greenish. Young: belly white, wing without green. Length: 14.5016.00, wing 7.00-7.50, bill 1.40-1.65.

Distribution. - North America, but chiefly east of Rocky Monntains ; in winter south to Ecuador.

Nest. - On dry ground, or in grass or reeds in marshes; made of grass and lined with feathers. Eggs: $\mathrm{S}$ to 12 , pale buffy.

The blue-winged teal is one of the commonest ducks throughout the middle portion of North America, but towards the west coast it becomes scarce, its place being filled by the more abundant cinnamon teal. It breeds through most of its United States and northern range and migrates early, before the really cold weather. By preference it inhabits the marshes and grass-fringed ponds, keeping out of sight when it can; but during migration, like many other ducks, it depends for safety on a wide expanse of open water.

Vervon Batley.

141. Querquedula cyanoptera (Vieill.). Cinnamon Teal.

Adult male. - Head, neck, breast, and sides bright cimnamon brown, 
fading to dull brown on belly and becoming blackish on chin and erown; back dusky, shoulders spotted and barred with dusky and brown; wing with lesser coverts light blue, middle coverts tipped with white, speculum green, tertials broadly striped with blue, greenish black, and rich buff. Adult female: crown dusky, rest of head and neck finely specked and streaked with dusky on buffy ground ; rest of upper parts dusky sealloped with buff; wing with large blue patch ; under parts brownish, mottled with dusky. Young: like female, but more streaked below. Length: 15.50-17.00, wing $7.20-7.25$, bill $1.65-$ 1.85.

Remarks. - The female cyanoptera differs from the female discors in

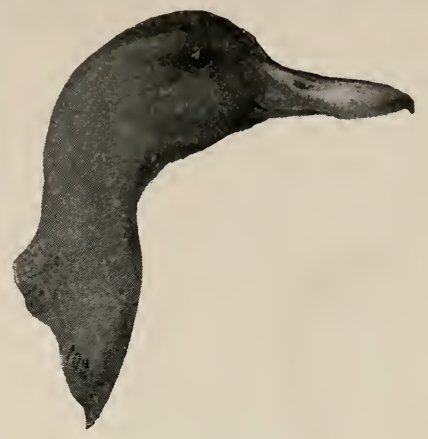

Fig. 69. Cinnamon Teal. darker coloration, with the breast browner, and more spotted.

Distribution. - From southern Canada and the western United States to Chili and Falkland Islands; east irregularly into the Mississippi Valley.

Nest. - On the ground. Eggs : $\mathrm{S}$ to 12, ereamy white.

Over most of the United States west of the hundredth meridian the cinnamon teal is one of the commonest ducks, breeding in abundance throughout the Great Basin country, and to some extent over the greater part of its United States range. Its farorite summer home is in the shallow tule-bordered lakes or tule marshes of the arid region, where, even in the breeding season, it is found in little companies feeding along shore or out in the open patches of water. The nest is usually in a dry marsh or on a grassy bank not far from the water, well lined with dusky down from the duck's breast. The young are protected in the tule cover until old enough to fly, but they have many enemies. The prowling coyote dines with equal relish on a nest full of eggs or an unwary duck, and there are hawks by day and owls by night.

The teals could hold their own against these old-time enemies, however, but a new danger has come to them in the form of the unrestrained market hunter. He goes to the breeding ground just before the young can fly and while the old ducks are moulting and equally helpless, and day after day loads his wagon with them for the train. This wholesale slaughter has gone on until some of the breeding grounds have been woefully thinned not only of teal, but of other ducks. Without speedy and strenizous efforts to procure and enforce protective laws, many species of ducks that breed principally within our limits will soon be exterminated.

VERNON BAILEY. 


\section{GENUS SPATULA.}

\section{Spatula clypeata (Linn.). Shoveller: Spoonbill.}

Bill long, much widened toward end; the long, fine comb-like teeth conspicuous along side of closed bill. Adult male: head and neck black, glossed on sides and back with green; wing coverts light blue with a white bar; seapulars streaked with blue, white, and black; speculum green; chest white, belly chestnut; bill black, feet orange. Adult female: plumage mainly spotted and streaked with dusky and brown; wing as in the niale, but duller. Young: in general like adult female. Length:17-21, wing $9-10$, bill 2.60-2.90, width of bill at base .60, near end 1.10-1.20.

Distribution. - Northern hemisphere, breeding in North America from Texas to Hudson Bay and Alaska.

Nest. - On ground in dry grass or under bushes, made of grass or weeds, lined with feathers. Eggs : 9 to 14 , olive greenish to buffy.

The shoveller is especially common over the plains and valleys of the western part of the continent, breeding from Texas to northern Alaska in the open country where there are shallow ponds and sloughs. They are usually found in pairs or small flocks, sitting on the bank or puddling in the shallow water close to shore, skimming flies and larvæ from the surface with their spoon-like bills, or with head and neck under water, sifting seeds, mollusks, and crustaceans - from the muddy bottom. They rarely become fat, and while fairly good eating are astonishingly thin and light for their apparent size.

VERNON BAILEY.

\section{GENUS DAFILA.}

\section{Dafila acuta (Linn.). Pintail.}

A large duck, with long neck and long, sharp tail of 16 feathers; head not crested. Adult male: sides of head snuff brown. with a purple gloss;

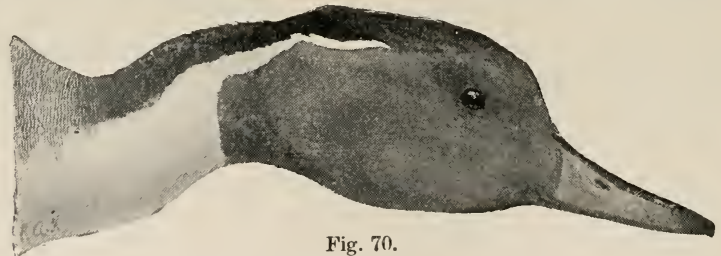

erown darker, back of neck blackish, a white stripe down side of neck; throat and uuder parts white; sides and upper parts gray crossed by wavy lines; wing slaty, with purple speculnm bordered above by a line of buff, and below by white; tertials with broad stripes of velvety black and white; under tail coverts black. Adult female: gray, with head and neck finely specked, and under parts, including under surface of wing, finely mottled with dusky; back and wings more heavily mottled with black, brown, and buffy; wing without speculum, but greater coverts tipped with white. Male: length 26-30, wing 10.25-11.20, bill 1.85-2.15, tail 7.25-9.50. Female: smaller, length 21.00-23.50, wing 9.60-10.10, bill 1.80 , tail $4.50-5.00$. 


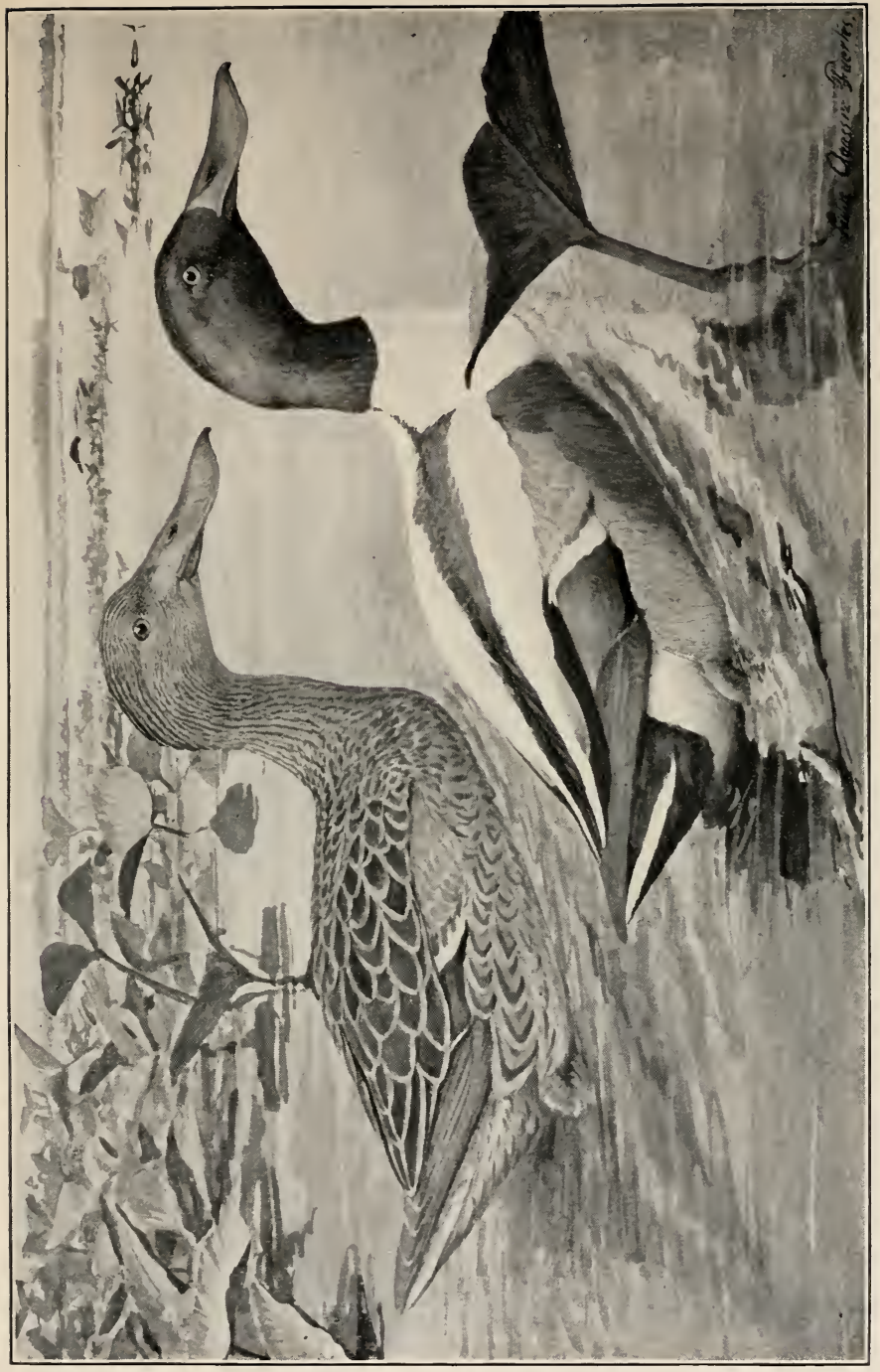

$\frac{1}{12}$ 

Distribution. - Northern hemisphere, breeding from Arizona, Missouri, and Illinois northward; migrating to Cuba and Panama.

Nest. - On the ground, in a well concealed depression; lined with grass and feathers. Eggs : 7 to 10, pale greenish to olive buff.

The pintail is a common and widely distributed species, breeding from southern California, Arizona, and Iowa north to Point Barrow. In Kansas, Goss says, it haunts the wet prairies, muddy flats, and edges of reedy, grassy waters, feeding largely on bulbous roots, tender shoots, insects and their larvæ, worms, snails, and, in the fall, various seeds of water plants, grain, and acorns. At Point Reyes, California, large flocks of the pintails were seen by J. A. Loring lying out in the bay waiting for the tide to come in. As soon as it covered the salt grass flats they would follow it in and go to feeding.

\section{GENUS AIX.}

\section{Aix sponsa (Linn.). Woop Duck.}

Bill narrow, higher than wide at base. Both sexes with drooping erests. Adult male: bill marked with black, white, red, and yellow; head and crest brilliant purple and green, with white stripes; throat white; chest rich chestnut, with rows of white triangles; sides gray, with black and white bars and erescents ; shoulder crossed by black and white bars; rest of upper parts black,varied with rich iridescent colors. Adult female: head dull grayish, glossed with green on crest and crown; sides of head and throat white; chest brown, belly white; back richly glossed grayish brown. Male: length 19.0020.50, wing 9.00-9.50, bill

\subsection{Female smaller.}

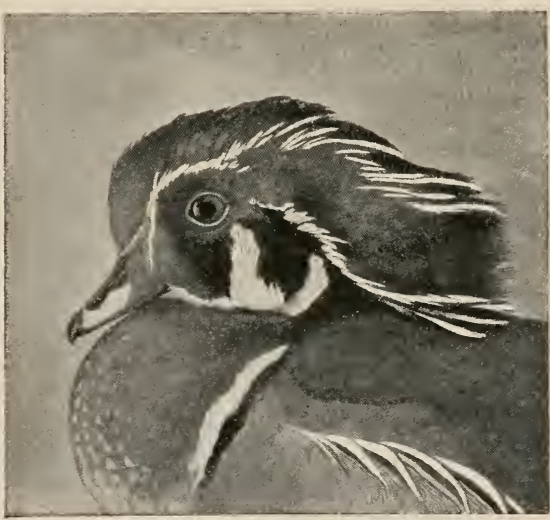

Fig. 71 .

Distribution. - Temperate North America, from southern Canada southward.

Nest. - Usually 30 to 40 feet from the ground in the natural eavity of a tree trunk, lined with down. Eggs: usually 8 to 14, creamy white.

If the end of a rainbow had touched a marsh and dabbled its colors over a plain brown duck, it could never have produced anything half so brilliant as one of these old male wood ducks in full breeding plumage. No wonder the handsome fellows are shy and deem it prudent to keep hidden in crooked forest creeks or ponds surrounded by tall grass, brush, and trees! A mossy $\log$ in a pond is a favorite 
resting place for the ducks, but as you walk through the woods in spring a pair will often fly from a branch overhead, uttering their shrill, plaintive cry as they dart through the trees.

The nest is sometimes placed in the old excavation of a pileated woodpecker, but usually in a natural cavity. A mass of gray down from the mother's breast generally protects the eggs. The parents are said to carry the young in their bills from the nest to the nearest water, but in some cases, whether accidentally or not, the young tumble to the ground. In autumn the families gather into large flocks to fatten on wild rice and acorns. When fat the flesh is scarcely excelled by that of any duck. They are becoming scarce, and unless protected will before long be a bird of the past.

\section{GENUS AYTHYA.}

General Characters. - Head not erested, but short, thick, and rounded ; tail short and rigid; wing with white or bluish speculum.

\section{KEY TO ADULT MALES.}

1. Head and neck bright brown.

2. Crown dusky . . . . . . . . . . . . vallisneria, p. 57.

2 . Crown reddish brown. . . . . . . . . americana, p. 56.

$1^{\prime}$. Head and neck greenish or purplish black.

2. Head glossed with green . . . . . . . . . . marila, p. 57.

$2^{\prime}$. Head glossed with purple.

3. Neck without chestmut collar . . . . . . . . affinis, p. 58.

3'. Neck with dark chestmut collar . . . . . . . collaris, p. 59.

146. Aythya americana (Eyt.). REDHEAD.

Bill little more than twice as long as wide. Adult male: whole head

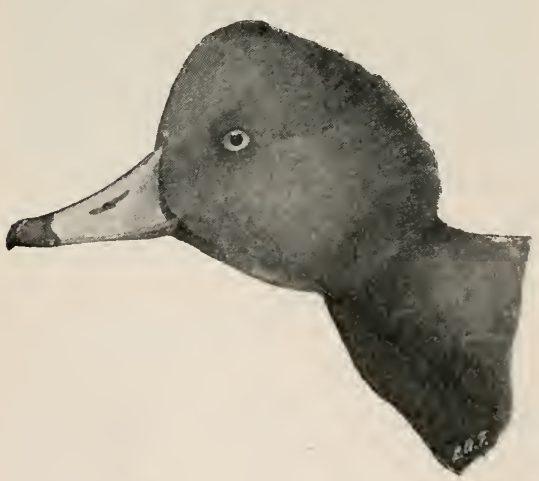

Fig. 72. and neck bright reddish chestnut ; shoulders and chest black; belly white; sides and back uniform gray, with fine lines of black and ashy; tail and feathers aroumd base black. Adult female: plumage dull grayish brown except for whitish chin, throat, and belly. Length: $17-21$, wing $8.50-$ 9.25, bill 2.05-2.25, width of bill .75-.85.

Distribution. - Nearly the whole of North America, breeding from California, Missouri, and Maine, northward. Not reported from Alaska.

Nest. - On marshy or grassy ground near water, loosely constructed of grass and weeds, and lined with down. Eggs: 7 to 10, grayish white or pale olive. 
The redhead is so similar to the canvas-back as to be easily mistaken for it at a little distance, and in habits the resemblance is equally close. Goss says that this deep water duck, though widely distributed, is not so common on the Pacific slope as east of the Rocky Mountains. It is usually found in flocks on the open water associated with canras-backs, and diving with them for its food, which consists of various kinds of submarine and fresh water plants, small mollusks, crustaceans. fish, frogs, and water newts.

147. Aythya vallisneria (Wils.). Canvas-Back.

Bill three times as long as wide. Adult male: head and neck rich

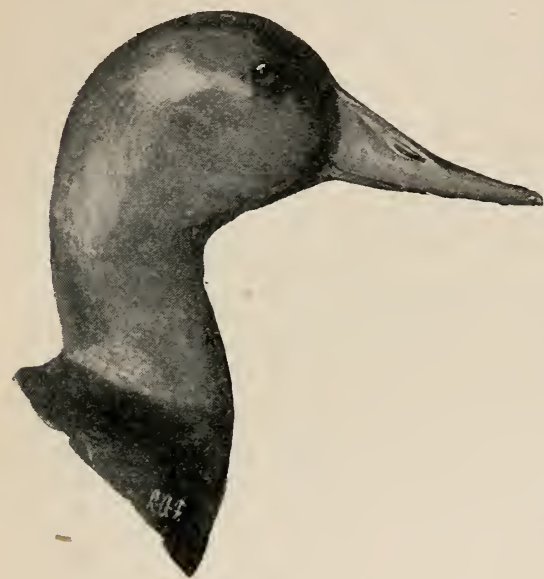

Fig. 73. chestnut brown, becoming dusky on crown and face; shoulders and chest black; sides and back light gray; belly white or grayish; tail and quills dark gray ; feathers around base of tail black. Adult female: plumage mainly umber brown, becoming whitish around face and chin. Length: 20.00-23.50, wing 8.75-9.25, bill 2.10-2.50.

Distribution. - Whole of North America, breeding in Colorado,Nevada, Minnesota, and northward to Fort Anderson and Fort Yukon.

Nest. - Usually in reeds, grass, or rushes, in shallow water, a bulky mass of grass stems lined with down. Eggs: 7 to 8 , pale olive green.

In its breeding range the canvas-back is largely a bird of the northern interior, while in winter it is found mainly in the bays and estuaries of the southern coasts, where it is attracted by its favorite food, the stems and bulbs of wild celery or eel grass, Vallisneria. While feeding on this plant the canras-backs become fat and so delicately flavored as to outrank all other ducks in quality and market price. Hunted wherever they go, they have learned that existence depends on eternal vigilance, and so keep out in open water as far from shore as their feeding grounds will allow.

VERxox BaIley.

\section{Subgenus Fuligula.}

\section{Aythya marila (Linn.). Scaup Duck: Blue-Bill.}

Bill short and wide, bluish with black tip. Male in breeding plumage: head black, glossed with green; shoulders, rump, and chest black; belly white, margined along sides with light grayish; crissum black. Post- 


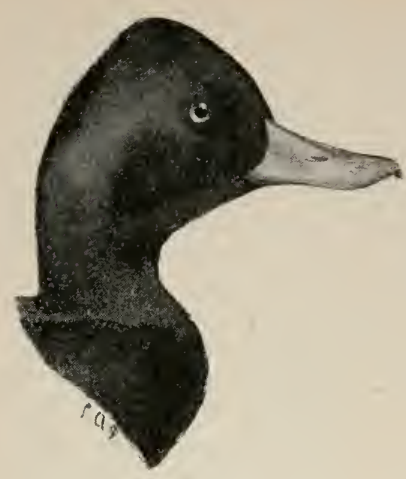

Fig. 74. Scaup Duck.

breeding plumage: similar to female but darker brown. Adult female: head, neck, chest, and sides brownish; region around base of bill, and belly, whitish. Length: 1S-20, wing about 8.50, bill 2.03 .

Distribution. - Most of the northern hemisphere; in North America breeding mainly north of the United States; south in winter to Guatemala and the West Indies.

Nest. - Usually in a marsh, or a depression in grassy ground near water, lined with down. Eggs: 9 to 12, pale olive gray.

The scaup duck, or blue-bill, is not so generally common in the United States as the lesser scaup, which has essentially the same habits and is sometimes mistaken for it. Flocks of both are found associated in the rice lakes, where the report of a gun will sometimes start thousands into the air with the roar of an avalanche. The two species are generally indistinguishable on the wing, and together often form the bulk of the ducks seen during the early spring or late fall migration.

Verion Bailey.

\section{Aythya affinis (Eyt.). Lesser Scaup Duck.}

Like A. marila, but smaller, with black of head glossed with purple instead of green, and sides more heavily lined with gray. Length : 15.0016.50 , wing $7.50-8.25$, bill $1.58-1.90$, width of bill $.50-.95$.

Distribution. - North America, south in winter to Guatemala, breeding mainly north of the United States.

Nest. - Similar to that of marila. Eggs : 7 to 9, pale olive gray.

The lesser scaup, or little blue-bill, is abundant during migrations over most of the United States, wintering from Okanagon and Lake Chelan south to Guatemala, and in spring following north close to the edge of the retreating ice, to breed mainly north of the United States.

Like all of the genus, the lesser scaups are great divers and keep much in the open lakes, often in large flocks, where they dive for food, or sleep and rest on the water in comparative safety. They cannot resist the temptation of the rice lakes, however, and swarm into them by thousands to fatten on the delicious grain, which they glean from the mud bottoms after it has been threshed out by the wind and the wings of myriads of coots and rails. While they eat, the hunters lie hidden in the tall rice and on the ridges which they must pass in going from lake to lake, and in spite of their bullet-like flight the sally thinned flocks show the penalty they hare paid for leaving the open water.

VERTON BaIlEy. 
150. Aythya collaris (Donov.). Ring-Necked Duck.

Bill narrower tlan in $A$. marila, black, erossed by blue band near end. Adult male: head, except small white triangle on chin, black, glossed with rich purple; neck encircled by narrow ehestnut collar; chest and back black, back glossed with greenish; wings blackish, with blue gray speculum ; middle of belly buffy white ; sides and back finely verniculated gray; crissum black. Adult female: throat and face whitish, rest of head, neck, and upper parts dull brown; wing with blue gray speculum as in male; chest and sides fulvous, belly white. Length: 15.50-18.00, wing 8.00 , bill $1.75-2.00$.

Distribution. - North America, south in winter to Guatemala, breeding from Minnesota and North Dakota northward.

Nest and eggs as in affinis.

In habits, as well as in general appearance, the ring-neck is very similar to the lesser scaup. At a little distance they are indistinguishable, either on the wing or on the water.

\section{GENUS CLANGULA.}

General Characters. - Bill short, high at base and narrowed toward end ; hearl with wide, high erest; males with head green and large white spot at base of bill ; females with head and erest plain brownish.

KEY TO ADULT MALES.

1. White patch on cheek, circular . . . . . . . americana, p. 59. $1^{\prime}$. White patch on cheek, triangular . . . . . . islandica, p. 60 .

KEY TO FEMALES.

1. Head light snuff brown . . . . . . . . . americana, p. 59.

$1^{\prime}$. Head dark umber brown . . . . . . . . . islandica, p. 60.

\section{Clangula clangula americana (Bonap.). Anericas} GoLDEN-EYE.

Adult male. - Head and erest rich dark green. a round white patch at base of bill; neck and under parts white; back black, shoulders white; wing with white central patch and white stripes on scapulars. Adult female: head and upper neck light snuff brown, neck with wide white or gray collar; belly white; chest, sides, and shoulders gray; wing dusky, with white 'on coverts and secondaries, the white greater coverts not tipped with duskr. Nail of bill not over 20 wide. Young male: like female, but sometimes with a suggestion of the white patch at base of bill, and less gray on chest. Male : length 18.50-2:3.00, wing 9.18, bill 1.95. Female: 16.50, wing 8.14, bill 1.64.

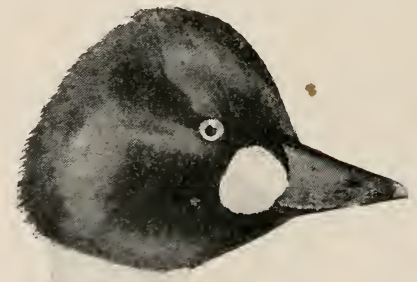

Distribution. - North America, breeding in the northern United States and northward; south in winter to Cuba and Mexico. 
Nest. - Usually in a hollow tree, sometimes in a log or stump, lined with down. Eggs: usually 9 to 12 , light greenish.

Although ranging practically over the whole of North America the golden-eyes are rarely common. They are generally found in small flocks on large lakes or rivers, where they dive for fresh water weeds, muscles, and crustaceans. Their strong rapid flight is accompanied by a loud whistling of the wings, which gives them the common name of whistler.

VernoN Bailey.

\section{Clangula islandica (Gmel.). Barrow Golden-eye.}

Similar to americana, but male with glossy blue black head, and triangular or crescent-shaped spot at base of bill; female with head and neck dark umber brown, white collar narrower, and white greater wing coverts tipped with dusky; nail of bill over .2:3 wide. Male: length 2123, wing 9.17, bill 1.75. Female: wing 8.46, bill 1.56.

Remarks. - In many of the females the characters do not hold, and it is difficult even with specimens of both species to name them all.

Distribution. - Northern North America, breeding from mountains of Oregon, Colorado, and Gulf of St. Lawrence northward to Alaska and Greenland; south in winter to Illinois, Nebraska, Utah, and San Francisco Bay.

Nest. - In hollow trees.

The Barrow golden-eye, though less common and less widely distributed in migration, breeds farther south than its near relative the American golden-eye, nesting in the crater basin of Paulina Lake, Oregon, and about many of the wild mountain lakes of the Rockies as far south as Colorado. In winter it is able to remain as far north as Minnesota or the Great Lakes by keeping in water that is too deep or rapid to freeze.

VERTON BaILEx.

\section{GENUS CHARITONETTA.}

\section{Charitonetta albeola (Linn.). Buffle-HEAd.}

A plump little duck with short, pointed bill and round, crested head.

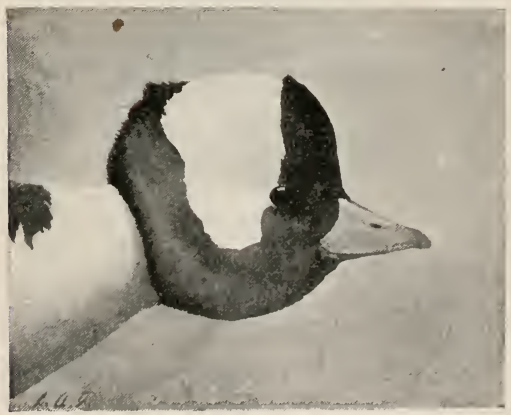

Fig. 76 . Adult male: head, except white patch, rich iridescent purple, violet, and green ; back and part of wings black; rump and tail gray; rest of plumage white. Adult female: mainly grayish or dusky, with a large white spot on ear coverts and white patch on middle of wing; belly white. Male : length $14.25-$ 15.25, wing 6.75-6.90, bill 1.10-1.15. Female : smaller. Distribution. - $\mathrm{N}$ or t h America, south in winter to Mexico ; breeds from Maine, Iowa, and British Columbia north to Alaska. 
Nest. - In hollow tree or hole in bank. Eggs : 9 to 14, grayish buff, unusually rounded, for a duck.

During migration the buffle-head is common and often abundant over most of the western United States. It is a conspicuous little duck, and the male is easily recognized by its small size, white sides, and breast. The flocks generally keep out in the open water of lakes and rivers, where they dive for their food, but are sometimes surprised in small ponds or creeks in the shelter of grassy banks. In fall they often remain till the last hole in the ice is closed up, and in spring are back again close to the retreating ice.

\section{VerNoN BaILEY.}

\section{GENUS HARELDA.}

154. Harelda hyemalis (Linn.). OLd-squaw.

A trim little duck with short bill; male with long slender tail; head not crested. Adult male in winter : head and fore parts to shoulders and breast white, except for patches of ashy and dusky on side of head; back, middle tail feathers, and breast black; belly white posteriorly, shading into pearl gray on sides. Adult male in summer: sooty, except for white belly, ash gray face. and white eyelids; back and scapulars streaked with chestnut. Adult female in winter : tail not lengthened; head, neck, and under parts mainly white ; chest gray-

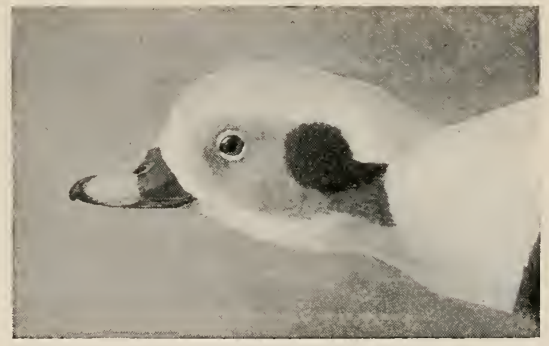

Fig. 7.

ish; crown dusky, rest of upper parts dusky brown, the seapulars bordered with lighter brown. Adult female in summer: head and neck grayish brown, with whitish spaces around eye and on side of neck. Young: similar to female in summer. Male: length 20.75-23.00, wing 8.50-9.00, middle tail feathers $8.00-8.50$, bill 1.10. Female: length $15-16$, wing $8-9$, tail 8 .

Distribution. - Northern part of northern hemisphere; south in winter nearly across the United States; breeding from Labrador to Alaska.

Nest. - Usually on the grassy bank of a pond or stream, made of grass and lined with down. Eggs: 5 to 9.

The old-squaw, or long-tailed duck, is mainly a bird of the arctic coasts, migrating south into the northern United States in winter.

\section{GENUS HISTRIONICUS.}

\section{Histrionicus histrionicus (Linn.). HARLEQUIN DUCK.}

A small duck with moderate erest, short bill, and long sharp tail. 


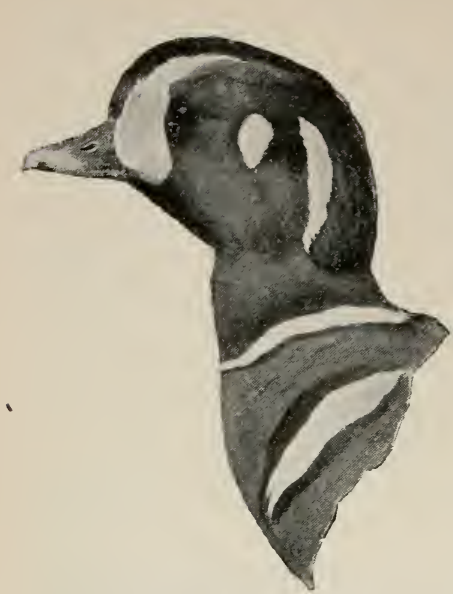

Fig. 78. Harlequin Duck.

Adult male in winter and spring: head and neck bluish black, with white patches; collar white; shoulder bar black and white; middle of crown black, bordered behind by chestnut; chest and shoulders dark plumbeous; belly sooty, sides bright rufous; wing with steel blue speculum and four white spots; rump black, with white spot on each side. Adult male in summer: colors much duller than in winter. Adult female: head, neck, and upper parts sooty, with a white spot on ear coverts and a large white patch on side of face; belly mottled grayish. Length: $15.00-$ 17.50, wing 7.40-8.00, bill 1.05-1.10.

Distribution. - Easte r n Asia, Greenland, Iceland, and northern North America; south to the middle states in winter; breeding from Newfoundland and the mountains of Colorado and California northward to the aretic coast. to 8 .

Nest. - In hollow tree or stump or under rocks or driftwood. Eggs : 6

The harlequin duck is rare enough in the United States to excite keen interest, especially when found on its breeding grounds. A little flock of the richly barred and spotted beauties fishing in a foaming mountain stream, diving, bobbing on the rough surface, drifting or darting down over the rapids, and then gathering in a bunch below to fly back up stream for another descent, suggests a lot of schoolboys on a coasting party rather than a flock of birds engaged in the serious business of getting breakfast. They seem to enjoy the icy water and their power to dare and buffet its torrents. Although breeding more or less commonly in the mountains from Colorado and California nortliward, little is known of their nesting habits. Nests are reported in the far north under shelter of rocks and driftwood.

Versox Bathey.

\section{GENUS OIDEMIA.}

General Characters. - Bill with base much swollen (except in female americana), partly orange in males, black in females; colors mainly black or dusky.

\section{KEY TO SPECIES.}

1. Feathering of hearl stopping far short of nostrils . americana, p. 63.

$1^{\prime}$. Feathering of head not stopping far short of nostrils.

2. Lores not feathered as far forward as forehead.

$2^{\prime}$. Lores feathered as far forward as forehead . . deglandi, p. 63. 


\section{Subgenus Oidemia.}

\section{Oidemia americana Swains. American Scoter.}

Plumage dark without white markings; eyes always brown. Adult male: bill swollen back of nostrils, with a large yellow and red spot at base, including nostrils; plumage black or sooty. Adult female: bill black, with a trace of yellow at base in breeding plumage, not swollen at base; upper parts dusky browu, under parts grayish brown. Young: like female but lighter and indistinctly barred below. Length: 17.00-21.50, wing $8.75-9.50$, bill $1.65-1.80$.

Distribution. - Northern part of North America, breeding in Labrador, Hudson Bay region, and Alaska; south in wiuter to New Jersey, Illinois. Colorado, and southern California.

Nest. - In grass or willows near water.

The American scoter is a duck of the norther'n seacoasts, migrating but sparingly into the United States.

\section{Subgenus Melanitta.}

\section{Oidemia deglandi Bonap. White-winged Scoter.}

Bill swollen at base over nostrils and on sides; tip orange in male; feathers of lores coming close to nostrils, as far forward as those of forehead. Adult male: eyes white; plumage black or sooty, with white eye patch and wing speculum. Adult female: eyes brown; plumage sooty gray, darker above ; wing speculum white. Length : 19.75$2: 00$, wing $10.65-11.40$, bill 1.40-1.70.

Distribution. - North e r $\mathbf{n}$

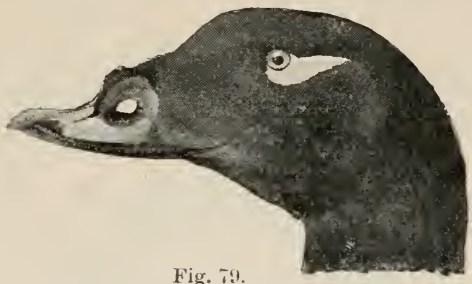

Nortl America, breeding in North Dakota but mainly north of the United States; south in winter to Chesapeake Bay, Colorado, and Lower California.

Nest. - A depression in the ground lined with grass, twigs, moss, and down; usually concealed among dwarf willows, rosebushes, or spruces. Eggs : 5 to 8, deep buff.

The white-winged scoter is more or less common along the Pacific coast, but rare inland in the United States.

\section{Subgenus Pelionetta.}

\section{Oidemia perspicillata (Linn.). SurF Scoter.}

Bill with swollen sides of base naked; feathers of forehead reaching to near nostril, of lores only to corner of mouth; bill black and less swollen in female; red, orange, yellow, and white in male, with large black spot on side of base. Adult male: entire plumage velvety black except for triangular white patch on forehead and another on back of head; eyes white. Adult female: upper parts sooty black, under parts sooty gray, usually with white patch at corner of mouth. Young: like female, but with whitish patches at base of bill and back of ear. Male: length 20-22, wing 9.25-9.75, bill 1.30-1.60. Female: smaller. 
Distribution. - North America, breeding from Sitka and the Gulf of St. Lawrence north to the arctic regions; south in winter to Florida, Colorado, and Lower California.

Nest. - In a bunch of marsh grass, on ground in tall grass, or under low branches of scrubby trees; made of plant stems and lined with down. Eggs : 5 to 8, cream color.

The surf scoters are abundant on both coasts, and during the breeding season quite common on the large northern inland waters.

Colonel Goss in describing their habits says that they are "at home as well in the surging surf as upon the smooth waters, resting and sleeping at night out on the open waters. . . . They rise in a running, laborious manner, but when fairly on the wing fly rapidly, and in stormy weather hug closely to the water." The ducks are very active when feeding, diving so constantly and rapidly one after another that they are continually disappearing and popping up. The bivalve is a favorite food with them, Colonel Goss says, its shell apparently digesting with as much ease as its contents. As they also eat fish, their flesh is coarse and rather rank.

\section{GENUS ERISMATURA.}

167. Erismatura jamaicensis ( $G m e l$.). Ruddy Duck.

Bill short and widest near end, bright blue in adult male. Adult male :

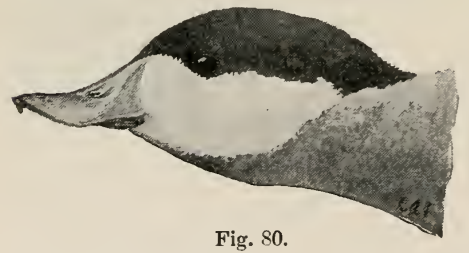
top and back of head black; neck and rest of upper parts chestnut; cheeks and chin white; belly gray, washed with silvery white, or sometimes rusty. Female and immature: upper parts plain grayish brown; sides of head whitish, with a dusky streak from corner of mouth to back of ear; under parts gray, washed with silvery white or rusty.

Length : $13.50-16.00$, wing 5.75-6.00, bill 1.50-1.60.

Distribution. - North America and south to Colombia, breeding over much of its North American range.

Nest. - A bulky mass of plant stems on the water among tules, reeds, or cat-tails. Eggs : 9 to 14, creamy or light buffy.

The ruddy duck is common over much of the western United States, and breeds abundantly in places that suit its taste, especially in the grass-fringed lakes of the northern plains and the big shallow tule lakes of the Great Basin country. It is a duck of much individuality. It sits jauntily on the water, its spike tail tilted up, and with bold audacity holds its ground till you are at close quarters, then as you think it is going to fly, and raise your gun for a wing shot, it suddenly dives. Its skill at hiding under water till it has gained the other side of a point or island would do credit to a grebe, 
and has doubtless come from its habit of feeding at the bottom of the lake. Goss gives its food as seeds, roots, and plant stems, shellfish and various forms of life found in both deep and slrallow water. He adds that when fat it is a good table duck. My own experience is that, roasted Indian fashion in the fire with the feathers on, its meat is juicy, tender, and of delicious flavor, particularly if you are hungry!

Verinon Batley.

\section{GENUS NOMONYX.}

\section{[168.] Nomonyx dominicus (Linn.). Masked Duck.}

Similar to the ruddy duck, but tail with 20 instead of 18 feathers, and bill smaller with wider nail - nail over .25 wide instead of .10 as in the ruddy. Adult male : front of head black; neck, sides, and back bright chestnut, streaked on back with black; wings black, with a large white pateh. Adult female : erown blackish ; side of head with two black and two buffy stripes; neck and sides dull brownish; back dusky. Length: 12.00-14.50, wing about 5.50-5.75, tail 3.50-4.50, bill 1.30-1.37.

Distribution. - Tropical America and West Indies; north on Gulf coast to Lower Rio Grande ; accidental in eastern United States.

\section{GENUS CHEN.}

General Characters. - Bill short and high at base, dull red, with whitish tip ; feet dull red ; plumage of adults white, except for wing, which has a black tip and adjoining gray patch. Young with head, neck, and upper parts light gray; rump, tail, and under parts white, feet and tail dusky.

KEY TO SPECIES.

1. Bill very stout, with black along edges.

2. Smaller, wing $14.50-17.00$. . .

Larger, wing $17.350-17.50 \cdot 0^{\circ} \cdot *^{\circ} \cdot \cdot$ nivalis, p. 66

$1^{\prime}$. Bill not very stout, without black on eutting edges; wing $13.75-15.50$.

rossii, p. 66.

\section{Chen hyperborea (Pall.). Lesser Snow Goose.}

Adults. - A conspicnous hard, black plate along side of lower mandible ; plumage pure white except for wing, which has black tip and gray patch; white of head and sometimes neck and breast washed or stained with rusty orange. Length : $23-28$, wing $14.50-17.00$, bill 1.95-2.30.

Distribution. - Western North America, breeding in Alaska; south in winter to southern California, Gulf of Mexico, and east to Kansas and southern Illinois.

The snow geese, or white brant, are common in migration over the western United States, wintering in California, southern Utah, Texas, and Mexico. They are oftenest seen on the wing high overhead in long diagonal lines or $\mathrm{V}$-shaped flocks, flying rapidly and uttering a chorus of shrill falsetto cries ; but not infrequently they are found in some big marsh, on the open prairie, or in a field of grain, massed till they look like a spring snow bank. Much of their food is gleaned from the stubble fields during the fall migration and from fields of 
sprouting grain in spring. In winter they feed largely on the tender white roots of a rush - Juncusbalticus (?) - dug from the river banks, marshes, and shores. They are usually lean, and their flesh is dark and generally tough.

VERNoN BAILEy.

169a. Chen hyperborea nivalis (Forst.). Greater Snow Goose.

Like hyperborea, but larger. Length : 30-38, wing 17.35-17.50, bill 2.552.70 .

Distribution. - Eastern North America, breeding in northern Greenland and probably west to Mackenzie River; south in winter along Atlantic coast to Cuba, and in the Mississippi valley to Nebraska and Colorado.

Nest. - Little known. Eggs : 5 to 8, cream color.

\section{Subgenus Exanthemops.}

170. Chen rossii (Cassin). Ross SNow Goose.

Adults. - Base of upper mandible often rougl and warty ; bill comparatively small and without black stripe along side; plumage as in hyperborea. Length: 20-26, wing 13.75-15.50, bill 1.50-1.70.

Distribution. - Interior of arctic America; south in winter to California and east to Montana. Rare.

\section{GENUS ANSER.}

\section{1a. Anser albifrons gambeli (Hartl). White-Fronted} Goose.

Bill comparatively low at base, yellow or orange; feet orange or red-

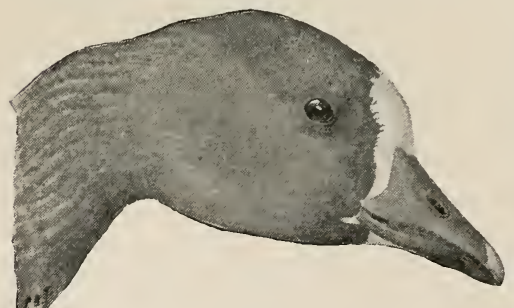

Fig. 81 . dish. Adults : face white, bordered with dusky ; rest of head and neck, also shoulders and chest, dark gray; belly and sides black or spotted with black, becoming white posteriorly and on under tail coverts; back dusky gray. Young: without white face or black on belly. Length : 2730 , wing $14.25-17.50$, bill $1.80-$ 2.35 , depth of upper mandible at base $.90-1.20$.

Distribution. - North America and Greenland, breeding from Vancouver Island to the Arctic Ocean; south in winter to Mexico and Cuba.

Nest. - A shallow cavity in the ground lined with grass, feathers, and down. Eggs: 5 to 7, creamy white.

The food of the white-fronted goose, according to Goss, consists chiefly of vegetable matter, tender aquatic plants, insects, snails, and frogs. In the San Joaquin and Sacramento valleys the geese are so abundant and their ravages to the growing wheat crop so serious that farmers often hire men by the month to drive them away. Dr. Merrill says that the numbers of these birds that migrate through western Oregon are so immense they cannot be appreciated until one 
has seen the spring flight, which, he has been told, extends from the coast inland two hundred and fifty to three hundred miles. Mr. A. M. Shields states that the white-fronted is the goose usually seen in the Los Angeles game market, being most easily secured by the pot-hunters.

\section{GENUS BRANTA.}

General Characters. - Bill and feet black at all ages; both sexes and young alike; neck long and slender; head and neck black, with white on cheeks, or else white collar; body mainly gray.

1. Cheeks white.

KEY TO SPECIES.

2. White of cheeks continuous under throat.

3. Length $35-43$. . . . . . . . . . canadensis, p. 67. $3^{\prime}$. Length 25-34 . . . . . . . . . . hutchinsii, p. 68.

$2^{\prime}$. White of cheeks separated by black of throat.

3. Wing $16.25-18.00$. . . . . . . occidentalis, p. 68. 3 . Wing $13.60-14.50$. . . . . . . . . . . minima, p. 68 . $1^{\prime}$. Cheeks black, collar white . . . . . . nigricans, p. 68 .

\section{Branta canadensis (Linn.). Canada Goose.}

Head and neck black except for broad white band across throat and cheeks; body deep gray, feathers tipped with lighter; rump, tail, and quills black; upper and lower tail coverts, and ventral region, white. Length : 35-43, wing 15.60-21.00, bill 1.5.5-2.70.

Distribution. - North America, breeding from the northern United States to Labrador and the lower Mackenzie; south in winter to Mexico.

Nest. - Usually on low monnd in marsh, made of grass and leaves, lined with down. Reported also in old nests of

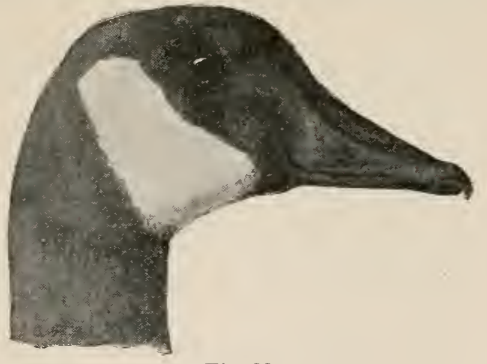

Fig. 82. hawks and eagles, in trees. Eggs: 6 to 7, dull white.

Few wild bird notes are more inspiring than the honk, honk, ha wank, honk, of a long line of Canada geese flying with apparent deliberation but with really terrific speed overhead, calling as they go in notes that carry for a mile over marsh, lake, and prairie. The big strong wings whish loudly overhead far out of shotgun range, and often a low conversational gabble can be heard under the loud honking. Few of our game birds, by intelligent caution and watchfulness, have withstood so successfully the deep laid schemes and murderous devices of pot-hunters and sportsmen as this noble, spirited bird. The widest expanse of water, marsh, or prairie is sought for the day's feeding and resting ground, and the country surveyed 
in lofty circles before the flock descends. Some of the long necks are always stretched and some keen eyes on guard, but danger lies in the hidden hunter, the decoy, and the lantern. The rice lakes are usually abandoned as too deadly, and much of the food of the geese is obtained in fall from stubble fields, scattered wheat, oats, barley, or corn; or in spring from fields of sprouting grain. In summer, grass furnishes most of their food, but many of the small water animals, such as snails, minnows, and tadpoles, are eaten. As the geese still breed over parts of the United States and Canada, the eggs are often found and frequently hatched under hens, tame geese, or turkeys. A hen can cover three eggs very nicely. The joung become perfectly tame, and are affectionate, exceedingly bright, interesting pets, always ruling the poultry yard and most of the barn yard.

VERNoN BAILEY.

172a. Branta canadensis hutchinsii (Rich.). Hutchins Goose. Like canadensis, but smaller. Length : 25-34, wing 14.75-17.75, bill 1.201.90 .

Distribution. - Japan. Siberia, and arctic America; south in winter through the United States. Breeds mainly in aretic regions, but reported as resident in British Columbia. Rare toward Atlantic coast.

Nest. - On ground in grass, lined with down. Eggs: usually 6, dull white.

The habits of the Hutchins goose are similar to those of the Canada goose.

\section{2b. Branta canadensis occidentalis (Baird). White- CHEEK ED GoOsE.}

Like canadensis, but under parts darker, white cheek patehes usually separated by black on throat; lower part of neck with a more or less distinct collar. Length: 35, wing 16.25-18.00, bill 1.40-1.65.

Distribution. - Pacific coast of North America, north to Sitka; south in winter to California.

172c. Branta canadensis minima Ridgw. Cackling Goose.

Like occidentalis but smaller. Length: 23-25, wing 13.60-14.50, bill $.95-1.15$.

Distribution. - Pacific coast of North America, breeding about Norton Sound and the lower Yukon; south in winter to California, and rarely east to the Mississippi valley.

Nest. - A depression in the ground, lined with grass and down. Eggs: 5 to 8 , white.

The cackling goose is reported by Nelson as common and breeding in Alaska, and by Fannin and Brooks as resident on the coast of British Columbia.

174. Branta nigricans (Lawr.). BLACk Brant.

Adults. - Head entirely black, neek almost encircled by a broad white collar open behind; upper parts dark sooty brown; breast black, shading 
to dark slaty; anal region white. Young: white collar indistinct or wanting; larger wing coverts and secondaries broadly tipped with white. Length: 22-29, wing 12.70-1:3.50, bill 1.20-1.35.

Distribution. - Western and arctic America, breeding at Point Barrow; south in winter along the coast to Lower California. Rare in eastern United States.

Nest. - A depression in marshy ground, lined with down. Eggs : 4 to 6.

\section{GENUS PHILACTE.}

\section{Philacte canagica (Sevast.). EMPEror Goose.}

Bill small and not much elevated at base, mainly light colored, bluish or pinkish white above; pit of nostrils reaching feathers of forehead ; feet orange. Adults: head and back of neck white or stained with rusty orange; chin and throat dusky or brownish black; rest of plumage, except white tail, bluish gray, each feather with a black bar and white tip. Young: similar to adult, but whole head dnsky, specked with white on top. Length: 26 , wing $14.30-15.75$, bill 1.40-1.65.

Distribution. - Coast of Alaska, chiefly in the region of Norton Sound and the lower Yukon; south in winter to Butte County, California. Rare in the United States.

\section{GENUS DENDROCYGNA.}

General Characters. - Feet and legs long and large for a duck; legs covered with small hexagonal plates; neck long and slender; head not crested; sexes similar.

KEY TO SPECIES.

1. Feet and legs pinkish, bill yellow . . . . autumnalis, p. 69 . 1'. Feet, legs, and bill black . . . . . . . . . fulva, p. 69 .

\section{Dendrocygna autumnalis (Linn.). Black-Bellied Tree Deck.}

Adults. - Crown, neck, breast, and back bright cinnamon brown; sides of head ashr gray; belly, rump, tail, and end of wing black; base of wing and quills with large white patches; under tail coverts white, spotted with black. Young: colors duller, bill and feet dusky. Length: 19.7524.00 , wing $9.20-9.70$, bill 1.90-2.15, tarsus $2.25-2.60$.

Distribution. - Middle America and north to the Rio Grande Valley and Nueces River, Texas.

Nest. - In hollow trees, often at considerable distance from water. Eggs : 12 to 16.

\section{Dendrocygna fulva (Gmel.). Fulvocs Tree-duck.}

Under parts, head, and shonlders plain bnffy brown or tawny, darkest on crown; back of neck with black stripe; back and wings blackish, feathers of middle of back broadly tipped with tawn; npper and lower tail coverts and stripes along sides ereamy white. Length: 20-21, wing 8.108.90, bill 1.65-1.95, tarsus 2.10-2.40.

Distribution. - Mexico and north to central California, Nevada, and Louisiana; also in South America, southern Asia, Africa, and Madagascar.

Nest. - In hollow trees or more commonly on ground in marsh or near water, a well built and often well concealed nest. Eggs: numerous, 15 to 30 or more. 
The fulvous tree-duck is a more or less common summer resident of the tule marshes and irrigated regions of southern California, breeding abundantly in favorite localities and migrating south in winter. Its usual nesting place seems to be on the ground in marshes, but it also breeds in trees. (See Bull. Cooper Ornithological Club, vol. i. No. 1, p. 9 ; and Condor, vol. iii. No. 3, p. 67.)

\section{GENUS OLOR.}

General Characters. - Size very large; neck longer than body; bill black, large, and high at base, with naked space reaching eyes. Plumage entirely pure white in adults. Young: ashy, or tinged with brownish; bill and feet grayish or flesh color.

\section{KEY TO ADULTS.}

1. Distance from eye to back of nostril greater than rest of bill.

$1^{\prime}$. Distance from eye to back of nostril less than rest of bill.

columbianus, p. 70. buccinator, p. 70 .

180. Olor columbianus (Ord.). Whistling Swan.

Bill black; lores usually with a small yellow spot. Length: $4 \frac{1}{2}$ feet, extent about 7 feet, wing $21-22$, bill 3.80-4.20.

Distribution. - North America, breeding far northward and probably in British Columbia; migrating south over the United States; wintering from British Columbia and Illinois southward.

Nest. - On ground usually on island or bank near water ; made of moss, grass, and leaves. Eggs : 5 to 7, dull whitish.

181. Olor buccinator (Rich.). Trumpeter Swan.

Adult male. - Bill and lores entirely black. Length : $5-5 \frac{1}{2}$ feet, extent 8 to nearly 10 feet, wing $21.00-27.50$, bill $4.30-4.70$.

Distribution. - Interior of North America, less common toward the coasts, breeding from Iowa and the Dakotas northward, but mainly far north; wintering from southern British Columbia to Gulf. of Mexico and southern California.

Nest. - On ground, made of grass, leaves, and feathers. Eggs: 5 to 7 , dull whitish.

Mr. Grinnell says that the trumpeter swan is a regular spring visitant to the fresh water ponds and lakes in the vicinity of Los Angeles .

\section{ORDER HERODIONES: HERONS, STORKS, IBISES, ETC.}

\section{(Families Ibidida, Ciconima, and Ardeide.)}

\section{FAMILY IBIDID丑: IBISES.}

KEY TO GENERA.

1. Head of adult mainly naked, crown with short feathers.

1'. Head feathered except on lores, crowu slightly crested.

Guara, p. 71 . Plegadis, p. 71. 


\section{GENUS GUARA.}

184. Guara alba (Linn.). White Ibis.

Size large; face and chin naked in adults; head not crested. Adults : tips of wings black; rest of plumage white, tinted with pink in life. Young: dark brownish except for white belly, rump, and tail coverts; head and neck specked with dusky. Lenyth:21.50-27.50, wing 10.3011.75, bill $4.15-6.30$, tarsus $3.10-4.00$.

Distribution. - Tropical America, the West Indies, and north to North Carolina, Indiana, Illinois, Great Salt Lake, and Lower California ; accidentally to Connecticut.

\section{GENUS PLEGADIS.}

General Characters. - Lores and eyelids naked, rest of head well feathered and crown slightly crested; bill long, scythe-shaped, grooved from nostril to tip; colors rich purplish brown, with metallic tints.

KEY TO SPECIES.

1. Feathers at base of bill black . . . . . . autumnalis, p. 71 . $1^{\prime}$. Feathers at base of bill white . . . . . . guarauna, p. 71.

\section{Plegadis autumnalis (Hasselq.). Grossr Iвis.}

Like guarauna, but larger, with green instead of red lores, and feathers at base of bill blackish instead of white. Length: 22-25, wing 10.2011.5.5, bill 4.30-5.45.

Distribution. - Southeastern United States and West Indies, and warmer parts of Old World; straggling to New England, Nebraska, and Arizona.

\section{Plegadis guarauna (Iinn.). White-Faced Glossx Ibis.}

Lores and eyelids naked, rest of head well feathered; bill long and narrow, ge n t ly curved downward, grooved from nostril to tip. Adults : lores red; face wh it is h; head. neck, shoulders, and under parts dark rich chestnut ; crown and wings glossed with iri-

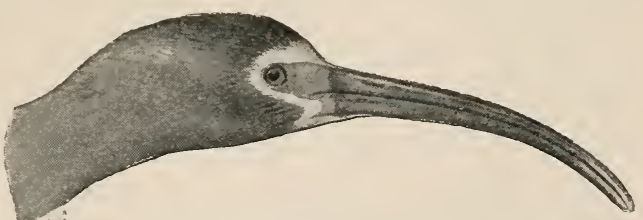

Fig. 83.

descent purplish and greenish. Young: head and neck streaked with white and dusky, and under parts grayish brown. Length: 19-26, wing 9.3010.80, bill 3.75-6.00, tarsus 3.00-i.40.

Distribution. - Tropical America and western United States, Texas, and Lower California to Oregon, and casually to British Columbia and Florida.

Nest. - Among or on rushes, made of stems of rushes and various other plants. Eggs : usually 3, greenish blue.

The glossy ibis is a marsh bird, usually seen in flocks varying from a dozen to fifty, circling overhead or wading in the shallow water of a marsh, slough, or irrigated field. At a distance the birds 
look as black as ravens, but their flight is crane-like, and walking or wading they have the dignified pose of the cranes and herons. No doubt the name black curlew comes from their curved bill, but they are neither cranes nor curlews. According to Goss, they feed on crawfish, snails, minnows, frogs, and insects. VERxon BaIlex.

\title{
FAMILY CICONIID君: STORKS AND WOOD IBISES.
}

\author{
KEY TO GENERA.
}

1. Bill curved downward and blunt at tip . . . . Tantalus, p. 72. $1^{\prime}$. Bill inclined upward and sharp at tip . . . . Mycteria, p. 72.

\section{GENUS TANTALUS.}

188. Tantalus ioculator Linn. Wood IBIs.

Adults. - Hearl and upper neck naked and, except for a smooth square patch on crown, scurfy. Plumage mainly white; wing quills and tail greenish and purplish black; under wing coverts pinkish in breeding plumage. Young: whole head and neck except face covered with greenish brown feathers, darker on back of head; rest of plumage dull whitish. Length : 35-45, wing 17.60-19.50, bill $6.10-7.30$.

Distribution. - Southern United States from Ohio, Colorado, Utah, and southeastern California south to Argentina; casually north to Wisconsin and New York.

Nest. - In trees, a loosely arranged platform of sticks, lined with moss or other soft material. Eggs : usually 3, dull white.

Goss says the white ibis is a common resident of all the Gulf states, and is found on the Colorado and Gila rivers in the vicinity of Yuma. During the breeding season the ibises assemble in large flocks, but they scatter more or less afterwards, when it is not uncommon to find a solitary bird on the feeding ground or perched on top of a tall tree. Their food consists of fish, crabs, frogs, and young alligators, together with the small forms of life that inhabit shallow lagoons, stagnant streams, and pools on overflowed land.

\section{[189.] Mycteria americana Linn. Jabiru.}

Size of a large crane; legs long, bill enormous and inclined upwards at tip. Adults : head and neck naked except for a hair-like crest on occiput ; bill, head, and legs black; skin of lower neck red in life; plumage white. Young: PInmage mainly brownish gray. Length: about $4 \frac{1}{2}$ feet; wing $24.50-27.00$, bill $9.7 .5-13.00$, tarsus $11.25-12.50$.

Distribution. - Tropical America; north casually to southern Texas.

FAMILY ARDEID㞋: HERONS, EGRETS, BITTERNS.

KEY TO GENERA.

1. Tail feathers 10 , short and very soft.

2. Plumage mainly striped . . . . . . . Botaurus, p. 73.

2'. Plumage not mainly striped, back black or brown . Ardetta, p. 74.

1'. 'Tail feathers 12 , normal. 
2. Bill long and slender, five times as long as deptl at base.

Ardea, p. 74.

$2^{\prime}$. Bill short and stout, less than four times as long as depth at base.

Nycticorax, p. 77 .

\section{GENUS BOTAURUS.}

190. Botaurus lentiginosus (Montag.). American Bittern.

Sexes alike and young very similar to adults; feathers lax and coarse;

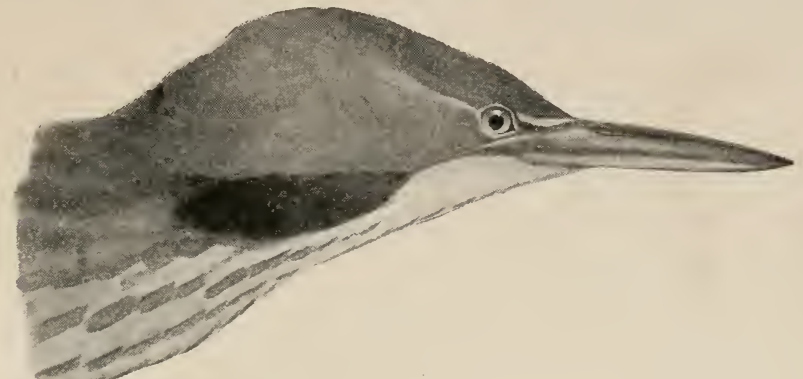

Fig. 84.

upper parts broadly striped with dusky on buff; erown and streak along jaw blackislı; throat and under parts ereamy buff, striped with brown. Length: 24-34, wing 9.80-12.00, bill 2.50-3.20, tarsus $3.10-3.85$.

Distribution. - Temperate Nortl America, and south to Guatemala, breeding in suitable locations over most of the United States.

Nest. - On the gromnd, usually in marshes; made of stems of grass, ruslies, weeds, or sticks. Eggs : 3 to 6, brownish drab.

Orer most of the United States the booming of the bittern is a familiar sound from

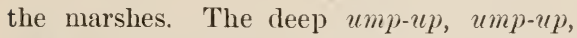

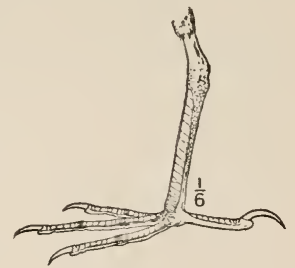

Fig. 85. $u m p$-up, has suggested such names as prairie pump, thunder pumper, and stake driver, and the gurgling tone has very naturally led to the belief that the call was produced with the bill under water. In reality it is the love-song and call-note of the breeding season, produced by inflating the throat and emitting the air with a gulping motion and the familiar booming sound. The skin of the neck becomes much thickened and of a gelatinous texture, as in the necks of the various grouse that boom, so that it serves as an elastic bellows. On a still spring morning the sound carries far over the marshes and to human ears gives little clue to distance or direction. But its ventriloquism is not the bittern's only protection. If the sound is successfully followed up and the bird actually seen, he may 
not be discovered. Standing in the high grass or rushes, at your step he points his bill to the sky as if turned to stone, his striped coat harmonizing so well with the straight lines of the surrounding vegetation that he is often passed by for a stick. His throat is his most protectively colored part, and it is said that if you walk around him he will turn as you do, so as to keep facing you. If discovered and flushed he will jump into the air with awkward haste and sometimes a startled squack. His flight would be heronlike but for the quicker strokes given by his smaller wings.

\section{Vernon Bailey.}

\section{GENUS ARDETTA.}

191. Ardetta exilis (Gmel.). Least Bittern.

Size very small, sexes and young different. Adult male: back, crown, rump, and tail greenish black; back of neck and patch on wing chestnut; throat and under parts light buff, with two dusky spots on breast. Adult female: back mainly chestnut, and buff of under parts striped with dusky. Young: like female, but brown feathers of back tipped with buff. Length : 12.00-14.25, wing $4.30-5.25$, bill 1.60-1.90, tarsus $1.50-1.75$.

Distribution. - Temperate North America, north to southern Oregon and the British Provinces, and south to the West Indies and Brazil.

Nest. - Usually in tall grass or rushes, a little above the ground or water, made of grass and rush stems. Eggs: 3 to 6 , bluish white.

The slender, dainty least bittern is mainly a bird of the marshes. Like the bittern, it avoids the trouble of flying whenever it can by making a bold bluff, and when it strikes its attitude may easily be mistaken for one of the yellow tule stems or dry cat-tails. Sometimes it eludes you by stealthy retreat, for it is almost rail-like in its manner of creeping under the grass and rushes. When the water is too deep to wade in, it walks by grasping the protruding stems.

Vernon Batley.

\section{GENUS ARDEA.}

General Characters. - Legs and neck long and slender; bill slender, straight, and sharp; crown, throat, or back with plumes or crests in adults.

KEX TO SPECIES.

1. Plumage entirely white.

2. Adult with long plumes on back only .

$2^{\prime}$. Adult with long plumes on erown, neck, and back.

egretta, p. 75 .

candidissima, p. 75 .

$1^{\prime}$. Plumage mainly blue, or brown and green; sometimes white in carulea.

2. Color mainly bluish gray or slaty.

3. Size large, wing over 17.

4. Lighter, upper parts bluish gray . . . . herodias, p. 75.

4'. Darker, upper parts slaty . . . . . . . . fannini, p. 75.

3 '. Size small, wing under 11 ; young, and sometimes adults, white.

cærulea, p. 76. 
2'. Color mainly dark green or slaty and brown.

3. Body dark green.

4. Neck dark chestıut . . . . . . . . virescens, p. 76.

4'. Neck light ehestnut . . . . . . . anthonyi, p. 77.

3'. Body slaty; neck cimnamon . . . . . . rufescens, p. 76.

Subgenus Ardea.

194. Ardea herodias Linn. Great Blue Heron.

Adults. - Upper parts bluish gray; top of head white, bordered by black and with black oceipital erest; shoulders black, striped with white; under parts heavily streaked with black and white; thighs and edge of wings cinnamon brown. In breeding season: erest with two or more slender white plumes. Young: whole crown and erest black; wing coverts without white or rufous spots. Length: 42-50, wing 17.90-19.85, bill 4.30-6.25, tarsus 6-S.

Distribution. - North America, except northwest coast, from Hudson Bay and Alaska south to Venezuela.

Nest. - Usually in tall swamp trees, but sometimes on rocks or the ground, a wide platform of sticks with little lining. Eggs : 3 to 6, dull greenish blue.

The blue cranes or great blue herons are common along river banks, lake shores, and marshes all over the United States, and are everywhere known both by their stilted pose as they stand in shallow water watching for fish, and by their heavy flight as they move evenly along with crooked neck and big slowly flapping wings.

\section{4a. A. h. fannini Chapm. Northwest Coast Heron.}

Similar to herodias, but with shorter tarsus and darker plumage, the upper parts being bluish slaty black instead of bluish gray; tibiæ more feathered. Wing: 17.50, tarsus 5.38, culmen 5.90.

Distribution. - Queen Charlotte and Vancouver Islands and coast region of British Columbia.

\section{Subgenus Herodias.}

\section{Ardea egretta Gmel. Egret.}

Plumage always pure white. Adult in nuptial plumage: scapular plumes of dissected filamentose feathers covering back and reaching well beyond end of tail ; head and neck without crests or long feathers; feet black, legs yellow; bill yellow, usually blackish near tip. Post-breeding plumage and young: back without plumes. Length: $37-41$, wing $14.10-16.80$, bill 4.20-4.90; tarsus 5.50-6.80.

Distribution. - Southern United States and south to Patagonia; north irregularly to Oregon, Minnesota, and Nova Seotia.

Nest. - In trees or bushes, near water. Eggs : 3 to 5, pale bluish.

The egret, one of the most beautiful of our birds, has been almost exterminated for its plumes, which are used in millinery as aigrettes.

\section{Subgenus Garzetta.}

\section{Ardea candidissima Gmel. Snowy Heron.}

Plumage always pure white. Adults in nuptial plumage: scapulars with long plumes of dissected filamentose feathers reaching beyond tail and recurved at tip; head and throat crested; feet yellow, legs black; 
bill black, with yellow base. Post-breeding plumage and young: back without plumes. Length : 20.00-27.25, wing $8.20-10.50$, bill $2.05-3.65$, tarsus 3.15-4.50.

Distribution. - Approximately the whole United States, and south to Argentina, South America.

Although widely distributed, the snowy heron is generally a rare bird. Throughout most of the western United States only an occasional wanderer is found.

\section{Subgenus Dichromanassa.}

\section{Ardea rufescens Gmel. Reddish Egret.}

Adults. - Feathers of head, sides of neck, and lower part of throat long and lanceolate; scapular plumes extending beyond end of tail and with fine dissected filaments; color plain slaty, with cinnamon or vinaceous rufous head and neck. Young: plain grayish, tinged here and there with rusty. Length: 27-3.2, wing 11.90-13.60, bill 3.30-4.00, tarsus 4.90-5.75.)

Distribution. - Cuba, Jamaica, and Mexico, from Guatemala north to Lower California, the Gulf states, and southern Illinois. One record for Colorado.

\section{Subgenus Florida.}

\section{Ardea cærulea Linn. Little Blue Heron.}

Adults. - Plumes on erown, back, and breast long and narrow; head and neck chestnut or maroon; rest of plumage dark slaty blue; plumage sometimes partly or mainly white, with bluish tips to quills. Young: without elongated plumes; mainly white with a tinge of blue on quills. Length: 20.00-29.50, wing 9.00-10.60, bill 2.70-3.30, tarsus $3.15-4.00$.

Distribution. - Eastern United States from New Jersey and Maine west to Nebraska and San Angelo, Texas; south to northern South America.

The little blue heron breeds in Tropical and Lower Sonoran zones, and after the breeding season wanders north, sometimes as far as Nebraska.

\section{Subgenus Butorides.}

201. Ardea virescens Linn. Green Heron.

Bill longer than tarsus, crown and back with long, lanceolate, but not

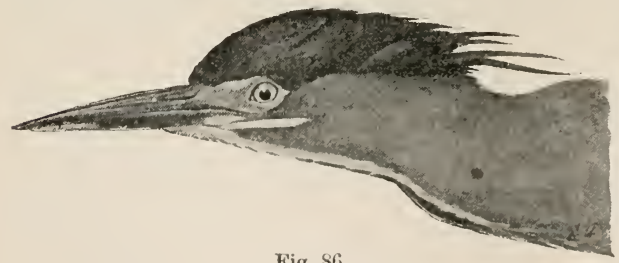

Fig. 86 .

dissected plumes. Adults : crown and crest, tail, and most of wings dark green; scapular phumes bluish green; sides of neck rich dark ehestnut; belly dusky. Young: similar to adults, bnt with seapular plumes sliorter and darker green; most of quills tipped with white and under parts coarsely streaked. Length: $15.50-22.50$, wing $(3.30-5.00$, bill 2.00-2.55), tarsus $1.7 .5-2.15$.

Mistribution. - Uregon and Ontario southward to West Indies and Venezuela. 



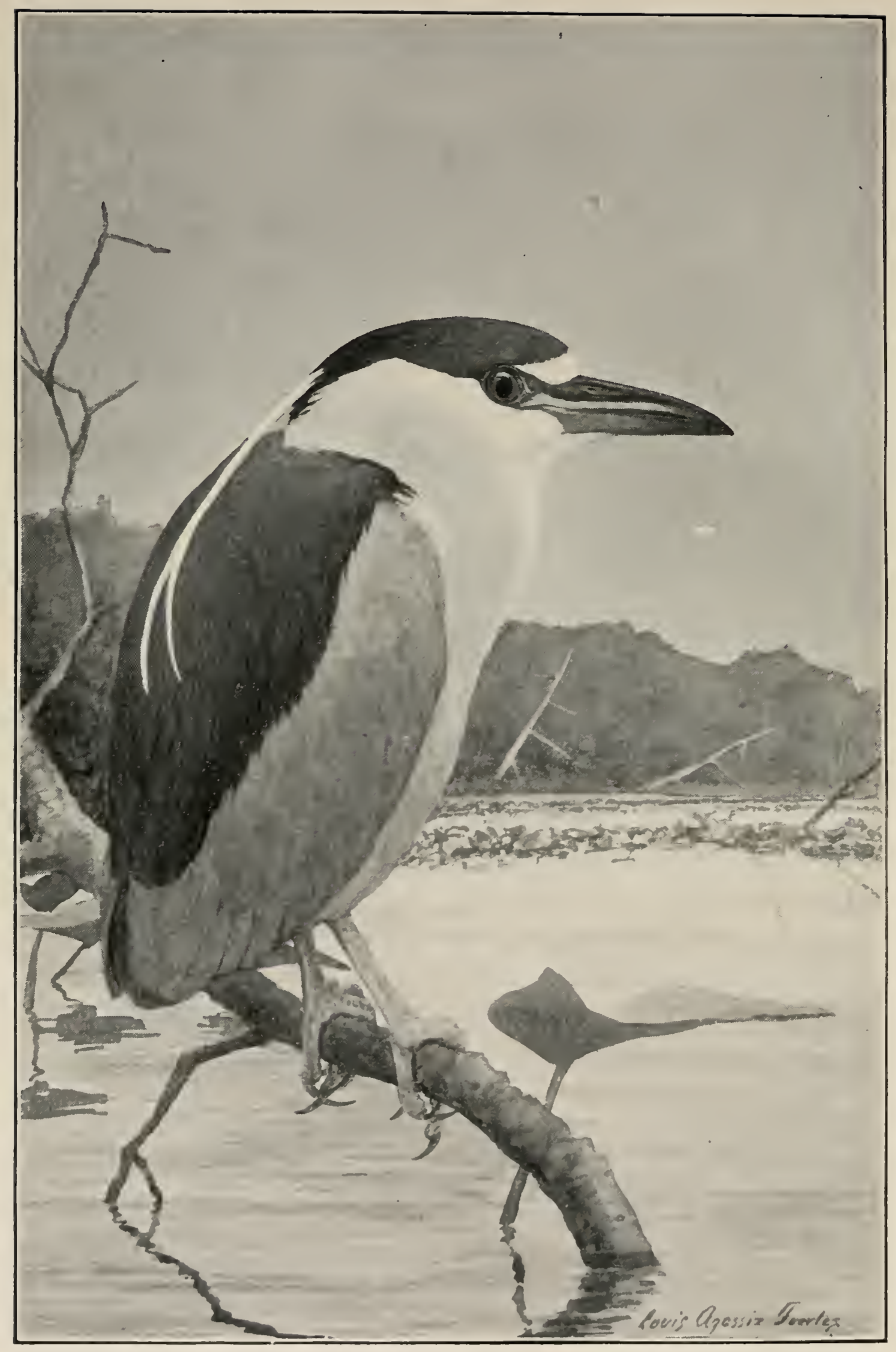

BLACK-CROWNED NIGHT HERON 
Nest. - On branches of trees and bushes near water; loosely made of sticks and lined with leafy twigs. Eggs : 3 to 6 , light bluish green.

The green heron, with other mainly nocturnal herons, lives in woody swamps, bogs, or sedgy marshes, and often hunts along streams and pouds. When startled it flies up with a 'hollow guttural scream,' but soon lights on a stump or tree, looking around with craned neck. It lives largely on small fish, frogs, larva, and grasshoppers, togethor with a variety of insects.

201b. A. v. anthonyi Mearns. Anthoxy Green Herox.

Similar to virescens, but decidedly lighter colored; sides of neck bright yellowish chestunt. Length : 19.10 , wing 8.20 , bill 2.35.

Distribution. - Arid region of the southwestern United States, and south through Mexico; north to Yreka, California.

Anthonyi is a pale desert form of virescens, with only local modifications of habit.

\section{GENUS NYCTICORAX.}

General Characters. - Bill comparatively short and stout; head crested, and, in breeding plumage, with a few long white cord-like plumes from back of crown.

KEY TO SPECIES.

1. Crown black, cheeks and chin ereany white . . . nævius, p. 77. $1^{\prime}$. Crown ereamy white, cheeks and chin black . . violaceus, p. 78.

\section{Subgenus Nycticorax.}

\section{Nycticorax nycticorax nævius (Bodd.). BLAcK- CROWNED Night HeroN.}

Bill abcut as long as tarsus. Adults : erown and back black; wings and tail ashy gray; forehead and throat creamy white, shading into light gray of sides and under parts. Young: erown blackish, streaked with buff; back dusky gray, spotted and striped, and quills tipped with buff; neck and under parts coarsely striped with buff and dusky. Length: 2:326 , wing $11.00-12.80$, bill $2.80-3.10$, tarsus $3.10-3.40$.

Distribution. - Most of South America and north to southern Canada; breeding througlont its range and wintering from the southern United States southward.

Nest. - Roughly made of reeds, rushes, or sticks placed on the ground among reeds, or on bushes or trees. Eggs : 3 to 6 , dull bluish.

The black-crowned is one of the commonest and most widely distributed of our herons. Pairs or small flocks pass hurriedly overhead morning and evening, uttering now and then the harsh guttural 'squawk' which gives them their commonest name. During the day you frighten them from their naps among the tules or reeds or from the leafy branches of the cottonwoods that overhang the streams; and whether one or a dozen are aroused, each loudly re- 
peats its name. True to their more dignified appellation, the herons feed mainly at night, but they are seen on the wing occasionally during the day.

Social at all times, they are especially so during the breeding season, nesting in small groups of three or four families to a tree, or in colonies numbering many thousands. The largest colonies usually have their nests on the ground, in tule swamps or reed patches, the nests, which are only a few feet apart, covering many acres.

VernoN BaIley.

\section{Subgenus Nyctanassa.}

\section{Nycticorax violaceus (Linn.). Yellow-Crowned Night Heron.}

Bill much shorter than tarsus; back with long narrow plume-like feathers reaching beyond end of tail. Adults: crown and patch under eye creamy white ; sides of head and chin black; rest of plumage bluish gray, striped with black and light gray on wings and back. Young: striped and mottled with brownish on back and belly. Length: 22-28, wing 10.50-12.65, bill 2.50-3.00, tarsus 3.10-1.20.

Distribution. - Tropical America and north to the Carolinas and Colorado, and casually to Massachusetts and Maine; south to Brazil.

Nest. - In trees, a platform of sticks. Eggs: 4 to 6, dull bluish.

\section{ORDER PALUDICOLÆ : CRANES, RAILS, ETC.}

\section{FAMIIY GRUID王: CRANES.}

\section{GENUS GRUS.}

General Characters. - Size very large, hind toe short and elevated; head partly naked, the warty skin covered with scattered bristly hairs.

KEY TO SPECIES.

1. Crown and cheeks naked in adults; plumage white.

americana, p. 78 .

$1^{\prime}$. Crown naked in adults, cheeks feathered; plumage gray and brown.

2. Larger, wing 21.00-22.50 . . . . . . mexicana, p. 79. $2^{\prime}$. Smaller, wing $17.50-20.00 \quad$. . . . . . . canadensis, p. 79.

204. Grus americana (Linn.). Whooping Crane.

Adults. - Plumage pure white except for black primaries and their coverts, and sometimes a slaty patch on back of head; naked skin of crown, face, and cheeks with stiff black bristles. Young: mainly white, but more or less washed with brownish on upper parts; head entirely feathered. Length: 50-54, wing 22-25, bill 5.35-5.80, tarsus 11-12.

Distribution. - Interior of North America, breeding from Illinois west to Colorado; nortl to Great Slave Lake, and migrating to central Mexico.

Nest. - On ground, usually in marsh. Eggs: 2, olive or buffy, spotted with brown and gray. 
205. Grus canadensis (Linn.). Little Brown Crane.

Like mexicana, but smaller. Length: 35, wing 17.50-20.00, bill 3.044.20 , tarsus $6.70-8.44$.

Distribution. - Northern North America, breeding from Hudson Bay and the arctic coast to Alaska; south in winter through the interior United States to Mexico ; west to Colorado and British Columbia.

\section{Grus mexicana (Mïll.). Sandhill Crane.}

Crown and lores naked except for scattered black bristles; cheeks and jaw well feathered. Adults : whole plumage slaty gray

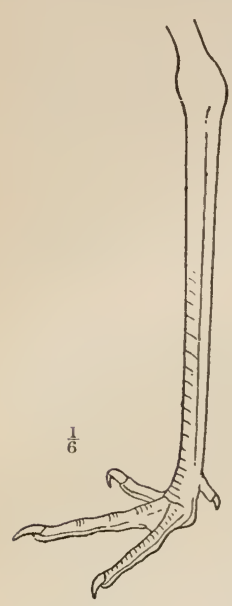

Fig. 87. or light brownish, wings darker; cheeks and throat lighter and sometimes whitish. Y Young: head entirely feathered; plumage rusty brown. Length : 40-48, wing $21.00-22.50$, bill 5.15-6.00, tarsus 9.90-10.65.

Distribution. - From southern Canada south to central Mexico and Florida; breeding from Canada to Arizona. Rare east except in Georgia and Florida.

Nest. - A wide platform of flags and rushes in a marsh. Eggs : 2, olive buff, spotted with brown.

On the big unfenced prairies and the treeless expanse of marsh where there is nothing to hide a lurking foe, you find the sandhill cranes, sometimes in small migracing flocks but usually in pairs, stalking about in dignified but ever watchful manner, stretching up to nearly a man's height to survey the surrounding country, then stooping to probe the earth for worms, catch a distant grasshopper, or spear a luckless frog or minnow. Let an enemy appear in the distance, and the long necks are up, and one of the most powerful, far-reaching of bird-notes rings out with its alarm challenge, a prolonged bugle-like cry, deeper and heavier than the loon's, and often heard a mile away. With a quick run the splendid birds mount on the wing, the bugle-notes resounding rhythmically with only the space of an inspiration between as they fly; and though their calls mellow in the distance, the cranes vanish as specks in the air before the sound of their magnificent voices is entirely lost.

Vernon BaILEY.

\section{FAMILY RALLID丑: RAILS, GALIINULES, AND COOTS.}

\section{KEY TO GENERA.}

1. Forehead entirely feathered down to base of bill.

2. Bill long and slender, as long as or longer than tarsus . Rallus, p. $\$ 0$.

2 . Bill short and stout, about two thirds the length of tarsus.

$1^{\prime}$. Forehead covered by naked shield at base of bill.
2. Toes deeply lobed along sides Fulica, p. 8:.
2 '. Toes slender, without lobes . Gallinula, p. 82 .

Porzana, p. 81 . 


\section{GENUS RALLUS.}

General Characters. - Bill slender, longer than tarsus; sexes alike.

KEY TO SPECIES.

1. Size large, wing over 5.50 .

2. Breast uniform deep cinnamon . . . . . obsoletus, p. 80 .

2 . Breast pale cinnamon buff . . . . . . caribæus, p. 80 .

$1^{\prime}$. Size small, wing not over 4.25 . . . . . . virginianus, p. 80 .

\section{Rallus obsoletus Ridgw. California Clapper Rarl. ${ }^{1}$}

Upper parts olive gray, striped on back and wings with dark brown;

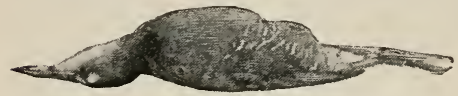

Fig. 88. breast and throat plain cinnamon brown ; chin white ; flanks dusky, narrowly barred with white. Length: $17-18$, wing $6.20-6.70$, bill $2.2 .5-2.50$, tarsus $2.10-2.30$.

Distribution. - Salt marshes of the Pacific coast from Washington (?) to Lower California.

Nest. - Usually in grass or tules at edge of slough or tide marsh, composed of dry grasses. Eggs : 6 to 12 (Henry Adams in The Condor, 1900, $31)$.

In Los Angeles County, Mr. Grinnell says, the clapper rails are tolerably common residents of the salt coast marshes. Their loud cackling notes are frequently heard, especially at high tide, when they are driven to the higher ground.

\section{[211.2.] Rallus longirostris caribæus Ridgw. Caribbean Clapper Rail.}

Under parts grayish, striped with darker; throat whitish ; breast brown ; sides and flanks barred with brown or dusky and whitish. Wing: 5.76, bill 2.38, tarsus 2.02 , middle toe 1.85 .

Distribution. - Lesser Antilles, Jamaica, and coast of sonthern Texas (Corpus Christi and Galveston).

Nest. - A platform-like structure of dried grasses, sedges, etc., in tufts of grass or sedges, in marshes or ponds. Eggs: 6 to 15, white, buffy white, or brownish buff, sparingly spotted with rnsty brown and purplish gray.

\section{Rallus virginianus Linn. Virginia Rail.}

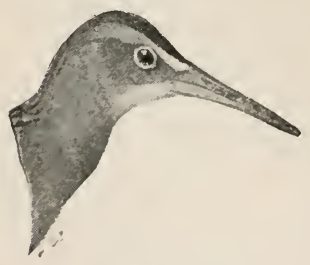

Fig. 89.

Adults. - Upper parts olive brown, streaked with black; wing with a large ehestmit patch ; sides of head slaty gray, lores blackish, and chin white; throat and breast cinnamon brown; flanks black, barred with white. Young: plumage much mottled with black, but chestnut wing patch always present. Length: 8.12-10.50, wing $3.90-$ 4.25 , bill $1.45-1.60$, tarsus $1.30-1.40$.

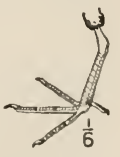

Fig. 90 .

Distribution. - Temperate North America, from Hudson Bay and British Colnmbia south

1 Rallus levipes Bangs. Like obsoletus, but smaller, bill more slender, and coloration darker.

Distribution, - Southern California.

Bull. N. Eng. Zoül. Club, i. 1899, 45. 
to Guatemala and Cuba, breeding over most of the United States and southern Canada.

Nest. - In marsh, under shelter of tall grass, composed of dry grass. Eggs: 6 to 10, ereamy white, spotted with brown and lilac.

The Virginia rail is common in almost all suitable marshes, whether salt or fresh, throughout the United States, but like all of its shortwinged kind it prefers a game of hide and seek to laborious flight, and is more often heard than seen. If you try to tramp one out of the marsh it will cackle and laugh on the right and then on the left of you, without ever showing itself; but if you sit quietly on the bank of a grassy, reedy pond or stream where one lives, it will soon come peeking and peering at you between the stems.

\section{Verson Batley.}

\section{GENUS PORZANA.}

General Characters. - Bill decidedly shorter than tarsus; sexes similar.

KEY TO SPECIES.

1. Back with narrow white streaks.

2. Back streaked longitudinally with white . . . carolina, p. 81 . 2 '. Back cross-lined with white . . . . noveboracensis, p. \&.? $1^{\prime}$. Back without white streaks.

2. Back finely dotted with white . . . . . jamaicensis, p. $\$ 2$. $2^{\prime}$. Back withont white markings . . . . coturniculus, p. 82 .

\section{Subgenus Porzana.}

214. Porzana carolina (Linn.). Carolina RaIL: Sora.

Adults. - Upper parts olive brown, spotted with black and finely lined

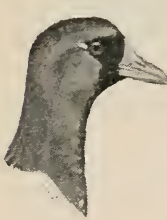

Fig. 91. with white; middle of crown, face, and throat black ; breast and cheeks bluish gray, sides barred black and white; belly whitish ; middle of lower tail coverts buff. Immature : similar to adult but without black face or bluish gray breast. Length: $7.55-9.75$, wing $4.15-4.30$, bill .75-. 80 , tarsus $1.25-$ 1.3.).

Distribution. - Temperate North Ameriea from Hudson Bay and British Columbia sonth to northem Sonth America, breeding over most of its United States and Canadian range.

Nest. - Usually on tussock in marsh, made of dry grasses or sedges. Eggs: usially 7 to 10 but sometimes 14 to 16 , grayish olive, spotted with reddish brown and purplish.

Carolina rails are the commonest of their family orer the eastern and middle Lnited States, or at least, being more commonly meadow birds, are oftener seen than the other species; but in the west they are less common than the Virginia rail. To avoid flying, when their field is being mowed they will often stay in the fast narrowing strip of grass until they must go or meet the sharp teeth of the sickle, when perhaps a dozen will rise one after another and fly to fresh cover. 
In the wild rice fields, I have frequently watched them walking daintily over the leaves and floating stems, swimming across the narrow channels where they could not wade, and running in and out of the thousand little trails that lead about under the grass; and have often clapped my hands to hear them answer back with their mocking, cackling laugh.

Verion Bailey.

\section{Subgenus Coturnicops.}

215. Porzana noveboracensis (Gmel.). Yellow RaIl.

Upper parts dark buff, mottled with brown and black, feathers of back

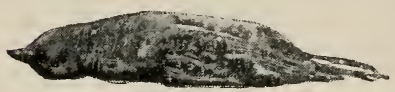

Fig. 92. narrowly tipped with white in wavy cross-lines; wing dusky, with large white pateh on secondaries; throat and breast plain buff or brownish; middle of belly whitish. Length: $6.00-7.75$, wing $3.00-3.60$, bill .50-.60, tarsus .80-100.

Distribution. - North America from Hudson Bay and Nova Seotia south to Cuba, and west to Nevada and California.

Nest. - In marsh, made of dry grass. Eggs : 6 to 10, creamy buff, finely specked with rusty brown.

In habits the yellow rail is much like the Carolina, but may readily be distinguished from it even on the wing by its smaller size and white wing patch. It is never a common bird.

\section{Subgenus Creciscus.}

216. Porzana jamaicensis (Gmel.). Black RaIL.

Adults. - Back and wings brownish black. finely dotted with white; shoulders dark rich chestnut; breast, throat, and sides of head deep plumbeous, shading to black on crown; flanks and ventral region specked and barred with white. Yonng: similar to adults but with grayish breast, whitish

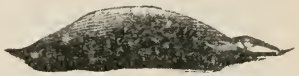

Fig. 93. throat, and brownish crown. Length: 5-6, wing 2.50-3.20, bill .50-.60, tarsus .8.j-.90.

Distribution. - From Oregon, Nebraska, and Massachusetts south through the West Indies and the greater part of South America.

216.1. Porzana coturniculus (Ridgw.). Farallone Rail. ings.

Size and general characters of jamaicensis, but back without white mark-

Known only from the type specimen from the Farallone Islands.

\section{GENUS GALLINULA.}

219. Gallinula galeata (Licht.). Frorida Gallinule.

Toes long and slender. not lobed; bill slender and sharp, nearly as long

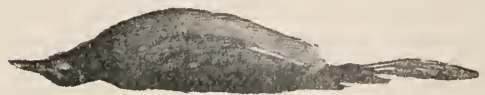

Fig. 94. as head; frontal shield extending from bill to erown, widest posteriorly; bill and shield bright red. Adults in summer : dark slaty or plumbeous, washed 
with brownish on back, and shading through darker on neck to blackish on head; edge of wings, lateral nuder tail coverts, and streaks on flanks white. ldults in winter : frontal plate smaller and belly suffused with white. Young: under parts, throat, and sides of head, whitish ; frontal plate rudimentary. Length: 12.00-14.50, wing 6.5.5-7.25, bill (inclnding shield) 1.70-1.50.

Distribution. - Whole of tropical and temperate America, from Brazil north to California and eastern Canada.

Nest. - In tules or grass on edge of pond or wet marsh; made of dry grass and tules. Eggs: $S$ to 11, buffy white, thinly spotted with brown.

The Florida gallinule is easily mistaken for a coot (Fulica), which it resembles in size and general appearance, but like the rails it is a bird of the shores and marshes, and although a good swimmer prefers to keep mainly out of sight in the grass and tules.

\section{GENUS FULICA.}

\section{Fulica americana Gmel. American Coot : Mud Hex.}

Toes lobed or scalloped along erlges; bill stout, nearly as long as

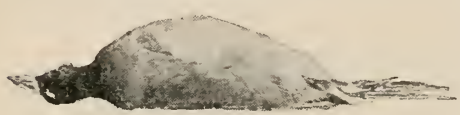

Fig. 96 .

head ; frontal shield narrow, ending in a point on crown. Breeding plumage: bill white, with brown spot near end, frontal shield brown; whole head and neck blackish; rest of body plum-

beous except for white under tail coverts, edge of wing, and tips of middle wing feathers. Winter plumage: belly whitish; frontal shield smaller than in summer. Young: like winter adults, but with white of belly extending onto throat; bill dull flesh color, frontal shield rudimentary. Length: 13-16, wing $7.25-7.60$, bill (to base of shield) $1.25-1.60$.

Distribution. - Whole of North America from Alaska

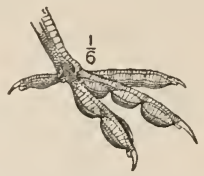

Fig. 97. and Greenland south to northern South America, IVest Indies, and Bermndas; breeding from Texas northward.

Nest. - Usually placed among tule stems on the water and bnilt of dry tule and grass stems. Eggs : 8 to 12 , creamy or buffy, finely specked with brown.

The omnipresent coots are among the most social and garrulous of our inland water birds. They are good swimmers and often gather in large flocks in open water, but their preference is always for the grassy shores of shallow lakes, or open ponds surrounded by wild rice, tules, or flags. Here they dive in the shallow water, paddle along shore, or run over the rafts of floating plant stems in little chattering, laughing groups. When forced to fly they make a long run on the water and after much kicking and spattering finally get launched on the wing.

Fortunately for them they are of little account as game birds and their plumage has no commercial value, so they will probably continue abundant and tame. 
According to Goss they feed on aquatic insects, snails, tender water plants, buds, blossoms, and seeds. Mr. Evermamn has found them feeding largely on wild celery. In the north they gather by thousands in the rice lakes in fall and stay until driven south by cold weather, feeding on the rich grain as it falls, or is scattered out by their wings, and becoming excessively fat. Verixon BaIley.

\section{ORDER LIMICOLÆ : SHORE BIRDS.}

(Families Phalaropodide, Recurvirostride, Scolopacide, Charadridde, Aphrizide, Hematopodide, and JACANIDE.)

\section{FAMILY PHALAROPODID A : PHALAROPES.}

KEY TO GENERA.

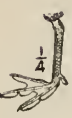

1. Bill wide and flattened, toes half webbed and with scalloped margins . . . . . . . . Crymophilus, p. st.

Fig. 98. 1'. Bill slender and approximately eylindrical.

2. Bill much longer than head, toes webbed at base, with straight margins . . . . . . Steganopus, p. 85. $2^{\prime}$. Bill not longer than head, toes nearly half webbed, and witl slightly sealloped margins . . . Phalaropus, p. 84.

\section{GENUS CRYMOPHILUS.}

222. Crymophilus fulicarius (Linn.). Red Phalarope.

Bill about as long as head. flat, widest toward end. Adult male in sum-

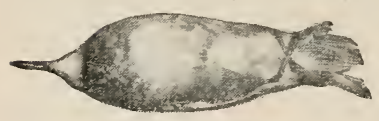

Fig. 99. mer: back streaked with black and buff; wing bluish and dusky. crossed by a white band; side of head whitish; under parts dark cimnamon browu. Adult female in summer: crown and face plumbeous or blackish, sides of head pure white. Ad dults in winter: head, neek, and under parts pure white, except for plumbeous on back of head and around eyes; upper parts plain blue gray. Young: upper parts blackish, the feathers edged with yellowish; under parts whitish. with dusky brown across breast. Length: 7.50-8.75, wing 5.2.55.50 , bill .8(0-.95.

1)istribution. - Northern part of uorthern hemisphere, breeding in aretic regions. In America south in winter to the middle of the United States and along the Pacifie coast to Cape St. Lucas; straggling to the Carolinas.

Nest. $-\Lambda$ slight depression in danip ground, usuaky without lining. Eggs: 3 to 4, heavily spotted with brown.

\section{GENUS PHALAROPUS.}

\section{Subgenus Phalaropus.}

223. Phalaropus lobatus (Linn.). Northere Phalarope.

Bill about as long as head, very slender and sharp; margins of toes 


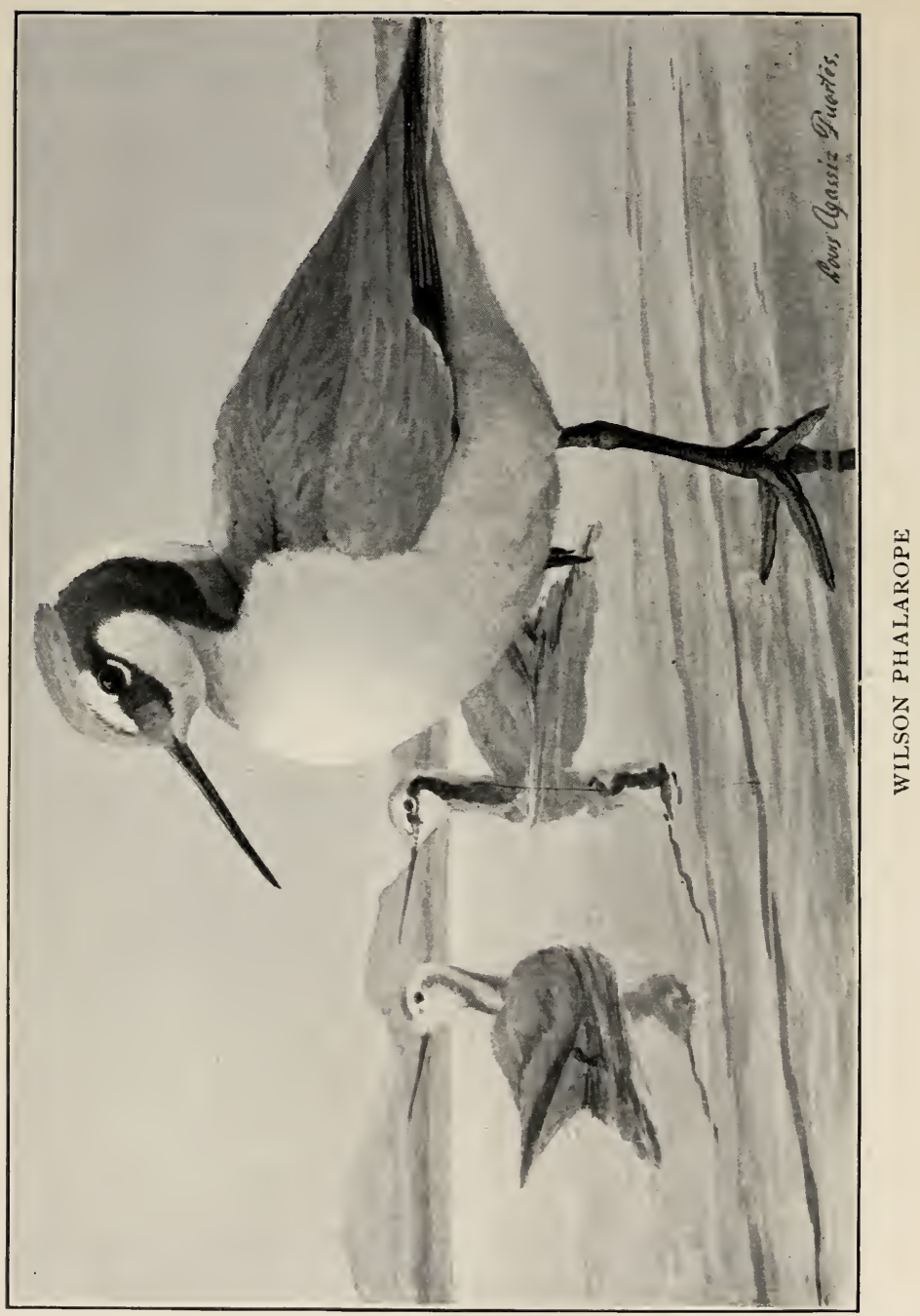


scalloped; wing with white bar in all plumages. Male in breeding plumage:

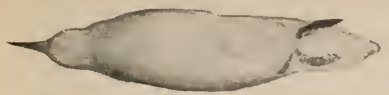

Fig. 100. Northern Phalarope.

upper parts dark plumbeous, striped on back with buff and black; sides of neck rufous; chest gray; upper throat and belly white. Female in breeding plumage: brighter colored, rufous extending across throat as well as on sides of neck. Fall and winter plumage: face, line over ere, and under parts white; line under eye, and back of head, dusky; upper parts mainly gray. Young: like winter adults, but upper parts darker, striped with buff and black. Length: 7-\&, wing 4.00-4.45, bill . $.80-.90$.

Distribution. - Northern part of northern hemisphere; in America, breeding from Alaska to Labrador and Greenland; south in winter to Guatemala.

Nest. - A slight depression in the ground near water; lined with leaves and grass. Eggs : 4, buffy or olive, irregularly spotted with dark browns.

\section{GENUS STEGANOPUS.}

\section{Steganopus tricolor Vieill. Wilson Phalarope.}

Bill slender, longer than head; toes with straight-edged marginal membranes; wing without white bar; female larger and handsomer than male. Male in breeding plumage: crown and npper parts dusky, touched with brown; sides of neck with a chestnut stripe; throat and chest buffy; stripe over eye, chin. and belly white. Female in breeding plumage: crown and back bluish gray; black stripe along sides of head and neck shading into rich chestnut along lower neck and shoulders; chest and lower part of throat delicate cinnamon buff; upper part of throat, belly, and line over eye white. Adults in winter plumage: upper parts plain gray, ehest and sides of breast grayish ; rest of under parts white. Young: upper parts dusky, streaked with light cimnamon; under parts white, with tinge of cinnamon across breast. Female: length 9.40-10.00, wing 5.20-5.30, bill $1.30-1.35$, tarsus $1.30-1.35$. Male: length $8.25-9.00$, wing $4.75-4.80$, bill 1.25, tarsus 1.20-1.25.

Distribution. - From British Colnmbia, Saskatchewan, and Quebec; south in winter to Brazil and Patagonia; breeding from Illinois, Colorado, and Kansas northward, mainly in the interior.

Nest. - On ground, in slight excavation; lined with grass. Eggs : 3 or 4, creamy, buff or drab, spotted with dark brown.

There is not among all our waders a more dainty, exquisitely colored bird than the Wilson phalarope, with its warm, richly blended tints, trim form, and soft plumage. You find it in small flocks, swimming on the ponds like tiny ducks, or sandpiper-like picking about on the muddy shores. Should you enter its marshy breeding grounds it will fly anxiously about your head with a low 'croaking' note, threatening and coaxing to get you away from its nest and young.

Like the other phalaropes the female is larger and brighter colored than the male and is said to leave most of the incubation and care of the young to her more protectively colored mate.

Verion BaILEx. 


\title{
FAMILY RECURVIROSTRID佂: AVOCETS AND STILTS.
}

\author{
KEY TO GENERA.
}

1. Bill strongly curved upward toward end, hind toe present but minute; front toes half webbed . . . . Recurvirostra, p. 86. $1^{\prime}$. Bill searcely or not at all eurved upwards, hind toe wanting, only a small web between outer and middle toes . Himantopus, p. 86.

\section{GENUS RECURVIROSTRA.}

225. Recurvirostra americana Gmel. Avocet.

Bill black, feet and legs bluish. Adults in summer plumage : head, neck,

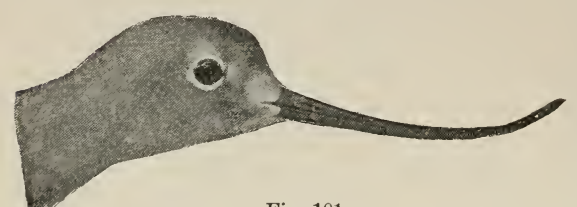

Fig. 101. chest, and shoulders light cinnamon, shading into whitish around base of bill ; under parts, rump, and large patehes on wing white; primaries, base of wing, and half of scapulars black. Adults in winter plumage : cinna-

mon of head, neck, and chest replaced by grayish white. Young: like winter adults, but quills and scapulars tipped with whitish, and back of neck tinged with buffy. Length: $15.50-18.75$, wing $8.50-9.00$, bill 3.403.65, tarsus $3.70-3.80$.

Distribution. - Temperate North America, breeding from Texas to Saskatchewan ; south in winter to Guatemala and West Indies. Not common east of the plains.

Nest. - In grass near water, made of grass stems. Eggs: 3 or 4, pale olive or buffy, thickly spotted with varying shades of brown.

Whether flying, walking, or swimming, the avocet is one of the most eonspicuous of our waders. Its long legs and neck, and strong black and white markings distinguish it from all others even when its turned-up bill is invisible. Its favorite haunts are the shores of shallow alkaline lakes and ponds on the plains and in the western valleys. Small floeks are often seen wading in water nearly up to their feathers, rapidly pieking up the small insects that gather on the surface. When the water becomes too deep for wading they swim freely, but do not usually go far from shore. They are seen occasionally feeding in a marsh or irrigated meadow, and in July I have found downy young hiding in the short grass just back from the lake shore.

VERNoN BaILEY.

\section{GENUS HIMANTOPUS.}

226. Himantopus mexicanus (Mïl.). BLACK-Necked Stilt.

Bill black, feet and legs pinkish. Atlult male: back of head and neck, shoulders, and wings greenish black; tail gray; rest of plumage white, breast tinged with dull pinkish in breeding plumage. Adult female: like 


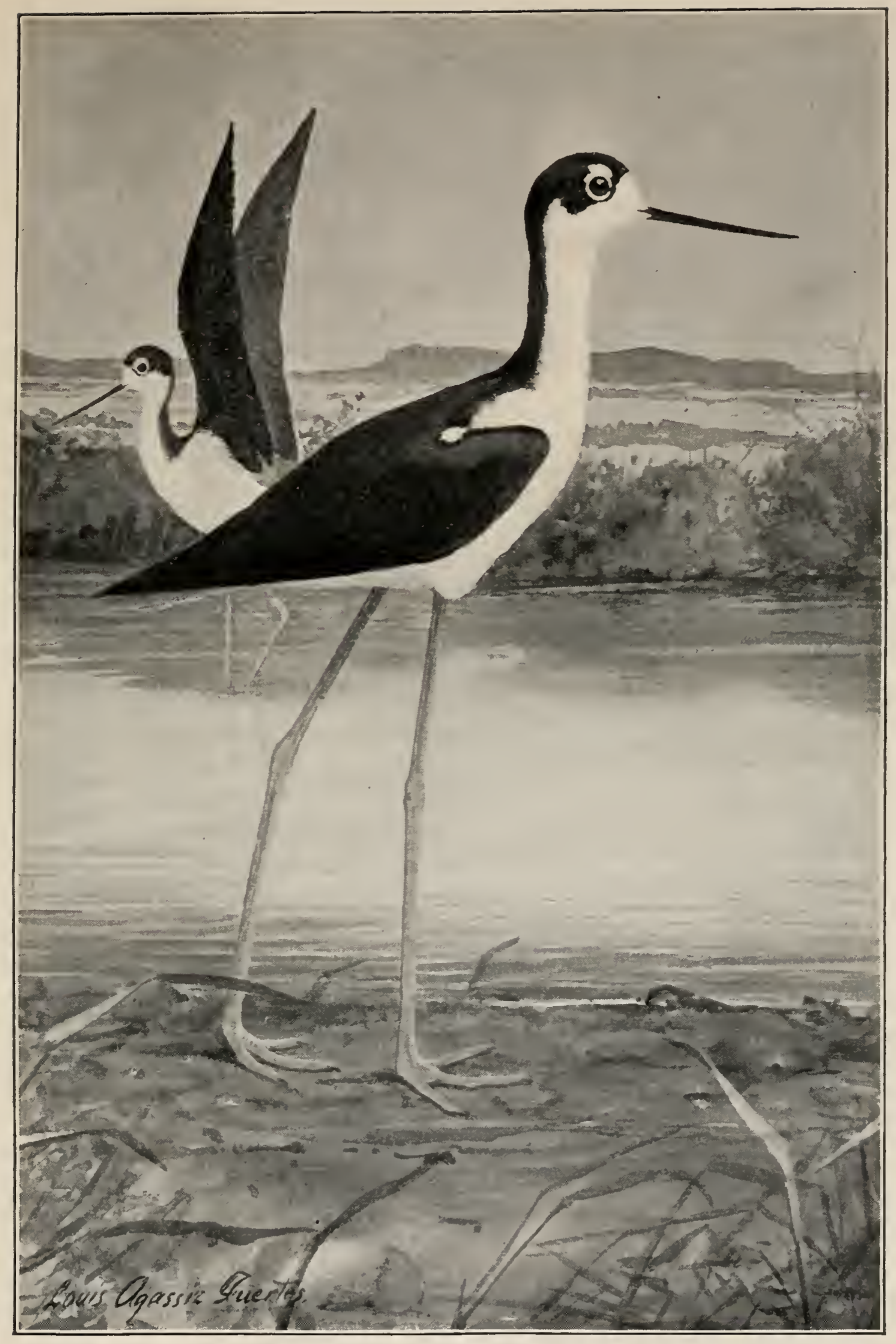

BLACK-NECKED STILT 

male, but black duller, or slaty. Young: similar to adult female, but feathers of back bordered with buffy, and blackish of head and neck mottled with bnffy. Length: 13.50-15.50, wing 8.50-9.00), bill 2.50, tarsus 4 .

Distribution. - The United States, mainly in the western interior, and sonthward to Brazil and Peru; north easually to Minnesota and New Brunswick. Breeds from southern Texas to Oregon.

Nest. - A slight depression in the sand or on wet ground; or eggs laid in a bunch of dry grass. Eggs : 3 to 4 , buff or olive brown, thickly spotted with dark brown.

In spite of its apparently extravagant length of legs the blacknecked stilt is a graceful, well-balanced bird, whether stepping daintily over the grass tops, wading in half a foot of water, swimming when beyond its deptl, or flying with head drawn back and legs straight out behind. As the birds alight they raise their black pointed wings over their white body a moment, assuming a pose that is not only strikingly beautiful but doubtless an important directive and recognition signal. Sometimes when quietly feeding one will lift its wings in this way, without apparent reason.

Much of the stilt's food is gleaned from the surface of the sliallow water or from plant stems rising from it, and its reason for prefering the flooded marsh to the open pond is presumably the greater abundance of minute insect life found among the aquatic plants.

Veryox Bailey.

\section{FAMHY SCOLOPACID $Æ$ : SNIPES, SANDPIPERS, ETC.}

KEY TO GENERA.

1. Back of tarsus covered with hexagonal scales

$1^{\prime}$. Back of tarsus with a row of transverse scutellæ.

2. Ears anterior to eyes, thighs wholly feathered . Philohela, p. 88.

2 '. Ears posterior to eyes or directly inder them.

:3. Ears directly under eyes, lower part of thighs naked.

4. Crown and back broadly striped . . . Gallinago, p. 88.

t'. Crown and back mottled, not striped.

3 '. Ears posterior to eyes.

Macrorhamphus, p. 89.

4. Hind toe wanting .

4 . Hind toe present.

5. No trace of web between toes.

6. Bill longer than middle toe and claw . Tringa, p. 90.

$6^{\prime}$. Bill shorter than middle toe and claw . Tryngites, p. 100.

5'. A distinct web between middle and one or both lateral toes.

6. Tail much graduated, about half as long as wing.

Bartramia, p. 99.

6 . Tail not much graduated, not nearly half as long as wing.

7. Bill longer than tail .

$7^{\prime}$. Bill shorter than tail.

Limosa, p. 95.

8. Bill distinctly widened and roughened at tip.

Micropalama, p. 90. 
$8^{\prime}$. Bill not distinctly widened and roughened at tip.

9. Wing less than 4 . . . . Ereunetes, p. 93. $9^{\prime}$. Wing over 4 .

10. Tarsus equal to middle toe and claw.

11. Wing under 4.60. $11^{\prime}$. Wing over 6.50 . . Heteractitis, p. 98. $10^{\prime}$. Tarsus much longer than middle toe and claw.

11. Wing with large white patch.

$11^{\prime}$. Wing without white patch.

Symphemia, p. 98.

12. Upper tail coverts white. $12^{\prime}$. Upper tail coverts dusky.

Totanus, p. 96. Helodromas, p. 97.

\section{GENUS PHILOHELA.}

\section{Philohela minor (Gmel.). American Woodcock.}

Bill long and slender, mandibles grooved and roughened toward end, tip of upper overlapping the under; nostril small at edge of feathers; three outer quills abruptly narrowed.

Upper parts grayish brown, mottled with black; back of head black, with narrow cross-bars of buffy ; under parts rich buff, darker on throat. Length: $10.50-11.75$, wing 4.50-5.70, bill 2.50-2.75, tarsus 1.25 .

Distribution. - Eastern United States north to Canada, west to Rocky Mountains in Colorado; breeds throughout its range.

Nest. - On ground in wooded bottoms, usually by a log or stump, made of leaves and grass. Eggs: :3 or 4, grayish to buffy white, spotted with reddish brown.

Dr. A. K. Fisher says: "This much sought game bird is in danger of extermination from the barbarous custom of hunting it in spring and summer, just before and during the breeding season."

\section{GENUS GALLINAGO.}

230. Gallinago delicata $(O r d)$. Wilson Snipe: JArk SNipe.

Bill long and slender, mandibles grooved, roughened, and widened

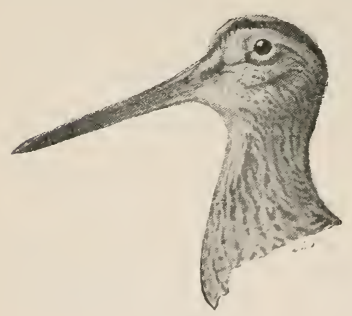

Fig. 102. toward end; tip of upper overreaching the lower mandible; nostril small and at edge of feathers.

Crown buff, with side stripes of black; back mainly black with stripes falling into two middle lines of buff and two outer lines of whitish; neck and breast spotted and streaked with buff, brown, and dusky ; sides barred with black and white; belly white. Length: $10.50-11.15$, wing $4.90-5.60$, bill $2.50-2.70$, tarsus $1.20-1.30$.

Distribution. - North America, and south in winter to northern South America, breeding from Colorado and Utah to north of the Aretic Circle.

Nest. - A grass-lined cavity in marshy ground. Eggs : 3 or 4, grayish olive, spotted and streaked with brown and black.

The plump jack snipe with the striped back is a prober rather than a wader, as his short legs and long bill attest. He pokes about 
in the muddy bottoms, under grass, flags, and tules, fishing up his food from the soft mud, the sensitive tip of his long bill enabling him to select the choicest worms and other dainty morsels.

He is a common bird wherever there are marshes to his taste, and most country folk are familiar with his song. On warm summer evenings or cloudy days before a storm he mounts high in air and with rapidly vibrating wings produces a prolonged whirr that increases to a diminutive roar, and repeats it every minute or two for sometimes half an hour. At other times he flies low over the grass, uttering a guttural chuck-chuck-chuck-chuck-chuck, and then drops out of sight. His common, all-the-year-round note is a nasal squank, uttered as he springs from the ground at your feet and makes off in quick zigzags.

The only excuse for considering so small a bird game is his swift irregular flight, which saves him from all but the expert wing shot.

VerioN BaILey.

\section{GENUS MACRORHAMPHUS.}

General Characters. - Bill similar to that of Gallinago; lower part of back white, rump spotted black and white; tail finely cross-barred with black, buff, and white.

KEY TO SUMMER ADULTS.

1. Belly rich cinnamon browu . . . . . . scolopaceus, p. 89. $1^{\prime}$. Belly white or buffy . . . . . . . . . . . . griseus, p. 89.

\section{Macrorhamphus griseus (Gmel.) Dowitcher.}

Similar to scolopaceus but smaller and adults in summer distinguished by whitish belly and dusky specking of sides and breast. Length: 10-11, wing $5.25-5.90$, bill $2.00-2.55$, tarsus $1.20-1.50$. Female decidedly larger than male.

Distribution. - Eastern North America, breeding far north; south in winter to Brazil ; west as stragglers (?) to Idaho and Oregon.

\section{Macrorhamphus scolopaceus (Say). Lovg-BIlled Dow- ITCHER.}

Adults in summer. - A light stripe over eye and dusky stripe from eye to bill ; upper parts, except rump and lower back, specked and mottled with black, brown, and buff ; rump white, spotted with black, tail feathers barred black and white; entire under parts

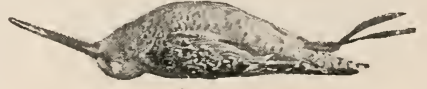

Fig. 103. bright cinnamon specked on throat and barred on sides and lower tail coverts with dusky. Adults in winter: belly and line over eye white; rest of plumage gray. Young: similar to adults but back and crown mottled with black and ochraceous; belly and chest suffused with light cinnamon. Length: $11.00-12.50$, wing $5.40-6.00$, bill $2.10-3.00$, tarsus $1.35-1.75$.

Distribution. - Western North America, breeding in British Columbia and Alaska ; migrating south through western United States and Mississippi valley to northern South America; less common in eastern United States. 
Nest. - A depression in the moss or grass, sometimes at considerable distance from water. Eggs: 4 , greenish olive to light clay color, spotted with dark umber brown.

By some ornithologists scolopaceus is considered merely a western subspecies of griseus, with intergrades between and probably a continuous breeding range across the arctic regions. In winter plumage the main difference is one of size, but as the females of both species are larger than the males only birds of the same sex should be compared.

In their migrations over the United States the long-billed dowitchers are usually found in little flocks along the coasts or among the prairie sloughs or marshes, flying swiftly low over the ground, or feeding in close bunches. Unfortunately they are considered legitimate game, and although wild and ever on the alert fall an easy prey to the pot-hunter.

For an interesting account of their luabits on their breeding grounds, see Nelson's Birds of Alaske.

VFrRNoN BaILEY.

\section{GENUS MICROPALAMA.}

233. Micropalama himantopus (Bonap.). Stilt SANdpiper.

Bill long and slender, conspicuously widened and roughened at tip ; toes

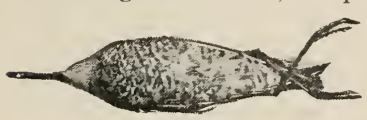

Fig. 104 . webbed at base, leg's long and slender. Adults in summer: upper parts mottled with dusky, black, buff, and brown; upper tail coverts white, barred with dusky; ear coverts and stripe along side of crown rusty brown; under parts thickly barred and mottled with dusky, buff, and white. Adults in winter: upper parts plain ashy gray, under parts including tail coverts white, specked on sides; throat and tail coverts marked with gray. Young: back browner, belly plain buffy, tail coverts nearly pure white. Length: 7.50-9.25, wing $5.00-5.30$, bill 1.55-1.75, tarsus $1.55-1.70$.

Distribution. - Eastern North America, breeding north of the United States; south in winter to Central and South America; west to Colorado and Wyoming.

Goss, in his Birds of Kansas, says: "I liave met with this rare species in the state on several occasions, at all times in small flocks and along the edges of old channels of rivers or muldy pools of water in which it wades while feeding."

\section{GENUS TRINGA.}

General Characters, - Toes slender, without webs at base; bill slender and narrow, tip hard and smooth.

\section{KEY TO SPECIES.}

1. Middle pair of tail feathers not longer than others . canutus, p. 91. $\mathbf{1}^{\prime}$. Middle pair of tail feathers sharp and longer than the others. 
2. Bill nearly twice as long as middle toe and claw . pacifica, p. 93.

2 '. Bill shorter or but little longer than mirldle toe and claw.

3. Upper tail coverts white, slightly streaked . fuscicollis, p. 92. 3'. Upper tail coverts blackish.

4. Wing over 5

maculata, p. 91 .

$4^{\prime}$. Wing under 5 .

5. Wing $4.80-4.90$

5 . Wing $3.50-3.75$

bairdii, p. 92. minutilla, p. 9:2.

Subgenus Tringa.

\section{Tringa canutus Linn. Ккот.}

The only species of Tringa in which the middle pair of tail feathers are not decidedly longer than the rest. Adults in summer: upper parts grayish and rlusky, tinged with buff; rump and upper tail coverts white, barred and spotted with dusky; line over eye and most of under parts pale cinnamon; flanks and

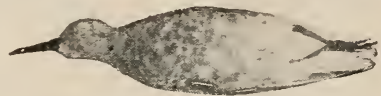

Fig. 105. under tail coverts white. Adults in winter : upper parts plain gray; under parts, rmmp, and tail coverts white, barred or streaked with dusky except on belly and under tail coverts. Foung: like adults in winter but gray feathers of back edged with whitish and dusky, and breast often suffused with buffy. Length: 10-11, wing 6.50 , tail 2.50 , bill 1.40 .

Distribution. - Northern hemisphere, cliefly on the seacoasts ; sonth in winter nearly through the southern hemisphere; breeding far north. Eggs
brown.

The knot is rare inland and apparently less common along the Pacific than on the Atlantic coast. It is a beach bird, getting its food from the wash of the waves.

\section{Subgenus Actodromas.}

\section{Tringa maculata Tieill. Pectoral Sandpiper.}

Bill longer than tarsus ; middle pair of tail feathers pointed and longer than the rest; shaft of onter quill only, pure white; rump, upper coverts, and niddle tail feathers, black. Adults: upper parts mottled dusky, black, and buffy; chest dark gray, finely streaked with

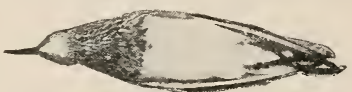

Fig. 106. dusky; chin and belly white. Young: similar to adults, but upper parts striped with ochraceous, brightest on edges of tertials and tail feathers; chest buffy, finely streaked with dusky. Length: 8.00-9.50, wing 5.005.50, bill 1.10-1.20, tarsus 1.00-1.10.

Distribution. - Whole of North America, the West Indies, and most of South America, breeding in aretic regions. Occasional in Europe.

Nest. - On dry ground, in the grass. Eggs : 4, greenish drab, spotted with brown.

The pectoral sandpiper is a common migrant in the eastern United States and the Mississippi valley, but less common westward. It is found in flocks, on the marshes and muddy flats rather than along the beache's. 


\section{Tringa fuscicollis Vieill. Bonaparte Sandpiper: White- RUMPED SANDPIPER.}

Rump dusky, the feathers tipped with buffy; upper tail coverts pure white or slightly streaked with dusky. Adults in summer : upper parts

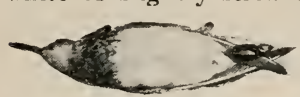

Fig. 107 . buffy and gray, broadly streaked on erown and back with black; chest and sides ashy gray, streaked with dusky; faint line over eye, chin, and belly white. Adults in winter: upper parts. sides, and chest dark gray, obseurely streaked with dusky. Young: similar to adults, but feathers of upper parts extensively margined with rusty, and chest tinged with buffy. Length: 6.T.58.00 , wing $4.90-5.00$, bill $.90-1.00$, tarsus .9.5-1.00.

Distribution. - Breeding in the far north and migrating south over eastern North America and Sonth America to Falkland Islands; west to Colorado. Casual in Enrope.

\section{Tringa bairdii (Coues). Baird SANDpIPER.}

Middle upper tail coverts plain dnsky. Adults in summer: upper parts spotted and streaked with black, grayish, and buffy ; chest buffy, streaked

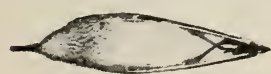

Fig. 108. with dusky; line over eye, chin, and belly whitish. Adults in winter: plain grayish brown, obsenrely streaked with dusky; under parts whitish, ehest suffused with buffy. Young: feathers of back tipped with whitish, and chest less sharply streaked with dusky than in summer adult. Length: 7.00-7.60, wing 4.60)-4.85, bill $.90-1.00$, tarsus 1.00 .

Distribution. - Most of North and South America. In North America, chiefly the interior, breeding in Alaska and on the Barren Grounds. Rare on the Atlantic, and apparently not recorderl from the Pacific coast.

Nest. - A depression in the ground, lined with leaves. Eggs: 4, light drab, specked and spotted with brown.

During migrations Baird sandpipers are common usually in small flocks along the shores of lakes and ponds over the western prairie country.

\section{Tringa minutilla Vieill. Least Sandpiper.}

Size very small, wing less than 4 . Adults in summer: median parts of tail, npper coverts, and rump black; sides of coverts white, streaked

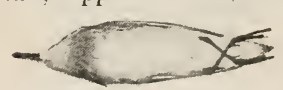

Fig. 109. with dusky; rest of upper parts mainly blackish, speckerl and spotterl with brown and buff; chest buffy gray, specked with dusky; belly and flanks white. Adults in winter: upper parts dark gray, obscurely spotted and streaked with dusky; chest light gray, finely streaked. Young: crown and back heavily streaked with rusty, and back spotted with white; chest buffy gray, faintly streaked. Length: 5.00-6.75, wing 3.50-3.75, bill .75-.92, tarsus .75.

Distribution. - The whole of North and Sonth America, wintering from the Gulf of Mexico south, breeding mainly north of the Uniter States. Accidental in Europe.

Nest. - On the ground, a slight depression lined with leaves and grass. Eggs : 3 or 4, creamy buff to drab, irregularly spotted with browu.

The least sandpipers are common, especially during migrations, over a great part of the United States. $\Lambda$ few remain in Dakota 
through the summer, probably breeding, and in winter the birds are not uncommon on the coast prairies of Texas. They go in close flocks, whether feeding among the larger waders on the shores and mud flats, or wheeling and circling in air on fast buzzing wings. They are nervous, active little birds, always on the move and quick to take alarm.

Verion Bailey.

\section{Subgenus Pelidna.}

243a. Tringa alpina pacifica (Coues). Red-BACked SANDPIPER.

Tarsus longer than middle toe and elaw ; bill longer than tarsus, slightly eurved; middle of wing with a large white patch. Adults in summer: crown, back, and upper tail coverts bright rnsty ochraceous, more or less spotted or streaked with black; middle of belly black ; chest grayish white, thickly streaked with dusky; sides and back part of belly white. Adults in winter:

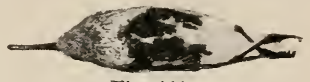

Fig. 110. upper parts plain ashy gray, obscurely streaked with dusky; chest light gray, more or less streaked with dusky ; rest of under parts, sides of rump, and upper tail coverts white. Young: like adnlts in winter but npper parts spotted and streaked with black and ochraceous, and breast coarsely spotted with black. Length: 7.60-8.75, wing 4.60-4.95, bill 1.40-1.75, tarsus $1.00-1.15$.

Distribution. - North America and eastern Asia. breeding far north and wintering in California, the Gulf States, and sonthward.

Nest. - A bed of dry grass. Eggs: :3 or 4, pale greenish to pale brownish clay color, spotted with dull chocolate and dark brown.

The red-backed sandpiper is common in migrations or in winter along the coasts of the United States, but is rarely seen in the interior. The breeding plumage marked by rusty back and black belly is sometimes acquired before the birds leave the United States for their northern breeding grounds, but the winter plumage is the more common dress up to the first of May.

\section{GENUS EREUNETES.}

General Characters. - Toes distinetly webbed at base; bill slightly widened and flattened at tip.

KEY TO SPECIES.

1. Bill shorter than tarsus.

$1^{\prime}$. Bill as long as or longer than tarsus . . . occidentalis, p. 94.

\section{Ereunetes pusillus (Linn.). Semipamated SandPIPER.}

Adults in summer. - Upper parts dusky and black, streaked with gray and pale buff; chest light gray, finely streaked; chin, belly, and sides white. Adults in winter : upper parts dull gray, obscurely streaked with dusky; nnder parts white tinged with gray across chest. Young: back spotted with black, and sealloped and streaked

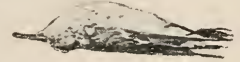

Fig. 111. with buff and white; chest tinged with gray; rest of under parts whitish. 
Male: length 6, wing $3.65-3.90$, bill .65-.75, tarsus .S0-.90. Female : length 6.40, wing $3.550-4.00$, bill .80-.92, tarsus .85-.95.

Distribution. - Breeding from Labrador to Alaska, migrating through the easteru and middle United. States as far west as the Rocky Mountains and Utah; south to the West Indies and northern Sonth America.

Nest. - A slight depression in the ground, lined with grass and leaves. Eggs : usually 4 , light drab, spotted with brown.

The semipalmated sandpiper is generally less common than the least, which it resembles in habits, general appearance, and small size, but from which it can always be distinguished by the webbed base of its toes.

\section{Ereunetes occidentalis Laur. Western Sandpiper.}

Adults in summer. - Ear coverts, back of head, back, and rump bright chestnut, mottled with black and buffy gray; breast thickly spotted with dusky on gray, and sides with a few dusky spots; rest of nnder parts white. Adults in winter: upper parts dull gray, obscurely streaked with dnsky; under parts white, with a few scattered triangular spots of dusky on breast

Fig. 112. and sides. Young: back spotted with black and scalloped with dark chestuut and white; chest tinged with pinkish buff; rest of under parts white. Male : wing $3.60-3.75$, bill .85-.95, tarsus .85.90 . Female: wing $3.70-3.90$, bill $1.00-1.15$, tarsus $.90-.95$.

Distribution. - Breeding in Alaska and British America, migrating through westeru North America to Central and South America. Cccasional on the Atlantic coast in migrations.

Nest. - A slight depression in bare or grassy ground. Eggs : usually 4, deep cimmamon buff, spotted with rusty brown or clestnut.

The western sandpiper is common along the Pacific coast during migration, but scarce and irregular in the interior.

\section{GENUS CALIDRIS.}

\section{Calidris arenaria (Linn.). Sanderling.}

Toes only 3 , short and flattened; bill slender, about as long as tarsus; feet and legs black. Idults in summer: upper parts specked and

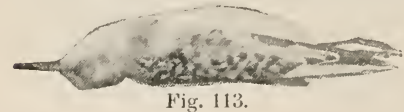
spotted with black, gray, and whitish, darkest on crown and back; whole nuder parts and bar on wiug white. Adults in uinter: npper parts hoary

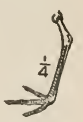

Fig. 114.

gray, except blackish quills aud bend of wing; under parts snowy white. Foung: npper parts coarsely spotted witl dusky and gray above; under parts white, sparsely marked with dusky and buffy on ehest. Length: 7.00-8.7.), wing 4.70-5.00, bill .95)-1.00, tarsns .90-1.0\%.

Remarks. - In having but three toes the sanderling resembles the plovers, but may be distinguished from them by its slender bill and transversely scaled tarsus.

Distribution. - Nearly cosmopolitan, but breediug only in arctic and subarctic regions; in America wintering from Texas and California south to Chili and Patagonia.

Nest. - $\Lambda$ depression in the ground lined with grass and leaves. Eggs : usually 4 , light olive brown, spotted with various shades of brown. 
The sanderlings are sometimes found on the inland lake shores and during migrations are abundant on the coasts, picking along the sandy beaches, chasing the retreating waves, and catching their food from the squirming life left on the sandy shore.

\section{GENUS LIMOSA.}

General Characters. - Bill long and slender, straight, or slightly inclined upwards, whole front and back of tarsus covered with transverse scutellæ.

KEY TO SPECIES.

1. Tail finely barred with cinnamon and dusky . . . . fedoa, p. 95. 1'. Tail black, tip and base white . . . . . . hæmastica, p. 95.

249. Limosa fedoa ( $\operatorname{limn}$.). Marbled Godwit.

Adults. - Plumage uainly light cimmanon brown. heavily mottled with black on upper parts, and finely barred with blackish on eliest, sides, and tail; throat streaked and chin whitislı; edge of wing black. Young: similar to adults but

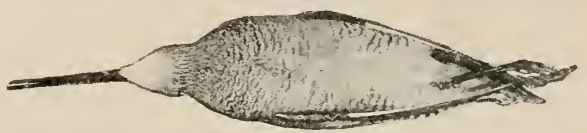

Fig. 115. more ochraceous brown, and breast and sides unmarked. Length: 16.5020.50, wing 8.50-9.00, bill 3.50-5.06.

Distribution. - Nearly the whole of North America, breeding in Transition zone from Iowa and Nebraska north to Manitoba, Saskatchewan, and Britislı Columbia ; migrating to Guatemala, Trinidad, Yucatan, and Cuba.

Nest. - A slight depression in grassy ground, lined with a little dry grass. Eygs : usually 4 .

On the prairies, Colonel Goss says, the marbled godwits are found in flocks on moist ground and fresh water marshes. Although widely distributed they are not generally common birds in the United States.

\section{Limosa hæmastica (Linn.). Hudsonian Godwit.}

Tail black, tipped witl white; upper coverts crossed by a wide white band. Adults in summer : back black, spotted with buff; under parts light chestnut, barred with dusky; head and neck speckled and streaked with buff and dusky; chin and line over eye whitish. Adults in winter: head, neck, and under parts buffy gray; upper parts plain gravish brown. Young: similar to winter adults but featlers of back scalloped with dusky and buff. Length: 14.00-16.75, wing 8.10-8.60, bill 2.5.5-3.45.

Distribution. - Breeding far north, and migrating tlirough the United States east of the Rocky MIountains; south to sonthern South America.

Nest. - A depression in the ground lined with a few leaves. Eggs: usually 4 , deep olive or light brown, spotted with darker brown.

The Hudsonian godwit has not been taken west of the Rocky Jountains. 


\section{GENUS TOTANUS.}

General Characters. - Bill longer than head, very slender; legs and toes long, slender, and yellow. Tarsus one and a half times as long as middle toe and claw.

\section{KEY TO SPECIES.}

1. Bill nearly as long as tarsus, grooved for less than half its length.

melanoleucus, p. 96. $1^{\prime}$. Bill nuch shorter than tarsus, grooved for more than half its length.

flavipes, p. 97.

\section{Subgenus Glottis.}

254. Totanus melanoleucus (Gmel.). Greater Yellow-Legs. Adults in summer. - Upper parts heavily mottled with black, gray, and

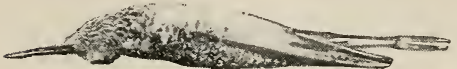

Fig. 116. white; quills black; upper tail coverts white, tail white barred with gray; under parts white, spotted on chest and barred on sides with black; throat gray, streaked with dusky. Adults in winter: upper parts dark gray, finely spotted with white; under parts mainly white, with fine spotting of gray on chest and throat. Young: like adults in winter, but darker above and with buffy instead of white spotting. Length: 12.15-15.00, wing 7.507.75 , bill 2.20-2.30, tarsus $2.50-2.75$.

Remarks. - In flight the whole tail and rump appear white, and are very conspicuous.

Distribution. - Nearly the whole of America, breeding from Nebraska and northern Illinois northward, and wintering from southern California and the Gulf states southward to South America.

Nest. - A slight depression in the gromnd lined with grass. Eggs : 3 or 4 , grayish or brownish buff, irregularly spotted with dark brown. Few nests have been recorded.

Over most of the United States the greater yellow-legs are conspicuous in spring and fall among the flocks of migrating snipes and sandpipers, not only about marshes and ponds, but on irrigated fields where silvery minnows have been washed over the land. As they walk about, the long bill and neck, slender gray body, and white breast are not markedly different from those of other sandpipers around them, nor is there much that is individual in the dovelike motion of their heads and the occasional tilting of the tail ; but when disturbed by your approach they rise in a close flock with their liquid tweep, tu-veep, and the white rump and tail, together with their large size, mark them unmistakably. Like others of their kind, unless too thoroughly alarmed they fly only a short distance before wheeling and circling back. Is they wheel and circle the shifting whiteness of the flocks against the blue of the sky is enough to rouse one's enthusiasm. As they get ready to alight they lean over and look down, set their wings, and then come to ground, raising their wings gracefully over their backs for a moment after their 
feet touch the earth. But though faseinating to wateh at their feeding grounds, they are seen at their best when they eome in high from a distanee on angular tern-like wings and sweep swiftly down through the sky.

\section{Totanus flavipes (Gmel.). Lesser YeLLOW-LEgS.}

Smaller than melanoleucus. Plumage similar in all its stages, but with finer markings. Length : 9.50-11.00, wing 6.10-6.65, bill 1.30-1.55, tarsus 2.01-2.15.

Distribution. - Nearly the whole of America, breeding mainly north of the United States; migrating to southern

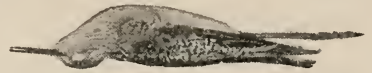

Fig. 117 .

Soutl America. Less common west of the Rocky Mountains; accidental in Europe.

Nest. - A mere depression in the ground, sometimes lined with leaves or grass. Eggs : usually 4, of varying shades of buff, spotted with dark browns.

In habits as well as general appearanee the lesser yellow-legs resembles its larger relative, with which it is often found, sometimes in the same floek but more often in separate floeks on the same feeding ground. When seen together the difference in size is most notieeable, though the birds are otherwise counterparts.

\section{GENUS HELODROMAS.}

General Characters. - Bill very slender, a little longer than head; legs and toes olive green, long, and slender; tarsus scarcely longer than middle toe and claw.

KEY TO ADULTS.

1. Specking of back white or creamy . . . . . solitarius, p. 97. $1^{\prime}$. Specking of back cinnamon brown . . . cinnamomeus, p. 98 .

\section{Helodromas solitarius (Wils.). Solitary Sandpiper.}

Adults in summer. - Upper parts, including upper tail coverts and two middle tail feathers. dark olive gray, finely specked with whitish ; rest of tail barred with white; outer quills and edge of wing deep black; under parts white, streaked with dusky on chest and throat. Adults

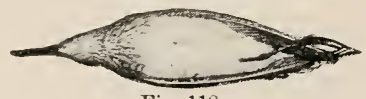

Fig. 118. in winter: upper parts more dusky and less olive, chest less streaked. Young: specking of back buffy, and dusky of chest and sides tinged with buff. Wing: $4.83-5.19$, tail $2.05-2.28$, bill 1.03-1.20.

Remarks. - The solitary is distinguished from the other sandpipers in the field by its dark color and black wings, and by its shrill note as it takes wing.

Distribution. - North America east of the Rocky Mountains, breeding from the northern United States northward, and migrating to Argentina and Peru.

Nest. - A slight depression in the ground lined with leaves and grass. Eggs : said to be 2 to 4, dull buffy, spotted with rich brown and purplish gray. Few nests have ever been found or well identified eggs collected. 
A little grass-fringed pond in the half open woods is a favorite wading-ground of the solitary sandpiper's, but the birds are often seen singly or in pairs by wayside puddles or meadow creeks, picking their food from the shallow water with easy graceful motions, pausing now and then with head erect to make a teetering bow. They are quiet, shy birds, but not unapproachable, and they show an interested curiosity in strangers.

VERTON BALLey.

\section{6a. H. S. cinnamomeus (Brewst.). Western Solitary Sand- PIPER.}

Slightly larger than solitarius, with the spotting of back in typical specimens cimnamon brown instead of white or creamy, and with sides of face lighter colored. Wing: $5.10-5.49$, tail $2.18-2.30$, bill $1.15-1.30$.

Distribution. - Western North America, migrating south through the Great Basin and Pacific coast region to Lower California and southward.

In general appearance and habits the western is the counterpart of the eastern solitary.

\section{GENUS SYMPHEMIA.}

258a. Symphemia semipalmata inornata Brewst. WesTeRN Willet.

Size large, bill slender, straight, about as long as tarsus; base of toes webbed; base of tail and large patch on wing always white. Adults in summer: upper parts mottled gray and dusky; end of tail gray; belly white; chest and sides buffy, barred with dusky, and throat streaked with dusky. Adults in winter : upper parts plain ashy gray; under parts white, grayish on sides of throat and breast. Young: like adults, but upper parts and sides more buffy or ochraceous. Wing: $7.88-8.26$, bill 2.28-2.70, tarsus $2.45-2.95$.

Distribution. - North America, west of the Mississippi valley, and north to about $56^{\circ}$, breeding from the Gulf coast of Texas north to Manitoba; south in winter to Mexico. Casual along the Atlantic states in migration.

Nest. - In a tussock of grass, rather bulky, and composed of grass and various plant stems. Eggs: 4, grayish buffy or olive, heavily spotted with dark brown and purplish gray.

The western willet differs from the eastern in slightly larger size and in shades of color, but not in general appearance or habits. The shores of lakes and ponds are its favorite feeding grounds, but it is sometimes found on the meadows or prairies not far from water.

After seeing the inconspicuous ashy gray birds feeding quietly along a sandy beach, there is something startling in the flash of strongly contrasted white and dark gray markings and the boisterous laugh as they take to wing. Once seen and heard, they can be confused with no other waders.

Verion BaIley.

\section{GENUS HETERACTITIS.}

259. Heteractitis incanus (Gmel.). Wandering Tatler.

Web between middle and outer toes, but not between middle and inner; 
bill straight and slender, longer than tarsus ; tarsus equal to length of middle toe and claw. Adults in summer: npper parts plain slaty or plumbeous gray; under parts thickly barred with white and dnsky, beconing more spotted on throat and pure white on anal region. Adults in winter: middle of belly and chin white ; chest, sides, and upper parts gray. Young: like winter adults but with fine specks and narrow scallops of white ou wings and back. Length: 10.50-11.30, wing 6.50-7.80, bill 1.50-1.60, tarsus 1.2.5-1.35.

Distribution. - Pacific coast of America, from Norton Sound to Lower California and Galapagos Islands; west to Kamschatka and the Hawaiian and Polynesian Islands; breeding from Vancouver Island northward.

Nest and eggs apparently not recorded, but young birds taken by Macoun on the west coast of Vancouver Island.

\section{GENUS BARTRAMIA.}

261. Bartramia longicauda (Bechst.). Bartranian SANDPIPER: UPLAND Plover.

Tail long and graduated, the end reaching well beyond tips of folded wings; base of toes webbed only between outer and middle. Adults : rump black, rest of upper parts dusky, or greenish black, scalloped and streaked with buff; crown blackish, with a median line of light buff; sides and lower surface of wing barred with black and white; throat streaked and chest marked with dusky; chin and belly white. Length: 11.00-12.75, wing $6.50-7.00$, bill 1.10-1.15, tarsus $1.90-2.05$, tail $3.40-3.50$.

Distribution. - Most of North America, but mainly the plains and prairie region east of the Rocky Mountains; north to Nova Scotia and Alaska; west to Utah and Oregon ; breeding from southern Kansas and Utah northward; migrating to Brazil and Peru. Accidental in Europe and Australia.

Nest. - A slight depression, usually in bare ground, sometimes with a little grass lining. Eggs : 4, creamy or buffy, spotted with dark brown and purplish gray.

While in habits more plover than sandpiper, Bartramia combines even more the characteristics of the curlew and the godwit. It is rarely found near water, being preëminently a bird of the prairie. Sometimes during migrations it gathers in large flocks but is usually found in pairs catching insects in the prairie grass and flowers or following the plough picking up worms from the fresh earth. To the plough-boy of the plains it is a confiding companion, trusting him at a friendly distance and confidently answering his low whistles, while he in turn marks its nests, leaving many a bit of unploughed ground for its home. The soft bubbling whistle of the old birds as they come over the prairie to meet you, and with curved trembling wings circle about, trying to coax you away from their nests or young, is one of the sweetest, most characteristic sounds of the prairie.

But, for the morsel of meat on their breasts, these beautiful, friendly birds are counted game, even on their breeding grounds, and in migration they are slaughtered by thousands on the southern prairies.

VERYON BaILEY. 


\section{GENUS TRYNGITES.}

\section{Tryngites subruficollis (Vieill.). Buff-Breasted Sand- PIPER.}

Toes not webbed; bill slender, straight, and about as long as middle toe without claw; under surface of wing beantifully mottled and marbled with black on white and creamy. Adults: upper parts dull brownish buff, the feathers with black or dusky centers; under parts plain rich buff. Young: like adults, but feathers of back edged with whitisl. Length : 7.00-8.90. wing 5.10-5.50, bill .75-.80, tarsus 1.15-1.30.

Distribution. - North America in general, especially the interior, breeding from the interior of British America and the Ynkon district to the arctic coast; south in winter to Uruguay and Peru. Occasional in Europe.

Nest. - A depression in the ground lined with a little moss or grass. Eggs : usually 4, grayish or pale olive buff, spotted with dark brown and purplish gray.

Although so widely distributed, the buff-breasted sandpipers do not seem to be common except on their northern breeding grounds, and in some of their southern stopping places. In the spring migration they are abundant on the coast prairies of Texas and Louisiana and are favorite game birds of the pot-hunters because they go in dense flocks on the open prairie and yield many birds to few shots.

\section{GENUS ACTITIS.}

\section{Actitis macularia (Linn.). SPotted SANdPIPER.}

Small and slender, bill approximately the length of tarsus, or of middle toe and claw. Adults in summer : entire upper parts bronzy or greenish olive, faintly marked with dusky ; under parts white, marked, except on middle of belly, with round spots of dusky; quills dusky, secondaries tipped with white, with a conspicuous white line along the middle of open wing. Adults in winter: white of under parts unspotted. Young: like winter adults but finely barred on wings and back with dusky and buff. Length : 7-S, wing 4.05-4.60, bill .90-1.05, tarsus .90-1.05.

Remarks. - In the field the spotted sandpiper can always be recognized by its small size, plain gray color, and the conspicuous white bar along the middle of the wing in flight.

Distribution. - Whole of North America, breeding throughout nost of its range; south in winter to Brazil and Uruguay.

Nest. - On dry ground in tuft of grass or under low bush, lined with leaves and grass. Eggs : 4, buffy, spotted with lilac, dark brown, and black.

Although never numerous or in flocks, the spotted sandpiper or river sand peep is the commonest and best known of our sandpipers over the country at large. There is hardly a patch of water from the brooks in the mountain meadows to the rivers in the lowlands which has not one or more pairs of these little quaker gray birds picking along their shores with teetering gait, and with shrill peetweet, buzzing from stone to stone so fast that their wing tips seem 



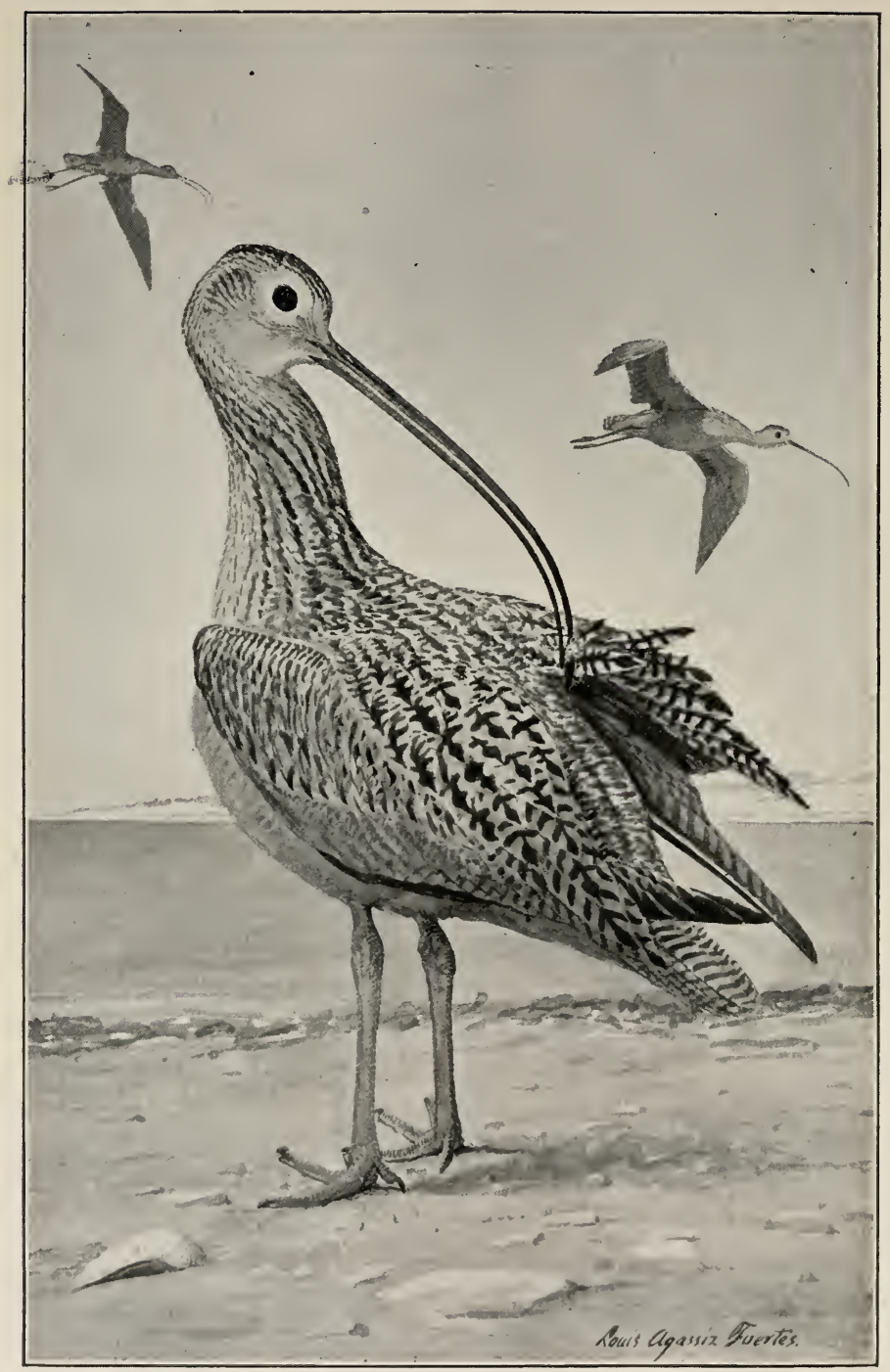

LONG-BILLEI) CURI,EW 
always to be pointing down as they fly, their whole bodies tipping violently when they alight. This teetering motion, which becomes ridiculously rapid under excitement or alarm, has given the bird its familiar names of tip-up and teeter-tail.

\section{GENUS NUMENIUS.}

General Characters. - Bill curved and slender, longer than tarsus ; front of tarsus with transverse seutellæ; toes webbed at base.

\section{KEY TO SPECIES.}

1. Bill of adult longer than tarsus and middle toe; crown not striped.

$1^{\prime}$. Bill not longer than tarsus and middle toe.

longirostris, p. 101.

2. Crown black with middle line of buff . . . hudsonicus, p. 102.

2'. Crown specked, without middle line of buff . . borealis, p. 102.

264. Numenius longirostris Wils. Long-Billed Curlew.

Plumage light cinnamon, barred and mottled on upper parts with dusky and black; outer webs of outer quills wholly black ; head, neck, throat, and chest streaked with dusky; crown mainly dusky; belly plain cinnamon; chin whitish. Length: 20-26, wing 10-11, bill 2.30 in young of year to 8.50 in old birds; tarsus $3.00-3.50$.

Distribution. - Whole of temperate North America, breeding from Texas to Canada, migrating to Guatemala, Cuba, and Jamaica.

Nest. - A depression in the ground lined with grass. Eggs : 3 or 4, grayish buff to pale buffy brown, spotted with dark brown and lilac.

On the prairies in migration you sometimes see a flock of a hundred curlew flying high overhead in long shifting lines of forming and dissolving wedges; and on the irrigated fields of the interior, in marked contrast to the white moving throng of small bobbing snipe and sandpipers, you often find a small company of the big, brown, round-backed Numenius with their long, curved bills down before them, stalking along with dignified demeanor. As they rise and fly you get a flash of rich, warm color, and your ear is startled by their stirring clarion call. When they come to earth, like other waders they raise their wings over the back for an instant with most striking effect.

When an intruder approaches their breeding grounds they often come over the prairie to meet him and circle around with wild cries and shrill laughter.

There is little excuse for killing these splendid birds for game, as they make too easy a mark for any true sportsman, and when taken are of little use, as their flesh is tough and dry.

Colonel Goss gives their food as worms, crickets, beetles, grasshoppers, small snails, crabs, and crawfish, and says that they reach for the crabs with their long bills and pull them out of their holes, and probe for larva that come near the surface in spring. 
265. Numenius hudsonicus Lath. Hudsonian Curlew.

Smaller than longirostris, with shorter bill and duller coloration; quills plain dusky. Upper parts specked, mottled, and barred with dusky and buff; crown black with middle and side lines of buff; a dusky stripe through eye ; under parts buffy, barred and streaked on sides, chest, and neck with dnsky. Length: $16.50-18.00$, wing $9.00-10.25$, bill $3-4$, tarsns 2.25-2.30.

Distribution. - Nearly the whole of North and South America and the West Indies, breeding in the far north and wintering in the southern United States and southward.

Nest. - A depression in the ground lined with grass and leaves. Eggs : usually 4 , creamy to pale olive, spotted with dull brown.

The Hudsonian curlew is common on the coasts but rare in the interior. In habits as well as general appearance it is similar to the long-billed curlew.

\section{Numenius borealis (Forst.). Eskimo CurLew.}

Similar to hudsonicus but smaller, with slenderer bill; crown faintly specked with buffy on black, and without a distinct median line of buff. Length : $12.60-14.50$, wing $8.00-8.50$, bill $2.25-2.50$, tarsus $1.70-1.80$.

Distribution. - Eastern North America, breeding in arctic regions and migrating to southern South America; west to Kansas and Nebraska. Recorded from San Diego, California (The Auk, i. 393).

Nest and eggs. - Similar to those of hudsonicus.

The Eskimo curlew is said to be an abundant migrant on the plains east of the Rocky Mountains.

\section{FAMILY CHARADRIIDA: PLOVERS.}

KEY TO GENERA.

1. Hind toe present but small . . . . . . . Squatarola, p. 102. $1^{\prime}$. Hind toe wanting.

2. Upper parts spotted, belly black in summer, grayish in winter.

$2^{\prime}$. Upper parts plain, belly always white . . . . Agialitis, p. 103.

\section{GENUS SQUATAROLA.}

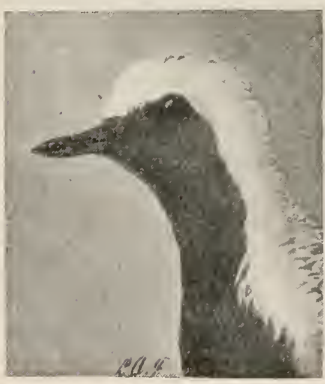

Fig. 119.
270. Squatarola squatarola (Linn.). BlaCK-YELlied Plover.

Hind toe minute; bill rather short. Adults in summer : face, throat, and belly black, bordered with white; upper parts spotted with black and white; npper tail coverts white at base; outer half of tail barred with dusky. Adults in winter: under parts white, overlaid, streaked, and mottled with dusky and gray, becoming creany or white on anal region; npper parts spotted with gray and dusky. Y oung : like winter adults, bnt spotted above with light yellow, gray, and black. Length: 10.50-12.00, wing 7.50, bill 1.10, tarsns 1.95 . Distribution. - Nearly cosmopolitan, but 
chiefly in the northeru hemisphere, breeding far north; south in winter in America to Brazil.

Nest. - A depression in the ground lined with old grass. Eggs : 4, light buffy olive, spotted with dark brown or black.

"I have found this species quite common upon both coasts but rare inland, where it seldom stops except to rest on its migratory flights to and from its breeding-grounds. . . In habits it is similar to the golden plover." (Goss.)

\section{GENUS CHARADRIUS.}

\section{Charadrius dominicus Miill. Golden Prover.}

Hind toe wanting, bill small and slender. Adults in summer: upper parts black or dusky, spotted with bright yellow and white; face, throat, and belly black, bordered with a line of white; tail dusky, barred with gray or yellow. Adults in winter: under parts mottled dusky gray; back less golden than in summer. Young: like winter adults, but with upper parts more golden, and yellow wash over neck and breast. Length: 9.5010.80 , wing $6.80-7.40$, bill $.80-1.00$, tarsus $1.55-1.82$.

Distribution. - North and South America, breeding in arctic regions, and migrating to Patagonia.

Nest. - A slight depression in the moss or dry grass. Eggs: 4, pale grayisin or olive buff to buffy brown, spotter with dark brown or black.

In the United States the golden plover is a common migrant east of the Rocky Mountains, but less frequently seen toward the Pacific coast.

For an interesting account of its breeding habits see Nelson's Birds of Alaska.

\section{GENUS ÆGIALITIS.}

General Characters. - Hind toe wanting; bill much shorter than head; colors plain, with or without black bands.

\section{KEY TO SPECIES.}

1. Chest without trace of black bars . . . . . montana, p. 105.

$1^{\prime}$. Chest with complete or interrupted bar of black or dusky in adults.

2. Chest with two black bars . . . . . . . vocifera, p. 103.

2 '. Chest with one complete or interrupted bar of black or dusky.

3. Chest with complete bar.

4. Bill not over .55.

5. Front toes connected by web at base . semipalmata, p. 104.

$5^{\prime}$. Middle and inner toe not comected by web at base.

circumcincta, p. 104.

$4^{\prime}$. Bill about . 80

wilsonia, p. 105.

3 . Chest with only a black spot on each side . . nivosa, p. 105.

\section{Subgenus Oxyechus.}

273. \#gialitis vocifera (Linn.). Killdeer.

Adults. - Chest crossed by two black bands, the upper encircling the 


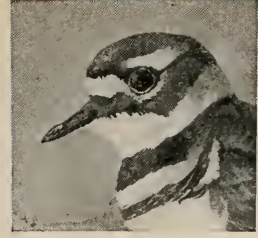

Fig. 120. Killdeer.

neck; forehead, collar, and under parts white; front of crown black; rump and sides of tail bright ochraceous yellow; rest of upper parts dull olive brown. Young: similar to adults but duller, with much rusty on back. Length: 10.00-11.25, wing 6.20-6.75, bill .70-.90, tarsus $1.40-1.55$.

Distribution. - Whole of temperate North America, breeding throughout its range, wintering from California and the Gulf coast of the United States and West Indies south to northern South America.

Nest. - A slight depression in bare ground. Eggs: 4, dull buffy, spotted with dark brown and black.

The killdeer is everywhere too common to need description, and even its name, dinned in our ears from morning till night from roadside puddles, barnyard, and meadow in the shrill kill-dee', killdee', kill-dee', kill-dee', becomes almost tiresomely familiar. Vociferous at all times, the plover becomes doubly so when the little downy striped young are trotting about in the short grass. Then the cries and frantic endeavors of the old birds to lead the intruder another way by running ahead, limping, falling over, fluttering the spread wings and tail, and uttering low notes of pain, would be ludicrous if not done in tragic earnest.

Vernon BaIley.

\section{Subgenus 洢gialitis.}

274. Ægialitis semipalmata Bonap. Sempalmated Plover.

Size small ; distinct basal webs between front toes; bill very small and short, less than middle toe without claw, the basal half yellow in adults.

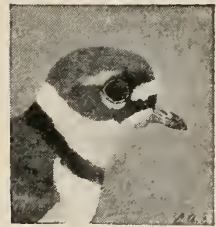

Fig. 121. Adults in summer : throat encircled by a black collar, bordered above on back of neck with a white band; face black, with a white bar across forehead; upper parts brownish gray, under parts white. Adults in winter: black of summer plumage replaced by dark gray. Young: like winter adults, but with feathers of upper parts edged with buffy. Length: 6.50-7.50, wing $4.65-5.00$, bill .4S-.55, tarsus .95-1.05.

Distribution. - In North America, breeding far north, wintering from Texas to Brazil, Peru, and the Galapagos Islands.

Nest. - A depression in the ground, sonetimes lined with grass and leaves. Eggs: 4, dull buffy or olive buff, spotted with dark brown and black.

"This species is quite common in suitable localities throughout the continent. They are often met with upon low, marshy ground, but seem to prefer the sandy shores to barren lands." (Goss.)

277a. Ægialitis meloda circumcincta Ridgw. Belted PipING Plover.

Middle and inner toes without basal web. Adult male in summer: upper parts buffy gray, a black bar across chest and one across front of crown; 



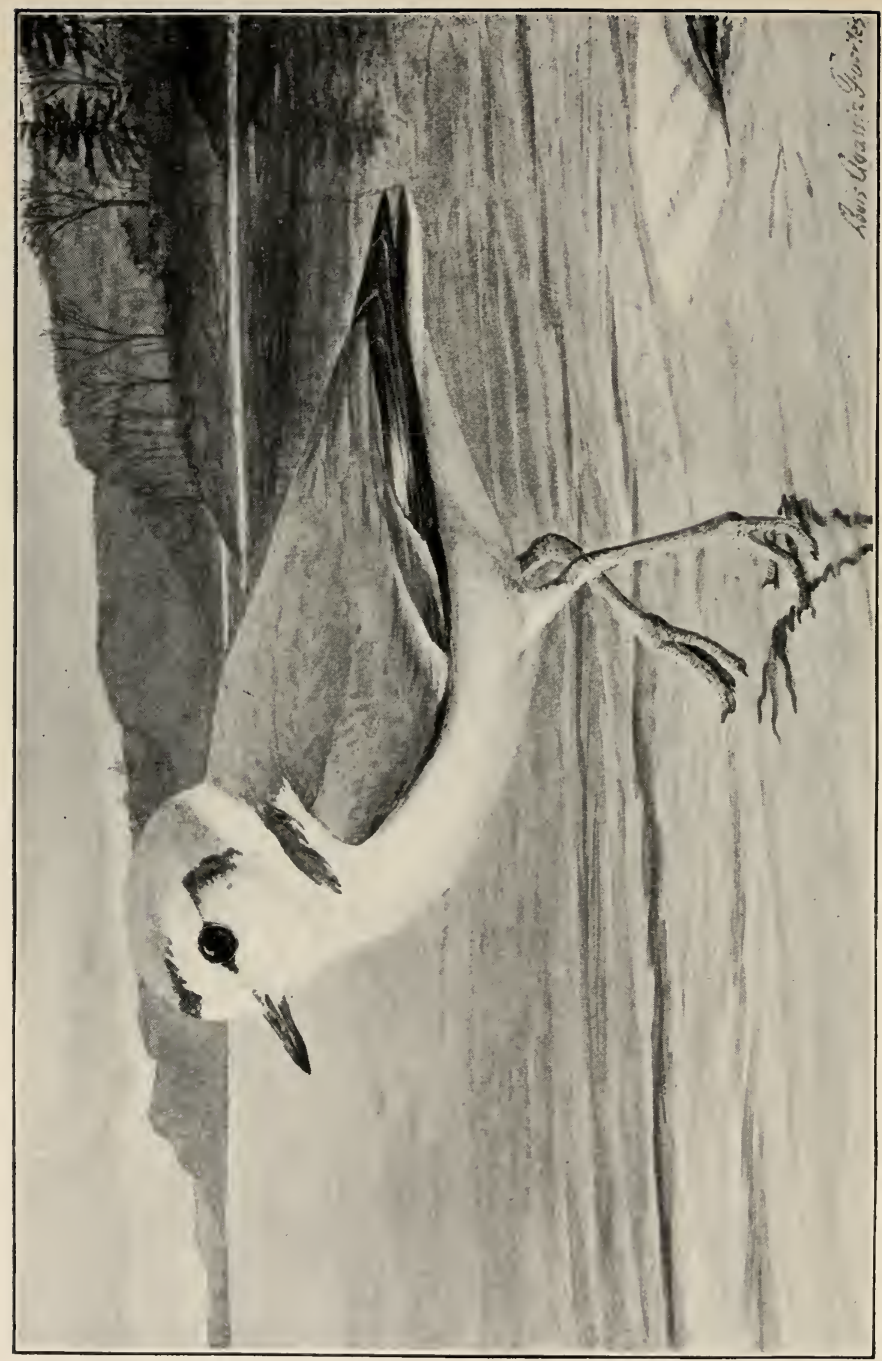

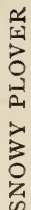


forehead, collar, and under parts white. Adult female in summer : duller black. Adults in winter: black replaced by buffy gray. Young: like winter adult, but with buffy edgings to feathers of back. Length: 6.257.50 , wing $4.50-4.80$, bill .45-.50.

Distribution. - Mississippi valley and north to Lake Wimnipeg, west to Cheyeme, Wyoming, east occasionally to the Atlantic; breeding from Illinois and Nebraska northward, and wintering on the Gulf coast and southward.

\section{8. Ægialitis nivosa Cass. Snowy Plover.}

Bill longer than middle toe without claw, slender, and entirely black. Chest band reduced to a spot at eacl side of breast. Adults in summer: crown and back pale buffy gray; face and under parts white; wide bar across front of crown, ear patch, and spot at side of chest black. Adults in winter: black replaced by dusky gray. Young: similar to winter adults, but with feathers of back tipped with white. Length: $6.25-7.00$, wing $4.20-4.30$, bill about .60, tarsis $.90-1.05$.

Distribution. - Western United States, east to western Nebraska, Kansas, and Texas; soutl in winter to Chili ; breeding over most of its United States range.

Nest.-A slight depression in the sand. Eggs : 3, dull light buff, spotted with dark brown and black.

On the shores of Salt Lake while the great white gulls disport themselves in the air and on the water, the plump little snowy plover is trotting along the beach gathering his food as he goes. If frightened, he drops into the deep footprint of a horse and is lost to view, so well does his back match the dull gray surface. Though so small, he is one of the most attractire bits of life in his big landscapes.

\section{Subgenus Ochthodromus.}

\section{0. Æigialitis wilsonia (Ord). Wilson Plover.}

Much smaller than the killdeer, with but one black band across ehest and without yellow on rump or upper tail coverts. Adult male: upper parts brownish gray, with black across front of erown, lores, and chest; forehead, superciliary line, collar, and rest of under parts white. Adult female: black of male replaced by brownish gray, more or less tinged witl rusty. Young: similar to female, but feathers of upper parts margined with gravish. Length: 7.50-7.90, wing 4.50, bill .80, tarsus 1.25 .

Remarks. - The Wilson plover may be distinguished from the other small plovers by its much longer bill.

Distribution. - Coasts and islands from southern California and Long Island south to Brazil and Peru. Casual to Nova Scotia.

\section{Subgenus Podasocys.}

\section{1. Æggialitis montana (Touns.). Mountain Plover.}

Bill slender; tail less than half as long as wing; chest without band; middle and inner toes not connected by basal web. Adults in summer:

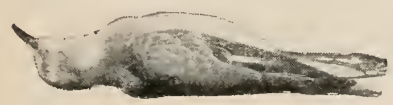

Fig. 122. upper parts plain grayish or buffy brown; under parts white or buffy ; forehead and line over eye white; front edge of crown and streak in front of eye, black. Adults in winter: without pure white or black 
markings, and with more of buffy. Young: like winter adults but still more buffy ; feathers of upper parts strongly tinged with buff. Length: 8.00-9.10, wing 6 , bill .80-.90, tarsus $1.50-1.60$.

Distribution. - Western United States, breeding from Texas to Dakota and Montana; west, mainly in winter, to California and south to Lower California and San Luis Potosi, Mexico; accidental in Florida.

Nest.-A slight depression in the prairie lined sparingly with leaves and grass. Eggs: 3 or 4 , cream color to light olive, spotted with purplish gray, dark brown, and black.

Totally disregarding its name, the mountain plover inhabits the high arid plains, breeding in considerable abundance from the Staked Plains of Texas to Montana, and in Colorado up to 8000 feet. It is a quiet bird, lacking the sharp markings and vociferousness of the killdeer. Instead of haunting the ponds and meadows, it spends its time picking up grasshoppers and other small insects from the short prairie grass.

Grinnell reports it a common winter visitor in Los Angeles County, California.

VerNoN BaILEY.

\section{FAMILY APHRIZID丑: SURF BIRDS AND TURN- STONES.}

KEY TO GENERA.

1. Bill stout, with rounded tip; tail slightly emarginate. Aphriza, p. 106. 1 '. Bill with sharp tip inclined upward; tail slightly rounded.

Arenaria, p. 106.

\section{GENUS APHRIZA.}

282. Aphriza virgata (Gmel.). Surf Bird.

Base of tail, upper coverts, and a broad bar on wing white. Adults in summer: upper parts, head, neck, and chest, slaty gray, specked and streaked

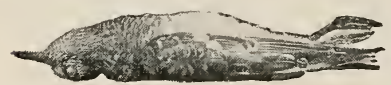

Fig. 123. with whitish, and spotted on scapulars with rufous; belly white, specked with dusky. Adults in winter: like summer adults, but with upper parts, head, and neck plain dusky or slaty gray. Young: back brownish gray, feathers edged with white; throat and breast white, streaked with dusky. Length: 10, wing 7, bill .95-1.00, tarsus 1.20-1.25.

Distribution. - Pacific coast of America from Alaska to Chili.

The surf bird has never been found in abundance, and its breeding grounds are unknown.

\section{GENUS ARENARIA.}

General Characters. - Bill short and sharp, with the tip inclined upwards; toes unwebbed; lower back and base of tail white; rump white, with black patch.

1. Throat white . . . . . . . . . morinella, 107.

$1^{\prime}$. Throat black . . . . . . . melanocephala, 107. 
283.1. Arenaria morinella (Linn.). Ruddy Turnstone.

Adults. - Throat and belly white, chest crossed by a broad black band; back coarsely mottled with rufous and black; head variously streaked. Young: similar to adult but duller, without rufous on back, and with the chest band mottled dusky gray. Length: $9.00-9.90$, wing 6.00 , bill $.80-.90$, tarsus 1 .

Distribution. - Aretic America, breeding from the Mackenzie River eastward; south in migration, chiefly coastwise, to Patagonia and the Falkland Islands. Rare in the interior and on the Pacific coast.

Nest. - A slight depression in ground lined with grass and leaves. Eggs : usually 4, grayish olive, spotted with dark brown.

284. Arenaria melanocephala (Vig.). Black Tunnstone.

Adults in summer. - Crown and upper back black, with greenish bronzy

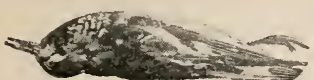

Fig. 124. Summer Plumage.

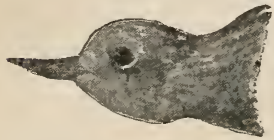
Fig. 125. Winter Plumage. Lower California ; breeding from British Columbia northward.

Nest and eggs as in morinella. gloss; rest of head, neck, throat, and chest black, spotted on forehead and sides with white; a white spot in front of eye; belly and sides white. Adults in winter: similar, but with head, neck, and chest unspotted, sooty black. Young: head more grayish than in winter adults and feathers of back edged with buffy. Length: 9, wing 5. 50-6.10, bill .85-1.00, tarsus 1.00-1.10.

Distribution. - Pacific coast of North America from Point Barrow to Santa Margarita Island,

\section{FAMILY HÆMATOPODID王: OYSTER-CATCHERS.}

\section{GENUS HAFMTOPUS.}

General Characters. - Bill straight and flattened, chisel-shaped; bright red in adult, brownish in young; feet and legs short and stout, red ; tail square across end.

KEY TO SPECIES.

1. Belly and base of tail white

1 . Belly and whole plumage blackish . . . . bachmani, p. 107.

286.1. Hæmatopus frazari Brewst. Frazar Oyster-Catcher.

Adults. - Head and neck greenish black; back rich dark brown; tail and wing quills brownish black; under parts, base of tail, and patch on wing, white. Length: 17-21, wing 9.75-10.27, bill 2.99-3.05, tarsus 2.18-2.30.

Distribution. - Coasts of southern and Lower California, north to Ventura County.

The white-bellied oyster-catchers reported from southern California are assumed to be frazari instead of palliatus of the Atlantic coast.

287. Hæmatopus bachmani iud. Black Orster-catcher. Adults. - Head and neck dull blnish black ; rest of plumage brown-

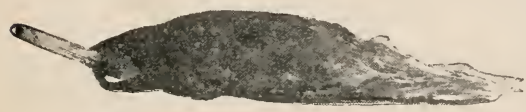

Fig. 126. ish black. Young: duller, more brownish. Length : 17.00-17.50, wing 9.60-10.75, bill 2.50-2.95, tarsus $1.85-2.25$.

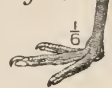

Fig. 127 . 
Distribution. - Pacific coast of North America from the Aleutian Islands to La Paz, Lower California, and the Kurile Islands ; breeding throughout most of its range.

Eggs. - 1 to 3, laid on the bare rock, sand, or gravel ; light buff or olive, spotted with brownish black and purplish gray.

Mr. Loomis has taken black oyster-catchers on the Seal Rocks at Monterey in July. They are said to be strictly littoral in their habits, always flying over the sea when moving from point to point.

\section{FAMILY JACANID㞋：JACANAS.}

\section{GENUS JACANA.}

[288.] Jacana spinosa (Linn.). Mexican Jacana.

Toes very long and slender, hind claw straight and longer than toe; bend of wing armed with a sharp spur; forehead covered by a leaf-like scale from base of bill. Adults: head and neck greenish black; wing quills yellowish green edged or tipped with dusky ; rest of plumage rich purplish chestnut. Young: with only a rudiment of frontal leaf; back olive gray, back of neck black ; rump brown ; under parts and stripe on side of head white. Length: 8.50 , wing $4.50-\tilde{5} .40$, bill $1.15-1.40$, tarsus $1.90-2.35$.

Distribution. - Middle America from southern Texas to Colombia; Cuba ; Hayti.

\section{LAND BIRDS.}

\section{KEY TO FAMILIES.}

\section{ORDER GALLIN Æ : GROUSE, QUAIL, TURKEYS,} PHEASANTS, ETC.

1. Hind toe short, raised above level of front ones.

2. Leg with spur, head naked or tail vaulted, plumage largely metallic . . . Phasianidæ:

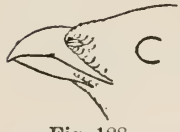

Fig. 128. Turkeys and Pheasants, p. 134.

1'. Hind toe long, on a level with front ones . . . . Cracidæ: Currassows and Guans, p. 137 .

\section{ORDER COLUMBA: PIGEONS OR DOVES.}

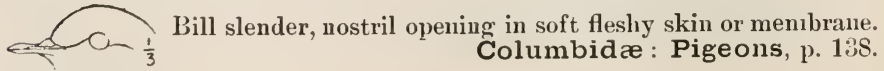

Fig. 129. 


\section{ORDER RAPTORES: VULTURES, EAGLES, HAWKS, OWLS, ETC.}

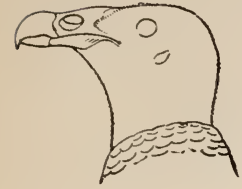

Fig. 130.

1. Head naked, feet not suited for grasping. . Cathartidæ : Vultures, p. 144.

$1^{\prime}$. Head feathered, feet especially adapted for grasping.

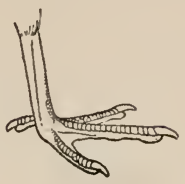

Fig. 131.

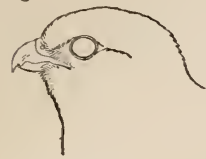

Fig. 132.

2. Eyes not surrounded by striking dises of radiating feathers. Falconidæ: Falcons, Kites, Hawks, Eagles, etc., p. 146 . Fig. 133.
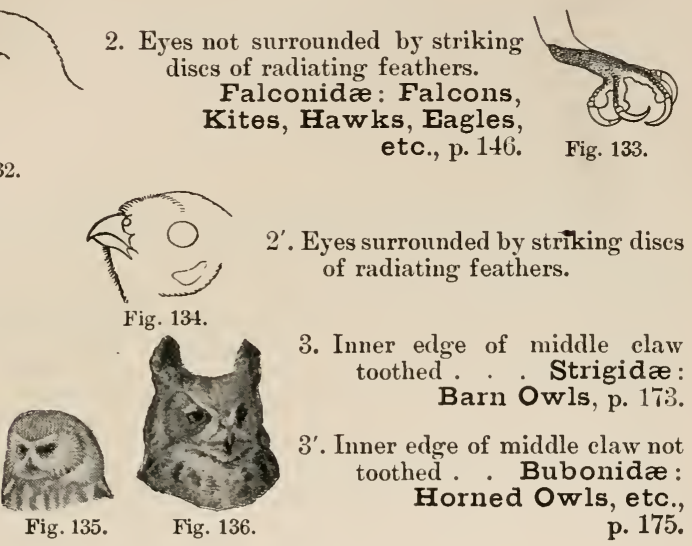

ORDER PSITTACI: PARROTS.

Toes 4,2 in front, 2 behind; outer toe permanently reversed. . . . Psittacidæ: Parrots, p. 192.

ORDER COCCYGES : CUCKOOS, TROGONS, KINGFISHERS, ETC.

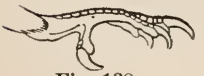

Fig. 138.

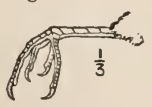

Fig. 139.

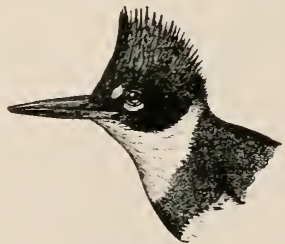

Fig. 137.

1. Toes 4,3 pointing forward, 1 back Alcedinidæ:

Kingfishers, p. 198.

$1^{\prime}$. Toes 4,2 pointing forward, 2 back. 


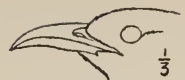

Fig. 140.

2. Bill long, cutting edges smooth . Cuculidæ : Road-runners, Cuckoos, etc., p. 193.

2.' Bill short, cutting edge toothed. Trogonidæ: Trogons, p. 197.

\section{ORDER PICI: WOODPECKERS.}

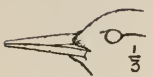

Fig. 141.

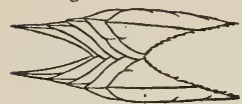

Fig. 142.
Toes 3 or 4 , only 2 in front; bill chisel-like; tail feathers stiff and pointed.

Picidæ : Woodpeckers, p. 200.

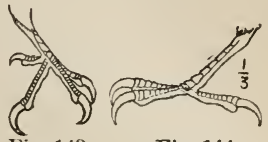

Fig. 143.

Fig. 144.

\section{ORDER MACROCHIRES: GOATSUCKERS, SWIFIS, AND HUMMINGBIRDS.}

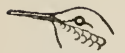

Fig. 145 .

1. Bill long and slender, gape not deeply cleft. Trochilidæ: Hummingbirds, p. 232 .

1'. Bill short, wide at base, gape cieeply eleft.

Fig. 146 .

2. Plumage moth-like, lax ; middle toe long, and inner edge toothed

Caprimulgidæe: Goatsuckers, p. 222.

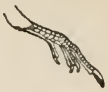

Fig. 147.

2 '. Plumage compact, middle toe normal, not toothed . . . Micropodidæe: Swifts, p. 229.

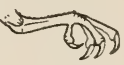

Fig. 148.

\section{ORDER PASSERES: PERCHING BIRDS.}

Toes 4, 3 pointing forward, 1 back ; never united for half their length.

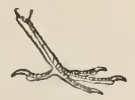
all on the same level and

1. Inner toe with basal phalanx united to that of middle toe.

Cotingida: Cotingas, p. 245.

$1^{\prime}$. Inner toe with basal phalanx not united to that of middle toe.

2. Back of tarsus rounded.

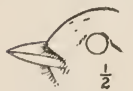

Fig. 150.

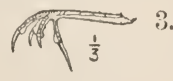

Fig. 151.

Hind claw longer than its toe and straight; bill rounded, not hooked at tip.

Alaudidæe: Larks, p. 265. 


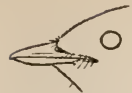

Fig. 152.

3'. Hind claw shorter than its toe and curved; bill flat, wider than high, slightly hooked at tip.

Tyrannidæ: Flycatchers, p. 245.

$2^{\prime}$. Back of tarsus sharp-edged.

3. Primaries apparently only 9 , the 10 th being only a rudiment.

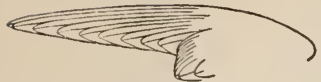

Fig. 153.

4. Outer primary twice as long as innermost. Hirundinidæ: Swallows, p. 382.

$4^{\prime}$. Outer primary not twice as long as innermost.

5. Bill slender and thin at base.

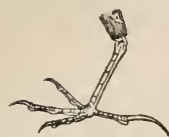

Fig. 154.

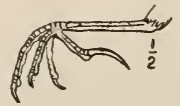

Fig. 155.

6. Hind claw as long as or longer than its toe . . . Motacillidæ : Wagtails and Pipits, p. 431. 6 . Hind claw shorter than its toe.

7. Head crested . Ampelidæ: Waxwings and Phainopeplas, p. 357.

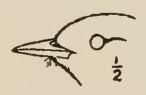

Fig. 156.

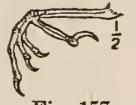

Fig. 157.
Mniotiltidæ: Wood Warblers, p. 401.

5. Bill short and thick or long and thick at base.

6. Bill notched at tip and with bristles at gape.

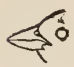

Fig. 158.

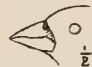

Fig. 159.

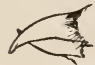

Fig. 160 .

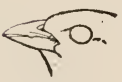

Fig. 163.

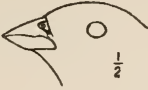

Fig. 161.

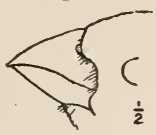

Fig. 162.

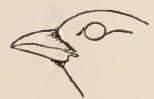

Fig. 164.

7. Nostril concealed or overhung, or else cutting edge of lower mandible forming a distinct angle . . Fringillidæ: Finches, Sparrows. etc., p. 303.

$7^{\prime}$. Nostril exposed, cutting edges of lower mandible without distinct angle; males with more or less red, females greenish and yellowish . Tanagridæ:

Tanagers, p. 379.

6 . Bill without notch at tip and without bristles at base.

7. Bill wider than high at base; plumage greenish, speckled. 


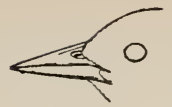

Fig. 165.

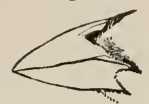

Fig. 166.

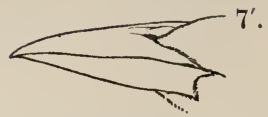

Fig. 167.
Bill not wider than high at base; plumage largely black or yellow. Icterida: Blackbirds, Orioles, etc., p. 285 .

3'. Primaries obviously 10 .

4. First primary more than half $\frac{1}{4}$ as long as second.

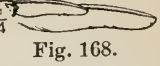

5. Bill hooked at tip . . . Laniidæ: Shrikes, p. 391.

Fig. 169.

5'. Bill not hooked at tip.

$\approx 0$ 6. Nasal feathers erect or inclined back-

ward (except genus Oroscoptes, in which the first primary is not half as long as second) Troglodytidæ: Wrens, Thrashers, Mockingbirds, and Catbirds, p. 433.

6 '. Nasal feathers pointing forward over bill.

7. Large; wing more than 4.

Corvidze: Crows, Jays, Magpies, etc., p. 269.

Fig. 171.

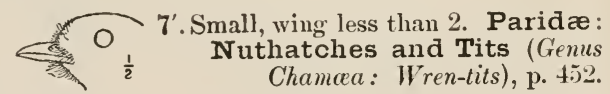

Fig. 172.

4'. First primary not more than half as long as second.

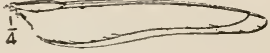

Fig. 173.

5. Tarsus not divided into plates except near toes.

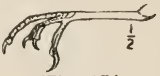

Fig. 174.

6. Tail abnormally short; plumage slate gray. Cinclidze: Dippers, p. 4:32.

6'. Tail normally long; plumage green or brown.

7. Small, wing less than 2.50 ; plumage greenish. Sylviida: Kinglets, Gnatcatchers, etc. (Genus Regulus : Kinglets), p. 46:).

7 . Large: wing more than 8 ; plumage brown or grayish.

Turdidæe: Thrushes, p. 467. 
$5 '$. Tarsus divided into plates.

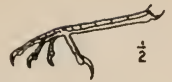

Fig. 175.

6. Bill slightly hooked or notehed at tip. 7. Small; wing 1.90-2.20.

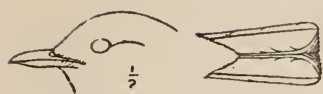

Fig. 176.

Fig. 177.

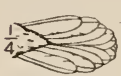

Fig. 178.

S. Upper parts greenish or grayish ; tail even. Vireonidæ: Vireos, p. 394.

$S^{\prime}$. Upper parts bluish; tail graduated Sylviida: Kinglets,

Gnatcatchers, etc.

(Genus Polioptila: Gnatcatchers), p. 463.

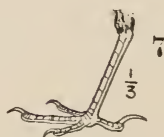

Fig. 179 .

$6^{\prime}$. Bill not hooked at tip.

\section{Troglodytidz: Wrens,} Thrashers, etc. (Genus Oroscoptes: Sage Thrashers), p. 49:3.

7. Tail feathers stiff, pointed at tip. Certhiidæ: Creepers, p. 451.

Fig. 180.

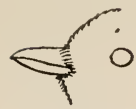

Fig. 182.

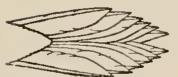

Fig. 181.

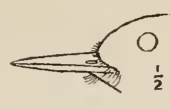

Fig. 183.

7'. Tail feathers normal (except genus Chamcea, in which the first primary is more than half as long as second) . . . Paridæ: Nuthatches and Tits, p. 452.

ORDER GALLIN $\nRightarrow$ : GALLINACEOUS BIRDS.

(Families Tetraonide, Phasianide, and Cracide.)

FAMILY TETRAONID尼: GROUSE, PARTRIDGES, QUAILS, ETC.

KEY TO GENERA.

1. Legs feathered down to base of toes.

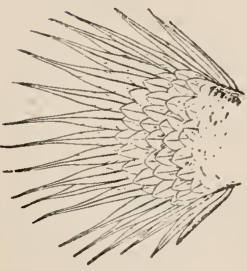

Fig. 184 .

2. Tail feathers narrow and pointed.

Centrocercus, p. 133.

2.' Tail feathers broad and rounded.

3 . Sides of neck with tuft of feathers.

Tympanuchus, p. 129. 
$3^{\prime}$. Sides of neck without tuft of feathers.

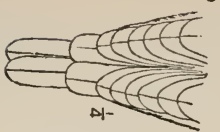

Fig. 185.

4. Tail strikingly graduated, middle feathers much the longest.

Pediœcetes, p. 131.

4'. Tail not strikingly graduated, middle featlıers not much the longest.

5. Toes feathered . . Lagopus, p. 128.

Fig. 186.

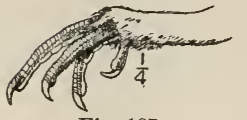

Fig. 187.

5'. Toes naked.

6. Tail of 20 feathers.

Dendragapus, p. 124.

6.' Tail of 16 feathers.

Canachites, 126.

1'. Legs not feathered down to base of toes.

2. Neck with two blackish or brownish ruffs.

Bonasa, p. 127.

Fig. 188. $\quad 2^{\prime}$. Neck without ruffs.

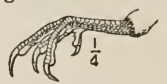

3. Tail much less than half as long as wing; claws long . . . . Cyrtonyx, p. 122.

Fig. 189.

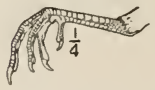

$3^{\prime}$. Tail more than half as long as wing; claws moderate.

Fig. 190.

4. Head not erested .

Colinus, p. 114. $4^{\prime}$. Head with erest.

5. Crest blended with feathers of erown.

Callipepla, p. 118.

5 '. Crest distinct from feathers of crown.

6 . Crest long and straight ( $2-3$ inches).

Oreortyx, p. 117.

$6^{\prime}$. Crest upright, recurved and clubshaped (about 1 inch).

Lophortyx, p. 119.

\section{GENUS COLINUS.}

General Characters. - Feathers of erown lengthened and erectile, but not forming a distinct crest; tail about three fifths as long as wing; wing less than five inches; plumage of upper parts spotted and barred.

KEY TO ADULT MALES.

1. Throat black . . . . . . . . ridgwayi, p. 116 .

1'. 'Throat white.

2. Under parts lightly and irregularly barred . virginianus, p. 115.

2 '. Under parts heavily and closely barred . . . texanus, p. 116. 


\section{KEY TO ADULT FEMALE COLINUS.}

1. Under parts narrowly barred with black . . . virginianus, p. 115. $1^{\prime}$. Under parts broadly barred with black.

2. Belly more heavily barred, cimnamon chest band usually more marked . . . . . . . . ridgwayi, p. 116.

$2^{\prime}$. Belly less heavily barred; cinnamon chest band usually less marked. texanus, p. 116 .

289. Colinus virginianus (Linn.). Bов-white.

Adult male. - Line through eye white; throat white, bordered below by black; rest of under parts buffy or brownish - reddish brown on sides - narrowly barred with black; upper parts reddish brown and black ; scapulars, tertials, and lower back strikingly blotched with black. Adult female: like

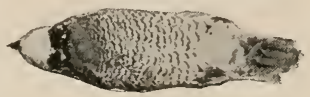

Fig. 191. male, but black of head replaced by brown, and white by buffy. Young: upper parts rusty, more or less spotted with black, and feathers with white shaft streaks widening at tip; breast grayish or brownish, streaked with white; throat and belly whitish. Length: $9.50-10.75$, wing 4.55 , tail 2.70 , bill .59.

Distribution. - Resident in Transition and Upper Sonoran zones in eastern United States, and spreading from Nebraska and Texas westward; also since introduction, in Colorado, New Mexico, Utah, Idaho, California, Oregon, and Washington.

Nest. - A saucer-shaped excavation in the ground, sometimes domed. but usually sheltered by bushes or weeds, and lined with dry grass or stubble. Eggs : 12 to 18, dull white.

Food. - Insects, grain, weed seed, beechnuts, and wild berries.

No picture of early spring among the farms, with the fields of dry cornstalks and the smoky, budding wood-lots, marked off by rail fences, is complete without an occasional stiff whirr of wings in the brush, a scudding of quick feet in the rustling leaves, and the distant clear whistle, bob-rohite.

The quail are in pairs now, and unless near enough together for their low conversational quit, quirk, queet, are sure to be calling back and forth in loud whistles from the fence tops, the stone piles, or low branches of trees. A little later the calling is hushed and the male may be seen hurrying about alone, or the two running mysteriously under the bushes; and still later there is a flock of little brown fluffy chicks to be led and guarded. By themselves they are a quiet, happy family, but when an intruder appears, all is excitement and confusion. There are two sputtering, fluttering, scolding old birds trying to lure or scare you away in several directions at once, and there is a scurrying flock of chicks, under your feet one moment, gone the next. They take to their heels now, but in a short time their quills sprout, and then when disturbed they take to wing like a lot of bumblebees.

As the summer passes the broods often join in larger flocks, and when they get scattered the call-whistle, bob-ıchite, is heard again 
about the farm. But dog and hunter are now abroad, and the quiet, happy days of the quail are over.

VerNox BAILEY.

289b. C. v. texanus (Lawr.). Texax Boß-white.

Adult male. - Similar to C. virginianus, but upper parts mainly brown

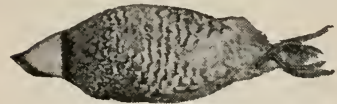

Fig. 192. rather than reddish brown, with distinct whitish barrings and with less striking black blotches on scapnlars, tertials, and lower back; under parts more heavily and thickly barred with brown, and usually with broader and more distinct band of pinkish brown below black collar. Adult female : like male, but without striking black or white markings; npper parts mixed black, white, and brown, from buffy brown to rnfous; throat patch and superciliary tawny; flanks less deeply rufons; median under parts less heavily barred than in male, but more heavily barred than in the female virginianus. Young: browner than in virginiamus. Wing: 4.39 , tail 2.44 , bill .59.

Distribution. - Resident in Upper and Lower Sonoran zones, from western Kansas south through Texas to eastern Nuevo Leon and Central Tamaulipas, Mexico.

Nest, eggs, and food like those of the bob-white.

The Texan bob-white is equally at home in the thorny thickets of southern Texas and in the brushy creek bottoms of western Kansas. At San Antonio, Texas, Mr. Atwater says the quail often come close to his ranch and lay eggs in hens' nests, perhaps on account of the protection afforded against snakes.

Except for the paler coloration so common in the more open and arid regions. the Texan is a true bob-white, and for habits and roice might have been bred in Ohio.

291. Colinus ridgwayi Brewst. Masked Boв-шнite.

Adult male. - Face and throat black, under parts reddish brown; upper

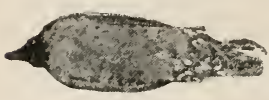

Fig. 193. parts finely mottled with cinnamon brown, black, and buff; back of neck finely streaked with white. Adult female: like the female of C. v. texumus, but nsually with a more marked chest band and heavier barring on belly. Wing: 4.49, tail 2.81, bill .60.

Distribution. - Southwestern Arizona and northwestern Sonora.

Nest. - By one record, a shallow excavation beside a tuft of grass. Eggs: 6, white, unspotted.

Food. - Red ants, grasshoppers, beetles, seeds, leaves, and berries.

The masked bob-white, first diseovered in southern Arizona by Mr. Herbert Brown, finds congenial cover in the high grass of the mesas and valleys, disappearing when stock destroy the grass. Mr. Brown describes the male as strikingly handsome when the sun reddens the deep chestnut of his breast. IIis two characteristic notes are the family bot-irhite, griven in bold full tones from the top of a rock or bush, and a 'hoo-we,' used when the birds are scattered, especially toward nightfail. 


\section{GENUS OREORTYX.}

General Characters. - Crest of two long slender plumes; bill and feet stout. tarsus equal to middle toe and claw; tail about three fifth the length of wing, broad, rounded, with long coverts; wing five inches or nore.

\section{KEY TO ADULTS.}

1. Upper parts olive brown from tail to crest . . . . pictus, p. 117. 1'. Upper parts grayish olive, bluish gray on nape. plumiferus, p. 117.

\section{Oreortyx pictus (Dougl.). Mountain Partridis.}

Adult male. - Crest black; upper parts deq olive broun, usually to crest, top of head bluish gray, stripes on sides of back buffy or yellowish brown, thront and flanks deep chestnut, flanks broadly banded with black and white; breast plain bluish slate. (See Fig. 194.) Adult female: crest usually shorter. Young: erest blackish, barred at end with pale brown, breast gray, marked with triangular spots. throat and belly whitish ; upper parts grayish brown, specked witl white. Length: 10.50-11.50, wing 5.255.40.

Distribution. - Resident nainly in humid Transition zone of Pacific coast region, from Santa Barbara, California, nortl to Washington.

Nest. - On the ground, alongside or under an old log, bush, or other shelter. Eggs : usually $\mathrm{S}$ to 12, creany or creamy buff, unspotted.

Food.- Grasshoppers, beetles, ants, and other insects, berries, seeds, buds, and leaves.

Though O. p. plumiferus has been given the name plumed partridge to distinguish it from $O$. pictus of the humil belt, both birds are known locally as mountain quail, and their habits are practically identical.

\section{2a. O. p. plumiferus (Gould). Plumed Partridge.}

Like O. pictus, but upper parts olive, the hind neck usually partly or wholly bluish slate like the breast; forehead generally paler, often whitish, inner edge of tertials lighter buff or buffy whitish.

Distribution. - Resident in arid Transition zone from the west side of the Cascades in northern Oregon, - except

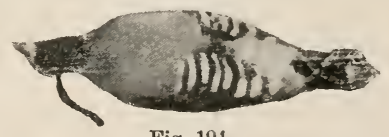

Fig. 194. near the coast, - south along both sides of the Sierra Nevada, and in the souther'n coast ranges to northem Lower California.

Nest. - A slight hollow in the ground lined with a few dry leaves. pine needles, and grasses, under shelter of thickets, bushes, weeds, or fallen treetops. Eggs : 5 to 14 , cream to reddish buff.

In winter when there are heary snows on the mountains, the quail come down to the foothills, and have even been seen in Pasa dena, three miles from the base of the mountains. In summer they are most abundant in the dense chaparral of Transition zone, though they go much higher.

Only once during two months spent in the Sierra, in the heart of the plumed quail country, did I come face to face with one of 
these handsome birds. It stood, marvelous to relate, upon a fencepost by the road, and, as we passed, its long plume and rich banded sides stood out more clearly than in a museum show-case. Even that exhibition, though it had such a casual air, we more than suspected was to hold our attention while a surprised family got to cover. But though plumiferus vouchsafed us so little of its society, the mountains seemed alive with its fleeing broods. In July the young changed from balls of down with brown stripes along their backs to well-feathered chicks, who essayed to fly with the best of their elders. Twenty-one of these stubby-crested fledgelings started up and trained across the road almost under our horses' noses one day by Donner Lake, with only two old birds in evidence, but these were probably joint mothers of the flock. From Donner to the Yosemite a glimpse of dark whirring forms ranishing through the trees was so common that at night we often asked ourselves, "How many broods have we seen to-day?" The clear pipe, and the hurried warning of the old guardian, kah, kah, kah, there's danger ne'ar, there's danger ne'ar, the low conversational notes of a family when undisturbed, and the motherly cluck and soft quieting talk of the old bird to her brood were so often in our ears that now, as we look back, they give life and richness to the memory of the majestic Sierra forest.

\section{GENUS CALLIPEPLA,}

General Characters. - Tail more than two thirds as long as wing; bill small and weak; erest short and not distinctly separated from feathering of crown; sexes essentially alike.

KEY TO ADULT MALES.

1. Belly buffy .

$1^{\prime}$. Belly with chestnut patch . . . . . . castanogastris, p. 119.

293. Callipepla squamata (Vig.). Scaled Partridge.

Addults. - Plumage pale, bluish gray and dull brownish; head and short, full crest fawn-colored, crest tipped with white; most of under parts and fore parts of back appearing scaled; bluish gray of anterior under parts changing to buffy on belly, sides dark gray streaked with white; posterior upper parts plain bluish gray, with conspienons white stripe on each side of back. Young: upper parts marked with black bars and white mesial streaks ending in triangular spots at tips of feathers; breast brownish, with white triangular streaks, sides barred with brown. Length: 9.5012.00, wing 4.50-5.00, tail abont 4.10-4.50.

Distribution. - Resident in Upper and Lower Sonoran zones from Arizona to western Texas and south to valley of Mexico.

Nest. - ()n the ground, often under shelter of a yueca or low bush, sometimes in grain-field or meadow. Eggs: 9 to 16, white to buff, uniformly spotted with buffy to reddish brown.

Food. - Small beetles, ants, grasshoppers, and small seeds, grain, berries, and plant tops. 


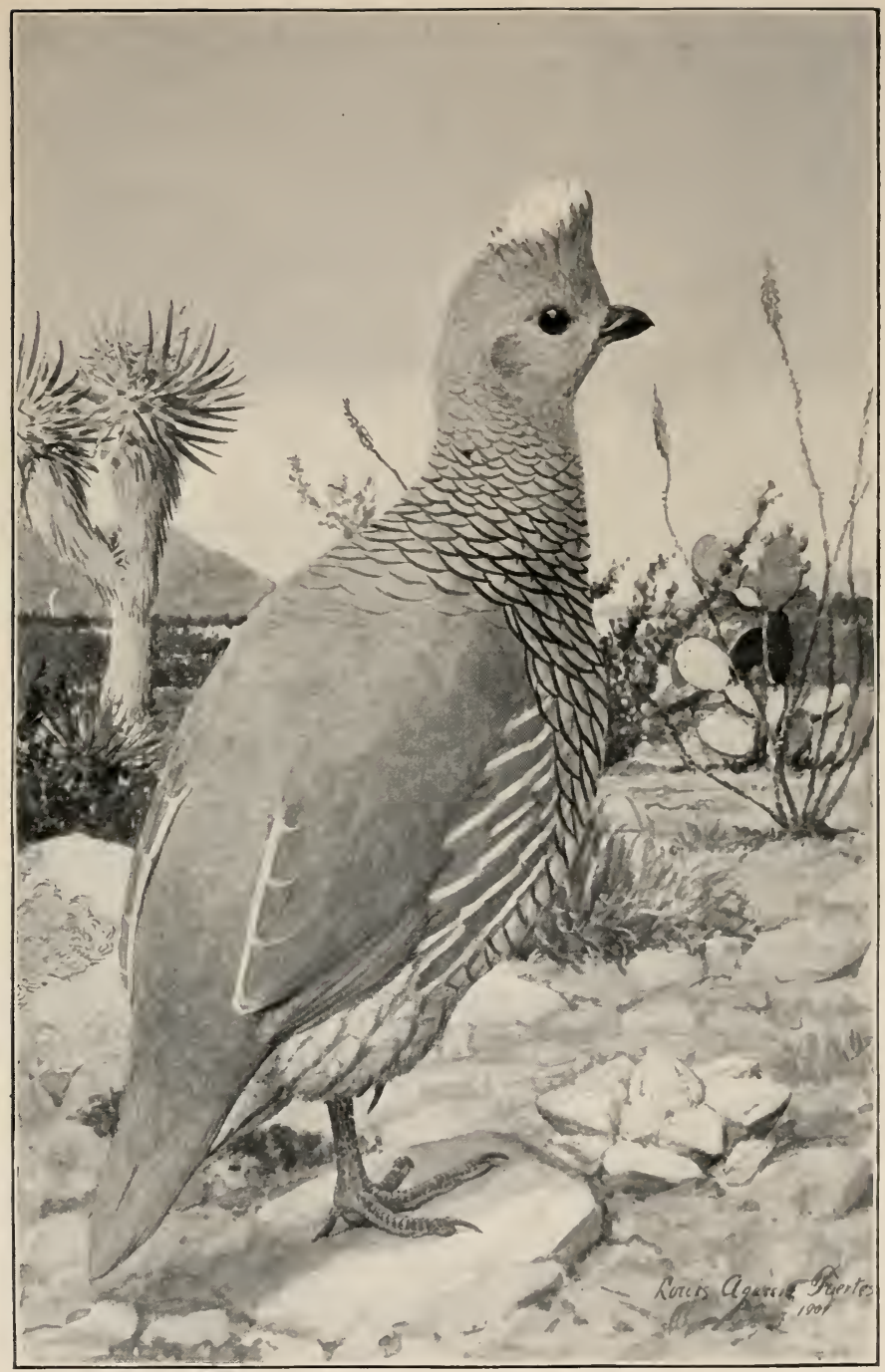

SCALED PARTRIDGE 

The scaled (quail live in the arid belt of scrub oak, chaparral, and mesquite extending from western 'Texas and New Mexico across southern Arizonit. 1)ry washes and gulches in the foothills seem to be their favorite haunts, but they may be found almost anywhere not ton far from water, even in valleys and out on open plains with only scattered brush and cactus for cover.

As the bluish gray birds rum from you over the gray ground, dodging this way and that among the bushes, the most conspicuous thing about them is the white tuft of their crest, and from its sug gestion of the cottontail they have been well dubbed cottontops. Perhaps because they are so protectively colored they usually trust to their feet to carry them ont of harm's way, rarely taking flight unless hard pressed. But when a fluck does scatter, the birds are astonishingly hard to find, though but a few yards away.

While shy in some places, they seem to be naturally rather trustful, and one of the most vivid mental pictures one carries away from their country is of a flock of the trim, delicately tinted quail standing together among the bushes, looking up out of their mild brown eyes with quiet interest and curiosity.

Though met with so commonly, the quail are more often heard than seen. In the Pecos Rirer country, where the rare blue sky comes low to the chaparral on the level plain, from the sun-filled brush day after day rings their companionable pe-cos', pe-cos'. The note, though sadly nasal, soon falls on the ear as one of the most musical of desert sounds, for like the, smell of the sagelorush and larrea it carries the charm of the big open plains.

\section{3a. C. S. castanogastris Brewst. Chestyet-pellifd Scaled PARTRIDGE.}

Like the scaled partridge, but upper parts browner, under parts deeper buffy or more rusty brown, belly with a brown patch in the male, sometimes indicated in the female.

Distribution. - Resident in Lower Sonoran zone from Eagle Pass through the lower Rio Grande valley in Texas to Coahuila and Ninevo Leon, Mexico.

Nest. - Usually a hollow in the sand, under sliclter of a clump of weeds, grass, or prickly pear, slightly lined with dry grass. Egys: about 15 , white to buffy, distinctly and uniformly spotted.

\section{GENUS LOPHORTYX.}

General Characters. - Crest distinct from feathers of crown, narrow at base, and recurved, the feathers inclosed between the more or less ap. pressed webs of the anterior plume; tarsus slightly shorter than midhle toe; wing four inches or more; tail abont four fifths as long as wing; sexes different. 
KEY TO ADULT MALE LOPHORTYX.

1. Back of head and flanks rufous gambelii, p. 121.

$1^{\prime}$. Back of head and flanks olive brown or gray.

2. Upper parts smoke brown, inner webs of tertials deep buffy or ochraceous . . . . . . . . . califormicus, p. 120 .

2 . Upper parts bluish gray, inner webs of tertials buffy or whitish. vallicola, p. 120.

\section{KEY TO ADULT FEMALE LOPHORTYX.}

1. Belly buffy, not scaled

gambelii, p. 121.

$1^{\prime}$. Belly not buffy, scaled.

2. Darker

califormicus, p. 120.

2 . Lighter . . . . . . . . . . . . vallicola, p. 120.

\section{Lophortyx californicus (Shaw). California Partridge.}

Adult male. - Crest black; patch on back of head olive or dark brown, bordered front and sides by black and white lines; upper parts deep smoky brown, with deep buffy or reddish brown stripes along sides of back; throat black, bordered by white, breast bluish gray ; belly scaled except for central deep chestnut patch; flanks dark olivaceons or smoky brown, streaked with white. Adult female: head without black or white markings; general color deep smoky brown; belly scaled, without chestnut patch or chestnut on sides; sides streaked with white. Young: upper parts grayish brown, feathers of back and wing coverts with dusky and whitish edgings; feathers of nape with faint white shaft streaks and dusky borders; under parts gray, barred with whitish. Length: 3.50 , wing $4.35-4.70$, tail $4.10-$ 4.70. (See Fig. 196, p. 121.)

Distribution. - Resident in humid Transition and Upper Sonoran zones along Pacific coast region from Monterey County, California, to southern Oregon and northward. Introduced in W'ashington and British Columbia.

Nest. - Usually a hollow lightly lined with grass beside a rock, under a brush pile or other shelter. Eggs: generally 12 to 16 , white or buffy, irregularly spotted over the entire surface.

Food. - Largely insects and weed seed.

The California partridge is the counterpart of the valley quail in labits (see 294a).

\section{4a. L. c. vallicola (Ridgw.). Vallex Partridge.}

Adults. - Like californicus, but lighter colored, upper parts grayish

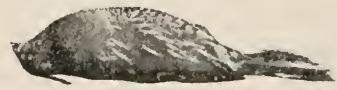

Fig. 195. Female. brown, edgings of tertials buffy or whitish; flanks olive grayish or grayish brown. Young: chest gray, marked with triangular white spots, belly faintly barred with grayish; upper parts brownish, streaked and spotted with whitish.

Distribution. - Resident in arid Upper and Lower Sonoran zones from Oregon sonth throngh California and western Nevada to Cape St. Lneas, Lower California.

When you come down the sides of the Sierra from the yellow pines into the digger pines and oaks of the Sonoran zones in the breeding season, the quail that fly before you are smaller and bluer than the mountain quail above, and the tlat toue of their quick cho- 
are-you-ah? who-ere-you-uh? strikes the car as a subtle expression of the difference between the hot lowlands and the cool mountains. The lowland bird has two forms diflering slightly in color, the valley quail occupying the arid sections and the California the humid.

The brushy parts of Golden Gate Park in San Francisco abound with quail, and from the benches one can watch the squads of plump hen-like little creatures as they move about with stately tread or stand talking sociably in low monosyllables. If they hear a footstep on the walk they start up and hurry across the path like hens before a wagon, topknots dropped over their bills, necks

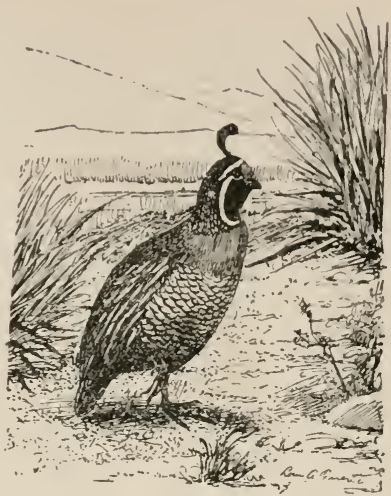

Fig. 196. Valley Partridge. craned forward, and legs stretched as they patter along in double quick time. When less in a hurry they run in a stiff, prim way, the cocks with a dignified gait, the hens with a demure feminine air.

Outside the parks, when the flocks are feeding the old quail act as sentries, to the wrath of young hunters, who complain that the cocks 'tell on them'!

As the country becomes settled, the former hordes of quail disappear, but they are still the game-birds of southern California, the roads are still patterned with their footprints, and through the val leys they are closely associated with the charm of the mellow California days, their melodious acho-are-you-ah? coming from the hillsides in the cool mornings when the high fog is dissolving into blue sky, coming from the chaparral in the warm noonday hours, and echoing softly from the vineyards through the quiet golden sunsets.

\section{Lophortyx gambelii Gamb. Gamber Partridge.}

Adult male. - Crest black, forehead and throat black, bordered by white. erown reddish brown; rest of upper parts plain bluish gray, tertials edged with white; breast gray, belly with buffy and black patches, flanks reddish broun streaked with white. Adult female: similar, but without striking markings; head plain brownish gray above, buffy streaked with darker on throat; belly uniform buffy, flanks chestnut. Young: eliest brownish gray, streaked with white; upper parts gravish brown, minutely mottled, feathers with

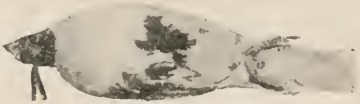

Fig. 197. Male.

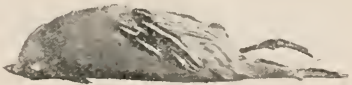

Fig. 19s. Female. white shaft streaks widening at tip and with black spot on either side; 
feathers of nape without dusky borders; belly white, unmarked. Length : $9.50-10.00$, wing $4.45-4.70$, tail $4.10-4.70$.

Remarks. - The Gambel partridge may be distinguished in nearly all plumages by its belly markings - the male by the black patch and absence of sealing; the female by chestnut flanks and absence of scales; and the young by the white, wholly unmarked belly.

Distribution. - Resident in Lower Sonoran zone from western Texas to southeastern California, and from southern Utah and Nevada south through central Sonora, Mexico.

Nest. - A slightly lined hollow often beside a bunch of tall grass, in freshet drift, or occasionally under a yucca. Eggs: usually 10 to 12 , white to buff, irregularly spotted, blotched, and clouded with brown, the blotehes with a pinkish or purplish bloom.

Food. - Insects, especially grasshoppers and ants; also seeds, grain, mesquite beans, berries, and tender leaves and buds.

The breeding season comes early in the valleys of the Gila and lower Colorado rivers. By February the deserts bloom, the aromatic creosote bush puts on its yellow robe, the big crimson and yellow cactus flowers, the fragrant evening primroses open wide, and yellow tassels dangle from the mesquite. In the balmy spring morning the first sound to greet your ears is the shrill cha chaa', cha chaa', of the cock quail from his perch on the blooming mesquite, and answering calls follow from up and down the valley. When the sun has risen higher you find the quail in pairs, hunting among the bushes for nesting-sites, talking in low, soft tones, the cock often bowing and strutting with important airs and crest low over his bill. When, after much careful prospecting, a nest spot is found safe from floods, hidden from enemies, and within daily reach of water, the birds settle down to home duties; and before the flowers are gone may be found leading about families of striped-backed chicks. The chicks must be guarded from a host of enemies, but the old birds are wise guardians, and early autumn shows large flocks of plump, nearly full-grown quail, always on the alert, quick to scatter, but sure to reassemble, calling back and forth in small piping voices till the last of the brood is in. Later in the season the families collect in large flocks, often of fifty or a hundred, and scatter in the daytime to feed in the open, returning at night with a roar of wings to roost in some dense thicket or brushy bottom-land, huddled together in a snug, feathery mass.

To the pot-hunter and trapper the birds are easy prey, but with proper protection they increase so rapidly as to be in no danger of extermination.

VERNoN BaILEY.

\section{GENUS CYRTONYX.}

296.1. Cyrtonyx montezumæ mearnsi Nelson. Mearns QUAIL.

Bill very stout; head with a full crest of soft, blended, depressed feath- 


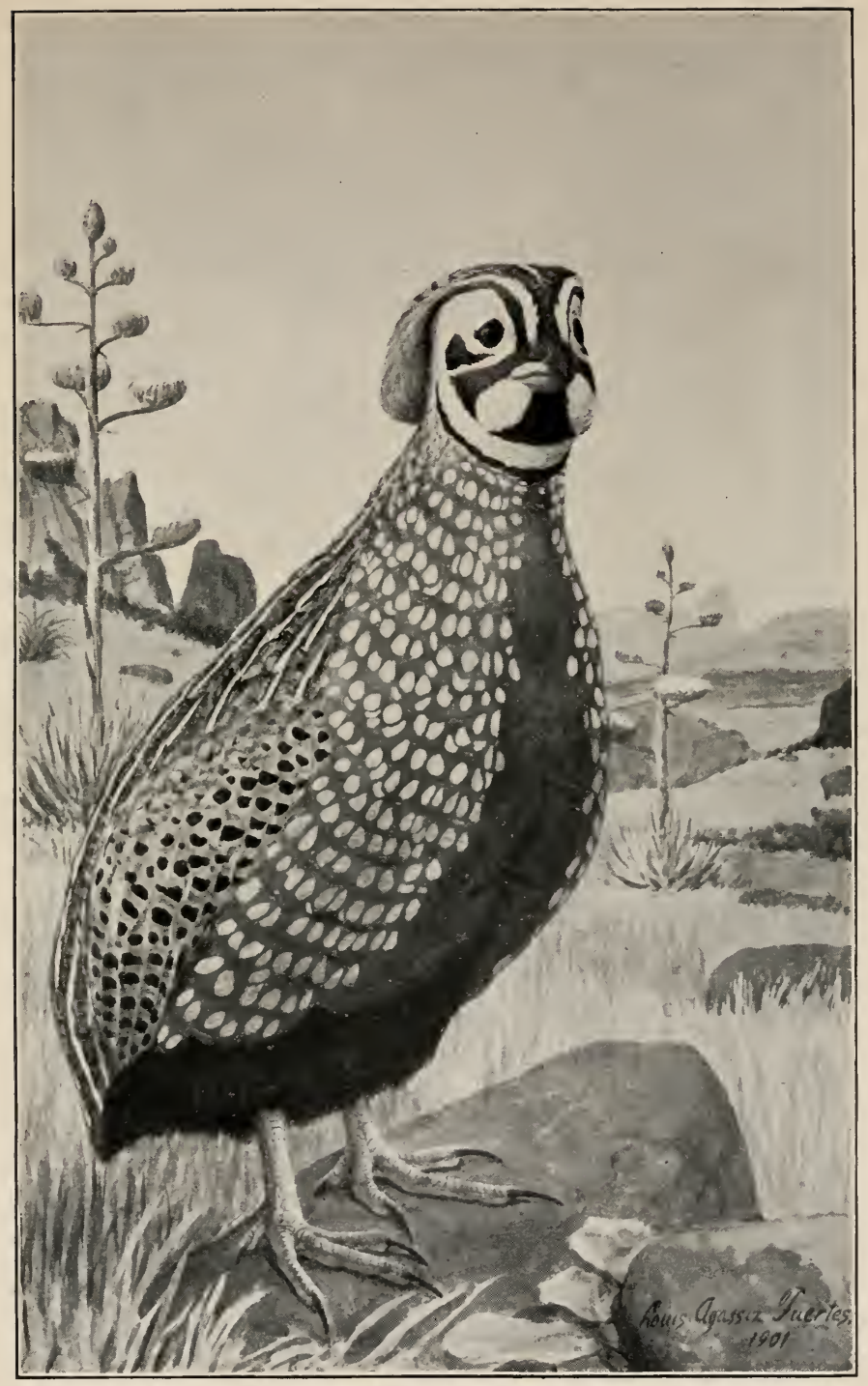

MEARNS QUAIL 

ers; tail much less than half as long as wing, its feathers soft, narrow at tips, and lardly distinguishable from coverts; wing coverts and inner quills highly developed, folding entirely over the primaries; tarsus and feet heavy, with long powerful claws; sexes very different. Adult male: head markings black and white; tip of crest fawn color; back pale brown, barred, vermiculated, and streaked with white; nnder parts with median line dark brown and sides slaty gray spotted with white. Adult female : head without stripes, prevailing color pale pinkish cinnamon; upper parts coarsely mottled and finely barred with black, brown, and lavender, and feathers with coarse white shaft streaks; chin whitish; neck with lavender cape specked and bordered with black; rest of under parts light cimnamon or lavender, breast and sides with black specks and shaft streaks. Young: similar to female, but under parts thickly spotted. Wing: 6.70 , tail 2.28 , bill .53.

Distribution. - Resident in arid Upper Sonoran and Transition zones of western Texas, sonthem parts of New Mexico, Arizona, and northern Mexico.

Nest. - On the ground, partly concealed by grass. Eggs : white.

Food. - Grasshoppers, weevils, caterpillars, larvæ, small beans, prickly pear and other seeds, and great numbers of small bulbs.

In the rugged little ranges rising from the deserts of western Texas, southern New Mexico, and Arizona, you find the Mearns quail, the United States form of the Massena quail, from the zone of junipers, oaks, and nut pines extending up among the big yellow pines, but always where there is plenty of grass or scattered brush for cover. When camping in its country we would often hear a soft $c h r-r^{2}-r^{r}-r^{r} r$ from the grass, and after locating it start for the spot, only to hear the quavering notes repeated just as far beyond. After another attempt the voice would be still across the gulch then back of us - till finally we gave up in despair, for at all times the ventriloquial call deceived us. Fruitless hours may be spent trying to tramp up the birds, and when you do find them you are looking for something else, and they burst from the grass at your feet with a stiff-winged roar and are around the hill out of sight or liave dropped into a thicket before you have recovered from your surprise.

While we were in the Chisos Mountains, Texas, Mr. Fuertes made the interesting discovery that the quail under excitement spread their crest laterally, as he has depicted it in the plate. In describing it he says : "Just after sumrise, while I was getting ready for the day's work, a cock Massena quail ran up beside the little knoll wliere I had placed my bed. He ran by me within fifteen or twenty feet, at first apparently not noticing me. When I turned to watch him he seemed to become more alert, quickened his trot, compressed his plumage, and raised his lead to its lighest, as a guinea hen will do when slightly alarmed. But accompanying this action lie displayed his curious crest in a peculiar and striking way. Instead of raising it as a bob-white would have done, he spread it out laterally, 
like half a mushroom. This curious feature combined with the compact neck and body feathers and striking facial markings gave him as unique an appearance as could well be imagined."

Verjox Batley.

\section{GENUS DENDRAGAPUS.}

General Characters. - Head not crested ; tail about length of wing, fanshaped, with twenty stiffish broad, obtuse feathers; tarsus feathered to toes.

\section{KEY TO SPECIES.}

1. Tail without distinet terminal band

$1^{\prime}$. Tail with bluish gray terminal band.

2. Tail band wide (.50-. 80 on outermost feather) . obscurus, p. 124. 2 '. Tail band narrow (not over .40 on outermost feather).

fuliginosus, p. 12.).

\section{Dendragapus obscurus (Say). Duskr Grouse.}

Adult male. - Upper parts dusky or bluish slate, finely mottled with

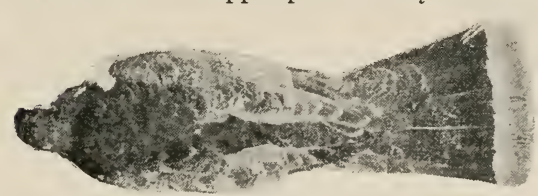

Fig. 199. gray and brown, buffy brown on wings; hinder scapulars usually with distinet shaft streaks and terminal spots of white; tail blackish, with wide bluish gray band - 1.00-1.50 wide ; under parts slaty, marked with white on sides of neck and

flanks. - Adult female : similar to male, but decidedly smaller, and upper parts, ehest, and sides barred and mottled with dark brown and buffy. Young: upper parts yellowish brown, with irregular barring or mottling, and black spots and white or buff shaft streaks widening at tip; under parts dull whitish, chest and sides spotted with black. Male: length 20$2: 3$, wing 9.40-10.00, tail 8, weight about $2 \frac{1}{2}$ to $3 \frac{1}{2}$ pounds. Female: length $17.50-19.00$, wing about 8.70 , tail 6 .

Distribution. - Rocky Mountains, from Idaho and Montana south to Arizona and New Mexico, and from the East Humboldt Mountains, Nevada, east to the Black Hills, Dakota.

Nest. - A slight depression alongside a log or under grass or bushes, lightly lined with pine needles and grass. Eggs : 7 to 10, cream or cream buff, spotted over entire surface with brown.

Food. - Grasshoppers, worms, grubs, and wild berries such as bearberries, raspberries, gooseberries, and currants, plant leaves and flowers, buds, and fir needles.

Among the ranches the dusky grouse is commonly known as the 'fool-hen,' on account of its natural tameness and its unsuspicious nature. Back in the mountain ranges where hunters are scarce and usually in quest of bigger game, the grouse are almost as fearless as barnyard poultry, walking out of your path with stately deliberation, or stopping to watch you near the trail. But after a little experience with hunters and dogs they become as will as deer and almost as difficult to approach. 
With the Indian as well as the white hunter they are favorite game birds, botlu because of their large size and the delicate flavor of their meat.

VERTOX BALEY.

\section{7a. D. o. fuliginosus Ridgu. Sooty Grovse.}

Adult male. - Similar to I). obscurus, but darker, sooty blackish with narrower tail band - usually about.60 on middle feather's and not more than .40 on outer pair - and withont white on sides of neck. Adult female: similar to female obscurus, but upper parts darker, sometimes washed with dark minty. Young : darker and more rusty. Length: 15.5019.00, wing $7.00-7.50$, tail $5.50-7.00$.

Distribution. - Northwest coast mountains, from Alaska south to California and Nevada.

Nest. - Similar to that of the dusky grouse. Eggs : 8 to 15.

The sooty grouse, like the wild turkey, is a bird of distinction and peculiar interest wherever found. Climb a mountain ridge toward sunset as the birds are going high to roost, and just before you reach the top, with a cluck and a whirr, down sails a great dark bird with widespread wings and banded tail; and as you climb on, a banded feather under a low fir bough discloses the hollow where it had been scratching in the soft woods earth. Ride along a trail and as you scan the trees beside you, though your horse hears no sound and detects no motion, your eye may distinguish a statue-like figure close to the tree trunk so like the bark in color that only its form reveals it. Explore a wind-swept granite crag at sunset and in one of its protected wooded niches warm in the erening liglit a mother grouse whirrs up into a tree and walks up and down a branch, craning her long neck with its small pointed head, clucking anxiously as she goes, and at the turns bobbing her tail and wobbling hard to keep her balance. As she calls, one after another her inrisible young burst from the brushy thicket at your feet and on stiff convex wing whirl away orer the rocks out of sight. Go to a canyon where the male is hooting and nearly a mile away you will hear his loud ventriloquial ahoo, shoo, whoo. Followed up, he proves to be near the top of a tall pine fifty to seventy-fire feet above your head, sitting close to the trunk, concealed by the branches. Through the glass he is seen to sit with spread tail and hanging wings, filling his yellow pouches till his neck looks almost as big as his body, when with a pumping motion of the head he gives his hollow muftled loot. If you stay to listen you may hear the booming at short intervals for hours.

In winter, Major Bendire says, the grouse spend most of their time in the tops of tall firs and pines, coming down only in the middle of the day to get water from a mountain spring, for the treetops supply buds and needles for their food. 
297b. D. o. richardsonii (Dougl.). Richardson Grouse.

Similar to 1 . obscurus, but tail without distinct terninal gray band, and

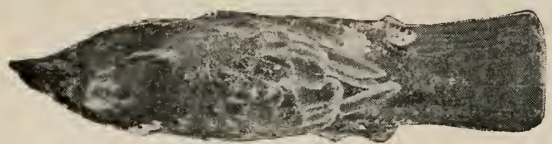

Fig. 200.

north to British Provinces. tail feathers more truncated at tip.

Distribution. - Resident in Canadian zone of the Rocky Mountains from northern Wyoming, Montana, and Idaho,

Nest and eggs similar to those of the dusky grouse.

Richardson grouse is said to remain in the mountains except in the breeding season, when it descends to the valleys.

\section{GENUS CANACHITES.}

299. Canachites franklinii (Dougl.). Franklin Grouse.

Similar to Dendragapus, but tail with sixteen feathers, which are more

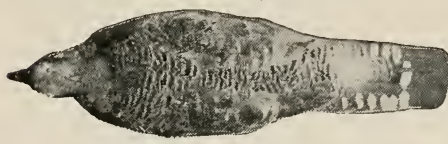

Fig. 201. truncated at tip. Adult male: orange comb over eye; upper parts dark, broadly marked with black bands and narrower bars of gray and brown; tail feathers black to tip, or narrowly edged with white ; upper tail coverts mottled and strikingly banded with white; throat and chest black, with white band between ; belly banded with white; flanks mottled and banded with brown and streaked with white. Adult female: upper parts blackish, irregularly banded, barred, and mottled with rusty brown and ash; white bands of tail narrower than in male; under parts uniformly banded with black, white, and rusty brown. Length : $14.70-16.20$, wing about $6.50-7.35$, tail $5.00-5.75$.

Distribution. - Resident in the mountains of western Montana and Idaho; westward to the coast ranges of Oregon and Washington; and northward through British Provinces to southern Alaska.

Nest. - On ground in woods. Eggs: 8 to 15 , buffy or pale brownish, more or less spotted with deep brown.

Food. - Grasshoppers, wild berries, and buds and leaves of spruces and tamaracks.

No bird is more characteristic of the deep fir forests of the northern Rockies and Cascades than the Franklin grouse. It is known locally as the 'fool-hen' from its misplaced confidence in man, its attitude toward him being one of mild curiosity and indifference rather than alarm. A grouse will sometimes walk slowly out of the way to avoid being stepped on, and will often sit quietly beside the trail as you pass. The danger the birds run in keeping quiet is not as great as it appears, however, for in the dark forest their dusky mottling renders them almost invisible. VERNon BaILey. 


\section{GENUS BONASA.}

General Characters. - Head with a short crest; sides of neck with a black or brown ruff of soft, broad-webbed feathers; tail nearly as long as wing, fan-shaped.

KEX TO SPECIES.

1. Upper parts dark rusty brown . . . . . . . . sabini, p. 128. 1 '. Upper parts not dark rusty brown.

2. Upper parts, including tail, gray . . . . umbelloides, p. 128. $2^{\prime}$. Upper parts gray and brown, tail sometimes ochraceous.

togata, p. 127 .

\section{0a. Bonasa umbellus togata (Linn.). Canadiax Rufred Grouse.}

Similar to B. u. umbelloides, but darker; upper parts mixed with gray, sometimes mostly gray; under parts more heavily marked with brown, flanks barred with dark brown or black; tail brown or gray.

Distribution. - Resident in the Canadian zone forests of the northeastern United States, British Provinces, and eastern parts of Oregon and Washington.

Nest and eggs similar to those of umbelloides.

Food. - Largely buds, leaves, berries, fungus, seeds, and nuts.

- While common in its various forms over much of the northwestern United States and the Rocky Mountain region, the ruffed grouse is less famed as a game bird in the west than in the east, probably because other and larger grouse claim more attention. Wherever flushed its quick flight and long, black-banded tail distinguish it from all others of the family, while a strutting old male, stepping daintily along a trail in the shady forest with black epaulettes slightly lifted and tail half spread, has a grace and elegance found in no other North American grouse.

Purely a bird of the forest, it relies largely upon cover and its mottled coat for protection, and when flushed, if possible puts a tree between itself and the hunter as it whirrs away to light out of sight on the far side of a gray trunk. There it draws itself up and stands as rigid as a branch. How well it knows how far to trust itself, breaking away at the first intelligent gleam from the pursuer's eye! But with all the skill and untamable wildness of the grouse, it needs rigid protection from the day it leaves the eggshell. A brood of bob-tailed young buzzing from the grass up on to the branches are easily potted, and in winter a flock noisily picking birch and alder-buds in the treetops are sadly exposed to the conscienceless hunter below.

While the snow is on the ground the birds feed mainly on buds, and usually have a warm bed under the snow. Before the snow is all gone in spring, each male selects his drumming ground, - a log, a rock, or merely an open spot of ground, - and begins his drunl. 
ming. The muffled wing-beats suggest distant thunder, though the sound is much the same at twenty feet or forty rods. I have often crept up within twenty or thirty feet of an old cock and watched him. Standing in a perfectly natural position, he begins without any warning. The wings are slightly raised and brought quickly down to the sides, one, two, three, four, five, six times, - you can count no farther, - the buzzing wings are lost in a blur, and the sounds blend in a crescendo roar. For lours at a time through the breeding season the drumming is kept up at intervals of from one to several minutes. It is heard mainly in the morning and evening, but irregularly at all times of day and night, though always from the same spot.

VERTON BAILEY.

\section{0b. B. u. umbelloides (Dougl.). Gray Ruffed Grouse.}

Adult male. - Rnffs black, with bluish green gloss to tips; upper parts

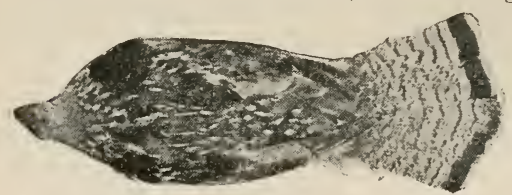

Fig. 202. gray, whole surface finely mottled gray and black, more or less washed with rufons, blotched with black, and streaked with white; tail always gray, with broad black subterminal band ; under parts white and buffy, barred with brown. Adult female: similar but smaller, with neck tnfts rudimentary or obsolete. Young: similar to adult female, but browner, barring paler, less distinct, dim white, and neck tufts wanting. Length: $15.50-19.00$, wing $7.00-7.50$, tail 5..50-7.00.

Distribution. - Breeds in Canadian and Hudsonian zones, in the central Rocky Mountain system of the United States, British America, and Alaska.

Nest. - A hollow at base of tree or rock, or by a fallen treetop or brush pile. Eggs: 8 to 14 , varying from white to pinkish buff, stained with brown.

Food. - Wild frnit and berries, seeds, buds, and green leaves.

\section{0c. B. u. Sabini (Dougl.). Oregon Ruffed Grouse.}

Like B. u. umbelloides, but mmel darker; npper parts black and dark rnsty or reddish brown, rarely with any gray; tail nsually deep' rnsty, rarely grayish; nnder parts heavily marked with blackish and washed with bnffy brown.

I)istribution. - Resident in hmmid Transition and Canadian zones in coast ranges from British Colmmbia sonth to Humboldt Connty, California.

Nest. - As described by Bendire, a hollow nuder fallen branches lined with dead leaves, sprnce needles, and a few feathers. Eggs: 7 to 13.

Food. - Similar to that of other grouse.

\section{GENUS LAGOPUS.}

General Characters. - Toes and tarsns densely feathered, tail less than two thirds as long as wing, with long coverts reaching to tip. 



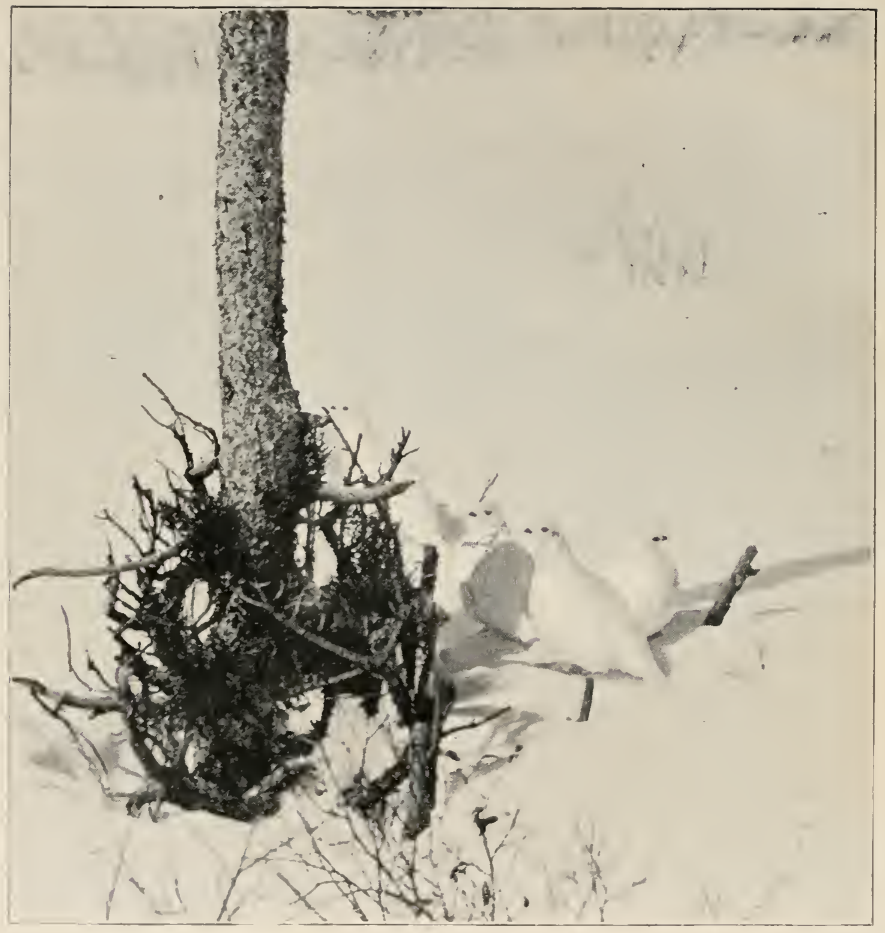

WHITE-TAILED PTARMIGAN 
KEY TO SPECIES OF LAfiOPUS.

1. General color of upper parts gray, in fall plumage.

$1^{\prime}$. General color of upper parts bnffy, in fall plumage.

leucurus, p. 1:?.

altipetens, p. 12!\%

304. Lagopus leucurus Swains. Aich. White-talled P'takMIGAN.

Adults in winter. - Pure white. Adults in summer: plumage spotted, barred, or mottled with black and rich buffy brown except for white wings, tail, legs, and belly; the white tail hidden from above by long mottled coverts. Adults in fall: similar to summer, but dark parts more uniformly gray, with finer markings and only a trace of buffy. Young: tail gray. IIing: $(3.37-6.75$, tail 3.81-4.07, bili .37, tarsus 1.1:3-1.22.

Distribution. - Above timber line in Alaska, momntains of British Columbia, and higher peaks of Cascades, south to Hood and Jefferson.

Nest. - On ground in open situations, a depression in the grass, or an actual nest of interlaced grass stems, weed tops, and feathers. Eggs : 10 to 16 , more or less heavily spotted or marbled with dark brown or black on a buffy or light rusty ground.

Fond. - Grasshoppers, caterpillars, beetles, and other insects, as well as young foliage, buds, flowers, and catkins.

Well above timber line along the crests of the higher mountain ranges these hardy furry-footed little grouse live among the rocks and heather beds, where, although the food supply is small, they find an abundance, there being little or no competition from birds of like habits.

In summer they keep close to the retreating snow-banks and often make their nests beside permanent glaciers. Their landscape is always patched with snow as their plumage is with white. But though they are colored for safety among the glaciers, the dark parts of their plumage make them blend in with the rocks so perfectly that they are almost invisible when not moving - a fact they seem to appreciate, for they sit still until you almost step on them.

Terisox Bailex.

\section{4a. L. 1. altipetens Osgood. Sonthekn White-tailed PtaR- MIGAN.}

Slightly larger than leucurus and similar to it in winter and summer plumages, bnt in fall plumage more brownish, the npper parts pale cinnamon rufons. Wing $7.10-$ 7.44, tail 4.30-4.72. bill about $.3 \overline{7}$, tarsis $1.13-1.28$.

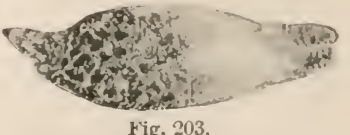

Distribution. - Colorado.

In Colorado the local name for the ptarmigan is 'white quail.

\section{GENUS TYMPANUCHUS.}

General Characters. - Sides of neck with a conspienons tuft of stiff. pointed feathers and an inflatable air sac; head witl a slight soft crest; 
tail short, rounded; tarsus scantily feathered to toes; toes extensively webbed at base.

\section{KEY TO SPECIES OF TYMPANUCHCS.}

1. Bars of back and rump single, broad and solid black.

2. Larger. . . . . . . . . . . . . americanus, p. 130.

2 '. Smaller. Coast of Texas . . . . . . . attwateri, p. 131.

1'. Bars of back and rump treble, a brown bar inclosed between two narrow black bars . . . . . . . . . pallidicinctus, p. 181.

305. Tympanuchus americanus (Reich.). Prairie Hex.

Adult male. - Upper parts yellowish brown and white, crossed by single black bars; under parts white, barred with brown; head deep buff except

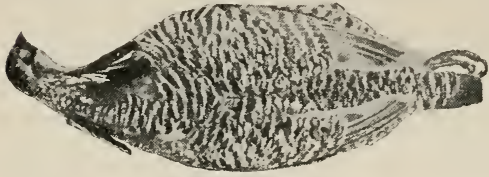

Fig. 204 for blackish brown stripes and blotches; neck with tufts above inflatable air sac, feathers of tufts 2.50 or more in length with broad rounded tips. Adult female: sinilar, but with neck tufts rudimentary. Young: upper parts light brownish, feathers with conspicuous white mesial streaks and large black blotches. Male: length 18-19, wing 8.60-9.40, tail 4.00-4.30. Female: length 17.50, wing 8.65, tail 3.80 .

Distribution. - Prairies of the Mississippi valley from Manitoba south to Texas and Lonisiana, and west to Colorado, with a general tendency toward extension of range westward and contraction eastward. Migrates locally nortl and south.

Nest. - A slight excavation in the ground amoug grass and weeds on open prairie, sometimes lined with matted grass and a few feathers. Eggs : usually 11 to 14 , cream, elive, or buffy, sometimes slightly specked with darker.

Food. - Grasshoppers, potato bugs, and various other beetles and insects, besides berries, grain, small seeds, green leares, and buds.

The few scared, hunted prairie chickens that remain scattered here and there over our great middle prairies are but a poor remnant of the abundant flocks that only a few years back feasted through the summer on grasshoppers and boomed loudly in spring from every lonely hilltop and wide expanse of open country. Perhaps no bird offers such tempting sport to hunters as these quick but straightflying grouse of the open country, ranging as they do in flocks of ten or twelve, lying close for the dogs, scattering as they fly, and lighting again on all sides to be worked up and shot by ones and twos. When besides their character as game birds their goodly size and delicious flavor are considered, it seems little wonder that they have been rapidly destroyed. In places they are still fairly common, and by wise protection could no doubt be kept from extermination.

Through the summer months they are quiet birds, nesting in the grass and keeping their young well out of sight in grainfields or 
berry patches. In winter, flocks of sometimes a hundred or more wary old birds gather together, but they light in the treetops to inspect the horizon for danger before settling down to breakfast in the cornfield, or else fly from their soft beds of snow to some big open field where there is not so much as a bush or stick to hide a lurking enemy. As the snow gets deeper it only brings them up nearer the berries, haws, and buds, which furnish the bulk of their winter food. When the snow hardens to a rigid crust and a few patches of bare ground appear you hear just at sunrise a low booming sound, perhaps a mile away, answered by one after another of the awakened cocks. This will be heard for hours every morning from the last of February till the first of May in the grouse country, for then the birds are having their famous dances. A few cocks and hens gather on a frozen lake or the open prairie, and the males fight and strut and boom in ardent rivalry before the apparently unconcerned females. They inflate the orange air sacs on each side of the neck, spread the yellow fringe over the eyes, and with widespread tail, drooping wings, erect neck tufts, and lowered head emit the air with the low booming sound. The booming is kept up throughout the breeding season. It is a most deceptive sound, at twenty feet often seeming far away, and at a long distance sounding close by.

\section{Verion Bailey.}

\section{5a. T. a. attwateri (Bend.). Attwater Prairif Hen.}

Similar to T. americanus, but smaller and darker; usually more chestnut on the neck; wing coverts with smaller, more tawny spots; tarsus more scantily feathered, feathers never reaching base of toes; in summer. greater part of tarsus naked; in winter, stripe of bare skin on back of tarsus.

Distribution. - Coast districts of southwestern Louisiana and Texas.

\section{Tympanuchus pallidicinctus Ridgw. Lesser Prairie HeN.}

Like the prairie hen but paler, and bars of back in threes, a wide brown bar inclosed by two narrow black bars. Male: wing 8.20-\$.30, tail 4.004.20. Female: wing 8.00-8.20, tail 3.50-4.00.

Distribution. - Eastern edge of the plains, from Kansas south to western Texas.

Nest. - On ground in meadows or other open situations. Eggs: $\&$ to 1:2 or more, grayish, olive, or buffy, usually plain, but sometimes spotted with darker.

\section{GENUS PEDICECTES.}

General Characters. - Head lightly crested, a naked patch over each eye; neck without obviously pecnliar feathers, but with a hidden patch of distensible skin, reddish in the breeding season, over which lies a series of slightly enlarged feathers; feet feathered to the toes; toes with a conspicuous fringe of horny processes in winter; tail much shorter than wings. graduated, feathers square at tips, the middle pair projecting much beyond ihe rest. 
KEY TO SPECIES OF PEDIOECETES.

1. Ground color buffy grayish . . . . . . columbianus, p. 132.

$1^{\prime}$. Gronnd color rusty or yellowish brown . . . . campestris, p. 132.

\section{8a. Pediœcetes phasianellus columbianus (Ord). Co-} lumbian Sharp-tailed Grouse.

Adults. - Upper parts grayish brown, with black and buffy markings; mnder parts bnffy or clear whitish, white or buffy prevailing in feathers with $\mathrm{V}$-shaped markings. Young : similar to adult female bnt grayer, and throat white. Length: 15-19, wing S.50-9.00, tail 4.00-5.50.

Distribution. - Breeds in northern part of Great Basin region, east to Montana and Wyoming, and north from Utah, Nevada, and northeastern California to central portion of Alaska.

Nest. - A hollow in the ground, lined with dried grass and feathers. Eggs: 11 to 14, creamy buff to olive brown, usually lightly spotted with reddish brown.

Nowhere so abundant as the pinnated grouse, the sharp-tailed has a wider range over more unsettled country and will probably last longer, especially in the northern part of its range. While a prairie or plains bird, it is usually flushed from a berry patch, low bushes beside a creek, a stubble field, or sagebrush. Its finely mottled plumage makes it very inconspicuous, and its tendency is to lie low and be flushed at fatally close quarters.

Though the grouse usually keep well hidden in summer, in winter when their plumage has become dense and their feet and legs rabbitlike, they may be seen crossing the fields on top of the snow or getting their breakfast of buds from the tops of trees and tall bushes. When the weather is cold and the snow deep and soft they often roost under the snow like the ruffed grouse, and come out in the morning fifteen or twenty feet from where they entered the white surface at night.

In spring the males have a loud cackling note, besides a scraping sound produced apparently by opening and closing their rigid tail feathers.

VERNON BAILEY.

308b. P. p. campestris Ridgu. Pramre Sharp-tailed Grouse. Nimilar to columbianus, bnt gromud color much lighter, prevailing shade

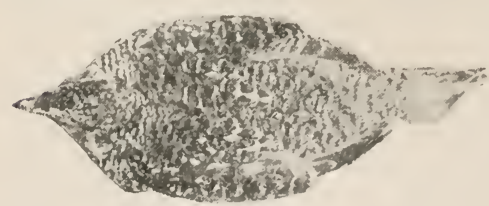

Fig. 205. rusty or yellowish brown; nnder parts mainly whitisl, and dark breast washed with whitish.

Distribution. - Breeds on plains and prairies in Transition and Upper Sonoran zones from Manitoba sonth to New Mexico, and from Wisconsin and Illinois west to the Rocky Momtains.

Nest. - A slight hollow in the ground, arched over by grass. Eggs : nsually 14 . blnish green with a purplish bloom when first laid, afterwards changing to dark chocolate with a few dark spots, and fading to white. 
Food. - Grasshoppers and other insects, fruit, berries, grain, buds, and leaves.

\section{GENUS CENTROCERCUS.}

General Characters. - Tail longer than wings, graduated, feathers pointed; neck with distensible air saes surmomnted by hair-like filaments and erect feathers; tarsus feathered to toes.

\section{Centrocercus urophasianus (Bonup.). Sage Grouse.}

Adult male. - L'pper parts mottled gray or bnffy, irregnlarly spotted or barred with black or brownish; in breeding season tufts of white downy feathers, mixed with black egretlike wiry plnmes on shonlders; yellow air saes on side of throat; chest blackish before the breeding season, with black wiry feathers depending from the chest band; chest white after the breeding season, during which time the blackish tips are worn off by rubbing on the gromnd. Aduit female: similar to male but smaller and without ruffs, air saes, or nuptial plnmes; throat white, chest band speckled grayish. Foung: somewhat like adult female but brownish above, markings on under parts, including black of belly, less distinct. Male: length 26-30, wing 12-13, tail 11-1:3, weight $4 \frac{1}{2}-8$ pounds. Female: length $21.50-23.00$, wing abont 10.50-11.00, tail S-9.

Listribution.-Breeds in sagebrush plains of the interior in Upper Sonoran and Transition zones from Assiniboia and Brit-

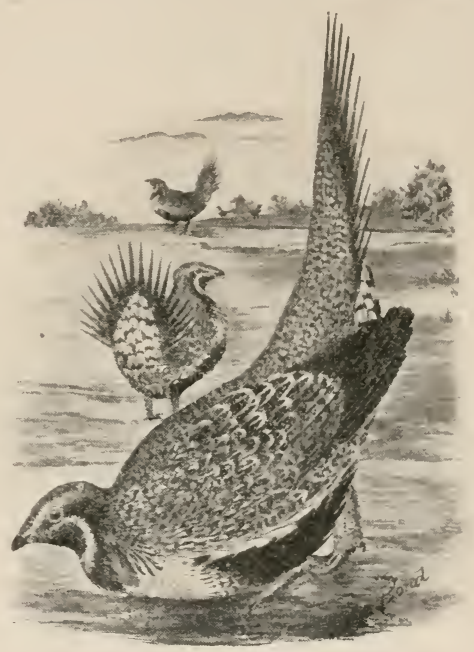

From Bond, in The Auk.

Fig. 206. ish Columbia to Utah, Nevada, and California, from the Sierra Nevada and Cascades east to the Black Hills, Nebraska, and Colorado.

Nest. - A slight hollow, with or without lining, nsually mnder the shelter of a sage bush, but sometimes near a creek sheltered by a bunch of high grass. Eggs: usually 7 to 9, olive buff to greenish brown, marked with round spots of dark brown.

Food.-Grasshoppers, ants, and other insects, with tender plants, leaves, buds, and flowers.

Throughout the Great Basin and arid plains country, where the most abundant and characteristic plant is the silvery-leaved aromatic sagebrush, we find this largest, stateliest of North American Tetraonide, the sage grouse. It is a bird of the open country, seeking no heavier cover than the low sagebrush and often wandering over barren slopes or short grass meadows, or in large flocks late in summer mounting above the timber belt of the mountains, to find new pastures in the stunted growth of sage close to perpetual snow. 
When much hunted the grouse become as wary as any game birds, but in a few far-away corners of their range they are still numerous. To the sportsman used to the quick whirr of the pinnated and sharp-tailed grouse the heavy roar and steady flight of a magnificent black-breasted long-tailed old sage cock offers far too easy a target, and the birds soon become scarce when the country is settled.

Considering their quiet dispositions and large size it seems strange that they have never been domesticated. The young birds are as delicious as any grouse, and while the old ones are often flavored with sage, a wholesome wormwood bitter, they can usually be cooked so that the flavor will not be noticed. VERYoN BaILEY.

Mr. Frank Bond explains the fact that the chest feathers of the grouse become worn off during the breeding season. He says: "During the months of April and May the sage cocks are usually found in small flocks of a half dozen or more, stalking about with tails erect and spread after the manner of the strutting turkey cock. ... Instead of dragging its wings upon the ground the sage cock will enormously inflate the air sacs of the neck until the whole neck and breast is balloon-like in appearance, then stooping forward almost the entire weight of the body is thrown upon the distended portion and the bird slides along on the bare ground or short grass for some distance, the performance being concluded by the expulsion of the air from the sacs, with a variety of chuckling, cackling, or rumbling sounds. This performance is continued probably daily during the pairing and nesting season, and of course the feathers are worn away by the constant friction." (The Auk, xvii. 325.)

\section{FAMILY PHASIANID佂: PHEASANTS AND TURKEYS.}

KEY TO GENERA.

1. Head naked, skin wrinkled and warted .

$1^{\prime}$. Head feathered, except sometimes around eye.

2. Head not crested

2 '. Head conspicuously crested.

3. Neck with conspicuous erectile ruff

3'. Neck without ruff .

Meleagris, p. 136.

Phasianus, p. 134.

Chrysolophus, p. 135. Gennæus, p. 135.

\section{GENUS PHASIANUS.}

General Characters. - Head not erested; male with brilliant metallic colors and handsome markings, tail lengthened, graduated, and vaulted, the feathers usually tapering to a point. Female much smaller and brownish, with upper parts more or less mottled, spotted, and marked with dusky.

A dozen or more pheasants have been introduced into the United States, but the ring-necked is the only one that has thus far gained a foothold in the west 
KEY TO ADULT MALE IHASIANTS.

1. Neck metallic greenish or bluish.

‥ Breast coppery chestnut . . . . . . . . torquatus, p. 13\%).

2 '. Breast dark green . . . . . . . . . versicolor, p. 1:3i).

$1^{\prime}$. Neck chestunt, with coppery and purple reflections.

sœmmerringii, p. 1\%).

\section{Phasianus torquatus Gmel. Ring-Necked Pheasant.}

Adult male. - Neck metallic greenish or bluish, back of head tufted; breast rich coppery chestnut, with metallic purple and coppery reflections; neck wholly or partly encircled by white collar. Adult femule: tail brown, barred with black and white. Male: length $2 \frac{1}{2}$ feet, wing 9.5010.50, tail 17.50-20.00. Female: length $20-24$, wing 5.50 , tail 11-12.

Distribution. - Southern Siberia, Corea, and northeastern China. Introduced into twenty-five states.

\section{Phasianus versicolor Vieill. Greex Pheasant.}

Adult male. - Neck metallic green or blue, back of head tufted; breast, sides, and flanks dark green. Idult female: tail barred over reddish or purplish ground. Male: length $24-27$, wing 9.60, tail 16. Female: length 20, wing \$.25, tail 10.50.

Distribution. - Japan, except Yezo. Introdnced, but apparently with little success, in western Oregon.

\section{Phasianus sœmmerringii Temm. Copper Pheasant.}

Adult male. - Chestnut and rnfous, glossed with coppery red and purplish; rump broadly streaked with white, tail broadly banded. Adult female: tail, except fonr middle feathers, brown, with subterminal black bar and white tip. Male: length 36, wing 9, tail 28. Female: length $18-20$, wing 8.25, tail 8.5\%.

Distribution. - Niphon and Kuisui. Japan. Introduced, but withont apparent snceess, in western Oregon.

\section{GENUS CHRYSOLOPHUS.}

General Characters. - Head crested, neck with conspicuous erectile ruff.

\section{Chrysolophus pictus. Golden Pheasant.}

Adult male. - Ruff or cape golden orange. barred with black; entire under parts. except chin and throat. bright red; tail brown, barred, and reticulated with black. Adult female: upper parts mottled brown. heavily barred with dusky on top and back of head, wings, neck, chest, sides, and flanks; rest of under parts plain light buff. Male: length 40, wing 7.70 , tail 27. Female: length 24 , wing 7 , tail 14 .

Distribution. - Mountains of sonthern China. Introdnced in western Oregon. and Protection Island. Washington, and recently in New Mexico.

\section{GENUS GENNÆUS.}

\section{Gennæus nycthemerus Linn. Silver Pheasant.}

Adult male. - Crest and under parts glossy blue black; face, legs, and feet bright red; rest of upper parts pure white, marked with $V$-shaped pencilings of black. Adult female: brown, under parts with paler shaft streaks, posterior parts and thighs irregularly mottled with zigzag lines of dusky; tail. except niddle feathers, irregularly barred with black and 
white; face, legs, and feet dull red. Male: length 40, wing 10.50, tail 24. Female: length 20.50, wing 9.10, tail 9.80.

Distribution. - Southern China. Introduced into western Oregon and Protection Island, Washington.

\section{GENUS MELEAGRIS.}

General Characters. - Head and upper neck naked; the skin wrinkled or warted, the forehead with extensile appendage, smaller in females; tail rounded, tarsus naked, spurred in male; sexes similar, but females duller.

\section{KEY TO SPECIES.}

1. Tail coverts tipped with buffy whitish . . . . merriami, p. 136. 1 '. Tail coverts tipped with brown.

2. Tail coverts tipped with dark chestnut

2 '. Tail coverts tipped with cimnamon or cinnamon buff.

fera, p. 136. intermedia, p. 136.

\section{Meleagris gallopavo merriami Nelson. Merriam Tur- KEY.}

Adult male. - Head and neck bare, dull bluish, strip of skin hanging from above bill; chest with bristly tuft of beard; feathers of under parts metallic bronzy green and reddish, tipped with velvet black; feathers of lower back and rump metallic, tipped with black; tail, tail coverts, and feathers of lower rump tipped with buffy whitish. Adult female: similar, but smaller, and colors duller. Male: length $45-50$, wing 21 , tail 18.50 .

Distribution. - Mountains of southern Colorado, New Mexico, Arizona, western 'Texas, and northern Chihuahua and Sonora, Mexico.

Nest. - A hollow lined with leaves, weeds, and grass, sometimes under shelter of a yucca, grass, or bushes. Eggs: 8 to 14, white, dotted over entire surface with reddish brown.

Food. - Insects, seeds, berries, plant tops, and cactus fruit.

In the mountains of New Mexico and Arizona one may occasionally find wild turkeys. In Arizona they have been seen by shepherds in the notches between the highest peaks of San Francisco Mountain.

\section{0a. M. g. fera (Vieill.). WiLd Turkey.}

Like $M$. g. merriami, but tail tipped with deep rusty, coverts and feathers of lower rump rich dark chestnut.

Distribution. - Eastern United States from sonthwestern Pennsylvania to the Gulf coast, and west to southwestern Kansas along wooded river valleys.

Nest. - On the ground, sometimes lined with leaves and pine needles. Eggs: 8 to 13 , creamy to buffy, marked with brown.

Food.-Grasshoppers, crickets, and other insects; acorns, nuts, seeds, grain, berries, and plant tops.

\section{0c. M. g. intermedia Sennett. Rio Grande Turkey.}

Similar to M. g. merriami, but lower back and rump jet black - feathers showing steel gray bars in certain lights - and tail and lower coverts tipped with cinnamon or cinnamon buff.

Distribution. - Lowlands of southern Texas and northeastern Mexico. 
Over most of the country where the wild turkeys were once plenty they have now beeome scarce or cxtinct, hut in a few places may' still be found in something like their original abundance, living much as their ancestors lived, breeding unmolested, strolling through the woods in flocks, and gathering at night in goodly numbers in their favorite roosting-places. Perhaps the best of these undevastaterl regions are on the big stock ranches of southern Texas, where the birds are protected not by loosely formed and unenforced game laws, but by the care of owners of large ranches, who woukd as soon think of exterminating their herds of cattle as of shooting more than the normal increase of game under their control. Here, at least through the breeding season, the turkeys are not more wary than many of the other large birds, and as we surprised them in the half open mesquite woods along the Nueces River would rarely fly, merely sneaking into the thickets, or at most running from us.

The ranchmen say that the turkeys always select trees over water to roost in when possible, and no doubt they do it for protection in this region where foxes, coyotes, and wildcats abound. On the edge of the flooded bottoms of the Nueces River they roosted in the partially submerged huisache trees. A loud gobble just at dusk led us to their cover, and crouching low to get the sky for a background we could see the big forms coming in singly or in twos or threes, and hear the strong wing beats as they passed on to alight in the huisaches out in the water. When the noise of their wings and the rattling of branches had subsided, with a few gobbles from different quarters they settled down for the night. The next morning, as the darkness began to thin and a light streak appeared in the east, a long loud gobble broke the stillness, followed by gobble after gobble from awakening birds in different parts of the bottoms, and before it was half daylight the heavy whish whish of big wings passed orerhead, as the turkeys with strong, rapid flight took their way back to the higher ridges.

VerNoN Balley.

\section{FAMILY CRACIDÆ: CURRASSOWS AND GUANS}

\section{GENUS ORTALIS.}

\section{Ortalis vetula maccalli Baird. Chachalaca.}

Adults. - Upper parts plain olive. slightly glossed with bronzy green; head and neck tinged with dull slaty ; tail fan-shaped. from duskr bronzr green to blue black, fan, except for middle feathers. broadls bordered with white; bare skin on throat orange ; chest dnll grarish green : rest of under parts dingy buffy brownish, deepening on under tail coverts. Length: 19.7.5-24.00, wing 7.50-8.50, tail $9.00-10.50$.

Distribution. - Resident in northeastern Mexico, from Vera Cruz north to lower Rio Grande valley in Texas.

Nest. - Usually in a twig-and-leaf-filled cavity of a mesquite-tree. Eggs : 3 or 4, white, rough, and strongly granulated. 
The chachalaca comes into the lower Rio Grande ralley of Texas, but probably does not range more than fifty miles north of the Mexican line. It keeps within the mesquite and chaparral, where it calls from the treetops at sunrise and sunset, pronouncing its local name, chachalac, in lond tones. Dr. Merrill says that it is much hunted for the Brownsville market.

\section{ORDER COLUMB王: PIGEONS.}

\section{FAMILY COLUMBID瓜: PIGEONS.}

\section{KEY TO GENERA.}

1. Tarsus shorter than side toes.

2. Tail slightly rounded, feathers broad at tips . Columba, p. 198.

2 . Tail graduated, feathers narrow and pointed at tips.

$1^{\prime}$. Tarsus longer than side toes.

Ectopistes, p. 140.

2. Wing less than 4 .

3. Tail equal to or longer than wing, narrowing to a point.

Scardafella, p. 143.

3 '. Tail shorter than wing, wide at end . Columbigallina, p. 14:3. 2 '. Wing more than 5 .

3. Tip of outer quill abruptly narrowed

3'. Tip of outer quill not abruptly narrowed.

4. Tail feathers 12, tail rounded . . . .

Leptotila, p. 141.

4 '. Tail feathers 14, tail graduated .

Melopelia, p. 142.

Zenaidura, p. 140.

\section{GENUS COLUMBA.}

General Characters. - Tail much shorter than wing, slightly romded, the feathers broad and rounded or nearly square at tip ; wings pointed : side toes of abont equal length.

KEY TO SPECIES.

1. Tail banded

1'. Tail mniform slaty black.

fasciata, p. 1:8. flavirostris, p. 140 .

\section{Columba fasciata siay. Band-tailen Pigfon.}

Adult male. - End of tail with broad - tuo inch - band, pale gray, bor-

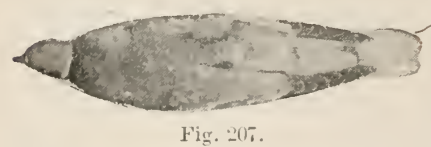
dered above by black; back of neck with white collar adjoined by iridescent bronzy patch spreading back as a greenisl wash; head and under parts purplish pink. fading to whitish on belly; fore part of back tinged with brownish. hinder part blnish grav; wing quills blackish, coverts blnish grar, faintly edged with white. Adult female: like nale but duller and much grayer: white nuchal hand often ohsolete. iridescent patch restricted, head gravish instead of pink. nnder parts largely grayish. Young: withont white on nape, under parts dnll grayish, tinged with brown on breast; "pper parts with feathers more or less lightly bordered with paler; head and neck dull bluish gray in male, light gravish brown in female. Length

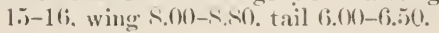


Distribution. - Transition zone, from British Columbia south though Mexico to Guatemala, eastward to Colorado and to western 'T:xas.

Nest. - When eggs are not laid on the gromnd or in the nest of some other bird, a slight platform of twigs on the flat limb of a tree. Eggs: 1 or 2, white.

Food. - Mainly acorns, but also young sycamore balls, grain, wild berries, such as elder, salmon, pigeon, mulberry, and manzanita; and honey from the century plant flowers.

Though the band-tailed pigeons are sometimes 'ommon in' the large river-bottoms where cottonwood balls, alder sceds, and berries abound, they live mainly on mast and breed principally on the edge of Upper Sonoran zone where the oaks and pines intermingle. The acorn crop of the year apparently governs their movements. In good acorn winters, Mr. Grinnell says, they sometimes appear in flocks of hundreds in the oak regions of southern California. Near Seattle, Mr. Rathbon reports, they are in need of protection, as they are hunted so continuously that they are in danger of becoming rare birds.

At Bearerton, Oregon, Mr. Anthony has found them abundant around a mineral spring, and in the arid mountains of the southwest they gather, often in large numbers, at the springs and water holes. When they come flying in to water the noise of their wings is startling. It is a loud flapping, as different from the musical whirr of the mourning dove as their heary flight is from the light swerring flight of the dore, and as the square tail is from the long pointed one of the dove. Though the noise made by the wings of fasciuta is striking at all times, when one of the birds projects himself down a mountain-side on his way to water, the sound produced has been compared to the escape of steam from an engine.

The band on their tails shows sometimes at a turn in flight, but most conspicuously on alighting, for then they spread their tails. and at a distance the band looks almost white.

If you follow the pigeons to their breeding-grounds in some remote canyon you will be struck by the owl-like hooting that fills the place, and you will locate the sound here and there along the sides of the canyon at dead treetops, in each of which a solitary male is sumning himself, at intervals pufting out his breast and hooting. The hooting varies considerably. Sometimes it is a calm rkoo'-7hohoo, whoo'-hoo-hoo, at others a spirited hoop'-rh-irhoo', and again a two syllabled $u h o^{\prime}-u g h$, made up of a short hard hoot and a long coo, as if the breath was sharply expelled for the first note and drawn in for the second.

The breeding season has been said to cover nearly erery month of the year in Arizona, and in the Guadalupe Mountains, Texas, we found nests with egg gs the latter part of $\mathrm{August}$. 


\section{Columba flavirostris Wagl. Red-Billed Pigeon.}

Adult male. - Head, neck, and under parts dull pinkish purple, except for tawny chin. slaty belly and under tail coverts; wing coverts with reddish brown patch, fore part of neck brownish, hinder part, wings, and tail bluish gray, blackish on quills and end of tail. Adult female: similar bnt smaller and duller. Young: colors dull, tinged with ashy. Length : 13.7514.60, wing abont 7.50-7.50, tail 5.40-5.50.

Distribution. - From sonthern parts of Texas and Lower California, sonth through Mexico and Central America.

Nest. - A platform of twigs, in thickets or groves of ash-trees. Egg: white.

The red-billed pigeon was found by $\mathrm{Mr}$. Sennett in the timber of the lower Rio Grande. He says it is a secluded bird, and that its cooing is clear, short, and rather high-pitched.

\section{GENUS ECTOPISTES.}

\section{Ectopistes migratorius (Linn.). Passenger Pigeos.}

Tail nearly as long as wing, graduated, the feathers narrow and pointed at tips; tarsus short, feathered part way down in front; side toes unequal.

Adult male. - Head and neck blnish gray; moler parts deep pinkish brown, becoming pinkish on sides and white on belly; uape and sides of head glossed with metallic reddish purple; wings and back brown, wings spotted with black; rump bluish gray, tail changing from blackish on middle feathers to white on onter webs of outer feathers; inner webs with black and rufous spots. Idult female: similar but head brownish, pink of nnder parts replaced by brown; metallie gloss less distinet. Foung : feathers of fore parts tipped with white, giving a mottled appenrance, quills edged with rusty. Length: $15.00-17.25$, wing $8.00-8.50$, tail $8.20-$ 8.75. Female somewhat smaller.

Distribution. - Formerly eastern North America from Hndson Bay southward, and west to the plains; accidental in Nevada and Washington. Now nearly extinct. A few pairs smpposed to be left in Canada, Manitoba, Wisconsin, and Michigan.

\section{GENUS ZENAIDURA.}

\section{Zenaidura macroura (Linn.). Moernisg Dove.}

Tail of fourteen feathers. gradnated. more than two thirds as long as

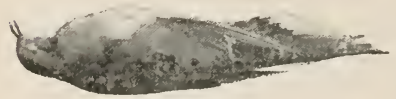

Fig. :0s. wing; feathers more or less narrowed at tips; wings pointed; tarsus naked; sirle toes of unequal length, the outer shortest; space aromnd the eve bare. Alult male: tail bordered with white and with subterminal black spots; back and wings with a few ronndish black spots; rest of upper parts brown; top of lead washed with bluish gray, sides of hearl with blue black spot and pink iridescence; under parts brownish, tinged with pink on breast. Adult female : sinilar but paler throughout, with little if any blnish gray on liead, black tar spot smaller, and metallic gloss less distinct. Young: duller than female, withont metallic gloss or distinct ear spot; feathers of upper parts and breast with grayish tips. Length: 11-1:), wing 5.70-6.10, tail 5.7(1--6.5), bill .is)-..5.).

Jistribution. - Breeds in Transition and Upper and Lower Sonoran zones 
thronghont the United States, and sonthern parts of Ontario. Manitoba, and British Colnmbiat, migrating to Panama and the West Indies. Migratory in the northern part of its range.

Nest. - A frail platform of twigs usually on a flat branch 10 to 20 feet from the ground, but also on the ground, on cliffs, in cactus, bushes, and trees as high as 50 feet from the ground. Egys: usually 2, white.

Food. - Snails and other mollusks, millepeds, cicadas and other insects, grain, weed seeds, acorns, berries, and plant tops.

The free, swift flight of the mourning dove and the skill with which he manages his airship proclaim him a traveler. Is he shoots by overhead he cuts the air with the hiss of a bullet, his plumage almost as compact and smooth as the nose of a mauser, his long tail narrowed to a frictionless knife-blade. As his powerful wings bear him swiftly on, their least turn swerves his course, but he never lessens speed till the goal is reached. After watching him it seems small wonder that he should be a cosmopolitan, bound to no one migration route, but as much at home in New England as Oregon, in Canada as southern California.

In the dry part of Arizona the doves often nest a long distance from water, but fly back and forth to it in pairs or small companies twice a day. The old mountaineers, knowing their habits, follow them when in search of the rare water-holes.

Although the dores abound in remote mountains and desert lands, they are also much given to human societ $y$, and often nest around barnyards and buildings, where they pick up grain that has fallen to the ground.

As many of the dores are seen in pairs during the winter, Iajor Bendire infers that a number remain mated throughout the year.

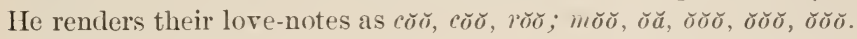

\section{GENUS LEPTOTILA.}

\section{Leptotila fulviventris brachyptera (sulvad.). Wніте- FRONTED DOVE.}

First primary abruptly ent out near end; tail much shorter than wings, rounded, feathers twelve; tarsus naked; side toes nearly equal. Idult male: forchead and throat whitish, breast pale pinkish; rest of under parts whitish; back of head and fore part of back iridescent; rest of upper parts dark brown; tail becoming blackish, tipped with white; under wing coverts and axillars deep reddish brown. Adult female: similar to the male but duller colored, and metallic gloss less distinct. Length : $11.50-12.50$, wings $6.00-6.50$, tail $4.25-4.50$.

Distribution. - Valley of the Lower Rio Grande in Texas and southward to Mexico and Guatemala.

Nest. - Rather bulky for a dove, made of branches and straw, and placed usually in thorny bushes. Eggs: :2, eream buff.

Food. - Said to be principally fruit.

The white-fronted dove frequents the timber of the lower Rio 
Grande valley, where it may be found, Mr. Sennett says, by the peculiar note which distinguishes it from all other pigeons.

\section{GENUS MELOPELIA.}

\section{Melopelia leucoptera (Linn.). White-Winged Dove.}

Tail rounded, shorter than wing, of twelve broad, rounded feathers;

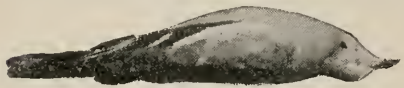

Fig. 209. wings pointed; bill slender and lengthened, equaling tarsus; a large bare space around eve. Adult male: wing with large white patch on coverts, conspicnous against black quills; tail bluish gray, broadly tipped with white preceded by black, two middle feathers brown; sides of head with bluish black spot next to bromzy iridescent patch; top of head and neck dull pinkish; rest of upper parts brownish, except for bluish gray of lower back; under parts soft fawn color, fading to whitish. Adult female: similar but smaller and duller. Toung: like female but still duller, feathers of upper parts tipped with paler and breast with rusty tinge. Length : 11.00-12.25, wing 6.30-6.80, tail $4.80-5.25$.

Distribution. - Resident in Lower Sonoran and Tropical zones from Florida and Texas to Arizona, and south through Lower California and Mexico to Costa Rica, Cuba, and Jamaica. Casual in Colorado.

Nest. - A frail platform of interlaced sticks, lined with weeds, dry grass, and often mesquite leaf stems, placed in mesquite, walnut, willow, or cactus, from 6 to 30 feet from the ground. Egys : 2, white. fruit.

Food. - Insects, sinall seeds, grain, berries, mesquite beans, and cactus

As the jay seems a part of the mountain forest, the horned lark of the prairie, and the sage thrasher inseparable from the sagebrush plains, so the white-winged dove belongs to the hot cactus and mesquite valleys of the lower Colorado, Gila, and Rio Grande. Though often seen perching on a giant cactus, its life is largely spent in the mesquite, and its plump form is so constantly seen through the thin mesquite foliage that it comes to seem almost like a fruit of the tree. Now the dore is only perching there, beside a water-pool, now on a branch acting as sentinel while a hungry flock is down in a patch of wild sunflower or the wheatfield of the rancheria; but in the nesting season it has taken up its abode in the tree and is builcling its nest and rearing its young in the protection of the thorny branches.

So closely is it associated with the mesquite country that even its

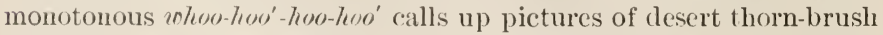
and dobe walls, over which the large, handsome bird is flying with white bands outspread on wings and tail. Its note is an exaggerated form of the coo commun to the family. To make it the dore puffs out his throat like a pouter pigeon, emitting the curious hollow sound which is more suggestive of the hooting of an owl than the languid cooing of a dove.

VERNON B.IItEY. 


\section{GENUS COLUMBIGALLINA.}

\section{0a. Columbigallina passerina pallescens (Baird). Mkx- ICAN Gruend Dove.}

Wings short and broad, with elongated imner secondaries nearly overreaching primaries in the folded wing; tail shorter than wing, nearly even, of twelve broad feathers; tarsus as long as middle toe without claw. Idult male: back of hearl and neck bluish. feathers suggesting scules; forehead, sides of head, and under parts pinkish; breast feathers broun centrally: upper parts grayish, wings with imer webs of quills bright reddish brown, coverts with blue

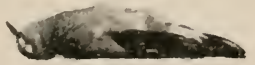

Fig. 210. black spots; tail nearly eren, blackish, except for middle feathers and white corners. Adult female: similar but much duller, pink replaced by pale brownish, blue by brownish gray; spots on wing coverts brown. Young: like female but duller, more grayish ; feathers, especially on upper parts. tipped with whitish. Wing: $3.30-3.60$, exposed cnlmen .4:-.47.

Distribution. - Breeds in Lower Sonoran and Tropical zones from Texas to Arizona and south through Lower California and other parts of Mexico to Central America.

Nest. - Small and sometimes compact, of twigs or plant stalks, sometimes lined with a few straws, placed in a bush or tree $: 3$ to 20 feet from the ground. Eggs : 2, usually white.

Food. - Small seeds, grain. and berries.

The ground dove is a friendly little bird, staying wherever it can find seeds or refuse grain, whether it be in town streets, horse corrals, or on the picket line of an army post. In the fall, when weed seeds are abundant, Mr. Herbert Brown has seen flocks of fift 5 about Tucson, Irizona, but ordinarily they are in pairs or small flocks.

\section{GENUS SCARDAFELIA.}

\section{Scardafella inca (Less.). Ixca Dove.}

Tail double rounded. middle and outside feathers both shorter than those between, twelve in number, all narrow and tapering; tarsus very short, slightly feathered above. Adults : uhole body apparently scaled; upper parts brownish; inner webs of wing quills mainly reddish brown: tail brown and black, two outer feathers largely

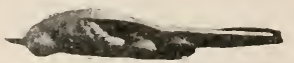

Fig. 211. white; nuder parts pale gravish pink, changing to buff on belly; under wing coverts partly black. Young: similar but duller. and upper parts somewhat mottled by occasional whitish tips to feathers. Length: 8.00 , wing $: .70-8.75$, tail t. $10-4.40$.

Distribution. - Breeds in Lower Sonoran zone from the Rio Grande valley of Texas and southern Arizona; south through Lower California and other parts of Mexico to Nicaragua.

Nest. - In cactus, mesquite, acacias, or small oaks, j) to 10 feet from the ground, made of twigs and grasses. Eggs: 2, white.

These dainty little doves are more than half cirilized. You find them on the roads, in the barnyard, the orchard, and the village street - rarely away from ground trampled by man. They join the poultry at breakfast, and pick the grain that is scattered along 
the roads, gathering the weed seeds by the way. From their quick motions and constant haste one might think they were catching flecing grasshoppers rather than stationary seeds. They go pattering about, bobbing their heads and keeping up a rapid, hard little cooing that has scarcely a suggestion of the soft dove tones. In the breeding season this is the first thing heard in the morning, and it is kept up well into the glowing heat of the day, usually given from the ground, but sometimes from the branches of trees.

Vernon BaIley.

\title{
ORDER RAPTORES: BIRDS OF PREY.
}

\author{
(Fanilies Cathartide, Falconide, Strigid
}

FAMILY CATHARTID瓜: VULTURES.

KEY TO GENERA

1. Wing 30 or more . . . . . . . Gymnogyps, p. 144.

$1^{\prime}$. Wing less than 25.

2. Head red . . . . . . . . . . Cathartes, p. 145.

2 .Head black . . . . . . . Catharista, p. 146.

\section{GENUS GYMNOGYPS.}

324. Gymnogyps californianus (Shaw). California VulTURE: CONDOR.

Wing 30 or more; head and entire neck bare, skin smooth ; plumage of under parts lanceolate or pencillate ; head much elongated, forehead flattened ; nostril small, its anterior end acute ; bill small, mandibles broader than deep; wings folding to or beyond end of square tail. Adults : head and neck bare, yellow, or orange in life; bill whitish or pale yellowish; plumage sooty blackish; outer webs of greater wing coverts and secondaries grayish, wing coverts tipped with white and outer secondaries edged with white; axillars and under wing coverts pure white. Young: like adults, bnt neck more or less covered with sooty grayish down, bill and naked skin blackish ; brown edgings of feathers of upper parts producing a sealed effect; white of mnder wings and gray webbing of coverts and secondaries wanting. Length : 44-5), extent $\$ \frac{1}{2}$ to nearly 11 feet; weight 20-2.5 pounds, wing :30-3.5, tail 15-18, bill 1.50.

Remarks. - The vulture can be distinguished in the field by its great size and its white under wing coverts.

Distribution. - Coast ranges of sonthern California from Monterey Bay sonth to Lower California, and east to Arizona.

Nest. - A cavity or recess among rocks, or hollow in a stump, log, or tree trunk. Eggs : 1 or 2, plain grayish green, or greenish white.

Food. - Carrion.

To come upon the California vulture alive and free is like suddenly coming to a giant sequoia towering above the forest. The sequoia awes you with the feeling of immensity, and the forest 
trees that you had looked up to as very large are suddeniy dwarfed. The same thrill strikes you when overhead the great wings of the vulture spread out and with mighty strokes carry the huge bird in wide circles up through the sky; and, as you look down, the turkey buzzards sailing below seem little more than circling swallows.

\section{VerNoN BAILEY.}

The sight of a single California vulture is more than is vouchsafed to most naturalists, but in 1894 Mr. Stephens actually encountered a flock of twenty-six of these magnificent birds.

The condor is certainly one of the glories of the splendid state of California, and every patriotic naturalist should do his part to enforce the law for its protection.

\section{GENUS CATHARTES.}

\section{Cathartes aura (Linn.). Turkey Vulture.}

Whole head and upper part of neck naked, the skin eorrugated and sparingly bristled; nostrils large, elliptical; wings long, pointed, folding to or beyond the short round tail. Adults : head bare and crimson in life, bill white; lores and top of head sometimes with wart-like papillæ; neck and under parts dull black; upper parts blackish glossed with green and purple, feathers broadly edged with grayish brown, secondaries edged with gray; shafts of quills and tail feathers varying from pale brown to yellowish white. Young: like

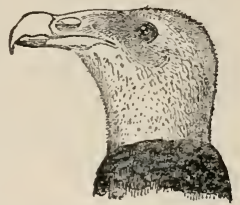

Fig. 212. adults, but bill and naked skin blackish, brownish margins to wing coverts less distinct. Length : 26-32, extent about 6 feet, wing 20-2:3, tail 11-12, bill 1 .

Distribution. - Breeds throughout most of temperate and tropical America, from the Saskatchewan sonth to Patagonia.

Eggs. - Laid in a cavern, a eavity between rocks, or a hollow in a $\log$, stump, or tree trunk; 2, white, buffy, or greenish white, more or less spotted or blotched with rich brown and purplish gray.

Food. - Carrion.

One of the most familiar sights in southern and western skies is the dark form of the turkey buzzard circling and soaring on outspread wings, its black body figure, as seen from below, set in a bordering of gray wing. As the birds float in the sky apparently wafted by every passing breeze they are keeping a sharp lookout over the land outspread beneath them, and so quickly discover any carrion that the ranchmen, who are numbered among their constituents, find it quite unnecessary to bury their offal, depending entirely upon the good offices of this self-constituted garbage committee of Nature's Board of Health. Along the Columbia River the buzzards dispose of the dead fish on the shores.

From the character of their food and their habit of eating on the ground instead of carrying their quarry to a tree, the bills and feet 
of the vultures are modified from the hawk types. The bill is less sharply pointed and powerful, while the feet instead of having curved talons have an elongated middle toe well adapted to walking on the ground, or steadying the large body as the bird stands on the carrion it is devouring.

When walking, the vultures often hold their wings out at their sides, harpy fashion ; and sometimes as they rise they fly so low over your head that you hear a loud puff, puff, puff', puff, as they flap past.

While usually solitary or in scattered companies they gather quickly at a carcass, and at night often assemble in large flocks to roost in a favorite grove of cottonwoods. Mr. Erermann reports over a hundred roosting in a eucalyptus grove.

\section{GENUS CATHARISTA.}

\section{Catharista urubu (Vieill.). Black Vulture.}

Head naked, but feathers of neck rimning up behind to a point on the back of the head; nostrils narrow; wings not folding to the end of the short, even, or emarginate tail. Adults: head bare, blackish, bill blackish, with yellowish or whitish tip; whole body dull black; wing quills with white shafts, and webbing on under side hoary whitish. Length: $2: 3-27$, extent about 54 , wing $16.50-17.50$, tail $7.50-8.50$, bill $.90-.95$.

Distribution. - Breeds in Lower Sonoran and Tropical zones from the Atlantic to western Texas, and from North Carolina, Indiana, and Kansas south over most of South America. Straggles to New England and South Dakota.

Eggs. - Laid on the gronnd under bushes or logs, or on rocks; 1 to 3 , pale grayish green, irregularly marked around the larger end with brown and sometimes lavender.

Food. - Carrion.

Although the turkey buzzard and black vultures resemble each other in general, you can recognize the black vulture in the sky at a glance by the shortness of its square tail. You also come to distinguish its flight, for while a turkey buzzard sails around smootluly on a level, the black vulture's short wings and abbreriated tail often give its body a peculiar tilt and a bat-like effect of climbing up the air. In flying to the ground, its whitish under wing tips are a striking character.

FAMILY FALCONID王: FALCONS, HAWKS, EAGLES, ETC.

KEY TO GENERA.

1. Wing 17-21.

2. Claws all the same length, rounder on under side.

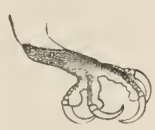

Fig. 213.

Pandion, p. 172. 
2'. Claws not all the same length. grooved on under side.

3. Tarsus feathered to base of toes . . . . Aquila, p. 163.

3 . Tarsus not feathered to base of toes. . . . Haliæetus, p. 165.

1 '. Wing less than 17 .

2. Wing with only one or two quills cut out on inner webs.

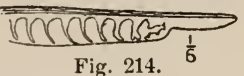

Fig. 214.

3. Nostril circular, with conspicuous bony tubercle.

Falco, p. 165.

Fig. 215. 3'. Nostril not circular, without bony tubercle.

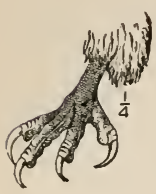

Fig. 217.
4. Tail deeply forked.

Elanoides, p. 148.

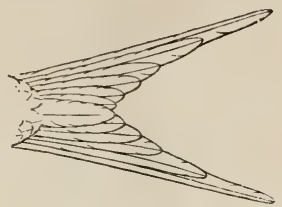

Fig. 216.

4'. Tail not deeply forked.

5. Tarsus minutely scaled in front

5 '. Tarsus coarsely sealed in front.

Ictinia, p. 149.

2 '. Wing with three to five quills cut out on inner webs.

3. Face with owl-like ruff of stiff feathers.

Circus. p. 150.

$3 '$. Face without owl-like ruff of stiff feathers.

4. Iegs feathered to toes.

Archibuteo, p. 162.

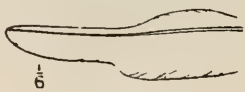

Fig. 218.

$t^{\prime}$. Legs not feathered to toes.

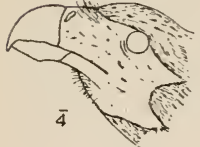

Fig. 219.
5. Nostrils oblique and linear. slanting forward to cutting edge of bill . . . . . Polyborus, p. 171.

5'. Nostrils not oblique or linear.

6. Tail decidedly more than two thirds as long as wing.

7. Lores nearly naked . . Parabuteo, p. 154.

7 '. Lores densely feathered . Accipiter, p. 151.

6 . Tail not more than two thirds as long as wing.

7. Primaries exceeding secondaries by less than naked front of tarsus . Urubitinga. p. 160

$7^{\prime}$. Primaries exceeding secondaries by much more than naked front of tarsus.

8. Adults with under parts barred gray and white; wing less than four times as long as tarsus . . . . . Asturina, p. 161.

$S^{\prime}$. Adults with under parts not barred gray and white; wing more than four times as long as tarsus... . . . Buteo, p. 155. 


\section{GENUS ELANOIDES.}

327. Elanoides forficatus (Linn.). Swallow-tailed Kite.

Wings long, slender, acute; tail forked, and nearly as long as wing;

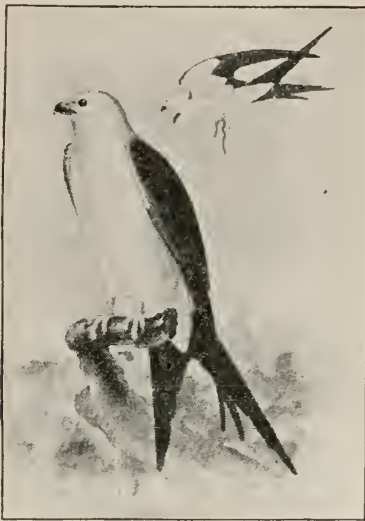

From Biologieal survey, U. S. Dept. of Agriculture.

Fig. 220. feet short but stout; tarsus feathered about half way down in front; bill rather weak. Adults: pure white except for back, wings, and tail, which are blackish, glossed with bronzy purple. Young: head and neck streaked, back brownish, with greenish instead of purple gloss; wings and tail feathers narrowly tipped with white. Length : 19.50-25.50, wing 15.40 17.70, outer tail feathers $12.50-14.50$, bill $.70-.80$.

Distribution. - From Assiniboia south to South America, and, in the United States, from the Carolinas west to the Plains; casually to Colorado and southern New England. Breeds irregularly throughout its United States range.

Nest. - In tops of tall trees, usually near watercourses, made of dry twigs and sometimes of gray moss. Eggs : 1 to 4 , white or buffy, boldly spotted or blotehed, chiefly around larger end, with browns.

Food. - Mainly reptiles and insects.

The swallow-tailed kite lives mainly on the wing and by virtue of its long tail has a remarkably graceful flight. When hunting it flies close to the ground like a marsh hawk, but at other times sails above the treetops, sometimes so far above that it takes a good eye to see it. The kite picks up both food and nesting materials while on the wing, earrying its food in its talons and eating as it goes.

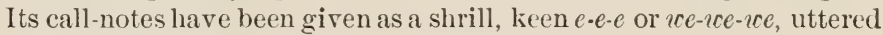
in a high key which carries a long distance.

\section{GENUS ELANUS.}

\section{Elanus leucurus (Vieill.). White-Tailed Kite.}

Bill rather weak and compressed; feet very small; tarsus feathered half way down in front, and below covered with minute roundish seales; claws not grooved beneath; hind toe very short, claws all small and little eurved; wings nearly or about twice as long as tail, pointed, first and second quills emarginate, the feathers broad, obtuse at tips. Adults : under parts white, upper parts plain bluish gray, except for white top of head and tail, and black patches around eye and on shoulders. Ioung: resembling adults, but tinged with rusty, extensively on under parts; upper parts indistinctly streaked; wing feathers tipped with white; tail with an indistinct subterminal dusky band. Length: 15.15-16.75, wing 11.5013.830, tail 5.9(0)-7.40, bill .(6.)-. .80 .

Distribution. - Tropical America, except the West Indies; north in the United States to about the latitnde of San Francisco on the Pacific coast, St. Louis in the interior, and South Carolina in the east. 
Nest. - Generally in live oaks, made of twigs, lined with stubble and grasses. Eggs : :3 to 5, ground color white, heavily marked over entire surface with blotehes of red and brown.

Food. - Small snakes, lizards, frogs, and insects such as grasshoppers and beetles.

The white-tailed kites frequent lowland valleys, breeding when possible near streams or marshes, where they hide their mests in the tops of oaks or willows.

Their Hight, Mr. Chester Barlow says, is graceful and often quite rapid, though it lacks the dash of the falcons. When hunting early in the morning, both birds often go together, when they may be seen hovering motionless in the air like sparrow hawks. Their principal call-note Mr. Barlow gives as a plaintive musical whistle.

The kites are resident in the oak groves of Santa Clara Valley, and frequent the marshes about San Francisco Bay, where Mr. WV. K. Fisher has found them catching large numbers of the Califoruia meadow mouse.

\section{GENUS ICTINIA.}

\section{Ictinia mississippiensis (Wils.). Mississippi Kite.}

Bill small but robust, cutting edge of upper mandible scalloped; wings and tail moderate, two outer primaries emarginate on inner web, and next two sinuate; feet short and stout; tarsus scantily feathered about half way down in frout, then crossed by large seales; outer and middle toes connected by web for whole length of basal joint of niddle toe; claws stout, much curved. Adults : head and band across wing grayish white; under parts dark gray ; upper parts bluish slate, with black tail and long black wing quills; quills with dull reddish brown webbing. Young: head streaked black and white, whiter on throat; under parts whitish, heavily streaked witl dark brown and buffy ; upper parts blackisl, feathers witl convex edges brown, gray, or white; tail and wing quills black tipped with white, and without rufous webbing. Length : $13.00-15.50$, wing $10.60-$ 12.30 , tail $6-7$.

Distribution. - Breeds chiefly in Lower From Biological Survey, U. S. Dept. Souroran zone of the southeastern United States, westward to western Texas, south

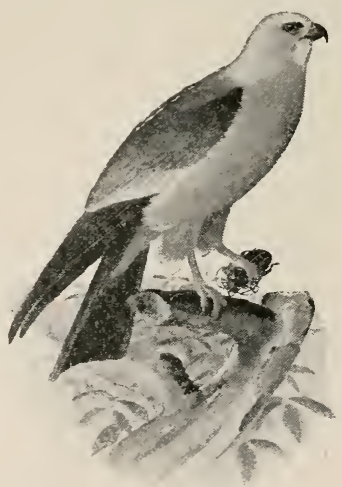
to Guatemala; casually in Upper Sonoran zone to Pennsylvania, Wisconsin, and Dakota.

Nest. - Usually an old one of its own or some other bird, in a ligh treetop; remodeled by patching up the sides with a few sticks and lining with Spanish moss or green leaves. Eggs: 2 or 3, pale bluish green, unspotted.

Food. - Lizards, small snakes, and frogs, together with insects, such as the larger beetles, grasshoppers, and locusts. 
This sturdy little kite, with its quick tlight and graceful form and motions, las much the appearance of a falcon, but its weak bill and talons give it an un-falcon-like character and mode of life. Its prey, instead of being birds and mammals, is mainly of such low order as insects, snakes, and frogs, and its hunting consequently lacks the excitement of the chase. It is seen Hying low over the prairies among the brush patches, or going from tree to tree along the streams.

Vernon BaIlex.

\section{GENUS CIRCUS.}

331. Circus hudsonius (Linn.). Marsh Hawk.

Bill with conspicuous bristles; face encircled by an owl-like ruff of short feathers; tarsus slender, much longer than middle toe and claw; a basal web between middle and outer toes; claws large and sharp, innch curved; four outer primaries cut out on inner webs, second to fifth on outer webs. Adult male: body bluish slate, streaked with white and becoming pure white on rump and belly; under parts lightly specked with reddish brown; tail with 6 or 8 bands, one nearest end widest and blackest; tips of wing black. Adult female and young: brown or rusty, more or less streaked. Length : $19.50-24.00$, wing $12.90-16.00$, tail $8.80-10.50$.

Remarks. - The facial ruff and large white rump patch are enough to distinguish the marsh hawk in any plumage.

Distribution. - Breeds from Alaska and Hudson Bay to the southern border of the United States and winters from about latitude $40^{\circ}$ southward to Panama and Cuba.

Nest. - Usually in a marsh or prairie on the ground among rushes, grass, or bushes, made of dry grass strengthened with sticks and lined sparsely with feathers. Eggs: generally 4 to 6, pale greenish or bluish white, plain, or blotclied and spotted with pale buff and brownish.

Food. - Largely meadow mice, young squirrels, rabbits, and ground squirrels; also lizards, frogs, snakes, birds, and insects.

Marsh hawk and mouse hawk are both appropriate names for these soft-winged still-hunters. Fields, marshes, and prairies are their hunting grounds, and you may see them sailing slowly and smoothly just above the surface of the grass tops, with round owl-like face and large eyes turned to the ground beneath, and wings ready for a quick dive. Woe to the mouse or gopher that moves in the grass under those eyes! Birds are not such easy prey, and few are captured except wounded game birds. Broken-winged quail, grouse, or ducks are not left to suffer long. They are quickly discovered and eaten.

The intelligent farmer usually recognizes the value of this hawk and the fact that it almost never touches his poultry. He sees it skimming over his meadows and diving into the grass for mice, and wisely lets it live; but nevertheless he would be surprised if he could figure out how many dollars it saves him during the year.

Verron BaIlex. 


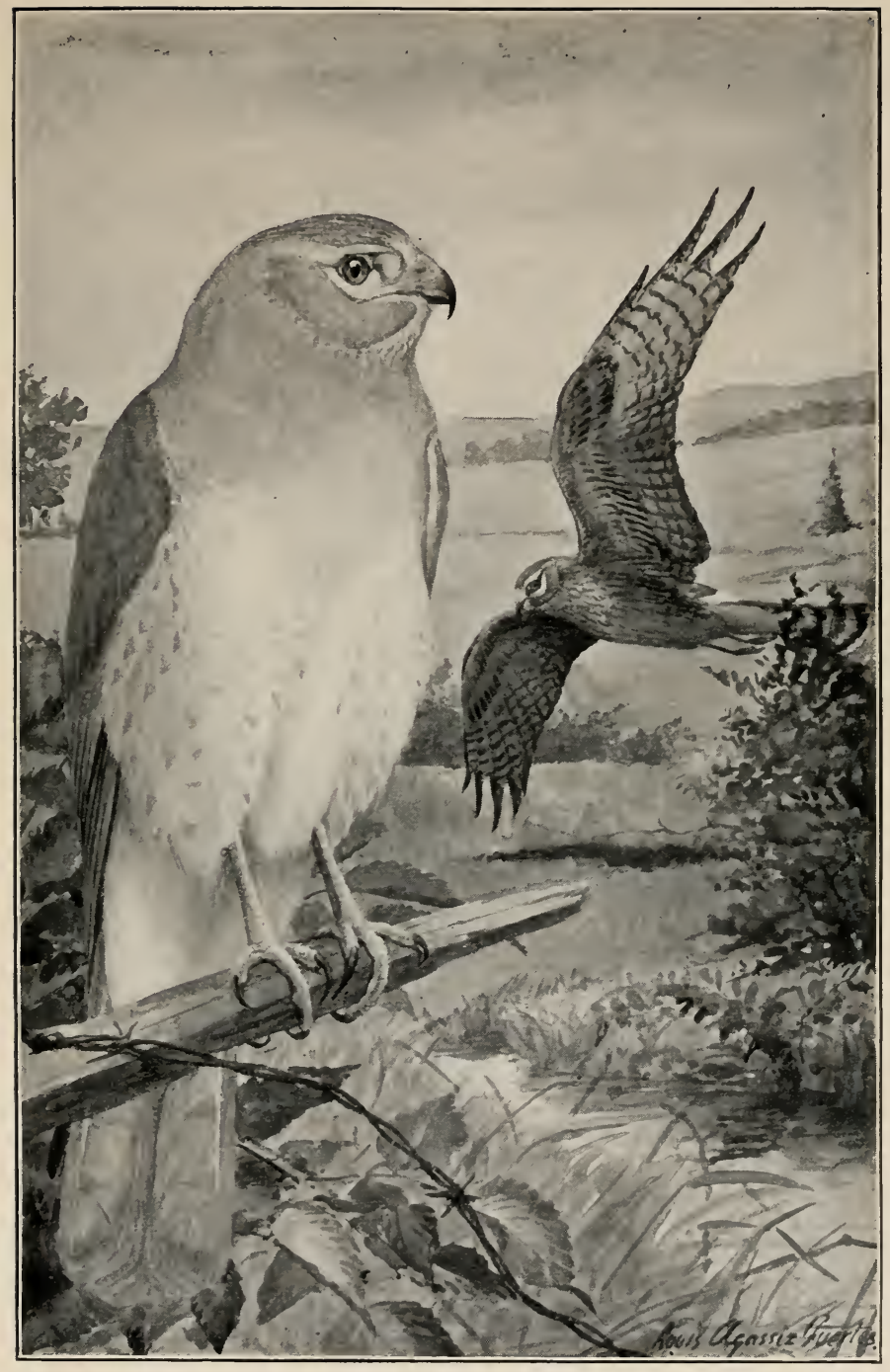

MARSH HAWK 



\section{GENUS ACCIPITER.}

General Characters. - Head small, wings short, tail and legs loug; three to five outer primaries eut ont on immer webs; tail s(juare or rommled, about equal to length of wing.

\section{KEY TO ADULT MALES.}

1. Under parts gray. finely barred with zigzag lines.

2. Upp:r parts clear bluish gray .

atricapillus, p. 1;2. 2'. Upper parts slaty blue inclining to sooty . . . striatulus, p. 15:). 1'. Untler parts white, coarsely barred with reddish brown.

2. Tail rounded

$2^{\prime}$. Tail even or emarginate.

cooperii, p. 15:. velox, p. 1ij 1 .

\section{Subgenus Accipiter.}

Length 20 or less; tarsus feathered for one third or less of its length.

\section{Accipiter velox (Wils.). Sнarp-shinned HaWk.}

Adult male. - Under parts white, heavily barred and spotted with reddish browu; upper parts nearly uniform bluish gray; tail even or slightly notched. with three or four narrow blackish bands, and narrow white tip. Adult female: similar, but duller. less blue above, less reddish below. Young: upper parts dark brown, edged with rusty and with hints of white spotting; under parts white, often tinged with bnffy, streaked vertically with brown; sides and flanks barred with redish brown. Male: length $10.0(1-11.5)$.

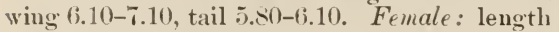
12.50-14.00, wing $7.80-8.80$, tail $6 .(60)-8.20$.

Remarks. - The young are decidedly larger than the adnlts, and the breast markings are vertical instead of horizontal.

Distribution. - Breeds throughout the United States, and in the British provinces as far north as the Aretic eircle; winters from $40^{\circ}$ nortl ; southward to Guateniala.

Vest. - A remodeled one of crow, magpie. or squirrel, or if new. made of dry sticks sparsely lined with inner bark or green leaves; placed usually in a dense conifer, about twenty feet

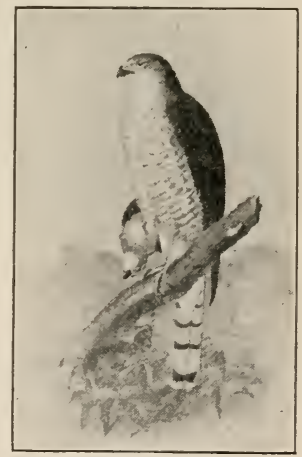

From Biologieal survey, U.S. Dept. of Arriculture.

Fig. 22:. from the ground. Eggs: 4 or 5, pale bluish or greenish white, fading to dull grayish white, most irregularly and heavily blotched, spotted, and nuabled with brown; in some specimens gronnd color almost hidden by confluent brown markings.

Food.-Chiefly birds and young poultry, with a few nice, reptiles, batrachians, and insects.

Among the hawks the sharp-shimerl is a veritable bushwliackser. His light body, short wings, and long tail enable him to louble and turn among the brush and branches, and in a noiseless, fox-like way pounce orer a hedgerow or brush heap into the midst of a flock of sparrows, swoop under the low branches and pick his bird from the ground, or dart through the treetops and snateh one in mirl air from the mirlst of a startled Heck. 
His small size is so much more than compensated by his audacity that one bird often becomes the terror of a poultry yard, taking the small and half-grown chickens regularly and sometimes killing and eating a full-grown hen of many times its own weight.

\section{Verion BaIley.}

\section{Accipiter cooperii (Bonap.). Cooper Hawk.}

Adult male. - Under parts white, heavily spotted and barred with red-

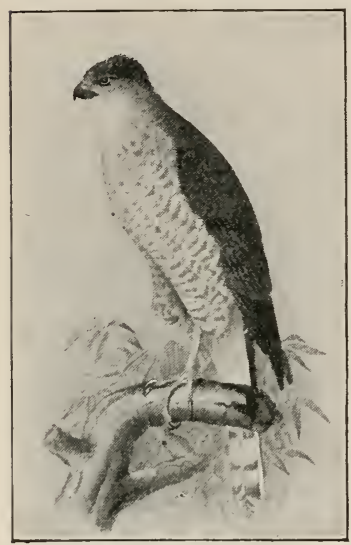

From Biological Survey, U. S. Dept. of Agriculture.

Fig. 223.

dish brown; top of head black contrasted with bluish gray of back; tail rounded, with 3 or 4 black bands and narrow white tip. Adult female: upper parts duller and less bluish than in male; top of head more brownish black; hind neck and sides of head washed with dull rusty. Young: upper parts dark brown, with rusty edgings and suggestion of white spotting; under parts streaked vertically. Male: length 14-17, wing 8.85-9.40, tail 7.80-8.30. Female: length $18-20$, wing $10.10-11.00$, tail $9.00-$ 10.50 .

Distribution. - Breeds throughout the United States and southern British Provinces, wintering regularly from about latitude $40^{\circ}$ southward to southern Mexico, though oceasionally staying in southern Canada.

Nest. - In trees, 20 to 50 feet from the ground, often a remodeled one of other hawks, crows, or squirrels, bulky, made of large sticks and lined with rough outer bark. Eggs: usually 4 or 5, pale bluish white to greenish white, unspotted or faintly and irregularly scrawled with brown or pale buffy.

Food. - Almost entirely wild birds and poultry, but occasionally small mammals, reptiles, batrachians, and insects.

"Cooper's hawk, which resembles the sharp-shinned hawk closely in everything except size, is less northern in its distribution. . . . The food of this hawk, like that of its smaller congener, consists almost entirely of wild birds and poultry, though from its superior size and strength it is able to cope successfully with much larger birds, and hence is much more to be dreaded. . . . The flight of this species is very rapid, irregular, and usually is carried at no great height from the ground, in all these particulars closely resembling that of the sharp-shinued hawk." (Fisher.)

\section{Subgenus Astur.}

Length over 20 ; tarsus feathered for about one half its length.

334. Accipiter atricapillus (Wils.). American Goshawk.

Bare portion of leg in front shorter than middle toe; wing more than 
12 inches. Adults: under parts with whitish ground uniformly covered with finely penciled gray zigzags, touched up with dark shaft streaks; upper parts dark bluish gray, with black shaft streaks, and becoming black on head; tail bluish gray, more or less tipped with white and crossed by about four dusky bands, sometimes obsolete on the upper surface. Young: upper parts dull brown, head and neck streaked with buffy salmon, and rest of upper parts spotted and edged with pale buffy and whitish ; under parts bright buffy, broadly streaked with dark brown. Male: length 22.00 , wing $12.00-13.25$, tail $9.50-$ 10.50. Female : length 24.50, wing 13.50 14.25 , tail $11.50-12.75$.

Distribution. - Breeds in northerm and eastern North Anerica, chiefly north of the United States but west to eastern parts of Washington and Oregon, and south in the Rocky Mountains as far as central New Mexico.

Nest. - Placed high up in a large

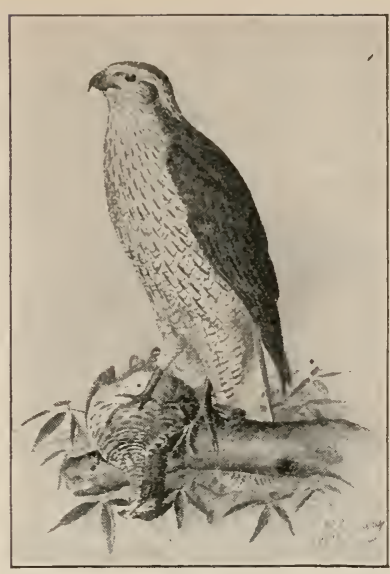

From Biological survey, U. S. Dept. of Agriculture.

Fig. 224. Goshawk.

tree, generally an evergreen, a bulky compact mass of twigs, lined with soft imner bark, weed stalks, or leaves, surrounded by loosely arranged sticks. Eggs : 2 to 5 , pale bluish white, unspotted.

Food. - Rabbits and other rodents, but mainly poultry, ducks, grouse, and smaller birds.

As the goshawk breeds in the mountains or in the far north it is little in evidence except in winter, but then it comes down into the valleys and even out over the deep snow of the middle prairies.

Game birds and poultry suffer more from it than from any hawk, and its rapid flight, size, strength, and daring combine to make it the most destructive of the American birds of prey.

\section{4a. A. a. striatulus Ridgw. Western Goshawk.}

Like A. atricapillus but darker; upper parts from dark bluish gray to sooty black; under parts dark gray, more heavily mottled, and marked with dark shaft streaks; belly and thighs barred. Young: upper parts brownish black, with buffy and rusty streakings and edgings; stripes on lower parts broader than in A. atricapillus, and deep black; tail with four blackish bands.

Distribution. - From Sitka south to Califormia and Idaho, and east to Colorado.

Nest. - In tall trees, made of sticks lined with juniper or other bark, grass, tree moss, weed stalks, and pine needles. Eggs : 3 to 5, indistinguishable from those of $A$. atricapillus.

Food. - Especially game birds, such as sooty, ruffed, and sharp-tailed grouse.

"According to my observations, the general habits of the western 
goshawk are very similar to those of its castem relative. It is equally destruetive to small game of all kinds . . . as well as to the fowls of the poultry yard. While nowhere abundant, it seems to be pretty generally distributed throughout the Blue Mountain region of Oregon and Washington, and breeds in suitable loealities where food is plenty. During spring and summer it is seldom seen in the more open districts, though it is abundant enough later on, when the heavy snows drive the game into the foothills and lower valleys. . . Besides a shrill seream of anger, they have a call-note resembling the word 'keeah, kecah,' or 'kree-ah,' frequently repeated, this note being often uttered in the early spring." (Bendire.)

\section{GENUS PARABUTEO.}

335. Parabuteo unicinctus harrisi (Aud.). Harris Hawk.

Lores nearly naked and bristled; middle toe much shorter than naked front of tarsus; inner webs of five outer quills cut out. Adults: upper parts dark brown, reddish broun on shoulders, under wing coverts and thighs; tail black with white base, white coverts, and broad white band at tip. Young: under parts broadly streaked with dark brown on buffy and whitish ground; upper parts dark brown, streaked on head and neck with yellowish brown; back marked with rufous, scapulars deep rufous; rump white; tail like adult, but with white terminal band narrower, and imer webs of feathers barred. Male: length 17.50-21.00, wing 12.35-13.75, tail 9.80-10.20, bill .90-.95. Female : length 21-24, wing 14.25-14.50, tail 10.8()$\div 11.00$, bill $1.08-1.10$.

Distribution. - From Mississippi to southern California, and south throngh Lower California and other parts of Mexico to Panama.

Nest. - A platform of sticks, lined with grass, bark, moss. and roots placed in cactus, Spanish bayonet, mesquite, or other trees. Eggs : 2 to 4 . soiled white, occasionally greenish, unmarked, or spotted lightly with pale brown or lavender.

Food. - Largely offal, mammals, small reptiles, and occasionally birds.

In southern Texas the rieh rufous marks and swift, clear-cut flight of the Harris hawk soon become pleasantly familiar, for he is one of the hawks that are both common and tame on the coast prairies. He is so tame that as you drive by a telegraph pole on which he is perching he will sometimes stand calmly on one foot looking down upon you with statue-like indifference. In the mesquite thiekets you may meet one at elose quarters as he dashes under the thorny bushes in quest of wood rats, ground squirrels, and the small game that abounds in these dwarf forests: and sometimes, as happened one day when we drove along the Nueees River, you will see him sitting on a low branch feasting on a wood rat captured at the door of its stick house close by. If you chance near the hawks' nest a long harsh Buteo-like scream may make you look up to find one or both anxious birds circling overhead. A nest that was pointed out to me by the owners in Texas was in the top of a moss-hung hack- 
berry, and on climbing the tree I found a heary platform of sticks three feet wide lined with spanish moss. The young blundered out on my approach, showing the nest to be fairly covered with bones of wood rats. There were a dozen skulls, and bones, legs, skin, and fur were strewn over the nest.

Verron Bathey.

\section{GENUS BUTEO.}

General Characters. - Size medium and large, form heavy ; wings longer than tail; entarginate primaries :3 or 4 ; sexes alike or similar; fenale larger than male; melanism frequent.

\section{KEY TO ADULT MALES.}

1. Three outer primaries with imer webs distinctly eut out

2. Primaries exceeding secondaries by nearly length of tail.

$$
\text { sennetti, p. 1.:8. }
$$

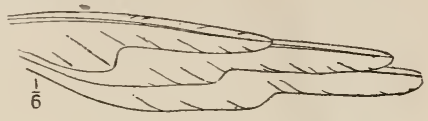

Fig. 2:5.

2 . Primaries exceeding secondaries by much less than length of tail.

3). Wing over 14

3 . Wing under 11.50 .

$1^{\prime}$. Four outer primaries witlı inuer webs eut out.

2. Outer webs of primaries spotted with white, buffy, or brownish . . . . . . . elegans, p. 157.

2 '. Outer webs of primaries without white, buffy, or brownish spots, but with quadrate bands.

3. Tail black or blackislı, crossed by white zones.

abbreviatus, p. 157 .

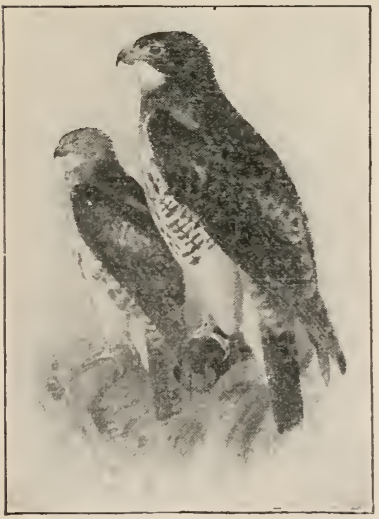

From Biological Survey, U. S. Dept. of Agriculture.

Fig. 228.

:?. Tail with more or less of reddish browu.

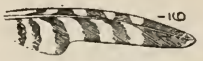

Fig. 226.

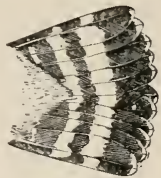

Fig. 227.

4. Upper parts strikingly marked and spotted with white. kriderii. p. 156 .

f'. Upper parts not strikingly spotted with white.

¿. Tail dark rufous.

borealis, p. 155 .

5'. Tail pale rufous. calurus, p. 156.

\section{Buteo borealis (Gmel.).} Red-Tailed HaWk.

Adults. - Upper parts blackish brown, with white and gray markings; tail reddish brown, usually with black subterminal band; under parts white to blackish, with or without rusty on breast. Young: tail gray, crossed by 6 to 10 dark bands; belly erossed by blackish zone. Male: length $19.00-2.250$, wing $13.50-16.50$, tail $8.50-10.00$, bill $.95-$ 
1.08. Female : length 23-25, wing 15.25-17.75, tail 9.50-10.50, bill $1.00-$ 1.15 .

Distribution. - Eastern North America, west to the Black Hills and Colorado, and south to northeastern Mexico. Breeds nearly throughout its range.

Nest.-Usually in tall trees. Eggs: 2 to 4, white or bluish white, more or less spotted or blotched with brown.

Food. - Mainly mice, ground squirrels, and other injurious mammals.

The eastern red-tail goes as far west as Colorado.

\section{7a. B. b. kriderii Hoopes. Krider Hawk.}

Adults. - Under parts entirely white or pale buffy; upper parts browu, largely marked with white; tail pale rufous, usually without subterminal band. Young: similar, but tail tipped with white and with about ten dark brown bands, feathers more or less tinged with reddish brown and with inner webs largely white between bands. Size of $B$. borealis.

Distribution. - Great Plains, from Minmesota to Texas, and from IVyoming east casually to Illinois.

Nest and eggs similar to those of the red-tail.

\section{7 b. B. b. calurus (Cass.). Western Red-tail.}

Adults. - Varying greatly in plumage - Light extreme: under parts white or buffy, with broad reddish brown streakings on throat, belly, and sides; tail bright reddish brown, with one or more subterminal blackish bars; rest of upper parts dark brown, more or less marked with yellowish brown and whitish. Dark extreme: uniform dark sooty brown except for rufous tail. Intermediates : reddish brown underneath, and with more or less reddish brown wash on upper parts. There are also all grades of plumage in this form between the light and dark extremes. Young: tail grayish brown varying to dull yellowish brown, crossed by 9 to 10 blackish bands; rest of plumage dark brown heavily spotted beneath, sometimes wholly dusky. Male: length $19.00-22.50$, extent of wings $49-53$, wing $13.50-16.50$, tail 5.50-10.00, bill .95-1.08. Female: length 2:3-25, extent 54.00-57.50, wing 15.25-17.75, tail 9.50-10.50, bill $1.00-1.15$.

Distribution. - Wester'n North America, from the Mississippi valley, casually east to Illinois, west to the Pacific, and south to Guatemala.

Nest. - Sometimes used a number of years, made of sticks and lined with roots or inner bark, placed usually 30 to 50 feet from the groumd, generally in decidnous trees, but also in evergreens and giant cactus, and occasionally on cliffs. Eggs: usually 2 or 3 , creamy white or bluish white, unspotted or irregularly blotehed with yellowish and reddish brown.

Food. - Rabbits, ground squirrels, chipmunks, mice, snakes, lizards, frogs, grasshoppers, and other insects.

"The western red-tail, though nowhere very abundant, is pretty generally distributed over western North America at large, and is, next to Swainson's hawk, the commonest of the larger raptores found in these regions. . . . It is fond of the tall timber bordering the banks of streams, and is as often found far in the momtain passes and deep canyons as in the more open country in the foothills and the aljacent plains, but seems to shum the dense and extensive forests, and is rarely seen except on the borders of these. In some of the 
desert regions of western Texas, southern New Mexico, and Arizona, it is not infrequently met with at long distances from water, and las eren been found breeding in such localities. . . . It is one of the earliest migrants to return to its breeding grounds, arriving about the latter part of February or the first week in Narch, and is readily noticed then, both on account of its size and its shrill squeals, uttered during the greater part of the day while circling high in the air, in proximity to its future summer home. They appear to be very much attached to certain localities and return to them front year to year. . . . In Washington, Idaho, Oregon, and California it lives principally on the different species of ground squirrels so comnon and destructive in these states." (Bendire.)

Mr. Grinnell says that this hawk, in common with other species, is popularly known as henhawk or chickenhawk and is relentlessly killed wherever chance is offered, and he adds that he attributes the great local increase in ground squirrels in part at least to the destruction of hawks and owls.

\section{9b. Buteo lineatus elegans (Cass.). Red-bellied Hawk.}

Adults. - Under parts bright reddish brown, usually plain across breast, lightly barred with white below; upper parts dark brown, streaked with white or rusty yellowish brown; shoulders reddish brown; wings and tail banded with white. Young: spots of buffy or yellowish brown on outer webs of wing quills. Male : wing 12.00-12.50, tail \$-9, bill .78. Female : wing 13 , tail 9.50 , bill .90 .

Distribution. - From British Columbia south to Lower California and northern Mexico; and from western Texas to the Pacific.

Nest. - Of twigs or sagebrush lined with leaves, pine needles, inner bark, and feathers ; placed in trees and giant cactus. Eggs : 2 to 5, white, marked lightly with lavender and brown.

Food. - Lizards, frogs, grubs, and insects; and sometimes small birds.

The red-bellied hawk usually makes its home in trees along river banks, especially in oak and willow regions, where it may be seen moving with a heavs flight suggestive of the owls.

In speaking of its food habits, Mr. Lyman Belding says that he once shot one of a pair that had for three years nested less than two hundred yards from a poultry jard, and on examination of its stomach found only small lizards, tree-frogs, grubs, and insects.

When disturbed at its nest, IIajor Bendire says, the red-bellied gives a shrill yee-ak, yee-al, repeated rapidly in a high kej.

\section{Buteo abbreviatus Cab. Zone-tailed Hawk.}

Adults. - Whole bird uniform black or blackish brown, feathers pure white at bases; tail crossed by three broad lighter zones, which are gray on outer and white on inner webs of feathers. Young: tail dark grasish brown instead of black, inner webs sometimes entirely white; crossed by numerous black narrow oblique lines. Male: length 18.50-19.60, extent 49.50, wing 15.00-15.60, tail 8.50-9.15. Female : length 20.85-21.50, extent 53.10 , wing $16.50-17.40$, tail $9.00-10.75$, bill $.90-1.00$. 


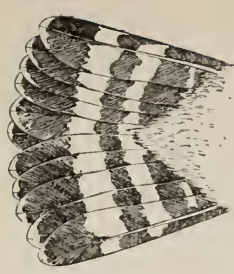

Fig. 229. Tail of Zonetailed Hawk.

Distribution. - From Sonthern California to Texas, and south to northern South America.

Nest. - On rock cliffs or in cottonwoods near streams, made of twigs lined with Spanish moss. green leaves, or inner bark of the cottonwood. Eggs : 1 to $:$, pale bluish white, mostly unspotted.

Food. - Small mammals, lizards, frogs, and fishes.

Major Bendire states that one or two pairs of the zone-tailed hawks may usually be found living in each of the larger cottonwood groves of Arizona, but that few are ever found far from the banks of streams. In southern Texas and New Mexico the hawks frequent canyons, where they circle about scouring the clifis, or, mounting ligh in the air, dive screaming almost to the water in the bottom. Their cry, which is loud and piercing, is said to resound commandingly through the canyons.

Fifty miles south of the Arizona line Mr. Price encountered a fire in the marsh-lands and canebrakes which brought hundreds of the zone-tails to feed on the cotton rats and other rodents driven out by the lieat. Some of the lawks circled high in the air over the flames, while others wheeled and plunged into the dense black smoke for their pres.

\section{Subgenus Tachytriorchis.}

Three outer primaries cnt out.

\section{Buteo albicaudatus sennetti Allen. Sennetr White- TAILED HAWK.}

Adult male. - Pure white on under parts, rump, and tail, except for black subterminal tail band, the white in places lightly scored with narrow dusky bars; upper parts dull bluish gray, wing coverts marked with rifous, quills blackish; three outer quills cut out on inner web. Adult female: similar, but rufous patch on wing coverts more extended, and colors generally darker. Young: brownish black, shonlders marked with reddish brown; moler parts marked with whitish buffy and yellowish brown; thighs buffy brown; tail gray, darkening toward end, and becoming rusty at tip, scored faintly with narrow dusky bars. becoming obsolete toward base of tail. Male: wing 14.50-16.75, tail 7.50-9.00. Female: wing 17.00-17.75, tail $8.25-10.30$, bill $.95-1.05$.

Distribution. - From sonthern Texas and Arizona sontl to Mexico.

Nest. - A platform of twig's almost without lining; placed in yucca tops, chaparral, or small trees on the prairie. Eggs: 22 or :3, dingy white. lightly marked with spots of pale brown.

In driving over the treeless prairic of souther Texas day after day, one of your keenest pleasures is to sight, across a long level foreground, the shining white breast of a stately white-tailed hawk. He stands on the ground, perches on a low bush, or perhaps on a fence post, if anything so high offers. Strikingly liandsome in repose, when he flies up as you drive near, his white tail with its black triminal band adds unique distinction to his appearance. 


\section{Buteo swainsoni Bonap. Swanson Hawk.}

Adult male in normal plumage: throat and belly white, white of throat sharply contrasted with reddish broun chest band; upper parts nearly uni-

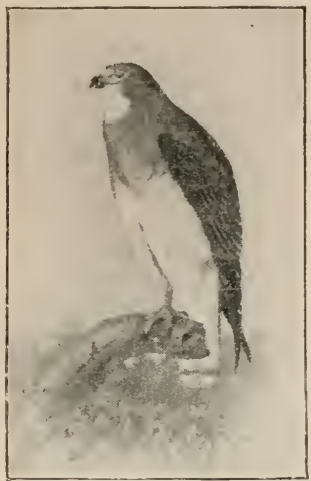

From Biological survey, U. S. Dept. of Agriculture. Fig. 230.

form dark grayish brown; tail crossed by abont 9 or 10 narrow blackish bands. Adult female in normal plumage: like male, but rhest patch grasish brown instead of rufous. Melanistic phase, both sexes: whole plumage uniform sooty brown. under tail coverts sometimes spotted or barred with rusty or whitish. Every possible gradation is shown by different individuals between this black phase and the light colored normal plumage. Young: upper parts blackish brown varied with buffy or yellowish brown; head, neck, and under parts bnffy brown, head and neck streaked with blackish; under parts usnally more or less blotched with blackish. Male: length 19.5020.00 . extent 45.00-50.50, wing 14.40-16.00, tail \$-9, bill .\$0-.90. Female: length 21-22, extent 50.50-56.00, wing $14.75-17.25$, tail $9-10$, bill .80-.95.

Distribution. - From the arctic regions sonth to Argentina; in the United States from the Pacific to Wisconsin, Illinois, and Arkansas; casually to Massachusetts. Migratory north of South Dakota and Nebraska.

Nest. - In cotton woods and other trees, and also in bushes and on rocks, made of sagebrush. willow, or other sticks, lined largely with green leaves and bark. Eggs: 1 to 4. greenish white, fading to yellowish, spotted inconspicuonsly with different shades of brown.

Food. - Almost entirely small rodents. principally striped gophers and mice, together with grasshoppers and crickets.

"On the arid wastes and tablelands of southern Arizona, as well as in the sage and bunch grass districts of Nevada, Oregon, Washington, and Idaho, Swainson's hawk is especially abundant, outnumbering, perhaps, all the otlrer Raptores of these regions combined. It is eminently a prairie bird, shunning the densely timbered mountain regions, and being more at home in the sparingly wooded localities usually found along the watercourses of the lowlands.

"Compared with the majority of our hawks it is gentle and unsuspicious in disposition, living in perfect harmony with its smaller neighbors. It is no unusual sight to find other birds, . . . nesting in the same tree; and the Arkansas kingbird goes even farther than this, sometimes constructing its home . . . under the nest of these hawks or in the sides of it.

"The food of Swainson's hawk consists almost entirely of the smaller rodents, principally striped gophers and mice, as well as grasshoppers and the large black cricket, which is rery common as well as destructive in certain seasons, and the bane of the farmers in eastern 
Oregon, Washington, Idaho, Nevada, and other localities in the Great Basin, destroying and eating up every green thing as they move along. . . .

"I cannot recall a single instance where one of these birds visited a poultry yard. . . . From an economic point of view I consider it by far the most useful and beneficial of all our hawks." (Bendire.)

During the migrations flocks of one or two hundred Swainson hawks are sometimes seen on the ground catching grasshoppers.

\section{Subgenus Buteola.}

\section{Buteo platypterus (Vieill.). Broad-winged Hawk.}

Adults. - Upper parts dark brown, wing quills and tail blackish, tail narrowly tipped with white, and with 2 to 4 broad grayish bands; under parts from dark brown to rusty or rufous. Young: tail narrowly tipped with white and erossed by 5 to 7 blackish bands; sides of head and under parts dull white or buffy, marked with long dark streaks, cordate spots on sides, and barring on thighs. Male: length 13.25-15.00, wing 9.85-10.70, tail $6.50-7.00$, bill .70. Female : length 16-18, wing $11.00-11.40$, tail 7-8, bill .70-.80.

Remarks. - In normal plumage the broad-winged and the Swainson suggest each other, but differ in the much smaller size of the broad-wing, as well as the white belly and thighs, and 9 or 10 tail bands of the Swainson.

Distribution. - Breeds in eastern North America from New Brunswick and Saskateliewan south - mainly east of the Mississippi - to Mexico; nigrating through Central America and the West Indies to northern South America. Recorded from $101^{\circ}$ in Texas.

Nest. - In trees, generally not more than 25 feet from the ground; of sticks, lined largely with strips of bark or leaves. Eggs: usually 2 or 3 , grayish or pale greenish, marked irregularly with lavender, pearl gray, and sometimes brown.

Food. - Ground squirrels, wood mice, field mice, shrews, moths, grasshoppers, crickets, and beetles.

The eastern broad-wing has been found along wooded rivers in western Texas.

\section{GENUS URUBITINGA.}

345. Urubitinga anthracina (Licht.). Мехісал Вцаск НАшк.

Tail about two thirds as long as wing, emarginate or nearly even; 4 outer primaries sinnate on inner webs; primaries exceeding secondaries by less than length of naked front of tarsus; tarsus much longer than middle toe and claw, only feathered for a short distance.

Adults. - Whole bird black except for tail, which has a white base, tip, and medium cross band. Young: under parts buffy, streaked with blackish; thighs heavily barred with blackish; upper parts blackish, streakerl with whitish, bnffy, and rnfons; tail banded obliqnely with black and white. Male: length 21.50, wing 13.15-14.90, tail 7.90-9.75, bill 1.00-1.05. Female: length $20.00-22.50$, wing $14.25-16.00$, tail 9.2.5-11.00, bill $1.05-$ 1.10 .

Distribution. - From Arizona and the Lower Rio Grande Valley in Texas south to northern Sonth Anerica.

Nest. - Bulky, of sticks and herbage, lined with dry leaves, and placed 
in a large tree near the border of a stream. Eggs : usually 2, white, irregularly blotched with brown, chiefly around the larger end.

Food. - Small mammals, reptiles, crustacea, insects, and rarely birds.

In Arizona Dr. Mearns usually found the anthracite or Mexican black hawk hidden in the foliage near water. Occasionally he saw one eating fish on the sandy margin of a river. They are very shy, he says, and their flight is swift and powerful.

\section{GENUS ASTURINA.}

\section{Asturina plagiata Schlegel. Mexican Goshawk.}

Proportions of Buteo but coloration of Astur; wings less than 4 times as long as tarsns : four outer primaries cut out on inner webs, second to fifth cut out on outer webs; tail even, long; about three fourths wing; legs long, as in Accipiter; feet stout.

Adults. - Under parts, except for white under tail coverts, everywhere barred gray and white; upper parts plain ash gray or very faintly barred; top of head and back of neck with five blackish shaft streaks; wing quills and upper tail coverts white, tail blackish, tipped with white, and crossed by 2 or 3 white bands. Young: under parts white, broadly streaked except on throat, and tinged with pinkish buff on sides and under wings; upper parts sooty brown, head and neck streaked, and wings spotted with buffy; upper tail coverts white; tail grayish brown, tipped with whitish, and crossed by 6 or 7 black bands. Iength: 16-18, wing 9.50-11.70, tail $6.70-8.20$, bill .75-1.00.

Distribution. - From southwestern border of United States to Panama.

Nest. - Of fresh cottonwood twigs with leaves attached, lined with dry leaves and strips of bark. Eggs: usually 2, pale bluish white, unspotted.

Food.-Ground squirrels, mice, birds, small reptiles, and insects.

The Mexican goshawk frequents open grores and the edges of timber, especially near watercourses.

Near Tucson, Arizona, Major Bendire had a good opportunity to study its habits. From the middle of April, he says, "not a day passed without my seeing two or three pairs of these handsome little goshawks (which were readily recognized by their light color) engaged in sailing gracefully orer the treetops, now sportively chasing each other, or again circling around, the female closely followed by the male, uttering at the same time a very peculiar piping note, which reminded me of that given by the long-billed curlew in the early spring (while hovering in the air in the manner of a sparrow hawk), rather than the shrill cries or screams usually uttered by birds of prey. To my ear, there was something decidedly flute-like about these notes. . . When in search of food, their flight is powerful, active, and easily controlled. I have seen one of them dart to the ground with arrow-like swiftness to pick up some bird, lizard, or rodent, continuing its flight without any stop whatever." 
Beetles and grasshoppers are caught by them on the wing, and twigs for their nests are broken off as they fly rapidly by.

\section{GENUS ARCHIBUTEO.}

General Characters. - Like Buteo, but tarsus feathered in front and on sides down to base of toes; wings long, four or five quills emarginate on inner webs.

\section{KEY TO SPECIES.}

1. Bill small and weak, gape across corners of bill only 1.35-1.4.).

$1^{\prime}$. Bill larger and stronger, gape across corners of bill 1.70-1.90.

sancti-johannis, p. 16:.

ferrugineus. p. 16:3.

347a. Archibuteo lagopus sancti-johannis (Gmel.). RovGHLEGGED HAWK.

Adults, normal phase. - Under parts varying from whitish to yellowish brown, more or less spotted with blackish, most heavily on breast; upper

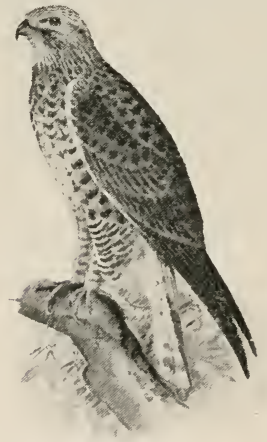

Fig. 231. parts grayish brown or dark brown, streaked with white and reddish brown; tail with base and upper coverts white and end with subterminal dusky band; wing quills with outer webs silvery gray. Toung, normal plumage: similar to adults, but end of tail plain gravish brown, the basal part plain whitish ; under parts whitish or buffy, crossed on belly by a broad belt of uniform dark brown. Melanistic phase in both young and old - connected with normal plumage by every variety of intermediate character - entirely deep black except for white forehead, white on inner webs of quills above enrargination, and narrow broken bands across base of tail. Male: length 19.50-2.2.00, wing 15.75-16.80, tail 9-10. Female : length 21.5023.50 , wing $16.15-18.00$, tail 9-11.

Remarks. - The white upper tail coverts and large size are good field characters.

Distribution. - Whole of North America north of Mexico, but breeding almost wholly north of the United States.

Nest. - Made of large sticks lined with grass, leaves. or feathers, in trees or on cliffs. Eggs: 2 to 5, greenish white, fading to dingy white, irregularly marked with blotches of brown and sometimes lavender.

Food. - Principally small rodents, such as mice and lemmings.

The rough-legged hawk is known mainly as a winter bird in the United States, coming down with the fall migrants and spreading over the country where he can find food to suit his taste, often remaining all winter in the northern states where the deep snow and intense colel drive less hardy species away. Where trappers are at work he finds plenty of food in the freshly skinned or frozen bodies of muskrats and other fur mammals left lying by the streams and lakes: but he is not dependent upon such supplies. He keeps 
mainly within the country inhabited by meadow mice, and at the season when they are at their worst eating the roots of the crops and gnawing the bark of fruit-trees under the snow he devotes himself to their destruction.

Dr. Fisher says that the rough-leg is one of the most nocturnal of our hawks, and that it "may be seen in the fading twilight watching from some low perch, or beating with measured, noiseless tlight, over its hunting ground."

\section{Subgenus Brewsteria.}

\section{Archibuteo ferrugineus (Licht.). Ferrugrous Rough- LEG: SQUIRREL HaWK.}

Adults, normal phase: under parts white. sometimes slightly streaked with brown; upper parts and flanks reddish brown; tail white. more or less stained with reddish brown, and sometimes marked with a subterminal band. Adults, melanistic phase: tail normal; upper parts chocolate brown, marked with rusty; under parts rusty and chocolate. Young: upper parts gravish brown, feathers edged with rusty or yellowish brown; flanks white, more or less spotted with dusky; tail whitish for basal third, the rest brownish gray, usually with several more or less distinct dark bands. Male: length 22.50, wing $15.90-17.00$, tail 9.5010.00. Female: length 24, wing 17.00-18.80, tail 10.50-11.00.

Distribution. - From the eastern Dakotas and Texas to the Pacific, and from the Saskatchewan to northern Mexico; casually to Illinois.

Nest. - Of sticks and herbage, lined with softer materials. Eggs: 2 to 5, creamy or pale greenish, irregularly blotched with different shades of brown and lavender.

Food. - Almost exclusively small manmals and reptiles, but also crickets.

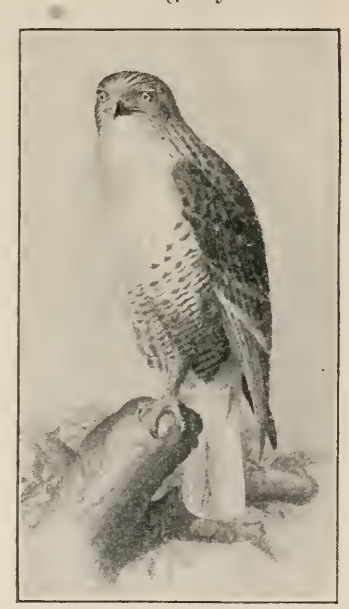

From Biological survey, U. S. Dept. of Agriculture.

Fig. 232.

"The squirrel hawk is preëminently a bird of the prairie, and, unlike the common rough-leg, shows little partiality to the vicinity of water, though in other respects it closely resembles the latter bird in habits. When this hawk is hunting its flight appears labored and heavy, but when circling high in the air its flight is graceful, and resembles closely that of the golden eagle. In fact, in parts of the west it is known by the name eagle." (Fisher.)

\section{GENUS AQUILA.}

349. Aquila chrysaëtos (Linn.). Golden EAgLe.

A bird of great size, robust form, and powerful physique. Tarsus closely 
feathered all around to the toes, outer and middle toes webbed at base;

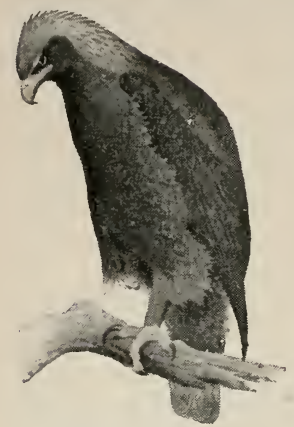

From Biological Survey, U. S. Dept. of Agriculture.

Fig. 233. Golden Eagle. bill large, long; wings long, pointed; tail moderate, rounded, or graduated; feathers of occiput and nape lanceolate. Sexes alike. Adults : whole bird dark brown, lanceolate feathers of hind neck and those on legs lighter brown; wing quills black; tail blackish, more or less clouded or irregularly banded with grayish. Young: like adult, but basal part of tail plain white, under parts white beneath the surface. Male: length $30-35$, extent about $6 \frac{1}{2}$ to 7 feet, wing $23.00-24.70$, tail 14-15, bill 1.50-1.62. Female: length 35-40, extent about 7 to $7 \frac{1}{2}$ feet, wing $25-27$, tail $15-16$, bill 1.68-1.S5.

Distribution. - Northern portion of northern hemisphere, chiefly in mountainous regions; sonth in North America to central Mexico. Breeds throughout its range.

Nest. - A platform of sticks lined with straw, grass, moss, leaves, fur, or feathers, placed in high trees or ou a ledge of a cliff. Eggs: usually 2, white, irregularly marked, some almost immaculate, others thickly blotched with brown.

Food. - Mainly mammals and birds, including squirrels, prairie dogs, spermopliiles, rabbits, fawms, lambs, turkeys, grouse, and waterfowl.

In his mountain home the golden eagle scours the ridges and sides of precipices for grouse and marmots, and when these become scarce or too wary from long acquaintance with his raids, he descends like a meteor on half folded wings to the valley, where he beats the sagebrush for jack rabbits, sage grouse, or any game worthy of his royal quest.

The eagles are often seen hunting in pairs, and doubtless find mutual advantage other than companionship in the method. In Salt Lake Valley, at the foot of the Wasatch Mountains, a pair were once found eating a full grown gray fox they had just killed. which it is doubtful if either could liave caught or overpowered alone. Under stress of hunger or when game is scarce, the birds are said to take young lambs or kids, and even to eat animals found dead on the prairie, in this way getting the poison put out for coyotes. But only extreme necessity could make them stoop to such ignominious quarry, as nothing short of the extermination of the buffalo and other legitimate game could have brought the haughty chiefs adorned with their regal feathers to beg alms.

The eagles sweep over the plains and valleys, but the mountains are their natural homes. On San Francisco Mountain in Arizona I found a pair coming every morning to drink and bathe in a pool of clear snow water above the timber at 11,000 feet.

VERTON BAILEY. 


\section{GENUS HALI ÆETUS.}

352. Haliæetus leucocephalus (Limn.). BaLD EAcile.

Tarsus feathered ouly half way down, middle and onter toes withont web; wing pointed, secondaries nuch shorter than primaries; tail less than two thirds as long as wing, rounded. Adults. - Head, neck, tail, and tail coverts snowy white; rest of plumage blackisl. or dark brownish, feathers edged with brown. Young: first year wholly black except for white bases of feather's showing throngh; second or third year under parts mixed black and white; head and neck black, rest of upper parts mixed gray, brown, black, and white. Male: length $30-35$, extent about 7 feet, wing $20.00-25.90$, tail $11.00-15.25$, bill $1.85-2.25$. Female : length 34-4:, extent about $7-8$ feet, wing $23.50-25.00$, tail $12.50-16.00$, bill $1.90-$ 2.35 .

Distribution. - Mainly in the United States and Mexico. Breeds in suitable localities throughout its range.

Nest. - A bulky mass of sticks, seaweed, rushes, tnrf, vines, or plant stalks, on cliffs or in tall trees. Eggs: usually 2, white.

Food. - Mainly fish, bnt also squirrels, rabbits, prairie dogs, lambs, carrion, and waterfowl.

The bald eagle was unfortunately selected as our national emblem instead of the nobler golden eagle, as it is at times both a scavenger and a robber. It lives largely on fish, diving for them and taking them itself, stealing them from a fish hawk, or, in company with ravens and vultures, feeding on dead fish cast up by the waves along river banks.

It must be acknowledged, however, that the eagles show great skill in their piratical exploits and courage in defense of their nests, and that they have a noble, commanding bearing which is not altogether belied by their daily deeds.

\section{GENUS FALCO.}

General Characters. - Cutting edge of upper mandible with a tooth-like projection separated by noteh from hooked tip; nostril small, circular, with a conspicuous bony tubercle; wings long and pointed.

\section{KEY TO ADULTS.}

1. One primary with inner web cut out.

2. Back of tarsus almost covered by feathers from sides.

$2^{\prime}$. Back of tarsns broadly bare.

rusticolus, p. 166.

3. Grayish brown above

mexicanus, p. 166. 
:3'. Slaty bluish above.

4. Top of head darker than back . . . . . . anatum, p. 167.

t'. Top of head and back uniform . . . . . . pealei, p. 168.

1'. Two primaries with imer webs cut out.

2. Tarsus not decidedly longer than niddle toe.

3. Middle tail feathers crossed by not more than four narrow blackish or six light bands.

4. Inner webs of quills distinetly barred or spotted.

4'. Inner webs of quills not distinctly barred or spotted.

columbarius, p. 168. suckleyi, p. 169.

3'. Middle tail feathers crossed by 5 darker and 6 lighter bands.

2 '. Tarsus decidedly longer than middle toe.

3. Side of head with one horizontal stripe.

fusco-cœrulescens, p. 170 .

3 . Side of lead with two black vertical stripes.

4. Darker. Eastern United States . . . . sparverius, p. 170.

4'. Paler. Western United States . . . deserticola, p. 171.

\section{Subgenus Hierofalco.}

Tarsus feathered two thirds of the way down in front and on sides, the edges of the feathering meeting on the posterior side.

\section{Falco rusticolus Limn. Gray Grrfalcon.}

Adults. - Top of head largely streaked with white ; anterior upper parts barred with grayish or whitish and darker; tail strongly banded; flanks and thighs more or less marked with slaty. Young: upper parts much spotted with white or buffy; mnder parts with dark stripes usually narrower than white interspaces. Male: length $20-21$, wing 14.10 , tail 8.51, bill .90, tarsus 2.40. Female: leugth 22.00-24.50, wing 15.i6, tail 9.7.2, bill 1.01, tarsus 2.46 .

Distribution. - Extreme northern portions of Europe (except Scandinavia), Asia, and North America, inchnding Iceland and sonthern Greenland; sonth in winter to northern border of United States.

The gyrfalcons are so rare in the United States that, as Dr. Fisher says, a man may consider himself fortunate if he sees one in a lifetime.

\section{Falco mexicanus Schlegel. Pratrie Falcon.}

Adult male. - Under parts and muchal collar white, sides of head with dark patches; median under parts lightly streakerl or spotted, and flanks heavily spotted or blotched with dusky; upper parts pale clay brou'n, usually tinged with rusty and indistinctly but broadly barred with pale clay color or dull buffy anteriorly, and with pale bluish gray posteriorly. Adult female: upper parts dull clay brown, feathers edged with rusty brown or dull whitish, paler toward tail; tail tipped with whitish and lighter on outer edges of feathers. Young: upper parts grayish brown. feathers edged with light rusty; under parts buffy with broader dusky streaks; dirk flunk pitch larger and more nuiform than in the adnlt, and axillars nubroken dusky. Ifale: length 17-1s, wing 11.60-12.50), tail (6.40-7.50, bill .70-.7.5. Female: length 15.50-20.00, wing 1:3.25-14.30, tail \$-9. bill .8.5-.90.

Distribution. - Inited States. from the eastern border of the Plains to 
the Pacific, and from the Dakotas south to Mexico; casually to Illinois. Breeds throughout its United Sitates range.

Nest. - Usually on ledges of rocky cliffs. Eggs : :3 to 5, usually creamy white, blotehed and spotted with reddish brown, spots sometimes covering whole surface.

Food. - Birds, mammals, reptiles. and the larger insects.

Over the western plains and sagebrush desert country one often sees a small, trimly-built, sharp-winged liaw $\mathrm{k}$ dashing about in the air, and on scanning the rugged cliffs discerns a white streak high on the rock wall and with a field glass a niche above in which perhaps the edge of a nest or the heads of young may be seen. Sometimes you will hear the high-pitched call, kee, lee, liee, as the old birds circle around above their aerie. As they hover about the cliffs their neat forms and quick, hard wing beats are so characteristic that they could be mistaken for no other bird, unless perhaps the duck hawk. Their nests are usually placed in the most inaccessible parts of high cliffs, and the birds are closely associated with many of the grandest western landscapes.

The falcons are bold freebooters when a farmyard happens to lie in the valley below and their hungry young are calling, but ordinarily ground squirrels and other small rodents supply most of their food. The few birds they get are mostly caught on the wing. One that shot past me in pursuit of a flock of Gambel quails in southern Ctah struck a quail from the flock with such force as to knock it to the ground amid a cloud of feathers, but fortunately for the quail it landed in the brush, where it escaped. Versos Batler.

\section{Subgenus Rhynchodon.}

Tarsus only slightly feathered in front. broadly bare behind; not longer than middle toe without claw.

\section{Falco peregrinus anatum (Bonap.). DeCK HAwh.}

Adults. - Sides of head and neck black. in striking contrast to white or buffy of throat and breast; rest of under parts deeper colored and spotted or barred with blackish; top of head sooty black. rest of upper parts slaty blue. lighter on rump, indistinctly barred with dusky : wing quills blackish. inner webs of quills spotted regularly with buffy or rellowish brown; tail blackish. crossed by \& to 10 light gravish bars. and with narrow white tip. Young: under parts yellowish brown or reddish brown, heavily streaked with dark brown; upper parts blackish, feathers edged with rusty; tail spotted

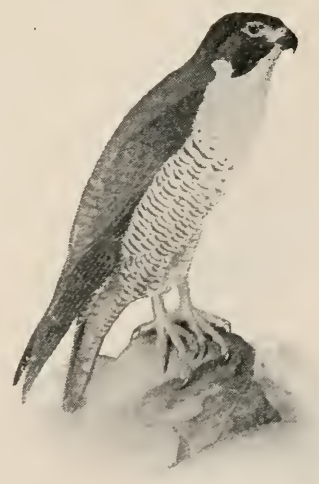

From Biological survey, C. S. Dept. of Agriculture.

Fig. 235. 
with reddish brown and conspicuously tipped with buffy. Male: length 15.50-18.00, wing 11.30-13.00, tail 6.00-7.50, bill .75-.80. Female: length 18-20, wing 13.00-14.75, tail 6.90-9.00, bill .S5-1.00.

Distribution. - America, north of Chili; migratory in the northern part of its range ; breeding locally throughout most of its United States range.

Eggs. - Usually laid on bare ground or rock, on a ledge or crag, or sometimes in hollows in trees or old nests of other hawks, generally 4, creamy or yellowish white, overlaid with brown or brick red.

Food. - Almost exclusively water birds.

As the duck hawk lives mainly on waterfowl and shore birds it follows them from the north on their migrations. Its flight is so rapid that it easily overtakes the swift-winged ducks, and it is so bold as to attack and kill birds twice its weight. It ranks next to the goshawk as a fierce bird of prey.

\section{6a. Falco peregrinus pealei Ridgw. Peale Falcon.}

Adults. - Like F. p. anatum, but head and upper parts uniform dark slate blue; barred on back of wings and tail; chest marked with tearshaped blackish spots, and rest of under parts broadly barred with blackish. Young: under parts sooty black, streaked with buffy or buffy white; upper parts with only faint traces of rusty feather margins. Male: wing 12.95, tail 6.75 , bill .84. Female : wing 14.66 , tail 7.84 , bill .96 .

Remarks. - The adult Peale falcon can be distinguished from the duck hawk by the uniform coloration of head and back, and the young by the black under parts.

Distribution. - Pacific coast region of North America from Oregon north to the Aleutian and west to the Commander Islands, breeding throughout its range.

Nest. - On ledges of high cliffs.

The Peale falcon is said to live largely on auklets and murrelets in Alaska.

\section{Subgenus Fsalon.}

Tarsus scarcely feathered above, longer than middle toe without claw.

\section{Falco columbarius Limn. Pigeon Hawk.}

Middle tail feathers crossed by not more than four blackish or five

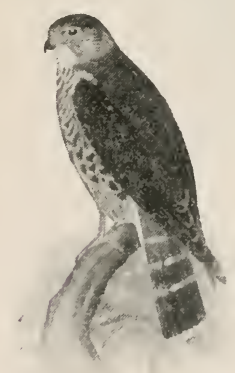

From Biological survey, $\mathbf{U}$. S. Dept. of Agriculture. Fig. 236. lighter bands. Adult male: under parts heavily striped on whitish, buffy, or rusty ground, striping lightest or wanting on throat; upper parts bluish gray, with black shaft streaks, hind neck mixed with whitish, buffy, or vellowish brown; wing quills blackish, inner webs distinctly barred or spotted. Idult female : upper parts brownish, top and sides of head streaked with blackish; under parts whitish or buffy, without rusty tinge. Young: like female but darker, or tinged with rusty or yellowish brown above, and whitish or buffy below. Male: length 10-11, wing 7.40-7.80, tail 4.65-5.20, bill .48-.50. Female : length 12.5013.25, wing $8.35-8.60$, tail $5.30-5.50$, bill .5.5- 60 .

Remarks. - In the field the pigeon hawk might be mistaken for the young sharp-shimned, but can readily be distinguished by the tail, that of the sharp-shin being grayish brown, with half inch 
black bands, that of the pigeon hawk being brown, with quarter inch whitish bands.

Distribution. - North Anerica from the Aretic Ocean sonth in winter to the IVest Indies, and from the southern states to northern South America; breeding mainly north of parallel $43^{\circ}$, except in the monutains, where it extends farther south.

Nest. - On ledges of eliffs and sometimes in trees or hollows of trees. The cliff nests have little material, the tree nests are bulky, made of sticks, grass, or moss, and lined with feathers, inner bark, and other soft material. Eggs: 4 or 5, ground color white, usually hidden by blotehed reddish browu suffusion.

Food. - Mainly birds and insects; oceasionally small mammals.

"This spirited little hawk is one of the most common birds of prey within its northern range. It feeds chiefly upon small birds, but often attacks birds much larger than itself. . . . It seldom watches from a perch, or hovers in the air as it sights its prey, but as a rule darts rapidly through the thickets and orer the open grounds, giving chase to the birds startled in its course. . . . In flight, like others of the falcon family, it strikes rapidly with its wings, never sailing except for a short distance." (Goss.)

\section{7a. F. c. suckleyi Ridgu. Black Meruin.}

Adult male. - Upper parts blackish brown, wing coverts and tertials slaty, tail coverts bluish slate; tail black, with three slaty whitish bars, and tip marked with whitish; throat white streaked with black; rest of under parts blackish brown with whitish and tawny markings. Adult female and young: under parts heavily marked with dusky; upper parts blackish brown, wing coverts and tertials slaty ; tail coverts bluish slate; inner webs of quills not distinctly spotted or barred; tail bands, except for whitish tip, indistinct or obsolete. Male: wing \&, tail 4.90, tarsus 1.40, bill .70. Female: wing 8.2.5-8.50, tail 5.70-5.80, bill .55-.60.

Distribution. - Northwest coast from northern Califoruia to Sitka.

Singularly enough the adult male black merlin had never been (lescribed till Mrs. Fannie Hardy Eckstorm published a description in T'he Auk, October, 1902, from a bird given Mr. Manly Hardy by Major Bendire, who shot it at Fort Klamath, Oregon.

The hawk is by no means as rare as this oversight would indicate. Ir. Rathbun has even seen one in Seattle, near the business part of the city, and noted the bird a number of times along Lake Washington.

\section{Falco richardsonii Ridgw. Richardson Mertin.}

Coloration much like that of the pigeon hawk, but averaging lighter; middle tail feathers crossed by 5 dark and 6 light bands.

Distribution. - Interior and western plains of North America, from the Mississippi to the Pacific; breeding from Saskatchewan south to Colorado; wintering in Texas, Arizona, and probably Mexico.

Nest, eggs, and food as in $F$. columbarius, p. 168 .

Male: wing 7.70-5.05, tail 4.90-5.30, bill .50-.60. Female: length $12.00-13.50$, wing $8.80-9.10$, tail $5.70-6.30$, bill .55-.60,

The habits of the Richardson merlin so far as known are the same as those of the pigeon hawk. 


\section{Subgenus Rhynchofalco.}

Tarsus scarcely feathered above, little longer than middle toe withont claw.

\section{Falco fusco-cœrulescens Vieill. Aplonado Falcon.}

Adults. - Sides of head black, with white central blotch; throat and chest white; sides and flanks slaty blackish, narrowly barred with white; npper parts plain bluish gray; wide stripe from eye becoming yellowish brown in encircling back of head; wing more than 9 inches, with one white bar; tail tipped with white and crossed by about eight narrow white bands. Young: similar to adult but colors duller, the upper parts less bluish, white of breast buffy, more or less marked with dusky, belly and thighs paler. Male: length 15 , wing $9.20-10.70$, tail $6.30-8.00$, bill .60.68. Female : length 17-18, wing 11.00-11.60, tail 7.S0-8.80, bill .71-.s0.

Distribution. - From southern Texas, New Mexico, and Arizona, south to Patagonia.

Nest. - A platform of twigs and plant stalks, generally lined with grass; placed in mesquite, yucca, or cactus. Eggs: usually :3, yellowish white, almost obscured by varying shades of brown.

Food. - Probably largely small mammals, birds, and insects.

The Aplonado falcon is a bird of the mesquite, cactus, and yucca plains, where it finds a goodly supply of its favorite foods. When hunting it often hovers in the air like a sparrow hawk, but unlike most hawks rests mainly on the ground. For a falcon it is said to be rather a quiet, spiritless bird.

\section{Subgenus Tinnunculus.}

Tarsms scarcely feathered above, longer than middle toe with claw.

360. Falco sparverius Limn.

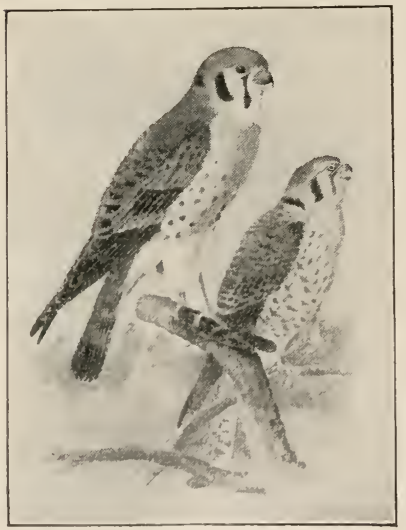

From Biologicul suriey, U. S. Dept. of Aırieulture.

Fig. 237 .

\section{SPARRow Hawk.}

Adult male. - Top of head bluish or slaty, with or without rufous crown patch; cheeks with two black stripes; back rufons, with or withont black bars or spots; wings bluisl gray ; tail rufous, with black subterminal band; muder parts varying from white to rufons, with or without black spots. Idult female: similar, but back, wings, and tail barred with dusky. Young: similar to adnlts, but colors more blended and - in male - feather's of npper parts edged with whitish. Wale: length $8.75-10.60$, wing 7.16 , tail 4.73, bill .50. Female: length $9.50-12.00$, wing 7.57 , tail 5.14 , bill $.50-.5)$.

Distribution. - North America from Great Slave Lake south. east of the Rocky Mountains, to northern Sonth Anerica.

Nest. - In holes, usually in dead trees. Eggs: 2 to 5, varying from 



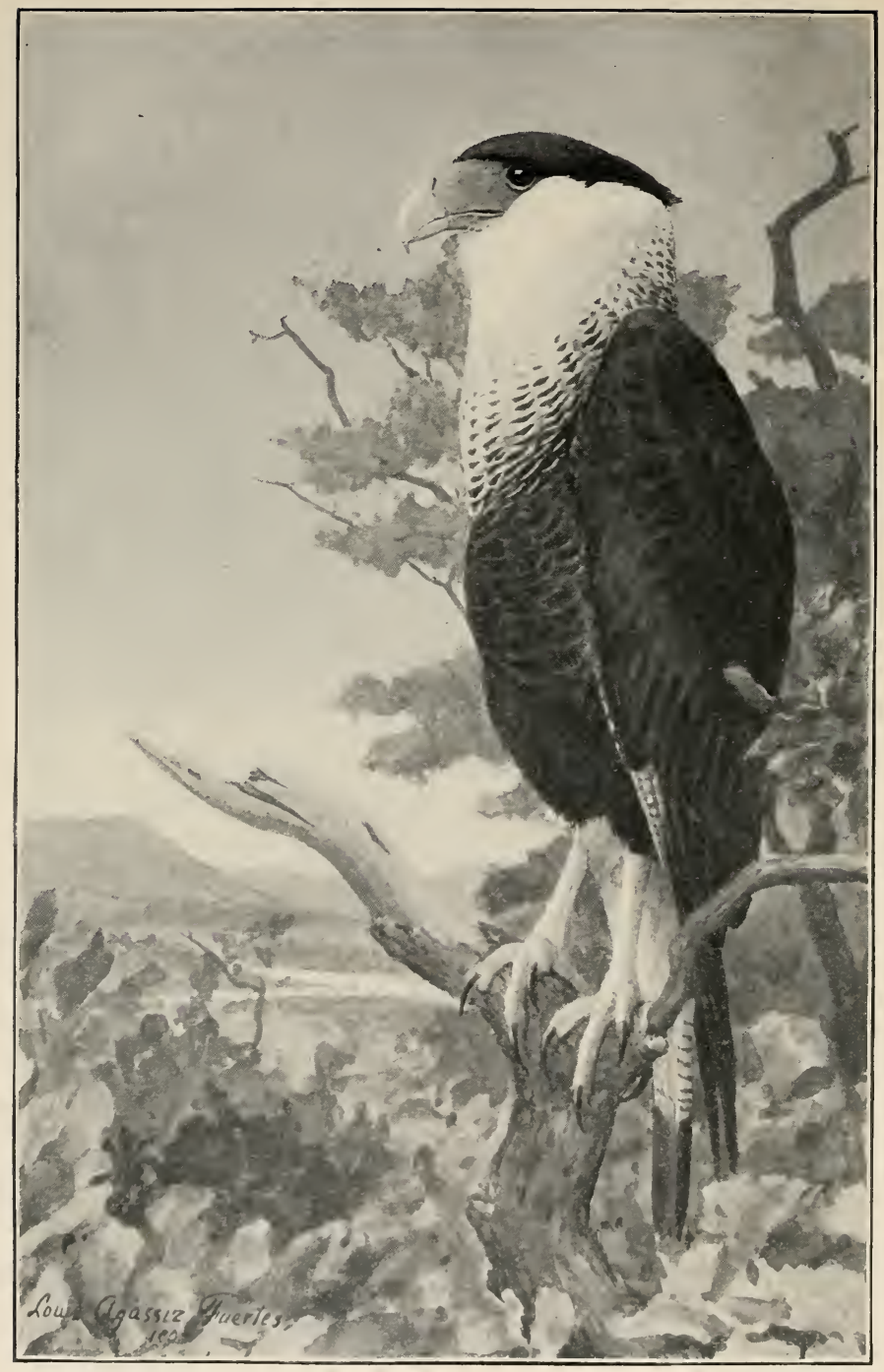

AUDUBON CARACARA 
pure white with few markings to deep cinnamon buff, more or less sprinkled or blotched with darker brown.

Food. - Mainly grasshoppers and crickets; also other insects, snails, small injurious mammals, and sometimes birds.

The habits of the eastern sparrow hawk are the same as those of the western.

\section{0a. F. S. deserticola Mearns. Desert Sparrow Hawk.}

Similar to $F$. sparverius but larger, with relatively longer tail and paler, more rufous coloration.

Distribution. - Western United States and British Columbia; south to Guatemala.

Food. - Small mammals such as nice and gophers, with grasshoppers and other insects.

The marsh hawk and the sparrow hawk are the two most familiar members of the hawk family. Instead of spending their time soaring high in the sky or darting back and forth through the treetops, Circus beats slowly low over our meadows for mice, while the sparrow hawk builds his nest in a knot-hole of a tree by the roadside and sits on a fence post when not hovering over the meadow looking for grasshoppers. His handsome, trim little person is familiar to passers by, while his shrill killy-killy-killy, given as he hovers, is one of the pleasant well-known sounds of the open country.

In the mountains the sparrow hawks often affect the high places. On Mount Shasta they hare been seen at about 13,000 feet. On Lassen Peak, Mr. W. K. Fisher saw one in such hot pursuit of a Clarke crow that it took refuge in a clump of hemlocks. In the Wind River Mountains they have been seen hovering over large tracts of slide rock as if in search of conies and chipmunks.

\section{GENUS POLYBORUS.}

\section{Polyborus cheriway (Jacq.). Acdubon Caracara.}

Bill long, compressed, only slightly hooked; nostrils linear, oblique, slanting down toward cutting edge of bill; upper mandible scalloped on cutting edge; tarsus nearly twice as long as middle toe withont claw, almost wholly naked.

Adults. - Skin of face nearly bare; horizontal crest and body blackish brown except for white collar and white on wings and tail. the white collar widening to a cape on back, grading from pure white throngh spotted and barred black and white to black; wings with white shaft streaks and grayish white patch on quills; tail white, with broad black terminal band and about 13 or 14 narrow dusky bars. Young : black of adults replaced by brown. mixed black and white eape of adult dingy whitish, striped with dark brown. Length: 20.50-25.00, wing 14.60-16.50, tail 8.80-10.(0. bill $1.20-1.48$.

Distribution. - Resident along the southern border of the United States (Florida, Texas. and Arizona) and Lower California ; extending sonth to South America, Ecuador, and Guiana. 
Nest. - A bulky mass of twigs, flags, weeds, coarse grass, leaves, cotton, or Spanish moss; placed according to the locality in low bushes or in high trees. Eggs : 2 or 3, ground color brown or white, generally entirely hidden by spots of darker brown.

Food. - Carrion, mice, rabbits, fish, and snakes.

The caracara or Mexican buzzard is the oddest looking bird found in that most interesting belt of strange Mexican types, the southern border line of the United States. In flight it has a wooden look, given probably by its curious color pattern and long neck. Head and neck appear like one stiff round-headed stick. Its wings look stiff and angular too, and as it flaps along their white tips add to the singular effect. On your first view of the bird you exclaim involuntarily, "What a queer looking creature!"

In driving from Corpus Christi to Brownsville, while we found the Swainson, Harris, and white-tailed hawks common on the open prairie, we saw caracaras only on the mesquite or shin oak prairie. In the mesquite one day we came to two of the birds standing in the road beside a dead snake. As they stood with heads raised, they had a proud, hawk-like bearing.

South of San Ignatius, in driving through the low shin oak, we found two caracaras perched on an isolated little round-topped oak. They were so big and the tree was so small that they more than filled it, looking like huge stuffed birds on meagre standards. They were so evidently at home, sitting pluming themselves calmly while we stared, that we looked about for a nest and soon discovered it, a mass of sticks, holding a fuzzy-headed nestling, on the top of another small round oak.

On the coast of southern Texas, Colonel Goss found the caracara playing the part the eagles do with fish hawks. When the brown pelicans were coming to shore with their pouches full of fish, the caracaras would dart down screaming and strike at them with their talons till the pelicans disgorged their fish, when the robbers would calmly take possession of the quarry.

\section{GENUS PANDION.}

364. Pandion haliaëtus carolinensis (Gmel.). Fisн НАwк.

Plnmage close, firm, imbricated, oily; feet large and strong, ronghly granular; toes all free to the base, onter toe reversible; claws all the same length; wings long, pointed; tail short. Adult male: Head, neck and under parts white, head more or less streaked with blackish, broad dark streak on side of head; breast sometimes slightly blotehed witl brown; tail narrowly tipped with white and crossed by 6 or 7 narrow blackish bands. Adult female: similar, but ehest heavily spotted with brown. Young: sexes similar to adults, but npper parts blackish brown, feathers tipped witl white or buffy. Length: 20.75-25.00, extent about 65, wing 17-21, tail 7-10, bill 1.20-1.45. 
Distribution. - Breeds from Iludson Bay and Alaska south throughout the United States and Mexico; nigrates to the West Indies and northern South America.

Nest. - On the ground, in trees, on telegraph poles, cliffs, or deserted buildings, made of large sticks, brnsli, and rubbish, such as weeds and cornstalks. lined with softer materials like seaweer. cedar bark, and corn leaves. Eggs: usually 3 , varying greatly in size, color, and markings. Ground color generally white, sometimes so evenly overlaid as to appear buffy or vinaceous. and usually heavily blotehed with brown and wine red.

Food. - Fish.

With almost gull-like persistency the fish hawk follows the rivers and lakes, circling on crooked wings above the surface of the water or perching near the shore on the top of some old dead tree overlooking the rippling

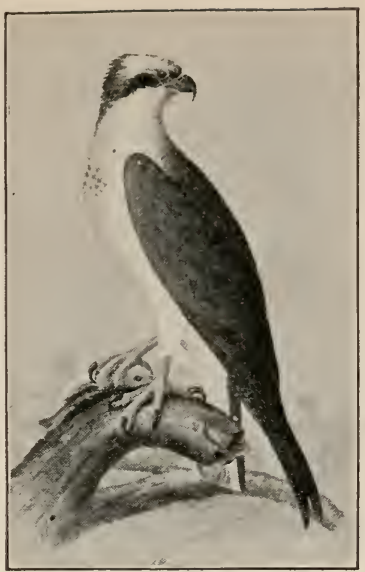

From Biological Survey, U. S. Dept. of Agriculture.

Fig. 238. Fish Hawk. surface. When a fish is sighted below the long wings are folded and with a meteor-like plunge the bird sinks into the water, imbedding the long hooked talons in the back of the fish. With a few powerful strokes of the wings it is up again, carrying the fish with talons planted one ahead of the other in its back, to make it go head first instead of sidewise, so that it will cut the air. With its prey the osprey makes for its nest, or if it has no nest flies to a branch where it can devour its quarry at leisure.

Every spring the fish hawks add a new layer to the old nest, and if undisturbed will use the same structure as long as the sticks hold together. The nests are generally scattered and by no means common, but in places where suckers and other fish are abundant and easily caught, the ospreys sometimes live in large colonies, coming back year after year to the same nests.

Verion Bailey.

\section{FAMILY STRIGID㘴 BARN OWLS.}

\section{GENUS STRIX.}

\section{Strix pratincola Bonap. BarN OwL.}

Wings long, pointed, folding beyond tail ; tail short, about half as long as wing; tarsus nearly twice as long as mirldle toe without claw, closely feathered above, slightly feathered and bristly below, as on toes ; feathers of back of tarsus pointing upward; inner toe as long as middle toe; inner edge of midldle claw pectinated.

Facial disk pure white to tawny; under parts pure

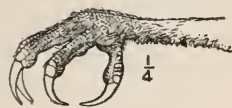

Fig. 239., 
white to yellowish brown. dotted with triangular brown or blackish spots;

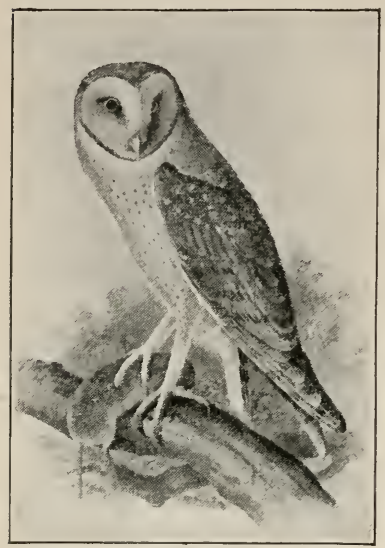

From Biological Survey, U. S. Dept. of Agriculture.

Fig. 240. Barn Owl. upper parts yellowish brown, more or less overlaid with mottled gray, finely streaked with black and white; wings and tail with a few dusky bands. Length: $14.75-18.00$. wing $12.50-14.00$, tail $5.50-$ 7.50 , bill $.90-1.00$.

Distribution. - Breeds in Upper and Lower Sonoran zones of the United states, from about latitude $41^{\circ}(\mathrm{Ne}-$ braska). and southward through Mexico. Migrates more or less in the northern part of its range.

Nest. - In hollow trees, holes in cliffs, barns, old houses, and bell towers.

Food. - In California, principally gophers and ground squirrels, together with rabbits, birds, and insects.

The barn owl, or more appropriately golden owl, spends its days in any dark crevice that it finds conrenient, from the hollow branch of a tree to barn lofts, garrets, wells, windmill tanks, and mining shafts. When driven out of its hiding place in the daytime, an old owl will draw itself up, snap its bill, and hiss at one in a way that might well terrify a nervous enemy. At twilight it leares its cover and with noiseless flight hurries to some low meadow or marsh to hunt.

In California it press mainly on gophers and ground squirrels, both of which rank among the worst pests in the country. The ejected pellets found around the owls' nests often contain nothing but gopher hair and bones, and in a number of instances Mr. Clark P. Streator has found an accumulation of two or three cubic feet of pellets in the trees in which the owls lived. Wherever the owls are found they rank among the most beneficial of rapacious birds, for they not only live on gophers and ground squirrels in the west, but cotton rats in the south, and rats and mice in the north.

When hunting, the owl's 'peevish scream' may often be heard, and sometimes also a note that Iajor Bendire compares to the call of the nighthawk. But the hungry young make the most noise. When camped beside an oak containing a family, Dr. Palmer found them a great nuisance from the hissing and shrieking which they kept up all night

In California in winter Mr. Evermann has found as many as fifty barn owls together in the oaks. 


\title{
FAMILY BUBONID丑: HORNED OWLS, ETC.
}

\author{
key to geNERA.
}

1. Small, wing : $: .40-7.50$.

2. With ear tnfts (incouspicuous in young) . . Megascops, p. 181. 2 '. Without ear tufts.

3. 'Tarsus more than twice as long as middle toe. Speotyto, p. 184.

:'. Tarsus less than twice as long as middle toe.

4. 'Tarsus scantily haired

Micropallas. p. 191.

4'. Tarsus densely feathered.

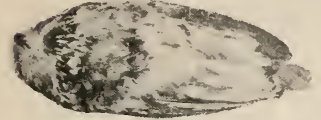

Fig. 241.

$1^{\prime}$. Large, wing 11.50-19.00.
5. Ear openings very large, the two unlike.

Nyctala. p. 17?.

j). Ear openings small, the two alike.

Glaucidium, p. 19().

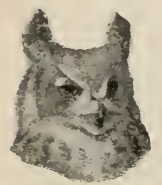

Fig. 242.

2. With ear tufts.

3. Ear openings small . . . . . . Bubo, p. 185.

3'. Ear openings large, reaching almost to top of skull.

$2^{\prime}$. Without ear tufts.

Asio, p. 17.5.

:3. Wing 9 inches

3 '. Wing 12 to 19 .

4. Ear openings small, the two ears not distinctly different . . . . . . . Nyctea, p. 187.

t'. Ear openings very large, the two strikingly different.

5. Toes feathered to claws. . Scotiaptex, p. 179.

5'. Tips of toes exposed . . . Syrnium, p. 17T.

\section{GENUS ASIO.}

General Characters. - Ear openings immense, almost equal to height of skull; ear tufts more or less developed; wings about twice as long as tail ; feet closely feathered to ends of toes.

KEY TO ADELTS.

1. Ear tufts shor't

accipitrinus, p. 177.

$1^{\prime}$. Ear tufts long

366. Asio wilsonianus (Less.). Long-Eared Owl.

Ear tufts dark brown, conspicuous; face mainly yellowish brown; under parts whitish and yellowish, with dark brown shaft streaks and horizontal bars on belly: flauks yellowish brown, unspotted; npper parts 
mottled gray, tawny, and blackish; wings and tail barred. Length :

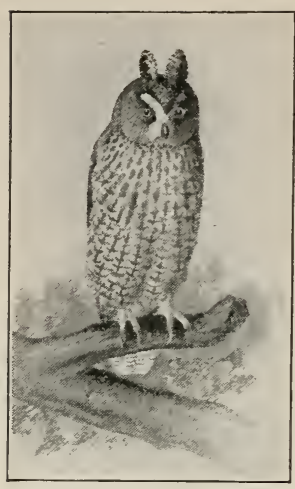

From Biological survey, U.S. Dept. of Agriculture.

Fig. 243. Long-eared Owl. $13-16$, wing $11.50-12.00$, tail $6.00-6.20$, bill .65.

Distribution. - Temperate North America, straggling south to Mexico in winter. Breeds throughout its range.

Nest. - Usually an old crow's nest built up on the sides and lined with grass, dead leaves, and feathers; generally 10 to 30 feet from the ground, in bushes or trees in swamps or on borders of streams. Eggs: 3 to 6, white.

Food. - Injurious rodents, which it destroys in vast numbers.

The long-eared owl spends its days mostly in the thickest cover it can find, but when this is not dense enough to prevent discovery it protects itself by many curious devices. It affords one of the interesting cases where 'unconscious protective coloration is combined with conscious protective attitudes.' When frightened, Dr. Fisher says, it rises up, 'draws the feathers close to the body and erects the ear tufts, resembling in appearance a piece of weatherbeaten bark more than a bird.'

Major Bendire surprised one while she was killing a ground squirrel. To his astonishment, as he says : "All at once she seemed to expand to several times her normal size, every feather raised and standing at a right angle from the body; the wings were fully spread, thrown up and obliquely backward, their outer edges touching each other over and behind the head, which likewise looked abnormally large." This remarkable performance was accompanied by a loud hissing.

The owls, though sometimes seen abroad on cloudy days, usually hunt at night. When in Sierra Valley, California, Mr. Walter K. Fisher encountered them as riral mammalogists. Ile writes: "I was out one bright moonlight night in the sage brush looking for Perodipus and observed about six of these owls flying swiftly and noiselessly over the plain, evidently hunting mice. They were very tame, and flew close about me, taking no notice of my presence. They made no sound whatever."

They are generally rather quiet birds, Major Bendire says, with low toned pleasing notes, one of which he describes as a low twittered whistle. In the breeding season, however, they hoot somewhat like screech owls.

In summing up its food habits, Dr. Fisher declares it one of the most beneficial species, as it destroys 'vast numbers of injurious 
rodents and seldom touches insectivorous birds.' Is it is easily destroyed, he says it is the owl that suffers most when short-sighted legislators enact laws for the destruction of birds of prey.

367. Asio accipitrinus (Pall.). ShorT-Eared OWL.

Adults. - Ear tufts inconspicuous; eyes with black ring and white evebrows; body varying from yellowish brown to buffy white, conspicuously streaked with dark brown; wings and tail irregularly banded with dark brown and buffy or sellowish brown. Young: face brownish black, under parts plain dull buffy, tinged with gray in front; upper parts dark brown, the feathers tipped with rellowish brown. Length: $13.80-16.75$, wing $11.80-$ 13.00, tail 5.80-6.10, bill .60-.65.

Distribution. - Entire western hemisphere except Galapagos Islands and part of the West Indies; also nearly throughout the eastern hemisphere, excepting Australia. Breeds in the United States irregularly and locally from about latitude $39^{\circ}$ northward.

Nest. - Of coarse grass and sticks, loosely put together, and sparsely lined with fine

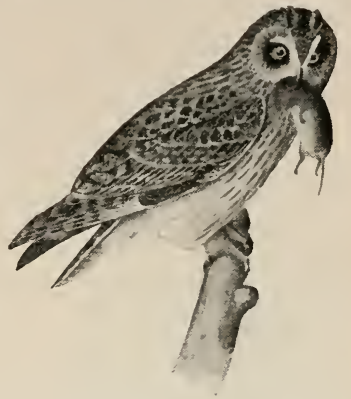

From Biological Survey, U. S. Dept. of Agriculture.

Fig. $24 t$. material and feathers of the bird. Eggs : 4 to 7 , white.

Food. - Largely mice; also gophers, shrews, rabbits, grasshoppers. crickets, and beetles.

The habits of the short-eared owl are quite unique. While most owls live in trees and woods this bird rarely lights in a tree, making its home in the open country, coast marshes, and islands corered with bushes and high grass. It hides in the grass on bright days, but in cloudy weather often hunts in the morning and evening or even the middle of the day, flying low over the ground in its search for gophers, mice, and grasshoppers, when its long wings make it seem very large. On the salt marshes of Gray's Harbor, where Mr. Lawrence found the owls flying about commonly in misty weather, he says they looked 'as big as eagles.' There, he says, they sat on the edges of the sloughs watching for rats. When flying high, sporting, or chasing some large bird, he heard them give a shrill barking call like the ki-yi of a small dog.

\section{GENUS SYRNIUM.}

General Characters. - Wing 12-15, rounded; no ear tufts ; ear opening large and with a distinct anterior flap, the two ears conspicuously different; tip of toe exposed.

KEY TO SPECIES.

1. Head and neck barred.

2. Upper parts dark brown .

nebulosum, p. 178.

2 . Upper parts pale yellowish brown . . helveolum, p. 178. 
1'. Head and neck spotted.

2. Wing broadly tipped with whitish . . . . occidentale, p. 17s.

2 '. Iring with white tips almost obsolete . . . . caurinum, p. 179.

368. Syrnium nebulosum (Forst.). Barred OwL.

Adults. - Head, neck, and breast widely barred with dark brown and

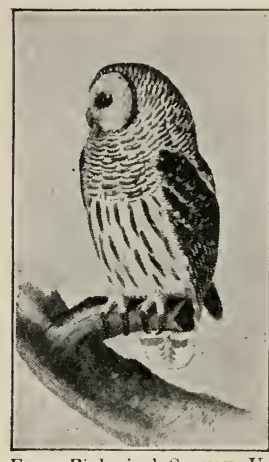

From Biological Survey, U S. Dept. of Agricuiture.

Fig. 245. white or buffy, belly streaked with dark brown on whitish or buffy ground; npper parts mixed dark brown, irregularly barred and spotted with buffy, whitish, and yellowish brown; wings and tail banded. Young: entire plumage barred except tail and wing quills, which are as in adult; back and wing coverts broadly barred, the end of each feather white, giving a spotted effect. Length: $19.75-24.00$, wing about $13-14$, tail about 9 .

Distribution. - Breeds in Transition and Upper fonoran zones from Nova Scotia south to Georgia and northern Texas, and west to Colorado.

Nest. - In hollows of trees, or that of hawk or crow. Eggs : 2 to 4, white.

Food. - Mainly mice and other small mammals ; also crawfish and insects.

"In the central and southern parts of its range it is quite common, frequenting mostly the heavy timbered and, preferably, swampy tracts near watercourses, and spending the days generally in natural hollows of trees or in dense shrubbery. Like most of the birds of this family, it is nocturnal in its habits, but nevertheless sees well enough, and even occasionally hunts in the daytime, especially during cloudy weather. . . .

"The flight of the barred owl . . is easy, and though quite swift at times, it is perfectly noiseless. A rapidly passing shadow distinctly cast on the snow-covered ground is often the sole cause of its presence being betrayed as it glides silently by the hunter's camp-fire in the still hours of a moonlight night. Far oftener, however, it announces itself by the unearthly weird call-notes peculiar to this species, which surpass in startling effect those of all other owls with which I am familiar." (Bendire.)

\section{8b. S. n. helveolum Bangs. Texas Barlen OWL.}

Pallid, back, wings, and tail pale yellowish brown or cinnamon, light bars and spots on wings large and white; light bars on tail wider and paler than in S. nebulosum: nnder parts paler, dark striping and barring browner, gromnd color whiter; feathers of tarsus buffy, without dnsky markings. Type: female: wing 13, tail 8.32. Topotype: male adult: wing 13.64 , tail 5.40 .

Distribution. - Sonthern Texas (and northern Tamanlipas, Mexico?).

369. Syrnium occidentale Xantus. SPotted OwL.

Upper parts brown, head and neck coursely spotted (instead of barred) with round white spots; wing quills spotted with pale brown and whitish. 
and broadly tipped with whitish; tail banded; under parts whitish, barred and spotted with brown. Length: 1!), wing 12.00-13.50, tail s.50-9.00, bill .90 .

Distribution. - From southern Colorado and New Mexico to California and south to Lower California and northwestern Mexico.

The spotted owl is the western representative of the barred owl, and is so closely confined to the thinly settled mountain regions of the west that little is known of its habits. Mr. Lyman Belding compares its call to the barking of a dog.

\section{9a. S. o. caurinum Merriam. Northern Spotted OwL.}

Similar to the spotted owl, but darker, with white spots and markings restricted, especially on head and back; wing quills darker, the broad white tip almost obsolete. Wing: 12.10 ; tail (middle feathers) 8.06 .

Distribution. - Coast region of Washington and British Columbia.

\section{GENUS SCOTIAPTEX.}

\section{Scotiaptex cinerea (Gmel.). Great Gray OwL.}

Ear tufts wanting; ear openings large, with conspicuous anterior flap, the two ears strikingly different; bill nearly hidden by feathers; toes entirely covered with feathers; eyes yellow, eye ring black; bill small, nearly lidden by feathers; face with concentric rings of gray and dark brown; upper parts sooty, mottled with gray and blackish; wing quills and tail banded; under parts mixed sooty and whitish, with irregular sooty streaking; flanks and legs barred. Length: 25-30, extent $54-60$, wing about $16-18$, tail 11.00-12.50.

Distribution. - Northern North America, south in winter to the northern border of the United States.

Nest. - In evergreens, made of sticks, feathers, and sometimes mosses. Eggs : 2 to 4. white.

Food. - Mainly rabbits, mice, and other small mammals, together with birds.

"Its great predilection for thick woods, in which it dwells doubtless to the very limit of trees, prevents it from being an inhabitant of the barren grounds or other open country in the north. It is crepuscular or slightly nocturnal in the southern parts of its range, but in the high north it pursues its prey in the daytime. In the latter region, where the sun never passes below the horizon in summer, it is undoubtedly necessity and not choice that prompts it to be abroad in the daylight. . . The note of this owl is said to be a tremulous, vibrating sound, somewhat resembling that of the screech owl." (Fisher.)

\section{GENUS NYCTALA.}

General Characters. - Wing 5.25-7.40; ear tufts wanting ; ear openings nearly equal to height of skull, with anterior flap, the two ears conspicuously different; feet thickly feathered to claws. 


\section{Nyctala tengmalmi richardsoni (Bonap.). Richard-} son OWL.

Adults. - Eye ring black, face whitish; under parts gray, heavily blotched with dark brown across breast and streaked with dark brown on belly; upper parts dark brown, spotted with white; flanks and feet usnally buffy, more or less spotted with brown; under tail coverts striped with brown. Young: face blackish, evebrows and malar streak white in sharp contrast; wings and tail like adult; body plain seal brown except for yellowish brown on belly and flanks; flanks more or less spotted with brown. Length : 9-12, wing 6.60-7.40, tail 4.10-4.70.

Distribution. - Northern North America from the limit of trees south in winter to Oregon and Colorado.

Nest. - Probably in holes in trees and, in absence of trees, in bushes. Eggs: probably 3 to 7 , white.

Food. - Mice, small birds, and insects.

"Richardson's owl is a boreal species inhabiting North America from the limit of trees south to the northern tier of states. . . It is common throughout northern Alaska, wherever trees or large bushes occur to afford it shelter. . . . It is nocturnal in its habits, remaining quiet during the day in the thick foliage of the trees or bushes. In fact, its vision is apparently so affected by bright light that many specimens have been captured alive by persons walking up and taking them in their hands. On this account the Eskimo in Alaska have given it the name of "blind one.", (Fisher.)

\section{Nyctala acadica (Gmel.). SAW-Whet OwL.}

Adults. - Eye ring whitish, face streaked with dark brown; under parts

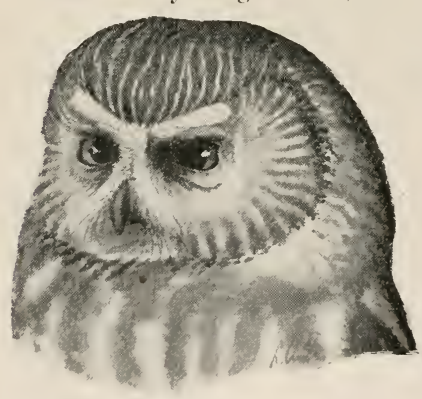

Fig. 246. white. streaked vertically with reddish brown, most thickly on breast; upper parts olive brown, marked with white. finely streaked on head, and coarsely streaked or spotted on back, wings, and tail ; feet plain white or buffy. I'oung: face blackish, in sharp contrast to white evebrows and white malar streak; upper parts and breast plain dark seal brown; wings and tail as in adult; belly yellowish brown. Length: $7.25-8.50$, wing $5.25-5.90$, tail $2.80-$ 3.2.5.

Distribution. - From about latitude $50^{\circ}$ to sonthern United States, breeding south to Penusylvania, New Mexico, and California.

Nest. - A deserted woodpecker hole, hollow of a tree, or old squirrel's nest. Eggs: :3 to 7 , white.

Food. - Almost wholly mice, but also other small mammals and insects.

The deeper and darker the forest the better it suits this little 
gray-coated night woodsman. In the daytime he snuggles up to some gray trunk under the thick branches of a dark spruce, or hides in the leafy canopy of a forest tree. At night he floats on noiseless wings along the edges of the open parks and meadows, passing from tree to tree and bush to bush, dropping on unsuspecting mice that rustle the grass or venture into the open spaces under the trees, finding an abundance of food eren when the snow is deep and the nights crisp and cold.

With the first thaws of early spring his love-song is heard, - a soft scraping note repeated monotonously in quick succession for half an hour at a time. It usually comes first from the woodpecker hole where he has been spending the day, but later in the evening is repeated from the branches in different parts of the woods. Before the snow has all gone the eggs are laid, sometimes in the woodpecker hole where his voice was first heard, sometimes in another near by. By the time the first really warm spring weather has come the young liave hatched. Then the old birds are too busy catching mice for their large family to give much time to music, and they are not heard again regularly until the next spring. But they have many soft little talking notes that you can hear by sleeping in their woods on still summer nights.

Versox BaILey.

\section{2a. N. a. scotæa Osgood. Northwest Saw-whet OWL.}

Similar to $N$. acadica, but darker, dark markings everywhere heavier ;

flanks, legs, and feet more rufescent. Wing: 3.33 , tail 2.66. tarsus 1.03.
Distribution. - Puget Sound region, north to Queen Charlotte Islands, B. C.

\section{GENUS MEGASCOPS.}

General Characters. - Wing: 5.40-7.\$0; ear tufts more or less conspicuous; ear openings small, the two ears alike; wings rounded, about twice the length of the short rounded tail; tarsus feathered.

KEY TO SPECIES.

1. Toes feathered or bristly.

2. Size large, wing averaging about $\bar{T}$ or more.

3. Plumage dark and heavily mottled.

4. Dichromatic; brown form with back deep sooty brown. Oregon to Sitka . . . . . kennicottii, p. 183.

4'. Monochromatic; back grayish brown. East of Cascades. macfarlanei, p. 184.

3'. Plumage pale ashy gray, lightly streaked. Rocky Mountains.

$2^{\prime}$. Size smaller, wing averaging 6.60 or less.

maxwelliæ, p. 183.

3. Wing averaging less than 6 ; plumage dichromatic.

4. Throat without fulvous collar. Southwestern Texas and Mexico.

mocalli, p. 18:3.

4'. Throat with partial collar of mottled fulvous in gray phase. Mexico and southern Arizona . . . . trichopsis, p. 184. 
:3'. Wing averaging over 6.40 .

4. Dichromatic, red or brownish gray. Eastern United States.

4'. Not dichromatic, always gray.

asio, p. 182.

5. Back brownish gray. Coast region of California.

5). Back clearer gray.

bendirei, p. 183.

Plumage light gray, narrowly and sharply streaked below with black. Mexico to southern Arizona and New Mexico.

cineraceus, p. 18:3.

6'. Plumage dark gray, heavily streaked with black. Southern Colorado, northern Arizona, and New Mexico.

aikeni, p. 184.

1'. Toes entirely naked to base.

2. Throat with conspicuous band of ochraceous, lower parts lightly mottled . . . . . . . . . idahoensis, p. 185.

2 '. 'Throat without distinct band of ochraceous, lower parts more heavily mottled . . . . . . . . . flammeola, p. 184.

\section{Megascops asio (Limn.). Screech Owl.}

Dichromatic; gray or reddish brown, without regard to age, sex, or

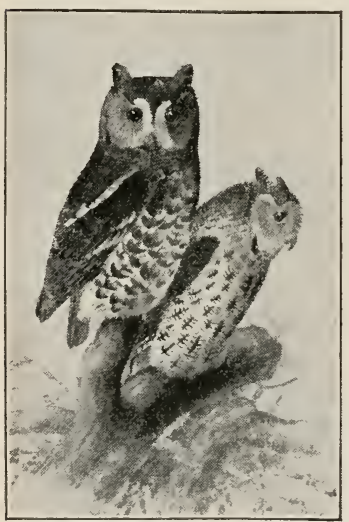

From Biologieal surrey, L. s. Dept. of Agriculture.

Fig, 247 season; ear tufts conspicuous; toes thinly feathered or bristly on top. Adults : gray phase: upper parts dull brownish gray, with shaft streaks and fine nottlings of dusky; edge of scapulars and row of spots on edge of wing white or creamy ; lower parts grayish white, with heavy shaft streaks and light cross-lines of black. Red phase: upper parts clear rich rufous, with a trace of black sliaft lines and with white scapular streaks and spots on edge of wing; lower parts streaked and mottled with rufous and white, and with faint black shaft streaks. Young: plumage barred or banded with gravish or whitish, without longitudinal markings. Length: 7.50-10.00, wing (i.00-7.10, tail $3.05-3.50$.

Distribution. - Temperate eastern North America, sonth to Georgia; west to about the $100^{\circ}$ meridian.

Nest. - A hollow in a tree or old woodpecker hole, 3 to 40 feet from the ground. Eggs : usually 4 or 5, white.

Food. - Mammals, birds, reptiles, batrachians, fisl, erustaceans, and insects.

"The rommon screch owl is distributed throughout the whole of the United States and the southern portions of the British Prorinces. It is separable into several geographic races as is usual in species having such an extensive distribution. . . Their food consists of a great variety of animal life. . . At nightfall they begin their rounds, inspecting the vicinity of farmhouses, barns, and corncribs, making trips through the orchards and nurseries, gliding silently 
across the meadows, or encircling the stacks of grain in search of mice and insects. Thousands upon thousands of mice of different kinds thus fall victims to their industry. Their economic relations, therefore, are of the greatest importance, particularly on account of the abundance of the species in many farming districts; and whoever destroys them through ignorance or prejudice should be severely condemned." (Fisher.)

\section{3b. M. a. mecalli (Cass.). Texas Sereech OWL.}

Dichromatic; gray or rufons. Gray phase: smaller and darker than asio, with more conspicuous dusky shaft streaks above and heavier shaft streaks and cross-lines of black below. Rufous phase: much as in asio, the rufous predominating on lower parts. Young: whole plumage, except wing quills and tail feathers, barred or banded with grayish or whitish; the black streaks wholly wanting. Length: $6.50-9.00$, wing 5.60-6.30, tail $3.10-3.40$.

Distribution. - From western and southern Texas across eastern border of tablelands of Mexico.

Nest. - In cavities of trees. Eggs: 2 to 5.

\section{3c. M. a. bendirei (Brewst.). California Screech Owl.}

Not dichromatic; gray only. Slightly larger than asio, with heavier, more marked shaft streaks of black both above and below, and less conspicuous cross-lining below. Smaller and lighter than kemnicottii to the north.

Distribution. - California.

Nest. - Usually in oaks or cottonwoods.

\section{3d. M. a. kennicottii (Elliot). Kennicott Screech Owl.}

Conspicnously larger and darker colored than asio or bendirei; upper parts dark sooty brown, mottled and streaked with black; scapular streaks and spots on edge of wings rich buff; lower parts heavily mottled, lined, and cross-lined with black; legs and feet rich buffy brown, finely mottled with buffy. Specimens from the southern and eastern part of the range lighter and grayer.

Distribution. - Northwest coast region from Oregon to Sitka.

\section{3e. M. a. maxwelliæ (Ridgw.). Rocky Mountain Screech OWL.}

Large and very pale; white predominating on lower parts ; upper parts light ashy or buffy gray, with narrow streaks and faint mottlings of blackish ; white streaks on scapulars and on edge of wings, large; lower parts white, with narrow shaft streaks of black, and fine cross-lines of brown.

Distribution. - Foothills and adjacent plains of the eastern Rocky Mountains from Colorado north to Montana.

\section{3f. M. a. cineraceus Ridgw. Mexican Screech OwL.}

Small and very gray; upper parts clear ashy gray, with numerous blackish shaft streaks; lower parts with narrow black shaft streaks and fine vermiculations and cross-lines of black, withont clear white interspaces; feet and legs finely and thickly mottled with dusky; little trace of brown anywhere in plumage. Length: $6.50-8.00$, wing $6.10-7.00$, tail 3.44 . 
Distribution. - Resident in Transition zone of New Mexico, Arizona, Lower California, and northwestern Mexico.

373g. M. a. aikeni Brewst. Aiken Screech Owl.

About the size of the California screech owl but more ashy, the dark markings coarser and more numerons both above and below. Wing: 6.56, tail 3.80, bill from nostril .47.

Distribution. - Plains, El Paso County, Colorado, and south probably to central New Mexico and northeastern Arizona.

\section{3h. M. a. macfarlanei Brewst. MacFarlane Screech OWL.}

Size large and colors dark, but lighter than kennicottii; upper parts brownish or sooty gray with black shaft streaks and ereamy stripes on seapulars and edge of wing; lower parts with heavy shaft streaks and numerous fine cross-lines of black; legs and feet buffy, slightly mottled with dusky. Male: wing 6.96 , tail 3.80 , bill from nostril .53. Female: wing 7.23 , tail 3.85 , bill from nostril .57 .

Remarks. - Macfarlanei is the size of kennicottii but with color and markings more as in bendirei.

Distribution. - Eastern Washington and Oregon to western Montana, and probably intermediate region, and north to the interior of Bitish Columbia.

\subsection{M. trichopsis (Wagl.). Spotted Screech OWl.}

A small dichromatic species. Gray phase: upper parts brownish gray, heavily lined with dusky; lower parts grayish white, with broad shaft streaks and cross-lines of blackish; a partial collar of mottled fulvous across throat and sides of neck. Red phase: mainly light rufous, obscurely streaked and barred with dusky. Length: 7.50, wing 5.66, tail 2.89, tarsus 1.17.

Distribution. - From southern Arizona to Guatemala.

\section{Megascops flammeola (Kaup). Flamulated Screech OWL.}

Adults. - Toes entirely naked to extreme base; ear tufts small ; upper parts grayish, finely mottled and marked with blackish; stripes on sides of back yellowish brown or orange, white beneath the surface; under parts whitish, marked with broad mesial streaks and narrow eross-bars; face, throat, and upper parts sometimes washed with orange browu. Young: upper parts mottled transversely with gray and white, but without black streaking; under parts similarly but coarsely and regularly barred. Wing: $5.10-5.60$, tail $2.60-3.00$.

Distribution. - From northern California and Colorado sonth to the highlands of Guatemala.

Nest. - ln old woodpecker loles. Eggs : 3 or 4, white.

Food. - Small nammals, scorpions, and beetles, and other insects.

"From what we know of the habits of the flammulated owl they seem to vary but little from the other races of the screech owl family. They are apparently strictly nocturnal, and their food consists of the smaller manmals, as well as beetles and other insects." (Bendire.) 


\section{4a. M. f. idahoensis Merriam. 1WARF SCREECH OWL.}

Similar to the Hammulated but smaller and paler, especially on under parts in which the ground is white, and the niarkings restricted; facial ring bright tawny brown. Wing: 4.86 , tail 2.4 .

Distribution. - Idaho and eastern Washington.

\section{GENUS BUBO.}

General Characters. - Length: 18-23: ear tufts conspicuous; ear openings small, without anterior flap, the two ears not distinctly different ; wing with 22 or 3 quills cut ont ; toes covered with short but dense feathers; claws wholly exposed.

\section{KEY TO SPECIES.}

1. Upper parts dark colored.

2. Feet barred with black and buffy

2 . Feet barred with black and rusty brown $1^{\prime}$. Upper parts light eolored.

2. Upper parts largely gray and buffy .

2 '. Upper parts largely white

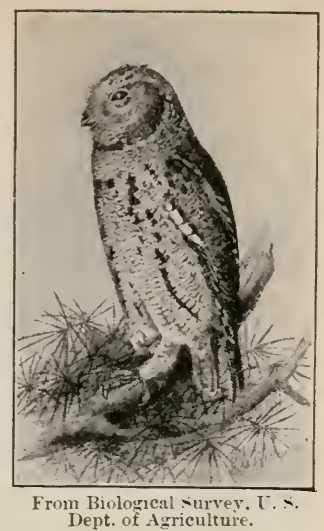

Fig. 245. Dwarf Screech Owl.

pacificus, p. 186. saturatus. p. 186.

pallescens, p. 185 . arcticus, p. 186 .

\section{5a. Bubo virginianus pallescens stone. Western Horned OWL.}

Adults. - Ear tufts blackish ; iris bright yellow ; ring around face black ; throat white; rest of under parts white or buffy, mottled and barred with brownish ; flanks buffy; upper parts mottled dark brown, light grayish, and buffy, lighter colors prevailing; wing quills and tail banded with dull brown; whole plumage irregularly varied with buffy, tawny, whitish, and dusky. Young: wing quills and tail feathers as in adult, rest of plumage dull buffy or ochraceous, everywhere barred with dusky. Male: length 18-2:3, extent about 49-5.2, wing about 14.50-15.25, tail 8.25. Female: length 22-25, extent about 57 , wing 16 , tail 9 .

Distribution. - Western United States, east through the Plains, casually to Wisconsin and Illinois; and from British Columbia and Nanitoba south over the Mexican tablelands.

Nest. - A hole in a hollow tree, cliff, bank, or cave, or an old nest of a erow or hawk. Eggs: usually 2 or 3, white.

Food. - Largely mammals such as rabbits, prairie dogs, ground squirrels, skunks, and wood rats, game birds, waterfowl, smaller land birds, and, in settled regions, poultry.

The eyesight of the horned owls seems to be better than that of most owls, and Dr. Fisher thinks that in the breeding season they hunt indifferently night or day. In disposition, he says, they are "fierce and untamable, and in point of strength and courage inferior to none of our rapacious birds." Speaking of their food habits, the doctor says that "a bird so powerful and roracious may at times be a source of great benefit, while at other times it may be the cause 


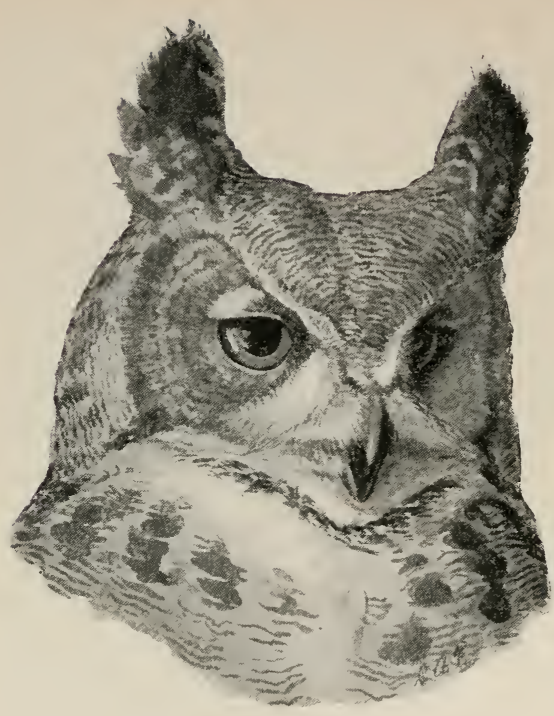

Fig. 249. Western Horned Owl.

of great damage. Now, the serious inroads it makes on the tenants of the poultry yard, as well as the destruction of many game and song birds, would seem to call for the total suppression of the species. Again, when engaged chiefly in the capture of injurious rodents, which threaten the very existence of the crops, it is the farmer's most valuable ally, and consequently should be most carefully protected."

The horned owl is one of the earliest breeders of the birds of prey. In the southern part of its range, eggs are laid in December and January, and in Alaska they hare been found in April when it was so cold that they froze on being taken from the nest.

\section{5b. B. v. areticus (Swains.). Arctic Horned Owl.}

Similar to the western horned owl, but ground color white and dark markings usually much restricted ; under parts pure white, or only slightly barred.

Distribution. - Arctic America, south in winter to Nebraska, and from Dakota to Idaho.

Nest. - In trees, of ten a deserted hawk's or erow's nest. Eggs : ㄹ or 3. white.

Food. - Largely waterfowl, ptarmigan, and aretic hares.

\section{5c. B. v. saturatus Ridgu. DUsky Horned OwL.}

Like $B$. v. pallescens, but plmmage extremely dark, face generally sooty brownish mixed with grayish white; plumage usually without excess of yellowish brown, sometimes with none.

Distribution. - West coast region from Monterey County, California, to Alaska, and eastward to northern Rocky Mountains.

Nest. - As described by Kemicott, in the top of a sprnce, made of dry branches, lined with feathers. Figgs: probably 2 to 4 , white.

375d. B. v. pacificus Cassin. Pacific Horved OwL.

Small, strongly mottled, npper parts grayislı, with more or less buffy admixture; dark markings of under parts slistinct; tarsus strongly mottled. Hing: $1: 3$. 
Distribution. - Valleys and southern coast of California, and east to San Franciseo Mountain, Arizona.

Eggs. - Usually :3.

\section{GENUS NYCTEA.}

376. Nyctea nyctea (Linn.). Sxow OwL.

Ear tufts rudimentary; ear openings small, without anterior flap, the two ears not distinctly different; tail not reaching beyond tips of longest under coverts; four outer quills emarginate; toes covered with long:

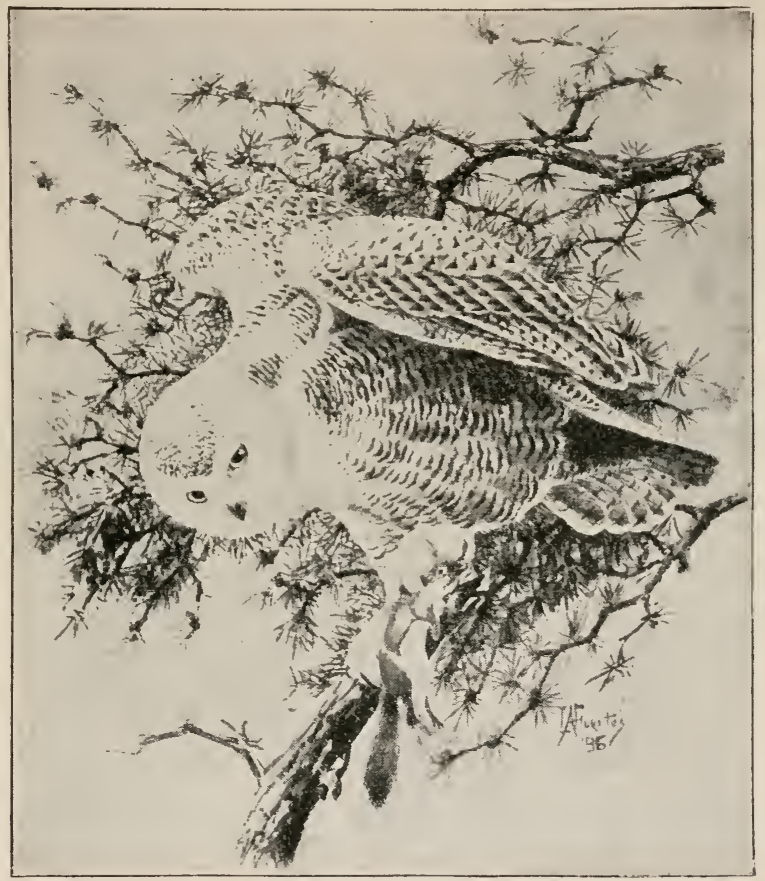

From The Osprey.

Fig. 250.

hair-like feathers, partly or wholly concealing the claws; bill nearly concealed by loral feathers. Adult male: body pure white, sometimes almost unspotted, but usually marked more or less with transverse spots or bars of slaty brown. Adult female: much darker, pure white only on face. throat, middle of breast and feet, the head spotted, and the rest of the body barred with dark brown. Male: length 20-23, wing 15.5017.30, tail $9.00-9.70$, bill 1. Female: length $29-27$, wing $17.30-18.70$, tail $9.70-10.30$, bill 1.10 . 
Distribution. - Breeds in arctic portions of the northern hemisphere, migrating south in North America almost across the United States and even reacling, accidentally, the Bermudas.

Nest. - In a slight depression of the ground, on a knoll, made of a few feathers, lichens, or moss. Eggs : usually 5 to 7, white.

Food. - In summer, lemmings and meadow mice; in winter, fish, hares, muskrats, squirrels, rats, ptarmigans, ducks, and even offal.

The snowy owl is a circumpolar species, breeding in the arctic parts of the northern hemisphere and coming south in winter.

Mr. Nelson, while traveling south of the Yukon in Decenber, shot an owl whose nearly immaculate milky white plumage was suffused with " a rich and extremely beautiful shade of clear lemon yellow. exactly as the rose blush clothes the entire plumage of some gulls in spring. The morning after the bird was killed the color was gone, the plumage being dead white.'

\section{GENUS SURNIA.}

377a. Surnia ulula caparoch (Mïll.). American Hawk Owl.

Head without ear tufts; ear openings small like Bubo and $N$ yctea; tail long, more than two thirds length of wing, graduated; tarsus scarcely or not longer

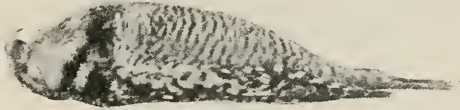

Fig. 251. than middle toe; feet thickly feathered to claws. Adults : face grayish white, encircled by heary black ring; patches on throat, sides of head. and back of neck black; cliest band whitish; rest of under parts closely and regularly barred with brown and white; top of head and hind neck blackish or brownish, dotted with white; rest of upper parts dark brown, mainly spotted or barred with white. Young: npper parts dark brown, feathers of top of head and hind neck tipped with grayish buff, those of back with indistinctly lighter tips; lores and ear coverts brownish black; rest of face whitish; under parts whitish, washed with sooty on ehest, barred below. Length: 14.75-17.50. wing about 9 , tail $6.80-7.00$.

I istribution. - Northern North America, south in winter to the northern United States, casually to Massachusetts, and rarely to the British Isles. Recorded from northern Montana and Newfoundland in the breeding season.

Nest. - Old woodpecker holes, natural cavities in trees, and old nests of other species relined with moss and feathers. Eggs: :3 to 7 , white.

Food. - Small mammals, such as mice, lemmings, and ground squirrels ; also ptarmigans and insects.

" The hawk owl is strictly diurnal, as much so as any of the hawks, and like some of them often selects a tall stub or dead-topped tree in a comparatively open place for a perch, where it sits in the bright sunlight watching for its prey. Although the flight is swift and hawk-like, it has nevertheless the soft, noiseless, character common to the other owls. When starting from any high place, such as the top of a tree, it usually pitches down nearly to the ground, and flies off rapiclly abore the tops of the bushes or high grass, abruptly ris- 
ing again as it seeks another perch. The note is a shrill cry which is uttered generally while the bird is on the wing." (Fisher.)

\section{GENUS SPEOTYTO.}

\section{Speotyto cunicularia hypogæa (Bonap.). Burkowing OWL.}

Tail only about half as long as wing; tarsus more than twice as long as middle toe, scantily feathered in front, bare behind; toes bristly.

Adults. - Upper parts dull earth brown. spotted and barred with white and buffy; under parts mainly buffy barred with brown. Young: under parts mainly buffy, unmarked; upper parts plain brown except wings and tail, which are as in adults. Length: $9-11$, wing $5.80-7.20$, tail $3.15-3.50$, bill .55-.60.

Distribution. - Plains region from the Pacific east to Dakota and Texas, and from British Columbia and eastern slope of Rocky Mountains south to Guatemala.

Nest. - At the end of an old burrow of prairie dog, badger, or ground squirrel, or in a similar eavity. Eggs: 6 to 11, white.

Food. - Ground squirrels, young prairie dogs, mice, gophers, small birds, frogs, liz-

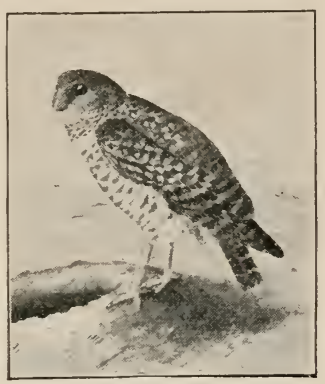

From Biological Survey, U.S. Dept. of Agriculture.

Fig. 252. ards, horned toads, and even fish, together with crickets, grasshoppers, beetles. scorpions, and centipeds.

When you are living in the owls' country, they, like the ground squirrels and prairie dogs, come to seem a part of the landscape, and as you ride over the great brown stretches you find yourself looking for the quaint little 'Billy owls' for life and interest on the monotonous way. In a region where there are only scattered holes suitable for their nests, solitary owls or families are most often seen, and sometimes there will be as many as nine around one burrow. But where a ground squirrel colony or prairie $\log$ town offers good nest holes the little owls gather in companies.

In $\log$ towns the $y$ often find spacious old badger holes to occupy. As rou walk about one of the towns and the $\operatorname{logs}$ lope off to their holes shaking their little yellow tails as they disappear, the owls stand statue-like around their burrows with their eyes upon jou. If you are bent on getting within good photographing range the young ones will go backing down their holes, their solemn round yellow eyes fixed on pours till they drop below the earth line. Their elders will probably fly before you get your focus, though it is only a low short flight to a neighboring mound. It rarely seems to occur to them to leave the town.

The association of owls, dogs, badgers, and rattlesnakes is far from being that of the happy family circle it was formerly supposed. The 
rattlesnakes are evidently attracted to the towns by the supply of tender spring dogs, and it has been suspected that the badgers relish a young owl for breakfast. The owls have been accused of joining in the neighborly round-robin feast and partaking of the young dogs, but, although they eat squirrels and mice in spring and fall, they live for the most part on grasshoppers and crickets. They hunt mainly in the evening and at night, but are often seen catching grasshoppers in the daytime.

\section{GENUS GLAUCIDIUM.}

General Characters. - Wing 3.50-4.40; head without ear tufts; ear openings small, without anterior flap, the two ears alike; nostril small, circular. opening near the middle of the inflated cere; tarsus not longer than middle toe, densely feathered; tail more than half as long as wing, rounded.

KEY TO SPECIES.

1. Sides plain brown, mspotted

1 '. Sides more or less spotted.

2. Back grayer

2 '. Back browner

phalænoides, p. 191.

. . gnoma, p. 190. californicum. p. 191.

\section{Glaucidium gnoma Wagl. Pygmy OwL.}

Adults. - Verv small, under parts white, thickly streaked with dark brown ; sides brownish. indistinctly spotted with lighter; upper parts dark

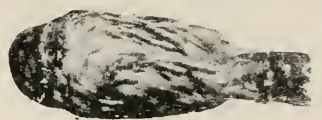

Fig. 253. slaty gray. olive brown. or dark rusty brown; head specked with white; tail blackish or brownish, barred with white. Young: like adult. but top of head plain gras. Length : 6.50-7.50. wing $3.40-4.00$, tail $2.40-2.80$.

Distribution. - Timbered monntain regions of western North America from British Columbia south through Sierra Madre of Mexico, except along the humid Pacific coast region.

Nest. - As far as known, in old woodpecker holes and hollow stubs from $S$ to 20 feet from the ground. Eggs: usnally 4, white.

Food. - Mainly insects, especially grasshoppers; but also mice and lizards.

"This little owl is diurnal in its habits, feeding and flying about in the bright sunshine, though it is more common in the early dusk and morning. Mr. Henshaw says it is fond of taking its station early in the morning on the top of an old stub, that it may enjoy the warmth of the sun's rays. In most places it is more or less solitary, though in New Mexico Mr. Henshaw found it extremely sociable, and in the fall it was usually met with in companies.

"It is tame and unsuspicious and may be decoyed from a considerable distance by imitating its call-note, to which it responds at once. It is confined mostly to wooded districts, though occasionally it is found some distance from timber. It hides in the pines or 
other thick foliage, where it sits upright near the trunk and is practically invisible to the observer.

"The flight is not very much like that of other owls, but resembles that of the sparrow hawk to some extent, and is not altogether noiseless. The love-notes, according to Captain Bendire, are somewhat musical, although they resemble to some extent those of the mourning dove." (Fisher.)

\section{9a. G. g. californicum ( $s c l$.). California Pygmy Owl.}

Similar to G. gnoma but browner, chest heavily washed with reddish brown. Young: nuch paler, ash gray on head and grayish brown on back. unspotted.

Distribution. - Humid coast region from southern British Columbia south to northern California.

Nest. - In deserted woodpecker holes. Eggs: usually 4, white.

Food. - Largely manmals and small birds.

\section{Glaucidium phalænoides (Daud.). Ffrrugrinous Pygmy OWL.}

Adults. - Similar to the pygmy owl, but sides of breast plain brown or rufous, upper parts varying from grayish brown to bright rufous; head finely streaked with whitish ; tail banded, bars varying from white to rufons and interspaces from grayish browu to blackish. Young: top of head plain. Length: $6.50-7.00$, wing $3.50-4.60$, tail 2.20-3.50.

Distribution. - From Texas, New Mlexico, and Arizona, south to southerı Brazil.

Nest. - As far as known, in hollow trees, or woodpecker holes. Eggs: - taken by Sennett - 4, white.

The little ferruginous owl is diurnal like the other pygmies, flying about hunting in bright sunlight. His note, as given by Mr. F. Stephens, is a "loud cuck repeated several times, as rapidly as twice each second," given with a jerk of the tail and a toss of the head.

\section{GENUS MICROPALLAS.}

\section{Micropallas whitneyi (Cooper). ELF OwL.}

Head without ear tufts; ear openings small; nostril small, circular, opening near the middle of the inflated cere; tarsus longer than middle toe, scantily haired; claws small and weak; tail even, less than one half as long as wing; smallest United States owl. Adults: face with white eyebrows; lores and throat band white, encir-

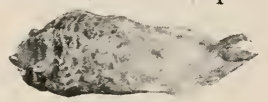

Fig. 254. cled by brownish ring; under parts whitish, with vertical blotehes of dark brown and rusty, finely mottled with darker; upper parts grayish or grasish brown, finely mottled with darker and rusty, and indistinetly specked with rusty ; tail brownish, crossed by 5) or 6 narrow pale brownish or rusty bands, usually interrupted on middle feathers. Length: 5.50-6.25, wing $4.00-4.40$, tail $1.90-2.30$.

Distribution. - From southern Texas to southern California. and south through Lower California and tablelands of Mexico.

Nest. - In old woodpecker holes in giant cacti or hollow trees. Eggs: 2 to 5 , white.

Food. - As far as known, small mammals, grasshoppers, and beetles. 
Unlike the pygmy owls the elf owls are nocturnal, spending the day either in thickets or old woodpecker holes. Major Bendire says they become active soon after sundown. He has had them come to his camp, attracted probably by the insects which gathered about the guard fire through the night.

When resting in the daytime the little owls are not too stupid to protect themselves, as is shown by a curious experience $\mathrm{Mr}$. F. Stephens had with one. He startled the owl in a willow thicket, and when he found it in the dense tangle, as he says, it was "sitting on a branch with its face toward me and its wing held up, shield fashion, before its face. I could just see its eyes orer the wing, and had it kept them shut I might have overlooked it, as they first attracted my attention. It had drawn itself into the smallest possible compass so that its head formed the widest part of its outline. I moved around a little to get a better chance to shoot, as the bush was very thick, but whichever way I went, the wing was always interposed, and when I retreated far enough for a fair shot, I could not tell the bird from the surrounding bunches of leaves. At length, losing patience, I fired at random and it fell. Upon going to pick it up I was surprised to find another which I had not seen before, and which must have been struck by a stray shot." (Quoted by Bendire.)

\section{ORDER PSITTACI: PARROTS, MACAWS, PAROQUETS, ETC.}

\section{FAMILY PSITTACIDA: PARROTS AND PAROQUETS.}

\section{GENUS RHYNCHOPSITTA.}

\subsection{Rhynchopsitta pachyrhyncha (Swains.). Tніск-} BILLED PARROT.

Bill large. tip of lower mandible elongated, cut off, and flattened; tail graduated for abont one third its length ; cere densely feathered, concealing the nostrils. Adults: bill blackish. body green except for poppy red on forepart of head and wings, and lemon vellow under wing coverts. Young: similar, but bill mainly whitish and red restrieted. Length: 16.00-16.75, wing $8.50-10.50$. tail $6.30-7.00$, graduated for $2.25-2.35$.

Distribution. - Mountains bordering tablelands of Mexico; northward casually to the Chiricaluna Mountains, Arizona.

A flock of nine or ten thick-billed parrots seen by Mr. Lusk in the Chiricahua Mountains came, as he says, scolding, chattering, and calling up a canyon to the edge of the piñon pine belt, where they devoted themselves to getting the piñones. "Investigation of their stomachs," he says, "showed nothing but a plentiful quantity of very immature piñones wrested from their cavities in the hearts of the hard, green cones by their powerful beaks." 


\section{ORDER COCCYGES: CUCKOOS, ETC.}

\section{(Familes Cuculid a, Trogonide, Axd Alcedinide.)}

\section{FAMILY CUCULID㞋: ANIS, ROAD-RUNNERS, AND CUCKOOS.}

KEY TO GENERA.

1. Tail feathers $S$

Crotophaga, p. 193.

1'. Tail feathers 10 .

2. Bill longer than head . . . . . . Geococcyx, p. 198.

2'. Bill not longer than head . . . . . . . . Coccyzus, p. 195.

\section{GENUS CROTOPHAGA.}

\section{Crotophaga sulcirostris Swains. Groove-billed AnI.}

Bill thick, with a convex crest; wings rounded; tail feathers broad, widening to very obtuse ends. Adults : dull black, feathers of body with metallic bluish, greenish. or bronzy edgings; wings and tail faintly glossed

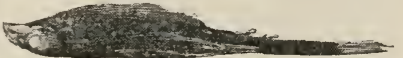

Fig. 255. with metallic bluish or violet; upper part of bill with several distinct grooves. Young: uniform sooty black. Length: 12.00-14.50, wing 5.506.50 , tail $7.30-8.30$.

Distribution. - In Lower Sonoran and Tropical zones from southern Texas south to Peru. Casual in southern parts of Califormia, Arizona, Louisiana, and Florida.

Nest. - Bulky, made of twigs and lined with green leaves, placed often in an orange or lemon tree. Eggs : 3 to 5, milky blue.

Food. - Grasshoppers, and parasites of cattle.

The groove-billed anis are residents of the lowlands, Major Bendire says, rarely being found at an altitude of more than 700 feet.

They resemble the cowbirds in their habit of following cattle, and not only catch the insects that the cows start up but do a great deal of good by relieving the animals of the parasites which infest them. When not disturbed the birds become very tame and roost in numbers about the houses. Their call-note, Dr. Ralph thinks, suggests that of the flicker - a plee-co repeated rapidly.

\section{GENUS GEOCOCCYX.}

\section{Geococcyx californianus (Less.). RoAd-RunNer.}

Bare space around eye, orange and blue; feathers of head and neck largely bristle-tipped; whole plumage coarse and harsh; eyelids lashed; wings short and concavo-convex, with long inner secondaries folded entirely over primaries; tail long and graduated; upper parts conspicuously streaked with brownish white, most heavily on wings; crest and fore parts of back glossed with bluish black, changing to bronzy green or brown; tail long, plain bronzy, blue black, and green, graduated, tips with white 


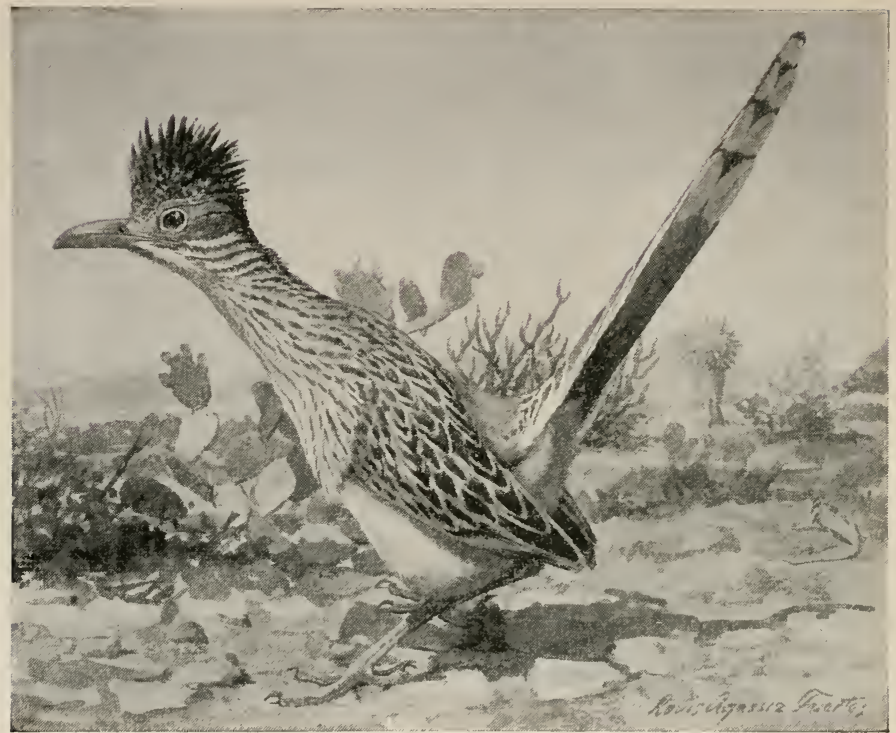

Fig. 256. Road-runner.

thumb marks except on middle feathers; chest brownish white. streaked with black; throat and belly whitish. Length: 20-24, wing 6.50-7.00. tail 11.50-12.00.

Distribution. - Breeds in Upper and Lower Sonoran zones. from Brownsville, Texas, to San Diego, California, and from central California, Nevada. and Kansas, south across tablelands of Mexico.

Nest. - Compactly built of sticks, lined variously with grass, manure chips, feathers, inner bark, mesquite pods, snakeskin. and roots; placed in eacti, bushes, or low trees. Eggs : usually 4 to 6, white or pale yellowish.

Food. - Mice, snakes, lizards, crabs. snails. grasshoppers, centipeds. caterpillars, beetles, and cactus fruit.

The road-rumer is one of the most original and entertaining of western birds. The newcomer is amazed when the long-tailed creature darts out of the brush and races the horses down the road, easily keeping ahead as they trot, and when tired turns out into the brush and throws his tail over his back to stop himself. Even the oldest inhabitant likes to talk about the swift rumer whom it takes a 'right peart cur to catch,' and who eats horned toads, comes to drink and feed with the hens in the dooryard one day, and the next may be hunted rainly in the dense chaparral or cactus where it make's its home. They tell you how they have seen it mount the 
granite boulders on the liils, and after strutting about with wings and tail hanging, put its bill down on the rock and pump out loud notes, which they interpret as love-calls for its mate in the brush below. Many marrelous yarns are spun over the pipes about the strange ways of this curious bird, especially about its deadly encounters with rattlesnakes.

The food of the ruad-runner may well make hin of interest to his neighbors. In southern California, where the passion vine is used extensively for house decoration, it is infested by a pestiferous caterpillar, which he eats with great aridity. He also affects other pests. In the stomach of one bird, which we got in New Mexico, there were a large black cricket, a number of big grasshoppers, remains of a caterpillar and some beetles, a centiped six inches long, and a garter snake a foot long! such an appetite surely deserves well at the hands of its friends.

\section{GENUS COCCYZUS.}

General Characters. - Bill not longer than head, and gently eurved for most of its lenǵth; loral feathers and general plumage soft and blended; tarsus naked. shorter than outer anterior toe and claw.

KEY TO SPECIES.

1. Bill with basal part of lower mandible yellow.

2. Smaller, wing 5.61. with comparatively smaller and weaker bill.

americanus, p. 195.

2'. Larger, wing 5.\$4, with comparatively larger and stouter bill.

occidentalis, p. 196.

1'. Bill wholly black or bluish

ery throphthalmus. p. 196.

387. Coccyzus americanus (Linn.). Yellow-Billed Cuckoo.

Adults. - Lower half of bill plain yellow; under parts white or ashy : upper parts plain grarish brown. faintlyglossed with green; wings with inner webs rufous; tail graduated, all but middle feathers blue black, the outer ones tipped with broad white thumb marks. Young: tail feathers duller and markings less distinet. Length: 11.00-12.70. wing 5.40-5.80, tail $6.00-6.15$ exposed culmen $.97-1.01$. depth of bill at base .32-.34.

Remarks. - The smaller size and smaller and weaker bill dis-

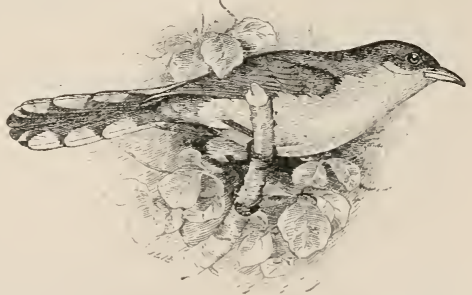

From Biological survey, $\mathbf{L}$. s. Dept of Agriculture. Fig. 25\%. tinguish this species from the California cuckoo.

Distribution. - Eastern temperate North America, breeding from Florida north to New Brmuswick. Canada, and Minnesota; west to South Dakota, Nebraska. Indian Territory, and Texas; wintering south to Costa Rica and the West Indies; casnally to eastern Colorado, Wyoming, and North Dakota. 
Nest. - A slight platform of sticks in trees. Eggs : 2 to 4, bluish green.

Food. - Largely caterpillars, but also grasshoppers, potato bugs, and other insects.

Though an eastern bird, the yellow-billed cuckoo is sometimes found in the cottonwoods bordering irrigation ditches in southern New Mexico. As it moves about in a treetop looking for caterpillars, it shows the large white thumb-marks of the under side of its tail, and as it flies down to a fence shows the striking reddish brown of its wings. As a family the cuckoos are little in evidence, being generally lidden in some thick leafy cover looking for caterpillars. When they do fly their long slender bodies pass swiftly by in a straight line to disappear in other cover.

Their presence would often be wholly unknown but for their notes, which, like the peacock's, are considered a sign of rain - rain crows they are commonly called in consequence. They have a variety of notes, the commonest being, as Major Bendire gives it, noo-coo-coo-coo or con-cow-cow. In the breeding season a number of males sometimes get together and give a veritable cuckoo concert.

\section{7a. C. a. occidentalis Ridgw. California Cuckoo.}

Adults. - Upper parts grayish brown, with faint green gloss; ander parts white, grayish across chest; lower half of bill mainly yellow; side of head with blackish streak; tail graduated, middle feathers like back, tipped with black, the rest blue black, with broad white thumb marks on tips; wing quills mainly rufous on imner webs. Young: like adults. but tail duller, without blue, and white not strikingly contrasted with brown. Length: $12.30-13.50$, wing $5.50-6.00$, tail $6.10-6.90$, bill $1.02-1.08$, depth of bill throngh base $.37-.40$.

Distribution. - Western temperate North America, breeding from southern British Columbia south to central Tamanlipas and northern Chihuahua, Mexico ; from the Pacific east over the eastern slope of the Rocky Momntains and western Texas; migrating to northern Lower California and tablelands of Mexico.

Nest. - A loose platform of twigs, sometimes lined with leaves. dry grasses, and flower blossoms ; placed nsually in willow or mesquite thickets, 10 to 15 feet from the ground. Eggs : generally 3 or 4 , light greenish blue, unspotted.

Food. - Caterpillars, black crickets, grasshoppers, and other insects.

The California cuckoo is in all respects the western counterpart of the yellow-billed, from which it can be told only by size.

\section{Coccyzus erythrophthalmus (Wils.). BLACK-BILled} Cuckoo.

Adults. - Upper parts grayish brown, faintly glossed with green, tail feuthers narrouly tipped with dull white, preceded

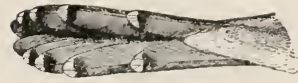

Fig. 258. by blackish bar; nuder parts gravish, fading to white on belly; bill blackish, naked eyelids bright red in life. Young: above dull brown, with eoppery bronzy lnster, becouning dull rusty 
on wings and greenish on tail; naked eyelids plain yellowish in life. Length: 11.00-12.70, wing 5.12-5.(i.), tail 6.25-7.00.

Riemarks. - The black bill, absence of rufous on wings, and of blue and wide white thumb marks on tail distingnish this from the yellow-billed forms.

Distribution. - Eastern North America, west to the eastern foothills of the Rocky Momtains, and from Labrador, Manitoba, and Assiniboia sonth in winter to the West Indies and the valley of the Amazon. Breeds mainly in Transition zone.

Nest. - Better built than that of the other species, its platform of twigs being mixed with imer bark, rootlets, and weed stems, lined often with catkins; placed usually not over 6 feet from the gromnd in trees or bushes, on logs, or even on the ground. Eggs : 2 to 5, bluish green.

Food. - Largely caterpillars.

The black-billed cuckoo closely resembles the yellow-billed in general habits. Both birds have a trace of the parasitism of the old world species, sometimes laying in each other's nests, and on rare occasions depositing their eggs in nests of other species. 'This is done more frequently by the black-billed, Major Bendire thinks. He holds that the real cause for such unnatural behavior on their part is not yet understood, as the cuckoos are most devoted parents.

\section{FAMILY TROGONID $巴$ : TROGONS.}

\section{GENUS TROGON.}

\section{Trogon ambiguus Gould. Coppery-talled Trogon.}

Bill short and thick, edges serrated. gape bristled; eyelids lashed; wings short and rounded; tail long with broad feathers; feet small and weak; plumage soft and lax. Adult male: face and throat black, bordered on breast by white crescent; rest of under parts rose pink; upper parts metallic bronzy green; wings mainly grayish; tail with middle

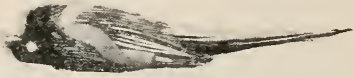

Fig. 259. feathers shading from bronzy to rich copper color, broadly tipped with black, outer feathers white, finely zigzagged with black. Aduit female: similar, but black of male replaced by gray, and metallic colors replaced by grayish brown, becoming reddish brown on middle tail feathers. Young: head, neck. and chest dull brownish gray, most of under parts grayish; eye ring and bar across ear coverts white; rest of upper parts brown; wings with large spots of buffy and black; tail much like adult female. Length: $11.25-12.00$, wing $5.10-5.50$, tail $6.50-7.20$.

Ihistribution. - From southern Texas and Arizona south to Mexico.

Food. - Fruit and grasshoppers and other insects.

The trogon lives in pines in the mountains of southern Arizona. Its note is described by Dr. Fisher as similar to that of a hen turkey. The bird the doctor saw calling sat upright on a pine branch with tail hanging, and at each note threw back its head and pointed its bill to the sky like a peacock. 


\section{FAMILY ALCEDINID㞋: KINGFISHERS.}

\section{GENUS CERYLE.}

General Characters. - Head with occipital crest; bill longer than head, stout, acute ; wings long and pointed; tail much shorter than wing; tarsus only about half as long as middle toe.

\section{KEY TO SPECIES.}

1. Upper parts bluish gray.

2. Belly white . . . . . . . . . . alcyon, p. 198.

2 . Belly rufous . . . . . . . torquata, p. 199. $1^{\prime}$. Upper parts metallic bottle green . . . . septentrionalis, p. 199. 390. Ceryle alcyon (Linn.). Belted Kingfisher.

Adult male. - Under parts white, with blue gray belt across breast; crest and upper parts bluish gray; nuchal collar white; wing quills black,

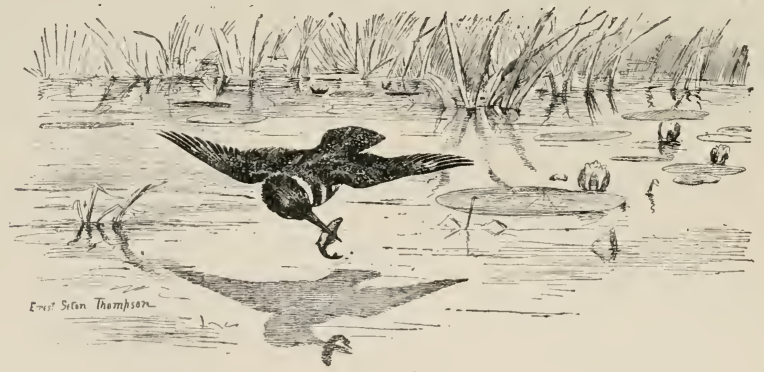

Fig. 260 .

marked with white; tail with middle feathers bluish gray, the rest black. spotted with white. Adult female: similar, but belly partly banded and sides heavily washed with rufous. Young: like adults, but male with breast band and sides tinged with rusty. Length : 11.00-14.50, wing 6.00(6.50, tail :3.80-4.80, bill 2 or more.

Distribution. - North America from the Arctic Ocean south to Panama and the West Indies. Breeds from the southern border of the United States northward; accidental at the Hawaiian Islands.

Nest. - A burrow 4 to 15 feet long, in railroad cuts or perpendicular banks over water. Eggs: usually 5 to \&, white.

Food. - Fish, and when not obtainable frogs, lizards, crustacea, and insects such as coleoptera, grasshoppers, and large black crickets.

So long as the fishing is good the kingtisher is equally at home in IIaine, southern T' 'xas, or the Yosemite, but in the Sierra Nevada mountains the brown streams polluted by placer mining have no attraction for him, and when you hear his rattle as you ride through the forest you may know that near by you will find a clear mountain brook where you may quench your thirst.

What rare spots the hirds recall! They are associated with the 
quieter phases of nature, with still woodland pools and smootl lakes, where they give a vivifying touch of active wild life. In a remote narrow canyon, how they thrill you as they dash by overhead - a flash of blue and white!

When you are idling beside a pellucid stream like the Merced, where each overhanging leafy branch is mirrored, each tiny tish seen as it lies in the still water, sometimes a sudden plunge and splash startles jou from a diver who before has been watching from his branch, as silent as the brook. He circles back to his perch, where his fish glints in the sun as he shakes it, and throwing up lis long bill, swallows, cleans his beak on the brancl, and with a satisfied rattle turns to look about, blue crest raised, white collar shining, and short tail tipped up in an animated way. Four plunges I have seen him make in almost as many seconds, stopping to preen himself only after the fourth wetting. Once when he dived in shallow water he did not take the trouble to fly up but stood on the sand with tail at an angle till he had finisher his fish. When watching a pool he will sometimes stand in air hovering over the water a moment, then rise and hover at a higher level.

Though generally found along woodland streams, the kingfishers are seen sometimes perched on the rigging of vessels in the harbors.

\section{[390.1.] Ceryle torquata (Linn.). Great Rufous-bellied King-} FISHER.

Adult male. - Upper parts bluish gray, more or less streaked with black ; tail spotted with white; throat and nuchal collar white; breast and belly rufous; under tail coverts and anal region white. Adult female: similar, but breast grayish blue, usually bordered behind by white, and lower tail coverts and anal region rufous. Length: $15.50-17.00$, wing about 7.50 .

Distribution. - Tropical America (except West Indies). Casual on the lower Rio Grande in Texas.

\section{Ceryle americana septentrionalis Sharpe. Texas KINGFISHER.}

Small; head not crested. Adult male: upper parts green, spotted on wings with white; chest crossed by broad band of chestnut, bordered below by green spots; throat. collar, and belly white. Adult female: similar to male but witliout ehestnut, and with two bands of green spots across breast. Young male: like adult, but

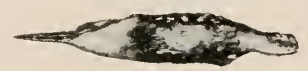

Fig. 261. breast more or less tinged with rusty. Length: 6.75-8.50, wing 3.40-3.50. tail $2.70-2.75$, exposed culmen 1.6.5-1.5.5.

Distribution. - From southern Texas and Sinaloa. Mexico, south to Panama.

Nest. - A burrow in a bank. Eggs : 5 to 6 , white.

Food. - Like that of Ceryle alcyon.

The habits of the little Texas kingfisler are said to be the same as 
those of its larger relative. In southern and western Texas many of its nests are destroyed by the cloud-burst floods which annually sweep the rivers there.

\section{ORDER PICI: WOODPECKERS, ETC.}

\section{FAMILY PICID王: WOODPECKERS.}

\section{KEY TO GENERA.}

1. Outside hind toe longer than outside front toe.

2. Toes 4,2 pointing forward, 2 back.

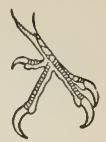

Fig. 262.

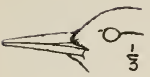

3. Nasal groove extending only about half way to tip of bill . . . . . . Sphyrapicus, p. 210.

Fig. 263.

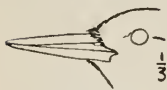

$3^{\prime}$. Nasal groove extending nearly to tip of bill.

Fig. 264.

4. Plumage wholly black except for white head and white patch on wings. . Xenopicus, p. 207.

4'. Plumage mainly white below and spotted with white above . . . . . Dryobates, p. 201.

2'. Toes 3, 2 pointing forward, 1 back . Picoides, p. 208.

Fig. 265.

$1^{\prime}$. Outside hind toe not longer than outside front toe.

2. Head with conspicuous erest. Ceophlœus, p. 213.

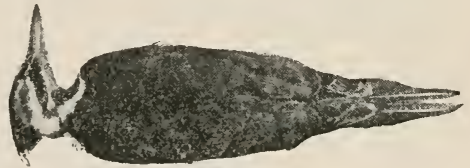

Fig. 266.

2 . Head without crest.

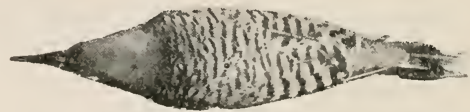

Fig. 267.

3. Under surface of wing and tail yellow or red.

Colaptes, p. 220.

3 '. Under surface of wing and tail not yellow or red ; upper mandible with a distinct lateral ridge and nasal groove. Melanerpes, p. 215. 


\section{GENUS DRYOBATES.}

General Characters. - Bill straight, square at tip, beveled toward end, with sharp culmen and distinct lateral ridges, and large nasal tnfts hiding the nostrils; tongue greatly extensile; feet with outer hind toe longer than outer front toe; wing long, pointed.

\section{KEY TO SPECIES.}

1. Upper parts brown .

arizonæe, p. :206.

1'. Upper parts black, marked with white.

2. Outer tail feathers plain white.

3. Upper parts black, barred with white. . . . nuttallii, p. 205. $3^{\prime}$. Upper parts black, with a white stripe down back.

4. Wing coverts and tertials conspicuously spotted with white.

leucomelas, p. 201.

4'. Wing coverts and tertials plain black or lightly spotted with white.

5. Under parts smoky gray .

harrisii, p. 202.

5 . Under parts pure white.
6. Simaller.
. hyloscopus, p. 202.

$6^{\prime}$. Larger .

monticola, p. 203.

$2^{\prime}$. Outer tail feathers white, barred with black.

3. Upper parts black, barred with white.

4. Onter web of outer tail feather barred for more than terminal half . . . . . . . . bairdi, p. 204.

t'. Outer web of outer tail feather barred for only terminal half or less . . . . . . . . . lucasanus, 205.

3'. Upper parts black, witlı white stripe down back.

4. Wing coverts couspicuously spotted with white. Middle and northern United States . . . . . . medianus, p. 204.

$4^{\prime}$. Wing coverts not conspicuously spotted with white.

5. Under parts pure white. Rocky Mountain region.

homorus, p. 203.

$5^{\prime}$. Under parts smoky gray or brown. British Colmubia to Califormia . . . . . . . gairdnerii, p. $20 \%$.

\section{3a. Dryobates villosus leucomelas (Bodd.). NorthenN HaIRY WOODPECKER.}

Adult male. - Upper parts black, with a scarlet band across back of crowu, white stripe down back and wing coverts and tertials conspicuously spotted with white; outer tail feathers plain white; nnder parts pure clear white. Adult female: similar, but without red on head. Young: crowu with red. Length: 10-11, wing 5.02-5.40, tail 3.60-3.80, bill 1.40-1.62.

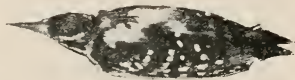

Fig. 268.

Distribution. - Northern North America, south to abont the northern border of the United States.

Vest. - In holes in trees. Eggs: white.

Food. - Larvæ of wood-boring insects, ants, and a small amount of wild frnit, berries, and beechnuts.

The hairy woodpecker, of whatever geographic race, is a quiet, solitary bird of the timber, and you may ride through the forests day after day without seeing it, as its surprising absence from your 
records on its breeding grounds attests. A sharp peek will sometimes reveal its presence, and if you look quickly you may catch sight of a vanishing back marked with a white vertical line.

In working, the hairy woodpecker takes short hops up the tree trunk, sidles around, or backs down with equal ease. It is a forest preserver, spending its life in ridding the trees of wood-borers and other insects that destroy them. When not engaged in getting food, it entertains itself by drumming on a resonant branch.

The Harris woodpecker is the humid Pacific coast form of villosus while Cabanis is the interior form. As villosus is a Transition zone bird it affects yellow pines and aspens, and in the ponderosa forests of Arizona I have seen it excavate in pine bark with wonderful dexterity. Instead of drilling straight down, with its head on one side, it would fleck off and send flying the thin flakes of bark which characterize the tree. In Arizona the young Cabanis woodpeckers leare their nests about the middle of June, Dr. Mearns says, and soon after make a partial vertical migration downward to the lower edge of the pine belt in company with other birds that breed at the higher levels. In winter when the timber gets icy the woodpeckers sometimes go as low as the cotton woods, where they are usually accompanied by flocks of Cassin finches, red-backed juncos, and their especial companions, the slender-billed nuthatches.

393c. D. v. harrisii (Aud.). HARRIS WOODPECKER.

Adult male. - Upper parts black, with scarlet nape, white stripe down back, wing coverts and tertials plain black or lightly spotted with white;

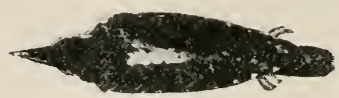

Fig. 269. onter primaries with white spots; onter tail feather plain white; under parts smoky gray or light smoky brown. Adult female: similar, but without scarlet nape. Young: similar, but forehead spotted with white and scarlet of nape extending partly or wholly over crown. Length: 9-10, wing $4.70-5.30$, tail $3.20-3.75$, bill $1.12-1.40$.

Remarks. - The plain black or very lightly spotted wing coverts and tertials of harrisii distinguish it from the northern and southern hairy woodpeckers, while its snoky under parts distinguish it from hyloscopus.

Distribution. - Pacific coast in hnmid Transition and Canadian zones, from Alaska south to northern California (Humboldt Bay).

Nest and egrs similar to that of the northern hairs.

Food. - Wood-boring larvie, wasps, weevils, beetles, ants, seeds, and wild berries.

\section{3d. D. v. hyloscopus (Cab.). Cabanis Wooppecker.}

Similar to D. v. harrisii, but white instead of smoky below, and somewhat smaller.

Distribution. - Resident in arid Transition zone of the sonthwestern United States and south to momtains of Zacatecas, Mexico - replaced by harrisii in the humid coast district.

Nest. - Usually 12 to 18 feet from the gronnd in pines, aspens, and other trees. Eggs: : 3 to ti, white. 
Food. - Mainly injurious larve and insect eggs, with small berries and seeds, piñon myts, pine seeds, and acorns.

\section{3e. D. $\nabla$. monticola Anthony. Rockx Mountaix Hairx WOODPECKER.}

Like hyloscopus, but larger, clearer white below, and with lores chiefly or wholly bhek. Male: wing 5.23, tail 4, bill from nostril 1.12. Female: wing 5.04 , tail 3.80 , bill from nostril . (\%).

Remarks. - The Rocky Mountain woodpecker is equal in size and intergrades with the northern hairy, but typical specimens of each can be distinguished by the unspotted wing eoverts and tertials of the Rocky Mountain bird.

Distribution. - Rocky Nountain region of the United States from New Mexico to Montana; west to Utah.

Food. - Moths, wood-boring beetles, ants, other insects, and spiders.

\section{4a. Dryobates pubescens gairdnerii (.1ud.). Gairdxer WOODPECKER. ${ }^{1}$}

Adult male. - Upper parts black, with dingy whitish forehead, scarlet nape, and white stripe down back; middle and greater wing coverts plain black, or only lightly spotted with white; outer tail feathers white, barred with black; under parts smoky gray or light smoke brown. Adult female: similar, but

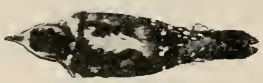

Fig. 270 . without scarlet on nape. Ioung: similar, but with red of nape extending partly or wholly over erown. Length: $6.25-7.00$, wing $3.5 .5-4.15$, tail $2.30-2.70$, bill .70-.80.

Remarks. - The black barring on the outer tail feathers and the small size of $D$. p. gairdnerii distinguish it from $D$. villosus harrisii, while its smoky under parts and barred tail feathers distinguish it from D. p. homorus, and its lack of conspicuous wing covert spotting from D. p. medianus.

Distribution. - From British Columbia south to southern California: east beyond the eastern slope of the Sierra Nevada and Cascade ranges. ${ }^{2}$

Nest. -4 to 20 feet from the ground in deciduous trees or old stumps.

Eggs : 4 or 5, white.

Food. - Noxious insects and larvæ, ants, eaterpillars, and scale insects.

The Gairdner woodpecker is the Pacific coast form of the downy, and though smaller resembles the hairy in appearance and habits. It is less solitary and less a bird of the forest than the hairy, being found in willows and along streams in the foothills, and in settled districts in orchards, where it does incalculable good by making way with wood-borers that ruin the trees.

\section{4b. D. p. homorus (Cab.). Batchelder Woodpecker.}

Like gairdnerii but larger, except for the feet, which are relatively

1 Dryobates pubescens turuti (Malh.). WiLLow WOODPECKER.

Like gairdnerii but smaller, with lighter under parts and spotted tertials.

Distribution. - Upper Sonoran and Transition zones of California except : desert ranges east of Sierra Nevada, including east slope of Sierra (?) coast region north of Mendocino County and region north of upper end of Sacramento valley. (The Condor, iv. 68.)

2 A typical Dryobates pubescens has been taken by Mr. Rathbun at Seattle. 
smaller; under parts pure white instead of smoky brown, and under tuil coverts immaculate instead of spotted or barred with black, and outer tail feathers nearly pure white. IVing 4 , tail 2.62 , bill .73.

Distribution. - Breeds in Transition and Canadian zones of the Rocky Mountain region in British Columbia and the United States, and in southern California.

Nest. - 5 to 50 feet from the ground. Eggs : 5 or 6 , white.

In Arizona Dr. Mearns found the Batchelder woodpecker nesting in the yellow pine belt, and going up into the spruces on the cone of San Francisco Mountain. One of the birds picked out a dry aspen, and drummed regularly about his camp.

394c. D. p. medianus (Swains.). Downy Woodpecker.

Like $D$. p. gairdnerii, but wing coverts conspicuously spotted with white and under parts soiled whitish. Wing: 3.72 , tail 2.40, bill .60.

Distribution. - Middle and northern parts of eastern United States, north to southern Keewatin.

The downy woodpecker is a quiet, friendly little bird who prefers to hunt wood-borers in orchards rather than in deep forests, and who will gladly come to a tree beside the house if a bit of suet is hung there for him. He is so absorbed in his good work that he goes about his business with little fear of man, and his sharp peek, peek, may often be heard even from city trees.

396. Dryobates scalaris bairdi (Malh.). Texan Woodpecker. Adult male: Upper parts, including entire onter tail feathers, barred

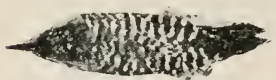

Fig. 271. black and white, but middle tail feathers plain black; forehead smoky and crown red, crown feathers with red preceded by specks of white; under parts smoky. lightly spotted with black. Adult female: similar, but crown black. Young: crown more or less extensively red. Length: 7.00-7.75, wing 3.90-4.25. tail $2.45-2.75$ exposed culmen . $83-.93$.

Remarks. - See remarks nuder Dryobates nuttallii.

Distribution. - Resident in Lower Sonoran zone from Texas to California, and from sonthern Colorado to Utah, Nevada, and south to northern Mexico.

Nest. - I'sually 5 to 14 feet from the ground in pines, oaks, jumipers, mesquite, hackberry, agaves, ynceas, and other trees; also fence posts and telegraph poles. Eggs: usually 4 or 5, white.

Food. - Wood-boring larvæ, weevils, ants, and the ripe fruit of the giant cactus.

The little 'Texan downy or 'speckle-check,' as it is called, is a bird of the lowlands, rarely going above five thousand feet. In western Texas it is more generally distributed than any other woodpecker, occurring alike in Upper and Lower Sonoran zones among the junipers, oaks, and piñon pines of the Chisos, Davis, and Guadalupe mountains, and among cottonwoods, willows, mesquites, and yuccas of the hot valleys. In the mountains it is found with 
the red-shafted flicker and the ant-eating woodpecker, and in southern Texas with the golden-fronted woodpecker. The thin voice of bairdi betrays his presence when be is hidden, but he is often in evidence, peeking around a post or tree trunk at you.

Where there are trees he nests in them, where there are none he accommodates himself to circumstances and nests in yuccas, fence posts, and telegraph poles. On throwing open a gate the traveler is sometimes surprised by the screams of a brood in the gate post.

\section{6a. D. S. lucasanus (Xantus). Saint Lucas Wooppecker.}

Similar to bairdi, but outer tail feather barred only on terminal half or less, except sometimes on inner web, and primary coverts with at least one row of small white spots. Length: $7.25-7.75$, wing $3.95-4.10$, tail 2.70-2.90, exposed culmen .91-.94.

Distribution. - From about latitude $34^{\circ}$ in the Colorado Desert, California, south through Lower California.

\section{Dryobates nuttallii (Gamb.). Nuttall Woodpecker.}

Adult male. - Upper parts barred with black and white, but forehead dingy; crown black, sometimes streaked with white; back of head with red patch; hind neck white; shoulders crossed by wide black band; middle tail feathers black, and outer feathers with not more than two distinct black bars;

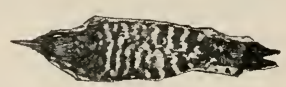

Fig. 272 . under parts almost pure white; sides spotted with black. Adult female: similar, but without red on head. Young: similar, but top of crown red, nape black, and under parts more thickly barred with black. Length: 7 , wing $3.90-4.20$, tail $2.60-3.05$, exposed culmen $.77-.82$.

Remarks. - The difference in color pattern of head and outer tail feathers distinguish nuttallii from scalaris bairdi.

Distribution. - Resident in Upper Sonoran (and Transition ?) zone, west of the Cascade and Sierra Nevada Mountains, from southern Oregon south to northern Lower California.

Nest. - In dead limbs or old stubs of oaks, sycamores, cottonwoods, elders, and willows, at no great height from the ground. Eggs : 4 to 6 , white.

Food.-Mainly insects and larvæ, including caterpillars, ants, weevils, seeds, and probably occasionally berries and fruit.

The cross-bars on the back and the white feathers on the sides of the tail mark this little woodpecker as it clings to a tree trunk or flies across to another bole. It has a nuthatch-like way of flying up to light on the under side of a limb, and when hanging upside down turns itself around with as much ease as a fly on a ceiling.

At times the small Nuttall waxes excited, and shakes his wings as he gives his thin, rattling call. All his notes are thin, and his quee-quee-quee-queep' has a sharp quality. His chit'tah is a diminutive of the $j a^{\prime} c o b$ of the California woodpecker. He is a sturdy little fellow, and in flight will sometimes rise high in air and fiy long and steadily, dipping only slightly over the brush. He has the full strength of his convictions and will drive a big flicker from 
a sycamore and then stretch up on a branch and call out triumphantly. Two Nuttalls trying to decide whether to fight are an amusing sight. They shake their feathers and scold and dance about as if they were aching to fly at each other, but couldn't quite make up their minds to so grave a matter.

\section{Dryobates arizonæ (Hargitt). Arizona Woonpecker.}

Adult male. - Upper parts plain broun, except for red nape bordered by conspicuons white patches, white spotting on wing quills, and white barring on outer tail feathers ; under parts, including under tail coverts heavily spotted with brown. Adult female: similar, but without red on head. Young: like adults of respective sexes, but top of head brown like back, and spotted with red. Length: $7.40-8.40$, wing 4.40-4.65, tail 2.55-2.95, exposed culmen .9:-1.05.

Distribution. - Resident in Upper Sonoran zone, from the mountains of southwestern New Mexico and southern Arizona south to northwestern Ilexico.

Nest. -10 to 20 feet from the ground. Eggs: 3 or 4, white.

"This rare woodpecker is a common species on the foothills of the Chiricahua Mountains, where it was one of the first birds that met my eye when the section where it abounds was first entered. . . . So far as I could ascertain, at this season at least, it is confined to the region of the oaks, ranging from about 4000 to 7000 feet, thus inhabiting a region about midway between the low valleys and the mountain districts proper. Here they appeared to be perfectly at home, climbing over the trunks of the oaks with the same ease and rapidity of movement that distinguish the motions of the downy or hairy woodpecker; though their habits, in so far as they are at all peculiar, are, perhaps, best comparable to those of the red-cockaded woodpecker of the south (Dryobates borealis), especially their custom of moving about in small companies of from five to fifteen, though they were occasionally found singly or in pairs.

"When in pursuit of food, they almost always alighted near the base of the trees, gradually ascending, and making their way along the smaller limbs and even out among the foliage, appearing to prefer to secure their food by a careful search than by the hard labor of cutting into the wood in the way the hairy woodpecker employs its strength. . . I I found them at all times rather shy, and gifted with very little of that prying curiosity which is seen in some of the better known species of this family; and if by chance I surprised a band feeding among the low trees, a sharp warning note, from some member more watchful than the rest, communicated alarm to the whole assembly, when they took flight immediately, showing great dexterity in dodging behind trunks and limbs, and making good their retreat hy short flights from one tree to another till they were out of sight." (Ienshaw.) 


\section{GENUS XENOPICUS.}

\section{Xenopicus albolarvatus (Cass.). White-HeAned Wood-} PECKER. ${ }^{1}$

Outer hind toe longer than onter front toe; bill with nasal groove extending nearly to tip; terminal half of bill not distinctly compressed; tongue very slightly extensile. Adult male: head and neck white. whole body black except for white patch on wings and red patch on back of head.

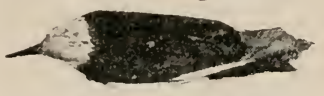

Fig. 273.

Adult female: similar, but without red on head. Young male: similar, but back and red on crown duller. Length: $8.90-9.40$, wing 5.(0)-5.10, tail $4.00-4.05$.

Distribution. - Breeds in Transition and Canadian zones of the nomntains from southern British Columbia to sonthern California, east to the Blue Mountains of Oregon, eastern Idaho, and along the eastern slope of the Sierra Nevada.

Nest. - Usually 4 to 15 feet from the ground in stub of pine or fir. Eggs: nsually :3 to 7 , white.

Food.- Insects and larvæ which are found under the scales of pine bark.

In the Transition zone forests of Mount Shasta and the sierra Nerada, one of the most striking birds is the white-headed woodpecker. Impossible as it would seem at first sight, I have found that the snow-white head often serves the bird as a disguise. It is the disguise of color pattern, for the black body seen against a tree trunk becomes one of the black streaks or shadows of the bark, and the white head is cut off as a detached white spot without bird-like suggestions. On the other hand, when the bird is exploring the light-barked young Shasta firs or gray, barkless tracts of old trees, the white of the head tones in with the gray and is lost, the headless back again becoming only a shadow or scar. But the most surprising thing of all is to see the sun streaming full on the white head and find that the bird form is lost. The white in this case is so glaring that it fills the eye and carries it over to the light streaks on the bark, making the black sink away as insignificant. All this applies, howerer, only when the bird is quiet; in motion he is strikingly conspicuous, and in flight his white wing streak makes another good recognition mark. Dr. Merrill noticed some interesting phases of this disguise at Fort Klamath. There, he says, the pines have stubs of branches projecting an inch or two from the trunk which, lit by the sun, appear white themselves and cast a black shadow.

Tenopicus works with apparent indifference on trunks or branches. Like the Nuttall woodpecker he often lights upside down. In hunting over the bark he easily backs down the trunk, or if he takes the

1 Fenopicus gravirostris Grinnell. Sodthern White-Headed Woodpecker. Like $\boldsymbol{X}^{\prime}$. albolarvatus, but bill much heavier, and size in general slightly greater.

Distribution. - Southern Sierra of California. (The Condor, iv. 89.) 
notion will fly, or perhaps drop backwards, a foot or so.. He will also light sidewise on a branch and grasp the limb with his tail as if afraid of falling off. It is interesting to see him explore cracks in the bark. Standing on the edge he pokes his head into the dark cavern, turning it from one side to the other inquiringly. Dr. Merrill has called attention to the fact that he uses his bill as a crowbar rather than a hammer or chisel as other woodpeckers do, prying off the layers of bark so quietly that you rarely hear him at work.

The call-note of Xenopicus is much like that of a Dryobates, though it seems duller and heavier.

\section{GENUS PICOIDES.}

General Characters. - Foot with 3 toes, 2 pointing forward and 1 back; bill broad and wide at base, straight, with beveled end, lateral ridges, and nasal tufts liiding the nostrils.

KEY TO ADULT MALES.

1. Back wholly black

$1^{\prime}$. Back marked with white.

2. Median line of back continuously white

$2^{\prime}$. Median line of back not continuously white.

3. Median line of back black and white, black prevailing.

americanus, p. 209.

3 . Median line of back usually black and white, white prevailing.

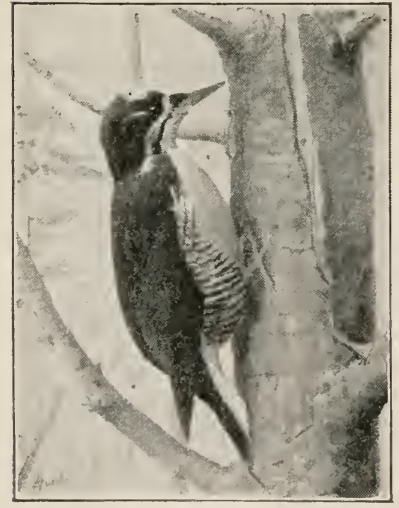

From Biological survey, U. S Dept. of Agrieulture.

Fig. 274.

fasciatus, p. 209.

400. Picoides arcticus (Swains.). Arctic Three-toed WoodPECKER. ${ }^{1}$

Adult male. - Upper parts glossy blue black except for squarish yellow crown patch, fine white spotting on wings, and plain white onter tail feathers; sides of head black and white; under parts white, heavily barred with black on sides. Adult female: similar, but without yellow on head. Young male: like adult, but yellow crown patch more restricted, black of upper parts duller, under parts tinged with brown. Young female: crowu black, sometimes with trace of yellow. Length: $9.50-10.00$, wing $4.55-5.25$, tail 3.60 , bill $1.40-1.60$.

Distribution. - Northern North America from the aretic regions to the northern United States (New England, New York, Michigan, Wisconsin, Minnesota,

Montana, Idaho, California, and Nevada.)

1 Picoides areticus tenuirostris Bangs.

A slender-billed form of $P$. areticus.

Distribution. - Cascades and Sierra Nevada in California, south to Lake Tahoe. (The Auk, xvii. 131.) 
Nest. - Usnally in dead trees or stumps rarely above $S$ feet from the ground. Eggs : generally 4, white.

Food. - Almost wholly wood-boring insects and larvæ.

"The arctic three-toec woodpecker is essentially a bird of the pine, spruce, fir, and tamarack forests, and is rarely seen in other localities. It is generally a resident, rarely migrating to any distance. ... Like the hairy woodpecker, they are persistent drummers, rattling away for minutes at a time on some dead limb, and are especially active during the mating season in April. I have located more than one specimen by traveling in the direction of the sound when it was fully half a mile away." (Bendire.)

\section{Picoides americanus Brehm. Auerican Three-toed Wood- PECKER.}

Adult male. - Upper parts mainly black, with whitish nuchal band and light spotting or barring on head and back; wing quills lightlly barred with white, outer tail feathers mainly plain white; crown with yellow patch, back of head glossed witl blue; under parts white, sides and flanks barred with black. Adult female: similar, but without yellow on crown. Length: 9 , wing $4.40-4.60$, tail $3.10-3.75$, bill $1.10-1.25$.

Distribution. - Northern North America east of the Rocky Mountains; south to the northern border of the United States.

Nest. - In holes in coniferous trees, 4 to 12 feet from the ground. Eggs : usually 4 , white.

Food. - Principally wood-boring insects and their larvæ.

The habits of the American are similar to those of the arctic three-toed woodpecker, though it is considered by Mr. Williams of Montana a much more silent bird, its calls resembling those of Dryobates rather than Picoides.

401a. P. a. fasciatus Baird. Alaskan Three-toed Woodpecker.

Similar to $P$. a. dorsalis, but back usually distinctly barred with black (rarely continuously white along middle line), secondaries more distinctly spotted with white (sometimes wing-coverts also spotted, more or less numerously with white), white spots on quills larger, and female sometimes with white prevailing on top of head. Length: 9.50, wing 4.50-4.70, tail $3.10-3.75$, bill $1.10-1.25$.

Distribution. - Alaska, south to northern Washington.

401 b. P. a. dorsalis Baird. Alpine Three-toed Woodpecker.

Adult male. - Similar to americanus, but middle of back continuously white, mostly streaked; side of head with two conspicuous white stripes. Adult female: similar, but browner, and under parts dingy white; head without yellow patch, blne black, lightly flecked with white. Young: like fe-

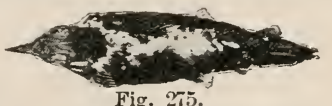

Fig. 275. male, but with more or less yellow streaking on erown. Length: 9.50, wing 4.65-5.00, tail :3.20-3.65, bill 1.15-1.30.

Distribution. - Breeds in Boreal zone from Arizona and New Iexico 
north through the Rocky Mountains region of the United States and Canada to Fort Liard.

Nest. - Described by Dr. Mearns, in a pine 30 feet from the ground, containing 5 white eggs.

Food. - Largely wood-boring larvæ.

The Alpine three-toed resembles the American, being found like it largely in the fire-blackened timber.

\section{GENUS SPHYRAPICUS.}

General Characters. - Bill not so stont and chisel-like as in Dryobates and Picoides, wedge-shaped, pointed, nasal groove extending only about half way to tip of bill; tongue scarcely extensile, the tip brushy; tail feathers long. pointed; feet with inner toe extremely short.

\section{KEY TO AIULT MALES.}

1. Head, neck, and chest red.

2. Belly yellow

2'. Belly olive yellow. Northwest coast

ruber, p. 211 .

1 . Head, neck, and chest with black, white, and red.

2. Upper parts glossy black . . . . . . thyroideus, p. 212.

?'. Upper parts black, spotted with white.

$\therefore$. Nape brownish white

$:^{\prime}$. Nape more or less tinged with red

- varius, p. 210 . nuchalis, p. 211.

402 Sphyrapicus varius (Linn.). Yellow-Bellied SaPsicker. Adult male. - Similir to the red-naped sapsucker (402a), but nape

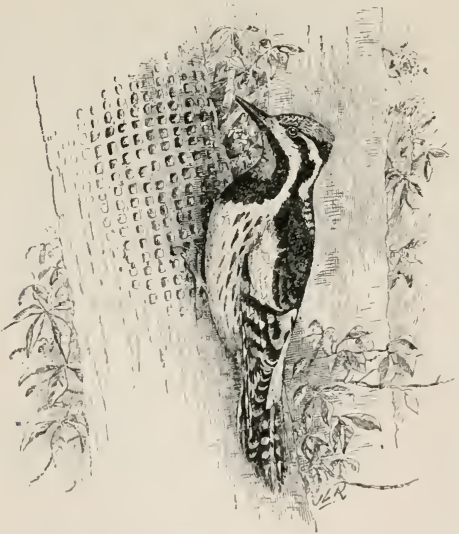

From Biologieal Survey, C. S. Dept. of Agriculture. Fig. 276.

brownish white, and black malar stripes separating red of throat from white cheek stripes. Adult female: throat entirely white, and crown sometimes without red. Young: head, neck, and chest mottled brown, the color pattern of adults only faintly indicated. Length: $7.75-8.75$, wing (male) $4.80-5.00$, tail $2.90-3.20$, bill $1.00-$ 1.08 .

Distribution. - Breeds in easteru North America, from north of Fort Simpson to Massachusetts; soutl in winter to West Indies, Mexico, and Costa Rica.

Nest. - In dead or decaving trees. 15) to (6) feet from the ground. Eggs : 4 to 7 , white.

Food. - Large number's of ants and flies, also bugs, wasps, crickets, and other insects, wild fruits, seeds, nuts, inner bark, and sap.

The eastern sapsucker has been found west of the humdredth meridian in Texas. Like the other sapsuckers it leaves a blazed trail behind it, - a girdle of squarish holes on its food trees. If 
the trees are delicate birches they will probably be killed in time, but the forest trees are too hardy to be affected by the loss of sap, and as the sweet syrup attracts a host of insects, the sapsucker does a good piece of work in destroying them. He ranks next to the flicker as an ant-eater, one third of his solid food consisting of ants. While watching his tly-trap he clings to the trunk as motionless as if glued there.

\section{2a. Sphyrapicus varius nuchalis Baird. Red-Naped SaP- sUCKER.}

Adult male. - Upper parts black. thickly marked with white; wing coverts plain black. with wide white onter stripe; head with red crown and red nuchal patch separated by a plain black area; sides of head with white stripes; chest black between red throat and pale yellow belly. Adult female:

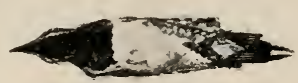

Fig. $27 \%$. similar, but duller. and black chest patch mostly mottled gray. Young: duller, red of head and throat wholly wanting or only suggested by pale claret-colored tinge. Length: $8.00-8.75$, wing (male) 4.92-5.10, tail $3.10-$ 3.40 , bill $.95-1.0 \%$.

Remarks. - In the field the black chest patch easily distinguishes the adult male muchalis from ruber (40:3).

Disfribution. - Transition and Canadian zones in the Rocky Mountain region, from British Columbia to northwestern Mexico, and eape region of Lower California, and from Colorado and Moutana west to the eastern slope of the Cascades and Sierra Nevada; casual to western Kansas and coast mountain region of California.

Nest. - Generally in aspens, 5 to 30 feet from the ground. Eggs: usually 4 or 5 , white.

Food. - Principally small beetles, spiders, grasslıoppers, ants, and larvæ under the loose bark of trees; also wild berries, and in fruit growing sections the sap of peach and apple trees, and willows.

The members of the genus Sphyrapicus form a marked group. They are sapsuckers, girdling the trees with small holes, from which they get a perennial supply of sap with a host of attracted insects to vary the diet. Their tongues are only slightly extensile, and have brushy tips in sharp contrast to the long barbed tongues of the Dryobates group, which spear their food from the depths of the wood.

In the nesting season, at least, the sapsuckers are extremely noisy, active birds, striding up the tree trunks, calling loudly in tantalizing tones, and chasing each other about in fine spirited fashion.

The red-naped breeds along the borders of streams in the mountains of the interior.

\section{Sphyrapicus ruber ( $G$ mel.). Red-Breasted Sapscker.}

Adults. - Whole head, neck, and chest plain red, or black and white markings of nuchalis only suggested; back, wings, and tail black. heavily marked with white ; belly

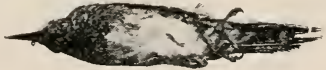

Fig. 278. 
dusky or yellowish. Young: duller, and color pattern less distinct, the red replaced by claret brown. Length: $8.50-9.25$, wing (male) $4.70-5.05$, tail $3.10-3.50$, bill 1.00-1.08.

Remarks. - The young of ruber is similar to the same stage of nuchalis, but can be distinguished usually by the dull reddish suffusion over its head, neck, and chest; while the adult may be recognized in the field by the absence of black chest patch and white stripes on the sides of the head.

Distribution. - Breeds in Transition and Canadian zone forests of the Pacific coast region from southern Oregon to northern Lower California; east to the western slope of the Sierra Nevada and eastern slope of the Cascades.

Nest. - In aspens, 15 to 25 feet from the ground. Eggs : 5 or 6 , white.

Food. - Beetles, spiders, ants, grasshoppers, centipeds, and larvæ, wild berries, sap, and inner bark.

In the Sierra Nevada the red-breasted sapsucker is one of the common woodpeckers. When riding through the forests there we often got a flash of color from its red head and neck as it flew before our horses. On a fir slope above Donner one July day we discovered chips at the foot of an old stub heavily covered with yellow lichen, and rapping on it sent the mother flying and roused a clamorous family of young.

- The last week in July at Donner Lake we found a family of dull colored young going about with their mother, a handsome old bird with dark red head and breast. They flew around in a poplar grove for a while, and then gathered in a clump of willows, where four young clung to the branches and clevoted themselves to eating sap. The old bird flew about among them and seemingly cut and scraped off the bark for them, at the same time apparently trying to teach them to eat the sap for themselves; for though she would feed them at other times she refused to feed them there, and apparently watched carefully to see if they knew enough to drink the sap. When the meal was finally over and the birds had flown, we examined the branch and found that lengthwise strips of bark had been cut off, leaving narrow strips like fiddle-strings between. At the freshly cut places the sap exuded as sweet as sugar, ready for the birds to suck.

In winter the red-breasted visits the cities, being seen, Mr. Grinnell says, in pepper-trees eren on noisy city streets. He has found it in Pasadena from October till the last of March.

\section{3a. S. r. notkensis (Suckow). Northelin Red-Breasted SAP- SUCKER.}

Similar to $S$. rulver. but darker, and belly olive yellow.

Distribution. - Northwest coast region of North America, from Sitka sonth in California through the Santa Cruz Mountains.

404. Sphyrapicus thyroideus (Cass.). Wilmamson Sarscrer Adult male. - Upper parts glossy black except white rump, large white 
patch on wing coverts, and fine white spots on quills; sides of head with two white stripes: throat and breast black, with a median stripe of bright red; belly bright sellow. Adult female: entire body barred with brown or black and white, except for brown head and white rump and, rarely, a

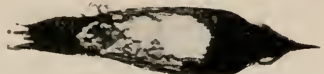

Fig. 2-9. Williamson Sapsucker. red median stripe on throat; chest usually with a black patch ; middle of belly yellow. Young male: similar to adult male. but black duller. belly paler. throat stripe white. Young female: similar to adnlt female, but markings and colors duller. belly whitish, and chest without black patch. Length: 9.00-9.7.5, wing 5.2.5-5.50, tail 3.80-3.90, bill 1.00-1.20.

Distribution. - Breeds in Transition and Canadian zones in the western United States from the eastern slopes of the Rocky Mountains to the western spurs of the Sierra Nevada, Cascades, and northern coast ranges; south to New Mexico and Arizona; winters in southern California, New Mexico. western Texas, and Sierra Madre to Jalisco, Mexico.

Nest. - In pines and aspens, 5 to 60 feet from the ground. Eggs : 3 to 7 , white.

Food. - Mainly insects and their larvæ.

The Williamson sapsucker is one of the handsomest birds one sees in the forest, but ordinarily it flies from tree to tree before you and its black back and white rump and wing patches are all that are seen. After sereral weeks of such fleeting glimpses in the Sierra Nerada, we were delighted by the discovery of a pair at home on their own breeding grounds. The place, Lincoln Valley above Sierra Valley, was close to the crest of the range, at an eleration of seven thousand feet. The nest was in a stub in a group of huge Murray pines on the edge of one of the most beautiful of the Sierra mountain meadows - a forest-encircled meadow brilliant with golden buttercups. It seemed a right royal home for such noble birds. While I watched the nest the male with his glossy coat, yellow belly, and red throat came flying in, his bill bristling with insects; but feeling himself observed, promptly sidled out of sight under the branches.

\section{GENUS CEOPHLCEUS.}

\section{5a. Ceophlœus pileatus abieticola Bangs. Northern Pileated WOODPECKER : Cock-OF-THE-IToOds.}

Head conspicuously crested ; bill longer than head, straight, with wedgelike tip, beveled sides, and strong ridges, broader than high at base; nostrils concealed by large nasal tufts; feet peculiar, outer hind toe shorter than outer front toe; tarsus shorter than immer front toe and claw.

Adult male. - Brownish or grayish black; entire top of head, occipital crest, and malar stripe bright red; chin and wide stripe on side of head white, or sulphur yellow; patches on wings and under wing coverts white; feathers of belly tipped with whitish. Adult female: sinilar, but forepart of head and malar stripe brown instead of red. Young: similar to female, but crest salmon. Male: wing 9, tail 6.31, exposed culmen 2.05.

Distribution. - Heavily wooded regions of North America from the southern Alleghanies northward to about latitude $63^{\circ}$ and westward to Pacific coast. 


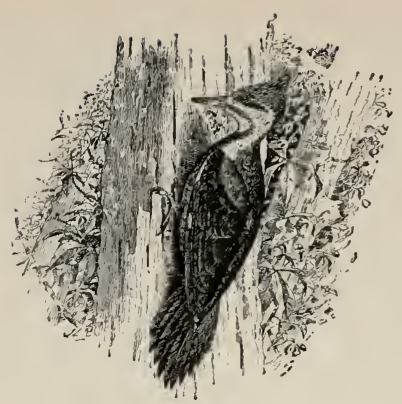

From Biological survey, U. S. Dept. of Agriculture.

Fig. 2S0. Northern Pileated Woodpecker.

Nest. - In aspens and coniferous trees, 40 to 50 feet from the ground. Eggs : usually 3 to 5, white.

Food. - Wood-boring beetles and larvæ which infest timbered tracts; also ants, wild grapes, berries, black gum, dogwood, pokeweed, and service berries, acorns. beechnuts, and chestnuts.

The pileated woodpecker is not a common bird in the western forests, but is found in the Cascades and Sierra Nevada, and when we were camping on Mount Shasta we would sometimes hear his slow deliberate hammering and his 'bugle call' at sunrise. Though often heard he was seldom seen, but we were occasionally fortunate enough to catch a glimpse of him with his conspicuous red crest winging his way with powerful bounding flight through the forest and over the woodland meadows.

Stubs, torn and excavated by his 'borings' were found quite commonly in the 'Transition belt. In many of the excavations I noticed that while the main cut might cover a section six inches long and three wide, at the bottom of the big excavation would be a small round hole that your thumb could fill, looking as if the worm were finally found there. One of our party who was fortunate enough to see the pileated at work described the process in detail. The bird began by flying hastily from tree to tree, from tree to stump, and stump to ground, finally going to work on a $\log$ on the ground. After some preliminary pecking he began chiseling near a branch. A steady pounding followed and the chips flew. The arc through which his head was swung was so wide it seemed as if his neck must break, but the bill came down straight, with the blow of a sledgehammer. After pounding awhile the bird stopped and pecked at the bark till a big slab slid off, suggesting that he had been digging deep holes, and then had worried off the surrounding bark. After this followed a long period of quiet when his head moved around busily without noise, as if he were probing the holes with his tongue and enjoying his meal.

In the Yosemite National Park where shooting is forbidden the pileated, instead of being one of the shyest of birds, is one of those most in evidence, and as you drive by actually makes itself conspicuous by flying freely among the trees so near that you can see his brilliant red head and the white spots on his wings, while he utters his loud ringing chuck, chuck, chuck, chuck, chuck, chuck, chuck. 
The nests of the cock-of-the-woods show their power more than their borings, for they are cut into the solid trunks of live trees. Though well up out of reach they are made conspicuous by half a bushel of fresh chips scattered over the ground around the tree. The cavity goes back for about six inches and then down a foot and a half, and the large white eggs rest on a soft bed of clean fresh chips. The same trce is often used year after year, but never the same hole. A fresh one is excavated each year and the old ones left for occupation by saw-whet owls, wood ducks, and flying squirrels.

\section{GENUS MELANERPES.}

General Characters. - Bill about as long as head, distinctly curved; upper mandible with an evident though short lateral ridge and nasal groove, tip of bill more or less wedge-shaped; outer hind toe not longer than onter front toe.

\section{KEY TO ADULT MALES.}

1. Back barred with black and white.

2. Forehead yellow

2 '. Forehead not yellow.

3. Middle of belly yellowish . . . . . . . uropygialis, 219.

$3^{\prime}$. Middle of beliy reddish. . . . . . . . carolinus, p. 218.

$1^{\prime}$. Back not barred.

2. Belly rose color . . . . . . . . . . torquatus, p. 217.

2 . Belly white.

3. Head and neck red . . . . . . . erythrocephalus, p. 215.

3 '. Head with black, red, and white or sellow.

4. Chest band streaked with white . formicivorus, p. 216. 4'. Chest band solid black . . . . . . . bairdi, p. 217.

\section{Subgenus Melanerpes.}

Colors in large masses; outer hind toe and outer front toe of equal lengths.

406. Melanerpes erythrocephalus (Linn.). RED-HEADED WOODPECK ER.

Adult male. - Whole head and neck deep crimson ; under parts, rump. and patch on wings, white; rest of npper parts, glossy blue black. Adult female: similar, but with more or less transverse black spotting on imner secondaries. and black collar more conspicnous than in male. Young: red and black of adults replaced by gray, streaked with darker on head and neck, barred on rest of npper parts; secondaries crossed near ends by one or more black bands. Length: 9.259.75, wing $5.30-5.70$, tail $3.60-3.7 .5$.

Distribution. - Breeding in Transition, Upper and Lower Sonoran zones from Manitoba south to the Gulf of Ilexico, and from the Atlantic to the

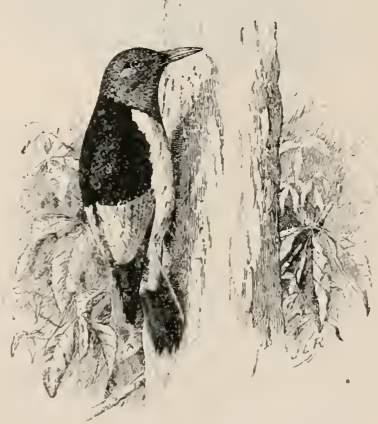

From Biological Survey, U. S. Dept. of Agriculture.

Fig. 281. 
eastern slope of the Rocky Mountains; casnal in Utah and sonthern Arizona.

Nest. - S to 80 feet from the ground in stumps, dead trmuks or branches, and on treeless prairies in fence posts and telegraph poles. Eggs: usually 4 to 7 , white.

Food. - In summer, insects such as grasshoppers, ants, beetles, flies. and larvæ, fruits and berries; in fall and winter, nuts, wild berries, and small grains.

The red-headed woolpecker is one of our handsomest birds. Its colors are all keen - the red, glowing red; the white, snow white; and the black, glossy black.

In its methods of hunting, like all the members of the genus Melanerpes, it combines the ways of the flycatchers and the woodpeckers that get their food almost wholly from tree trunks and branches.

In the east, where it depends largely on beechnuts for its fall and winter supplies, its movements are very erratic, its appearance depending on the crop.

407. Melanerpes formicivorus (Swains.). Ant-eativg WoodPECKER.

Adult male. - Feathers around base of bill and chin black, bordered by

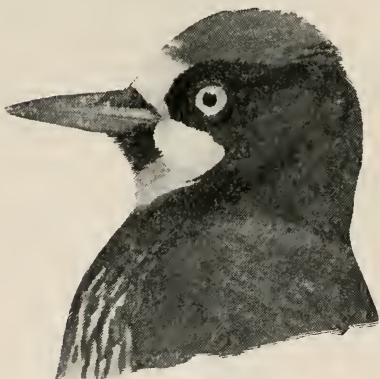

Fig. 282.

band of white or yellow; crown red; sides of head, upper parts, and chest band glossy greenish; blue black chest streaked with white; rump, wing patch, and belly, white. Adult female : similar, but with a black band separating white or yellow forehead from red crown. Young: similar to adults and with same sexual differences in crown, but colors duller. Wing: $5.30-5.90$, tail 3.10-3.60, bill 1.10-1.22.

Remarks. - The squarish white patch on the forehead is enough to distinguish the formicivorus gronp from all other woodpeckers.

Distribution. - Breeds in Lower Transition zone from Texas to Arizona, and south to Isthmus of Tehuantepec, Mexico.

Nest. - Usually in white oaks, but also in pines. Eggs : 4 or 5, white.

Food. - Principally acorns, but also fruit, flies, ants, beetles, and grasshoppers.

One of the most pleasantly familiar sounds in the live-oak belt inhabited by formicivorus and its allies is the ja-cob, ja-cob, ja-cob, ja-cob uttered by these handsome woodpeckers as they fly from tree to tree, their white rump and wing patches showing as they go. In coming down from the fir forests of the mountains where the only visible woodpeckers have fled silently before you, the soft cheery voices of these birds have a friendly ring grateful to the ear. They 
always have a great deal to say, whether it be in a canyon of the Guadalupe Mountains in New Mlexico, where their chatter interrupts the solemn hooting of the band-tailed pigeon, or on the campus of a California university, where much is to be learned by silent listeners.

But their small talk nerer seems to interfere with their work, and the acorn-filled tree trunks and telegraph poles attest their industry. of all our woodpeckers they are the prime storers, and though they do not live in a land of snow, ground squirrels infest most of their territory and make it important to have secure cupboards. Dr. Mearns says their stores are the source of unending quarrels between them and their numerous pilfering enemies, and confesses that when short of provisions in the mountains he himself has filled his saddlebags with acorns from under the bark of a pine. The birds are true to their Melanerpes instincts, although they do spend so much of their time storing acorns, and vault into the air after insects in regulation flycatcher style.

\section{7a. M. f. bairdi Ridgu. Californian Woodpecker.}

Like M. formicivorus, but with heavier bill and chest band solid black.

Distribution. - Breeds in Upper Sonoran zone of the Pacific coast region from Oregon south to northern Lower California.

Nest. - 15 to 25 feet from the ground in oaks, sycamores, cottonwoods. willows. and telegraph poles. Eggs: usually 4 or \%,, white.

Food. - Acorns during the greater part of the year; also grasshoppers. caterpillars, ants, beetles, flies, small fruits, berries, and green corn.

\section{Subgenus Asyndesmus.}

Bill combining characters of Colaptes and Melanerpes: wings long, folding nearly to end of tail ; feathers of under parts and nuchal collar bristly.

408. Melanerpes torquatus (Wils.). Lewis WoODPecker.

Adults. - Upper parts iridescent greenish black except for gray collar; face dull crimson; throat and chest gray changing to soft rose on belly; plumage of lower parts harsh and hairlike. Young: head without red, neck without collar, under parts with less

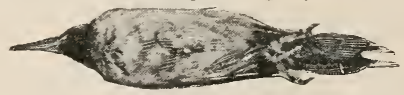

Fig. 2S3. red. Length: $10.50-11.50$, wing $6.50-6.80$, tail $4.40-4.70$.

Distribution. - Breeds in Transition and Upper Sonoran zones from Black Hills and eastern slope of Pocky Mountains to Pacifie slope; from southern parts of British Columbia and Alberta to Arizona; winters in southern California and western Texas; casual in western Kansas.

Nest. -6 to 100 feet from the ground, usually high up in tall pines or cottonwoods, or in decayed branches or stumps of oaks, sycamores, junipers, and willows. Eggs: usually 6 or 7 , white.

Food. - In summer mainly insects. such as grasshoppers, crickets, ants, beetles, flies, larvæ, acorns, pine seeds, wild berries, and in cultivated districts fruit.

When you reach the mountains on the west-bound Overland, from the car windows you recognize with delight the crow-like figure of 
your old friend tlying with sweeping, powerful strokes straight over the forest. You are in no danger of mistaking him, for his wide wings and short tail distinguish him from all other birds as far as he can be seen.

He is found high in the mountains mainly after the breeding season, for he nests in the Transition zone orchard and yellow pine country, but like the redhead is an erratic wanderer. At Fort Klamath flocks of two hundred have been reported coming from the north in August, and from Klamath Falls to Susanville Mr. Bailey found them the commonest woodpeckers, perching on the tall stakes of rail fences along the roads, flying up into the air after grasshoppers or other insects in true Melanerpes style. As it is said, the 'acorn bird' never comes in great numbers unless there is a good crop of mast, for his movements depend on the food supply. In the Black Hills Mrr. Cary says the wood pecker is partial to burnt timber on the sides of canyons.

\section{Subgenus Centurus.}

Upper parts barred; outer hind toes shorter than outer front toe.

409. Melanerpes carolinus (Linn.). Red-beltied Woodpecker. Adult male. - Top and back of head and neck bright red; rest of upper

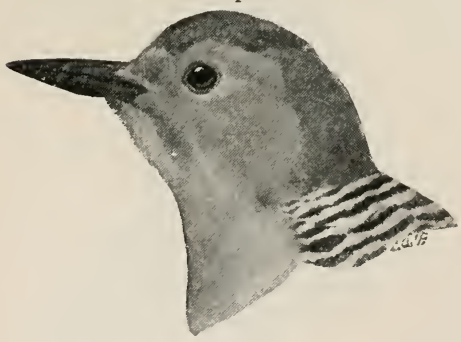

Fig. 284 . parts barred black and white; under parts gray except for reddish wash on middle of belly. Adult female: similar, but red of head interrupted by gray crown patch. Young: duller, markings obscured. red of head indistinct, that of belly often replaced by dull buffy. Length: 9.0')-10.10, wing $4.8 .5-5.50$, tail :3.50-:3.95, bill $1.00-$ 1.20 .

Distribution. - Breeds in Lower and Upper Sonoran zones of eastern United States, from Ontario

to Florida, and west to the base of the Rocky Mountains.

Nest. - In tree truiks or branches, 15 to 60 feet from the ground. Eggs : 3 to :), white.

Food. - Beetles, ants. weevils, caterpillars. grasshoppers, flies. larvæ, wasps, and other insects, with acorns, nuts, seeds, grain, and berries.

In parts of Texas the red-bellied is the most common woodpecker. and often nests in telegraph poles, but over most of its range it is shy and retiring, living preferably in heavily timbered bottom lands and swampy wookts.

410. Melanerpes aurifrons (Wagl.). Golden-Fronted WoodPECKER.

Adult males. - Forehead yellow, crown red, and nuchal patch yellow. 
orange, or red; back finely barred with black and white; rump plain white, tail black. outer feathers barred with white; under parts light gray, washed with yellowish on belly. Adult female : similar, but withont red crown, and yellow of plumage paler. Young: colors duller, markings less distinct. Wing: $5.20-5.65$, tail $3.40-$ 3.To, bill 1.20-1.40.

Distribution. - Central and southern Texas, south to the city of Mexico.

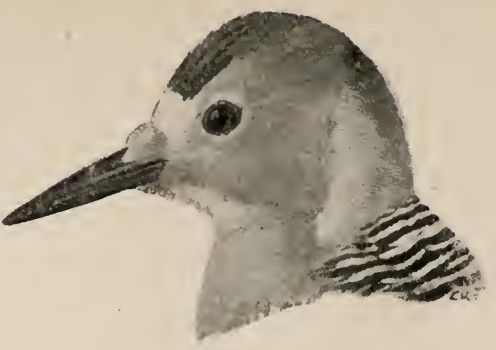

Fig. 285. Golden-fronted Woodpecker.

Nest. -6 to 25 feet from the ground, generally in mesquites, pecans, oaks, or telegraph poles. Eggs: + to 7 , white.

Food. - Insects of varions kinds, such as beetles, ants, grasshoppers, and larvæ - anong them one injurious to corn; also acorns, Indian corn, wild berries, and fruit.

In San Antonio the golden-fronted woodpecker nests in telegraph poles and bird boxes about houses as well as in pecans, aaks, and mesquites. In Eastland County. Texas, Mr. Hasbrouck says it is often seen in the same tree with the red-bellied. On the mesquite prairie of southern Texas the little Texan woodpecker is the only one occurring at all commonly with aurifrons and there is no danger of confusing them.

Aurifrons makes noise enough for a dozen, his loud penetrating voice ringing across the road as you drive through the mesquites. One of his common calls is a rattle like that of the California woodpecker. When he flies he shows his white rump and wing spots, and on the rare occasions when you catch a glimpse of him you can see the yellow of his neck above the black and white barring of his back.

411. Melanerpes uropygialis (Baird). Grla Woodpecker.

Adult male. - Head and nnder parts grayish brown, crown red; middle

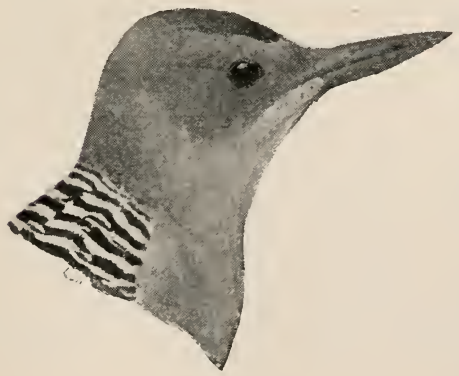

Fig. 286. of belly yellowish; back and rump finely barred with black and white ; middle and outer tail feathers marked with white. Adult female: similar, but without red. Young : similar, but colors duller. and markings less distinct. Wing: $5.00-5.30$, tail $3.50-3.90$, bill .951.25.

Remarks. - This species may be distinguished from aurifrons by its brownish tinge, the absence of yellow on its head, barred rump, white markings on middle tail feathers, and absence of marks on those next the middle. 
Distribution. - Colorado River in southeastern California, southern Arizona, and southwestern New Mexico; south through Lower California to Jalisco and western Mexico.

Nest. - Mainly in giant cactus, but also in cottonwoods, sycamores, and mesquites. Eggs : 3 to 5 , white.

Food. - Lizards, insects such as ants, beetles, grasshoppers, and larvæ, with giant cactus fruit and mistletoe berries.

Major Bendire-says that the general habits of the Gila woodpecker are similar to those of the California woodpecker. Its ordinary callnote he gives as dchürr dchürr, and a flight note as huit huit, which he says resembles the call-note of the phainopepla. In Arizona in October, Mr. Bailey found two of the birds roosting in a tank every night.

\section{GENUS COLAPTES.}

General Characters. - Bill acute, curved; slender and weak for a woodpecker; without lateral ridges or beveling; nostrils not concealed by nasal tufts; outer hind toe shorter than outer front toe; wings and tail lengthened.

\section{KEY TO SPECIES.}

1. Under sides of wings and tail red.

2. Darker. Sitka to northern California . . . saturatior, p. 221.

2'. Lighter. Western United States . . . . . . collaris, p. 221.

1'. Under side of wings and tail yellow.

2. Back of neck with red band. Eastern North America.

2'. Back of neck without red band. Arizona and southward.

luteus, p. 220 . chrysoides, p. 222.

\section{2a. Colaptes auratus luteus Bangs. Northers Flicker.}

Adult male. - Upper parts brown, barred with black, except for red

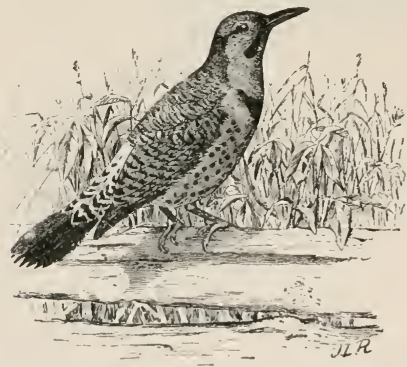

From Biological survey, U. S. Dept. of Agriculture.

Fig. 287. nuchal band, white rump, and black tail; wings and tail with shafts and under side of feathers bright yellow'; throat and sides of head pinkish brown, with black malar stripe or - mustache and black crescent on chest; rest of under parts brownish white, washed with yellow and spotted with black. Idult female: similar, but without black mustache, though sometimes with faint indications of one. Foung male: similar to adnlt male, but crown marked with dull red. nuchal band dull scarlet. Young female: with dark mustache. Male: wing 6.18 , tail 4.09 , exposed culmen 1.:3. Female: wing 6.06 , tail $t$, exposed culmen 1.25.

Distribution. - Eastern and northern North America, south to North Carolina and west to the Rocky Mountains; occasional on the Pacific slope from California northward. 
Nest. - Usually 10 to 20 feet from the ground in stubs or trees. Eggs : usually 5 to 9 , white.

Food. - Largely ants; also beetles, bugs, grasshoppers, crickets, and eaterpillars, weed seeds and berries.

The flickers of whatever local name or race are striking, forceful birds. Their clear ringing clape and piute command attention, while their rapidly uttered if-if-if-if-if-if-if is no less stirring. As they fly in undulating line over a field there is a splendid flash of red or golden from under their wings. At work or play they show the same vigor and whole-souled absorption, and their courtship is accordingly both ardent and amusing.

As a genus the flickers are the least woodpecker-like of the family. Instead of getting their food from the tree trunks or in the air, they live largely on ants which they get from the ground, which accounts for the brown of their backs, the slenderness of their bills, and the character of their tongues. As they probe ant-hills to get the ants their tongues are very long and provided with large salivary glands whose sticky secretions hold the ants. As they do not spear their food the tongue is freer from barbs than that of most other woodpeckers.

413. Colaptes cafer collaris (Tigors). Red-shaften Flicker.

Adult male. - Ground color of head and body brownish. back barred and under parts spotted with black; rump white and tail black; nuchal band and mustache red; chest marked with black crescent; under side of wings and tail red. Female: Similar, but usually with a buffy or brown malar stripe. Young: similar, but without mustache. Length: 12.7514.(10, wing $6.45-7.15$, tail $4.40-5.20$, exposed culmen 1.34-1.5.3.

Remarks. - Birds with varying combinations of the characters of C.collaris and $C$. luteus may be met with anywhere from the eastern border of the plains to the Pacific.

Distribution. - Rocky Mountain region from British Columbia south to northern border of Jiexico; west to the coast ranges in Oregon and Washington. and to the Pacific coast from northern California southward to Lower California.

Nest. - From 2 to 70 feet from the ground in rotten stubs or trees, also in holes in banks, in sides of houses, and gate posts. Eggs: 5 to 10, white.

Food. - Insects and larvæ, especially ants, grasshoppers, and erickets, acorns, seeds, and wild berries.

\section{0a. Colaptes cafer saturatior (Ridgu.). Northwesterx FliCKER.}

Similar to collaris, but darker. Wing: 6.35-7.00, tail 4.70-5.20, exposed eulmen 1.35)-1.60.

Distribution. - Breeds in humid Transition and Canadian zones of the northwest coast from Sitka to northern California.

Vest, eggs. and food same as in collaris. 
414. Colaptes chrysoides (Malh). Gilden Flick ER.

In general similar to collaris, but back of neck without red, and under side of wings and tail yellow; adult female with only occasional traces of malar stripe, and young without malar stripe.

Remarks. - The combination of red mustache and yellow of under wings and tail distinguish this species.

Distribution. - Breeds in Lower Sonoran zone from Arizona south to southern Sonora, and Lower California south of latitude $30^{\circ}$.

Nest. - ( $;$ to 40 feet from the ground in giant cactus or cottonwoods. Eggs : 2 to 5, white.

Food. - To a large extent fruit of the giant eactus and insects found on its flowers.

The gilded flicker is largely a bird of the giant cactus belt, and feeds to some extent upon the sweet fruit of the cactus.

\title{
ORDER MACROCHIRES: GOATSUCKERS, SWIFTS, AND HUMMINGBIRDS.
}

\section{(Families Caprimulgide. Micropodide, and Trochi- LIDE.)}

\section{FAMILY CAPRIMULGID丑: GOATSUCKERS.}

\author{
KEY TO GENERA.
}

1. Gape without conspicuous bristles, tail emarginate.

1 '. Gape with conspicuous bristles, tail even or rounded.

Chordeiles, p. 226.

2. Tarsus featliered in front almost to toes . Antrostomus, p. 222.

$2^{\prime}$. Tarsus entirely naked in front.

3. Tail even

Phalænoptilus, p. 224.

3'. Tail much rounded. . . . . . . . Nyctidromus, p. 225.

\section{GENUS ANTROSTOMUS.}

General Characters. - Bill short, gape wide; nostrils oval with raised rim not prolonged into a tube, opening upward and outward ; feet small, hind toe short, front toes connected by webbing, middle toe much longer than side toes, its claw pectinated (see Fig. 290); tarsus not longer than middle toe without claw, feathered in front nearly to toes; wing folding to or beyond rounded tail; plumage lax, primaries weak.

KEY TO ADULT MALES.

1. Bristles of gape with lateral filaments . . . carolinensis, p. 222.

$1^{\prime}$. Bristles of gape without lateral filaments.

2. Throat bar chiefly or wholly white. . . . . vociferus, p. 223.

2 '. Throat bar chiefly or wholly yellowish . macromystax, p. 223.

416. Antrostomus carolinensis (Gmel.). CHUCK-WILl's-WIDow. Adult male. - General color dark brown or blackish brown, mottled, barred, and spotted with tawny and blackish. reddish brown on wings and 
tail; tail with at least terminal third of onter feathers white or buffy; throat tawny, bristles of gape with lateral filaments. Adult female: similar, but without white or buffy on tail. Young: similar, but much lighter, top of head grayish and wings tawny. Length: 11-12, wing 8.70-8.90, tail 6.2.5-6.30.

Distribution. - Breeds in Lower Sonoran zone in the southeastem United States. from sonthern parts of Virginia. Illinois, Indiana, and Kansas south to the Gulf of Mexico, and from the Atlantic west to Fort Clark, Texas; migrates to the IVest Indies, and through eastern Mexico to Sonth America.

Eggs. - Usually laid on dry leaves on the ground; 2, creamy or pinkish white, blotched, narbled. and spotted with browns and purples.

Food. - Moths, beetles, winged ants, other insects, and birds.

Like all the C'rprimulgide, the chuck-will's-widow is crepuscular, flying about mainly in the dim morning or evening hours. Its call of chuck-rcills-roidow is markedly different from that of the whip-poorwill.

\section{Antrostomus vociferus (Wils.). WhIP-Poor-WiLL.}

Adult male. - Throat blackish, bordered by white band; rest of under parts mixed tawny and black; upper parts mottled aray, streaked, spotted. and barred with blackish. black streaks of erown wide medially; wings much marked with reddish brown; three outer tail feathers white for more than terminal third. Adult female: similar, but white of tail much restricted and obscured. Young: top of head mottled grav. spotted instead of streaked with black; rest of upper parts bright tawny, scapulars with large black spots; nuder parts almost plain buffy. Length : 9.50-10.00,

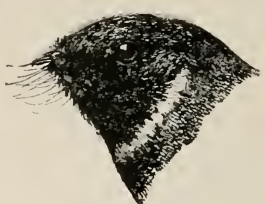

Fig. 2s8. wing $5 . \$ 0-6.70$, tail $5.10-6.50$.

Distribution. - Breeds from the Atlantic to the Plains, and from Manitoba south through western Nebraska to Texas; migrates to Guatemala; casual to Porto Rico and the W'est Indies.

Eggs. - Deposited on dry leaves on the ground; 2. white, with blotches, spots, and tracings of brown and purple.

Food. - Night-flying insects, including liocky Mountain locusts.

417a. A. v. macromystax (Wagler). Stephexs Whip-Pook-Will. Adult male. - Similar to A. vociferus, but slightly larger and more tawny, throat band largely tawny in adult male, and white of tail restricted to less than terminal third. Adult female: similar, but white of tail tawny and restricted. Length: 9.60-10.20, wing 6.27-6.65, tail 4.035. 45 .

Distribution. - Arizona, New Mexico, and southwestern Texas; south over mountains bordering tablelands of Mexico to Guatemala.

Test. - A slight depression in the gromnd. Eggs: 1 or 2, white, or with faint markings.

Food. - Among other things, large brown beetles.

When we were spending a night in the head of McKittrick canyon in the Guadalupe Mountains, Stephens whip-poor-wills came close enough to our camp-fire for us to hear distinctly the marked burr of 
their whip-pur'r'r-will. Sometimes the notes are repeated faster and faster till they all run together.

In the Santa Catalina Mountains, Arizona, Mr. Bailey found one sitting in the shade of a rock in the daytime. At his approach, with a quick spring it would dart out of sight around the next rock and drop into the darkest shade. Its flight was perfectly noiseless and very swift.

\section{GENUS PHALAFNOPTILUS.}

General Characters. - Bill short with wide gape, nostrils tubular, cylindrical, opening forward and outward; rictal bristles conspicuous; feet small, hind toe short, middle toe long, its claw pectinated, front toes webbed (see Fig. 290); tarsus as long as middle toe without claw, naked except for joint; tail square. much shorter than wings.

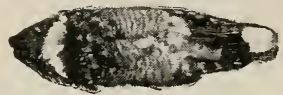

Fig. 289.

KEY TO SPECIES.

1. Upper parts blackish or dark brown

1'. Upper parts light brown or grayisl.

2. Smaller and paler. Kansas to Texas and Arizona . nitidus, p. 225. 2 '. Larger and not so pale. Nebraska to Cascades . nuttallii, p. 224.

\section{Phalænoptilus nuttallii (Aud.). Poor-wilL.}

Adult male. - Plumage of upper parts moth-like, soft, and velvety, finely mottled grayish brown with sharply contrasting velvety black bars and sagittate markings; tail with all but middle feathers tipped with white; sides of head and chin black, white throat patch bordered by black below; rest of under parts barred except for plain buffy under tail coverts. Adult fenale: similar, but with white tips to tail feathers narrower. Young: upper parts more silvery gray mixed with rusty; black markings smaller and less distinct; white of throat and tail restricted and tinged with buffy. Wing: 5.78, tail 3.67.

Distribution. - Breeds in Upper Sonoran and Transition zone of British Columbia and the western United States, from the Cascades and Sierra Nevada east to central Nebraska; winters from deserts along the southern border south to Guatemala.

Eggs. - Usually laid on the bare ground ; 2, white, unspotted or lightly marked.

Food. - Night-flying moths, beetles, locusts, and other insects.

In southern California in the dim evening light 1 have often seen poor-wills hunting insects along the roads and had them come close to me in a ranch dooryard when they would make short sallies from the ground, fluttering around with soft, noiseless flight, uttering a low chuck, chuck: In the daytime their eyes are of little use. A pair of the birds that Mr. Bailey once came upon at Emigrant Gap showed this sun blindness rery strikingly. They had been sitting 


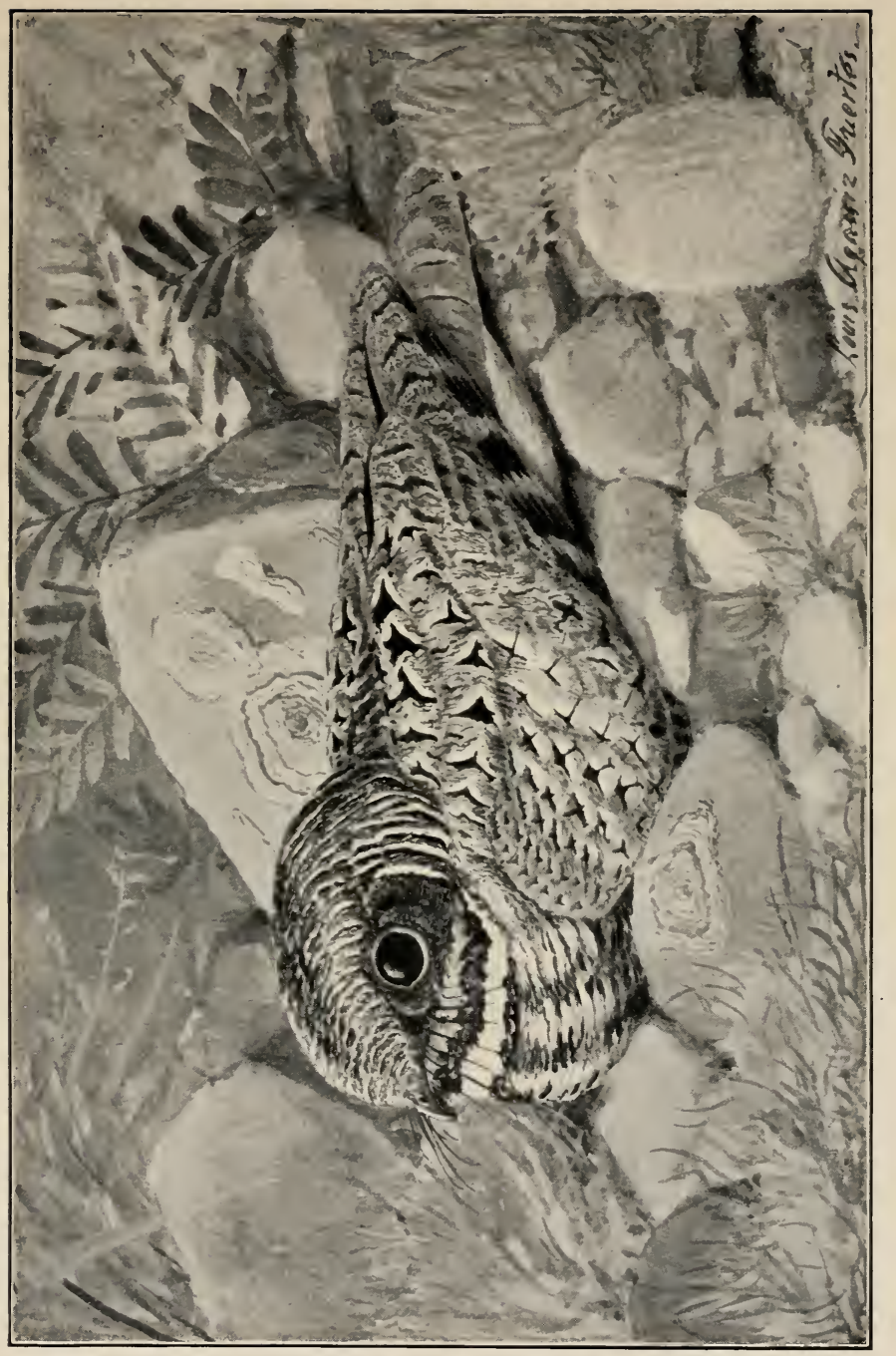

겅 

in the shade of a bush, and flew from his feet as he approached. One of them lit again in a patch of bright sunlight, and, apparently blinded by the light, sat there calmly until he walked up within a few feet of it. He experimented with the birds, flushing them a number of times, and found that when they lit in the shade, as they usually did, they were not only much less conspicuous than in the sun, blending in with the leaves and rocks, but the shade enabled them to see him clearly enough for them to recognize what he was so that they would tly while at a distance of four or five rods.

The poor-will himself is less known than his roice, which is insep. arably associated with the warm still western evenings. Coming from the canyons in the moonlight it is one of the softest, most soothing sounds in nature.

\section{8a. P. n. nitidus Brewst. Frosted Poor-will.}

Similar to nuttallii, but smaller and paler, prevailing color of upiper parts brownish gray inclining to silvery or hoary, with black markings smaller and much restricted; chin and sides of head mottled grayish brown; chest with little if any solid black. Wing: 5.44 , tail 3.52.

Distribution. - Texas to Arizona and from western Kansas south to northern Mexico.

Eggs. - Deposited on ground in open places, sometimes under a bush; 2, white, usually faintly tinged with buffy.

\section{8b. P. n. californicus Ridgw. California Poor-will.}

Similar to nuttallii, but much darker; middle of crown largely blackish ; hind neck extensively marked with black, back dull blackish gray or wood brown instead of light brown.

Distribution. - Coast region of California.

Eggs. - Similar to those of nuttallii.

\section{GENUS NYCTIDROMUS.}

Nostrils prolonged as cylindrical tubes opening forward and outward; rictal bristles heavy ; tarsus lengthened, but not exceeding middle toe without claw ; wing scarcely rounded; plumage not so lax as in the whip-poorwill.

\section{Nyctidromus albicollis merrilli Senn. Merrill PA- RACQUE.}

Adult male. - Upper parts finely mottled gray and brown, the crown broadly streaked with velvety black, and scapulars strikingly patterned with triangular velvety black and buffy markings; wing quills crossed by white band; tail with second and third feathers largely white, throat with wide white band, rest of under parts buffy, barred. Adult female: similar, but smaller. browner, duller, and white of wings and tail restricted. Young: similar to sexes of adults, but much paler, crown with markings triangular or tear-shaped with light border. Male: length 12.00-13.50, wing 6.757.50, tail $6.75-7.40$. Female : length 10.50-11.50, wing 6.00-6.30, tail 5.806.00 .

Distribution. - From southern Texas sonth to the Isthmus of Tehuantepec. 
Eggs. - Placed on the ground, usually near a clump of bushes; cream or buff, spotted and splashed with browns, buff, pink, and lavender.

Food. - Moths, beetles, and other insects.

When in southern Texas near the Mexican line we were startled at our camp-fire supper one evening by a strange new note, a hoarse pa-rau'-que, and hurrying out into the dusk found a large bird hunting insects on the road in poor-will fashion, flying from one bare spot of ground to another among the mesquites. As we followed him he repeated his call from each spot, and once gave it from the top rail of a fence.

\section{GENUS CHORDEILES.}

General Characters. - Bill short with wide gape; bristles not decidedly

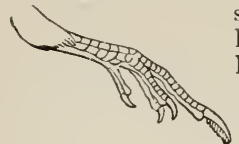

Fig. 290 . shorter than bill; nostrils cylindrical and rimmed about, hardly tubular, opening outward and upward; feet weak, hind toe short, front toes connected by web, middle toe long, its claw pectinated; tarsus feathered part way down in front; tail lightly forked, much shorter than the long narrow wing.

KEY TO SPECIES.

1. Wing band back of tip of seventh quill (Figs. 292 and 293 ).

texensis, p. $22 \mathrm{~S}$.

1'. Wing band mainly or wholly forward from tip of seventh quill.

2. Upper parts glossy black, mottled with lighter virginianus, p. 226. 2 . Upper parts mainly grayish or brownish.

3. Paler. Plains . . . . . . . . . sennetti, p. 228. $3^{\prime}$. Darker. Western states . . . . . . . henryi, p. 227.

420. Chordeiles virginianus (Gmel.). Nightнawk. Adult male. - White throat patch bordered below by blackish chest

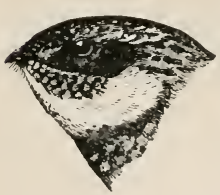

Fig. 291. patch; belly barred with blackish and white; upper parts glossy black mottled with gray and

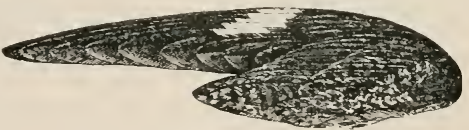

Fig. 292. lightly marked with buffy brown; white or buffy wing band mainly or uholly forward from tip of seventh quill; space between white band and primary coverts plain blackisl, secondaries indistinctly if at all spotted with buffy or brownish; tail except middle feathers crossed with broad white band near tip. Adult female: white of tail restricted or wanting. Young: more finely and profusely mottled than arlults. Wing: $7.30-8.25$, tail $4.30-4.75$.

Distribution. - Breeds from the Hudson Bay region and the Mackenzie River at $65^{\circ}$ south through the United States, east of the Plains, and in wooded districts to Washington, Oregon, and northern California; south in winter to the Bahamas, Central America, and the greater part of South America.

Eggs. - Laid on the bare ground in exposed situations ; 2, creamy, olive 
buff, or gray. profusely blotched or speckled with blackish, brownish gray, and lavender.

Food. - Insects, such as flies, ants, mosquitoes, small beetles, grasshoppers, crickets, and moths.

The three forms of virginianus resemble each other so closely in habit and appearance that they are difficult to distinguish except in the hand. Their distribution is little help in determining them except during the breeding season when sennetti retires to the Dakotas; for at other times henryi and sennetti range together from Dakota to Texas; and even in the breeding season the eastern form makes irregular irruptions into the range of the western.

The nighthawks, while wholly absorbed in their own aerial pursuits, nevertheless beguile many an hour for the weary wayfarer in the west. As the ambulance-like 'hack' or prairie schooner makes its slow way over the hot bare plains, the traveler hails with delight the sight of the little black stick lying on the ground in the midst of the glaring flatness. The bird's eyes are shut and his long wings folded close to his sides, but at the sound of horses' hoofs he is up in the sky, sailing this way and that, a bit of active life in the lifeless plain.

Then when nightfall approaches and camp is pitched by a waterhole in the rocks, in the midst of the desolate expanse the traveler feels a thrill of homelike companionship as the 'peent' of a nighthawk makes him glance up and he finds a score of the old familiar forms zigzagging about showing their white wing crescents at the turns of their flight.

How wonderfully at home they seem in the sky! Now they soar with wings set at an angle, then flap along in a straight line, to dive suddenly straight down almost into camp with a loud, whizzing boom.

In the nesting season as the hunter crosses a bare space among the rocks on the mountains, sometimes a nighthawk will start from under his very feet and with wings outspread and tail langing trail lamely off till satisfied with her ruse, when with swift strong flight she makes a wide circle and returns either to trail once more before lim or to settle down on a rock where she can watch to see if he has discovered her almost invisible young.

\section{0a. C. $\nabla$. henryi (Cass.). Western Nighthawk.}

Similar to virginianus, but paler; upper parts mainly light grayish buffy or ochraceous; dark bars on under parts spaced with tawny white.

Remarks. - Though lighter than virginianus, henryi is much darker than sennetti, which is light brown. buffy, and on wing coverts mainly whitish.

Distribution. - Breeds in Transition and Canadian zones of the western 
United States from the plains to the Pacific, and to British Columbia west of Cascades; migrates to northern South America.

Eggs. - Laid on the ground in open situations; 2, like those of virginianus.

\section{0c. C. $\boldsymbol{\nabla}$. sennetti (Coues). Sennett Nighthawk.}

Similar to henryi, but much paler; top of head brownish instead of blackish; wing coverts largely whitish ; under parts with dark bars brown instead of black, spaced with white instead of buffy.

Distribution. - Treeless region of the plains, from the Saskatchewan south to Texas.

\section{Chordeiles acutipennis texensis (Laur.). Texan} Nighthawk.

Adult male. - White throat patch without adjoining black chest patch,

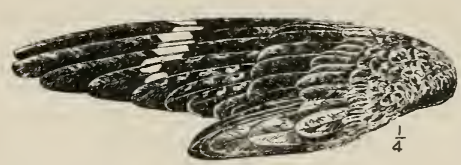

Fig. 293. belly barred with blackish and buffy ; upper parts dull mottled gray, streaked with blackish; uhite wing band back of tip of seventh quill; space between white band and primary coverts spotted with brown. Adult female: similar, but with white tail band restricted or wanting and wing band buffy. Young: more finely mottled, with less blackish above. less barring beneath, and upper parts often suffused with einnamon or rusty buff. Length: $8-9$, wing $6.60-7.30$, tail $4.10-4.75$.

Distribution. - Breeds in Lower Sonoran zone from Texas to southern California, and from Nevada and Utah south to Cape St. Lucas and Veragua.

Eygs. - Deposited on the bare ground ; 2, clay color to creamy, minutely marbled with dots of grays, browns, and lilac.

Food. - Partly motlis, cicadas, and beetles.

Mr. Anthony found the Texan nighthawks 'fairly swarming' at Deming, New Mexico; and in Phœnix and Yuma, Arizona, and in the southwestern parts of Texas, Mrr. Bailey found them abundant. They sit in the shade during the day, but at night the air is filled with their 'bubbling cry,' especially about water. At Yuma they would come to the river just after sundown to drink. Hovering close to the water with neck bent down they would take a sip, then fly a little way and repeat it. After drinking they would circle over the water till dark in pursuit of insects. At Owen Lake, California, they were found skimming close to the water in pursuit of a small fly which was swarming on and near the shore.

Mr. Anthony says they do not indulge in the aerial evolutions of other nighthawks, but fly low, doing much of their hunting within two feet of the ground, jumping up after passing insects much as the poor-wills do.

On the wing they are easily told from other nighthawks by their brownness and by the position of the wing bar near the tip of the 
wing. Their voice also marks them. They do not boom or give the quanli characteristic of other members of the family. Mr. Bailey describes their notes as a low rapid chuck, chuck, chuck, followed by a soft $\mu^{\prime \prime \prime} r^{\prime} r^{\prime} r^{\prime} r^{\prime} r r^{\prime} r$, which, when several birds are about, becomes almost incessant.

In parts of southwestern Texas during the breeding season the Texan is the only niglithawk, and Dr. Mearns states that he has never known henryi to infringe on the territory of texensis in the breeding season, henryi nesting in the pines and spruces of Transition and Boreal zones; texensis below the pines in Lower Sonoran zone. In California, Mr. Grimnell says, texensis nests in dry parts of river-beds and sandy places among sagebrush.

\section{FAMILY MICROPODID君: SWIFTS.}

KEY TO GENERA.

1. Tarsus and part of toes feathered . . . . . Aëronautes, p. 2:32.

1. Tarsus and toes naked.

2. Tail feathers tipped with spines . . Chætura. p. 230 .

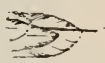

Fig. 294.

2 . Tail feathers not tipped with spines . Cypseloides, p. 229.

\section{GENUS CYPSELOIDES.}

\section{Cypseloides niger borealis (Kenn.). BLACK SwIFT.}

Tail slightly forked; tarsus and toes naked, the hind toe pointing backward. Adults: dusky or blackish. lighter on head and neck, the forehead hoary, a velvety black area in front of eye. Young: similar, but feathers tipped with whitish. Length: $7.00-$ 7.50, wing 6.50-7.50, tail $2.30-3.00$.

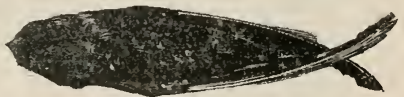

Fig. 295.

Distribution. - From the Rocky Mountain region west to the Pacific, and from British Columbia south to Lower California and Costa Rica.

Nest. - On eliffs or about buildings. One described by MI. H. Gormley, on the cornice of a building, made of straws. chips, and horsehair, lined with green leares and paper. Eggs : 5, white.

Food. - Insects.

The black swift has been found breeding on inaccessible cliffs in various parts of the west, but little that is peculiar has been discovered about its habits except that it is less noisy than most of the swifts. A nest was accidentally discovered by Mr. Vrooman at Santa Cruz when collecting cormorants' eggs on the cliffs.

Mr. Rathbun says the swifts may be seen circling about above the city of Seattle, rarely being seen, except when rain threatens, lower than from 3000 to 5000 feet. 


\section{GENUS CHÆTURA.}

General Characters. - Tail less than half as long as wing, rounded or even, the feathers usually with distinct spines; wing less than 5.50 ; tarsus and toes naked, hind toe directed backward.

\section{KEX TO SPECIES.}

1. Wing 5 or more. Eastern . . . . . . . pelagica, p. 230. $1^{\prime}$. Wing decidedly less than 5. Pacific to Sierra Nevada.

423. Chætura pelagica (Linn.). Chimnex Swift.

Sooty gray, the throat paler. Length: $4.75-5.50$, wing $5.00-5.25$, tail, including spines, 1.90-2.15.

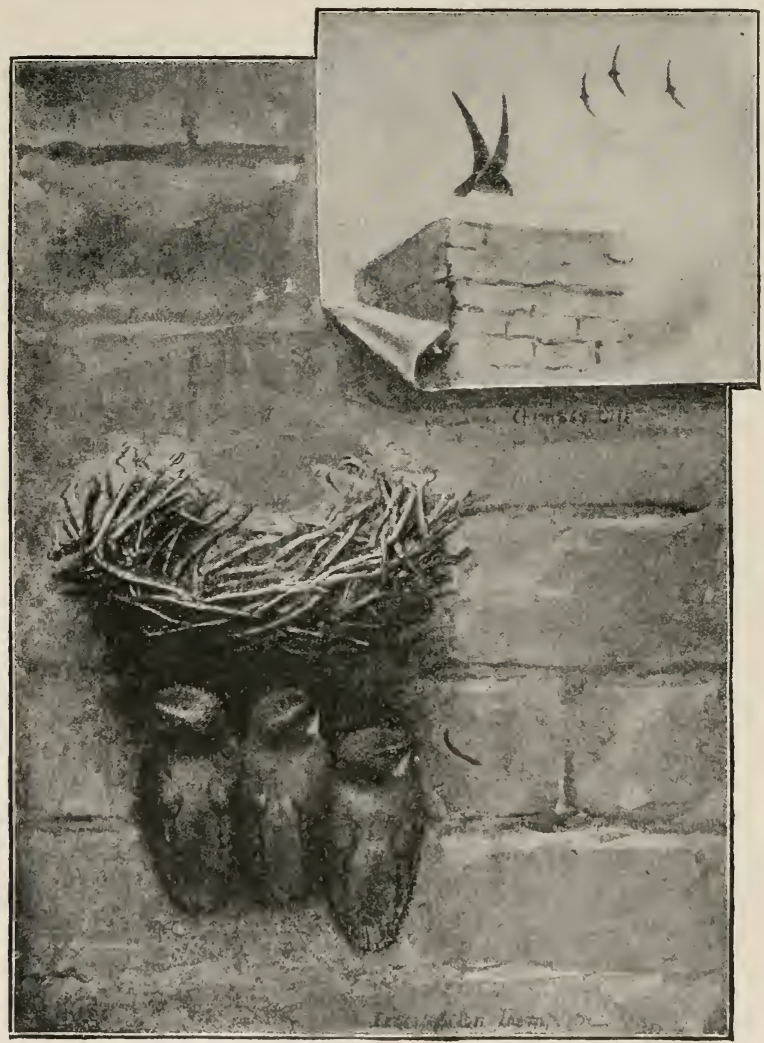

Fig. 296. 
1)istribution. - Breeds in eastern North America from northern Manitoba and Labrador southward, west to the Great Plains ; migrates beyond the United States as far as Yucatan and Jalapa, Mexico.

Nest. - A wall pocket of twigs, glued together with saliva and fastened to inside of hollow tree or chimney. Eggs : 4 to 6 , white.

Food.- Insects.

The eastern chimney swifts are said to be common in western Kansas. "They are dark little birds who row through the air like racers, twittering sociably as they go. Sometimes as you watch them on a village street you will see them suddenly stop short and pitch down the black mouth of a chimney, for it is now only the most old-fashioned ones who nest in hollow trees. . . . There is actually no record of their alighting anywhere except in a hollow tree or a chimney. They even gather their nesting materials on the wing, breaking off bits of twig in their feet, and it is said with their bills, literally, in passing. . . . It would be quite impossible for an ordinary bird to fasten a wall-pocket of twigs to a perpendicular chimney, but the swift is provided with a salivary glue that defies anything but heary rain." (Birds of Villege and Field.)

\section{Chætura vauxii (Touns.). Vaux Swift.}

Upper parts sooty brown, lighter on rump and tail ; tail tipped with spines; under parts gray, lighter on throat. Length: 4.15-4.50, wing 4.30-4.75, tail (including spines) $1.50-1.90$.

Distribution. - Pacific coast region from British Columbia south to Lower Califormia, and

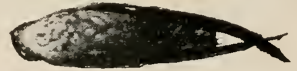

Fig. 297. east to western Montana and Arizona - rare and sporadic east of the Caseades and Sierra Nevada; migrates to Mexico and Central America.

Nest. - Of small twigs glued together and fastened to the inside of a hollow tree. Eggs: 8 to $\tilde{\text {, }}$, white.

Food. - Aerial insects.

Major Bendire says that the Vaux swift usually reaches the United States on its way back from Central America about the middle of April, and leaves in October. It migrates in flocks of from fifty to a hundred, but when at home generally hunts in small flocks of fifteen or twenty. Mr. Anthony once found a pair nesting in a large stub, and says that in going to the nest they would 'circle about fully two hundred feet above the stub, until directly over the opening ; then, darting down like a flash, would disappear with a sharp twitter.'

IIr. Littlejohn, of Redwood, California, has found a pair of swifts nesting in a chimney, and it will be interesting for observers to watch the birds to sce how soon they acquire the habits of the more civilized swifts. 


\section{GENUS AËRONAUTES.}

425. Aëronautes melanoleucus (Baird). White-throated SwIFT.

Tail about one half as long as wing, forked, with stiffish and narrowed

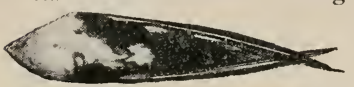

Fig. 298. but not spiny feathers; tarsus and part of toes feathered; hind toe directed either forward or to the side, but not backward. Upper parts blackish; throat and breast and patches on wing and sides of rump white; sides blackish; tail without bristles. Length: $6.50-7.00$. wing 5.:30-5.90, tail $2.50-2.70$.

Remarks. - The white markings distinguish this swift from vauxii, whether seen from above or below.

Distribution. - Western United States from the Pacific coast east to the region of the Black Hills, western Nebraska; and from Montana south to Lower California and Guatemala.

Nest. - On cliffs or in caves, glued to the rocks, made of regetable matter and stiff feathers, lined with bark fiber and a few feathers. Eggs : 4 or 5 , white.

Food. - Aerial insects.

There is one bird that needs no protective legislation for itself or nest. The home of the white-throated swifts is in the air around lofty peaks and cliffs, where they circle and wheel and dart on curved, cutting wings with arrow-like speed. As you stand on the crest of a ridge where they pass, there is a flash of black and white and a bullet-like whizz as one after another goes by, and you wonder that any living thing can move with such speed. I have seen collectors who were good wing shots fire till their gun barrels were hot and turn away with empty belts and only a single specimen of the swifts. As the birds seldom come to low altitudes it is not strange that they should be rare in collections. Their nests, placed in crevices or caves half way up inaccessible cliffs, have rarely been taken.

Verion Batiex.

\section{FAMILY TROCHILID王：HUMMINGBIRDS.}

\section{KEY TO GENERA.}

1. 1st and 2d primaries about equal .

Atthis, p. 241.

$1^{\prime} .1$ st primary the longest.

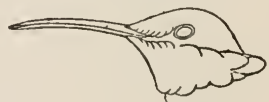

Fig. 299.

2. IBill curved

Calothorax, p. 242.

¿'. Bill not curved.

3) Nostrils nearly or wholly naked.

4. Tail blue black in both sexes, upper parts metallic grass green. 4'. Tail not blue black.

Iache, p. 244 . 
5. Exposed culmen not more than half as long as tail ; with white stripe back of eye . . . . . . Basilinna, p. 24.3.

5 '. Exposed culmen more than half as long as tail; without white stripe back of eye . . . . . . . Amizilis, p. $24 \%$.

3. Nostrils nearly or wholly feathered.

4. Ving more than 2.40 .

5. Tail chiefly black - gorget of male intense blue.

Coligena, p. $2: 34$.

5'. Tail wholly (male) or partly (fenale) greenish bronze, gorget of male emerald green . . . . . Eugenes, p. 23.3.

4'. Wing less than 2.25.

5. Middle tail feathers broader near end than toward base - spatulate . . . . Stellula, p. 241.

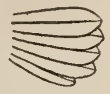

Fig. 300.

5 . Middle tail feather's narrower near end than toward base.

6. Tail partly rufous . . . . . Selasphorus, p. 238.

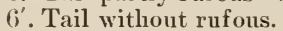

7. Adult males with top of head like gorget; females witl outer tail feathers broadly lineal . . . . . Calypte, p. 236.

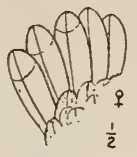

Fig. 301.

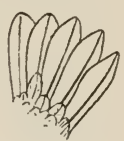

Fig. 30 ?.

\section{Eugenes fulgens (Swains.). Rivoli Humingrind.}

Bill flattened and slightly widened at base; tail slightly forked in male. double rounded in female; tarsus feathered. Adult male: top of head metallic purplish, gorget brilliant emerald green; rest of upper parts bronzy green; under parts blackish green or dull bronzy. breast black in some lights. Adult female: top of head dull brownish. small white spot behind eye; rest of upper parts bronzy green; lower parts brownish gray, sides washed with green ; tail with outer feathers very broadly tipped with pale gray or whitish. Young: similar to adult female, but feathers of upper parts with pale buffy edgings. Male : length $4.50-5.00$, wing $2.90-3.10$, tail $1.90-$ 2.00, bill 1.00-1.20. Female: wing 2.60-2.75, tail $1.70-1.90$, bill $1.00-1.15$.

Distribution. - Mountains of southeastern Arizona and nountains bordering tablelands of Mexico to Nicaragua.

Nest. - Usually in maples, sycamores. or firs. 35 to 50 feet from the ground, made of silky plant

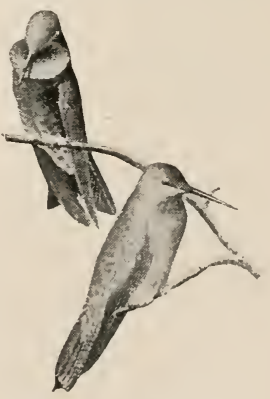

From Ridgway, smithsonian.

Fig. 303. fibers and grass tops, coated witl lichen and lined with sycamore down and feathers.

Food. - Largely insects from flowers such as honeysuckle and agave. 
Mr. Willard of Tombstone, Arizona, says that the noise made by the wings of the Rivoli hummingbird lacks the sharpness of that of the smaller hummers and compares it to the buzzing of an immense beetle or bumblebee. He adds that the male may often be seen near the top of some dead tree catching insects like a flycatcher. Mr. W. W. Price reports that the hummers feed from iris and also agave flowers. In the Chiricahua Mountains Dr. Fisher found them gleaning from the flowers of a boreal honeysuckle. Mr. Price records them only between the altitudes of from 6500 to 9500 feet.

\section{GENUS CGELIGENA.}

427. Cœligena clemenciæ Less. Blue-throated Hummígbird.

Tail more than two thirds as long as wing, slightly rounded, feathers

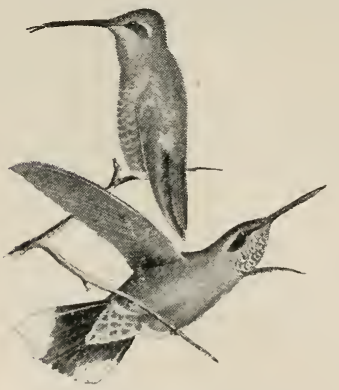

From Ridgway, Smithsonian.

Fig. 304. very broad; bill less than one third as long as wing. Adult male: gorget azure blue; streak from bill and back of eye white; upper parts dull bronzy green, changing to purplish black on upper tail coverts and tail, onter tail feathers tipped with white; under parts slate gray washed with green on sides. Adult female: similar, but throat buffy instead of blue. Length: 4.50-5.40, wing $2.90-3.20$, tail $1.85-2.20$, exposed culmeu .S5-1.00.

Remarks. - The females of the bluethroated and the Rivoli can be easily distinguished by the tail, which in the bluethroated is blue black, in the Rivoli largely bronzy green.

Distribution. - Southern Arizona, western Texas, and mountains of the tablelands of Mexico to Oaxaca.

Nest. - Fine mosses and oak catkins, bound together with web, placed in the fork of a small shrub, or on a fern. (Breniger.) Eggs:2, white.

Among the little restless, darting, scintillating hummers of the United States, the big, quiet, sober-colored blue-throats seem more like foreign birds, and really are only visitors across our border from Mexico. Whether bathing in the spray of a slender mountain fall, or feeding from flower to flower, they have a low hum and quiet ways, perching frequently on a branch to twitter a little song and preen their feathers, or climbing about among the flowers of a big agave in search of food in real oriole fashion. VERNon BaIlex.

\section{GENUS TROCHILUS.}

General Characters. - Male with metallic gorget not elongated on the

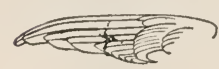

Fig. 305.

or toothed at tip. sides; tail forked or deeply emarginate, the feathers pointed, but the outside ones not extremely narrow; six imner ptimaries abruptly and conspicuously smaller than the rest with their imer web more or less notched Females with outer tail feathers concave on side. 
KEY TO ADULT MALE TROCHILUS.

1. Throat velvety black. Rocky Monntains to the Pacific.

1'. Throat metallic crimson. Plains to Atlantic . . colubris, p. 23\%.

Subgenus Trochilus.

\section{Trochilus colubris Linn. Ruby-throated Humingrird.}

Adult male. - Chin velvety black, scules of gorget brilliant crimson. upper parts bronzy green; under parts dark gray glossed with green; wing with six imer primaries abruptly shorter than the rest. Adult female: tail with middle feathers all green, the rest green basally, then black ; three outer pairs broadly tipped with white. Young male : similar to adult female. but throat streaked with dusky, and feathers of upper parts edged with pale buffy. Young female: similar, but throat without streaks, and tail more rounded. Male : length $3.07-$ 3.25 , wing 1.60 , tail 1.25 , tail forked for about .30-.35, exposed culmen .5. male: length 3.50-3.5.5, wing 1.80 , tail 1.20 , bill .70.

Distribution. - B reeds from the Atlantic to western parts of Nebraska and Texas, and from Labrador south to

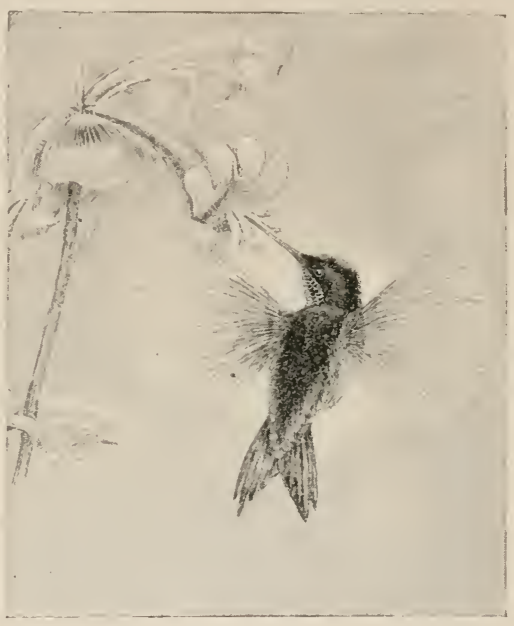

Fig. 306. Florida; migrates to Cuba, Mexico, and Central America.

Nest. - A felted cup of soft vegetable fibers coated with lichen and fastened with web ; saddled on to a twig or small branch of a tree, nsually 10 to 20 feet from the ground. Eggs: 2, white.

Food. - Largely minute spiders and insects.

The ruby-throated hummingbird has been reported as breeding in the western parts of Nebraska and Texas.

\section{Trochilus alexandri Bourc. \& Muls. Black-chinned Hun- MINGBIRD.}

Adult male. - Gorget above opaque velvety black, below metallic violet glittering with purple. blue, and peacock green lights; npper parts greenish; under parts soiled whitish, green on sides. Adult female: upper parts bronzy green; under parts grarish; tail much rounded, middle pair of feathers about the longest and wholly green, next two feathers green tipped with black, outer three tipped with white. Young: similar to adnlt female. but feathers of upper parts tipped with buffy or rusty and

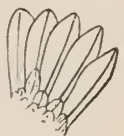

Fig. 30\%. throat of male streaked with dusky. Male: length 3.30-3.75, wing 1.701.75, tail 1.2.5, bill .70-.75. Female: length 3.90-4.10, wing 1.90-2.00. 
Distribution. - Breeds in Transition and Upper Sonoran zones from British Columbia south to Lower California and from the Rocky Mountains and Texas to the Pacific; winters in Mexico.

Nest. - In trees or bushes 4 to 8 feet from the ground, made of white or sponge-colored plant down, covered with spider web, sometimes with addition of leaves or flowers. Eggs : 2 or 3, white.

Food. - Largely minute insects.

In southern California the black-chinned hummer may often be seen sunning himself on an oak twig, his dull black throat relieved by a violet band that glints green and blue as he turns his head. Ordinarily he seems the quietest, most unemotional of hummingbirds, but if fortunate you may come on him when performing his aerial love-dance. One that I once watched took his stand below his lady's perch and fixing his eyes upon her swung shuttling from side to side in an arc, with the sound and regularity of a machine. He never turned around or took his eyes from hers, but at the end of the arc-less than a yard in length - always threw himself back by a quick spread of his tail. She sat as if hypnotized, her long bill turning as he turned, her eyes following every motion with iroll absorption. In spite of her flattering attention, however, when his dance was over and he looked up for approval, she apparently made some slighting remark, for he whizzed off in a hurry and was seen no more.

In Los Angeles County, California, Mr. Grinnell says the blackchins are resident from the lowlands to the summit of the mountains, but most abundant in the foothills, where they breed in canyons some years by the thousands. Their numbers vary with the rainfall, as the abundant flowering plants that follow a wet winter afford them ample food. At Phonix, Arizona, Mr. Bailey found that one of their favorite feeding flowers was the desert Fouqueria.

\section{GENUS CALYPTE.}

General Charucters. - Adult males with tail emarginate or

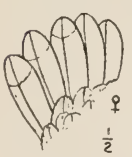

Fig. 308. slightly forked, ontside feathers abruptly narrower than the rest. Adult females with outer tail feathers decidedly narrower than the rest, but with broad rounded end.

1. Males with gorget and top of head purplish red; females with under parts brownish gray . . . . . . . . . anna, p. 2:37.

1'. Males with gorget and top of head metallic violet; females with under parts white

costæe, p. $2: 36$.

430. Calypte costæ (Bourc.). Cost 1 Hummanirim. Adult male. - Head, gorget. and long flaring ruff brilliantly burnished 
metallic amethyst violet changing to blne and green; back, rump, and middle tail feathers green or bronze. onter feather's purplish lusky; tail slightly forked, outer feathers abruptly narrower than pair next them; under parts whitish, belly glossed with green. Adult female: mnder parts whitish. throat more or less spotted with metallic purple; sides greenish; upper parts and middle tail feathers bronzy green, other feathers crravish brown at base, with black subterminal band and white tip. Young: similar to female, but duller. and feathers of npper parts narrowly tipped with buffy whitish. Male: length 2.7.5-3.20, wing 1.751.90, tail 1.10. bill .65-.6.5. Female: length 3.5.)3.70 , wing 1.70 , tail 1.05 , bill .70.

Remarks. - The scales on the erown distingnish costce from any common hummingbird except amna, and in costce the glitter is bluish purple, never pinkish as in anna. The females of anna

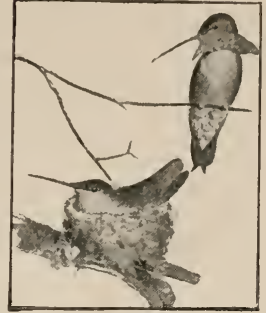

From kidgway, smithsonian. Fig. 310. Costa Hummingbird. and costce may be distinguished by the small size of costor. and female costce from females of Selasphorus and Atthis by absence of rnfous on tail.

Distribution. - Breeds in Lower Sonoran zone from sonthern parts of New Mexico and Utah to sonthern Califormia; migrates to Lower California and other parts of western Mexico.

Nest. - Loosely made of plant down or shreds of plant fiber lined sometimes with feathers and covered with bits of gray lichen, bark, and leaves. bound with web; placed from 1 to 6 feet from the ground, on cactus, in bushes or trees. Eggs : 2, white.

Food. - Insects found on plants and shrubs such as squaw cabbage, wild rose, plum, and cherry.

The habits of the Costa hummingbird seem to differ little from those of the family except that it is somewhat more of a desert-loving species. Dr. Fisher states that it is the common hummingbird of the desert valleys and mountains of southern California and Nevada. He has seen it hovering over a bunch of flowers by moonlight. Mr. F. Stephens reports the rare sight of a male hummer helping to build the nest.

\section{Calypte anna (Less.). Axna Humungrird.}

Adult male. - Top of head, gorget, and long ruff brilliant metallic deep rose pink with bronzy and green lights; upper parts and middle tail feathers metallic green or bronzy; tail decidedly forked, without rufous or white; feathers widening gradually from outside to middle; under parts whitish glossed with green. Idult female: similar except on head and tail; erown green like back; throat usually

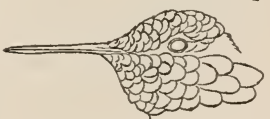

From Ridgway, Smithsonian.

Fig. 311. specked with rose. Young: similar to adult female, but feathers of upper parts edged with brown. Male: length 3.40-3.60, wing 1.90-2.00, tail 1.30-1.45, bill .65-.70. Female: length $3.80-4.15$, wing 2.05 , tail 1.30 , bill .75.

Remarks. - Female anna is larger than the females of costce, or of Trochilus alexandri or colubris. 
Distribution. - Central and southern California, chiefly west of the mountains, southern Arizona, and Lower California.

Nest. - Plant down covered with bits of green mosses and lichens, fastened by web, sometimes lined with feathers or fur; placed usually 8 to 15 feet from the ground, in trees or bushes often overhanging water. Eggs : 2 , white.

Food. - Spiders, small insects, and nectar from flowers; also sap exuding from sapsucker punctures.

"Like all the hummingbirds this species follows the flowers, and its local presence or absence is governed by their abundance or scarcity. Thus, in August and September hundreds of Anna hummers are to be found over the stubble fields and sunflower patches, attracted by the flowers of the 'tar-weed.' During the winter months they are found in profusion about the blossoming eucalyptus trees. In January and February when the weather is mild, they appear high on the mountain sides among the flowering manzanitas; and in March and April in the blossoming orange groves in the valley, and about the currant bushes on the hillsides." (Joseph Grinnell.)

\section{GENUS SELASPHORUS.}

General Characters. - Adult males with outer primary narrow and pointed; tail feathers partly rufous, more or less graduated.

Fig. 312.

KEY TO ADULT MALES.

1. Top of head red like gorget . . . . . . . . floresii, p. 238.

1'. Top of head greenish, unlike gorget.

2. Upper parts mainly rufous . . . . . . . . . . rufus, p. 239.

$2^{\prime}$. Upper parts mainly green.

3. Gorget purple

$3^{\prime}$. Gorget scarlet

[431.1.] Selasphorus floresii Gould. Floresi Hummarird.

idult male. - Top of head and gorget brilliant metallic red; middle tail feathers green bordered with rufous, outer tail feathers wholly dusky; belly white; sides and flanks green. Idult female: unknown. Length: 3.25 , wing 1.75, tail 1.40, exposed culmen .(i.).

Distribution. - Mexico. Recorded at San Francisco and Haywards.

432. Selasphorus platycercus (Swains.). Broad-tailed HumMINGBIRD.

Adult male. - Gorget without elongated sides, deep rose pink; top of head bronzy green like back and middle tail feathers; other tail

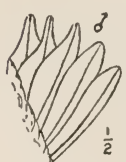

Fig. 313. feathers purplish black, some of them edged with rufous; under parts whitish, sides glossed with green. Adult female and young: upper parts bronzy green; under parts whitish, the throat with dark specks, sometimes with a few central feathers like grorget of male; sides brownish; three outer tail feathers rufous at base, with a black subterminal band and white tip; a touch of green on the second and third 
feather between the rufous and black, the fourth feather green but marked with a terminal or subterminal spot of black, and edged with rufons, tip often white. Male: length $4.00-4.25$, wing $1.9 \%-$ 2.05 , tail 1. $40-1.60$, bill .(i2)-.70. Female : length 4.10-4.70, wing $2.00-2.10$, tail $1.45-1.50$, bill $.70-.72$.

Remarks. - The females of platycercus and rufus must be carefully discriminated. In platycercus the middle tail feathers are wholly green, in rufus brown at base; in platycercus the rufous of the outer feathers is basal and of less extent

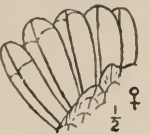

Fig. 314 . than the black; in rufus the rufous equals or exceeds the black; in platycercus the next to the middle feather is mainly green, in rufus the rnfous covers as much ground as the green, black, and white all together ; in platycercus the outer feather is .25 broad, in rufus .12 broad.

Distribution. - Breeds in Transition and Canadian zones of the Rocky Mountain district from Idaho and Wyoming to monntains of Arizona and New Mexico; west to the Sierra Nevada ; migrates to Guatemala ; recorded from Oakland.

Nest.-Usually within 15 feet of the ground on branches of trees. often overhanging a mountain stream, made of willow or cottonwood down covered with lichen alone, or lichen, bark, leaves, and plant fibers. Eggs : 2, white.

Food. - Insects found on flowers of Castilleia, Fouqueria, Gilia, Agave, and others.

Iajor Bendire says that the broad-tailed hummingbirds breed in the lower foothills and valleys on their first arrival from the south, but by the time the young are able to fly the flowers have ceased blooming and the country is getting so dry that they go to the mountain parks to raise their second broods.

At 9000 feet in the Sacramento Mountains we found the birds abundant the last of May feeding from the gooseberry bushes. The noise they made in buzzing about the bushes and flying through the air was a metallic rattle strikingly different from the noise made by rufus, colubris, alexandri, or any other hummingbird I had ever heard. In addition to a squeaky little song the hummers had some small staccato notes.

When camped at Little Spring, San Francisco Mountain, Dr. Merriam found platycercus very abundant. They came to the spring to drink and bathe at daylight. He says: "They were like a swarm of bees, buzzing about one's head and darting to and fro in every direction. The air was full of them. They would drop down to the water, dip their feet and bellies, and rise and shoot away as if propelled by an unseen power."

\section{Selasphorus rufus (Gmel.). Rufous Humingarid.}

Adult male. - Gorget fire red, orange, and brassy green; general body color bright reddish broun, glossed with bronzy green on crown and sometimes back, and fading to white next to gorget and on belly ; tail feathers rufous, with dark mesial streaks; middle tail feather broad, pointed at tip, second from middle deeply notched on inner web, sinuated on outer web. 
Adult female: upper parts bronzy and rufous, rufous on rump and tail coverts; under parts whitish, throat sometimes with a few central brilliant feathers; sides shaded with rufous; tail feathers rufous at base, the middle ones green nearly to base; outer ones with broad blackish subterminal band and white tips; outside feather more than .10 wide. Young males: similar to adult female, but feathers of upper parts edged with rusty. rump rufous, and throat showing specks of metallic red. Young females: similar to young males, but rump green and throat

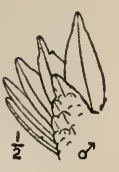

Fig. 315. specked only with green. Male: length 3.25-3.70, wing $1.50-1.60$, tail

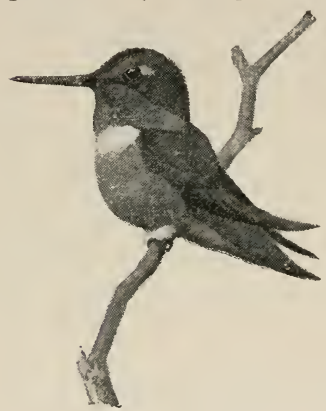

Fig. 316. Riufous Hummingbird.

1.30-1.35, bill .60. Female : length 3.50-3.90, wing $1.75-1.80$, tail $1.25-1.30$, bill $.65-70$.

Remarks. - The male may be told by its reddish back and the nick in the second tail feather. see remarks under S. platycercus.

Distribution. - Breeds in Transition and Canadian zones of western North America from the higher mountains of southern California and Arizona north to latitude $61^{\circ}$ in Alaska ; during migrations east to Montana. Wyoming. Colorado. New Mexico, and western 'Texas; winters in southern Mexico.

Nest. - Lined with down, and decorated with nosses, lichens, and bark; often placed in ferns, bushes, trees, and vines overhanging embankments. Eggs: usually 2, white.

Food. - Insects such as those found on wild currant and gooseberry bushes, cherry-tree blossoms, fire-weed, Castilleia, Gilia, Pentstemon, and Agave flowers.

During the spring migration rufus, the big brown hummer, is common in southern California, especially about the blooming orange groves and the wild gooseberry bushes scattered through the chaparral.

On the birds' breeding ground the flowers they feed on, as far as I have observed, are mainly red, as the hummer's coloration might suggest. On San Francisco Mountain, Arizona, they were especially fond of the scarlet pentstemons. On Mount Shasta they fed. from the painted-cups, tiger lilies, and columbines. Any spot of red would attract them as it does other lıummers, and they investigated it fearlessly even when it adorned the person of a collector.

One of the birds actually crossed a wide meadow of green brakes straight to a single columbine standing most inconspicuously near the woods. But the painted-cups were their especial delight on Shasta, and a meadow full of the flowers was fairly alive with them. When attending strictly to his meal a hummer would circle systematically around the cup, probing its tubes as he went, but for the most part the squeaking, pugnacious little scraps would be whizzing in and out, gleams of green, gold, or scarlet glancing from their gorgets as they streaked after one another, climbing the 
air bill to bill, or shooting up and sweeping down apparently from sheer exuberance of spirits. They seem to be always quarreling among themselves, and when it eomes to other species of their family they attack and drive them off with promptness and decision.

As soon as the last brood is out of the nest, Mr. Henshaw salys, the males, warned by the frosty nights and the decreasing supply of food, start at once for their winter quarters, leaving the females and young to follow later.

\section{Selasphorus alleni Henshu. Allen Humingird.}

Adult male. - Similar to rufus, but whole back as well as crown bright

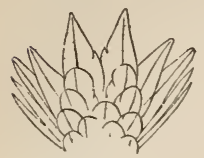

Fig. 31\%. bronzy green, two outer tail feathers very narrow, and second from middle without notch or sinuation; outer feather much less than .10 wide. Adult female: similar to female rufus, but with outer tail feathers not more than 10 wide. Male: length $3.25-3.30$. wing 1.50-1.5.5, tail 1. 10-1.20,

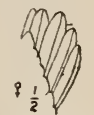
exposed culmen .60-.6.). Female: length 3.40. wing 1.6.5-1.70. tail 1.05-1.15, exposed culmen .68-.70.

Distribution. - Breeds in Transition and Upper Sonoran zones from southern British Columibia south along the coast, and east to southern Arizona ; migrates to Lower California and Sonora, Mexico.

Nest. - A cup compactly made of plant down covered with green mosses, usually placed on weed stalks, hedges, or bushes overhanging water. Eggs : 2 , white.

\section{GENUS ATTHIS.}

\section{Atthis morcomi Ridgw. Morcon Huming Bird.}

Similar to Stellula, but tail feathers not inclining to spatnlate, the outer two or three broadly tipped with white in both sexes; feathers of gorget in male broader and without white bases. Adult male: unknown. Adult female: upper parts bronzy green, becoming brownish on forehead; tail rufous at base, then, on middle feathers. green; other feathers narrowly green and then black. tipped with white, white tip wanting on fourth feather; nnder parts white, with tear-shaped flecks of dusky green on throat; sides marked with black and rufous.

Distribution. - The only specimen known eame from the Huachuca Mountains. Arizona.

\section{GENUS STELLULA.}

\section{Stellula calliope Gould. Calliope Humingbird.}

Six middle tail feathers contracted in the middle and widened at end; adult male with feathers of chin and throat narrow, those on the outside of the ruff elongated; base of ruff white.

Adult male. - Gorget rose purplish, white bases giving effect of streaking; upper parts metallic green; tail feathers dusky, bases edged with rufous. tip wider than base; nnder parts white;

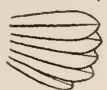

Fig. 319 . sides tinged with brown and green. Adult femule: upper parts bronzy green; tail romded and tail feathers greenish gray basally with touch of rufous, black-banded, and tipped with white, except middle pair, which are green, ending in dusky. Young: similar. but under parts washed with rufous, throat specked with dusky. Male: length 2.75-3.00, wing 1.50- 


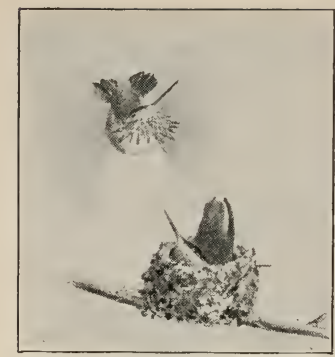

From Ridgway, smithsonian.

limb of a pine. Eggs : 2, white.

1.60, tail .90-1.10, exposed eulmen .55-.58. Female: length 3.50 , wing $1.75-1.80$, tail 1.10-1.15. bill .58-60.

Remarks. - This is the smallest hummingbird in the United States, and may be distinguished by its size together with the large amount of rufous on its under parts and the small amount on its tail.

Distribution. - Breeds in Canadian and perhaps Transition zone in western mountains from British Colnmbia to sonthern California. and east to Colorado ; migrating as far south as mountains of Guerrero, Mexico.

Nest. - Willow down, protectingly colored with bits of bark and shreds of cone, placed on or against a dry cone or dead

"The Calliope hummingbird is the smallest of the Trochilida found within the United States. It is a mountain-loving species, and during the breeding season is rarely met with below altitudes of 4000 feet, and much more frequently between 6500 to 8000 feet. Its favorite resorts are the open timber found about the edges of mountain meadows and parks, and the rocky hillsides covered here and there with straggling pines and small aspen groves." (Bendire.)

At Fort Sherman, Idaho, Dr. Merrill says its arrival in spring is coincident with the blossoming of the wild hawthorn.

\section{GENUS CALOTHORAX.}

\section{Calothorax lucifer (Swains.). Lucifer Hummingrird.}

Bill distinetly curved; tail forked, three outer feathers narrow ; females with tail donble-romnded and deeply emarginate.

Idult male. - Bill long and curved; gorget elongated on sides, metallic

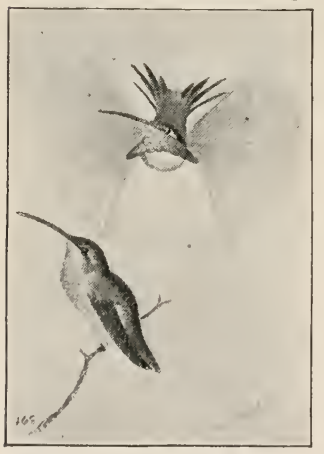

From Ridgway, smithsonian. Fig. 321. lilac. or violet purple; upper parts bronzy green; forked tail with narrow outer feathers purplish black, four middle feathers green; median under parts white; sides green and mfons. Adult female: similar, but bronzy green above, under parts plain pale rnfons; tail less deeply forked than in male and feathers broader, the three onter ones rnfous at base and white at tip. Male: length $3.40-3.60$, wing $1.40-1 .(00$, tail $1.25-1.35$. exposed cnlmen .\$5-.90. Female: wing 1.651.50, tail 1.20-1.2.), exposed culmen .75-.90.

Remarks. - The female may be distinguished by its curved bill.

7)istribution. - From western Texas and sonthern Arizona sonth to the city of Mexico and Pnebla.

Nest. - Cotton or thistle down covered with scales of white lichen. Eggs: 2, white. Food. - Insects fonnd in flowers of agaves and other plants. 
In the Chisos Mountains in western Texas Mr. Bailey found the Lucifer hummer with several other species common in June about the big agares, which were then in full flower.

\section{GENUS AMIZILIS.}

General Characters. - Nasal scale large and swollen, nasal slit entirely exposed; bill light-colored, dark-tipped, broad and flattened at base; tail forked or emarginate; sexes alike.

\section{KEY TO ADULTS.}

1. Upper tail coverts brown 1 '. Upper tail coverts green

tzacatl, p. $24 \%$. chalconota, p. 243.

\section{Amizilis tzacatl (De la Llave). Rieffer Humingrird.}

Adults. - Whole body dark peacock green except belly, which is brownish gray; wings purplish; square tail and its coverts chestnut, tail feathers marked with bronze. Young: similar, but rump tinged with rufous and forehead washed with rusty. Length: 4, wing 2.00-2.35, tail 1.45-1.70, exposed culmen $.70-.90$.

Distribution. - From the valley of the Lower Rio Grande in Texas south through Central America to Ecuador.

Nest. - Grass and plant fiber covered with green moss, often in orange, lemon, or lime trees, 4 or 5 feet from the ground. Eggs: 2, white.

The Rieffer hummingbird is a Central American species apparently only straggling across the Mexican line in Texas.

\section{Amizilis cerviniventris chalconota (Oberh.). BuFF- BELLIED HUMMINGBIRD.}

Adults. - Upper parts mainly light bronzy green, upper tail coverts green; tail forked, brown, feathers (except outer) tipped with bronzy or violet; throat green; rest of under parts buffy brown. Length: 4.00-4.50, wing 2.15-2.30, tail 1.50-1.70, exposed culmen. .70-.80.

Distribution. - From the lower Rio Grande Valley, Texas, south in winter to eastern Mexico.

Nest. - In bushes or small trees, made of shreds of vegetable fiber, lined usually with thistle down; covered with bits of blossoms, lichen, and shreds of bark fastened by spider web.

"The buff-bellied hummingbird proves to be an abundant summer visitor, and I have nowhere found it so abundant as on the military reservation at Fort Brown. Here it seems perfectly at home among the dense tangled thickets, darting rapidly among the bushes and creeping vines, and is with difficulty obtained. A rather noisy bird, its shrill cries usually first attract one's attention to its presence." (Dr. Merrill, quoted by Bendire.)

GENUS BASILINNA.

440.1. Basilinna leucotis (Vieill.). White-eAred HummagBIRD.

Nostrils exposed; tail emarginate, the feathers broad and rather stiff; tarsus densely feathered. 
Advlt male. - Forehead and ehin deep blue, throat and upper parts of chest metallic emerald green ; a conspicuous white stripe behind eve; tail mainly blackish. Adult female and young: under parts gray, spotted with green; head marked with stripes as in male ; middle tail feathers entirely green or bronzy, the others black, the outer pairs tipped with grayish. Length : 3.25-3.40, wing 2.00-2.30, tail 1.30)-1.50, exposed culmen .65-.68.

Distribution. - From mountains of sontheastern Arizona, south to Nicaragua.

Food. - Insects found in honeysuckles and other flowers.

In the Chiricahua Mountains Dr. Fisher found a white-eared hummingbird on a bush of the wild honersuckle from which the other hummingbirds of the neighborhood - the broad-tailed, Rivoli, and blue-throated - were regularly feeding.

\section{GENUS IACHE.}

\section{Iache latirostris (Swains.). Broad-billed Humingarird.}

Bill wide at base; tail deeply emarginate in male, less so in female. Adult male: gorget peacock blue; rest of body metallic green, sometimes bronzy on back; tail blue black, tipped with gray. Idult female:

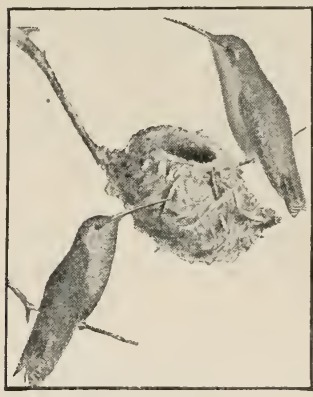

From Ridgway, smithsonian.

Fig. 322. upper parts green, becoming gray on forehead; under parts soiled gravish ; tail with middle feathers and basal half of onter green, corners blue black tipped with gray ; a whitish streak behind eye, with dusky streak below it. Young male: similar to adult female, but tail as in male; lower tail coverts white, feathers of upper parts edged with buff; new feathers on throat bluish green, becoming more bluish toward chin. Young female: similar to adult. but featliers of upper parts bordered with pale buff. Male : length :3.503.75 , wing $2.00-2.20$. tail 1.3.5-1.50 (forked for .25-.55), bill .7.)-.85. Female: length $3.88-4.10$, wing $2.00-2.15$, tail $1.25-1.30$ (forked for .15), bill .78-.85.

Distribution. - From mountains of southern Arizona and southwestern New Mexico south to the city of Mexico.

Vest. - Saddled to a drooping twig made of bark and plant fibers, outside decorated with strips of bark, fine stems, and lichen.

In Arizona where Mr. Stephens found the broad-billed hummingbirds they were always near water, usually along streams in high mountain canyons. They perched on dead twigs where they could command a view, apparently preferring sycamores to other trees. He describes their notes as flat, differing from those of other humminghirds. 


\title{
ORDER PASSERES : PERCHING BIRDS.
}

\author{
(Fanilies Cotingide, Trrannide, Alaudide, Corvide, \\ Sturyide, I(teride, Fringillide, 'Taxagride. Hirux- \\ dixide, Ampelide, Laxitde, Vireonide, Mxiotilti- \\ D.e. Motacillid e, Cinclid.e. Troglodytid.e, Certhitde. \\ Paride, Sylvitd.e, Turdid e, etc.)
}

\section{FAMILY COTINGID丑: COTINGAS.}

\section{GENUS PLATYPSARIS.}

\subsection{Platypsaris albiventris (Laur.). Xaxtus Becard.}

Nostrils partly hidden by bristly featlers; tip of bill slightly hooked : second quill in male small or rudimentars. Adult male: throat mainly rose pink; rest of under parts gras, fading to white below; top of liead black: rest of upper parts slate gray, paler on foreliead and back of neck.

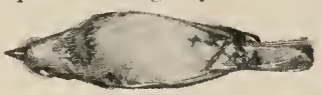

Fig. 323. Adult female and young male: top of head slaty ; rest of upper parts brownish gray or gravish brown; under parts shading from deep brown to whitish. Length: $6.50-7.00$, wing :3.40-3.68. tail 2.70-3.00. exposed culmen. .5s-.65.

Distribution. - Western Mexico; recorded from Huachuca Mountains, Arizona.

As Mr. W. W. Price found an adult male becard in the Huachuca Mountains, Arizona, in breeding plumage, apparently accompanied by its mate, the interesting birds will doubtless be found breeding in the mountains of southern Arizona.

\section{FAMILY TYRANNID㞋: TYRANT FLYCATCHERT.} KEY TO GENĖRA.

1. Tail edged or tipped with white.

2. Tail deeply forked . . . . . . . . Muscivora, p. 246.

2'. Tail not forked . . . . . . . . . . . . Tyrannus, p. 247.

$1^{\prime}$. Tail not edged or tipped witl white.

2. Upper mandible curved on both edges . . . . Ornithion, p. 265.

$2^{\prime}$. Upper mandible straight for most of its length.

3. Tail marked with rufous or rusty (except sometimes Myiarchus lavrencei olivascens).

4. Breast ash gray in contrast to yellow belly. Myiarchus, p. 251.

$4^{\prime}$. Breast rellow like belly; throat white.

5. Streaked .

Myiodynastes, p. 250.

5 . Not streaked. . . . . . . . . Pitangus, p. 250.

3 '. Tail not marked with rufous or rusty.

4. Wing at least six times as long as tarsus. . Contopus, p. 256.

4 '. Wing not more than five times as long as tarsus.

5. Sexes different, male scarlet, females and roung gravish brown .

Pyrocephalus. p. 264 . 
$5^{\prime}$. Sexes similar, largely olivaceous, brown, or black.

6. Wing more than 3.25 . . . . . Sayornis, p. 254. 6'. Wing less than 3.25 . . . . . . Empidonax, p. 259.

\section{GENUS MUSCIVORA.}

General Characters. - Outer primary cut out ; tail deeply forked; bill flattish, notched, and hooked; feet small and weak.

KEY TO SPECIES.

1. 3 or 4 primaries emarginate

tyrannus, p. 246.

1'. Only 1 primary emarginate

forficata, p. 246.

[442.] Muscivora tyrannus (Linn.). Fork-TAlled Flycatcher. Adult male. - Tail black, long, and forked, outer feathers edged with white ; under parts pure white; head black, with concealed yellow patch; back gray; wings blackish brown, with grayish edgings. Adult female: similar, but smaller, tail shorter, and yellow crown patch restricted. Foung: like adults, but tail shorter, sometimes scarcely forked, colors duller, wing coverts bordered with rusty, and crown patch absent. Male: length 12.00-14.50, wing 4.10-4.75, tail 9-10.

Distribution. - From southern Mexico south through Central America and most of South America; accidental in the United States (Mississippi, Kentucky, New Jersey, and southern California).

Nest. - Of soft materials, often almost entirely wool, lined with thistle down, which is cemented with gum. making a hard smooth bottom. Figgs : 4 , cream color, spotted chiefly at the larger end with chocolate.

Food. - Aerial insects; also elderberries and other small fruits.

The fork-tailed flycatcher is only an accidental straggler in the United States.

\section{Muscivora forficata (Gmel.). Scissor-tailed Flycatch- ER.}

Adult male: Tail forked, white, tipped with black; body ash gray, whiter on throat; wings blackish; under wing coverts, axillars, and tail coverts salmon; head with concealed red spot and upper parts marked with red. Adult female : similar, but smaller; tail shorter and colors duller. Young: like adult female, but crown patch wanting. Male: length 12-15, wing 4.40-5.).

Distribution. - Breeds in Lower Sonoran zone from southwestern Missouri to western Texas; migrates to Costa Rica ; straggling rarely to Manitoba and Hudson Bay (York Factory).

Nest. - Generally 5 to 15 feet from the ground, in open situations, preferably mesquite, but also other trees and thorny bushes; made usually of fine rootlets and plant stems lined with plant fibers, wool, and feathers; but sometimes of gray moss, cotton, rags, and seaweed. Eggs: usually 5 , generally clear white, marked with browns and purples.

Food. - Moths, butterflies, beetles, grasshoppers, locusts, crickets, cotton-worms, and some berries.

In visiting the southwestern prairie country the scissor-tail is one of the first new birds you notice. Discovering him first perched on the chaparral you are struck by his long white tail and glistening black, white, and salmon plumage. In perching, the tail is closed 


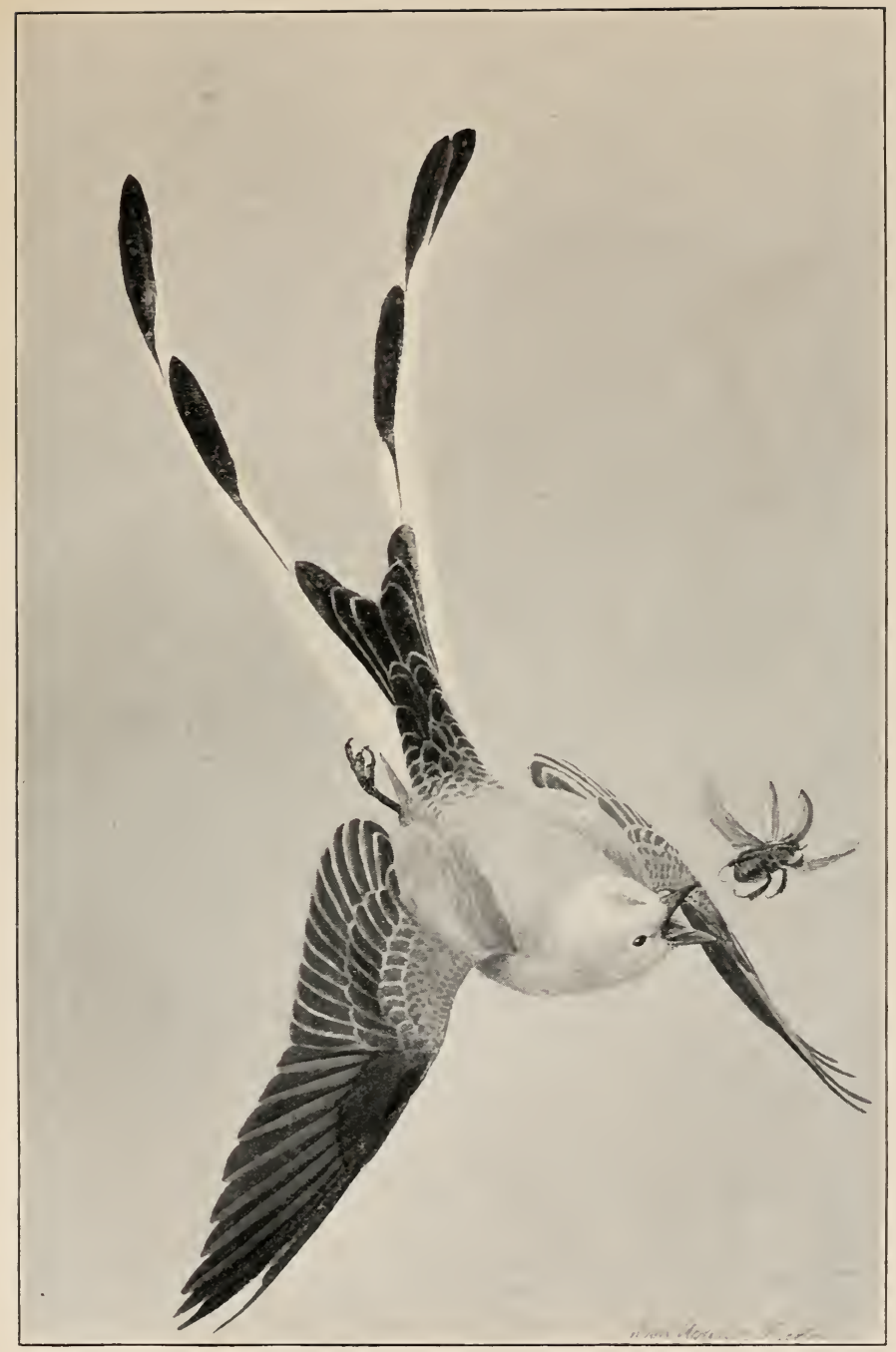

SCISSOR-TAILED FIYCATCHER 

thin, and the black of the wings contrasts well with the bright salmon sides. He sits quietly like any every-day bird, giving only an occasional bee-bird like note, till suddenly up he darts into the air, and with delighted wonder you watch his odd tigure and odder gyrations in the sky.

One of his favorite performances is to fly up and, with rattling wings, execute an acriai seesaw, a line of sharp-angled VVVVVVV's, helping himself at the short turns by rapidly opening and shutting his long white scissors. Is he goes up and down he utters all the

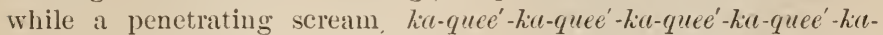
quee . the emphasis being given each time at the top of the ascending line.

Frequently when he is passing along with the even flight of a sober-minded crow and you are quietly admiring the salmon lining of his wings, he shoots rattling into the air, and as you stare after him, drops back as suddenly as he rose. He does this apparently because the spirit moves him, as a boy slings a stone at the sky, but fervor is added by the appearance of a rival or an enemy, for he is much like a Tyrannus in his masterful way of controlling his landscape. He will attack caracaras and white-necked ravens, lighting on their backs and giving them vicious blows while screaming in their ears.

\section{GENUS TYRANNUS.}

General Characters. - Adults with a bright-colored concealed crown pateh; feet small and weak; tarsus not longer than middle toe with elaw ; bill notehed and hooked, broad at base, its width at nostrils much more than half the distance from nostril to tip; adults with outer quills abruptly narrowed at tip.

KEY TO ADLLTS.

1. Under parts white

1 . Under parts yellow.

2. Tail even.

3. Primaries with gradually narrowed tips . . verticalis, p. 24 s.

3 '. Primaries with abruptly narrowed tips . . vociferans, p. 24?.

$2^{\prime}$. Tail decidedly emarginate .

couchii, p. 245 .

\section{Tyrannus tyrannus (Linn.). KingBird.}

Adults. - Under parts and band on end of tail pure white; head and tail black; rest of upper parts slate gray; middle of erown with a concealed patch of orange red. Young: erown patch wanting and colors duller, wing and tail coverts edged with brownish. tail band and chest tinged with brownish. Length: $8-9$, wing $4.45-4.75$, tail $3.40-3.75$, bill from nostril $.50-.57$.

Distribution. - Breeds in Transition and Sonoran zones of temperate North America from the British Provinces chiefly east of the Rocky Mountains to the southern border of the United States. Not recorded from New Mexico or Arizona. Migrates to middle and South America. 
Nest. - Made largely of weed stems, twine, wool, or Spanish moss, lined with grass, rootlets, and horsehair, placed in bushes or trees 4 to 40 feet

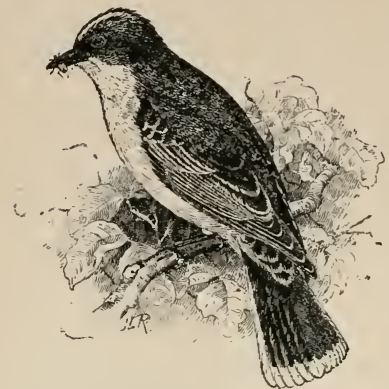

From Biological Survey, U. S. Dept. of Agriculture.

Fig. 324. Kingbird. from the ground. Eggs : 3 or 4 , from white to rose pink, spotted or blotched with brown or lavender.

Food. - Principally grasshoppers, erickets, butterflies, weevils, wild bees, wasps, caterpillars, and gadflies.

In general habits the eastern kingbird resembles the western members of the Tyrannus family, though more commonly a bird of the garden and orchard.

He has been accused of eating honey-bees, but in the stomach examinations made by the Department of Agriculture, of 218 only 14 contained any trace of honeybees, and nearly all these were drones. Ninety per cent. of his food consists of insects, mostly injurious kinds.

\section{Tyrannus melancholicus couchii (Baird). Couch KING- BIRD.}

Adult male. - Belly brilliant yellow, fading through greenish gray to white on throat and under tail coverts; upper parts gray washed with green; wings and tail brownish edged with whitish, tail notched; concealed orange patch on head. Adult female: similar, but smaller, tail less notehed and crown patch restricted. Young: like female, but without crown patch, yellow duller, and wing coverts bordered with buffy. Length: (male) 910, wing 4.40-5.00, tail 3.75-4.40.

Distribution. - From the valley of the lower Rio Grande in Texas sonth to Guatemala.

Nest. - As described by Sennett, Spanish moss and twigs, lined with rootlets; placed near the end of a horizontal limb on a large elm. Eggs : 3 or 4 , ereamy pink, blotehed with brown and purple over whole surface, or in wreath around larger end.

\section{Tyrannus verticalis Say. Arkansas Kivgrird.}

Adult male. - Upper parts and breast light ash gray ; throat paler ; belly

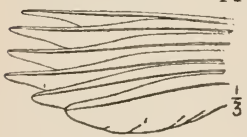

Fig. 325 . lemon yellow; tail black, onter web of outer feather abruptly white; wings brown, end of long quills with gradually narrowed points; concealed crown patch red. Adult female: similar, but tips of onter quills less narrowed and erown pateh restricted. Young: like adults, but crown patch wanting and colors duller, wing coverts bordered with buffy. Length: 8.00-9.50, wing 4.75-5. 25 , tail $3.6 .5-4.00$, bill from nostril .50-5.5.

Remarks. - Terticalis, though very similar to vociferans, can be distinguished in the field by the abruptly white and sharply contrasting onter edge of the black tail, and in the hand by the attemated wing feathers.

Distribution. - Breeds in Transition and Upper Sonoran zones of western United States from Nebraska and Kansas to the Pacific; and from 



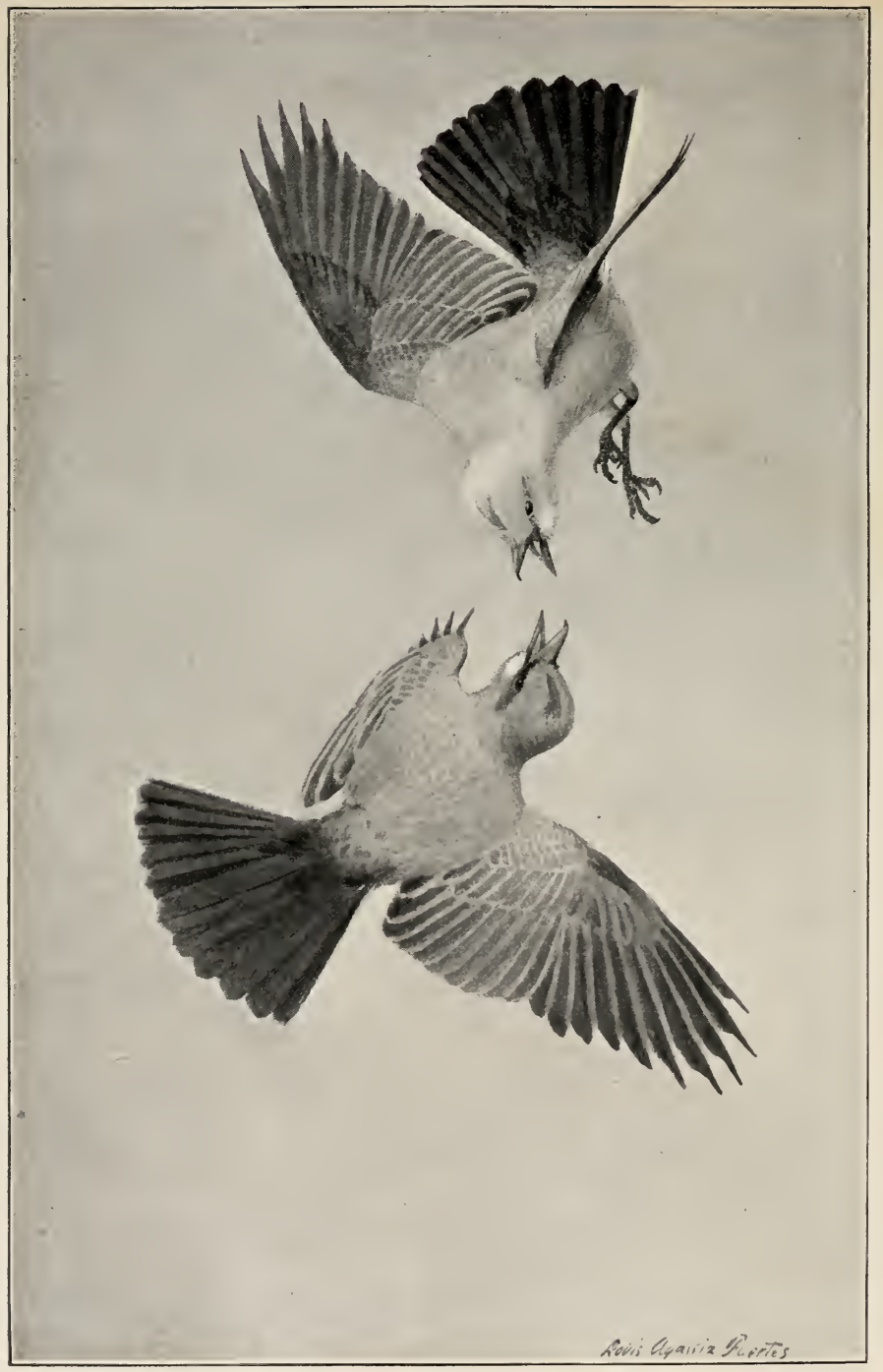

ARKANSAS AND CASSIN KINGBIRDS 
Assiniboia and British Columbia south through Lower California ; migrates through western Mexico to Guatemala.

Nest. - In bushes or trees usually not far from the ground, made of twigs, weed stems, plaut fibers, rootlets, wool, cocoons, hair, feathers, string, thistle down, and paper. Eggs: usually 4, similar to those of Tyrannus tyrannus.

Food. - Mainly grasshoppers, with moths, butterflies, flies, winged ants, caterpillars, and large black crickets.

The Arkansas kingbird is a masterful, positive character, and when you come into his neighborhood you are very likely to know it, for he seems to be always screaming and scrimmaging. If he is not overhead twisting and turning with wings open and square tail spread so wide that it shows the white lines that border it, he is climbing up the air claw to claw with a rival, falling to ground clinched with . him, or dashing after a hawk, screaming in thin falsetto like a scissor-tail flycatcher. A passing enemy is allowed no time to loiter but driven from the field with impetuous onslaught and clang of trumpets. Be he crow, hawk, or owl, he is escorted to a safe distance, sometimes actually ridden by the angry kingbird, who, like the scissor-tail, enforces his screams with sharp pecks on the back.

When there is no one within scrapping distance he may be seen perching on a meadow fence or telegraph wire, for he is a bird of the open country. When perched he is on the lookout for insects, and dashes out for one to soar back on outspread wings and tail, shrieking triumphantly as he comes. His notes have the thin high pitch and something of the emphasis and iteration of the coyote.

\section{Tyrannus vociferans Swains. Cassin KingBird.}

Adults. - Upper parts and breast dark gray, chin abruptly white; belly - lemon yellow; tail dull black indistinctly tipped with grayish, outer web of outer feather indistinctly edged with grayish ; wing with tips of longest primaries abruptly cut out; crowu with concealed red patch. Young: duller, wing coverts edged with rusty, crown pateh wanting.

Fig. 326. Length: 8.75-9.00, wing 5.00-5.40, tail 3.704.20, bill from nostril .50-.60.

Distribution. - Breeds irregularly in Transition, but chiefly in Upper and Lower Sonoran zones from the eastern slopes of the Rocky Mountains to southern Wyoming, western Texas, New Mexico, and Arizona, and from Oregon sonth to Lower California and the mountains bordering the Mexican tablelands ; straying south to Costa Rica.

Nest. - Bulky, of similar materials to that of verticalis, placed generally 20 to 40 feet from the ground, near the end of a horizontal limb in sycamore, cottonwood, or other tree. Eggs : 2 to 5, similar to those of Tyrannus tyrannus.

Food. - Mainly insects, including grasshoppers, locusts, and caterpillars.

The Cassin kingbird, Major Bendire says, is neither as noisy nor as quarrelsome as the Arkansas. Though it nests in the valleys with 
the Arkansas, it also breeds at higher altitudes, and is, apparently, more a bird of the mountains.

\section{GENUS PITANGUS.}

\section{Pitangus derbianus (Kaup). Derby Flycatcher. ${ }^{1}$}

Bill as long as head, straight, narrow; wings rounded; tail shorter than wings, nearly even; tarsus about as long as middle toe and claw; under parts, except for white throat, and including under wing coverts, bright sulphur yellow; top and sides of head black. separated by white line which incloses black crown; crown erectile, with partly concealed rellow center; rest of npper parts brown, rufous on wings and tail. Length: $10-11$, wing $4.90-5.10$, tail 3.90-4.00, exposed culmen 1.15-1.25.

Distribution. - Breeds from Central America to the lower Rio Grande Valley in Texas; migrates to northern South America.

Nest. - Dome-shaped, with entrance on the side, composed of such coarse materials as straw and lichens; placed usually on forks of branches or thorny trees, 25 or 30 feet from the ground. Eggs : generally 5, light cream color with small reddish specks.

Food. - Mainly insects, but also small fish - minnows.

The derby flycatcher is rather a rare summer visitor in the lower Rio Grande Valley in Texas.

\section{GENUS MYIODYNASTES.}

451. Myiodynastes luteiventris Scl. Sulphur-Bellied FlyCATCHER.

Bill turgid, broader than high at nostrils; wings long and pointed; tail shorter than wings, nearly even; feet small and weak. 1dults : broad blackish $\Lambda$ from bill inclosing white throat patch; rest of under parts sulphur yellow, streaked along sides; upper parts brownish, streaked with black; head with concealed yellow crown patch and white or yellowish bands over eye and along sides of throat; rump and tail bright rufous ; bill very broad. Young: without erown patch. Length: 7.75-8.00, wing 4.25-4.60, tail :3.30-3.60, bill .80-.90.

Distribution. - From the mountains of southern New Mexico and Arizona south to Panama.

Nest. - 25 to 50 feet from the ground, a hole in a sycamore, lined thickly with stems of walmut leaves. Eggs: 3, creamy buff, profusely blotehed, principally around the larger end, with purple and reddish brown.

Mr. Lusk, who found the sulphur-bellied flycatcher in Arizona, states that they frequent streams bordered with large trees. "The width and size of their bills, together with their short necks," he says, "gives them a peculiar appearance even at a distance." MIr. $\mathrm{O}$. W. Howard found the birls very quiet during the breeding season, but bold and noisy afterwards. He compares their notes to the squeaking of a wheelbarrow.

1 [450.] Myiozetetes similis superciliosus (Bonap.). Giraud Flycatcher. This species is omitted from doubt of Giraud's Texas record. 


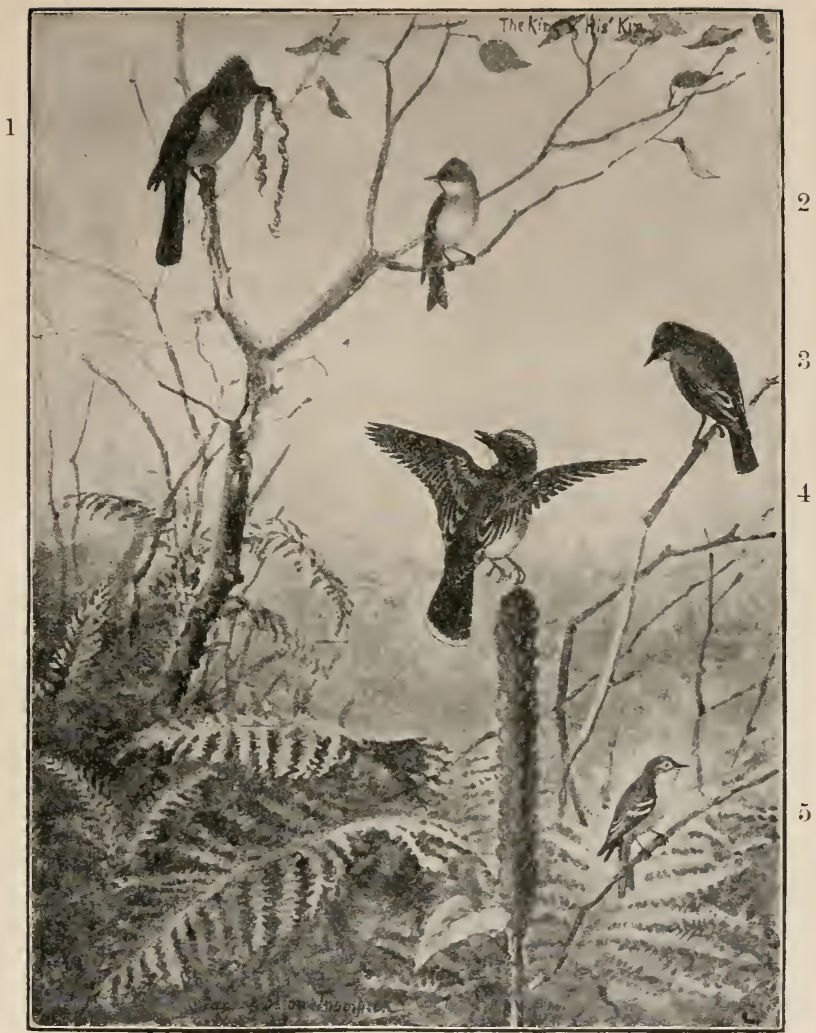

Fig. 327. Flycatchers.

1. Crested Flycatcher. 2. Wood Pewee. 3. Phobe. 4. Kingbird. 5. Least Flycatcher.

\section{GENUS MYIARCHUS.}

General Characters. - Head slightly crested by lengthened erectile feathers; primaries cut out; tarsus about length of middle toe with claw.

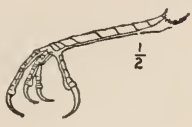

Fig. 328.

KEY TO ADIL'S.

1. Wing $2.90-3.25$; inner webs of tail feathers chiefly dark brown. Arizona. . . . . . . . . olivascens, p. 253.

1'. Wing $3.40-3.60$; inner webs of tail feathers chiefly rufous.

2. Outer tail feather with uniform dark stripe along inner web.

3. Smaller. Lower Rio Grande Valley, Texas . mexicanus, p. 252. 
3'. Larger. Southern Arizona . . . . . . magister, p. 252. $2^{\prime}$. Outer tail featler without uniform dark stripe along inner web.

3. Throat and chest dark ash gray. Eastern United States.

crinitus, p. $2 \% 2$.

3'. Throat and chest pale ash gray, throat sometimes whitish.

4. Outer tail feather witl outer web whitish and inner web dusky at tip. Colorado to Pacific . . . . cinerascens, p. 258.

4'. Outer tail feather without white edge or dusky tip. Southern Arizona . nuttingi, p. 25:3.

\section{Myiarchus crinitus (Limn.). Crested Flycatcher.}

Adults. - Throat and breast dark ash gray; rest of under parts bright sulphur yellow; upper parts olive; wings with two whitisl bars, primaries edged with rufous and tertials with yellowish; tail with middle feathers dusky brown, other feathers with imer webs chiefly reddish brown; onter feather with broad dusky stripe confined to end, if present at all. Young: tail with more of reddish brown than in adult. Length: $8.50-9.00$, wing 3.90-4.40, tail 3.50-4.20, bill from nostril .5.)-.65, tarsus .75-.82.

Distribution. - Eastern United States and southern Canada, west to Manitoba, the Plains, and southwestern Texas; migrates to Costa Rica, Panama, and Colombia.

Nest. - An old woodpecker lole or natural cavity in a tree or stump, lining varying in bulk and composition but generally containing snake skin. Eggs : 4 to s, creamy to deep buff, overlaid with irregular blotches and longitudinal pen lines in shades of brown and purple.

Food. - Insects, such as beetles, flies, grasshoppers, butterflies, and larvæ, varied with berries.

\section{Myiarchus mexicanus (Kaup). Mexicay Crested Fur- CATCHER.}

Adults : Throat and breast light ash gray, rest of under parts pale sulphur yellow ; upper parts olive, browner on head; wings with two white bars; primaries edged with reddish brown; tail with middle feathers dusky brown, outer tail feather with a wide dusky streak of uniform width along inner side of shaft. Young: with more rufons on tail than in adult. Length: $8.50-9.00$, wing $3.80-4.20$, tail $3.80-4.25$, bill from nostril .62-.75, tarsus . $82-.92$.

Distribution. - Lower Rio Grande Valley south to Guatemala and Salvador.

Nest. - In natural cavities or woodpecker holes in stumps, trees. and telegraph poles, made of.felted strips of bark, hair. feathers, wool, and sometimes snake skin. Eggs : 4 to 6 , like those of $M$. crinitus.

\section{3a. M. m. magister Ridgw. Arizona Crested Flycatcher.}

Like $M$. mexicanns, but larger. Length: 9.40-10.00, wing 4.04-4.60, tail $4.10-4.60$, bill from nostril .(\$§-.82, tarsus .97-1.02.

Distribution. - Breeds from sonthern $\Lambda$ rizona (and southwestern New Mexico?) to western Mexico; migrates to Tehuantepec, Mexico.

Nest. - So far as known, in holes in giant cactus and sycamores, about $s$ feet from the ground, lined with hair and bits of snake and lizard skin. Eggs : 3 to 5 , like those of $M$. crinitus.

Major Bendire writes: "The Arizona crested flycatcher is the largest representative of the genus Myiarchus found within our borders, and its breeding range seems to be confined mainly to 



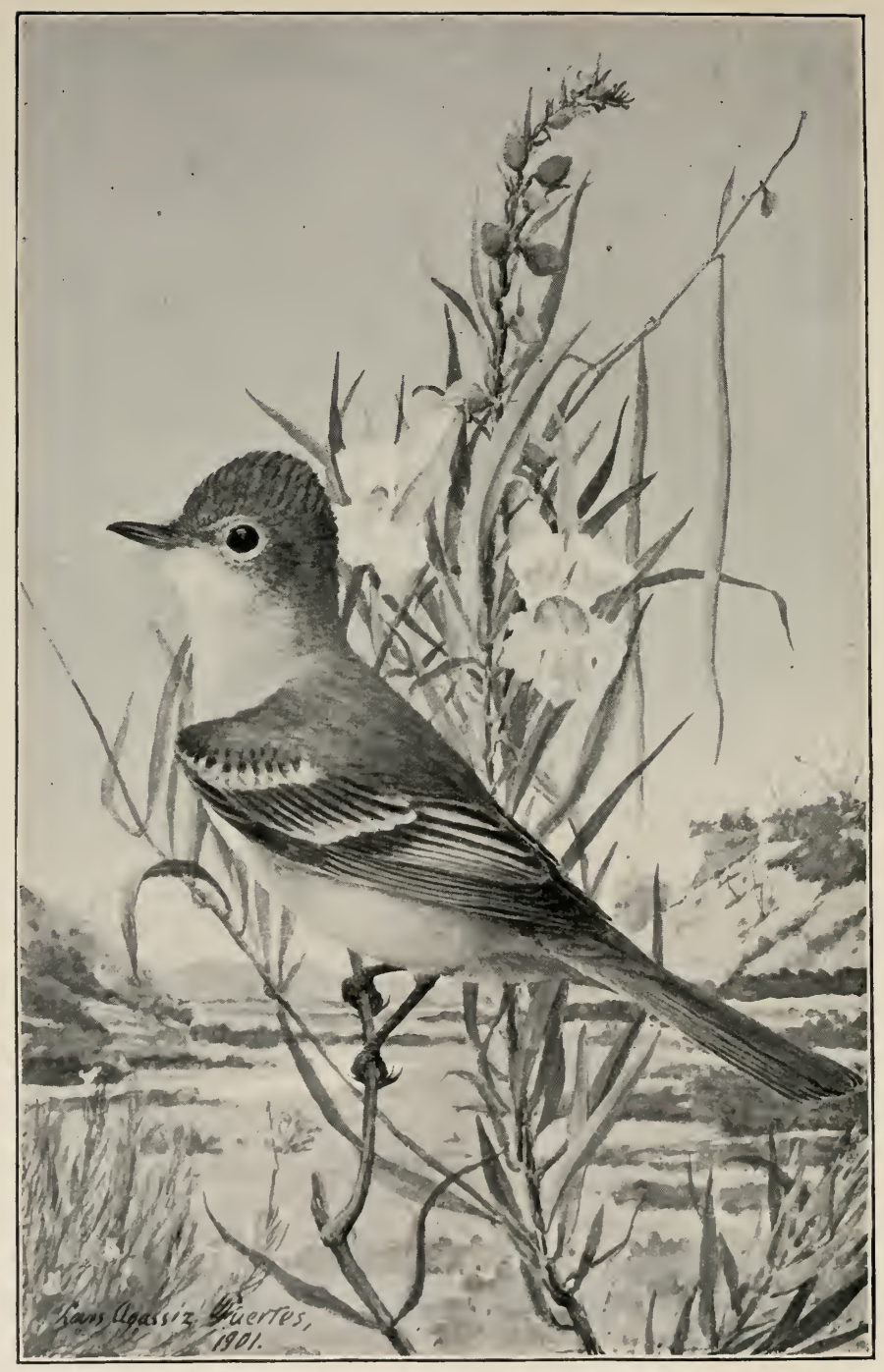

ASH-THROATED FLYCATCHER 
the giant cactus belt of southern Arizona, where it appears to be a rather irregular summer resident, not uncommon in some seasons and rare in others."

Mr. Stephens found it frequenting low mesquites, and reports that it was 'tame and rather noisy, having a variety of loud calls, some almost thrasher-like.'

\section{Myiarchus cinerascens (Lawr.). Ash-throated Fly- CATCHER.}

Adults. - Throat and chest pale ashy, sometimes almost white on throat; belly pale sulphur yellow; upper parts grayish brown; wings with two white bars, quills edged with reddish brown, tertials edged with white; tail with middle feathers dusky brown, the rest chiefly brown on inner webs; outer tail feather with inner web dusky at tip, outer web distinctly whitish. Young: tail feathers rufous, with dark median stripe. Length : $8.00-8.50$, wing $3.80-4.25$, tail $3.6 .5-4.20$, bill from nostril $.52-.60$, tarsus . $85-.95$.

Distribution. - Breeds in Upper and Lower Sonoran zones in the western United States from northern Oregon to Mexico, and east to Colorado and southwestern Texas; migrates to Guatemala.

Vest. - Usually less than 20 feet from the ground in knot-holes of mesquite, giant cactns. and trees, in cavities of stumps, woodpecker holes, and occasionally behind pieces of bark; lined with rootlets, grass, dry horse manure, hair, fur, and oceasionally snake skins. Eggs: 3 to 6 , creamy to pinkish buff, covered with longitudinal streaks and hair lines of purple.

Food. - Mainly ants, grasshoppers, caterpillars, beetles, butterflies, flies, moths, and occasionally berries, especially mistletoe.

The noisy bickering bee-bird is quite put to shame by the dignified demeanor of the ash-throated flycatcher, who with raised crest and erect carriage goes about his business in a quiet, self-contained manner.

He is a common resident of the desert regions of southern California, Nevada, Utah, and northern Arizona, and where the desert mountains do not afford water he sometimes breeds as much as five miles away from it, needing less water, perhaps, because his insect food aflords a good deal of hiquid.

\section{4a. M. c. nuttingi (Ridgu.). Nutting Flycatcher.}

Similar to M. cinerascens, but onter tail feather without either distinctly white outer web or dusky tip to inner web; tail never decidedly shorter than wing; upper tail coverts not distinetly rusty. Wing: 3.40-3.70, tail 3.35-3.3.80. bill from nostril . $4(1-.56$, tarsns . $80-.85$.

Distribution. - From sonthern Arizona sonth to Costa Rica.

Test. - As described by Dr. Fisher, $t$ feet from the ground in an old woodpecker hole in a giant cactus, containing 4 eggs, creamy, covered with longitudinal pnrple streaks and hair lines.

455a. Myiarchus lawrencei olivascens Ridgu. Olvaceous Flycatcher.

Addults. - Head and back olive lrown; wing and tail feathers usually 
without distinct rusty edgings and inner webs of tail feathers usually without rusty edgings. Length: $7.00-7.30$, wing $2.90-3.25$, tail $3.00-3.25$, bill from nostril .45-.55, tarsus $.70-.75$.

Remarks. - The olive coloration is enough to distinguish this flycatcher.

Distribution. - Breeds in Lower Sonoran zone of Arizona and western Mexico ; casual to Fort Lyon, Colorado.

Nest. - Usually in holes in trees, 15 to 40 feet from the ground, made, in two recorded cases, of fur and feathers. Eggs: 3 to 6, curiously marked with fine lines and intricate pencillings of black and various shades of purplish brown over buffy or creamy ground.

The olivaceous flycatcher, which is the smallest of the United States species of Myiarchus, lives in brushy canyons in the mountains of southern Arizona, frequenting the banks of streams, where it perches on dead limbs looking for insects. The only note heard by Mr. Stephens, who discovered it, was a ' mournful peeur.'

\section{GENUS SAYORNIS,}

General Characters. - Wing more than 3.25, but not more than five times as long as tarsus; tarsus longer than middle toe with claw; tail emarginate.

KEY TO SPECIES.

1. Tail olive gray. Colorado to Atlantic

phœbe, p. 254 .

1'. Tail black.

2. Under parts partly brown

2'. Under parts partly black.

3. Under tail coverts streaked with black. . . nigricans, p. 255.

$3^{\prime}$. Under tail coverts pure white . . . . . semiatra, p. 256.

456. Sayornis phœbe (Lath.). Рнюеве.

Upper parts olive gray, darker on head; under parts whitish, tinged

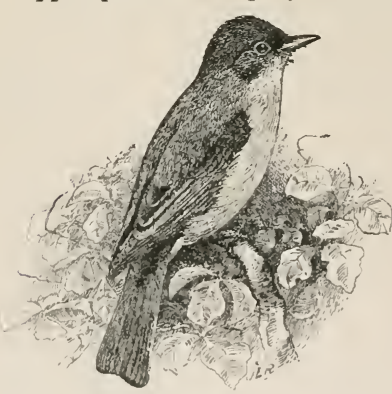

From Biological Survey, U. S. Dept. of Agriculture.

Fig. 329 . below with pale yellowish, sides of breast with olive gray. Length: 6.257.00, wing $3.25-3.55$, tail $3.00-3.40$.

Distribution. - Breeds chiefly in Transition and Upper Sonoran zones in eastern North America, west to Colorado; south to the Gulf of Mexico: winters from the southern Atlantic and Gulf states to Mexico and Cuba; recorded from Los Angeles Co., California, in winter.

Nest. - A bulky felted mass, made largely of mosses and lined with feathers; attached to rocks, bridges, and beams of buildings. Eggs: 3 to 8 , white, sometimes finely but sparsely speckled around larger end with brownish.

Food. - Cliefly injurious insects.

The habits of the phobe are very similar to those of the black 
phobe, but the names 'house' and 'barn' pewee apply better to it, and more popular affection attaches to this confiding bird than to its handsome western relatice. It builds under bridges and culverts most frequently, but barns and sheds, piazza crotches, and window sills all offer it congenial homes.

Its nest, found year after year in the same place or only a rafter away, though big and loosely put together, seems a marrel of beauty with its touches of green moss. The bird herself with her plain roice, jerky motions, and abrupt manners but homely virtues comes to hold a place in our affections that no bickering, domineering rociferans could ever hope to win.

\section{Sayornis saya (Bonap.). SAy Phobe.}

Adults. - Anterior lower parts grayish, posterior tawny brownish ; upper parts dark gray, wing quills and tail black. Young: like adults, but wing coverts tipped with brown. Length: 7.50-8.05, wing 3.90-4.25, tail 3.853.7.).

Distribution. - Breeds from the Aretic Circle in Alaska south to Lower California, and from westem Nebraska and Kansas west to the Pacific ; migrates to Oaxaca. Mexico.

Nest. - Under bridges. about barns and houses, in eaves, or wells. and under shelves of cliffs; made of materials such as weed stems, grasses, moss, wool, hair. cocoons, and feathers. Eggs: 3 to 6, white, sometimes finely dotted with reddish brown about the larger end.

Food. - Grasshoppers, crickets, weevils, beetles, flies, moths, butterflies, and other insects.

The Say flycatcher of the brown belly and black tail is the commonest of the western flycatchers, nesting not only about every cattle ranch, stage station, and mining camp, but at the Arctic Circle and on the deserts of the southwestern United States, where it builds in caves with wood rats and on cliffs with the prairic falcon.

In rocky canyons it may be seen perched on boulders darting out after passing insects. On the Plains, where it flits silently from bush to bush, at a distance its black tail and dull colors would often lead you to mistake it for the omnipresent Amphispiza but for its plaintive phee-eur. Besides this note, during the nesting season it is said to have a plaintive twittering warble.

Saya is a true flycatcher, and Major Bendire has seen it catch goodsized grasshoppers on the wing. He calls attention to its power, which many of the flycatchers share with the hawks and owls, of ejecting indigestible parts of its food in the form of pellets.

\section{Sayornis nigricans (Swains.). Black Рнжве.}

Adults. - Black, except for white belly, outer web of outer tail feathers, edges of inner secondaries. and under tail coverts which are white striped with dusky. Young: head and neck sooty black; wing bands and bend of wing rusty; back, rump, and edges of black on breast washed with brownish. Length : $6.25-7.00$, wing $3.55-3.50$, tail $3.45-3.75$. 
Distribution. - Breeds in Lower Sonoran zone from Texas to eastern Arizona and south through Mexico, except Yucatan and the Pacific coast north of Colima.

Nest. - A wall pocket made of small pellets of mud mixed with dried grass, weed fibers, and hair, placed in wells and on sides of buildings and cliffs. Eggs: :3 to 6, white, or finely dotted with reddish brown around the larger end.

Food. - Insects and wild berries.

The sharply contrasted black and white plumiage of the black plicbe of whichever form make him the handsomest of the common flycatchers. He is not averse to civilization and may be met commonly just off the highways usually near water. I have found him in a San Francisco cemetery, in Sutro Heights Park, in Pasadena, bathing in a reservoir beside the street, and in Santa Cruz perched on the tip of a century plant leaf in front of a hotel. He has all the flycatcher mannerisms, and as he sits watching for insects jets his tail and quivers his wings at his sides, darts out with a liquid hip', a rising kee-ree', and falling kee-toray', snaps up an insect, and settles back again on his perch.

At Twin Oaks, California, I found the phoebes nesting in a deserted well and also inside a whitewashed chicken house, and was told of their having built under the eaves of a kitchen, the pair getting their meals about the fly screens before the window. Such centers of civilization are not always chosen by them, however, and I have found them in the foothills of the sierra and in a narrow lonely canyon of the mountains of southern California, where their wallpoeket nest was fastened against a cliff behind a hanging vine.

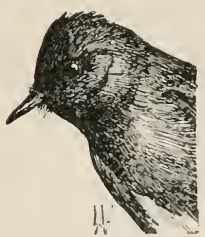

Fig. 3:31).

458a. S. n. semiatra (Tigors). Western Black Phome.

Similar to S. niyricans but under tail coverts pure white.

Distribution. - Mainly in Lower Sonoran zone on the Pacific coast, from Oregon to Colima, Mexico ; also most of Arizona.

Food. - I argely winged insects.

\section{GENUS CONTOPUS.}

Generul Characters. - Feet extremely small; wing at least six times as long as tarsus; tarsus not longer than bill, but longer than midille toe with claw, or with a conspicuous white cottony patch on each side of rump.

Fig. 331 .

1. Length $7.10-8 .(00$.

KFY TO SPECLES.

2. With conspicnous white cottony tufts on sirles of rump; muler parts withont yellow borealis, p.

2 '. Withont cottony rump tufts; belly yellowislı. Arizona. pallidiventris, p. $25 \%$ 
$1^{\prime}$. Length $5.90-6.75$.

2. Wings and tail shorter. Western Nebraska to Atlantic.

virens, p. 258 .

$2^{\prime}$. Wings and tail longer. Plains to Pacific . . richardsonii, p. 258.

\section{Subgenus Nuttallornis.}

459. Contopus borealis (Suains.). Olive-sided Flycatcher.

Adults. - Under parts with whitish median tract between dark, somewhat streaked lateral parts, white sometimes faintly tinged with yellow; upper parts sooty, conspicuous tuft of white cottony feathers on sides of rump (usually concealed by wings). Young: similar, but wing coverts tipped with buffy, or brown-

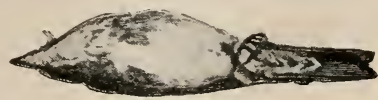

Fig. 332. ish instead of white. Length : $7.10-7.90$; wing $3.90-4.50$, tail 2.80-3.50, exposed eulmen .58-.70, tarsus .55-.60.

Remarks. - This is the only Contopus that has white cottony tufts on the sides of the rump, or first quill longer than fourth.

Distribution. - Breeds in Canadian zone forests of North America from Hudson Bay south through the higher parts of the United States; migrates to Peru, Central America, Columbia, and northern Peru.

Nest. - Small, of wiry materials fastened skillfully to brauches of coniferous trees, 40 to 60 feet from the ground. Eggs : usually 3, creamy, generally wreatlied with spots of brown and lavender.

Food. - Winged insects, such as beetles, butterflies, moths, gadflies, and grasshoppers.

In the high Sierra as in the Canadian forests throughout the United States the pu-pip' of the olive-sided calls your attention to a solitary bird with a dark gray breast and white median line, perched on the tip of an evergreen spire. Its body is quiet, but its head is turning from side to side, and suddenly it launches into the air, catches an insect, turns, and with wings and tail spread sails back to its perch.

It calls a great deal in the twilight, and in the fir belt of Mt. Shasta, where its voice is one of the commonest forest sounds, as the evening shadows gathered over the noble trees under which we were camped, the mellow $p u-p i p^{\prime}, p u-p u-p i o^{\prime}, p u-p i p^{\prime}, p u-p u-p i o^{\prime}$, came down to us in soothing cadence till the camp-fire shone in the dark. ness.

\section{Subgenus Contopus.}

460. Contopus pertinax pallidiventris Chapm. Coues FlyCATCHER.

Adults. - Upper parts grayish brown, tinged with olive; under parts nearly uniform olive gray, chin slightly whitish, belly and under tail coverts dull yellowish; first quill much shorter than fourth. Young: similar, but wing coverts tipped with buffy or brownish. Length : 7.70-8.00, wing $3.80-4.45$, tail $3.60-3.90$.

Remarks. - The Coues flycatcher is

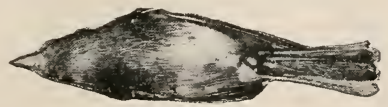

Fig. 333. about the size of the olive-sided, but its under parts arc strikingly uniform 
compared with those of borealis, in which the dark sides are sharply contrasted with the white median line; it also lacks the conspicuous cottony rump tufts of borealis.

Distribution. - From mountains of central and southern Arizona, south through northwestern Mexico.

Nest. - As far as known, of grass tops, moss, lichens, catkins. leaves, spider's web, fragments of insects and their exuviæ, placed on an oak or pine branch 15 to 20 feet from the ground. Eggs : On one record, 3, cream buff, spotted in a ring around the larger end with brown and lilac gray.

Food. - Flies, beetles, and other insects.

In the mountains of southern Arizona Mr. Henshaw found the Coues flycatcher in the pines or in rocky gulches of mixed pine and oak, launching out from the branches, circling around the high pine stubs, and making the sudden erratic flights from point to point which are especially characteristic of the species.

Its notes, though similar to those of the olive-sided flycatcher, Mr. Henshaw says, can easily be distinguished from them, the last syllable being prolonged and raised.

\section{Contopus virens (Linn.). Wood Pewee.}

Adults. - Upper parts grayish brown, tinged with olıve; two wing bar's dull whitish; under parts uhitish, more or less washed with olive gray and tinged with pale yellowish; wing at least six times as long as torsus, tarsus longer than middle toe with claw; exposed culmen much less than twice the width of bill at nostrils. Young: with buffy or brownish wing: bars. Length 5.90-6.50, wing 3.00-3.45, tail \%.50-2.90, exposed culmen $.43-.52$, wilth of bill at base .24-.30, tarsus .48-.53.

Distribution. - Breeds from sonthern provinces of Canada to Florida, and from the Atlantic west to the Dakotas, Nebraska, and Kansas; migrates through eastern Mexico to South America.

Nest. - Usually in deciduous trees 5 to 50 feet from the ground, made largely of plant fibers, rootlets, and moss, coated with lichen. Eggs: 2 to 4 , white, irregularly wreathed aronnd larger end with browns and purples.

Food. - Insects, including grasshoppers, locusts, and caterpillars.

The wood pewee is sometimes met with west of the hundredth meridian in Texas, and though it is ahmost indistinguishable from its western congener in coloration and habit, its notes identify it the instant they reach the car. The call of the western is a commonplace pueer, but that of the wood pewee is a plaintive musical pee-ah-rce.

462. Contopus richardsonii (Suains.). Westekn Woon Pewee.

Adults. - Upper parts dark gravish brown; under parts heavily washed with dark gray; belly and mider tail coverts whitish or pale yellowish; wing at least six times as long as tarsus; tarsns longer than niddle toe with claw; exposed culmen mmeh

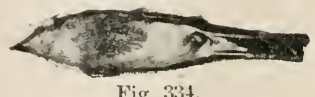

Fig. 334 .

1 Contopus richarlsomii saturatus Bishop. Alaskan Wood Pewee.

Like richarisonii but darker, with smaller bill.

Distribution. - Yukon Valley, southerm Alaska and British Colmmbia, near the coast in summer, migrating south through California. (The Auk, xvii. 116.) 
less than twice the width of bill at nostril. Young: with buffy or brownish wing bars. Length: 6.20-6.75, wing 3.15-3.55, tail $2.50-2.95$, exposed culmen $.4-.51$, width of bill at base $.27-.52$, , tarsus $.49-.56$.

Remarks. - In richardsonii the wings and tail are slightly longer than in C. virens.

Distribution. - Breeds in Transition zone from the Plains to the Pacific, and from the interior of British America to Lower California; migrates to South America.

Nest. - Saddled on horizontal limb of orchard or forest tree, 6 to 40 feet from the ground; made of wood, plant fibers, down, imer bark, sage, and grass tops, rarely lined with a few feathers, and sometimes covered with spider's web. Eggs : 2 to 4, white, irregularly wreathed around the larger end with blotches and minute specks of brown and purple.

Food. - Flies and other insects, with a few wild berries.

In the lower Canadian zone forests the western wood pewee is frequently met with, and in the Murray pine meadows of the Sierra is one of the commonest birds seen. It sits with its long thin body erect, and as it watches for insects gives its quiet call, well rendered by Dr. Mierrill as treer or deer. In Arizona its setting is altogether different, mesquite and yucca stalks being its principal perches.

\section{GENUS EMPIDONAX.}

General Characters. - Wing less than 3.25, not more than five times as long as tarsus.

KEY TO ADULT MALES.

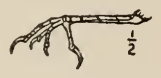

Fig. 335.

1. Under parts buffy. Arizona and New Mexico . . pygmæeus, p. 263.

1'. Under parts whitish or sulphur yellow.

2. Width of bill at nostrils decidedly greater than half the exposed culmen.

3. Under parts wholly yellowish or brownish.

4. Under parts darker, washed witl brown . . difficilis, p. 260 .

$4^{\prime}$. Under parts lighter, with little or no brown wash. Santa Barbara Islands . . . . . . . . . insulicola, p. 260.

3 '. Under parts partly white.

4. Wing 2.30-2.60; tail distinctly emarginate. Rocky Mountains to Atlantic . . . . . . . . . . . minimus, p. 261.

4'. Wing $2.60-3.00$; tail even or slightly rounded.

5. Colors weaker; bill longer and narrower . . traillii, p. 260.

5 . Colors stronger; bill shorter and broader. Eastern.

alnorum, p. 261.

2 '. Width of bill at nostrils not greater than half the exposed culmen.

3. Bill narrower . . . . . . hammondi, p. 262.

3'. Bill broader.

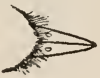

Fig. 337.

4. Under mandible blackish

wrightii, p. 262.

$4^{\prime}$. Under mandible flesh-colored, tipped with black. Moun-

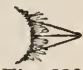

Fig. 338. tains of southern Arizona . 


\section{Empidonax difficilis Baird. Western Flycatcher.}

Adults. - Upper parts olivaceous (brownish in winter), wing bars dull

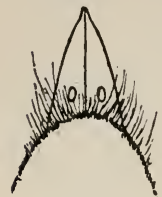

Fig. 339 . buffy (brighter in winter); under parts dull yellow, shaded with brown across breast, brightening to sulphur yellow on belly and inder tail coverts; under wing coverts buffy, deepening to ochraceous on edge of wing; width of bill at nostrils decidedly greater than half the length of exposed culmen. Young: similar, but browner above, with wing bands yellowish brown or rusty buff, sulphur yellow of belly replaced by dull white. Length: 5.50-6.00. Male: wing $2.50-2.90$, tail $2.35-2.60$, bill $.57-63$, bill from nostril .29.33 , width at base $.25-.28$, tarsus .6t-.69. Female: wing $2.30-2.60$, tail $2.20-2.45$.

Remarks. - The distinct yellow tone of the under parts distinguishes difficilis from all western flycatchers.

Distribution. - Breeds in Transition and Canadian zones from the eastern foothills of the Rocky Mountains and adjacent ranges to the Pacific, and from southern Alaska south to northern Lower California; migrates to Costa Rica.

Nest. - Usually not far from water, in alders, trees, stumps, roots, under stream banks, on rock ledges, in natural cavities, or about buildings; made of plant stems and fibers, down, inner bark, rootlets, leaves, and moss, lined with horsehair and feathers, often coated with green moss. Eggs : 3 or 4, white, blotched and spotted with brown and buff pink.

Food. - Largely injurious insects.

The western flycatcher is a widely distributed bird, as Mr. Allen says, shade apparently being its principal requirement, for it ranges from the lowlands almost to timberline. It is said to have a song and a sweet call, beside a sharp chirp uttered when augry or frightened.

\subsection{Empidonax insulicola Oberh. Santa Barbara Fly-} CATCHER.

Adult male. - Upper parts olive brown, slightly darker on head and paler and more greenish on rump; wings with two conspicuous brownish white bars; throat grayish, faintly washed with yellow: rest of under parts straw yellow, slightly tinged on breast and sides with olive brown. "Wing: $2.6 \mathrm{~S}$, tail 2.40 , exposed culmen .47 , tarsus .88 .

Remarks. - E. insulicola differs from $E$. difficilis in its darker upper parts and paler under parts, the breast having little of the brown wash of difficilis.

Distribution. - Santa Barbara Islands, California.

Nest. - In the side of a cliff, a cave, or pocket in a boulder, made of strips of bark and vegetable fibers. Eggs : ' 2 or 3 , white or creamy, dotted with reddish about the larger end.

\section{Empidonax traillii (Aud.). Traill Flycatcher.}

Width of bill at nostrils decidedly greater than half the length of exposed eulmen. Adults: eye ring whitish; upper parts olive, darker on head from dusky centers of coronal feathers; wing bars varying from brownish to whitish ; under parts white, shaded with gray across breast, tinged with yellow beneath; under wing eoverts yellowish white. Young: browner above, yellower beneath; wing bands buff or yellowish brown. Miale: length 
5.80-6.25, wing 2.70-2.S5, tail 2.35-2.60, bill .64-.73, bill from nostril .35.40 , width at base .27-.31, tarsus .65-.72. Female: leugth $5.55-6.00$, wing $2.50-2.65$, tail $2.20-2.50$.

Remarks. - The wide bill, whitish under parts, and olive or olive brown - not greenish - upper parts are characteristic.

Distribution. - Western North America from the Mississippi valley to the Pacific, and from the Mackenzie River valley south to Mexico.

Nest. - In low shrubs or bushes near water, 1 to 6 feet from the ground, made of dry grasses, pine needles, shreds of bark, and plant fibers, lined with fibers, bark, grass tops, fern down, and horsehair. Eggs: 2 to 4, white or pinkish buff, marked with dots or blotches of brown, mostly about the larger end.

Food. - Largely caterpillars, moths, ants, grasshoppers, and other harmful insects.

The Traill flycatcher is said by Major Bendire to be especially fond of 'willow-covered islands, and the shrubbery along watercourses, beaver meadows, and the borders of the more open mountain parks,' where it sometimes reaches an altitude of 8000 feet, especially in Colorado, Utah, and California. Its note, given in the breeding season, is described by Professor Cooke as a shrill hurried 'pree-pe-deer,' characteristic of the energetic, aggressive disposition of the bird. In hunting, Mr. Ridgway says, it never stays long in one place, but moves from perch to perch, snapping up insects as it flies.

\section{6a. E. t. alnorum Brewst. Alder Flycatcher.}

Similar to Traill flycatcher, but averaging more olivaceous above and more yellow below, the bill shorter and broader and tarsus shorter. Male: wing 2.60-3.00, tail 2.40-2.60, bill .60-.64, bill from nostril .32-.37, width at base .29-.30, tarsus .64-.67. Female: wing 2.50-2.65, tail 2.25-2.35.

Distribution. - Breeds in Canadian zone in eastern North America from New England west to western Nebraska; migrates to Central America.

Nest and eggs. - Like those of the Traill flycatcher.

\section{Empidonax minimus Baird. Least Flycatcher.}

Width of bill at nostril decidedly greater than half the length of exposed culmen; tail slightly emarginate. Adults : upper parts dark olive; wing bars uhitish; throat whitish; chest washed with gray; belly faintly tinged with pale yellowish. Young: like adults but more olive, and wing bars brown. Male: length 4.90-5.50, wing 2.30-2.60, tail 2.10-2.40, bill $.53-.59$, bill from nostril $.27-.31$, width at base $.23-.27$, tarsus $.59-.68$. Female: wing 2.20-2.40, tail 2.10-2.25.

Distribution. - Breeds in Transition and Boreal zones in eastern North America from about latitude $63^{\circ}$ sonth to the northern United States; and from the Atlantic west to eastern Colorado and Montana (casually to Utah); migrates to Central America and Pananı:

Nest. - Compactly made of shreds of bark, plant fibers, dry grasses, weeds, cocoons, and down, placed usually in bushes or trees in an upright fork from 8 to 25 feet from the ground. Eggs: 3 to 6 , white, unspotted. Food. - Insects.

The che-beck' of the friendly little flycatcher, heard from choke- 
cherry thickets in canyons or more commonly from orchards and villages, is pleasantly associated with a fluffy, white-breasted little figure flitting about among leafy branches, snapping its bill and shaking its wings and tail in its flycatching. Like most of its relatives it makes up for lack of song by a variety of pleasing little conversational notes and twitterings.

468. Empidonax hammondi (Tantus). Hammond Flycatcher. Adults. - Upper parts grayish olive, grayer anteriorly ; wing bars whit-

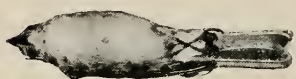

Fig. 340 . ish or yellowish; outer tail feather more or less edged with whitish; throat grayish; breust olivaceous, almost as dark as back; belly and under tail coverts yellowish; width of bill at nostrils less than half the exposed culmen. Young: tinged with brown, wing bars vellowish brown. Male: length 5.50-5.75, wing $2.60-2.80$, tail $2.30-2.50$, bill .5:3-.59, bill from nostril .26-.29, width at base, $.22-.24$, tarsus .60-.68. Female: length 5.25 , wing $2.45-2.75$, tail $2.15-2.40$.

Remarks. - Hammondi has the smallest and narrowest bill of any of the genus Empidonax except fulvifrons and $f$. pygmea, and it differs from them by having a dark chest band.

Distribution. - Breeds in Transition and Canadian zones of western North America east to the eastern slopes of the

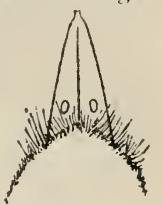

Fig. 341.

Rocky Mountains and adjoining ranges, and from Lesser Slave Lake and interior of Alaska south probably to mountains of Arizona and New Mexico ; migrates to Lower California and southern Mexico.

Nest. - In willows, cottonwoods, or aspens, or on horizontal limbs of pine or fir, 2 to 50 feet from the ground; made of plant stems and fibers, bark, and down, sometimes lined with grass-tops, hair, feathers, scales of conifer buds, and hypnum moss. Eggs: usually 8 or 4, creamy white, generally unspotted, or if spotted, minutely so, with brown around the larger end.

Food. -- Insects, especially ants.

In northern Idaho Dr. Nerrill found hammondi more abundant than in Montana or Oregon, and as common among young cottonwoods and willows along rivers and near swamps as in dry woods among pines, its notes being heard almost everywhere. Mrr. Dawson gives its notes as a 'brisk sewick, serrick: and at rarer intervals suritch-on, or sirecehoo.'

\section{Empidonax wrightii Baird. Wright Flycatcher.}

Similar to hammondi, but bill wider, plumage grayer above, whiter below, throat of ten whitish ; outer web of outer tail feather abruptly

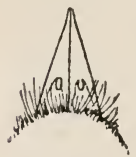

Fig. 342 . paler than inner web, usually whitish. Length: 5.75-6.40. Male: wing $2.70-2.95$, tail $2.55-2.80$, bill . $62-69$, bill from nostril . 32-.38, width at base $.24-.27$, tarsus .71-.77. Female: wing $2.5 .5-2.75$, tail $2.50-2 .(6.5$.

Remarks. - The white onter tail feather and light breast distinguish wrightii from hammondi, for thongh hammondi often lias a white edge to its tail feather its chest band is dark gray. 
Distribution. - Breeds in Transition and Canadian zones in British Columbia and the western United States from Oregon and Montana to the eastern slopes of the Rocky Monntains and south to New Mexico and Arizona; migrates to Lower California and southern Mexico.

Nest. - Fastened to twigs or against the trunk of saplings, or in upright forks of bushes from 2 to 1 s feet from the ground, made of plant fibers and strips of bark, partially lined with feathers, hair, and sometimes tree moss. Eggs: 3 to i, dull white, unspotted.

Food. - Insects, spiders, and caterpillars.

In the Great Basin country wriglıtii is as much at home in the sagebrush as most other species of Empidona.x are in shady woods or around grassy meadows. His trim little form is often noticed on top of a sagebrush by the roadside, sometimes far from water, but more often within reach of pond or stream. A favorite place for the nest is in the fork of a sage.

When found in the mountains vrightii is usually in the open or half forested parks, brushy slopes, old burnings, or edges of aspen groves.

VERYON BAILEY.

\subsection{Empidonax griseus Breust. Gray Flycatcher.}

Nearest to urightii, but larger and much grayer, washed with darker on chest; bill longer, basal half of lower mandible flesh colored in strong contrast to blackish tip.

Distribution. - From the southern part of California and Arizona throngh Lower California and Sonora. Mexico, to the sonthern end of the tablelauds.

Nest and eggs. - Unknown.

In Mr. Grinnell's list of the birds of Los Angeles County he gives some interesting records for the little known gray flycatcher. He thinks it can be found in some parts of the county throughout the 5ear. A few specimens have been taken in fall, winter, and spring near Pasadena and El Monte, and in July Mr. Grinnell found it at an altitude of from 7500 to 8500 feet on the side of IIt. Waterman. There, he says, it was 'not uncommon though very shy, keeping in the tallest pines on the mountain sides.' He secured full fledged Joung as early as July 11 .

\section{0a. Empidonax fulvifrons pygmæus (Coues). BuFr- BREASTED Flycatcher.}

Adults. - Upper parts dull grayish brown; wing bars grayish; under parts pale buffy, washed with ocliraceous on breast and sides. Young: wing bands buff; lower parts paler and duller. Length: 4.75-5.10, wing $2.20-2.45$, tail $1.95-2.14$, bill .50-.5.5, bill from nostril . $25-.27$, width at base $.20-.22$, tarsus .51-.60.

Distribution. - Breeds from southwestern New Mexico and Arizona south to western Mexico.

Nest. - In forks or on branches :30 to 50 feet from the ground, about the size and shape of a blue-gray gnateatcher's; made of bits of soft leaves, 
fine straws, and rootlets, lined with fine fibers. Eggs: 3 or 4, oval, buff or dull white.

Mr. R. D. Lusk, who discovered the nest of the buff-breasted in the Chiricahua Mountains, found the bird well named, the bright Arizona sunlight bringing out the buff of its breast. He says that the soft pit, pit', of a pair he was watching was varied by a great number of other notes, among them the chicky-whew of the male.

\section{GENUS PYROCEPHALUS.}

\section{Pyrocephalus rubineus mexicanus (Scl.). Vermilon Flycatcher.}

Head of male with full rounded crest; bill slender, narrow at base much as in Sayornis; tail nearly even, of broad feathers ; tarsus scarcely longer than middle toe with claw. Adult male: erectile crown and under parts brilliant scarlet; upper parts grayish brown, darker on wings and tail. Adult female: upper parts brownish gray; under parts whitish, breast streaked with gray; belly tinged with yellow, salmon, or red. Immature male: like adult female, but with red appearing in crown and on breast. Young: upper parts brownish gray, feathers edged with whitish; under parts whitish, streaked across breast, without reddish tinge on belly. A rare melanistic phase of plumage is uniform dark brown tinged in male with wine purple on crown and lower parts. Length : 5.50-6.25, wing 3.203.40 , tail $2.60-2.80$.

Distribution. - Breeds in Lower Sonoran and Tropical zones from southwestern Utah through southern New Mexico, Arizona, southwestern Texas, southern California, and Lower California to Central America; accidental in Florida.

Nest. - Frail and flimsy, made of short twigs, cocoons, down, plant tops and fiber, lined with feathers, wool, hair, fur, or down, saddled on a horizontal fork 6 to 50 feet from the ground in mesquite, palo verde, cottonwood, oak, and rarely willow. Eggs: 2 or :3, cream or buff, marked most heavily about the larger end with bold irregular blotehes and spots of brown and purple.

Food. - Insects, including grasshoppers and small beetles.

Of all the rare Mexican birds seen in southern Arizona and Texas the vermilion flycatcher is the gem, his brilliant scarlet body glowing red even in the dim twilight.

In an 'oak mott' of southern Texas, where we found jackdaws and scissor-tail flycatchers, the little Pyrocephalus was at home the last of $A$ pril, so he doubtless nested there too. One of his favorite perches was a dead oak twig close to the ground, and in making his sallies for insects he swept out over the flower-covered field we were trying to photograph, his image in the camera more beautiful than the flowers themselves.

When flycatching he often hovered over the grass in the regulation flycatcher way, but besides he had a unique nuptial performance of his own. When high in the air he would puff out the red feathers of his breast and hold himself up, twittering volubly as long as 
he could hover, then with a tine ecstasy come floating back to the field like a ball of down.

His usual twitter was like that of the wood pewee, a conversational aside. His call-notes were persistent and quite loud. For so small a flycatcher he took a surprisingly distinct part in the noisy jackdaw and scissor-tail chorus.

\section{GENUS ORNITHION.}

General Characters. - Bill curved, compressed, almost without bristles ; tarsus longer than middle toe and claw.

KEY TO SPECIES.

1. Smaller and browner . . . . . . . . . imberbe, p. 265. $1^{\prime}$. Larger and grayer . . . . . . . . . .ridgwayi, p. 265.

472. Ornithion imberbe (Scl.). Beardless Flycatcher.

Adults. - Upper parts plain brownish gray; wings with light edgings; under parts grayish white, tinged with yellow. Young: under parts buffy. Length: 4.50 , wing 2.10-2.15, tail 1.70-1.95, bill .39-.40.

Distribution. - From lower Rio Grande Valley in Texas to Central America.

\section{2a. O. i. ridgwayi Brewst. Ridgway Flycatcher.}

Like imberbe, bnt larger, grayer, and with under parts almost or wholly without yellow. Length: $4.30-4.80$, wing $2.04-2.28$, tail $1.78-2.02$, bill $.40-.42$.

Distribution. - From southern Arizona south through western Mexico to Mazatlan.

"Mr. Stephens found the curious little bird at Tucson. . . . The males had a habit of perching on the tops of the tallest trees in the vicinity of their haunts, and at sunrise occasionally uttered a singular song which Mr. Stephens transcribes as 'yoop-yoop-yoop eédeedledeè,' the first half given very deliberately, the remainder rapidly." (Bendire.)

\section{FAMILY ALAUDID丑: LARKS.}

KEY TO GENERA.

1. Crown with blunt erectile crest

Alauda, p. 26.5.

$1^{\prime}$. Crown with horn-like tufts of black feathers . . Otocoris, p. 266.

\section{GENUS ALAUDA.}

\section{[473.] Alauda arvensis Linn. Skylark.}

Wing with spurious primary; tail deeply emarginate; tarsus equal to middle toe and claw. Adults: Upper parts light brownish, streaked with black; wings dusky, feathers bordered with brown; tail with onter feathers white, dusky along edge of inner web; under parts and snperciliary whitish; chest pale tawny, streaked; ear coverts brownish, sometimes blackish along upper margin. Adults in winter: pluniage more tawny and feathers of erown and back with more or less whitish margins. Young: tawny, with white margins to feathers of upper parts conspicuous, marked with a subterminal spot of brown; tertials widely bordered with buffy, 
edged inside with dark brown; chest brownish buffy, indistinctly streaked or spotted with tawny.

Distribution. - Europe and portions of Asia and Africa; introdnced and naturalized in Oregon.

Nest.-On ground in meadows or open grassy places. Eggs : 3 to 6 , buffy whitish or pale grayish brown, thickly speckled with brown.

\section{GENUS OTOCORIS.}

General Characters. - Crown with horn-like erectile tufts; primaries apparently only nine; tail nearly even; bill conoid, acute; tarsus round behind, in young divided into plates on back; hind claw equal to or longer than its toe, nearly straight.

KEY TO ADULT MALES IN SCMMER.

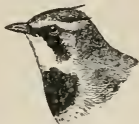

Fig. 343 .

1. Upper parts pale grayish brown or pinkish.

2. Upper parts uniform scorched brown or pinkish. Central southern Arizona . . . . . . . . . . . . adusta, p. 269.

2 '. Back of neck pinkish, contrasting with back.

3. 'Throat usually white or whitish. To Utah in winter.

leucolæma ${ }^{1}$ (arcticola of Oberholser), p. 266.

3'. Throat usually yellowish. Great Plains and Great Basin.

4. Superciliary yellow. Coast of Texas . . . giraudi, p. 268 .

4. Superciliary white.

כ. Back paler. Western United States.

arenicola 2 (leucolcema of Oberholser), p. 268.

5'. Back darker. Eastern United States . . praticola, p. 268.

1'. Upper parts dark brown and ruddy or pinkish.

2. Back heavily streaked with blackish.

3. Back of neck rinddy brown . . . . . . . strigata, p. 268.

3. Back of neck pinkish . . . . . . . . merrilli, p. 269.

2'. Back not heavily streaked with blackish.

3. Back of neck light ruddy brown. Coast of California.

chrysolæma ${ }^{3}$ (actia of Oberholser), p. 268.

3'. Back of neck deep ruddy brown. Sacramento and San Joaquin valleys, California . . . . . . . . . rubea, p. 268.

\section{4a. Otocoris alpestris leucolæma (Coues). Pallid Horxed IA A K. ${ }^{4}$}

Adult male in breeding plumage. - Front of erown, horn-like tufts, lores,

1 Lencolirma of anthors (not of Coues) has been named arcticola by Mr. Oberholser. (See Oberholser, "A Review of the Larks of the Genus Otocoris," Proc. U. S. Nat. Mus., vol. xxiv. pp. $801-884$.

2 This should stand as leucolixma of Coues.

3 r'hrysolama has been restricted to Mexico, and the California coast bird referred to this race has been named actiu by Mr. Oberholser.

4 This is the same subspecies as arenicola of Henshaw.

Otocoris alpestris lencausiptila Oberholser.

Palest of American horned larks. Iike leucolema, bnt smaller and with more uniform upper parts.

Distribution. - Extreme southwestern Arizona, extreme sontheastern corner of Cali- 
cheeks, and shield on breast black; back of head and neck, upper tail coverts, and bend of wing; pinkish cimnamon ; forehead, smperciliary stripe. and ear coverts white, egebrow usually yellow ish ; throat yellowish white; rest of under parts white, sides and flanks shaded with cimnamon. Adult female in breeding plumage:

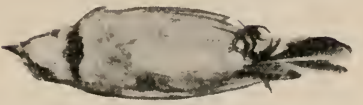

Fig. 34t. Pallid Horned Lark. like adult male. but black of head replaced by brownish and buffy ; back of neck. bend of wing, and upper tail coverts, cimmamon without pinkish tinge; back of neck narrowly streaked; superciliary and ear coverts buffy; sides and flanks streaked with dusky. Adult male in winter plumage: like summer male, but upper parts more uniform, the brownish areas nore pinkish, on back of head and neck almost hidden by grayish tips to feathers ; superciliary vellowish ; throat deeper vellow; black areas obsenred; breast tinged with buff and spotted with disky; sides and flanks darker. Young: upper parts brownish, feathers with subterminal bar of brown and spot or bar of white or buffy; supereiliary buffy, throat and sides of head spotted. Male: length 7.50-8.00, wing 4.30-4.(i5, tail 2.8.5-3.20. Female: wing 4.00-4.20, tail $2.60-2.80$.

Distribution. - Great Plains and Great Basin of the United States, south in winter to northern Mexico.

Nest. - On the gromnd, made of fine liay, lined sometimes with deer hair. Eggs : 3 or 4, grayish or greenish marked variably with shades of brown.

In following the roads that lead on and on through the limitless stretches of brown barren plains in the west the monotony of the way is often relieved by the grateful sight of a little companion wayfarer with back colored to match the soil and black horns that set off its delicate tints perching confidently beside the road, pattering fearlessly along ahead of your horse, or feeding and singing in the field as you pass. A quaint ditty theirs is, but it lends cheer and brightness to your journey. It is rendered with great good heart, the little larks springing up from the ground and singing as they hold themselves on fluttering wings in the air and sunshine. In the riesting season, they sing a rapturous love-song, sometimes fiying up quite out of sight and circling around in the air for several minutes, stopping on poised wing for an outpouring of song.

The larks cover so much country that they meet with varied con-

fornia, and northeastern Lower California along the international boundary line, north to southern Nevada.

Otocoris alpestris arcticola Oberholser.

The type of leucolie ma of Coues proving to be a smaller and more highly colored form, the pale large form (the leucoliema of authors) is left without a name, and Mr. Oberholser consequently calls it arcticola.

Otocoris alpestris enthymia Oberholser.

Like $O$. a. arcticola, but decidedly smaller, upper parts paler, throat usually yellow.

Distribution. - Breeds from Saskatchewan to northern North Dakota; migrates to Colorado and Kansas and sometimes to Utah and Arizona.

Otocoris alpestris hoyti Bishop.

Like arcticola, but upper parts darker, more rufescent, and throat generally distinctly yellow.

Distribution. - Breeds in British America; migrates to Nevada, Utal, Kansas, and Michigan ; casually to Ohio and New York. 
ditions, the northern ones encountering snow, and the Mexican ones such intense desert heat that they are sometimes seen with mouths open standing in rows in the shade of fence posts and weeds.

\section{4b. O. a. praticola Hensh. Prairie Horned Lark.}

"Like leucolcema but darker, less ochraceous above, the superciliary stripe usually without yellow." (Oberholser.)

Distribution. - Breeds from southern Canada to Pennsylvania and Kansas, and from Maine to eastern Nebraska ; migrates to the Carolinas and Texas; casually west to Colorado aud Arizona.

\section{4c. O. a. arenicola Hensh. Desert Horned LaRk.}

Arenicola and leucolama are identical forms, as has been shown by the rediscovery of the type of leucolcema. (See Oberholser, pp. S22, S23.)

\section{4d. O. a. giraudi Hensh. Texan Horned Lark.}

Upper parts grayish (especially in female); male with superciliary, throat, and breast usually pale yellow, breast usually marked with grayish brown in both sexes. Male: length 6.50-6.75, wing about $3.80-3.85$, tail 2.60. Female : length 5.80-6.00, wing about 3.50, tail 2.35 .

Distribution. - Coast region of Texas and northeastern Tamaulipas, from Galveston Bay to the Rio Grande.

\section{4e. O. a. chrysolæma (Wagl.). Mexican Horned Lakk. ${ }^{1}$}

Upper parts ruddy, more brownish in female; nape, shoulders, and rump light ruddy brown in marked contrast to back; breast pure white, unnarked in both sexes. Male: length 6.75-7.25, wing $3.80-4.15$, tail $2.80-$ 3.00. Female : length 6.50-7.00, wing 3.75-3.80, tail 2.70-2.80.

Distribution. - Coast district of Califoruia and south to Lower California.

\section{4f. O. a. rubea Hensh. Rudpy Horned Lark. ${ }^{2}$}

Similar to chrysolema, but smaller and brighter colored; whole upper parts ruddy, colors of nape merging into those of back; forehead, supereiliary, and throat yellowish; sides marked with reddish brown. Male: length $6.50-7.00$, wing :3.70-4.10, tail 2.60-2.90. Female: length 6.00-6.50, wing :3.50-3.70, tail 2.3.5-2.65.

Distribution. - Sacramento and San Joaquin valleys, California.

\section{4g. O. a. strigata Hensh. Streaked Honned Lark. ${ }^{3}$}

Back heavily streaked with black in sharp contrast to deep ruddy nape; mider parts partly or wholly yellow. Male: length 6.75-7.25, wing 3.704.10, tail 2.70-3.05. Female: length 6.25-6.50, wing 3.60-3.5.5, tail 2.502.80 .

1 The California bird has been found to be separable from chrysolizma of Mexico and has been naned $O$. $\because$. actia by Mr. Oberholser.

2 Otocoris alpestris ammophila Oberholser.

Like ruber, but neck and back paler, less reddish.

Distribution. - In summer, the Molhave Desert, north to Owens Valley, south to the Mexican boundary line.

3 Otororis alpestris insularis Townsend. IsLand Horned LARK.

Like strigata, but without yellow tinge on uncler parts; much darker than chrysola mu, witl streaks on back sharper, and sides much darker.

Distribution. - The Santa Barbara Islands, Califormia. 
Distribution. - Coast region from British Columbia south to California.

Nest. - In a hollow, on dry ground, usually frail, made of fine dead weeds. Eggs: usually 22 or 3, dull greenish or grayish, marked over entire surface with gray or reddish, heaviest around larger end.

\section{4h. O. a. adusta Dwight. Scorched Horsed Lakк. ${ }^{1}$}

Pale like chrysolema, but upper parts uniform scorched pink or pinkish brown. Male: wing 4 , tail 2.83 , bill from nostril .36. Female : wing 3.73 , tail 2.45, bill from nostril .34.

Distribution. - From central southern Arizona, south to Mexico.

474i. O. a. merrilli Dwight. DUsky HoRned LaRk.

Similar to strigata, but larger, grayer above, streaking of back blacker and back of neck paler, pinkish instead of ruddy brown; less yellowish below; eyebrow usually yellowish. Male: wing 4.07, tail 2.80, bill from nostril .35. Female: wing 3.72 , tail 2.50 , bill from nostril .34.

Distribution. - From British Columbia south between the Cascades and Rocky Mountains; in winter to Nevada and California.

\section{FAMILY CORVIDÆ: CROWS, JAYS, MAGPIES, ETC.}

KEY TO GENERA.

1. Wing long and pointed.

2. Plumage black .

2 '. Plumage mainly gray or blue.

3. Plumage blue

3 '. Plumage gray, black, and white.

1 '. Wing short and rounded.

2. Plumage black and white

$2^{\prime}$. Plumage not black.

3. Head crested

$3^{\prime}$. Head not crested.

4. Plumage mainly gray or blue.

5. Plumage gray .

5 . Plumage blue

$4^{\prime}$. Plumage mainly green and black

Corvus, p. 279.

Cyanocephalus, p. 284. Nucifraga, p. 282.

Pica, p. 269.

Cyanocitta, p. 271.

Perisoreus, p. 277. Aphelocoma, p. 274.

Xanthoura, p. 277.

\section{GENUS PICA.}

General Characters. - Tail much longer than wing, graduated for half its length or more, the feathers becoming narrower toward tips; nostrils covered by bristles; orbits partly naked; feet stout.

KEY TO SPECIES.

1. Bill and naked skin around eye black . . . . hudsonica, p. 270.

1'. Bill and naked skin around eyes yellow . . . . nuttalli, p. 271.

1 Otocoris alpestris occidentalis (MIcCall).

Like adustu, but much larger, and decidedly less ruddy above, nape more pinkish, back more dusky.

Distribution. - In summer, central New Mexico, west to central Arizona; in winter south to Sonora and Chihuahua, Mexico, and southeast to Texas.

Otocoris alpestris aphrasta Oberholser.

Like adusta, but back less reddish, back of neck and bend of wing more pinkish.

Distribution. - Extreme southeastern Arizona, southwestern New Mexico, and Chihuahua, Coahuila, and Durango, Mexico. 


\section{Pica pica hudsonica (Sab.). Black-billed Magpie.}

Adults. - Black, varied with bronzy iridescence, except for white belly and wing patches; tail long and graduated; bill and naked skin of orbital region black. Young: head without bronzy gloss. Length: 17.40-21.75, wing 7.30-8.40, tail 9.30-11.95, exposed culmen 1.15-1.42, tarsus $1.70-1.92$.

Distribution. - Resident, except perhaps in extreme northern part of its range, from Alaska and Hudson Bay to northern parts of Arizona and New Mexico; and from western Nebraska, west to eastern slopes of Sierra Nevada and Cascades.

Nest. - A mud cup lined with rootlets, grass, hair, and pine needles, surrounded by a globular mass of coarse sticks sometimes as big as a bushel basket, placed usually :3 to 20 feet from the ground in willows, thorn bushes, bullberry bushes, small oaks, cottonwoods, and pines. Eggs: usually 7, grayish, heavily and evenly blotched with brown, often almost hiding the ground color.

Food. - Small mammals, birds, their young and eggs, and crawfish, but mainly insects, including a destructive black cricket, grasshoppers, grubs, and larvæ, together with some fruit, berries, and green leaves.

The magpie is a feature of the landscape, whether seen in flight as a black air-ship with white side-wheelers and long black rudder moving against a background of red cliffs in the Garden of the Gods, or seen standing as a lay figure on a stone wall in a Mormon village. There is always a freetlom and largeness about his proceedings. Sometimes he will take wing so near that you see the green gloss on his back, flying with even water level flight far and away till he becomes a black dot and disappears beyond your field of vision. His masterful, positive character is not lost even when he goes squacking about his daily business. Whatever he does or says he claims the attention of the neighborhood, except when he has a secret to hide. when he is as silent and wary as any wise parent.

Like all great talkers the magpies are fond of company and where one is seen others are usually within calling distance. Their notes have a conversational tone and varied inflections and it seems small wonder that they learn to talk when kept in confinement.

They are keen observers and eager investigators of anything new that does not appear dangerous. If a line of traps are set through the sagebrush for small rodents and marked with bits of cotton on bush tops, the cotton soon catches their eyes and is promptly investigater. If some of the traps have caught meadow mice they are carried off to a convenient place, the mice eaten and the traps left sometimes causing a slight umpleasuntness between magpie and mammalogist. In cases where the birds are common they talie up the traps so systematically that the collector has to leave his line unmarked or devise a method obscure enough to escape their keen eyes. A flock of six or eight once came to examine into the blankets of a naturalist sleeping on a haycock. Sereral of them lit on his head and one was so absorbed in its explorations that the awakened rollector caught it in his hand. 


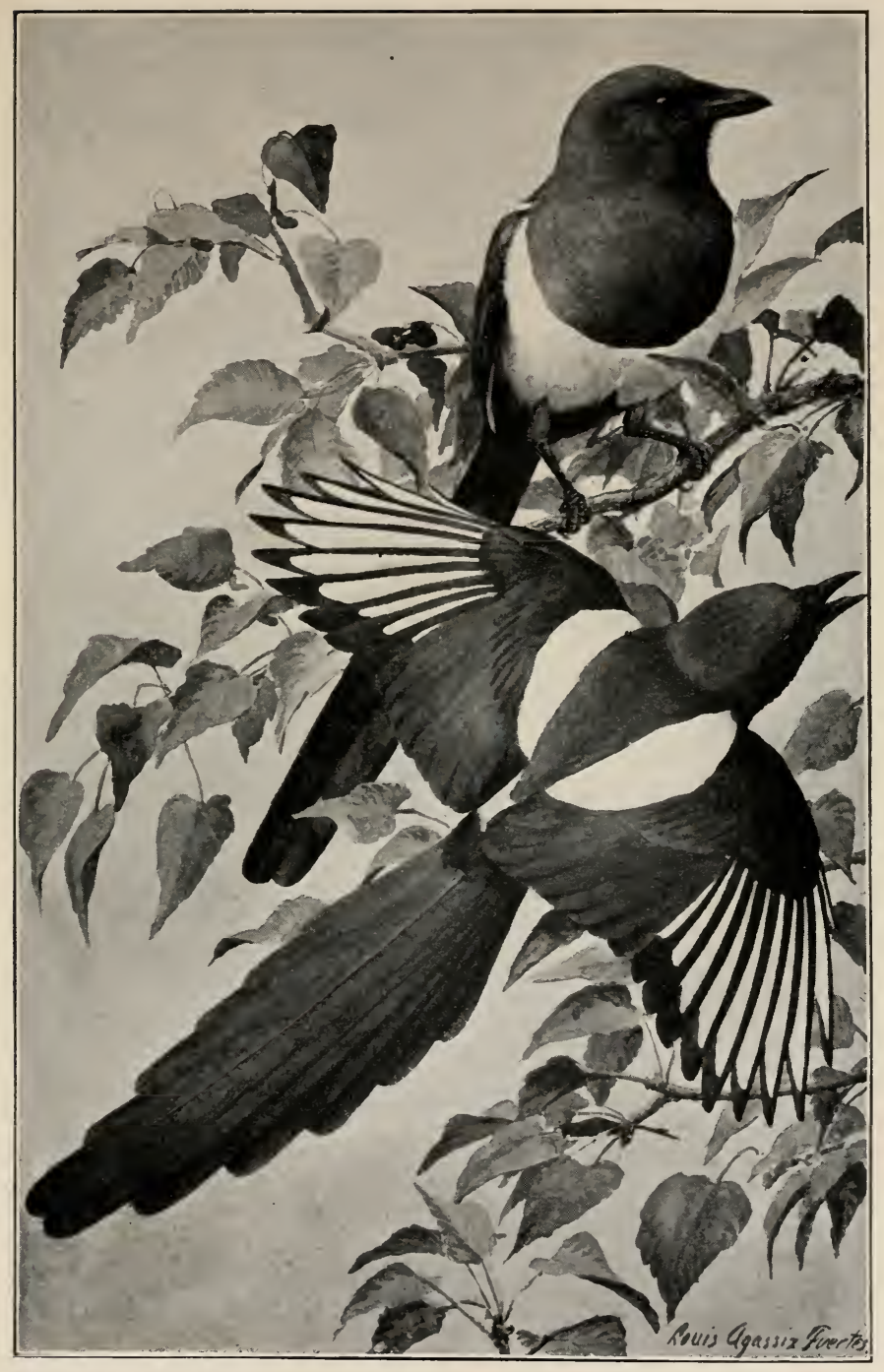

MAGPIE 

The birds are quick to take advantage of circumstances, and have been found living largely on dead fish at Lake Winnemucca, Nevada, feeding with the chickens in Utah, and during deep snows in Oregon keeping their toes warm by spending a large share of their time perched on the backs of horses and mules.

\section{Pica nuttalli Aud. Yellow-Billed Magpie.}

Similar to the P. p. hudsonica, but smaller and with bill and naked skin back of eye bright yellow. Length: 16-18, wing 7.20-7.70, tail 9.3010.30, exposed culmen 1.04-1.17, tarsus 1.(6:3-1.8!)

Distribution. - Resident in California west of the Sierra Nevada mountains from Sacrameuto Valley south to about latitude $34^{\circ}$, locally distributed.

Nest. - Similar to that of hudsonica, with the addition of cow manure and inner bark of the cottonwood; placed in oaks, sycamores, cottonwoods, and willows, usually :30 to 60 feet from the ground. Eggs: about 7 . like those of the black-billed, but a trifle smaller and with a more greenish tinge.

Food.- Grasshoppers, ants, worms, grubs, offal, carrion, seeds, and waste grain.

In a restricted area of the San Joaquin and Sacramento valleys in California some of the yellow-billed magpies are still left, but they are so much in evidence and afford such a tempting target that the days of the little band are probably numbered. In June, 1900, in the grain and oak fields of the Sierra foothills we counted nineteen of the splendid fellows flying about in one meadow near the mouth of a low canyon. They are tame and familiar if their suspicions are not arouserl, but let a man appear with a gun and they are over the treetops and away.

They are as bold, as shy, and as garrulous as their black-billed cousins across the range. Half a dozen in a tree of over-ripe figs reminds one of the chatter of an afternoon tea.

\section{GENUS CYANOCITTA.}

Generul Characters. - Conspicuously crested; nostrils concealed; wings and tail about equal, rounded; hind claw equaling or exceeding its toe in length.

1. Under parts whitish KEY TO SPECIES.

$1^{\prime}$. Under parts blue.

2. With white spot over eye.

3. Belly pale blue

:3'. Belly dark blue

2 '. Without white spot over eye.

3. Under parts dark blue

3 . Under parts light blue

. . cristata, p. 271 .

diademata, p. 273. annectens, p. 273.

stelleri, p. 272 . . frontalis, p. 273.

477. Cyanocitta cristata (Linn.). BLUE JAY.

Adults. - Crest and back light purplish blue; wings and tail blue, 
barred with black; throat gray or purplish white; middle of breast and

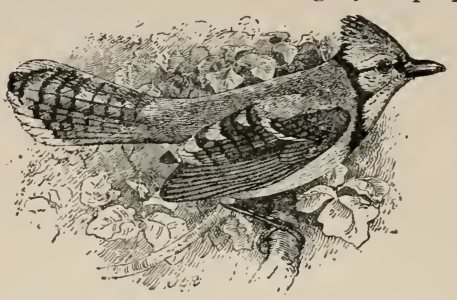

Fig. 345. Blue Jay. sides grayish or brownish, belly white; white on outer tail feather an inch or more deep. Young: similar, but colors duller. Length: $11.00-12.50$, wing 5.00-5.70, tail $5.05-5.70$, exposed culmen .931.06 .

Distribution. - Breeds in eastern North America from about latitude $52^{\circ}$ south to Florida, and from the Atlantic west to eastern parts of Nebraska, Kansas, and northern Texas.

Nest. - Usually in trees, ofter in orchards about houses, made largely. of dried twigs and rootlets. Eggs : 3 to 6, pale olive, greenish, or buffy, sparsely spotted with brown.

Food. - Largely mast; also corn, grain, beetles, grasshoppers, and caterpillars.

Observers in the western parts of Kansas, Nebraska, and Texas may be fortunate enough to know the spirited eastern biue jay. In voice and general habits he resembles his western relatives, though perhaps more awake to the advantages to be had from human neighborhood when snow covers the acorns and nuts on which he feeds.

\section{Cyanocitta stelleri (Gmel.). Steller JAy.}

Adults. - Fore parts of body dull blackish, changing to pale blue on lower back and belly; wings and tail purplish blue, barred with black. Young: similar, but duller ; wing bars faint or wanting. Length : 12-13, wing 5.5.)-6.20, tail 5.30-6.35, bill .96-1.18.

Distribution. - Resident in Transition and Canadian zones from Cook Inlet south along coast to Monterey, California, and east to the Cascades.

Nest. - 25 to 50 feet from the ground, usually in firs, but sometimes other trees, vines, and bushes, made of twigs, moss, and dry grass, cemented with mud and lined with fine roots. Eggs: 3 to 5, pale bluish green, spotted or blotched over whole surface with brown and lavender, thickest about the larger end.

Food. - In winter largely pine seeds, though almost anything is eaten.

There are many handsome blue-jays, but stelleri in its numerous forms, with its blue body and high crest, is one of the lords of its race, fittingly associated with the noblest forests of the west.

The Steller jay (stelleri) may be found at Cloud Cap Inn on Mt. IIood, feeding with the Clark crows and Oregon jays, and gires a touch of color to the solemn redwood forests of California as well as the dark, jungle-like roods of the Puget Sound country. The blue-fronted (stelleri frontalis) enlivens the forests of the Sierra, while the long-crested (stelleri diademata) lives in the southern Rocky Mountains, wandering about in the mountain ranges of New Mexico and the pine forests of Arizona. At Cloudcroft, New Mexico, 



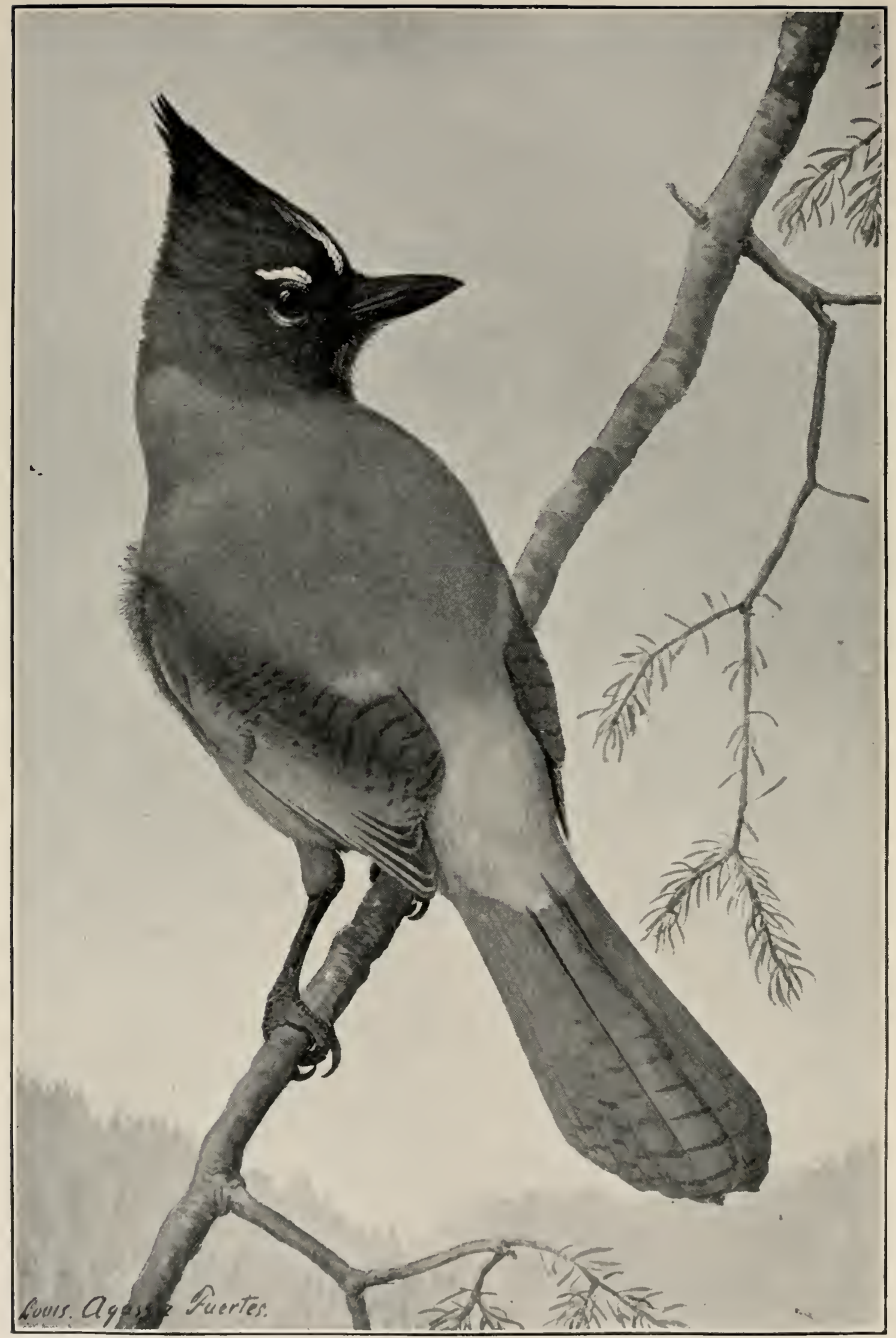

LONG-CRESTED JAY 
it gleans from abandoned camps, and in Arizona, though resident up to 10,000 feet, is often seen on the high rail fences built to keep range cattle within bounds.

Chack-ah, chack-ah, chack-ah, chack, the jay squalls, jerking his tail and dashing about, soaring down with short wings wide-spread, lighting on the side of a tree to inspect the cracks in the bark, or dropping to the ground to hunt for fallen mast.

In flight the crest is sometimes lowered almost to the horizontal, but, as a small Arizona observer noted, "when they holler they stick that right straight up." This 'hollering' includes a squeal which is so close to that of the red-tailed hawk as to be a good test to the ear of the observer.

478a. C. s. frontalis (Ridgw.). Blue-Fronted Jay. ${ }^{1}$

Adults. - Fore parts of body brownish slate, with blue tinge to crest and blue streaks on forehead; wings and tail dark blue, barred; rump and under parts dull turquoise. Length : $11.75-13.00$, wing 5.50-6.10, tail 5.105.75 , exposed culnien 1.00-1.20.

Distribution. - Southern coast ranges and Sierra Nevada of California and western Nevada, from Fort Crook south to northern Lower California.

Nest. - Like that of stelleri usually in firs, cedars, and pines, but sometimes in snowsheds and natural cavities in trees and stubs, from 4 to 50 feet from the ground. Eggs: 3 to 5, like those of stelleri. ter.

Food. - Acorns, pine seeds, and a variety of animal and vegetable mat-

\section{8b. C. S. diademata (Bonap.). LoNG-CREsted JAY.}

Like C. s. annectens, but white spot over eye always conspicuous and streaking on forehead whitish; black of head in sharp contrast to gray of back; chest bluish; blue of belly and rump dull turquoise as in frontalis. Length: $11.75-13.75$, wing 5.65-6.40, tail 5.25-6.25, exposed culmen 1.031.14 .

Distribution. - Resident in Transition and Canadian zones in the soutlern Rocky Mountains from southern Wyoming south to Zacatecas, Mexico, west to Uintah Mountains, Utah, and high mountains of Arizona.

Nest. - Similar to that of stelleri, usually in small bushy pines or other conifers 8 to 15 feet from the ground. Eggs: 3 to 6 , similar to those of stelleri.

Food. - Partly grasshoppers and pine seeds.

478c. C. S. annectens (Baird). BLACK-HEAdED JAY.

Head black, back slaty, blue of under parts dark as in stelleri; streaks on forehead bluish white, sometimes indistinct; small white spot over eye.

Remarks. - The black-headed has the general body colors of the Steller jay, with the eye spot and streaks approaching those of the long-crested. Length : $12-50-13.75$, wing 5.90-6.60, tail 5.80-6.65, exposed culmen .971.08 .

1 Cyanocitta stelleri carbonacea Grinnell.

Like frontalis, but darker, frontal blue spots restricted; head darker than back, back warm slate gray.

Distribution. - Coast of California, Monterey County, north to Oregon; Oregon west to Cascades, including east slope of Cascades. (The Condor, ii. 127; iv. 41.) 
Distribution. - Resident in Canadian zone in British Columbia and the northern Rocky Mountain region, south to the Wasatch Mountains, and from Wyoming west to eastern Oregon and Washington.

Nest. - As described by Ridgway, base of coarse fir sticks with nud bowl lined with fine wiry roots, saddled on a horizontal branch, 15 feet from the ground, containing 3 eggs, similar to those of stelleri.

\section{GENUS APHELOCOMA.}

General Characters. - Head not crested, tarsus longer than middle toe with claw.

\section{KEY TO SPECIES.}

1. Tail shorter than wing.

2. Tail 5.50 or less . . . . . . . . . . couchi, p. 276.

2 . Tail more than 5.50 . . . . . . . . . . . . . arizonæ, p. 276 .

1. Tail longer than wing.

2. Back slaty gray. East of Sierra Nevada . . woodhouseii. p. 274.

2 . Back brown.

3. Sides of head blackish. Sierra Nevada to Pacific.

:'. Sides of head blie.

californica, p. 275.

4. Upper parts, except back, bright blue.

j. Chest broadly streaked with white . . . cyanotis, p. 274.

5 . Chest obsoletely streaked with grayish . . texana, p. 275.

4'. Upper parts, except back, dark purplish blue.

insularis, p. 276.

\section{Aphelocoma woodhouseii (Baird). Woonhotse JAy.}

Upper parts dull blue except for slate gray back and scapulars; under parts gray except for blue tail and under tail coverts, and throat, which is whitish streaked with dark gray. Young: back darker than in young of californica; under parts dark gray instead of white. Length: $11.50-12.75$. wing 4.70-5.35, tail 5.20-6.20, bill .93.-1.06.

Distribution. - Resident in Upper Sonoran zone from southeastern Oregon south along the east side of the Sierra Nevarla to northern Mexico, and east to Montana, Colorado, and Texas.

Nest. - Found at Prescott, Arizona, a small. slight platform of sticks lined with fine roots and horsehair, placed in the centre of a thick bush about 5 feet from the ground. Eggs : 3 to 6 , pale green, sparingly flecked over the whole surface with irregular brown and lavender markings, usually heaviest about the larger end.

Food. - Varied, including insects. acorns, and pine nuts.

The habits of the Woothouse jay are similar to those of the California jay (see p. 275).

\subsection{Aphelocoma cyanotis Ridgu. BLte-Fared JAY.}

Head, wings, and tail, bright blue; bark aurk slaty brown, washed with blue; sides of head blue like top of head; under parts light grayish blne, broadly streaked with white; lower part of breast brownish gray, changing to white on belly. Length (skin) : 11.50, wing 5.40, tail 5.70, exposed eulmen .95.

Distribution. - Mexican tablelands north easually to Sutton Connty, Texas. 


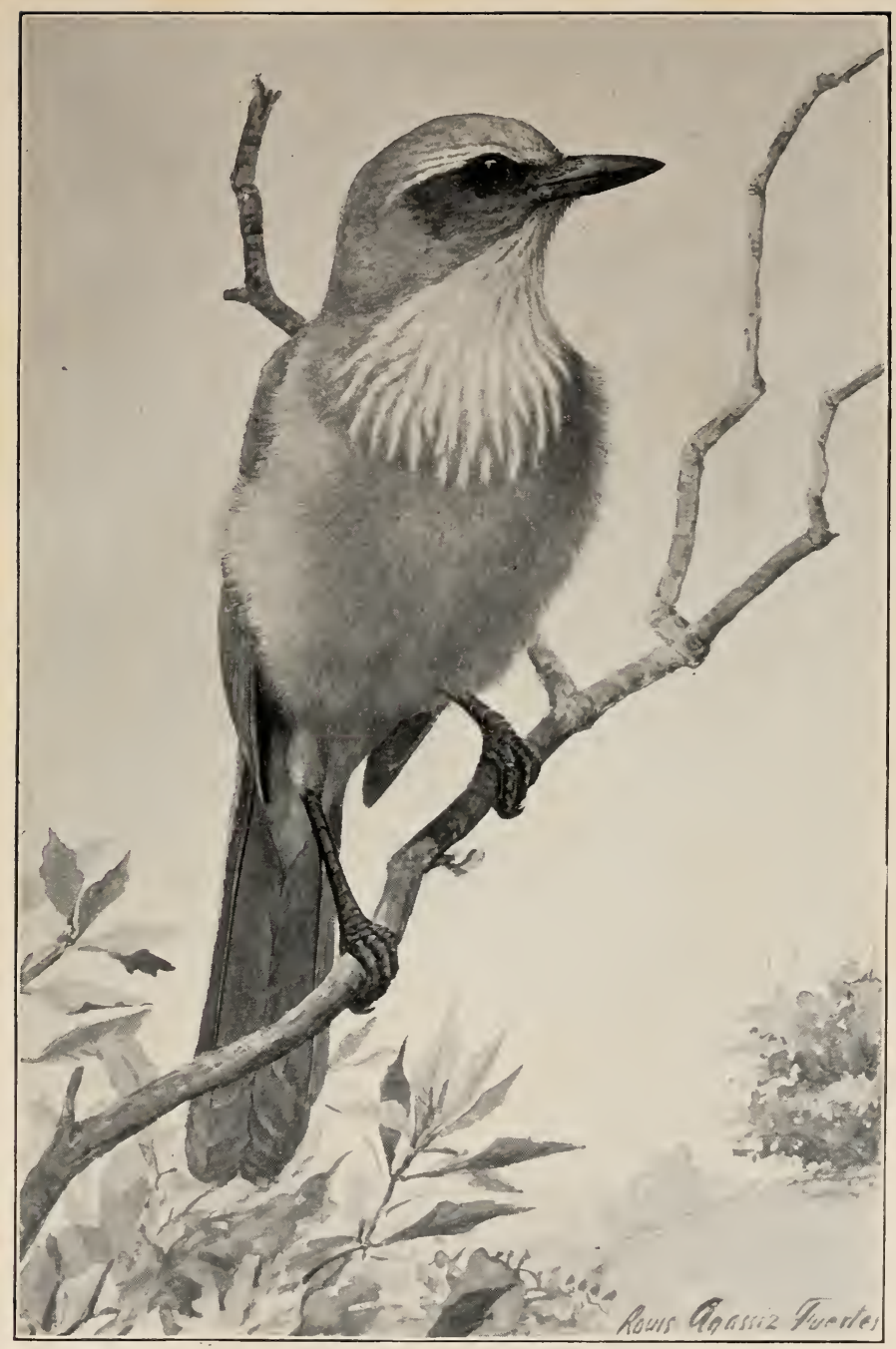

WOODHOUSE JAY 

Nest. - A loosely constructed mass of thorn brush lined with finer materials. Eggs: greenish blue, heavily spotted with brown and lavender, especially at larger end.

\subsection{Aphelocoma texana Ridgw. Texan Jay.}

Like cyanotis, but white superciliary more distinct, under parts paler and browner gray, lower throat and ehest with obsolete grayish streaks instead of blue streaks.

Remarks. - Texana differs from woodhouseii in obsolete streakings of chest, paler, browner breast, and white under tail coverts.

Distribution. - Southeastern Texas, from Concho and Kerr counties west to the Davis Mountains.

\section{Aphelocoma californica (Vig.). Califorxia Jay.}

Adults. - Upper parts blue except for brownish back and scapulars; under parts white except for bluish streaking on throat and partial blue and brownish necklace; white superciliary clearly defined; sides of head blackish. Young: head only tinged with blue, nearly uniform with brownish back ; throat white, unstreaked ; chest washed with brownish gray; belly whitish. Length: 11.50-12.25, wing 4.70-5.20, tail 5.45-6.10, bill .87-1.03.

Remarks. - Californica and woodhouseii are easily told apart, as californica is whitish instead of brownish gray below, and brown instead of gravish on back.

Distribution. - Pacific coast region from the Columbia River southward, including both slopes of the Cascades and Sierra Nevada, to northern Lower California.

Nest. - Interlaced twigs, mixed sometimes with moss, stubble, and grass, surrounding an inner nest of fine roots sometimes mixed with horsehair; placed usually in low bushes, but also in trees 3 to 30 feet from the ground, generally not far from water. Eggs: 3 to 6 , buffy or green, varying greatly in shade, the buffy ones spotted and blotched with brown, the green with markings generally scattered over the entire surface.

Food. - Bird's eggs, insects, acorns, pine nuts, wild fruits, and berries ; also, about settlements, hens' eggs and grain.

In coming down the Sierra Nevada you sometimes find that the range of the blue-fronted is overlapped by that of the California jay; but in the main you see the dark-crested frontalis sailing down from the fir-tops, and hear the light-colored, flat-headed California jays squacking through the digger pines and chaparral of the low country, where the valley quail has replaced the mountain quail. 'Blue squackers' the birds are called locally, and the name seems most appropriate when the hot thick air over the oaks and chaparral is ribrating with their cries. The Aplelocoma voice differs strikingly from that of frontalis, having a flat tone and being uttered with unseemly haste. Its notes vary greatly in expression and are so emphatic and often peremptory that one cannot doubt that something important is being said. A favorite cry, used apparently to rouse attention, is a quick "quay-quay-quay-quay-quay-quay-quay." Another still more emphatic one is boy'-ce boy'-ee, while an inquiring quay-kee? is often heard. Sometimes when a jay flies down to a 
companion it gives its quay-quay-quay-quay-quay and is answered by a high keyed queep-queep-queep-queep - however that may be interpreted.

481.1. Aphelocoma insularis Hensh. Santa Cruz Jay.

Upper parts dark purplish blue except for dark brown back and scapulars; breast and sides brownish, under tail coverts blue. Length: 11.5012.25, wing 5.20-5.30, tail $6.05-6.25$, bill 1.15-1.30.

Distribution. - Santa Cruz Island, southern California.

\section{Aphelocoma sieberii arizonæ Ridgw. Arizona Jay.}

Upper parts dull blue, grayish on back, and sometimes brownish between shoulders; under parts grayish white, sometimes brownish or buffy gray; tail decidedly rounded. Length: $11.50-13.00$, wing $6.10-6.50$, tail 5.6.)6.10 .

Remarks. - This and couchi are the only United States members of the genus Aphelocoma with wings longer than tail.

Distribution. - Resident in Upper Sonoran zone from southern New Mexico and Arizona south to northern Sonora and Chihuahua.

Nest. - In oaks, 12 to 30 feet from the ground, made of sticks and rootlets, sometimes lined with horsehair. Eggs : 4 to $\tau$, glossy green, unspotted.

Fond. - Largely acorns; but also grasshoppers and other insects, wild fruits and seeds.

The Arizona jay is an abundant resident of the live-oak belt of the Chiricahua, Huachuca, Santa Catalina, and some of the other Arizona mountains, from an altitude of from 3000 to 7000 feet. In severe winter weather the jays sometimes come about houses, and can be attracted by bones or meat hung on trees. Although their principal food is acorns, when they are out of season the birds depend largely on grass, seeds, grubs, beetles, young birds, and eggs. In habits, Mr. Scott says, the jays are as terrestrial as crows.

\section{Aphelocoma couchi (Baird). Coбch JAY.}

Adults. - Back and scapulars dull grayish blue; rest of upper parts and sides of head bright azure blue ; throat dull white; breast brownish gray ; belly and under tail coverts pure white. Length: 11.50, wing 5.80-5.90, tail 5.30-5.40, graduated for about .30, bill 1.05-1.10.

Distribution. - Eastern Mexico, extending to western Texas in the Chisos Mountains.

Nest. - Nade of sticks, lined with rootlets. Eggs : 4, robin's-egg blue.

In the Chisos MIountains, Texas, Mr. Bailey, Mr. Fuertes, and Mr. Oberholser found the Couch jay, which was previously known only in Mexico, common from the lower edge of the oaks and junipers to the top of the range. It was especially abundant in the shady gulches near water. Iike most other jays, though noisy and conspicuous, it was shy and suspicious. During the first half of June old and young were flying together, busily catching and eating the large cicadas that swarmed in the oaks. 


\section{GENUS XANTHOURA.}

483. Xanthoura luxuosa glaucescens Ridgw. Green Jay.

Adults. - Throat and sides of head jet black, in sharp contrast to pale green or yellowish green of under parts; top of head and malar streak bluish purple, with touch of white on forehead; rest of upper parts bluish green, usually extensively tinged with pale blue; tail with middle feathers bluish green, outer feathers pale yellow. Young: similar, but duller, head greenish blue instead of purple ; upper parts apple green without bluish tinge; under parts buffy, faintly tinged with green. Length: 11-12, wing $4.40-4.80$, tail $5.10-5.80$.

Distribution. - From Valley of the Lower Rio Grande in Texas south to Vera Cruz and Prebla.

Nest. - Concealed in thickets, made of thorny twigs sparingly lined with rootlets, moss, grass, and hair. Eggs : usually 4, grayish, greenish, or buffy, marked with lilac and brown, massed around the larger end.

\section{GENUS PERISOREUS.}

General Characters. - Head not crested; plumage soft, full. and loose ; bill short and wide at base, nostrils exposed; wings and tail about equal, tail graduated.

\section{KEY TO SPECIES.}

1. Whole top of head white . . . . . . capitalis, p. 27\%.

$1^{\prime}$. Top of head black except for white forehead.

2. Back brownish . . . . . . . obscurus, p. 278.

2 '. Back gray. East of Coast and Cascade ranges . . griseus, p. 279.

\section{4a. Perisoreus canadensis capitalis Ridgw. Rocky Moun- TAIN JAY.}

Adults. - Top of head white sliading to dark gray on back of neck; rest of upper parts light slate gray; tail tipped with white; throat whitish ; rest of under parts brownish gray. Young: top of head dull white. tinged with grayish brown. Length: $11.25-13.00$, wing $5.90-6.30$, tail 5.80-6.35, bill .97-1.08.

Distribution. - From British America south to Arizona and New Mexico in the Rocky Mountain regions.

Nest. - As described by Dr. Brewer, of pine twigs holding a compactly woven inner nest of stems, plant

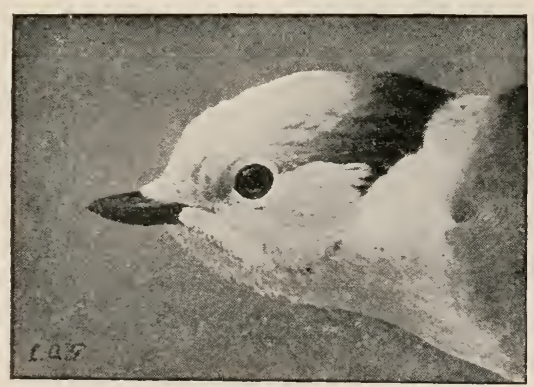

Fig. 346. fibers, feathers, bark, and down, placed on the horizontal branch of a pine 40 feet from the ground, containing 3 eggs, grayish white blotched with purplish brown, in two, only around the larger end, in one, over the entire egg.

Food. - Meat, insects, acorns, and whatever offers.

The Rocky Mountain jay, like the other species of the Perisoreus genus, is notoriously a camp bird. As it, lives all the year in the deep 
coniferous forests where it is rarely shot at, it seems to regard the few campers who come to its preserves as fellow foresters who should naturally share their living with it. The jays have been known to carry these reprehensible socialistic sentiments so far as to fly down on the carcass of a deer which a man was skinning. At such a time Mr. Anthony has had them light on his head and back, uttering a low, plaintive cry. In the Yellowstone National Park, where no shooting is allowed, a band of the big fluffy birds came trooping into $\mathrm{Mr}$. Bailey's camp to breakfast with him every morning. Once they came before the camp was awake and flew around calling and scolding as if angry that the people were not up. One bird dropped softly down on the blankets of one of the party and, while the man held his breath and looked at it out of one eye, sat there calmly glancing around for breakfast.

485. Perisoreus obscurus Ridgw. Oregon JAy.

Adults. - Like P. c. capitalis, but white only on forehead; top of head

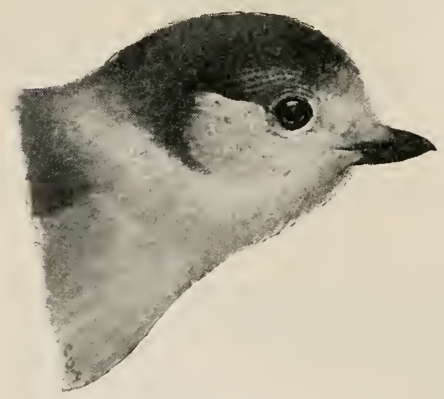

Fig. 347 . and back of neck blackish, and rest of upper parts brownish gray; feathers of back with white shaft streaks; tail only slightly if at all tipped with white; under parts white. Young: dull sooty brown, darkest on head. browner below. Length : 9.50-11.00, wing 5.15-5.75. tail 5.20-5.90, bill .84-.99.

Distribution. - Resident in higher mountains of northern California, Oregon, Washington, and part of British Columbia.

Nest. - Outside of interlaced twigs, dry grass, tree moss, and plant fibers; inside dark tree moss ; placed usually in a high bushy fir. ish gray, spotted with lavender and gray. Eggs : 4 or 5, pearl gray or green-

The Oregon and Rocky Mountain jays are alike in habits. The Oregon bird is found in numbers on Mit. Hood. About Govermment Camp a band of the jays visited Mr. Bailey's camp, and the men amused themselves at the jays' expense by throwing soggy pancakes to them. The birds could not fly off with the heary cakes, but considered then such unwonted delicacies that they would drag them around over the ground worrying off pieces to fly away with.

At Cloud Cap Imn the Oregon jays come to the house for food and water, and when I was there were so tame that by coaxing them with a plate of meat I was able to photograph them only four feet away. The voices of the jays were heard around the log house from morning till night. Their notes were pleasantly varied. One call 
was remarkably like the chirp of a robin. Another of the commonest was a weak and rather complaining cry repeated several times. A sharply contrasting one was a pure, clear whistle of one note followed by a three-syllabled call something like $k a-v e e^{\prime}-a h$. The regular rallying cry was still different, a loud and striking two-syllabled kictwhee.

At the Inn the birds spent a large part of their time storing food. Observers who are in the woods in winter should try to find if such stores are utilized.

\section{P. o. griseus Ridgw. Gray JaY.}

Similar to the Oregon jay. but decidedly larger except for feet, and much grayer; back dark gray instead of brown, and under parts grayish white instead of brownish white.

Distribution. - From British Columbia south to northern California east of the Coast and Caseade ranges.

\section{GENUS CORVUS.}

General Characters. - Wing 9 or more; long and pointed; tail mucl shorter than wing; bill compressed. much higher than broad; nasal bristles about half as long as bill; feet stout.

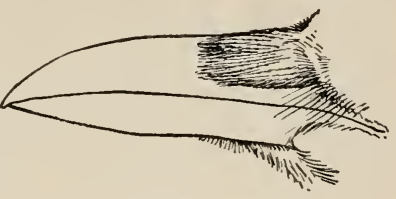

Fig. 348.

\section{KEY TO SPECIES.}

1. Feathers of neck gray or white at base.

2. Feathers of neck pure white at base . . . cryptoleucus, p. 280 .

$2^{\prime}$. Feathers of neck dull gray at base.

3. Bill larger, tarsus stouter. Washington . . principalis, p. 280.

3 '. Bill smaller, tarsus more slender. . . . . . sinuatus, p. 279.

$1^{\prime}$. Feathers of neck not gray or white at base.

2. Wing 10.0\%. Sitka to Oregon

2 . Wing 12.15 .

\section{Corvus corax sinuatus (Wagl.). American Raven.}

Black, entire plumage glossed with lustrous purplish, tinged with dull greenish on belly; feathers of throat lanceolate, distinct from one another; feuthers of neck dull gray at base; nasal tufts covering more than basal half of npper mandible. Length: 21.50-26.00, wing 15.10-18.00, tail 9-11, exposed culmen $2.4(1-3.3 .0 .5$.

Distribution. - Resident from upper border of arid Tropical to Alpine zone in the western United States from the Rocky Mountains to the Pacific coast. and from Canada to Guatemala.

Nest. - Usually on cliffs, a mass of well-interlaced sticks lined with cottonwood bark, moss. cattle hair, and wool. Eggs : 5 to 7, pea green, olire, or drab, usually profusely spotted and blotched with shades of brown. lavender, and ḋab.

Food. - Principally carrion, dead fish and frogs, varied with rodents, mussels, grasshoppers, large black crickets, and worms.

Where tall, bare cliffs rise from the valleys and deep, steep-walled canyons cut into the mountain ranges, the hoarse croaking of the 
ravens echoes back from cliff and wall. The higher and more inaccessible the cliff and the more barren and deserted the valley below the better suited are the ravens and the more freely do they soar and croak, flying singly or in pairs, up and down along the face of the cliff with a spirited wildness that harmonizes well with their background. Suspicious, wary pirates they are, always on the defensive to evade attack, keeping well out of rifle range of man, and often forced to mount to almost invisible heights to avoid mobbing attacks from small birds that seem to have permanent wrongs to avenge.

They descend to lake and river shores for dead fish or whatever the waves wash up in the way of food, make a few meals from a dead sheep, feast on what is left when a hunter dresses a deer, and are accused of helping out their varied bill of fare with eggs and young from any birds' nest that comes handy. Their own nests, placed in a niche half way up some perpendicular cliff, usually bids defiance to all enemies.

VerNoN BaILEy.

\section{6a. C. c. principalis Ridgw. Northern Raven.}

Like the American raven, but larger, with larger and heavier bill ; tarsus shorter and stouter; more of upper part concealed by feathering of thighs. Length : 22.00-26.50, wing 16.50-18.00, tail 9.20-10.50, exposed culmen $2.65-3.45$.

Distribution. - Northern North America from Greenland west to Alaska, south to Washington, northern Michigan, New York, and Maine, and south in the mountains to North Carolina.

Nest. - On cliffs and in trees, made of sticks lined with seaweed, grasses, mosses, or hair. Eggs : 4 to 6, greenish or drab, usually profusely blotched and spotted with browns, drab, and lavender.

Food. - Largely fish offal and refuse; also clams, and eggs and young of waterfowl.

The northern raven resembles the American in general habits and call-notes, and is usually most abundant in the immediate vicinity of Indian camps on the seashore or on the banks of large rivers in the interior.

487. Corvus cryptoleucus Couch. White-necked Raven.

Black, upper parts glossed with purplish ; feathers of neck pure white at base, nasal tufts covering more than basal half of upper mandible. Length: 18.75-21.00, wing 13.10-14.25, tail 7.50-8.60, exposed eulmen $2.00-2.35$.

Distribution. - Mainly Lower Sonoran zone from Texas to southern California, and from western Kansas and southern Colorado south through northern Mexico.

Nest. - Poorly made, usually of thorny twigs lined with yucea fibers, deer hair, rabbit fur, bark, grass, or moss; placed only 7 to 20 feet from the ground, often in a yucea top. Eggs : 3 to 8, green, with longitudinal marks of gray, brown, and lavender, sometimes partly hidden by brown spots and blotehes.

Food. - Principally animal matter, including eicadas; also refuse grain. 


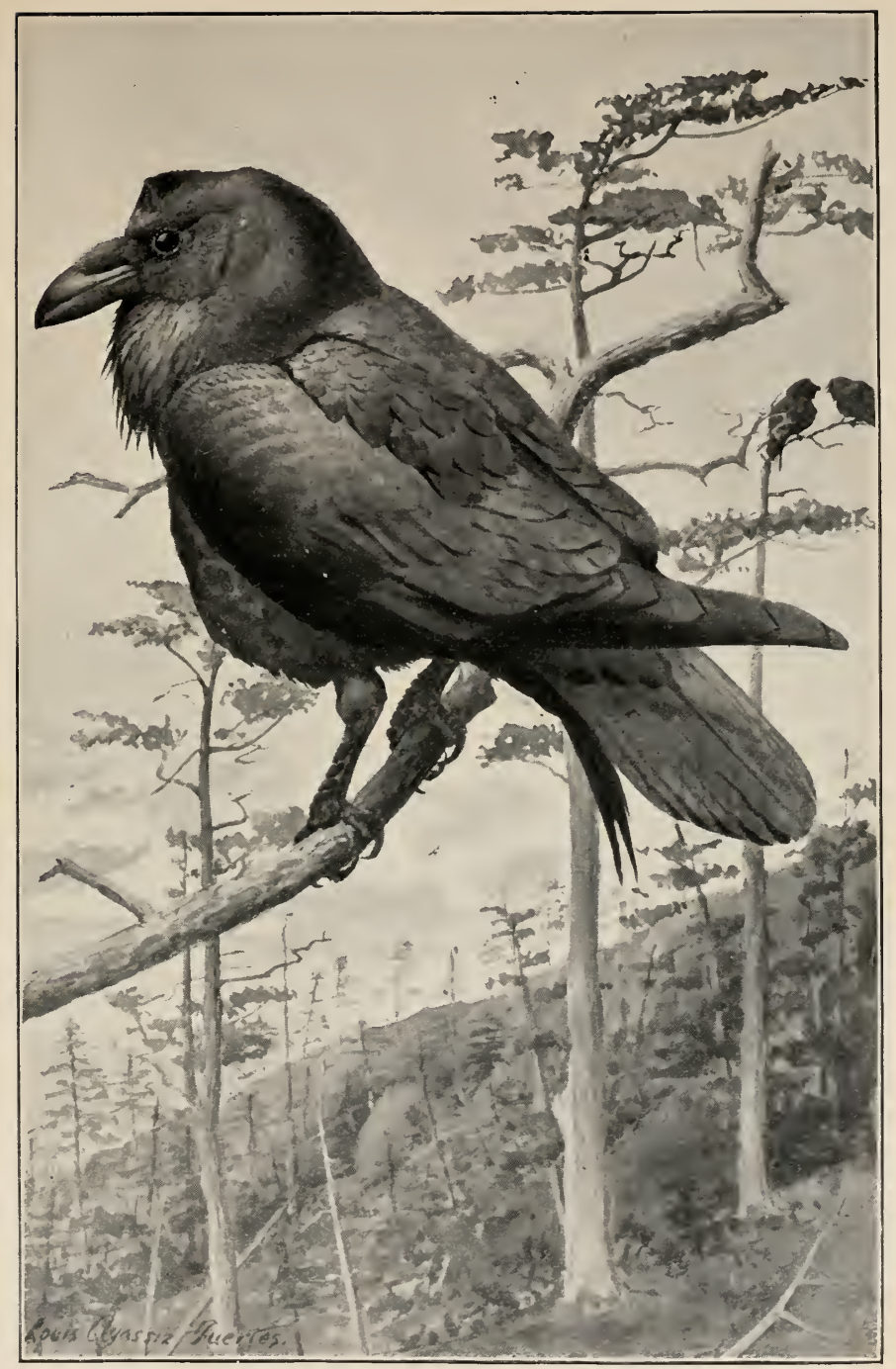

NORTHERN RAVEN 

The white-necked raven is a typical bird of the hot Lower Sonoran deserts, where it seems permanently associated with tall yuccas, juicy-fruited cactus, and the thousand thorny things of the halfbarren valleys. Half crow and half raven in size, voice, and habits, cryptoleucus is still readily distinguished from either by both size and roice. Social in disposition, the birds gather in crow-like flocks in winter and feed about stockyards and corrals and even in city streets, where they are surprisingly tame considering their shyness outside. Even in the breeding season they are often seen in small companies on the mesas foraging for food or mobbing a pair of the big, hoarse-roiced sinuatus which have inadvertently entered their domain. But more commonly they are seen in pairs flying low over the cactus and yucca tops.

So partial are they to the tall bayoneted yuccas for nesting sites that in western Texas few of these tree-like growths that have reached a height of ten or twelve feet have escaped bearing one or more loads of sticks.

Verion Ballex.

\section{Corvus americanus $A u d$. American Crow. ${ }^{1}$}

Black, whole plumage glossed with violet, more strongly on upper parts; feathers of throat short, blended. Length: 17-21, wing 11.90-13.2.5, tail 6.90-8.00, exposed culmen 1.80-2.05.

Distribution. - North American continent, except extreme aretic regions, and Florida in summer; south to northern Mexico.

Nest. - In trees, bulky, of sticks, weed stalks, and other coarse materials, lined with roots, grass, leaves, straw, wool, or hair. Eggs : 4 to \&, from pale bluish green to olive green or olive buff, with irregular spots or blotches in grays and browns.

Food. - Mice, rabbits, gophers, eggs and young of other birds, grasshoppers, weevils, cutworms, and many injurions insects; also grain and fruit.

The crow excites interest from many points of view. As an individual his droll originality and keen intelligence attract the bird student, as a social animal his famous roosts are a seren days' wonder to his neighbors, while as an economic problem at his name friends and foes rise in clamor. His roosts sometimes number a population of 300,000 , when his importance as a seed-planter may be well appreciated. But the economic point at issue in discussing him is, does he eat more grubs than corn? Professor Beal's conclusions, based on the examination of large numbers of crow stomachs, are that "in the more thickly settled parts of the country the crow probably does more good than harm, at least when ordinary precautions are taken to protect newly planted corn and young poultry against his depredations." The best way to protect corn-

1 Corvus americanus hesperis Ridgw. California Crow.

Smaller than americamus, with relatively smaller and more slender bill.

Distribution. - From Puget Sound to northern Mexico and east to the Rocky Mountains. (Ridgway's Manual of North American Birds, p. 362.) 
fields is to soak some corn in tar and scatter it on the borders of the field subject to their attacks. A few quarts of corn used in this way will protect a field of eight or ten acres. This is worth while because of the amount of good the crow does by destroying insect pests and field mice, rabbits, and other harmful rodents.

489. Corvus caurinus Baird. Northwest Crow.

Black, upper parts glossed with dull violet. Length : 16-17, wing 10.1011.50, tail 5.90-7.00, exposed enlmen 1.60-1.90.

Remarks. - The northwest erow differs from the American erow in smaller size.

Distribution. - Coast districts from Sitka to Oregon.

Nest. - In a crotch, 10 to 18 feet from the ground, made of fine sticks and mud, lined with cedar bark. Eggs: usually 4 or 5, like those of americunus, but smaller.

Food. - Mussels, fish, and berries.

On the Makah Indian Reservation at Neah Bay near Cape Flattery I was much impressed by the sight of these small crows fearlessly walking or flying about on the beach among the long-beaked boats of the Indians, where they picked up dead fish and refuse with the assurance of chickens or pampered pets. They are said to contend with the $\operatorname{logs}$ for possession of the refuse fish on the beach, and even go so far as to carry off fish from poles on the housetops where the Indians have left them to dry. Their good oftices as scavengers are especially appreciated about salmon canneries and rivers when the salmon are running.

\section{GENUS NUCIFRAGA.}

Subgenus Picicorvus.

491. Nucifraga columbiana (Wils.). Clarke Nutcracker. Bill exlindrical, nostrils concealed by a tuft of feathers; wings long and

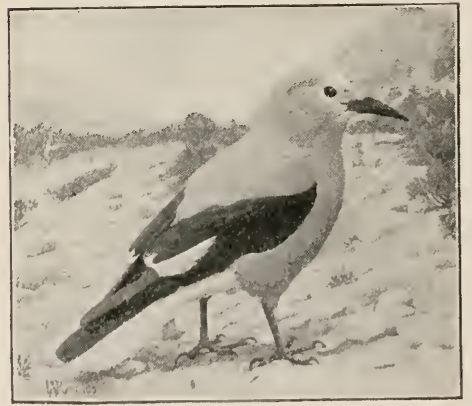

Fig. 34!9. pointed, folding to the end of tail ; tail little over half as long as wing; tarsus shorter than middle toe and claw; claws large, sharp, and much eurved.

Adults. - Body ash gray, whiter on forehead and chin; wings black, with white pateh on secondaries; tail with middle feather's black, onter ones white. Young: similar. but colors duller and npper parts brownish gray; under parts brownish ash indistinetly barred. Length: 12-13. wing $7.10-8.00$, tail 5.10-5.40.

Distribution. - Breeds in Canadian and Hndsomian zones in the monntainous parts of western North Ameriea from Alaska south to New Mexico and Arizona, and from 
the Black Hills and eastern slopes of the rocky Mountains to the Pacific. Casual from Dakota through Kansas. Missonri, and Arkansas.

Nest. - In evergreens 8 to 40 feet from the gromnd, composed of twigs and white sage, bound together by strips of imner bark, lined with fine strips of bark, grasses, and pine needles. Eggs: 3 to 5, pale green, minutely and sparingly marked with brown, gray, and lavender, either most heavily around the larger end, evenly distributed, or with the lower half unspotted.

Food. - In winter, seeds of conifers; at other seasons, berries, lupine seeds, insect larvæ, butterflies, grasshoppers, beetles, and the destructive black cricket. The young are fed on hulled pine seeds.

What an independent, positive character the nutcracker is! In the mountains the sound of his rattling kar'r'r, kar'r'r, as he comes Hying in with strong, free flight, leading a black and white liveried band through the treetops, always stirs the blood with memories and anticipations, for he is associated with the mountain-tops, where the conies bleat and the glacial streams flow only when the sum is high.

Jiving mainly on the crests of the ranges, the birds fly to the high peaks to get the first rays of the sun, and when warmed go for food and water to lower slopes. Their method of getting down is startling at first sight. Launching out from a peak with bill pointed downward and wings closed they drop like a bullet for a thousand feet to the brook where they wish to drink. Sometimes they make the descent at one long swoop, at other times in a series of pitches, each time checking their fall by opening their wings and letting themselves curve upward before the next straight drop. They fall with such a high rate of speed that when they open their wings there is an explosive burst which echoes from the canyon walls.

On Mt. Hood the nutcrackers stay with the Oregon jays around Cloud Cap Inn, under the peak. On IIt. Shasta a few of them come into the fir belt as low as $5 \tilde{6} 50$ feet, but while we were there the majority we saw were with the alpine henlocks and the dwarf pines of timberline, from 7750 to 8300 feet. They ate green caterpillars in the hemlocks and caught grasshoppers on the neighboring rocky slopes. In places they are seen flying about anong the dwarf pines carrying the cones in their bills to branches where they can get at the seeds by hammering off the scales. In the Sierra Nevada in fall they feed largely on the seeds of Pinus monticolı, and at such times their movements are irregular, depending on the supply of pine cones. When feeding it is amusing to watch them. As you walk along the edge of the timber a flash of white and the sound of tlapping wings orerhead call your attention in time to see the bird light with a jet of the tail and a jerk of the wings on a terminal cluster of cones. He hardly gets his balance so that his figure 
resumes its trim form before he starts, his tail flips up, and a cone loosened by his foot goes to the ground with a rattling thump. And so he keeps it up, till you know when you are in his neighborhood by the sound of cones hitting the ground. In Idaho, Dr. Merrill found the abundance of the nutcrackers was coincident with that of the crossbills, the presence of both birds being dependent on the food supply.

On San Francisco Mountain, Dr. Mearns found the birds breeding while the mountains were still covered with snow.

\section{GENUS CYANOCEPHALUS.}

492. Cyanocephalus cyanocephalus ( Hied.). PIÑon J $_{A Y}$.

Head not crested; bill cylindrical ; nostrils exposed ; tail nearly square, much shorter than wings; feet stout, claws large, strong, and much eurved. Adults : almost uniform grayish blue, brightest on liead; throat with white streaks. Young: dull grayish blue, lighter beneath. Length: 10.00-11.75, wing 5.70-6.00, tail 4.80-4.55.

Distribution. - Breeds in piñon belt in Upper Sonoran and Transition zones in the plateau regions of western North America from southern British Columbia sonth to Lower California and northern Mexico, and from the region of the Black Hills west to the Pacific ; casually to Kansas and Nebraska. Migrates from the northern part of its range.

Nest. - Deep, bulky, compact, made of twigs or sagebrush, lined with plant and tree fibers, rootlets, and grass; placed usually in piñons or junipers 5 to 12 feet from the ground. Eggs: 3 to 5, bluish white, sometimes covered with minute specks, at other's wreathed around the larger end with coarse spots.

Food. - Juniper berries, piñon nuts, grain, and insects, especially grasshoppers.

The piñon jays are so inseparably associated with the piñon pines that you can no more think of them without mental visions of sage-covered foothills spotted with junipers and piñons, than you can think of these dwarf forests of the desert ranges of the Great Basin country without calling up images of straggling flocks of short-tailed birds flapping along with crow-like flight and a weird, crow-like $c\left(t-w^{\prime} c c t-w^{\prime}\right.$.

The nut pine furnishes a great part of their food, and only in the juniper and yellow pine country of eastern Oregon are they found straying far beyond its range.

They are eminently social birds, sometimes even breeding in colonies, and after the breeding season gathering in flocks of several humdreds. A flock often seems to have no end, reaching for miles as the birds scatter out and straggle noisily along through the trees. At other times they fly in close bodies, rising and wheeling like blackbirds and settling down together to pick grain in a stubble field.

VEliNON BAILEY. 


\section{FAMILY STURNIDA: STARLINGS. \\ GENUS STURNUS.}

[493.] Sturnus vulgaris Linn. Staklivg.

Primaries ten, but first quill minute; bill straight, nasal feathers erect or inclined backward; nostrils with conspicuous nasal scale. Adults in summer: glossy greenish or purplish black, speckled with buffy brown and whitish; wing and tail feathers largely edged with brownish buff; bill yellow. Adults in winter: upper parts light brown; under parts whitish, spotting often so conspicuous as to obseure the underlying green and purple. Length: 7.50-8.50, wing 5.00-5.10, tail 2.60-2.90, bill .95-1.00.

Distribution. - Europe and Asia; accidental in Greenland. Introduced about New York city and in the vicinity of Portland, Oregon.

Nest. - In holes in trees or about buildings. Eggs : 4 to 7 , pale greenish blue or bluish white.

\section{FAMILY ICTERID㞋: BLACKBIRDS, ORIOLES, ETC.}

1. Bill short and conical.

KEY TO GENERA.

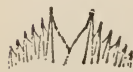

2. Tail feathers stiff and pointed.

Fig. 350 .

Dolichonyx, p. 286.

2 '. Tail feathers normal.

3. Four outer primaries eut out . . Callothrus, p. 288.

3 '. Primaries normal .

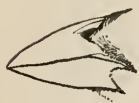

Fig. 352.

1'. Bill not short and eonical.

2. Tail feathers stiff and pointed.

Sturnella, p. 292.

2 '. Tail feathers not stiff and pointed.

3. Tail graduated and folded laterally.

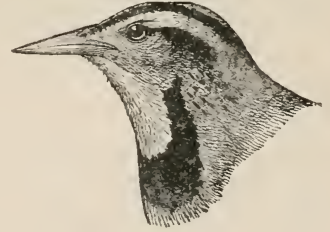

Fig. 353 .

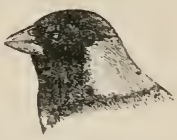

Fig. 351.
Quiscalus, p. 301.

3'. Tail mainly even, not folded laterally.

3. Tail mainly even, not folded laterally.

4. Feet weak, for perching

$t^{\prime}$. Feet strong, for walking.

5. Claws of side toes reaching beyond middle toe; males in summer black with yellow heads.

Xanthocephalus, p. 2 s.

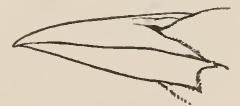

Fig. $35 t$.

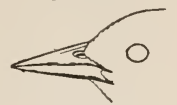

Fig. 355.

Icterus, p. $29:$.

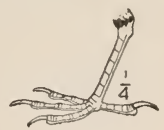

Fig. 356. 
5 5. Claws of side toes not reaching berond middle toe.

6. Side claws not reaching to end of middle toe; summer males glossy blue black. . . . . Scolecophagus, p. 299.

6 . Side claws reaching to end of middle toe; males with red shoulder patches.

Agelaius, p. 289.

\section{GENUS DOLICHONYX.}

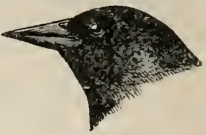

Fig. $35 \%$.

\section{Dolichonyx oryzivorus (Linn.). Вовоцик.}

Bill conic-acnte, entting edges bent in; tail shorter than wing, with stiffened acnte feathers; wings long and pointed; feet stout, tarsus shorter than middle toe and claw; claws all very large. Adult male in spring: under parts wholly black; upper parts black, with eream or buffy brown pateh on hind neck, light streaking on wing and fore parts of back, grayish scapulars, and white hind back, rump, and upper tail coverts. Adult female: ground color yellowish brown, paler and plain on under parts

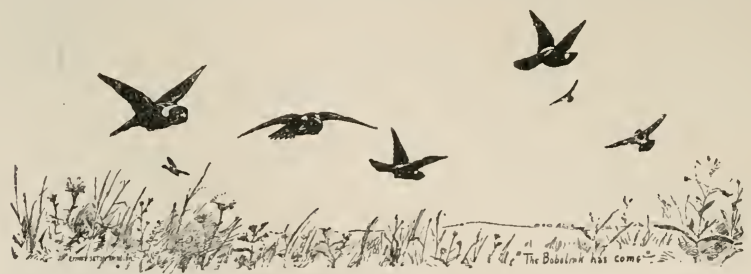

Fig. 358.

except for blackish streaks on flanks; heavily streaked on npper parts; crown with buffy brown median stripe. Adult male in fall and winter: similar to adult female, but streaking of upper parts blacker. Young, first fall and winter: like adult female. Young, first plumiage: like adult female but more buffy, with necklace of faint dusky spots; flank streaks obsolete. Mule : length (skins) 6.30-7.40, wing 3.69-4.00, tail 2.47-2.70, bill .58-.69. Female: length (skins) 6.00-6.55, wing 3.85-3.5.3, tail 2.312.54 , bill .57-.61.

Distribution. - Breeds in Transition zone in open prairies and cleared districts from Assiniboia south through the middle states, and from the Atlantic west to Idaho and eastern Nevada; migrates to the West Indies and Soutl America.

Nest. - In a slight depression in the ground, made of dried weed stems and grasses. Eggs: ") to 7 , from gray to reddish brown. irregularly spotted and blotched with browns and purples.

Food. - Insects, including grasshoppers, locusts, weevils, and caterpillars; also rice, oats, and weed seed.

The bobolink seems to be gradually spreading westward, and wherever it goes adds another rare song bird to the country. "Robert o' Lincoln' is a rollicking, joyous fellow, his song bubbling up from a well of good spirits. To eastern orchard or meadow seems quite complete without him and May is not May until he has come. 


\section{GENUS MOLOTHRUS.}

General Characters. - Bill short, stout, conic, about two thirds as long as head, broad ridge ruming well up on forehead; wings moderate or long and pointed ; tail shorter than wings, even, or a little rounded; feet strong; tarsus not shorter than middle toe with claw.

\section{KEY TO SPECIES.}

1. Length (male) 6.60-7.6.5)

1'. Length (male) 6.00-7.10. 'Texas and Arizona . ater. p. 287. obscurus, p. $28 \mathrm{~s}$.

\section{Molothrus ater (Bodel.). Cow Bird.}

Adult males. - Head, neck, and chest uniform brown; rest of plumage glossy black with green and purple reflections. Idult female: smaller than male, streaked brownish gray, darker above, lighter on throat. Foung male: upper parts dull grayish brown or dark brown, feathers bordered with pale

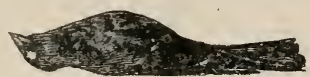

Fig. 359 . buffy or grayish brown and whitish; under parts broadly streaked with brownish, dull buffy, or whitish. Young female: like young male, but paler, under parts mainly dull buffy, streaked with grayish brown. Male: length (skins) $6.60-7.6 .5$, wing $4.15-4.56$, tail 2.76-3.15. bill .68-.77. Female: length (skins) 6.10-7.10, wing 3.68-4.12, tail 2.4:-2.77, bill .60-.67.

Distribution. - From southern British America south throughout the Cnited States. breeding west to eastem Oregon; migrating to eastem Mexico. Less common in the western part of its range.

Eggs. - Deposited, usually singly, in nests of other birds, 8 to 12 , whitish, whole surface covered with brown specks and blotehes. usually heaviest about the larger end.

Food. - Nainlr noxious weed seed and insects, with a small amount of grain.

'. Buffalo birl' used to be one of the names of the cowbird on the Plains, and IIajor Bendire says that in the prairie states now 'one will rarely see a bunch of cattle without an attendant flock of cowbirds, who perch on their backs, searching for parasites.' This occupation is not interrupted by the ordinary cares of family life, for the cowbird builds no nest of its own, but foists its offspring upon its neighbors.

"Probably the historic cause for this remarkable habit would give us more charity for the bird, but it does such violence to the one redeeming instinct of the lowest types of man and beast, that it is hard not to regard the bird with unqualified aversion. Not only is it entirely lacking in the maternal but in the conjugal instincts, for it practices polyandry. On the other hand, the male cowbird is polygamous. . . The only thing that can be said in faror of the female cowbird is that she takes pains to place her eggs where they are most likely to be hatched. Major Bendire gives a list of ninetyone birds in whose nests she has been known to leave her eggs; but though this includes woodpeckers, flycatchers, orioles, thrushes, 
sparrows, vireos, wrens, and warblers, the birds most frequently imposed upon are so small that the cowbird's big, crowding nestling will be the one to survive when it is a question of size and resisting power." (Birds of Village and Field.)

\section{5a. M. a. obscurus (Gmel.). Dwarf Cowbird.}

Similar to M. ater, but smaller. Male : length (skins) 6.00-7.10, wing 3.78-4.10, tail 2.4:3-2.87, bill .62-.70. Female: lengtl (skins) 5.61-6.30, wing 3.37-3.70, tail $2.27-2.62$, bill .5.5-.62.

Distribution. - Breeds from southern Texas to southwestern Arizona, and south to Lower California and Mexico.

Eggs. - Deposited in nests of other birds, similar to those of M. ater.

\section{GENUS CALLOTHRUS.}

\section{Callothrus robustus ( $C a b$.). RED-Eyed CowBird.}

Bill shorter than head, stont, conical, distinctly ridged, upper outline slightly cnrved; neck with soft, dense, erectile ruff; four outer primaries with imner webs curiously sinuated and emarginated. Adult male: iris bright red; body and erectile ruff black, with soft bronzy luster; wings and tail glossed with bluish, greenish, and purplish. Adult fernale: dull black, somewhat glossed with bluish green; neck ruffs much smaller than in male. Young male: sooty black, under parts with feathers edged with paler. Young female: paler and grayer than young male. Male: length (skins) 7.75-8.80, wing 4.40-4.73, tail 2.98-3.24, bill .88-.94. Female: length (skins) $6.50-8.10$, wing $3.84-4.16$, tail 2.52-2.94, bill .78-.84.

Distribution. - Breeds from soutliem Texas south through eastern Mexico to Central America; migrates to Panama.

Eggs. - Deposited in nests of other birds, usually 4, pale bluish green, unspotted.

On the coast prairies of the Rio Grande Valley in Texas the redeyed cowbird may be seen on the roadside fences. His strikingly red eyes and handsome glossy black coat mark him at a glance from the other cowbirds, and when he raises his neck ruff he seems indeed a distinguished personage.

\section{GENUS XANTHOCEPHALUS.}

\section{Xanthocephalus xanthocephalus (Bonap.). Yellow- HEADED BILACKBIRD.}

Bill decidedly shorter than head, its depth through base less than half the length of the exposed culmen ; culmen straight, flattened; sexes different in size; wing long and pointed; tarsus nearly one fourth as long as wing; claws large, lateral ones reaching beyond base of middle one. Adult male in summer: black except for yellow or orange of head, throat, and ehest, and white patch on wings. Adult male in winter: similar, but yellow of top of head obscured by brownish tips to feathers. Adult female: brownish, throat and chest dull yellowish, breast nixed with white. Young male in first winter: similar to female, but larger and deeper colored. Male : length (skins) 8.60-10.10, wing 5.32-5.79, tail 3.66-4.27, bill .8:-.99. Female: length (skins) $7.50-8.30$, wing 4.33-4.64, tail $3.10-$ 3.45 , bill .77-.83.

Distribution. - Western North America from British Colnmbia and Hud- 


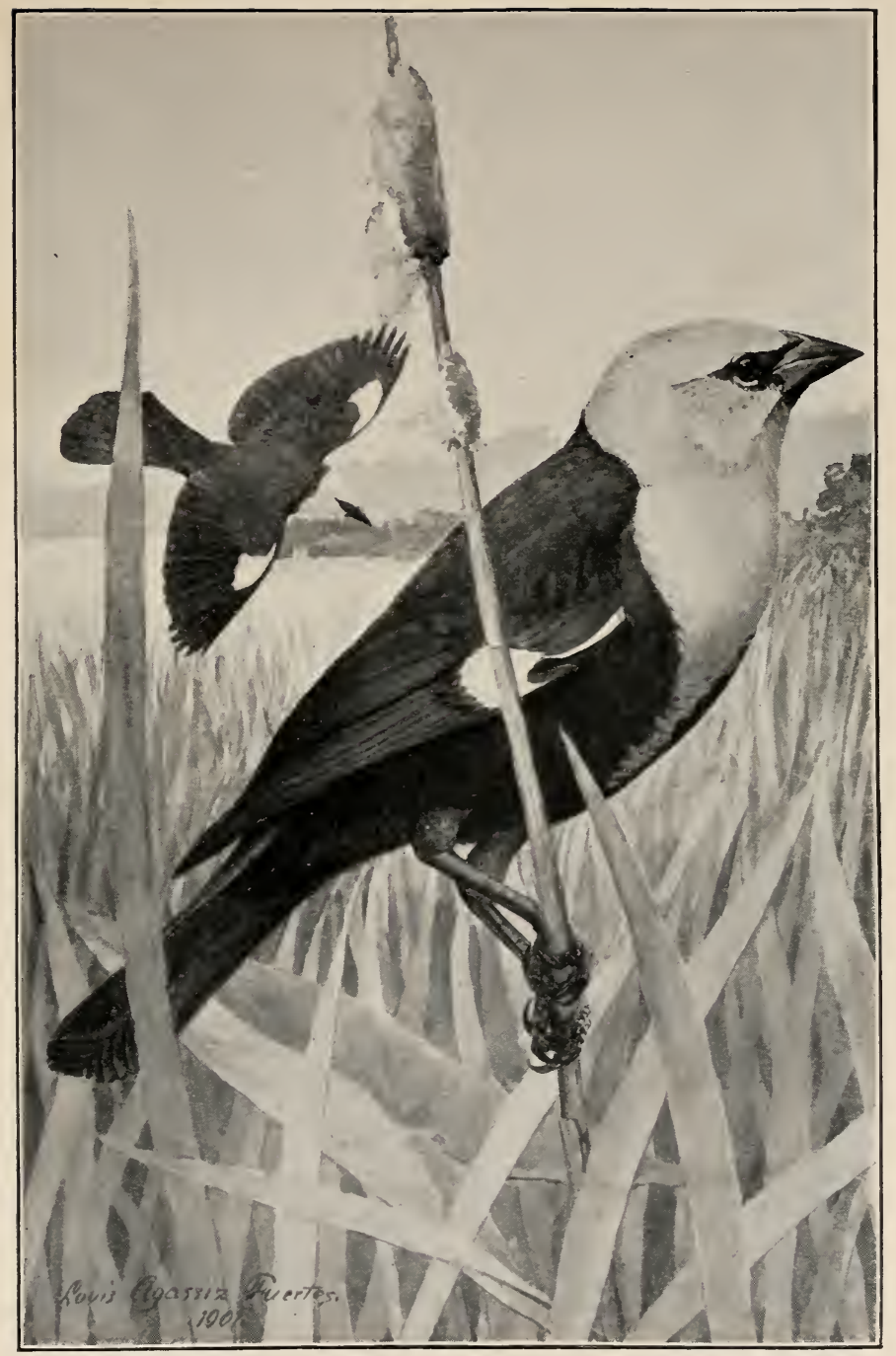

YELLOW-HEADED BLACKBIRD 

son Bay. sonth across Mexican tablelands and east to Wisconsin, Indiana, and Texis: casmally to Ontario and the eastern United States.

Nest. - Fastened to tule stems or rushes 10 to :30 inches above the water of a marsh. mate of coarse marsh grasses, tules. reeds. and rushes. woven together and lined with finer grasses. Eggs: ; to j. from grayish to greenish white, profusely and evenly blotched and speckled with browns and grays.

Food. - Pmall seerls, such as wild rice, and, in cultivated districts, occasionally corn, vats, and wheat; but mainly insects, especially grasshoppers and locnsts, together with their egg's and larvæ.

From their breeding grounds in the sloughs and tule marshes the yellow-headed blackbirds seatter out and wander over the whole of the westem plains country, appearing in flocks with grackles, redwings, or cowbirds in the characteristic hordes of the fall migration, or in flocks by themselves in fields and meadows, along the roadsides, often in barnyards and corrals, and sometimes in city streets, flocks with pompous, yellow-caped males strutting about among the dull-colored females and young, talking in harsh, guttural tones.

Noisy at all times, they are doubly so on the breeding grounds, where they try to sing, and their hoarse voices come up from the tule borders like the croaking of frogs and creaking of unoiled gates.

As the young are learing the nests in July, it is not unusual to find tlocks of old males away in the hills by themselves, taking a racation after their arduous duties; but usually the fall flocks are made up of both sexes and young.

VERNoN BaIley.

\section{GENUS AGELAIUS.}

General Characters. - Bill shorter than head, stout at base, deeper than broad, high and flattened on forehead, broadly parting the feathers, rapidly tapering to acute point; wings pointed, tail even or rounded; claws small, lateral ones scareely reaching to base of middle one; sexes different in size.

\section{KEY TO ADULT MALES.}

1. Wing with middle coverts black at tips . . . californicus, p. 291. $1^{\prime}$. Wing with middle coverts buffy, brownish, or white at tips.

2. Smaller.

3. Females lighter, buffy tints prevailing on upper parts. Southern Arizona and New Mexico . . . . . Sonoriensis, p. 290.

3'. Females darker, buffy tints not prevailing on upper parts.

t. Winter females with little if any rusty on upper parts. Great Basin district to southern California . . neutralis, p. 291 .

$4^{\prime}$. Winter females with rusty on upper parts. Oregon and Califor2'. Larger. nia, west of Cascades and Sierra Nevada

3. Bill relatively shorter and thicker. Manitoba to Mexico.

3'. Bill relatively longer and more slender.

fortis, p. 291.

4. Wings longer. Northwest coast district

4'. Wings shorter. Eastern United States to base of Rocky Momntains

phœniceus, p. 290. 


\section{Agelaius phœniceus (Linn.). Red-Wixged Black Bird. ${ }^{1}$}

Adult male in breeding plumage. - Black except for red and buffy brown or whitish shoulder patches. Adult male in winter: like summer

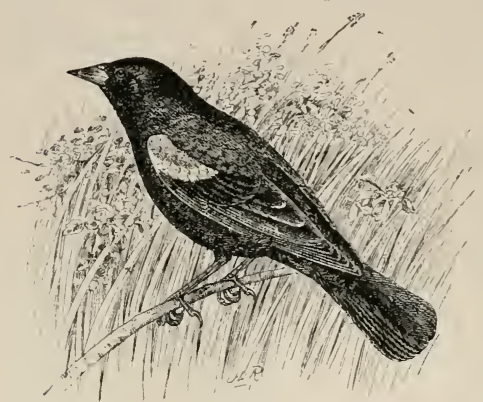

Fig. 360 . male, but buff of wing coverts deeper and scapulars and interscapulars edged with rusty. Adult female in breeding plumage: plumage of harsh texture compared with the silky plumage of the male; streaked, top of head dark brown, with buffy median crown stripe and superciliary; nape and fore part of back dark brown, lightly marked with buffy; shoulders faintly tinged with red; under parts whitish, heavily streaked with dark brown; throat variably tinged with creamy, buff, or pinkish. Adult female in

winter: lighter markings of upper parts more conspicuous, under parts tinged with buffy. Immature male: epaulettes flecked with black and varying from orange to red; black of plumage obseured by heavy rusty and buffy edgings above, and light ashy or brownish tips below. Young: like adult female, but throat, superciliary, and malar stripes yellowish; ground color of under parts pale buffy or rellowish with narrow dusky streaks. Male: length (skins) 8.10-9.30, wing 4.58-4.95, tail 3.49-3.78, bill .8\$-1.00. Female : length (skins) $6.80-7.45$, wing $3.75-4.00$, tail $2.76-$ 3.0\%, bill .68-.80.

Distribution. - Eastern North America to Rocky Mountains.

Nest. -- Attached to mpright stems of sedges or reeds, or to branches of bushes or small trees in marshes or swamps; made compactly of dried grasses. Egys : :3 to 5, pale blnish, varying to olive, marked with black, brown, or purplish gray, usually with pen lines and blotches.

Food. - Injurious insects, grain, and weed seed.

In the semi-arid parts of the west where a bit of marsh is the one green acre when the hills and valleys have turned brown in summer, the marsh birds have a peculiar charm. The red-wing, with his black coat and the gleam of keen red from his epaulettes, is a strong note in the landscape, but best of all is his flute-like o-ka-lee, with its cool suggestions of marsh grass and eat-tails.

\section{8a. A. p. sonoriensis Ridgw. Sonorax Red-wing.}

Like A. phoniceus, but smaller; female much lighter, buffy tints prevailing on upper parts; throat pinkish, streaking of nuder parts much duller and less striking; bill thicker. Male: length (skins) 8.15-9.35, wing 4.80-5.09, tail 3.85-3.98, bill .89-1.00. Female: length (skins) 6.80-7.86, wing $3.88-4.15$, bill .70-.84.

1 Agelaius phreniceus richmondi Nelson. Vera Cruz Red-wing. (The Auk, xiv. 58.) Like phoniceus but smaller, adult male with wing coverts deeper colored, at least in winter; adult female lighter colored.

Distribution. - Coast district of lower Rio Grande Valley in Texas, and south to Costa Rica. (Ridgway's Birds of North "mel Middle America, ii. 335.) 
Distribution. - From the Lower Colorado Valley in southern California and Arizona south to Tepic, western Mexico.

At Phonix, Arizona, the red-wings have been seen eating a treeworm which was a pest at the time.

\section{8d. A. p. fortis Ridgw. Thick-billed Red-wing.}

Like A. phaniceus, " but decidedly larger, with bill relatively much shorter and thicker; adult females, adult male in winter, and immatnre males similar in coloration to the same of A. p. sonoriensis, but distinguished by very different measurements." (Ridgway.) Male: length (skins) 8.35-9.50, wing 4.86-5.21, tail 3.45-4.15, bill .7 $8-1.04$, depth of bill at base .50-.59. Female: length (skins) 6.80-7.68, wing 4.00-4.30, tail 2.80-3.27, bill .67-..33, depth of bill at base .43-.50.

Distribution. - Central North Anerica, in migrations from Manitoba south to Illinois, Indian Territory, and western Texas, westward to and including the Rocky Mountains, and south to Arizona and Chiliuahua.

\section{8e. A. p. neutralis Ridgw. Sax Diego Red-wing.}

"Similar to A.p. sonoriensis, but smaller, adult female much darker, with streaks less strongly contrasted above, those on under parts rather broader and grayer, the upper parts with little if any rusty, even in winter." (Ridgway.) Male: length (skins) $7.85-9.00$, wing $4.60-5.00$, tail 3.35-3.85, bill .55-.98. Female: length (skins) 6.60-7.68, wing 3.80-4.10. tail 2.64-3.0s, bill .73-.83.

Distribution. - Great Basin district of United States, sonthward to southern California and northern Lower California.

\section{8f. A. p. caurinus Ridgu. Northwestern Red-wing.}

Similar to A. pheniceus, "but wings and bill longer, the latter more slender; adult male with buff of middle wing coverts deeper, deep ochraceous-buff or ochraceons in winter; adult females more heavily streaked with black beneath, and, in winter plumage, with upper parts much more conspicuonsly marked with rusty." (Ridgway). Male: length (skins) 8.60-9.10, wing 4.57-5.10, tail 3.39-3.83, bill .90-1.01. Female: length (skins) $6.80-7.80$, wing $3.85-4.22$, tail $2.80-3.27$, bill .7.-.86.

Distribution. - Northwest coast district from British Columbia south through western Washington and Oregon to northern California.

\section{Agelaius gubernator californicus Nelson. Bicoloned BLACKBIRD.}

Adult male. - Black, shoulder patch red, the middle wing coverts having their buffy or brownish bases concealed by black tips. Adult female in breeding plumage: nearly uniform blackish brown, throat bnffy and streaked. Adult female in winter: feathers edged with rusty. Young: corresponding to phases of the red-wing. Male: length (skins) 7.80-8.60, wing 4.66-5.(19, tail 3.20-3.78, bill .78-.91. Female: length (skins) 6.907.50 , wing $3.9 \overline{7}-4.23$, tail $2.68-3.02$, bill $.73-.78$.

Distribution. - Western Oregon and northern and central coast district of California.

Nest. - In or near marshes. on tufts of marsh grass or weeds, 1 to 3 feet above the water; made of grasses and strips of soft bark, usually lined with grass-tops and sometimes horsehair. Eggs: usually 2 to $\dot{4}$, pale bluish green, generally spotted, marbled, and streakerl. mostly about the larger end, with browu, black, and purple. 
500. Agelaius tricolor (Aud.). Tricolored Blackirird.

Adult male. - Glossy blue black, plumage with silky luster; epaulettes dark red, bordered with white, more or less tinged with buff; in winter, plumage softer, more glossy, and white on epaulettes more or less tinged with buff. Adult female: texture of plumage like that of male; upper parts dusky with greenish or bronzy luster; crown narrowly streaked; scapulars and interscapulars with grayish edgings; wings with grayish and whitish bands; head with superciliary and malar streaks; throat and chest streaked; rest of under parts dusky, with paler edgings to feathers. Immature female, first winter: like adult female, but browner. Young: like female, but browner, and under parts narrowly streaked; wings with two bands. Male: length (skins) 8.00-9.05, wing 4.6:3-4.87, tail 3.32-3.75, bill $.87-.95$. Female: length (skins) 7.10-7.85, wing 4.11-4.32, tail 2.92-3.16, bill .78-.S3.

Distribution. - Valleys of Oregon, California, and Lower California, west of the Cascades and Sierra Nevada.

Nest and eggs similar to those of phrniceus. Eggs: 1 to 4 .

Food. - Young fed entirely on grasshoppers.

\section{GENUS STURNELLA.}

General Characters. - Bill about as long as head, narrowly wedgeshaped, acute and depressed at tip; tail less than two thirds as long as wing, the feathers sharp-pointed ; wing short, tertials leugthened - reach-

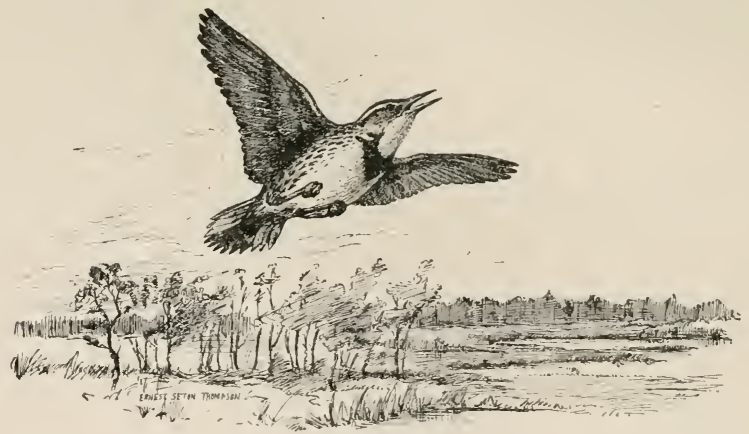

Fig. 361 .

ing almost to tips of primaries - feathers of top of head with stiffened glossy shafts; outstretehed feet reaching beyond tip of tail.

KEY TO SPECIES.

1. Yellow of throat enoroaching on malar region . . neglecta, p. 293. $1^{\prime}$. Yellow of throat not encroaching on malar region . hoopesi, p. 292.

501a. Sturnella magna hoopesi stone. Texas Mradowlark.

Adult male. - Similar to S. m. neglecta. but yellow of throat restricted. not encroaching on cheeks, and yellow somewhat deeper and more intense than in neglecta. Adnlt female: similar. but vellow more orange. Young: colors much duller and markings less distinct; black mark on ehest only 
faintly indicated. Male: length (skins) 7.90-9.08, wing 4.45-4.96, tail $2.5(1-3.12$, bill 1.19-1.4). Female: length (skins) 7.70-8.10, wing 3.95-4.32, tail $2.52-2.90$, bill $1.20-1.3 \% 2$.

Distribution. - From southeastern Texas west to southern New Mexico and Arizona; south to northern Mexico.

\section{1b. Sturnella magna neglecta (Aud.). Western Meadow- LARK.}

Adult male in breeding plumage. - Crown with median buffy stripe ; lores vellow; superciliary buffy; rest of npper parts grayish brown, with buffy white streaks and black streaks and bars; middle of back heavily marked with black, and tertials. rump, and tail heavily barred; outer tail feathers mainly white; under parts bright vellow, yellow of throat spreading over cheeks; crescent on breast and spotting on sides black. Adult female in breeding plumage: similar. but paler, and yellow restricted. Adults in ninter plumage: upper parts lighter, from unworn light tips and edgings of feathers; black and yellow of under parts veiled by light edgings. Male: length (skins) 8.31-10.14, wing 4.66-5.08, tail 2.69-3.25, bill 1.171.44. Female: length (skins) $7.74-9.00$, wing $4.12-4.59$, tail $2.39-2.84$, bill 1.09-1.2s.

Distribution. - Western United States from Wisconsin, Illinois, and Texas to the Pacific, and from British America south to Lower California and northern Mexico. Resident south of $39^{\circ}$ and near Seattle.

Nest. - Usually at the foot of a bunch of grass, made of grass, generally loosely covered over. Eggs: 3 to 7 , generally white, spotted variably over the entire surface with different shades of brown and purple.

Food. - Mainly grasshoppers and their eggs, beetles, the destructive large black cricket, and other insects.

The voice of the western meadowlark is so different from that of the eastern bird that in going west you recognize it the instant the pure clarion notes strike your ear, whether at a wayside station amid the puffing of the engine, or from the moving train when, with a turn of the wing, the bird flies over the car carolling as it goes, regardless of all but the song in its heart. "There's the westeru meadowlark !" you cry out in eager delight, and as the train leaves him behind and you lean back on the dusty car cushions, you rest in a world of blue sky and celestial song. The lark's notes have been written down in sharps and flats, but the pure, heavenly quality of the song can nerer be reproduced.

\section{GENUS ICTERUS.}

General Characters. - Bill abont as long as head, very acute; feet fitted for perching rather than walking; tarsus not longer than middle toe and claw; side toes equal. or outer longest; tail rounded or gradnated.

KEY TO ADELT MALES.

1. Plumage black and yellow or orange.

2. Head mainly yellow.

3. Breast pale orange

$8^{\prime}$. Breast light lemon yellow .

sennetti, p. 295.

2'. Heat mainly black.

nelsoni, p. 296. 
3. Under parts bright lemon yellow.

4. Tail shorter than wing, graduated for less than length of bill.

parisorum, p. 294.

4'. Tail longer than wing, graduated for more than length of bill.

3 '. Under parts orange yellow or orange red.

audubonii, p. 294.

4. Malar region and streak over lores yellow or orange.

4 '. Whole head black .

bullocki, p. 298.

$4^{\prime}$. Whole head black
$1^{\prime}$. Plumage black and brown

galbula, p. 297.

spurius, p. 296.

Subgenus Icterus.

503. Icterus audubonii Giraud. Auduron Oriole.

Adults. - Under parts bright lemon yellow with sharply contrasting black head, chest patch, wings, and taiï; back varying from lemon yellow to yellowish green; wings with white edgings and yellowish green on coverts ; tail gradnated and narrowly tipped with lighter. Young: withont any black, upper parts olive-green, under parts yellow. Male: length (skins) $8.45-9.20$, wing $3.79-4.0 .3$, tanl 4.04-4.18, bill 1.01-1.11. Female: length (skins) 8.00-9.30, wing 3.70-3.86, tail 3.92-4.17, bill .86-1.04.

Distribution. - Resident from southern Texas to central and eastern Mexico.

Nest. - Semi-pensile, woven of fine, wiry grasses and lined with grasstops, hmig usually 6 to 14 feet from the gronnd in mesquite trees, thickets, or open woods. Eggs : 3 to 5, pale bluish or grayish white. with light hair lines of brown and dark purple; or else the ground color obscured by pale purple suffusion, blotched and streaked with brown and lavender.

Mr. Atwater has twice found the Audubon oriole near San Antonio in the high pecan timber, and considers it a rare winter wanderer. Dr. Merrill states that it is resident in the lower Rio Grande Valley near Brownsville. In summer, he says, it is usually found in deep woods away from houses, but in winter is less shy and retiring.

\section{Icterus parisorum Bonap. Scott ORIOLE.}

Adult male in spring and summer. - Black, except for bright lemon yellow belly, shoulders, posterior parts of back, and white and yellow markings on wings and tail ; rmmp and upper tail coverts usnally tinged with

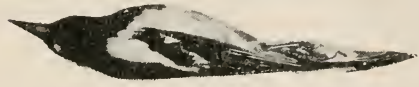

Fig. 362. olive. Adult male in winter: like summer male but white markmgs on wings broader; feathers of back more or less edged with gray; rump and upper tail eoverts more strongly washed with olive or gray; flanks tinged with olive. Adult female: nnder parts greenish rellow; npper parts olive green, becoming yellowish on rump and outer tail feathers, marked with gravish brown on back; wing crossed by two white bars, and quills edged with whitish. Immature male: plumage varying from that of female to that of male, according to age. Young of year: simnlar to adult female, bnt with all the wing feathers edged and tipped with white, wing band yellowish, tail tipped with yellow, breast obscured by brownish, and yellow of mider parts paler and greener. Male: length (skins) 7.40-8.30, wing :3.88-4.20, tail $3.12-3.62$, bill .82-.97. Female: length (skins) 7.2.5-8.00, wing $3.72-4.02$, tail 3.203.45 , bill . $.80-.90$. 
Remarks. - 1)r. Allen has recorded two females showing great variation in phumage - both with throat and breast black, and one with whole head blackish like yearling males, the other with head like the ordinary adult female.

Distribution. - Resident in Lower Sonoran zone from western Texas to California, and from southern parts of Utah and Nevada south to Lower California and Mexico.

Nest. - Woven of grass, vucea fibers, horsehair, cotton, and string when available, placed usually in yuceas, but sometimes in other trees. Eggs: 2 to 4, pale blue, blotched and streaked with browns and grays.

Food. - Grasshoppers, beetles, caterpillars, larvæ, fruit, and berries.

The name purisorum is associated with interesting desert canyons whose wide-sloping sides are covered with stones, agaves, dasylirions, yuccas, and other arid thorn brush, and crowned with the fouquiera whose widely spreading arms are silhouetted against the blue sky. In the midst of a cactus wren's song, it may be, you will hear the clear meadowlark-like note of the oriole., One that we found in such a situation in New Mexico was a brilliant black and lemon adult in a low juniper feeding a brood of dingy greenish yellow young who looked like commoners in camp clothes beside a personage in broadcloth. Although his family were grown and picking about feeding themselves, their indulgent parent was diligently hunting caterpillars for them, having time for only an occasional outburst of his beautiful song. On the hills back of the Pecos River we often found parisorum nests in the yuccas, sometimes in the same one with a whitenecked raven's nest. They were generally hung under the sharp drooping blades of the 5 ucca and woren of fibers frayed from the edges of yucca leares.

In the Chisos Mountains, Mr. Bailey often found the orioles feeding among the flowers of a giant agave, the greenish yellow color of which they match in a suggestively protective manner.

\section{Subgenus Pendulinus.}

\section{Icterus cucullatus sennetti Ridgw. Sennett Oriole.}

Adult male. - Back, wings, and tail black, the wings marked with white ; rest of plumage deep cadninm yellow. Adult female: under parts dull or pale gamboge. back and scapulars grayish. Male: length (skins) 7.407.86, wing 3.17-3.36, tail 3.46-3.90. bill .78-.81. Female: length (skins) 7.00-7.50, wing 3.07-3.20, tail 3.30-3.3.48, bill .72-.7\%.

Distribution. - From the lower Rio Grande Valley in Texas, south to Mexico.

In the narrow strip between the Rio Coloral and the Mexican line in Texas, where the dense, thorny thickets are full of cactus and low yucca trees, the Sennett oriole makes its home. Here, as we were looking for the nest of a verdin one day, an oriole flew from under the drooping spears of a yucca. On inspection we found one of the 
most skillfully wrought nests a bird ever made, a perfect basket, hung by the handle to the drooping bayonets in such a way that the sharp points protected it and yet left the bird an easy entrance. The nest was made of yucca fiber, decorative touches being given by bits of gray moss stuck on here and there.

\section{5a. Icterus cucullatus nelsoni Ridgu. Arizona Hoodm Oriole.}

Adult male. - Plumage yellow, except for black of oval throat patch, fore part of back. wings, and tail, white bars and edgings of wings, and

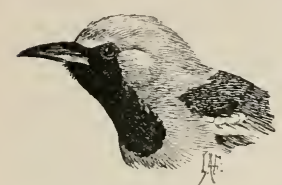

Fig. 363 . tip of tail. Adult female: plain yellow below ; olive green above. washed with gray on back; wings brownish with two white bands and whitish edgings to quills. Foung males in second year: like adult females. but throat patch as in males. Young in first year: like adult feniale, but colors duller. plumage especially on upper parts suffused with brownish. Male: length (skins) 6.90-7.80, wing 3.40-3.56, tail 3.2.2-3.78, bill .82-.87. Female: length (skins) $6.90-7.30$, wing $: 3.18-3.26$, tail $: 3.17-9.28$, bill .78-.82.

Distribution. - Breeds from Tepic, western Mexico, and Lower California north to southwestern New Mexico, Arizona, and through the southern half of California west of the Sierra Nevada.

Nest. - Cup-shaped, semipensile or securely attached to twigs on sides, woven of materials like fresh wiry grass and yucea fibers, and placed in such trees as sycamores, oaks, blue gums, figs, and palms; usually made of Spanish moss, often built in tufts of moss. Eggs: :3 to $\bar{\zeta}$, speckled with hair brown and with zigzag markings.

Food. - Insects and larvæ. including hairless caterpillars and small grasshoppers.

In southern California the Arizona form of cucullutus has an aggravating way of spending his time lunting about in the chaparral. coming into sight only as he makes short sallies into the air or dashes past you from one section of brush to another.

He sings when out of sight, but the song is delivered with such fervor that you can follow him by it when he is invisible. It is a typical oriole song, a clear whistle with a rhythmic rise and fall, and a chatter interposed between the high and low notes that sounds as if he were taking breath. His mate is a quasi-musician, giving his chatter and the first strain of his song.

In southern Arizona, where nulsomi is most abundant, Major Bendire says that its farorite haunts are dense, shady groves of cottonwoods and mesquites in the creek bottoms.

\section{Icterus spurius (Limn.). Orchard Oriole.}

Adult male in spring and summer. - Black except for dark chestnut bellr. shoulders, and hinder part of back; browu and whitish edgings of wings. and light tip to tail. Adult male in fall and winter: like smmmer male. but feathers of scapulars. interscapulars, and sometimes head and neck. edged with buffy gray, olive, or chestunt; those of under parts sometimes 
edged with yellowish. Adult female: under parts plain canary yellow; upper parts olive green, grayish brown across back; wings brownish, with white bars and edgings. Male in second year: like adult female, but lores and throat black. 'The rest of the black and the chestnut appear in increasingly large patches till the adult plumage is reached. Young in first plumage: similar to female. bnt lighter wing nuakings tipped with buff. Male: length (skins) 5.80-6.50, wing 2.91-3.2.5, tail 2.50-2..45), bill .59-.69. Female: length (skins) 5.90-6.30, wing 2.70-3.05), tail 2.50-2.90, bill .60.6S.

Distribution. - Breeds in Upper and Lower Sonoran zones from the eastern United States, west to the Rocky Mountains, and Texas; migrates to Cuba and South America.

Nest. - Basket-like, sometimes pensile, woven of fresh grass and placed in bushes or trees usually 12 to 20 feet from the gromnd. Eggs: nsnally 4 to 6 , bluish white, marked most heavily about the larger end with blotches and scrawls of browns and purples.

Food. - Mainly small beetles, plant lice, flies, hairless caterpillars, cabbage worms, grasshoppers, rose bugs, and larvæ.

In the prairie states. Major Bendire says, the orchard oriole is found mainly in trees and shrubbery along streams. When liring in orchards and gardens it makes itself most useful by destroying the insects with which the fruit and vegetable grower have to contend.

\section{Subgenus Yphantes.}

\section{Icterus galbula (Linn.). Baltimore Oriole.}

Adult male in spring and summer. - Under parts and hinder part of back bright orange or orange red; head, neck, and fore parts of back black: wings with yellow shoulder patch and white wing bar; tail black with vellow corners. Adult male in winter: like summer male, but scapulars and interscapulars edged with dull orange ; orange of rump and upper tail coverts more or less obscured with olive; white wing edging's broader. Adult female in summer: under parts orange or brownish rellow, varying from almost ummarked to the black color pattern of male in duller. less uniform strle: upper parts rellowish olive, streaked more or less with

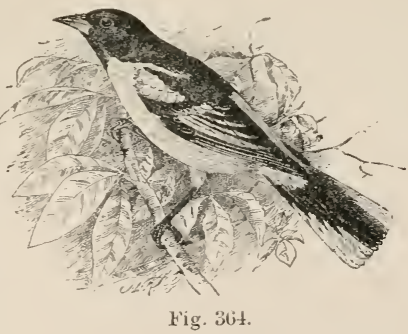
black, if not with solid black of male: rump yellowish, tail greenish yellow; wings brownish. with whitish wing bars. Adult female in uinter: like summer female, but plumage softer and back tinged with gras. Immature male: varying between adult male and female or indistingnishable from female. Toung in first fall and winter: similar to adult females, which are without black on throat. Young, first plumage: like lighter colored female, but upper parts grayer and under parts with softer colors. Male: length (skius) 6.80-7.40, wing $3.60-4.02$, tail 2.78-3.15, bill .(6)-.78. Female: length (skins) $6.20-6.70$, wing 3.35-3.62. tail 2.60-2.83, bill .63-.71.

Distribution. - Breeds in Transition zone of eastern Nortl America from latitude $55^{\circ}$ in Saskatchewan to Texas, west to the Roeky Mountains: migrates through eastern Mexico to Panama. 
Nest. - Long, bag-shaped, hung from the rim, usually to slender branches 8 to 50 feet from the ground; woven of hemp, horsehair, or twine, lined largely with hair and grass. Eggs: 4 to 6, grayish, irregularly streaked and blotched, most heavily about the larger end, with black. brown, and lavender.

Food. - Mainly noxious insects and larvæ, including click beetles, locusts, grasshoppers, weevils, ants, plant lice, and caterpillars.

The Baltimore oriole goes as far west as Colorado and Montana, but bullocki, its western congener, is more abundant west of the Plains.

\section{Icterus bullocki (Swains.). Bullock Oriole.}

Adult male in summer. - Under parts, sides of head and neck, and superciliary orange; narrow throat patch, crown. back of neck, back. and

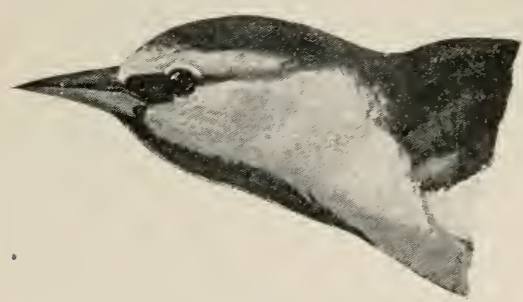

Fig. $36 \tilde{.}$ stripe through eye, black; wings with conspicuous white patch and edgings; tail with middle feathers black, changing to almost pure yellow on onter feathers. Adult male in winter: like summer male, but scapulars and interscapulars edged with gray, feathers of rump and upper tail coverts tipped with gray, of under parts edged with whitish. Adult female: under parts lemon yellow, fading to gray on belly; throat usually with more or less of black; upper parts olivaceous, fading to brownish and sometimes streaked with black on back, but brightening to olive yellow or deeper on rump and tail; wings with white bands. Immature male in second year: similar to adult female, but lores and median line of throat black. Young in first plumage: similar to female, but colors duller, washed more or less with buffy, with no trace of black on the throat, and yellow sometimes almost wanting. Male: length (skins) 6.75-7.60, wing $3.82-4.0 \%$, tail $2.98-3.2 \%$, bill .65-.81. Female: length (skins) 6.60-7.50, wing 3.52-3.47, tail 2.75-3.12, bill .67-.75.

Distribution. - Breeds in Upper and Lower Sonoran zones of western North America from southern parts of British Columbia, Alberta, and Assiniboia, sonth to western Texas and Lower California; and from Dakota and Texas to the Pacific; migrates to the valley of Mexico and Puebla.

Nest. - Hnng by rim and fastened to sides of a branch 6 to 40 feet from the ground, often in bunches of mistletoe in cottonwoods, poplars, and mesquites, woven of horsehair or vegetable fibers and inner bark, lined with horsehair, down, and wool. Eggs : 3 to 6 , grayish or bluish white or pale buffy, marked with irregnlar hair lines. mainly around the larger end.

Food. - Principally injurious insects and larvæ, with a few wild berries.

In southern California, where the Arizona hooded and Bullock orioles occur together, the light, yellow-headed nelsoni usually comes north later and lives largely in the chaparral, while the dark orange 
bullocki lives in the treetops. The neighborhood of water is not considered a necessity by the Bullock, but in irrigated districts it is especially fond of the sumny cottonwood hedges bordering irrigation ditches, and abounds on the rolling prairie country, finding most congenial nesting grounds in the groves that fringe the streams. It also nests in towns, as the Baltimore oriole does in the east. When possible it hangs its nest from a tall sycamore or other large deciduous tree, but if nothing better offers builds in low willows. In the bottom lands near Chinese Camp, on the Yosemite Valley road, we have seen small willows fairly hung with the bag-like nests. The young birds are much less skilful builders than the adults, Mr. Illingworth notes, their nests being loosely supported and made of coarse vegetable tibers instead of horsehair and twine.

In general habits as well as appearance bullocki resembles the Baltimore oriole. The ranges of the two birds overlap along the eastern part of the range of bullocki.

In regard to the food of the hooded and Bullock orioles Mr. Illingworth says: "The orioles are very beneficial to the horticulturist, although they eat some early fruit, such as berries, cherries, etc., but no fruit man will begrudge them these if he thoroughly understands their habits. The chief food of the orioles consists of insects and injurious caterpillars, and I have often watched them while ther were searching among the branches for this latter food. They are particularly fond of a small green caterpillar that destroyed the foliage of the prune-trees a few years ago. The orioles are often seen in the berry patches, but they are usually in search of insects, as is proven by the examination of a great number of stomachs." (The Condor, July, 1901, p. 100.)

In Phœnix, Arizona, they have been seen eating a tree caterpillar, which was a pest at the time.

\section{GENUS SCOLECOPHAGUS.}

General Characters. - Bill not longer than head, slender like that of a robin, tip decurved, cutting edges bent in; wings pointed, longer than tail ; side toes short, with moderate claws.

KEY TO ADULT MALES IN SUMMER PLUMAGE.

1. Plumage glossy black with faint greenish luster; bill stout. Nebraska to the Pacific . . . . . cyanocephalus, p. 300.

1'. Plumage glossy greenish black; bill slender. Colorado to Atlantic.

carolinus, p. 299.

\section{Scolecophagus carolinus (Miill.). Resty Blackirird.}

Adult male in summer. - Uniform glossv'black, with bluish luster on head and neck and bluish green luster on bodr; under tail corerts more or less edged with whitish. Adult male in vinter: black, more or less 
obscured by rusty brown above and buffy below. Adult female in summer: brownish slate, faintly glossed with bluish green on upper parts. Adult female in winter: brownish gray or slaty, washed with rusty above and buffy beneath. Ioung: like female in winter, but colors duller and plumage looser; wings with rusty bands. Male: length (skins) $8.25-9.30$, wing 4.50-4.60, tail 3.39-3.65, bill .72-.78. Female: length (skins) 7.80-8.30, wing $4.21-4.39$, tail $3.11-3.30$, bill .6S-.75.

Distribution. - Breeds in Boreal zone from Alaska and Hudson Bay south to northern New York, New England, and Michigan, and west in the United States to western Nebraska and Colorado; migrates to the Gnlf of liexico.

Nest. - A bulky structmre of dried twigs, slmeds of bark, and mosses. placed in bushes. Eggs : 2 to 8 , pale bluish green, olive, or rusty brown, speckled or blotehed with brown.

Food. - Preferably animal matter, including insects, especially beetles and grasshoppers; also grain and weed seed.

The rusty blackbird is mainly a bird of the eastern states, but occasionally goes as far west as the eastern slope of the Rocky Mountains. Unlike most other blackhirds, it is fond of forests.

\section{Scolecophagus cyanocephalus (Wagl.). BREwer} BLACK PIRD.

Adult male in summer. - Glossy greenish black. head and neck purplish

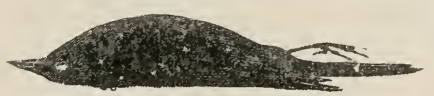

Fig. 366. black. Adult male in winter: similar to summer male, but more highly glossed. Adult female in summer : head, neck, and under parts brownish gray, faintly glossed with violet on head and neck and with green on under parts; upper parts darker. wings and tail more glossed with bluish green. Adult female in uinter: similar to summer female, but paler, more buffy gray anteriorly. Immature male in first winter: like adult male, but feathers largely tipped with gravish brown. Young: like winter females, but feathers with different texture and without gloss. Male: length (skins) S.4(-9.75, wing 4.7.3-5.27, tail $3.62-4.20$, bill $.83-.9 \%$. Female : length (skins) 7.80-8.70, wing 4.564.71, tail :3.4:-3.(i.), bill .75-.8.2.

Distribution. - Transition and Upper Sonoran zone from Manitoba and British Columbia sonth in the mountains to Lower California and Gnatemala, and from northwestern Minnesota and Nebraska west to the Pacific.

Nest. - Low, in trees or bnshes made of sticks, plant stallis, grass, bark, and rootlets, generally cemented with earth or manure, and lined witl rootlets or hair. Eggs : usually 4 to 6, grayish or greenish ground color, variably marked but usually profusely blotehed. streaked, and spotted with browns and lavender.

Food. - Largely grain. weed seed, and grasshoppers.

The Brewer blackhird, whose glossy blue black coat makes him one of the handsomest of his race, is the familiar dooryard blackbird of the west. Ile often nests in oaks beside ranch houses, and lords it over the barnyard fowls with erreat airs of proprictorship.

Like all blackbirds he has mannerisms. When disturbed at the nest he spreads his tail nervously and calls chuck, and when sitting 
on a fence sometimes looks at you out of his pale yellow eyes and then bristles up and gives a loud shrill whistle.

Although quick to appreciate the advantages of civilization, ryunocephalus is by no means exclusively a dooryard bird, nesting principally, incleed, in unsettled districts, in willows in the pine belt of Arizona and in sagebrush around the edges of marshes in the arid Great Basin country. It nests in much smaller colonies than many of the blackbirds, five to ten pairs being the common number.

After the breeding season the birds may be seen as high as timberline on MIt. Shasta, solemnly walking over the rocks around snow streams, or as low down as sea-level, at places like Santa Cruz, where they run around on the hard sand beach, feeding and bathing in the shallows filled with seaweed.

Their food raries with the season and the locality. On ranches they do a great deal of good by following the plough and destroying grubs, but after the nesting season they gather in large flocks and often do serious harm in the grain fields.

\section{GENUS QUISCALUS.}

General Characters. - Bill about as long as head, crow-like, but more tapering and acute; tail graduated and folded laterally ; feet stout ; tarsus about equal to middle toe and claw.

\section{KEY TO ADULT MALES.}

1. Body bronzy, size medium . . . . . . . . . . æneus, p. 301. $1^{\prime}$. Body greenish, size very large . . . . . macrourus. p. 302 .

\section{Subgenus Quiscalus.}

\section{1b. Quiscalus quiscula æneus (Ridgu.). Bronzed GraCKLE.}

Adult male. - Whole head and neck purple, dark peacock blue or green, in sharp contrast to uniform bronze of body; wings and tail plum purple, not metallic. Adult female : similar. but smaller and duller. Young: from plain dark brown to colors of adults. Yale: length (skins) $10.90-12.50$. wing 5.35-ti.0:3, bill 1.21-1.32.2. Female : length (skins) $9.2 .5-$ 10.60, wing 4.5.3-5.15, tail $4.16-$ 4.46. bill 1.1:3-1.2:?,

Distribution. - From Great Slave Lake south to Lonisiana and western Texas. and from the Alleghanies and sonthern New England west to the Rocky Mountains; migrating to the southeastern states except the coast districts. Breeds throughout its range, but chiefly north of its winter range. 
Nest. - A coarse and bulky but compact structure of dried grasses, built in trees (often cavities). Eggs: :3 to 7 , pale green or greenish blue, olive or olive whitish, coarsely spotted and irregularly lined with brown and black.

Food. - Largely noxious insects, corn, and the small grains.

The bronzed grackles may be seen as far west as the eastern base of the Rocky Mountains. Like all the grackles they spend a good share of their time on the ground walking over the grass, turning their heads this way and that, when the sun glances from their handsome bronzy backs. When they fly their tails turn into rudders, and they move along with as straight and steady a course as a skillfully guided boat. Their gurgling, squeaky notes cannot be called musical, but have a crisp spring sound, and their clatter has a hearty social ring as they fill a treetop or scatter over a park lawn. Although they do considerable damage when descending in hordes on grain fields, their steady work through the year balances on the right side, for they are not only assiduous in following the plough for grubs, but devote themselves largely to catching grasshoppers, crickets, locusts, and other destructive insects.

\section{Subgenus Megaquiscalus}

\section{3a. Quiscalus major macrourus (Swains.). Great-TaILED GRACKLE: JACKDAW.}

Adult male. - Head, neck, and breast purple, changing throngh steel blue to greenish on belly and back. Adult female: under parts hair brown; head dark brown, darkening on back to blackish, glossed with green and purple. Immature male (first year): upper parts black, more or less glossed with bluish green; under parts sooty black. Young: like adult female, but browner, without gloss above, more buffy below. Male: length (skins) 15.50-18.00, wing $7.25-7.83$, tail $7.70-9.25$, bill $1.56-1.89$. Female: length (skins) 11.20-14.00, wing 5.60-6.24, tail 5.08-6.50, bill $1.3 ; \%-1.5 \%$.

Distribution. - Sonthern Texas and south through Mexico (west to edge of plateau) to northern South America.

Nest. - Bulky, made largely of dried grass and spanish moss, usualiy with an inside coating of mud; built in low trees or bushes, often in swampy places, sometimes in towns. Eggs : ;) to 5, pale bluish or greenish. drab. olive, or purplish gray, grotesquely marked with brown and black lines.

Food. - Insects and their larvæ, crustaceans, dead fish, seeds, and grain.

The jackdaws, as the grackles are called in southern Texas, nest in the 'oak motts' of the shin oak prairie between Corpus Christi and Brownsville. We found them building the last of April at San I gnatia mott, an oasis-like grove in the middle of the prairie. They made the noisiest blackbird colony one could wish to camp below ; and when to their squeaking clangor and hubbub was added the 
shrill clatter of the scissor-tail flycatchers, the rattle of woodpeckers, the vociferations of mockingbirds, the cooing of doves, the piping notes of the vermilion flycatcher, and the voices of passing birds, it was quite like camping in an aviary. Though usually visited by only an occasional Mexican, the birds went about their business as if camp-fires were an everyday occurrence, and paid little heed to us except when we shot a rattlesnake or made other undue signs of our presence.

Much to our surprise the blackbirds sang in notes that were sweet and astonishingly like the call-notes of the goldfinch. But they appeared particularly fond of making a noise that sounded like the breaking of sticks, and it took a prominent part in a ludicrous performance which they went through. Seated on an oak top, where his humble spouse could see him to the best adrantage, an old male would begin by spreading his wings and tail to their fullest breadth and making a crackling 'breaking brush' sound which he evidently considered a striking prelude. This done he would quiver his wings frantically and opening wide his bill emit a high falsetto squeal, quee-ee, quee-ee, quee-ee, quee-ee, perhaps attuned to the feminine blackbird ear. But his coup d'état, which should have wrung admiration from the most unappreciative mate, consisted in striking an attitude, his long bill pointed as nearly straight to the sky as his neck would permit. Posed in this way he would sit like a statue, with a most ludicrous air of greatness. Incredible as it may appear, instead of standing spellbound before him, his spouse, practical housewife that she was, whatever her secret admiration may have been, through all his lordship's play calmly went about gathering sticks.

\section{FAMILY FRINGILLID $巴$ : FINCHES, SPARROWS, ETC.}

\section{KEY TO GENERA.}

1. Wing conspicuously long and pointed. primaries exceeding secondaries by nearly or more than twice the length of tarsus.

2. Tips of bill crossed in adults

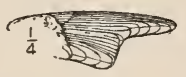

Fig, 368.

Loxia, p. 313 .

Fig. 369 .

$2^{\prime}$. Tips of bill not crossed.

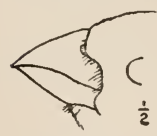

3. Depth of bill at base greater than length of hind toe with claw . . . . . Coccothraustes, p. 307.

Fig. 370 .

3 . Depth of bill at base much less than length of hind toe with claw.

4. Hind claw longer than its toe. 
5. Wing $2.75-3.10$

Acanthis, p. 318 .

Fig. 371.

5'. Wing $3.80-4.50$.

6. Nostril wholly concealed; phumage blackish or brown, sometimes marked with rose or white.

Leucosticte, p. 315.

6.' Nostril partly exposed. . . Passerina, p. 325.

Fig. 372.

t'. Hind claw shorter than its toe.

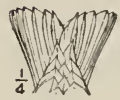

5. Upper tail coverts pointed.

Rhynchophanes, p. 32s.

Fig. 373 .

5'. Upper tail coverts not pointed; males largely reddish.

(part of) Carpodacus, p. 309.

1'. Wing not conspicuonsly long and pointed, primaries exceeding secondaries by less than twice the length of tarsus.

2. Primaries exceeding secondaries by more than length of tarsis.

3. Outer tail feathers marked with white or yellow.

4. Tail marked with yellow . . . : Spinus, p. 323 .

Fig. 374.

$t^{\prime}$. Tail marked with white.

5. Under wing coverts yellow or rose; plumage largely black in males, streaked in females.

Zamelodia, p. 371.

Fig. 375 .

5'. Under wing coverts not yellow or rose.

6. Tail graduated.

Chondestes, p. 336 .

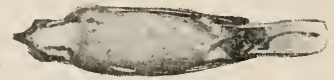

Fig. 376.

6'. Tail nearly even or emargiuate.

7. Hind diaw longer than its toe. and not sharply curved . . . . Calcarius, p. 32:.

Fig. 377 .

7'. Hind claw shorter than its toe, and sharply curved.

\&. Plumage streaked, largely brown.

Fig. 378.

Poœcetes, p. 32:9.

S'.Plumage unstreaked, summer males yellow beneath . . Astragalinus, p. 319. 
3 . Outer tail feathers not marked with white or yellow.

4. Upper parts streaked.

5. Under parts more or less yellow . . Spiza, p. 377.

j'. Under parts mainls gray ; males with chin and throat black. Passer, p. :32t.

Fig. 379.

4'. Upper parts not streaked.

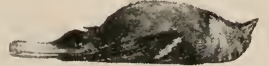

Fig. 380 .

5. Nostrils concealed, plumage rose, or gray mixcd with orange brown . . . . . Pinicola, p. 308.

Fig. 381.

$\therefore$ Nostrils exposed, males blue . Guiraca, p. 373. 2 '. Primaries exceeding secondaries by less than length of tarsus.

:3. Head crested.

4. Upper mandible greatly curved.

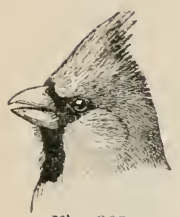

Pyrrhuloxia, p. ::70.

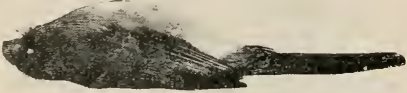

Fig. 382.

t'. Upper mandible only slightly curved.

Cardinalis, p. $36 \%$.

Fig. 383.

:3'. Head not erested.

4. Tarsus longer than middle toe with claw.

(5) Hind claw longer than its toe.

6. Tail with white outer tips (except fuscus group).

Pipilo. p. 36:3.

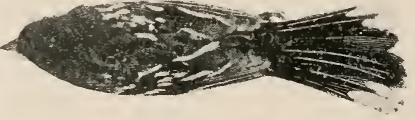

Fig. 384 .

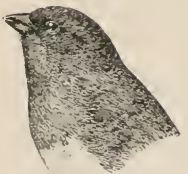

6'. Tail with white edges, plumage largely gray or black . . . . Junco. p. 34\%.

Fig. 385 .

5 '. Hind claw shorter than its toe.

6. Tail black.

6'. 'Tail not black.

7. Tail olive green . . . Arremonops, p. 363.

7. Tail brown.

\&. Tail deeply emarginate . Spizella, p. 341.

8'. Tail rounded or graduated. 
9. Wing rounded or truncate at tip.

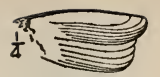

Fig. 386.

10. Edge of wing yellow . Peucæa, p. 352. $10^{\prime}$. Edge of wing white or grayish.

Aimophila, p. 353.

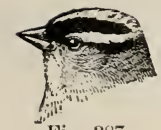

Fig. 387.

$9^{\prime}$. Wing rather pointed at tip (except Z. albicollis, in which tarsus is same lengtl as middle toe with claw).

Zonotrichia, p. 337.

4'. Tarsus about equal to middle toe with claw.

5. Inner claw reaching beyond tip of middle toe.

6. Wings and tail green.

Oreospiza, p. 868.

$6^{\prime}$. Wings and tail rufous.

$$
\text { Passerella, p. } 360 \text {. }
$$

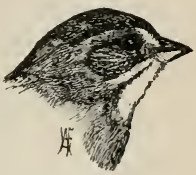

Fig. 388.

Fig. 389.

5. Inner claw not reaching to tip of middle toe.

6. Length about 8 to 9.

( fuscus group) Pipilo, p. 36:3.

$6^{\prime}$. Length less than 8.

7. Wing with whitish patches

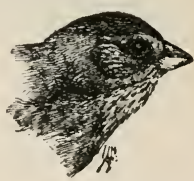

Fig. 390.

(summer males black) Calamospiza, p. 377.

$7^{\prime}$. W'ing without white patehes.

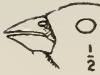

Fig. 391.

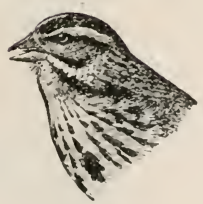

Fig. 392 .

8. Under mandible decidedly deeper than upper ; adult males with blue, and sometimes red, green, or purple. . Cyanospiza, p. 37t.

$S^{\prime}$. Upper mandible deeper or equal to under.

9. 'Tail feathers sharp-pointed at tip.

10. Bill sharply curved.

$10^{\prime}$. Bill not sharply curved.

Sporophila, p. 376. Ammodramus. p. : $: 30$.

9 9' Tail feathers not sharp-pointed at tip. 10. Tail graduated. Melospiza, p. 35\%.

10 '. 'Tail even or emarginate, adult males with plumage partly reddish.

Carpodacus, p. 309. 


\section{GENUS COCCOTHRAUSTES.}

\section{Subgenus Hesperiphona.}

\section{4a. Coccothraustes vespertinus montanus (Ridgw.). Westers EveNiNg GROsBeAK.}

Bill large, swollen, depth at base greater than length of hind toe with claw; wing long, pointed, more than five times as long as tarsus; tail short, emarginate; feet small and weak; tarsus little if any longer than culmen. Adult male: forehead and superciliary bright yellow ; crown, wings, and tail black, wings with large white patches; rest of upper parts olive, grading through yellowish green to yellow on rump; under parts greenish rellow, becoming lemon yellow on under wing and tail coverts. Adult female: prevailing color sellowish or yellowish brown; throat bordered by dusky; whitish patch on wings. Foung: similar to female, but duller and markings less defined. Male: length (skins), 6.70-7.30. wing 4.184.59, tail 2.50-2.87, bill .7s-89, width of bill at base .49-.60. $\mathrm{Fe}$ male: length (skins), $6.50-7.30$, wing 4.10-4.40, tail 2.40-2.78, bill .74.83 , width of bill at base, .51.-5\%.

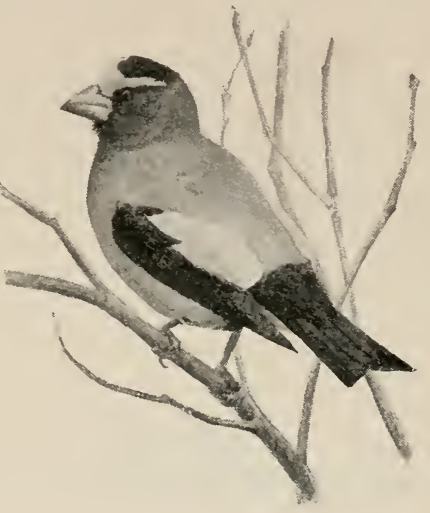

Fig. 393.

Distribution. - Breeds in Canadian and Hudsonian zones in western United States from the Plains to the Pacific, and south through nountains . of northwestern Mexico.

Nest. - 15 to 50 feet from the ground in the top of a conifer or thick willow, a comparatively flat, slight structure of small sticks, roots, and sometimes tree lichens lined with finer roots. Eggs: 3 or 4, clear green, blotehed with pale brown.

Food. - Insects, sucl as caterpillars ; seeds, and the fruit or buds of mistletoe, hackberry, box elder, juniper, maple, ash, alder, and related species.

In the Canadian zone forests after the nesting season you occasionally see a wandering flock of evening grosbeaks. Sometimes there will be only seren or eight in the flock, sometimes twenty fire or more. Their commonest call, as they pass over or light in a fir top, is a short whistle that can always be recognized by its wild, free quality, but they have also a loud 'beady' note something like that of the waswing.

In the mountains of Arizona the grosbeaks breed in canyons and near water, Dr. Mearns says, afterwards descending to the oaks of the foothills with their young.

In winter, grosbeaks are very common in Portland, Oregon. where Mr. Anthony says large flocks feed in the maples, picking up the fallen seeds at the feet of passers-by. 
On a Sierra grade we have passed a flock busily gatliering wild cherries in a bush beside the road, and when camped under the firs of MIt. Shasta have had wandering bands stop for a drink from the camp brook, delighting us by their striking yellow and white plumage. Although they are so highly colored and in flight their white wing patches make such prominent directive marks, this very yellow and white coloration often becomes positively protective. While watching the birds on Mt. Shasta one day, I was struck by the conspicuousness of one that flew across an open space. As it lit on a dead stub whose silvery branches were touched with yellow lichen, to my amazement it simply vanished. Its peculiar greenish yellow toned in perfectly with the greenish yellow of the lichen. The breeding range of the grosbeak is largely coincident with the range of the lichen, the lichen being a striking feature of the forests of the Sierra Nevada, Cascades, and northern Rockies, so that the unusual coloration of the bird may be of marked significance.

\section{GENUS PINICOLA.}

Bill short. broad. and thick. npper mandible strongly eurved; nasal

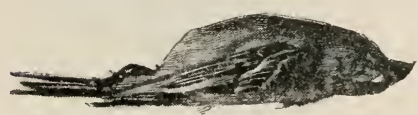

Fig. 394. plumules conspicuous, hiding nostrils; wing about five times as long as tarsus ; tail long, emarginate; feet small, tarsus not longer than middle toe withont claw.

\section{KEY TO ADELT MALES.}

1. Feathers of back with conspicnously dusky ceuters.

1'. Feathers of back without distinctly dusky centers.

alascensis, p. :30\%.

2. Bill and body smaller. High mountains of California.

2'. Bill and body larger. Rocky Mountains

californica, p. 308 .

515a. Pinicola enucleator montana Ridgu. Rocky Mountain Pine Grosbeak.

Like P.e.californica, but larger and slightly darker, adult male carmine red instead of vermilion. Wale: length (skius), $8.00-8.55)$, wing $4.72-4.86$, tail 3.67-4.00, bill .61-.68. Female: length (skius), 8.00-8.30, wing 4.65)4.69. tail $3.45-3.50 .0$.

Distribution. - Breeds in Hudsonian zone in the Rocky Monntains from Montana aud Idaho to New Mexico.

Nest. - A rather flat thin structure, largely of fine rootlets placed in coniferons trees. Eggs: greenish or bluish, spotted with brown and black.

Food. - Caterpillars, cocoons, coniferons seeds. needles, buds. and blossoms.

515b. P. e. californica Price. California Pine Grosbeak.

Adult male. - Iight vermilion red, head slightly tinged with yellow and pink, and changing to ash gray on seapulars, beliy, flanks. and under tail 
coverts; plumage everywhere gray beneath the surface, giving an effect of immaturity; scapulars and feathers of the central back with only faint trace of dusky centers; wings and tail dusky, feathers tipped and edged with whitish. Adult female: general color clear ash gray, bright tawny yellow on top and sides of head, back of neck, and middle of breast; tail with faint yellow wash on upper coverts. Young: like female, but brownish gray, with brownish and grayish edgings to wings and tail. Male: length (skins), 7.75, wing 4.5:3-4.52, tail 3.60-4.21, bill .5.5-.59. Female: length (skins), 7.40-7.95, wing 4.05-4.25, tail 3.58-4.05, bill .55-.62.

Distribution. - Breeds in Hudsonian zone in the higher parts of the Sierra Nevada, central California.

The pine grosbeaks are associated with patches of snow and furry hemlocks on the mountain heights where Townsend solitaires live and nutcrackers come from the dwarf pines of the peaks.

The California form of Pinicola is found in the high Sierra, and in July, 1900, when climbing the wooded side of the old crater of Lincoln Peak, we had the good fortune to meet with a pair of the lovely birds at $; 800$ feet. They were as characteristically tame and trustful as they always are in gunless regions. Flying down to a snowbank in front of us they hopped over its surface, busily picking up what we supposed to be seeds from the hemlock cones, quite regardless of us, though so near that we could easily have photographed them had the evergreens let in enough light for a snap-shot.

Afterwards, in camp, three hundred feet lower, a number of the grosbeaks stopped at different times in the beautiful little hemlocks over our tent. Mlost of them were in the yellowish plumage, but one or two were rare rose-colored beauties that would excite the admiration of the most insensible. While resting they gave their soft call-notes and warbled their sweet rolling song, and though they were soon off and away they had lent a new distinction to the hemlocks that, in memory, will always be graced by their gentle presence.

\section{5c. P. e. alascensis Ridgu. Alaskan Pine Grosbeak.}

Adult male. - Body mainly red. pinkish in winter, fading to gray on belly; back with centers of feathers strikingly dark brownish; wings with two white bars, whitish tips, and edgings; bill short and turgid, upper mandible only slightly longer than lower. Adult female: top and sides of head and upper tail coverts tawny yellow, dark centers of feathers of back distinctly brounish. Mule: length (skins), 8.60-9.69, wing 4.41-5.00, tail 3.34-4.03, bill .5.5.60. Female: length (skins), 7.69-8.70, wing 4.48-4.73, tail 3.46-3.84, bill .57-.61.

Distribution. - Northwestern North America except Pacific coast, including wooded interior of Alaska; south in winter to Montana.

\section{GENUS CARPODACUS.}

General Characters. - Bill shorter than head, conical. thick, its depth at base greater than width; tarsus short, about equal to middle toe with claw. 


\section{KEY TO ADULT MALE CARPODACIS.}

1. Tail emarginate.

2. Top of head strikingly brighter than rump.

3. Under tail coverts conspicuously streaked .

cassini, p. 311.

3 . Under tail coverts not conspicuously streaked. Eastern United States . . . . . . . . . purpureus, p. 310 .

$2^{\prime}$. Top of head about color of rmmp . . . californicus, p. 310 .

1'. Tail even.

2. Wings longer, feet smaller . . . . . . . . frontalis, p. 312.

$2^{\prime}$. Wings shorter, feet larger . . . . . . . . clementis, p. 31:).

\section{Subgenus Carpodacus.}

\section{Carpodacus purpureus (Gmel.). Purple Finch.}

Like C. p. californicus, but wing longer, tail shorter ; adult male lighter, rump paler, upper parts less uniform; adult female lighter, less uniform. and less greenish.

Distribution. - Eastern North America, breeding from Hudson Bay to Pennsylvania; in winter south to Gulf coast ; accidental in Colorado.

Mr. Anthony shot a female purple finch at Denver, Nov. 15, 188.5.

\section{7a. Carpodacus purpureus californicus Baird. Califor-} NiA PURPle Finch.

Adult male. - Upper parts dark dull madder pink, wine purple on head

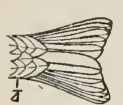

Fig. 395 . and paler, nore pinkish on rump; back streaked; under parts lighter rose pink and fading to unstreaked white on middle of belly and under tail coverts; sides and flanks usually strongly washed with brownish and broadly streaked with darker; tail much shorter than wing, deeply emarginate. Adult female: upper parts olivaceons, heavily streaked with brown; under parts whitish, narrowly streaked; side of head with white stripe crossing brown of ear coverts and side of throat. Young: similar to female, but colors duller and markings less distinct, edgings of wing feathers more buffy or tawny. Male: length (skius). 5.20-6.10, wing :3.03-3.20, tail 2.282.4:, bill .42-.49. Female: lengtl (skins) 5.09-5.84, wing 2.95-3.10, tail $2.10-2.33$, bill . $41-.49$.

Remarks. - The male California finch may be distingnished from the house finch by its under parts, which are streaked only on the sides. It differs from the Cassin finch in having crown and rump about the same color, and the back not strikingly streaked. The female California differs from the female house finch in being strongly olivaceous above, and having a white stripe on the side of the head through the brown area, and its tail much shorter than wing, and deeply emarginate. The female Cassin is more sharply streaked on the back with darker brown streaks.

Jistribution. - Breeds in mountains in Transition and Upper Sonoran zones of the Pacific coast region, from British Columbia south; migrates to southern California and Arizona.

Nest. - A rather thin, flat structure, composed largely of fine rootlets and grasses, placed on horizontal branches of trees. Eggs : 2 to 4 , greenish blue, or bluish green, finely speckled on larger end with black and dark brown.

The California purple finch is a bird of higher breeding range and less domestic nature than its relative the house finch. In central California, Mr. Belding says, it is common from 3000 to 5000 feet in summer, though of course it comes lower in winter. In Los Angeles 


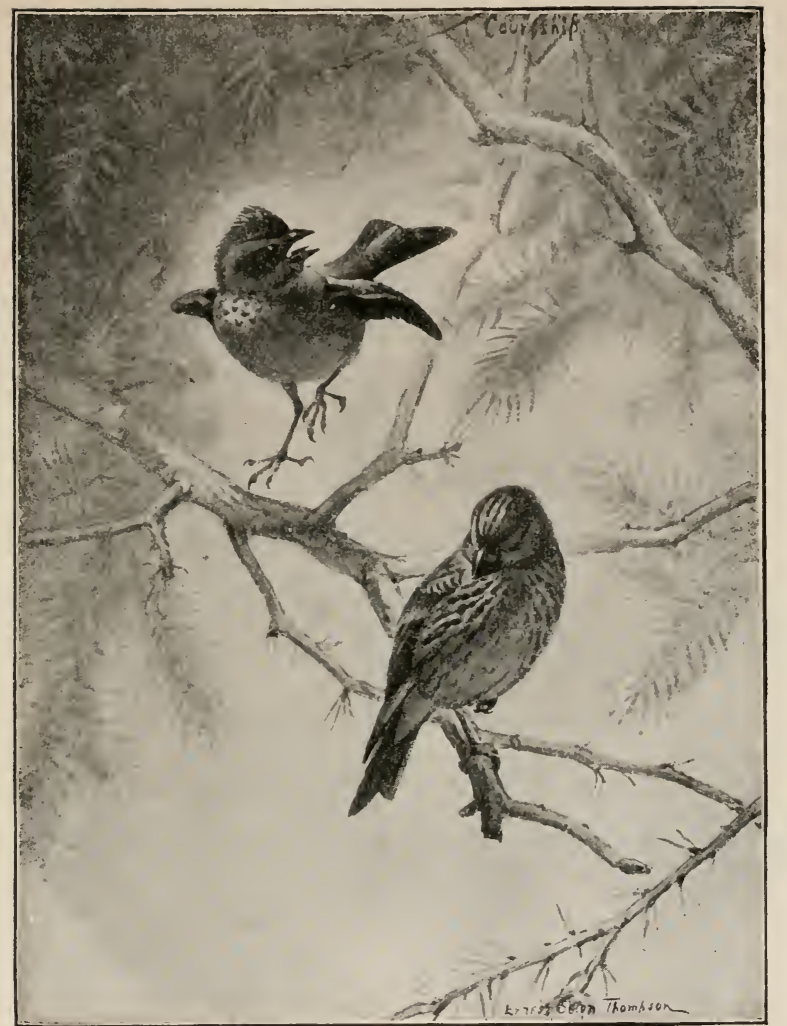

Fig. 396. Purple Finch.

County Mr. Grinnell finds it a common winter visitant of the mesas and lowlands, haunting thickets and brushy places in small companies.

\section{Carpodacus cassini Baird. Cassin Purple Finch.}

Adult male. - Top of head with squarish patch of bright erimson ; rump dull rose pink; back and seapnlars dull pinkish brown. sharply streaked with dark brown; under parts pale pink fading to unstreaked white on belly; lover tail coverts usually conspicuously streaked with dusky: wing feathers edged with reddish; tail much shorter than wing, deeply emarginate. Adult female: whole body sharply streaked with dusky; ground color of upper parts olive gray; of under parts white. Young: similar to female, but streaks of lower parts narrower and wing edgings more ochraceous. Male: length (skins) 5.89-6.29, wing 3.52-3.80, tail $2.34-2.71$, bill $.47-.51$. Female: length (skins) 5.55-6.0.5, wing $3.42-3.60$. bill .49-.50. 


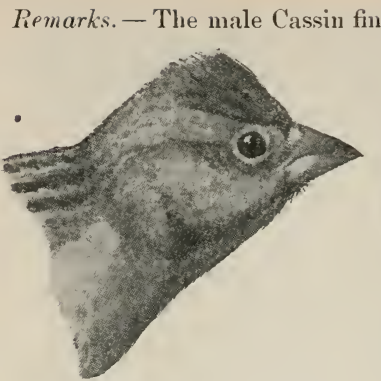

Fig. 397. Cassin Purple Finch.

ch may be distinguished by its large size, bright squarish erown pateh, dull rump, unstreaked under parts, and distinct streaks on under tail coverts.

Distribution. - Breeds in Canadian zone from British Columbia to Mexico; from the eastern slope of the Rocky Monntains to the Pacific; and migrates through Mexico to Mt. Orizaba.

Nest. - Near tops of young firs and pines on a horizontal branch; rather thin and flat, composed largely of rootlets and grasses. Eggs : 2 to 4, finely speckled, chiefly around the larger end, with black and dark brown.

The Cassin finch is the purple finch of the mountains, breeding from the lower edge of the firs to timberline. Its square crimson crown patch is a striking sign mark in the shade of the woods, and its sweet song gains richmess from its forest setting. Even in winter the birds stay as high as they can. In southern California, Mr. Grinuell says they rarely come as low as the foothills, but go about in small flocks, ferling in the brush as long as it is not entirely covered with snow.

\section{Subgenus Burrica.}

519. Carpodacus mexicanus frontalis (Say). House Finch. Adult mule. - Forehead, superciliary, and rump rose pink, orange red, or searlet; rest of upper parts brownish gray. sometimes washed with reddish; back not distinctly streaked; throat and breast reddish; belly whitish. sharply and closely streaked with broun;

Fig. 398, Male. tail not decidedly shorter than wing, nearly even ; wing feathers edged with pale gravish instead of reddish. Adult female:

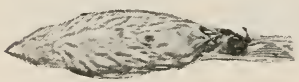

Fig. 399. Female. upper parts gravish brown. indistinctly streaked; under parts white. broadly streaked. Young: similar to female. bnt back more distinctly streaked, under parts more narrowly and less distinctly streaked: wing coverts tipped with buffy. Male: length (skins) 4.80-(j.10, wing :2.99-3.3:3, tail 2.14-2.60, bill

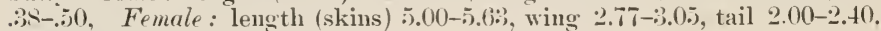
bill .:3(9-.4:3.

Remarks. - The sharp uniform streaking of under parts distinguish the house finch from the California and Cassin. Individuals suggest dichromatisu in varying anount of yellow in plumage. (See Condor, Jan. 1901, 13.)

Distribution. - Breeds in L T pper and Lower Sonoran zones from westem parts of Kansas and Texas to the Pacific, and from Oregon to northern Lower California and northern Mexico.

Nest. - Compactly woven, largely of dived grass stems and plant fibers. placed in trees, eactris. or sagebrusl, but preferably about houses. Eggs : 3 to 6 , bluish white or pale greenish blue sparsely speckled, chiefly aromnd larger end, with black. 
The house finch in the west is even more familiar than the robin in the east, nesting preferably in rines and odd nooks about houses, though it adopts any site that offers, from a stew-pan hung on a nail to a cactus. Its one requirement, is water, and this is so absolute that in the arid country the sight of one of these birds encourages the explorer to go on looking, for there is surely one water hole that has not dried up, be it ever so small, and he has only to follow the birds to find it.

The pretty finch is a charming, companionable little fellow, singing cheerily from morning till night a happy, bright song that goes well with the warmth and sunshine of the low country it lives in. The flight song of the male is quite characteristic, for he is so full of music that he never can contain himself, on the wing or off. He fairly bubbles orer with it when he goes a-courting and dances before his demure little brown lady-love.

The only objection to the familiarity of these pretty finches is their unfortunate though flattering appreciation of western fruit, but happily this is of smail moment in many of the cities within their range. In El Paso, Texas, the sweet song of the finch comes in through the open windows with most grateful cheer, suggesting forcibly the relief it would be if the English sparrow with his unmusical jabbering could be exchanged for our lovely native songster. In some of the country districts the fact that it has been seen eating Russian thistle seeds should weigh in its faror.

\section{9c. C. m. clementis (Mearns). Island Hodse Finch.}

Like C. m. frontalis, but with shorter wings, larger legs and feet, larger, more convex bill, heavier coloration, and broader striping on mnder parts. Male: length (skins) 5.20-5.8:3, wing 2.92-3.17, tail 2.11-2.42, bill .39-.50. Female : length (skins) $5.32-5.67$, wing $2.92-3.00$, tail 2.10-2.30, bill .41-.46.

Distribution. - Santa Barbara Islands. California; and 'Todos Santos Island, Lower California.

\section{GENUS IOXIA.}

General Characters. - Tips of bill erossed in adnlts, nasal plumnles conspicnons, concealing nostrils; wing more than five times as long as tarsus; tail short, deeply emrarginate; tarsus short.

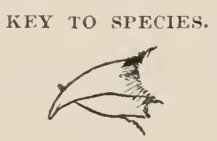

Fig. 400 .

1. Wing with two white bands

1 '. Wing without white bands.

2. Bill heavier, wing nearly 4

2 '. Bill lighter, wing abont 3.40

leucoptera, p. 315.

stricklandi, p. 314. minor, p. 314 . 


\section{Loxia curvirostra minor (Brehm). Crosssill. ${ }^{1}$}

Adult male. - Dull red, generally brighter on rump; gray showing through on under parts; feathers of back indistinctly streaked; wings and tail plain dusky. Adult females : olivaceous, often shading to bright yellow. Young: streaked, on olive gray ground. Young male: mixed with yellow and red before reaching adult stage. Male: length (skins) 5.046.64, wing 3.15-3.66, tail 1.72-2.16, bill .57-.73. Female: length (skins) $4.92-6.06$, wing $3.10-3.57$, tail $1.50-2.12$, bill $.54-.70$.

Distribution. - Northern North America, but chiefly northward and east of the Plains; irregularly abundant in winter.

Nest. - In coniferous trees, rather flat, composed externally of spruce twigs and shreds of soft bark, lined with horsehair and fine rootlets. Eggs: usually 4, pale greenish, spotted with various shades of brown mixed with purplish gray.

Food. - Chiefly seeds of conifers.

Crossbills, like other little pensioners of the trees, go and come whenever the branches spread hospitable feasts. If the trees yield no nuts, do not look for the jays or acorn-eating woodpeckers; if it is not a cone year do not expect the crossbills. But when the time is ripe, some red letter day from high up in the treetops you may catch the kimp, Kimp, kimp, of a busy flock, and on some still luckier day, like a whirl of snowflakes down will come a parti-colored band with their queer crossed bills and coats of red or greenish yellow. Then, if seeds and cones favor, perchance the flock will take up its abode in the neighborhood and act as if it had always been there, till suddenly some day it has disappeared and is seen no more.

At Fort Sherman, Idaho, Dr. Merrill hàs seen crossbills in every month of the year, though their occurrence was irregular. At times they were as common and fearless as English sparrows, and on warm bright days in February and March he says 'their pleasing song was heard in every direction.'

When Dr. Mearns was in Arizona he chanced on a good year and found them among the commonest birds, drinking and bathing at the springs and water places at all times of day.

\section{1a. Loxia curvirostra stricklandi Ridgw. Mexican Cross- BILL.}

Similar to minor, but larger, colors averaging brighter, and louer mandible averaging heavier. Male : length (skins) 5.94-6.54t, wing $3.67-4.05$, tail 2.08-2.32, bill .74-.86. Female: length (skins) 5.71-6.30, wing 3.42-3.88, tail $1.88-2.14$, bill .70-.S1.

Distribution. - Mountains from Colorado west to the Sierra Nevada, and from Wyoming to Guatemala.

1 Loxin curvirostra bendirei Ridgw.

Like L.c.minor, but decidedly larger, adult male averaging lighter or brighter in color, adult female slightly lighter and grayer.

Distribution. - More northern and central mountain districts of western United States from Colorado to the Cascades and Sierra Nevada; during migration east to eastern Nebraska and Kansas, west to the coast district of California ; casually to Guadalupe Island, Lower Califormia, and south to New Mexico. (N. Am. Fenent, No. 16, 123.) 


\section{Loxia leucoptera Gmel. White-Wingen Crosspill.}

Adult male. - Dull rose red, oceasionally tinged with yellow or orange; dark bases of feathers showing throngh and back clonded with black; wings and tail black, wings with two white bands, confluent at upper portion. Adult female: olive green or gray above, indistinctly streaked with dusky; rump yellowish; wings as in male, but not so black; under parts

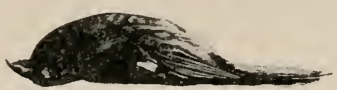

Fig. 401 .

lighter, more tinged with yellowisl. Young: similar to female, but colors duller and streaking pronomnced. Male: length (skins) 5.39-6.54, wing $3.3 ; 3-3.60$, tail 2.00-2.34, bill .62-.69. Female: length (skins) 5.20-6.22, wing $3.26-3.55$, tail $1.92-2.32$, bill $.59-.66$.

Distribution. - Breeds in Boreal zone forests of northern North America; winters in the United States to about $39^{\circ}$.

Nest. - As described by Adams, deeplr saucer-shaped, made of spruce twigs and lichens, lined with hairs and inner bark. Eggs : pale blue, spotted around larger end with black and lilac.

Food. - Spruce seeds, buds, and berries.

In general habits the white-winged closely resembles the other species of Loxiu.

\section{GENUS LEUCOSTICTE.}

General Characters. - Bill much shorter than head, short-conical; nasal plumules covering nostrils; wing long, pointed; tail about two thirds as long as wing, emarginate; tarsus short; hind claw equal to or longer than its toe, strongly curved.

KEY TO ADULTS.

1. Body black

$1^{\prime}$. Body brown.

2. Body light brown

$2^{\prime}$. Body dark brown.

3. Gray of crown spreading down over sides of head.

3'. Gray of crown not spreading down over sides of head.

littoralis, p. 316. tephrocotis, p. 315.

\section{Leucosticte tephrocotis Suains. Gray-crowned Leu- COSTICTE.}

Adult male in summer. - Bill black; crown black, bordered behind and on sides with gray, the gray not spreading down over sides of head; general body color deep chestnut brown, lighter, and with blackish mesial streaks on back, belly, and rump; upper tail coverts, wings, and tail more or less tinged with pink. Adult male in winter : bill yellow, tipped with blackish ; brown feathers edged with whitish ; black of crown restricted. Adult female: like male, with the same seasonal changes, but averaging paler and duller. Young: plain brownish, withont black or gray on head, or rosy tail coverts. Male: length (skins) 5.70-6.81. wing $4.00-4.40$. tail $2.42-2.80$, bill .42-.4s.

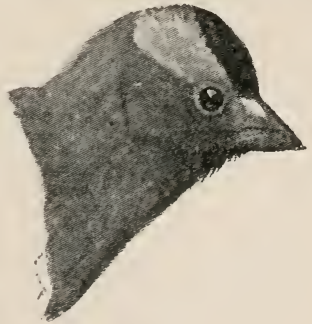

Fig. 402. 
Female : length (skins) 5.60-6.50, wing 3.50-4.19, tail 2.39-2.78, bill .43.56 .

Distribution. - Interior of British America; wintering in the Rocky Mountain region of the United States, most abundantly on the eastern slope, and extending to western Nebraska. Recorded as breeding in the Sierra Nevada and the Thite Mountains in California.

Food. - Ants, small beetles, and other insects, pine seeds and plant seeds.

The leucostictes are birds of the mountain snow-banks and glaciers. They feed on seeds and insects blown to the heights and left to be picked up about the border of the melting snow. They are often found at an altitude of from 11,000 to 12,000 feet, and under the crest of Mt. Whitney, at about 15,000 feet, Mr. Frank Daggett found a pair picking up insects from a snow-drift. When a hailstorm passed over the peak the birds took refuge under granite slabs, but as soon as it was over they were back on the snow.

At Fort Keough, Montana, Capt. Thorne reports that the leuco stictes come in November and stay in varying numbers till the last of March, picking up grain in the corrals and often taking shelter in old cliff swallow nests. When it is cold and stormy, he says, they gather in the post by thousands, but when a warm day comes they scatter out again.

Along the crests of the Sierra Nevada and Rocky Mountains and the higher peaks of the Cascade range, the first September snowstorms bring flocks of the rosy finches, scurrying with the driving snow, or, on clear days, basking in the sunshine about the old snowbanks and ice-fields.

While I was running a line of traps along the slope above Mono Pass in the Sierra Nevada one morning early in September, with my eyes half shut to keep out a fine driving snow, a little flock of nine rosy finches dropped down near me and began getting their breakfast from a last year's snow-bank, hopping about and picking rapidly here and there over the rough surface, fluffing their feathers and facing the cutting wind to keep from being blown away, all the time talking in cheery little notes among themselves. Now and then one would suuggle up in the lee of a chunk of ice or a stone, fluff his feathers, and hold up his feet to warm his toes just as the snowbirds do in winter, then hop out again and pick up more chilled bugs from the surface of the snow, looking up at me with a frank trustfulness that had surely never been betrayed.

TERTON BAILEY.

\section{4a. L. t. littoralis (Baird). Hepburn Leucosticte.}

Similar to the gray-erowned, but gray of crown spreading down over sides of head, sometimes covering all but black frontal patch. Ifale: length (skins) 6.04-6.80, wing 4.00-4.92, tail 2.36-2.75, bill .4.9-.49. Female: length (skins) (i.0s-(i.47, wing $3.94-4.10$, bill .4.)-.49. 
Distribution. - In summer, momtains of southeastern Alaska and probably the interior mountain regions of British Columbia. sonth at least to snow-capped monntains of W ashington; in winter, northwest coast from Kadiak southward; extending east to the eastern base of the Rocky Mountains.

"A pair of this rare species was found feeding full grown young on the moraines just below the glacier of Wright's Peak (Okanogan County, Washington), at an altitude of 8000 feet. North and west of this station there is an immense area of glacier-tlanked peaks, where the birds are sure to find a congenial summer home." (Dawson.)

In Paradise Park, on IIt. Rainier, Dr. Fisher found the Hepburn leucosticte common in the moraines and along the edges of bare ground, feeding on grasshoppers and other insects benumbed by the snow.

\section{Leucosticte atrata Ridgu. BцAск Leucosticte.}

Adult male in summer. - Crown black, set in gray, which does not extend over sides of liead; body blackish or deep clove brown; feather's of belly and sides tipped with peach-blossom pink; feathers of lind neck, back, and scapulars with more or less distinct brownish or buffy edgings; rump and patch on wings peach-blossom pink. Adult male in winter: similar, but bill yellowish, tipped with duskr, the brownish edgings to scapulars and interseapulars broader, feathers of under parts more or less edged with grayish, and pink markings of a softer. more rosy hie. Immature male: like adult male. but pink markings paler. mainly replaced on wings by buffy white. Adult female: much duller than the male, under parts grarish brown. upper parts brownish. and pink paler and restricted or replaced by whitish. Immature female: like adnlt female, but dnller and browner. feathers conspicuonsly edged with brownish and buffy. Male: length (skins) 5.90-6.20, wing 4.21-4.27, tail 2.62-2.75. bill .41-.48. Female: length (skins) 5.60-6.18, wing :3.89-4.19, tail 2..382.5s, bill .4.5-.47.

Remarks. - The head has the same color pattern as in tephrocotis, but the body is blackish or very dark brown.

Distribution. - Breeds in the Salmon River Mountains, Idaho. and probably northern ranges; winters in mountains of Colorado and Utah.

\section{Leucosticte australis Ridgu. BRowr-CAPPED Letco- sTICTE.}

Adult male in summer. - Bill black. crown blackish anteriorly, shading toward brown of back; body light brou'n, becoming pink on belly, rump. and wing coverts, and sometimes tinged with red on throat and breast. Adult male in winter : similar. but bill yellowish. tipped with dusky; crown brownish gray on back and sides, and feathers with gravish edgings that give scaled effect to head. Immature male: similar to adult, but greater wing coverts with buffy edgings in winter, dull whitish in summer. Adult female: similar to male, with same seasonal changes. but much duller, and pink markings indistinct. Young: grarish buffy brown, paler on posterior under parts; patehes on wings and tail coverts buffy. Male: length (skins) 5.71-6.45, wing 3.99-4.40, tail 2.39-2.86, bill .40-.50. $\mathrm{Fe}$ male : length (skins) 5.63-6.15, wing $3.90-4.25$, tail $2.40-2.70$, bill $.45-47$. 
Distribution. - Breeds in Alpine zone on the mountains of Colorado, descending into the lower zones of the valleys, and south to New Mexico in winter.

In his Birds of Colorado Mr. Cooke says that the brown-capped leucosticte is never seen below timberline in summer, and nests from 12,000 feet to the tops of the highest peaks. In August, he says, "old and young swarm over the summits of the peaks, picking insects off the snow. By the last of October or early in November they descend to timberline and remain there through the winter, except as they are driven a little lower by the severest storms. At the same time a few come into the lower valleys almost to the base of the foothills."

They have been reported from Silverton, where they came in large flocks and were killed for food.

\section{GENUS ACANTHIS.}

General Characters. - Bill conical, strongly compressed toward end, and uswally acute at tip; nasal plumules nearly covering basal half of bill except in summer plumage ; wing long, pointed; tail long, deeply forked; tarsus very short, side toes much shorter than the middle.

\section{KEY TO ADULTS.}

1. Upper parts brownish, rump streaked . . . . . linaria, p. 319. 1'. Upper parts whitish, rump not streaked . . . . exilipes, p. 318.

\section{7a. Acanthis hornemannii exilipes (Coues). Hoary Red-} POLL.

Adult male in spring. - Bill dusky ; patch on top of head erimson ; chin

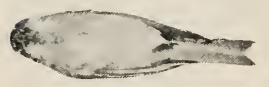

Fig. 403. black; under parts almost pure white, except for pinkish chest and fine streaking on sides; upper parts grayish white streaked with dusky; rump white, tinged with pink. Adult male in winter: similar. but bill yellowish, with dusky tip; upper parts tinged with buffy, dusky streaks narrower. Adult female in spring: like male in spring but withont pink on rump or chest. Adult female in winter: similar. but upper parts more strongly tinged with buff, dusky streaks narrower, and bill yellowish, with dnsky tip. Male: length (skins) 4.60-5.40, wing 2.85-3.07, tail 2.13-2.50, bill .27-.34. Female: length (skins) 4.59-5.16, wing 2.74-2.94, tail $2.1(1-2.29$, bill .27-.34.

Distribution. - Breeds in northeastern Asia and arctic America; south in winter, oceasionally to the northern United States. Recorded from Massachusetts, Illinois. Maine, and Michigan.

Nest. - A rather bulky structme. composed largely of small twigs and straws mixed with feathers and lined with feathers; placed in bushes or small trees. Eggs: 22 to 5, pale bluish green, speckled, chiefly around larger end with reddish brown, sometimes mixed with a few black specks or lines.

The hoary redpoll, Mr. Nelson says, is the most abundant of the redpolls in northern Alaska, where it occurs in great numbers. Its 
habits are identical with those of the common redpoll. Both forms are resident, making only a partial migration into the interior in the severest weather.

\section{Acanthis linaria (Linn.). Redpoll.}

Adult male in breeding plumage. - Chin pateh and feathers aronnd bill blackish ; crown erimson ; throat, sides, and rump more or less washed with pink or crimson; rest of under parts white, sides streaked with dusky; upper parts streaked, dark brown and buffy, lighter but streaked on rump, rump washed with pink ; bill horn color, dusky at tip. Adult male in winter plumage: much lighter, wing bands more or less buffy, pink paler; bill

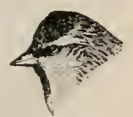

Fig. 404. light yellow, black at tip. Adult female: similar to the male, but pink of under parts replaced by buffy or whitish; seasonal difference same as in male. Young: like adults, but without pink or red, crown streaked and sides and wing bands more or less buffy. Male: length (skins) 4.31-5.32, wing 2.78-3.01, tail 1.91-2.29, bill .31-.38. Female: length (skins) 4.295.43 , wing $2.76-3.00$, tail $1.99-2.30$, bill $.30-.39$.

Distribution. - Breeds in the northeru parts of the northern hemisphere; south irregularly in winter, in North Annerica as far as California, Missouri, and Alabania.

Nest. - In bushes or small trees, bulky, made of twigs, straws, and feathers. Eggs : 2 to 5, pale bluish green, speckled, chiefly around larger end, with reddish brown, sometimes mixed with a few black specks or lines.

Food. - Buds and weed seed.

The redpolls are common in Colorado, from November to March, from the plains to 10,000 feet. Prof. Cooke says they remain high in the mountains, even when the temperature is thirty degrees below zero, which does not seem strange, as most of them winter in Alaska. In spring, Mr. Nelson tells us, "they are beautiful objects, with their bright rosy hues and fluffy plumage. On warm sunshiny days during April they come familiarly up to the very windows and doors, and peer about with an odd mixture of confidence and curiosity, examining everything and scarcely deigning to move aside as the people pass back and forth." After the nesting season, he says, "they come trooping about, young and old, in large parties, with great confidence and a peculiar pertness, taking possession of the premises and using the roofs and fences for convenient perches. making excursions thence to whatever point appears likely to yield food, or chasing each other playfully about." Through July and August they are extremely abundant in Alaska, but by the end of September the majority have left the coast, most of them going into the interior, where they brave the severest weather.

\section{GENUS ASTRAGALINUS.}

General Characters. - Bill conical, acute ; wing long and pointed ; tail emarginate; tarsus as short or shorter than middle toe with claw. 
KEY TO ADULT MALES.

1. Throat with black patch

$1^{\prime}$. Throat without black patch.

2. Back yellow.

3. Body pale yellow. Rocky Mountain plateau . pallidus, p. 321. $3^{\prime}$. Body bright yellow.

4. In winter, browner, with broader wing markings. Pacific coast. salicamans, p. 321 .

4 . In winter less brown, with narrower wing markings. East of Rocky Mountains to Atlantic coast . . . . tristis. p. 320 . 2 '. Back olive green or black.

3. Back without black. Rocky Mountains to California.

3 '. Back wholly or partly black.

psaltria, p. 322.2.

4. Back and ear coverts solid black. Mexico and Central Texas.

mexicanus, p. 322.

$4^{\prime}$. Back or ear coverts mixed with olive green. Colorado and New Mexico to Pacific

arizonæ, p. 3\%2.

529. Astragalinus tristis (Linn.). Goldfinch.

Adult male in summer. - Whole body canary yellow, in sharp contrast to black crown, wings, and tail ; wings with white bars and tail feathers with white patches. Adult female in summer: upper parts olive brown, sometimes tinged with green or gray; wings and tail dull blackish brown; white markings duller; under parts grayish white, more or less tinged with yellow. Adult male in winter: similar to female in summer, but wings and tail deep black, broadly and clearly marked with white. Adult female in winter: similar to sumner plumage, but more tinged with brownish, white markings broader and more tinged with buffy. Young: similar to winter adults, but browner, wing markings and general suff usion cinnamon; shoulder patch mixed with black instead of unicolored as in the male. Male : length (skins) 4.26-4.79, wing 2.78-2.96, tail 1.71-2.02, bill .38-.41. Female: length (skins) $427-4.76$, wing 2.59-2.79, tail 1.56-1.54, bill :37-.41.

Distribution. - Breeds in Transition and Upper Sonoran zones from the southern British Provinces sonth to Kentucky and Kansas, east of the Rocky Mountains; winters south to the Gulf of Mexico.

Vest. - A neat cup-shaped structure of compactly woren plant fibers, lined with down and other soft materials; placed in tall bushes or low trees. Eggs: :? to 5, plain pale bluish or bluish white.

Food. - Largely weed seed.

The goldfinches, or wild canaries, as they are popularly called in their many forms, if not as cultivated songsters as their caged relatives. have much sweeter call-notes and a happy round of their own. Their indolent lisping notes have a tinge of salness. but as they raise their heads from a thistle or sunflower to give them, and then flit lightly off and go sauntering in undulating flight through the air the gentle-spirited hirds seem as light-hearted as butterflies.

In their home life they are among the most charming of birds. being tender, deroted mates and watchîl parents. 


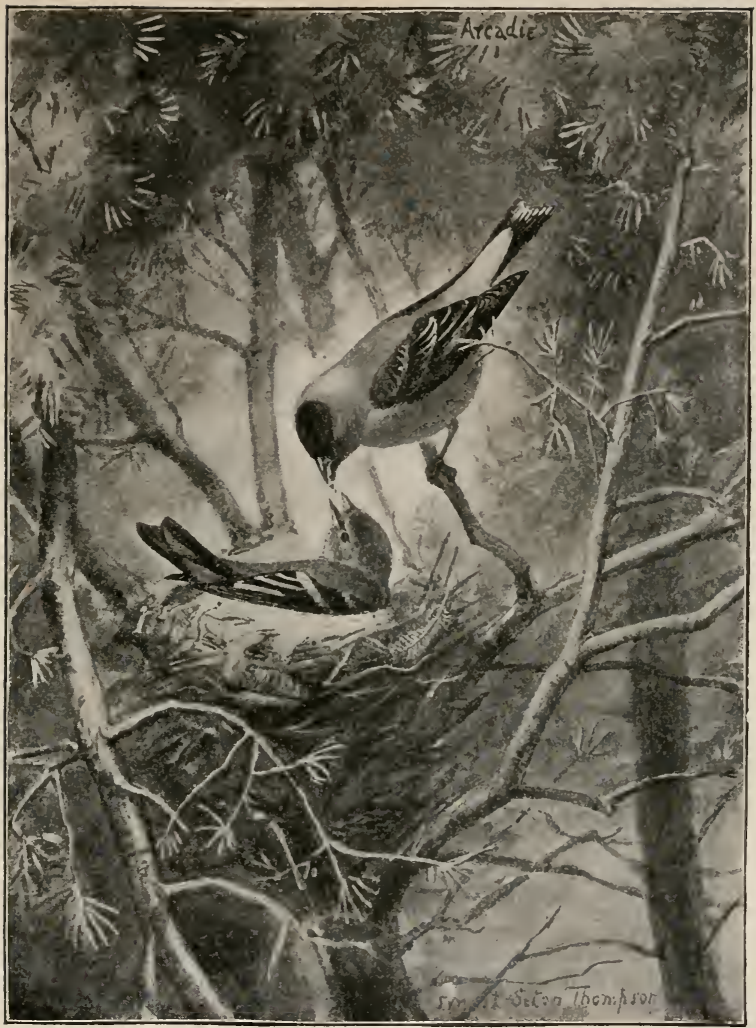

Fig. 405. Goldfinch.

529a. A. t. pallidus (Mearns). Pale Goldfinch.

Adult male in summer. - Similar to tristis. but larger and paler. white markings of wings and tail more extended. Adult male in winter: mnch lighter than tristis, with tints purer and white more extended. Male: lengtl (skins) $4.30-5.09$, wing $2.81-3.08$, tail 1.72-2.05, bill .38-.43. $\mathrm{Fe}$ male: length (skius) 4.42-5.00. wing 2.71-2.92, tail 1.70-2.03, bill :39-.44.

Remarks. - The principal difference between pallidus and tristris is in winter plnmage.

Distribution. - Rocky Momtain platean distriet from British Columbia and Manitoba sonth to northern and eastern Mexico.

529b. A. t. salicamans (Grinn.). Willow Goldfinch.

Adult male in summer. - Except for shorter wings and tail searcely distinguishable from tristis; black eap, if anything, not so extended and 
yellow not so intense; the white edgings on wings worn off so there is scarcely a trace of white left. Idult female in summer: much darker than female of tristis, dull greenish yellow on throat instead of bright yellowish green. Young: dark colored. Adult male in winter: similar to tristis, but browner and with much broader wing markings; back dark olive brown; sides and flanks shaded with brown; throat bright yellow, shading to dull green on breast and to pure white on belly. Adult female in winter: similar to male, but wings, tail, and throat duller; bill dusky. Male: length (skins) t.08-4.82, wing 2.60-2.89, tail 1.70-1.82, bill .39-.42. Female: length (skins) $4.28-4.70$, wing $2.63-2.72$, tail $1.70-1.79$, bill $.39-.42$.

Distribution. - Pacific coast, from Washington south to Lower California.

\section{Astragalinus psaltria (Say). Arkansas Goldfinch.}

Adult male. - Under parts canary yellow ; erown, wings, and tail black ;

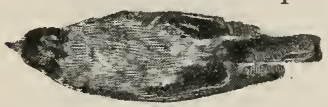

Fig. 406. ear coverts and back plain olive; wing quills with a white patch at base; tail feathers with inner webs of all but middle pair white from base to dark tips. Adult female: upper parts plain dull olive green; under parts light greenish yellow ; head without black; wings and tail as in male, but black duller and white more restricted, sometimes obsolete on tail. Young: similar to female, but tinged with buffy, and wing coverts tipped with buff. Male: length (skins) 3.83-4.19, wing 2.45-2.5.5, tail 1.52-1.61, bill .35-.39. Female: length (skins) 3.\$1-4.23, wing 2.39-2.49, tail 1.48-1.64, bill .35-.39.

Remarks. - The subspecies of psaltria are easily distinguished from it in the field by the amount of black on the back.

Distribution. - Breeds in Transition and Upper Sonoran zones in the western United States from the Plains to the Pacific, and from Colorado and southern Oregon sonth to San Pedro Martir Mountains, Lower California ; in winter to Cape St. Lucas.

Nest and eggs like those of tristis.

Food. - Largely weed seed.

In southern California, Mr. Grinnell says, the Arkansas goldinch is not only abundant about gardens and orchards, but goes up to 6000 feet in the mountains. In Colorado, Mr. Cook states, it breeds from the Plains to over 9000 feet. It is a late migrant there, scarcely reaching northern Colorado before the middle of June, being a late breeder like the other goldfinches.

\section{0a. A. p. arizonæ (Coues). Arizona Goldfinch.}

Adult male. - Similar to psaltria, but ear coverts and back darker, mixed olive and black. Idult female : similar to female psaltria. Male: length (skins) $: 3.79-4.21$, wing $2.52-2.61$, tail 1.52-1.75, bill .35-.39. $F e$ male: length (skin) 3.82 , wing 2.41 , tail 1.50 , bill .:7.

Distribution. - Breeds in I pper Sonoran zone of New Mexico and Arizona, and from Utah and Colorado to northwester? Mexico; casual in California.

530b. A. p. mexicanus (Swains.). Mexican Goldfinch.

ddult male. - Under parts wholly vivid canary yellow; top of head, 
ear coverts, and back solid glossy black, wings and tail heavily narked with clear white. Adult female: similar to psaltria and arizonce. Male: lengtl (skins) $3.85-4.30$ wing, 2.4t-2.70, tail $1.50-1.75$, bill $.37-.42$. Female: lengtl (skins) 4.01-4.19, wing 2.40-2.58, tail 1.50-1.69, bill .3.5-.40.

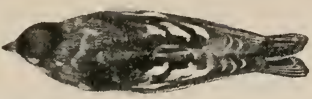

Fig. 407. Mexican Goldfinch.

Distribution. - South from central Texas throngl Mexico, except extreme northwestern and sonthern parts; accidental in Colorado.

531. Astragalinus lawrencei (Cass.). Lawrence Goldfinch.

Adult male. -- Face and throat as well as crown black; median under parts yellow, surrounded by gray; rump and wings washed with greenish yellow. Adult female: similar to male, but withont black on head or throat, and colors duller. In winter: both sexes colored as in simmer, but colors

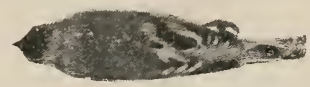

Fig. 408. more subdued. Young: similar to adult female, but duller, and lower parts indistinctly streaked. Male: length (skins) 3.92-4.64, wing 2.612.76 , tail 1.81-2.00, bill :31-.33. Female: leugth (skins) 4.04-4.50, wing $2.48-2.64$, tail 1.66-1.57, bill .31-.35.

Distribution. - Breeds in Upper and Lower Sonoran zones from abont latitude $40^{\circ}$ in California. west of the Sierra Nevada, sonth to Lower California ; occurs during winter in sonthwestern Arizona and New Mexico.

Eggs. - Pure white.

Food. - Largely weed seed, including that of the Russian thistle.

In Los Angeles County, California, MIr. Grinnell says lucrencei is found mainly on the mesa, in the mountain canyons, and pine forests below 6000 feet. From December until the last of March small flocks feed in weed patches along the banks of the arroyos.

\section{GENUS SPINUS.}

\section{Spinus pinus (Wils.). Pine Siskin: Pine Finch.}

Similar to Astragalinus. but plunage streaked gray and brown, withont sellow or black except for yellow patches on wings and tail. Adults: whole body finely streaked with brown. on brownish ground above, on whitish below; basal portions of secondaries and tail feathers sulphur yellow. Young: upper parts mustard yellow, tinged with brownish olive, feathers streaked, except on belly; wing bands and patches brown. Male: length (skins) 4.20-4.85, wing 2.72-3.00, tail 1.571.83 , bill .3S-.44. Female: length (skins) 4.23-5.14, wing

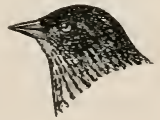

Fig. 409. 2.63-2.97, tail 1.60-1.81, bill .39-.47.

Remarks. - The siskin is easily recognized in the field, as the vellow wing and tail patehes show in flight.

Distribution. - Breeds in Canadian and Hndsonian zone forests in the mountains of western North America, also in the northeastern United States; may occur in winter in almost any part of the United States and Mexico.

Nest. - Usually rather flat though compactly made of fine twigs, rootlets, and plant fibers, lined with fine rootlets and hair. Eggs: usually 3 or 4 , pale greenish blne. speckled, chiefly around the larger end, with reddish brown, usually with a few sulall black markings. 
The pine finch resembles the goldinch in general, but its home is in the evergreen mountain forests, and after the nesting season it wanders erratically over the country in high-flying flocks, giving its plaintive cha, cha, as it goes, and coming to earth when a weed patch or the cones of an evergreen offer it a meal. It might easily be mistaken for a striped sparrow, but as it spreads its wings and tail to get its balance in feeding, the yellow patches identify it at a glance. When disturbed at a meal the flocks often make short circling flights, loath to give up their harvest.

In Colorado, Prof. Cooke says it is a common resident, abundant along the foothills during migrations, and from 7000 feet to timberline in summer. Some stay near timberline through the winter, but the bulk scatter over the lower valleys and plains. In southern California Mr. Grimnell finds it irregularly in the willow regions and lowlands in winter.

\section{GENUS PASSER.}

\section{Passer domesticus (Linn.). E NGLISH SPARROW.}

Form stout and stocky; bill very stout, curved, side outlines bulging to near the end; wing pointed; tail shorter than

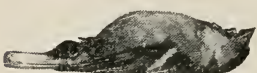

Fig. 410. Male. with chestmut patch and two white bands; rest of upper parts brown, back

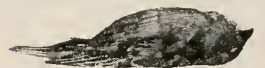

Fig. 411. Female. about $2.85-3.00$, tail $2.85-2.50$. streaked with black; upper parts dull brown; under parts dull gray. Adult female: crown and hind neck grayish brown or olive; entire under parts browuish white or gray; back browner, less refuscent than in male. Length: 5.50-6.25, wing

1)istribution. - Europe in general, except Italy; introduced and naturalized in Canada and the United States, from the Atlantic west to Utah and New Mexico, with colonies in central California, Portland, Oregon, and Seattle, Washington; also Bahamas, Cuba, Bermudas, Nova Scotia, and sonthern Greenland.

Nest. - About houses or in trees, bulky, made largely of dried grasses. Eggs : 4 to 7, thickly spotted with dark brown and purplish.

"The introduction of the English sparrow is one of the most fanniliar examples of acclimatization. Brought over to the United States in 18.50, the bird dereloped such a marvelous ability to adapt itself to new surroundings and increased so rapidly that by 1870 it had gained a foothold in twenty states and the District of Columbia, as well as in two provinces of Canada. It the present time [1899] it is found in every state and territory except Alaska, Arizona, MIontana, and Nevada." (Palmer.) 


\section{GENUS PASSERINA.}

\section{Passerina nivalis (Linn.). Sxowflake.}

Under mandible thicker than upper, gonys very short, nostrils concealed by plumules; wing nearly five times as long as tarsus; tail emarginate, about two thirds hidden by coverts; hind claw about as long as its toe. curved. Adult male in summer: white, with black on bill. middle of back, scapulars, greater part of primaries, and four to six middle tail feathers. Idult male in winter: washed with rusty on upper parts, sides of head, and chest; bill yellow, with dusky tip. Idult female in summer: upper parts broadly

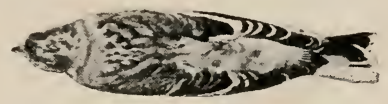

Fig. 412 . streaked with black; wing and tail with black of male replaced by blackish brown; wing with much less white. Adult female in winter : like summer female, but upper parts more or less stained with rusty brown and feathers of back more edged with buffy. Young: under parts dull whitish; upper parts gray ; wings and tail niainly dusky and brown; white of wing much restricted. Male : length (skins) 5.5-7.21, wing 4.19-4.5. tail $2.40-2.91$, bill .35-.45. Female: length (skins) 5.95-6.6.2, wing $3.90-$ 4.10, tail $2.39-2.62$, bill .3S-.43.

Remarks. - The September birds may be distinguished by feathers of head, nape, and rump, which are basally white in the male, basally black in the female.

Distribution. - Breeds in the arctic regions of the northern hemisphere ; in North America south in winter to the northern United States, irregularly to Georgia. Illinois, Kansas, Colorado, and Oregon.

Nest. - On ground, composed of dried grasses, lined with finer grasses and feathers. Eggs: usually 5, whitish, varying from dull purplish to greenish, speckled chiefly on larger end with shades of brown, usually with a few small black markings.

Food. - Largely weed seed, grass seed, and refuse grain in winter, and small crustaceans, mollusks, insects, and seeds in summer.

" The snowflake is a well known summer bird in all the circumpolar regions, and none of the various arctic expeditions have extended their explorations beyond the points where this handsome species is found. It chooses indifferently the bleak shores of the arctic islands encircled by an icy sea, or the warmer shores to the south as far as the Aleutian Islands, and nearly as far on the opposite Siberian shore of Bering Sea. Although it rears its young far from the usual haunts of man, it passes to the south and is one of the most familiar and well-known birds through the northern states." (Nelson.)

\section{GENUS CALCARIUS.}

General Characters. - Bill small, acutely conical, deeper than broad at base ; nostrils exposed; wing long, pointed; tail more than half hidden by pointed upper coverts; hind elaw about length of its toe, slender, and nearly straight. 


\section{KEY TO SPECIES OF CALCARIUS.}

1. Tail feathers chiefly white at base.

ornatus, p. 328 .

$1^{\prime}$. Tail feathers chiefly dusky at base.

-2. Inner web of outer tail feather chiefly white

2 '. Inner web of outer tail feather chiefly dusky.

pictus, p. 327.

3. Darker

3 '. Paler.

lapponicus, p. 326. alascensis, p. 327 .

\section{Calcarius lapponicus (Linn.). Lapland Longspur.}

Imer web of outer tail feather chiefly dusky. Adult male in summer:

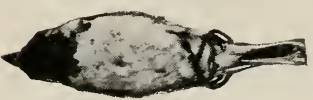

Fig. 413. Summer male. fore parts black, contrasting strikingly with white of belly, and white or buffy line from eye to hind neck; hind neck deep rufous; back streaked black, brown, buffy, and whitish; wings dusky, with brown and whitish edgings; tail chiefly blackish brown. Adult male in winter: black area and rufous nape patch greatly restricted, and more or less obscured by white

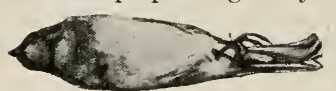

Fig. 414. Winter male. or brownish tips to feathers; sides of head mainly light brownish. Adult female in summer: like winter male but smaller, markings sharper, black of chest more restricted, and hind neck streaked with blackish. Adult female in winter : similar to summer female, but browner and less sharply streaked above; hind neck often without trace of rufous; under parts dingy white, chest markings only suggested. Young: upper parts tawny buff, broddly streaked with black except for wings and tail; under parts pale buffy, throat, chest, and sides broadly streaked with black. Male: length (skins) $.58-6.80$, wing $3.55-3.96$, tail $2.35-2.62$, bill .41-.48. Female: length (skins) 5.34-6.20, wing 3.45-3.63, tail 2.30-2.55, bill .41-.45.

Remarks. - The long, nearly straight hind claw distinguishes this genus and Rhynchophanes from the other Fringillida, and the black-tipped tail marks off Rhynchophanes. In Calcarius the white breast and belly distinguish the Lapland from the buff-breasted Smith longspur.

Distribution. - Breeds far north in the northern hemisphere; migrates in North America south to Texas, but most abundantly to Kansas and Colorado.

Nest. - On ground, composed mainly of dried grasses, lined largely with feathers. Eggs: 3 to 6, dull whitish, spotted or speckled with brown.

Food. - Insects such as weevils, grasshoppers, and beetles; locust eggs. weed seed, and grain.

The Lapland longspurs reach Colorado in October, Prof. Cooke states, going up into the lower mountain parks at first but descending to the plains when severe weather comes.

Colonel Goss says that they wander over the prairies and treeless plains of Kansas in enormous flocks, subsisting on seeds of weeds and grasses. In looking for food, he says, "they skim over the ground in a wavy, zigzag form, and on alighting run swiftly and heedlessly about, squatting close to the ground at the near approach of an intruder and remaining motionless, hoping to be passed unobserved. When started they rise in a quick, uncertain manner," which prairie falcons and other enemies often take advantage of, 
"dashing in and striking dow u many of the birds before the flock is well under headway."

In their summer home, Mr. Nelson says the longspur is "a widely spread circumpolar bird, whose presence is recorded from nearly every point visited by explorers along the shores of the arctic coast. . . . When they arrive early in May," he adds, "the ground is still largely covered with snow with the exception of grassy spots along southern exposures and the more favorably situated portions of the tundra, and here may be found these birds in all the beauty of their elegant summer dress. The males, as if conscious of their handsome plumage, choose the tops of the only breaks in the monotonous level, which are small rounded knolls and tussocks. The male utters its song as it flies upward from one of these knolls, and when it reaches the height of ten or fifteen yards it extends the points of its wings upwards, forming a large $\mathrm{V}$-shaper figure, and floats gently to the ground, uttering, as it slowly sinks, its liquid tones, which fall in tinkling succession upon the ear, and are perhaps the sweetest notes that one hears during the entire springtime in these regions."

\section{6a. C. 1. alascensis Ridgu. Alaskax Loxgspur.}

Similar to the Lapland longspur, but decidedly paler. especially in winter; summer adnlts with ground color of npper parts light buffy grayish brown, with little if any rusty tinge, even on wings; and the black streaks relatively narrower. Male: length (skins) 5.7.5-6.5.5. wing 3.593.92, tail $2.30-2.68$, bill $.41-.49$. Female : length (skins) $5.34-6.25$, wing $8.39-3.67$, tail $2.19-2.48$, bill .40-.47.

Distribution. - Breeds in Alaska. migrating in the United States to Nevada, Colorado. and western Kansas.

\section{Calcarius pictus (Swains.). Suith Lovgsper.}

Inner web of outer tail feather chiefly white. Adult male in summer: top and sides of head black marked with three white stripes - behind eye, across ear coverts. and down sides of neck; hind neck and entire under parts brow'nish buff, hind neck streaked with black; rest of upper parts streaked buffy

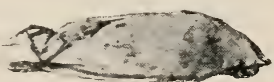

Fig. 415. Summer male. brown and black. Adult male in winter: black of head replaced by streaked brownish, like rest of upper parts : throat and chest also more or less streaked. Adult female in summer: like winter male, but smaller. paler, and grayer, and without clear black or white on wing coverts; entire npper parts streaked brown and blackish. In winter, similar, but more buffy. Young: similar to winter adults. but markings wanting or obscure. entire under parts yellowish brown or buffy; throat obscurely streaked; tail white only on two or three outer feathers. Male : length (skins) 5.8t6.81, wing $3.40-3.79$, tail 2.3:-2.71, bill .40-.44. Female: length (skins) $5.53-5.76$. wing $3.41-3.54$, tail $2.18-2.32$. bill $.40-.45$.

Distribution. - Interior of North America, breeding north to the arctic coast and migrating in the United States to Texas and sonthern Arizona.

Eggs. - Like those of the Lapland longspur, but averaging lighter, the whitish distinctly spotted style prevailing.

Food. - In winter largely weed seed. 
In winter, Colonel Goss says, the Smith longspur is often associated with other species of longspurs and horned larks. "Their favorite resorts," he states, "are along old trails and abandoned wagon roads upon the prairies, where the grass is short."

\section{Calcarius ornatus (Towns.). Chestrut-collared Long-} spur.

Tail feathers with bases of all but middle pair white. Adult male in

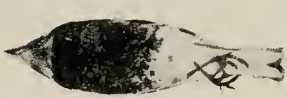

Fig. 416. Summer male. summer : throat and sides of head white or buffy, in striking contrast to black under parts; black sometimes invaded by reddish brown; npper parts with black crown, markings on sides of head and shoulder patch; nape bright rufous; rest of upper parts streaked; in full plumage shoulder pateh deep black tipped with white. Idult male in winter: similar, but black and rufous

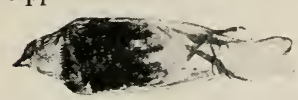

Fig. 417 . Winter male. obseured or concealed by brownish or buffy tips to feathers. Adult female: buffy brownish, streaked with blackish on upper parts and sometimes lightly streaked on breast and belly. Plumage softer and colors more blended in winter. Young: blackish feathers bordered with whitish and brownish; wing eoverts tipped with whitish; superciliary indistinct; ear coverts streaked; throat white, flecked with dusky ; rest of under parts dull buff, streaked, especially on breast. Male: length (skins) 4.63-5.59, wing 3.203.5.5, tail 2.00-2.39, bill .38-.44. Female: length (skins) 4.67-5.64, wing $2.97-3.33$, tail $1.89-2.25$, bill $.39-43$.

Remarks. - The female is an obseure bird, but may be recognized by its generic characters and extensively white tail.

Distribution. - Breeds in Transition and Upper Sonoran zones on the Plains from Assiniboia to Kansas; winters from Nebraska south through Texas, New Mexico, and Arizona, to Orizaba, Mexico.

Nest. - On ground, made largely of dried grasses, lined with feathers. Eggs: :3 to 6, white, tinged with pink, buff, or green; distinctly spotted with blackish or shades of brown.

Food. - Largely weed seed.

In a list of the birds of Fort Hays, Kansas, Dr. Allen states that the chestnut-collared is abundant over the plains, being "one of the most interesting and characteristic species." He adds that it has a "short, shrill, but rery sweet song, which is often uttered on the wing."

Flocks of several hundred have been seen by Mr. Bailer in southern Arizona in October and Norember.

\section{GENUS RHYNCHOPHANES.}

539. Rhynchophanes mecownii (Laur.). McCown Longspur. Bill stout, conieal; nasal phumules nearly concealing nostrils; wings

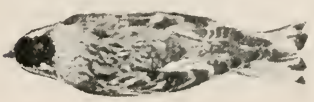

Fig. 418. nearly five times as long as tarsus; tail more than half hidden by pointed coverts; tarsus longer than middle toe with elaw; hind claw abont equal to its toe, nearly straight; tail feathers, except middle pair, white broadly 
tipped with black - outer feather almost entirely white. Adult male in summer : crown black in sharp contrast to white snpereiliary; shoulder patch reddish broun; back brownish gray, streaked with black; sides of head and throat whitish, with black streak from bill alongside of throat; chest with black crescentic patch; rest of under parts white, more or less mixed with black, especially on sides. Adult male in winter: upper parts uniform brownish buff, streaked with blackish brown; black of ehest largely hidden by buffy tips to feathers. Adult female: like winter male, but withont black chest patch or rufous shoulder patch, brownish above and buffy below; in summer grayer above and whiter below. Young: upper parts dusky, the feathers broadly bordered with pale buff; under parts white, distiuctly washed with buff across chest, chest sometimes indistinctly streaked. Male : length (skins) 5.26-5.71, wing 3.50-3.69, tail 1.90-2.20, bill .44-.52. Female: length (skins) 5.02-5.41, wing 3.15-3.42, tail 1.80-1.98, bill .42-.47.

Distribution. - Breeds on the interior plains from the Saskatchewan south to eastern Nebraska; winters sonth through Texas and Arizona to northern Mexico.

Nest. - On ground in open places, composed largely of dried grasses, lined usually with hair and feathers. Eggs: 3 to $i$, similar to those of the chestnut-collared longspur, but usually with ground color more olive.

Food. - Largely weed seed.

The habits of Rhynchophanes are very similar to those of the other longspurs. When disturbed at a meal they circle in undulating flight uttering, Colonel Goss says, 'a chip note at each stroke of the wing.' In the breeding season they have a flight song like that of the Lapland longspur, hovering with wings pointed almost straight upwards.

\section{GENUS POCECETES.}

General Characters. - Bill small, conical; wing long and pointed; tail emarginate; tarsus longer than middle toe with claw.

KEY TO SPECIES.

1. Larger, coloration grayer above. Plains to Pacific . confinis, p. 329. $1^{\prime}$. Smaller, coloration browner above. In California and Oregon. affinis, p. 330.

540a. Poœcetes gramineus confinis Baird. Westerx VesPER SPARROW.

Upper parts brownish gray narrowly streaked with dusky; bend of wing

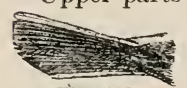

Fig. 419. reddish brown; outer tail feathers partly white; inder parts dull white, more or less tinged with pale buffy; streaked along sides of throat and across cliest. Male: length (skins) 5.50-6.25, wing 3.12-3.41, tail 2.49-2.70, bill .4346. Female: length (skins) 5.21-6.00, wing 3.00-3.30, tail 2.2- -2.68 , bill $.41-.49$.

Remarks. - The western vesper sparrow may be distinguished from the eastern by its grayer color, narrower streaks, and nsually more slender bill and longer wing and tail.

Distribution. - Upper Sonoran and Transition zones from the Plains to the Pacific, and from British Columbia, Assiniboia, and Manitoba south to Lower California and southern Mexico. Breeds from northern New Mexico and Arizona northward. 
Nest. - On the ground, made of grass. Eggs : 3 to 6 , greenish or brownish white, spotted, and often blotehed, and streaked with reddish brown and lavender.

In the San Francisco Mountain country, Dr. Mearns says the western vesper sparrow is a common summer resident in the upper pines, and was found breeding in the grassy openings up to 10,000 feet. It is also common in the sagebrush districts, and in settled parts of the west is commonly seen on roadside fences. It may be recognized by its white outer tail feathers as it flies, or, as it sits on a post, by its dull coloration and pale bay shoulder patches.

When it flies to the ground it is lost in the dry grass or disappears on bare ground, so perfectly do its dull streaks and mottlings blend with the earth colors.

In spring and early summer the resper sparrow perches on a post or tall weed and trolls over his sweet, simple song at regular intervals for hours at a time. At its best, at sunset, the song has a rich, serene melody.

\section{0b. P. g. affinis Miller. Oregon Vesper Sparrow.}

Like confinis, but smaller, bill more slender, coloration browner; ground color of upper parts buffy brown rather than grayish brown, and all the light areas of the plumage, inclnding under side of wings, suffused with pinkish buff. Male: length (skins) 5.17-5.5.5, wing 2.90-3.15, tail 2.082.38 , bill .40-.45. Female: length (skins) 5.04-5.65), wing 2.85-3.00, tail $2.20-2.27$, bill $.40-.46$.

Distribution. - Breeds in California and western Oregon.

\section{GENUS AMMODRAMUS.}

General Characters. - Tail feathers narrow, the middle ones, at least, pointed; primaries exceeding secondaries by less than length of tarsus; middle toe with claw not shorter than tarsus.

KEY TO SPECIES.

1. Tail rounded or graduated.

2. Nape marked with rusty brown.

3. Median crown stripe pale buffy; back streaked with rusty and black. leconteii, p. 3:3:\%

3'. Median crown stripe slaty gray; back streaked with chalky white.

$2^{\prime}$. Nape marked with olive. nelsoni, p. 38\%.

3. Back rusty brown streaked with black . occidentalis, p. 334. 3'. Back grayish olive streaked with chalky white and dusky.

1'. Tail emarginate. semnetti, p. 33\%.

2. Hind toe little if any longer than inner toe; wing exceeding tail by decidedly more than length of tarsus; tail feathers broader, less sharp pointer.

:). Upper parts not distinctly streaked or spotted . rostratus, p. 38:3.

:'. Upper parts distinctly streaked or spotted. 
4. Upper parts olivaceous. Coast of southern California.

4'. Upper parts grayish or grayish brown.

beldingi, p. 3:5\%.

5. Larger. Alaska; sonth along Pacific coast in winter.

5 '. Smaller.

sandwichensis, p. 331.

6. Paler and grayer. Western North America.

alaudinus, p. 332 .

6'. Darker and browner. Coast of central California in summer. bryanti, p. $3: 32$.

2 '. Hind toe decidedly longer than inner toe; wing exceeding tail by little more than length of tarsus; tail feathers narrower, more sharp pointed.

3. Edge of wing white; head and neck yellowish brown or buffy.

bairdii, p. 38:3.

3'. Edge of wing yellow; head not yellowish brown or buffy; nape rnfons . . . . . . . . bimaculatus, p. 334 .

\section{Subgenus Passerculus.}

Hind toe little if any longer than inner toe; wing exceeding tail by decidedly more than length of tarsus; tail feathers broader, less sharply pointed.

542. Ammodramus sandwichensis (Gmel.). SANDWICH SPARRow.

Adults. - Crown stripe and superciliary well marked. and superciliary

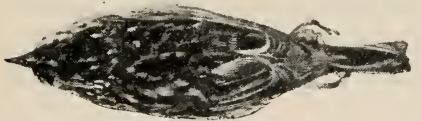

Fig. 420 . usually decidedly yellow ; upper parts grayish brown, heavily streaked with black, the streaks in sharp contrast to feather edgings of whitish, grayish, or buffy; under parts white, sometimes, especially in fall and winter, tinged with buffy on sides and chest; sides of throat, chest, sides, and flanks streaked with blackish; longer under tail coverts with concealed streaks. Young: similar. but light streaks of upper parts buffy, dark streaks of lower parts less defined, smperciliary usually without yellow, and finely streaked with dusky. Male: length (skins) 4.93-5.75, wing 2.92-3.14, tail 2.00-2.20, bill .44-.50. Female: length (skins) 4.85-5.74, wing 2.70-3.06, tail 1.8.-2.10, bill .4t-.50.

Remarks. - The sandwichensis group is distinguished by black streaks on upper parts in connection with distinct superciliary and median crown stripe, and streaks on under tail coverts being concealed. The exposed culmen is also longer than hind toe without claw, and wing less than seven times as long as exposed culmen, the bill straight or even concave in the middle.

Distribution. - Northwest coast, from Alaska to the Colnmbia River, rarely to northern California.

Nest. - On the ground, in meadows or other grassy places. Eggs : 3 to 6 , pale brownish, varying to dull whitish or greenish white, spotted with brown, occasionally with a few darker marks.

Food. - Insects, and weed and grass seed.

In Alaska Mr. Nelson found the Sandwich sparrow mainly on rocky beaches, though it also frequented grassy flats. He describes 
its song as a "short, weak succession of notes, somewhat similar to those of alaudinus."

\section{2b. A. S. alaudinus (Bonap.). Western Savanna Sparrow.}

Similar to sandwichensis, but smaller and averaging grayer, superciliary stripe often white. Male: length (skins) 4.50-5.55, wing 2.56-3.3.06, tail 1.81-2.25, bill .3४-.43. Female: length (skins) 4.50-5.20, wing 2.56-2.57, tail $1.76-2.10$, bill $.38-.45$.

Distribution. - Breeds from the Plains to the Pacific coast, and from the aretic coast to southern end of Mexican tablelands; in winter south to highlands of Guatemala.

Among the many inconspicuous, plain, little striped-backed sparrows of the western United States, rlandinus is one of the commonest, plainest, and most inconspicuous. Anywhere in the meadows, prairie grass, or weed patches, one may dart out from under your

- feet, zigzag over the grass-tops for a little way, and drop into the grass, hopelessly lost until he is again forced to take wing. At a distance you see and hear the birds giving their plain little song from the top of a tall weed or fence stake, but on nearer approach they drop into the grass and are lost. While really abundant they often escape notice until you tramp 'cross lots' through the meadows.

Veriox Balley.

\section{2c. A. s. bryanti Ridgw. Bryant Marsh Sparrow.}

Like sanduichensis, but darker and browner, with under parts more heavily streaked with black, and in winter plumage. chest. and sides strongly tinged with brownish buff. Male: length (skins) 4.5:3-5.00, wing 2.51-2.80, tail 1.74-2.00, bill .40-.45. Female: length (skins) 4.40-4.65, wing $2.47-2.69$, tail $1.70-1.92$. bill .40-.43.

Distribution. - Breeds in salt marshes abont San Francisco Bay ; south in winter along the coast to southern California; occasional in winter in Valley of Mexico.

\section{Ammodramus beldingi Ridgu. Belding Marsh Spar- row.}

Adults. - Ifedian crown stripe and superciliary usually very indistinct or wanting: ground color of upper parts olivaceous, streaked with black very broadly on back; lower parts thickly and broadly streaked witl black; fore part of superciliary stripe olivaceons yellow ; under tail coverts with concealed streaks. Young: sinilar. but upper parts with more buffy; dusky streaks of lower parts less slrarply defined. and snperciliary finely streaked and usually without vellow. Male: length (skins) 4.54-5.50. wing 2.52-2.82, tail 1.8.5-2.(10, bill .41-.5). Female: length (skins) 4.355.50, wing $2.40-2.66$, tail $1.67-1.5 \%$, bill .40-.4\%)

Remarks. - The Belding sparrow may be distingnished fron the sandwichensis group by the absence of distinct superciliary and crown stripes. and darker general coloration.

Distribution. - Salt marshes along coast of southern and Lower California from Santa Barbara to San Quentin Bay and Todos Santos Island.

Nest. - In salt grass about 6 inches from the ground; made of straws and horselıair or feathers. Eggs : usually 3, light blne, irregularly marked with lilac and reddish brown at larger end or over entire surface. 
The Belding marsh sparrow is an abundant resident of the salt water marshes along the coast of southern California, nesting in the marsh grass just above the reach of the tile.

544. Ammodramus rostratus Cass. LARgF-Billed Srarrow.

Upper parts light grayish brown, indistinetly streaked ; under parts extensively streaked with sandy brown; bill long and suollen and regulurly curved from base. Male: length (skins) 5.105.70, wing $2.72-2 .(12$, tail 1.9.$)-2.17$, bill .48-.54. Female: length (skins) 5.20-5.70, wing $2.52-2.8 .3$, tail $1.8: 5-$ 2.14 , bill $.42-.51$.

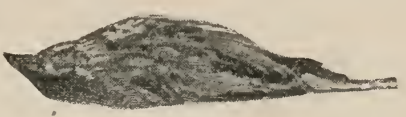

Fig. 4:1.

Remarks. - The large bill and nearly uniform light brown coloration of upper parts distingnish this sparrow from the rest of the group.

Distribution. - Breeds in salt uarshes on the coast of southern and Lower California; migrates to Cape St. Lucas and northwestern Mexico.

Mr. Stephens reports that the large-billed sparrow is a common winter resident of the seacoast of southern Califormia, where it is seldom found more than half a mile from the water's edge, but that it prefers streets and the neighborhood of buildings to marshes. In San Pedro Harbor, Mr. Grinnell tells us, it "frequents the wharres and breakwaters, and even hops fearlessly about the decks of ressels, feeding on crumbs and flies."

\section{Subgenus Centronyx.}

Hind toe decidedly longer than imner toe; wing exceeding tail by little more than length of tarsus; tail feathers narrow, sharp pointed.

\section{Ammodramus bairdii (Aud.). Baird Sparrow.}

Adults. - Head yellowish brown or buffr, crown streaked with black laterally; back light brown. spotted with black. feathers with light edgings; inder parts white, throat bordered by black stripes; chest, sides, and flanks streaked with black; tail deeply emarginate. the lateral feathers longest, the feathers all narrow and pointed at tip. Young: similar, bnt feathers of crown and back distinctly bordered with buffy

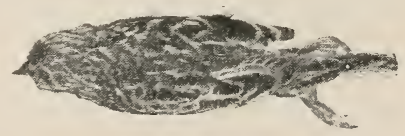

Fig. 422 . and streaks on chest less sharply defined. In winter the buffy color more pronounced than in summer. strongly tinging chest and sides. Male: length (skins) 4.80-5.40, wing 2.80-2.86, tail 2.05-2.10, bill .41-.43. Female: length (skins) 4.(6i)-4.95, wing 2.(c-2.70, tail 1.00-2.10, bill .40-.4.2.

Remarks. - The feathers of the nembers of the snbgenus Passerculus are streaked, the dark center of the feather being a narrow shaft streak; but in A. bairdii and others of the sharp-tailed group the darkest part of the feather instead of being a line is a wide stripe, an oval, or a terminal eve spot, narrowly and quite uniformly bordered with lighter, giving an effect of spotting rather than streaking.

Distribution. - Breeds from the Saskatchewan plains to Nebraska and migrates through Colorado. Texas, New Mexico. and Arizona, to northwestern Mexico; casually westward to Washington. 
Nest. - On ground in open situations, composed of dried grasses. Eggs : 3 to 5 , whitish, varying in tint, and spotted with reddish brown and lined with black.

In North Dakota, Dr. Fisher has found the Baird sparrow common in "low depressions of the prairie where the high grass has been left standing."

\section{Subgenus Coturniculus.}

Tail weak, of narrow lanceolate featlers; wing short, with inner secondaries reaching nearly to tip when closed, seventh secondary much the longest.

\section{6a. Ammodramus savannarum bimaculatus (Swains.). WESTERN GRASShOPPER SPARROW.}

Adults in summer. - Under parts buffy on throat and sides, unmarked; upper parts reddish brown, black, gray, and buffy; crown with median

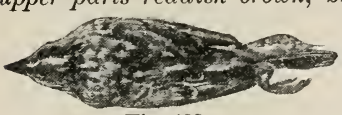

Fig. 423. buffy stripe between two blackish stripes; nuchal patch ash gray, marked with reddish brown; feathers of back with black eye spots nicked with reddish brown; edge of wing yellow; tail double rounded and feathers sharp pointed. Adults in winter: brighter colored, chest and sides sometimes indistinctly streaked with brown. Young: with little or no reddish brown on upper parts, the feathers being more conspicuously bordered with buffy and whitish; median crown stripe more ashy; lower parts entirely dull buffy whitish, chest distinctly streaked with dusky. Male: length (skins) $4.20-5.10$, wing 2.25-2.61, tail $1.69-2.02$, bill .40-.46. Female: length (skins) $4.40-4.55$, wing $2.39-2.51$, tail $1.82-2.00$, bill $.40-.44$.

Distribution. - Breeds in the western United States from the Plains to the Pacific coast, from British Columbia, Dakota, and Montana south to southern California and Arizona ; migrates to Cape St. Lucas, Lower California, and Central America.

Vest. - On ground, bulky, with deep cavity, often more or less arched over on top, and composed of dried grasses. Eggs: 3 to 5, white, spotted, chiefly on larger end, with reddish brown, sometimes mixed with a few small black markings and touches of lilac gray.

The western grasshopper sparrow lives in grassy fields, where it often sings from the top of a tall weed for an hour at a time. When startled, instead of flying, it drops down and runs off through the grass. Like most members of the genus Ammodramus, Dr. Judd says, it feeds much less on vegetable matter than most other sparrows. "Insects form their staple diet, and of these, beetles, grasshoppers, and caterpillars are the most important. As a destroyer of insect pests the grasshopper sparrow is most efficient."

\section{7a. Ammodramus henslowii occidentalis Brewst. West- ERN HENSLOW SPARROW.}

Adults. - 'Top of head and nape grayish olive, head with two broad stripes of black spots, nape more finely and sparsely spotted; feathers of back with coarse median streaks of black, bordered with pale chestnut. changing to a broad grayish margin; under parts dull white, breast and 
sides finely streaked, flanks more broadly ; sides of head buffy white, with a tonch of yellow above the eye; two narrow black stripes from bill, and one back of eve; shoulders tinged with greenish yellow and bend of wing yellowish white. Length: (skins) $4.50-4.59$, wing $2.12-2.13$, tail 1.85-1.90, bill .45-.48.

Distribution. - South Dakota in summer, and probably other regions along the eastern border of the Plains.

\section{Ammodramus leconteii ( $A u d$.). Leconte Sparrow.}

Adults. - Crown with two blackish stripes in sharp contrast to buffy and grayish median stripe; sides of head and snperciliary buffy or yellowish brown; hind neck chestnut, feathers edged with grayish ; rest of upper parts brownish, marked strikingly with blackish and buffy, the feathers black, notehed with grayish, with rufous and buffy eream U-shaped edgings; throat, breast, and sides buffy; belly white; sides and flanks streaked; bill small and slender; tail graduated. Young: much more buffy, deeper above, paler beneath, body streaked with blackish, more narrowly on under parts. Male: length (skins) 4.15-4.74, wing 1.94-2.12, tail 1.81-2.05. bill $.33-.40$. Female: length (skins) 4.35-5.00, wing 1.932.10 , tail $1.83-2.20$, bill $.33-.39$.

Distribution. - Breeds in prairie marshes of Transition and Upper Souoran zones. from Assiniboia and Manitoba southeast to Indiana; winters in the sonthern states; accidental in Idaho.

Nest. - Near the ground in dense fallen grass, made of grass, cupshaped. Eggs : 4 or $\tilde{5}$, pale greenish white, heavily spotted with reddish brown and lavender.

\section{Subgenus Ammodramus.}

Tail rounded, feathers sharp pointed; wing short and rounded, secondaries nearly even.

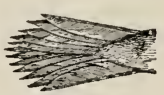

Fig. 424.

\subsection{Ammodramus nelsoni (Allen). Nelson Sparrow.}

Adults. - Superciliary bright buff. sharply contrasting with dark brown or blackish sides of crown ; middle of crown, back of head, and hind neck gray, more or less mixed with rusty; middle of back dark brown, strikingly marked with chalky white streaks; edge of wing yellow; tail rounded; under parts white, sides of throat, chest, and sides washed with buffy or yellowish brown, and indistinctly streaked with darker. Young: upper parts dull yellowish brown; sides of erown chiefly black; back broadly streaked with black; under parts buff, streaked on chest with dusky. Yale: length (skins) $4.50-4.90$, wing $2.10-2.48$. tail $1.80-2.07$, bill $.40-.42$. Female: length (skius) $4.40-4.80$, wing $2.05-2.20$, tail 1.70-1.90. bill .40.42.

Distribution. - Breeds in prairie marshes of the interior from Manitoba to northern Illinois; migrates to the Atlantic coast, and winters south to Gulf coast of 'Texas; accidental in California.

Eggs. - Similar to those of leconteii.

Food. - Insects, especially leaf-hoppers, midges, and horseflies, together with weed seed.

\section{0b. Ammodramus maritimus sennetti Allen. Texas SEASIDE SPARROW.}

Adults. - Upper parts olive gray, streaked with black and whitish; lores and edge of wing bright yellow; throat white; rest of under parts grayish 
or buffy, faintly streaked with gray. Young: upper parts grayish brown. streaked with black; under parts pale fulvous white, strongest on sides of neck and flanks. Male: length (skins) 5.20-5.50, wing 2.30-2.42, tail $1.92-2.27$, bill .50-.53. Female: length (skins) $4.95-5.40$, wing $2.15-2.30$, tail 2.00-2.15, bill .49-.52.

Distribution. - Coast of Texas.

Eggs. - 3 or 4, pale greenish white, finely spotted over entire surface and wreathed around larger end with reddish brown and plum color.

\section{GENUS CHONDESTES.}

General Characters. - Bill conical; wing long and pointed; tail long, rounded; tarsus about twice as long as exposed culmen.

KEY TO SPECIES.

1. Averaging darker and grayer .

$1^{\prime}$. A veraging paler and browner.

grammacus, p. 336. strigatus, p. 336.

\section{Chondestes grammacus (Say). Lark Sparrow.}

Similar to the western lark sparrow, but averaging darker and grayer, with black streaks on back broader and chestnut on head rather darker; wings and tail shorter. Male: length (skins) 5.50-6.40, wing 3.23-3.69, tail 2.54-3.08, bill .41-.48. Fenale: length (skins) 5.80-6.15, wing 3.203.38, tail $2.54-2.70$, bill $44-.47$.

Distribution. - Breeds in Upper Sonoran zone in southern Ontario and through the Mississippi Valley region to Texas and Alabama; and from Ohio west to western Nebraska; casually to Atlantic coast and (during migration) Florida.

Nest and eggs like those of strigatus.

552a. C. g. strigatus (Swains.). Western Lark Sparrow.

Adults. - Sides of head with chestnut patch and black and white streaks; crown chestnut, with white or buffy median stripe; rest of upper parts brownish gray, the back streaked with blackish; tail blackish brown with white corners, all but middle feathers tipped with white; under parts white, with a small black central spot on breast. Young: without chestnut patch or black and white streaks on head; entire upper parts buffy or brownish. streaked ; chest with wedge-shaped blackish streaks. Male: length (skins) 5.60-6.60, wing $3.20-3.62$, tail $2.52-3.00$, bill .41-.54. Female: length (skins) 5.50-(3.75, wing $3.12-3.51$, tail $2.40-2.81$, bill .42-.51.

Distribution. - Breeds in Transition and Upper Sonoran zones, from British Columbia and Manitoba south to the plateau of Mexico, and from the plains to California; migrates to Guatemala.

Nest. - On ground or in bushes or trees. sometimes in mistletoe or mesqnite, made of dried grasses, plant stems, and fibers. Eggs : 3 to 6, white, sometimes with a faint bluish or brownish tinge, speckled and lined chiefly on larger end with black and brown.

Food.-Grasshoppers, locusts, and weevils, with seeds of weeds and grass, and waste grain.

The lark sparrow is one of the commonest, most familiar western birds, sceming equally at home when walking over the smooth lawn of a Pasadena millionaire, singing from the top of the sagebrush, or perching on a Spanish bayonet on a rocky Texas mesa. 


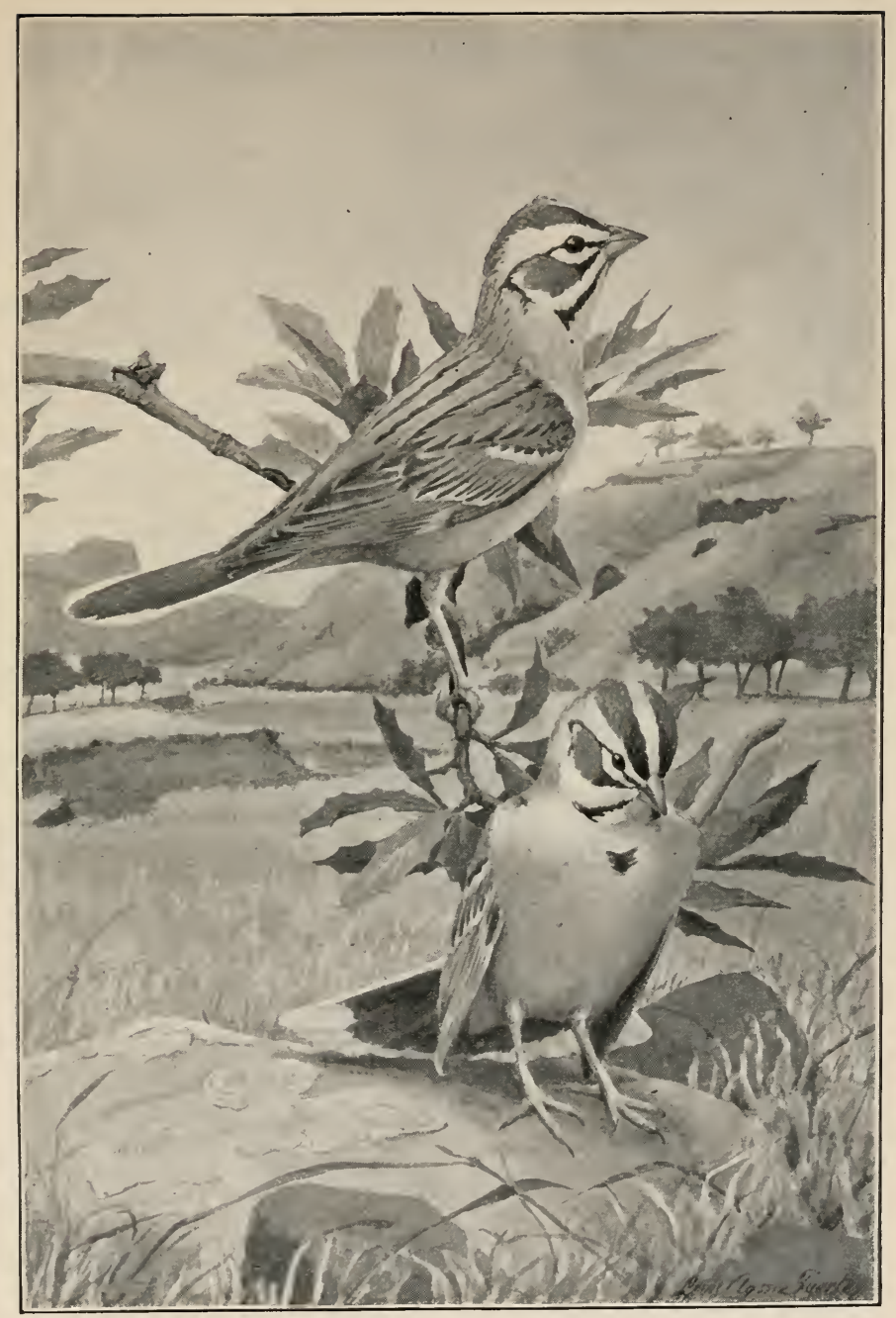

WESTERN LARK SPARRUW 

As he sits he has a trick of raising his crown every few minutes, calling especial attention to his directive face marking, and the moment he flies his white tail crescent shows conspicuously.

He is much in evidence, not only from his abundance and his conspicuous markings but from his misical song, which is heard almost continuously wherever he is found. The song is long and varied and has a purring phrase which is especially characteristic. Like the house finch he sings with fine fervor when dancing before his mate with spread tail and quivering wings.

\section{GENUS ZONOTRICHIA.}

General Characters. - Bill small, compressed, conical ; tail nearly or quite as long as wing, slightly rounded; tarsus not more than a third the length of tail.

\section{KEY TO ADCLT MALES.}

1. Top of head wholly black or mottled . . . . querula, p. 337.

1'. 'Top of head striped.

2 . Crown with yellow pateh

2 . Crown striped black and white.

3. Throat with white patch

3'. Throat without white patch.

4. Lores black

$4^{\prime}$. Lores not black.

5. Back ashy, marked with brown. . . . gambelii, p. 339.

5'. Back olivaceous, marked with blackish . . nuttalli, p. 339.

\section{Zonotrichia querula (Nutt.). Harris SPArrow.}

Adults. - Top of head and throat solid black, black streaking down over middle of breast; rest of under parts white; sides and flanks buff $y$ brown. streaked with darker brown: upper parts brown: back and scapulars streaked with blackish : wings with two white bars. Young. first

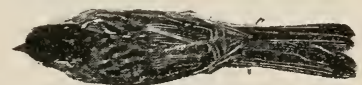

Fig. 425 . plumage (described by Preble): upper parts blackish. feathers edged with buffy and brown; wing quills edged with buff $\mathrm{s}$ and brown; tail feathers edged and tipped with whitish; sides of head and under parts buff $\mathrm{Y}$ : malar stripe conspicuous; chest and sides streaked with black. Male: length (skins) $6.46-7.33$. wing $3.43-3.60$. tail $3.14-3.35$, bill $.50-.52 . \quad F e$ male: length (skins) 6.66-6.95, wing 3.15-3.35. tail 3.04-3.16, bill .t5-.51.

Remarks. - Some specimens have black throat patch and crown feathers tipped with grarish. Mr. Ridgway thinks these may be roung birds.

Distribution. - Interior of British America (Fort Churchill and Hudson Bay), wintering south over the interior plains to southern Texas; accidental in British Columbia and Oregon.

The breeding range of the Harris sparrow is unknown except for Ir. Preble's Fort Churchill record. The last of July among the dwarf spruces of Fort Churchill he found an adult male and female with young just from the nest. ${ }^{1}$

1 "Biological Investigation of Hulson Bay Region." By Edw. A. Preble. Fauna 2:2, Biol. Surv. 
The habits of the Harris sparrow are largely common to those of the genus. In describing them Colonel Goss says: "The birds inhabit the thickets bordering streams and the edges of low woodlands. They are usually met with in small flocks. A favorite resort is in and about the brush heaps. where the land is being cleared. They seldom mount high in the trees, but keep near the ground, upon which they hunt and scratch among the leaves for seeds and insect life.

"They commence singing early in the spring, and upon warm, sunshiny days their song can be heard almost continually, as one after the other pours forth its pleasing, plaintive, whistling notes, in musical tone much like the white-throated sparrow; but delivered in a widely different song." Prof. Cooke says that in addition to their albicollis whistle they have a 'queer, chuckling note.' (See Cooke on "Distribution and Migration of Zonotrichia querula," The Auk, i. 332.)

\section{Zonotrichia leucophrys (Forst.). White-crowned SPAR-} Row.

Adult male. - Top and sides of head striped with black and white, white

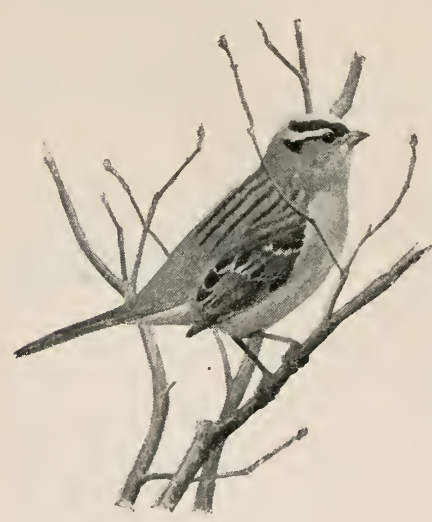

Fig. 4:6. median stripe usually as wide as adjoining black stripes; lores black, white superciliary stripe not extending forward of eye; edge of wing white; under parts plain gray; back with fore parts gray; rump brown. Adult female: like male and sometimes indistinguishable, but usually with median erown stripe narrower and grayer. Young: like adults, but head stripes brown and buffy instead of black and white; under parts buffy, and ehest, sides of throat. and sides streaked. Male: length (skins) 5.84-6.7.t, wing 2.98-3.28, tail 2.683.2:3, bill .43-.47. Female: length (skins) 6.00-6.63, wing 2.89-3.17, tail 2.69-3.00, bill .41-.47.

Distribution. - Breeds in Upper Canadian zone in the United States and Canada. from Quebec and Labrador north to Hudson Bay and Greenland and throughout most of the Sierra Nevada and Rocky Mountains, south to New Mexico and Arizona ; winters south through the United States and Lower California to Guanajuato, Mexico.

Nest. - On or near ground. in sub-alpine meadows, often in willows along streams, made of fine twigs, rootlets. and grasses. Eggs : 3 to \%, pale greenish blue, varying to brownish, spotted with reddish brown.

Food. - Caterpillars, ants, wasps, and weed seed, including that of Johnson grass and ragweed.

The white-crowned sparrow is preeminently the sparrow of the 
mountains. Along the willow bordered streams that run through the mountain meadows in the Sierra its thin, sharp chip of parental anxiety is often heard, and it's song dominates the bird chorus. The song is composed of two long whistled notes, the first sliding up to the second with grace notes, the second followed by a lower note repeated rapidly three times. The two long whistled notes are rich and plaintive in tone, suggesting the whistle of the pine woods sparrow, and as they ring through the cool, pure air day after day seem to give expression to the deep pervading peace and serenity of the mountains.

\section{4a. Z. I. gambelii ( $N$ utt.). Gambel Sparrow : Ivtermediate SPARROW.}

Similar to leucophrys. but lores not black. white superciliary stripe reaching to bill. Male: length (skins) $5.85-6.48$, wing $3.00-3.2 .25$, tail $2.58-$ 2.92, bill .39-.4t. Female: length (skins) $5.73-6.43$, wing $2.90-3.25$, tail 2.64-2.93, bill .39-.43.

Distribution. - Breeds from Alaska to Montana and eastern Oregon; migrates south through the western United States to Lower California and Central Mexico; straggling east to Iowa.

Eggs. - Similar to those of the white-crowned, but cinuamon colored or rusty style prevailing.

Food. - Cutworms, caterpillars, and other insects as well as weed seed.

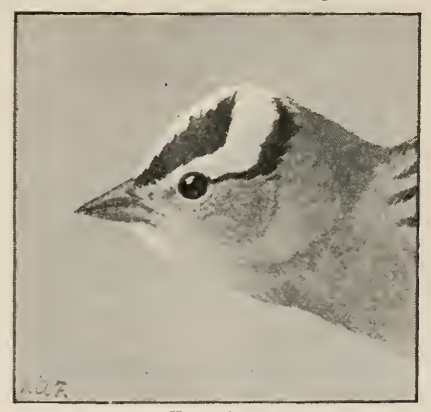

Fig. 427 .

\section{4b. Z. 1. nuttalli Ridgu. Nutrall Sparrow.}

Adults. - Like leucophrys, but lores not black and smpereiliary stripe extending to bill; median erown stripe usually narrower than lateral stripes, edge of wing yellow, and adults with upper parts brou'n instead of gray, streakings dark brown or blackish. and under parts brownish gray. Young: ground color of upper parts light buffy olive; under parts pale yellowish. Male: length (skins) 5.86-6.67, wing 2.83-2.96, tail 2.68-2.96, bill .41-.47. Female: length (skins) 5.87-6.40, wing 2.66-2.79, tail 2.502.73 , bill .89-.47.

Remarks. - Of the three sparrows. the white-crown, the Nittall, and the Gambel, the white-erown may be distinguished br its black or dark brown lores; the adult Nuttall sparrow by brownish instead of grarish eoloration; and usually a median erown stripe that is narrower than the lateral stripes; and the adult Gambel by the combination of white lores, gray coloration, and broad median crown stripe.

Distribution. - Breeds from British Columbia to Monterey, California; migrates to Lower California.

Food. - Insects. grain, and weed seed.

כ̃̃7. Zonotrichia coronata (Pall.). Goldex-Crowned Sparrow. Adults. - Crown inclosed by black stripes, with median stripe yellow in 
front, ash gray behind; rest of upper part olive brown, streaked on back with blackish brown: rump and tail plain; wing with two white bands; under parts gray ; sides and flanks washed with brown. Young: similar, but black crown stripes Fig. 428. Golden-crowned Sparrow. replaced by brown streaked with black, and median stripe dull brownish yellow flecked or streaked with dusky. the ash gray wanting; upper parts washed with brownish; under parts soiled whitish. Male: length (skins) 5.93-7.13, wing 2.99-3.28, tail 2.893.28 , bill .44-.52. Female : length (skins) 6.15-6.65. wing $2.90-3.17$, tail $2.71-3.25$, bill $.45-.50$.

Distribution. - Breeds in Alaska; migrates south along the Pacific coast to Lower California, straggling east to Nevada, Colorado, and Wisconsin.

Nest. - In alder patehes. Eggs: usually j, colored like the more distinetly spotted style of the white-crowned sparrow.

In winter the golden-crowns are among the common birds of the San Francisco parks and cemeteries and are so tame they will hop over the grass and down the paths close to the bench on which you are sitting. The sparrow flock usually includes more white-crowns than goldens, but all are equally and delightfully familiar. In some of the parks the birds seem especially fond of sunning themselves on the budding laurestium bushes.

Though the golden crowns live mainly on seeds, you often see one jump up from the ground for an insect or run after one and swallow it as unconcernedly as if he were not supposed to be a vegetarian.

In Los Angeles County, Mr. Grinnell says, they winter commonly from the mesas up to 5000 feet on the bushy mountain sides.

\section{Zonotrichia albicollis (Gmel.). White-throated Sparrow.}

Adult male. - Throat pure white sharply contrasted with gray of breast ; hearl striped with black aud white; superciliary yellow from bill to eyes;

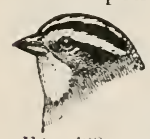
edge of wing yellow ; back and scapulars rusty brown streaked with blackish; rump olivaceous or brownish. Adult female; sometimes indistinguishable from male, but usually with coloration of head and under parts decidedly duller, crown stripe tinged with brown and buffy. Young in first winter: like

Fig. 429 . adult female, but duller, crown stripes browner. Young: throat not distinetly whitish, and stripes on head brown and buffy instead of black and white; yellow in front of eyes more or less distinct; under parts brownish white, streaked, except on belly. Male: length (skins) 6.12-6.56, wing 2.8.5-3.04, tail 2.80-3.00, bill .42-.48. Female: length (skins) 5.91-6.80, wing 2.74-2.88, tail 2.68-2.90, bill .44-.46.

Remarks. - The young of albicollis ean be distinguished from that of leucophrys by their deeper brown lateral erown stripes and more rusty back and wings.

Distribution. - Breeds in Canadian and Hudsonian zones from Hudson Bay and Labrador south to the northern United States, chiefly east, but also in Dontana and Wroming: winters to Florida and sonthern Texas. straggling west to Oregon and California.

Nest. - On the ground or in bushes, made largely of coarse grasses, 
rootlets. moss, and strips of bark, lined with finer grasses. Eggs : 4 or $\overline{\text {, }}$ finely and evenly speckled or heavily and irregularly blotched with biowll.

Food. - Insects, weed seed. and wild berries.

The white-throated sparrow is one of the best whistlers of the musical genus Zonotrichia, his clear I, I, per-body, pea-body, perbody, ringing finely through the spring air. Though chiefly an eastern bird, he may be seeu in Montana and Wroming.

\section{GENUS SPIZELLA.}

General Characters. - Wing less than 3; bill small. conical : tail emarginate or double rounded, middle feathers shorter than longest; tarsus about length of middle toe with claw.

\section{KEY TO SPECIES.}

1. Bill reddish brown or orange.

2. Chin black, head slaty gray

2 '. Chin whitish, head rufous and buffy

atrogularis, p. 345 .

1 '. Bill black or yellowish brown.

2. Crown rufous.

3. Breast with pectoral blotch .

$\because$ '. Breast without pectoral blotch.

arenacea. p. 341 .

4. Forehead and streak behind eye black. Rocky Mountains to Pacific coast . . . . . . . . . arizonze, p. 34:.

$4^{\prime}$. Forehead without black and no black streak behind eye.

$2^{\prime}$. Crown without rufous.

wortheni. p. : 344 .

3. Head and back grayish brown, uniformly and finely streaked with black . . . . . . . . . . . breweri, p. 343 .

3 . Head and back gray and buffy, coarsely and irregularly streaked with black. Plains . . . . . . . . pallida, p. 342.

\section{9a. Spizella monticola ochracea Brewst. Western Tree SPARROW.}

Adults. - Bill yellow in adults; crown, stripe behind eye, and patch on sides of chest rufous, crown often. especially in winter, with ashy median stripe. or rufous obscured by gravish edges to feathers; middle of back buffy, streaked with black and rusty ; wings

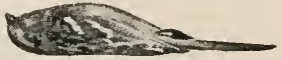

Fig. 430.

with two conspicuous white bars; under parts grayish, chest with small dusky spot. Young: streaked beneath. Male: length (skins) 5.61-6.00, wing 2.87-3.24, tail 2.59-2.88, bill .38-.41. Female: length (skins) 5.415.69. wing 2.57-3.10. tail 2.60-2.70, bill .3.5-.89.

Distribution. - Breeds from near the arctic coast through Alaska ; migrates as far east as the eastern border of the Plains, and south to New Mexico, Texas, and Arizona.

Nest. - On ground or in low bushes, composed largely of dried grass and feathers. Eggs: :3 to 5. pale greenish blue, varying to browuish, speckled with reddish brown.

Food. - Mainly seeds, largely weed seed.

In its Alaskan home Mr. Nelson says the western tree sparrow is the most numerous of the sparrows that frequent the bushes, espe- 
cially along the coast of Bering Sea, where, on entering a thicket, the protesting tsip of the gentle bird may be heard on all sides.

Coming south in fall, ochracea reaches Colorado in October and spends the winter, Prof. Cooke says, on the Plains and the lower part of the mountains, being common up to 7000 feet and occasionally seen as high as 9000 feet.

\section{0a. Spizella socialis arizonæ Coues. Western Chipping SPARROW.}

Adults in summer. - Bill black; top of head rufous, sometimes with in-

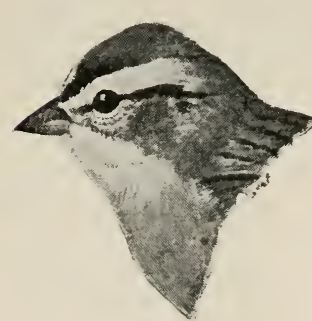

Fig. 431 . dication of ashy median line and dark streaking : forehead blackish, cut by median white line; superciliary stripe white or grayish, bordered below by narrow black eye stripe; back brownish or pale buffy, streaked with black; rump and upper tail coverts gray; sides of head dull gray; under parts white or ashv. Adults in winter : similar, but colors duller and darker, tinged with brown on lower parts, black on forehead obscure or wanting, crown usually streaked with dusky, bill brown. Young: top of head brownish, streaked with blackish; superciliary buffy, streaked; breast streaked; tarsus less than twice as long as bill. Male: length (skins) 4.82-5.43, wing 2.64-3.00, tail 2.11-2.57, bill .36-.41. Female: length (skins) 4.87-5.26, wing 2.62-2.98, tail $2.12-2.42$, bill $.35-.40$.

Remarks. - The paler coloration of the western chipping sparrow distinguishes it from the eastern, while the absence of pectoral blotch and striking wing bars distinguishes it from the western tree sparrow, and the black marks on the forehead and belind the eye still further separate it from the Wortlien sparrow.

Distribution. - Breeds in Transition and Upper Sonoran zones fron Alaska, perhaps to northern Mexico, and from the Rocky Mountains and western Texas to the Pacific coast; migrates to Lower California and southern border of Mexican tablelands.

Nest. - In trees or bushes, made of grass stems and lined with horsehair. Eggs : 3 to 5, light greenish blue, speckled chiefly around the larger end with black and brown.

Food. - Mainly eaterpillars and other injurious insects and weed seed.

In southern California, Mr. Grinnell says the western chippy is common about gardens and orchards in the mesa regions, breeding in the conifers on the mountains to 8500 feet. In Colorado and Arizona it breeds up to nearly 10,000 feet, though most commonly from 6000 to 7000 feet.

At St. Mary's Lake, Montana, Mr. Howell heard one sing near his camp several nights as late as nine o'clock.

\section{Spizella pallida (Swains.). Clay-colored Sparkow.}

Adults in summer. - Crown light brown with pale median stripe and black-streaked sides; superciliary buffy or whitish; sides of head buffy 
brown bordered above and below by narrow blackish streak ; malar region whitish. bordered below by dusky streak along side of throat; hind neck gray, narrowly streaked; back and scapulars brown. broadly streaked with black; wing bars buffy; under parts whitish, washed with brown on chest and sides. Adults in uinter: crown streaks narrower, and plumage more buffy. Young: upper parts buffy or clay-colored; chest and sides buffy, streaked with black. Male: length (skins) 4.64-5.41, wing $2.34-$ 2.49, tail 2.18-2.44, bill .34.-.39. Female: length (skius) 4.64-5.25, wing $2.28-2.51$, tail $2.08-2.40$, bill .35-.39.

Remarks. - The clay-colored and the Brewer sparrow both have streaked upper parts, but the clay-colored has only a median crown stripe and plain gray hind neck, while the Brewer is uniformly streaked on head, neck, and back.

Distribution. - Breeds in Transition and Canadian zone from the Saskatchewan plaius south to Iowa and Nebraska and from Illinois west to western Montana; migrates south to Lower California and southern end of Mexican tablelands.

Nest. - In bushes in open situations. Eggs: usually 4, light greenish blue, speckled chiefly around the larger end with brown.

The clay-colored sparrow is said to be almost exclusively terrestrial, though during the nesting season the males $\operatorname{sing}$ from the tops of bushes almost continually. The song Coues gires as three notes and a slight trill. Along the Red River in Dakota, he says, they nest in "open low underbrush by the river side and among the innumerable scrub-willow copses of the valley."

\section{Spizella breweri Cass. BRewer SPARRow.}

Adults. - Entire upper parts streaked with black on grayish brown ground; under parts soiled grayish. In winter, similar but more buffy. Young: like adults, but chest and sides streaked. streaks of upper parts broader and less sharply defined, and wings with two distinct bands. Male: length (skins) 4.745.13, wing $2.37-2.59$, tail $2.26-2.44$, bill .34.35. Female : length (skins) 4.60-5.19, wing 2.20-2.59, tail $2.26-2.50$. bill .34-.36.

Distribution. - Breeds in Transition zone sagebrush from British Columbia south to

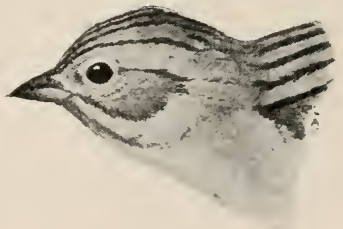

Fig. 432. southern Arizona, and from western Nebraska and western Texas to the Pacific coast; south in winter along the western border of the Mexican tablelands.

Nest. - In sagebrush, made of fine grass stems and leaves, lined with long horsehairs. Eggs: usually 4, and generally like those of the claycolored sparrow, but more distinctly marked.

The Brewer sparrow, known locally as the sagebrush chippie, is marked down as an 'arid transition' species, and, true to his zonal colors, if any arid transition sagebrush strays to the sunny side of a high mountain ridge he will appear there with it, though his normal home is in the bottom of a desert. We once found him singing at 8400 feet on the snowy crest of the Sierra, but on the sunny slope below was the ineritable sage. 
When among its favorite bushes the small sparrow is hard to see, for its quick darting flight ends on the earth and it runs over the ground like a mouse. The best view you can get of it is when it mounts a bush and throws up its finely striped head to sing. And what an odd little song it gives! It has the metallic, insect-like quality of a marsh wren's song, and something the jingle of a canary's, but though unmusical the ditty is so cheery and bright as to be distinctly pleasing.

The sparrows' morning and evening choruses are especially interesting, the evening the more so perhaps when the birds are feeding young, as they have more time when their broods are attended to for the night. I heard the chorus for the first time in Sierra Valley, California, when we rode in through the sagebrush and camped on the edge of the pines just at sunset. The curious little tinkling song was coming up from all over the brush, and it seemed as if we had come upon a marsh full of singing, though subdued, marsh wrens.

563a. Spizella pusilla arenacea Chadb. Western Field Sparrow. Adults. - Bill rufous or orange; broad median crown stripe and sometimes whole erown gray between reddish brown lateral stripes, which are sometimes indistinct; postocular streak rufous; back grayish, rufous, and buffy, streaked with black; wing with two distinct bars; under parts whitish, slightly tinged with rufous. Young: similar but colors duller and more suff used; markings of head less distinct and lower parts streaked. Male: length (skins) 5.58-6.02, wing 2.69-2.80, tail 2.60-2.8:3, bill .37-.39. Female: length (skins) 5. wing 2.44 , tail 2.47 , bill .37 .

Remarks. - The reddish bill and absence of pectoral blotch are enough to distinguish this sparrow from the western tree sparrow.

Distribution. - Breeds in the northwestern part of the Plains in Nebraska, Sonth Dakota, and Montana; migrates to northern Mexico.

Nest. - On or near the ground, in old weed grown fields and thickets. made mainly of grass stems. Eggs: 3 to 5, white, tinged with green or buff. and speckled with reddish brown.

Food. - Insects and weed seed.

564. Spizella wortheni Ridgw. Worthen Sparrow.

Top of head dull reddish brown, indistinctly streaked with darker, rest

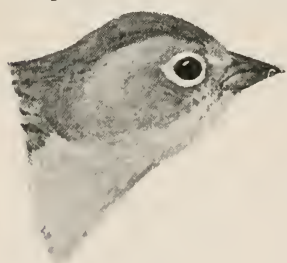

Fig. 433. of head, including forehead, ashy; back pale tawny, broadly streaked with black; under parts whitish, tinged with buffy gray on cheeks and sides; bill pinkish brown or cimmamon rufous. Male: length (skins) 4.98-5.07, wing $2.63-2.76$, tail $2.35-2.5 \%$, bill .37-.39. Female: length (skins) 5.0(i-5.25), wing 2.55-2.69. tail $2.27-2.50$, bill $.35-.36$.

Remarks. - The Worthen sparrow may be distingnished from the western chipping by the absence of black on forehead and black streak behind eye.

Distribution. - From Silver City, New Mexico, sonth on platean of northeastern Mexico to sonthern Piebla. 
565. Spizella atrogularis (Cab.). Black-Chinned Sparrow.

Adult male. - Throat and ring around bill black; head, neck, and lower parts gray, becoming white on belly and under tail coverts; back and scapulars rusty brownish narrowly streaked with blackish; bill pinkish brown. Adult female: like male, but usually

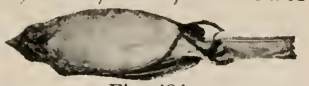

Fig. 434 . with black of ehin restricted, often wanting. Young: similar. but black replaced by gray, streaking on back narrower, chest indistinctly streaked. Male: length (skins) 4.80-5.53, wing 2.37-2.75, tail 2.41-2.92, bill .34-.42. Female: length (skins) $4.90-5.45$, wing $2.37-2.55$, tail $2.333-2.75$, bill .34.39 .

Distribution. - Breeds from the desert ranges of California. Arizona. and southern New Mexico south to Lower California and to southern end of Mexican tablelands.

Nest. - In bushes. Eggs : 3 to 5, plain light greenish blue.

The black-chinned sparrow is common in Los Angeles County, California, in summer, on brushy mountain sides from the base of the foothills up to $r 000$ feet. Its song is said to resemble closely that of the eastern field sparrow.

\section{GENUS JUNCO.}

General Characters. - Bill conical ; wing rounded, primaries exceeding secondaries by much less than length of tarsus; tail double-rounded: tarsus decidedly longer than middle toe with claw; hind claw nearly or quite as long as toe.

KEY TO ADULT MALES.

1. Head black or blackish.

2. Black of head not sharply contrasted with brown of back.

2 . Black of head sharply contrasted with brown of back.

connectens, p. 847 .

3. Back dark brown

oreganus, p. 347 .

3'. Back light brown.

4. Sides of head and throat deep black . . . thurberi, p. 347.

4'. Sides of head and throat slaty black . . . . pinosus, p. 348.

1'. Head gray or brownish.

2. Upper parts wholly gray.

3. Wing with two white bars . . . . . . . aikeni, p. 345.

3 . Wing unmarked . . . . . . . . hyemalis. p. 346.

2'. Upper parts gray and brown.

3. Back bright rufous.

4. Wing coverts and tertials rufous . . . palliatus, p. 349.

4'. Wing coverts and tertials not rufons.

5. Under parts uniform ashy white

$5 '$. Under parts not ashy white.

6. Sides gray . . . . . . . . . . caniceps. p. 349.

6 . Sides pinkish . . . . . . annectens, p. 348.

3'. Back dull brown.

4. Sides slightly pinkish . . . . . . montanus, p. 348.

4 4. Sides broadly pinkish . . . . . . . . mearnsi, p. 348.

566. Junco aikeni Ridgw. White-Winged Junco.

Adult male. - Entire body almost uniforn light slaty gray except for 
abruptly white belly; wings usually with two white bars and tail with three outermost feathers almost wholly white. Adult female: similar, but paler, upper parts tinged with brownish; wing bars less distinct, often obsolete. Young: entire body profusely streaked; under parts with whitish ground. Male: length (skins) (3.1S-6.69, wing $3.21-3.66$, tail $2.96-3.10$, bill .46-.51. Female: length (skins) 5.89-6.62, wing 3.19-3.32, tail $2.80-3.00$, bill $.45-.49$.

Remarks. - This is the only junco with white wing bars, and there is only one other in the west in which back and chest are of the same color.

Distribution. - Breeds in northwestern Nebraska, the Black Hills, North Dakota, and Wyoming; migrates to Colorado and Kansas; casually to Indian Territory and IV isconsin.

$N$ est. - On the ground. usually near canyon bottoms, made of grass, lined with grass and hair. Eggs: greenish white, lightly spotted with reddish brown and lavender.

The white-winged junco winters in Colorado from the Plains to an altitude of 8000 feet in the mountains, where Professor Cooke finds it the commonest winter junco.

\section{Junco hyemalis (Linn.). Slate-colored Junco.}

Adults. - Whole body, except white belly, dark slaty gray, of ten blackish

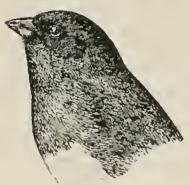

Fig. 435 . on head in male and washed with brownish in immature male and female, when the sides are also washed with pinkish brown; two pairs of outer tail feathers white; bill in life pinkish white or flesh-color. Young in first plumage: streaked on brown upper parts, and buffy white under parts, wings with brownish band. Male: length (skins) 5.44-6.23, wing $3.02-3.24$, tail 2.4!)2.80 , bill .40-.46. Female : length (skins) 5.22-6.10, wing 2.78-3.08, tail 2.45-2.64, bill .39-.46.

Distribution. - Breeds in Transition and Canadian zones of North America, chiefly east of the Rocky Mountains, and south in the mountains of northeastern United States to Pennsclvania; winters south to the Gulf States; casual in Arizona and California; straggling to Siberia.

Nest. - Usually on the ground, rather bulky, composed largely of dried grass stems and rootlets, lined with softer materials. Eggs: usually 4 or 5, white, greenish, or buffy, speckled with reddish brown.

Food. - Insects and weed seed.

Juncos are foresters or mountaineers who are driven down from the mountains into the mild valleys when the severe snows come. In this way the Sierra species spends the winter in the parks and cemeteries of San Francisco. Others come from the far north and go on to spend their winters in the south. Several species winter in the Great Basin country. Some members of the west coast contingepcy spread out over the interior valleys or even go to such popular resorts as Pasadena, where they hop about over the ground under the pepper-trees as if finding the pink aromatic berries a feast spread to their taste.

When seen away from home, or at any time except the nesting season, they are quiet, social birds, always sitting around in flocks, 
flying up together with a twitter and a flash of their white outer tail feathers, or singing in concert a sunny, pleasing warble.

In the breeding season the gray-headed junco may be found nesting on the cold crests of the desert ranges in Nevada and the Great Basin, the pink-sided in grassy parks in the pine forests of Montana, and the Point Pinos at Monterey, where the fragrance of the pines is mingled with the distant roar of the Pacific. In their homes you find them more interesting than when in flocks, because they are now leading individual lives, but they are still the same trustful, gentle birds, ready to come into camp or to let you examine their nests. On MIt. Shasta and in the Sierra Nevada the Thurber junco nests in the fir forests and mountain meadows from an altitude of i000 to 8000 feet, frequently building near a brook under shelter of a broad-leafed hellebore. One nest found on Donner Peak was sunk in a bed of blooming heather. The brooding birds as a rule are very tame, though they sit around and tsip at you when you come near, and on rare occasions the mother will decoy.

\section{7a. J. h. oreganus (Towns.). OREgon Junco.}

Adult male. - Head, neck, and chest black or dark slaty, the black chest pattern outlined on the white of the under parts as a black convex; middle of back dark broun; sides deep pinkish brown; three outer tail feathers with white, outside pair wholly white. Adult female: black of male replaced by slaty; crown and hind neck washed with brown, and rest of upper parts brownish ; sides and flanks duller; bill in life pinkish, tipped with dusky, and iris dark brown or claret color. In winter: colors stronger, and feathers of chest tipped with whitish. Young: streaked, on brown above, buffy below. Male: length (skins) 5.50-6.07, wing 2.863.08, tail 2.43-2.69, bill .41-.45. Female: length (skins) 5.17-5.79, wing 2.78-2.86, tail $2.34-2.46$, bill .41-.45.

Remarks. - The subspecies of hyemalis are black-headed and chested instead of gray as in hyemalis, aikeni, and annectens, and the chest line is convex instead of straight across from wing to wing. Of the hyemalis subspecies oreganus is the darkest, the head, neck, and chest of the adult male being deep black and the back dark chestnut brown.

Distribution. - Breeds on the Pacific coast from Alaska to British Columbia; winters south to California; straggling to eastern Oregon and Nevada.

\section{7b. J. h. connectens Coues. Ixtermediate Junco.}

Similar to oreganus, but head and neck blackish slate instead of jet black, back dull brown and sides pinkish brown. Male: length (skins) 5.5.5-6.20, wing 3.00-3.22, tail 2.62-2.84, bill .42-.46. Female: length (skins) 5.40-5.92, wing 2.82-3.08, tail 2.30-2.71, bill .41-.43.

Distribution. - Breeds in the Rocky Momntain region from British Columbia and Alberta to Washington and northern Oregon ; east probably to Montana and Idaho ; winters over the Rocky Mountain plateau to western Texas and northern Mexico ; straggling to California.

567 c. J. h. thurberi Anthony. Thurber Junco.

Similar to oreganus, but wings and tail longer; head, throat, and breast 
deep black, sharply contrasting with light brown of back; sides buffy rather

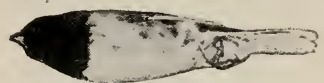

Fig. 436. Thurber Junco. than pink; young resembling oreganus, but upper parts lighter. Male: length (skins) $5.32-5.95$, wing $2.94-3.12$, tail $2.48-2.68$, bill $.40-.46$. Female: length (skins) 5.00-5.67, wing $2.82-2.94$, tail $2.38-2.56$, bill $.41-.43$.

Distribution. - Breeds from southern Oregon south through the Sierra Nevada, desert, and coast ranges, probably to northern Lower California; straggles to Arizona in winter. Migration mainly vertical.

Nest. - On the ground, usually under a weed or bush or in a bank, made largely of fine grass and other plant stems, shreds of inner bark, lined with vegetable fibers and long porcupine or horse hairs.

\section{7d. J. h. pinosus Loomis. Point Pinos Junco.}

Like thurberi, but black replaced by slaty on sides of head and throat; bill longer, general dimensions somewhat less. Young much more strongly tinged with buff below. Male: length (skins) 5.00-5.49, wing 2.40-2.90, tail 2.30-2.55, bill .40-.45. Female: length (skins) $4.90-5.65$, wing $2.62-$ 2.79 , tail 2.31-2.39, bill .40-.45.

Distribution. - Southern coast range of California (Point Pinos, near Monterey).

Nest. - As described by Emerson, in a slight hollow at the foot of a bunch of grass, made of leaves and lined with dead grass and a few cow hairs.

\subsection{Junco montanus Ridgu. Montana Junco: Molntain Junco.}

Adult male. - Head, neck, and chest slate color; back, dull light brown ; sides pale pinkish; belly white; outer tail feathers largely white. Adult female: similar, but duller, and brown of back extending up over crown. Adults in winter: plumage softer. Young in first winter: similar to winter adults, but duller, feathers edged largely with brownish. Male: length (skins) 5.49-6.00, wing $3.02-3.28$, tail 2.58-2.78, bill .39-.44. Female: length (skins) 5.25-5.69, wing 2.85-3.0:3, tail 2.85-2.65, bill .39-.44.

Remarks. - Montanus resembles connectens, but is paler. It also suggests mearnsi, but its wings and tail are shorter, and the color of the head, neck, and chest darker.

Distribution. - Breeds from Alberta south to Montana and Idaho; winters south to Texas, Arizona, and Chihuahua, Mexico; irregnlarly or casually to the Mississippi Valley and eastward.

\section{Junco mearnsi Ridgw. Pixk-sided Junco.}

Adult male. - Head, neck, and chest clear light slaty gray; sides extensively pink; lores blackish; back and scapulars dull brown. Adult female: similar, but brown of back extending up on crown; sides less pinkish. Young: head and back brownish, streaked with blackish; wings with brownish bars; under parts streaked, on buffy or grayish ground. Male: length (skins) 5.67-(i.11, wing 3.14-3.34, tail 2.64-2.89, bill .40-.45. Female: length (skins) 5.43-5.94, wing 2.90-3.37, tail $2.59-2.90$, bill .40-.45.

Distribution. - Breeds in Rocky Mountain region of Idaho and Montana; migrates to Arizona, New Mexico, and northern Mexico.

\subsection{Junco annectens Baird. Ridgway Junco.}

Nimilar to caniceps, but with sides and flanks pinkish vinaceons as in mearnsi. Length: 6.40, wing 3.13, tail 3.05, bill .47. 
Distribution. - Not well defined; has been taken in Nevada. Wyoming, Colorado, Arizona, and New Mexico.

\section{Junco caniceps (Woodh.). Gray-headed Junco.}

Adults. - Ash gray, except for white on middle of belly, bright rufous back, black lores, and white outer tail feathers; iris dark brown or claret color. Young: streaked; ground color of upper parts brown. Male: length (skins) 5.62-6.19, wing 3.21-3.41, tail $2.70-2.94$, bill $.42-.47$. $F e$ male: length (skins) 5.54-5.94, wing 2.95-3.30, tail 2.48-2.51, bill .41-.46.

Remarks. - The gray sides distinguish this junco from all but the adult male hyemalis, which has no reddish brown back patch.

Distribution. - Breeds in Rocky Mountain region, from the Black Hills to the Guadalupe Mountains in New Mexico and Texas; west from Colorado to Nevada; migrates to northwestern Mexico; casually to southeru California.

\section{Junco phæonotus palliatus Ridgu. Anizona Junco.}

Adults. - Top of head and rump ash gray; back bright brown; greater wing coverts and tertials with outer webs chiefly rusty or rufous; under parts whitish; outer tail feathers largely white; iris rellow. Young: streaked. Male: length (skins) 5.91-6.5.3. wing 3.00-3 26 . tail 2.72-3.01, bill .4445. Female: length (skins) 5.56-5.94, wing 2.91-3.00, tail 2.46-2.82, bill .4t-.ts.

Remarks. - The Arizona and the red-backed juncos have the under parts nearly uniform, but the brown on the wings distinguishes palliatus from dorsalis. These two, with caniceps and male hyemalis, are all without pink on the sides.

Listribution. - Breeds in mountains of southern Arizona and probably of northern Mexico.

\section{0a. J. p. dorsalis (Henry). Red-Backed Jusco.}

Adults. - Upper parts ashy gray, except for bright rufous back; under parts ashy white; iris brown. Young: streaked; back reddish brown. Nale: length (skins) 5.81-6.45, wing 3.22-3.41, tail 2.8.-3.03, bill $.44-.50$. Female: length (skins) 5.49-6.12, wing $3.00-3.21$. tail $2.69-2.92$, bill .45-.48.

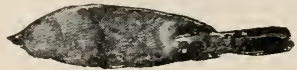

Fig. 437 .

Remarks. - The absence of brown on the wings distinguishes this subspecies from palliatus.

Distribution. - Breeds in Transition and Canadian zones in mountains of New Mexico and northern Arizona; winters south to western Texas and northern Mexico.

Nest. - In clumps of oaks on hillsides. or. as described by Dr. Mearns. on ground in pine woods, concealed br bunch of wire grass. composed of loosely put together roots, stems of plants, grasses, and an occasional feather. Eggs : 4, greenish white, marked with lilac and reddish brown around one end.

The coloration of most of the juncos is not particularly protective except as the color pattern disguises the bird's form, but the redbacked on the pine plateau of San Francisco Mountain, Arizona, spends a large part of its time about the fallen pine-tops, where the red of its back and the red of the dead pine needles and old bark make a protective combination that, added to the gray of the body, 
which offsets the gray of the branches, results in a most effective disguise.

\section{GENUS AMPHISPIZA.}

General Characters. - Bill small, nearly straight ; wing slightly rounded, but without elongated inner secondaries; tail not shorter than wings, feathers rounded at ends; tarsus longer than middle toe and claw, side toes of unequal length.

1. Throat black.

KEY TO SPECIES.

2. Smaller; upper parts darker. Kansas to central Texas.

bilineata, p. 350 .

2'. Larger, upper parts paler and browner. Western Texas to California.

1'. Throat white.

deserticola, p. 350 .

2. Smaller and darker. West of Sierra Nevada . . . belli, p. 351.

2 '. Larger and paler. Sagebrush plains . . . nevadensis, p. 351 .

573. Amphispiza bilineata (Cass.). Black-throated Sparrow.

Adults. - Lores and throat patch black; sides of head dark gray with

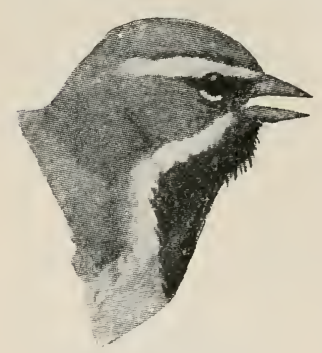

Fig. 438 . two white stripes, under parts mainly white; upper parts plain grayish brown; tail, except middle feathers, marked with white. Young: without distinct black markings; throat white, of ten marked with gray; chest streaked; wing coverts and edges of tertials light buffy brown. Male: length (skins) 4.80-5.25, wing 2.4:3-2.60, tail $2.27-2.47$. bill .38-.39. Female: length (skins) 4.7.5-5.35, wing 2.35-2.60, tail 2.15-2.45, bill .38-.40.

Distribution. - From western Kansas south to middle and eastern Texas and northeastern Mexico.

Nest. - In bushes, sagebrush, and other desert shrubs. composed of fine shreds of bark.

Eggs : 3 or 4, plain greenish or bluish white, rarely lightly spotted.

573a. A. b. deserticola Ridgu. Desert Sparrow.

Adults. - Similar to $A$. bilineata "but averaging larger; upper parts paler and browner. and white spot at end of inner web of outermost tail feather much smaller.' (Ridgway.) Young: feathers of back edged with buffy rufous; breast streaked with gray; belly white. Male: length (skins) 4.90-5.45, wing 2.52-2.78, tail $2.40-2.69$, bill .39-42. Female: length (skins) 4.(0-5.20. wing 2.45-2.60, tail 2.32-2.49, bill .36-.41.

Distribution. - Breeds in Lower Sonoran zone on the arid plains from western Texas and New Mexico - west of $10: 3^{\circ}$ - to the coast of southerm California, and from northern Ltah and Nevada south to northern Mexico and Lower California.

Nest. - In sagebrush, cat's-claw, cactus, or other bushes, loosely made of dry grass and fine plant stems, lined with feathers, horsehair, and wool. Eggs: :; or 4, bluish white.

On long hot rides over the larrea and low mesquite plains of New Mexico the desert sparrow is the commonest bird of the way, its 
black tail always disappearing in the bushes ahead of the horses as you pass.

When we were camped on the arid mesa of the Pecos River, among the sounds that were oftenest in our ears were the songs of the mockingbird and nonpareil, the iterant $p e-\cos ^{\prime}$ of the scaled quail, and the calls of the verdin and roadrunner, while, mingled with them, always tinkling from the bushes, was the cheery little tune of Amphispiza. Tra-ree'-rah, ree'-rah-ree was one of the commonest of its varied modifications, and it was generally given with a burr like that of the lark sparrow. On all our walks through the thorn brush and climbs over the agave-speared hills we found the lovely little bird everywhere, sitting on top of the bushes singing with head thrown back in fine enjoyment of his bright lay.

One small father bird, trying to attract us when we were taking notes on the first plumage of his brood, after twittering and calling in vain, flew excitedly to a bush top and fairly burst into song while his mate was trailing over the ground beside us, with the result that the brood grew so unmanageable that they popped out of the nest faster than we could put them back!

\section{Amphispiza belli (Cass.). Bell Sparrow.}

Adults. - Throat bordered with black and white stripes; breast with black blotch; rest of under parts white; orbital ring and spot above lores white; upper parts brownish gray. grayer on head. usually without distinct streaks; wing coverts and tertials edged with buffy; edge of wing yellowish ; tail feathers black, indistinctly marked with lighter. Young: npper parts light grarish brown, streaked with black; under parts buffy, streaked except on throat; wing with two rather distinct buffy bands. Male: length (skins) $4.90-5.70$. wing $2.32-2.79$, tail $2.32-2.87$, bill $.32-.41$. Female: length (skins) 5.00-5.60, wing 2.40-2.61, tail 2.30-2.70, bill .31.39 .

Distribution. - From about latitude $38^{\circ}$ in valleys and foothills of California, west of the Sierra Nevada and San Bernardino Mountains, to northern Lower California.

Nest. - About 3 feet from the ground, made of grasses and slender weeds, lined partly with hair. Eggs: 4, pale greenish, thickly spotted with reddish brown dots.

In Los Angeles County, California, Mr. Grimuell finds the Bell sparrow locally common on the brush-covered washes of the mesas, extending up to 5000 feet in summer.

\section{4a. A. b. nevadensis (Ridgu.). SAGE SPARrow.}

Adults. - Sides of throat with a series of narrow blackish streaks, but no continnons stripe; chest with black spot; sides and flanks faintly tinged with light brown; rest of under parts whitish; upper parts light grayish brown, back usually streaked narrowly but clearly; onter web of lateral tail feather white. Young: like adults but upper parts and chest streaked. and wings with two buffy bands. Male: length (skins) 5.50-6.20, wing 


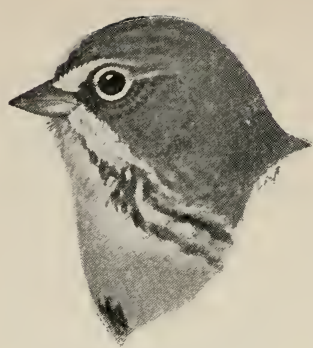

Fig. 439. Sage Sparrow.

3.05-3.20, tail 2.75-3.09, bill .37-.41. Female : length (skins) $5.40-6.20$, wing $2.85-3.15$, tail $2.65-2.98$, bill ..87-.41.

Remarks. - The absence of a continuous stripe on the side of the throat is enough to distinguish the sage sparrow from the Bell.

Distribution. - Breeds on sagebrush plains of Upper Sonoran zone from Oregon and Idaho south to California and New Mexico; winters in western Texas, New Mexico, Arizona, and southern California.

Nest. - In sage and other low bushes, made largely of fine shreds of sagebrush bark and dried grass stems. Eggs: 3 or 4, greenish white or dull grayish white, speckled, chiefly around larger end, with reddish brown, mixed with a few darker markings.

As Amphispiza bilineata is the bird of the creosote and mesquite deserts of the Lower Sonoran zone, so nevadensis is one of the most characteristic birds of the sagebrush deserts of the Upper Sonoran. He is indeed well named, for you find him everywhere throughout the sagebrush valleys of the Great Basin. His soft gray tones and faint streakings blend in well with the gray green brush. As he sits on top of the tallest bushes his long black tail and its gently tilting motion are good long range recognition marks.

IIost of the year the birds are silent, but during the breeding season the sagebrush fairly rings with their simple but exquisitely sweet song.

VerNoN BaILEY.

\section{GENUS PEUC丑A.}

General Characters. - Similar to Aimophila, but edge of wing yellow.

KEY TO SPECIES.

1. Upper parts ashy, back spotted and barred with sandy brown.

cassini, p. 352 .

$1^{\prime}$. Upper parts gray, streaked with dull rufous and spotted with black.

botterii, p. 352 .

576. Peucæa botterii (Sclat.). Вотteri Sparkow.

Adults. - Upper parts grayish, streaked with dull rufous and spotted with black; edge of wing yellow; under parts plain dull buffy. Y oung: upper parts buffy, streaked with dusky; under parts buffy; throat, chest. and sides streaked. Male: length (skins) 5.10-6.35, wing 2.35-2.75, tail 2.65-2.75, bill .4.5-.50. Female : length (skins) 5.20-5.70, wing 2.30-2.68, tail $2.22-2.5: 3$, bill .4:3-.50.

Distribution. - From southern Arizona and the lower Rio Grande Valley in Texas south over the platean of Mexico to (Chiapas.

Nest. - On or near the ground. Eggs: (1 set) 4, pure white.

578. Peucra cassini (Woodh.). Cassix Sparrow.

Adults. - Upper parts ashen, streaked with sandy brown; feathers of back 
sandy browu with black shaft streak and black cross bar near tip, the edges gray; upper tail coverts with transverse, roundish, or crescentic dusky streaks; middle tail feathers with indication of transverse bars from median black shaft streak; edge of wing yellow, and shoulder tinged with yellow; under

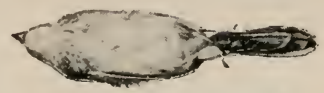

Fig. 440. Cassin Sparrow. parts grayish, tinged with brown on chest and sides. Young: chest and upper parts distinctly streaked. Male: length (skins) 5.15-5.50, wing $2.35-$ 2.65, tail 2.40-2.52, bill .40-.46. Female: length (skins) 5.30-5.80, wing $2.40-2.53$, tail $2.50-2.75$, bill .40-.47.

Remarks. - In the field the sandy brown streaking of the gray upper parts is characteristic.

Distribution. - Breeds in Lower Sonoran zone from Kanzas south to Arizona and northern Mexico, and from Texas northwest to Nevada.

Nest. - On ground, in low bushes, or tufts of grass. Eggs: $;$ to 5, white or bluish white.

When going quietly through the stunted bushes that make up a large part of the mesquite plains you often find yourself in the midst of a chorus of Cassin sparrows. Scattered through the bushes around you the little brown choristers one by one spring up several feet above the brush and with heads high and wings outspread in a rapture of song give themselves to the air, floating slowly down as they sing. The song is always melodious and pleasing, but at its best has something of the uplift and fine spiritual quality of that of the pine woods sparrow, gaining impressiveness from the abandon with which it is uttered.

The birds sing in spring and early summer, and through the breeding season at least keep it up all day, closing with a blithe sunset concert.

\section{GENUS AIMOPHILA.}

General Characters. - Wing short, much rounded or truncate at tip, primaries exceeding secondaries usually by less than length of bill; tertials not elongated; tail graduated; feathers narrow, but with rounded tips ; tarsus longer than middle toe with claw.

KEY TO SPFCIES.

1. Wing with bright rufous patch . . . . . . carpalis, p. 353.

$1^{\prime}$. Wing without bright rufous patch.

2. Upper parts mainly gray. In southwestern Texas.

$2^{\prime}$. Upper parts mainly rufous.

eremœca, p. 355 .

3. Smaller. In California . . . . . . . ruficeps, p. 354.

3'. Larger. Western 'Texas to Arizona . . . . . scottii, p. 354 .

579. Aimophila carpalis (Coues). Rufous-WINGED SPARRow : BENDIRE SPARROW.

Adults. - Wings with conspicuous bright rufous patch; crown heavily streaked with rufous, mixed with gray, and divided by narrow gray line; rusty streak behind eye, and two blackish stripes from bill down side of 


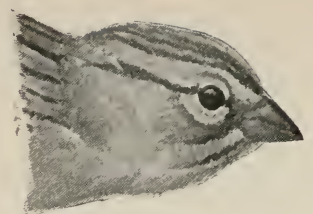

Fig. 411. Rufous-winged Sparrow.

throat; back buffy brown, sharply streaked with black ; under parts grayish white. Young: entire upper parts grayish brown, broadly streaked with blackish; patch on wing coverts dusky, margined with pale brownish buff; under parts whitish, chest and sides broadly streaked with dusky. Male: length (skins) $5.00-5.35$, wing $2.40-2.60$, tail $2.50-2.68$, bill .40-.42. Female: length (skins) 4.8.5-5.25, wing $2.34-2.50$, tail $2.43-2.65$, bill $.38-.42$.

Remarks. - The uniform bright rufous wing patches of the adults of carpalis are diagnostic.

Distribution. - Arizona and northwestern Mexico.

Nest. - On or near the ground. Eggs: 3 to 5, plain bluish white.

In the foothills of the Santa Catalina Mountains, Arizona, Mr. Scott found small flocks of the rufous-winged sparrows from an altitude of 3000 to 4500 feet. They were sometimes associated with the chipping sparrows, whose habits are similar.

\section{Aimophila ruficeps (Cass.). Rufous-crowned Sparrow.}

Adults. - Crown chiefly reddish brown; rest of upper parts grayish or

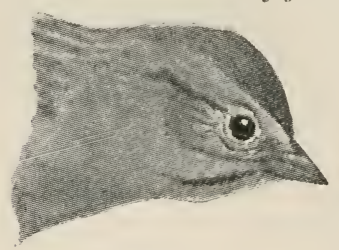

Fig. 44:. gravish brown, broadly streaked with reddish brown; throat bordered by black stripe; sides of head and neck and under parts pale buffy or brownish. I'oung: like adult, but upper parts dull brownish, streaked; under parts dingy buff, chest and sides streaked. Male: length (skins) 5.(0-5.5.5, wing 2.20-2.40, tail 2.252.65, bill .41-.50. Female: length (skins) $5.00-5.20$, wing $2.18-2.30$, tail $2.32-2.60$, bill $.43-.50$.

Remarks. - The prevailing dull reddish brown of the upper parts, together with the size, marks the rufous-crowned sparrow.

Distribution. - From northern California - latitude $40^{\circ}$ - south along the Pacific coast to northern Lower California.

Nest. - On or near the gromud, made of grasses, lined with stems and sometimes a few hairs. Eggs : :3 to 5, plain white or bluish white.

In Los Angeles County, Mr. Grinnell says, the rufous-crowned is tolerably common locally in the foothills throughout the sear, but is most abundant in April. In the Crafton Hills, where Ir. Williams found it nesting, it was very shy and rarely scen, the brooding bird gliding from her nest and dodging around the tufts of grass until hislden behind a bush.

\section{0a. A. r. scottii (Senn.). ScotT Sparrow.}

Similar to ruficeps, but larger, and sometimes not quite so bright. Male: length (skins) 5.30-6.10, wing 2.50-2.7T, tail 2.60-2.92, bill .45-.5\%. Female : length (skins) 5.50-5.50, wing $2.37-2.5 .2$, tail 2.5()$-2.67$, bill .45-.50.

Instribution. - From western 'Texas to southern Arizona and sonth to Durango. Mexico. 
Nest. - As described by Scott, on bare ground, bulky, loosely made of coarse dried grasses. Eggs: :3, white.

In the Santa Catalina Mountains of Arizona, Mr. Scott found the Scott sparrow a common resident from 2000 to 4000 feet in winter, and nearly up to 10,000 feet in summer. When flushed, he says, instead of hiding in the thick grass it flies to the nearest tree, making little effort to conceal itself.

In New Mexico we found it about rocky ledges of the Guadalupe Mountains. Its song in August was short and rather mechanical.

\section{0b. A. r. eremœca (Brown). Rock Sparrow.}

Similar to ruficeps, but prevailing color of upper parts ashy, feathers of back dull brownish centrally with black shaft streaks. Male: length (skins) 5.40-6.00, wing -2.58-2.70, tail $2.60-2.80$, bill .46-.51. Female: length (skins) 5.45-5.90, wing 2.41-2.57, tail -2.45-2.85, bill .45-.51.

Distribution. - From niddle and southwestern Texas to Orizaba, Mexico; breeds in limestone hills of middle Texas; migrates to Vera Cruz, Mexico.

Nest. - On or near the ground, nsually sheltered by a bush. One in Chisos Mountains - under soto, bulky, made of grass and lined with fine plant fibers; with 4 bluish white eggs.

\section{GENUS MELOSPIZA.}

General Characters. - Wing short, rounded, primaries exceeding secondaries by much less than length of tarsus; tail rounded; tarsis abont equal to middle toe with claw.

\section{KEY TO SPECIES.}

1. Chest buffy.

2. Streaks on upper parts finer, not so black

$2^{\prime}$. Streaks on npper parts coarser and blacker

$1^{\prime}$. Chest not buffy.

2. Chest faintly if at all streaked .

$2^{\prime}$. Chest distinctly streaked.

3. Upper parts mainly pale rufous

3 . Upper parts not pale rufous.

lincolnii, p. 359 . . striata, p. 360.

georgiana, p. 360 .

. fallax, p. 357.

4. Upper parts sooty, rusty, brown, or olive.

5. Upper parts dark sooty or rusty.

6. Sooty, larger. Alaska; to Olsmpies in winter.

$6{ }^{\prime}$. Rustr, smaller.

rufina, p. 358 .

7. Bill larger; darker. Southern Alaska to Oregon ; to southern California in winter. . . morphna. p. 35.

7 . Bill smaller; lighter. Idaho to northern California; to Mexico and Arizona in winter . . merrilli, p. 359.

$5^{\prime}$. Upper parts brown or olive.

6. Larger; wing (male) 2.42-2.80. Central valless of California . . . . . . . .heermanni, p. 357.

6'. Smaller ; wing (male) 2.21-2.51. Santa Cruz to Humboldt County, California . . . . . samuelis, p. 358.

4'. Upper parts grayish.

5. Interseapulars streaked with black and brown. 
6. Wing (male) 2.49-2.84; bill stouter. Atlantic watershed. melodia, p. 356.

6'. Wing (male) 2.58-2.91; bill more slender. Rocky Mountain platean . . . . . . . montana, p. 357.

5 . Interscapulars without distinct brown streaks.

6. Larger ; wing (nale) 2.45-2.60. San Clemente, San Miguel, and Santa Rosa Islands, California . clementæ, p. 359.

6 '. Smaller ; wing (male) 2.29-2.41. Santa Barbara and Santa Cruz Islands, California . . . . . graminea, p. 358.

\section{Melospiza melodia (Wilson). Song Sparrow.}

Adults. - Crown brown, narrowly streaked with black and with a narrow gray median stripe; scapulars and interseapulars streaked with black;

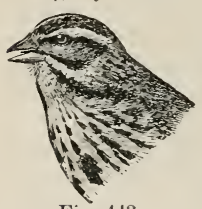

Fig. 443. wings and tail brown; middle and greater wing coverts brown. edged with lighter; middle tail feathers with blackish shaft streaks; superciliary olive gray; malar stripe dull white or pale buffy; under parts white; chest with wedge-shaped streaks of black edged with rusty brown, forming an irregular median spot; sides and flanks streaked with black and rusty brown. Young: like adults, but without gray on upper parts; ground color of back and scapulars buffy brownish or dull buffy; under parts duller white, of ten quite buffy, with the streaks narrower, less distinct. Male: length (skins) 5.30-6.48, wing 2.49-2.84, tail 2.442.79, bill .45-.52. Female : length (skins) 5.15-6.10, wing 2.42-2.81, tail $2.19-2.77$, bill $.45-.51$.

Remarks. - In summer the colors are grayer and streaks on chest narrower, sometimes with brown edgings worn off; in winter the general coloration is browner, the brown more rusty, the gray more buffy.

Distribution. - Eastern United States west to the Rocky Mountains, north to Norway House, Lake Winnipeg.

Nest. - In low bushes or on the ground, made chiefly of grasses lined with slender stems. Eggs: 4 or 5, dull greenish white, spotted with reddish brown, sometimes concealing ground color.

Food. - Mainly injurious insects and weed seed.

As his name denotes, the song sparrow is one of the most tuneful of the sparrow family. He is not a great or showy musician, but a singer of songs, plain every-day home songs with the heart left in them. His content and good cheer are so contagious that you welcome his voice wherever you hear it. And you may hear it in erery state of the Union, for, under whaterer name he is known, he is a song sparrow still.

At Neah Bay, Washington, where the rainfall reaches the maximum for the United States, and the regetation is dense and the soil lark, we find him almost sable brown, but on the deserts of the southwest his colors are pale sandy to match the light open ground. Indeed, his coat is so sensitive to slight changes of environment that he is a sore problem to makers of subspecies. But whatever trouble he unwittingly makes in the ornithological world, he is the same quiet, gentle bird, sunning limself in the bushes, rumning orer the ground when attending to his affairs with wings close at his sides 
and tail perked up ; guarding his family with watchful care, and between times, as at all times, singing his glad little lay.

581a. M. m. fallax (Baird). Desert Song Sparrow.

General color light rufous; upper parts light gray, streaked on back with rusty, nsually without blackish shaft streaks; streaks on chest clear rusty or rufous. Young: dull brown or buffy above, back streaked with brown; buffy white below, chest streaked. Male: length (skins) 5.86-6.12, wing $2.56-$

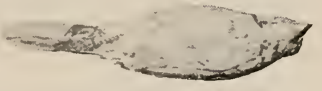

Fig. 44.

2.71, tail 2.59-2.81, bill .44-.50.' Female: length (skins) 5.10-5.8*2, wing $2.47-2.62$, tail $2.39-2.75$, bill $.45-.48$.

Remarks. - The light color and rusty streaking distinguish this from all other song sparrows.

Distribution. - Breeds in Lower Sonoran zone from southern Nevada and southeastern California to Lower California and Sonora, Mexico.

Nest. - In tufts of grass, low bushes, or on the ground. Eggs : 4, light greenish or dull bluish white, more or less spotted with brown.

\section{1b. M. m. montana (Hensh.). Mountain Song Sparrow.}

Upper parts grayish streaked with black and brown; wings and tail brown; under parts white, chest and sides streaked with brown, streaks more or less confluent on breast. Male: length (skins) 5.58-6.49, wing 2.58-2.91, tail 2.50-3.02, bill $.44-.55$. Female: length (skins) 5.35-6.34, wing 2.46-2.75, tail 2.46-2.86, bill .41-.50.

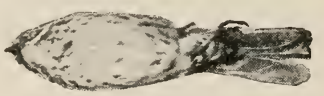

Fig. 445.

Remarks. - Montana is like melodia, but wings, tail, and tarsus average longer. bill smaller and relatively more slender; coloration grayer; the young paler, whitish instead of buffy below, less tawny above than in young of melodia.

Distribution. - Breeds in Transition zone in the Rocky Mountain and Sierra Nevada region of the United States; migrates to western Texas and northern Mexico.

\section{1c. M. m. heermanni (Baird). Heerman Song Sparrow. ${ }^{1}$}

Ground color brown or olive, streaked both above and below with blackish ; spots on ehest distinct instead of massed in a pectoral blotch. Male: length (skins) 5.10-(i.31, wing 2.42-2.80, tail $2.35-2.79$, bill .45-.5\%. Female: length (skins) 5.46-5.64, wing $2.40-2.51$, tail 2.25-2.58, bill .48-.50.

Remarks. - The seasonal changes in plumage are marked, the summer birds being much more sharply and narrowly streaked than winter ones. Heermanni is like melodia, but smaller and browner. streaks on back averaging broader, those on chest darker; young like that of melodia, but deeper tawny above, streaks broader; under parts tinged with brownish buff. chest streaks broader.

Distribution. - Breeds in Lower Sonoran zone in central valleys of California ; migrates southward ; casnally to Nevada.

1 Melospiza jasciata cooperi Ridgw. San DIego Song Sparrow.

Like heermanni, but slightly smaller and much lighter and grayer.

Distribution. - Southern coast district of California (north to Monterey Bay, east to Fort Tejou. San Bernardino, etc.), and Pacific coast of northern Lower California. (The Auk, xvi. 35.)

Melospiza melodia santrerucis Grimmell. Santa Cruz Songr Sparrow.

Like cooperi, but smaller, with weaker bill, and brown markings deeper and more extensive.

Distribution. - Along fresh water streams heading in the Santa Cruz mountain region, from San Francisco south to Monterey Bay. (The Condor, i. 92.) 
581d. M. m. samuelis (Baird). Samuels Song Sparkow. ${ }^{1}$

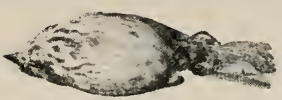

Fig. 446.

Like heermanni, but smaller, with slenderer bill. Male: length (skins) 4.99-5.90, wing 2.212.51 , tail 2.09-2.43, bill .43-.50. Female: length (skins) 5.0.5-5.61, wing 2.21-2.38, tail 2.10-2.35, bill .45-.49.

Distribution. - Breeds on the coast region of California from Santa Cruz to Humboldt County.

\section{1e. M. m. morphna Oberh. Rusty Song Sparkow.2}

Adults. - Upper parts rusty olive, the rusty brown and black streaks

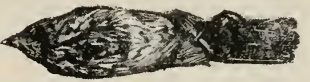

Fig. 447 . obscured; chest widely marked with heavy dark rufous streaks; flanks olivaceous instead of tawny. Young: back dark brown streaked with blackish; under parts whitish or buffy gravish : chest and sides buffy or brownish streaked with sooty brown. Male: length (skins) 5.69-6.46. wing 2.552.81, tail 2.39-2.57, bill .47-.54. Female: length (skins) 5.58-6.19, wing $2.45-2.70$, tail $2.28-2.67$, bill .45-.5.2.

Distribution. - Breeds in Canadian zone in the Pacific coast region from sonthern Alaska to Oregon; migrates to southern California.

Nest. - As described by Kobbé, on horizontal branch of a small spruce, about 5) feet from the ground, made of coarse grass stems lined with fine grass.

The rusty song sparrow is said to be an especially water-loving subspecies, being found in swamps, brush patches along streams, and coast waters.

\section{1f. IM. m. rufina (Bonap.). Sooty Song Sparrow. ${ }^{3}$}

Like morphna, but decidedly larger (except bill), darker, and more uniform sooty rather than rusty; back obsoletely streaked. Male: lengtl (skins) 5.85-6.85, wing 2.6.3-3.02. tail 2.60-2.90, bill .45-.50. Female: length (skins) 5.50-6.00, wing 2.52-2.7 , tail 2.30-2.76, bill .42-.50.

Distribution. - Southern Alaska; in winter to coast of British Columbia. Vancouver Island, and Olympic Mountains, Washington; accidental in California.

581h. M. m. graminea (Towns.). Santa Barbara Song Sparrow. Similar to samuelis, but decidedly grayish above, the streaks both above

1 Melospiza fasciuta pusillula Ridgw. Salt Marsh Song Sparrow.

Like $M$. m. stmuelis, but smaller, especially wings and tail; less rusty above, superciliary and under parts tinged with yellowish.

Distribution. - Salt marshes of San Francisco Bay. (The Auk, xvi. 35.)

Melospiza melodia cleonensis MeGregor. Mendocino Song Sparrow.

Size of samuelis, but lighter and more rusty.

Distribution. - Coast of Mendocino County, California. (Bull. Cooper Orn. Club, i. 87.$)$

2 Melospiza fasciata ingersolli. McGregor. Tehama Song Sparrow.

Similar to morphna, but darker and without rusty wash.

Distribution. - Northern Sacramento Valley, south in winter to San Francisco Bay. (Bull. Cooper Orn. Club, i. 3.).)

3 Melospiza cinerea phar Fisher. Oregon Song Sparrow.

Almost identical with rufinu in color and markings, but between cleonensis and morphne in size.

Distribution. - Immediate vicinity of coast from Rogue River to Yaquima, Oregon. (The Condor, iv. 36.) 
and below blackish and narrower, contrasting more sharply with the ground color; about the size of samuelis, but with shorter tail and larger feet. loung: like those of montana, with grayish instead of brownish ground color. Male: length (skins) 5.18-5.46, wing 2.2!)-2.41. tail 2.112.31, bill .47-.49. Female: length (skins) 5.:30-5.45, wing $2.30-2.37$, tail $2.19-2.31$, bill .46-.47.

Distribution. - Santa Barbara Islands, and, in winter, adjacent mainland of California.

\section{1i. M. m. clementæ (Touns.). San Clemente Song Sparrow.}

Similar in color and markings to graminea, but much larger, the bill longer. Male: length (skins) $5.70-6.15$, wing 2.45-2.60, tail 2.35-2.64, bill .47-.49. Female: length (skins) 5.44-5.81, wing 2.40-2.50, tail 2.392.50 . bill . $45-.50$.

Distribution. - San Clemente. San Miguel, and Santa Rosa Islands, California; and Coronados Islands. Lower California.

\section{1k. M. m. merrilli (Brewst.). Merrill Soxr Sparrow.}

Similar to morphna, but with smaller bill and ground color of upper parts lighter and more ashy; dark markings - especially on back blacker and more sharply defined; the white of under parts clearer and more extended. Wale: length (skins) 5.(6.)-6.40. wing $2.5(j-2.7 .5$, tail 2.512.83, bill .4.5-.51. Female: length (skins) 5.48-6.21, wing 2.50-..68, tail $2.40-2.76$, bill $.4-.50$.

Remarks. - Merrilli is like montana, but slightly darker and more uniform above. the gray and brown of interscapnlars less strongly contrasted.

Distribution. - Breeds from Fort Sherman. Idaho. south through Oregon and Washington east of Cascades to northern California; migrates to Nevada, Utah. Arizona, and northern sonora.

\section{Melospiza lincolnii (.Aud.). Lricoly Sparrow.}

Adults. - Lpper parts dark brown aud olive. finely and sharply streaked with black; crown with light median stripe; malar region, chest. and sides buffy ; sides and broad buffy chest band narrowly streaked with black. Ioung: colors more suffused and streaks less sharply defined. Male: length (skins) 4.SS-5.76, wing $2.26-$

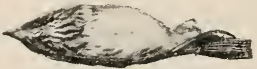

Fig. 448, $2.6 * 2$, tail $2.07-2.44$, bill $.41-.47$. Female: length (skins) $4.54-5.43$, wing. $2.15-2.45$. tail $2.01-2.34$, bill .:3-.46.

Distribution. - Breeds in Boreal zone of North America from Fort Yukon east to York Factory, Hudson Bay, and south to the higher parts of the Rocks Monntains and Sierra Nevada; winters from southern United States to Panama.

Nest. - On the ground, made of grass. Eggs : as described by Davie. light greenish white. heavily marked, chiefly around larger end, with chestmut and lavender gray.

Food. - Mainly insects and grass and weed seed.

The Lincoln sparrow might be mistaken for a song sparrow but for his buffy chest band, finely penciled breast. and wholly individual, ribrant song.

Willows in mountain meadows attract him, and when you surprise him on a willow stalk with his bill full of insects for his brood, 
he will cling there switching his tail and uttering his sharp call-note till you leave.

583a. M. 1. striata Brewst. Forbush Sparrow.

Similar to lincolnii, but superciliary stripe and upper parts more strongly olivaceous, and dark streaks, especially on back and upper tail coverts, coarser, blacker, and more numerous. Wing: 2.35, tail :2.23.

Distribution. - British Columbia and western Washington; migrates to California.

\section{Melospiza georgiana (Lath.). Swamp Sparrow.}

Adults. - Crown chestnut, forehead black or broadly streaked with black and divided by a gray or buffy median line; rest of upper parts rusty brown, back broadly streaked with black; tail with middle feathers with narrow blackish median stripe; under parts gray, darker on chest, but unstreaked or very indistinctly streaked; sides and flanks brown. Young: upper parts heavily streaked and under parts streaked on ehest and sides. IIale: length (skins) 5.11-5.79, wing 2.30-2.5s, tail 2.18-2.51, bill .43-.47. Female: length (skins) $4.80-5.54$, wing $2.27-2.45$, tail $2.06-2.41$, bill .42-.47.

Distribution. - Breeds from the Hudson Bay south to the northeastern United States; west to the Plains; winters from Massachusetts south to the Gulf states and to western Texas.

Nest. - On low, wet, grassy land, made of grasses and lined with leaves and stems. Eggs: 4 or 5, pale bluish to greenish white, spotted with lilac and shades of yellowish and brown, most thickly about larger end.

Food. - Mainly insects and seeds.

\section{GENUS PASSERELIA.}

General Characters. - Bill moderate or swollen, conical ; feet and claws large, side claws reaching much beyond end of middle toe; tarsus about twice as long as bill, stout.

KEY TO SPECIES.

1. Back brown or marked with brown.

2. Back streaked or spotted with brown. Winters from Atlantic to Rocky Mountains . . . . . . . . iliaca, p. 360.

$2^{\prime}$. Back plain brown. Alaska ; in winter to southern California.

1'. Back gray. unalaschcensis. ${ }^{1}$ p. 361.

2. Smaller, with more slender bill. Rocky Mountain district.

2 '. Larger, with thicker bill.

schistacea, p. 362.

3. Depth of bill at base .49. Sierra Nevada and Coast Range. California . . . . . megarhyncha, p. 362

3 3. Depth of bill at base .56. San Bernardino Mountains, California. stephensi, p. 363 .

585. Passerella iliaca (Merr.). Fox Sparrow.

Adults. - Upper parts mixed with strongly contrasting slate gray and reddish brown in varying proportions amounting to gray and brown phases; brown brightest on wings, rump, and tail; wings with two white

${ }_{1} \mathrm{Mr}$. Ridgway has restricted unalascheensis to Alaska. See Birds of North and Middle America, i. 389. 
bars; under parts white, sides of throat and chest spotted and blotched with reddish brown; flanks streaked with rufous. Young: similar. but colors duller and markings less sharply defined. Male: length (skins) 5.94-6.80, wing 3.40-3.61, tail 2.61-2.91, bill .42-.51. Female: length (skins) 6.1S-6.70, wing $3.30-3.46$, tail $2.63-2.85$, bill . $40-.45$.

Distribution. - Northern North America, breeding from Magdalen Islands to Bering Sea; south in winter to Florida. middle Texas, and eastern base of Rocky Mountains.

Nest. - On ground or in bushes, made largely of moss and leaves. Eggs: 3 to 5 , bluish green spotted with reddish brown.

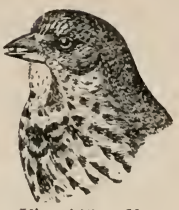

Fig. 449. Fox Sparrow:

Food. - Insects, a large proportion of ragweed and polygonum seed, and wild fruit.

\section{5a. P. i. unalaschcensis (Gmel.). Towrsexd Sparkow. ${ }^{1}$}

Upper parts reddish brown, more or less mixed with slaty gray, becoming dark brown or foxy on rump, wings, and tail; under parts white, thickly marked with triangular spots of dark brown converging on breast. Male: length (skins) 6.5()6.70, wing $: 2.28-3.39$, tail $2.88-2.98$, bill . $49-$

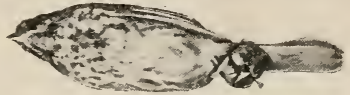

Fig. 450 . .50 . Female: length (skins) 6.20-6.65, wing 3.14-3.19, tail 2.71-2.80, bill $.50-.52$.

Remarks. - The dark reddish brown upper parts, converging spots on the breast, and the long wings distinguish this subspecies.

Distribution. - Breeds on Alaskan peninsula and islands. and migrates to southern California; casually to Lower California.

Nest. - Near the ground in dense thickets, made largely of moss and leaves. Eggs: 3 or 4, pale bluish green, or greenish gray. speckled and blotched with brown and lilac.

The members of the genus Passerella are large, strongly marked sparrows, with loud, rather rich voices. As the size and strength of their feet show, they are diggers. A bird that I watched in Golden

$1 \mathrm{Mr}$. Ridgway has restricted unalaschcensis to Alaska and separated from it the form which comes to northern California as townsendi, adding several new subspecies which winter in California.

Passerella iliaca insularis Ridgway.

Like unalaschcensis, but back warm sepia brown, spots on chest large and deep brown, under tail coverts strongly tinged with buff.

Distribution. - Kadiak Island (and Middleton Island?), Alaska, in summer; sonth to California in winter. (The Auk, xvii. 31.)

Passerella iliaca annectens Ridgway. Yakutat Fox Sparrow.

Similar to insularis, but smalier, especially the bill, and coloration slightly browner.

Distribution. - Coast of Alaska, from Cross Sound to Prince William Sound (to Cook Inlet?), south in winter to Caiifornia. (The Auk, xvii. 30.)

Passerella iliaca meruloides (Vigors).

Like insularis, but bill smaller and coloration throughout darker.

Distribution. - Breeds in Yakutat Bay district (?) and winters in Santa Cruz district.

(The Condor, iv. 45.) Perhaps a synonym of annectens.

Passerella iliaca townsendi (Aud.). Townsend Sparrow.

Like annectens, but darker, spots on chest larger.

Distribution. - Coast of southern Alaska; in winter to northern California.

Passerella iliaca fuliginosa Ridgway. Sooty Fox SPARrow.

Like townsendi, but darker and less rufescent, spots on under parts larger and more confluent than in other forms.

Distribution. - Breeds in coast district of southwestern British Columbia and northwestern Washington; south in winter to coast of northern California. (The Auk. xvi. 36.) 
Gate Park, San Francisco, one day gave a good exhibition of their methods. He took a little run forward and then kicked back with both feet, and if there were any diminutive hillocks back of him, leveled them, sending a shower of sand up behind him. Sometimes he used his bill to push a bit of earth aside. After working in this way with artisan-like regularity for some time, he hopped up on a plant label and sat there with his long toes over the edge looking up with wimning friendliness.

The fox sparrows were to be found through the winter not only in Golden Gate Park, but also in the small parks and cemeteries of the city, with the white-crowned and golden-crowned sparrows. But though with the others, Passerella was not of them, and while the crowned sparrows were in goodly flocks he shoveled alone or possibly with a few comrades. When chased by a white-crown he gathered his feathers trimly about him and ran meekly back into the bushes. He was evidently not as used to city life as they, for when he came out in view it was with his red tail perked up, his wings close at his sides. and a conscious air of appearing in public, and at the least alarm he would scud back to cover in nervous haste.

When at home the thick-billed sparrows live in dense laurel or evergreen thickets, Major Bendire says, but the slate-colored prefers the more open country, living in rose and willow thickets along streams near foothills.

In the Sierra Nevada one of the loudest and richest of the finch songs that brighten the Transition zone forest can be traced to the thick-billed, perched on top of a bush, his big bill and mixed reddish brown and gray plumage distinguishing him. His song is not of the high grade of the white-crown, but is particularly pleasing on account of its loud, cheery quality. His call-note is a sharp chip.

\section{5b. P. i. megarhyncha (Baird). Thick-Billed Sparrow.}

Upper parts plain slaty or brounish gray. becoming rusty on wings. upper tail coverts, and tail; under parts with chest spots smaller, more scattered;

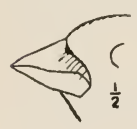
tail longer than wing, bill thick. Male: length (skins) 6.607.20, wing 3.12-3.42, tail 3.0.2-3.42. bill .45-.54. depth of bill at base .49-.52. Female: length (skins) 6.50-7.56, wing 2.973.37 , tail 3.02-3.49, bill .4.5-.5.3, depth of bill at base .4.-.50.

Remarks. - The gray back and the thick bill distinguish

Fig. 451. megarhyncha from unalaschcensis. and its larger size and thicker bill from schistacea; while its smaller bill distinguishes it from stephensi.

Distribution. - Breeds in Transition zone in the Sierra Nevada and Coast. Range; migrates to Los Angeles County, California.

Nest. - In evergreens and thickets. nsilally on or near the ground, made of plant fibers and willow bark, lined with grasses and horsehair. Eggs: 3 or 4 , markings tending to run longitudinally.

585c. P. i. schistacea (Baird). Slate-colored Sparmow.

Like megarhyncha, but smaller body and bill. Male: length (skins) 
6.23-7.16, wing 3.08-3.43, tail 2.85-3.4:3, bill .44-.50. Female: length (skins) $6.02-6.55$, wing $3.0 .2-3.21$, bill $4.5-.50$.

Distribution. - Breeds in Transition zone in the Rocky Mountain region of British Columbia and the United States; from Colorado to California ; wanders in winter to Kansas, Arizona, Nevada, and California.

Nest. - Usually less than $\ddot{z}$ feet from the ground, bulky and well made of plant fibers, willow bark, and grass, lined

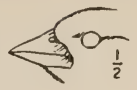

Fig. 452 . Slate-colored Sparrow. with horsehair. Eggs : usually 4, green or olive buff, marked with purple and browns.

\section{5 d. P. i. stephensi Anthony. Stephens Spakrow.}

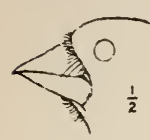

Fig. 453 .

Like megarhyncha, but averaging larger, with much larger bill. Male: length (skins) 6.61-7.34, wing :3.30-3.37, tail 3.17-3.58, bill .59-.65. Female: length (skins) 6.61-6.92, wing $3.13-3.30$, tail $3.10-3.41$, bill .52-.59.

Distribution. - Mountains of southern California.

\section{GENUS ARREMONOPS.}

\section{Arremonops rufivirgatus (Lawr.). Texas Sparrow.}

Tail shorter than wing; wing short and much rounded. Adults: upper parts plain olive green, wings and tail brighter; top of head with wide olive median stripe bordered by dark brown or blackish brown stripes; superciliars gravish ; lores and stripe back of eye brown; edge of wing bright reliow; under parts dull whitish, chest, sides, and flanks tinged with pale buffy. Young: dull brownish; head without distinct stripes; wings and tail with greenish edgings; belly buffy or fulvous. Male: length (skins) $5.3(1-6.00$, wing $2.45-2.65$, tail $2.45-2.75$, bill $.45-.55$. Female : length (skins) 5.5(1-5.55, wing 2.32-2.45, tail 2.23-2.50, bill .47-.52.

Distribution. - Valley of the Lower Rio Grande, in Texas, and eastern Mexico; casually to Lonisiana.

Nest. - In open thickets, made of dried weed stems, bark. grasses, and leaves, sometimes lined with hair. Eggs: 4 . dull white.

\section{GENUS PIPILO.}

General Characters. - Bill moderate; wings short, greatly rounded; primaries exceeding secondaries usually by much less than bill : tail long, rounded; feet large and strong. claws stout, and much eurved.

\section{KEY TO ADULT MALES.}

1. Upper parts light grayish brown.

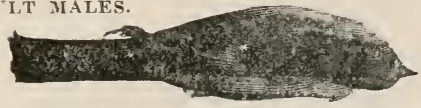

Fig. 454 .

2. Lores and chin blackish

2 . Lores and chin not blackish.

3. Crown rufons, throat buffy

3 . Crown not rufous, throat rufous.

4. Smaller. Southern ('alifornia senicula, p. $36-$ t'. Larger. . . . . . crissalis, p. $36^{\top}$.

1'. Upper parts black.

aberti, p. 368 .

mesoleucus. p. 366 .

Fig. 455. 
2. Scapulars and wing coverts almost always wholly black. Easterm.

2 '. Scapulars and wing coverts marked with white.

erythrophthalmus, p. 364 .

3. White markings inconspicuous

3'. White markings conspicuous.

4. White on outer tail feathers covering more than exposed half (beyond coverts) . . . . . . . . . . arcticus, p. 364.

$4^{\prime}$. White on outer tail feathers not covering more than exposed half.

5. White on outer tail feather covering more than an inch.

6. Darker; bill and feet relatively smaller. Rocky Mountains to Pacific . . . . . . . . megalonyx, p. 365.

6 '. Lighter colored; bill and feet relatively larger. San Clemente Island, California . . . . clementæ, p. 366.

5 . White on outer tail feather reduced to less than an inch.

atratus, p. 366 .

587. Pipilo erythrophthalmus (Linn.). Towhee: Chewink.

Adult male. - Black, except for white belly, brown sides, and white

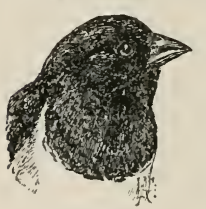

Fig. 456. patch on primaries, white edgings to tertials, and white corners to tail; iris bright red. Adult female: similar, but black replaced by brown. Young: similar to adults of same sexes, but streaked, and without dark chest patch. Male: length (skins) 7.36-S.10, wing 3.29-3.72, tail 3.45-3.91, bill .53-.58. Female : length (skins) 6.80-7.52, wing 3.00-3.30, tail 3.173.5 .2 , bill .51-.5s; white on end of outer tail feather 1.30-1.60.

Remarks. - The absence of white on the scapular and wing coverts distinguishes the eastern towhee from the western forms.

Distribution. - Breeds from southern Canada to the Lower Mississippi Valley, and from the Atlantic to the western parts of Dakota and Nebraska; winters from the middle districts sonthward.

Nest. - On the ground or occasionally in low bushes, bulky, made of leaves, twigs, and vines, and lined with grass stems and rootlets. Eggs: usually 4 , white, pinkish white, or brownish, thickly speckled with reddish brown.

Food. - Insects and seeds.

\section{Pipilo maculatus arcticus (Swains.). Arctic Townee.}

Adult male. - Head, neck, and chest black; back black, more or less

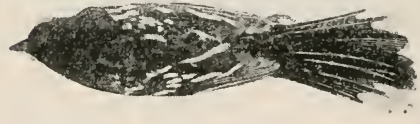

Fig. 457. mixed with olive gray; belly white; flanks reddish brown; wings and tail with extensive white markings; wing bars and white edgings of primaries sometimes forming a conspicuous patch, and scapulars heavily streaked witl white; white on outer tail feather covering more than half exposed portion beyond coverts (1.30-1.70). Adult female: Black, replaced by dull olive brown; back streaked with black; throat and chest gravish brown; white markings obscured. Young: streaked with black over brownish ground above, buffy below ; lighter in female; markings of wings and tail as in adult, more or less restricted on wings. Male: length (skins) $6.90-8.34$, wing 3.38-3.59, tail 3.58-4.10, bill .47-.5\%. Female: length (skins) 7.19-8.30, wing 3.103.58 , tail $3.40-4.10$, bill .48-.5. 
Distribntion. - Breeds in Transition and Upper Sonoran zones on the Plains and eastern foothills of the Rocky Mountains from the Saskatchewan south to southern Colorado, and from the Missouri west to western Montana; winters south to Texas and west to Washington; easually to Iowa and Wisconsin.

Nest. - On the ground, made at times of pine needles and lined with grass.

The towhees of the maculatus group are shy birds of the chaparral, and when caught singing on top of a bush, where you can study the amount of white mixed with the black and brown of their plumage, they are liable to stop short in their song and pitch down to the ground with only an aggravating flash of the white tail corners. And though you wait patiently, all the reward you are likely to get is a nasal uthank or a mewing toc-hee as they rattle the dead leaves, scratching for worms under the dense cover of brush.

Both their call-notes and songs have a quaint twang that give them peculiar zest. One of the commonest songs in general time and emphasis may be giren as yang', kit-er-er.

\section{8a. P. m. megalonyx (Baird.). Spurred Towhee.}

Like arcticus, but with tail, tarsus, and hind claw longer. bill larger, and coloration darker; upper parts black, except for grarish rump; uhite markings much restricted, and rufous of sides deeper; middle of back and tertials usually without white; white edgings of primaries

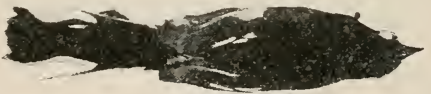

Fig. 458 . not developed into a patch. and white space on outer tail feather not occupring more than half of space beyoud coverts (1.10-1.35 long). Adult female: darker than female arcticus, streaks on back less conspicuous, white tail patch smaller. Young: similar to young of arcticus, but darker. Male: length (skins) $7.12-8.30$. wing $3.29-3.65$, tail $3.55-4.39$, bill .48.58. Female : length (skins) 7.12-8.09, wing $3.13-3.48$, tail $3.42-4.16$, bill $.49-.59$.

Distribution. - Breeds in Transition and Upper Sonoran zones from the Rocky Mountains to California and from British Columbia south to Lower California and northern Mexico.

Nest. - On the ground or in a bush. made variously of inmer bark. leares, and small sticks. lined with grass. Eggs : 4 or 5, pale greenish or bluish. finely specked with brown and lavender, massed around larger end.

588 b. P. m. oregonus (Bell). OREgon TowheE.

Adult male. - Upper parts mainly black, white markings inconspicuous; streaks on back mainl obsolete or concealed; wing bars reduced to disconnected round white spots. white of outer tail feather reduced to "thumb mark." less than an inch in length, outer web mainly black:

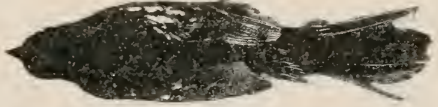

Fig. 459 . rufous of sides very dark. Adult female: black replaced by dark sooty 
brown or sooty black, indistinctly streaked with black; rufous of sides deep. Young: Darker and more uniform than young megalonyx; throat and chest sooty, not streaked. Male : length (skins) 7.05-8.18, wing 3.223.47 , tail $3.42-3.87$, bill .54-.59. Female: length (skins) 6.95-8.00, wing $3.03-3.38$, tail $3.31-3.85$, bill .52-.5s.

Remarks. - In the Oregon towhee the general size and hind claw are much smaller than in the spurred, while the absence of white markings makes a good field character.

Distribution. - Breeds in humid Transition zone from British Columbia to San Francisco; winters south to southern California.

\section{8c. P. m. clementæ (Grinn.). San Clemente Towhee.}

Adult male. - Like megalonyx, but bill and feet relatively larger and coloration grayer; upper parts sooty, washed with olive gray; rump lighter, upper tail coverts finely barred with dusky. Adult female: head and neck dnll dark brown; wings and tail darker; rmmp gray, feathers with dark centers and light edgings. Male: length (skins) 7.44-8.10, wing $3.14-3.56$, tail 3.48-4.06, bill .55-.60. Female: length (skins) 7.028.30 , wing $: 3.06-3.24$, tail $3.45-3.76$, bill $.54-.58$.

Distribution. - San Clemente Island, southern California.

588d. P. m. atratus Ridgw. San Diego Towhee.

Adult male. - Deep glossy black; wings and scapulars heavily marked with white; outer tail feathers with white thumb marks. Adult female: upper parts clove brown; throat and chest clove brown or sooty black.

Remarks. - 'The San Diego towhee is like the spurred, but decidedly darker, and with white markings more restricted.

Distribution. - From coast distriet of southern California south to Lower California.

\section{Pipilo fuscus mesoleucus (Baird). Canyon Towhee.}

Adults. - Top of head light rufous; rest of upper parts and sides plain dull gravish brown; throat buffy, finely spotted, obsolete chest patch formed by large spots; middle of belly whitish, hinder part of belly, flanks, and lower tail coverts yellowish brown. Ioung: upper parts dull grayish brown, indistinctly streaked with darker; wing coverts largely edged and tipped with pale rufous; lower parts dull white. changing to brownish on under tail coverts, largely streaked with dusky. Male: length (skins) $7.64-8.77$, wing $3.49-3.94$, tail $3.77-4.2: 3$, bill $56-66$. Female: length (skins) 7.75-8.72. wing $3.39-3.92$, tail $3.71-4.31$, bill .57-.64.

Distribution. - Upper and Lower Sonoran zone from western Texas to Arizona, and from eastern Colorado sonth to Sonora and Chihnahua.

Nest. - In mesquite trees rarely over 8 feet from the ground, sometimes in thick bunches of cholla cactus and between the leaves of ynceas, deep, bulky, and loosely made of coarse grasses lined with rootlets and horsehair. Eggs: usually :3. bluish white or pearl gray, spotted and scrawled with brown and sometimes black, and with purple shell markings.

The fuscus group of towhees, while chaparral birds of the same general habits as the maculatus group, seem more like big fluffy brown sparrows than chewinks.

The canyon towhee, when sitting on a bush, shows his rufous under tail coverts and raises his crown so that the color shows there. He has a loud metallic chip, a call of four loud repetitions of the 
same note, and in flight the robin-like screep'-eep-eep of his group. In the mountains, the canyou towhees are found among rocks and along ledges of canyons. At Mineral Park, Arizona, Mr. Bailey found them abundant in February. They were noisy and so tame that they would come into camp to feed on scattered crumbs and grain. In New Mexico outside of the mountains, Mr. Batchelder found them about Mexican villages and irrigated fields.

\section{$59 \mathrm{lb}$. P. f. crissalis (Vig.). Califorma Towhee.}

Adults. - Entire upper parts plain dull grayish brown, slightly deeper on head; throat light rufous, usually marked with dusky; niddle of belly whitish or dull buffy, sides grayish brown; under tail coverts reddish brown. Young: like adults, but browner. wing bars and edgings pale brownish; under parts dull buffy, deepening to tawny on throat and belly, and grayish brown along sides; anterior lower parts streaked. Male: length (skins) 8.3.59.50, wing $3.7 .5-4.08$, tail $4.2 .2-4.5 .5$, bill .56-.65. Female:

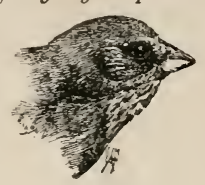

Fig. 460 . length (skins) $8.24-8.100$, wing $3.57-3.85$, tail $4.14-4.38$, bill .56-.63.

Remarks. - Crissalis is like mesoleucus, but larger and darker.

Distribution. - California, west of Sierra Nevada, north to Mendocino and Shasta counties, south to Santa Barbara and Kern counties, and northern part of San Bernardino County.

Nest. - In bushes or trees, usually 2 to 6 feet from the ground, made of inner bark, twigs, and weed stems, lined with plant stems and sometimes horsehair and wool. Eggs : 4 or 5, pale blue, spotted with purplish brown.

The California members of the fuscus group have a thin chip which gives them the name of brown chippies, the robin-like call of mesoleucus, and a song which, though a trifle squeaky for such a large bird when heard too close at hand, has a quiet, contented quality that matches the bird's disposition and is very pleasing. When given in concert in the canyons at dusk the song is said to be most effective. Though shy and wary about his nesting grounds, when his family cares are over the brown chippie comes to the dooryard and stays there more familiarly than the Brewer blackbird. Although he also makes limself at home on city lawns and in parks, he is especially fond of barnyards and hay lofts, where he can scratch in the straw and pick up seeds to his heart's content. When he flies his short wings and long tail give him a bobbing, awkward motion, but when sitting about the dooryard his plump, fluffy figure affords him a most comfortable domestic look.

\section{1c. P. f. senicula Anthony. San Fernando Towhen: Anthoni TOWHEE.}

Like crissalis, but smaller, upper parts darker. and lower parts grayer. Male: length (skins) $8.05-8.12$, wing :3.48-3.97, tail $3.95-4.42$, bill .56-.6\%. Female: Wing $3.38-3.56$, tail $3.93-4.02$, bill $.57-60$.

Distribution. - From southern California south to Lower California. 


\section{Pipilo aberti Baird. Abert Towhee.}

Adults. - Lores and chin blackish; upper parts plain grayish brown, darkest on head; quills edged with grayish; lower parts pinkish brown, lighter on belly, and deepening to tawny on under tail coverts. Young: paler and duller, breast indistinctly streaked. Male: length (skins) 8.2.29.14, wing 3.54-3.81, tail 4.17-4.72, bill .59-.64. Female: length (skins) 7.97-8.68, wing 3.36-3.62, tail 3.97-4.31, bill .59-.62.

Distribution. - Breeds in upper and lower Sonoran zones from Colorado to southeastern California, Arizona, and New Mexico.

Nest. - Rarely more than 5 feet from the ground, in willow thickets, canebrake, low bushes, or mesquite ; bulky, loosely made of weed stalks, inner bark, grass, and sticks, sometimes lined with inner bark or horsehair. Eggs: 2 to 4, pale blue, sparsely marked with dark brown and black.

The cinnamon colored aberti is the largest of the plain towhees. It is said to be extremely shy. Major Bendire gives its alarm note as huit huit. At Phœnix it is common among the mesquites and cottonwoods.

\section{GENUS OREOSPIZA.}

\subsection{Oreospiza chlorura (Aud.). Green-talled Towhee.}

Bill small, conical; wing rather long and pointed; tail long, rounded;

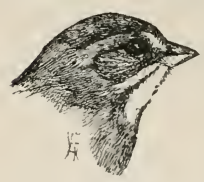

Fig. 461. tarsus long, nearly a third the length of wing; hind claw longer than its toe. (Structurally intermediate between Zonotrichia and Pipilo.) Adult male: top of head bright rufous; throat white; upper parts olive gray, becoming bright olive green on wings and tail; malar stripe and middle of belly white ; edge of wing, under wing coverts, and axillars bright yellow. Adult female : usually slightly duller. Young: olive grayish, streaked with dusky; lower parts dingy white, chest and sides streaked with dusky; wings and tail like adults, but wing bars brownish buffy. Male: length (skins) 6.217.05, wing 3.01-3.28, tail 3.14-3.42, bill .4S-.51. Female: length (skins) $6.52-7.10$, wing $2.80-3.10$, tail $2.98-3.33$, bill .45-.51.

Distribution. - Breeds in Transition zone in the interior plateau region from the western edge of the Plains to Coast Range in California, and north to Montana ; migrates to southern Lower California and central Mexico.

Nest. - On or near the ground in sagebrush, chaparral, or cactus, made of sticks lined with grass. Eggs : 4, whitish, speckled or sprinkled with reddish brown.

The name Oreospiza calls to mind one of the most attractive and gentle of birds, with the memory of warm days when the smell of the aromatic mint and Ceanothus filled the air. The green-tail follows the Transition zone chaparral from the zonal level, where a dense brush thicket covers wide areas, and where he is one of a number of brush birds, up to the extreme limit of the chaparral, where there are only scattered patches of dwarf brush on high rock slides, and where he is the one brush bird, conspicuous among the boreal solitaires and nutcrackers.

His mewing call-note, a soft mew, mero-ah-eep, seems his most 
chewink-like character and proclaims his presence, as does his song when the ear has caught the difference between it and that of the Passerella. Though phrased some what like the song of the maculatus group, it is wholly different in quality and rendering, being more of the bright finch type with the Chondester-like burr heard in so many tinch songs, and its two emphasized notes standing out in a medley of short notes.

His familiar voice is often heard from a wall of chaparral, but he may generally be found perched on top of a bush, and at sight of you will raise his rufous cap inquiringly, turning to look down so that his white chin shows to good advantage. When seen hopping over the ground he is as trim and alert as a song sparrow, looking about and flashing his green tail till he disappears to scratch in the brush. When surprised on the ground he will of ten run rather than take wing. One that Mr. Bailey found on its nest at 7900 feet on Donner Peak, California, ran silently ifor five or six rods through the brush, and then stopped, to tempt him away from its brood.

\section{GENUS CARDINALIS.}

General Characters. - Head with conspicuous erest; bill stout, conical, much deeper than broad at base; wing short, much rounded, primaries exceeding secondaries by less than length of exposed culmen; tail longer than wing.

\section{KEY TO ADULT MALES.}

1. Feathers all around base of bill black.

2. Black frontlet wider. Eastern United States . cardinalis, p. 369.

2'. Black frontlet narrower. 'Texas to Mexico . canicaudus, p. 370. $1^{\prime}$. Feathers around base of bill not black across forehead. Arizona to Mexico superbus, p. 370 .

\section{Cardinalis cardinalis (Linn.). Cardinal.}

Adult male. - Crest, head, and lower parts bright red, feathers around base of bill black; back dull red, feathers tipped with olive gray, wearing away in midsummer. Adult female: wings and tail dull red; erest partly red; upper parts olive grayish; under parts grayish buffy ; chest of ten tinged with red; featlers around base of bill and upper parts of throat dull gravish; under wing coverts pinkish red. Young: like adult feinale. but duller, the bill blackish. Male: length (skins) 7.408.40, wing 3.60-3.93, tail 3.78-4.85, bill .71-.80. Female: length (skins) $7.40-8.15$, wing $3.48-3.78$, tail $3.70-4.22$, bill $.65-. \leqslant 0$.

Distribution. - Resident in eastern United States from the Gulf north regularly to about latitude $41^{\circ}$; casually northward to Ontario; west to edge of great Plains, rarely in western Kansas and Colorado.

Nest. - A rather frail structure of sticks or fine rootlets, leares, grasses, or strips of bark, sometimes covered with gray moss; placed in bushes. brambles, grapevines, or low trees. Eggs: 2 to 4 . white, irregularly spotted with purple and reddish brown.

Food. - Insects, berries, seeds, and grain. 
The cardinals are the most striking of chaparral birds where they occur. Seen against a background of dingy brush their red plumage fairly glows in the sun till you are led to marvel at its brilliancy.

Then how their loud whistle pierces the air! How exquisitely rounded comes their clue-cue, and with what force follows the rapid hip'-ip-ip-ip-ip-ip-ip.

593a. C. c. superbus Ridgw. Arizona Cardinal.

Adult male. - Top of head and long erest brilliant red; lores and chin black, black of lores not connected across forehead unless by narrow black line; rest of under parts brilliant red; back dull red washed with gray; wings and tail dark red; bill very heavy. Adult female: crest, wings, and tail partly red; under parts dark buffy, chest tinged with redi ; lores and chin gray; forehead dull yellowish mixed with red; back dull gray; under wing coverts bright rose. Young: similar to adult female, bnt colors duller; bill blackish. Male: length (skins) $8.40-9.00$, wing $3.92-4.11$, tail 4.67-5.00, bill .80-.89. Female: length (skins) 7.8.5-8.30, wing 3.79-4.00, tail $4.48-4.75$, bill .82 .

Remarks. - Superbus differs from cardinalis in larger size, relatively shorter bill, pale red of male, and broken ring around bill.

Distribution. - From southern Arizona south to Sonora, Mexico.

The Arizona, like the eastern cardinals, are birls of the thickets and brush patches, making themselves known by brilliant flashes of color and their rollicking, spirited song. At Phœnix they build in the thickets just out of town, and, though shy birds, seem not to object to civilization.

Verion Balley.

\section{3c. C. c. canicaudus Chapm. Gray-tailed Cardinal.}

Male similar to cardinalis, but with less conspicuous black frontlet; female averaging grayer than female of cardinalis, and with the tail feathers broadly margined with gray instead of olive brown. Male: length (skins) $7.60-8.60$, wing $3.48-3.80$, tail $3.85-4.58$, bill .71-.82. Female: length (skins) $7.00-8.20$, wing 3.22-3.67, tail 3.58-4.12, bill .70-80.

Distribution. - From Texas south to Central Mexico.

\section{GENUS PYRRHULOXIA.}

General Characters. - Head with conspienons erest; bill very short, thick, and deep, culmen convex; wing short, much rounded; tail long, rounded.

KEY TO ADULT MALES.

1. Ring around bill conspicuonsly marked with black . texana, p. 371 . $1^{\prime}$. Ring aronnd bill rose red . . . . . . . . . sinuata, p. 370 .

594. Pyrrhuloxia sinuata Bonap. Arizona Prrohuloxia.

Bill short and parrot-like, yellow or orange in summer, duller in winter. Adult male : ring around bill, throat, breast patch, thighs, and under side of wing light rose red; lateral under parts light gray; tip of erest darker red ; ring around bill with only faint trace of black; npper parts light gray tinged with brown; wings and tail blackish and dark red. 1dult female: like male, but red of face and under parts wanting or only suggested; under parts buffy brown. Young male: like adult female, but paler, 



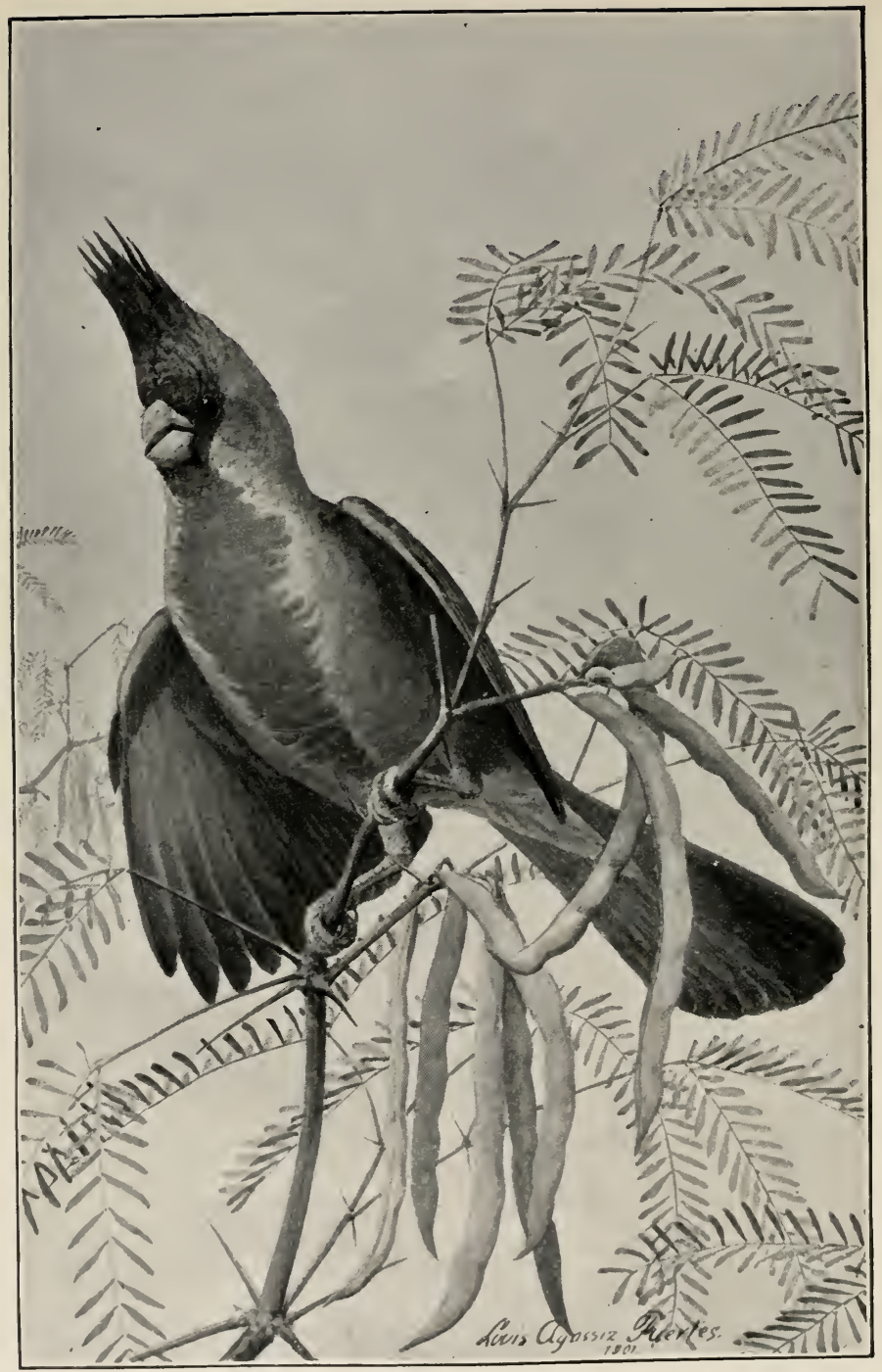

TEXAS PYRRHULOXIA 
buffy below and on wing bands; median under parts and face more or less tinged with red. Young female: like young male, but without red. Male: length (skins) $7.45-8.41$, wing $3.52-3.58$, tail $3.72-4.25$, bill $.59-.63 . \quad F e$ male: length (skins) 6.90-7.94, wing $3.46-3.67$, tail $3.69-3.82$, bill .58-.62.

Distribution. - Lower Sonoran zone from southern Arizona to western Texas and northwestern Mexico.

Nest and eggs similar to those of the cardinals, but eggs averaging smaller.

Though not so brilliant as the Cardinalis group, the Pyrrhuloxias when among their native mesquites seem eren more beautiful. The rose-colored vest that lights up their soft gray plumage gives an exquisite delicacy and freshess that adds charm to their individuality and sprightliness. Their expression changes astonishingly with the movement of their crest. When it is flattened the short curved bill and round head suggest a bored parrot in a cage, but when the crest is raised to its full height and thrown forward, the beautiful bird is the picture of alert interest and viracity.

The call-note of the Pyrrhuloxias, instead of a single chip, is made up of several flat, thin notes. Their whistle, though of similar character to the cardinals', instead of being a scooped cue note is a clear straight whistle.

A pair whose nest we stumbled on in the mesquite showed their mutual solicitude in such a charming manner, the male bursting into song to draw our attention from his mate and nest, that it seemed as if rare pleasure lay in store for the bird student with leisure to study their attractive ways.

\section{4a. P. s. texana Ridgw. Texas Pyrrhuloxia.}

Adult male. - Similar to sinuata, but bill much heavier and coloration darker ; ring round bill conspicuously marked with black; upper parts dark gray. Adult female: similar to female sinuata, but under parts grayish on front and sides. Male: length (skins) 7.5) - 8.10 , wing 3.45-3.88, tail 3.684.21 , bill .60-.67. Female: length (skins) $7.10-8.10$, wing $3.39-3.79$, tail $3.30-4.26$, bill .60-.65.

Distribution. - Lower Sonoran zone in northeasteru Mexico and southeru Texas, north to Nueces, Bee, Bexar, Kendall, and 'Tom Green counties.

Nest. - In mesquite and other thorny bushes, small and compact, made of inner bark, grasses, and twigs, lined with a few rootlets. Eggs : 3, spotted with brown and lavender massed at the larger end.

\section{GENUS ZAMELODIA.}

General Characters. - Bill heavy, short, conical, much deeper than broad at base; nostrils exposed; wing pointed; tail even or slightly rounded; tarsus about as long as middle toe with claw.

KEY TO ADULT MALES.

1. Under parts brown and yellow . . . . melanocephala, p. 372. $1^{\prime}$. Under parts white and rose pink . . . . ludoviciana, p. 372. 
595. Zamelodia ludoviciana (Limn.). Rose--3reasted GrosBEAK.

Adult male in breeding plumage. - Head and upper parts black. except for white rump and white markings on wings and tail ; under parts white,

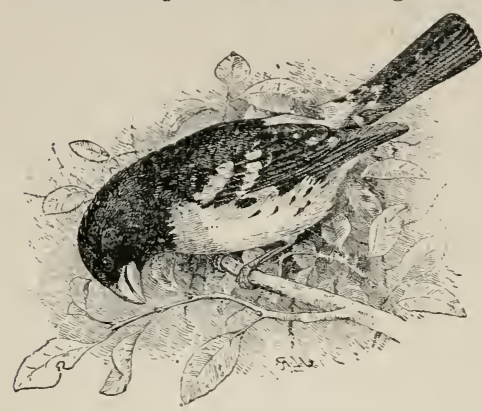

Fig. 413. except for rose red patches on breast and nuder wings. $1 d$ ult female: dusky brown, streaked; head with whitish median stripe and superciliary; under parts gray ish or buffy brown, streaked on breast and sides: under wing: coverts yellow. Adult male in winter plumage : wings, tail, and upper tail coverts as in summer; upper parts reddish brown; head with buffy median erown stripe, superciliary, and nalar stripes; back streaked with black; under parts brownish, more or less streaked, and with pale rose on breast and under wings. Young male in first winter: like arnlt winter male, but wings, rump, upper tail coverts, and tail brownish, tail without white; wings with white markings reduced and tinged with brown; cliest. sides, and flanks deeper brown and more heavily streaked; chest with little if any pink; under wing coverts rose pink as in adult. Male: length (skins) 6.50-7.20, wing 3.85-4.10, tail 2.87-3.08, bill .59-.69. Female: length (skins) 6.75-7.00, wing $3.7 .5-3.99$. tail $2.7 .5-2.95$, bill $.61-.70$.

Distribution. - Breeds in Transition and Upper Sonoran zones from Canada sonth to Kansas. and from the Atlantic to Colorado; winters in Cuba, Central America. and northern Sonth America; accidental in California.

Nest. - A thin saucer-shaped strneture made largely of wiry rootlets, placed in bushes or low trees. Eggs : 2 to 4. bluish green or greenish blue spotted with brown.

Food. - Potato bngs and other insects, with seeds, and buds and blossoms of forest trees.

While the female rose-breasted grosbeak is brown and streaked like the female black-headed, the male is a rare beauty, the clear black, white, and rose of his plumage being handsomer than the black and brown of melanocephata. His song lacks the exquisite finish of the westerner's, but is loud and musical and sung with a joyous swing. His thin eek, like that of the black-hearled, announces him, whether he be in an apple-tree or hiclden in a thicket by a river.

596. Zamelodia melanocephala (Swains.). ВLACK-HEAdED Grospeak.

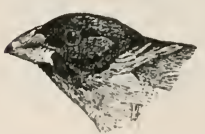

Fig. 464

Adult male. - Under parts cinnamon brou'n brighteniny to lemon yellow on belly and under wing coverts: upper parts mainly black, with cinnamon bown collar and rump. and sometimes brown stripes back of eye, throngh middle of crown. and on back; wings and tail black, wings with two white bars and white patch at base of quills, tail with white corners. Winter male: lighter 
brown on upper parts. Adult female: upper parts blackish brown, streaked witl pale brownish or buffy; collar buffy white; wing bar white; under parts dull buffy, yellowish on beliy, flanks. and sonetimes breast; sides streaked; under wing coverts lemon yellow. Winter female: with buff 5 or brown stronger; lateral crown stripe streaked with black. Young: much like adult female, but under parts paler. without yellow on belly; back spotted; crown stripes uniform blackish brown. Male: length (skins) (6.60-7.70, wing :3.72-4.30, tail 2.79-:3.30. bill .60-.80. Female: length (skins) 6.15-7.40, wing :3.7:-4.12, tail 2.70-3.40. bill .61-.78.

Distribution. - Breeds in Transition and Upper Sonoran zones of the westerı United States, from eastem Nebraska to California, and from British Columbia to northern Lower California and southern part of Mexican plateau.

Nest. - Usually in chaparral, made loosely of sticks and weeds. Eggs : 3 or 4 , pale bluish white, thickly spotted with brown.

Food. - Similar to that of the rose-breasted grosbeak.

When sou hear the call-note of the black-headed grosbeak for the first time, you naturally hunt through the greenery for a small bird, for the note is a peculiarly insignificant eek, and when you discover the goodly sized bird with strongly marked black and golden brown coat and great bill, his small voice seems much out of character. You marvel at it still more when you hear his wonderful song. At its best, given from a poplar or live-oak top in the leisure of a sunny afternoon, it is one of the most varied, exquisitely finished, and musical of birl songs. It has the swinging rhythm and clearness characteristic of grosbeak songs, but is smooth and rounded, and its highest notes are dwelt on and trolled over with rare tenderness, repeated not as a thrasher's notes are repeated, but with the enjoyment of an artist consciously perfecting his work. In Arizona Mr. Henshaw has heard tle birds give sunset concerts from the tops of the tallest pines.

The nature of the grosbeak is not belied by his song, for like others of the family he has a gentle spirit. His derotion to the nest is shown by his habit of brooding in the absence of his mate.

\section{GENUS GUIRACA.}

\section{7a. Guiraca cærulea lazula (Less.). Western Bute Gros- BEAK.}

Bill large, conical. compressed; nostrils exposed; wing longer than tail ; tarsus about as long as middle toe witl claw. Adnit male in summer: plain bright blue; wing with two brownish bands. that across tips of greater coverts usually. . ( $-.3 n$ wide, and decidedly paler than the anterior band; nuder tail coverts witl white borders. Adult male in winier: blue of bods more or less obscured by brownish or buffy tips to feathers. $F e$ male and young: grarish brown. usually more or less tinged with blue. Immature males : plumage of arlult male and female mixed in various proportions. according to age. Male: length (skins) 5.90-7.00. wing 3.409.80, tail $2.62-3.10$, bill ..55-.70. Female : length (skins) 5.60-6.50. wing $3.02-3.48$, tail $2.41-2.80$. bill .55-.68. 
Distribution. - Breeds in Upper and Lower Sonoran zones from eastern Texas to southern California; north to northern Colorado and central valleys of California to about $40^{\circ}$; migrates to southern Mexico and south to Costa Rica.

Nest. - A compact, enp-shaped structure, composed largely of dried grasses and plant fibers, placed in bushes and tall weeds. Eggs: 3 or 4, plain pale greenish blue or bluish white.

Food. - Insects, seeds, buds, and berries.

The blue grosbeak is less arboreal than its relatives, being found mainly in brush, often along streams in foothill canyons. Its song, Mr. Henshaw says, while suggesting the songs of other grosbeaks and possessing much sweetness, "lacks the full rich mellowness of tone and variety of modulation" of its relatives.

\section{GENUS CXANOSPIZA.}

General Characters. - Bill small, under mandible conspicuously deeper than upper; wing pointed; tarsus about equal to middle toe with claw ; side claws not reaching to base of middle claw.

Fig. 465 .

KEY 'TO ADULT MALES.

1. Under parts partly or wholly red.

2. Back yellowish green . . . . . . . . . . . ciris, p. 376.

2 . Back purplish red . . . . . . . . . . versicolor, p. 375.

1'. Under parts not red.

2. Upper parts light blue . . . . . . . . . amœna, p. 375.

2'. Upper parts dark purplish or greenish blue . . . cyanea, p. 374.

\section{Cyanospiza cyanea (Linn.). Indigo Bunting.}

Adult male. - Head, throat, and sometimes median under parts purplish blue; rest of body cerulean blue changing to blnish green in some lights; lores, wings, and tail black or dusky, tinged with blue. Adult female: upper parts olive brown; wings and tail faintly tinged with blue; under parts dull whitish washed with buffy, faintly streaked ou chest. Immature males: varionsly intermediate in coloration between fully adult males and females. Young: similar to adult female, but browner, obsoletely streaked. Male : length (skins) 4.59-5.21, wing 2.58-2.81, tail 1.91-2.13, bill .40-.44. Female: length (skins) 4.46-5.23, wing 2.47-2.62, tail 1.861.92 , bill .39-.43.

Distribution. - Breeds ehiefly in Upper Sonoran and Transition zones of the northeasteru United States, but extends west to Colorado, and from southern Canada to the Gulf ; migrates to Central Ameriea.

Nest. - In low bushes, made of leaves, plant fibers, and grasses, lined with grass stems and horsehair. Eggs: usually 4, white, with faint bluish tinge.

Food. - Largely insects and seeds.

The indigo bunting. the eastern representative of the genus, has been found in Colorado and western Texas, but comes west regularly only as far as eastern Kansas. In habits it is the counterpart of the lazuli bunting. 


\section{Cyanospiza amœna (Say). Lazeli Bunting.}

Adult male. - Cpper parts bright turquoise blue, changing to greenish blue, darker and duller on middle of back; wings with two white bars; breast and sometimes sides bronnish; belly white. Idult female: upper parts grayish brown, tinged with blue on rump; hack sometimes streaked; wing bars dingy; anterior lower parts pale buff $y$, deeper on chest, fading to white on belly and lower tail coverts. Young: like female, but without blue tinge on rump, and chest and sides usually streaked. Male: length (skins) 5.01-5.54, wing $2.78-3.01$, tail $2.07-2.27$, bill .39-.41. $F e$ male : length (skins) 4.91-5.58, wing 2.59-2.8:, tail 2.00-2.31, bill .36-.41.

Distribution. - Breeds in Transition and Upper Sonoran zones of the western United States from Kansas to California; and from British Columbia to Arizona and New Mexico; migrates to Lower California and the Valley of Mexico.

Nest. - Usually near water in weeds, willows, manzanitas, and other bushes. Eggs: :3 or 4, plain bluish white, or pale greenish blue.

The natural home of the blue-coated, brown-breasted lazuli is in the chaparral of warm valleys like those of southern California or in village shrubbery in climates like that of the Salt Lake plain, but like the green-tailed towhee it follows the chaparral to the higher levels, and though nominally a Transition and Upper Sonoran zone bird, is sometimes found in willows of the Canadian zone. In the Sierra above Donner the middle of July we found it as high as 7900 feet, singing gayly in a patch of willows in a tiny mountain meadow surrounded by firs and overhung by snowbanks; and one of the hardy little fellows has even been reported from Fremont Pass.

The song of the lazuli is of the bright, musical finch type, and like that of Oreospiza and Chondestes has a marked burr. The call-note is an emphatic quit' or sometimes chack:

Though less demonstrative than the house finch, the lazuli sometimes spreads his blue feathers before his mate in pretty gallantry ; and as a parent, though not boldly aggressive, he is watchful and devoted, singing on his way to the nest eren with a bill full of insects.

\section{Cyanospiza versicolor (Bonap.). Varied Bunting.}

Upper mandible curved. Adult male in summer: forehead and rump bright bluish purple. or purplish blue; back of neck bright red, changing to purplish red on middle of back; under parts plum red fading to plum purple on belly. Adult female in summer: upper parts brownish, tinged with olive and sometimes with bluish, becoming dull blnish on rump; wings and tail with gray or blue edgings; under parts dull whitish and brown. Adult male in winter: color of crown, back, and seapulars partly obscured by grayish brown tips to feathers; under parts with buffy tips. Adult female in winter: browner. Young: brown; wing with buffy bands; under parts whitish medially, brown on chest and sides. Male: length (skins) 4.5.5-5.46, wing 2.49-2.80, tail 1.97-2.26, bill .37-.44. $\mathrm{Fe}$ male : length (skins) 4.44-5.35, wing 2.39-2.55, tail 1.93-2.10, bill .37-.41.

Distribution. - From southern Arizona and the valley of the Lower Pio Grande in Texas sonth to Lower California and Guatemala. 
601. Cyanospiza ciris (Linn.). Painted Bunting: Nonpareil.

Adult male. - Entire under parts bright red; liead and back of neck pnrplish blne, in sharp contrast to yellowish green of back and scapulars; rump and tail dnll red; wings green and reddish. Adult female: upper parts, inclnding tail, plain olive green; under parts dnll greenish yellow, brighter on belly. Young: grayish brown, tinged in places with greenish : wings with buffy bands; under parts dull buffy. Male: length (skins) 5.005.60, wing $2.72-2.91$, tail $2.06-2.24$, bill .40-.44. Female: length (skins) $4.70-5.4 \overline{7}$, wing $2.51-2.80$, tail $1.90-2.18$, bill .40-.42.

Remarks. - Individuals are sometimes found having vellow feathers.

Distribution. - Breeds in the south Atlantic and Gulf States west to sonthern Arizona and north to sonthern Kansas; winters south to Panama.

Nest. - In hackberry, cat-claw, or chaparral, made of grasses and sometimes leaves, lined with finer grasses and hairs. Eggs : 4 or 5, creamy to bluish white, spotted with purple and reddish brown.

When we were working on the Pecos River, in southern New Mexico, the loud bright song of the nonpareil was heard at camp all through the middle of the hottest days, and from the mesa we could look down on the chaparral by the river and see sometimes the red breast and sometimes the green sheen on the back of the cheery songster. His song, though short, has a clear, carrying quality, and is very pleasing.

On the mesquite prairie of southern Texas the nonpareils were common, and we often heard their song and caught glimpses of them as we drove along.

The courtship of the male is said to be very entertaining. To attract the attention of the female he hops to the ground, spreads his wings and tail, and struts around with all his colors flying. It is said that he takes little part in domestic matters, but this may be due to his dangerously striking plumage.

\section{GENUS SPOROPHILA.}

\section{Sporophila morelleti sharpei Laur. SHARPE SEED- EATER. 1}

Bill short and greatly swollen; upper mandible convex above, concave below ; wings short and ronnded; tail shorter than wings, slightly ronnded; tarsns equal to middle toe and claw. Idult male: upper parts and chest band black; sides of neck. under parts and markings ou wings, and rump white. Idult female: upper parts olive brown with two buffy wing bands; under parts buffy brown. Immature males: intermediate between adnlt male and female. Immature females: lighter, tinged with olive. Male: length (skins) 3.68-4.42, wing $1.88-2.15$, tail $1.58-1.86$, bill .32.36. Female: length (skins) 3.72-4.28, wing 1.89-2.02, tail 1.52-1.78, bill $.32-.35$.

Distribution. - Southeastern Texas and adjacent parts of Texas.

At Lomita, Mr. Sennott found the little seed-eater frequenting low bushes and weeds.

1 Mr. Ridgway recngnizes only one form of Sporophila morelleti. (Birds of North and Middle Amerien, 5.5.$)$ 



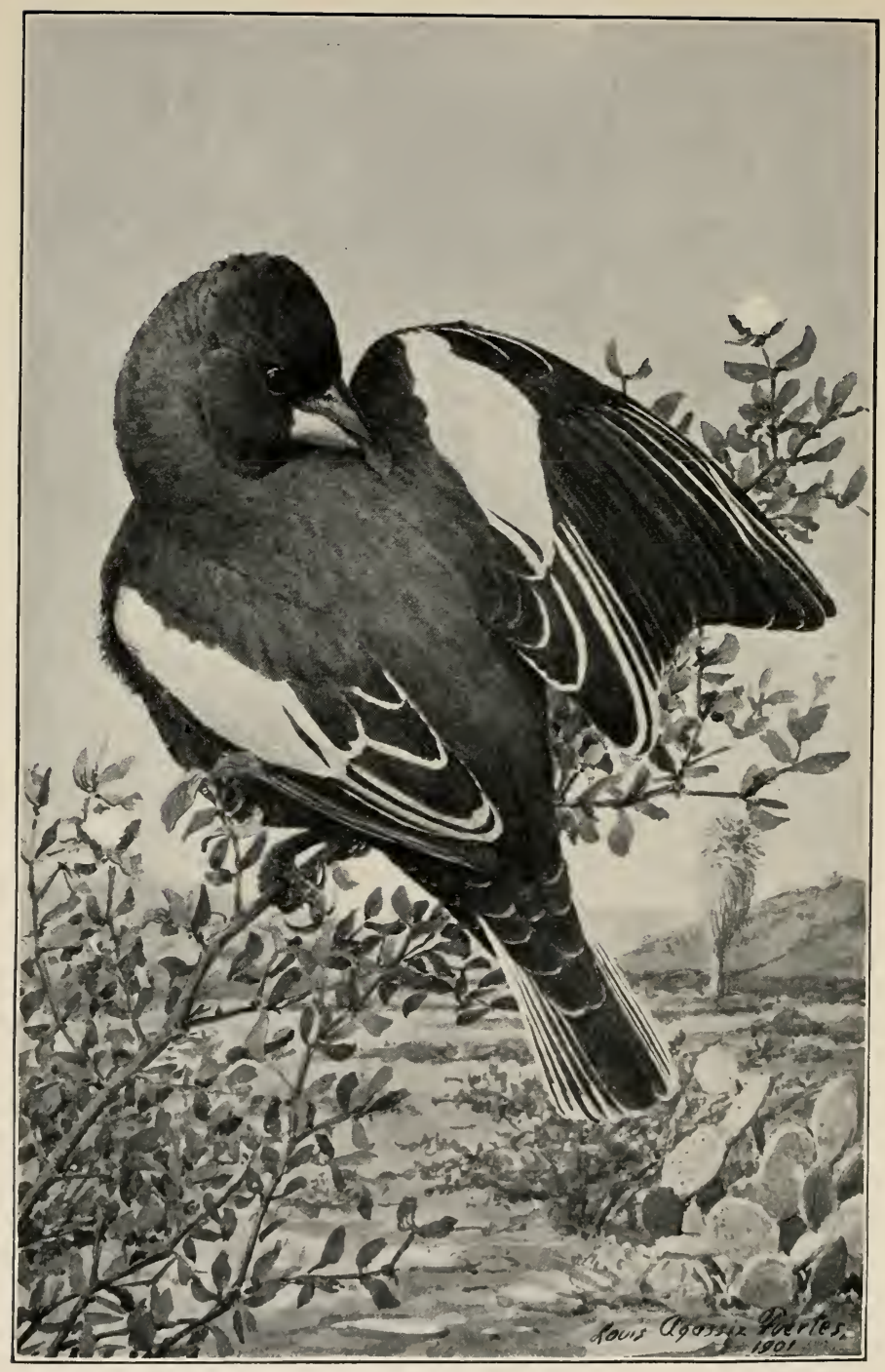

LARK BUNTING 


\section{GENUS SPIZA.}

\section{Spiza americana (Gmel.). Dickcissel.}

Bill stout, conical, compressed; wing long aud pointed; tarsus longer than middle toe with claw. Adult male: under parts whitish, with variable black throat pateh and vellow breast, yellow sometimes deepening to salmon in the breeding season; wing with deep rufous patch; forehead, lores, superciliary, and malar stripe washed with yellow; head and neck gray, top of liead usually olivaceons; back brownish, streaked with black. Adult female: similar, but duller, rellow more restricted, often wanting, except

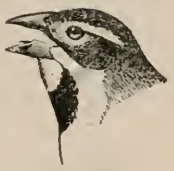

F.g. 466. on breast; throat white, bordered by dusky streaks; the black of the male usually wanting. Young in first winter: like adult fenale, but everywhere tinged with dull buffy or clas color. Male: length (skins) 5.55-6.31, wing :3.11-3.38, tail 2.17-2.4\%, bill ..8-.61. Female: length (skins) 5.50-5.74, wing $2.94-3.05$, tail $1.97-2.17$. bill .50-.56.

Distribution. - Breeds chiefly in Upper Sonoran zone of the central eastern United States from the Alleghanies to the Rocky Mountains. Colorado, and Wroming; and from Ontario south to Texas; casially southwest to Arizona and Lower California; migrates to northern soutl A merica.

Nest. - Largely of dried grasses, built near the ground in bushes or low weeds, on meadows or prairies. Eggs: : to 5, plain pale blue.

Food. - Largely grasshoppers and crickets; also grain and weed seed.

When in southern Texas during the spring migration we met with flocks of dickcissels on their way to the north. In places on the open prairic two or three hundred would be sitting in rows on the wire fences like swallows on telegraph wires. They could be recognized at a distance by their outlines-- round heads and straight hanging tails. When not in compact flocks they were scattered through the chapparal singing on the tops of the bushes. Their song had a mouthed, furry quality, but was none the less sumny and enjoyable. When they are on their breeding grounds their song is one of the pleasantest features of the big grain fields.

\section{GENUS CALAMOSPIZA.}

\section{Calamospiza melanocorys Stejn. LARK Bunting.}

Bill conical, much deeper than broad at base, gently convex at tip and base, nearly straight in middle ; wing about four times as long as tarsus, its tip almost truncated; tail about three fourths as long as wing. much more than basal half overlaid by upper coverts: slightly double-rounded or nearly even, feathers rather narrow. Adult male in summer: whole bird black or slaty except for white patch on wings and sometimes white marks on tail feathers. Adult female in summer: above gravish brown, streaked with blackish; wing patch restricted and tinged with buffy: tail except middle feathers spotted with white; under parts white, streaked on breast and sides. Adult male in winter: similar to fenale, but wings and tail blackish instead of brown, and feathers of lower parts black beneath the surface and showing throngh more or less; chin black. Adult female in uinter: like summer female, but less grayish and more buffy. Young: 
similar to adult female, but more buffy, feathers of lower parts bordered with buffy white, streaks on lower parts narrower. Male: length (skins) 6.10-7.25, wing $3.35-3.62$, tail 2.58-2.80, bill .52-.58. Female: length (skins) 5.70-6.50, wing $3.22-3.35$, tail $2.35-2.70$, bill .50-.52.

Distribution. - Breeds in Upper Sonoran and Transition zones of the high plains from Assiniboia south to Colorado and Kansas; migrates through New Mexico, Arizona, and southern and Lower California to plateau of Mexico; occasional west of Rocky Mountains, and accidental in Atlantic states in migration.

Yest. - Sunk in ground, sometimes under a bunch of weeds, made of grass and fine roots. Eggs : 4 or 5, plain pale blue.

The striking black and white of the lark bunting probably accounts for its shyness. While in southern Texas we could almost drive alongside of a flock of dull-colored dickcissels sitting on the roadside fence, but a flock of the northbound whitewings would fly in instant alarm on our approach. They fed on the ground among the prairie flowers, but it was hard to get near enough to observe their habits, for at the least unguarded motion or footfall they would arise simultaneously and dash into the brush. When not disturbed they scattered through the chaparral, and, as a man aptly observed, were always sitting around as if they had nothing to do.

A flock of forty or fifty in April showed great variety of pluriage, for many of the males were only in process of donning their black summer plumage. The young males showed the white on their wings when sitting and on their tails in flight, but the dull gray females showed the white wing patch only when flying.

On the prairies, where there were neither bushes nor fences to perch on, the buntings, and doves also, sat on the oval slabs of the tuni cactus, and it was amusing to see the whitewings sidle gingerly along the spiny edges.

The buntings sang in chorus, and sometimes we would catch a delightful wave of song from them as we drove along. On their breeding grounds they are said to have a 'rich and varied flight song.'

Having met the birds on their way north in Texas one year, the following year we were overtaken by them in New Mexico on their way south. During the last of July the flocks were mixed black and brown, but from the last of August they were mainly brown. In the Guadalupe Mountains bands passed our camp every day, with their soft hoo-ee, a peculiarly sweet note given with a cheery, rising inflection. 


\section{FAMIIY TANAGRIDÆ: TANAGERS.}

\section{GENUS PIRANGA.}

General Characters. - Bill straight, stout, conoidal; nostrils exposed; rictal bristles well developed; wing of nine primaries lengthened and pointed; tail shorter than wings, emarginate; tarsus not longer than middle toe, scaled.

KEY TO ADULT MALES IN SPRING.

1. Upper mandible with a tooth-like projection on entting edge.

2. Plumage marked with black.

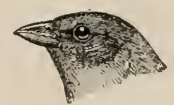

Fig. 467 . 3. Plumage scarlet and black . . . . . erythromelas, p. 380. 3'. Plumage red, black, and yellow . . . . ludoviciana, p. 379. 2 '. Plumage not marked with black; red, with grayish back and brownish ear coverts . . . . . . . hepatica, p. 381.

$1^{\prime}$. Upper mandible without tooth-like projection.

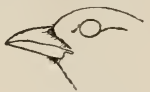

Fig. 468.

2. Under parts vermilion or poppy red rubra, p. 382 . 2 . Under parts rose pink . . . . . . . . . . cooperi, p. $3 \$ 2$.

607. Piranga ludoviciana (Wils.). Louisiana Tanager: WestERN TANAGER.

Upper mandible with a tooth-like projection on eutting edge. Adult male in summer: head and neck bright orange or red; rest of under parts bright yellow; upper parts black, with yellow rump and wing patches. Adult female in summer: upper parts olive green, back and scapulars grayish; wing bars dull yellowish; under parts pale grayish yellow, becoming sulphur yellow on under tail coverts; anterior part of head sometimes tinged with red. Adult male in winter: like summer female, but with head yellow or slightly tinged with red, more or less obscured on occiput and hind neck with olive green or dusky tips to feathers; feathers of back usually more or less distinctly edged with yellowish olive; tertials broadly tipped with white or pale yellow; tail feathers more or less tipped with white. Young male in first autumn: like adult female, but clearer yellow below and rump yellower. Young female in first autumn: like adult female, but duller; upper parts more brownish olive, under parts washed with brownish olive; wing bars narrower, and buffy. Young male, first plumage: upper parts olive green; wings blackish, with yellow wing bars; tail with outer webs of feathers edged with olive green; throat and chest grayish, chest tinged with yellow and streaked; chin and under tail coverts yellow; rest of under parts white. Male: length (skins) 6.20-6.95, wing 3.71-3.83, tail 2.64-2.98, bill .57-.62. Female: length (skins) 6.30-6.90. wing 3.5t-3.S5, tail 2.68-2.S9, bill .53.63.

Distribution. - Breeds in Canadian zone in mountains from British Columbia to Arizona, and from northwestern Nebraska to California ; straggles eastward in migration to the Atlantic states; winters south to Guatemala. 
Nest. - Usually on the horizontal branch of a fir, pine, or oak, 15 to 30 feet from the ground, made of twigs, sometimes with mosses and coarse grass, lined with rootlets and horsehair. Eggs: 3 or 4, pale bluish green, lightly spotted with browns and purples.

Food. - Insects.

The western tanager breeds abundantly in the high mountain forests, being common at 10,000 feet in Colorado. In the forests of British Columbia on their first arrival the males have been found singing at daybreak from the tops of the tallest trees, sometimes 300 feet from the ground. In the Sierra Nevada they are common from an altitude of 3000 feet to the summit, and in the heavily timbered parts, though a flash of red and yellow between the treetops is often the most you get, their calls and songs are among the commonest bird notes heard.

Their song has the rough-jointed, swinging rhythm characteristic of the tanagers, but there are also a chattering call which suggests the scold of an oriole, rendered as pitic, pitictic, and a plaintive tu-veep ${ }^{\prime}$, which is particularly noticeable when the birds are going about with their young. At that time the tanagers descend to the lower levels. I have seen them on the scrub oak and sagebrush of the Wasatch foothills in cottonwood hedges, and even along barbed wire roadside fences, making sallies to the ground for insects. On San Francisco Mountain they come to the springs for water, and I have seen one drinking from a pan in a ranch dooryard.

The tanagers must eat a large variety of insects, for they are not only expert fly-catchers and glean from the treetops, but are also especially fond of caterpillars, judging by the numbers we have seen probing tent-caterpillars' nests.

608. Piranga erythromelas Vieill. Scarlet Tanager.

Adult male in spring and summer. - Brilliant scarlet; wings and tail deep black; nnder wing coverts white. Adult female in spring and summer: upper parts yellowish olive green, usually graver on back and scapulars; muder parts light vellow, washed with olive green on sides; under tail coverts canary vellow. Adult male in fall and winter: similar to adnlt female, but wings and tail black. Young male in first autumn: like adnlt female, but yellow of under parts clearer; wings with two yellowFig. 469.

ish bands; black first appearing on wing coverts and scapulars. Young male, nestling plumage: upper parts olive green. faintly mottled with dnsky ; wings and tail with olive green edgings; wings with two yellowish bands: under parts white, tinged with yellow behind; chest and sides streaked. Male: length (skins) 6.25)-6.75, wing $: 3.62-3.91$, tail $2.5(6-2.82$, bill $.57-.62$. Female : length (skins) 6.20-6.70, wing 3.4.)-3.3.2, tail $2.52-2.77$, bill .57.62 .

Distribution. - Breeds in Upper Sonoran and Transition zones of the 
eastern United States from Canada and Manitoba south to the Temnessee Mountains, and from the Atlantic west to the Plains; casually or occasionally to Colorado and Wyoming; winters in the West Indies, eastern Mexico, Central America, and south to northern South America; accidental in Bermuda.

Nest. - On a horizontal branch, 10 to 30 feet from the ground, a flat, loose structure, made of stems and plant fibers, lined with fibers and rootlets. Eggs : 3 to 5, essentially like those of the summer tanager.

Food. - Insects and wild berries.

The songs of the tanagers have a strong resemblance, but their call-notes are very different. That of the scarlet tanager is a distinctly enunciated chip-churr, and so unique that it will identify him when his glowing scarlet body and black wings and tail are hidden in the greenery.

\section{Piranga hepatica Swains. Hepatic TAnager.}

Upper nandible with tooth-like projection on cutting edge. Adult male in spring and summer: under parts scarlet, brownisl on sides; ear coverts brownish, with white shaft streaks; crown bright red; rest of upper parts dull red; back and scapulars tinged with grayish broun; lower mandible bluish gray in life. Adult female in spring and summer: upper parts olive green, graver on back; under parts olive yellow, darker on sides. Adult male in fall and winter: back and scapulars more brownish gray; red of under parts duller, some of the feathers with paler tips. Adult female in fall and winter: like summer female, but brighter. Young, nestling plumage: streaked, on grayish olive above, pale buffy below; wings with buffy bars. Male: length (skins) 6.90-7.80, wing :3.96-4.13, tail 3.123.37, bill .66-.7.). Female: length (skins) 6.90-7.74, wing $3.85-3.99$, tail 2.94-3.34, bill .67-.71.

Remarks. - The hepatic tanager may be distinguished from the Cooper by its dull grayish red back and the scarlet tone of its under parts, compared with the nearly uniform coloration and rose pink tones of the Cooper. Its gray cheeks are a good field character. The males are three years in acquiring the brilliant adult plumage, and breed in a mixture of the red and yellow of their parents.

Distribution. - From southwestern Texas, southern New Mexico, and Arizona soutl to Guatemala.

Nest. - On low oak branches, a slight structure nade of coarse rootlets and dried plant stems. lined with finer materials. Eggs: 3 or 4, very pale bluish green, lightly spotted chiefly around larger end with browns and purples.

In the wooded bottom of the Pecos River canyon, near where the river flows into the Rio Grande, we found the hepatic tanager in May, evidently at home and established for the summer. Its song. strikingly like that of the scarlet tanager, rang out so loud that across the river it seemed to be close at hand. The call was a single note.

In the Guadalupe Mountains, New Mexico, we found the beautiful bird quite common in the oaks and pines on the edge of the Transition zone, at about $6 \% 00$ feet, especially on the rock $y$ wooded lillsides. 
610. Piranga rubra (Linn.). Sumuer Tayager.

Adult male (summer and winter). - Upper parts dull dark red; wings

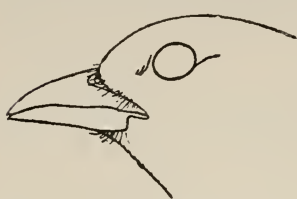

Fig. 470 . and tail brownish red; under parts vermilion or poppy red. Adult female (summer and winter): upper parts plain yellowish olive; under parts dull yellow. Immature male: red mixed with patches of yellowish green. Young male in first autumn: like adult female, but colors richer, upper parts more ochraceous ; crown, upper tail coverts, tail, and edges of wing quills tinged with dull orange. Male: length (skins) 6.407.20, wing 3.64-3.92, tail 2.80-2.94, bill .66-.76. Female: length (skins) $6.50-7.20$, wing $3.50-9.77$, tail $2.62-2.91$, bill $.69-.72$.

Disiribution. - Breeds in Upper and Lower Sonoran zones in the eastern central United States, west to western Texas ; migrates to Cuba and through eastern Mexico sonth to Peru.

Nest. - In trees, 6 to 60 feet from the ground, made of weeds, grasses, leaves, and catkins. Eggs : :, or 4, green, spotted with browns and purples.

\section{0a. P. r. cooperi Ridgw. Cooper Tanager.}

Similar to rubra, but larger, with relatively longer bill, wing, and tail, and under parts rose pink.

Remarks. - The Cooper tanager differs from the hepatic by the absence of gray on the back and by the rose pink tone of its under parts. Male: length (skins) 6.60-7.50, wing $3.66-4.18$, tail 2.98-3.35, bill .72-.78. Female: length (skins) 7.00-7.S.5, wing 3.80-4.02, tail 2.95-3.26, bill .70-. 80 .

Distribution. - Breeds from southwestern 'Texas to the Colorado Valley, California, and from Arizona and New Mexico to northwestern Mexico; sonth in winter to western Mexico; casually to Colorado.

The Cooper tanager seems to be especially fond of the cotton woods of the lower levels, and migrates early in the fall.

\section{FAMILY HIRUNDINIDA: SWALLOWS.}

KEY TO GENERA.

1. Tail forked for more than length of tarsus.

2. Tail forked for about half its length.

Hirundo, p. 384.

2'. Tail forked for less than half its length.

Progne, p. :3:?.

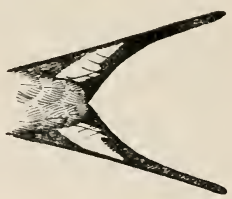

Fig. 471.

1'. Tail forked for less than length of tarsus.

2. Under parts entirely pure white

2 '. Under parts not entirely pure white.

3. Tarsus witl tuft of feathers above hind toe . . Riparia, p. 386.

3 '. 'Tarsus without tuft of feathers.

4. Wing with onter quill hooked in male, roughened in female.

Stelgidopteryx, p. 387.

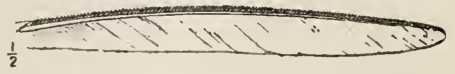

Fig. 472.

4'. Wing with outer quill normal; forehead white, buffy, or brown. Petrochelidon, p. $3 \S 3$. 


\section{GENUS PROGNE.}

General Characters. - Bill long, stout, and convex ; feet large, with strong, curved claws; tarsus shorter than middle toe and claw; tail forked for less than half its length.

\section{KEY TO SPECIES.}

1. Females with under tail coverts streaked subis, p. $3 \times 3$. $1^{\prime}$. Females with under tail coverts not streaked . . hesperia, p. :383.

611. Progne subis (Limn.). Purple Martix.

Adult male. - Whole body glossy blue black; wings and tail black; feathers of ventral region entirely sooty grayish beneath the surface. Adult female and immature males with forehead grayish and upper parts sooty glossed with blue black, interrupted by grayish collar; lower parts grayish in front, whole under parts streaked, the feathers, especially on chest, with distinctly sooty grayish centers. Length : 7.25-S.50, wing 5.656.20, tail 3.00-3.30 (forked for .70-.90).

Distribution. - Temperate North America from Ontario and Hudson Bay south to the southern end of Mexican tableland; wintering in South America.

Nest. - In holes of trees or about buildings and in bird boxes. Eggs : 3 to 5 , plain white.

Food.-Insects.

The peculiar vibrant and at the same time mouthed quality of the martin's song tells of his presence, eren when his big steel blue body is not seen floating around overhead. His song, though unpretentious, is a talkative twitter very pleasant and companionable.

But, although we usually associate him with bird boxes and towns, large numbers, especially of the western subspecies, still nest in hollow trees in the mountain forests.

611a. P. S. hesperia Brevst. Western Martin.

Adult male. - Indistinguishable from male of subis. Adult jemale: similar to female subis, but light gray of forehead extending back into crown; feathers of back and rump conspicnously edged with grayish or pale brown; bend of wing and under coverts mottled profusely with whitish; anterior under parts and nuchal collar grayish white; and whole tract from abdomen to under tail coverts almost immaculate white.

Distribution. - Breeds in Pacific coast region from Oregon south through California and Arizona to southern Lower California; migrates to Nicaragua.

The examination of birls from British Columbia may show that they should be referred to this form.

\section{GENUS PETROCHELIDON.}

General Characters. - Tail short. nearly even; nostrils without nasal scale, opening directly upward; tarsus with tuft of feathers above hind toe.

KEX TO SPECIES.

1. Forehead white or pale isabella

$1^{\prime}$. Forehead rich chestnut; rarely fawn color

lunifrons. p. 384 . melanogastra, p. 384. 
612. Petrochelidon lunifrons (Say.). Cliff Swallow.
Adults. - Forehead white, buffy, or brown; crown, back, and patch on

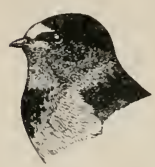
Fig. 473. chest glossy blue black; throat and collar chestuut, sides and flanks brown; rest of under parts white. Young: sim- ilar, but colors duller and pattern less sharply defined; throat nsually. and other parts of head sometimes, spotted with white; tertials and tail coverts edged with brown, chestunt of head partly or wholly wanting; upper parts dull blackish. Length: 5-6, wing 4.0.5-4.55, tail 2.00- 2.20 .

Distribution. - North America, from the limit of trees south to the southwestern United States; nigrates to Central and South America. Not recorded from Florida or the West Indies.

Nest. - A gonrd or retort shaped structure made of pellets of mud mixed with a few straws. lined with feathers; attached to cliffs or buildings. Eggs: :3 to 5, white, speckled or spotted with brown and lilac.

Food. - Ants and other insects.

In regions where there are no houses, the retort-shaped nests of the cliff swallows are usually found in colonies massed on the side of a cliff, under the roof of a cave, or plastered to the branches of a giant tree; but in the settled part of the country the birds seem to prefer eaves of barns and houses, and their nests have been found in deserted buildings plastered to ceilings and walls.

There is such a common prejudice against these swallows that hoys are often encouraged to shoot them with sling-shots in the rities, and ranchmen drive them away from their barns, fearing that the parasites which infest them will spread to the stock. But, as a matter of fact, birl parasites will not live on mammals, and the swallows do great good by eating annoying insects.

\subsection{Petrochelidon melanogastra (Swains.). Mexican ClifF SWALLOW.}

Like lunifrons. but "smaller, with foreliead chestmit, like throat and sides of head (rarely fawn colored). and rump deep cinnamon." (Ridgwav.) Length: 4.5()-5.00, wing $3.9 \%-4.30$, tail $2.00-2.20$.

Distribution. - Mexico, soutl to Guatemala, north to southern Arizona.

The Mexican cliff swallow has recently been added to the list of United States hirds by Dr. E. A. Mearns, who found it breeding in southern Arizona.

\section{GENUS HIRUNDO.}

\section{Hirundo erythrogastra Bodd. Barx Swallow.}

Tail forked for about half its length, outside feather tapered to point;

1 Hirmmlo erythrogast)" palmeri Grimmell.

Like erythrogastri, but color of under parts deeper, and frontal chestuut band broader and darker; wing and tail somewhat longer and bill smaller.

Distribution. - Western North America, summering from southern California to Kotz.ebue Somul, Alaska; west to Unalaska and east to and including the Rocky Mountains. (The Condor, iv. 71.) 
tarsus shorter than mirldle toe and claw; upper part An feathered. Adults: under Fig. 474. parts tawny brown, darkest on throat; forehead dark brown, rest of upper parts glossy steel blue; wings and tail tinged with purple and green: tail feathers - except middle pair-marked with large whitish spots. Young: fork of tail shorter; npper parts paler, under parts duller, brown of forehead indistinct or wanting; throat and chest light rusty. Length: $5.75-7.75$, wing $4.60-4.90$, tail $3.70-4.10$, forked in adult male for about 1.85-2.10.

Distribution. - Breeds from the Aretic Circle south to southem end of Mexican tableland; migrates

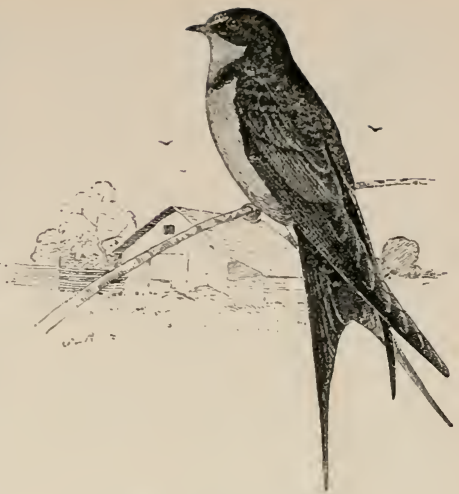

Fig. 475. Barn Swallow. through the West Indies and Mexico to Central and South America.

Nest. - A bowl-sliaped wall-pocket, made of pellets of mud mixed with straws and lined with feathers, attached to side or roof of a cave or to timbers in barns or other buildings. Eggs: 3 to 5 , white, speckled with brown and lavender.

Food. - Insects, largely flies.

The long forked tail of the barn swallow gives it a peculiarly easy, graceful flight, and one of its farorite feats is to catch the insects that accompany a horse and carriáge along the road, easily circling around and around them as the horse carries the wagon along at full swing.

While the other swallows hunt more habitually in the sky, the barn swallow is usually seen beating low over a meadow. When resting on a telegraph wire it sings a bright, squeaky little warble. Its call-note is given as a soft witt, witt, and its alarm-note as a harsh t'r'r'r', t'r'r'r.

Though generally associated with barns and meadows, it is often found in towns, and along the line of the Canadian Pacific is one of the commonest birds seen in the mountain canyons.

\section{GENUS TACHYCINETA.}

General Characters. - Tail forked for less than length of tarsus ; tarsus entirely naked.

$$
\text { KEY TO SPECIES. }
$$

1. Upper parts metallic steel blue or greenish . : . . bicolor, p. 38.̆. 1 . U pper parts green and purple . . . . . . . lepida, p. $3 \varsigma 6$.

614. Tachycineta bicolor (Vieill.). White-BELLied SWALlow: TrEe SWALLOW.

Adult male. - Ender parts pure white; ipper parts burnished steel blue: 
lores deep black; wings and tail blackish, slightly tinged with green.

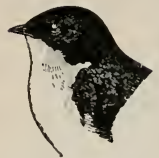

Fig. 476. Whitebellied Swallow. Adult female: upper parts usually duller than in male, but sexes often indistinguishable. Young: above entirely dull brownish slate. Length: 5.00-6.25, wing about $4.50-$ 4.80, tail 2.30-2.50.

Distribution. - Breeds from the limit of trees south to New Jersey, the Ohio Valley, Kansas, and California; winters from South Carolina and the Gulf States south to the West Indes and Guatemala.

Nest. - In holes, usually of trees, lined with grasses, leaves, and feathers. Eggs: usually 4 or 5, pure white.

The white-bellied swallow, with its shining white breast and metallic bluish green back, may be seen skimming over the water or sailing about in the sky in almost any suitable place in North America. In southern California it is said to be abundant in the lowland willow regions, especially about ponds and marshes, while in Colorado it breeds up to an altitude of 10,000 feet.

\section{Tachycineta thalassina lepida (Mearns). NortherN VIOLET-GREeN SWALLOW.}

Adult male. - Top of head parrot green; nape with a narrow purple collar; back bottle green, glossed with violet in some lights; rump and upper tail coverts violet, shaded with purple; wing and tail quills black, glossed with indigo; wing coverts violet, edged with green; rump with white patches on sides almost confluent in life; under parts white. Adult female: similar, but smaller and duller. Young: like those of bicolor, but feathers of under parts grayish beneath the surface, and bill smaller. Length: 5.30 , wing 4.65, tail 1.97, bill .26.

Distribution. - Breeds in western United States to the eastern base of the Rocky Mountains; north to Alaska; migrates to Guatemala and Costa Rica.

Nest. - In cliffs or hollow trees, lined with feathers. Eggs : 4 or 5, white.

Let a violet green swallow once come fleeing down a canyon past you, so that you see its remarkable violet back as it flashes by, and you will always have a vivid interest in the handsome bird.

It is especially fond of the oaks and pines of the mountains, but nests not only in hollow trees and woodpecker holes but often in the walls of canyons. Dr. Mearns has found it breeding in limestone cliffs about the hot springs and geysers of the Yellowstone. It is not exclusively a bird of the wilds, however, but sometimes comes about ranches.

\section{GENUS RIPARIA.}

\section{Riparia riparia (Linn.). BaNK SWALloW.}

Tarsus with a small tuft of feathers on back near toes; bill

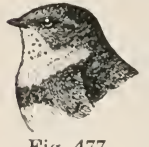

Fig. 477. small, nostrils opening laterally; tail much shorter than wings, emarginate. Upper parts sooty, darkest on head and wings; under parts white, with sooty band across chest and sides, and sometimes sooty spot on breast. Young: similar, but feathers of wings and rump with buffy or whitish edgings. Length: $4.75-5.50$, wing 3.70-4.25, tail 2.10-2.25. 
Distribution. - Northern hemisphere; in America breeding from the limit of trees south to the central United States; wintering from the sonthern border of the United States south to the West Indies, Central, and northern South America.

Nest. - In horizontal holes or burrows, excavated in sand banks, cuts, and banks of streams. Eggs: 3 to 6 , white.

Food. - Insects.

The colonies of chattering little bank swallows with dull colored backs and dark chest bands seem to require little more than a sand bank and a telegraph wire for complete happiness, and given these, blow the wind east or blow the wind west, they gossip merrily on.

\section{GENUS STELGIDOPTERYX.}

\section{Stelgidopteryx serripennis (Aud.). Rovgh-WINged Swat- Low.}

Bill small; tail short and slightly emarginate; tarsus slightly feathered above; lateral claws curved

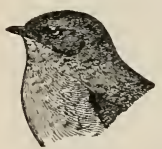

Fig. 479. and not reaching beyond the base of the middle claw ;

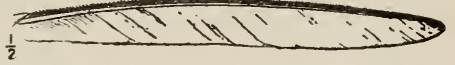

Fig. 478 , outer web of outer primaries saw-toothed in male, roughened in female. Adults : upper parts dull grayish brown, darker on wings and tail, tertials usually margined with grayish; under parts soiled gray, belly and under tail coverts white.

Young: like adults, but plumage more or less washed with brown; wings with broad cinnamon tips and margins. Lenyth: $5.00-5.75$, wing 4.004.70 , tail $2.05-2.35$.

Distribution. - Breeds in Sonoran and Transition zones of British Columbia. Ontario, the United States. and Mexico ; migrates to Guatenala.

Nest. - In holes, usually in banks, but often in abutments of bridges, Eggs : 3 to 6, white.

Food. - Flies and other insects.

The dingy rough wings are less sociable than the bank swallows during the nesting season, but afterwards assemble in large flocks and are in less of a hurry to start for the south.

In Nevada, during a shower, Mr. Oberholser once found a flock congregated about a small cliff in a cave.

\section{FAMILY AMPELID $巴$ : WAXWINGS AND PHAINO- PEPLAS.}

KEY TO GENERA.

1. Wings pointed

$1^{\prime}$. Wings rounded

Ampelis, p. 387. Phainopepla, p. 390.

\section{GENUS AMPELIS.}

General Characters. - Head crested; bill short, broad, flat, rather obtuse, plainly notched near tip of each mandible; wings long and pointed, much longer than tail; primaries apparently only nine, the first being 
minute; inner quills generally, and tail feathers sometimes, tipped with red horny appendages like sealing wax; tail short; feet rather weak; tarsus shorter than middle toe and claw.

\section{KEY TO ADULTS.}

1. Forehead and cheeks dark brown in contrast to crest.

1'. Forehead and cheeks fawn color like crest $\quad$ garrulus, p. 388.

\section{Ampelis garrulus Linn. Bohemian Waxwing.}

Adults. - Whole body, including high crest, soft fawn color, fading to grayish on rump and flanks, and washed with yellowish on middle of belly; forehead, cheeks, and under tail coverts deep brown; chin, lores, and eye streak extending back under erest, velvety black; wings and tail blackish, wing coverts extensively tipped with whitish or yellow, the tertials sometimes with red wax-like appendages; tail with a terminal band of yellow. Young: duller; under parts streaked. Length: 7.40-5.75, wing $4.40-4.60$, tail $2.7 .5-2.90$.

Distribution. - Northern parts of northern hemisphere; breeds in northern North America to Fort Churchill, Hudson Bay; migrates into the United States as far as Pennsylvania, Illinois, Colorado, and California.

Nest. - In trees, 6 to 20 feet from the ground, bulky, made of twigs, rootlets, leaves, grass stems, and sometimes lichens and mosses; lined with rootlets, grasses, and feathers. Eggs: 3 to 5, bluish white to purplish gray, spotted with lilac and dark brown, most thickly about the larger end.

Food. - Insects, fruits, and berries, including juniper and mountain ash berries.

The Bohemian waxwing, though an irregular wanderer from the north, is not uncommon in the mountains of Colorado in winter, going as high as $8000^{\circ}$ feet. It comes in November and leaves in February or March.

\section{Ampelis cedrorum (Vieill.). Cedar WaxWING.}

Adults. - Streak throngh eye velvety black; crest, liead, and under parts fawn color, fading to olive yellow on flanks; upper parts olive gray becoming blackish on wing quills and tail ; tail tipped with yellow and both wing and tail sometimes tipped with red wax-like appendages. Young: similar, but duller, and under parts strongly, upper parts lightly, streaked. Length: (i.50-7.5), wing 3.60-5.90, tail 2.30-2.60.

Remarks. - The Cedar waxwing differs from the Bohemian in being smaller, and in lacking the dark brown of forehead, cheeks, and under tail coverts, and the yellow and white wing markings.

Distribution. - Breeds mainly in Transition and Lpper Sonoran zones of North America, from Saskatchewan soutl to Virginia, western North Carolna, and the monntains of New Mexico and Arizona; winters from the northern border of the United States to the West Indies and Costa Rica.

Nest. - In bushes or low trees, a deep. bulky structure, made of twigs, weed stems, grasses, and vegetable fibers, lined with leaves and fine rootlets. Eggs. usually 4, bluish or purplish gray, spotted with brown or black.

Food. - Insects, including elm-leaf beetles and bark or scale lice, with seeds or berries of trees, such as pepper, juniper, mulberry, and mistletoe. 


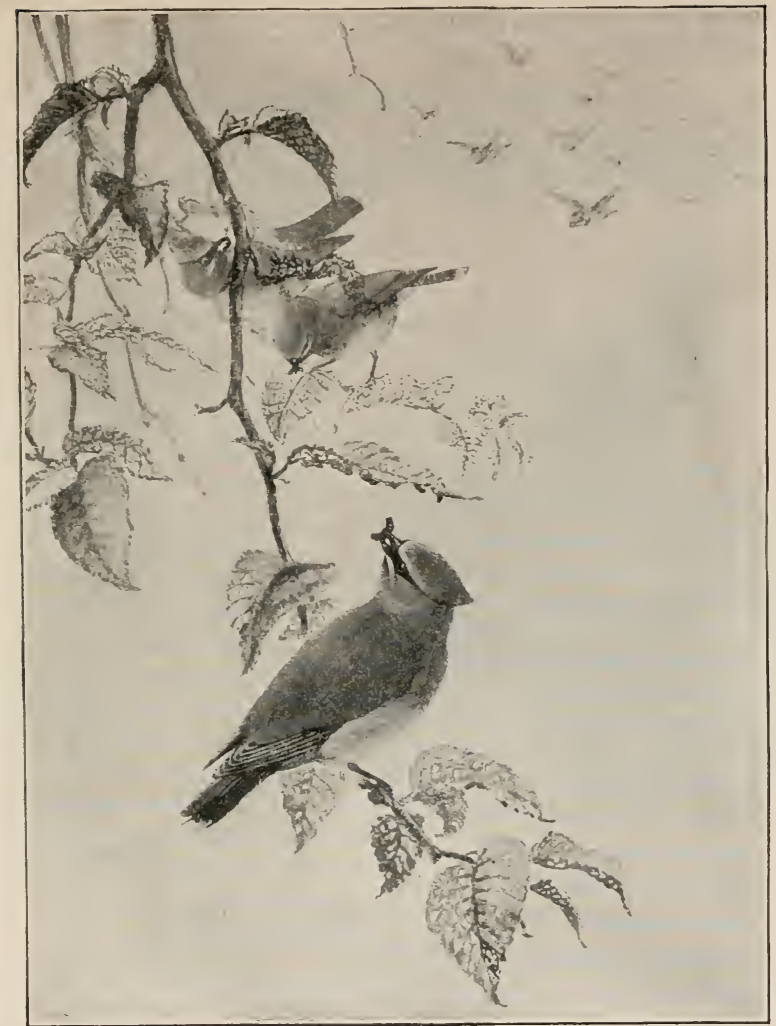

Fig. 480. Cedar Waxwing.

Like the Bohemian waxwing the cedar-birds are wanderers, tra reling orer the country in flocks except during their late breeding season. Sometimes they appear in small bands of less than a score, at others in such large companies that when they alight in a peppertree and fall to eating the berries their plump, moving forms seen through the foliage make the trees seem alive with their numbers.

Though they all talk at once, as they usually do, their sibilant notes are so soft and subdued that a passer-by would scarcely heed their presence.

However much romance there may be in the famous stories reciting the politeness and affection of these gentle birds, thes merit all 
the study that can be given them, and if watched through a nesting season win their own place in the affections of the bird-lover.

\section{GENUS PHAINOPEPLA.}

620. Phainopepla nitens (Swains.). Phainopepla.

Head with long thin oceipital erest; wing rounded, of ten feathers, but

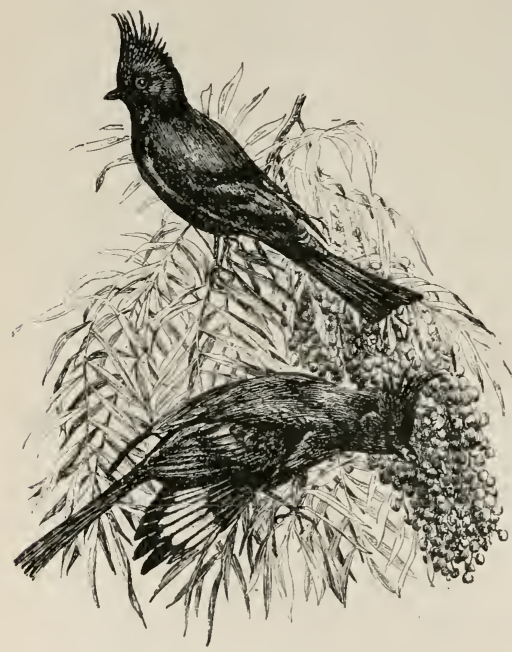

Fig. 481. first only about half as long as second ; tail long and fanshaped; hind toe very short. Adult male: glossy blue black except for white patch on inner webs of primaries. In winter: many of the feathers bordered with white. Adult female and young: plain browuish gray, lighter below; white on primaries restricted, but wing coverts, secondaries, and lower tail coverts with whitish edgings. Length: 7.007.75 , wing $3.60-3.80$, tail 3.80-4.10.

Remarks. - In the field the Phainopepla may be recognized at a distance by his black body and white wing patehes.

Distribution. - Breeds in arid Lower Sonoran zone from southwestem Texas to the Pacific, and from southern Utah, Nevada, and Cali-

fornia south to Cape St. Lucas and the Valley of Mexico.

Nest. - Sancer shaped, compactly made of plant fibers, stems, and blossoms, small twigs and plant down; placed in elders, peppers, oaks. and blue gums, and of ten in parasitic plants. Eggs: 2 or 3 , grayish or greenish white, thickly spotted with brown, blackish. or faint lilac.

Food. - Insects and berries such as those of the pepper, choke cherry, elder, sumac, the mistletoe and other parasitic plants.

The phainopepla is a bird of the southwest ilesert country, and in Arizona Mr. Scott has found flocks of fifty or more gathered in juniper covered canyons when the berries were ripe; but when a single individual strays up to the foothills of the Sierra it is a delightful surprise to meet him. In southern California the phainopepla seems as much at home on the telegraph wires of Pasadena and in the parks of Riverside as in the canyons, and wherever found is the same dashing, distinguished beauty.

When flying at an intruder he lowers his crest threateningly, but ordinarily it stands as a high plume adding distinction to his refined, 
dignified presence. Though so reserved in bearing he is full of vivacity and song, and will sometimes dart up in the air and come down singing.

His sallies often appear to be made for insects, being in regular kingbird manner, and at times in southern California when the brush is full of millers, the birds seem to be "catching them. But berries are their ordinary food, the mistletoe, pepper, and juniper being prime favorites.

In the breeding season in leaving the trees to go back to their nesting grounds, they often rise obliquely for perhaps a hundred feet and then fly on evenly straight to their destination, though sometimes while flying level and high they change their course by odd, sudden jerks. When near the nest the male often closes his wings and shoots obliquely down with tilting tail.

About the nest the birds have a variety of notes. The commonest, which resembles the call of a young robin, is given by both male and female, with a flash of the tail. The male has also a scold, a meadowlark-like note, and a harsh alarm-call drawn out like ca-rack or ca-rac-ack. His ordinary song, though with weak, squeaky notes, has phrases of rich quality suggesting the o-keclee of the redwing; and taken as a whole, jumbled notes, flutelike tones, musical outbursts, and all, the song is most pleasing because of its vivacity and brightness.

The nests of the few individuals I have watched were built mainly by the males, the females of a brush patch going off by themselves while their lords worked at home.

\section{FAMILY LANIID仺: SHRIKES.}

GENUS LANIUS.

General Characters. - Bill large and powerful, notched, toothed, and hooked; wing with ten primaries; wing and tail rounded; feet large and strong; tarsus distinctly scaled.

KEY TO ADULTS.

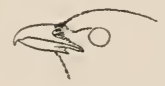

Fig. 482.

1. Lores and nasal tufts never wholly black .

$1^{\prime}$. Lores and nasal tufts alwars wholly black.

2. Under parts pure white . . . . . . excubitorides, p. 392.

2 . Under parts dull white, grarish, or brownish, often finely barred with grayish.

3. Upper parts tinged with brownish . . . . . gambeli. p. 398. 3'. Upper parts dark slate grar . . . . . . .anthonyi, p. 39.3. 


\section{Lanius borealis Vieill. Northern Sнrike.}

Adults in summer. - Wide streak on side of head, and wings and tail black, wings and tail extensively marked with white; under parts white, barred or undulated with grayish; upper parts pale ash gray becoming whitish on forehead, superciliary, and rump; lores black and grayish, a whitish spot on lower evelid. Idults in winter: similar, but basal half of lower mandible light brownish horn color. gravish in life, and lores

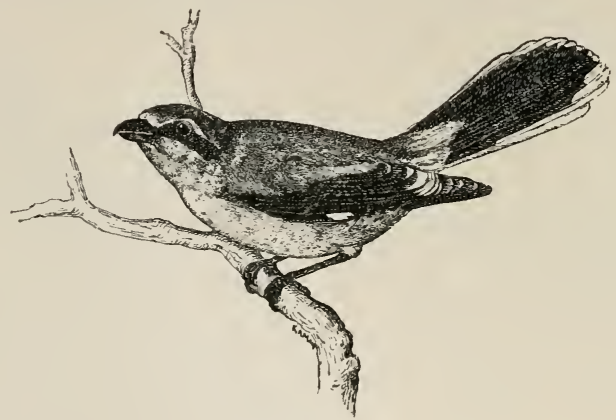

Fig. 483.

chiefly light grayish or whitish. Young: largely washed with brownish. Length : $9.25-10.75$, wing $4.35-4.60$, tail $4.50-4.70$, bill from nostril .50 .55.

Distribution. - Breeds from Labrador, Hudson Bav, and Cook Inlet, Alaska, northward; migrates south in winter as far as Virginia. Kansas, Arizona, and northern California.

Nest. - In bushes or thorny trees, a rude, bulkr structure of twigs. grasses, and stems, lined with mosses. lichens, and feathers. Eggs : 4 to 6 , pale bluish green, spotted with brown and purple.

Food. - In winter, mice, English sparrows, grasshoppers, and other birds and insects.

The northern shrikes reach Colorado in October, Prof. Cooke says, first appearing on the mountains above timberline. Some of them winter as high as 9500 feet in the mountain parks, but most of them work their way down to the plains, where they find abundant food in the shape of horned larks. In other regions they are often tempted to visit cities by the unfailing supply of English sparrows, for in habits they are miniature birds of pres.

622a. Lanius ludovicianus excubitorides (Suains.). WhiтьRUMPED SHRIKE.

Adults. - Bill. lores, and nasal tufts wholly black; upper parts light slate

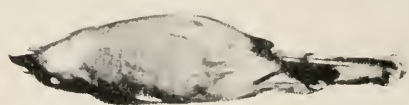

Fig. 484 . grar: upper tail coverts whitish ; under parts pure white, very lightly, if at all. marked. Ioung : like adults, but base of lower mandible lightcolored. general color's less strongly 
contrasted, washed with brown and narrowly barred, the wing coverts tipped with buffy. Length: $8-10$, wing $: 3.7 .5-4.10$, tail $: 3.75-4.30$, bill from nostril . $.^{-2}-.50$, depth of bill at base .:30-.35.

Distribution. - Breeds from British Columbia and Hudson Bay south to Lower California and over the northem tablelands of Mexico.

Nest. - In thorn-trees, hedges, briers, and eactus; bulkv, made of sticks and stems, leaves, wool, and feathers; lined with stems of grass and weeds, and sometimes hairs. Eggs: 4 to 6 , grayish to yellowish white. spotted with brown and lilac.

Food. - Mice, birds, and insects - chiefly grasshoppers.

A shrike may be recognized as far as seen by his level flight, the beating of his short little wings, and the way he holds up his big head: and when he alights his clear grays and sharply contrasting blacks and whites mark him afar. He is partial to Surcoloctus Hats, hedges, thorny bushes, and barbed wire fences, even when not using the barbs as letter files for his superfluous catch of grassioppers. In spite of all accusations the shrike probably impales his rictims less because of original sin than because of original scarcity of supplies, and only a short time ago he was seen by a California observer returning to his catch and eating it with marked relish. (The Condor, iv. 49.) Nor is he such a villain as to be wanting in sound domestic virtues, and harsh and strident as his voice may be in the main, it has interesting if not musical moments.

\section{2b. L. l. gambeli Ridgw. Califoria Shrike.}

Upper parts slate gray, tinged with brownish; upper tail coverts sometimes abruptly whitish as in excubitorides; under parts dull uhite or gray$i s h$, darker on sides. breast usually distinctly vermieulated and sometimes tinged with pale brown. Length: $8-10$, wing $: 3.70-4.00$, tail :3.7.)-4.50, bill from nostril .4.3-.48, depth at base $.30-.35$.

Remarks. - The California shrike may be distinguished from the whiterumped by the darker coloration of the under parts. In excubitorides they are pure white, in gambeli usually vermiculated, darkened on the sides and sometimes tinged with pale brown.

Distribution. - Coast region of California.

Nest. - 5 to 30 feet from the ground in willows, cypress, or oak; bulkr, made of coarse twigs and soft materials such as straw, grass, feathers, cotton, and wool. Eggs: 4 to 7 . gray, sometimes tinged with green. spotted with light brown and sometimes purple, usually heaviest around the larger end.

Mr. Grimmell saps that the California shrike is such a persistent destroyer of the Jerusalem cricket and other injurious insects that it is undoubtedly one of our most beneficial birds from the agricul. turalist's standpoint and should be protected.

\section{2c. L. 1. anthonyi Mearns. Island Shrike.}

Similar to gambeli. but much darker and smaller ; under parts gray, becoming white on throat and under tail coverts ; upper parts dark slate gras : white areas on wings and tail more restricted than in any of the ludovicianus gromp. Length: 8.77 , wing 8.74 , tail 4.00 , bill .63 .

Distribution. - Santa Barbara Islands, California. 


\section{FAMILY VIREONIDÆ: VIREOS. \\ GENUS VIREO.}

General Characters. - Bill similar to that of the shrikes, distinetly hooked and notehed at tip ; rictal bristles conspicuous; wings equal to or longer than tail ; tail nearly even; claws stout, strongly curved ; side toes unequal in length.

\section{KEY TO ADULTS.}

1. Head strikingly marked.

2. Lores and orbital ring white in sharp contrast to gray or black of head.

3. Top and sides of head black. atricapillus, p. 397.

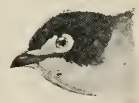

Fig. 485.

3'. Top and sides of head gray.

4. Back gray. Southerm Rocky Mountain region.

4 . Back olive green.

plumbeus, p. 397 .

5. Brighter olive green. Eastern United States.

solitarius, p. 396 .

5'. Duller olive green. Western United States. cassinii. p. 896 .

2 '. Lores and orbital ring not white in sharp contrast to head.

3. Sides and flanks tinged with olive gray.

olivaceus, p. 395 .

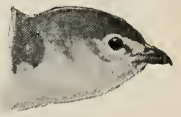

Fig. 486 .

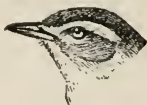

Fig. 487 .

3'. Sides and flanks bright olive yellow . . . flavoviridis, p. 895. $1^{\prime}$. Head not strikingly marked.

2. Upper parts gray. Western Texas to southern California.

2 '. Upper parts bright olive green or tinged with olive.

vicinior, p. 400.

3. Upper parts bright olive green.

4. Larger and brighter . . . . . noveboracensis, p. 398.

4'. Smaller and duller. Rio Grande Valley . . micrus, p. 399.

3 '. Uppes parts tinged with olive green.

4. Wings numarked gilvus, p. 395 .

4'. Wings marked with white.

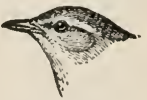

Fig. 488.

5. Wing about 2.18 .

6. Wing with two distinct bands. Mississippi Valley and Plains. bellii, p. 399 . 6 . Wing usually with only one band. Arizona and California.

5 . Wing about 2.50. pusillus, p. 400. 6. Wing bars white. 
7. Darker, wing bars narrower. California.

huttoni, p. :399.

7'. Paler and grayer, wing bars broader. 'Texas and Arizona. stephensi, p. :399.

6'. Wing bars tinged with yellow. Washington and Oregon, wintering in California . . . . obscurus. p. 399.

\section{Subgenus Vireosylva.}

Spurious primary if present decidedly shorter than tarsus; wing without light bands.

\section{Vireo olivaceus (Linn.). RED-Eyed VIREo.}

Adults. - Top of head gray, conspicuously bordered by white superciliary and narrow black line; blackish line through eye; rest of
upper parts olive green; wings without bands or spurious primary; under parts clear white. Young: similar, but back brownish ash; sides washed with brown. Length: 5.50-6.50,

Fig. 489. wing about $3.10-3.30$, tail $2.15-2.30$, exposed culmen, .50.$\check{.}$.

Distribution. - Breeds from the aretic regions south chiefly in the northeastern United States, but extending through Florida and to the Gulf of Mexico; west to Montana and Washington; migrates to South America.

Nest. - Hung rather low from a forked twig of a tree, made of strips of birch and imner bark, dead leaves, and vegetable fibers, often patched with bits of wasp nest and lined with pine needles, or stems and rootlets. Eggs : 3 to 5, white, lightly specked with reddish brown, chiefly around the larger end.

Food. - Insects and small berries.

The eastern red-eyed vireo is found occasionally in Colorado at the base of the foothills, and has been recorded as far west as British Columbia.

\section{Vireo flavoviridis (Cass.). Yellow-green Vireo.}

Like olivaceus, but sides and flanks bright olive green, axillars and under tail coverts sulphur yellow. Length: 6.25-6.75, wing 2.80-3.20, tail $2.05-2.50$.

Distribution. - Valley of the Lower Rio Grande in Texas, south to South America; accidental in Quebec and at Riverside, California.

\section{Vireo gilvus (Vieill.). Warbling Vireo.}

Adults. - Upper parts olive 'gray, grayest on head and most olive on rump and upper tail coverts; white streak through eye; wings and tail dusky brown, ummarked, wing with a well-developed spurious primary; sides of head pale brownish or buffy; under parts white, shaded with olive yellow on sides. Young: top

Fig. 490 . of head and hind neck pale grayish buff; rest of upper parts buffy, wings with buffy bars; under parts pure white, except for yellowish tail coverts. Length: 5.00-5.50, wing $2.65-2.95$, tail $2.10-$ 2.40 , bill from nostril .30-.32, depth at base .15-.18.

Distribution. - North America in general from Great Slave Lake to northern Mexico; breeds throughout the greater part of this range. In winter to southern Mexico.

Nest. - Similar to that of the red-eye, but smoother and more compact; hung in trees, usually at a considerable height, in open copses, along banks 
of streams, or in shade-trees along streets. Eggs: 4 or 5, white, spotted around larger end with reddish, dark brown, and lilac.

Colorless as this small leaf-tinted bird may seem in coat, character, and song, its voice is nevertheless one of the sunny warbled rounds that gives good cheer to the western mountain forests.

In Colorado, Prof. Cooke says, it breeds sparingly on the plains and abundantly in the mountains up to 10,000 feet, especially in the aspens. On San Francisco Mountain, Arizona, Dr. Mearns found it in fall in the rank growth of annuals along streams in company with terrestrial warblers.

But, though a mountain dweller, the little vireo is also a village bird, leaning over and craning its neck to examine the leares for worms as carefully in a Utah garden as in the retirement of the forest.

\section{Subgenus Lanivireo.}

Spurious primary if present decidedly shorter than tarsus; wing with two white bars.

\section{Vireo solitarius (Wils.). Blue-headed Vireo.}

Adults. - Top and sides of head dark gray in sharp contrast to white loral streak, orbital ring and throat; back olive green ; wings with two white bars; under parts clear white, shaded with olive and yellow on sides and flanks. Young in first winter : anterior upper parts grayish brown, under parts dull buffy white. Length : 5-6, wing 2.90-3.00, tail 2.10-2.20, bill from nostril $.2 S-.30$.

Distribution. - Breeds from Great Slave Lake and Hudson Bay to southern New England and the northern part of the lake states, and from the Atlantic coast to Dakota; migrates to Guatemala.

Nest. - In woods, in undergrowth, or hung from lower branches of small trees, like that of the red-eye, bnt often decorated with eatkins. Eggs : nsually 5 , white, spotted mainly with reddish brown around the larger end.

Food. - Chiefly insects.

629a. V. S. cassinii (Xantus). CAssin Vireo.

Adults. - Top and sides of head gray in sharp contrast to white of loral streak. orbital ring, and throat; back dull

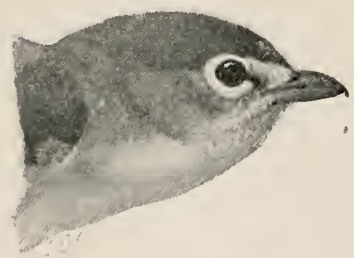

Fig. 491 . olive green; wings with two clear white bands; under parts clear white. washed with yellow and olive on sides and flanks. Young in first winter: dull grayish brown above, dull buffy below. Lenigth: 5.005.60 . wing $2.85-3.00$, tail $2.10-2.30$, bill from nostril .2S-.31, tarsus .70-. 7 .

Distribution. - Breeds from British Columbia and Idaho south along the Pacific coast region and Nevada to Lower California; migrates to Arizona, New Mexico, and northern Mexico.

Nest. - In oaks, manzanita, and bnck brush. pendant. compactly woven and lined with light-colored grasses, decorated with pieces of white cocoon. Eggs : 4 or 5. 
The Cassin vireo is more often heard in the oaks and conifers than the warbling, though it also frequents alders and aspens. In southern California, Mr. Grinnell finds it breeding in the mountain canyons from the foothills to 4000 feet, and Mr. Anthony, writing from Oregon, says, "Its clear, metallic notes ring through our forests from earliest dawn until dark."

\section{9b. V. S. plumbeus (Coues). Plumreous Vireo.}

Adults. - Entire upper parts and sides of head dark gray, in sharp contrast to white loral streak, orbital ring, throat, and wing bars; under parts white, sides and flanks strongly tinged with olive gray. Young: similar, but upper parts more or less tinged with brown, and sides with more olivaceous. Length: 5.75-6.15, wing $3 .(15-3.3 .30$, tail $2.30-2.55$, bill from nostril .30-.35.

Remarks. - In the plumbeous vireo the contrasts between the gray and white markings of the head and under parts are the same as in other members of the solitarius group, but in plumbeus there is hardly a trace of the olive on back and sides which mark the other members of the group.

Distribution. - Breeds in the southern Rocky Mountain region from the Black Hills westward to the desert ranges of the Great Basin; also in northern Mexico ; migrates from southern W yoming to southern Mexico.

Nest. - In pine or oak, pendant, made of inner bark and vegetable fibers, lined with fine grass stems and rootlets, and decorated with lichen, cocoon cases, web, plant blossoms, and sometimes feathers. Eggs: often 4, white, lightly specked around the larger end with black and brown.

In the wooded canyons of the Guadalupe Mountains in Texas the loud, rich whistle of plumbeus often calls your attention to the gray bird with the white eye rings who stops his work to sing in a sunny pine top. There is something peculiarly attractive about him; it may be the harmony of his quaker garb with his sweet, rich voice and quiet ways.

In New Mexico, through the breeding season, Mr. Henshaw found the birds as high as 10,000 feet; but in migration he found that they scattered over the country, taking to the deciduous trees along streams.

\section{Subgenus Vireo.}

Spurious primary equal to or longer than tarsus.

\section{Vireo atricapillus Woodh. Black-CAPped Vireo.}

Adult male. - Top and sides of head black in sharp contrast to white loral streak, orbital ring, and median under parts ; back bright olive green; wing bar yellowish white. Adult female: similar, but duller. and black of head usually slaty. Young in first winter: top and sides of head dull brownish ; lores, orbital ring. and median under parts dull buffy; upper parts brownish green. Length: 4.40-4.75, wing 2.152.30, tail $1.30-2.00$.

Distribution. - Breeds from southwestern Kansas to central and western Texas; winters in southerı Mexico.

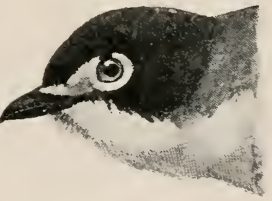

Fig. 492. 
Nest. - Hung in thickets, in bushes, or small trees, 2 to 6 feet from the ground, made of dry leaves, cocoons, and spiders' webs, lined with fibers of grass and bark. Eggs: usually 3, plain white.

Food. - (3 stomachs) caterpillars.

At Pecos High Bridge, in the bottom of the Pecos River canyon, which rang with the songs of an hepatic tanager, canyon wrens, and cardinals, we were delighted to find the rare little spectacled blackcap actually common, adding his loud song to the rich canyon chorus. His song was unusually varied for a vireo, though of the general character of the white-eye or bellii type rather than that of gilvus. One song contained a run, and its last notes were liquid, loud, and emphatic, something like come here, right-now-quick', or there now, wait-a-bit. The alarm-note was hoarse.

The calm deliberation of the vireo blood seems wanting in the black-cap even though he does live in Texas. He hops about or flies around in the most alert, energetic way. A pair were busy building in a dense vine grown thicket against one of the canyon walls, that is to say, the male was busy singing near by while his mate worked on the nest, weaving spider web over the skeleton leaves and cocoon cases.

Though the black-caps are partial to ravines, Mr. Bailey found them common on scrub-oak ridges about Kerrville, hunting low in the scrub oaks and junipers.

\section{Vireo noveboracensis (Gmel.). White-eyed Vireo.}

Adults. - Upper parts bright olive green, wings with two sharply marked bands; lores, forehead, and orbital ring bright yellow; throat and chest white, sides and flanks bright sulphur yellow. Young: olive gray, greener posteriorly ; wings crossed with two buffy bands; under parts white, buffy on flanks; loral streak white. Length: 4.50-5.00, wing 2.352.50 , tail $1.90-2.10$, bill from base $.55-.58$, bill from nostril $.27-.30$, tarsus $.72-.78$.

Distribution. - Breeds in Upper and Lower Sonoran zones from New England south to Louisiana and northern Texas, west to the Rocky Mountains; winters from Florida to Guatemala and Honduras.

Nest. - Hung in bushes or vines, in thickets or along borders of woods or swamps, seldom over 4 feet from the ground; made of vegetable fibers, leaves, mosses, and lichens, lined with stems of weeds and grasses. Eggs: 4 or 5 , white, lightly spotted with purple and reddish brown around the larger end.

Food. - Insects and their larvæ.

The white-eyed vireo ranges west as far as the Rocky Mountains, and in Kansas, Colonel Goss says, lives in thickets of briars and vines on the low prairies, and also on the edges of woods bordering streams and swamps. In Bermuda, where its jolly little relative abounds, it is known as the 'chick of the village,' and its song is rendered as Chick-(t-dee-chick'-de-villet. 
631c. V. n. micrus Nelson. Sirall White-eyed Vireo.

Like noveboracensis, but smaller and duller colored, with a paler wash of yellow on flanks. Wing: 2.29 , tail 1.97 , bill .38, tarsus .78. ico.

Distribution. - Rio Grande Valley, Texas, to central Tamaulipas, Mex-

The breeding range of the small white-eyed vireo in Texas extends from Kinney and $\mathrm{U}$ valde counties to the Gulf of Mexico.

\section{Vireo huttoni Cass. Hutton Vineo.}

Adults. - Lores and orbital ring dull whitish; upper parts dull olive brown, greener on rump, wings, and tail ; wing bars narrow, white ; under parts dingy, tinged on sides with olive yellow: spurious primary well developed. Young: similar, but upper parts lighter brown, sides of head buffy browu. under parts paler. Length: 4.25-4.75, wing 2.40-2.45, tail $2.00-2.10$, bill from nostril $.26-.29$, tarsus $.72-.76$.

Distribution. - Southern and central California, west and south of the Sierra Nevada.

Nest. - As described by Cohen, hung in scrub oak heavily draped with moss; made mainly of moss. Eggs: usually 4, white, lightly dotted around larger end with shades of brown.

Mr. Grinnell says that the Hutton vireo is common throughout the year in Los Angeles County. While occurring from the willow regions of the lowlands up to 6000 feet in the mountains, it prefers the oak regions of the mesas and foothills.

\section{2a. V. h. stephensi Brewst. Stephens Vireo.}

Similar to huttoni, but paler; olive gray above, greenish toward tail ; wing bands pure white, broader. Length: 4.90-5.20, wing 2.50-2.65, tail 2.102.20, bill from nostril .25-.30, tarsus .70-.75.

Distribution. - Mountains of western Texas, Arizona, Mexico, and Lower California.

\section{2b. V. h. obscurus Anthony. Anthony Vireo.}

Like huttoni, but averaging smaller, with plumage darker and olive tints brighter.

Distribution. - Breeds on the Pacific coast from British Columbia south to Oregon, and winters in California.

Nest. - As described by Bowles, hung from twigs of a young fir, 9 feet from the ground, woven of hanging moss and lined with fine dried grasses thickly interwoven. Eggs: 2, white, marked about the larger end with black spots.

\section{Vireo bellii Aud. Bell Vireo.}

Loral streak and orbital ring dull white; upper parts brownish olive, olive green on rump; wings and tail brownish, wing bars narrow, dull white; throat white; rest of under parts washed with sulphur yellow; under tail and wing coverts yellow. Length: 4.20-5.25, wing 2.05-2.30, tail 1.80-1.95, bill from nostril .28-.30, tarsus .70-.75.

Distribution. - Breeds in the Mississippi Valley and on the Great Plains. from Indiana to Dakota, and south through Texas to Mexico; accidental in New Hampshire.

Nest. - Hung from vines or forks of twigs, made of plant fibers and 
dead leaves, lined with stems and sometimes hairs. Eggs : usually 4, white, thinly spotted around larger end with reddish brown.

Food. - Insects and their larvæ.

The Bell vireo is a common bird in its range, abounding in the pium thickets of Nebraska, dense patches of brush and briers in Kansas, and the tangled mesquite woods of southern Texas.

Its song, like that of many vireos, is heard all through the hot noonday hours. It resembles that of the white-eje, but leaves off the interrogative $e h$ ? after the who-are-you? It has a harsh, scolding note, Mr. Henshaw says, which it often repeats as it goes through the brush searching for food.

\subsection{Vireo pusilius Coues. Least V'rreo.}

Adults. - Upper parts gray, faintly tinged with olive on rump, wings, and tail ; wings witl one and sometimes two narrow bars; lores gray and white; under parts white, sides washed with olive. Young: lores wholly white; top of head and hind neck pale brown; back dull green, rump greenish. Length: $4.80-5.25$, wing $2.10-2.30$, tail $2.03-2.20$, bill from nostril .2.)-.29, tarsus . $70-80$.

Distribution. - Upper and Lower Sonoran zones in Arizona and California; south to Cape St. Lueas and northwestern Mexico.

Nest. - In bushes, in thickets. Eggs: 3 or 4, white, lightly dotted with brown, more thickly around the larger end.

The least vireo is common in southern Califoruia in the willow regions and along streams up to the foothills.

\section{Vireo vicinior Coues. Gray Vireo.}

Adults. - Upper parts and sides of head dull gray, with faint tinge of greenish on rump; lores and orbital ring white; wings brownish with wing band indistinet or wanting; under parts clouded grayish white. Young: like adults, but upper parts with brownish tinge and wing bar buffy white. Length: 5.60-5.75, wing 2.50-2.60, tail 2.40-2.55.

Remarks. - The gray vireo differs from the plumbeous in its duller, less sharply contrasted coloration and absence of striking wing bars.

Distribution. - From western Texas to southern California and from southern Nevada to northwestern Mexico.

Nest. - In thorny bushes or trees, 4 to 6 feet from the ground, sometimes supported underneath or on sides so that it is not pensile; made of loosely woven coarse grass and mesquite bark lined with fine grasses. Eggs : 3 or 4, white, sparsely marked with irregular spots, chiefly around larger end.

In the foothills of the Santa Catalina Mountains Mr. Scott found the gray vireo breeding in comparative abundance where the oaks begin at the upper edge of the mesquite.

Mr. Henshaw found it in New Mexico frequenting rocky hills covered with seanty growth of bushes and scrub. In hunting, he says it takes a midllle line between that of the treetop solitary vireos and the low hunting white-eyed group, spending most of its time 
from six to twelve feet from the ground. The gray vireo's song Mr. Henshaw considers the finest of all vireo sougs, as it has not only beauty and raricty of note but mellowness of expression.

\title{
FAMILY MNIOTILTID $Æ$ : WOOD WARBLERS.
}

\author{
KEY TO (IENERA.
}

1. Gape with conspicuous bristles.

2. Under parts mainly clear yellow . . . . . Wilsonia, p. 427 .

2'. Under parts marked with red, orange, or yellow (except
young Cardellina).

Fig. 493.

3. Bill broad and much flattened at base . . Setophaga, p. 429 .

3 . Bill narrow and deep at base. Face and throat red in adnlts, brown in young . . . Cardellina, p. $4: 30$.

1'. Gape without conspicnous bristles.

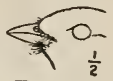

Fig. 494 .

2. Tarsus about equal to middle toe and claw; upper parts conspienously streaked with black and white. . Mniotilta, p. 402 .

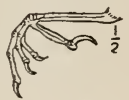

Fig. 495 .

Fig. 496.

2'. Tarsus longer than middle toe with slaw ; upper parts not distinctly streaked with black and white.

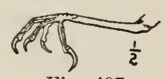

Fig. 497 .

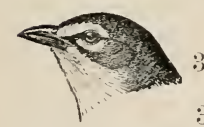

Fig. 498 .

3. Bill deep. and strongly curved

Icteria, p. 426 .

3'. Bill not deep. nor strongly eurved.

4. Bill narrowly wedge-shaped.

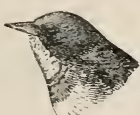

5. Rictal bristles obvious; upper parts blue with olive patch . . Compsothlypis, p. 406.

Fig. 499 .

5 '. Rictal bristles obsolete; upper parts not blue with olive pateh. Helminthophila, p. 402.

4'. Bill slenderly conical.

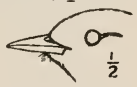

5. Tail marked with white or vellow. Fig. 500 .

Dendroica, p. 407.

5 '. Tail not marked with white or yellow.

6. Tarsus less than one third as long as wing; under parts streaked . . Seiurus, p. 4:3.

(i'. Tarsus decidedly more than one third as long as wing; under parts not streaked; partly yellow . . . Geothlypis. p. 424. 


\section{GENUS MNIOTILTA.}

\section{Mniotilta varia (Linn.). Black and White Warbler.}

Bill shorter than head, very slender, notched and slightly decurved at tip; rictal bristles minute ; wing long, pointed; tarsus about one fourth as long as wing or less, its scutella rather indistinct; middle toe with claw about equal to tarsus. Adult male: whole bird streaked glossy blue black and white except for plain white on middle of belly; throat closely streaked, sometimes solid

Fig. 501. black; wing with two white bars ; tail with white spots near end on inner webs of two outer feathers. Young male: similar to adult male. but throat white, unstreaked, and markings duller. Adult female : similar to young male, but duller, the black not so deep, and white of under parts dingy. Male: length (skins) 4.30-4.75, wing 2.62-2.79, tail 1.68-2.01, bill $.40-.51$. Female: length (skins) 4.30-4.65, wing 2.56-2.66, tail 1.79-1.91, bill .40-.4s.

Distribution. - Breeds from the Atlantic to the Plains and from Fort Simpson to Virginia and southern Kansas; winters in the Gulf states, West Indies, and south to Sonth America; accidental in California.

Nest. - Inibedded in gromnd in woods, made of plant fibers, grasses, moss, and leaves. lined with stenıs and hair; sometimes partially roofed over. Eggs : 4 or 5, creany white, thickly speckled, chiefly on larger end, with reddish brown.

Food. - Insects and their eggs and larvæ.

\section{GENUS HELMINTHOPHILA.}

General Characters. - Bill much shorter than head, narrowly wedgeshaped, straight, tip without notch, very acute; rictal bristles obsolete; wing with three or four outermost primaries abruptly longest; tarsus nearly one third as long as wing (except in $H$. peregrina), its scutella indistinet.

KEY TO ADLLT MALES.

1. Crown patch chestnut.

2. Pump chestnut . . . . . . . . . . luciæ, p. 402.

2 '. Rump yellowish green.

3. Under parts white with yellow chest patch . . virginize, p. 403.

3'. Under parts bright yellow. Rocky Mountains to California . . . . gutturalis, p. 404.

1'. Crown patch orange or wanting.

2. Crown patch orange; under parts yellow.

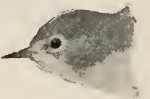

Fig. 502 .

3. Under parts dull yellow. Rocky Mountains. . celata, p. 404. 3 '. Under parts bright greenish yellow. Rocky Monntains to Pacific coast.

4. Lighter. Western States . . . . . . lutescens, p. 405.

4'. Darker. California Islands . . . . . . . sordida. p. 405.

2 '. Crown patch wanting; under parts grayish white.

peregrina, p. 406.

\section{Helminthophila luciæ (Cooper). Lecy ITArblar.}

Adult male in spring and summer. - Upper parts gray, crown chestunt. feathers more or less tipped with gray ; upper tail coverts bright chestnut; 
lores, eye ring, and under parts white, tinged with brownish on sides and buffy on chest. Adult female in spring and summer: like summer male, but chestnut of crown and upper tail eoverts lighter, crown patch restricted, sometimes obsolete. Idult male in fall and winter: upper parts tinged with brown; crown patch concealed by gray tips to feathers; under parts brownish buff. beconing whitish on belly. Young in first plumage: like adults, but without erown patch ; upper tail coverts buffy brown instead of ehestnut; wings with two bars; under parts white. Male: length (skins) $3.60-4.05$, wing $2.17-2.29$, tail 1.62-1.73, bill .3:3-.35. Female: length (skins) $3.62-3.75$, wing $2.03-2.08$, tail $1.47-1.57$, bill $.30-$ .3.j.

Distribution. - Breeds in Lower Sonoran zone from the Santa Clara Valley, Utah, south through Arizona and Sonora to Jaliseo, Mexico.

Nest. - Usually in deserted woodpecker holes, behind bark of trees, in giant cactus, or by roots along river banks, 2 to 20 feet from the ground, made of fine straws, leaves, horsehair, and feathers. Eggs: 3 to \%, white or ereamy, finely speckled, usually in dense ring around larger end, with reddish brown.

Mr. O. W. Howard found the Lucy warblers fairly common along the river-bottoms throughout southern Arizona, especially in the willow and mesquite thickets, and $\mathrm{Mr}$. Scott found them breeding at the base of the Santa Catalina Mountains up to 4000 feet.

Among the nests found by Mr. Howard some were in deserted verdin and woodpecker nests. He says that many are destroyed by wood rats and snakes.

\section{Helminthophila virginiæ (Baird). VirgiNia Warbler.}

Adult male in spring and summer. - Upper parts gray, rump and upper tail coverts bright yellowish green; croun with chestnut patch concealed by gray tips in fresh plumage; orbital ring white, conspicuous ; under parts dull white with chest and usually throut yellow. Adult female in spring and summer : Like adult male, but duller. especially on rump and upper tail coverts ; crown patch restricted, sometimes almost obsolete ; back browner. Adult male in fall and winter: like summer male, but sellow duller, crown patch concealed by gravish tips to feathers; upper parts and flanks strongly tinged with brown. Young in first plumage: two wing bars dull buffy ; under parts brownish gray; median parts of breast and belly white. Male: length (skins) 4.08-4.30, wing 2.40-2.42. bill .35-.39. Female: length (skins) 4 , wing $2.26-2.38$, tail 1.79-1.84, bill .37.

Distribution. - Rocky Mountain region of the United States from $\mathrm{Wr}$ oming to Nevada and south to Guanajuato and Jaliseo.

Nest. - On the ground under a bush or tuft of grass; made of straws, rootlets, and fibers, loosely put together. Eggs: of ten 4 , creamy white. finely and rather densely speckled over whole surface or around larger end with chestnut and purplish gray.

Mr. Ridgway found the Virginia warbler common in the Humboldt and Wasatch Mountains, and MIr. O. W. Howard states that it is quite common in the pine regions of Arizona above 5000 feet. In Coloxado MIr. Aiken rarely finds it above 7500 feet, and he thinks that it prefers the foothills.

Unlike other warblers found in Arizona, Mr. Howard says, during 
the summer it stays almost wholly in the underbrush, where it keeps continually on the move, uttering a quick chirp as it goes.

During the migrations, Mr. Aiken reports, it has been found among cottonwoods and willows bordering streams, and often among the pines. He says: "The male is very musicalduring the nesting season, uttering his sweet little ditty continually as he skips through the bushes in search of his morning repast; or, having satisfied his appetite, he mounts to the top of some tree in the neighborhood of his nest, and repeats at regular intervals a song of remarkable fullness for a bird of such minute proportions."

\section{5a. Helminthophila rubricapilla gutturalis (Ridgw.). Calaveras Warbler.}

Adult male. - Under parts bright yellow; upper part of head gray, with

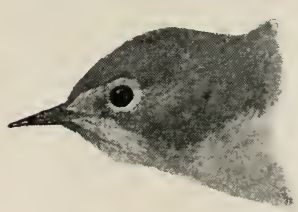

Fig. 503. conspicnons white orbital ring and chestnut croun patch, but feathers tipped with gray; back olive green, brightening to yellowish green on rump and upper tail coverts; wings and tail mmmarked. Adult female: similar, but duller, and erown with little if any chestnut. Young: throat, chest, and under tail coverts dnll yellowish; belly buffy brown; upper parts brownish gray, becoming olive gray on rump. Male: length (skins) 4.054.75, wing $2.32-2.46$, tail 1.70-1.88, bill $.37-.40$. Female: length (skins) 3.8.5-4.10, wing 2.12-2.19, tail 1.5.8-1.62, bill .34-.38.

Remarks. - The sharply contrasting yellow throat and gray sides of head make a striking field character.

Distribution. - Breeds on monntains in Transition and Canadian zones from the Pacific coast of North America eastward during migrations to the Rocky Mountains and central Texas, and from British Columbia south to Lower California and northern Mexico.

Nest. - On or near the ground, made of weed stems, grasses, and bark, lined with soap-root fiber. Eggs: usually 5, creamy white, spotted with reddish brown mixed with lavender in wreath around larger end.

In California the Calaveras warbler is often met with in the chaparral. It looks up at you shçly as it clings to the stalk of a bush, and you have barely time to note how the dark sides of its throat contrast with its yellow body before it has hopped off to a twig and is making its way through its dense little forest. In the breeding season, at Fort Klamath, Oregon, Dr. Merrill says, it hunts mostly among the aspens, though flying up occasionally into the pines. He compares its song, which is loud and constant, to that of the yellow warbler.

646. Helminthophila celata (Say). Orange-CroWned Warbler. Adult male.-Upper parts dull olive green, brighter on rump; sometimes tinged with gray, especially on head; croun with dull orange patch concealed except in worn midsummer plumage by grayish olive tips to feathers ; orbital ring and supereiliary yellow ; under parts dull yellowish, 
indistinctly streaked with darker on throat and chest. Adult femule: crown patch usually duller and restricted, sometimes obsolete. Young: generally without erown patch. Young in first plumage: erown patch wanting; upper parts dull olive; wings witl two light bands; belly white; rest of under parts brownish gray, tinged with buffy. Male : length (skins) $4.25-$ 4.80, wing $2.39-2.49$, tail $1.92-2.07$, bill $.37-.41$. Female: length (skins) $4.35-4.65$, wing $2.26-2.33$, tail $1.7 \mathrm{~s}-1.94$, bill .37-.42.

Distribution. - Breeds from the Yukon and Mackenzie River districts sonth through the Rocky Mountains to New Mexico; migrates to southeastern United States and central Mexico.

Nest. - On the ground, hidden in a bank or among bushes; made of strips of bark, plant stems, and grasses, lined with grasses, or hair and fur. Eggs : 4 to 6, white or creamy, finely speckled, chiefly around the larger end with reddish brown.

Food. - Leaf worms and other insects.

646a. H. c. lutescens (Ridgw.). Lutescent WARBLER.

Similar to celata, but brighter colored; upper parts bright olive green; under parts bright greenish yellow, streaks on under parts dull olive greenish. Young in first plumage : upper parts olive green, wing bars paler or buffy; under parts buffy or straw color shaded with olive on chest, sides, and flanks. Male : length (skins) 4.20-4.45, wing 2.29-2.41, tail 1.76-1.93, bill $.37-.38$. Female: length (skins) $4.00-4.40$, wing $2.24-2.40$, tail $1.80-1.85$, bill $.39-.40$.

Distribution. - Breeds along the Pacific coast from Kadiak to the mountains of southern California; east in migrations to the Rocky Mountains, south to Mexico and Central America.

Nest. - On the ground, in eavities in banks or in ferns along small streams. Eggs: 4 or 5, colored like those of the orange-crowned.

The lutescent warbler is often seen during migration stretching up for an insect on top of the chaparral, or darting out from the blooming top of an oak, with whose golden brown tassels the pretty bird harmonizes. He seems a peculiarly dainty, airy little creature, his wings lifting him off his feet if an insect is a bit beyond his reach, and holding him up like a hummingbird under an oak tassel, or carrying him about from branch to branch while he looks for food, warbling his short lay in the intervals. In the breeding season he goes to the mountain sides where he is found in the shrubbery, in aspens, or on the ground, sometimes above an altitude of 11,000 feet.

646b. H. c. sordida Touns. Dusky Warbler.

Like lutescens, but decidedly darker, bill and feet larger, wing shorter, tail longer. Male: length (skins) 4.35-4.70, wing 2.27-2.36, tail 1.94-1.97, bill .42-.47. Female: length (skins) $4.60-4.70$, wing $2.23-2.26$, tail $1.93-$ 1.97 , bill .41.

Distribution. - Santa Barbara Islands, California; visiting adjoining mainland after the breeding season.

Mr. Grinnell states that dusky warblers appear in the vicinity of Pasadena in July or August in large numbers in the oak regions and along the arroyos. 


\section{Helminthophila peregrina (Wils.). Tennessee WAR- BLER.}

Adult male. - Crown and hind neck dark gray; rest of upper parts olive green, brightest on rump; loral streak dark gray bordered by white above ; wings and tail unmarked, tail gray, feathers with outer webs edged with olive green, inner webs with white, outside feather usually with a white spot. Adult female : similar, but gray of head more or less mixed with green, and superciliary and under parts lightly washed with olive yellow. Young male in first autumn: npper parts olive green, including crown and hind neck; under parts strongly tinged with olive yellow except for white belly and under wing and tail coverts. Young female in first autumn: like young males, but yellow brighter. Male : length (skins) 4.05-4.70, wing 2.46-2.67, tail 1.61-1.81, bill .37-.39. Female: length (skins) $4.20-4.70$, wing $2.30-2.40$, tail $1.54-1.67$, bill .37-.40.

Distribution. - Breeds from Alaska, British Columbia, Great Slave Lake, and Hudson Bay south to the northern United States; migrates mainly through the Mississippi Valley south to Cuba and northern South America; accidental in southern California.

Nest. - On or near the ground, made largely of grass, leaves, and moss, sometimes with hair lining. Eggs: 4 or 5, white, spotted with reddish brown around the larger end.

Food. - Winged insects, caterpillars, and other leaf-eating insects.

The Tennessee warbler is a rare migrant in the eastern part of Colorado, passing north the latter half of May. In Kansas, Colonel Goss says, it is found in low bushes, in tall weeds, about gardens and orchards, along banks of streams, and the edges of woodland.

\section{GENUS COMPSOTHLYPIS.}

General Characters. - Bill much shorter than head, narrowly wedgeshaped and acute, but distinctly curved, at least toward tip; rictal bristles distinct; wing tip decidedly shorter than tarsus; tarsus decidedly less than one third as long as wing, its scales indistinct.

KFY TO SPECIES.

1. Eyelids white

$1^{\prime}$. Eyelids dusky. Lower Rio Grande Valley, Texas. nigrilora, p. 407.

648a. Compsothlypis americana usneæ Brewster. Norther PARULA WARBLER.

Adult male. - Sides of head and upper parts bluish gray, with triangular olive green patch on back; wings with two white bars. tail with white spots on inner webs of two outer feathers; throat and breast yellow, chest more or less tinged with orange brown, and often crossed by blackish band; feathers sometimes tipped with chestmut; eyelids white; lores black. Idult female: similar, but colors duller, less pronomnced. Young in first autumn: whole npper parts tinged with olive green, nnder

Fig. 504 . parts pale yellow. Young: yellow of under parts replaced by gravish,
chin tinged with yellow; 1 pper parts gravish, more olive on back. Male: length (skins) $3.52-4.45$, wing $2.24-2.45$, tail $1.5 .5-1.77$, bill $.35-.43 . \mathrm{Fe}$ male: length (skins) $: 3.66-4.13$, wing $2.13-2.34$, tail $1.52-1.65$, bill .8.5-.41.

Distribution. - Breeds ehiefly in Canadian zone north of $41^{\circ}$, but locally 
from the Atlantic to the base of the Rocky Mountains; migrates to the West Indies, eastern Mexico, and Nicaragua; casual in Greenland.

Nest. - Placed within lianging tufts of lichens or 'beard' mosses, bunches of dead leaves or other rubbish, eanght on hanging branches during freshets. Eggs: 3 to 5, white or creamy, thickly speckled with reddish brown, ehiefly around larger end.

Food. - Insects.

The parula warbler is taken occasionally in southeastern Colorado. It is most at home in swampy woods, where it may be seen in the treetops quietly looking for insects, raising its head as it hunts so that the dark chest band shows to good adrantage.

649. Compsothlypis nigrilora (Coues). Sennett Warbler.

Adult male: Upper parts bluish gray with olive green patch on back; wings with two broad white bands; throat, breast, and sides jellow, becoming saffron on chest; rest of under parts white, sides tinged with grayish and sometimes brown; eyelids dusky; lores blackish. Adult female: similar, but slightly smaller and much duller; npper parts tinged with olive green ; lores grayish dusky, under parts paler yellow. Length: $4.2 .5-$ 4.75, wing $2.00-2.20$, tail $1.58-1.75$.

Distribution. - Lower Rio Grande Valley in Texas and sonthward to Nuevo Leon, Tamaulipas, and sontheastern San Luis Potosi.

Nest. - As described by Sennett, a eavity excavated in a mistletoelike air-plant, lined with eottony wood fibers. Eggs: dull white, flecked with lilac and brown over the whole surface, and with a broad band around the larger end.

\section{GENUS DENDROICA.}

General Characters. - Bill slenderly conical, tapering gradually to tip; rictal bristles obsolete; tarsus a quarter to a third as long as wing; scutella indistinct.

Fig. 505.

KEY TO ADULT MALES IN SPRING.

1. Throat yellow or orange yellow.

2. Throat orange .

blackburniæ. p. 41 .

Fig. 506.

2'. Throat yellow.

3. Tail with yellow patches on outer tail feathers.

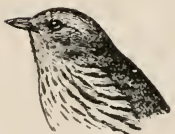

4. Under parts yellow, broadly streaked with reddish brown . . . . . æestiva, p. 411.

Fig. 507 .

t'. Under parts yellow, narrowly streaked with reddish brown.

5. Upper parts yellowish green. sonorana, p. 411 .

5 . Upper parts olive green . . rubiginosa. p. 412.

$3^{\prime}$. Tail withont yellow patches on onter tail feathers.

t. Rump yellow. 
5. Crown plain gray . . maculosa, p. 415.

Fig. 508. 5'. Crown gray with yellow patch.

6. Forehead and cheeks black. Arizona. nigrifrons, p. 41 i).

$6{ }^{\prime}$. Forehead and cheeks not black. Western States.

4'. Rump not yellow. auduboni, p. 413 .

5. Crown chestnut . . . palmarum, p. 422. 5'. Crown gray streaked with black; superciliary and spot on lower eyelid yellow . . graciæ, p. 41 i.

1 '. Throat black, white, or brown.

2. Throat brown.

olivacea, p. 410 .

2 '. 'Throat black or white.

3. Throat black.

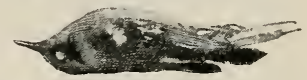

Fig. 509.

4. Sides of head black, or black and white.

5. Sides of liead black. Eastern United States. cærulescens, p. 412.

Fig. 510 .

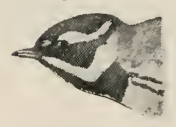

5 '. Sides of head black and white. nigrescens, p. 41 .

Fig. 511.

4. Sides of head partly or wholly yellow.

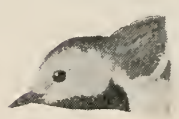

5. Sides of head wholly yellow.

occidentalis, p. 421 .

Fig. 512. 5'. Sides of head not wholly yellow.

6. Sides of head marked with olive. Eastern United States. . . . . . . virens, p. 420.

Fig. 513.

$6{ }^{\prime}$. Sides of head marked with black.

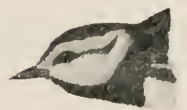

7. Cheeks crossed by narrow black eye streak.

chrysoparia, p. 419.

Fig. 514.

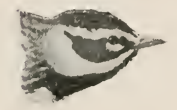

7. Cheeks crossed by wide black band. townsendi, p. 421.

Fig. 515. 
3'. Throat white.

4. Crown blue or black.

5. Crown blue. Eastern United States. rara, p. 416.

j’. Crown black

striata, p. 416 .

Fig. 516 .

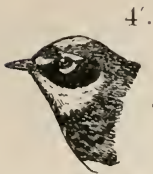

4'. Crown yellow or with yellow pateh.

5. Rump yellow ; under parts white, black, and yellow. coronata, p. 412 .

Fig. 517.

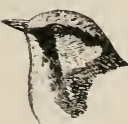

5'. Rump not yellow ; under parts white, with chestnut sides . . . . . pensylvanica, p. 416 .

Fig. 518.

KEY TO ADULT FEMALE DENDROICA IN SPRING.

1. Tail with yellow on inner webs.

2. Upper parts grayish yellow. Arizona to Texas. sonorana, p. 411. $2^{\prime}$. Upper parts greenish.

3. Upper parts greenish yellow . . . . . . . æstiva, p. 411.

3 . Upper parts dull olive green . . . . rubiginosa, p. 412.

$1^{\prime}$. Tail without yellow on inner webs.

2. Rump yellow.

3. Under parts bright yellow, streaked with black. Eastern United States . . . maculosa, p. 415.

3'. Under parts mainly whitish.

4. Throat yellowish.

5. More heavily streaked on darker ground. nigrifrons. p. 415.

$\tilde{5}^{\prime}$. Less heavily streaked on lighter ground. auduboni, p. 413 .

4'. Throat whitish .

2 . Rump not yellow.

3. Plumage not conspicuously marked with yellow or green.

4. Upper parts gray and black . . . nigrescens. p. 418.

4. Upper parts streaked black and white . . . striata, p. 416.

3'. Plumage conspicuously marked with yellow or green.

4. Sides of head or throat marked with bright lemon yellow.

5 . Sides of head gray or white.

6. Throat, chest, and loral streak yellow . . graciæ, p. 418.

6 . Under parts white, with chestnut sides.

pensylvanica, p. 416.

5 '. Sides of head yellow, or yellow and olive.

6. Upper parts grayish . . . . . occidentalis, p. 421.

$6^{\prime}$. Upper parts mainly or partly olive green.

7. Upper parts olive green and gray. Texas.

7 . Upper parts plain olive green.

chrysoparia, p. 419 . 
S. Upper parts bright green, unstreaked. Eastern United States . . . . . . . . virens, p. $4 \div 0$.

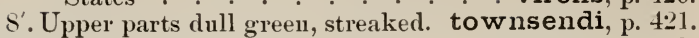

4 '. Neither sides of head nor throat marked with bright lemon yellow.

j. Upper parts olive brown or greenish.

6. Upper parts olive brown. Eastern United States.

palmarum, p. 422 .

6'. Upper parts greenish.

7. Wings and tail edged with greenish. Eastern United States.

7 . Wings and tail not edged with green.

8. Under parts greenish buff . cærulescens, p. 412 .

5 '. Upper parts neither olive brown nor greenish.

6. Head with yellow or orange crown patel.

blackburniæ, p. 417.

$6^{\prime}$. Whole head buffy yellow. New Mexico and Arizona. olivacea, p. 410 .

\section{Subgenus Peucedramus.}

651. Dendroica olivacea (Giraud). Olive Warblek.

Adult male in summer. - Head, neck, and chest orange brown, sometines

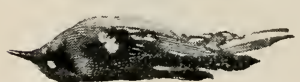

Fig. 519. tinged with olive; belly soiled whitish; lores and ear coverts black; nape olive, sometimes extending over back of head; rest of upper parts gray; wings with two white bars and white patch at base of primaries; tail with two onter pairs of feathers mainly white. Adult femule in summer and male of second year : crown and hind neck olive green; sides of throat and chest yellowish, throat sometimes nearly white; lores grayish; wing bars narrower than in adult male; white spot at base of primaries smaller, sometimes obsolete. Adult male in winter: like summer male, but head, neck, and chest duller, more clay color ; sides and flanks browner; back more olivaceous. Adult female in winter: like summer female, but plumage softer in texture and posterior wing band more or less tinged with yellowish. Young male, first plumage: like adult female, but upper parts dull olive or brownish olive ; sides of head and neck dull buffy, neck tinged with olive; throat and chest buffy. Young female, first plumage: like young male, but paler. Male: length (skins) $4.45-5.0$, wing 2.84-3.07, tail $1.97-2.20$, bill $.36-.47$. Female: length (skins) $4.33-4.92$, wing $2.64-2.87$, tail $1.86-2.09$, bill $.35-.47$.

Distribution. - Breeds in Upper Transition and Canadian zones from mountains of New Mexico and Arizona soutl to Guatemala.

Nest. - In fork of a conifer, 30 to 50 feet from the ground, made sometimes like a gnateateher's nest, of rootlets, flower stalks, moss, lichens, or fir blossoms and spider's web, lined with rootlets. Eggs : 3 or 4, olive gray or sage green, thickly covered with black specks, sometimes almost obscuring the ground color.

Mr. Scott found the olive warblers in southern Arizona associated with Mexican bluebirds in the pines. In looking for food, he says, their motions were very deliberate, though occasionally suggesting kinglets or titmice in their way of hunting over the tips of the boughs.

Mr. W. W. Price found them breeding in the mountains of Ari- 
zona between 9000 and 10,000 feet, the male following the female about while she collected material for the nest, uttering at times 'a liquid quirt, quirt, quirt, in a descending scale.'

\section{Subgenus Dendroica.}

652. Dendroica æstiva (Gmel.). Yellow Warbler.

Adult male. - Under parts vellow; breast and belly streaked with rufous ; forehead bright yellow, front of crown often tinged with orange; lind neck and rest of upper parts yellowish green, brightest on rump; wing edgings yellow; inner

webs of tail feathers, except middle pair, light yellow.
Adult female and male in first autumn: upper parts plain Fig. 520 . yellowish green, usually darker than in male, lighter on forehead and rump; under parts paler and duller, usually unstreaked. Young female in first autumn: like adult female, but duller olive green above, olive whitish slightly tinged with yellow below; under tail coverts pale yellow. Male : length (skins) 3.94-4.92, wing 2.36-2.80, tail 1.65-2.09, bill .39-.43. Female: length (skins) 4.02-4.57, wing 2.242.68 , tail $1.54-1.77$, bill .39-.43.

Remarks. - The yellow on the inner webs of the tail feathers, together with the general yellow coloration, are enough to distinguish the cestiva group in all ages and sexes.

Distribution. - North America, except Alaska and sonthwestern United States ; migrates to Central America and northern South America. Breeds nearly throughout its North American range.

Nest. - Compact and cup-shaped, made largely of gray plant fibers, lined with down and feathers; placed in bushes or trees. Eggs: 2 to 6, greenish, spotted usually around larger end with brown, black, and lilac gray.

Food. - Insects.

The yellow warblers are birds of the chaparral, of willows, and thickets along streams in uninhabited regions, and of parks and gardens where the gods provide. When seen in the chaparral thickets the glimpse of yellow tail patches is enough to identify them as they disappear, but in towns where they are tame the bricky streaking of the breast can be seen as they stand on a flowering bush and lift their heads to sing. They have so much singing to do and so many insects to catch that it keeps them busy. Their song is loud and cheery and they have the fine clip of their family. In their manner of life they belong to the quiet part of the warbler tribe, hunting usually in a leisurely way as if they knew that their song was needed to add the real summer feeling to the blooming shrubs.

\section{2a. D. a. sonorana Brewst. Soxora Yellow Warbler.}

Like astiva, but much paler; adult male lighter, more yellowish olive green above, back often streaked with brown, crown usually clear yellow ; under parts lighter yellow than in astiva; chest and sides more narrowly streaked ; adult female conspicuously paler than in cestiva, upper parts of ten largely pale gravish; under parts usually pale buffy yellow. Male: length (skins) 4.21-4.76, wing 2.32-2.60, tail 1.7i-2.20, bill :39-.43. Female: length (skins) $4.33-4.57$, wing $2.24-2.40$, tail $1.65-1.77$, bill .39 . 
Distribution. - From southern Arizona to western Texas and south to northwestern Mexico ; in winter to Guatemala and Nicaragua.

\section{2b. D. a. rubiginosa (Pall.). Alaskan Yellow Warbler.}

Like cestiva, but slightly smaller and much duller; adult male with upper parts darker, duller olive green, crown like back or only slightly yellower on forehead; adult female duller olive green above, duller yellow below. Male: length (skins) $4.02-4.45$, wing $2.40-2.48$, tail 1.5 $\mathbf{i}-1.81$. bill .39. Female : length (skins) :3.90-4.33, wing 2.24-2.44, tail 1.61-1.73, bill .39.

Distribution. - Alaska, south to Vancouver, migrating southward.

\section{Dendroica cærulescens (Gmel.). Black-throated Blue WARBLER.}

Adult male in spring and summer. - Face, throat, sides, and flanks black,

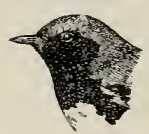

Fig. 5:1. sides and flanks streaked with white ; rest of under parts white ; upper parts grayish blue; wing with conspicuous white patch at base of primaries. Adult female in spring and summer: upper parts olive, usually with white spot at base of primaries; tail feathers edged with bluish or greenisl gray; inner web of outside feather sometimes with paler or whitish spot; erelids with whitish streaks, that of upper lid extending over ear coverts; under parts pale olive yellowish, shaded with olive laterally. Adult male in fall and winter: like spring male, but white of flanks faintly tinged with brownish buff and bill brownish instead of black. Adult female in fall and winter: like summer female, but upper parts greener; under parts yellower. Young male in first fall and winter: like adult winter male, but white of under parts more or less tinged with yellowish, bluish gray of upper parts tinged with olive green; black feathers of throat edged with whitish. Young male, first plumage: wings and tail as in fall males; white spot at base of primaries fully developed; lores black; rest of upper parts dark olive brown; throat and superciliary buffy; breast and sides ashy; belly sulphur yellow. Ioung female, first plumage: wings and tail like winter female; spot at base of primaries soiled white; rest of upper parts light olive brown; lores dull black; under parts buffy, olive buff on breast and sides. Male : lengtl (skins) 4.33-4.72, wing $2.44-2.64$, tail 1.9:3-2.13, bill .3:3-.39. Female : length (skins) 4.33-4.76, wing 2.36-2.45, tail 1.87-2.01, bill .85-.37.

Distribution. - Breeds in Transition and Canadian zones from Hudson Bay to the northeastern United States, soutl to Pennsylvania in the mountains; migrates casually to base of Rocky Mountains; winters in Guatemala, the West Indies, and northern Sonth America; accidental in Colorado and on the Farallone Islands.

Nest. - In bushes, compact and deep; made of fine grass, spider's web, lichen, and strips of fine bark. Eggs: usually 4, buffy whitish or greenish white, more or less heavily spotted with reddish brown.

Food. - Insects.

655. Dendroica coronata (Linn.). Yellow-Rumped Warbler.

Adult male in spring and summer. - Crown patch and rump bright yellow; rest of upper parts bluish gray, streaked with black; wings with two white bars; tail black with gray edgings; outer pair of tail feathers with large spots of wlite ; throat uhite; rest of under parts black, yellow, and white. Adult female in spring and summer: similar. but smaller and duller; upper parts tinged with brown; color patches restricted. Adult male in fall

Fig. 522. and winter: upper parts grayish brown, streaked with black 
on back and scapulars; yellow crown patch concealed by brown tips to feathers; throat and chest brownish white or buffy brown, chest streaked with black; yellow patches obscured, black patches with white edges to feathers. Adult female in fall and winter: like winter male, but smaller, upper parts browner, yellow crown patch restricted or obsolete; under parts pale buffy brown in front and on sides; median parts of breast and belly yellowish white; yellow breast patches indistinct or obsolete. Young, first plumage: streaked above and below; wings and tail much as in adults. Male: length (skins) 4.72-5.51, wing $2.76-3.07$, tail 1.97-2.36, bill .35-.4:3. Female: length (skins) 4.65-5.51, wing 2.64-2.95, tail 2.022.32 , bill .32-.41.

Remarks. - The yellow-rumped and Audubon warblers are similar, but can be distinguished by the throat, which is white in coronata and yellow in auduboni.

Distribution. - North America, chiefly east and north of Rocky Mountains (to Hudson Bay region), straggling westward to the Pacific; breeds from Alaska to northern United States, wintering from southern New England and the Ohio valley south to the West Indies and Panama; accidental in Greenland and eastern Siberia.

Nest. - Usually low in coniferous trees, made of grasses, twigs, and rootlets, lined with finer grasses, feathers, and hair. Eggs: 3 to 6, white, creamy, or buffy, spotted or blotched chiefly on or around larger end with brown and lilac, sometimes mixed with small black markings.

Food. - Insects, their eggs and larvæ, and wild berries.

The jellow-rump, the eastern representative of the Audubon warbler, migrates through Colorado, and Prof. Cooke says it is not uncommon for two or three weeks on the plains along the foothills of the Rocks Mountains, where a few range up to 9000 feet. It migrates from ten days to two weeks ahead of auduboni, but in May the two species are often found together.

\section{Dendroica auduboni (Touns.). Ađdubon Warbler.}

Adult male in spring and summer. - Throat and rump yellow; under parts with patches of white, yellow, and solid black; npper parts bluish gray, streaked with black; wing coverts with large white patches; tail black. inner webs of four or five outer feathers with large subterminal patch of white. Adult female in spring and summer: like summer male, but duller, and with less black on under parts : npper parts usually more or less tinged with brown: yellow crown patch restricted. and partly tipped with brownish gray; wings with narrower bands; chest and sides grayish, marked with black; color patches restricted. Adult male in fall and winter: duller and browner than summer males, upper parts washed with brown, wing markings tinged with brown; black of chest

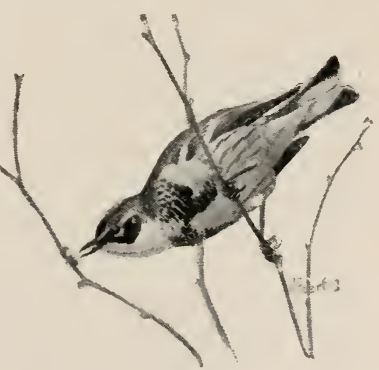

Fig. 523. and sides mostly concealed by brownish white edges to feathers. Adult female in fall and winter: like winter male, but smaller and duller, back without sharply defined streaks; yellow patches paler and more restricted; 
black chest spots more sharply defined. Young, first plumage : upper parts thickly streaked with dusky on brownish gray ground; lower rump grayish white, narrowly streaked with dusky; under parts grayish white, streaked. Male: length (skins) 4.80-5.39, wing 2.95-3.19, tail 2.09-2.42, bill .39-.43. Female: length (skins) 4.80-5.08, wing 2.87-3.07, tail 2.132.32, bill .39-.43.

Remarks. - The yellow throat distinguishes the adult Audubon warbler from the yellow-rump, and the amount of white on the tail distinguishes the young, auduboni having four or five feathers marked with white, coronata, only two or three.

Distribution. - Breeds in Canadian and Transition zones from British Columbia south to Arizona, and from California to Sioux County, Nebraska; winters from western United States to Guatemala, and eastward to western parts of Texas and Kansas; accidental in Massacluusetts and Pennsylvania.

Nest. - Usually in pines or spruces, but sometimes in deciduous trees and bushes a few feet from the ground, made largely of strips of fine bark and pine needles, lined with fine roots, hair, and a few feathers. Eggs : usually 4 , generally olive white or greenish, sparsely spotted and dotted with black, brown, and lilac gray.

Food. - Similar to that of the yellow-rumped warbler.

The Audubon warbler in its dull, streaked winter dress is a com mon winter bird in the warm valleys of the west, and one of the commonest in the San Francisco parks. Its flight and all its movements seem to be regulated by gnats, its days one continuous hunt for dinner. When insects are scarce it will fly hesitatingly through the air looking this way and that, its yellow rump spot always in evidence, but when it comes to an invisible gauzy-winged throng it zigzags through, snapping them up as it goes; then, perhaps, closing its wings it tumbles down to a bush, catches itself, and races pellmell after another insect that has caught its eye. In the parks it is especially fond of the palm tops frequented by the golden. crowned sparrows, and dashes around them in its mad helter-skelter fashion. The most straight-laced, conventional thing it ever does is to make flycatcher sallies from a post of observation when it has caught its insect. If it actually sits still a moment with wings hang. ing at its sides, its head is turning alertly, its bright eyes keen for action, and while you look it dashes away with a nervous quip' into midair, in hot pursuit of its prey.

Auduboni is so preoccupied with its lumting that it pays little heed to observers. At Stanford, in December, when the birds were common, one has flown in from the rosebushes to the piazza rail near me, looked around for a moment, and then ignoring my presence flown down to the floor and gone hopping jauntily about in the shadow of the vines looking for insects.

When spring comes these warblers are off to the mountains, for they are true Canadian zone birds. In July we have met them near 
the crest of the Sierra in full plumage and full song. There is little to suggest the dull, streaked bird of winter in this warbler, whose handsome yellow pointed plumage makes such a brilliant showing against the dark green of the firs.

His song is of a strong warbler type, opening toward the end, chree, chrce-chrce-rth, chree, between the song of the yellow warbler and that of the junco.

By the third week in July we saw the Audubons feeding a trailing family of streaked young in the fir tops, the abstracted chase for insects going on more strenuously than ever.

\subsection{Dendroica nigrifrons Brewst. Black-Fronted Warbler.}

Like auduboni. but larger and darker; adult summer male with forehead, sides of crown, and cheeks mainly black instead of gray; back black with feathers edged with bluish gray; under parts more solidly black; winter male with less black on upper parts, forehead only streaked with black, bluish gray of upper parts with little if any brown, black of under parts with only narrow whitish tips to feathers; adult female more heavily streaked on darker ground; young more heavily streaked with dusky. Male: lengtlı (skins) 5.00-5.55, wing $3.05-3.31$, tail 2.28-2.53, bill .37.35. Female : length (skins) 5.00-5.10, wing $2.97-3.04$, tail $2.26-2.35$, bill $.35-.38$.

Distribution. - From Huachuca and Chiricahua Mountains, Arizona, south to northwestern Mexico.

\section{Dendroica maculosa (Gmel.). Magnolia Warbler.}

Adult male in spring and summer. - Under parts bright yellow, strikingly marked by black necklace and black streaking down breast; top of head and hind neck plain gray, sides of head and back black; rump yellow, partly streaked with black and sometimes partly olive green; upper tail coverts, wings, and tail black; wings with conspicuous white pateh and tail with subterminal band of white. Adult male in fall and winter: crown and hind neck brownish gray, back and scapulars olive green, feathers with mostly concealed

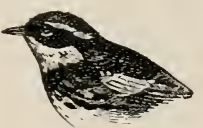

Fig. 5:4. black centers; wing patch replaced by two narrow wing bars; chest without black streaks or spots. Adult female: duller; back mainly olive green; wing with two white bands; streaks on under parts narrower. Young male in first fall and winter: chest with broad gravish or whitish band. Young female in first fall or winter: like voung male, but smaller and much duller, crown browner, back without concealed black markings, white of tail restricted, flanks indistinctly streaked. Male: length (skins) 4.1:3-4.65, wing 2.24-2.5.2, tail 1.86-2.04, bill .34-.49. Female: length (skins) 4.25-4.41, wing $2.14-2.28$, tail 1.81-1.91, bill .35.

Remarks. - The white subterminal tail band is enough to distinguish the magnolia warbler in any plumage.

Distribution. - Breeds in Boreal zone in eastern North America, west to the Rocky Mlountains; from Hudson Bay south to northern parts of New England and Michigan and soutluward in the Alleghanies ; casually to California ; wiuters in Cuba, the Bahamas, and south through Mexico to Panania ; accidental in Greenland.

Nest. - Largely of fine twigs, grass. and weed stalks, lined with fine 
black rootlets; placed in small spruces and hemlocks, 3 to 35 feet from the ground. Eggs: 4 or 5, creamy, blotched or spotted with lilac and shades of brown.

Food. - Insects.

The handsome magnolia warbler is a rare migrant in Colorado, but whenever seen may be recognized as it goes about with wings drooping and tail spread enough to show its black terminal tail band.

\section{Dendroica rara (Wils.). Cerulean Warbler.}

Adult male. - Upper parts light grayish blue, crown bordered by two blackish stripes; back streaked with black; wings and tail black with grayish blue edgings, wings with two clear white bands; tail feathers broadly spotted with white; under parts white, with narrow bluish throat band and bluish streaking along sides. Adult female : upper parts from light bluish gray to grayish olive green; supereiliary stripe, if present, pale greenish yellow like mider parts; wings and tail as in male, but edgings greenish instead of bluish. Fall and winter adults: more highly colored. Young male in first autumn: like female, but whiter below and more blnish above. Young male, nestling plumage: upper parts gray, crown with median stripe, and dark postocular stripe; sides of head and under parts white. Male: length (skins) 4.05-4.55, wing '2.44-2.66, tail 1.70-1.88, bill .37-.4\%). Female: length (skins) $4.10-4.35$, wing $2.29-2.47$, tail $1.62-1.68$, bill $.39-$ .41 .

Distribution. - Breeds in Upper Sonoran zone of the eastern central United States and Canada from Tennessee and Missouri to Michigan, western New York, and southern Ontario ; south in migration to western Texas, southern Mexico, Central America, northern South America, and rarely Cuba ; occasionally to Rocky Momtains.

Nest. - In trees in high deciduous woods, 2)-50 feet or more from the ground; compact, cup-shaped, composed largely of plant fibers. strips of fine bark, and spider web. Eggs: usually 3 or 4, white or dull greenish or bluish white, speckled with brown, chiefly around the larger end.

Food. - Insects.

659. Dendroica pensylvanica (Limn.). Chestnut-sided WarBLER.

Adult male. - Crown yellow, bordered with black; sides of head and

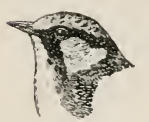
neck and under parts white; sides with broad stripe of chestmit; back striped with black and olive, mixed with yellowish. Adult female: like male, but duller, upper parts greener, black markings on head indistinct, and chestnut restricted. Young in first autumn: npper parts bright olive green; wing Fig. 525. bars rellowish ; sides of head and body ash gray; median under parts white. Length: 4.60-5.2.5, wing 2.40-2.65, tail 1.95-2.10.

Distribution. - Eastern United States and southem Canada, west to Manitoba and the Plains, accidentally to Cheyenne; sontl in winter to the Bahamas, eastern Mexico, Central America, and Panama.

Nest. - In small trees or undergrowth near clearings, loosely woven of stems, grasses, and plant fibers, lined with hairs. Eggs: usually 4, white or creamy, spotted with reddish brown and lilac, thickest aromd the larger end.

661. Dendroica striata (Forst.). Black-Poll Warbler.

Idult male in spring and summer. - Crown lblack. rest of upper parts 
olive. gray, or brown, streaked with black except sometimes on rump; wings and tail dusky, wings with two white bands and greenish edgings; imer webs of two or three outer tail feathers with subterminal white patches; under parts white. chin nswally black and sides heavily streaked with black. Adult female in spring and summer : similar, but upper parts dull olive green, streaked with black; wing bars tinged with yellow; under parts washed with pale vellowish, sides streaked with dusky. Adult male in fail and winter: upper parts olive green shading to gray on upper tail coverts; back and scapulars. sometimes crown

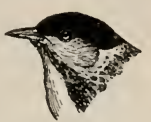

Fig. 526.

Black-poll Warbler. and rump. streaked with black; wing bars usually tinged with rellow; superciliary olive yellowish; throat, breast, and sides rellowish; sides and flanks indistinctly streaked; belly white. Young in first fall and winter: like adult fall male, but under parts rellow except on under tail coverts; upper tail coverts olive green instead of gray, back less distinctly streaked. Young. first plumage: upper parts light grayish brown, streaked with black except on rump, which is barred or mottled with black; under parts whitish, tinged with olive yellow in front, and mottled with dusky ; wings and tail as in winter birds. Male : length (skins) 4.65-5.51, wing 2.81-3.05, tail 1.91-2.13. Female : length (skins) 4.5.3-5.00, wing 2.72-2.95, tail 1.77-2.01, bill .35-.43.

Distribution. - Breeds from northern New Fngland and the Catskill Mountains west to the Pocky Mountains and north to Hudson Bay and Alaska ; migrates west to New Mexico, Colorado, and Montana. and south to northern South America. through West Indies; not recorded from Mexico or Central America; accidental in Greenland.

Nest. - On lower branches of coniferous trees, in the north often on the ground; bulky, warmly lined with feathers. Eggs: usually 4, white, creamy, or buffy, spotted or blotched, often wreathed with brown and lilac gray.

Food. - Insects.

The eastern black-poll, Prof. Cooke says, comes regularly, but in small numbers, west to the Rocky Mountains, occasionally being common during migrations both on the plains and at the base of the foothills. There is one breeding record for Seven Lakes, near Manitou, Colorado, at an altitude of 11,000 feet.

\section{Dendroica blackburniæ (Gmel.). Blackburnian Wak- BLER.}

Adult male in spring and summer. - Throat brillant orange vellow; rest of under parts pale rellowish; sides streaked with black; crown black with yellow or orange patch; superciliary yellow or orange; rest of upper parts black, streaked with white on back; wings with broad white patch; tail with three outer feathers white except shafts and tips. Adult female: similar,

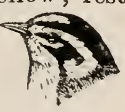

Fig. 527. but black replaced by olive brown, streaked; orange replaced by yellow ; wings and tail duller. white markings restricted. Young male in first fall and winter: like adult female, but without yellow spot on crown; yellow of throat and chest paler. Young female in first fall and winter: similar to adult female, but upper parts browner, streaks less distinct; white markings restricted; under parts buffy; throat sometimes pale buffy; streaks on sides dull brownish. Young, first plumage: upper parts brown, middle of crown lighter; back and rump indistinctly streaked; superciliary stripe and throat pale buffy; chest darker, faintly spotted; rest of 
under parts white, sides spotted; wing and tail as in fall birds, but wing bars brownish buff. Male: length (skins) 4.40-4.70, wing 2.57-2.73, tail 1.8.3-1.94, bill .37-.41. Female: length (skins) 4.25-4.60, wing 2.45-2.58, tail 1.82-1.s

Remarks. - The young may be distinguished by buffy superciliary and throat.

Distribution. - Breeds in Canadian and Transition zones of the southern British Provinces, northeastern United States, and mountain regions south; casually to Utah, western Texas, and New Mexico; migrates to the Bahamas, and through eastern Mexico to South America; accidental in Greenland.

Nest. - In evergreen trees, bulkv, composed of downy materials, especially cat-tail down, lined with fine lichens, and horsehairs. Eggs : 4 or 5, greenish white or pale bluish green, speckled or spotted chiefly on or around larger end with brown, reddish brown, or lilac gray.

Food. - Largely winged insects.

\section{Dendroica graciæ Baird. Grace Warblẹr.}

Adult male in spring and summer. - Superciliary, spot on lower lid, throat and chest bright yellow; rest of under parts white, streaked with black; upper parts including ear coverts and sides of neck ash gray; crown and back narrowly streaked with black; wings with two white bands; two outer tail feathers largely white on inner webs. Adult female in spring and summer: like male, but duller, gray of npper parts tinged with brown, black streaks indistinct, wing bars narrower, yellow paler, white of under parts duller. Adult male in fall and winter: upper parts slightly tinged with brown, streakings on back more or less concealed; under parts brownish buffy. Adult female in fall and winter: like winter male, but washed with olive brown above, wing bars brownish buff, and white of under parts strongly buffy. Young male in first fall and winter: upper parts strongly tinged with brown, black streaks on back concealed, and flanks strongly brownish buff. Young female in first fall and winter : colors duller, streaking indistinct or obsolete. Male: length (skins) 4.9.3-4.(60. wing 2.52-2.60, tail 1.55-1.97, bill .39. Female: length (skins) 4.45-4.5:, wing 2.37-2.44, tail 1.S1-1.S5, bill .39 .

Distribution. - Southwestern United States and adjacent parts of northwestern Mexico, breeding from Colorado to Chihuahua and Sonora. Mexico; casual in southern California.

Nest. - By two specimens, in pines. 50 to 60 feet from the giound, made of vegetable fibers, straws, and horsehair; also, in one case, strings, oak catkins, bud scales, wool, vegetable down, and insect webbing. Eggs : 3 or 4 , white, lightly spotted with reddish brown.

The Grace warblers are hirds of the coniferous forests of the southwestern mountains. In the Guadalupe Mountains, Texas, we met a small flock of them passing through the pines at about 8000 feet.

\section{Dendroica nigrescens (Towns.). Black-throated Grar T'ARBLER.}

Adult male in spring and summer. - Whole head, throat, and shest black, except for white streaks on side of head and along throat, and bright yellou' spot over lores; breast and belly pure white; sides streaked with black: back gray, more or less streaked with black; wings with two white bars; tail with inner webs of two outer feathers mainly white. Idult female in spring and summer: similar, but colors dnller; crown nsually gray, 
streaked with black; black of throat largely mixed with white. Adult male in fall and winter: like summer male, but gray of upper parts tinged with brown, and black markings restricted, sometimes nearly obsolete. Adult female in fall and winter: like summer male, but plunige softer and streaks on back and upper tail coverts obsolete or wanting. Young male in first fall and winter: like adult winter male, but gray of upper parts browner; crown brownish gray except on front and sides; streaks on back and upper tail coverts obsolete or concealed; black of throat with white tips to feathers; white of under parts tinged with yellowish. Ioung female in first

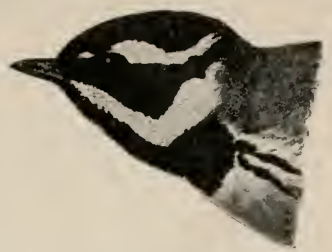

Fig. 5:8. Black-throated Gray Warbler.

fall and winter: entire upper parts brownish gray, crown bordered with dusky; white of under parts strongly tinged with brown. Male: length (skins) 4.13-4.65, wing 2.35-2.62, tail 1.92-2.17, bill .32-.3ऽ. Female: length (skins) 4.21-4.80, wing 2.13-2.47, tail 1.55-2.01, bill .33-.38.

Remarks. - The yellow spot over lores is diagnostic.

Distribution. - Breeds in Transition and Upper Sonoran zones from British Columbia to Lower California and sonthern Arizona, and from Colorado to the Pacific coast; migrates to southern Mexico.

Nest. - Low down in dense thickets of scrub oak, or high up in pines, compact, cup-shaped, like that of $D$. cestiva, made of gray plant fibers, lined with feathers. Eggs: 3 or 4, white, tinged with pink or cream, spotted on or around larger end with reddish brown and lilac gray, usually mixed with a few darker specks.

Food. - Frequently green caterpillars.

The quiet little black-throated gray warbler is a restful contrast to the whirligig of perpetual motion, the omnipresent Audubon warbler of the Sierra Nevada. It seems to be especially a bird of Transition low growth, such as scrub oaks, piñons, junipers, and manzanitas.

Along the North Fork of the Yuba River in the Sierra we found it singing in the bushes along the road, and in the junipers on a hillside near camp. Its song is a simple warbler lay, zee-ee-zee-ee, $z e, z e$, ze, with the quiet woodsy quality of virens and comulescens, so soothing to the ear.

666. Dendroica chrysoparia Scl. \& Salv. Golden-Chenked WARBLFR.

Adult male in spring and summer. - Upper parts and throat black, upper parts sometimes tinged with olive green; sides of head bright yellow. interrupted by narrow black streak through eye: forehead usually with vellow spot or streak: breast and belly white, sides streaked with black: wings and tail black, wings with two white bands and tail with three outer pairs of feathers with inner web largely white. Adult female in spring and summer: like summer male. but upper parts olive green.

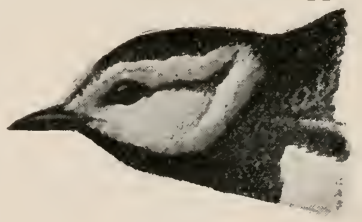

Fig. 529. indistinctly streaked; throat yellowish. black showing through; wings 
and tail duller, wing bands narrower. Adult male in fall and winter: like summer male, but feathers of black throat patch edged with white or yellowish. Ioung male in first fall and winter: like adult fall male, but upper parts streaked with olive green and black, upper tail coverts edged with olive green and gray, wings and tail duller, wing bars with black shaft streaks. Young female in first fall and winter: like adult female, but upper parts plain olive green, or indistinctly streaked; throat and chest grayish, throat tinged with rellow; sides and flanks indistinctly streaked with dusky. Young, first plumage: upper parts grayish brown or brownish gray; sides of head, throat, chest, and sides pale brownish gray; rest of under parts whitish, breast indistinctly streaked; wings and tail like adults, but wing coverts with dark mesial wedge-shaped marks. Male: length (skins) 4.61-4.84, wing 2.45-2.58, tail 2.04-2.15, bill .86.40. Female: length (skins) 4.57-4.92, wing $2.28-2.43$, tail $1.87-2.05$, bill $.38-.42$.

Remarks. - The black eye line through the bright yellow cheeks marks both sexes of the golden-cheeked warbler.

Distribution. - From western. central, and southern Texas south to Guatemala.

Nest. - Usually in red cedars, 10 to 20 feet from the ground, between upright branches; made of strips of inner cedar bark fastened with web and lined with hair and feathers. Eggs : 3 or 4, white, spotted with reddish brown, sometimes mixed with lavender.

The golden-cheeked warbler is said to be common among the junipers or 'cedar brakes,' as they are called locally, in central Texas. It is said to be always on the alert for insects, hunting over the branches and occasionally darting out for a passing insect. The song of the male is giren as tserr reasy-reasy treah.

667. Dendroica virens (Gmel.). Black-throated Green WarBLER.

Adult male in spring and summer. - Throat and chest black, sides streaked with black; rest of under parts white or yellowish white; forehead sometimes with yellow spot; sides of head bright yellow, olive streak through eye; upper parts bright olive green; back sometimes narrowly streaked with black; wings with two white bars, tail with inner webs of two outer feath-

Fig. 530. ers mainly white. Adult female in spring and summer: similar to nale. bint black of throat and chest obscured by yellowish, and whitish tips to feathers. Young male in first fall and winter: like adult female, but olive green of upper parts and yellow of sides of head brighter, and under parts yellower. Male: length (skins) 4.38-4.72, wing $2.40-2.52$, tail $1.77-1.98$, bill .8.5-.89. Female : length (skins) 4.10-4.5:, wing 2.282.40, tail 1.7.-1.5.), bill .:.5-.4:).

Remarks. - The bright olive green npper parts and whitish belly distimguish virens in all plumages.

I) istribution. - Breeds in 'Transition and Canadian zones from Hudson Bay to northern Illinois and ('omecticnt, and along the Alleghanies south to South Carolina: migrates to Cuba and through western Texas and Mexico to Central America and Panama.

Nest. - In coniferous trees, usually at considerable height, made of strips of bark. plant stems. leaves, twigs, and feathers, lined with hair and plant down. Eggs : nsully 4 , white or creamy, spotted with reddish brewn and lilac gray, mixed with a few darker specks.

Food. - Largely leaf worms, spiders, beetles, and flies. 
668. Dendroica townsendi (Towns.). Townsend Warblek.

Adult male in spring and summer. - Head and throat black, except for bright yellow superciliary and malar streak bordering throat; breast bright yellow fading to white on middle of belly ; sides streaked with black; back bright olive green, with black arrow-point streaks; wings and tail blackish, wing with two white bars, tail with inner webs of three lateral feathers white at ends. Adult female in spring and summer: like winter male, but black streaking of upper parts and sides restricted or obsolete;

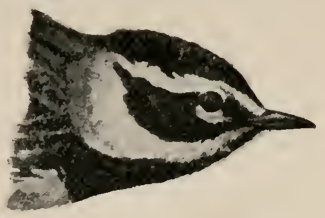

Fig. 531. crown sometimes blackish; throat of ten blotched with black. Adult male in fall and winter: like summer male, but black obseured; erown and hind neck with olive green edges to feathers; cheek patch with olive green tips to feathers; throat lemon yellow; chest and sides spotted with black. Adult female in fall and winter: like summer female, but upper parts slightly brownish, streaks indistinct; sides and flanks brownish. Young male in first fall and winter: like adult winter male. but streaks on crown and back obsolete, and yellow of throat paler. Young female in first fall and winter: like adult fall female, but yellow paler, and markings less distinct. Male: length (skins) 4.21-4.80, wing 2.56-2.7.2, tail 1.89-2.01, bill .32-.35. Female: length (skins) $4.25-4.92$, wing $2.48-2.60$, tail $1.93-$ 1.97 , bill $.32-.39$.

Remarks. - The wide band of black or olive on the sides of the head, green back and bright yellow breast, are enough to distinguish townsendi in any plumage.

Distribution. - Breeds in Transition and Boreal zones in western North America north to Sitka and east to Oregon and Idaho; migrates to Colorado, western 'Texas, and south to Guatemala; accidental in Pennsylvania.

Nest. - Attributed to tounsendi by Bendire, in willows, about 4 feet from the ground, made of rotten plant fibers and roots, lined with rootlets, hair, and plant down. Eggs: 3, pinkish white, spotted mainly about the larger end with brown, lavender, and dark amber.

The Townsend warbler is a difficult bird to study, as it affects the tops of lofty firs and spruces, hurrying from one to the other in what may well appear unseemly haste to the observer below.

Dr. Merrill ascribes to it a virens-like drawled $d e e^{\prime}-d e e^{\prime}-d e e^{\prime}-d \breve{e}$ dĕ.

\section{Dendroica occidentalis (Towns.). Hermit Warkler.}

Adult male in spring and summer. - Top and sides of head bright yellou, crown spotted with black, occiput usually mainly or wholly black; throat black; rest of under parts white, sometimes streaked on sides; hind neck streaked black and olive green; rest of upper parts gray, tinged with olive green and streaked with black; wings and tail black, wings crossed by two white bands; tail with two outer pairs of feathers largely white. Adult female in spring and summer: like winter male, but forehead and crown largely vellow ; streaks on back restricted ; body less brownish; throat and chest often with

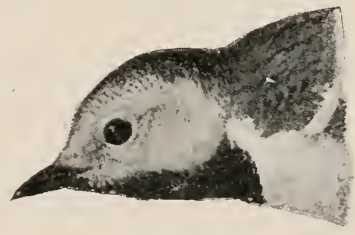

Fig. 53:. 
dusky patch. Adult male in fall and winter: like summer male, but yellow of crown and occiput obscured by olive tips to feathers, black streaks of back obscured by grayish edges to feathers, and black throat patch with whitish tips. Adult female in fall and winter: upper parts plain grayish olive, crown with traces of yellow; under parts brownish white, throat and chest with feathers dusky below the surface. Young male in first fall and winter: like adnlt fall male, but crown olive green, back more olive, streaking concealed or obsolete; sides of head paler yellow washed with olive; throat and ehest whitish or yellowish, feathers black under the surface; rest of under parts soiled white; sides and flanks tinged with olive brown. Male: length (skins) 4.41-4.80, wing 2.48-2.72, tail 1.93-2.05, bill $.37-.43$. Female: length (skins) 4.37-4.72, wing 2.44 z.4S, tail 1.83-2.01, bill .35-.39.

Remarks. - The adult males of this group of warblers may be distinguished by the color pattern of the side of the head. In the hermit it is plain yellow; in the black-throated green, crossed by an olive eye streak: in the yellow-cheeked, by a narrow black streak; and in the Townsend by a wide black band between superciliary and malar streaks.

Distribution. - Breeds in high mountains from British Columbia to California, and from the Pacific coast district of the United States to the Rocky Mountains; migrates to Lower California, Mexico, and Guatemala.

Nest. - In coniferous trees, made of weed stems and pine needles, bound by cobwebs and woolly materials, and lined with strips of cedar bark. Eggs : duli white or grayish, spotted or blotched with lilac gray or browns, chiefly around larger end.

"The hermit warbler is a frequenter of the conifers, although it feeds in the bushes and black oaks in common with other species. Its song is different from that of any other Sierra warbler, and seems well represented by the words zeegle-zeegle-zeegle-zeel, which I borrow from Mr. Bowles, of Waldo, Oregon. At close range the song of the hermit warbler appears weak rather than otherwise, yet at Fyffe I was impressed with its penetration. The bird will often mount to the higher branches of the conifers by successive hops, much after the manner of the blue-fronted jay." (Barlow.)

\section{Dendroica palmarum (Gmel.). Palm IVarbler.}

Adults in summer. - Crown chestnut, bordered by yellow superciliary; back olive or brown, narrowly streaked with darker and beconing olive green on rump and upper tail coverts; two outer tail feathers witl large terminal spots of white; throat. breast, and under tail coverts light yellow ; chest, and sometimes sides of throat, more or less streaked; belly whitish, more or less mixed with yellowish. Adults in winter : chestnut of erown obscured or concealed; throat and chest whitish instead of yellowish. Young in first fall and winter: similar, but upper parts browner, supereiliary less distinct, and markings of under parts more suffused. Length : $4.50-5.50$, wing 2.52 , tail 2.24 .

Distribution. - Interior of North America, north to Fort Churchill, Hudson Bay, and Great Slave Lake; migrates through the Mississippi valley, wintering in the South Atlantic and Gulf states, the West Indies, and eastern Mexico; accidental at Denver, Colorado, and on the Pacific coast, California.

Nest. - On the ground, made of grass, strips of bark, and moss, lined 
with down and feathers. Egys: yellowish or creamy white, spotted chiefly around the larger end with brown and purple.

\section{GENUS SEIURUS.}

General Characters. - Bill with rictal bristles short, but evident; wings pointed, much longer than tail ; tail nearly even ; tarsus longer than middle toe and claw.

KEY TO ADULTS.

1. Crown with orange brown patch inclosed by blackish stripes.

aurocapillus, p. 423 .

$1^{\prime}$. Crown plain brown like back . notabilis, p. 423 .

674. Seiurus aurocapillus (Linn.). Oven-BIRd.

Adults. - Crown with orange brown patch bordered by two blackish stripes : rest of upper parts olive green; under parts white, streaked with blackish across breast and on sides. In winter, colors rather brighter. Young: crown without stripes, back deep brown, narrowly streaked with blackish; under parts strong buffy, with narrow lines of blackish. Male: length (skins) 5.00-5.65, wing $2.79-3.11$, tail $2.05-2.28$, bill $.4+-49$. $\mathrm{Fe}_{e-}$ male: length (skins) $4.90-5.45$, wing $2.75-3.11$, tail $1.96-$

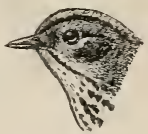

Fig. 533 2.34 , bill . $45-.47$.

Distribution. - Breeds in eastern North America northwest to Alaska and from the Arctic Circle to Virginia and southern Kansas; west to the base of the Rocky Momntains; winters in southern Florida, the West Indies. and southern Mexico to Panama.

Nest. - In dry woods imbedded in ground, made of dry leaves usually roofed over, the entrance on one side. Eggs: 3 to 6 , white or creamy, spotted with reddish brown and lilac gray.

\section{5a. Seiurus noveboracensis notabilis (Ridgw.). Grin- NELL WATER-THRUSH.}

ddults. - Upper parts sooty olive brown; superciliary dingy white; stripe through ese dark brown; under parts usually white with little if any yellow tinge; throat finely, and breast and sides broadly streaked with blackish. Young: like adults, but streaks on under parts less distinct, and feathers of upper parts tipped with light fulvons, producing a spotted appearance.

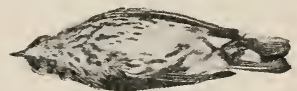

Fig. 534. Male: length (skins) 5.14-5.84, wing 2.90-3.20, tail 2.00-2.25. bill .49-.63. Female: length (skins) 5.01-5.99, wing 2.88-3.11, tail 1.92-2.28, bill .45-.56.

Distribution. - From Alaska and British America (Fort Churchill) sonth to Mexico, and from Illinois west to the Pacific coast; winters from the sonthern border of the United States south to Lower California, Mexico, and northern South America.

Nest. - On or near the ground, in wet woods or on borders of swamps; made of moss and grass, sometimes lined with fur. Eggs : 3 to 6, white, spotted with reddish brown and lilac gray.

The Grinnell water-thrush, like the other water-thrushes, is a solitary bird walking quietly orer the banks of forest brooks or wading in their shallows tilting its tail like a pipit. When its emotions are stirred, it bursts forth into a loud musical song. 


\section{GENUS GEOTHLYPIS.}

General Characters. - Bill slender, its greatest depth less than half the distance from nostril to tip; tail rounded or'graduated, or with basal two thirds hidden by coverts.

\section{KEY TO ADULT SPRING MALES.}

1. Head, neck, and chest gray.

2. Lores black; a distinct white spot on each eyelid. Western.

2'. Lores not black; a continuous white orbital ring. Eastern.

tolmiei, p. 424. agilis, p. 424 .

1'. Head, neck, and chest mainly yellow; sides of head black.

2. Bill slender, its greatest depth much less than half its length from. nostril.

3. Larger, with wider frontal band . . . occidentalis, p. 425.

3 '. Smaller, with narrower frontal band. Pacific coast region.

arizela, p. 426.

2 '. Bill very stout, its greatest depth much more than half its length from nostril. Rio Grande Valley, Texas. . . ralphi, p. 426.

\section{Subgenus Oporornis.}

Wings pointed, longer than tail; tail nearly even, more than basal half concealed by coverts.

\section{Geothlypis agilis (Wils.). Connecticut Warbler.}

Adult male in spring and summer. - Head, neck, and chest ash gras; eye with conspicuous white ring; gray of chest sharply contrasting with yellow of under parts; sides and flanks olive green; back dark olive green. Adult female in spring and summer: similar, but top of head uniform with back; throat and breast brownish. Adult male in fall and winter: like summer niale, but gray of forehead and crown tinged with browu. and feathers of throat and chest tipped with paler. Young male in first fall and winter: like adult female. but crown brownish olive, and chest darker, more olivaceous. Young female in first fall and winter: like young male, but smaller, and with throat and chest more strongly tinged with brownish buffy. Male: length (skins) 5.00-5.42, wing 2.79-2.97, tail 1.84-2.08, bill $.45-.49$. Female: length (skins) 4.80-5.81, wing 2.65-2.83, tail 1.84-1.94, bill $.46-.47$.

Distribution. - Eastern North America, breeding in Manitoba and Ontario; migrating to northern South America; accidental in Colorado.

Nest. - On ground in swampy woods; very compact. Eggs : 4, white or creamy, spotted with lilac gray and shades of brown.

\section{Subgenus Geothlypis.}

Wings short and much rounded; tail rounded.

\section{Geothlypis tolmiei (Towns.). Macgillivray Warbler.}

Adult male in spring and summer. - Head, throat, and breast slate gray; throat feathers edged with ash; rest of under parts yellow; lores deep black; eyelids with distinct white spots; back olive green, sometimes tinged with gray. Adult female in spring and summer: like adult male, but crown, hind neck, and sides of head and neck monse gray, fading to pale grayish or grayish white on throat and breast. Adult male in fall 
and winter: like summer male, but feathers of crown and hind neck tipped with brown and light edges of feathers on throat and chest broader, sometimes almost concealing black centers. Adult female in fall and uinter: like summer female, but plumage softer. and sides of throat and chest more grayish. Young female in first autumn : like fall adult female. but crown and hind neck like back instead of gray, throat and chest yellowish instead of grayish; marks on eyelids yellowish, and streak over lores pale yellow. Male: length (skins) $4.67-5.44$. wing $2.34-2.56$, tail $2.08-2.48$, bill $.43-.46$. Female: length (skins) 4.63-5.04, wing 2.152.36 , tail $1.91-2.28$. bill .4.2-.48.

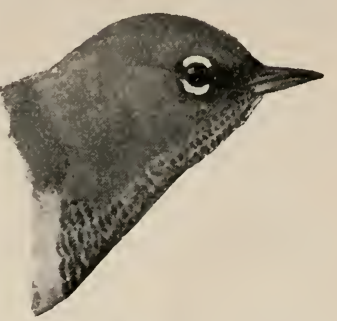

Fig. 535. Macgillivray Warbler.

Distribution. - Breeds in British Columbia and western United States, from the eastern foothills of the Rocky Mountains to the Pacific coast ranges; winters in Lower California and Mexico, and from Central America to Colombia.

Nest. - Near ground in clumps of weeds or bushes, of ten in open places in mountains, made of dried grasses lined with finer grass, and sometimes horsehair. Eggs : 3, white or buffy, speckled on larger end with dark brown and lilac gray, with a few pen lines and rusty stains.

The Macgillivray warbler is one of the commonest of western warblers, frequenting chaparral and underbrush especially near water, from the lower levels to the high mountains, and the appearance of a little gray head peering out shyly from the bushes becomes a pleasantly familiar mountain sight.

\section{1a. Geothlypis trichas occidentalis Brewst. Westerx YELLOW-THROAT. ${ }^{1}$}

Adult male. - Forehead and sides of head black, bordered above with white, sometimes tinged with sellow; rest of upper parts plain olive green; under parts deep sellow. In winter. washed with brown. Adult female: without black, ashy, or white; upper parts olive brown, often tinged with reddish brown on crown, greenish on tail; under parts pale vellowish or vellowish white. Young male in first winter: like adult, but black mask less distinct. Male: length (skins) 4.5.3-5.00, wing $2.17-2.36$, tail $2.01-$ 2.22, bill .43-.47. Female : length (skins) $4.33-4.76$, wing $2.05-2.15$, tail $1.93-2.09$, bill .41-.43.

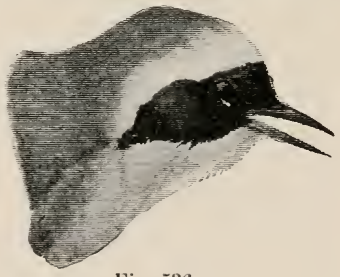

Fig. 536.

1 Geothlypis trichas scirpicola Grinnell. Tule Yellow-throat.

Like occidentalis, but brighter colored and larger, with longer tail.

Distribution. - Resident in fresh water tule beds along coast of southern California. (The Condor, iii. 65.)

Geothlypis trichas sinuosa Grimell. Salt Marsh Yellow-throat.

Like occidentalis, but smaller, and back and sides darker.

Distribution. - Resident about salt marshes of San Francisco Bay and vicinity. (The Condor, iii. 65.) 
Distribution. - Breeds from British Columbia to Arizona, and from the Mississippi Valley to the Sierra Nevada and Cascades; migrates to Central America.

Nest. - On or near the ground, supported by weed or sedge stalks, deeply cup shaped, usually with a thick foundation of grass or leaves, sometimes lined with hair. Egys : often 4, white, finely speckled on larger end with dark brown and black, sometimes with a few larger spots or lines.

The yellow-throats are found in damp brushy thickets, swampy patches of rank vegetable growths, and tule marshes. As they clamber over the stalks the little yellow birds stop to raise their odd black-masked heads, and sing out a loud penetrating, ringing wreechity, wreech-ity, wreech-ity, wreech-ity, which-varies greatly with the individual. In addition to this ordinary song they have an impassioned love-song which they give in air with something of the excited posturing of the chat.

The songs of the males are as conspicuous as their coats, and they look out from their thickets upon passers-by with mild interest, but their mates, with only the family chack and plain dull yellowish coats are timid little creatures, and if they accidentally come to the edge of their bush when you are by, slip back out of sight in a trice.

\section{1c. G. t. arizela Oberh. Pacific Yellow-throat.}

Similar to occidentalis, but smaller, and with smaller bill, shorter wing and tail, duller coloration, and white band on head narrower; yellow of under parts less orange. Male: length (skins) 4.49-4.92, wing 2.07-2.28, tail 1.94-2.24, bill .39-.43. Female: length (skins) 4.25-4.72, wing 2.002.08, tail 1.89-1.97, bill .39.

Distribution. - Pacific coast region from British Columbia to northern Lower California. east to the Cascades and the Sierra Nevada; south in winter through Lower California and westeru Mexico.

\section{Subgenus Chamæthlypis.}

682.1. Geothlypis poliocephala ralphi Ridgw. Rio Gravde YELLOW-THROAT.

Adult male. - Lores black; top of head bluish gray; rest of upper parts olive green, tinged with gray, especially on tail ; under parts yellow, becoming buffy whitish on belly and anal region. Male: length (skins) 5.16-5.6\%. wing 2.17-2.44, tail 2.20-2.64, bill .39-.47. Female: length (skins) 5.00-5.31, wing 2.00-2.16, tail 2.17-2.36, bill .43-.47.

Distribution. - Lower Rio Grande Valley, in Texas.

\section{GENUS ICTERIA.}

683a. Icteria virens longicauda (Lawr.). Long-talled Chat. Bill curved. stont, higher than broad at nostrils, without noteh or bris-

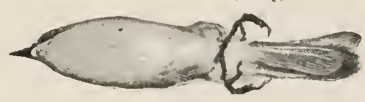

Fig. 53i. tles; wings much ronnded; tail long, feet stout; ontside of tarsus almost without scales; tarsus decidedly longer than middle toe with claw, its seutella indistinct or obsolete on onter side. Adults: throat and breast vivid yellow; belly white; upper parts olive gray; superciliary, 
orbital ring, and malar stripe, white; lores, and line under eye black. Young: upper parts olive; lores gray instead of black; throat whitish, chest, sides, and flanks grayish; rest of under parts white. Male: length (skins) $6.26-7.28$, wing $2.95-3.31$, tail $3.01-3.39$, bill $.530-.59$. Female : length (skins) 6.38-6.97, wing $2.87-3.15$, tail 2.83-3.2:3, bill $.53-.59$.

Distribution. - Transition and Upper Sonoran zones, from British Columbia south to Lower Califoruia and northern Mexico, and from the Plains to the Pacific coast; breeds sonth to Valley of Mexico; United States birds mainly migrate to southern Mexico.

Nest. - In briery thickets, made largely of dry leaves, strips of grapevine bark, and grasses, lined with finer grasses. Eggs: 3 to 5, white or pinkish, spotted with gray and shades of brown.

Food. - Beetles and other insects, and berries.

The chat's coming in the spring is like the arrival of a brass band. In Farmington, Utah, oue May, when he appeared he fairly pervaded the village - that is, his voice did - his yellow-fronted person was in sight just once, to my best knowledge. But as you went along. the streets he fairly shouted in your ears - from inside dark thickets behind fences. And if you appeared in front of the bush on which he was singing, he would at once raise his voice from the next bush behind! And so he would lead you through bush and briar, skulking out of sight and crying as if consciously deriding your awkward attempts at intrusion, $s_{0}$ ! ho! tut-tut-tut-tut-tut-tut-tut! One of his favorite amusements is to give a whistle, as if he were calling a dog and meant to be obeyed. When not whistling, or scolding like an oriole, calling like a cuckoo, or piping like a shrill-voiced rock squirrel, he will bark like a dog.

The chat is not only moved to mock his neighbors, but performs in most remarkable manner in his own proper person - in air. Mr. Torrey gives a good description of chat antics. "I caught the fellow," he says, "in the midst of a brilliant display of his clownish tricks, ridiculous, indescribable. At a little distance it is hard to believe that he can be a bird, that dancing, shapeless thing, balancing itself in the air with dangling legs, and prancing, swaying motions."

\section{GENUS WILSONIA.}

General Characters. - Bill not more than half as long as head, broad and flattened at base ; rictal bristles distinct; wings pointed, longer than tail; tarsus decidedly longer than middle toe with claw.

\section{KEX TO ADULT MALES.}

1. Throat with black necklace; crown gray . canadensis, p. 428.

$1^{\prime}$ ' Throat without black necklace; crown black.

2. Upper parts brighter green, forehead often orange. Great Basin to Pacific

2'. Upper parts dul pileolata, p. 42. Rocky Monntains northeast . pusilla, p. 428. 


\section{Wilsonia pusilla (Wils.). WILSON WARBLER.}

Similar to pileolata, but not so bright; wings and tail shorter, bill broader and darker colored. Male : length (skins) 4.05-4.45, wing 2.092.64 , tail 1.83-1.97, bill .2S-.35. Female: length (skins) $4.10-$ 4.45 , wing $2.05-2.17$, tail 1.81-1.95, bill .31-.35.

Distribution. - Breeds from the Hudson Bay region and Lake

Fig. 538. Athabasca south to Maine and higher Rocky Mountains; migrates to eastern Mexico and Central America.

Nest. - Imbedded in ground in swampr woods, made of leaves and grasses, lined with finer grasses and hairs. Eggs : 4 or 5, white or creamy. speckled with reddish brown and purplish.

Food. - Largely winged insects.

\section{5a. W. p. pileolata (Pall.). Pileolated Warbler. ${ }^{1}$}

Adult male. - Crown glossy blue black; back bright yellowish olive green; under parts vivid yellow; forehead often orange yellow. Adult female: similar, but crown patch often wanting. Young: like adult male, but black of crown nearly obscured by olive wash. Male: length (skins) 4.13-4.49, wing 2.17-2.36, tail 1.55-2.05, bill .28-.35. Female: length (skins) 4.13-4.57, wing 2.15-2.24, tail 1.87-1.97, bill .30-.35.

Distribution. - Breeds from the Great Basin to the Pacific, and north to Alaska, migrating through western Texas to Costa Rica.

Nest. - In willow thickets and among blackberry vines, on or near the ground, made of willow leaves, weed stems, and grasses. Eggs : 2 to 4, creamy, spotted with reddish and lilac over entire surface or around larger end.

Seen in migration when the dainty pileolated warbler has plenty of leisure, his airy ways are peculiarly charming. He usually hunts in low bushes, and as he suddenly appears through a chink in the dull chaparral wall the intense brilliant yellow of the little beauty set off by his shining jet black crown gives you a thrill of surprise and delight.

He is winningly trustful and will come close to you and with wings hanging turn his head and look up at you from under his jaunty cap, then whip along with a jerk of his tail. As he goes he stops to run up a twig, leans down to peck under a leaf, flutters under a spray like a hummingbird, and then flies off singing his happy song.

On his breeding grounds in the mountain meadows when feeding young he has much to occupy his mind, and flies back and forth through his willow thicket in a preoccupied way, giving his flat chip and inspecting you with an anxious parental air in passing.

\section{Wilsonia canadensis (Linn.). Canadian Warkler.}

Adult male. - Under parts yellow ; throat bordered by black lines, and

1 Wilsonia pusilla chryseola Ridgway. Golnen Pileolated W arbler.

Like pileolata, but slightly smaller and much brighter colored.

Distribution. - Pacific coast district of United States and British Columbia, breeding from British Columbia to southern California; migrating to eastern Oregon, Arizona, Lower California, and northern Mexico. (Birds of North and Middle America, ii. 714.) 


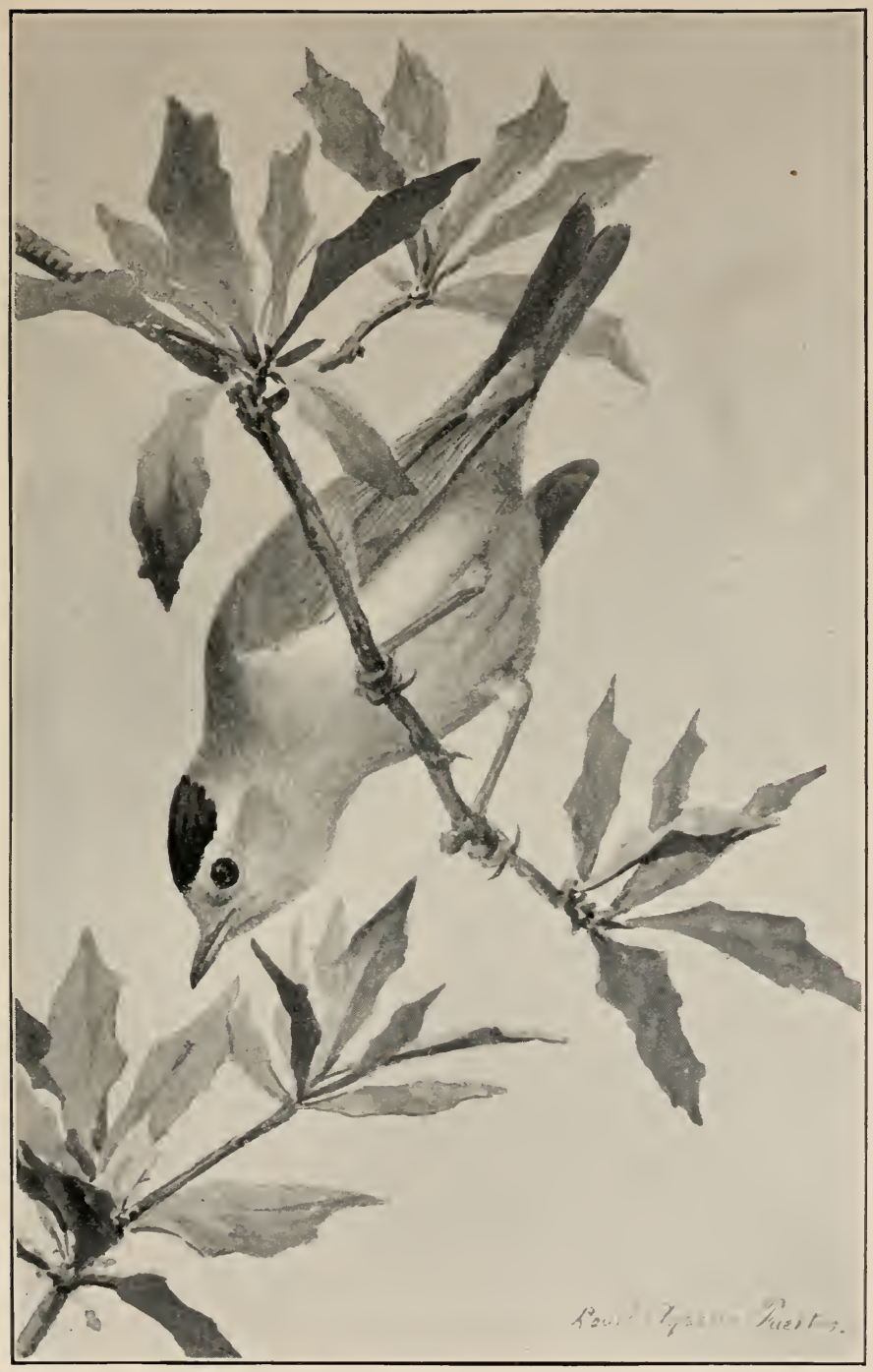

PILEOLATED WARBLER 

chest with necklace of black streaks; orbital ring white or yellowish; crown black, feathers edged with gray; rest of upper parts gray. Adult female and young in fall: similar, but black replaced by gray tinged with olive. Young female: ehest markings sonetimes obsolete. Young, first plumage: upper parts brownish, gray below the surface; wings with two buffy bars; sides of head, throat, and chest buffy brown; rest of under parts yellow. Male: length (skins) 4.76-5.1\%, wing 2.54-2.64, tail 2.15-2.26, bill .40-.44. Female: length Cauadian War(skius) $4.57-4.91$, wing $2.38-2.54$, tail $2.00-2.10$, bill $.39-.45$.

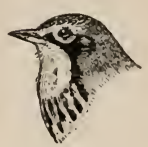

Fig. 539 .

Distribution. - Breeds in Canadian zone of northeastern North America, from Lake Winnipeg, Hudson Bay, southern Labrador, and Newfoundland south to southern New England, W' iscousin, and the Alleghanies; casnally to Colorado : winters from Mexico south to South America.

Nest. - In clumps of weeds or tussocks of grass in swampy woods, made of leaves and lined with pine needles, rootlets, and horsehair. Eggs: :3 to 5 , white or buffy white, spotted around larger end with reddish brown and lilac, usually mixed with a few black specks or pen lines.

\section{GENUS SETOPHAGA.}

General Characters. - Bill about half as long as head, much depressed, broad at base, sharply ridged for basal half or more, straight, decurved at tip ; rictal bristles reaching beyond nostrils; wings pointed. tail loug and fan-shaped. witl broad flat feathers widening at ends; feet slender; tarsus with scutella distinet.

\section{KEY TO ADULT MALES.}

1. Under parts mainly white, with orange patches . . ruticilla, p. 429. $1^{\prime}$. Under parts mainly dark rose red. picta, p. 430 .

\section{Setophaga ruticilla (Linn.). Americax Redstart.}

Adult male. - Black with bluish gloss, except for white belly and under tail coverts, and salmon or orange patches on sides of breast, wings, and tail. Adult female: black of male replaced by grayish olive, and orange by rellow. Immature male: similar to female, but smaller, browner, and color patches deeper; after first winter plumage interspersed with black feathers. Immature female: like adult female, but gras more brownish. throat and chest tinged with brownish buff; rellow of breast less distinet, and that on wings partly or wholly concealed.

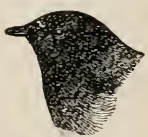

Fig. 540 . Young, first plumage: upper parts grayish brown; under parts gravish white. pale gray on chest; breast witlout yellow; wings and tail like older birds, but with two whitish or yellowish bands. Male: length (skins) 4.61-5.00, wing 2.40-2.64, tail 2.05-2.28, bill .28-.35. Female: length (skins) 4.41-4.76, wing 2.28-2.60, tail 1.93-2.28, bill .31-.35.

Distribution. - Breeds from British Columbia and Fort Simpson to the Gulf of Mexico and from the Atlantic west regularly to the Great Basin; casually to California, Oregon. Arizona. and Lower California; winters in the ITest Indies, and from southern Mexico to northern South America.

Nest. - Cup-shaped, compact, made largely of plant fibers and strips of bark and web, 7 to 30 feet from the ground. Eggs: 3 to 5, white. greenish or grarish, spotted chiefly around larger end with brown and lilac.

Food. - Insects. 
The American redstart is a bird of the open deciduous woods, building usually in saplings. It goes about its work with drooping wings, its long fan-tail opening and shutting to show its bright color patches as it flashes about tumbling through the air after insects. Of its two characteristic songs the longer one is hurried and accented at the end.

\section{Setophaga picta Swains. Painted Redstart.}

Adults. - Black, except for red belly, white band on wing and white on outer tail feathers. Young, first plumage: upper parts sooty black; wings and tail like adults, but white wing patch tipped with buff; under parts sooty gray, becoming white on middle of belly; breast spotted or streaked with blackish. Male: length (skins) 4.St-5.04, wing 2.6S-2.95, tail 2.402.68, bill .31-.35. Female: length (skins) 4.92-5.32, wing 2.64-2.76, tail 2.36-2.54, bill .33-.35.

Distribution. - From mountains of New Mexico and Arizona south to Mexico, Vera Cruz, Hidalgo, and Oaxaca.

Nest. - In cavities in banks or among rocks, near water; made of vegetable fibers and leaves, and lined with grass and hair. Eggs: 3 to 4 , white, finely speckled with reddish brown and lilac.

The red, white, and black painted redstarts frequent the evergreen oaks and the pines and alders of the mountain ranges of southern Arizona. They are usually found near springs and waterfalls. In motions they are typical redstarts, Mr. Henshaw says, passing rapidly along the branches of trees with half-shut wings and outspread tail, now and then darting after a passing fly. Mr. H. O. Howard says they may be seen hopping about on mossy banks and stumps of large trees.

\section{GENUS CARDELLINA.}

\section{Cardellina rubrifrons (Giraud). Red-Faced Warbler.}

Bill not more than half as long as head, high at base, curved; rictal bristles stiff; wings long; tail shorter than wings, nearly even; feet small; tarsus longer than middle toe and claw.

Adults. - Throat, forehead, and stripe back to nape bright red; crown black; nuchal patch and rump white; rest of upper parts grar; under parts soiled whitish. Young in first fall and winter: duller, black replaced by brown; red paler ; white of under parts and nuchal patch tinged with buffy or salmon. Male: length (skins) 4.65-5.32, wing 2.58-2.78, tail $2.24-2.40$, bill .31-.35. Female : length (skins) 4.45-4.96, wing 2.48-2.76, tail $2.18-2.40$, bill $.29-.35$.

Distribution. - From sonthern Arizona and New Mexico south to Gnatemala.

Nest. - On the ground, under a vine or bunch of grass, or near a fallen log; made largely of fine straws, rootlets, strips of bark, leaves, and hair. Eggs: 4, white, spotted with reddish brown over the entire shell, most thickly around the larger end.

The red-faced warbler is found on the mountains in the southern parts of Arizona and New Mexico among the pines and spruces. Its habits, Mr. Henshaw says, combine those of the chickadees, red- 
starts, and other warblers. Its favorite hunting places are the tips of spruce branches, over which it passes with a quick motion and a peculiar and constant sidewise jerk of the tail. Mr. Scott says it has a clear whistling song.

\section{FAMILY MOTACILLID㘴: WAGTAILS.}

\section{GENUS ANTHUS.}

General Characters. - Bill shorter than head, about as wide as high at base, compressed, acute, and notehed at tip; wings longer than tail.

\section{KEY TO ADULTS.}

1. Hind claw decidedly longer than toe $1^{\prime}$. Hind claw about equal to toe.

spragueii, p. 432. pensilvanicus, p. 431 .

\section{Subgenus Anihus.}

697. Anthus pensilvanicus (Lath.). Pipit.

Hind claw about equal to toe. Adults in summer: upper parts gray-

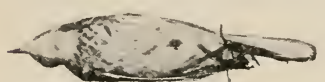

Fig. $5+1$ ish brown, indistinctly streaked; wing blackish brown, with two buffy wing bars and light edgings; tail blackish, inner web of outside feather largely white, second feather tipped with white; superciliar? stripe and under parts light buffy. chin lighter, chest streaked with duskr.

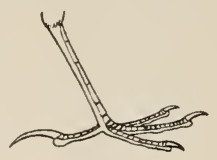

Fig. 5t2. Adults in winter: browner above, lighter below, streaks on breast usually broader. Young: similar, but washed with brown. and more distinctly streaked. Length : $6-7$, wing 3.20-3.50, tail 2.65-2.55.

Distribution. - North America at large, breeding in the higher parts of the Rocky Mountains, Cascades, and subarctic districts, wintering in the Gulf states, Nevada, California, Mexico. and Central America.

Vest. - On ground, bulky and rather compact. made of dried mosses and grasses, lined with hair and feathers. Eggs: 4 to 6 , nearly uniform brown from dense spotting.

Food. - Small shells, crustaceans, insects, and small seeds.

Flocks of these strange little northerners with demure garb, plaintive roices, and the ways of wanderers are often met abroad in the land in spring and fall. In some parts of the drs country they are seen more generally in the seasons of heavy rainfall. They may be met in a ploughed rineyard, on a vacant city lot, or in the open country. If startled they rise from the ground showing their white tail feathers, with a wild cleep fly for a short distance, wheel, and return to their feeding ground. The earth usually matches their tints so well that it is difficult to see them. though their wagging heads and tilting tails help to catch the eye.

In Colorado the pipits nest above timberline at an altitude of from 11,000 to 13,000 feet. and in August many of the birds wander to the 
tops of the peaks at 14,000 feet. In the breeding season the males have a flight song similar to that of the oven-bird, often ascending a hundred feet singing as they go, and afterwards dropping almost straight to the ground.

\section{Subgenus Neocorys.}

\section{Anthus spragueii (Aud.). Sprague Pipit.}

Hind toe and claw longer than tarsus. Adults in summer: upper parts

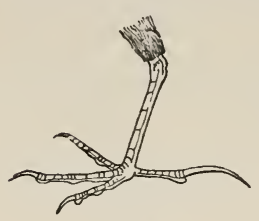

Fig. 543 . broadly streaked with blackish brown and grayish buff; wings dusky, with pale edgings; two outer pairs of tail feathers chiefly white; outside pair sometimes wholly white; under parts dull buffy white, more buffy across chest, where narrowly streaked with dusky. Adults in winter: browner above. more buffy below, and chest streaks broader. Young: upper parts brownish buff, broadly streaked with black; feathers of back and scapulars tipped with buffy or whitish; chin, throat, and sides of neck whitish, lower throat and sides of neck streaked with dusky; rest of under parts light buff; chest and sides of breast streaked with black. Length : $5.75-7.00$, wing 3.20-3.40, tail 2.35-2.60.

Distribution. - Breeds on the interior plains of North America from the Saskatchewan to Nebraska, and from the Red River west, probably, to the Rocky Mountains ; winters in Louisiana, Texas, and northern Mexico ; accidental in South Carolina.

Nest. - Like that of $A$. pensilvanicus, but eggs pale purplish buffy or buffy white, thickly spotted with purplish brown.

Food. - Insects, and seeds of weeds and grasses.

The habits of the Sprague pipit closely resemble those of the other pipits. In Coues's Birds of the Northeest there is an enthusiastic description of the flight song of spragueii.

\section{FAMILY CINCLID仺: DIPPERS.}

\section{GENUS CINCLUS.}

701. Cinclus mexicanus Swains. Water Otzel: Dipper.

Bill shorter than head. slender, and compressed; wing short, stiff,

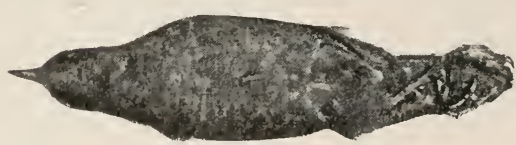

Fig. $5+4$. rounded, with ten primaries, the first spurious; tail shorter than uing, soft. of twelve broad rounded feathers almost hidden by coverts; tarsus without scales; claws strongly curved. Adults in summer: whole body nearly uniform slate gray. a trifle lighter below; head and neck faintly tinged with brown. Adults in winter: similar, but feathers of wings and under parts lightly tipped with white. Young: similar to winter plumage, but under parts more or less mixed with white and tinged with rusty. Length: 7.00-8.50, wing $3.40-3.81$, tail 1.90-2.12. bill .6()-.70.

Distribution. - Mountainous parts of central and western North America 
from the Yukon to Guatemala; east, in the United States, to the eastern base of the Rocky Mountains; mainly resident throughout its range.

Nest. - Among rocks, near ruming water, often behind a cascade; a bulky oven-shaped structure open on the side, made of green mosses. Eggs : 3 to 5, white.

To all his friends, the name water ouzel calls up pictures of foaming cascaded streams in the heart of the grand old western mountains. What a quickening touch of life and good cheer the songster gives to the lonely canyons and forests! And how fascinating it is to watch him as he pokes about in wren-like fashion under the banks of streams, disappearing in dark grottoes and behind miniature waterfalls or stepping off into the pools, where he sinks under water as easily as a grebe!

When resting against the background of dark rocks he would be almost invisible did he not keep up a persistent winking, for at each wink you get a flash from his white nictitating membrane. He also has a trick of bobbing, winter wren style, that tells the tale of his whereabouts.

In a southern California canyon we once found a typical ouzel nest on a ledge of rock opposite a waterfall whose spray doubtless kept the moss of the nest fresh. While we were admiring the nest, one of the old birds appeared and ran up the slippery face of the wet rock beside the waterfall with easy unconcern.

The ouzels do not leave their breeding grounds when their family cares are over, but stay in the mountains until the streams are frozen, and Mr. Batchelder has seen one swim downstream under the ice. In the Wasatch in December, one crisp, clear morning when the still pools were frozen over and there was ice along the edges of the streams and iced spray on the bushes, Mr. Bailey's ear was caught by a beautiful song, and following upstream he discovered an ouzel sitting on a cake of ice in the bright sun singing as gayly as a bobolink in June.

(See Muir's Mountains of California and Olive Thorne Miller's Bird-Lover in the West.)

\section{FAMILY TROGLODYTIDA: WRENS, THRASHERS, ETC.}

KEY TO GENERA.

1. Rictal bristles conspicuous.

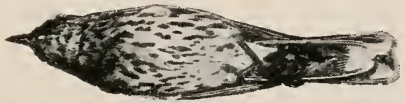

Fig. 545 .

2. Tail shorter than wing

2 . Tail longer than wing.

Oroscoptes, p. 435. 
3. Exposed culmen equal to or longer than middle toe withont claw. Toxostoma, p. 437.

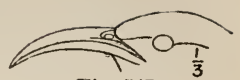

Fig. 547 .

Fig. 546 .

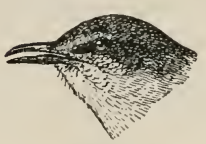

:3. Exposed culmen decidedly shorter than middle toe withont claw.

4 . Plumage light gray, marked with white.

Mimus, p. 435.

Fig. $5+8$.

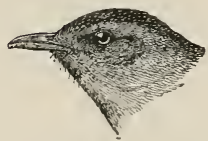

4. Plumage slaty, not marked with white.

Galeoscoptes, p. 4:37.

Fig. 549 .

1'. Rictal bristles not conspicuous.

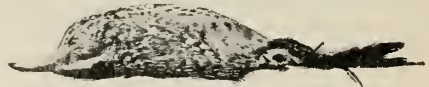

Fig. 550.

2. Length $7-8$

$2^{\prime}$. Length $3.50-(i .50$.

3. 'Tail equal to or longer than wing' tail mainly blackish.

Thryomanes, p. 446.

3'. 'Tail shorter than wing; tail not mainly blackish.

4. Ontside toe much longer than immer.

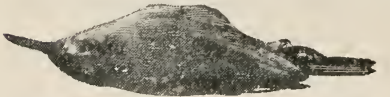

5. Exposed culmen longer than tarsus ; largely rusty brown.

Catherpes, p. 444.

Fig. 551.

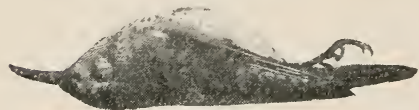

5 '. Exposed culmen shorter than tarsus; largely grarish brown.

Salpinctes, p. $44: 3$.

Fig. $55 \%$.

4'. Ontside toe not markedly longer than inner.

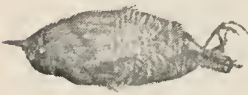

Fig. 553 .

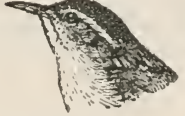

Fig. 555 .

5. Tail less than three fourths as long as wing.

Olbiorchilus, p. 449.

5'. Tail more than three fourths as long as wing.

6. Head without white superciliary. Troglodytes p. 448.

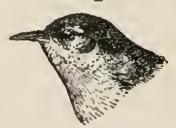

Fig. 554 .

6 . Head with white superciliary.

7. Back streaked with white.

Cistothorus, p. 449. 


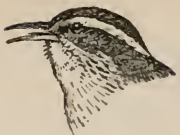

$7^{\prime}$. Back rusty brown.

Thry othorus, p. 446.

Fig. 556 .

\section{GENUS OROSCOPTES.}

702. Oroscoptes montanus (Touns.). Sage Thrasher.

Bill much shorter than head; rictal bristles well developed; wings and tail of equal length; tail nearly even. Adults : upper parts dull grayish brown, indistinctly streaked; wings with two narrow white bars; tail with iminer web of 2 to 4 outer feathers tipped with white; under parts whitish,

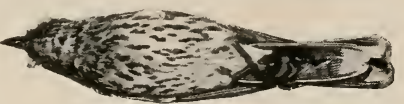

Fig. 557 .

buffy on flanks and under tail coverts; breast and sides heavily marked with black spots. Young: like adults, but upper parts indistinctly streaked with darker, and streaks on under parts less sharply defined. Length : S9 , wing $3.95-4.19$, tail 3.20-3.35, bill .60-.65.

Distribution. - Sage plains from Montana south to northern Mexico and Lower California, and from western Nebraska to the Caseades and the Sierra Nevada.

Nest. - Bulky, composed largely of coarse plant stems, dry sage shreds, and sage bark, lined with fine rootlets, and sometimes hair; placed usually in sagebrush. Eggs: $: 3$ to $\tilde{5}$, rich greenish blue, spotted with clove brown.

The sage thrasher, and the Brewer, Bell, and lark sparrows, are among the commonest birds of the sagebrush country, and the sage thrasher's big gray body with its white tail corners shows from a distance as he disappears with long undulating flight over the face of the sage plain.

In the land of telegraph poles he often mounts one to sing, but his commonest perch is the top of a tall sage bush, and as his song is poured out even long after dark and sometimes by moonlight, with scarcely less richness than the true thrasher's, you are glad he lives in the deserts. In winter he leaves the sagebrush and wanders south over the lower valleys.

\section{GENUS MIMUS.}

\section{3a. Mimus polyglottos leucopterus (Vigors). WEsTERN MOCKINGBIRD.}

Bill much shorter than head, notched near end; rictal bristles well developed; wings rounded; tail longer than wings, rounded ; tarsus longer than middle toe and claw; seales of tarsus distinct. Adults: upper parts grayish drab; wings and tail blackish, wings with large white pateh at base of primaries, wing bars, white-tipped wing quills, and tertials with whitish edgings : under parts white, washed with clay color. Young: more brownish above; back indistinctly spotted or streaked; breast spotted. Male: wing 4.29-4.72, tail 4.53-5.32, bill .61-.75. Female: wing 4.25-4.65, tail $4.43-5.08$, bill .59-.71.

Distribution. - Southwestern United States from the Gulf of Mexico 
(Texas) to the Pacific coast, and from Indian Territory south to Oaxaca, Mexico, and over Lower California; resident in the southern and lower portions of its range; migratory in the northern and higher portions.

Nest. - Bulky, made of sticks, often thorny ones, lined with finer materials, sometimes gray moss or cotton ; placed in thick bushes, thorny trees, yuccas, hedgerows, and vines. Egys: 4, pale bluish or greenish, spotted with reddish brown.

Food. - Earthworms, insects, and berries.

The mocker almost sings with his wings. He has a pretty trick of lifting them as his song waxes, a gesture that not only serves to show off the white wing patches, but gives a charming touch of vivacity, an airy, almost sublimated fervor to his love-song. His fine frenzies often carry him quite off his feet. From his chimneytop perch he tosses himself up in the air and dances and pirouettes as he sings till he drops back, it would seem, from sheer lack of

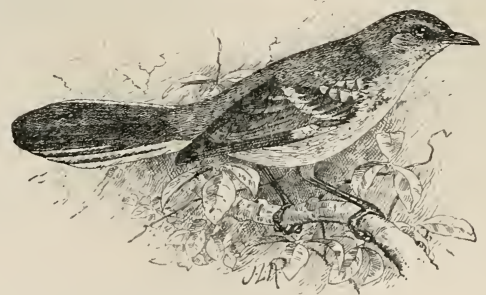

Fig. 558. Eastern Mockingbird.

breath. He sings all day, and often - if we would believe his audiences - he sings down the chimney all night, and when camping in mockerland in the full of the moon you can almost credit the contention. A mocker in one tree pipes up and that wakes his brother mockers in other trees, and when they have all done their parts every other sleepy little songster in the neighborhood - be he sparrow or wren - rouses enough to give a line of his song. The wave of song is so delightful that even the weary traveler gladly lies a wake to listen.

But in broad daylight the mocker's ebullitions are not always pleasing. In Texas the birds are so common and their mimicry so perfect, that it is positively tormenting to the ornithologist. They imitate everything from the squack of the blue jay, the varied notes of the Cassin kingbird, the shrike, and the gnatcatcher, to the shrill call of the rock squirrel. Whenever you hear a new bird and hurry through brush and briars to see it, at the end of your heated search there sits a calm mocker! As the birds are omnipresent and always singing somebody else's song, they sadly interfere with the ornithologist's serenity of spirit. 


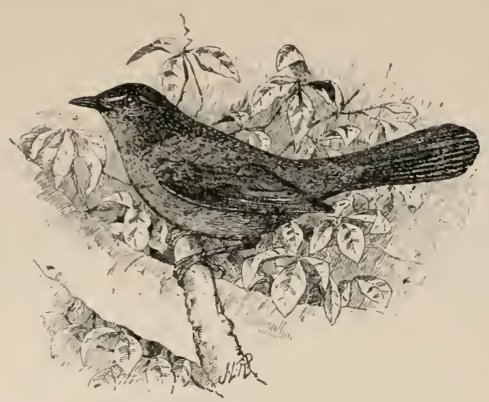

Fig. 559

\section{GENUS GALEOSCOPTES.}

\section{Galeoscoptes carolinensis (Linn.). CAтвIRd.}

Rictal bristles well developed; tail longer than wing, much rounded; seales of tarsus indistinct. Adults : dark slaty gray; crown and tail black; under tail coverts dark rufous. Young: similar, but washed with brownish. Length: 8.00-9.35, wing 3.45-3.75, tail 3.70-4.25, bill .65-.75.

Distribution. - Breeds from the Saskatchewan to the Gulf states and from the Atlantic west over the Rocky Mountains; occasional on the Pacific coast. Winters in the southem states, Cuba, and from Mexico to Panama. Resident in Bermuda.

Nest. - Largely of rootlets, placed in thickets and orchards. Eggs : ? to 5 , plain, deep bluish green.

Food. - Ants, beetles, caterpillars, grasshoppers, and other insects, small fruits and wild berries.

In Colorado the catbird breeds from the plains to about 8000 feet, quite commonly on the eastern slope of the Rocky Mountains, but rarely in the western part of the state. In Utah it plays its eastern rôle, Mr. Henshaw says, living in shrubbery on the edges of towns and even coming familiarly to the gardens.

\section{GENUS TOXOSTOMA.}

General Characters. - Bill varying from shorter than head and straight to longer than head and greatly curved; rictal bristles well developed; feet large and strong; tarsus conspicuously scaled in front; wings and tail rounded, tail decidedly the longer.

\section{KEY TO ADULTS.}

1. Under parts without dark markings.

2. Upper parts pale brown

lecontei, p. 441.

2 . Upper parts not pale brown.

3. Under tail coverts dark rufous

$3^{\prime}$. Under tail coverts buffy or tawny.

4. Throat brownish . . . . . . . redivivum, p. 440.

4 '. Throat white . . . . . . pasadenense, p. 411. 
1'. Under parts with dark markings.

2. Strikingly marked with blackish.

.. Upper parts deep rufous . . . . . . . . . rufum, p. 438.

$3^{\prime}$. Upper parts washed with golden brown . . . sennetti, p. 438.

$2^{\prime}$. Faintly marked with dusky.

3. Under mandible yellowish at base . . . . . bendirei, p. 439.

3'. Under mandible blackish at base.

4. Wings barred and tail strikingly tipped with white.

curvirostre, p. 439.

4'. Wings plain or obsoletely barred, and tail only indistinctly tipped with lighter . . . . . . . . . . . palmeri, p. 439.

\section{Subgenus Toxostoma.}

Tarsus longer than exposed culmen.

705. Toxostoma rufum (Linn.). Brown Thrasher.

Adults. - Upper parts reddish brown; wings with two white bars; under

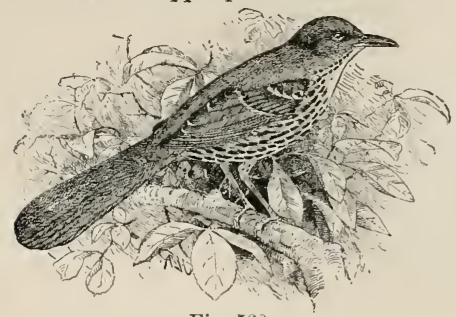

Fig. 560 . parts buffy white, spotted with brown. Young: spots on under parts thicker, blackish; rump golden brown; spotting on wing coverts fawn color. Length: $10.50-$ 12.00 , wing $4.10-4.60$, tail $5.00-$ 5.75 , exposed culmen .90-1.10.

Distribution. - Breeds from Canada to the Gulf of Mexico and from the Atlantic to the Rocky Mountains.

Nest. - In thorny trees, vines, or bushes, a coarse, bulky structure of sticks, rootlets, leaves, and weed stems, lined with rootlets and horsehair. Eggs : 3 to 5, buffy, or tinged with green, minutely spotted with reddish brown, this sometimes becoming the prevailing color.

Food. - Beetles, grasshoppers, caterpillars, bugs, and spiders; small fruits and seeds.

The eastern brown thrasher is a fairly common resident of the Colorado plains, breeding as high as $\% 500$ feet.

706. Toxostoma longirostre sennetti (Ridgw.). Sennetr THRASHER.

Upper parts golden brown, with two whitislı wing bars; under parts white,

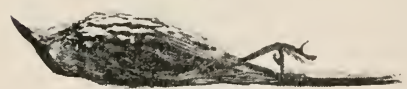

Fig. 561 . breast and sides with black wedgeshaped or tear-shaped marks; bill curved from base. Length: $10.50-$ 12.00 , wing $3.80-4.20$, tail $4.80-5.45$, bill $1.0 \%-1.2 \mathrm{~S}$.

Distribution. - Breeds in Lower Sonoran zone in southern Texas from Corpus Christi and Laredo south to northeastern Mexico.

Nest. - In bushes or thickets, made of sticks, vines, and sometimes straws, lined with rootlets. Eggs : 3 or 4, whitish to greenish, elosely dotted with reddish brown, often most heavily around larger end.

Food. - Insects and larve, and berries.

The Sennett thrasher occurs with enrivostre in southern Texas, 
but is much less common, only a few of the brown birds being seen, while the pale, clay-colored curve-bill ranks as one of the commonest brush birds.

\section{Toxostoma curvirostre (Swains.). Curve-BILled THRASHER.}

Adults. - Upper parts light brownish gray; wings with two narrow white bars; tail blackish. four pairs of outer feathers strikingly tipped with white; throat white; breast and sides thickly spotted and clouded with gray; flanks buffy. Young: similar,

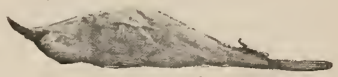

Fig. 562 . but wing coverts and rump tinged with fulvous, and markings on breast narrower and darker. Length: $10.50-11.40$, wing 4.15-4.5.5, tail 4.40-4.6.5, exposed culmen 1.10-1.30.

Distribution. - Lower Sonoran zone from New Mexico and western Texas to Oaxaca, Mexico.

Nest. - In cactus and trees, made of thorny twigs lined with a few grasses. Eggs : 3 or 4 , colored like those of palmeri.

The curve-billed thrasher is abundant and tame as you go through the thorn brush of southern Texas, especially as you approach Mexico. Its big clay-colored figure is largely in evidence, perched on the brush or flying on short wings with long tilting tail across the road. Cactus, yuccas, and thorn brush are all liberally supplied with its big thorny nests. When we were photographing one the owner came so close that we could see the bright red of its eyes. As the birds watched us they gave their liquid two-syllabled call, which is one of the loud, dominant notes of the country. In a dry wash in southern New Mexico, when we were preparing to photograph one of the yucca nests, the brooding bird, who had been entirely hidden by the yucca spears, quietly slipped out of the nest and disappeared in the brush.

\section{7a. T. c. palmeri (Coues). Palmer Thrasher.}

Upper parts uniform dark brownish gray or grayish brown; wings with bars obsolete or wanting; tail indistinctly tipped with lighter; throat whitish; rest of under parts grayish, obsoletely spotted with darker. Length : 11.00-11.50, wing $4.20-4.60$, tail $4.80-5.20$, exposed culmen 1.18-1.40.

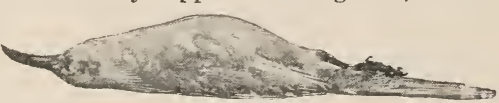

Fig. 563.

Distribution. - Resident in Lower Sonoran zone in southern Arizona and Sonora. Mexico.

Nest. - In cactus. of sticks, usually lined with dried grass. Eggs : 2 to 4, pale bluish green, finely and uniformly speckled with brown.

The Palmer thrasher is abundant on the cactus deserts of southern Arizona, being resident up to 3000 feet.

708. Toxostoma bendirei (Coues). Bexdire Thrasher.

Upper parts pale grayish brou'n; wings with indistinct bars; tail dark 
brown, onter feathers tipped with white; under parts brownish white, indistinetly spotted with brown; flanks brownish. Young: similar, but

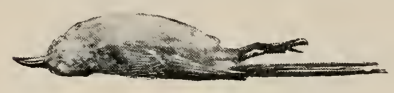

Fig. 564. Bendire Thrasher. wings and rump washed with tawny buff; under parts whiter, with narrower streaks. Length : 9.50-10.50, wing $3.90-4.20$, tail $4.25-4.90$, exposed culmen $.87-.95$.

Distribution. - Breeds in desert regions of Upper and Lower Sonoran zones, in Arizona and southeastern California; accidental in Colorado.

Nest. - In trees, bushes, or cactus, small and daintily built for a thrasher, of sticks and grass, lined with soft materials, such as grass, horsehair, rootlets, wool, or feathers. Eggs: 3 or 4, generally greenish white, spotted with pale reddish brown, usually heaviest about the larger end; sometimes grayish or pinkish white, spotted with salmon and lavender.

Mr. Herbert Brown, who has an extended acquaintance with the Bendire thrasher, says it is largely confined to the central part of southern Arizona, unlike palmeri seldom or never leaving the flat country. It is migratory, smaller and less common than palmeri, and strangely silent for a thrasher. Only once in all his experience has Mr. Brown heard it give its splendid song, and only rarely, when disturbed at the nest, has he heard it give its call of tirup, tirup, tirup.

\section{Subgenus Harporhynchus.}

Bill longer than head; breast not spotted.

710. Toxostoma redivivum (Gamb.). Californian Thrasher. Upper parts dull dark grayish brown; wings and tail unmarked, tail dark-

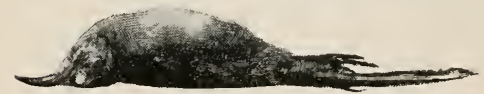

Fig. 565 . er; under parts, including throat, dull buffy or brownish, darker on chest; under tail coverts tawny. Length: $11.50-13.00$, wing $3.90-$ 4.30 , tail $4.90-5.80$, bill $1.35-1.75$.

Distribution. - Coast region of California ; south to Lower California.

Nest. - In bushes, a rude platform of twigs, roots, grasses, and leaves. Eggs : 3 or 4, light greenish blue, speckled with elove brown.

The California thrasher is one of the most vociferously rollicking jolly good fellows of his tribe. Perched on top of the highest bush in sight, he shouts out kick'-it-now, kick'-it-nov, shut'-up, shut'-up, dor'-o-thy, dor'-o-thy; and then with a rapid change of mood, drawls

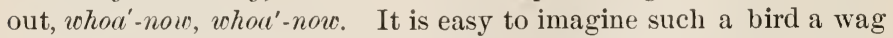
and mimic, and attention has recently been called to his imitative power by Mr. John J. Williams. He says that interwoven with its own song are the quare, quare, quare of the California jay, the quirring note of the slender-billed nuthatch, and the cackling note of the red-shafted flicker, besides the call of the valley quail, the kree-kroe-kuk of the western robin, and the trill of the wren-tit, which the mimic does so well that the birds answer back. 
When he is singing, the thrasher's bill makes him look comically as if he were trying to turn himself inside out; but the bill, awkward as it appears, is really an admirable pickaxe. Instead of having to depend on his feet for scratching away the leaves, as the shortbilled birds do, the thrasher clears the ground by rapid strokes of the bill, and then probes the earth with it for his food.

710a. T. r. pasadenense Grimell. Pasadena Thrasher.

Similar to redivivum, but duller; throat white; chest band darker than in redivivum. Wing: 3.92 , tail 5.30 , bill from nostril 1.21 .

Distribution. - Interior of sonthern California.

\section{Toxostoma lecontei Lawr. Lecoxte Thrasher.}

Adults. - Upper parts pale brownish gray; wings uumarked; tail distinctly tipped with lighter; throat white; rest of under parts dove color and whitish; under tail coverts bright tawny brou'n. Young: similar, but upper tail coverts more rusty, and

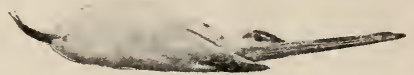

Fig. 566. under tail coverts paler. Length: $10.50-11.00$, wing $3.70-3.90$, tail 4.57 5.20 , bill $1.08-1.35$.

Distribution. - Resident in Lower Sonoran zone in the desert region from southwestern Utah to southern California, and south to Sonora, Mexico.

Nest. - Very bulky, composed of thorny twigs, grasses, and weeds, lined with grass and feathers, and placed in eactus bushes or mesquite trees. Eggs: 3 or 4, pale bluish green or greenish blue, minutely and rather sparsely speckled with reddish brown, or yellowish brown and lavender.

In the lowest, hottest, barest deserts of the country, where dwarfed thorn bushes, queer species of cactus, and rigid Spanish bayonets space the baked mesas and valleys, the Leconte thrasher is one of the most interesting bits of desert life. The sand-colored bird seems, like all of its surroundings, to have had the color baked out of it, or like them to have taken on the colors which best fit it to endure the desert temperature, sometimes $130^{\circ}$ in the shade, and much higher in the glaring sun. After a cool night on the desert in March, when the morning air is loaded with the fragrance of abronias, ruccas, and primroses, and the crimson and gold cups of the cactus are brilliant among the creosote bushes, the thrashers are heard fairly splitting their throats from the mesquite tops, and seen running about chasing each other over the bare stretches between the bushes. Later in the day they rest in the shade of the chaparral, and if frightened simply run from one cover to another, rarely flying to escape pursuit. They easily outrun a man, and if followed soon disappear, going with head low and tail straight out behind like the road-runner, keeping always on the far side of each bunch of bushes. With a good horse one can usually force them to take 
wing, if they do not get out of sight before the horse gets started, though they have many advantages in a country where a horse is liable to fall into badger holes and kangaroo rat dens or come to deep washouts too wide for a jump.

Vernox BaIley.

\section{Toxostoma crissalis Henry. Crissal Thrasher.}

Adults. - Bill long. sharply curved; upper parts dark grayish brown;

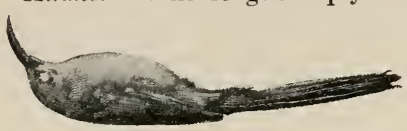

Fig. $\check{6} 6$. wings without bars; tail faintly tipped with rufous; throat and malar stripe white, in contrast to dark fawn or grayish under parts; under tail coverts dark rufous. Young: similar, but more rusty above, especially on rump and tips of tail feathers; lower parts more fulrous. Length : $11.40-12.60$, wing $3.90-4.10$, tail 4.80-6.40, exposed culmen 1.20-1.50.

Distribution. - Breeds in the southwestern United States from western Texas to California, and from Utah and Nevada to Lower California.

Nest. - In bushes or desert willow, made of coarse twigs, lined with strips of plant bark. Eggs : 3, plain pale bluish green.

The crissal, or red-vented thrasher, lives on the rough sides of rocky canyons, where there are junipers and low mesquites. In fall he is said to eat juniper berries and other small fruits, and then, food being plentiful, has a distinct revival of his powerful song. Though ordinarily shy, individuals come about ranches and become quite tame. (See The Auk, iii. 292.)

\section{GENUS HELEODYTES.}

General Characters. - Length about \&; tail broad, with wide feathers; tarsus scaled behind; rictal bristles obsolete or very indistinct.

KEY TO ADULTS.

1. Belly lightly marked with linear spots . brunneicapillus, p. 442. $1^{\prime}$. Belly heavily marked with ovate spots . . . . . bryanti, p. 443.

713. Heleodytes brunneicapillus (Lafr.). CActus Wren. ${ }^{1}$ Adults, - Throat and breast white, heavily marked with black roundish

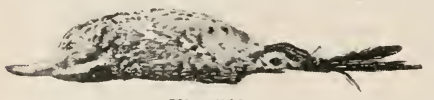

Fig. 568. spots, in sharp contrast to buffy brown belly, which is sparsely marked with linear spots; superciliary white; upper parts brown. streaked on back with black and white; tail with middle feathers brownish, spotted with black. the rest black, only outside feather barred with white for whole length. Young: similar, but streaks on back

1 Heleodytes brumeicapillus couesi (Sharpe). Texan Cactus Wren.

Coloration dark, throat mainly black, back narrowly striped with white.

Distribution. - Rio Grande region of Texas, south over Mexican tableland. (The A $u k$, xix. 143.)

Meleodytes brunneicapillus anthonyi Mearns. Desert Cactus Wren.

Coloration pallid, tail mostly black.

Jistribution. - Interior deserts of southwestem United States south to Chihuahua, Sonora, and northeastern California. (The Auk, xix. 143.) 



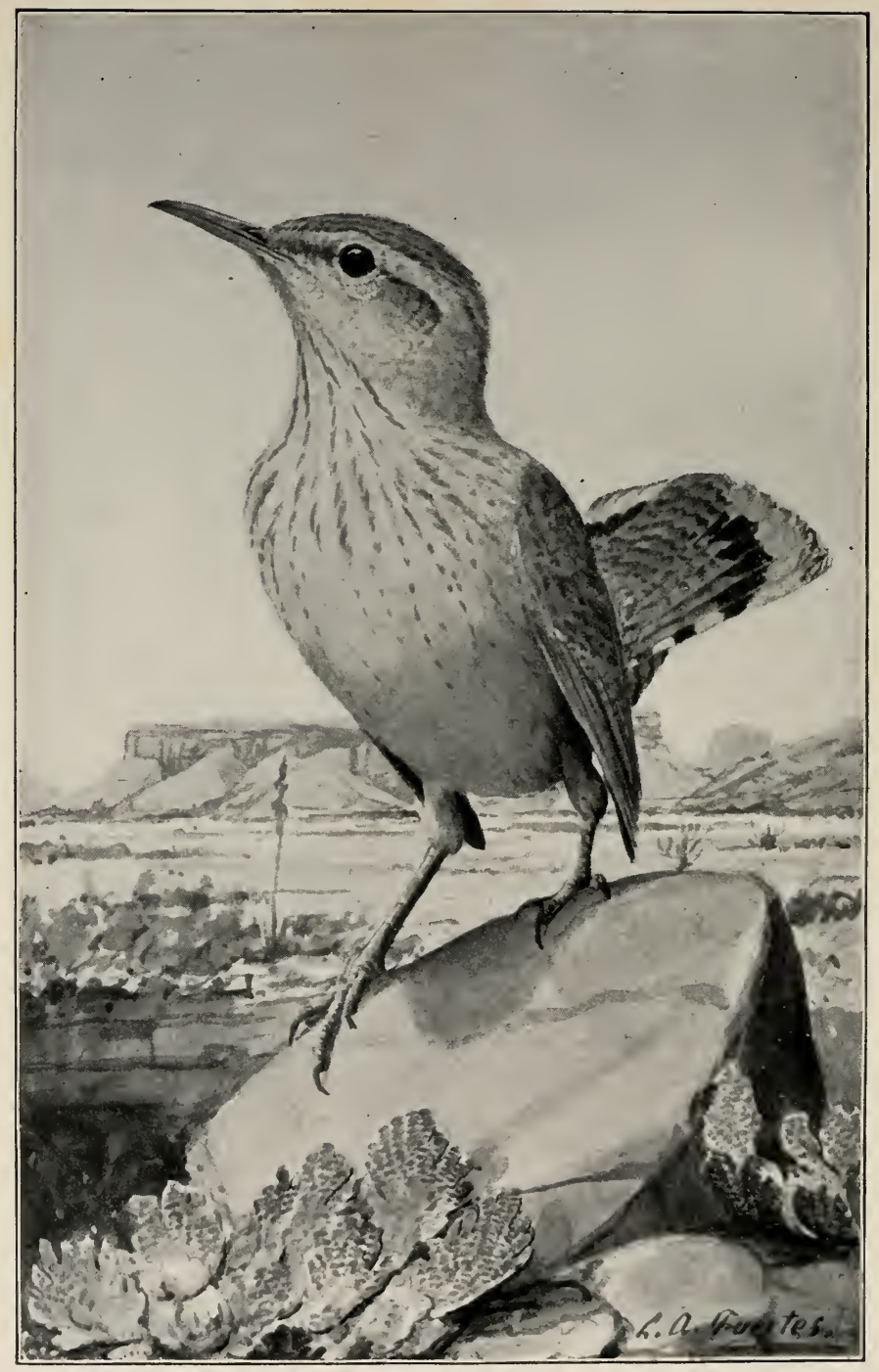

ROCK WREN 
less sharply defined, spots on under parts smaller, and colors more suffused. Length: $5.00-8.7 .5$, wing $: 3.30-3.50$, tail $3.25-3.50$, exposed culmen .8(0-.95.

Distribution. - Resident in Lower Sonoran zone, from sonthern Texas west to southern California, and from southwestern Utah to central Mexico.

Nest. - In cactus, yucea, or thoruy bush, bulky, flask-shaped, in horizontal position, entrance at month of flask; made of sticks and coarse straws, lined with feathers. Eggs : 4 to 7 , whitish or buffy of ten hidden by reddish brown spotting.

Brunneicapillus seems on first acquaintance, in a cactus and mesquite thicket, the most unwren-like of wrens. Its big size, blackish color, aud grating, monotonous chut, chut, chut, chut, have little to suggest its small brown, sweet-voiced relatives. Its pose, however, is like that of the Carolina wren, for it sings on top of a bare branch, with head up and tail hanging. It is a conspicuous bird in that strange land of cactus, mesquite, and yucca, and fits into its desert surroundings as well as its odd nest does in among the yucca bayonets or cactus thorns. Its nests are so common that in driving through the country one comes to pass them without comment, unless the eye is caught by a particularly perfect retort form for a photograph.

In New Mexico, Mr. Anthony found the wrens repairing their nests in the fall, and thinks that the 5 roost in them in winter, and use them for protection against storms. He believes that each pair of wrens keep several nests in order for this purpose.

\section{3a. H. b. bryanti Anthony. Bryant Cactus Tren.}

Similar to brunneicapillus, but thick ovate spotting extending over belly and sides; under parts washed with rusty, and tail with middle feathers more or less perfectly barred.

Distribution. - From sonthern California south to Lower California.

\section{GENUS SALPINCTES.}

\section{Salpinctes obsoletus (Say). Rock Wrex. ${ }^{1}$}

Bill about as long as head, slender, compressed, decurved at tip; wing louger than tail: tail rounded, feathers broad; feet small and weak; tarsus longer than middle toe, scaled behind. Adults: Upper parts dull grayish brown, finelvflecked with black and white dots; rump light brown;

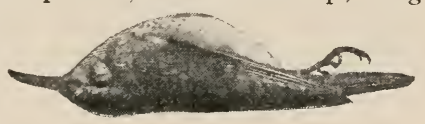

Fig. 569. tail graduated, tipped with buffy brown and with subterminal band of black; middle tail feathers narrowly barred with blackish; under parts dull whitish, brownish on flanks; chest usually finely speckled. Young: upper parts rusty gras; under parts whitish anteriorlv, brownish on flanks and under tail coverts. Length: 5.12-6.35). wing 2.65-2.80. tail 2.12-2.40, bill from nostril . $+4-.54$.

1 Salpinctes obsoletus pulverius Grimnell. SAN Nicolas Rock Wrex. Like obsoletus, but entire plumage suffused with ochraceous or dust color. Distribution. - San Nicolas Island, California. (The Auk, xv. 238.) 
Remarks. - The pale grayish coloration and the black crescent on the tail are good field characters.

Distribution. - From British Columbia south to Lower California and to Chiapas, Mexico; from western Nebraska to the Pacific ; breeds throughout its range and is resident from about the southern border of the United States southward.

Nest. - Usually in clefts or crevices among rocks, sometimes in hollow stumps or about buildings. Eggs: 7 or 8, white, finely spotted on or around larger end with chestnut brown.

Salpinctes! To the worker in the arid regions of the west this name calls up most grateful memories. On the wind-blown rocky stretches where you seem in a bleak world of granite or lava with only rock, rock, everywhere, suddenly, there on a stone before you, stands this jolly little wren, looking up at you with a bob and a shy, friendly glance. The encounter is as cheering as the sight of a bird at sea, and before such meetings have been repeated many times, you love the little wren as you do the barking conies that give life and a touch of companionship to the barren rock slides of the mountains.

Even his song, which at first hearing seems the drollest, most unbird-like of machine-made tinklings, comes to be greeted as the voice of a friend on the desert, and its quality to seem in harmony with the hard, gritty granites among which he lives. Its phrases are varied, but one of its commonest - given perhaps from the top of a cliff while his mate is feeding their brood on a ledge below - is little more than a harsh kra-vee, kra-zee, lira-vee, kra-vee, giveu slowly at first, then after a little bob repeated in faster time.

As you watch him he seems well fitted to escape his enemies who soar over the mountains, for he is a perfect rock color, and his only striking mark is the black fan-shaped band that flashes from his tail as he disappears from view.

Altitude seems to make little difference with him if the conditions of barrenness are met, but he is most commonly found in the mountains. Dr. Mearns reported him from the summit of San Francisco Mountain, Arizona, at a time when the hollows were filled with ice and snow and fierce storms were raging.

\section{GENUS CATHERPES.}

General Characters. - Bill about as long as head, longer than tarsus; side toes of unequal lengths; wing longer than tail.

KEY TO ADULTS.

1. J)arker colored. Lower Rio Grande . . . . . albifrons, p. 445.

1'. Lighter colored.

2. Larger, bill longer, spotting on back not so thick. Great Basin and Rocky Mountain region . . . . . . conspersus, p. 44i).

2'. Smaller, bill shorter, spotting on back thicker. Oregon and California west of Cascades and Sierra Nevada - punctulatus, p. 445. 



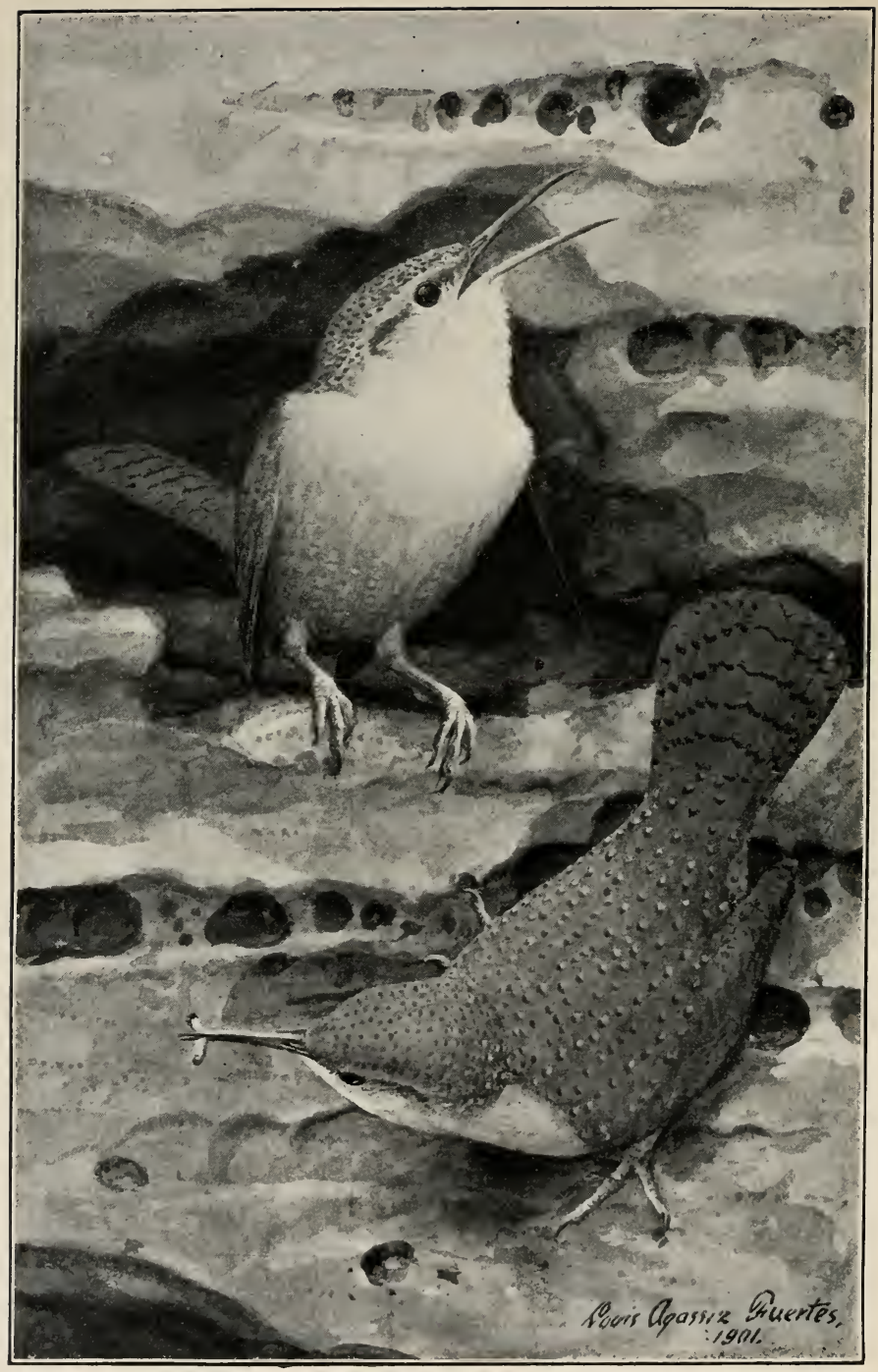

CANYON WREN 


\section{Catherpes mexicanus albifrons (Giraud). WhiтE- THROATED WREX.}

Like conspersus, but larger and darker : upper parts from dark rusty to sepia; wings barred with rusty. Length: $6.00-6.50$, wing $2.40-2.90$, tail $2.30-2.45$, exposed culmen $.70-.95$.

Distribution. - Lower Rio Grande Valles, Texas, and northeastern Mexico.

717a. C. m. conspersus Ridgu. CANyox Wrex.

Adults. - Brown except for white throat and breast; upper parts light brown, grayish on head, speckled with white and blackish; tail rusty brown, crossed by narrow black bars; belly dark rusty brown. Foung: essentially like adults, but usually without white specks

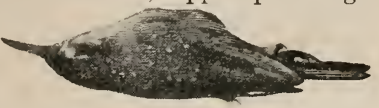

Fig. 570 . on upper parts or posterior under parts. which are, instead, mottled, more or less, with dusky. Length: $5.50-5.5 \%$, wing $2.20-2.40$, tail $2.00-2.40$, exposed eulmen $.70-.85$.

Distribution. - Great Basin and Rocky Mountain region from the Sierra Nevada and Cascades east to Colorado, and from Idaho south to Aguas Calientes, Mexico; breeds nearly throughout its range and is resident in the southern parts of its United States distribution.

Nest. - In erevices of rocks, on ledge in tunnel or eave, or about buildings, made with thick soft walls covered with green moss. Eggs : 3 to 5 , white, spotted chiefly on larger end with reddish brown and lilac gray.

Sometimes, as at Austin, Texas, canyon wrens will stray into cities and sing from the chimney tops with the mockingbirds, and when they do, what cool, grateful canyon memories they awaken in the midst of the town! When heard afterwards on their own native canyon cliffs it seems impossible that they could ever sing in a city, their song is so attuned to the wild mountain fastnesses.

The bit of a wren may be on a ledge so high above your head that jou pick him out among the rocks only by the round white spot which is his throat and which shows as his head is thrown back to sing, but jet his voice is so powerful that the canyon fairly rings with his song. What joyous notes! They sound as if his happiness were so great that he needs must proclaim it. His song comes tripping down the scale growing so fast it seems as if the songster could only stop by giving his odd little flourish back up the scale again at the end. The ordinary song has seven descending notes, but often, as if out of pure exuberance of happiness, the wren begins with a run of grace notes, ending with the same little flourish. The rare character of the song is its rhapsody and the rich vibrant quality which has suggested the name of bugler for him, - and a glorious little bugler he surely is.

\section{7b. C. m. punctulatus Ridgw. Dotted CAxyon Wren.}

Similar to conspersus, but smaller and bill shorter, and more thickly spotted on back.

Distribution. - Oregon and California west of the Caseades and Sierra Nevada to Lower California; resident from southern California southward. 


\section{GENUS THRYOTHORUS.}

\section{Thryothorus ludovicianus (Lath.). CARolina Wren.}

Wing less than 3; tail not longer than wings, like back in color. Adults. -

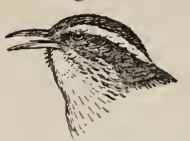

Fig. 571 .

Upper parts rusty brown; crown bordered by an indistinct blackish line and buffy white superciliary; broad rusty stripe back of eye ; wings indistinctly barred with rusty and spotted witl white : under parts varying from white on throat to tawny buff below. Young: crown blackish; under parts more cinnamon brown, with indistinct cross exposed culmen $.60-.70$.

lines. Length: 5.25-6.00, wing 2.18-2.50, tail 1.80-2.35,

Distribution. - Upper and Lower Sonoran zones from the Atlantic to the Plains and western Texas, and reported by Capt. Thorne from Montana; from southern Michigan south to the Gulf of Mexico; resident nearly throughout its range.

Nest. - Usually in woods, in holes in logs and rocks; made of twigs, grasses, and leaves, lined with feathers. Eggs: 3 to 6 , white, pinkish, or creamy, thickly speckled on or around larger end with reddish brown.

Food. - Insects.

\section{GENUS THRYOMANES.1}

General Characters. - Wing less than 3 ; tail longer than wing's, blackish, outer feathers tipped with white or gray; white superciliary stripe conspicuous.

KEY TO THRYOMANES.

1. Large, wing averaging 2.25 .

2. Upper parts reddish brown. Texas . . . . . cryptus, p. 447.

2 '. Upper parts grayish brown. Texas to California.

leucogaster, p. 447 .

$1^{\prime}$. Smaller, wing averaging 2.00-2.07.

2. Bill averaging .50, upper parts dark sooty brown. California.

2 '. Bill averaging . $.54-.56$.

spilurus, p. 446.

3. Upper parts dark, rich brown. Northwest coast region.

3'. Upper parts grayish brown.

calophonus, p. 447.

4. Under tail coverts heavily barred with black. Southern and Lower California . . . . . . charienturus, p. 447.

4'. Colors paler, under tail coverts less heavily barred with black. San Clemente Island . . . . . . . leucophrys, p. 448.

719a. Throymanes bewickii spilurus (Vig.). Vigors Wren.

Upper parts dark broun, with a conspicuous white superciliary; tail with middle feathers grarish brown, barred, only sightly contrasting with color of back, outside feathers blackish, spotted and barred; under parts gray. sides and flanks tinged with brown. Length: wing 2, tail 1.96, exposed eulmen ..j).

Distribution. - California west of Sierra Nevada and south to Santa Cruz Island.

Nest. - Usually around buildings except in unsettled districts; bulky, made largely of sticks and lined with feathers. Eggs: usually ij to 7 ,

1 See Oberholser's "Revision of the Wrens of the Genus Thryomanes," Proc. $U$. S. Tat. Mus. xxi. 421-450. 1898. 
white or pinkish, finely speckled or sprinkled on or around larger end with reddish brown and lilac.

The bexickii group are strongly marked wrens with their striking superciliary, light spotty cornered tails, and melodious songs. The song of the Vigors wren, when heard in southern California with the Parkman, though not so ebullient, is richer, sweeter, more musical, and altogether of decidedly superior quality.

Where there are houses, Thryomanes nests like the house wrens in odd nooks and corners about buildings, but otherwise on brushy hillsides and in such congenial places. One Texan Bewick was found by Mr. Bailey nesting in a tin can turned over

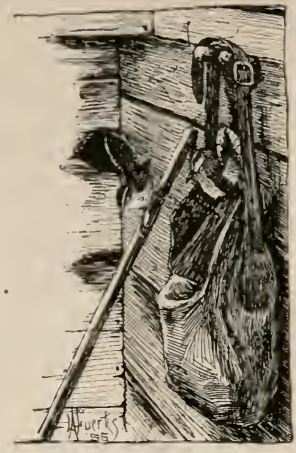

Fig. 572. Vigors Wrell. a fence post, the entrance being through an enlarged bullet hole.

\section{9b. T. b. leucogaster (Baird). Baird Wren.}

Upper parts pale grayish brown. tinged with rufous on rnmp; niddle taii feathers brown, barred witl black, rest of feathers mainly black, the three outer pairs with grayish white tips; superciliary white; nnder parts whitish, purer on throat; under tail coverts heavily barred with black. Wing: 2.20 , tail 2.23 , bill .5.

Distribution. - Western Texas to southeastern California, and from southern Nevada, Utall, and Colorado south over tablelands of Mexico to Zacatecas.

\section{9c. T. b. cryptus Oherh. Texas Bewick Wrex.}

Superciliars white ; upper parts rich warm brown, more rufous on rump ; tail with middle feathers and bases of outer webs of all bnt outside pair hair brown, barred with black; rest of tail black, faintly barred with lighter; two outer pairs of feathers tipped with grayish white; under parts grayish. Wing: 2.25, tail 2.24, exposed culmen .5.5.

Distribution. - Texas, except extreme western corner; Nuevo Leon and Tamaulipas, Mexico, and probably Kansas, Indian Territory. and Oklalioma ; migratory north of Texas.

\section{9d. T. b. charienturus Oberh. Southwest Bewick Wren.}

Superciliary white; upper parts grayish brown, slightly rufous on rump; tail black except for middle feathers which are hair brown, barred with black, outside feathers tipped with gray, onter webs barred with dingy white, rest of feathers tipped with brown ; under parts white or grayish ; crissum heavily barred with black. Wing: 2.03, tail 2.02, exposed culmen .ist.

Distribution. - Resident from Pasadena along the coast region of California to Lower California ; Santa Catalina Island.

719e. T. b. calophonus Oberh. NoRthwest Bewick Wren.

Superciliary white; upper parts rich dark brown, slightly deeper on liead; tail black, middle feathers sepia brown barred with black, the rest 
tipped with gray and barred with brown, onter pair barred toward end with whitish; under parts grayish white, lightest on throat, tinged with brown on sides and flanks; under tail coverts barred with black. Wing: 2.07 , tail 2.03 , exposed culmen .56.

Remarks. - Calophonus is most nearly allied to spilurus, but has a conspicuously larger bill and averages larger and darker.

Distribution. - Pacific slope from Oregon north to southern Vancouver Island and the Fraser River valley. Resident probably throughout its range, at least from Puget Sound southward.

\subsection{Thryomanes leucophrys (Anthony). San Clenente WREN.}

Similar to charienturus, but paler, grayer above and on flanks ; under tail coverts less heavily barred; bill longer. Wing: 2.07 , tail 2 ; bill .56.

Distribution. - San Clemente Island, California.

\section{GENUS TROGLYODYTES.}

General Characters. - Wing less than 3, about length of tail ; stretched feet not reaching beyond end of tail; inner toe united at base to middle toe.

KEY TO ADULTS.

1. Upper parts brown. Pacific coast region . . . parkmanii, p. 448. $1^{\prime}$. Upper parts grayish brown. Western states except coast region.

aztecus, p. 449.

\section{2la. Troglodytes aëdon parkmanii (Aud.). Parkman Wren : Pacific House Wren.}

Upper parts dull brown, all but head barred with blackish; tail coverts

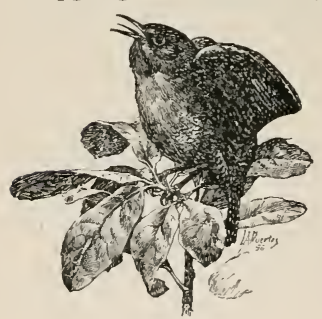

Fig. 573 . barred with black and whitish; under parts dingy, lightly barred. Length: $4.25-5.25$, wing 2.02 , tail 1.85, exposed culmen 49 .

Distribution.-Pacific coast region from British Columbia south to California.

Nest. - In holes in trees or about buildings, made largely of twigs. lined with feathers. Eggs : 5 to 7, pinkish white, thickly spotted with reddish brown or brownish purple.

The house wrens are just ordinary birds, with no striking marks and nothing musical or brilliant about their songs, but they are such persistently jolly little songsters that their charm is quite irresistible. Wherever you meet them they are always singing, be it about house or barn, deserted cabin, or old sycamore. Ebullient is the only word that expresses them. Their notes fairly tumble over each other, they are poured out so fast. At times the little musicians become ecstatic, and raise their quivering wings till they almost meet over the back. Besides their song the wrens have an anxious scolding chatter, and the mother bird a quieting krup-upup which she uses to soothe her brood.

Raising a brood is a protracted process with the wrens. With one 
family that I watched in southern California it was six weeks from the time they began building before the soung left the nest.

721b. T. a. aztecus Baird. Aztec Wrex.

Like parkmanii, but grayish brown.

Distribution. - IVestem United States except the Pacific coast, east to the Mississippi Valley; south to southern Mexico.

Aztecus is the same jolly little songster as parkmanii, clambering over your tent and balancing the twigs he carries to his nest, saying and doing the same things at 9000 feet in the coniferous forest of the mountains of New Mexico as the Parkman at sea-level in the hot valless of southern California.

\section{GENUS OLBIORCHILUS.}

\section{2a. Olbiorchilus hiemalis pacificus (Baird). Westers WINTER WREN.}

Tail less than three fourths as long as wing; outstretched feet reaching far beyond its end. Upper parts dark brown, brighter on rump and upper tail coverts; wings, tail, and often back and rump narrowly barred with blackish; superciliary stripe, throat, and breast, tawny; belly and under tail coverts barred; flanks darker. Length: $3.60-4.25$, wing $1.80-$ 1.90, tail 1.20-1.35, exposed culmen .40-.45.

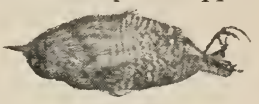

Fig. 574 .

Distribution. - Breeds on Pacific coast from Sitka south to southern California and east to Idaho; ranges to western Mexico in winter.

Nest. - In coniferous woods in crevices of dead logs or stumps, made of moss and lined with feathers. Eggs: 5 to 7 , white or ereamy, finely but sparingly spotted with reddish brown.

Food. - Largely worms and small white grubs found in the bark of trees.

While the roluble house wrens are always coming to the front singing with heads up and tails hanging, loudly publishing all their affairs, the quiet little winter wrens, with heads peering down and stubby tails cocked over their backs, are silently creeping over the logs and investigating all the darkest cracks and crannies of the fallen timber. In the redwood forests Mr. Bailey has found them bobbing out from under old logs, diring into hollow stumps or brush heaps, their somber color blending with the brown leaves, brown bark, and brown wood. In the deeper shade of the darker nooks and hollows they disappear entirely, droll Lilliputians making their homes among the giant redwoods.

\section{GENUS CISTOTHORUS.}

General Characters. - Back streaked with black and white; tail graduated for about half its length.

1. Bill as long as head.

KEY TO ADLLTS.

2. Bars on tail coverts indistinct or wanting. East of Rocky Mountains.

2'. Bars on tail coverts distinct. palustris, p. 450 . 
3. Paler. East of Pacific coast region to Rocky Mountains.

3'. Darker. Pacific coast region plesius, p. 451 . 1'. Bill much shorter than head paludicola, p. 450 . stellaris, p. 450 .

\section{Subgenus Cistothorus.}

724. Cistothorus stellaris (Licht.). SHORT-BILled MARsh Wrex.

Bill much shorter than head; plumage brown; top of head as well as back sireaked with black and white; upper tail coverts barred; under parts buffy or brownish, whiter on throat and belly. Length: $3.75-4.50$, wing 1.7.2-1.90, tail 1.58-1.70, bill from nostril .24-.28.

Distribution. - Breeds from Lake Winnipeg (Norway House) southeast to Georgia; in the United States west to the Plains; casually to Utah; winters in the south Atlantic and Gulf states.

Test. - In tussock of reeds or coarse grass, the tops of which are woven into a spherical nest with entrance on one side, lined with finer grasses and sometimes vegetable down. Eggs : 6 to 8 , pure white, unmarked.

At Provo, Utah, Mr. Henshaw found that the short-billed marsh wren bred in the marshes.

\section{Subgenus Telmatodytes.}

\section{Cistothorus palustris (Wils.). LoNg-BILled Marsh ITren.}

Adults. - Like paludicola, bnt brown of upper parts averaging more rusty, bars on middle tail feathers usually more indistinct or incomplete, and bars on tail coverts usually indistinct or wanting. Length: $4.25-5.50$, wing 1.80-2.12, tail 1.60-1.90, bill .5.5-.61. Young: top of head, nape, and back dull black without white spots or streaks.

Distribution. - Breeds in Transition and Upper Sonoran zones from Manitoba and Ontario sonth in the eastern United States; west to the Rocky Mountains; winters locally from southern New England to the Gnlf states and eastern Mexico.

Nest. - Globular, with entrance on one side, attached to upright reeds in marshes. Eggs : 5 to 9, chocolate, sometimes nearly uniform, but usually sprinkled with a deeper shade.

\section{5a. C. p. paludicola Baird. Tule Wren.}

'Top of head and triangular patch on middle of back black; middle of crown washed with brown; back pateh streaked with white; rest of back light brown; middle tail feathers and tail coverts generally distinctly and contimuously barred with black; under parts soiled whitish. flanks brownish. Length: 4.50-5.7.5, wing 1.9.5-2.2.2. tail 1.80-2.05, bill .48-.5.5.

Jistribution. - Breeds in Pacific coast region from British Columbia to California; sonth in winter to extreme nortliwestern Mexico.

Vest. - A large globular structure fastened to tule stalks, and woven of wet tule stems, with wet grass and alga matted in, and with a lining of dry algre and tule pith. Eggs (1 set) : 5), lavender brown. clouded or mottled.

Food. - Insects.

The wrens of the marshes are as full of soug as the house wrens, and as they live in colonies where they all $\operatorname{sing}$ at once their swamps are as noisy as a pond full of frogs. hut their voices are 


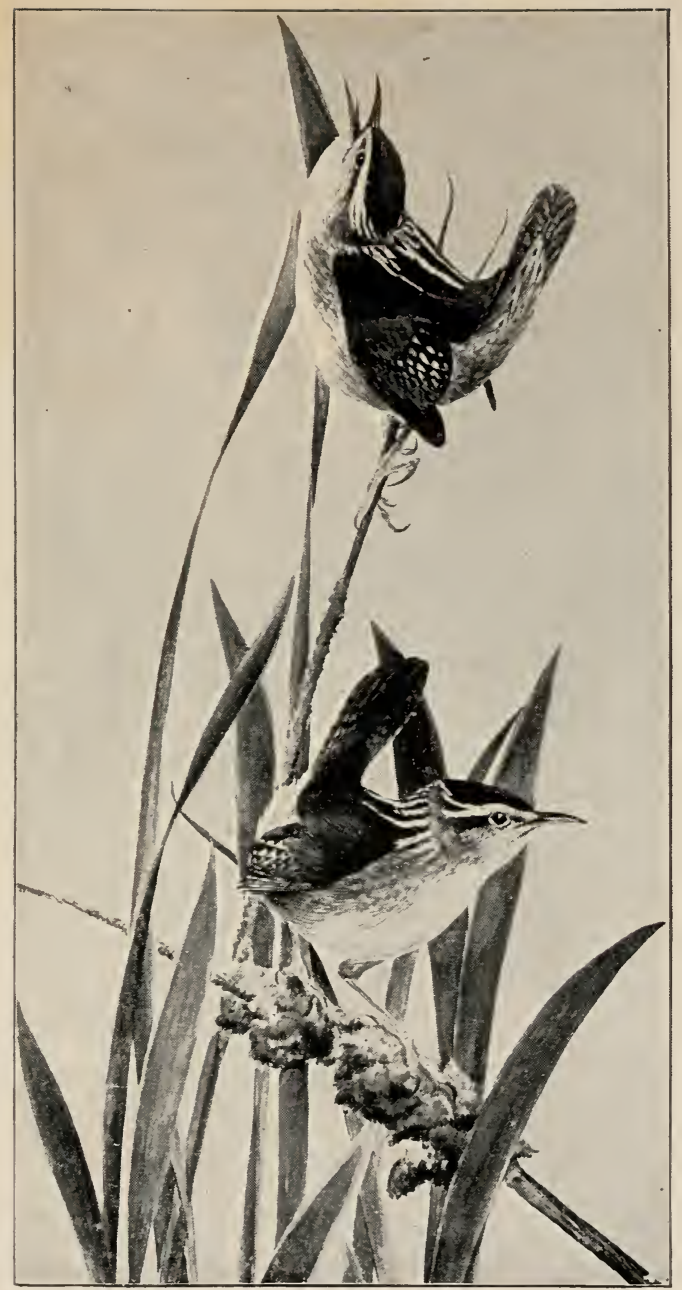

By courtesy of The Osprey

LONG-BILLED MARSH WREN 

most unfrog-like, having the tinkling machine-made quality of a music-box.

Like the house wrens they sing all over, and sometimes as they cling to a tule stem bend almost double, comically swaying from side to side.

Their big globular nests make conspicuous objects hung on the tule stems, and a walk among them with the birds singing at you as well as around you is an experience quite to a bird-lover's heart.

While the tule swamps are their breeding grounds, in fall and winter they are found in weed patches and rank grass.

\section{5c. C. p. plesius Oberh. Interior Tule Wren.}

Like palustris, but upper parts paler, under parts grayer, middle tail feathers heavily barred, and upper and lower tail coverts barred ; paler and more sharply barred than paludicola. Wing: 2.06 , tail $1 . \bullet^{\circ}$, bill .50 .

Distribution. - From British Columbia and Alberta east of the Pacific coast district south to Mexico; east to the Rocky Mountains and Texas; breeds nearly throughout its range and winters from Oregon southward.

\section{FAMILY CERTHIIDA: CREEPERS.}

\section{GENUS CERTHIA.}

General Characters. - Bill slender, sharp, and decurved: tail rounded, equal to or longer than wing, of rigid. sharp-pointed feathers; tarsus

Fig. 575. scaled; claws greatly curved, and sharp.

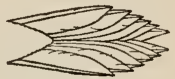

Fig. 576.

KEY TO CERTHIA.

1. Upper parts grayish. Rocky Mountains . . . . montana, p. 451.

$1^{\prime}$. Upper parts brownish or dusky.

2. Upper parts rusty brown. Pacific coast from California to Sitka.

$2^{\prime}$. Upper parts not rusty brown.

3. Upper parts dark brown. Arizona and sonthward. occidentalis, p. 452 .

albescens, p. 451 .

$3^{\prime}$. Upper parts dusky anteriorly. Sierra Nevada and Caseades.

zelotes, p. 452 .

\section{6a. Certhia familiaris albescens (Berlepsch). Mexican Creeper.}

Upper parts dark brown, becoming deep rusty on rump; under parts brownish gray, white only on throat ; flanks dark rusty. Length: $4.80-$ 5.60 , wing $2.55-2.60$, tail 2.65 , bill $.70-.73$.

Distribution. - From southern Arizona south through Sierra Madre of northwestern Mexico.

Nest. - Behind loosened bark or in similar openings, about stumps or dead tree trunks. made of felted materials and feathers. Eggs: 5 to 9, white, spotted chiefly on or around larger end with reddish brown.

Food. - Insects, and their eggs and larvæ.

726b. C. f. montana Ridgu. Rocky Mouvtain Creferer.

Upper parts grayish, head and back streaked conspicnonsly with white; rump tawny. Wing: 2.56 , tail 2.71 , bill .75 .

Distribution. - Rocky Mountains from New Mexico north to Alaska. 
In the stillness of the high mountain forests your ear sometimes catches the thin, finely drawn pipe of the brown creeper, and if you watch patiently on the dark-shaded boles of the lofty trees you may discover the little dark-colored creature - seeming small and weak in the great solemn fir forest - creeping up the trunks, examining the cracks with microscopic care as he goes. If he feels that his work lias not been done thoroughly enough, he drops back and does it over again; and when one tree has been gone orer to his satisfaction, he often flies obliquely down to the bottom of another trunk and creeps patiently up that. On Mount Shasta, where the firs are decorated with yellow moss, the Sierra creeper goes around its pads when he comes to them, but works carefully over the dark lichen-covered branches. Sometimes he lights upside down on the under side of a branch, and clings like a fly, but with the aid of his pointed tail well pressed against the bark. In New Mexico, Mr. Batchelder has found the creepers eating more seeds than insects.

\section{6c. C. f. occidentalis Ridgu. Califorviax Creeper.}

Upper parts rusty broun. brightest on rump; superciliary and streaks

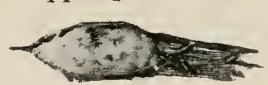

Fig. 57\%. on head and back often tawny. Wing: 2.47. tail 2.45 , bill .72.

Distribution. - Pacific coast from Sitka to Marin Comnty, California.

Nest. - Behind bark of redwood or cedar. 3 to 5) feet from the gromnd. made of soft shredded bark, lined with feathers. cocoons, and silk.

\section{6d. C. f. zelotes Osgood. Sierra Creer'er.}

Upper parts dusky anteriorly, becoming bright rusty on rump; superciliary, streaks on seapulars, and spots on primaries white; throat and breast pure white, sides and flanks tinged with brownish.

Remarks. - The Sierra creeper is intermediate between the California and Rocky Momntain creepers.

Distribution. - Cascade Mountains of Oregon and Sierra Nevada.

Nest. - As described by Barlow, under the bark of a dead pine, about 20 feet from the ground, made of cedar bark, mixed with a few feathers. Eggs: 5, white, spotted with flakes and conflnent blotehes of reddish brown, with shell markings of lavender.

\section{FAMILY PARID仺: NUTHATCHES AND TITS.}

KEY TO GENERA

1. Tail much shorter than wing'

Sitta, p. 453 .

$1^{\prime}$. Tail equal to or longer than wing.

2. Tail graduated for about half its length . . . Chamza, p. 459.

2 '. Tail graduated for mmeh less than half its length.

3. Plumage compact

3'. Plimage loose.

4. Length 4.00-4.5)

Auriparus. p. 462 .

4. Length $4.50-6.00$.

Psaltriparus, p. 460.

Parus, p. 45.). 


\section{GENUS SITTA.}

General Characters. - Bill about as long as head, compressed, slender, acute, tip inclined upward; nostrils concealed by bristly tufts; tongue horny, barbed; wings much longer than short, even tail; tarsus shorter than middle toe and claw ; toes all long, with long curved claws ; plumage compact.

\section{KEY TO SPECIES.}

1. Side of head striped black and white . . . . canadensis, p. 4jt.

1 '. Side of head not striped.

2. Top of head grayish . . . . . . . . . pygmæa, p. 454.

2'. Top of head black.

3. Longest tertial with black patch pointed at tip. aculeata, p. 453.

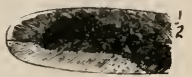

Fig. 578 .

8'. Longest tertial with black oblong rounded at tip. carolinensis, p. 453 .

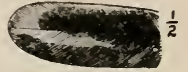

Fig. 579 .

\section{Sitta carolinensis Lath. White-breasted Nuthat'h. ${ }^{1}$}

Sinilar to S. c. aculeata. but tertials light bluish gray, witl sharply de-

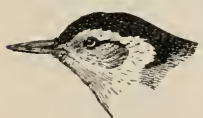

Fig. 580. fined oblong black patches, patch on outer web of longest feather rounded at tip; white of side of head mixed with gray. Length: 5.25-6.15, wing 3.50-3.75, tail 1.95-2.20, bill from extreme base . $50-.90$.

Distribution. - Resident from sonthern Canadian provinces south throngh the eastern United States to Georgia and west to the Rocky Momntains; casually north to Hudson Bay. Nest. - In holes of trees or stumps, marle of soft felted materials and feathers. Eggs : 5 to S, white, spotted with reddish brown.

Food. - Insects, their eggs and larvæ, and nuts.

\section{7a. S. c. aculeata (Cass.). Slender-Billed Nuthatch.}

Adult male. - Top of head and back of neck glossy blue black in sharp contrast to clear white of sides of head and under parts; back bluish gray; wings and tail marked with black and white, tertials dark or dull bluish gras, with black patch along shaft of longest feather pointed at tip. Adult female: top of head grayish. Length: 5.00-6.10, wing 3.35-3.75, tail $1.90-2.20$, bill $.80-.95$, greatest depth of bill .13 .

Distribution. - Breeds in Transition and Canadian zones of western North America. east to the Plains and south to Mexico.

Nest. - In oaks, in natural cavities or old woodpecker holes, lined with grass, moss, fur, hair, and feathers. Eggs: 5 to 7 , creamy white, lightly dotted with reddish brown and lilac, usually chiefly around larger end.

As you ride through the forest in the Transition and Canadian zones of the western mountains, the unmistakable yang, yang, henk' ah, henk'-ah, are frequently heard, together with the notes of kinglets, mountain chickadees, and Audubon warblers, for the birds are

1 Sitta carolinensis nelsoni Mearns. Rocky Mountain Nuthatch.

Dark and large ; bill large, maxilla convex rather than straight. Length: 5.95 , wing 3.70, tail 2.17 .

Distribution. - Wooded mountains of northern Chihuahua and Sonora, Arizona, Nevada, Colorado, and northward. (Proc. L. S. Nat. Mus. xxiv. 923.) 
sociable little creatures, and their flocks often join the ranks of other small foresters. If you catch sight of a nuthatch on the side of a tree trunk and he turns his head to look at you, you are struck by his white neck patch. It can be seen from a distance, and becomes a striking directive mark in the dark forest, being conspicuous when the outlines of the bird's body are almost indistinguishable. In the Sierra Nevada, when passing the birds on horseback, I have lost sight of one I was watching till it turned its head, and then a spot of white stood out against the dark bole of a tree, placing it instantly.

Like the brown creepers the blue-gray nuthatches are tree-trunk birds, but they do not hunt as systematically as the creepers, and are as likely to be found hanging head down as up, while they walk along under a branch as calmly as flies on a ceiling, though they have no stiff pointed tails to aid them.

\section{Sitta canadensis Linn. Red-Breasted Nuthatch.}

Adult male. - Top of head glossy black, side of head with white superciliary and black eye stripe; under parts reddish brown; back bluish gray;

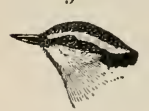

Fig. 581 . wings plain ;' tail with white patches on outer feathers. Adult female : black of head replaced by bluish gray ; under parts lighter reddish brown. Young: similar, but auller. Length: 4.12-4.75, wing $2.60-2.85$, bill about .60.

Distribution. - Breeds in Canadian zone of North America; in the United States in the higher mountain ranges; wintering south to the southern border of the United States.

Nest. - Described by Henshaw, in stub a few feet from the ground, lined with fine shreds of pine bark. Eggs: 4 to 8, grayish white, thinly spotted with red at larger end.

The red-breasted nuthatch is often found with the slender-billed in the west.

\section{Sitta pygmæa Vig. Руgмy Nuthatch.}

Adults. - Top of head grayish brown or olive grav, nape usually white; rest of upper parts bluish gray; tail with basal half of middle feathers white; eye stripe black; chin white; rest of under parts dull buffy. Young: wing coverts usually more or less distinctly edged with pale buffy. Length: $3.80-4.55$, wing about 2.60 , bill .60-.65.

Distribution. - Breeds in Transition and Canadian zones from British Columbia south to Mt. Orizaba, Mexico; and from the Rocky Mts. to the Pacific.

Nest. - In crevice of bark or holes in trees 20 or more feet from the ground, lined with feathers, down, wool, and hair. Eggs: 6 to 9, white, covered with red spots, most thickly about the larger end.

The nuthatches are all interesting, but there is a peculiar charm about the little pygmy. In the Sierra Nevada aculeata and pygmea are sometimes seen together in the pines about camp. When you see the slender-billed coming down the tree trunk over your head 


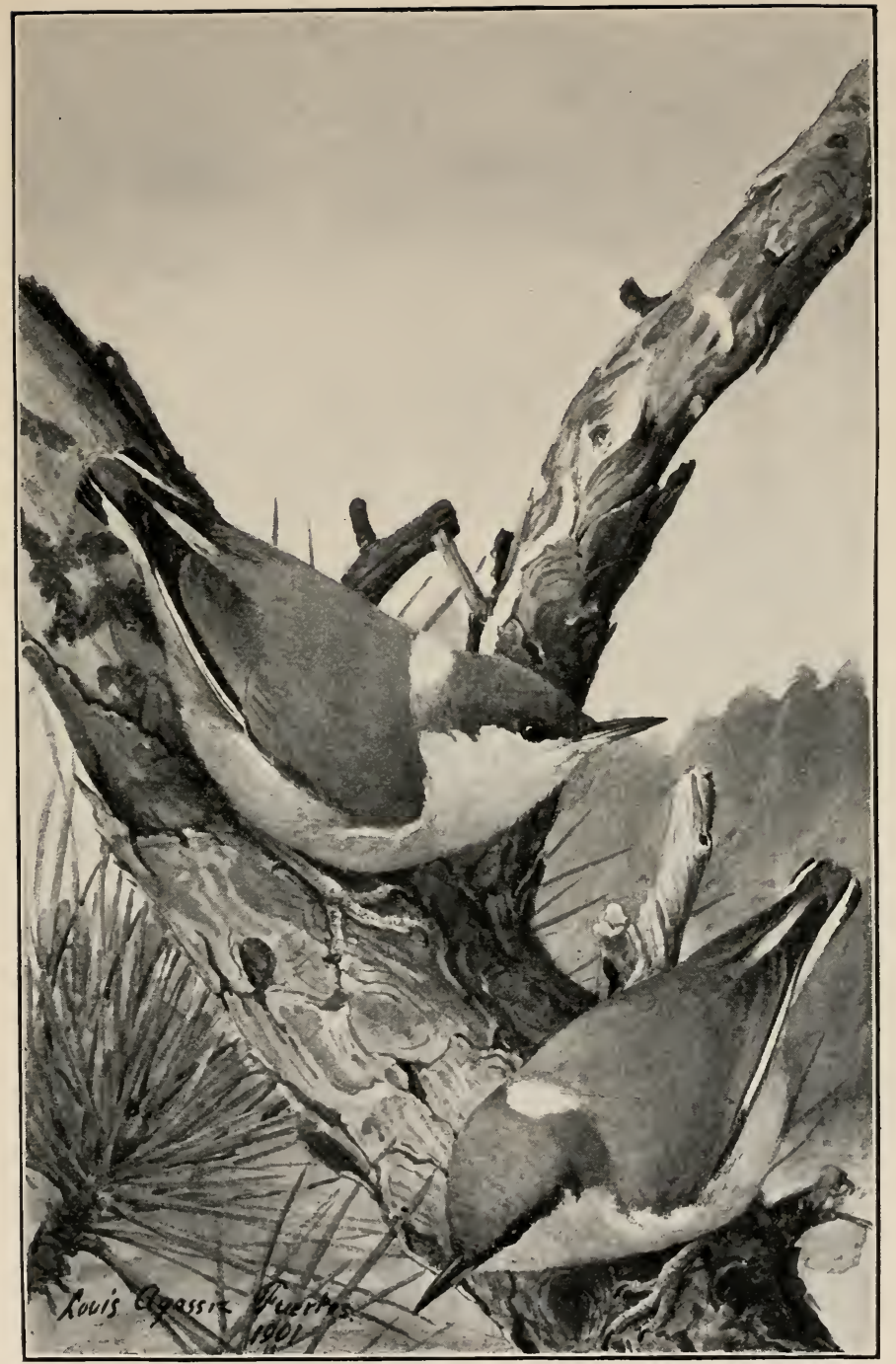

PIGMY NUTHATCH 

you look up and think, " What an alert, bright bird," but when the fluffy, bob-tailed little pygmies come trooping in and alight upside down against the tips of the pine branches, talking in soft little liquid notes, you feel like exclaiming, "Oh, you winsome little mites, how jolly it is to see you again !"

A pair feeding nearly grown young were discovered by Mr. Bailey in the Sierra Nerada toward the last of July. Their small nest hole was widened from a crack in the hard shell of a half decayed pine, where the digging was probably easy. The old birds came freely with food, though Mr. Bailey stood at the foot of the tree, and when the young came up to be fed their parents passed inside, and after feeding sat a moment talking and fluttering their wings at the door.

\section{GENUS PARUS}

General Characters. - Bill much shorter than head. curved; wings and tail about equal and rounded; plumage loose.

1. Head crested.

KEY TO SPECIES.

2. Throat black

$2^{\prime}$. Throat not black.

3. Crest black or brown, contrasting with gray of back.

3 '. Crest gray like back.

atricristatus. p. 45.5 .

4. Upper parts dark brownish or olive gray. Pacific coast region of Califoruia and Oregon . . . . inornatus, p. 456. 4'. Upper parts light gray. Colorado to Sierra Nevada.

$1^{\prime}$. Head not crested.

griseus, p. 456.

2. Top of head brown.

3. Back brownish gray . . . . . . columbianus, p. 459.

$3^{\prime}$. Back dark rufous.

4. Sides and flanks rufons . . . . . . rufescens, p. 459.

4 '. Sides and flanks grav, faintly tinged with ruforts.

2 '. Top of head black.

neglectus, p. 459.

3. With white line over eye

$3^{\prime}$. Without white line over eye.

gambeli, p. 458 .

4. Tail longer than wing. Rocky Mountain platean.

4 '. Tail equal to or shorter than wing.

5. Sides gray like back

septentrionalis. p. 457.

$5^{\prime}$. Sides not gray.

6. Sides buffy (whitish in summer). Eastern.

6 . Sides brown

sclateri, p. 45s.

atricapillus, p. $4 \tilde{5}$.

occidentalis, p. 458 .

Subgenus Lophophanes.

Crested.

732. Parus atricristatus Cass. Black-Crested Titrocse. Adults. - Forehead white or smoky brou'n, crest black; rest of upper 
parts plain gray; under parts white. Young: usually with black of crest mixed with ash; upper parts slaty gray, washed with olive; under parts with sides washed with brown; throat and middle of belly lighter. Length : j-6, wing 2.70-3.05, tail $2.50-2.90$.

Distribution. - From southeastern Texas west to El Paso, south to eastern Mexico.

Nest. - Often in old woodpecker holes, 4 to 12 feet from the ground, made of wool. inner bark, and snake skin. Eggs: usually 6, white, flecked with reddish brown.

In Uvalde, Texas, I have seen this little Mexican stranger singing on the ridgepole of a village house. His black crest gave him a jaunty, dressed-up air, but withal he was the same winning, fluffy, domestic little body as the rest of his race. He sang a cheery abbreviation of the Peter-Peter of his United States relatives, - a PetePete-Pete-Pete. In the Chisos and Davis mountains, Mr. Bailey found the black-crest one of the most abundant birds of the Upper Sonoran zone, flying about conspicuously among the junipers, nut pines, and scrub oaks.

733. Parus inornatus Gamb. Plain Titmouse.

Adults. - Plain, unmarked; upper parts brownish or olive gray; under

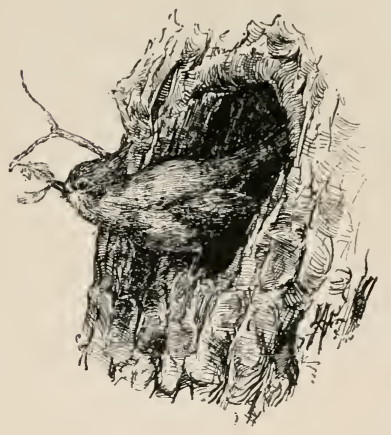

Fig. 5x.-. parts gray, becoming whitish on belly. Young: upper parts washed with brown; under parts ashy white. Length: $5.00-$ 5.60 , wing $2.68-2.90$, tail $2.20-2.60$, bill $.38-.40$.

Distribution. - Resident in Pacific coast region of California and Oregon.

Nest. - In holes of trees or stumps, made of soft felted materials and feathers. Eggs : 6 to 8, plain white.

There is an indefinable charm about the slow, clearly enunciated tu-whit, tu-vchit, tu-rrlit, that echoes through the oaks, telling of the presence of the plain titmouse. Its soft quaker garb and quiet, gentle ways suit well with

the feeling of rest and content that comes under the sun-filled liveoaks. There is a pleasant sense of mystery, too, till one has discovered which particular knot-hole has been intrusted with the safe keeping of the little bird's treasures; and after the discovery there is an added delight in watching them, for the titmouse parents are gentle lovers and most attractive housebuilders.

\section{3a. P. i. griseus Ridgw. Gray 'Titmouse.}

Similar to inornatus. but lighter; upper parts light gray; under parts whitish gray. Length: $5.7 .5-6.10$, wing $2.80-3.00$, tail $2.40-2.70$, bill .40.4s. 
Distribution. - Resident from the Sierra Nevada to Colorado, and south to New Mexico and Arizona.

\section{Parus wollweberi (Bonap.). Bridued 'Timsouse.}

Adults. - Throat and crest black; erown pateh gray; sides of head white, marked or bridled with black; back olive gray; under parts dingy whitish. Young: similar, but throat gray, except for black on chin ; head markings less defined. Length: $4.50-5.00$. wing $2.60-2.80$, tail $2.40-2.65$.

Distribution. - Breeds in Upper Sonoran zone from western Texas to southern Arizona and sonthward to Orizaba, Mexico.

Nest. - As described by Scott, $3 \frac{1}{2}$ to 6 feet from the ground in oaks, cavity lined with cottonwood down, ferns, grasses, and cotton waste. Eggs : 5 to 7, plain white.

The oddly marked little collweberi is an eminently social bird, Mr. Henshaw tells us, going about, except in the nesting season, in

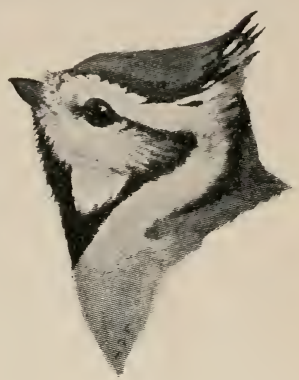

H'ig. 583. flocks of twenty-five or more. It hunts for food largely in oaks, passing along more quietly than other titmice.

\section{Subgenus Parus.}

Not crested.

\section{Parus atricapillus Lim. Chickadee.}

Adults. - Top of head and throat black; back asliy or olive grayish, sometimes tinged with buffy; sides buffy; rest of inder parts white. Young: upper parts dark slate; nuder parts salmon color. faintest on breast. Lenith: $4.70-5.75$, wing $2.5 .5-2.75$, tail $2.50-2.70$.

Distribution. - Breeds in eastern North America north of the Potomac and Ohio valleys and west to westeril Nebraska.

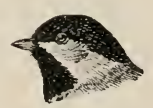

F'ig. 584. Recorded from Fort Sherman, Idaho.

Nest. - In holes in trees or stumps. made of moss. fur. hair, and sometimes feathers. Eggs : 4 to 8, white, spotted with reddish brown and lilac. chiefly around larger end.

Food. - Injurious insects and their eggs, inclnding tent-caterpillars, cankerworms, and plant lice; also seeds and small frinit.

At Fort Sherman, Idaho, the chickadee appears, strangely enough, to be practically identical with the far removed eastern blackcapped.

\section{5a. P. a. septentrionalis (Harris). Long-tailed Chickadee.}

Like atricapillus, but paler; throat, top of head, and nape black; back pale ash, tinged with brownish ; wings with white patch and edgings; tail feathers edged with white; sides of head and under parts white; sides and flauks washed with pale buffy. Length: $4.75-6.00$, wing $2.55-2.80$, tail $2.55-3.00$.

Distribution. - From British Columbia and Lake Winnipeg south over the Rocky Mountain plateau region, and east to the Plains. 
The long-tailed chickadee is common in the mountains of Montana, and in Colorado breeds from 7000 to 10,000 feet, wintering, Prof. Cooke says, on the plains and foothills, occasionally up to 8000 feet. It is sometimes found with flocks of the mountain chickadee, and is also common in willows along streams.

\section{5b. P. a. occidentalis (Baird). Oregon Chickadee.}

Top of head and back of neck glossy jet black, back dark gray, tinged with olive brown; sides of head clear white, in sharp contrast to black of head and throat; median under parts white, contrasting with tawny brown sides. Length : $4.50-5.25$, wing 2.35 -2.60, tail $2.30-2.50$.

Remarks. - The Oregon chickadee differs from the long-tailed in darker coloration and shorter tail.

Distribution. - Northwest coast region from Sitka to northern California.

\section{Parus sclateri Kleins. Mexican Chickadee.}

Top of head and back of neck jet black, sides of head clear white; black of throat spreading fan-shaped over chest; median under parts white, contrasting with dark gray of sides. Length: 4.70-5.20, wing 2.60-2.80, tail $2.2 .5-2.40$.

Distribution. - Mountains of southern Arizona and Mexico to Orizaba.

\section{Parus gambeli Ridgw. Mountain Chickadee.}

Throat and top of head jet black; black of head broken by white superciliary line; sides of head white; back gray; median under parts grasish white; sides dark gray, tinged with light brown. Length : 5.00-5.75, wing $2.70-3.00$, tail $2.40-2.60$.

Distribution. - Breeds in Canadian and Transition zones of the mountains throughout the western United States as far east as the eastern slope of the Rocky Mountains, and from British Columbia south to Lower California.

Nest. - In an old woodpecker hole or natural cavity, 3 to 15 feet from the ground, usually lined with rabbit fur. Eggs: 5 to 9, plain white or spotted with reddish brown, chiefly around the larger end.

The whistles of the mountain chickadee are perhaps the commonest notes heard in the forests of the Sierra Nevada. In the usual forms of the whistle either the one long note is followed by two or three short notes - pha'-de-de or $p h \alpha^{\prime}$-de-de-de, or else the long note stands between the short notes, as de-de-pho'-de-de.

Gambeli is a typical chickadee in all its motions, making short tilting flights from one treetop to another, and clinging upside down to the tips of the branches. It is an unsuspicious little friend, most pleasant to meet in the dark coniferous forests, always ready with a cheery word.

It makes a snug nest in some old woodpecker hole. The female usually sits very close, Dr. Merrill says, and when disturbed 'keeps u1) a constant hissing so much like that of some snakes, that no prudent squirrel would venture to enter the hole.' 


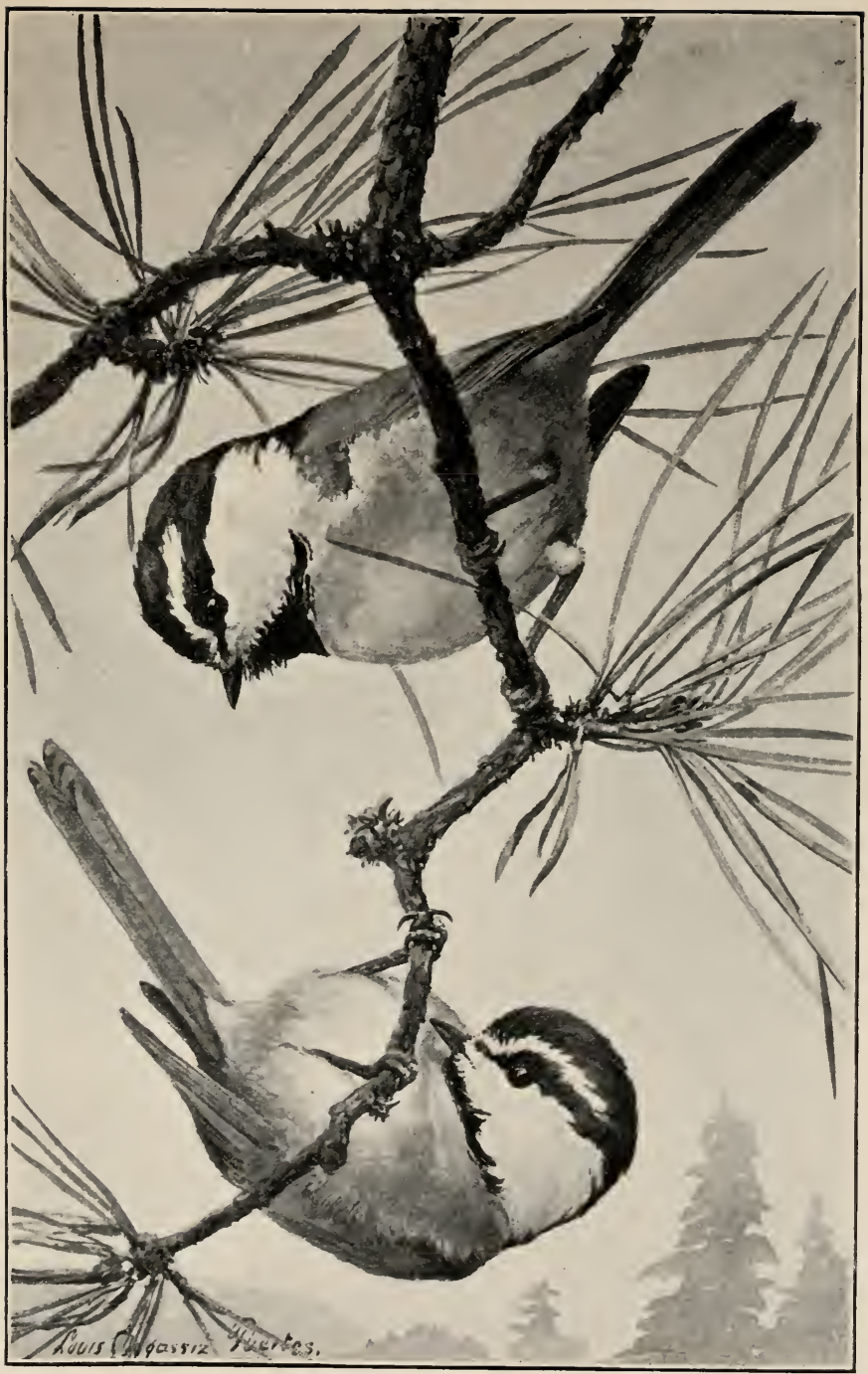

MOUNTAIN CHICKADEE 

740b. Parus hudsonicus columbianus Rhoarls. Columbian Chickadee.

Top of head hair brown; back lighter brown; sides of head white; throat blackish ; flanks dark reddish brown; median under parts whitish. Wing: 2.70 , tail 2.64 .

Distribution. - Rocky Mountains from Liard River south to Montana.

741. Parus rufescens 'Towns. Chestnut-backed Chickadee.

Adults. - Throat blackish brown; top of head and back of neck hair brown; supereiliary black; back, sides, and flanks dark reddish brown; rest of under parts and sides of head white. Young: top of head, back of neck, and throat dark sooty brown; back dnll chestnut, tinged with olive; sides ashy, partly washed with brown. Length: $4.50-5.00$, wing $2.35-2.60$, tail $2.00-2.30$.

Distribution. - From Alaska south to California, east to Idaho.

Nest. - In stub, 12 to 40 feet from the ground. lined with cow hair, rabbit fur, feathers, or moss. Eggs : white, unmarked or minutely spotted with reddish.

At Cape Disappointment, Washington, Mr. Kobbé found the chestnut-backed chickadees affecting preferably the more open woods along roads and trails. They were very common all the year around, especially during the rainy winters, when large flocks of them could be seen scrambling about on the branches of the dripping firs in search of insects. They were often found with Oregon chickadees and golden-crowned kinglets. Their call-note Mr. Kobbé gives as a lisping the-the-the-te-te.

Mr. Walter Fisher found the birds very abundant on MIt. St. Helena in August and September.

\section{4la. P. r. neglectus Ridgw. California Chickadee.}

Similar to the chestnut-backed chickadee, but sides and flanks light grayish, only lightly tinged with brown. Wing: $2.30-2.60$, tail 2.00-2.20.

Distribution. - Coast of California, from Monterey northward.

\section{GENUS CHAMAFA.}

General Characters. - Plımage soft and loose; lores and gape bristled; rounded wings much shorter than graduated tail; bill much shorter than head, stout; nostrils naked.

KEY TO SPECIES.

1. Under parts dark ruddy brown. Coast region of Oregon and California. phæa. p. 460.

$1^{\prime}$. Under parts light pinkish or vellowish brown. California. except northwest coast district . . . . . . . fasciata, p. 459

742. Chamæa fasciata Gamb. PAllid Wrex-Tit. ${ }^{1}$

Upper parts gray, tinged with olive or brown on posterior part; tail

1 Chamora fasciata intermedia Grinnell.

Back and upper tail coverts sepia ; throat and breast cinnamon rufous.

Distribution. - Type locality, Palo Alto, California. (The Condor, ii. 86.) 
long, graduated; nnder parts fawn, buffy brown, or pinkish brown, more or less obscurely streaked with dusky. Wing: 2.37 , tail 3.41 , bill .4:.

Distribution. - Resident in Upper Sonoran Fig. 585 . zone from San Francisco Bay south to northern Lower California.

Nest. - In low bushes, made of twigs and straws mixed with feathers. Eggs : 3 to 5, plain pale greenish blue.

One of the most persistent of the pleasant memories of the chaparral-covered hills of California is that of the bell-like descending kieep-keep-kieep-keep-kieep-it, keep-it, keep-it, of the wren-tit. Scalebird he is well called because of it, for while the song has many variations it always contains a descending scale. But though his voice is continually ringing in your ears the wren-tit is a secretive. mysterious bird like the chat, and you may hunt through the chaparral full many a merry day before you see him run his scale. When you accidentally come face to face with him on his own domains, he makes it appear such a casual meeting in a neighborhood in which he has no interest, that the worldly wise observer is fairly maddened with curiosity and desire to discover his nest.

The appearance and mannerisms of the birds stimulate this interest. They are brown, with light yellow eyes, and long tails which tilt up and down as they fly, and are often held up as they hunt in a wren-like, careful way over the chaparral branches.

742a. C. f. phæa Osgood. Coast Wren-Tit.

Upper parts dark brown becoming sooty on head; under parts dark ruddy brown, indistinctly streaked with dusky.

Distribution. - Resident in Transition zone on coast of Oregon and California from Astoria to Nicasio.

\section{GENUS PSALTRIPARUS.}

General Characters. - Plumage loose; bill much shorter than head; nostrils concealed; wings rounded, shorter than long, graduated tail.

1. Top of head brown.

$$
\text { KEY TO SPECIES. }
$$

2. Top of head sooty brown. Pacific coast region, from northern California to Washingtor . . . . . . . minimus, p. 460.

$2^{\prime}$. Top of head light brown. California. except northern coast district.

$1^{\prime}$. Top of head gray. californicus, p. 461.

2. Sides of head black

2 '. Sides of head brown.

3. Head with blackish streak along side of oceiput.

3'. Head plain bluish gray

santaritæ, p. 462. plumbeus, p. 462 .

743. Psaltriparus minimus (Towns.). Bush-Tiт.

Top of liead sooty brown; back dark grayish browl or brownish gray; 
under parts smoky brownish on sides. Length : 4.00-4.5), wing 1.95, tail 2.20 .

Distribution. - Transition zone of the Pacific coast region from Washington to northern California.

Nest. - Hung in thickets of ash and willow. bulky, purse-shaped, with entrance usually on one side near top; made of mosses, plant fibers. lichens, and feathers. Eggs : 5 to 9 , white, unmarked.

Food. - Black olive seale and other insect food.

In Golden Gate Park, San Francisco, while the white-crowned and golden-crowned sparrows are busy on the lawns, faint notes come from the undergrowth, which on inrestigation prores to be astir with flocks of diminutive bush-tits, though their gray coats disguise them so well that unless you look sharp the oak leaves seem to be merely rustling in the wind. When watched carefully the little balls of feathers are seen

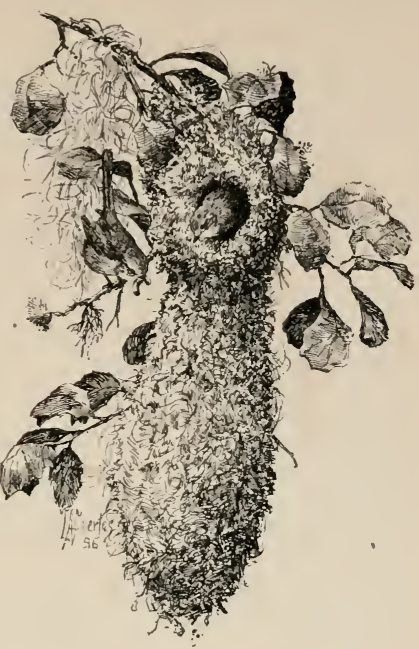

Fig. 586. to be busily looking for insect eggs quite after the fashion of their larger chickadee cousins. Flitting from branch to branch they fly up to light upside down on the underside of a bough, and then without taking the trouble to turn right side up drop down backwards to catch upside down on the tip of another twig, where thes bend double over the terminal buds looking for food.

In southern California, where the California bush-tits breed very abundantly, their long gray hanging nests are common objects as you ride about among the oaks, so common that the birds, which might well be overlooked but for their nests, are known familiarly as 'hang-birds.'

In a nest which came to grief, apparently pulled down by its own weight, I counted over three hundred little feathers in addition to a mass of fine gray moss and oak blossoms.

\section{3a. P. m. californicus Ridgu. Californa Bush-Tit.}

Similar to minimus, but lighter, top of head light brown, contrasting more sharply with light gray of back; under parts light brownish. Length: $4.00-4.50$, wing $1.85-2.10$, tail $2.00-2.30$.

Distribution. - Breeds in Transition and Upper Sonoran zones of California, except along the north coast.

Food. - Black seale, weevils, caterpillars, cocoons, insect eggs, bark lice and large numbers of otler injurious insects. 
744. Psaltriparus plumbeus Baird. Lead-Coloned Bush-Tit.

Upper parts plain bluish gray; sides of head brown; under parts grayish white, faintly tinged with pale brownish on belly. Length: 4.12-4.60, wing $2.00-2.15$, tail $2.35-2.50$.

Distribution. - Upper Sonoran and Transition zones from eastern Oregon and westem Wyoming to Arizona, and from western Texas to California.

Nest. - In Chisos Mountains, Texas, 12 to 15 feet from ground, in a nut pine, a greenish gray bag 6 or 8 inches long, made of lichens, oak flowers, and catkins, woven with cocoon silk. Eggs: 4, white.

When we were working in the Guadalupe Mountains of Texas and New Mexico, while the ant-eating woodpecker was calling and bandtailed pigeons were flying noisily to water, our attention would often be attracted by small voices in the brush, and presently a large flock of the tiny lead-colored bush-tits would swarm in and pass from juniper to juniper and piñon to piñon through camp, disappearing as they came, full of small talk and business.

\subsection{Psaitriparus santaritæ Ridgw. Santa Rita Bush-Trt.}

Similar to plumbeus, bnt smaller, sides of head paler brown, and with a more or less distinct blackish line along sides of oceipnt.

Distribution. - Santa Rita Momtains, sonthern Arizona.

\section{Psaltriparus lloydi Senn. Lloyd Bush-Tit.}

Upper parts gray ; sides of head and partial collar aromd back of head

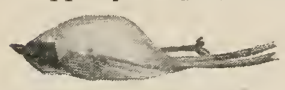

Fig. 587. black; under parts grayish. faintly washed with pale brownish.

Distribution. - Mountains of western Texas, between the Pecos and Rio Grande rivers; south to northern Mexico.

\section{GENUS AURIPARUS.}

\section{Auriparus flaviceps (Sund.). Verdin.}

Bill nearly straight; plmmage compact; wings pointed, decidedly longer than tail. Adult male: head, neck, and chest bright yellow; olive on crown and sometimes orange on forehead; shonlder patch reddish chestmit; rest of npper parts gray; under parts whitish. Adult female: similar, but vellow restricted and duller. Young: withont yellow or reddish brown, and gray of upper parts tinged with brown. Length: 4.00-4.60. wing $1.90-2.12$, tail $1.75-2 .(15)$

Distribution. - Resident in Lower Sonoran zone from sonthern Texas to the Pacific and from sonthern Utah and Nevada to Mexico and northern Lower California.

Nest. - Bulky, globnlar, flask or retort-shaped, the entrance a small romnd hole on one side; composed of sticks. thorny twigs, and coarse grass stems, lined with feathers and down; placed in thorny bushes or low trees. Eggs: :3 to (i, bhinsh or greenish white, speckled, chiefly aronnd larger end, with reddish brown.

The verdin lives in the lower mesquite valleys along the Rio Grande and the Colorado, the Gila and the Pecos rivers, seeming to prefer brushy valleys to open desert. It is an active little body, bobbing 
about in the thorn bushes like a kinglet, scolding and sputtering when you are near its nest. Very much of a stay-at-home little person it is, too, sleeping all the winter nights in the old nests, relined with feathers and hair, or in new ones built for the especial purpose. It shows almost as much anxiety when its winter house is approached as if it contained eggs or young. Poke your finger into the small round hole at the side of the nest early in the morning or after sundown in January, and you will feel a flutter of feathers or get a sharp peck on the fingers to teach you better manners. Even in the breeding season the bird not engaged in incubation spends the nights in a nest not far away, probably an old one used for eggs the previous year.

The song of the verdin seems eren more out of proportion to his inches than his nest, and on following it up you expect to find a big warbler or sparrow instead of such a tiny bird.

I once saw a verdin pick a scarlet lysium berry, and with it grasped firmly in one foot, his tarsus resting across a branch, eat the juicy pulp from around the seeds with more ease and grace than a hawk could boast in picking a sparrow.

Verion Bailey.

\section{FAMILY SYLVIID君: KINGLETS, GNATCATCHERS, ETC.}

KEY TO GENERA.

1. Tail graduated, marked with white . . . . Polioptila, p. 46.5. $1^{\prime}$. Tail emarginate, not marked with wlite . . . Regulus, p. 463.

\section{GENUS REGULUS.}

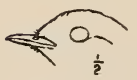

Fig. 588 .

General Characters. - Bill shorter than head, straight, slender; nostrils concealed; wings pointed, longer than emarginate tail; tarsus slender, longer than middle toe and claw, not scaled.

KEY TO SPECIES.

1. Crown marked with black and yellow.

2. Coloration duller . . . . . . . . . Satrapa, p. 463.

2 . Coloration brighter

1'. Crown not marked with black and yellow; male with red crown patel.

2. Upper parts grayish olive . . . . . . calendula. p. 464.

$2^{\prime}$. Upper parts sooty olive . . . . . . grinnelli, p. 465.

748. Regulus satrapa Licht. Golden-Crowned Kivglet.

Adult male. - Crown encircled anteriorly with black, bordered inside by yellow, with a central orange patch; rest of upper parts grayish olive, more olive toward rump ; wings with two whitish bands; under parts dingy whitish. Adult female: similar, but crown pateh wholly yellow. Young: crown patch wanting and head markings obsenred: breast washed with fawn

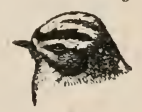

Fig. 589. 
color. Length : $3.15-4.55$, wing $2.10-2.25$, tail $1.60-2.00$, exposed culmen $.25-.30$.

Distribution. - North America generally, breeding in Boreal zone forests of the northern parts of the United States northwara; migrating to Guatemala.

Nest. - A ball-like mass of green moss attached to end of branch in pine or fir; lined with hair and featlers. Eggs : 5 to 10, white or buffy, faintly specked, chiefly around larger end, with deeper buffy.

\section{8a. R. S. olivaceus Baird. Western Golden-Crowned KINGLET.}

Similar to satrapa, but brighter, crown colors sharper, upper parts greener, and under parts more washed with buffy brown.

Distribution. - Pacific coast region of North America from California north ward; migrates to Guatemala.

In the high Sierra one of the notes that you hear most frequently from the impenetrable tops of the highest firs comes apparently from this bit of a kinglet; and as you crane your neck and strain your eyes day after day and week after week in riding under the trees in the vain attempt to see him do it, the rolling notes shape themselves ungrammatically to your aggravated query, vho-be'-you? who-be'-you? who-be'-you? The call-note of the little fellow seems to be a thin $t i$-ti, quite different from the chatter of the ruby-crowned kinglet.

\section{Regulus calendula (Linn.). Ruby-Crowned Kinglet.}

Adult male. - Crown patch bright red; upper parts grayish, brightening to greenish on rump, and with greenish yellow edges to feathers; wings with two narrow whitish bands ; under parts dingy whitish. Adult female and young: similar, but without erown pateh. Length: $3.75-4.60$, wing $2.20-2.30$, tail

Fig. 590. $1.85-1.90$. bill from nostril .20-.22.

Distribution. - North America from the arctic coast to Guatemala; breeds in Boreal zone chiefly north of the United States, and in the Rocky Mountains, Sierra Nevada, and mountains of Arizona; migrates to Guatemala.

Nest. - Semi-pensile, bulky, made of shreds of bark, feathers, and green moss, lined with hair and feathers; attached to end of pine or spruce branch, or placed in the top of a small tree, 10 to 20 feet from the ground. Eggs : 5) to 9, whitish or buffy, faintly spotted, chiefly around larger end, with light brown (sometimes nearly plain).

The scolding chatter of the ruby-crowned kinglet with the plump little figure's lift of the wing, however far overhead, always tells an unmistakable tale. The cheery, busy little chap brings his own welcome in the timber, chatting sociably as he hunts with microscopic care over the twigs and flutters hummingbird-fashion under the green sprays; but when he sings you regard him with a new feeling of wondering admiration, - such a volume of song and such a well-modulated, liquid, ringing melody! 
749a. R. c. grinnelli W. Palmer. Sitkan Kinglet.

Adult male. - Similar to calendula, but smaller and darker; upper parts sooty olive, darkening to blackish along sides of vermilion crown patch; wing with dark parts nearly black; throat and breast dusky gray; belly whitish, tinged with yellowish. Young male: rich brownish olive, much darker than corresponding calendula, and under parts brighter. Wing: 2.17 , tail 1.70 , bill .16.

Distribution. - Sitka district, Alaska ; migrating south to California.

\section{GENUS POLIOPTILA.}

General Characters. - Bill shorter than head, broad and flattened at base, narrowing to slender notehed and hooked tip; nostrils exposed; wings rounded; tail graduated; tarsus scaled; toes short, side ones only about half as long as tarsus.

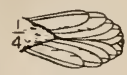

Fig. 591.

\section{KEY TO SPECIES.}

1. Outer tail feather with exposed portion entirely white.

2. Crown light bluish gray. From Colorado east. cærulea, p. 405

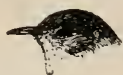

Fig. 592 .

2'. Crown dark bluish gray. Western Texas to California.

$1^{\prime}$. Outer tail feather with exposed portion partly black.

obscura, p. 466.

2. Outer tail feather with outer web entirely white.

Fig. 593 .

plumbea, p. 466 .

2'. Outer tail feather with outer web black, edged with

Fig. 594. white. Southern California . californica, p. 466.

\section{Polioptila cærulea (Linn.). Blue-gray Gnatcatcher.}

Adult male. - Upper parts bluish gray, brightest on crown, fading to lighter on runp; forehead and line over eye black: tail black with exposed part of outer feathers entirely white; inder parts white washed with bluish on sides. Adult female and young: similar, but duller, and without black on head ; young with upper parts washed with einnamon. Length: $4.05-5.50$, wing $2.00-2.20$, tail $2.05-2.20$.

Distribution. - Breeds in Upper Sonoran zone in the eastern and central United States west to Colorado and western Texas ; winters from the southern Atlantic and Gulf states to Guatemala. Cuba, and the Bahamas.

Nest. - In trees. cup-shaped,

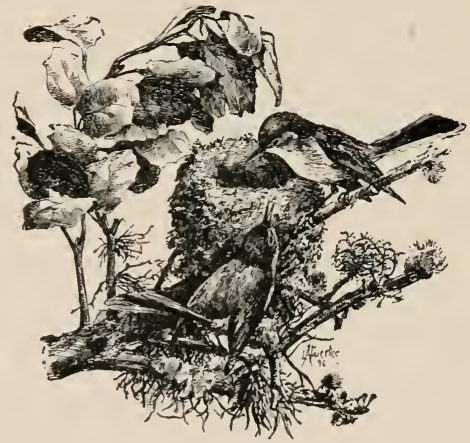

Fig. 595. 
compact, made of leaves, feathers, and plant fibers, and decorated with lichens. Eygs : 4 or 5, pale greenish white, spotted with reddish brown, lilac, and slate, confluent around larger end.

The gnatcatchers are active, high-strung little sprites, never still a minute, but going about whipping their tails from side to side, cocking their heads over to look up or gaze down, and crying tsang', tsang', here' I am, here' I am, with nervous emphasis, talking to themselves when no one is by. They are most entertaining birds to watch, always saying or doing something original, jaunty individual scraps, full of their quaint airs and graces.

With all their airs they are most painstaking, skillful builders, and parents who know no fear, flying boldly at the big birds who molest them and driving them off with good set blows.

\section{1a. P. c. obscura Ridgw. Western Gnatcatcher.}

Similar to cerulea, but darker, less blue above, and black supereiliary less distinct; white on tail feathers more restricted.

Distribution. - Western Texas and New Mexico to Arizona, California. Lower California, and Mexico.

Nest. - As described by Nelson, in a bush 3 feet from the ground, made of shreds of bark lined with finer shreds and feathers. Eggs: 4 or 5, marked with reddish brown and purplish, most heavily around larger end.

\section{Polioptila plumbea Baird. Plumbeous Gratcatcher.}

Aduit male. - Top of head glossr blue black. in sharp contrast to light

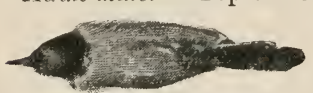

Fig. 596. gray of back; tail black, outer tail feather with outer web entirely white, inner web tipped with white; under parts white. washed with bluish gray on sides. Adult female and young: similar, but without black on head, and gray of back sometimes washed with brownish. Length: $4.25-4.60$, wing $1.90-2.00$, tail 2.15-2.25.

Remarks. - The plumbeous and black-tailed gnatcatchers may be distinguished by the outer web of the outer tail feather. which in the blacktailed is black edged with white; in the plumbeous. wholly white.

Distribution. - Breeds in Lower Sonoran zone from western Texas to the eastern edge of the Mohave Desert; south along eastern coast of Lower California.

Nest. - One near Terlingua, Texas, in fouquiera bush, made of gray fibers of wood and bark, wound with spider web, and lined with cactus wool. Eggs : 2, pale blue, spotted with brown, most thickly around larger end.

The small bluish figure of plumber is a familiar sight in the brushy canyon mouths of the Guarlalupe Mountains in Texas and in the orchard-like juniper and pinon pine tops of the mountains.

\section{Polioptila californica Brevst. Black-tailed Gnat- CATCHER.}

Adult male. - Crown black; rest of upper parts dark gray; tail black, outer feather with outer web bluck edged with white, and inner web narrowly 
tipped with white; under parts gray, tinged with brown on lower belly. Adult female: similar, but without black on head. Young: like female, but with browner wash and black of adult male appearing gradually. Length: $4.15-4.50$, wing $1.90-2.00$, tail $2.15-2.25$.

Distribution. - From sonthern California along the Pacific coast of Lower California.

Nest. - As described by Anthony, in fork of a weed, $2 \frac{1}{2}$ feet from the ground, made of shreds of weeds and grass stalks lined with rabbit hair. Eggs: 4, bluish green, lightly spotted and wreathed around larger end with reddish brown.

\section{FAMILY TURDIDÆ: THRUSHES, SOLITAIRES, BLUE- BIRDS, ETC.}

KEY TO GENERA.

1. Plumage largely or wholly blue

Sialia, p. 475 .

1 . Plumage largely gray or brown.

2. Under parts reddish or yellowish brown.

3. Cliest with a dark band . . . . . . Ixoreus, p. 473.

3 . Chest without dark band . . . . . . . . Merula, p. 472.

$2^{\prime}$. Under parts white, buffy, or grayish.

3. Tail white basally, black terminally . . . Saxicola, p. 475.

3 '. Tail not white basally or black terninally.

4. Wings with two light bars

4 '. Wings plain.

Myadestes, p. 467. Hylocichla, p. 468 .

\section{GENUS MYADESTES.}

\section{Myadestes townsendii (Aud.). Townsend Solitaire.}

Bill short, flattened. widened at base, deeply cleft; legs weak; tail feathers tapering. Adults: brownish gray, paler beneath; wings with two whitish wing bars, bases of primaries and secondaries buffy or yellowish brown; tail feathers with outer web and tip of inner web grayish white.

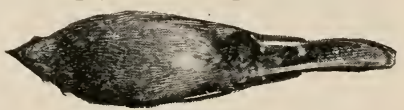

Fig. 597. Young: wings and tail as in adult; rest of plumage, including wing coverts, conspicuously spotted with buff. Length: 7.80-9.50, wing 4.35-4.85, tail $4.15-4.70$.

Distribution. - Breeds in monntains mainly in Canadian zone from British Columbia south to Zacatecas, Mexico, and from the Black Hills to the Pacific; winters south to southern Arizona and northern Lower California.

Nest. - On the ground. on logs or stumps, on banks of streams or among rocks, bulky, made largely of sticks and pine needles. Eggs: 3 to 6, whitish, spotted with reddish brown.

The name Myadestes is associated with the choicest spots of the mountain heights. In the Sierra Nevada we found the birds on their nesting ground on the granite knob above Donner Pass, at 7900 feet. They evidently had a nest somewhere along a steep, wooded stream bed, which was flanked with bare granite, from which woodchucks whistled and conies barked. But while nutcrackers, Richardson 
pewees, green-tailed chewinks, and mountain song sparrows made themselves conspicuous, the pair of solitaires were too conscious of intruders to give any information. The male, who suggested a meek mockingbird, guarded the brook in an aggravatingly non-committal way, perching on dead branches or flying to the ground, where he ran over the rocks with the run-and-halt motion of a robin, or sat on a stone quivering his wings slightly at his sides. His mate would sometimes slip away from the nest and appear on a branch by his side, and once I followed the pair over the boulders and up the cliff, thinking they had gone to their nest in some other place, only to be led back over the rocks to their little brook under the evergreens. Then. as the setting sun lit up the tops of the hemlocks that stood by the brook, turning their yellow lichen-covered branches to golden arms, the solitaire, perched on a sunlit branch, sang a low evening song in the mellow light. At other times, and when not on guard, the bird's song would fairly ring through the air. When given freely it is a strong, clear song with a flavor all its own. Heard from the tips of the highest trees on the crest of the range, as it so often is, the song has the freshness and invigoration of the air from the snow-banks, and is given with the strong freedom of the mountain tops. In the rocky solitudes of the Garden of the Gods it is said that the solitaire's voice is sometimes all that breaks the silence.

\section{GENUS HYLOCICHLA.}

General Characters. - Bill slender, but widened and flattened at base, notched near end; tarsis decidedly longer than middle toe and claw.

\section{KEY TO SPECIES.}

1. Sides as well as breast heavily spotted; head golden brown. Eastern United States . . . . . . . . mustelina, p. 469. 1'. Sides gray or brown, unspotted; head not golden brown.

2. Eve withont distinet lighter orbital ring.

3. Upper parts and cheeks dark gray. Migrant in Rocky Mountains.

aliciæ, p. 469.

:'. Upper parts and cheeks light brown. Rocky Mountain region.

2'. Eye with distinct white or buffy eye ring. salicicola, p. 469 .

3. Chest marked with narrow triangular spots.

4. Upper parts olive brown. Pacific coast region.

ustulata, p. 470 .

4'. Upper parts olive gray. Oregon and California. œdica. p. 470. 3'. Chest marked with wide triangular spots.

4. Tail rufous in sliarp contrast to back.

5. Tail dark rufous; length 6 to 7 .

6. Lighter. Breeds mainly north of United States; migrates to Colorado and Texas . . . . . guttata, p. 471.

6'. Darker. Breeds from Washington to Sierra Nevada; migrates to Arizona and Mexico . . . . nana, p. 472. 
5 5'. Tail light rufous; length 7.50-8.25. Rocky Mountain region.

4'. Tail not sharply contrasted with back. auduboni, p. 471 .

5. Upper parts olive. Migrant in Colorado and Texas.

5'. Upper parts hair brown. Alaska and Rocky Monntains.

swainsoni, p. 470 .

almæ, p. 471 .

\section{Hylocichla mustelina (Gmel.). Wood Thrush.}

Adults. - Head and back of neck rusty or golden brown, fading to olive on rump and tail ; under parts white, marked with large blackish wedge-shaped spots. Young : like adults, but feathers of erown streaked with buff; wing coverts tipped with rnsty yellow triangnlar spots; breast washed with brownish yellow. Length:

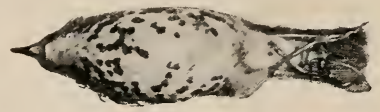

Fig. 598 . 7.50-8.2.5, wing 4.10-4.50, tail 3.00-3.30, exposed cnlmen .62-.75.

Distribution. - Breeds in the Upper Sonoran and Transition zones of the eastern central United States west to western Kansas; migrates to Cuba and Guatemala.

Nest. - Usually saddled on a horizontal branch of a small tree, very compact, composed partly of mud. Eggs: 2 to 5, plain greenish blue.

Food. - Partly ants, beetles, millipeds, and berries.

\section{6a. Hylocichla fuscescens salicicola Ridgw. WILlow Thrush.}

Upper parts uniform olive brown, chest pale buffy, marked with triangular brown spots ; median under parts white, sides gray. Length: 6.90-7.90, wing $3.50-4.25$, tail $2.95-3.40$, bill $.55-.60$.

Distribution. - Breeds in Transition and Canadian zones from Hudson Bay and British Columbia south through the Rocky Mountain region to southern Colorado, east to the Dakotas and Newfoundland, and oceasionally to Illinois; winters south to southern Brazil.

Nest. - On or near the ground, made largely of leaves. Eggs: 4, plain greenish blue, very rarely with a few specks of brown. fruit.

Food. - Caterpillars. ants, and other insects, with wild berries and

In Montana, Mr. Williams says, salicicola is the commonest and most widely distributed of the thrushes, ranging from the lower valleys to the foothills and canyons, but keeping near water in thickets of willow, rose, or box elder, away from the heavy timber. Its notes are the same as those of its eastern representative, the veery, who has the curious bleating call, the quiet whistle vchee-ough, and the tremulous beautiful song.

\section{Hylocichla aliciæ (Baird). Gray-cheeked Thrush.}

Upper parts grarish olive; sides of head gray; chest buffy, with wedgeshaped spots of brown; median under parts white; sides olive grar. Length: $7.00-7.75$, wing $3.75-4.40$, tail $2.95-3.40$, bill .45-.58.

Remarks. - In general coloration the gray-cheeked resembles the olivebacked, but it lacks the buffy eye ring and tawny wash on sides of head.

Distribution. - Breeds north of the United States from the aretic coast, Siberia, and Alaska, southeast through Hudson Bay region to Labrador; 
migrates through the United States west to the Rocky Mountains and south to Costa Rica.

Nest. - In low bushes or on the ground, bulky, and compact, composed largely of mosses. Eggs: 3 or 4 , greenish blue, spotted with rusty brown.

\section{Hylocichla ustulata (Nutt.). Russet-Backed Thrush.}

Upper parts olive brown, wings and tail often browner; buffy eye ring distinct; sides of head tinged with tawny; chest pale buff, whitish in summer, marked with narrow triangular spots; under parts white, sides tinged with olive brown. Length: $6.90-7.60$, wing $3.60-4.00$, tail $2.80-$ 3.30 , bill .50-.60.

Remarks. - The ustulata group is distinguished by conspicuous buffy eye ring and tawny or buffy cheeks; and ustulata and its subspecies odica and almo are to be distinguished from swainsoni by their brown tails, that of suainsoni being olive like the back.

Distribution. - Breeds in Boreal and Transition zones of the Pacific coast region from Alaska to California; winters in Lower California and from Mexico to Guatemala.

Nest. - In bushes or small trees, usually near water, bulky and compact, made largely of mosses and shreds of bark. Eggs : 4 or 5, light greenish blue, averaging decidedly paler than those of alicice, spotted with rusty browl1.

Food. - Ants, caterpillars, weevils, beetles, moths, and other insects, with small fruit.

At Gray's Harbor, Washington, Mr. Lawrence says, the russetbacked thrush is very common throughout the river-bottoms, and common on the small prairies and in the timber. It comes about the time the salmon berry bushes blossom, and goes when their berries are gone.

\section{8a. H. u. swainsoni (Cab.). Olive-Backed Thrush.}

Upper parts uniform olive or grayish olive; buffy eye ring conspicuous; sides of head buffy, marked with darker; chest bright buff, marked with wide blackish streaks; under parts white, sides olive brown. Length: 6.35-7.55, wing $3.80-4.10$, tail $2.80-3.10$, bill .50-.5う.

Remarks. - The olive-backed is distinguished from the rest of the ustulata group by having the tail of the same or nearly the same color as the back, and by its darker and broader chest streaks. It is also distinguished from the gray-cheeked by its buffy cheeks and buffy eye ring.

Distribution. - Breeds in Canadian zone in eastern North America; migrates to Cuba and through Colorado and Texas, south to Guatemala and South America.

Nest and eggs. - Like those of the russet-backed thrush.

Food. - Among other things, caterpillars, rose hips, and the fruit of smilax and hackberry.

\section{8b. H. u. œdica Oberh. Monterey Thrush.}

Similar to swainsoni, but olive of upper parts somewhat tinged with brown, tail and tail coverts brown, and sides and flanks browner. Compared with ustulata, odica is much less rufous.

Distribution. - Breeds from the interior of southeru Oregon sonth through California, except along the northern coast; winters in Arizona and Mexico. 


\section{8c. H. u. almæ Oberh. Alma Thrush.}

Similar to suainsoni, but grayer, especially on rump and upper tail coverts; the npper parts hair brown, only lightly tinged with green instead of being clear olive, and the tail partly clear brown and partly miform with back.

Distribution. - Yukon Basin sonth to the Rocky Mountain region of the United States, west to Utalı and eastern Nevada; in winter south to Mexico.

\section{Hylocichla guttata (Pallas). Alaska Hernit Thresh. ${ }^{1}$}

Upper parts dark grayish brown, more olive in winter, tail deep rufous; chest thickly marked with broad, wedge-shaped spots. Length: 6-7, wing $3.25-3.30$, tail $2.60-3.00$, bill $.45-.52$.

Remarks. - The Alaska hermit thrush can be distinguished from the Audubon hermit by its smaller size and darker coloration.

Distribution. - Northwest coast region from Alaska to southern British Columbia, and southward in winter.

Nest. - On ground in damp or swampy woods, composed largely of dead leaves and dried grasses. Eggs : 4 or $\check{5}$, plain greenish blue, paler than in the wood and willow thrushes.

Food. - Flies, weevils, ants, caterpillars, moths, pepper berries, and small fruits.

The hermit thrushes have a marked habit of raising and lowering their reddish tails, and their call-note is a single chuck. As a group their songs rank as the best of the rare thrush songs.

\section{9a. H. g. auduboni (Baird). Audubon Hermit Thrush.}

Similar to guttata, but larger, and upper parts lighter, grayer, with rufous of tail much lighter (fulvous). Length: 7.50-8.25, wing $3.65-4.35$, tail 2.95-3.45, bill .5. -.60 .

Distribution. - Rocky Mountain region, from near the northern border of the United States south to Guatemala; east to Texas and west to the mountains of Arizona and sonthern Sierra Nevada in California.

Nest. - In bushes or low trees, 3 to 10 feet from the ground; partly uade with moss.

Food. - Flies, ants, weevils, and other insects and berries.

As you travel through the spire-pointed fir forests of the western mountains, you know the thrush as a voice, a bell-like sublimated voice, which, like the tolling of the Angelus, arrests toil and earthly thought. Its phrases can be expressed in the words Mr. Burroughs has given to the eastern hermit, 'Oh, spheral, spheral! oh, holy, holy!' and the first strain arouses emotions which the regularly falling cadences carry to a perfect close. The fine spirituality of the song, its serene uplifting quality, make it fittingly associated with nature's most exalted moods, and it is generally heard in the solemn stillness of sunrise, when the dark fir forest is tipped with gold, or

1 Hylocichla guttata slevini Grinnell. Monterey Hermit Thrush.

A pale ashy form ; upper parts hair brown; upper tail coverts and tail isabella color ; spots on breast few and small.

Distribution. - Breeds in humid coast belt of California from southern Monterey County to Sonoma County. (The Auk, xviii. 259.) 
in the hush of sunset, when the western sky is aglow and the deep voice rises from its chantry in slow, soul-stirring cadences, high-uphigh-up, look-up, look-nl).

\section{9c. H. g. nana (Aud.). Dwarf Hermit 'Thrush.}

Like guttata, but color darker and richer; upper parts brownish olivaceous, tending toward raw umber; top of head and rump browner than back; upper tail coverts and tail burnt umber; under parts more buffy than in guttata. Wing: 3.25 , tail 2.75 , bill .50, tarsus 1.12 .

Distribution. - Pacific coast region, from Washington southward, breeding south to Sierra Nevada region; east in migrations to Nevada and Arizona, and south to Lower Califormia and western Mexico.

\section{GENUS MERULA. ${ }^{1}$}

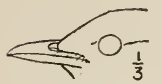

Fig. 599.

General Characters. - Bill slender and compressed, notched near end; nostrils wholly exposed; tail more than three times as long as tarsus; under parts spotted in young.

\section{KEY TO SPECIES.}

1. Outer tail feather with distinct white spot at tip of inner web; colors darker. . . . . . . migratoria, p. 472. $1^{\prime}$. Outer tail feather without distinct white tip to inner web; colors paler. propinqua, p. 472.

\section{Merula migratoria (Linn.). Roвın.}

Like $\boldsymbol{M}$. m. propinqua, but outer tail feather with a distinct white spot

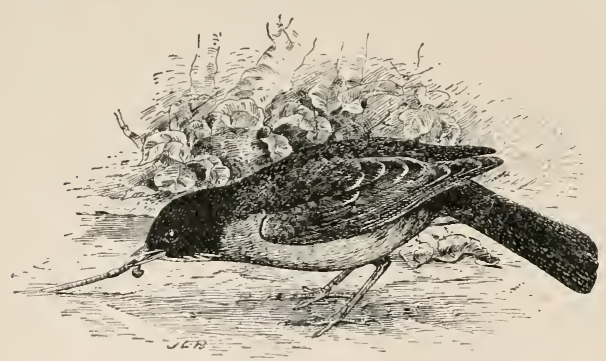

Fig. 600 . at tip of inner web; anterior portion of back usually somewhat clouded with black in fully adult birds. Length : 9-10, wing $4.90-5.40$, tail $4.10-4.50$, bill .85-.92. Distribution.Breeds from Alaska and the arctic coasts southeast through Hudson Bay region and the Rocky Momntains to Kansas, Vir-

tic coast; winters from sonthern Canada southward. ginia, and the Atlan-

Nest and eggs. - Like those of M. m. propinqua.

Food. - Crickets, grasshoppers, and other noxious insects, seeds, wild fruit, and berries.

761a. M. m. propinqua Ridgw. Western Robin.

Adults. - Head, wings, and tail blackish; rest of upper parts slaty

1 A specimen of Merula confinis was taken by Mr. Emerson at Haywards, Cal., in January, 1882. (Zoe, i. 46.) 
gray, black of hind neck sharply contrasting with gray of anterior part of $b a c k$; outer tail featlier without distinct white tip, often with no white; throat black. streaked with white ; rest of under parts, except tail coverts, rufous; in female paler and duller. In winter: upper parts tinged with brown; under parts with feathers edged with wlite. Young: under parts spotted; upper parts streaked with white. Young in first winter: liead and neck brownish gray, like upper parts; rufous of breast paler, more olivaceous. Length: $10-11$, wing $5.20-5.70$, tail $3.80-4.70$, bill .85-.95.

Distribution. - Breeds in Transition and Boreal zones in the western United States from the eastern base of the Rocky Momintains to the Pacific, and from British Colmmbia south to Lower California and Oaxaca, Mexico.

Nest. - On prairies, on the ground. and. in timber, near the ground; compact and bulky, made of leaves, stems, twigs, and grasses, plastered together with mud, and lined with fine stems and rootlets. Eggs : usually 4 , greenish blue.

Food. - Largely ants, caterpillars, grasshoppers, and the injurious large. black crickets; also hackberry, mistletoe and pepper berries, and other small fruit.

In the east the robin is the familiar bird of the dooryard, like the mockingbird of the south, or the brown chippie, the house finch, and the lark sparrow in parts of California. But in the west he nests in the mountains or far north, and when seen in winter is shy and nervous. Flocks are sometimes seen eating ivy berries in the cemeteries of San Francisco, but are so timid they hide in the brush in great trepidation on the approach of man.

The robin song, one of the most familiar and best loved of the east, is not often heard, but in southern California during the spring migration I have seen flocks of twenty birds in an oak top singing their soft evening song, and at Stanford I once heard a wonderful robin chorus equal to the best daybreak chorus one hears in the east.

In the Sierra as in the mountains of New Mexico and Arizona, in both Transition and Canadian zones, the robins breed abundantly, and as you pass are seen shaking their tails as they chirrup in their old familiar way. In the neighborhood of Lake Tahoe we found large numbers of them gathered in a field alive with grasshoppers, and they were running about in all directions, tipping forward to catch the insects in characteristic manner.

\section{GENUS IXOREUS.}

General Characters. - Like Merula, but bill not notehed.

KEY TO FEMALES.

1. Browner, with white markings restricted. Sitkan district.

$1^{\prime}$. Grayer, white markings more extensive. Interior Alaska.

nævius, p. 473.

meruloides, p. 474 . 


\section{Ixoreus nævius (Gmel.). VARIEd Thrush.}

Adult male. - Under parts bright rusty brown, throat crossed by blackish necklace; belly mixed white and gray; upper parts dark bluish slate, feathers edged with lighter; wings banded and edged with brown; side of head black, bordered above by brown streak. Adult female: similar, but much duller; upper parts washed with brown - deeper in winter and collar obscured by brown feathers. Young: like female, but duller; collar less distinct, and more or less spotted with yellowish brown; feathers of breast edged with dusky and those of upper parts with ${ }^{4}$ distinct paler shaft streaks. Length: 9-10, wing 4.90-5.20, tail about $3.60-3.80$, bill about 1.

Distribution. - Breeds in Boreal zone along the Pacific coast from Bering Strait to Humboldt County, Cal.; winters from Washington to Lower California.

Nest. - Compact and bulky, in bushes and small trees. Eggs : 4, pale greenish blue, sparingly speckled with brown.

Food. - Caterpillars, weevils, ants, millipeds, mast, and wild berries.

The varied thrushes reach California in November, and flocks of the splendid beauties, with orange breast and dark necklace, may be seen in winter in the arboretum at Stanford and other places where California holly berries are to be found. The birds are also especially fond of manzanita berries. In Placer County, Mr. Williams says, they live on insect food in winter, and are extremely shy, rarely leaving the dark, heavily wooded canyons or hillsides. In Oregon, Mr. Anthony tells us they are timid on their first arrival, but grow tame enough to visit the ranches. They leave California in March, and at that time Dr. Mearns found them abundant and tame at Fort Klamath, coming about the houses fearlessly in great numbers.

Mr. Fuertes, in describing the song of the varied thrush as he heard it in Alaska, says that it is "most unique and mysterious, and may be heard in the deep still spruce forests for a great distance, being very loud and wonderfully penetrating. It is a single longdrawn note, uttered in several different keys, some of the highpitched ones with a strong vibrant trill. Each note grows out of nothing, swells to a full tone, and then fades away to nothing until one is carried away with the mysterious song. When heard near by, as is seldom possible, the pure yet resonant quality of the note makes one thrill with a strange feeling, and is as perfectly the voice of the cool. dark, peaceful solitude which the bird chooses for its home as could be imagined. The hermit thrush himself is no more serene than this wild dweller in the western spruce forests."

\section{3a. I. n. meruloides (Swains.). Pale VAried Thrush.}

Adult female. - Nimilar to female novius, but grayer and paler, white markings more extended, wing longer, more pointed.

Distribution. - Breeds in interior of northern Alaska; migrates to southern California. 


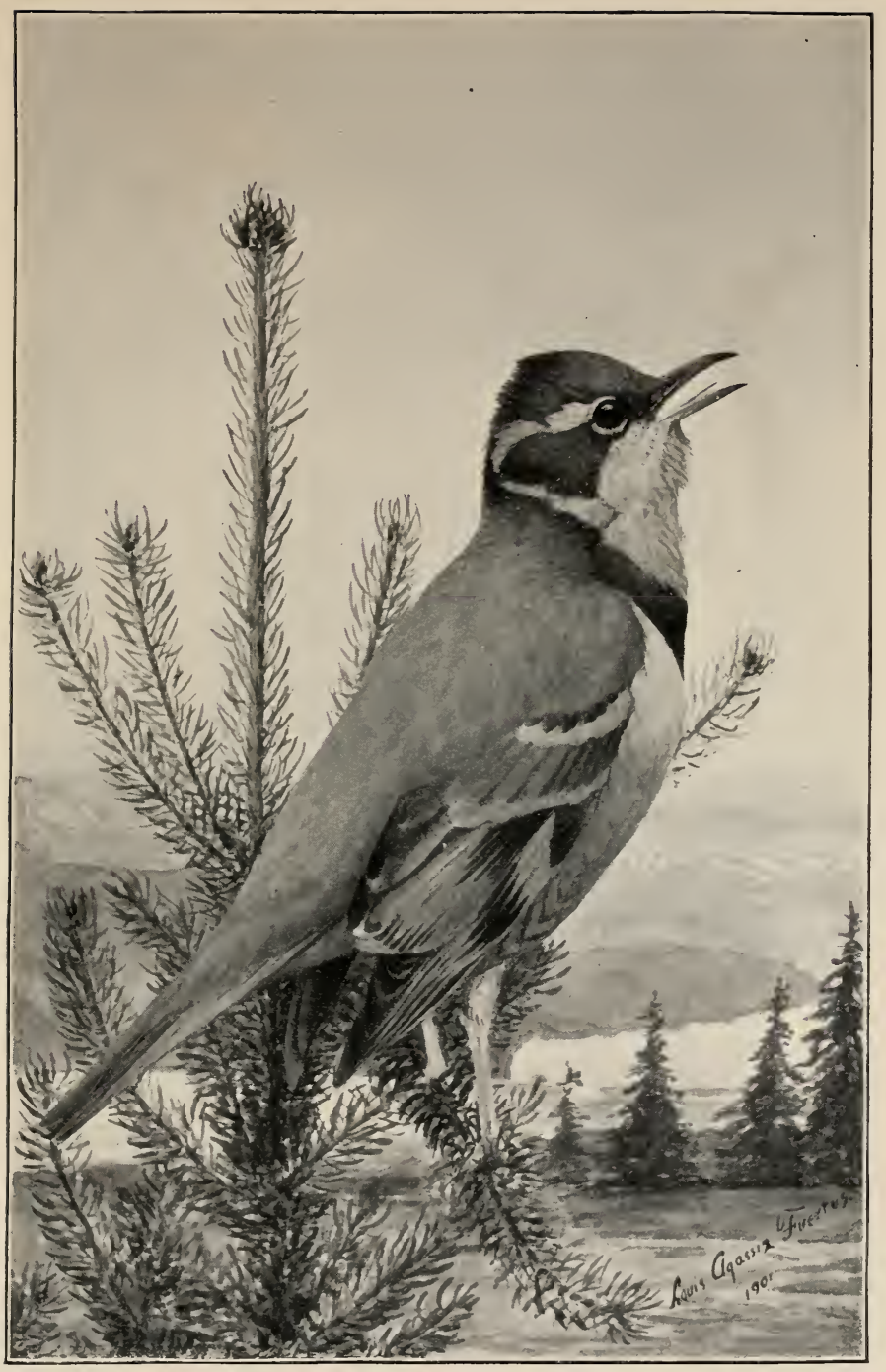

VARIED THRUSH 



\section{GENUS SAXICOLA.}

765. Saxicola œnanthe (Linn.). Wheatear.

Adult male. - Upper parts ash gray; wings and terminal third of tail black; basal two thirds of tail, except middle feathers, white; forehead, supereiliary, and upper tail coverts, white; side of head with black stripe; under parts buffy anteriorly, white posteriorly. Idult female: duller, black replaced by dusky. Winter plumage: upper parts brown; white on tail as in summer; wings with lighter edgings; under parts rusty buff; side of head without distinct streak. Young: like female, but feathers with dark bars and pale centers at tip. Male: wing 3.58-3.98. Female: wing $3.54-3.90$.

Distribution. - Breeds in Alaska; migrates to Asia ; accidental in Colorado.

Nest. - Among rocks and stone walls, made of grasses, lined with feathers. Eggs: 3 to 6, pale greenish blue.

A specimen of the wheatear was taken at Boulder, Colorado, by Hinot, in 1880.

\section{GENUS SIALIA.}

General Characters. - Bill not more than half as long as head, notched near tip; feet short and stout; tarsus not longer than middle toe; side toes unequal; claws strongly curved.

KEY TO ADULT MALES.

1. Under parts without blue.

2. Sides of neck blue. Rocky Mountains to Atlantic . sialis, p. 475.

2 '. Sides of neck brown. Southern Arizona . . . . azurea, p. 476.

$1^{\prime}$. Under parts with blue.

2. Under parts wholly blue and white. . . . . arctica, p. 476.

2 '. Under parts blue and brown.

3. Back wholly chestnut . . . . . . . bairdi, p. 476 .

$3^{\prime}$. Back blue in middle, chestnut on sides . occidentalis. p. 476 .

766. Sialia sialis (Linn.). Bluebird.

Adult male. - Upper parts bright blue; under parts reddish brown. fading to white on belly. In winter, feathers of back bordered with brown. Adult female: upper parts gray, deepening to blue on rump, wings, and tail; under parts dull brown, becoming whitish on belly. Young: upper parts dark gray, streaked with white; under parts gray, spotted with white. Male: length 5.70-7.00, wing, $3.90-$ 4.15 , tail $2.60-2.90$, bill $.62-.67$. $\mathrm{Fe}-$ male : wing $3.80-3.90$, tail $2.50-2.60$.

Distribution. - Breeds in Transition and Upper Sonoran zones from Manitoba and Ontario south to Gulf of Mexico, and from the Atlantic to the

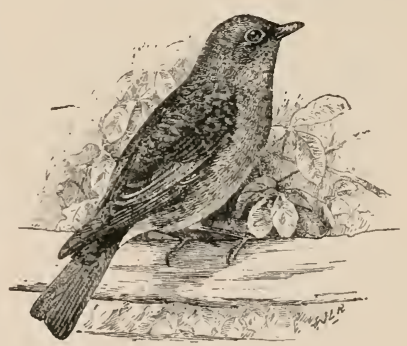

Fig. 601. Rocky Mountains; winters from the middle states to the Gulf states and Cuba. 
Nest. - In holes in trees, stumps, posts, or bird-boxes; made largely of dried grasses. Eggs: 4 to 7 , plain pale greenish blue.

Food. - Largely caterpillars, grasshoppers, and crickets; also wild berries, like hackberry and woodbine.

The eastern bluebird ranges west to the base of the Rocky IIountains, being a rare summer resident in Colorado.

\section{6a. S. S. azurea Baird. Azure Bluebird.}

Similar to sialis, but sides of neck brown, and under parts less ruddy brown; upper parts sometimes greenish blue, suggesting arctica. Length: 6.40-7.10. Male: wing 4.05-4.20, tail 2.70-2.95, bill .4- -.50 . Female: wing 3.90 , tail 2.55 .

Distribution. - Southern Arizona and Mexico.

\section{Sialia mexicana occidentalis (Towns.). Westerx Blue-} BIRD.

Adult male. - Upper parts dark purplish blue and chestnut; throat purplish blue; breast dark rufous; rest of under parts mixed brown, dull purplish and gray. Adult female: head, neck, and upper parts gray, washed with brown on back; rump and tail bright blue; outside tail feathers edged with white. Young: like young of sialis, but bill slenderer. Male: length $6.50-7.12$, wing $3.95-4.45$, tail $2.62-3.05$, bill .45-.50. Female: wing about 4 , tail 2.50 .

Distribution. - Breeds in Transition zone of the Pacific coast. from British Columbia to California. and east to western Nevada and Idaho; casually during migrations to New Mexico.

Nest. - In woodpecker hole high in a pine or other tree. Eggs: (1 set) i, pale blue.

Food. - Largely caterpillars ; also crickets, weevils, ants, moths, locusts, and grapes in winter months when insect food is less abundant.

The western bluebird is often seen on roadside fences from which it flies down to pick up insects. In the pine woods it sits close to the tree trunks on short broken-off branches. It has the soft warble of its kind, and the delicate bluebird way of lifting the wings while perching.

\section{7a. S. m. bairdi Ridgw. Chestnut-backed Bluebird.}

Similar to occidentalis, but back wholly chestnut.

Distribution. - Transition and Canadian zones of the Rocky Mountain district, sonth to Arizona, Texas, and northwestern Mexico.

Food. - Partly grasshoppers, weevils, crickets, and sumac berries.

The chestnut-backed bluebird extends east as far as Pueblo, Colorado, during migration, and breeds from the base of the foothills up to 9500 feet.

\section{Sialia arctica Swains. Mountain Bluebird.}

Adult male.-Upper parts light purplish blue or greenish blue; under parts pale greenish blue. In winter color dulled by dull brownish tips to feathers above and below. Adult female: npper parts brownish gray, wings and tail bright blie; under parts fawn color, with blue showing through. 
Young: brownish or grayish, streaked with white; wings and tail blue. Male: length $6.50-7.90$, wing $4.60-4.80$, tail :3.00-3.15. Female: length $7.00-7.20$, wing about 4.25 , tail $2.75-2.90$.

Distribution. - Breeds in Boreal zone, chiefly in the interior from Great Slave Lake south to New Mexico, and from the western part of the Plains to the Pacific.

Vest. - In old woodpecker hole; among rocks or about houses. Eggs : 5 to $T$, pale greenish blve.

Food. - Largely crickets, also cicadas, grasshoppers, auts, weevils, and, in winter, unpicked grapes and seeds of mistletoe and hackberry.

The exquisite coloring of the arctic bluebird makes it seem the gentlest, most beautiful of all the lorely bluebirds.

In the Sierra Nevada in August, families of young are common in the Murray pine meadors. The birds hunt largely in the open, and are in the habit of horering a few feet from the ground as they look about for insects. In Colorado, Prof. Cooke says, the birds wander up above timberline to at least 13,000 feet. 



\section{APPENDIX.}

For the use of beginners who do not collect and have not access to collections of skins, and who may consequently find the technical keys difficult, the following color key has been made to the more conspicuous birds one meets in the field. Its use by any one who has skins to consult is earnestly deprecated, as it is much better to work a little harder and learn more - to begin at the beginning, with 'Keys to Orders,' and follow through to the species, so learning something of the classification of birds, something of their fundamental relations, rather than to find their mere names arbitrarily by the use of purely superficial characters.

\section{FIELD COLOR KEY TO GENERA OF SOME OF THE COMMION PASSERINE BIRDS.}

(All birds preceding the Order Passeres are omitted, including all the water birds, grouse, quail, turkeys, doves, hawks. owls, cuckoos, kingfishers, woodpeckers, goatsuckers, swifts, and hummingbirds.)

\section{ADULT MALES IN BREEDING PLUMAGE.}

$$
\text { BIRDS WITH PLUMAGE PARTLY OR WHOLLY }
$$
I. BLACK.
IV. BLUE.
II. YELLOW.
V. GREEN.
III. RED.
VI. BROWN OR GRAY.

\section{BIRDS WITH BLACK IN PLUMAGE.}

1. Plumage mainly or wholly black.

2. Wholly black (with more or less gloss).

3. Length about 16-26 . Crows axd Ravers; see Corvus. p. 279.

$3^{\prime}$. Length about 8.20-13,50.

4. Tail even. not folded laterally.

Brewer and Rusty Blackbirds; see Scolecophagus. p. 299. 4'. Tail graduated, folded laterally.

2'. Mainly black.

$$
\text { Grackles; see Quiscalus. p. } 301 .
$$

3. Under parts largely white. 
4. Wings and tail metallic

$4^{\prime}$. Wings and tail not metallic.

Magries; see Pica, p. 269.

5. Sides brown . . . (part of) Towhees ; see Pipilo, p. 363. 5 . Sides not brown.

6. Sides pinkish or buffy . (part of) Juncos; see Junco, p. 345 . 6 '. Sides white like belly.

3 '. Under parts not white.

Black Phakbes; see Sayornis, p. 254.

4. Head yellow or brown, in contrast to black body.

5. Head yellow . . Yellow-headed Blackbird, p. 288. 5 . Head brown . . . . Cowbirds ; see Molothrus, p. 287.

4'. Head partly or wholly black like body.

5. Back of head whitish or buffy brown - . BовоLink, p. 286.

5'. Head wholly black.

6. Wings conspicuously marked with red.

Red-Winged Blackbirds; see Agelaius, p. 289.

6 . Wings conspicuonsly marked with white.

7. Crested; white pateh on quills . Phainopepla, p. 390. $\tau^{\prime}$. Not erested ; white patch on coverts.

1'. Plumage not mainly or wholly black.

LaRk Bunting, p. 377.

2. Under parts partly or wholly yellow.

3. Head and neck red . . . . . Lounsiana TANAger, p. 379.

3 . Head and neck not red.

4. Back streaked on brownish or grayish.

5. Chest with black patch or erescent.

6. Under parts deep yellow, except for black crescent.

6 . Under parts mainly or partly white.

MEAdowlarks; see Sturnella, p. 292.

7. Under parts white or pale yellow, except for black chest patch ; wings without brown patcl.

Horned Larks, see Otocoris, p. 266.

7 . Breast bright yellow; throat patch black; wings with brown patches . . . . . Dickcissel. p. 377.

5 '. Chest without black crescent, under parts black, white, and vellow . . . . . . Addubon WARbler, p. 413.

$4^{\prime}$. Back not streaked on brownish or grayish.

5. Head and breast gray ; tail black.

Arkansas and Cassin Kingbirds; see Tyrannus, pp. 248.249.

$\therefore$. Head and breast not gray; tail not always black.

6. Plumage largely black and brown.

Black-headed Grospeak, p. :?7:2.

6 . Plumage almost wholls black and yellow or olive green.

7. Wholly yellow or olive green, except for black on head.

8. Head with black eap . Pileolated Warbler, p. $42 \mathrm{~S}$.

$\mathrm{S}^{\prime}$. Head with black patch on sides of face.

YkLLOW-THкоAтs; see Geothlypis, p. 424.

7 . Wings and tail, if not back, as well as erown. black.

8. Length about $4.50-5.40$.

Goldfinches ; see Astragalinus, p. 319.

$s$ '. Length about (i.5)-10.09.

9. Bill long and slender . Onioles; see Irterus, p. 293.

('). Bill short and thick.

Western Evening Grosbeak, p. :307. 
$2^{\prime}$. Under parts without yellow.

3. Upper parts browi, streaked.

4. Crown striped black and white; nnder parts gray or white.

4 '. Crown black; ehest black.

Crown Sparrows; see Zonotrichia, p. 337.

3'. Upper parts not brown streaked.

Lapland Longspur; see Calcarius, p. 325.

4. Throat with black patch.

5. Back strealied with black.

5'. Back not streaked.

Black-throated Gray Warbler, p. 418.

6. Black of throat extending over chest.

Black-throated Sparrows; see Amphispiza, p. 350.

6 . Black of throat not extending over chest.

4'. Throat without black pateh.

Chickadees; see Parus, p. 45.5.

5 . Tail forked. plumage marked with salmon or red.

Scissor-tailed Flycatcher, p. 246.

5 . Tail not forked, plnmage not marked with salmon or red.

6. Back blue black or bluish gray; length $4-6$.

7. Back blue black ; throat eliestnut.

7 . Back bluish gray.

Cliff Swallow, p. $38 t$.

S. Tail extremely short . Nuthatches; see Sitta, p. 45\%.

$S^{\prime}$. Tail long . . GNatcatchers; see Polioptila, p. 465.

6 '. Back gray, brownish gray, or ash gray; length $8-13$.

7. Tail mainly black or white; back of head gray.

8. Tail mainly white; length abont 12-13.

Nutcracker, p. 282.

$\mathrm{S}^{\prime}$. Tail mainly or wholly black; length about $7.50-10.75$.

9. Belly brown . . . . . . SAY PHEEBe, p. 255.

9 . Belly gray or white SHRIKes; see Lanius, p. 391.

7 . Tail mainly gray; back of head black.

Oregon and Rocky Mountain Jays; see Perisoreus, p. $27 \%$.

\section{BIRDS WITH YELLOW IN PLUMAGE.}

1. Under parts mainly or wholly yellow.

2. Upper parts streaked . . MEADowlarks ; see Sturnella, p. 292. 2 . Upper parts not streaked.

3. Plumage yellow and green, without gray or black.

Yellow WARBLERs; see Dendroica, p. 407.

3'. Plumage with gray or black.

4. Length about $6.50-10.50$.

5. Head and neck red, yellow, black, or yellow and black.

6. Head and neck red . . . Louisiana TANAGER, p. 379.

6 . Head and neek black, or yellow and black.

7. Upper parts olive green, lores black.

$\tau^{\prime}$. Upper parts black and sellow.

Long-tailed Chat, p. 426.

$5^{\prime}$. Head and neck gray.

OrIoles ; see Icterus, p. 293.

6. Wings and tail nuarked with rufous.

Crested Flycatchers; see Myiarchus, p. 251. 
6' Wings and tail not marked with rufous.

Cassin and Arkaxsas KingBirds; see Tyramus, pp. 248, 249. 4'. Length about 4.00-5.40.

5. Wings and tail black.

$5^{\prime}$. Wings and tail green.

Goldfinches; see Astragalinus, p. 319.

6. Crown black.

6'. Patches on sides of face black.

Yellow-throats ; see Geothlypis, p. 424.

$1^{\prime}$. Under parts not mainly or wholly yellow.

2. Upper parts largely black.

3. Head and neck yellow; under parts black and yellow.

YELLOW-HEADED BLACKBIRD, p. 288.

3 . Head and neck black; under parts brown and yellow.

2 '. Upper parts not largely, if at all, black.

Black-headed Grosbeak, p. 372.

3. Head and neck yellow or slate gray.

4. Head and neck yellow; wings with chestnut patches.

4 '. Head and neck slate gray; wings without chestnut.

TERDIN, p. 462.

3 '. Head and neck not yellow or slate gray.

Mactillivrax Warbler, p. 424.

4. Head with black, yellow, and red crown patch.

4 '. Head withont crown patch.

Golden-CROWNED KingLets, p. 46:3.

5. Head with black horn-like appendages, throat yellow, tail black, edged with white.

(part of) Horned Larks; see Otocoris, p. 266.

5 '. Head without horn-like appendages; throat not yellow; tail with yellow terminal band.

WAXWIngs; see Ampelis, p. 387.

\section{BIRDS WITH RED OR PINK IN PLUMAGE.}

1. Under parts mainly or wholly red or pink.

2. Upper parts largely reddish or pinkish.

3. Bill crossed . . . . . . . Crossbills; see Loxia, p. 313.

$3^{\prime}$. Bill not crossed.

4. Head crested . . . . . Cardinals; see Cardinalis, p. 369.

4'. Head not crested.

5. Bill thick and short.

6. Length about 5.50-7.00.

6 '. Leng'th about $8-9$.

Purple Finches; see Carpodacus, p. 309.

Pine Grosbeaks; see Pinicola, p. 308.

5'. Bill not slort and thick . 'Tanagkrs; see Piranga, p. 379.

2'. Upper parts not largely reddish or pinkish.

3. Head purplish blue

1'. Under parts not mainly red or pink.

2. Plumage strikingly colored.

3. Plımage salnon or pink, black, and white.

4. Tail forked . . . . SCissor-talled Flycatcher, p. 246.

4'. Tail not forked.

5. Under parts white, with rose patch.

Rose-breasted Grosbiak, p. 372. 
5'. Under parts black, white, and salmon or red.

ReDstart, p. 429.

3'. Plumage black or brown, marked with red or rose color.

4. Body black, with red wing coverts.

RED-WINGED BlackBIRDs; see Agelaius, p. 289.

t'. Body brownish, with rose on under parts.

2 '. Plumage not strikingly colored.

Pyrrhuloxias; see Pyrrhuloxia, p. :370.

3. Crown with red, sellow, and black.

3 '. Crown with concealed red patch.

GOLDEN-CROWNED KingLet, p. 463.

4. Rest of plumage wholly black, slate gray, and white.

4'. Rest of plumage not wholly black and white.

KINGBIRD, p. 247.

j. Upper parts olive green ; under parts dull whitish.

Kinglets ; see Regulus. p. 46:3.

5'. Upper parts grayish ; under parts gray and yellow.

Arkansas and Cassin Flycatchers; see Tyrannus, p. 247 .

\section{BIRDS WITH BLUE IN PLUMAGE.}

1. Upper parts glossy steel blue.

2. Tail forked for about half its length . . BARN Swallow, p. 384.

2 '. Tail forked for much less than half its length.

$1^{\prime}$. Upper parts not glossy steel blue.

Purple Martins; see Progne, p. 38:3.

2 . Length about 11.00-13.7.5.

3. Crested . . . . . Steller JAYs; see Cyanocitta, p. 271.

3'. Not cresterl.

4. Plumage blue and gray or white.

California and Woodhouse Jays; see Aphelocoma, p. 274.

$4^{\prime}$. Plumage uniform grayish blue . . . PIÑon JAY, p. 284.

2 '. Length about 4.25-8.00.

:3. Bill long and slender . . . . Bluesirdos; see Sialia, p. 475.

:'. Bill short and thiek.

4. Under parts red or partly brownish.

5. Under parts bright red, head purplish blue, back green.

NonPareil, p. 376.

5 '. Under parts blue, white, and brown, head and back blue.

Lazuli Bunting, p. 375.

$4^{\prime}$. Under parts dark blue like upper parts.

5. Wings with brown patehes; length $7-S$.

Western Blue Grosbeak, p. $37 \%$.

5 .' Wings without brown patches; length $4.75-5.75$.

INDigo Bunting, p. 37 .

\section{BIRDS WITH GREEN IN PLUMAGE.}

1. Plumage green and yellow, marked with black.

2. Wings and tail black.

3. Lengtlı about $4.00-4.50$.

(part of) Golpfinches ; see Astragalinus, p. 319.

3 . Length about 7.00-8.50 . Western Evening Grosbeak, p. 307.

2 . Wings and tail not black. 
3. Head and neck gray . . Macgillivray W 3'. Head and neck yellow, marked with black.

4. Crown black . . . . Pileolated Warbler, p. 428. 4 . Crown not black.

5. Face with black lores . . . Long-tailed Chat, p. 426. 5 '. Face with black side patches.

Yellow-Throat's; see Geothlypis, p. 424.

1'. Plumage not green and yellow marked with black.

2. Head with crown patch.

3. Crown patch bright red, or red, yellow, and black.

Kinglets; see Regulus, p. 463. 3 '. Crown patch reddish brown . GREeN-TAILED TowheE, p. 368. $2^{\prime}$. Head without crown patch.

3. Under parts red, head purplish blue, back glossy green.

NoNpareil, p. 376. 3 '. Under parts yellowish or whitish; head and back mainly green or gray . . . . . . . . Vineos; see Vireo, p. 394.

\section{BIRDS WITH PLUMAGE LARGELY BROWN OR GRAY.}

1. Back streaked.

2. Crown bright reddish brown or black.

3. Crown black.

4. Back streaked with white.

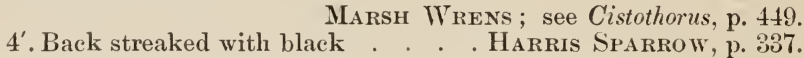

$3^{\prime}$. Crown bright reddish brown.

$2^{\prime}$. Crown not reddish brown or black.

Western Chipping Sparrow, p. 342.

3. Top of head streaked.

4. Head and back uniform; tail feathers wholly brown, sharp pointed . . . . . Creepers ; see Certhia, p. 451.

4'. Head and back not uniform; tail feathers marked with white. not sharp pointed . . . . . . LARK SPARRow, p. 336.

$3^{\prime}$. Top of head not streaked.

4. Under parts heavily spotted; outer tail feathers not white.

Cactus Wrens; see Heleodytes, p. 442.

4'. Under parts more or less streaked; outer tail feathers marked with white . . . . . . PrPITs; see Anthus, p. 431.

$1^{\prime}$. Back not streaked.

2. Under parts reddish or orange or more or less spotted.

3. Under parts reddish or orange.

4. Chest with dark necklace. VARIED Thrushes; see Ixoreus, p. 47:3.

4'. Chest without dark necklace. . Robins; see Merula, p. 47.2.

:3'. Under parts not reddish or orange.

4. Tail strikingly marked.

5. Tail with white corners . . . . SAGE Thrasher, p. 435.

5 . Tail with black crescent . . . . Rock WREN, p. 44:3.

4'. Tail not strikingly marked.

5. Tail cinnamon brown, barred with black.

Canyon Wrens; see Catherpes, p. 444.

5'. Tail not cinnamon brown, nor barred with black.
6. Tail 3.00-:3.40
Thrushes; see Hylocichla, p. 468.

6'. 'Tail $4.25-5.80$

Thrashers; see Torostoma, p. 437. 
2'. Under parts not reddish or spotted.

3. Upper parts bluish gray.

4. 'Tail very short. . . . . Nethatches ; see Sitta, p. 4is.

4'. Tail not very short . Gratcatchers; see P'olioptila, p. 465. 3'. Upper parts gray or brown.

4. Throat black. . . . . . . Chick a deEs ; see Parus, p. 45i.

$4^{\prime}$. Throat not black.

5. Head crested . . . . . . . Tiтnice; see Parus, p. 45.5.

5 . Head not erested.

6. Tail very short.

7. Plumage slate cray . . . . . Water Ouzel. p. 432.

7 . Plumage dark brown.

$6^{\prime}$. Tail not very short.

Western Wintfir Wrex, p. 449.

7. Wings and tail strikingly marked with white.

NOCKINGBIRD. p. 435.

7. Wings and tail not strikingly marked with white.

S. Plumage dark slate gray . . . C CATBIRD, p. 497.

S'. Plumage not dark slate gray.

1. Plumage deep brown; wings and tail barred with black.

10. Head with white superciliary.

BewICK WRENS; see Thryomanes, p. 446.

10 . Head without white supereiliary.

House Wrens; see Troglodytes, p. 448.

(1'. Plumage dull smoky gray or brown; wings and tail not barred. Bush-Trts; see Psaltriparus, p. 460. 



\section{INDEX}

A bert Towhəe, 368.

Acanthis, $304,318$.

hornemamii exilipes, 318 .

linaria, 318, 319.

Accipiter, 147, 151.

atricapillus, 151, 152.

striatulus, 151, 153.

cooperii, 151, 152.

velox, 151.

Actitis, $8 \&, 100$. macularia, 100.

Actochelidon, 28.

Actodromas, 91.

Echmophorus, 5. occidentalis, 5 .

Egialitis, 102, 103.

meloda eircumeincta, 103, 104.

montana, 10:3, 105.

nivosa, 103, 105.

semipalmata, 10:, 104.

vocifera, 103.

wilsonia, 103, 105.

Aëronautes, 229, 232.

melanoleucus, 232.

Esalon, 168.

Agelaius, 286, 289.

gubernator californicus, 289, 291.

phœniceus, 289, 290.

caurinus, 289, 291.

fortis, $289,291$.

neutralis, $259,291$.

richmondi, $289,290$.

sonoriensis, 2S9, 290.

tricolor, 289, 292.

Aiken Screech Owl. 184.

Aimophila, 306, 353.

carpalis, 353.

ruficeps, $35: 3,354$.

eremoec, 8.53. 355.

seottii, 35:3, 354 .

Aix, 44,55 .

sponsa, 55 .

Alaska Hermit Thrush, 471.
Alaskan Longspur, 327.

Pine Grosbeak, 309.

Three-toed Woodpecker, 209.

Wood Pewee, 258.

Yellow Warbler, 412.

Alauda, 265.

arvensis, 265.

Alaudidæe, 110, 245, 265.

Albatross, Black-footed, 32 .

Short-tailed, 32.

Sooty, 33.

Yellow-nosed, 33.

Alcedinidæe, 109, 19:, 198.

Aleidæ, 2, 11.

Alder Flycatcher, 261.

Allen Hummingbird, 241.

Alma Thrush, 471.

Alpine Three-toed Woodpecker, 209.

American Bittern, 73.

Black Terı, 31 .

Coot, 83.

Crow, 281.

Golden-eye, 59.

Goshawk, 152.

Hawk Owl, 188.

Merganser, 46.

Raven, 279.

Redstart, 429.

Scoter, 63.

Three-toed Woodpecker, 209.

White Pelicall, 42.

Woodeock, 88.

Amizilis, 2:3:, 243.

cerviniventris chalconota, 243 . tzacatl, 243.

Ammodramus, 306. 330, 335.

bairdii, :3:31, 333.

beldingi, 3:31, 332.

henslowii occidentalis, 330, 334.

leconteii, 3:30, 335.

maritimus sennetti, 330, 335 .

nelsoni, 330, 335.

rostratus, $330,333$. 
sand wichensis, 331 .

alaudinus, 381, 332 .

bryanti, 331, 332.

savannarum bimaculatus, 331, 334 .

Ampelidæ, 111, 245, $38 \%$.

Ampelis, 387. cedrorum 388. garrulus, 388.

Amphispiza, 25.5, 305, 350. belli, :350, 351. nevadensis, 350, 351 . bilineata, 350 . deserticola, 350 .

Anas, 44, 47. boschas, 48 . fulvigula maculosa, 4S, 49 .

Anatidæ, 3, 44.

Ancient Murrelet, 15.

Anhinga, 39. anhinga, 39.

Anhingidæ, 3, 39.

Ani, Groove-billed, 193.

Anna Hummingbird, 237.

Anser. 45, 66. albifrons gambeli, 66 .

Anseres, 1, 3, 44.

Ant-eating Woodpecker, 216.

Anthony Green Heron, 77.

Towhee, 367 .

Vireo, 399.

Anthus, 431.

pensilvanicus, 431. spragueii, 431, 432.

Antrostomus, 222.

carolinensis, 222.

vociferus, 222,223 . macromystax, 222. 223.

Aphelocoma, 269), 274.

ealifornica, 274,275 .

couchi, 274,276 .

eyanotis, 274.

insularis, 274,276 .

sieberii arizone, $274,276$.

texana, $274,275$.

woodhouseii, 274,275 .

Aphriza, 106.

virgata, 106.

Aphrizidæe, 4, S4, 106.

A plomado Falcon, 170.

Aquila, 147, 163. chrrsaëtos, 163

Archibuteo, 147, 162. ferrugineus, 162, 163. lagopus saneti-johannis, 162.

Aretic IIorned Owl, 186. Tern, 30.
Three-toed Woodpecker, 208.

Towhee, 364.

Ardea, 73, 74.

cærulea, $74,76$.

candidissima, 74,75 .

egretta, 74,75 .

herodias, $7+75$.

fanuini, 74,75 .

rufescens, 75,76 .

virescens, 75, 76 .

anthonyi, 75, 77 .

Ardeidæ, 4, 70, 72.

Ardetta, 72, 74.

exilis, 74.

Arenaria, 106.

melanocephala, 106, 107.

morinella, 106, 107.

Arizona Cardinal, 370.

Crested Flycatcher, 252.

Goldfinch, 322.

Hooded Oriole, 296, 299.

Jay, 276.

Junco, 349.

Pyrrhuloxia, 370.

Woodpecker, 206.

Arkansas Goldfinch, 322.

Kingbird, 248.

Arremonops, 305, 363.

rufivirgatus, 363.

Ash-throated Flycatcher, 253.

Ashy Petrel, 38.

Asio, 175.

accipitrinus, 175, $17 \%$.

wilsonianus, 175.

Astragalinus, 304, 319.

lawrencei, :320, 323.

psaltria, 320, 322.

arizonæ. 320, 322.

mexicanus, $320,322$.

tristis, $320,821$.

pallidus, :320, 321.

salicamans, 320, 321.

Astur, 152.

Asturina, 147, 161.

plagiata, 161.

Asyndesmus, 217.

Atthis, 232, 2937, 241.

moreomi, 241.

Attwater Prairie Hen, 131.

Audubon Caracara, 171.

Hermit Thrush, 471 .

Oriole, 294.

Warbler, 413.

Auklet, Cassin, 13.

Least. 14.

Paroquet, 14. 
Rhinoceros, 13.

A uriparus, 452, 462. flaviceps, 462.

Arocet, 86.

Aythya, 45, 56. affinis, 56,58 . americana, 56. collaris, 56,59 . marila, $56,57,59$. vallisueria, 56,57 .

Aztec Wren, 449.

Azure Bluebird, 476.

Baird Sandpiper, 92. Sparrow, 333.

IVren, 447.

Baldpate, 50 .

Baltimore Oriole, 297.

Band-tailed Pigeon, 138.

Bank Swallow, 386.

Barn Owl, 173.

Swallow, 384.

Barred Owl, 178, 179.

Barrow Golden-eye, 60.

Bartramia, 87. 99. longicauda, 99.

Bartramian Sandpiper, 99.

Basilinna, 283, 243. leucotis, 243.

Batchelder Woodpecker, 203.

Beardless Flycatcher, 265.

Becard, Xantus. 245.

Belding Marsh Sparrow, 332.

Bell Sparrow, 351.

Vireo, 399.

Belted Kingfisher. 198.

Piping Plover, 104.

Bendire Sparrow. 353.

Thrasher, 439.

Bicolored Blackbird, 291.

Bittern, American, 73.

Least, 74.

Black and White Warbler, 402.

-bellied Plover, 102.

Tree Duck, 69.

-billed Cuckoo, 196.

Magpie, 270.

Brant, 68.

-capped Vireo, 397.

-chinned Hummingbird, 235.

Sparrow, 345.

-crested Titmouse, 455.

-crowned Night Heron, 77.

-footed Albatross. 32.

-fronted Warbler, 415.

-headed Grosbeal:, 372.
Jay, 273.

Leucosticte, 317.

Merlin, 169.

Oyster-catcher, 107.

Petrel, 38.

Phobe, 255.

-poll ITarbler, 416.

Rail, 82.

Swift, 229.

-tailed Gnatcatcher, 466.

-throated Blue Warbler, 412.

Gray Warbler, 418.

Green Warbler, 420.

Loon, 10.

Sparrow, 350.

Turustone, $10 \%$.

-vented Shearwater, 35.

Vulture, 146.

Blackbird, Bicolored, 291.

Brewer, 300.

Red-winged, 290.

Rusty, 299.

Tricolored. 292.

Yellow-headed, 288.

Blackburnian WTarbler, 417.

Blue-bill, 57.

-eared Jay, 274.

-fronted Jay, 273.

-gray Gnatcatcher, 465.

-headed Vireo, 396.

-throated Humminglird, 234.

-winged Teal, 52.

Bluebird, 475.

Azure, 476.

Chestnut-backed, 476.

Mountain, 476.

Western, 476.

Bobolink, 286.

Bob-white, 115.

Masked, 116.

Texan, 116.

Bohemian Waxwing, 388.

Bonaparte Gull, 25, 26.

Sandpiper, 92.

Bonasa, 114, $12 \%$.

umbellus sabini, 127, 128.

togata, 127.

umbelloides, 127, 128.

Botaurus, 72, 73.

lentiginosus, 73.

Brachyramphus, 12, 15.

hypoleucus, $15,16$.

marmoratus, 15.

Brant, Black, 68 .

Branta, 45, 67.

canadensis, $6 \%$. 
hutehinsii, 67,68 .

minima, $67,68$.

occidentalis, $6 \overline{7}, 68$.

nigricans, 67,68 .

Brewer Blackbird, 300.

Sparrow, 343.

Brewsteria, 163.

Bridled Titmouse, 457 .

Broad-billed Hummingbird, 244. -tailed Hummingbird, 238.

-winged Hawk, 160.

Bronzed Grackle, 301.

Brown-capped Leucosticte, 317. Thrasher, 438.

Bryant Cactus IVren, 443. Marsh Sparrow, 332.

Bubo, 175, 185. virginianus arcticus, 18.), 186. pacificus, 185, 186. pallescens, 185. saturatus, 18̃̃, 186.

Bubonidæ, 109, 144, 175.

Buff-bellied Hummingbird, 243. -breasted Flycatcher, 263. Sandpiper, 100.

Buffle-head, 60.

Bullock Oriole, 298.

Bunting, Indigo, 374.

Lark, 377.

Lazuli, 375 .

Painted, 376.

Varied, 375.

Burrica, 312.

Burrowing Owl, 189.

Bush-Tit, 460.

Califoruia, 461.

Lead-colored, 462.

Lloyd, 462.

Santa Rita, 462.

Buteo, 147, 155.

abbreviatus, 15.), 157.

albicaudatus sennetti, $15 j, 158$.

borealis, 155 .

calurus, 15.), 156.

kriderii, 15.), 156.

lineatus elegans, 15.5, $15 \%$.

platypterus, 15.), 160.

swainsoni, 15i), 159.

Buteola, 160).

Butorides, 76 .

Cabanis Woodpecker, 202.

Cackling Goose, 68.

Cactus Wren, 442.

Calamospiza, :306, 377.

melanocorys, 377.
Calaveras Warbler, 404.

Calcarius, 304, 325. lapponicus, 326. alascensis, :326, $32 \%$. ornatus, $326,328$. pictus, 326,327 .

Calidris, $87,94$. arenaria, 94 .

California Brown Pelican, 43. Bush-Tit, 461.

Chickadee, 459.

Clapper Rail, 80.

Crow, 281.

Cuckoo, 195, 196.

Gull, 23.

Jay, 275 .

Murre, 16.

Partridge, 120, 121.

Pine Grosbeak, 308.

Poor-will, 225.

Purple Finch, 310, 312.

Pygmy Owl, 191.

Sereech Owl, 183, 184.

Shrike, 393.

Towliee, 367.

Vulture, 144.

Californian Creeper, 452.

Thrasher, 440.

Woodpecker, 217.

Calliope Hummingbird. 241.

Callipepla, 114, 118.

squanata, 118.

castanogastris, 118, 119.

Callothi'us, 285, 288.

robustus, 288.

Calothorax, 2:3:2, 242.

lucifer, 242.

Calypte, 2:3:), 236.

anna, 237.

costr, 236.

Canachites, 114. 126.

franklinii, 126.

Canada Goose, 67.

Canadiau Ruffed Grouse, 127.

Warbler, 428.

Canvas-back, ,5), 57 .

Canyon 'Towhee, 366.

IV'ren, 445.

Caprinulgidae, 110, 222.

Caracara, Andubon, 171.

Cardellina, 401. 430.

rubrifrons, 430 .

Cardinal, 369.

Arizona, 370.

Gray-tailed. 370.

Cardinalis, :30.5, 369. 
eardinalis, 369 .

camicaudus, :)(69), 370.

superbus, :36!), 370.

Caribbean Clapper Rail, 80.

Carolina Rail, 81.

IVren, 446.

Carpodacus, :304, 306, 309, 310.

cassini, $310,311$.

mexicanus clementis, : 10,313 .

frontalis, $: 10,312$.

purpureus, 310 .

californicus, 310 .

Caspian Terı, 28.

Cassin Auklet, 13.

Kingbird, 249.

Purple Finch, 310, 311.

Vireo, 396.

Catbird, 437.

Catharista, 14t, 146.

urubu, 146.

Cathartes, 14t, 145.

aura, 145.

Cathartidæ, 109, 144.

Catherpes, 434.

nexicanus albifrons, $444,445$. conspersus, $444,445$. punctulatus, 444,445 .

Cedar Waxwing, 388.

Centrocercus, 113, 133.

urophasianus, 133.

Centronrx, 33:3.

Centurus, 213.

Ceophlceus, 200, 213.

pileatus abieticola, 213.

Cepphus, 12, 16.

columba, 16.

Cerorhinca, 12, 13. monocerata, 13.

Certhia, 451.

familiaris albescens, 451 . montana, 451.

occidentalis, 451, 452 .

zelotes, 451,452 .

Certhiidæ, 113, 245, 451.

Cerulean IVarbler, 416.

Ceryle, 198.

aleyon, 198.

americana septentrionalis, 19s, 199 . torquata, 195. 199.

Chachalaca, 137.

Chrtura, 229, 230.

pelagica, 230.

vauxii, 2:30, 231.

Chamæa, 4.52, 459.

fasciata. 459 .

intermedia, 459. phrea, 459, 460.

Chamethlypis, 4:6.

Charadriidie, $4,84,102$.

Charadrius, 102, 103.

dominieus, 103.

Charitonetta, $45,60$.

albeola. 60 .

Chat, Long-tailed, 426.

Chaulelasmus, 44,49 . streperus, 49.

Chen, 45, 65. hyperborea, 65 . nivalis, (i.), 66 . rossii, 65, 66 .

Cliestnut-backed Bluebird, 476. Chickadee, 459.

-bellied Scaled Partridge, 119.

-collared Longspur, 328.

-sided WVarbler, 416.

Chewink, 364.

Chickadee, $45 \%$.

California, 459.

Chestnut-backed, 459.

Columbian, 459.

Long-tailed, $45 \%$.

Mexican, 458.

Mountain, 458.

Oregon, 458.

Chimmey Swift, 230.

Chondestes, 304, 336.

grammacus, 336 . strigatus, 336 .

Chordeiles, 2:2, 226.

acntipennis texensis, 226, 228 .

virginianus, 226.

henryi, 226;, 227, 229.

sennetti, 226, 227, 228.

Chrysolophus, 1:4, 135. pictus, 135.

Chuck-will's-widow, 222.

Ciconiidæ, 4, 70, 72.

Cinclidæ, 112, 245, 432.

Cinclus, 432.

mexicanus, 432.

Cinnamon Teal, 52.

Cireus. 147, 150. luudsonius, 150.

Cistothorus, 4:34, 449, 450 .

palustris, 449, 450 .

paludicola. 450 .

plesius, 450, 451 .

stellaris, 450 .

Clangula, $45,59$.

clangula americana, 59 .

islandica, 5.), 60 .

Clarke Nuteracker, 282. 
Clay-colored Sparrow, 342.

Cliff Swallow, 384.

Coast Wren-Tit, 460.

Coccothraustes, 30:3, $30 \%$.

vespertinus montanus, 307 .

Coccyges, 2, 109, 193.

Coccyzus, 193, 195.

americanus, 195.

occidentalis, 195, 196.

erythrophthalmus, 195, 196.

Cock-of-the-woods, 213.

Coligena, 283, 234.

clemenciæ, 234.

Colaptes, 200, 220.

auratus luteus. 220.

cafer collaris, 220, 221, 222. saturatior, 220, 221. chrysoides, 220, 222.

Colinus, 114.

ridgwayi, 114, 115, 116.

virginianus, 114, 115.

texanus, 114, 115, 116.

Columba, 138.

fasciata, 138.

flavirostris, 138, 140 .

Columbæ, 1, 108, 138.

Columbian Chickadee, 459.

Sharp-tailed Gronse, 132.

Columbidæ, 108, 138.

Columbigallina, 138, 143. passerina pallescens, 143.

Colymbus, 5,6 .

auritus, 6,7 .

dominicus brachypterus, 6 .

holbøllii, 6 .

nigricollis californicus, 6.7 .

Common Tern, 29.

Compsohalieus, 41.

Compsothlypis, 401, 406.

americana usneæ, 406.

nigrilora, 406,407 .

Condor, 144.

Connecticut Warbler, 424.

Contopus. 24.), 256. 257.

borealis, 25) $(3,257$.

pertinax pallidiventris, 256, 257 .

richardsonii, 25), 258.

saturatus, 258.

virens, $257,258,259$.

Cooper Hawk, 152.

Tanager, 31, 382.

Coot, American, 83.

Copper Pheasant, 135.

Coppery-tailed Trogon. 197.

Cormorant, Baird, 42.

lirandt, 41.
Donble-crested, 40.

Farallone, 40.

Mexican, 41.

Pelagic, 41.

White-crested, 40.

Corvidæ, 112, 245, 269.

Corvus, 269, 279.

americanus, 279, 281.

hesperis, 281.

caurinus. 279, 282.

corax principalis, $279,280$.

sinuatus, 279,281 .

crsptoleucus, $279,280$.

Costa Hummingbird, 236.

Cotingidæ, 110, 245.

Coturnicops, 82.

Coturniculus, 334.

Couch Jay, 276.

Kingbird, 248.

Coues Flycatcher, $25 \%$.

Cowbird, $28 \%$.

Dwarf, 288.

Red-eyed, 288.

Cracidæ, 108, 113, 137.

Crane, Little Brown, 79.

Sandhill, 79.

Whooping, 78.

Creciscus, 8:.

Creeper, California, 452.

Mexican, 451.

Rocky Mountain, 451.

Sierra, 452.

Crissal Thrasher, 442.

Crossbill, 314.

Mexican. 314.

White-winged, 315.

Crotophaga, 193.

sulcirostris, 193.

Crow, American, 281.

California, 281.

Northwest, 282.

Cuckoo, Black-billed, 196.

California, 196.

Yellow-billed, 195.

Cuculide, 110, 193.

Crrmophilus, 84.

fulicarius, 84.

Curlew, Eskimo. 102.

Hudsonian, 102.

Long-billed, 101.

Curve-billed Thrasher, 439.

Cyanocephalus, 269, 284.

evanocephalus, 284.

Cranocitta, 269, 271.

cristata, 271.

stelleri, 271, 272. 
amectens, 271, 273.

carbonacea, 273.

diademata, 271, 27:2, 273.

frontalis, $271,272,273,275$.

Cyanospiza, :306, 374 .

amcena, 374,375 .

ciris, 374,376 .

cyanea, 374 .

versicolor, 374,375 .

Cyclorrlyynchus, 12, 14.

psittaculus, 14.

Crpseloides, 229.

niger borealis, 229.

Cyrtonyx, 114, 122.

montezumæ mearnsi, 122.

Cyrtopelicanus, 42 .

Dabchick, 8.

Dafila, 44,54 . acuta, 54 .

Dark-bodied Shearwater, 36.

Dendragapus, 11 , 124. obscurns, 124, 126 .

fuliginosus, 124, 125.

richardsonii, 124, 126.

Dendrocygna, 44, 69.

autumnalis, 69 .

fulva, 69 .

Dendroica, 401, 407, 411. æstiva, $407,409,411,412$. rubiginosa, $417 \%, 409,412$. sonorana, $407,4(09,411$. auduboni, 40s, 409, 413.

blackburniæ, $407,410,417$. cærulescens, 408, 410, 412 . chrysoparia, 40s, 409, 419. coronata, $409,412,414$. graciæ, 40), 409, 418.

maculosa, 408, $409,415$. nigrescens, 40 s, $409,418$. nigrifrons, $408,409,415$. occidentalis, 408, 409, 421 . olivacea, 408,410 .

palmarnm, $408,410,422$.

pensylvanica, 409,416 .

rara, $409,410,416$.

striata, 409,416 .

townsendi, $408,410,421$.

virens, 408, 410,420 .

Derby Flycatcher, 250.

Desert Cactus IVren, 442.

Horned Lark, 268.

Song Sparrow, 357.

Sparrow, 350. Hawk, 171.

Dichromanassa, 76 .
Dickissel, 377.

Diomedea, 32. albatrus, 32. nigripes, 32.

Diomedeidæ, 3, 32.

Dipper, 432.

Dolichonyx, 2s.), 286. oryzivorus, 286.

Dotted Canyon IVren, 445.

Dove, Inca, 143.

Mexican Gromnd, 143.

Mourning, 140.

White-fronted, 141. -winged, 142.

Dowitcher, Long-billed, 89.

Downy Woodpecker, 204.

Dryobates, 200, 201.

arizonæ, 201, 206.

nnttallii, 201, 204, 205.

pubescens, 203.

gairdnerii, 201, 203, 204 .

homorus, 201, 203.

medianus, 201, 203, 204.

turati, 203.

scalaris bairdi, 201, 204.

lucasanus, 201, 205.

villosus leucomelas, 201 .

harrisii, 201, 202, 203.

hrloscopus, 201, 202.

lucasanns, 201, 205.

monticola, 201. 203.

Duck, Black-bellied Tree, 69.

Fulvous Tree, 69.

Harlequin, 61.

Hawk, 167.

Lesser Scaup, 58.

Masked, 65.

Mottled, 49.

Ring-necked, 59.

Ruddy, 64.

Scaup, 57.

IVood, 55.

Dusky Grouse, 124.

Horned Lark, 269.

Owl, 186.

IT arbler, 405.

Dwarf Cowbird, 288.

Hermit Thrush, 472.

Screech Owl, 185.

Dytes, 7 .

Eagle, Bald, 165.

Golden. 163.

Eared Grebe, 7.

Ectopistes, 138.

migratorius, 140. 
Egret, 75 .

Elanoides, 147, 148. forficatus, 148.

Elanus, 147, 148. lencurus, 148.

Elegant Tern, 29.

Elf Owl, 191.

Emperor Groose. 69.

Empidonax, 246, 259. difficilis, $259,260$.

fulvifrons pygmæus, 2.59, 262, 263. griseus, 259, 263.

hammondi, 2.59, 262.

insulicola, 259, 260.

minimus, 2.59, 261.

traillii, $259,260$.

alnorum, 259, 261.

wrightii, 259, 262.

English Sparrow, 324.

Erennetes, s8, 93. occidentalis, 93, 94 . pusillus, 93.

Erismatura, 44, 64 . jamaicensis, 64 .

Eskimo Curlew, 102.

Eugenes, 233.

fulgens, 233.

European Teal, 51.

Exanthemops, 66.

Falco, 147, 165. columbarius, 166,168 . suckleyi. 166, 169.

fusco-cerulescens, 166,170 .

mexicanus, 165, 166.

peregrinus anatum, 166, 167 . pealei, $166,168$.

richardsonii, 166, 169.

rusticolus, 16.). 166. sparverius, 166,170 . deserticola, 166, 171 .

Falcon, A plonuado, 170. Peale, 168.

Prairie, 166.

Falconidæ. 109, 144, 146.

Farallone Rail, 82.

Ferruginous Pygmy Owl, 191. Rough-leg, 163.

Finch, California Purple, 310. Cassin, 311.

House, 312.

Island House, 313.

Pine, 323.

Purple, 310

Fish Hawk. 172.

Flammulated Sereech Owl, 184, 18.).
Flicker, Gilded, 222.

Northern, 220.

North western, 221.

Red-shafted, 221.

Floresi Hummingbird. 238.

Florida, 76 .

Florida Gallinule, 82.

Flycatcher. Alder, 261.

Arizona Crested, 252.

Ash-throated, 253.

Beardless, 265.

Buff-breasted, 2f?

Cones, $25 \%$.

Crested, 252.

Derby, 250.

Fork-tailed, 246.

Giraud, 250.

Gray, 263.

Hammond, 262.

Least, 261.

Mexican Crested, 252.

Nutting, 253.

Olivaceous, 253.

Olive-sided, $25 \%$.

Ridgway, 265.

Santa Barbara, 260.

Scissor-tailed, 246.

Sulphur-bellied, 250

Traill, 260, 261.

Vermilion, 264.

TVestern, 260.

Wright, 262, 263.

Forbush Sparrow, 360.

Fork-tailed Flycatcher, 246.

Forked-tailed Petrel, 37.

Forster Terı, 29.

Fox Sparrow, 360 .

Franklin Gronse, 126.

Gull, 25.

Frazar Oyster-catcher, 107.

Fregata, 43.

aquila, 43.

Fregatidie, 3, 39, 43.

Fringillide. 111, 245, 303.

Frosted Poor-will, 225.

Fulica, 7!?, 83.

americana, 83.

Fuligula, 5\%.

Fuluiar. Giant. 34.

Pacific, 34 .

Rodgers, 34 .

Slender-billed. 34.

Fulmarus, : ::3, 34.

glacialis glupischa, 34 .

rodgersi. 34.

Fulvous Tree-duck, 69. 
Gadwall, 49 .

Gairdner Woodpecker, 203.

Galeoscoptes, $4: 4,437$. carolinensis, 437.

Galline, 1, 10s. 113.

Gallinago, s7. 88. delicata, 88.

Gallinula, 79. 82. galeata, 82 .

Gallinule. Florida. 82.

Gambel Partridge, 121. Sparrow, 339.

Garzetta, 7.5 .

Gavia, 9.

aretica, 9, 10.

imber, 9 .

lnume, 9, 11.

pacifica, 9,10 .

Gaviidæ, 2, 9.

Gelochelidon, 19, 27. nilotica, 27.

Gennæus, 134, 135. nycthemerus, 135.

Geococerx, 193. californianus, 193.

Geothlspis, 401, 42t, 426. agilis, 424 .

poliocephala ralplii, 424 .

tolmiei, 424.

trichas arizela, 424, 426. occidentalis, 424,425 .

scirpicola, 425 .

sinuosa, 425.

Giant Fulmar, 34.

Gila Woodpecker. 219.

Gilded Flicker, 222.

Giraud Flycatcher. 250.

Glaucidium, 175, 190. ealifornicum. 190, 191. gnoma, 190. plialænoides, 190, 191.

Glaucous Gull. 21. -winged Gull, 21.

Glossr Ibis. 71.

Glottis, 96.

Guateateher, Black-tailed, 466.

Blue-grar, 465.

Plumbeous. 466.

Western, 466.

Godwit, Hndsonian, 95. Marbled, 95.

Golden-cheeked Warbler, 419. -crowned Kinglet, 463. sparrow, 339.

Eagle, 163.

-eye, American, 59.
- Barrow, 60.

-fronted Woorlyeeker, 218.

$\mathrm{O} w 1,174$.

Pheasant. 135.

Pileolated Warbler, 428.

Plover, 103.

Goldfinch, 320.

Arizolia, 322.

Arkansas, 322.

Lawrence, 323.

Mexicall, 322.

Pale, 321.

Tillow, 321.

Goose. Canada, 67, 68.

(ackling. 68.

Emperor, 69.

Greater Snow, 66.

Hutchins. 68.

Lesser snow, 65.

Ross Show, 66 .

Thite-eheeked, 68.

White-fronted, 66.

Gosliawk. American, 152.

Westeru, 153.

Grace Warbler, 418.

Grackle, Bronzed, 301.

Great-tailed. 302.

Gray-cheeked 'Thrush. 469.

-crowned Lencosticte, 315.

Flycatcher, 263.

Grifaleon. 166.

-lieaded Junco, 349.

Jav, 279.

Rinffed Grouse, 128.

-tailed Cardinal, 370.

Titnıouse, 456.

Vireo, 400 .

Great Blue Heron, 75.

Gray Owl, 179.

Northern Diver, 9.

Rufous-bellied Kingfisher, 199.

-tailed Grackle, 302.

Greater Suow Goose, 66.

Yellow-leg's, 96.

Grebe, Eared, 7.

Holboll, 6.

Horned, 7.

Least, 8.

Pied-billed, 8.

Western, 5.

Green Heron, 76.

Jay, $27 \%$.

Pheasant, 135.

-tailed Towhee, 368.

-winged Teal. 51.

Grimell Water-Thrush, 423. 
Groove-billed Ani, 193.

Grosbeak, Alaskan Pine, 309.

Black-headed, 372.

California Pine, 308.

Rocky Mountain Pine, 308.

Rose-breasted, 372.

Western Blue, 373.

Evening, $30 \%$.

Grouse, Canadian Ruffed, 127.

Columbian Sharp-tailed, 132.

Dusky, 124.

Franklin, 126.

Gray Ruffed, 128.

Oregon Ruffed, 128.

Prairie Sharp-tailed, 132.

Richardson, 126.

Sage, 133.

Sooty, 125.

Gruidæ, 4, 78.

Grus, 78.

americana, 78.

canadeusis, 78, 79 .

mexicaua, 78, 79.

Guara, 70, 71.

alba, 71 .

Guillemot, Pigeon, 16.

Guiraca, 305, 373.

eærulea lazula, 373.

Gull, Bonaparte, 26.

California, 23.

Franklin, 25.

Glaucous, 21.

Glancons-winged, 21, 23.

Heermann, 24.

Herring, 22.

Laughing, 25.

Mew, 24.

Riug-billed, 23.

Sabine, 27.

Short-billed, 24.

Vega, 23.

Western, 21, 23, 25.

Gull-billed Tern, $2 \%$.

Gymmogyps, 144.

californianus, 144.

Gyrfalcon, Gray, 166.

Hæmatopodidæ, 4, S4, 107.

Hæmatopus, $10 \%$.

bachmani, 107.

frazari, 107.

Halixetus, 147, 165.

leucocephalus, 165.

Hammond Flycatcher, 262.

Harelda, 45, 61.

hyemalis, 61 .
Harlequin Duck, 61.

Harporhynchus, 440.

Harris Hawk, 154.

Sparrow, 337.

Woodpecker, 202.

Hawk, Broad-winged, 160.

Cooper, 152.

Duck, $16 \%$.

Fish, 172.

Harris, 154.

Krider, 156.

Marsh, 150.

Mexican Black, 160.

Pigeon, 168.

Red-bellied, $15 \%$. -tailed, 155.

Rough-legged, 162.

Sennett White-tailed, 158.

Sharp-shinned, 151.

Squirrel, 163.

Swainson, 159.

Zone-tailed, 157.

Heermann Gull, 24.

Song Sparrow, 357.

Heleodytes, 434, 442 .

brunneicapillıs, 442 .

anthonyi, 442 .

bryanti, 443 .

couesi, 442.

Helminthophila, 401, 402.

celata, 402, 404.

lutescens, 402, 405 .

sordida, 402, 405 .

luciæ, 404.

peregrina, 402, 406 .

rubricapilla gutturalis, 402, 404 .

virginiæ, 402, 403.

Helodromas, S8, 97.

solitarius, 97.

cinnamomeus, $97,98$.

Hepatic Tanager, 381.

Hepburn Leucosticte, 316.

Hermit Warbler, 421.

Herodias, 75.

Herodiones, 1, 70.

Heron, Anthony Green, 77.

Black-crowned Night, $7 \%$.

Great Blue, 75.

Green, 76.

Little Blue, 76.

Northwest Coast, 75.

Snowy, 75.

Yellow-crowned Night, 78.

Herring Gull, 22.

Hesperiphona. 307.

Heteractitis, S8, 98. 
incauns, 98.

Hierofalco, 166.

Himintopus, 86. mexicanns, 86.

Hirundinidee, 111, 245, 382.

Hirundo, :38:2, 384. erythrogastra, 384 . palmeri, 384.

Histrionicns, 45. 61 . histrionicus, 61 .

Hoary Red-poll, 318.

Holbœll Grebe, 6.

Hooded Merganser, 47.

Horned Grebe, 7.

House Finch, 310, 312.

Hudsonian Curlew, 102.

Godwit, 95 .

Hunmingbird, Allen, 241.

Anna, 23\%.

Black-chinned, 235.

Blue-throated, 234.

Broad-billed, 244. -tailed, 238.

Buff-bellied, 243.

Calliope, 241.

Costa, 236.

Floresi, 238.

Lucifer, 242.

Morcom, 241.

Rieffer, 243.

Rivoli, 233.

Rinbr-throated, 235.

Rufous, 239.

White-eared, 243.

Hutchins Goose, 68.

Hutton Vireo, 399.

Hydrochelidon, 19, 31. nigra surinaneensis, 31

Hylocichla, 467, 468.

aliciæ, $468,469$.

guttata, $468,471$.

anduboni, 469, 471 .

nana, 468.472 .

slevini, 471.

fuscescens salicicola, 468,469 .

mustelina, 468,469 .

ustulata, 468,470 .

alnı⿱ 469,471 .

cdica, 468,470 .

swainsoni. 469,470 .

Iache, 2:32, 244.

latirostris, 244.

Ibididse, 4,70 .

Ibis. Glossv, 71.

White, 71. -faced Glossy, 71.

Wood, 72.

Icteria, $401,426$.

virens longicanda, 426 .

Icteridæ, 11:2, 24.5, 285.

Icterus, 285, 293, 294 .

audubonii, 294.

bullocki, $294,298$.

cnenllatus nelsoni, 29:3, 296, 298. sennetti, 29:3, 295.

galbula, $294,297$.

parisormin, 294.

spurius, 294, 296.

Ietinia, $147,149$.

mississippiensis, 149.

Inca Dove, 143.

Indigo Bunting, 374.

Intermediate Junco, $34 \%$. Sparrow, 339.

Island Horned Lark, 268.

Honse Finch, 313.

Shrike, 393.

Ixoreus, $467,473$.

nævius, 473. mernloides, 473,474 .

Jabiru, 72.

Jacana, 108.

Mexican, 108.

spinosa, 108.

Jacanidæ, 108.

Jack Snipe, 88.

Jackdaw. 302.

Jaeger, Long-tailed, 18.

Parasitic, 18.

Pomarine, 18.

Jay, Arizona, 276.

Black-headed, 273.

Blue, 271.

-eared, 274.

-fronted, 273.

California, 275 .

Conch, 276.

Gray, 279.

Green, 27\%.

Long-crested, 273.

Oregon, 278.

Piñon, 284.

Rocky Mountain, 27\%.

Santa Crnz, 276.

Steller, 272.

Texan, 275.

Woodhouse, 274.

Junco, 30.5, 345.

aikeni, 345 .

annectens, 345), 348. 
Arizona, 349.

caniceps, 345, 349.

Gray-lieaded, 349.

hyemalis, 345,346 .

convectens, 345, 34\%.

oreganus, 345,347 .

pinosus, $345,348$.

thurberi, $345,34 \%$.

Intermediate, 347 .

mearnsi, :345, 348.

Montaua, 348.

montanus, 345, 348.

Mountain, 348.

Oregon, 347.

phæonotus dorsalis. 345, 349. palliatus, 345, 349.

Pink-sided, 348.

Point Pinos, 348.

Red-backed, 349 .

Ridgway, 348.

Slate-colored. 346.

Thurber, 347 .

White-winged, 345.

Kaeding Petrel, 37.

Kennicott Screech Owl, 183, 184.

Killdeer, 103.

Kingbird, $24 \%$.

Arkansas, 248.

Cassin, 249.

Couch, 248.

Kingfisher, Belted, 198.

Great Rufous-bellied, 199.

Texas, 199.

Kinglet, Golden-crowned, 463.

Western, 464.

Ruby-crowned, 464.

Sitkan, 465.

Kite, Mississippi, 149.

Swallow-tailed, 148.

White-tailed, 148.

Kittiwake, Pacific, 19.

Knot, 91.

Krider Hawk, 156.

Lagopus, 114, 128.

leneurus, 129.

altipetens, 129.

Laniilie, 11\%, 245, 391.

Lanius, 391.

borealis, 391, 392 .

ludovicianus anthonyi, 391, 393.

excubitorides, 391, 392.

gambeli, 391, 393.

Lanivireo, 396.

Lapland Lougspur, 326.
Large-billed Sparrow, 333.

Laridæ, 2, 17, 19.

Lark Bunting, 377.

Desert Horned, 268.

Dusky Horned, 269.

Island Horned, 268.

Mexican Horned, 268.

Pallid Horned, 266.

Prairie Horned, 268.

Ruddy Horned, 268.

Seorched Horned, 269.

Sparrow, 336.

Streaked Horned, 268.

Texan Horned, 268.

Larus, 19, 20.

argentatus, 20, 22.

atrieilla, 20, 25 .

brachyrhynchus, 20, 24 .

californicus, 20, 23.

canus, 20, 24.

delawarensis, 20, 23.

franklinii, 20, 25.

glaucescens, 20, 21.

glaueus, $20,21$.

heermanni, $20,24$.

occidentalis, 20, 21.

philadelphia, 20, 26.

vegæ, 20, 23.

Laughing Gull, 25.

Lawrence Goldfinch, 323.

Lazuli Bunting, 375.

Lead-colored Bush-Tit, 462.

Least Auklet, 14.

Bittern, 74.

Flveateher, 261.

Grebe, 8.

Sandpiper, 92.

Tern, 30.

Vireo, 400.

Leconte Sparrow, 335.

Thrasher, 441.

Leptopelicanus. 43.

Leptotila, 138, 141.

fulviventris brachyptera, 141.

Lesser Prairie Hen, 131.

Seaup Duck, 58, 59.

Snow Goose, 65 .

Yellow-legs, 97.

Lencosticte, $304,315$.

atrata, 315,317 .

australis, 315, $31 \%$.

Black, 317.

Browu-capped, 317.

Gray-crowned, 315.

Hepburn, 316.

tephrocotis, 315,317 . 
littoralis, $315,316$.

Lewis Woodpecker, 217.

Linicol:e, 4, 84.

Limosa, 87, 95.

fedoa, 95 .

hremastica, 95 .

Lincoln Sparrow, 359.

Little Blue Heron, 76.

Brown Crane, 79.

Lloyd Bush-Tit, 462.

Long-billed Curlew, 101.

Dowitcher, 89.

-crested Jay, 273.

-eared Owl, 175.

-tailed Chat, 426.

Chickadee, 457.

Jaeger, 18.

Longipennes, 1, 2, 17.

Longspur, Alaskan, 327.

Chestnut-collared, 328.

Lapland, 326.

McCown, 328.

Smith, 327.

Loon, 9.

Black-throated, 10.

Pacific, 10.

Red-throated, 11.

Lophodytes, 44, 47.

cucullatus, 47.

Lophophanes, 455.

Lophortyx, 114, 119, 120.

californicus, 120.

vallicola, 120 .

gambelii, 120, 121.

Louisiana Tanager, 379.

Loxia, :308, 313.

curvirostra bendirei, 314 .

minor, 313, 314.

stricklandi, 313, 314.

leucoptera, 31:3, 315.

Lucifer Hummingbird, 242

Lucy Warbler, 402.

Lunda, 11, 12. cirrhata, 12.

Lutescent Warbler, 405.

MacFarlane Screech Owl, 184.

Macgillivray Warbler, 424.

Macrochires, 2, 110, 222.

Macrorhamphus, S7, 89. griseus, $\mathbf{8 9}, 90$.

scolopacens, 89 .

Magnolia Warbler, 415.

Magpie, Black-billed, 270. Yellow-billed, 271.

Mallard, 48, 49, 51.
Man-o'-War Bird, 43.

Marbled Godwit, 95.

Murrelet, 15.

Mareca, 44, 49.

atuericana, 49, 50 .

penelope, 49.

Marsh Hawk, 150.

Martin, Purple, 383.

Western, 383.

Masked Bob-white, 116.

Duck, 65.

Massena Quail, 123.

McCown Longspur, 328.

Meadowlark, Texas, 292.

IVestern, 293.

Mearns Quail, 122.

Megaquiscalus, 302.

Megascops, 175.

asio, 182.

aikeni, 182, 184.

bendirei, 1S2, 183.

cineraceus, 18:-, 183.

kennicottii, 181, 183.

macfarlanei, 181, 184.

maxwelliæ, 181, 183.

mecalli, 181, 183.

flammeola, 18\%, 184.

idahoensis, 182, 185.

trichopsis, 181, 184.

Melanerpes, 200, 215.

aurifrons, $215,218$.

carolinus, 215, 218.

erythrocephalus, 215.

formicivorus, $215,216$.

bairdi, $215,217$.

torquatus, 215, $21 \%$.

uropygialis, 215 , 219.

Melanitta, 6:3.

Meleagris, 134, 136.

gallopavo fera, 136.

intermedia, 136.

merriami, 136.

Melopelia, 138, 142.

leucoptera, 142.

Melospiza, 306, 355.

cinerea phæa, 358.

fasciata cooperi, 357 .

ingersolli, 358.

pusillula, 358 .

georgiana, 35̃), 360

lincolnii, 35.5, 359.

striata, 35\%, 360 .

melodia, 356.

clementæ, 356, 359

cleonensis, 358.

fallax, 35\%, $35 \%$. 
graminea, 856, 358. heermanni, 355, 357, 358. merrilli, 359 . montana, 356, 357, 359 . morphna, 355, 358. rufina, 35., 358. samuelis, 35.5, 358. santæcrucis, 357.

Mendocino Song Sparrow, 358.

Merganser, 44, 45.

American, 46.

americanus, 45, 46.

Hooded, 47.

Red-breasted, 46. serrator, $45,46$.

Merlin, Black, 169. Richardson, 169.

Merriam Turkey, 136.

Merrill Parauque, 225. Song Sparrow, 359.

Merula, $467,472$. migratoria. 472 . propinqua, 472.

Mew Gull, 24.

Mexican Black Hawk, 160.

Buzzard, 172.

Chickadee, $45 \%$.

Cliff Swallow, 384.

Creeper, 451.

Crested Flyeatcher, 252.

Cross-bill, 314.

Goldfinch, 322.

Gosliawk, 161.

Gronnd Dove, 143.

Horned Lark, 268.

Jacana, 108.

Sereech Owl, 183.

Micropalama, $87,90$.

himantopus, 90.

Micropallas, 175, 191 whitneyi, 191.

Micropodidæ, 110, 229.

Mimus, 434, 435. polyglottos lencopterus, 435 .

Mississippi Kite, 149.

Mniotilta, 401, 402. varia, 402.

Mniotiltidxe, 111, 245, 401.

Nockingbird, WVestern, 435.

Molothrns, 285, 287. ater, $28 \%$.

obseurus, 288.

Montanat Juneo, 348.

Monterey Hernit Thrush, 471. Thrush. 470.

Noreom Humningbird, 241.
Motacillidæ, 111, 245, 431.

Mottled Duck, 49.

IIountain Bluebird, 476. Chickadee, 458.

Junco, 348.

Partridge, 117.

Plover, 105.

Song Sparrow, 357.

Mourning Dove, 140.

Mud Hen, 83.

Murre, California, 16. 22.

Mnrrelet, Ancient, 15.

Marbled, 16.

Xantus, 16.

Muscivora, 24.5, 246.

forficata, 246.

tyrannus, 246.

Myadestes, 467.

townsendii, 467 .

Mycteria, 72.

americana, 72 .

Myiarchus, 245.

cinerascens, $252,253$.

nuttingi, 252, 253.

crinitus, 252.

lawrencei olivascens, 251, 253.

mexicanus, $251,252$.

magister, 252.

Myiodynastes, 245. 250.

lifteiventris, 250.

Myiozetetes similis supereiliosus, 250.

Nelson Sparrow, 335.

Neocorys, 432.

Nettion, 45, 51.

earolinensis, 51 .

crecea, 51.

Nighthawk, 226.

Sennett, 228.

Texan, 228.

Western, 227.

Nomonyx, 44, 65.

dominieus, 65.

Nompareil, 326.

Northern Flicker, 220.

Hairy Woodpecker, 201, 20:3.

Parula Warbler, 406.

Phalarope, 84.

Pileated Woodpecker, 213.

Raven, 280.

Red-breasted Sapsucker, 212.

Shrike, 392.

Spotted Owl, 179.

Violet-green Swallow, 386.

Northwest Bewick Wren, 447

Coast Heron, 75. 
Crow, 282.

Saw-whet Owl, 181.

Northwestern Flicker, 221.

Red-wing, 291.

Nucifrage, $260,282$.

columbiana, 282.

Numenius, sั 101.

borealis, 101, 102.

liudsoniens, 101, 102.

longirostris. 101.

Nutcracker, Clarke, 282.

Nuthatch, Pygmy. 454.

Red-breasted, 454.

Rocky Mountain, 453.

Slender-billed, 453.

White-breasted, 453.

Nuttall Sparrow. 339.

Woodpecker, 205.

Nuttallornis, 2:7.

Nutting Flycatcher, 253.

Nyctala, 1\%. 179.

acadica, 180 .

scotea, 180, 181.

tengmalmi ricliardsoni, 179, 180.

Nyctanassa, $7 \mathrm{~S}$.

Nyctea, 175, 187.

nvetea, 187.

Nycticorax, 73, 77.

nycticorax nævius, $7 \%$.

violaceus, 78.

Nyetidromus, 222. 225.

albicollis merrilli, 225 .

Oceanodroma, 33, 37.

furcata, $3 \%$.

homocliroa, 37, 38 .

kaedingi, 37 .

leucorhoa, :37

melania, $37,38$.

socorroensis, 37, 38 .

Ochthodromus, 10.5 .

Oidemia, 45. 62. 63.

americana, 62,63 .

deglandi, 62, 63.

perspicillata, 62,63 .

Olbiorchilus, $4: 34,449$.

hiemalis pacificus, 449 .

Old-squaw, 61.

Olivaceous Flycatcher, 253.

Olive-backed Thrush, 470.

-sided Flycatcher, 257.

Warbler, 410.

Olor, 4i), 70.

buecinator, 70 .

columbianus, 70 .

Oporomis, 424 .
Orange-crowned Warbler, 404.

Orcliard Oriole, 296.

Oregon Chickadee, 458.

Jay, 278.

Junco, 347.

Rinffed Grouse, 128.

Song Sparrow, 358.

Towhee, 365.

Vesper Sparrow, 330.

Oreortyx, 114, $11 \%$.

pictus, 117 .

plumiferus, 117.

Oreospiza, $306,368$.

chlorura, 368.

Oriole, Arizona Hooded, 296.

Audubon, 294.

Baltimore, 297.

Bullock, 298.

Orchaid, 296.

Scott. 294.

Selmett, 295.

Ornithion, :-45, 265.

imberbe, 265.

ridgwayi, 265.

Oroscoptes, 43:3, 435.

montanus, 435 .

Ortalis, 137.

vetula maccalli, $13 \%$.

Ossifraga, 3:3, 34. gigantea, 34 .

Otocoris, 2(6), 266.

alpestris actia, 266, 268 .

adusta, 266, 269.

ammophila, 268.

aphrasta, 269.

arcticola, $266,26 \%$.

arenicola, 266, 268.

chrysolæma, 266, 268.

enthymia, 267.

giraudi, 266, 268.

hoyti, 267.

insularis, 268.

leucausiptila, 266.

leucolæma, 266, 268.

merrilli, ¿266, 269.

occidentalis, 269.

praticola, 266, 268.

rubea, 266,268 .

strigata, 266, 268.

Ouzel, Water. 432.

Oven-bird, 423.

Owl, Aiken Sicreecl, 184.

American Hawk, 188.

Aretic Horned, 186.

Barn, 173.

Barred, 178. 
Burrowing, 189.

California Pygmy, 191. Screech, 183.

Dusky Horned, 186.

Dwarf Screech, 185.

Elf, 191.

Ferruginous Pygmy, 191.

Flammulated Screech, 188.

Great Gray, 179.

Kennicott Screech, 183.

Long-eared, 175.

Mac Farlane Screech, 184.

Mexican Screech, 183.

Northern Spotted, 179.

Northwest Saw-whet, 181.

Pacific Horned, 186.

Pygmy, 190.

Richardson, 180.

Rocky Mountain Screech, 183.

Saw-whet, 180.

Screech, 182.

Short-eared, 177.

Snowy, $18 \%$.

Spotted, 178. Screech, 184.

Texas Barred, 178. Screech, 183.

Western Horned, 185.

Oxyechus, 103.

Oyster-catcher, Black, $10 \%$. Frazar, 107.

Pacific Fulmar, 34.

Horned Owl, 186.

House Wren, 448.

Kittiwake, 19.

Yellow-throat, 426.

Painted Bunting, 376.

Redstart, 430.

Pale Goldfinch, 321.

Varied Thrush, 474.

Pallid Horned Lark, 266.

IV ren-Tit, 459.

Paln Warbler, 422.

Palmer Thrasher, 439.

Palndicolæ, 1, 4, 78.

Pandion, 146, 172.

haliaëtus carolinensis, 172.

Parabuteo, 147, 154. unicinetus harrisi, 154.

Parasitic Jaeger, 18.

Parauque, Merrill, 225.

Paridæ, 112, 113, 245, 452.

Parkman Wren, 448.

Paroquet Anklet, 14.

Parrot, Thick-billed, 192.
Partridge, California, 120.

Chestnut-bellied Scaled, 119.

Gambel, 121.

Mountain, $11 \%$.

Plumed, 117.

Scaled, 118.

Valley, 120.

Parus, 452, 455, 457.

atricapillus, $455,457$.

occidentalis, 455,458 .

septentrionalis, $455,45 \%$.

atricristatus, 455 .

gambeli, $455,458$.

hudsonicus columbianus, $455,459$.

inornatus, $455,456$.

griseus, 45.5, 456.

rufescens, $45 \%, 459$.

neglectus, 45.5, 459 .

sclateri, $455,458$.

wollweberi, $455,457$.

Pasadena Thrasher, 441.

Passenger Pigeon, 140.

Passer, 305, 324.

domesticus, 324.

Passerculus, 381, 333.

Passerella, 306, 360.

iliaca, 360.

annectens, 361.

fuliginosa. 361 .

insularis, 361.

megarhyncha, 360, 362 .

meruloides, 361 .

schistacea, 360, 362.

stephensi, :360, 363.

townsendi, 361 .

unalaschcensis, 360, 361 .

Passeres, 2, 110, 245.

Passerina, 304, 325.

nivalis, 325.

Peale Falcon, 168.

Pectoral Sandpiper. 91.

Pedicecetes, 114, 131.

phasianellus campestris, 132. columbianus, 132.

Pelecanidæ, :3, 39, 42.

Pelecanus, 42.

californicus, 42, 43 . erythrorhynchos, 42 . occidentalis, $4: 3$.

Pelican, American White, 42.

California Brown, 43.

Pelidna, 9:3.

Pelionetta, 6:3.

Pendulinus, 295.

Perisoleus, 269, 277.

canadensis capitalis, 277 . 
obscurus, 278. griseus, 279.

Petrel, Ashy, 38.

Black, 38.

Forked-tailed, 37 .

Kaeding, $3 \%$.

Socorro, 38.

Petrochelidon, 382, 383.

lunifrons, 3̊3, 384.

melanogastra, $383,384$.

Pencrea, 352.

botterii, 352 .

cassini, 352 .

Pencedranuus, 410 .

Pewee, Wood, 258.

Phainopepla, 387, 390. nitens, 390.

Phalacrocoracidæe, 3, 39.

Phalacrocorax, 39, 40. dilophus, 39, 40 . albociliatus, 39, 40 . cincinatus, 39, 40.

mexicanus, 39, 41 . pelagicus, 40, 41 . resplendens, 40, 42 . penicillatus, 39,41 .

Phalæuoptilus, 222, 224. nuttallii, 224. californicus, 224, 225 . nitidus, $224,225$.

Phalarope, Northern, 84. Red, 84.

TVilson, 85.

Phalaropodid:e, 4, 84.

Phalaropus, 84. lobatus, 84.

Phasiauidæ, 108, 113, 134.

Phasianus, 134, 135 . sœemmerringii, 135. torquatus, 135 . versicolor, 135.

Pheasant, Copper, 135.

Golden, 135.

Green, 135.

Ring-necked, 135.

Silver, 135.

Philacte, 45, 69. canagica, 69.

Philohela, S7, 88. minor, 88.

Phøbe, 254. Black, 255. Say, 255. Western Black, 256.

Phøebetria, 32, 33. fuliginosa, 33 .
Pica, 269. pica hudsouica, $269,2 \dot{2} 0$. nuttalli, 269 , 271.

Pici, 2, 110, 200.

Picicorvus, 28\%.

Picidie, 110, 200.

Picoides, 200, 208. americanus, 20太, 209. dorsalis, 208, 209. fasciatus, 20s, 209. arcticns, 208. tenuirostris, 208.

Pied-billed Grebe, 8.

Pigeon, Band-tailed, 138. Guillemot, 16.

Hawk, 168.

Passenger, 140. Red-billed, 140.

Pileolated Warbler, 428.

Pine Finch, 323. Siskin, 323.

Pinicola, 305, 308. euucleator alascensis, 308, 309. californica, 308. montana, 308.

Pink-footed Shearwater, 35. -sided Juuco, 348.

Piñon Jar, 284.

Piutail, 54.

Pipilo, 306, 363. aberti, 36:3, 368. erythrophthalmus, 364 . fuscus crissalis, $363,36 \%$. mesoleucns, 36:3, 366. senicula, 363,367 . maculatus areticns, 364 . atratus, 364,366 . clementæ, $364,366$. megalonyx, 36+. 365 . oregonns, 364,365 .

Pipit, 431. Sprague, 432.

Piranga, 379. erythromelas, 379, 380. hepatica, $379,381$. ludoviciana, 379 . rubra, 379, 382 . cooperi, 379. 382.

Pitangus, 245. 250. derbiauus, 250.

Plain Titmouse, 456.

Platrpsaris, 245. albiventris, 245.

Plegadis, 70,71 . antumualis, 71 . guarauna, 71 . 
Plover, Belted Piping, 104.

Black-bellied, 102.

Golden, 103.

Nountain, 105.

Semipalmated, 104.

Snowy, 105.

Upland, 99.

Wiilson, 105.

Plumbeous Gnatcatcher, 466.

Vireo, 397.

Plumed Partridge, 117.

Podasocys, 105.

Podiceps, 8 .

Podicipidæ, 2, 5.

Podilymbus, 5, 8. podiceps, 8.

Point Pinos Junco, 348.

Polioptila, 468, 465. cærulea, 465. obscura, 465, 466. californica, 465 , 466 . plumbea, 465, 466.

Polyborus, 147, 171. cheriway, 171.

Pomarine Jaeger, 18.

Pocecetes, 30t, 329. gramineus affinis, 329, 330. confinis, 329.

Poor-will, 224.

California, 225.

Frosted, 225.

Porzana, 79, 81.

carolina, 81.

coturniculus, 81, 82.

jamaicensis, 81, 82 .

noveboracensis, 81, 82 .

Prairie Falcon, 166.

Hen, 130.

Horned Lark, 268.

Sharp-tailed Grouse, 132.

Priocella, 33, 34.

glacialoides, 34 .

Procellariidæe, 3, :32, 33.

Progne, :382, 383.

subis, 383 .

hesperia, 383.

Psaltriparus, 452, 460.

lloydi, 460, 462 .

minimus, 460.

californicus, 460,461 .

plumbeus, 460,462 .

sautaritæ, 460, 462.

Psittaci, 1, 109, 192.

Psittacide, 109, 192.

Ptarmigan, Southern White-tailed. 129.
White-tailed, 129.

Ptychoramphus, 12, 13. aleuticus, 13.

Puffin, Tufted, 12.

Puffinus, 35.

bulleri, 35, 36 .

creatopus, 35 .

griseus, $35,36$.

opisthomelas, 35 .

temuirostris, $35,37$.

Purple Finch, 310.

Martin, 383.

Pygmy Nuthatch, 454.

Owl, 190.

Pygopodes, 1, 2, 5.

Pyrocephalus, 245, 264.

rubineus mexicanus, 264.

Pyrrhuloxia, 305, 370.

Arizona, 370.

sinuata, 370 .

texana, 370 .

Texas, 371 .

Quail, Mearns, 122.

Querquedula, 45, 52.

cyanoptera, 52 .

discors, 52, 53.

Quiscalus, 285, 301.

major macrourus, 301, 302.

quiscula æneus, 301.

Rail, Black, 82.

California Clapper, 80.

Caribbean Clapper, 80.

Carolina, 81.

Farallone, 82.

Tirginia, 80.

Yellow, 82.

Rallidæ, 4, 79.

Rallus, 79.

levipes, 80 .

longirostris caribæus, 80 .

obsoletus, 80 .

virginianus, 80 .

Raptores, 1, 109, 144.

Raven, American, 279.

Northern, 280.

White-necked, 280.

Recurvirostra, 86.

americana, 86.

Recurvirostridie, 4, 84, 86.

Red-backed Junco, 349.

Sandpiper, 93.

-bellied Hawk, 157.

Woodpecker. 218.

-billed Pigeon, 140. 
-breasted Merganser, 46. Nuthateh, 454.

Sapsncker, 211.

-eyed Cowbird, 288.

Vireo, 395.

-faced Warbler, 430.

-headed Woodpecker, 215.

-naped Sapsucker, 211.

Phalarope, 84.

-shafted Flicker, 221.

-tail, Western, 156.

-tailed Hawk, 155.

-throated Loon, 11.

-winged Blackbird, 290.

Redwing, Northwestem, 291.

San Diego, 291.

Solloran, 290.

Thick-billed, 291.

Vera Cruz, 290.

Reddish Egret, 76 .

Redhead, 56.

Redpoll, 319.

Hoary, 318.

Redstart, American, 429.

Painted, 430.

Regulus, 463.

ealeudula, $463,464$. grinnelli, 463,465 .

satrapa, 463.

olivacens, 463, 464 .

Rhinoceros Anklet, 13.

Rliynehodon, 167.

Rhynch ofaleo, 170.

Rhynchoplianes, 304, 326, 328. mecownii, 328.

Rhynclopsitta, 192. pachyrhrucha, 192.

Richardson Gronse, 126.

Merlin, 169.

Owl, 180.

Ridgway Flycatcher, 265. Junco, 348.

Rieffer Hummingbird, 243.

Ring-billed Gull, 23.

-necked Duck, 59.

Pheasant, 135.

Rio Grande Turkey, 136.

Yellow-throat, 426.

Riparia, 382, 386. riparia, 386.

Rissa, 19.

tridactyla polliearis, 19 .

Rivoli Hummingbird, 233.

Road-rumner, 193.

Robin, 472.

Westerı, 472.
Rock Sparrow, 355.

Wren. 44:3.

liocky Mountain Creeper, 451.

Hairy Woodpecker, 203.

Nuthatch, 453.

Pine Grosbeak. 308.

Screech Owl, 183.

Rodgers Fulmar, 34.

Rose-breasted Grosbeak, 372.

Ross Snow Goose, 66.

Rough-legged Hawk, 162. -winged Swallow, 387.

Royal Teru, 28.

Ruby-crowned Kinglet, 464. -throated Hummingbird, 235.

Ruddy Duck, 64. Horned Lark, 268.

Turnstone, 107.

Rufous-erowned Sparrow, 354. Hummingbird, 239.

- winged Sparrow, 353.

Russet-backed Thrush, 470.

Rusty Blackbird, 299.

song Sparrow, 358.

Sabine Gull, 27.

Sage Grouse, 133.

Sparrow, 351 .

Thrasher, 435.

Saint Lueas Woodpecker, 205.

Salpinctes, $434,443$. obsoletus, 443.

pulverius, 443.

Salt Marsh Song Sparrow, 358.

Yellow-throat, 425.

Samuels Song Sparrow, 358.

San Clemente Song Sparrow, 359. Towhee. 366 .

Wren, 448.

San Diego Red-wing, 291. Song Sparrow, 357.

Towhee, 366.

Fernando Towhee, 367.

Sanderling, 94.

Sandhill Crane, 79.

Sandpiper, Baird, 92.

Bartramian, 99.

Bonaparte, 92.

Buff-breasted, 100.

Least, 92.

Pectoral, 91.

Red-backed, 93.

Semipalmated, 93.

Solitary, 97.

Spotted, 100.

Stilt. 90 . 
Upland, 99.

Western, 94. Solitary, 98.

White-rumped, 92.

Sandwich Sparrow, 331.

Santa Barbara Flycatcher, 260. Song Sparrow, 358.

Cruz Jay, 276. Song Sparrow, 357.

Rita Bush-Tit, 462.

Sapsucker, Northern Red-breasted, 212.

Red-breasted, 211.

Red-naped, 211.

Williamson, 212.

Yellow-bellied, 210.

Savanna Sparrow, Western, 332.

Saw-whet Owl, 180.

Northwest, 181.

Saxicola, $467,475$.

cenanthe, 475 .

Say Phœbe, 255.

- Sayornis, 246, 254.

nigricans, $254,255$.

semiatra, $254,256$.

phœbe, 254.

saya, $254,255$.

Scaled Partridge, 118.

Scardafella, 138, 143.

inca, 143.

Scarlet Tanager, 380.

Scaup Duck, 57.

Scissor-tailed Flycatcher, 246.

Scolecophagus, 286, 299. carolinus, 299.

cyanocephalus, 299,300 .

Scolopacidæ, 4, 84, 87.

Seorehed Horned Lark, 269.

Scoter, American, 63.

Surf, 63.

White-winged, 63.

Scotiaptex, 175, 179. cinerea, 179.

Scott Oriole, 294. Sparrow, 354.

Screech Owl, 182.

Seed-eater, Sharpe, 376.

Seiurus, 401, 423. aurocapillus, 423. noveboracensis notabilis, 423 .

Selasphorus, 2:33, 2:37, 238. alleni, $238,241$.

floresii, 238.

platycercus, $238,240$.

rufus, 238, 239.

Semipalmated Plover, 104.
Sandpiper, 93.

Sennett Nighthawk, 228.

Oriole, 295.

Thrasher, 438.

Warbler, 407.

White-tailed Hawk, 158.

Setophaga, 401, 429. pieta, 129,430 . ruticilla, 429 .

Sharp-shinned Hawk, 151.

Sharpe Seed-eater, 376.

Shearwater, Black-vented, 35.

Dark-bodied, 35, 36.

Pink-footed, 35.

Slender-billed, 37 .

Sheldrake, 46.

Short-billed Gull, 24.

-eared Owl, 177.

-tailed Albatross, 32.

Shoveller, 54.

Shrike, California, 393.

Island, 393.

Northern, 392.

White-rumped, 392.

Sialia, 467,475 .

aretica 475,476 .

mexicana bairdi, 475,476 . oceidentalis, $475,476$.

sialis, 475 .

azurea, 476.

Sierra Creeper, 452.

Silver Pheasant, 135.

Simorhynchus, 12, 14. pusilius, 14.

Siskin, Pine, 323.

Sitkan Kinglet, 465.

Sitta, 452,453 .

canadensis, 453, 454 .

carolinensis, 453 .

aculeata 453 .

nelsoni. 453.

pygmæa, 45:3, 454.

Skylark, 265.

Slate-colored Junco, 346.

Sparrow, 362.

Slender-billed Fulmar, 34.

Nuthateh, 453.

Shearwater, 37 .

Small White-eyed Vireo, 399.

Smith Longspur, 326327.

Snipe, Jack. 88.

Wilson, 88.

Snowflake, 325 .

Snowy Heron, 75.

Owl, 187.

Plover, 105. 
Socorro Petrel, 38.

Solitaire, Townsend. 467.

Solitary Sandpiper, 97.

Song Sparrow, 356.

Sonora Yellow Warbler, 411.

Sonoran Red-wing, 290.

Sooty Albatross, 33 .

Fox Sparrow, 361.

Grouse, 125.

Soug Sparrow, 358.

Sora, 81 .

Southeru White-tailed Ptarmigan, 129.

Southwest Bewick IV ren, 447.

Sparrow, Baird, 333.

Belding Marsh, 332.

Bell, 351.

Bendire, 353.

Black-chinned, 345. -throated, 350 .

Botteri, 352.

Brewer, 343.

Bryant Marsh, 332.

Cassin, 352.

Clay-colored, 342.

Desert, 350. Song, 357.

English, 324.

Forbush, 360.

Fox, 360.

Gambel, 339.

Golden-crowned, 339.

Harris, 337.

Hawk, 170.

Heermann Song, 357.

Intermediate, 339 .

Large-billed, 333.

Lark, 336.

Leconte, 335.

Lincoln, 359.

Mendocino Song, 358.

Merrill Song, 359.

Mountain Song, 357.

Nelson, 335.

Nuttall, 339.

Oregon Song, 358. Vesper, 330.

Rock. 355.

Rufous-crowned, 354. -winged, 353.

Rusty Song, 358.

Sage, 351.

Salt Marsh Song, 358.

Samuels Song, 358.

San Clemente Song, 359.

Diego Song, 357.
Sandwich, 331.

Santa Barbara Song, 358. Cruz Song, 357.

Seott, 354.

Slate-colored, 362.

song, 356.

Sooty Fox, 361.

Song, 358.

Stephens, 363.

Swamp, 360.

Tehama Soung, 358.

Texas, 363.

Seaside, 335.

Thick-billed, 362.

Townsend, 361.

Western Chipping, 342.

Field, 344.

Grasshopper. 334.

Henslow, 334.

Lark, 336.

Savanna, 332.

Tree, 341.

Vesper, 329.

White-crowned, 338.

-throated, 340.

Worthen, 344.

Yakutat Fox, 361.

Spatula, 44, 54.

clypeata, 54 .

Speotyto, 175, 189.

cunicularia hypogæa, 189.

Sphyrapicus, 200, 210.

ruber, 210, 211.

notkensis, 210, 212.

thyroideus, 210, 212.

varius, 210.

nuchalis, $210,211,212$.

Spinus, 304, 323.

pinus, 323.

Spiza, 305, 377.

americana, 377 .

Spizella, 305, 341.

atrogularis, 341, 345 .

breweri, 341, 343 .

monticola ochracea, 341 .

pallida, 341, 342.

pusilla arenacea, 341,344 .

socialis arizonæ, $341,342$.

wortheni, 841,344 .

Spoonbill, 54.

Sporophila, 306, 376 .

morelleti sharpei, 376 .

Spotted Owl, 178.

Sandpiper, 100.

Screech Owl, 184.

Sprague Pipit, 432. 
Spurred Towhee, 365, 366.

Squatarola, 102. squatarola, 102.

Squirrel Hawk, 163.

Starling, 285.

Steganopodes, 1, 3, 39.

Steganopus, 84, 85. tricolor, 85.

Stelgidopteryx, 382, 387. serripennis, 387 .

Steller Jay, 272.

Stellula, 233, 241. calliope, 241.

Stephens Sparrow, 363. Vireo, 399.

Whip-poor-will, 223.

Stercorariidæ, 2, 17.

Stercorarius, 17. longicaudus, 18. parasiticus, 18. pomarinus, 18.

Sterna, 19, 27, 29. antillarum, 27,30 . caspia, $27,28$. elegans, 27, 29. forsteri, $27,29$. hirundo, 27, 29. maxima, $27,28$. paradisæa, 27,30 .

Stemula, 30.

Stilt Sandpiper, 90.

Streaked Horned Lark, 268.

Strigidæ, 109, 14t, 173.

Strix, 173. pratincola, 173.

Sturnella, 285, 292. magna hoopesi, 292. neglecta, 292 .

Sturnidre, 111, 245, 285.

Sturnus, 285. vulgaris, 285.

Sulphur-bellied Flycatcher, 250.

Summer Tanager, 382.

Surf Bird, 106. Scoter, 63.

Surnia, 175, 188. nlula eaparoch, 188.

Swainson Hawk, 156, 159.

Swallow, Bank, 386. Barn, 384. Cliff, 384. Mexican Cliff, 384. Northern Violet-green, 386. Rough-winged, 387. Tree, 385.

W'lite-bellied, 385.
Swallow-tailed Kite, 148.

Swamp Sparrow, 360.

Swan, Trumpeter, 70. Whistling, 70.

Swift, Black, 229. Chimney, 230. Vaux, 231. White-throated, 232.

Sylviidæ, 112, 11:3, 245, 463.

Symphenia, 88, 98. semipalmata inornata, 98.

Synthliboramplius, 12, 15. antiquus, 15.

Syruium, 175, 177. nebulosum, 177, 178. helveolum, 177, 178. oceidentale, 178. caurinum, 17s, 179.

Tachycineta, 38:2, 385. bicolor, 385 . thalassina lepida, 385, 386.

Tachytriorchis, 158 . Tanager, Cooper, 382.

Hepatic, 381.

Louisiana, 379 .

Scarlet, 380 .

Summer, 382.

Western, 379.

Tanagridæ, 111, 245, 379.

Tantalus, 72. loculator, 72.

Tatler, Wandering, 98.

Teal, Blue-winged, 52.

Cimmamon, 52.

European, 51.

Green-winged, 51.

Tehama Song Sparrow, 358.

Telmatodrtes, 450.

Temnessee Warbler, 406.

Teru, American Black, 31.

Aretic, 30.

Caspian, 28.

Common, 29.

Elegant, 29.

Forster, 29.

Gull-billed, 27.

Least, 30.

Roval, 28.

Tetraonidie, 108, 113.

Texan Bob-white. 116.

Cactus Wren, 442.

Horned Lark, 268.

Jay, 275.

Nightlatwk, 228.

Woodpecker, 204. 
Texas Barred Owl, 178.

Bewick Wren, 447.

Kingfisher, 199.

Meadowlark, 292.

Pyrrhuloxia, 371.

Nicreech Owl, 183.

Seaside sparrow, 335.

sparrow, 363.

'Thalasseus, 20's.

Thalassogeron, :'2, 33.

culminatus, 33.

'Thick-billed Parrot, 192.

Red-wing, 291.

Sparrow, 362.

Thrasher, Bendire, 439.

Brown, 438.

Californian, 440.

Crissal, 442.

Curve-billed, 439.

Leconte, 441.

Palmer, 439.

Pasadena, 441.

Nage, 435.

Simnett, 438.

Thrush, Alaska Hermit, 471.

Alma, 471 .

Audubon Hermit, 471.

Dwarf Hermit. 472.

Gray-cheeked, 469.

Monteres, 470.

Hermit, 471.

Olive-backed, 470 .

Pale Varied, 474.

Riusset-backed, 470 .

Varied, 473.

IVillow, 469.

IVood, 469.

'Thryomanes, 434.

bewickii calophonus, $4+6,447$.

charienturus, 446,447 .

cryptus, 446, 447 .

leucogaster, $446,447$.

spilurıs, 446, 448 .

leucophrss, $446,448$.

Thrrothoris, 435. 446.

ludovicianus, 446.

Thurber Junco, 347 .

Tinnunculus. 170 .

Titmouse, Black-crested, 455.

Bridled, $45 \%$.

Gray, 456.

Plain, 456.

Totanus, SS, 96.

flavipes, 97,97 .

melanolencus, 96 .

Towhee, 364.
Abert, 368 .

Anthony, 367.

Aretic, 364.

('alitornia, 367.

Canyon, 366.

Green-tailed, 368.

Oregon, 365.

San Clemente, 366.

Diego, 366.

Fernando, 367.

Spurred, 365.

Townsend Solitaire, 467.

Sparrow, 361.

IV arbler, 421.

Toxostoma, $434,437,438$.

bendirei, 4:3, 439 .

crissalis, $437,442$.

curvirostre, 4:3, 439.

palmeri, 4:3s, 439.

lecontei, 437, 441.

longirostre semnetti, 438.

redivivum, $4: 37,440$.

pasadenense, $437,441$.

rufum, 438.

Traill Flycatcher, 260.

Tree-duck, Black-bellied, 69.

Fulvous, 69.

Swallow, 385.

Tricolored Blackbird, 292.

Tringa, 87, 90.

alpina pacifica, 91, 93 .

bairdii, 91, 92 .

canutus, $90,91$.

fuscicollis, 91, 92 .

maculata, 91.

minutilla, 9192.

'T'rochilidæ, 110, 22\%., 232.

Trochilus, 23:3, 234, 2:35.

alexandri. 235, 237.

colubris, 235, $28 \%$.

Troglodstes, $434,448$.

aëdon parkmanii, 448.

aztecus, 449.

Troglodytidæe, 112, 113, 245, 433.

Trogon, 197.

ambiguus, 197.

Coppery-tailed. 197.

Trogonidze, 110, 19:), 197.

Trimpeter Swan, 70.

Tryngites, 87, 100.

subrnficollis, 100.

Tubinares, 1, :3, 32 .

Tufted Puffin, 12.

Tule Wren, 450.

Yellow-throat, 425.

Turdidæ, 112, 245, 467 . 
Turkey, Merriam, 136.

Rio Graude, 136.

Vulture, 145.

Water, 39.

Vild, 136.

Turnstone, Black, $10 \%$.

Ruddy, 107.

Tympanuchus, 113, 129.

americanus, 130 .

attwateri, 130, 131

pallidicinctus, 1:30, 131 .

Tyramidæ, 111, 245.

Tyrannus, 245, 247.

melancholicus couchi, 247, 248.

tyramnus, 247, 249.

verticalis, 247,248 .

vociferans, $24 \overline{7}, 248,249$.

Upland Plover, 99.

Uria, 11, 16.

troile californica, 16.

Urile, 41.

Urubitinga, 147, 160. antlıracina, 160.

Valler Partridge, 120.

Varied Bunting, 375. Thrush, 473.

Vaux Swift, 231.

Vega Gull, 23.

Verdin, 462.

Vermilion Flycatcher, 264.

Vigors Wren, 446.

Vireo, 394, 397.

Anthonv, 399.

atricapillus, 394, 397.

Bell, 399.

bellii, :394, 399.

Black-capped, 397.

Blue-headed, 396.

Cassin, 396.

flavoviridis, :394, 395.

gilvus, 394, 395 .

Gray, 400.

Hutton, 399.

huttoni, 3!5, 399.

obseurus, 39:5, 399.

stephensi, 39.), 399.

Least. 400 .

noveboracensis, :394, 398. micrus, 394, 399.

olivaceus, :394, 395.

pnsillus, 394, 400 .

Red-eyed, 395.

Small White-eyed, 399.

solitarins, 394, 396. cassinii, 394, 396.

plumbeus, 394, 397.

Stepliens, 399.

vicinior, 394, 499.

Warbling, 395.

White-ejed, 398.

Yellow-green, 395.

Vireonidæ, 11:3, 245, 394.

Vireosylva, 395.

Virginia Rail, 80.

WVarbler, 403.

Vulture, Black, 146.

California, 144.

Turkes, 145.

Wandering Tatler, 98.

Warbler, Alaskan Yellow, 412.

Audubon, 413.

Black and White, 402. -fronted, 415.

-poll, 416.

-throated Blue, 412.

Gray, 418.

Green, 420.

Blackburnian, $41 \%$.

Calaveras. 404.

Canadian, 428.

Cerulean, 416.

Chestnut-sided, 416.

Connecticut, 424.

Dusky, 405.

Golden-cheeked. 419. Pileolated, 428.

Grace, 418.

Hermit, 421.

Luer, 402.

Lutescent, 405.

Maegillivrar, 424.

Magnolia, 415.

Northern Parula, 406.

Olive, 410.

Orange-crowned, 404.

Paln, 422.

Pileolated, 428.

Red-faced, 430.

Sennett, 407.

Sonora Yellow, 411.

Temessee, 406.

Townsend. 421.

Virginia, 403.

Wilson, 428.

Yellow, 411.

-rumped, 412, 414.

Warbling Vireo, 395.

Water Ouzel, 432.

-tlırush, Grimell, 423. 
Turkey, 39.

Waxwing, Bohemian, 388.

Cedar, 388.

Western Black Phcebe, 256.

Bluebird, 476.

Blne Grosbeak, 373.

Chipping Sparrow, 342.

Evening Grosbeak, 307.

Field Sparrow, 344.

Flycatcher, 260.

Gnatcatcher, 466.

Golden-crowned Kinglet, 464.

Gosliawk, 153.

Grasshopper Sparrow, 334.

Grebe, 5.

Gull, 21.

Henslow Sparrow, 334.

Horned Owl, 185.

Lark Sparrow, 336.

Martin, 383.

Meadowlark, 293.

Mockingbird. 435.

Nighthawk, $22 \%$.

Red-tail, 156.

Robin, 472.

Sandpiper, 94.

Savanna Sparrow, 332.

Solitary Sandpiper, 98.

Tanager, 379.

Tree Sparrow, 341.

Vesper Sparrow, 329.

Willet, 89.

Winter Wren, 449.

Wood Pewee, 258.

Yellow-throat, 425.

Wheatear, 475.

Whip-poor-will, 223.

Stephens, 223.

Whistling Swan, 70.

White-bellied Swallow, 385.

-breasted Nuthatch, 453.

-cheeked Goose, 68.

-crowned Sparrow, 338.

-eared Hummingbird, 243.

-eved Vireo, 398.

-faced Glossy Ibis, 71.

-fronted Dove, 141.

Goose, 66 .

-headed Woodpecker. 207.

Ibis, 71 .

-necked Raven, 280.

-rumped Saudpiper, 92.

Shrike, 392.

-tailed Kite, 148.

Ptarmigan, 129.

-throated Sparrow, 340.
Swift, 232.

Wren, 445.

-winged Crossbill, 315.

Dove, 142.

Junco, 345.

Seoter, 63.

Whooping Crane, 78.

Widgeon, 49.

Vild Turkey, 136.

Willet, Western, 98.

Willianson Sapsucker, 212.

Willow Goldfinch, 321.

Thrusli, 469.

Woodpecker, 203.

Wilson Plialarope, 85.

Plover. 105.

Snipe, 88.

Warbler, 428.

Wilsonia, 401, 427.

canadensis, 427,428 .

pusilla, $42 \bar{\tau}, 428$.

chryseola, 428.

pileolata, 427,428 .

Wood Duck, 55.

Ibis, 72.

Pewee, 258.

Thrush, 469.

Woodeock, American, 88.

Woodhouse Jav, 274.

Woodpecker, Alaskan 'Three-toed, 209.

Alpine Three-toed, 209.

American Three-toed, 209.

Ant-eating, 216.

Aretic Three-toed, 208.

Arizona, 206.

Batchelder, 203.

Cabanis, 202.

Californian, 217.

Downy, 204.

Gairdner, 203.

Gila, 219.

Golden-fronted, 218.

Harris. 202.

Lewis, 217.

Northern Hairy, 201.

Pileated, 213.

Nuttall, 205.

Red-bellied, 218. -headed, 215.

Rocky Monntain Hairy, 203.

Saint Lueas, 205.

Texan, 204.

White-headed, 207.

Worthen Sparrow, 344.

Wren, Aztec, 449. 
Baird, $44 \%$.

Bryant Cactus, 443.

Cactus, 442.

Canyon, 445.

Carolina, 446.

Desert Cactus, 442.

Dotted Canyon, 445.

Interior Tule, 451.

Long-billed Marsh, 450.

Northwest Bewick, 447.

Pacific House, 448.

Parkman, 448.

Rock, 443.

San Clemente, 448.

Nicolas Rock, 443.

Short-billed Marsh, 450.

Southwest Bewick, 44\%.

'Texan Cactus, 442.

Texas Bewick, $44 \%$.

Tule, 450.

Vigors, 446.

Westeru Winter, 449.

White-throated, 445.

Wren-Tit, Coast, 460 . Pallid, 459.

Wright Flycatcher, 262.

Xanthoceplialus, 285, 288. xanthocephalus, 288.

Xanthoura, 269, 27\%. luxuosa glaucescens, $27 \%$.

Xantus Becard, 245.

Murrelet, 16.

Xema, 19, 2\%.

sabini, $2 \%$.
Xenopicus, 200, $20 \%$.

albolarvatus, $20 \%$.

Yakutat Fox Sparrow, 361.

Yellow-bellied Sapsucker, 210. -billed Cuckoo, 195, 197.

Magpie, 271 .

-crowned Night Heron, 78.

-green Vireo, 395.

-headed Blackbird, 288.

-legs, Greater, 96.

Lesser, 97.

-nosed Albatross, 33.

Rail, 82.

-rumped W'arbler. 412.

-throat, Pacific, 426.

Rio Grande, 426.

Salt Marsh, 425.

Tule, 425.

Western, 425.

Yphantes, 297.

Zamelodia, 304, 371.

ludoviciana, 371, 372.

melanocephala, 371, 372 .

Zenaidura, 138, 140. macroura, 140.

Zone-tailed Hawk, $15 \%$.

Zonotrichia, 306, 33\%, 341 .

albicollis, 3:37, 340 .

coronata, $337,339$.

leucophrys, 337, 338, 340.

gambelii, 337, 339.

inttalli, 337, 339.

querula, 337. 



\section{(che Atureside pregt}

Electrotyped and printed by H.O. Houghton \& Co. Cambridge, Mass., U.S. A. 


\section{BOOKS ABOUT BIRDS}

\section{EVERYDAY BIRDS}

Elementary Studies. By Bradford Torrey. With I 2 colored Illustrations. I $2 \mathrm{mo}, \$ \mathrm{I} .00$.

"The text is so fresh and readable and is written in such sympathy with the subject that bird lovers will enjoy perusal of Mr. Torrey's sketches, and cannot consider their ornithological libraries complete without including 'Everyday Birds.' " - The Auk.

Mr. TORREy's other books are :-

\section{SPRING NOTES FROM TENNESSEE}

\section{A RAMBLER'S LEASE}

BIRDS IN THE BUSH

THE FOOT-PATH WAY

A FLORIDA SKETCH-BOOK

A WORLD OF GREEN HILLS

Each, I6mo, \$1.25.

FOOTING IT IN FRANCONIA

I $2 \mathrm{mo}$, \$I.IO, net. Postage, 9 cents.

\section{THE WOODPECKERS}

By Fannie Hardy Eckstorm. With five full-page colored designs by Louis Agassiz Fuertes, and many text Illustrations. Square I2mo, \$I.OO.

"Selecting a group of widely distributed and easily identified birds, Mrs. Eckstorm has treated certain of its members as living object lessons in a study of the relation between structure and habit. The book forms not only a contribution to our knowledge of Woodpeckers, but is an admirable exposition of methods of observation and presentation in philosophic ornithology, and as such it should be in the hands of every thinking student." - Bird Lore.

Houghton, Mifflin \& Co., Boston and New York 


\section{BIRD BOOKS}

\section{BY MRS. FLORENCE MERRIAM BAILEY}

\section{BIRDS OF VILLAGE AND FIELD}

A Bird Book for Beginners. With over 300 Illustrations. I $2 \mathrm{mo}, \$ 2.00$

"The accuracy of the writer's statements and the breezy originality of her bits of bird biography commend her work to every bird lover, be he scientifically or otherwise minded. ... Its 'Outline for Field Observations' is probably the most complete key as to the proper use to make of one's eyes in the field ever formulated." - Science (New York).

\section{BIRDS THROUGH AN OPERA GLASS}

In Riverside Library for Young People. Illustrated. I6mo, 75 cents

"Its title sufficiently reveals its purpose, which is to invite laymen, and lay women as well, to the woods and pastures, where, glass in hand, they are to seek an introduction to the birds, study their habits, and by so doing gain at once a knowledge of bird life which books cannot supply, and reap the sure rewards which Nature always confers on her votaries. . . . A book wisely planned, well written, and sure to please its readers." - New York Evening Post.

\section{A-BIRDING ON A BRONCO}

With many Illustrations. I6mo, \$I.25

"Every lover of nature is indebted to Florence A. Merriam for her delightful book. The reader goes over the prairies, through the hedges and woods, with this writer. There is evinced a rare sympathy with bird life that gains revelations of these shy creatures, of their home ways." - The Outlook (New York).

\section{HANDBOOK OF BIRDS OF THE WESTERN UNITED STATES}

With 34 full-page and numerous text Illustrations. I 2 mo. $\$ 3.50$, nct; postage extra.

This book fills a growing demand for a manual of the birds of the West which should do for that part of the country what Mr. Chapman's "Handbook" does for eastern North America. It gives in a scientific, yet not unduly technical form, descriptions and life histories of all the bircls of the West. There are several hundred illustrations, including thirty-three full-page plates from drawings by Louis Agassiz Fuertes.

Houghton, Mifflin \& Co., Boston and New York 


\section{BIRD BOOKS}

\section{BY MRS. OLIVE THORNE MILLER}

\section{THE FIRST BOOK OF BIRDS}

With many Illustrations, including eight full-page colored plates. Square ismo, \$I.00. School Eidition, 6o cents, net, postpaid.

"Charming series of chapters on the life, dress, habits, qualities, travels, language, and other peculiarities of the little feathered creatures. The book will interest young people in the study of birds and stimulate them to further study." - Boston Herald.

\section{THE SECOND BOOK OF BIRDS}

Bird Families. With many Illustrations, including 8 full-page colored plates. Square I2mo, $\$ 1.00$, net; postage, Io cents.

"This book supplements and extends Mrs. Miller's 'First Book of Birds' by delightful studies of well-known bird families to the number of twenty-nine. It is written in a way to interest boys and girls as well as to instruct." - Educational Review.

\section{UPON THE TREE-TOPS}

With ten Illustrations by J. CARTER BEARD. I 6 mo, $\$ 1.25$

"Bird individualities are studied with minute care, and every little manifestation of character is dwelt upon in a way that brings the reader at once into sympathetic relation with the very human ways of the birds." - The Book Buyer, New York.

\section{LITTLE BROTHERS OF THE AIR \\ I $6 \mathrm{mo}, \$ 1.25$}

"In this book the author tells of kingbirds, thrashers, pewees, bluebirds, thrushes, blue jays, bobolinks, robins, and even crows, bringing us into closer acquaintance with these little brothers of the air." - Lowell Times.

\section{A BIRD-LOVER IN THE WEST \\ I $6 \mathrm{mo}, \$ 1.25$}

"The chapters detail the experiences of three seasons spent respectively in Utah, Colorado, and Southern Ohio. They are bright, piquant narratives, embodying the noteworthy incidents occurring in her observation of WVestern birds." - The Dial, Chicago.

\section{BIRD-WAYS}

I6mo, \$1.25. Also in Riverside SCHOOL Library, 60 cents, net.

"The author gives the result of her own observation of birds, either in the natural open-air life, or in the mild captivity in which they become her intimate companions.... Its fresh and simple style and pleasant animation of detail render further praise unnecessary." - Philadelphia-American.

\section{IN NESTING TIME}

\section{6mo, \$I.25}

"A record of careful and most sympathetic observations of bird-life and habit, by a genuine lover of nature. It is a truly charming chronicle. . . . Few closer or fuller studies of our song-birds have been made than are contained in this rolume." $-N . Y$. Tribune.

\section{Houghton, Mifflin \& Co., Boston and New York}




\title{
OUTDOOR BOOKS \\ BY JOHN BURROUGHS
}

"Mr. Burroughs has probably interpreted nature to a greater number of his contemporaries than any other writer of his time." - The Outlook.

\author{
WAKE-ROBIN \\ WINTER SUNSHINE \\ BIRDS AND POETS \\ LOCUSTS AND WILD HONEY \\ PEPACTON AND OTHER SKETCHES \\ FRESH FIELDS \\ SIGNS AND SEASONS \\ RIVERBY \\ Each I6mo, \$I.25
}

\section{A YEAR IN THE FIELDS}

Selections from the writings of JoHn Burroughs. With an Introduction and 20 Illustrations from photographs by Clifton Johnson. I2mo. \$I.5O.

\section{SQUIRRELS AND OTHER FUR BEARERS}

With I5 Illustrations in color after Audubon, and a

Frontispiece from life. Square I2mo, \$I.00. School. Edition, 60 cents, net, postpaid.

"Mr. Burroughs is one of nature's most persuasive prophets. His love for the woods and the fields, and all that is therein, is so sincere and ardent that the reader is brought under its spell almost unawares. Add to this that he is a man of singularly subtle imaginative perception, with a rare sense of humor, whose style is simplicity itself, and the charm of his writings can be imagined." - Philadelphia North American.

Houghton, Mifflin \& Co., Boston and New York 






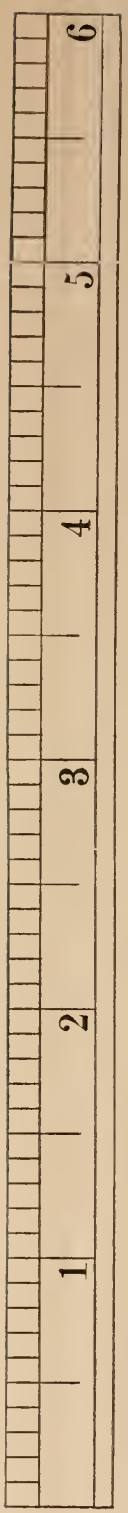


